3). 


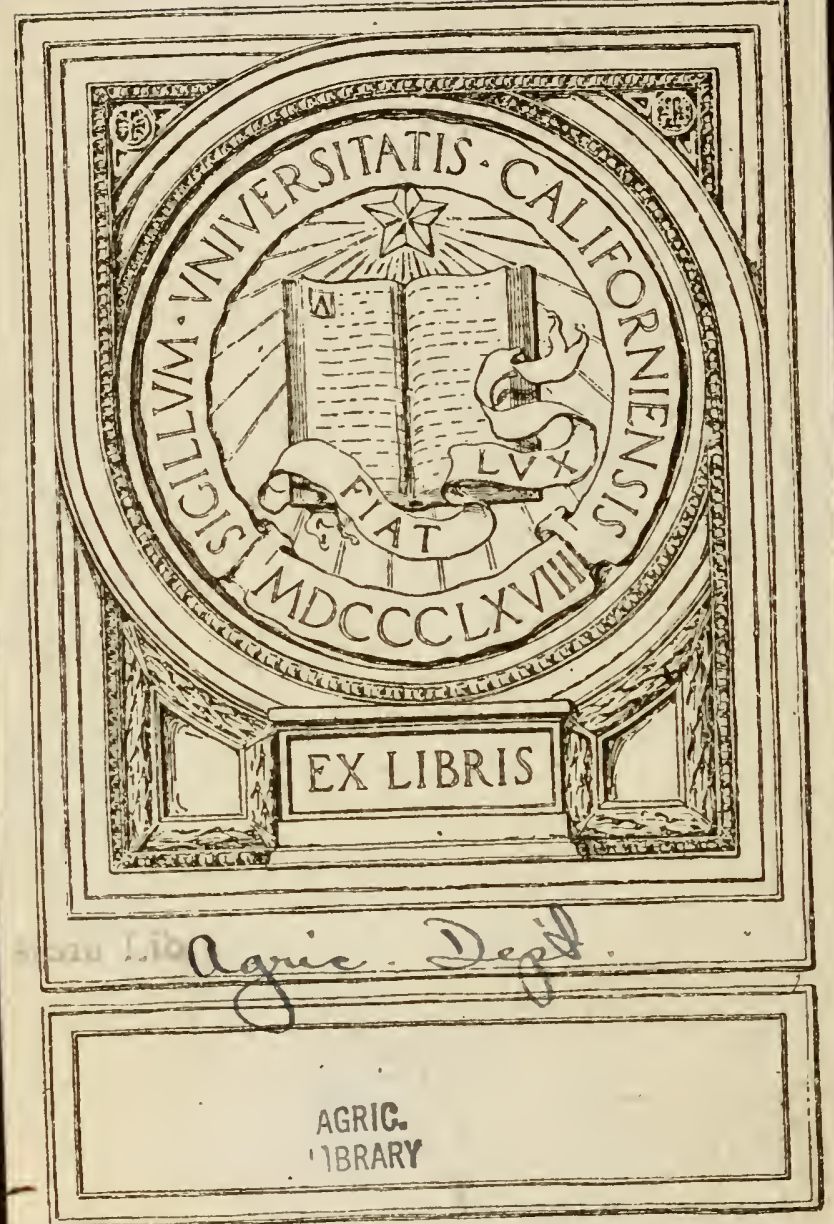



WORKS OF PROF. F. W. WOLL.

A Handbook for Farmers and Dairymen. Sixth Edition. New York, I9I4. xv+490 pp. \$1.50.

Grotenfelt's Modern Dairy Practice. American Edition by F. W. Woll. Third Edition, Revised. New York, I910. $286 \mathrm{pp} . \$ 2.00$.

A Book on Silage. Second Edition. Chicago, Ill., 1900. 234 pp. (Out of print.)

Decker's Cheese Making, Domestic and Foreign. Fifth Revised Edition, by F. W. Woll. Madison, Wis., 1913. 2II pp. SI.75.

Jointly with Prof. E. H. Farrington.

Testing Milk and Its Products. Twenty-second Edition. Madison, Wis., 1914. 297 pp. \$1.25. 


\section{A \\ $\mathrm{HAN}$ D B OOK}

FOR

\section{FARMERS AND DAIRYMEN}

BY

F. W. W O L L,

Professor of Animal Nutrition. University of California

WITH THE ASSISTANCE OF

WELL-KNOWN SPECIALISTS

ขextitb Ellustrations

SIXTH EDITION, REVISED

TOTAL, "EX THOUSAND ...

NEW YORK

JOHN WILEY \& SONS, INc.

LONDON: CHAPMAN \& HALL, LIMITED 
ARIVE

RGRARY

$\angle 18$

COPYRIGHT, I897, I900, I907, I908, I9I4

BY

F. W. WOLL

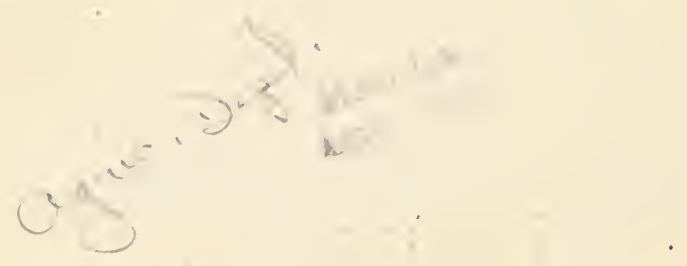




\section{PREFACE TO SIXTH EDITION.}

THE present edition of the Handbook has been carafully revised, with a view to including therein only the latest and best information on agricultural topics of importance to American farmers and dairymen. A number of new subjects have been added, and tables and articles have been brought up to date where better data were available. It is hoped that the changes and additions made will further increase the usefulness of this little volume to American farmers and students of agriculture.

F. W. WOLL.

June, 1914.

\section{PREFACE TO FIRST EDITION.}

THE effort of the author has been to make this small volume a compendium of useful information on farm and dairy topics. Brief discussions on subjects of importance and interest to farmers and dairymen have been introduced, and useful facts, tables, formulas, receipts, agricultural statistics, etc., are given to such an extent as the plan of the work permitted. Valuable data scattered throughout our agricultural literature, in the publications of our experiment stations and the scientific divisions of the United States Department of Agriculture, as well as in other public documents, and in farm papers and standard 
works, have been gathered in this Handbook and arranged in such a manner as to make them easily accessible and convenient for reference purposes.

The present volume is founded on the Dairy and Agricultural Calendars previously published by the author. Much new material, both original and compiled, has, however, been included, and special articles, tables, statistics, etc., have been verified and brought up to date, making the book, as it is hoped, of considerable value, and securing for it as favorable a reception as was accorded its predecessors.

The author takes this opportunity of thanking the following specialists who have so materially increased the usefulness of the book by comprehensive, concise contributions on subjects in their particular lines of study: Professors W. H. Caldwell, J. A. Craig, John W. Decker, L. H. Dewey, F. H. Farrington, B. E. Fernow, E. S. Goff, A. W. Richter, H. L. Russell, Thos. Shaw, Wm. P. Wheeler; and Messrs. John Boyd, W. G. Clark, M.D.C., N. S. Fish, J. D. Frederiksen, H. B. Gurler, S. Hoxie, J. Noer, M.D., J. H. Pickrell, H. B. Richards, L. P. Sisson, J. McLain Smith, and C. M. Winslow. 


\section{TABLE OF CONTENTS.}

\section{PART I. AGRICULTURE.}

\section{FEEDING STUFFS.}

Composition of Feeding Stuffs .................. I Table Showing Average Composition of American Feeding Stuffs.. 3 Ready Reference Table of Composition of Feeds............. 6 Classification of Cattle Foods . . . . . . . . . . . . . . I I Classification of Concentrates According to Protein Content ..... I I Feeding Standards for Farm Animals................ I 2 Rations for Dairy Cows..................... 14 r6 Calculation of Components of Feed Rations. . . . . . . . . I4 Average Weights of Concentrated Feeding Stuffs........... I 8 Food Requirements of Farm Animals ............... I 8 Comparative Value of Cattle Foods................... Io Calculated Value of Fruits Compared with Hay, Grains, etc..... I 9 Amounts of Different Feeds Required to Equal One Feed Unit.... I9a Pounds of Dry Matter, Digestible Matter, and Digestible Protein to be Furnished in Rations for Dairy Cows................ Igb

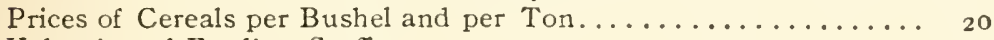

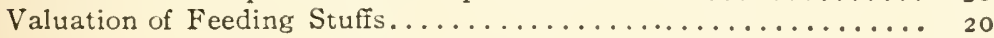

\section{FARM ANIMALS.}

Characteristics of Breeds of Live Stock. By the Late Prof. John A. Craig, of Iowa Agricultural College............... 2 I

Market Classes of Farm Animals.. .................. 28

Table for Estimating Live Weight of Cattle............. 35

Determination of the Age of Farm Animals by Their Teeth...... ${ }_{36} 6$

Body Temperature of Farm Animals................. 38

Duration and Frequency of Heat in Farm Animals............... 38

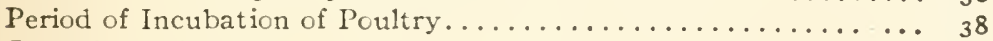

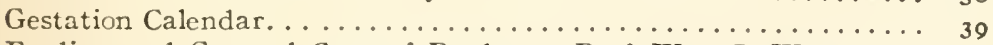

Feeding and General Care of Poultry. Prof. Wm. P. Wheeler, of N. Y. (Geneva) Experiment Station............... 4 I

Loss in Weight of Eggs During Incubation................. 46

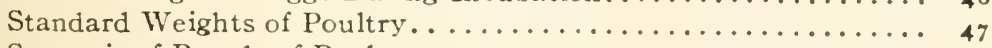

Synopsis of Breeds of Poultry........................ 48

Heredity. Prof. Thos. Shaw, late of Minnesota Experiment Sta-

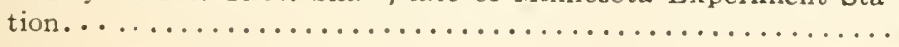




\section{VETERINARY SCIENCE.}

Common Diseases of Farm Animals. W. G. Clark, M.D.C., Marinette, Wis.

Veterinary Remedies and Doses. W. G. Clark, M.D.C., Marinette, Wis.

Suppression of Hog Cholera and Swine Plague.

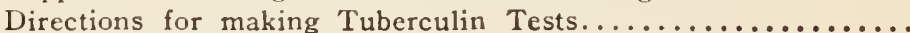

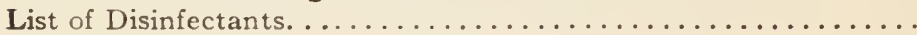

Rules for the Disinfection of Stables. . . . . . . . . . . . . . .

Regulations for the Government of Dairies and Dairy Farms in the District of Columbia.

\section{FIELD CROPS.}

Quantity of Seed Required to the Acre.................

Seed Mixtures for Hay and Permanent Pastures..............

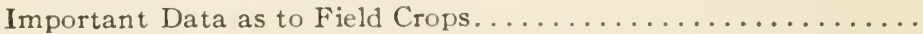

The Weight and Average Composition of Ordinary Crops, in Pounds per Acre. . . . . . . . . . . . . . . . . . . .

Soiling Crops Adapted to Northern New England States......... 8r

Time of Planting and Feeding Soiling Crops............ $8_{2}$

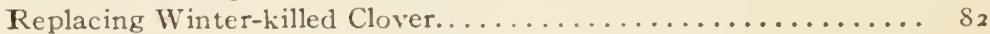

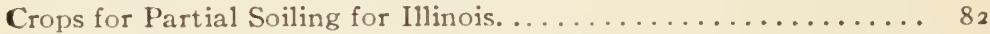

Succession of Soiling Crops for Dairy Cows. ............. 84

Capacity of Cylindrical Silos. ........................ 85

Relation of Horizontal Feeding Area and Number of Cows Kept for Silos 24 and 30 Feet Deep................... 85

Relation between Size of Silos and Number of Cows They Will Keep 86

Number of Plants or Hills for an Acre of Ground... . . . . . . 86, 87

Yield of a Good Crop of Farm Products per Acre............ 87

\section{HORTICULTURE.}

Gardener's Planting Tables. . . . . . . . . . . . . . . . . .

Distances Apart for Fruit-trees, Time Required to Bear Fruit, and Longevity. . . . . . . . . . . . . . . . . . . . . 90

Time of Germination of Vegetable Seeds and Maturity Table..... 90

Average Yields per Acre of Various Crops. .............. gr

A Combined Fruit and Vegetable Garden................ 92

A Vegetable Forcing Calendar. . . . . . . . . . . . . . . . 93

Seasons of Varieties of Apples in Various Storages........ 94

Packages Used is Shipping Fruit.......................... 94

Relation of Specific Gravity, Dry Mlatter, and Starch Content of

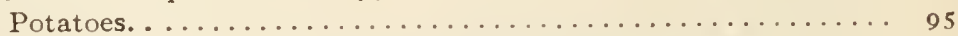

Specific Gravity, Sugar Content, and Boiling-point of Maple Sirup. $\quad 96$

Weight of Sugar Obtained from roo lbs. of Maple Sirup. . . . . . . 97

Sorghum Sirup Obtained from Juice of Different Densities....... 97

Temperatures to which Perishable Goods may be Subjected With-

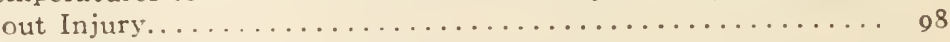

Temperatures Injurious to Plants. . . . . . . . . . . . . . 99

Best Temperatures for Preserving Horticultural Products, . . . . . . r roo 
The Preservation of Soft Fruits for Exhibition Purposes......... roo The Standards of the Baltimore Canned Goods Exchange...... I I 2 Packages Used in Shipping Fruit. .................. I

\section{SEEDS.}

Seed-testing for the Farmer, by the late Gilbert H. Hicks, of U. S.

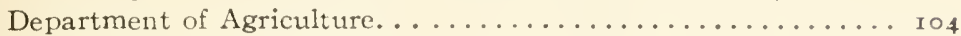

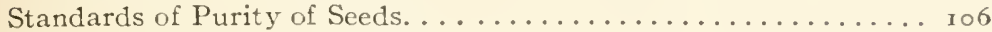

Table of Germination Standards..................... I . .

Number, Weight, Cost of Grass Seeds, and Amount to Sow per

Acre................................ Iog

Notes on the Adaptability and Uses of Grasses and Clovers...... II I

Vitality of Seeds if Properly Kept................... I 3

Seedsmen's Customary Weights per Bushel of Seeds. . . . . . . . . I I 4

Weight and Size of Garden Seeds................... I I 5

Average Time Required for Garden Seeds to Germinate......... I I 5

Yield of Seeds from an Acre.................... I I 5

VII. WEEDS.

Table of Noxious Weeds. L. H. Dewey, Assistant Fotanist U. S. Department of Agriculture. . . . . . . . . . . . . 6

\section{ENEMIES OF FARM CROPS.}

Treatments for Injurious Insects and Fungous Diseases of Plants, by the late Prof. E. S. Goff, of Wisconsin Experiment Station... I 2 I

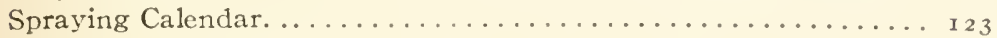

A Cheap Orchard-spraying Outfit.................. I 26

Prevention of Oat-smut................... I 27

The Formaldehyd Treatment for the Prevention of the Smuts of Cereal Grains and of Potato Seab. .................... r 29 Fighting the Chinch-bug by Means of Kerosene Emulsion........ I 30

\section{FORESTRY.}

Forestry for Farmers. Dr. B. E. Fernow, late Director N. Y. State College of Forestry..................... I 3 I Number of Trees on an Acre................... r 35 Fuel Value and Specific Gravity of Some of the More Important

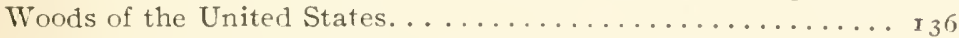

Distance Table for Tree-planting.................. I 38

States and Territories Observing Arbor Day, with Dates........ I 39 Forest-fire Laws in the United States................. I40

\section{MANURES AND FERTILIZERS.}

Manures and Fertilizers...................... r 44

Approximate Losses of Fertilizing Materials in Different Systems of Farming.............................. 45 Average Chemica Composition of American Soils............ I 46 Manuria. Value of Feeding Stuffs. . . . . . . . . . . . . . . 147

Fertilizing Constituent of Feeding Stuffs and Farm Products..... $\mathbf{1}_{4} 8$ 
Amount of Soil Ingredients Withdrawn by Various Crops. . . . . . . I 50 Amount of Fertilizing Materials Contained in Different Crops Grown on One Acre.......................... I 5 I

Farmyard Manure Required to Replace Ingredients Abstracted from the Soil by an Acre of Different Crops. . . . . . . . . . I 52 Amount and Quality of Manure Produced by Stoc.......... I 52

Composition, Amount, and Value of Manure Produced by Different Kinds of Farm Animals. . . . . . . . . . . . . . . I 53

Quantities of Nitrogen and Ash Constituents Voided by Animals. . I 53

Percentage Composition of Commercial Fertilizing Materials. ..... I 54

Exhaustion of Fertilizers. . . . . . . . . . . . . 56

Equivalent Quantities of Fertilizing Materials............ 157

Proportion of Plant Food Recommended for Crops........... I58

Valuation of Manures and Fertilizers. . . . . . . . . . 58

Trade Values of Fertilizing Ingredients in Raw Materials and

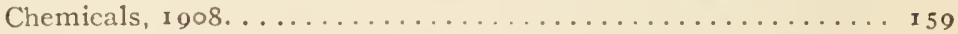

Conversion Table for Calculating Fertilizing Ingredients. . . . . . I 60

Prices of Nitrate of Soda on the Ammoniate Basis............ I60

XI. AGRICULTURAL ENGINEERING.

Drainage: Reasnns for Tile-training Land.............. I 6 I

Number of Rods and of Tiles per Acre, with Drains at Various

Distances Apart....................... I 62

Size of Tiles Required for Draining under Average Conditions. . I6z

Table of Size of Tile Pipe of Main Drain.............. I 63

Rule for Obtaining Size of Main Pipes................ I 63

Number of Acres which a Tile of a Given Diameter and Per Cent

Grade will Drain when Used as an Outlet. . . . . . . . . . I 64

Number of Acres Drained by Tiles Removing $\frac{1}{d}$ in. Depth of

Water in Twenty-four Hours. . . . . . . . . . . . . I 65

Number of Acres Drained by Open Ditches. ............ 166

Advice to Land Owners About to Construct Drains. ......... 168

Points to Note in Planning a Drainage System........... I 69

Sizes of Drain-pipe Required for Culverts in Proportion to

Capacity and Fall. ...................... 60

Areas from which $\$$ in. of Water will be Removed in Twenty-four

Hours by Outlet Tile Drains of Different Diameters and

Lengths with Different Grades.................. 1 70

Rise of the $\mathrm{S}$ l ppe for roo Feet.................... I 7 I

Quantity of Earth Removed per Rod of Drains of Various Dimensions.

Limit of Size of Tile to Grade and Length............ 172

Rainfall. ........................ I 72

Windmills: Table Showing the Force and Velocity of Wind..... I 73

Number of Square Feet and Acres Irrigated by Windmills of Different Sizes.

Table Showing Capacity of Windmills............... I74

Table Showing Economy of $\mathbb{T}$ indmills................ 175

Nominal Horse-power Required for the Discharge of Given Quantities of Water with Lifts of 10 and $20 \mathrm{Ft} . \ldots \ldots \ldots$ I 76 
Irrigation: Definition of Technical Terms. ............ I 6

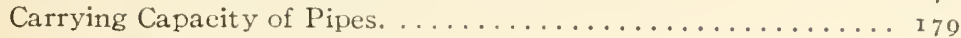

Flow of Water Through Straight Pipes................ I 79

Power Required to Raise Water from Deep Wells by Pumping.. I 80 Approximate Cost of Different Kinds of Pipe used for Irrigation. I 30 Average Cost per Mile of Constructing Irrigation Canals and Ditches. . ............................. I 80

Capacity of Windmills and Pumps................ I 8 I

The California Weir Table.................... I 82

Capacity of Cisterns and Tanks. . . . . . . . . . . . $8_{2}$

Capacity of Cisterns in Barrels, per Foot in Depth........... I 83

Koads: Road-making....................... I 83

Importance of Good Roads...................... I 85

Tractive Force Required for Carriages. ................ I 85

Fraction of the Weight of a Vehicle and Load Required to Move

Same on a Level Road........................ I86

Tractive Power of Horses at Different Speeds. . . . . . . . . . I 86

Effect of Inclination on Tractive Force ............... r 8 7

Effects of Surface on Tractive Force............... I 88

Cost of Hauling Farm Produce in the United States......... r 88

Transportation on the Farm................... I 89

Labor Done by one Horse on Canals, Railroads, and Turnpikes. . I 89

Labor Done by Team in Plowing . . . . . . . . . . . . . . . . . . I s9

The Effect of Wide Wagon Tires................... I 90

Average Quantity of Stone Required to Keep Rnads in Repair. . I9o Interior Dimensions of Farm Buildings ............... I I I Recipe for Whitewash ...................... I Table of Cut Nails ........................... I $9_{2}$

\section{HUMAN FOODS.}

Composition of Human Food Materials ............... I0.3, i 98 Percentages of Nutrients, Water, and Refuse in Food Naterials... I97 Pecuniary Economy of Food ...................... 200 Amounts of Nutrients Furnished for 25 Cents in Food Materials... 20I Dietary Standards........................... 203 Summary of American Dietary Studies ................. 203 Diagram of a Good Steer's Carcass as Cut up and Priced in Eastern Markets............................. 204 Diagrams of Cuts of Vea1, MIuttnn, and Prik............ 205 Live Weight and Dressed Weight of Steers of Different Breeds

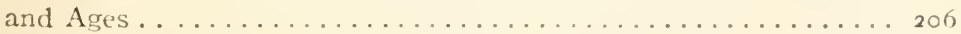
Proportion of Beef to the Live Weight of Cattle............. 206 Comparative Results Obtained with Fattening Animals......... 207 Live Weight and Gains Made by Swine . . . . . . . . . . . . . . 207 Proportions of the Various Parts of Cattle, Sheep, and Swine... 208 


\section{PART II. DAIRYING.}

\section{DAIRY COWS.}

On the Origin and Charactristics of the Different Breeds of Dairy

Cattle..................................

I. Jersey Cattle. By the Author ............... 2 I r

II. Guernsey Cattle. Prof. IV. H. Caldwell, Sec'y........ 2 I 4

III. Holstein-Friesian Cattle. M. H. Gardner, Supt. Adv. Reg. 213

IV. Ayrshires. C. M. Winslow, Sec'y . . . . . . . . . . 222

V. Shorthorns as Dairy Cows. By the Late J. H. Pickrell,

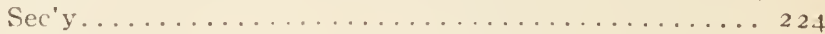

VI. Red Polled Cattle. By the Late J. McLain Smith, Sec'y 227

VII. Devon Cattle. L. P. Sisson, Sec'y . . . . . . . . . . . 230

VIII. Dutch Belted Cattle. H. B. Richards, Sec'y ........ 232

IX. Brown-Swiss Cattle. N. S. Fish, Sec'y . . . . . . . 234

Yield of Milk and Fat from Dairy Cows................. 236

Results of Tests of Dairy Breeds Conducted by American Experiment Stations.............................. 237

Results of Breed Tests Conducted at World's Columbian Exposi-

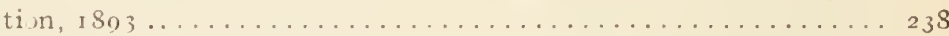

Results of "Cow Demonstration" at La. Purchase Exposition, St.

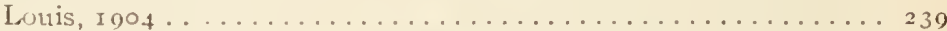

Highest Recurd for Yield of Fat Nade by any Cow in a Public Test

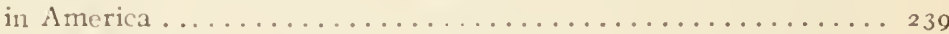

Official Milk and Butter Records of Holstein Jersey, Guernsey, and

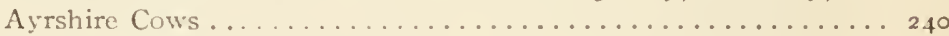

Results of English Milking Trials.................. 24I

Requirements for Admission to the Advanced Register of American Cattle Clubs............................ 24

Average per Cent of Fat and Production of Milk and Butter Fat by Pure-bred Dairy Cows, per Breed................... 242 Average Percentage Composition of Milk from Different Breeds... 242 Method of Judging the Value of Dairy Cows............... 243 Buying and Selling Cows by Tests of Their Milk........... 244 Fifty Dairy Rules.......................... ${ }_{244}$

\section{MILK.}

Percentage Composition of Various Kinds of Milk.......... 248 Average Analyses of American Samples of Dairy Products....... 248 Average Composition of Cow's' Milk, with Variations........... 249 Composition of Morning and Evening . Iilk, and of Morning, Nonn, and Evening Milk......................... 249

Composition of Different Parts of the Same Milkings.......... 249

Calculation of Components of Cows' lilk.............. 250

Relation of Fat to Casein and Other Solids ............... 250

Fertilizing Ingredients in Dairy Products.............. 25

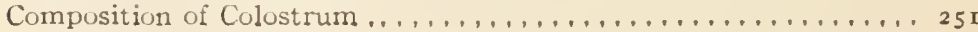


Composition of Ash of Cows' Milk and Colostrum........... 25 I

A Chapter on Milk Testing ................................ 25

Table for Converting N. Y. Board of Health Lactometer Degrees to

Qucvenne Lactometer Degrees ................... 255

Temperature Correction Table for Specific Gravity of Milk...... 256

Calculation of Total Solids of Milk................. 258

Table for Calculating Total Solids from Specific Gravity and Fat. . 260

Calculation of Specific Gravity of Milk Solids............. 26r

Standards for Dairy Products . . . . . . . . . . . . . . 262

Government Standards of Purity for Milk and its Products...... $26_{4}$

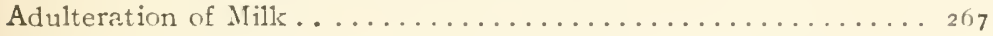

Ranges of the Variations in the Composition of Herd Mlilk...... ${ }_{2} 68$

Tables for Converting Quarts of Milk into Pounds, and vice versa. . 260

Milk Prices by Measures...................... 269a

Relative Value of Milk and Cream of Different Fat Contents. 26g b Amounts of Milk, Crean, or Skim-milk to be used in Modifying

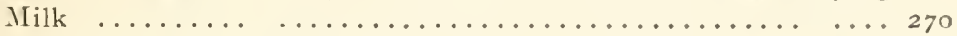

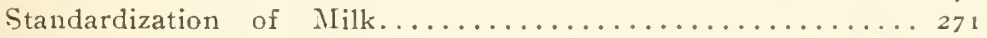

Rules and Regulations for Care of Cows and Handling of Milk 272

\section{CREAM.}

Percentage Composition of Cream and Other Dairy Products.... 273

Yield of Cream from Milk of Different Richness............. 274

Calculation of Per Cent Fat in Cream............... 275

Hand and Power Cream Separators on the American Market, 19 13. 276

Formulas for Finding the Fat Content of Cream............... 278

Formula for Diluting Cream to a Desired Fat Content......... 2 ;9

Handling and Care of Crcam Separators. J. D. Frederiksen, Mgr.

Chr. Hansen's Laberatory, Littl. Falls, N. Y............ 270

Per Cent Fat in Centrifugal Skim-milk. . . . . . . . . . . . 2 so

Loss of Butter Caused by Inefficient Skimming. . . . . . . . . . $2 s_{5}$

Standardization of Cream ....................... 286

Steam-boiler and Engine Management. Pruf. A. Wi. Richter, of the University of Montana.................... 286

On the Preservation of Milk and Cream by Hcat. Dr. H. L.. Russell of Wisconsin Experiment Station. . . . . . . . . . . . 290

Directions for the Sterilization of Milk................ 293

Quantity of Water or Ice Required for Cooling Milk or Cream... 294

\section{BUTTER.}

Butter-making. H. B. Gurler, ex-President Illinois State Dairy"men's Association . . . . . . . . . . . . . . . . . . . 295

On the Use of Pure Cultures in Butter- and Cheese-making..... 297

Boyd's Process of Cream-ripening. John Boyd. Chicago, Ill..... 30 r

The Alkaline Tablet Test of Acirlity in Milk or Cream. Prof. E. H.

Farrington, of Wisconsin Dairy School. . . . . . . . . . 304

Directions for the Use of Manns' Test for Ascertaining the Acidity

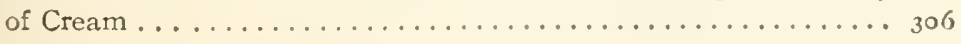


Percentage Composition of Butter......................... 307

Average Chemical Composition of Sweet-cream and Sour-cream

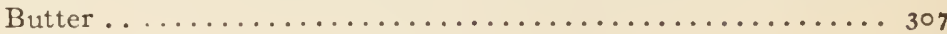

Analyses of American Premium Butters................ 308

Analyses of Foreign Samples of Buttcr............... 308

Commercial Grades of Butter ........................... 309

Formula for Calculating the Yield of Butter............. 3 I I

Conversion Factor for Calculating Yield of Butter from the Yield of Butter Fat ..................... 3 r

Yield of Butter from roo Pounds of Cream of Different Richncss.. 3 I 1

Yeld of Butter Corresponding to Yield of Butter Fat, per Day and per Week.................................. 312

Value of $\frac{\text { IOns }-100}{s}$ for Specific Gravities r.019 to r.0399 ....... 3 3

Relation of Fat Content to Acidity of Skim-milk, Milk, and Cream. 313 The Sliding Scale Overrun................... 314 Comparative Prices of Milk, Cream, Butter-fat, and Butter... 314 Pounds of Milk Required for Making One Pound of Butter...315, 316 Distribution of Milk Ingredients in Butter-making......... 3 ז6 Score for Judging Butter.................... 316 English Scale of Points for Judging Butter.............. 317 Score in Judging, Proficiency of Butter-makers............ 317 Analyses of American Dairy Salts ................. 3 i 8 Temperatures at which Dairy Products should be Stored in Cold Storage ................................ 318

\section{CHEESE.}

How American Cheese is Marle. By the Latc Prof. John W. Decker, of Ohio Dairy School.................... 3 I9

A. Factory or Cheddar Chcesc................... 319

B. Cheese Made on the Farm................... 32 I

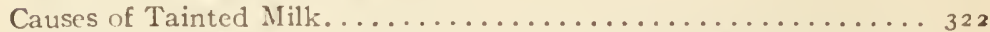

Detecting Bad Milk. Dircetions for Operating the Wisconsin Curd

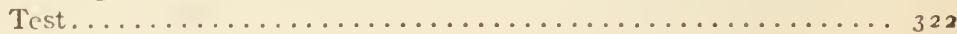

The Fermentation Test ........................... 324

Determination of Humidity in Cheese-curing Rooms.......... 326

Table Showing Relative Humidity of the Air............. 327

Score for Judging Checse........................ 329

Percentage Composition of Cheese.................... 329

Varieties and Analyses of Cheese.................. 330

Distribution of Ingredients in Cheese-making............ 330

Formulas for Finding Yield of Cheddar Cheese............. $33 \mathbf{r}$

Yield of Different Kinds of Cheese from roo lbs. of Milk....... 332

Average Loss of American Cheddar Cheese in Curing.......... 333

Loss in Weight of Different Kinds of Cheese During Curing...... 333

Yield of Cheese from, and Relative Cheese Value of, Milk of Different

Richness. . . . . . . . . . . . . . . . . . . . . 334

Synopsis of IIanufacture of Principal Varieties of Cheese . . . . . 336

The Cheese Market of the United States........................... $336 a$

Commercial Grades of American Cheddar Cheese......... $336 a$

Quantities of Whey to be Returned to Patrons........... 337 


\section{MANAGEMENT OF CREAMERIES AND CHEESE FACTORIES.}

PAGE

Directions for Taking and Preserving Composite Samples of Milk

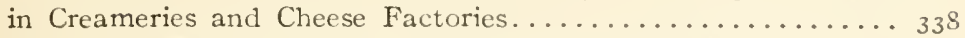
Payment for Milk at Creameries and Cheese Factorics......... 340 Methods of Payment for Milk at Cheese and Butter Factories.... 34 I Price of Milk of Different Richness per Hundred Pounds. . . . . . 343 Directions for Making Dividends in Creameries and Cheese Factories 345 Yield of Butter from roo 1bs. Milk, according to Different Overruns 3.40 Table Showing Average Per Cent of Fat in Milk... . . . . . . 347

Suggestions to Patrons of Cheese Factories and Creameries. . . . . . 349 By-laws and Rules for Co-operative Creamery Associations. . . . . . 35 I By-laws and Rules for Co-operative Cheese Factories......... 354 Rules for Patrons and Instructions to Cream or Milk Gatherers... 350

\section{PART III. GENERAL TOPICS.}

\section{CONSTITUTIONS OF AGRICULTURAL ASSOCIATIONS.}

Constitution and By-laws of Agricultural Clubs. . . . . . . . . . . 359 Constitution of Village-improvement Societies .............. 364

Constitution of Road Leagues . . . . . . . . . . . . . . . 366

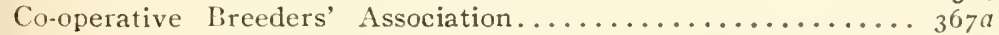
Dairy Test Associations ........................... 36 b

\section{MISCELLANEOUS SUBJECTS AND TABLES.}

Explanation of Flag and Whistle Signals Adopted by the U. S.

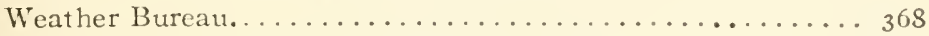
Explanation of Storm and Hurricane Warnings............. 369

List of Headquarters of State Weather Services............. 370 Beneficial and Harmful Hawhs and Owls................ 370 How Patents are Issued . . . . . . . . . . . . . . . . 37 I

Legal Holidays............................... 375

What to do in Case of Accidents. J. Noer, M.D., Stoughton, Wis. 377 Treatment for Poisoning ....................... 380

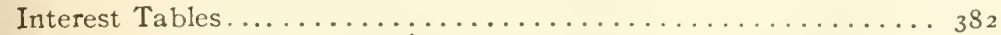

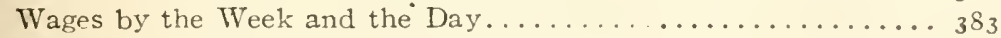

Number of Days between Dates within Two lears ........... 384

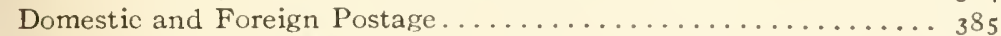

Postal and Express Money Order Rates................. 386

\section{WEIGHTS AND MEASURES.}

Customary System of Weights and Measures............. 387

Metric System of Weights and Measures.............. 388

Conversion of U.S. Weights and Measures to Metric, and vice versa 389 Kilograms Converted into Pounds, and vice versa........... 390 Inches Reduced to Decima.s of a Font.................. 390 Ounces Reduced to Decimals of a Pound................ 390 W/eight and Measure Conversion Table..................... 39 I 
Table of Reciprocals of Numbers.................... 392

Comparisons of Fahrenheit, Centigrade, and Réaumur Thermometer Scales. . . . . . . . . . . . . . . . . . . . . . . 392

Government Land Measures. . . . . . . . . . . . . . . . 396

To Measure Corn on the Cob in Cribs................. 397

Reckoning of Amount and Value of Hay in Mows or Stacks... . . 397

Strength of Hemp, Manila and Wire Ropes. . . . . . . . . . . . . 399

Legal Weights of Grain, Seeds, etc.................. 400

Commercial Grades of Grain.................... 40 I

Grades of Hay and Straw .................... 406 a

Specific Gravity of Various Substances ................. 407

Values of Foreign Coins........................ 409

Money Conversion Table ..................... 4 I

\section{STATISTICAL TABLES.}

United States, Area and Population, 19 і0.............. 4 I I

Canada, Area and Population, $1012 \ldots \ldots \ldots \ldots \ldots \ldots \ldots \ldots \ldots$ II I

Normal Mean Temperature of the Air in the United States.... 4 12

Average and Actual Date of Last and First Killing Frost...... . 413

Normal Precipitation in the United States........................ 415

Neteorological Data for Canada..................... 4 I 6

Comparison of Leading Industries in the Lnited States........ 416

Areus of Appropriated, Vacant, and Reserved Lands in the United

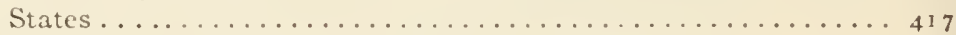

Farming Ponulation of the United States, $1880-1000 \ldots \ldots \ldots \ldots .417$

Number and Classification of the Agricultural Population, ro Years

and Over............................... 418

Number of Farms in the United States, and their Value....... 4 8

Statistics Concerning Farms in the United States............. 419

Statistics of the Principal Crops in the United States in I9I2.. . . 420

Average Agricultural Wages in the United States in I893-1895 . . 424

Industry Groups in the United States.................. 424

Area, Production, and Value of Principal Crops in the United

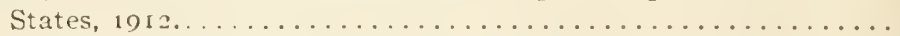

The Principal Cereal Products of the United States, I850-I910... .

Production of Various Crops in Canada, I901.............. 425

Average Cost per Acre of Raising Wheat, Corn, and Cotton in the

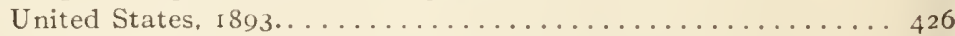

Average Farm Price of Agricultural Products, 1890-1910........ 426

Number and Value of Farm Animals in the United States, I880-I910 427

Values of Farm Property and Products in Canada, 1901....... 427

Number of Farm Animals and Animal Products in Canada, I90 I . 427

Breeds and Number of Registered Live Stock in the United States, Dec. 3I, I905............................. 428

Pure-bred Cattle of Breeds Used for Dairying. . . . . . . . . . . . . 429

Number and Average Price of Farm Animals in the United States,

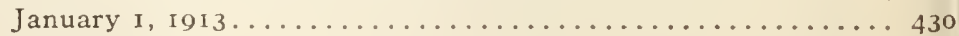

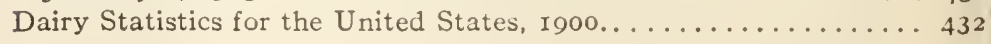


Statistics of Butter, Cheese, and Condensed-milk Factories (Twelf PAGE

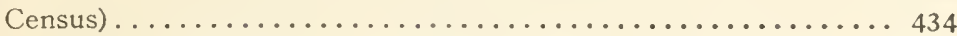

Butter- and Cheese-making in Canada, I90r............. 435

Wool Product of the United States, I9r2............... 435

Production of Sugar in the United States. I870-I9Ir.......... 435

Statistics of Beet-sugar Factories in the United States for I9r 2.. . 436

Production of Cane- and Beet-sugar, I903-I9II............. 436

Maple-sugar and Sirup, and Sorghum Sirup Produced in the

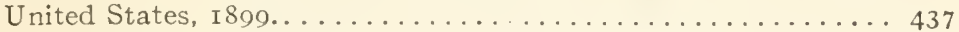

Statistics of the Lumber Industry of the United States, I906.... 437

Poultry and Egg Products in the United States, I $879-1899 \ldots \ldots 438$

Production of Honey and Beeswax in the United States, According to Census Returns of $1869-1899 \ldots \ldots \ldots \ldots \ldots \ldots \ldots \ldots \ldots \ldots \ldots \ldots \ldots$

Bees, Honey, and Wax in the United States, I $899 \ldots \ldots \ldots \ldots \ldots 438$

Imports and Exports of Agricultural Products in the United States,

I9I I-I9I2 . . . . . . . . . . . . . . . . . 439

Domestic Exports of Butter and Cheese, I870-I9I2........... 446

Exports of Dairy Products from Canacla, I87o-19ro.......... 446

The Fertilizer Industry of the United States............. 447

Imports and Exports of Fertilizers in $s_{9} 6 \ldots \ldots \ldots \ldots \ldots \ldots 4: 7$

Imports of Fertilizers and Fertilizer Materials, $1896 \ldots \ldots \ldots \ldots$. 4.47

Rank of States as Regards Value of Agricultural Products....... 448

\section{DIRECTORY OF AGRICULTURAL INSTITUTIONS.}

Organization of the U.S. Department of Agriculture........ 452

Ministers and Commissioners of Agriculture in Canada........ 453

State Officials in Charge of Agriculture in the United States..... 453

American Educational Institutions Having Courses in Agriculture. 454

Statistics of Agricultural Schools and Colleges in the United States. 456

List of American Veterinary Colleges................. 456

Veterinary and Sanitary Officers in Charge of Live-stock Interests. 456

Dairy Schools in the United States and Canada............ 457

Schools of Forestry............................. 457

Agricultural Experiment Stations in the United States and Canada. $45^{8}$

Officials in Charge of Farmers' Institutes............... 459

\section{AGRICULTURAL AND DAIRY LITERATURE.}

More Important Works on Dairying................. 460

A List of Sixty Agricultural and Horticultural Books........ $46_{2}$

List of American and Foreign Dairy Papers............. 464

The Main American Agricultural and Horticultural Papers....... 466

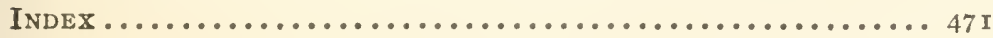




\section{COMPOSITION OF FEEDING STUFFS}

Chart showing Pounds of Water and of Digestible Matter in $100 \mathrm{lbs}$.

$\begin{array}{ccc}\text { Digestible } & \text { Digestible } & \text { Digestible } \\ \text { Protein } & \text { Carbohydrates }\end{array}$

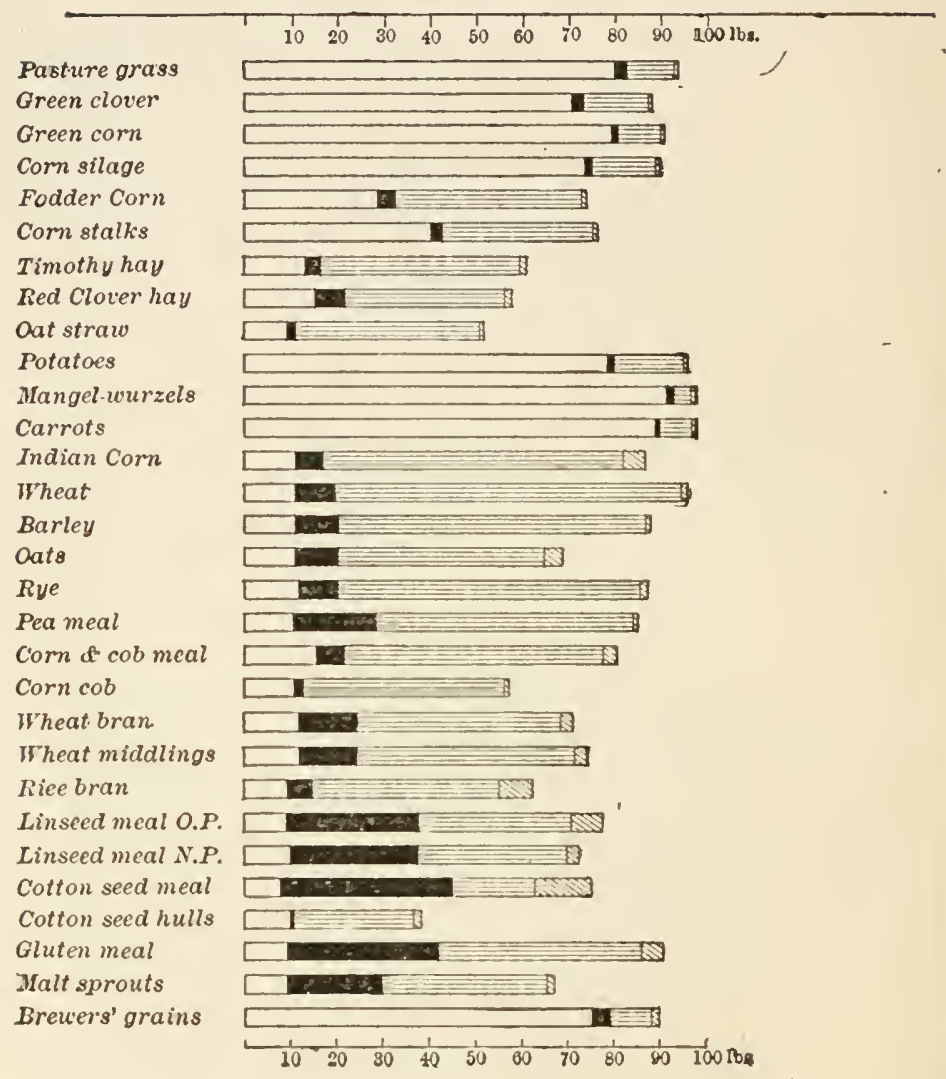




\section{PART I. AGRICULTURE.}

I. FEEDING STUFFS.

\section{COMPOSITION OF FEEDING STUFAS.}

In the ordinary chemical analysis of feeding stuffs the following constituents are determined, viz., water, ash, protein, crude fiber, nitrogen-free extract, ether extract (fat).

Water is present in all feeding stuffs, from above 90 per cent in green foods and some kinds of roots, to below ro per cent in very dry hay and in concentrated food stuffs.

Ash, or mineral matter, is the non-combustible part of plants, and goes to make the bones of the animal, or to supply material for the maintenance of other parts of the animal body.

Protein is the name of a large group of substances, ali characterized by the fact that they contain the element nitrogen; hence they are also called nitrogenous substances, and foods rich in protein are spoken of as nitrogenous foods. The protein substances supply the material necessary for the formation of lean meat, ligaments, tendons, hair, horns, hoofs, etc., and also of casein of the milk. Crude protein includes albuminoids and amides; among the former are found white of egg, lean meat, curd of milk, and gluten: among the latter, asparagin and other crystallizable and water-soluble substances, generally speaking, of a somewhar inferior nutritive value.

Crude Fiber or woody fiber is the framework of plants, forming the walls of their cells; it is usually the least digestible portion of feeding stuffs, and the nutritive value of a plant is decreased as its cruce fiber content increases.

Nitrogen-free Extract includes starch, sugar, gums, organic acids, etc., and forms a most important and usually a very large part of cattle foods. Together with cellulose, nitrogen-free extract forms the group of bodies called curbo. 
hydrates. A general name for carbohydrates is heat-produc* ing substances, as against flesh-forming substances, i.e., nitrogenous compounds, the names indicating the main effices of the substances in animal nutrition.

Ether Extract, or crude fat (oil) includes a group of com. pounds dissolved out by ether in the analysis of foods; fat fcrms the main part of the extract; most feeding stuffs contain only a small quantity of fat, but this component is nevertheless of considerable importance in the fecding of animals.

Organic Matter signifies the combustible portion of chemically dry feeding stuffs, i.e., all the components given in the preceding except water and ash.

Digestible Components. - The food stuffs used in the feeding of farm animals are only partly of direct value to the animals, the portion which their digestive fluids are unable to dissolve being voided in the excrements. The digestibility of fodders has been determined by direct experiments with different kinds of farm animals, in this country or abroad. The digestion coefficients (sec pp. 6-3) mean the percentages of any one component which have been found to te digested by the animals experimented on.

Nutritive Ratio signifies the ratio between the digestible nitrogenous and non-nitrogenous components in a feeding stuff, or a combination of such. As fat has been found to yield about 2.2 times more heat, when burned, than do starch. sugar, and other carbohydrates, the per cent of digestible fat in a food is multiplied by 2.2 when the nutritive ratio is to be calculated; the product is added to the per cent of digestible carbohydrates (nitrogen-frce extract + crude fiber), and this sum is divided by the per cent of digestible protein. (The factor $2 \frac{1}{2}$ or $2 \frac{1}{4}$ is sometimes used for obtaining "the starch equivalent" of fat.)

Example: Clover hay contains on the average 6.5 per cent digestible protein, 34.9 per cent digestible carbohydrates, and r.6 per cent digestible fat (sce following table):

$$
\text { I. } 6 \times 2.2=3.52 ; \quad 34.9+3.52=38.42 ; \quad 38.42 \div 6.5=5.9 \text {. }
$$

Nutritive ratio, $1: 5.9$. 


\section{AVERAGE COMPOSITION OF AMERICAN FEEDING S'TUFAS.}

\begin{tabular}{|c|c|c|c|c|c|c|c|c|c|c|c|}
\hline \multirow[b]{2}{*}{ Feeding Stuffs. } & \multirow[b]{2}{*}{ 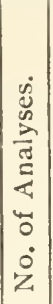 } & \multicolumn{7}{|c|}{ Percentage Composition.* } & \multicolumn{3}{|c|}{$\begin{array}{l}\text { Per cent } \\
\text { Digestible } \\
\text { Matter. }\end{array}$} \\
\hline & & 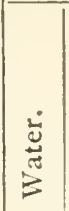 & $\frac{\dot{5}}{4}$ & 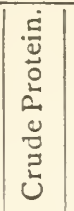 & 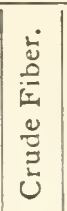 & 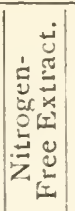 & 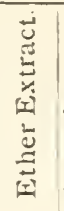 & 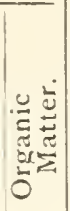 & 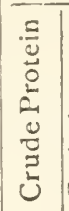 & 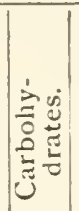 & 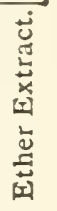 \\
\hline \multicolumn{12}{|l|}{$\begin{array}{c}\text { Green Fodders and } \\
\text { Silage. }\end{array}$} \\
\hline $\begin{array}{l}\text { Pasture grass............ } \\
\text { Green fodder corn }\end{array}$ & . & 80.0 & 2.0 & $3 \cdot 5$ & $4 \cdot 0$ & $9 \cdot 7$ & .8 & 18.0 & 2.6 & $5 \mid 10.6$ & \\
\hline 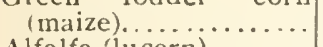 & 126 & $79 \cdot 3$ & I. 2 & 1.8 & 5.0 & 12.2 & .5 & 19.5 & $1 \cdot 3$ & 311.8 & \\
\hline Alf & 23 & 71.8 & $2 \cdot 7$ & 4.8 & $7 \cdot 4$ & $12 \cdot 3$ & I.O & & 3.6 & 511.4 & .4 \\
\hline & 43 & 70. & 2 . & $4 \cdot 4$ & 8.1 & $13 \cdot 5$ & I. $\mathrm{I}$ & 27 & 2.9 & $9 \mid \mathbf{I} 4 \cdot \mathbf{I}$ & \\
\hline & 4 & 74.8 & 2.0 & $3 \cdot 9$ & $7 \cdot 4$ & II.O & .9 & 23 & $2 \cdot 7$ & 713.1 & \\
\hline & 7 & 76.6 & $\mathbf{1} .8$ & 2.6 & II. 6 & 6.8 & .6 & 21 . & $2 . \mathrm{I}$ & I $4 . \mathrm{I}$ & \\
\hline & 5 & 62.2 & 2.5 & $3 \cdot 4$ & II .2 & $19 \cdot 3$ & I 4 & $35 \cdot 3$ & 2.7 & $722 \cdot 7$ & 1.0 \\
\hline & 11 & $79 \cdot 4$ & I. I & $1 \cdot 3$ & $6 . \mathrm{r}$ & $\begin{array}{llllll}1 & 1 & 6\end{array}$ & .5 & I9 & .8 & 8. 12.7 & \\
\hline Red top, in bloom...... & 5 & 64.8 & $2 \cdot 3$ & $3 \cdot 3$ & $9 \cdot 4$ & 19.1 & I. 2 & 32.9 & $2 \cdot 3$ & 320.5 & .7 \\
\hline \multicolumn{12}{|l|}{ 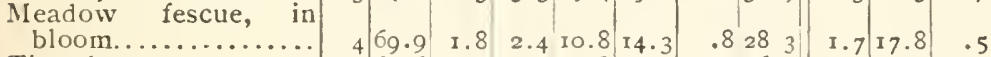 } \\
\hline Timothy.................... & $\begin{array}{r}4 \\
56\end{array}$ & 61.6 & & 3.1 & I1.8 & 20.2 & $\begin{array}{r}.0 \\
1.2\end{array}$ & 36.3 & $\begin{array}{l}1.7 \\
2.2\end{array}$ & $2 \mid \begin{array}{ll}17.0 \\
23.0\end{array}$ & - 5 \\
\hline & 81 & 65.1 & 2.8 & $4 \cdot 1$ & 9. I & 17.6 & I 3 & 32 & 29 & 919.2 & \\
\hline & $4 \mathrm{I}$ & 88.4 & 2.2 & 2.4 & 1. 6 & $5 \cdot 1$ & .3 & & 1.4 & 4.6 & .2 \\
\hline$\cdot \cdots$ & 99 & $79 . \mathrm{I}$ & I. 4 & .7 & 6.0 & 11.1 & .8 & & .8 & 8 I 1.6 & .7 \\
\hline nal. & 7 & 73.6 & & 2.7 & 7.8 & 12.9 & .9 & $24 \cdot 2$ & $\mathbf{t} \cdot 3$ & 314.0 & \\
\hline & 5 & & 2.6 & $4 \cdot 2$ & $8 \cdot 4$ & I 1.6 & 1.2 & $25 \cdot 4$ & 2.0 & $13 \cdot 5$ & 1.0 \\
\hline Sor & 6 & 76.1 & I.I & .8 & 6.4 & 15.3 & $\cdot 3$ & 22.8 & .6 & 514.9 & .2 \\
\hline \multicolumn{12}{|l|}{$\begin{array}{c}\text { Hay and Dry Coarse } \\
\text { Fodders. }\end{array}$} \\
\hline $\begin{array}{l}\text { Fodder corn (maize), } \\
\text { field cured. }\end{array}$ & & & & & & & & & & & \\
\hline$e$, wis. analys & $\begin{array}{r}35 \\
5\end{array}$ & 42.2 & 2.7 & $\begin{array}{l}4.5 \\
6.5\end{array}$ & $14 \cdot 3$ & 34.7 & I. 6 & $\begin{array}{l}55.1 \\
66.8\end{array}$ & 2.6 & $33 \cdot 3$ & I. I \\
\hline Corn stalks (sto & & & & & & $3^{0} .5$ & & & $3 \cdot 7$ & $7+40.4$ & 1.2 \\
\hline ed clov & $\begin{array}{l}60 \\
38\end{array}$ & 40.1 & $\begin{array}{l}3.4 \\
6.2\end{array}$ & 3.8 & $19 \cdot 7$ & $3 \mathbf{I} \cdot 9$ & I. I & 56.5 & 2.0 & $33 \cdot 4$ & \\
\hline & $3^{\circ}$ & $j \cdot 3$ & & $12 \cdot 32$ & $24 \cdot 8$ & 38.1 & $3 \cdot 3$ & 78 & 6.5 & 54.9 & I. 6 \\
\hline & 10: & $2 \mathrm{I} \cdot 2$ & 6. I & 10.7 & $24 \cdot 5$ & 33.6 & $3 \cdot 9$ & & $5 \cdot 7$ & 32.0 & I.9 \\
\hline & $2 \mathrm{I}$ & 8.4 & $7 \cdot 4$ & & & $+2 \cdot 7$ & 2.2 & & 10.3 & 41.4 & I. $x$ \\
\hline & & $\cdot 7$ & & & $25 \cdot 6$ & 40.7 & 2.9 & & 6.8 & 36.8 & 1.4 \\
\hline & $\begin{array}{r}6 \\
68\end{array}$ & 8.9 & 0.2 & $7.6=$ & $29 \cdot 3$ & $45 . I$ & 2.9 & & $4 \cdot 3$ & 46.4 & 1.5 \\
\hline ea- & 68 & 13.2 & $4 \cdot 4$ & $5 \cdot 9=$ & 29.0 & 45.0 & 2.5 & & 30 & 43.9 & 1.2 \\
\hline & is 1 & 16.0 & 4.6 & $6.4=$ & 29.9 & 41.0 & 2.1 & 79.4 & 3.6 & $5+2.7$ & I. O \\
\hline$\cdots$ & I2) & $\mid 7.7$ & 6.o & $7 \cdot 5$ & $27 \cdot 7$ & 49.0 & 2.1 & 86.3 & $4 \cdot 5$ & $5+6.4$ & I. 0 \\
\hline & II & $14 \cdot 3$ & $5 \cdot 5$ & 15.03 & $32.0\}$ & $30.1 \mid$ & 3.1 & 80.2 & $7 \cdot 2$ & 36.6 & I. 8 \\
\hline & 21 & 10.3 & $7 \cdot 3$ & 6.93 & 32.9 & $4 \mathrm{I} .0$ & 1.6 & & 2.2 & 42.8 & .6 \\
\hline & 2 & $7 \cdot 9$ & $5 \cdot 2$ & $7 \cdot 8 \mid=$ & $|30.1|$. & $46 \cdot 3$ & 2.7 & & $3 \cdot 5$ & $44 \cdot 7$ & I. 7 \\
\hline & 12 & & $5 \cdot I$ & 4.03 & & & $2 \cdot 3$ & & I.6. & $+1 \cdot 4$ & $\cdot 7$ \\
\hline & 97 & 14.2 & $5 \cdot 7$ & & & & I. 5 & & .9 & $+x \cdot 3$ & \\
\hline & 7 & 9.6 & $4 \cdot 2$ & 3.43 & $3^{8.1}$. & & $1 \cdot 3$ & & .8 & 37.9 & $\cdot 5$ \\
\hline & 7 & $7 \cdot 1$ & 3.2 & 3.03 & $3^{8.9}$ & 46.6 & 1.2 & & .8 & $+2 \cdot 7$ & .4 \\
\hline ea vinet.... .... & $\begin{array}{r}3 \\
14 \\
1\end{array}$ & $\begin{array}{r}9.9 \\
\mathrm{r} 3.6\end{array}$ & $\begin{array}{l}5.5 \\
6.6\end{array}$ & $\begin{array}{l}5.24 \\
9.03\end{array}$ & $\begin{array}{l}43.0 \\
35.5\end{array}$ & $\begin{array}{l}35 \cdot: \\
33 \cdot 7\end{array}$ & $\begin{array}{l}1.3 \\
1.6\end{array}$ & $\begin{array}{l}84.6 \\
79.8\end{array}$ & $\begin{array}{l}2 \cdot 3 \\
4 \cdot 3\end{array}$ & $\begin{array}{l}37 \cdot 7 \\
32.3\end{array}$ & .8 \\
\hline & & & & & & & & & & & \\
\hline
\end{tabular}

* Largely from Jenkins and Wintun's Compilation of Analyses of American Feeding Stuffs. † Könis. 


\section{AVERAGE COMPOSITION OF AMERICAN \\ FEEDING STUIS.-Continued.}

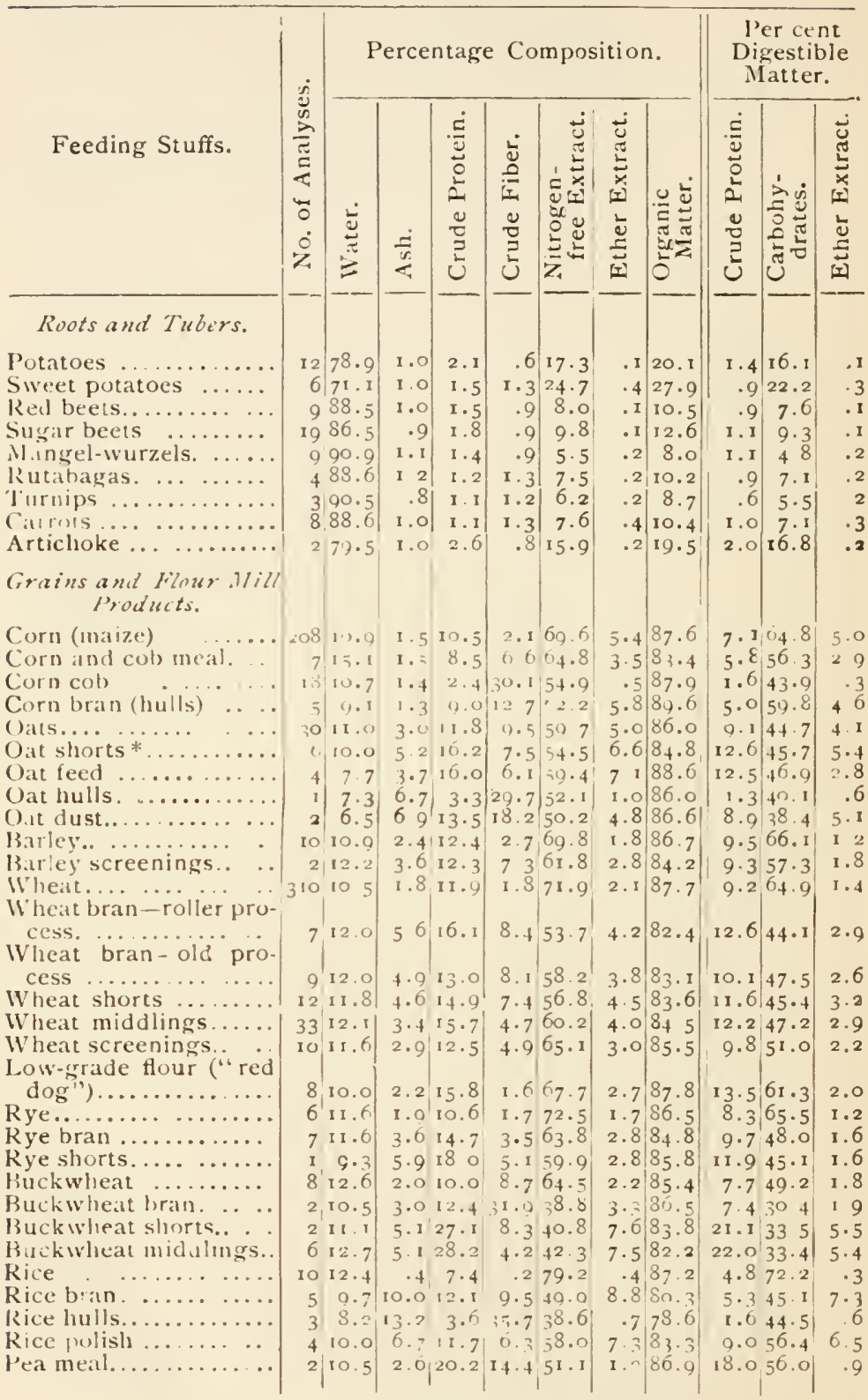




\section{AVERAGE COMPOSITION OF AMERICAN FEEDING STUES-(Continud).}

\begin{tabular}{|c|c|c|c|c|c|c|c|c|c|c|c|}
\hline \multirow[b]{2}{*}{ Feeding Stuffs. } & \multirow[b]{2}{*}{ 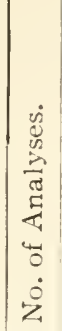 } & \multicolumn{7}{|c|}{ Percentage Composition. } & \multicolumn{3}{|c|}{$\begin{array}{c}\text { Per cent } \\
\text { Digestible } \\
\text { Matter. }\end{array}$} \\
\hline & & $\stackrel{\dot{d}}{\stackrel{d}{J}}$ & $\frac{\dot{1}}{4}$ & 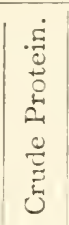 & 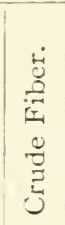 & 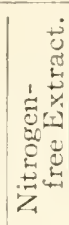 & 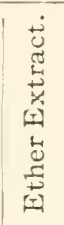 & 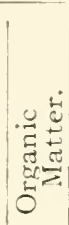 & 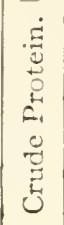 & 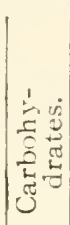 & 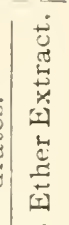 \\
\hline mb & Io & 12.8 & I & 0.1 & 2.6 & 60.8 & 3.6 & 85.1 & 7.0 & 52.1 & 3.1 \\
\hline & 2 & I I .5 & $3 \cdot 4$ & 10.2 & 7.1 & 63.6 & 3.0 & & 7.4 & 48.3 & 2.9 \\
\hline & 50 & 9.2 & 4.3 & 22.6 & 7.1 & 23.2 & 33.7 & & 20.6 & 17.1 & 29.0 \\
\hline & 5 & 14.8 & 3.2 & 20.8 & 4.1 & 5.5 .7 & I. 4 & 82.0 & 18.3 & 54.2 & 2 I.I \\
\hline 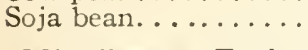 & $\ddot{8}$ & 10.8 & 4.7 & 34.0 & 4.8 & $2 S .8$ & 16.9 & 84.5 & 20.6 & 17.9 & 15.9 \\
\hline$c c d s$ & & & & & & & & & & & \\
\hline . & 5 & 9.6 & 5.9 & 24.8 & I I.O & 47.0 & I. 7 & 84.5 & I 9.8 & 36.2 & 1.7 \\
\hline & I 5 & 75.7 & I.O & 5.4 & 3.5 & 12.5 & I. 6 & $2.3 \cdot 3$ & 3.0 & 0.5 & I. 3 \\
\hline ied. & 5 & $7 \cdot 7$ & & 22.2 & I 2.3 & 47.0 & 6.3 & & I 6.2 & $35 \cdot 5$ & $5 \cdot 3$ \\
\hline al). & 14 & 10.9 & 2.5 & 0.9 & 3.7 & 64.4 & 8.5 & 86.6 & 8.9 & 61.0 & 7.8 \\
\hline & 7 & 8.3 & & 21.6 & 6.5 & 40.6 & I 2.7 & 90.8 & 18.6 & 48.3 & $3 \mathrm{II} . \mathrm{I}$ \\
\hline & 5 & 8.2 & I. 3 & 32.8 & 1.7 & 42.0 & I 4.1 & & 29.5 & 30.6 & 5 I 2.8 \\
\hline & 3 & 9.5 & .9 & 35.8 & I. 5 & 46.8 & 5.6 & 80.6 & 32.2 & 44.I & I 5.1 \\
\hline & 3 & 9.0 & & 24 & 6.7 & 43.6 & I 3.5 & & 22.3 & 42.0 & $\begin{array}{ll}12 & 2.3\end{array}$ \\
\hline & 4 & 10.4 & & 10.0 & 5.0 & 61.2 & 6.8 & 86.0 & 0.0 & $6 \mathrm{I} .2$ & 26.2 \\
\hline & 3 & $5 \cdot 7$ & 2.7 & 31.0 & I I I. 4 . & 34.8 & I 4.2 & 91.6 & 26.7 & 38.8 & 512.4 \\
\hline & 12 & 65.4 & .3 & 6.1 & 3.1 & 22.0 & 3.1 & & 5.5 & 21.7 & $\begin{array}{ll}7 & 2.3\end{array}$ \\
\hline & 37 & 8.2 & & 42.4 & 5.6 & 23.8 & I 2.9 & 84.6 & 36.9 & 18.1 & $\begin{array}{ll}1 & \text { I } 2.3\end{array}$ \\
\hline $\begin{array}{l}\text { Cot } \\
\text { Lin }\end{array}$ & 10 & 9.9 & 2.9 & 4.2 & 47.4 & 33.2 & 2.2 & 87.2 & 1.0 & 26.2 & 21.8 \\
\hline Lin & $2 \mathrm{I}$ & 9.2 & $5 \cdot 7$ & 32.9 & 8.9 & 35.4 & 7.9 & & 28.3 & 32.8 & 7.1 \\
\hline & $I_{4}$ & IO.I & 5.8 & 33.2 & 0.5 & 38.5 & 3.0 & 84.1 & 27.2 & 32.9 & 2.7 \\
\hline $\mathrm{Pal}$ & 600 & 10.4 & $4 \cdot 3$ & 16.8 & 24.0 & 35.0 & 9.5 & 85.3 & 16.0 & 52.6 & 9.0 \\
\hline & & 88.0 & 2.4 & 2.6 & 2.2 & 4.4 & .4 & 0.6 & 1.7 & 4.6 & .2 \\
\hline$\ldots$ & $4 \mathrm{I}$ & 88.4 & 2.2 & 2.4 & I. 6 & $5 . I$ & .3 & 9.4 & I. 4 & 4.6 & \\
\hline & 2 & 84.5 & 2.0 & 2.3 & 2.6 & 8.4 & .5 & 1.3 .5 & I. 5 & S. I & \\
\hline & & 90.9 & .5 & I. 3 & 1.7 & 5.2 & .4 & 8.6 & 1.0 & 5.8 & \\
\hline & 36 & 84.8 & .5 & .4 & I. 5 & 12.5 & .3 & 1.4 .7 & .3 & 1 2.8 & .2 \\
\hline & 7 & 76.7 & .5 & I. 4 & 3.9 & 16.2 & 1.3 & 22.8 & I.O & I 1.0 & I.I \\
\hline & 35 & 20.8 & 10.6 & 9.1 & & .50 .5 & & 68.6 & 0.1 & $59 \cdot 5$ & $5 \ldots$ \\
\hline & I 6 & 89.8 & .6 & .0 & 2.4 & 6.3 & ... & $=9.6$ & .0 & $7 \cdot 3$ & \\
\hline & I & 4.4 & & S. 3 & I 0.0 & 6.3 .5 & .7 & 91.5 & 5.8 & 67.7 & .0 \\
\hline & $\mathrm{I}$ & 3.7 & 4.5 & 0.8 & 18.6 & 62.7 & .7 & 01.8 & 6.6 & 67.9 & .6 \\
\hline & 144 & 10.7 & 4. I & 71.2 & $\ldots$ & .3 & I 3.7 & 85.2 & 68.4 & .3 & 13.5 \\
\hline & 3 & 8.5 & 4.7 & 84.4 & $\ldots$ & $\ldots$ & 2.5 & 86.8 & 58.1 & $\ldots$ & 2.3 \\
\hline 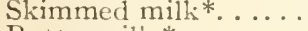 & 96 & 90.4 & .7 & 3.3 & $\ldots$ & 4.7 & .8 & 8.9 & 3.1 & 4.7 & .8 \\
\hline & 85 & 90. & - & 4.0 & & 4.0 & I. I & 0.2 & 3.0 & 4.0 & I. I \\
\hline 0.9 & 40 & 93.4 & .7 & .9 & & 4.8 & .3 & 5.0 & .8 & 4.7 & \\
\hline
\end{tabular}

* König. 


\section{READY REFERENCE TABLE OF COMIOSITION OF FEEDS. (Hills.)}

The following tables save calculations of percentages, since, the weights and contents being given in pounds, it is only necessary to find the kind and desired amount of a certain feed, and the tables give the exact food contents in pounds; e.g., I 5 lbs. of Green Fodder Corn contain 3.I lbs. of dry matter, 0.1 7 lbs. of digestible protein, and r.9 lbs. digestible carbohydrates and fat.

\begin{tabular}{|c|c|c|c|c|c|c|c|c|c|}
\hline $\begin{array}{l}\text { Pounds of } \\
\text { Feed. }\end{array}$ & 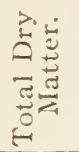 & 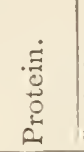 & 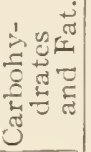 & 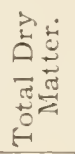 & $\frac{.3}{3}$ & 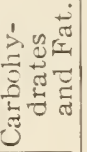 & 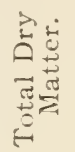 & 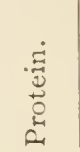 & 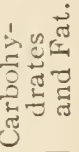 \\
\hline $\begin{array}{c}\text { Green } \\
\text { Fodders. } \\
\end{array}$ & \multicolumn{3}{|c|}{$\begin{array}{c}\text { Pasture Grass } \\
\text { I }: 4.8\end{array}$} & \multicolumn{3}{|c|}{$\begin{array}{c}\text { Timothy Grass } \\
I: 14.3\end{array}$} & \multicolumn{3}{|c|}{$\begin{array}{c}\text { Ky. Blue Grass, } \\
\text { I }: 9.2\end{array}$} \\
\hline $2 \frac{1}{2} \ldots \ldots$ & 0.5 & 0.06 & 0.3 & 1.0 & 0.04 & 0.5 & 0.9 & 0.05 & 0.5 \\
\hline $5 \ldots \ldots$ & 1.0 & O. I 2 & 0.6 & I. 9 & 0.08 & I. I & I. 8 & 0.10 & 0.9 \\
\hline Io $\ldots \ldots \ldots$ & 2.0 & 0.23 & I . I & 3.8 & 0.15 & 2. I & $3 \cdot 5$ & 0.20 & 1. 8 \\
\hline I $5 \ldots \ldots$ & 3.0 & 0.35 & I. 7 & 5.8 & 0.23 & $3 \cdot 2$ & 5.2 & 0.30 & 2.7 \\
\hline $20 \ldots \ldots \ldots$ & 4.0 & 0.46 & 2.2 & $7 \cdot 7$ & 0.30 & $4 \cdot 3$ & 7.0 & 0.40 & $3 \cdot 7$ \\
\hline $25 \ldots \ldots \ldots$ & 5.0 & 0.58 & 2.8 & 9.6 & 0.33 & $5 \cdot 4$ & 8.7 & 0.50 & $4 \cdot 7$ \\
\hline $30 \ldots \ldots$ & 6.0 & 0.69 & $3 \cdot 3$ & I I. 5 & 0.45 & 6.4 & 10.5 & 0.60 & $5 \cdot 5$ \\
\hline $35 \ldots \ldots$ & 7.0 & $0.8 I$ & 3.9 & I $3 \cdot 4$ & 0.53 & 7.5 & I 2.2 & 0.70 & 6.4 \\
\hline \multirow[t]{2}{*}{$40 \ldots \ldots$} & 8.0 & 0.02 & $4 \cdot 4$ & I 5.4 & 0.60 & 8.6 & 14.0 & 0.80 & $7 \cdot 3$ \\
\hline & \multicolumn{3}{|c|}{$\begin{array}{l}\text { Green Fodder } \\
\text { Corn, I : I I.7 }\end{array}$} & \multicolumn{3}{|c|}{$\begin{array}{l}\text { Green Oat Fod- } \\
\text { der, I }: 8.7\end{array}$} & \multicolumn{3}{|c|}{$\begin{array}{l}\text { Green Rye Itorl- } \\
\text { der, I }: 7.2\end{array}$} \\
\hline $2 \frac{1}{2} \ldots \ldots$ & 0.5 & 0.0 .3 & 0.3 & 0.9 & 0.06 & 0.5 & 0.6 & 0.05 & 0.4 \\
\hline $5 \ldots \ldots$ & I. O & 0.06 & 0.6 & I. O) & 0.12 & 1.0 & I. 2 & 0.11 & 0.7 \\
\hline Io $\ldots \ldots$ & 2. I & 0. II & 1. 3 & 3.8 & 0.24 & 2. I & $2 \cdot 3$ & $0.2 \mathrm{I}$ & I. 5 \\
\hline I $5 \ldots \ldots$ & $3 \cdot 1$ & 0.17 & I. 9 & $5 \cdot 7$ & 0.36 & 3.1 & $3 \cdot 5$ & 0.32 & 2.3 \\
\hline $20 \ldots \ldots$. & $4 \cdot 1$ & 0.22 & 2.6 & 7.6 & 0.48 & 4.2 & $4 \cdot 7$ & 0.42 & 3.0 \\
\hline$\ldots \ldots$ & 5.2 & 0.28 & 3.2 & 9.5 & 0.60 & $5 \cdot 2$ & $5 \cdot 9$ & 0.52 & 3.8 \\
\hline$\ldots \ldots$ & 6.2 & 0.33 & $3 \cdot 9$ & I I.3 & 0.72 & 6.2 & 7.0 & 0.63 & $4 \cdot 5$ \\
\hline$\ldots \ldots$ & $7 \cdot 2$ & 0.39 & $4 \cdot 5$ & 13.2 & 0.84 & $7 \cdot 3$ & 8.2 & 0.74 & $5 \cdot 3$ \\
\hline $40 \ldots . .$. & 8.3 & 0.44 & 5.2 & 15.1 & 0.96 & S. 3 & 9.4 & 0.84 & 6.0 \\
\hline & \multicolumn{3}{|c|}{$\begin{array}{c}\text { Oats and Peas, } \\
I: 4.2\end{array}$} & \multicolumn{3}{|c|}{$\begin{array}{c}\text { Barley and Peas, } \\
\text { I : } 3.2\end{array}$} & \multicolumn{3}{|c|}{$\begin{array}{l}\text { Red Clover } \\
\text { (rreen) I : } 5.7\end{array}$} \\
\hline $2 \frac{1}{2} \ldots \ldots$ & 0.5 & 0.07 & 0.3 & 0.5 & 0.07 & 0.2 & 0.7 & 0.07 & 0.4 \\
\hline $5 \ldots \ldots$ & I. I & 0.14 & 0.5 & I.O & 0.14 & 0.4 & I. 5 & 0.15 & 0.8 \\
\hline$\ldots \ldots$ & 2. I & 0.27 & I. I & 2. I & 0.28 & 0.9 & 2.9 & 0.20 & 1. 6 \\
\hline$\ldots \ldots$ & 3.2 & 0.41 & & $3 \cdot I$ & 0.42 & I. 4 & $4 \cdot 4$ & 0.44 & $2 \cdot 5$ \\
\hline$\ldots \ldots$ & $4 \cdot 3$ & 0.54 & $2 \cdot 3$ & 4. I & 0.56 & I. S & $5 \cdot 9$ & 0.58 & $3 \cdot 3$ \\
\hline$\ldots \ldots \ldots$ & $5 \cdot 3$ & 0.68 & 2.9 & $5 \cdot 2$ & 0.70 & $2 \cdot 3$ & $7 \cdot 3$ & 0.73 & $4 \cdot 1$ \\
\hline$\ldots \ldots \ldots$ & 6.4 & $0.8 \mathrm{I}$ & .4 & 6.2 & 0.84 & 2.7 & 8.8 & 0.87 & $4 \cdot 9$ \\
\hline$\ldots \ldots \ldots$ & $7 \cdot 5$ & 0.05 & 4.0 & $7 \cdot 2$ & 0.98 & $3 \cdot 2$ & 10.2 & I. 02 & $5 \cdot 7$ \\
\hline 40 & 8.5 & I. .08 & 4.6 & 8.2 & I. I 2 & 3.6 & I I . 7 & I. 16 & 6.6 \\
\hline & \multicolumn{3}{|c|}{$\begin{array}{c}\text { Corn Silage, } \\
\mathbf{r}: \mathbf{1} 4.8 \\
\end{array}$} & \multicolumn{3}{|c|}{$\begin{array}{l}\text { Corn Stover Si- } \\
\text { lage, I : } 16.6\end{array}$} & \multicolumn{3}{|c|}{$\begin{array}{c}\text { Clover Silage, } \\
\text { I }: 4.7\end{array}$} \\
\hline $2 \frac{1}{2} \ldots \ldots$ & 0.7 & 0.02 & 0.4 & 0.5 & 0.02 & 0.3 & C. 7 & 0.07 & 0.3 \\
\hline$\ldots \ldots$ & I. 3 & 0.06 & 0.8 & I. O & 0.03 & 0.5 & I. 4 & 0.14 & 0.6 \\
\hline$\ldots \ldots$ & 2.6 & 0.12 & I. 8 & I. 9 & 0.06 & I. O & 2.8 & 0.27 & I. 3 \\
\hline$\ldots \ldots$ & $3 \cdot 9$ & ○. I S & $2 \cdot 7$ & 2.9 & 0.09 & I. 5 & $4 \cdot 2$ & $0.4 \mathrm{I}$ & I. 9 \\
\hline$\ldots \ldots$ & $5 \cdot 3$ & 0.24 & 3.6 & 3.9 & 0.12 & 2.0 & 5.6 & 0.54 & 2.6 \\
\hline$\ldots \ldots$ & 6.6 & 0.30 & $4 \cdot 5$ & 4.8 & 0.15 & $2 \cdot 5$ & 7.0 & 0.68 & $3 \cdot 2$ \\
\hline$\ldots \ldots$ & $7 \cdot 9$ & 0.36 & $5 \cdot 3$ & 5.8 & O. I 8 & 3.0 & 8.4 & $0.8 \mathrm{I}$ & $3 \cdot 9$ \\
\hline$\ldots \ldots$ & 9.2 & 0.42 & 6.2 & 6.8 & $0.2 \mathrm{I}$ & $3 \cdot 5$ & 9.8 & 0.95 & $4 \cdot 5$ \\
\hline 40 & I0. 5 & 0.48 & 7.1 & $7 \cdot 7$ & 0.24 & 4.0 & I I. 2 & 1.08 & $5 \cdot 1$ \\
\hline
\end{tabular}


COMPOSITION OF FEEDS-(Continued).

\begin{tabular}{|c|c|c|c|c|c|c|c|c|c|}
\hline $\begin{array}{l}\text { Pounds of } \\
\text { Feed. }\end{array}$ & 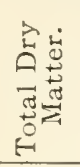 & 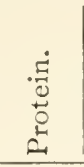 & 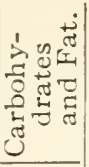 & 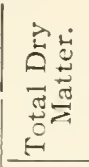 & 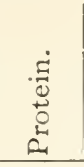 & 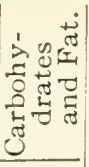 & 点芯 & 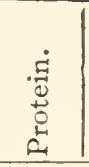 & 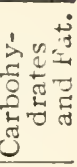 \\
\hline Roots. & \multicolumn{3}{|c|}{ Potatoes, $1:$ I 7.3} & \multicolumn{3}{|c|}{ Sugar Beets, I : 6.8} & \multicolumn{3}{|c|}{ Carrots, I : 9.6} \\
\hline $2 \frac{1}{2}$. & 0.5 & 0.02 & 0.4 & 0.3 & 0.04 & 0.3 & 0.3 & 0.03 & 0.2 \\
\hline 5. & I. I & 0.05 & 0.8 & 0.7 & 0.08 & 0.5 & 0.5 & 0.05 & 0.5 \\
\hline Io $\ldots . .$. & 2.1 & 0.09 & 1. 6 & I. 4 & 0.16 & I. I & I. I & 0.10 & I. 0 \\
\hline I $5 \ldots \ldots$. & 3.2 & 0.14 & $2 \cdot 3$ & 2.0 & 0.24 & 1.7 & I .6 & 0.15 & I. 4 \\
\hline $20 \ldots \ldots$ & $4 \cdot 2$ & 0.18 & $3 \cdot 1$ & 2.7 & 0.32 & 2.2 & $2 \cdot 3$ & 0.20 & I .9 \\
\hline $25 \ldots$ & $5 \cdot 3$ & 0.23 & 3.9 & $3 \cdot 4$ & 0.40 & 2.7 & 2.9 & 0.25 & 2.4 \\
\hline $30 \ldots \ldots$ & 6.3 & 0.27 & $4 \cdot 7$ & $4 \cdot 1$ & $0.4^{8}$ & $3 \cdot 3$ & $3 \cdot 4$ & 0.30 & 2.9 \\
\hline $35 \ldots \ldots$ & $7 \cdot 4$ & 0.32 & $5 \cdot 4$ & $4 \cdot 7$ & 0.56 & 3.8 & $4 \cdot 0$ & 0.35 & $3 \cdot 4$ \\
\hline \multirow[t]{2}{*}{$40 \ldots \ldots$} & 8.4 & 0.36 & 6.2 & $5 \cdot 4$ & 0.64 & $4 \cdot 4$ & $4 \cdot 6$ & 0.40 & 3.8 \\
\hline & \multicolumn{3}{|c|}{$\begin{array}{c}\text { Mangel Wurtzels. } \\
\text { I }: 4.9\end{array}$} & \multicolumn{3}{|c|}{$\begin{array}{c}\text { Rutabagas, } \\
\text { I: } 8.6\end{array}$} & \multicolumn{3}{|c|}{ Turnips, $x: 7.7$} \\
\hline $2 \frac{1}{2} \ldots$ & 0.2 & 0.03 & 0.1 & 0.3 & 0.03 & 0.2 & 0.2 & 0.03 & 0.2 \\
\hline $5 \ldots$ & 0.4 & 0.06 & 0.3 & 0.5 & 0.05 & .4 & 0.5 & .05 & 0.4 \\
\hline 10 & 0.9 & 0.11 & 0.5 & I. I & & .9 & 1.0 & 0.10 & 0.8 \\
\hline 15 & I. 4 & 0.17 & 0.8 & I. 6 & 0.15 & I. 3 & I. 4 & ‥ 5 & I. 2 \\
\hline 20 & 1.8 & 0.22 & I. I & 2.3 & 0.20 & 1.7 & & 0.20 & I. 5 \\
\hline 25 & $2 \cdot 3$ & 0.28 & I. 4 & 2.9 & 0.25 & 2.2 & 2.4 & 0.25 & I. 9 \\
\hline 30 & 2.7 & 0.3 .3 & I. 6 & $3 \cdot 4$ & 0.30 & 2.6 & 2.9 & 0.30 & $2 \cdot 3$ \\
\hline $35 \ldots$ & 3.2 & 0.30 & 1.9 & 4.0 & 0.35 & 3.0 & $3 \cdot 3$ & 0.35 & 2.7 \\
\hline $40 \ldots$. & 3.6 & 0.44 & 2.2 & $4 \cdot 6$ & 0.40 & $3 \cdot 4$ & 3.8 & 0.40 & $3 \cdot \mathbf{I}$ \\
\hline Milk. & \multicolumn{3}{|c|}{ Skim Milk, I : 2.0} & \multicolumn{3}{|c|}{ Buttermilk, I: I.7 } & \multicolumn{3}{|c|}{ Whey, I : 8.7} \\
\hline $2 \frac{1}{2} \ldots$ & 0.2 & 0.07 & $0 . I$ & 0.2 & 0.10 & 0.2 & 0.2 & 0.02 & $0 . I$ \\
\hline & .5 & 0.15 & 0.3 & 0.5 & 0.19 & 0.3 & 0.3 & 0.03 & 0.3 \\
\hline & 0.9 & 0.29 & 0.6 & I.O & 0.38 & 0.6 & 0.6 & 0.06 & 0.5 \\
\hline I 5 & 1.4 & 0.44 & 0.9 & 1.5 & 0.57 & 1.0 & 0.9 & 0.00 & 0.8 \\
\hline $20 \ldots$ & 1.9 & 0.58 & I. 2 & 2.0 & 0.76 & I. 3 & I. 2 & 0.12 & I . O \\
\hline $25 \ldots$ & 2.4 & 0.73 & I. 6 & $2 \cdot 5$ & 0.95 & I. 6 & I. 5 & o. I 5 & 1. 3 \\
\hline 30 & 2.8 & 0.87 & I. 8 & 3.0 & I. 1.4 & I. 9 & I. 9 & 0.18 & I. 6 \\
\hline $35 \ldots$ & 3.2 & 1.02 & 2.1 & $3 \cdot 5$ & I. 33 & 2.2 & 2.2 & $0.2 \mathrm{I}$ & I. 8 \\
\hline $40 \ldots$ & $3 \cdot 7$ & I. I 6 & 2.4 & 4.0 & I. 52 & 2.6 & $2 \cdot 5$ & 0.24 & $2 . I$ \\
\hline Hays. & \multicolumn{3}{|c|}{$\begin{array}{l}\text { Mixed Hay, } \\
\text { I : } 10.0\end{array}$} & \multicolumn{3}{|c|}{$\begin{array}{c}\text { Timothy Hay. } \\
\text { I : } 16.5 \\
\end{array}$} & \multicolumn{3}{|c|}{$\begin{array}{c}\text { Ky. Blue Grass } \\
\text { Hay, I : } 10.6\end{array}$} \\
\hline $2 \frac{1}{2}$. & 2. I & $0.1 \mathrm{I}$ & I. I & 2.2 & 0.07 & I. 2 & I. 9 & 0.09 & 1.0 \\
\hline 5. & $4 \cdot 2$ & 0.22 & 2.2 & 4.3 & 0.14 & 2. & 3.7 & 0.10 & 2.0 \\
\hline & 6.4 & 0.33 & $3 \cdot 3$ & 6.5 & $0.2 \mathrm{I}$ & 3 . & 5.6 & 0.28 & 3.0 \\
\hline $10, \ldots$ & 8.5 & 0.44 & $4 \cdot 4$ & 8.7 & 0.28 & 4. & $7 \cdot 4$ & 0.37 & $3 \cdot 9$ \\
\hline$I 2 \frac{1}{2} \ldots \ldots$ & 10.6 & 0.55 & $5 \cdot 5$ & 10.9 & 0.35 & 5.8 & 9.2 & 0.46 & $4 \cdot 9$ \\
\hline I $5, \ldots \ldots$ & I 2.7 & 0.66 & 6.6 & 13.0 & $0 .+2$ & 6.9 & I I . I & 0.56 & $5 \cdot 9$ \\
\hline $17 \frac{1}{2} \ldots$ & 14.8 & 0.77 & 7.7 & I 5.2 & 0.40 & 8. I & 13.0 & 0.65 & 6.9 \\
\hline & 16.9 & 0.88 & 8.8 & I 7.4 & 0.56 & 0.2 & 14.8 & 0.74 & $7 \cdot 9$ \\
\hline $25 \ldots \ldots$ & 21.2 & I. IO & I I .O & 21.7 & 0.70 & 11.6 & 18.5 & 0.93 & 9.9 \\
\hline
\end{tabular}


COMPOSITION OF FEEDS-(Continued).

\begin{tabular}{|c|c|c|c|c|c|c|c|c|c|}
\hline $\begin{array}{l}\text { Pounds of } \\
\text { Feed. }\end{array}$ & 点总 & $\begin{array}{c}\Xi \\
0 \\
0 \\
0 \\
E \\
\end{array}$ & 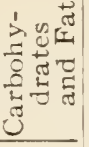 & 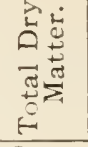 & 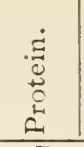 & 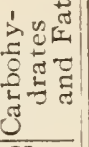 & 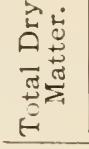 & 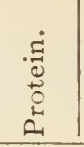 & 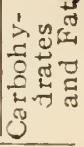 \\
\hline Hays. & \multicolumn{3}{|c|}{ Oat Hay, r : $9 . n$} & \multicolumn{3}{|c|}{$\begin{array}{c}\text { Oat and Pea Hay, } \\
\text { I : } 4.1\end{array}$} & \multicolumn{3}{|c|}{ Hungarian, I : ro.0 } \\
\hline $2 \frac{1}{2}$. & 2.3 & 0.10 & 1.0 & 2.2 & 0.28 & I. 2 & $2 . I$ & 0.12 & I. 2 \\
\hline & 4.6 & $0.2 \mathrm{I}$ & 2.0 & $4 \cdot 4$ & 0.56 & 2.3 & $4 \cdot 2$ & 0.23 & 2.4 \\
\hline & 6.8 & $3 I$ & 3.0 & 6.6 & 0.84 & 3.5 & 6.3 & .37 & 3.6 \\
\hline 10 & 9. I & .41 & 4.0 & 8.9 & I. I 2 & 4.6 & 8.4 & 049 & $4 \cdot 9$ \\
\hline$\cdots$ & I I. 4 & $0.5 \mathrm{I}$ & $5 \cdot 1$ & I I . I & I. 40 & 5.8 & 10.4 & 0.62 & 6.2 \\
\hline I 5 & $3 \cdot 7$ & 0.62 & 6.1 & $13 \cdot 3$ & I. 68 & 6.9 & I 2.5 & 0.74 & $7 \cdot 4$ \\
\hline $17 \frac{1}{2}$. & 16.0 & 0.72 & 7.1 & $15 \cdot 5$ & I. 96 & 8.1 & 14.6 & 0.86 & 8.6 \\
\hline & 18.2 & 0.82 & 8. I & I $7 \cdot 7$ & 2.24 & 9.2 & 16.7 & .98 & 9.8 \\
\hline & 22.8 & 1.03 & 10.2 & $22 \therefore 1$ & 2.80 & I I . 6 & 26.9 & I. 23 & 12.3 \\
\hline & \multicolumn{3}{|c|}{$\begin{array}{c}\text { Red Clover Hay, } \\
1: 5.9\end{array}$} & \multicolumn{3}{|c|}{$\begin{array}{c}\text { Alsike Clover Hay, } \\
\text { I }: 5.5 \\
\end{array}$} & \multicolumn{3}{|c|}{$\begin{array}{c}\text { Uat Straw, } \\
\text { I }: 38.3\end{array}$} \\
\hline & 2. I & 0.18 & I. 0 & $2 \cdot 3$ & $0.2 \mathrm{I}$ & I. 2 & 2.3 & 0.03 & I. 2 \\
\hline & 4.2 & .36 & 2.1 & $4 \cdot 5$ & 0.42 & $2 \cdot 3$ & 4.6 & .06 & 2.3 \\
\hline & 6.4 & 53 & 3.2 & 6.8 & 0.63 & 3.5 & 6.8 & .09 & 3.5 \\
\hline & 8.5 & 0.71 & 4.2 & 9.0 & 0.84 & 4.6 & 9.1 & 0.12 & 4.6 \\
\hline $12 \frac{1}{2}$. & 10.6 & 0.89 & 5.2 & I I . 3 & I.05 & 5.8 & II. 4 & & 5.8 \\
\hline & I 2.7 & 1.07 & 6.3 & $3 \cdot 5$ & I. 26 & 6.9 & 13.9 & .18 & 6.9 \\
\hline $17 \frac{1}{2}$. & I 4.8 & 1.24 & $7 \cdot 3$ & 5.8 & I. 47 & 8.1 & 16.0 & $0.2 \mathrm{I}$ & 8.1 \\
\hline & I 6.9 & I. 42 & 8.3 & IS. I & 1.68 & 0.2 & I 8.2 & 0.24 & 9.2 \\
\hline 25 & 2 I. 2 & 1.78 & 10.5 & 22.6 & 2.10 & II .6 & 22.7 & 0.30 & I I. .5 \\
\hline $\begin{array}{c}\text { Dry } \\
\text { Fodders. }\end{array}$ & \multicolumn{3}{|c|}{$\begin{array}{c}\text { Corn Fodder, } \\
I: 14.3\end{array}$} & \multicolumn{3}{|c|}{$\begin{array}{c}\text { Corn Stover, } \\
1: 23.6\end{array}$} & \multicolumn{3}{|c|}{$\begin{array}{c}\text { Wheat Straw, } \\
1: 93.0\end{array}$} \\
\hline $2 \frac{1}{2}$. & I. 4 & 0.06 & & I. 5 & 0.04 & 0.8 & $2 \cdot 3$ & $0.0 \mathrm{I}$ & 0.9 \\
\hline & 2.9 & 0.13 & I. 8 & 3 . & 0.07 & I . & $4 \cdot 5$ & 0.02 & 1.0 \\
\hline & $4 \cdot 3$ & 9 & 2.7 & $4 \cdot 5$ & 0.11 & 2.5 & 6.8 & 0.03 & 2.8 \\
\hline 10 & $5 \cdot 8$ & 0.25 & 3.6 & 6.0 & 0.14 & $3 \cdot 3$ & 9.0 & 0.04 & $3 \cdot 7$ \\
\hline $12 \frac{1}{4}$. & 7.2 & & & 7.5 & 0.18 & $4 \cdot I$ & I I. 3 & & \\
\hline 15. & 8.7 & 0.38 & & 9.0 & $0.2 \mathrm{I}$ & 5 . & I 3.5 & 0.06 & 5.6 \\
\hline $17 \frac{1}{2}$. & 10.1 & 0.44 & 6.2 & 10.5 & 0.25 & & 15.8 & 0.07 & 6.5 \\
\hline $20 \ldots$ & I I . 6 & 0.50 & & 2.0 & $0.2 S$ & 6.6 & I 8.1 & 0.08 & 7.4 \\
\hline $25 \ldots \ldots$ & 14.5 & 0.63 & 8.9 & I 5.0 & 0.35 & 8.3 & 22.6 & 0.10 & $9 \cdot 3$ \\
\hline Grains. & \multicolumn{3}{|c|}{$\begin{array}{c}\text { Corn Meal, } \\
\text { I : I I. } 3\end{array}$} & \multicolumn{3}{|c|}{$\begin{array}{l}\text { Corn and Cob } \\
\text { Meal, I : I } 3.9\end{array}$} & \multicolumn{3}{|c|}{ Oats, $1: 6.2$} \\
\hline & 0.2 & 0.02 & 0.2 & 0.2 & 0.01 & 0.2 & 0.2 & 0.02 & 0.1 \\
\hline & 0.4 & & 0.4 & 0.4 & 0.02 & 0.3 & 0.4 & 0.05 & 0.3 \\
\hline & 0.9 & 0.06 & & 0.9 & 0.05 & 0.7 & 0.9 & 0.09 & 0.6 \\
\hline $2 \ldots$ & I. 7 & O. I 3 & I. 4 & I. 7 & 0.10 & I. 3 & I. 8 & 0.18 & I. I \\
\hline $3 \ldots$ & 2.6 & 0.19 & 2. I & 2.6 & 0.14 & 2.0 & 2.7 & 0.28 & I. 7 \\
\hline & $3 \cdot 4$ & & & $3 \cdot 4$ & 0.19 & 2. & 3.6 & 0.37 & 2.3 \\
\hline & $4 \cdot 3$ & 0.32 & 3.6 & $4 \cdot 3$ & 0.24 & $3 \cdot 4$ & $4 \cdot 5$ & 0.46 & 2.8 \\
\hline $7 \frac{1}{2} \ldots \ldots$ & 6.4 & 0.48 & $5 \cdot 4$ & 6.4 & 0.36 & $5 \cdot 1$ & 6.7 & 0.69 & $4 \cdot 3$ \\
\hline $10 \ldots \ldots$ & 8.5 & 0.63 & $7 \cdot 1$ & 8.5 & 0.48 & 6.7 & 8.9 & 0.92 & $5 \cdot 7$ \\
\hline
\end{tabular}


COMPOSITION OF FEEDS-(Continued).

\begin{tabular}{|c|c|c|c|c|c|c|c|c|c|}
\hline $\begin{array}{l}\text { Pounds of } \\
\text { Feed. }\end{array}$ & 点志 & 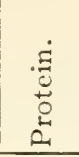 & 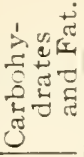 & 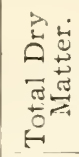 & 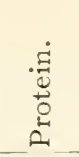 & 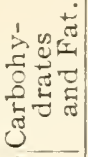 & 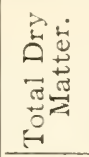 & 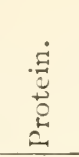 & 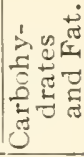 \\
\hline $\begin{array}{c}\text { By- } \\
\text { products. }\end{array}$ & \multicolumn{3}{|c|}{ Barley, I : 8.0} & \multicolumn{3}{|c|}{$\begin{array}{c}\text { Barley Screenings, } \\
\mathrm{x}: 7.7 \\
\end{array}$} & \multicolumn{3}{|c|}{ Wheat Bran, } \\
\hline & 0.2 & 0.02 & 0.2 & 0.2 & 0.02 & 0.2 & 0.2 & 0.0 .3 & 0.1 \\
\hline & 0.4 & 0.04 & 0.3 & 0.4 & 0.04 & 0.3 & 0.4 & 0.06 & 0.2 \\
\hline & 0.9 & 0.09 & 0.7 & 0.9 & 0.09 & 0.7 & 0.9 & 0.12 & 0.5 \\
\hline & I. 8 & O. I 7 & I . 4 & I. 8 & 0.17 & I. 3 & I. 8 & 0.24 & I. 0 \\
\hline & 2.7 & 0.26 & $2 . I$ & 2.6 & 0.26 & 2.0 & 2.6 & 0.36 & I. 4 \\
\hline & 3.6 & 0.35 & 2.8 & 3.5 & 0.34 & 2.7 & 3.5 & $0.4^{8}$ & I. 8 \\
\hline & $4 \cdot 5$ & 0.44 & $3 \cdot 5$ & 4.4 & 0.43 & $3 \cdot 3$ & 4.4 & 0.60 & 2.3 \\
\hline & 6.7 & 0.65 & 5.2 & 6.6 & 0.65 & 5.0 & 6.6 & 0.90 & 3.4 \\
\hline \multirow[t]{2}{*}{10} & 8.9 & 0.87 & 6.9 & 8.8 & 0.86 & 6.6 & 8.8 & I. 20 & 4.6 \\
\hline & \multicolumn{3}{|c|}{$\begin{array}{c}\text { Wheat Middlings, } \\
\text { I }: 4.6\end{array}$} & \multicolumn{3}{|c|}{$\begin{array}{l}\text { Wheat Screen- } \\
\text { ings, } 1: 5.2\end{array}$} & \multicolumn{3}{|c|}{$\begin{array}{c}\text { Red-dog Flour, } \\
\text { I }: 3 \cdot 3\end{array}$} \\
\hline & 0.2 & 0.03 & $0 . I$ & 0.2 & 0.02 & $0 . I$ & 0.2 & 0.04 & $0 . I$ \\
\hline & 0.4 & 0.06 & 0.3 & 0.4 & 0.05 & 0.2 & 0.5 & 0.09 & 0.3 \\
\hline & 0.9 & 0.13 & 0.6 & 0.9 & 0.10 & 0.5 & 0.9 & 0.18 & 0.6 \\
\hline & I. 8 & 0.25 & I. 2 & I. 8 & 0.20 & I. . & I. 8 & $0.3^{6}$ & I. 2 \\
\hline & 2.6 & 0.38 & I. 7 & $2 \cdot 7$ & 0.29 & I. 5 & 2.7 & 0.53 & I. 7 \\
\hline & $3 \cdot 5$ & 0.50 & $2 \cdot 3$ & 3.5 & 0.39 & 2.0 & 3.6 & $0.7 \mathrm{I}$ & 2.3 \\
\hline & $4 \cdot 4$ & 0.63 & 2.9 & 4.4 & 0.49 & 2.5 & 4.6 & 0.89 & 2.9 \\
\hline & 6.6 & 0.94 & $4 \cdot 4$ & 6.6 & 0.74 & 3.8 & 6.8 & I. 34 & $4 \cdot 4$ \\
\hline \multirow[t]{2}{*}{$10 \ldots \ldots$} & 8.5 & I. 25 & 5.8 & 8.8 & 0.98 & 5.1 & $9 . I$ & 1.78 & 5.8 \\
\hline & \multicolumn{3}{|c|}{ Rye, I : 7.8} & \multicolumn{3}{|c|}{ Rye Bran, I : 5.I } & \multicolumn{3}{|c|}{$\begin{array}{c}\text { Cottonseed Meal, } \\
\text { I : } \mathbf{x} .0\end{array}$} \\
\hline & 0.2 & 0.02 & 0.2 & 0.2 & 0.03 & 0.2 & 0.2 & 0.10 & $0 . I$ \\
\hline & 0.4 & 0.04 & 0.3 & 0.4 & 0.06 & 0.3 & 0.5 & 0.20 & 0.2 \\
\hline & 0.9 & 0.00 & 0.7 & 0.9 & O. I 2 & 0.6 & 0.9 & 0.40 & 0.4 \\
\hline & I. 8 & 0.18 & I. 4 & I. 8 & 0.25 & I. 3 & I. 8 & 0.80 & 0.8 \\
\hline & 2.7 & 0.27 & 2. I & 2.7 & 0.37 & I. 9 & 2.8 & 1. 20 & I. 2 \\
\hline & $3 \cdot 5$ & 0.36 & 2.8 & $3 \cdot 5$ & 0.49 & $2 \cdot 5$ & $3 \cdot 7$ & I. 60 & I. 6 \\
\hline & 4.4 & 0.46 & $3 \cdot 5$ & & 0.62 & $3 \cdot I$ & 4.6 & 2.00 & 2.0 \\
\hline & 6.6 & 0.67 & 5.2 & 6.6 & 0.92 & 4.7 & 6.9 & 3.00 & 3.0 \\
\hline \multirow[t]{2}{*}{$10 \ldots \ldots$} & 8.8 & 0.89 & 6.9 & 8.8 & I. 23 & 6.3 & 9.2 & 4.00 & 4.0 \\
\hline & \multicolumn{3}{|c|}{ Cottonseed Hulls, } & \multicolumn{3}{|c|}{$\begin{array}{c}\text { Linseed Meal, o. p. } \\
\text { I : } 1.5\end{array}$} & \multicolumn{3}{|c|}{$\begin{array}{c}\text { Linseed Meal, n.p. } \\
\mathrm{I}: \mathrm{r} .3\end{array}$} \\
\hline & 0.2 & & 0.1 & 0.2 & 0.08 & $0 . I$ & 0.2 & 0.08 & 0.1 \\
\hline & 0.4 & & 0.2 & 0.5 & 0.15 & 0.2 & 0.4 & 0.16 & 0.2 \\
\hline I & 0.9 & $\cdots$ & 0.4 & 0.9 & 0.31 & 0.5 & 0.9 & 0.32 & 0.4 \\
\hline & I. 8 & & 0.7 & I. 8 & 0.62 & I. 0 & I. 8 & 0.65 & 0.8 \\
\hline & 2.7 & & I. I & 2.7 & 0.92 & I. 4 & 2.7 & 0.97 & I. 3 \\
\hline 4 & 3.6 & & I. 5 & 3.6 & I. 23 & I. 8 & 3.6 & I. 30 & I. 7 \\
\hline & 4.5 & & I. 8 & 4.9 & I. 54 & 2.3 & $4 \cdot 5$ & I. 62 & $2 . I$ \\
\hline $7 \frac{1}{2} \ldots$ & 6.7 & & 2.7 & 0.8 & $2.3 \mathrm{I}$ & 3.4 & 6.7 & 2.43 & 3.2 \\
\hline 10 $\ldots$. & 8.9 & & $3 \cdot 7$ & 9.0 & 3.08 & 4.6 & 8.9 & 3.24 & $4 \cdot 2$ \\
\hline
\end{tabular}


COMPOSITION OF FEEDS-(Continued).

\begin{tabular}{|c|c|c|c|c|c|c|c|c|c|}
\hline $\begin{array}{l}\text { Pounds of } \\
\text { Feed. }\end{array}$ & 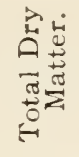 & 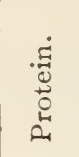 & 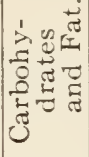 & 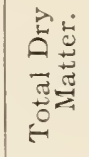 & 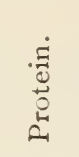 & 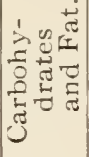 & 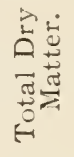 & 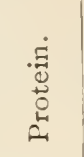 & 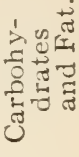 \\
\hline $\begin{array}{c}\text { By- } \\
\text { products. }\end{array}$ & \multicolumn{3}{|c|}{ Flax Meal, I : I.4 } & \multicolumn{3}{|c|}{$\begin{array}{c}\text { Gluten Meal(Chi.), } \\
\text { I : I.5 }\end{array}$} & \multicolumn{3}{|c|}{$\begin{array}{l}\text { Gluten Meal, } \\
\text { Crea'n, I : 1.7 }\end{array}$} \\
\hline & 0.2 & 0.08 & $0 . \mathrm{I}$ & 0.2 & 0.08 & 0.1 & 0.2 & 0.07 & 0.1 \\
\hline & 0.4 & 0.16 & 0.2 & 0.4 & 0.16 & 0.2 & 0.4 & o. I 5 & 0.2 \\
\hline$\ldots \ldots$ & 0.9 & 0.32 & 0.4 & 0.9 & 0.32 & 0.5 & 0.9 & 0.30 & $\circ 5$ \\
\hline$\ldots \ldots$ & I. 8 & 0.64 & 0.9 & I. 8 & 0.64 & 0.9 & I. 8 & 0.59 & I. O \\
\hline$\ldots \ldots$ & 2.7 & 0.96 & I. 3 & 2.6 & 0.96 & I. 4 & 2.7 & 0.89 & I. 5 \\
\hline$\ldots \ldots$ & 3.6 & I. 2 & & 3.5 & 1.28 & I. 9 & 3.6 & I. IO & $2 . I$ \\
\hline & $4 \cdot 5$ & 1.60 & 2.2 & $4 \cdot 4$ & I. 60 & 2.3 & $4 \cdot 5$ & I. 49 & 2.6 \\
\hline $7 \frac{1}{2} \ldots \ldots$ & 6.7 & 2.40 & $3 \cdot 3$ & 6.6 & 2.40 & $3 \cdot 5$ & 6.7 & 2.23 & $3 \cdot 9$ \\
\hline \multirow[t]{2}{*}{$10 \ldots \ldots$} & 8.9 & $3.2 \mathrm{I}$ & $4 \cdot 3$ & 8.8 & 3.21 & $4 \cdot 7$ & 9.0 & 2.97 & $5 \cdot I$ \\
\hline & \multicolumn{3}{|c|}{$\begin{array}{c}\text { Gluten Feed, } \\
\text { Buffalo, } \mathrm{x}: 2.4\end{array}$} & \multicolumn{3}{|c|}{$\begin{array}{c}\text { Hominy Chop, } \\
\text { I : } 9.2\end{array}$} & \multicolumn{3}{|c|}{$\begin{array}{l}\text { Dried Brewers' } \\
\text { Crains, I : } 3.0\end{array}$} \\
\hline & 0.2 & 0.06 & $0 . \mathbf{I}$ & 0.2 & 0.02 & 0.2 & 0.2 & 0.04 & $0 . I$ \\
\hline & 0.4 & 0.12 & & 0.5 & 0.04 & 0.4 & 0.5 & 0.08 & 0.3 \\
\hline I & 0.9 & 0.23 & 0.6 & 0.9 & 0.00 & 0.8 & 0.9 & 0.16 & 0.5 \\
\hline 2 & I. 8 & 0.47 & & I. 8 & 0.17 & I. 6 & I. 8 & $0.3 \mathrm{I}$ & 0.9 \\
\hline 3 & 2.7 & 0.70 & & 2.8 & 0.26 & 2.4 & 2.8 & 0.47 & I. 4 \\
\hline & 3.6 & 0.03 & $2 \cdot 3$ & $3 \cdot 7$ & 0.35 & 3.2 & 3.7 & 0.63 & I. 9 \\
\hline & $4 \cdot 5$ & I. 1 & 2.8 & 4.6 & 0.44 & 4.0 & 4.6 & 0.79 & 2.4 \\
\hline $72 \ldots \ldots$ & 6.8 & I. 75 & $4 \cdot 3$ & 6.0 & 0.65 & 0.0 & 6.9 & I. 18 & $3 \cdot 5$ \\
\hline \multirow[t]{2}{*}{,$\ldots \ldots$} & 9.0 & 2.33 & $5 \cdot 7$ & 9.2 & 0.87 & 8.0 & 9.2 & I. 57 & $4 \cdot 7$ \\
\hline & \multicolumn{3}{|c|}{$\begin{array}{l}\text { Atlas Gluten } \\
\text { Meal, } 1: 2.6\end{array}$} & \multicolumn{3}{|c|}{$\begin{array}{c}\text { Malt Sprouts, } \\
\text { I : } 2.2\end{array}$} & \multicolumn{3}{|c|}{ Pea Meal I : 3.2} \\
\hline & 0.2 & 0.06 & 0.2 & 0 . & 0.05 & o. & 0.2 & 0.04 & $0 . I$ \\
\hline & 0.5 & 0.12 & & 0.4 & 0.00 & 0.2 & 0.4 & 0.08 & 0.3 \\
\hline I $\ldots \ldots$ & 0.9 & 0.25 & 0.6 & 0.9 & O. I 9 & 0.4 & 0.9 & 0.17 & 0.5 \\
\hline$\ldots$ & I. 8 & 0.49 & I. 3 & I. 8 & 0.37 & 0.8 & 2.8 & 0.33 & I. I \\
\hline $3 \ldots \ldots$ & 2.8 & & & 2.7 & 0.56 & I. 2 & 2.7 & 0.50 & I. 6 \\
\hline $4 \ldots \ldots$ & 3.7 & 0.98 & 2.6 & 3.6 & 0.74 & 1.6 & 3.6 & 0.67 & 2. I \\
\hline $5, \ldots$ & 4.6 & I. 23 & 3.2 & $4 \cdot 5$ & 0.93 & 2.0 & $4 \cdot 5$ & 0.84 & 2.7 \\
\hline $7 \frac{1}{2} \ldots$ & 6.9 & I. 85 & 4.9 & 6.7 & I. 40 & 3.0 & 6.7 & r. 26 & 4.0 \\
\hline $10 \ldots$ & 9.2 & $2 \cdot 46$ & 0.5 & 9.0 & 1.80 & 4.0 & 9.0 & I. 68 & $5 \cdot 3$ \\
\hline
\end{tabular}


CLASSIFICATION OF CATTLE FOODS. (LINDEY.)

A. Coarse Feeds (Roughage).

I. Low in protein, high in carbohydrates:

(a) 50-65 per cent. digestible: Hays, straws, corn fodder, corn stover, and silage.

(b) $85-95$ per cent. digestible: Carrots, potatoes, sugar beets, mangels, turnips.

II. Medium in protein and in carbohydrates, $55-65$ per cent. digestible: Clovers, vetches, pea and bean fodders and brans.

B. Concentrated Fieeds (Concentrates).

III. Low in protein, high in carbohydrates, 80-90 per cent. digestible: Wheat, rye, barley, oats, Indian corn.

IV. High in protein, medium in carbohydrates, 8o-9o per cent. digestible: Bean and pea meals, gluten feeds and meals, linseed meals, cottonseed meal.

\section{CLASSIFICATION OF CONCENTRATES, ACCORDING TO PROTEIN CONTENT:}

(a) Very rich in protein (about So per cent.): Dried blood, meat scraps, cottonseed meal.

(b) Rich in protein (25-40 per cent.): Gluten meal, Atlas meal, linseed meal, buckwheat middlings, soja beans, grano-gluten.

(c) Fairly rich in protein (12-25 per cent.) Malt sprouts, dried brewers' grains, gluten feed, cow pea, pea meal, wheat shorts, rye shorts, oat shorts, wheat middlings, wheat bran, low-grade flour (red-dog).

(d) Low in protein (below I2 per cent.): Wheat, barley, oats, rye, corn, rice polish, rice, hominy chops, germ meal. 


\section{FEEDING STANDARDS FOR FARM ANIMALS.}

(WOLFF-LEHMANN.)

(Per day and per rono lbs. live weight.)

1. Steers at rest in stall.......... lbs

Steers slightly worked,...........

Steers moderately worked......... 25

Steers heavily worked........... 28

2. Fattening steers, ist period........ 30

$$
\begin{array}{lllllll}
\because & 4 & \text { 2d } & \ldots & \ldots \ldots \ldots & 30 \\
& 4 & 3 \mathrm{~d} & \cdots & \ldots \ldots \ldots & 26
\end{array}
$$

3. Milch cows, daily milk yicld, I I lbs. 25

$$
\begin{aligned}
& \text { " " " } " \text { " }
\end{aligned}
$$

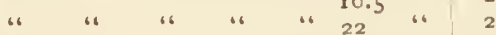

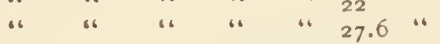

4. Wool sheep, coarser brceds.......

$$
\text { ". finer breeds............ }
$$

5. Breeding ewes, with lambs.......

6. Fattening sheep, ist period........

7. Horses lightly worked...........

Horses moderately worked.........

Horses heavily worked...........

8. Brood sows, with pigs.

9. Fattening swine, ist period.... ..

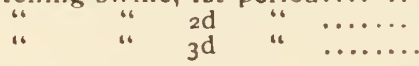

10. Growing cattle:

\section{Dairy Breeds.}

Age, Months.

$2-3$
$3-6$
$6-12$
$12-18$
$18-24$

Aver. live weight per head.

$1541 \mathrm{lbs} . \ldots \ldots$
309
507
705
882
882

Nutritive (Digestible) Substances.

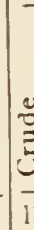

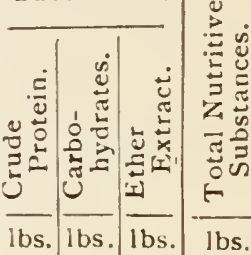

$\begin{array}{lllll}0.7 & 8.0 & 0.1 & 8.9\end{array}$

1.410 .00 .3

\begin{tabular}{ll|l|l|l}
2.0 & II. 5 & 0.5
\end{tabular}

$2.8 \times 3.00 .8$

12. 1

$14 \cdot 7$

$17 \cdot 7$

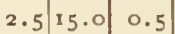

3.014 .5

18.7 I: 6.5

2.715 .0

0.7

19.2 I: 5.4

, 6

1.610 .0

2.011 .0

2.513 .0

3.313 .0

0.4

19.4

I: 6.2

$\begin{array}{ll}\text { I. } 2 & 10.5\end{array}$

$1.512 .0 \quad 0.3$

1.512 .00 .3

$12.3 \quad 1: 6.7$

14.0 1: 6.0

16.7 1: 5.7

$18.2 \quad 1: 4.5$

2.975 .0

5 I9.1 I: 5.6

\begin{tabular}{lll|l|l}
3.0 & 15.0 & 0.5 & 19.2 & I: 5.4
\end{tabular}

\begin{tabular}{ll|l|l|l}
3.5 & 14.5 & 0.6 & 19.4 & $1: 4.5$
\end{tabular}

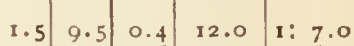

$2.011 .0) 0.6$

14.5 $1: 6.2$

\begin{tabular}{l|l|l}
2.5 & 13.3 & 0.8
\end{tabular}

$17.7 \quad 1: 6.0$

\begin{tabular}{l|l|l}
2.5 & $15 \cdot 5$ & 0.4
\end{tabular}

$19.0 \quad 1: 6.6$

\begin{tabular}{l|l|l}
4.5 & 25.0 & 0.7
\end{tabular}

4.024 .00 .5

2.718 .0

$3^{x} \cdot 2$

29.2

22.0

I: $5 \cdot 9$

I: 6.3

$\because 7.0$ $\begin{array}{llllll}4.0 & 13.0 & 2.0 & 21.8 & 1: 4.5\end{array}$

$\begin{array}{llllll}3.0 & 12.8 & 1.0 & 18.2 & 1: 5.1\end{array}$

\begin{tabular}{l|l|l|l|l}
2.0 & 12.5 & 0.5 & 15.7 & $1: 68$
\end{tabular}

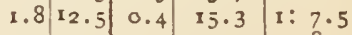

\begin{tabular}{l|l|l|l|l}
1.5 & 12.0 & 0.3 & 14.2 & $1: 8.5$
\end{tabular} 


\section{FELDING STANDARDS FOR FARM ANIMALS.}

(Concluded.)

1r. Growing cattle:

\section{Beef Breeds.}

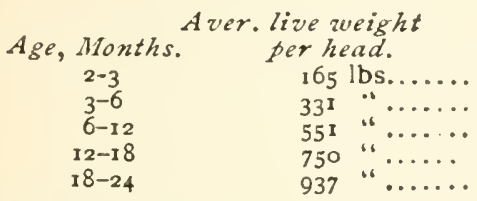

12. Growing sheep:

Wool Breeds.

$4-6$
$6-8$
$8-11$
$11-15$
$15-20$

13. Growing sheep:

Mutton Breeds.

$4-6$
$6-8$
$8-11$
$11-15$
$15-20$

14. Growing swine:

Breeding Animals.

$2-3$
$3-5$
$5-6$
$6-8$
$8-12$

15. Growing fat pigs:

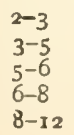

62 lbs.......

75 “" $\cdots \cdots .$.

84 " "........

9o

99

(6.......

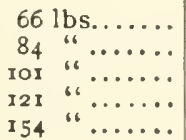

26

26

24

23

22

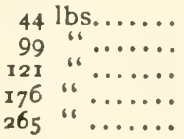

25

23

22

22

\begin{tabular}{l|l|l|l}
3.4 & 15.4 & 0.7 & 20.5
\end{tabular}

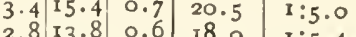
2. I I. 5 0.5 $18.0 \quad 1: 5.4$

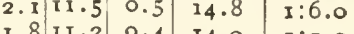
$\begin{array}{lllll}1.8 & I I .2 & 0.4 & \text { I } 4.0 & I: 7.0\end{array}$ \begin{tabular}{l|l|l|l|l} 
I. 5 & 10.8 & 0.3 & I 3.0 & $1: 7.7$
\end{tabular} \begin{tabular}{l|l|l|l|l}
4.4 & I 5.5 & 0.9 & 22.1 & $\mathrm{I}: 4.0$
\end{tabular} \begin{tabular}{l|l|l|l|l}
3.5 & 15.0 & 0.7 & 20.2 & $I: 4.8$
\end{tabular}

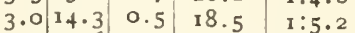
2.212 .6 o 5 16.0 $1: 6.3$ 2.012 .0 0.4

15.0 I :6. 5

\begin{tabular}{l|lll}
7.6 & 28.0 & 1.0 & 38.0
\end{tabular} \begin{tabular}{ll|l|l|l}
5.0 & 23.1 & 0.8
\end{tabular}

$3 \cdot 72 I \cdot 3$

\begin{tabular}{l|l|l|}
2.8 & 18.7 & 0.3
\end{tabular}

2. I $15 \cdot 3$.

0.2

$30.0 \quad 1: 5.0$

$26.0 \quad 1: 6.0$

22.2

I:7.0

I:7.5

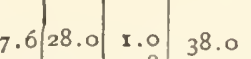




\section{RATIONS FOR IAIRY COJW.}

\begin{tabular}{|c|c|c|c|c|c|c|}
\hline & \multirow{2}{*}{$\begin{array}{l}\text { Org'nic } \\
\text { Matter. }\end{array}$} & \multicolumn{4}{|c|}{ Digestible. } & \multirow{2}{*}{$\begin{array}{l}\text { Nut. } \\
\text { Ratio }\end{array}$} \\
\hline & & Protein & $\begin{array}{c}\text { Carbo- } \\
\text { hydrates }\end{array}$ & Fat. & Total. & \\
\hline $\begin{array}{l}\text { Woods \& Phelps....... } \\
\text { Woll. . . ........... } \\
\text { Wolff 'German Stand'. } \\
\text { Wolff-Lehmann... }\end{array}$ & $\begin{array}{l}\text { lbs. } \\
25 \cdot 0 \\
24 \cdot 5 \\
24 \cdot 0\end{array}$ & $\begin{array}{l}\text { lbs. } \\
2.5 \\
2.2 \\
2.5\end{array}$ & $\begin{array}{l}\text { Ibs. } \\
\text { 12.5 } \\
13.3 \\
12.5 \\
\text { (Sce pag }\end{array}$ & $\begin{array}{c}\text { lbs. } \\
.65 \\
.7 \\
.4 \\
.12\end{array}$ & $\begin{array}{l}\text { lbs. } \\
\text { I } 5.65 \\
\text { I } 6.2 \\
\text { I } 5.4\end{array}$ & $\begin{array}{l}1: 5.6 \\
1: 6.9 \\
1: 5 \cdot 4\end{array}$ \\
\hline
\end{tabular}

\section{CALCULATION OF COMPONENTS OF FEED RA'TIONS.}

Let us suppose that we have at our disposal the following common feeding stuffs: Fodder corn, clover hay, and wheat bran, and that we want to know how much is required to keep a milch cow of $1000 \mathrm{lbs}$. live weight in good condition and to secure a maximum yield of milk. We will feed 15 lbs. of corn fodder, 5 lbs. of clover hay, and Io lbs. of wheat bran. According to the table these quantities contain the following number of pounds of digestible matter:

\begin{tabular}{|c|c|c|c|}
\hline & \multirow[b]{2}{*}{$\begin{array}{c}\text { Dry } \\
\text { Matier. }\end{array}$} & \multicolumn{2}{|c|}{ Digestible. } \\
\hline & & Protein. & $\begin{array}{l}\text { Carbohy- } \\
\text { dratesand } \\
\text { Fat. }\end{array}$ \\
\hline $\begin{array}{r}\text { I } 5 \text { lbs. of corn todder } \ldots \ldots \ldots \ldots \ldots \\
5 \text { lbs. clover hay..... } \\
\text { Io lbs. wheat bran. } \ldots \ldots \ldots \ldots \ldots \ldots\end{array}$ & $\begin{array}{l}\text { Lbs. } \\
8.7 \\
4.2 \\
8.8\end{array}$ & $\begin{array}{r}\text { Lbs. } \\
.38 \\
.36 \\
1.20\end{array}$ & $\begin{array}{l}\text { Lbs. } \\
5 \cdot 4 \\
2.1 \\
4.6\end{array}$ \\
\hline 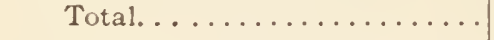 & 21.7 & 1.94 & I 2.1 \\
\hline
\end{tabular}

This ration falls somewhat short of the feeding standard in both total dry matter and digestible substances. To bring it nearer to the standard, we add a couple of pounds of some concentrated feed. In selecting the feeds and deciding the quantities to be given in each case, the market prices of the feels must be considered. We will suppose that a supply of corn meal is available in this case, and will add two pounds of this feed to the above ration. 


\begin{tabular}{|c|c|c|c|c|}
\hline & \multirow[b]{2}{*}{$\begin{array}{l}\text { Dry } \\
\text { Matter. }\end{array}$} & \multicolumn{2}{|c|}{ Digestible. } & \multirow[b]{2}{*}{$\begin{array}{l}\text { Nutritive } \\
\text { Ratio. }\end{array}$} \\
\hline & & $\begin{array}{l}\text { Crude } \\
\text { Protein. }\end{array}$ & $\begin{array}{l}\text { Carbohy- } \\
\text { drates. }\end{array}$ & \\
\hline $\begin{array}{l}\text { Ration as above......... } \\
2 \text { lbs. of corn meal...... }\end{array}$ & $\begin{array}{l}\text { Lbs. } \\
21 \cdot 7 \\
1.7\end{array}$ & $\begin{array}{l}\text { Lbs. } \\
\text { I. } 94 \\
.13\end{array}$ & $\begin{array}{r}\text { Lbs. } \\
\text { I } 2.1 \\
\text { I. } 4\end{array}$ & \\
\hline 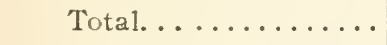 & $23 \cdot 4$ & 2.07 & $13 \cdot 5$ & I $: 6.5$ \\
\hline $\begin{array}{l}\text { Proposed American feeding } \\
\text { ration for. milch cows. } \\
\text { Wolf's feeding standard for } \\
\text { milch cows. . . . . . . . . }\end{array}$ & $\begin{array}{l}24.5 \\
24.0\end{array}$ & $\begin{array}{l}2.2 \\
2.5\end{array}$ & $\begin{array}{l}\text { I } 3.3 \\
\text { I } 2.5\end{array}$ & $\begin{array}{l}\text { I }: 6.9 \\
I: 5.4\end{array}$ \\
\hline
\end{tabular}

The ration now corresponds fairly well with the proposed American feeding ration; there is a small deficit of dry matter and of digestible protein; but there is no nccessity of trying to follow any standard ration blindly, as they are only intended to be approximate gauges which the farmer may use in estimating the quantities of nutrients required by farm animals in order to do their best, cost and product both being considered. Cows, like all farm animals, vary greatly in their productive capacity, as well as in their food requirements, and their capacity to make economical use of their feed; hence feeding standards can only be applied to average conditions, a point which should always be kept in mind in using them.

In constructing rations according to the above feeding standards, several points must be considered besides the chemical composition and the digestibility of the feeding stuffs; the standards cannot be followed directly without regard to bulk and other properties of the fodder; the ration must not be too bulky, and still must contain a sufficient quantity of roughage to keep up the rumination of the animals, in case of cow and sheep, and to secure a healthy condition of the animals generally. The local market prices of cattle foods are of the greatest importance in determining which feeds to buy; the conditions in the different sections of our continent differ so greatly in this respect that no generalizations can be made. Generally speaking, nitrogenous concentrated feeds are the cheapest feeds in the South and the East, and flour-mill, brewery, and starch-factory-refuse feeds the cheapest in the Northwest. 


\section{PRACTICAL RATIONS FOR DAIRY COWS.}

\section{Fed by 16 American Dairymen Producing 325 lbs. of Butter or more per Cow per Year.*}

I. Colorado.-30 lbs. silage, Io lbs. alfalfa hay, Io lbs. clover hay, 5 lbs. wheat bran, 2 lbs. corn meal.

2. Connecticut. -35 lbs. corn silage, Io lbs. hay, 3 lbs. wheat bran, 3 lbs. corn and cob meal, 2 lbs. cotton-seed meal, 2 lbs Chicago gluten meal.

3. Illinois. $-7 \frac{1}{2}$ lbs. clover hay, $7 \frac{1}{2}$ lbs. timothy hay, I 2 ;bs. corn and cob-meal, 8 lbs. bran, I $\frac{1}{3}$ lbs. linseed meal, I $\frac{1}{6}$ lbs. colton-seed meal.

4. New Jersey. - 2t lbs. corn silage, 8 lbs. corn meal, 2 lbs. wheat bran, 4 lbs. oats, 2 lbs. oil meal.

5. Nea York. - 2o lbs. hay, 2 lbs, wheat bran, 2 lbs. cotton. seed meal, 2 lbs. hominy meal.

6. New York.-I2 lus. timothy hay, I lb. wheat bran, I lb. middlings, 2 lbs. corn meal, 2 lbs. cotton-seed meal, to lbs. skim-milk.

7. Nerv York. -42 lbs, corn silage, $2 \frac{1}{2}$ lbs. clover hay, $2 \frac{1}{2}$ lbs. timothy hay, $8 \mathrm{lbs}$. corn and cob meal, I4 lbs. dried brewers grains.

8. North Carolina.-30 lbs. corn silage, 8 lbs. fodder corn, 3 lbs. corn meal, 3 lbs. wheat bran, I lb. cotton-seed meal.

9. Pennsylvania. -24 lbs. corn fodder, 5.I lb. wheat bran, 5. I lbs. corn meal, 3 lbs. cotton-seed meal, 2 lbs. oil meal.

io. Pennsyliania.- - Io lbs. corn fodder, $6 \mathrm{lbs}$. hay, $3 \frac{1}{2} \mathrm{lbs}$.

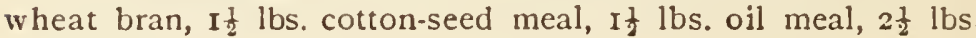
corn meal.

I I. Texas. -30 lbs, corn silage, I $3 \frac{1}{2}$ lbs. sorghum hay, I. 3 lts. corn meal, 2.6 lbs. cotton-seed meal, 2.2 lbs. cotton-seed, I. 3 lbs. wheat bran.

I2. Vermont. -30 lbs. corn silage, ro lbs. hay, $4.2 \mathrm{lbs}$. corn meal, 4.2 lbs. wheat bran, $.8 \mathrm{lb}$. linseed meal.

13. West Virginia. -48 lbs. corn silage, $2 \frac{1}{2} \mathrm{lbs}$. corn and cob meal, $2 \frac{1}{2}$ lbs. ground wheat, $2 \frac{1}{2}$ lbs. oats, $2 \frac{1}{2} \mathrm{lbs}$. barley meal.

* See Woll, "One Hundred American Rations for Dairy Cows," Bul. letin No. $3^{8}$, Wisconsin Agricultural Experiment Station. 
14. Wisconsin. - 26 lbs. corn silage, 10 lbs. clover hay, 5 lbs. tinullyy hay, 8 lbs. wheat middlings, $1 \frac{1}{2}$ lbs. oil meal.

15. Il isconsin.-50 lus. corn silage, 5 lbs. sheaf oats, 5 lbs. coin fodder, I lb. clover hay, a lb. millet, 2.7 lbs. cotton.seed meal, r. 3 lbs. oil meal, 6 lbs. wheat bran.

16. Canada. - to lbs. corn silage, $7 \frac{1}{2} \mathrm{lbs}$. clover hay, $3 \mathrm{lbs}$. straw. $1 \frac{1}{3}$ lbs. oats, $1 \frac{1}{3}$ lbs. barley, I $\frac{1}{3}$ lbs. pea meal, 3 lbs. wheat bran, i lb. cotton-seed meal.

The preceding rations contain approximately the following amounts of nutrients, calculated for I000 lbs. live weight :

\begin{tabular}{|c|c|c|c|c|c|c|}
\hline \multirow{2}{*}{ No. } & \multirow{2}{*}{$\begin{array}{l}\text { Organic } \\
\text { Matter. }\end{array}$} & \multicolumn{4}{|c|}{ Digestible. } & \multirow{2}{*}{$\begin{array}{c}\text { Nutritive } \\
\text { Ratio. }\end{array}$} \\
\hline & & Protein. & $\begin{array}{c}\text { Carbo- } \\
\text { hydrates. }\end{array}$ & Fat. & Total. & \\
\hline & lbs. & lbs. & Ibs. & lbs. & lbs. & IUs. \\
\hline $\mathbf{I}$ & $3^{1.09}$ & 2.70 & 15.78 & .80 & 1928 & $x: 6.5$ \\
\hline 2 & 2570 & 2.69 & 13.96 & .97 & 17.62 & $1: 6.0$ \\
\hline 3 & 22.09 & $2 \cdot 37$ & 12.06 & .75 & 15.18 & I : 5.8 \\
\hline 4 & 19.41 & 2.06 & II .71 & .87 & 14.64 & $1: 6.5$ \\
\hline 5 & 26. 19 & $2 \cdot 3^{0}$ & $13 \cdot 7^{8}$ & .79 & I 6.93 & $1: 6.6$ \\
\hline 5 & 25.73 & 3.50 & 14.05 & I. 12 & 18.67 & $1: 4.7$ \\
\hline 7 & $31 \cdot 30$ & $3 \cdot 37$ & 16.31 & $1 \cdot 31$ & 20.99 & I : $5 \cdot 7$ \\
\hline$\varepsilon$ & $20.3^{8}$ & 1. 79 & 11.98 & .80 & 14.57 & $1: 7.7$ \\
\hline 9 & 26.52 & 2.53 & 15.74 & .90 & 19.17 & $1: 7.0$ \\
\hline 10 & 20.05 & $2.3 x$ & 11.00 & .72 & 14.03 & I : 5.4 \\
\hline $1 \mathrm{I}$ & $26.5^{8}$ & $2.2 \mathrm{I}$ & $12 \cdot 3^{I}$ & 1. 30 & 15.82 & I : 6.9 \\
\hline 12 & 24.23 & I. 86 & 14.03 & .75 & 16.64 & $x: 8.4$ \\
\hline$\times 3$ & $22 \cdot 37$ & 1.54 & 14.15 & .72 & 16.41 & $1: 10.2$ \\
\hline 14 & 31.00 & 3.01 & 16.02 & .87 & 19.90 & $I: 6.0$ \\
\hline$\times 5$ & 23.79 & 2.73 & 12.46 & .99 & 16.28 & $1: 5.4$ \\
\hline 16 & 22.96 & 2.08 & 12.17 & .71 & 14.96 & $x: 6.6$ \\
\hline
\end{tabular}




\section{AVERAGE WEIGHTS OF CONCENTRATED FEEDING STUFFS.}

\begin{tabular}{|c|c|c|}
\hline Feeding Stuff. & $\begin{array}{c}\text { One Quart } \\
\text { Weighs. }\end{array}$ & $\begin{array}{l}\text { One Pound } \\
\text { Measures. }\end{array}$ \\
\hline 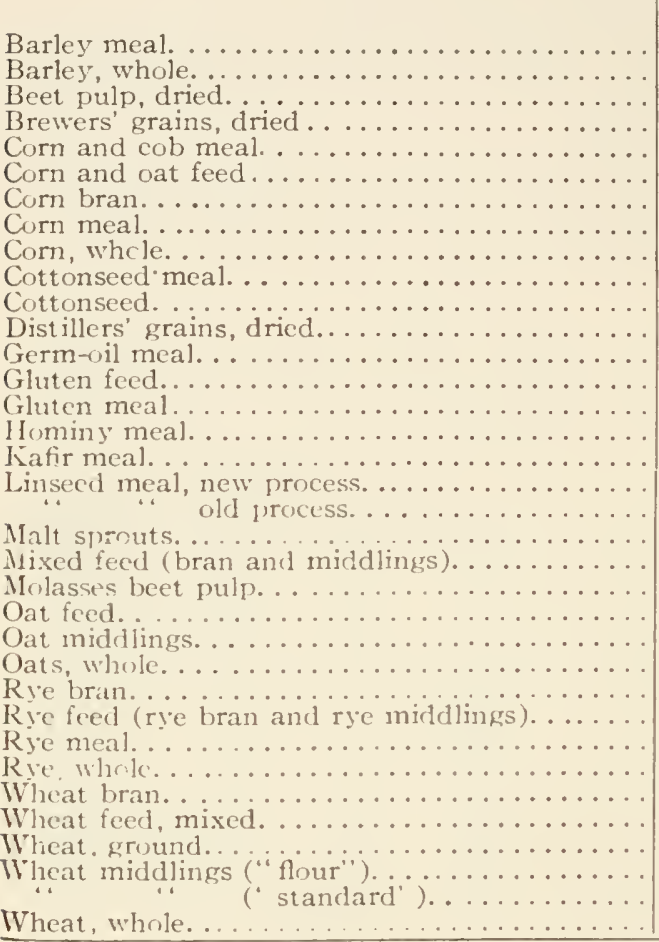 & $\begin{array}{c}\text { Pounds. } \\
\text { I.1 } \\
\text { I.5 } \\
.55 \\
.6 \\
1.4 \\
.7 \\
.5 \\
1.5 \\
1.7 \\
1.5 \\
1.0 \\
.5-.7 \\
1.4 \\
1.3 \\
1.7 \\
1.1 \\
1.6 \\
.9 \\
1.1 \\
.6 \\
.6 \\
.75 \\
.8 \\
\text { I.5 } \\
1.0 \\
.6 \\
1.3 \\
1.5 \\
1.7 \\
.5 \\
.6 \\
1.7 \\
1.2 \\
.8 \\
1.9 \\
1.9\end{array}$ & $\begin{array}{c}\text { Quarts. } \\
.9 \\
.7 \\
1.8 \\
1.7 \\
.7 \\
1.4 \\
2.0 \\
.7 \\
.6 \\
.7 \\
1.0 \\
2.0-1.4 \\
.7 \\
.8 \\
.6 \\
.0 \\
.6 \\
1.1 \\
.9 \\
1.7 \\
1.7 \\
1.3 \\
1.3 \\
.7 \\
1.0 \\
1.7 \\
.8 \\
.7 \\
.6 \\
2.0 \\
1.7 \\
.6 \\
.8 \\
1.3 \\
.5 \\
\end{array}$ \\
\hline
\end{tabular}

\section{FOOD REQUHEMENTS OF FARM ANIMAS.}

It is generally assumed in comparing the food requirements of the different classes of farm animals that one cow at pasture will eat about seventenths as much daily as a full-grown horse, or as much as two yearling colts, heifers, or young bulls, or as three to five calves, or four colts taken from the mare, or ten to twelve sheep, or as twelve to twenty three-months-old lambs, or as four to five swine. It may be figured that the quantity of pasture grass eaten by a cow per day, which of course will vary with the season and the condition of the pasture, will equal 25-3o lbs. of good meadow hay or $40 \mathrm{lbs}$. hay of inferior quality. 


\section{COMPARATIVE VALUE OF CATTLE FOODS.}

Comparing concentrated foods with coarse feeds, one pound of the former may be considered a food unit; the quantity of grass eaten by one cow at pasture during one day is assumed equivalent to I 2 to I 3 food units during the early part of the summer, and to 4 food units in the late fall, io units being considered an average figure.

The following quantities of different feeding stuffs are considered approximately equivalent, as determined by European, largely Danish, feeding experience (Schroll):

I lb. concentrated feed (cereals, mill refuse-feeds, oil meals, etc.) $=2 \frac{1}{2}$ to $3 \mathrm{lbs}$. of good meadow hay $=4 \mathrm{lbs}$. of poorer quality hay $=$ Io lbs. rutabagas $=\mathrm{I} 2 \frac{1}{2}$ lbs. turnips $=6 \mathrm{lbs}$. potatoes $=$ ro lbs. green fodder $=6 \mathrm{lbs}$. buttermilk $=6 \mathrm{lbs}$. skim-milk = I2 lbs. whey $=\mathrm{I}$ lb. new milk. (See table on p. Iga, also Wis. Exp. Sta., Circ. 37.)

\section{CALCULATED VATUE OF FRUITS COMPARED WITH HAY, GRAINS, ETC. (JAFFA AND ANDERSON.)}

\begin{tabular}{|c|c|c|c|c|c|c|c|c|c|c|}
\hline Fresh Fruits. & íbs. & Lbs. & Lbs. & Lbs. & Lbs. & Lbs. & Lbs. & Lbs. & Lbs. & $\mathrm{b}$ \\
\hline Apples. . . . . . . . . & 34 & 20 & 24 & I 5 & 17 & 16 & IS & 16 & 13 & \\
\hline Oranges........ & 33 & I0 & 23 & It & 16 & I 5 & 17 & 15 & 12 & \\
\hline Pears............ & 40 & 23 & 30 & 17 & 20 & I 9 & 20 & I 9 & I 5 & I I \\
\hline Plums........... & 50 & 30 & 36 & 22 & 25 & 24 & 26 & 24 & 20 & 4 \\
\hline s.......... & 46 & 27 & 33 & 20 & 23 & 22 & 24 & 22 & is & 13 \\
\hline$\ldots \ldots$ & 40 & 23 & 29 & I 7 & 20 & I 9 & 20 & I 9 & 15 & I \\
\hline Nectarines. . . . . . . & 43 & 26 & 30 & 10 & 22 & $2 \mathrm{I}$ & 23 & $2 \mathrm{I}$ & 17 & \\
\hline Figs. . . . . . . . . . & 50 & 30 & 37 & 23 & 26 & 25 & 27 & 25 & 20 & \\
\hline Grapes........ & 50 & 32 & 37 & 23 & 26 & 25 & 27 & 25 & 20 & \\
\hline Watermelons...... & 22 & I 3 & I6 & 10 & I I & I I & I 2 & I I & 8 & 6 \\
\hline Nutmeg melons... & 19 & II & I 3 & 8 & 9 & 9 & IO & 9 & 7 & \\
\hline DRIED FrUITS. & & & & & & & & St & 67 & +8 \\
\hline Apricots. .. & $\begin{array}{l}175 \\
194\end{array}$ & $\begin{array}{ll}10 & 4 \\
1 & 1\end{array}$ & $\begin{array}{l}125 \\
138\end{array}$ & $\begin{array}{l}75 \\
86\end{array}$ & $\begin{array}{l}53 \\
97\end{array}$ & $\begin{array}{l}54 \\
93\end{array}$ & $\begin{array}{r}92 \\
102\end{array}$ & $\begin{array}{l}54 \\
93\end{array}$ & $\begin{array}{l}07 \\
74\end{array}$ & $\begin{array}{l}43 \\
53\end{array}$ \\
\hline Peaches. ......... & 190 & 113 & I 3.5 & 85 & 05 & 91 & 100 & 01 & 72 & 51 \\
\hline & 186 & 110 & 132 & 83 & 03 & sol & 07 & So & 71 & \\
\hline & 216 & 123 & I 53 & 97 & 108 & 103 & I I I I & 103 & $\mathrm{~S}_{2}$ & 59) \\
\hline
\end{tabular}


AMOUNTS OF DIFFERENT FEEDS REQUIRED TO

EQUAL ONE FEED UNIT. (WIS, EXP. StA., Circ. 37.)

Feed.

Feed Required to Equal I Unit.

\section{CONCENTRATES:}

Corn, wheat, rye, barley, hominy feed, dried brewers' grains, wheat middlings, oat shorts, peas, Unicorn Dairy Ration, molasses beet pulp...... Cotton seed meal.

Oil meal, A jax Flakes (dried distillers' grains), gluten feed, soy beans. . . . . . . . . . . . . . .

Wheat bran, oats, dried beet pulp, barley feed, malt sprouts, International Sugar Feed, Quaker or Sugarota Molasses or Dairy Feed, Sucrene Dairy Feed, Badger Dairy Feed, Schumacher Stock Feed, molasses grains.......................... Alfalfa meal, Victor teed, June Pasture, alfalfa molasses feeds.......................

HaY aNd StRaw:

Alfalfa hay, clover hay.

Mixed hay, oat hay, oat and pea hay, barley and

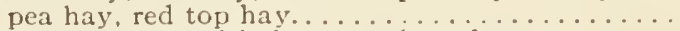

Timothy hay, prairie hay, sorghum hay.........

Corn stover, stalks or fodder, marsh hay, cut straw

Solling Crops, Silage, and Other Succulent Feeds

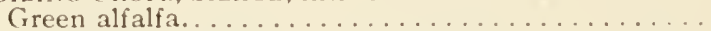

Green corn, sorghum, clover, peas and oats, cannery

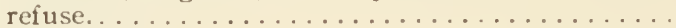

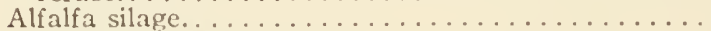

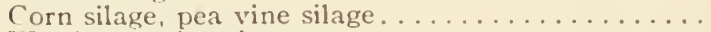

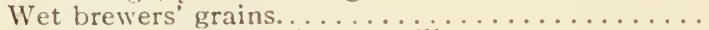

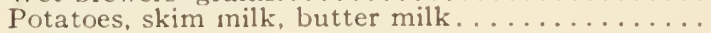

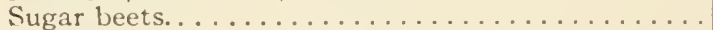

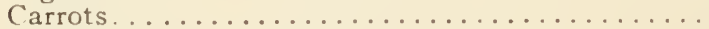

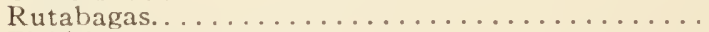

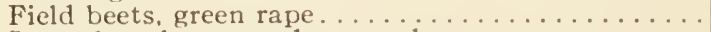

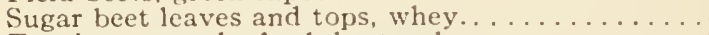

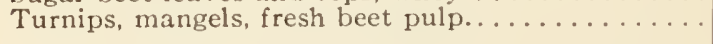

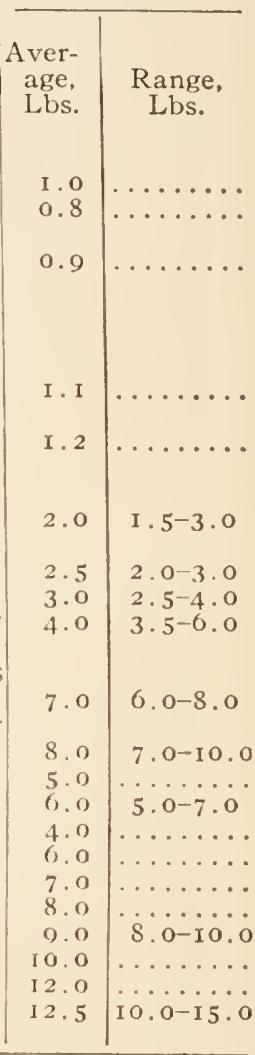

The value of pasture is generally placed at 8 to $I 2$ units per day. on the average, varying with kind and condition. 
POUNDS OF DRY MA'TER, DIGESTIBLE MATTER, AND DIGESTIBLE PROTEIN TO BE FURNISHED IN RATIONS FOR DAIRY COWS. (Wis. Eyp. Sta. Bul. 200.)

\begin{tabular}{|c|c|c|c|c|c|c|c|c|}
\hline \multirow[b]{2}{*}{$\begin{array}{c}\text { Live } \\
\text { Weight, } \\
\text { L.bs. }\end{array}$} & \multirow[b]{2}{*}{$\begin{array}{l}\text { Dry } \\
\text { Cows. }\end{array}$} & \multicolumn{7}{|c|}{ Production of Butter Fat per Day, Pounds. } \\
\hline & & $\begin{array}{c}\text { Less } \\
\text { than } \\
0.5 \mathrm{lb} \text {. }\end{array}$ & ${ }^{0.5^{-}} .75$ & $\mid \begin{array}{r}0.75- \\
1.0\end{array}$ & $\begin{array}{r}\text { I. O- } \\
\text { I. } 25\end{array}$ & \begin{tabular}{|} 
I. $25^{-}$ \\
I. 5
\end{tabular} & $\begin{array}{r}1.5- \\
1.75\end{array}$ & I. $75^{-2}$ \\
\hline
\end{tabular}

POUNDS DRY MATTER TO BE FURNISHED IN RATIONS.

\begin{tabular}{r|l|l|l|l|l|l|l|l}
\hline 800 & I0.0 & 13.7 & 16.2 & I8.6 & 21.1 & 23.5 & 26.0 & 28.4 \\
900 & I I.3 & 15.0 & 17.5 & 19.9 & 22.4 & 24.8 & 27.3 & 29.7 \\
1000 & 12.5 & 16.2 & 18.7 & 21.1 & 23.6 & 26.0 & 28.5 & 30.9 \\
1100 & 13.8 & 17.5 & 20.0 & 22.4 & 24.9 & 27.3 & 29.8 & 32.2 \\
& & & & & & & & \\
1200 & 15.0 & 18.7 & 21.2 & 23.6 & 26.1 & 28.5 & 31.0 & 33.4 \\
1300 & 16.3 & 20.0 & 22.5 & 24.9 & 27.4 & 29.8 & 32.3 & 34.7 \\
1400 & 17.5 & 21.2 & 23.7 & 26.1 & 28.6 & 31.0 & 33.5 & 35.9 \\
1500 & 18.8 & 22.5 & 25.0 & 27.4 & 29.9 & 32.8 & 34.7 & 37.2 \\
\hline
\end{tabular}

POUNDS DIGESTIBLE PROTEIN TO BE FURNISIED IN RATIONS.

\begin{tabular}{r|r|l|l|l|l|l|l|l}
\hline 800 & .56 & 1.04 & 1.35 & 1.66 & 1.97 & 2.29 & 2.60 & 2.91 \\
900 & .63 & 1.11 & 1.42 & 1.73 & 2.04 & 2.36 & 2.67 & 2.98 \\
1000 & .70 & I.18 & 1.49 & 1.80 & 2.11 & 2.43 & 2.74 & 3.05 \\
1100 & .77 & 1.25 & 1.56 & 1.87 & 2.18 & 2.50 & 2.81 & 3.12 \\
& & & & & & & & \\
1200 & .84 & 1.32 & 1.63 & 1.94 & 2.25 & 2.57 & 2.88 & 3.19 \\
1300 & .91 & 1.39 & 1.70 & 2.01 & 2.32 & 2.64 & 2.95 & 3.26 \\
1400 & .98 & 1.46 & 1.77 & 2.08 & 2.39 & 2.71 & 3.02 & 3.33 \\
1500 & 1.05 & 1.53 & 1.84 & 2.15 & 2.46 & 2.78 & 3.09 & 3.40 \\
\hline
\end{tabular}

POCNDS TOTAL DIGESTIBLE MATTER TO BE FIRNISIIED IN RATIONS.

\begin{tabular}{r|r|r|r|r|r|r|r|r}
\hline 800 & 6.3 & 9.0 & 10.7 & 12.5 & 14.2 & 16.0 & 17.7 & 19.5 \\
900 & 7.1 & 9.8 & 11.5 & 13.3 & 15.0 & 16.8 & 18.5 & 20.3 \\
1000 & 7.9 & 10.6 & 12.3 & 14.1 & 15.8 & 17.6 & 19.3 & 21.1 \\
1100 & 8.7 & 11.4 & 13.1 & 14.9 & 16.6 & 18.4 & 20.1 & 21.9 \\
& & & & & & & & \\
1200 & 9.5 & 12.2 & 13.9 & 15.7 & 17.4 & 19.2 & 20.9 & 22.7 \\
1300 & 10.3 & 13.0 & 14.7 & 16.5 & 18.2 & 20.0 & 21.7 & 23.5 \\
1400 & 11.1 & 13.8 & 15.5 & 17.3 & 19.0 & 20.8 & 22.5 & 24.3 \\
1500 & 11.9 & 14.6 & 16.3 & 18.1 & 19.8 & 21.6 & 23.3 & 25.1 \\
\hline
\end{tabular}


PRICES OF CEREAIS PFR BUSHEL AND PER TON.

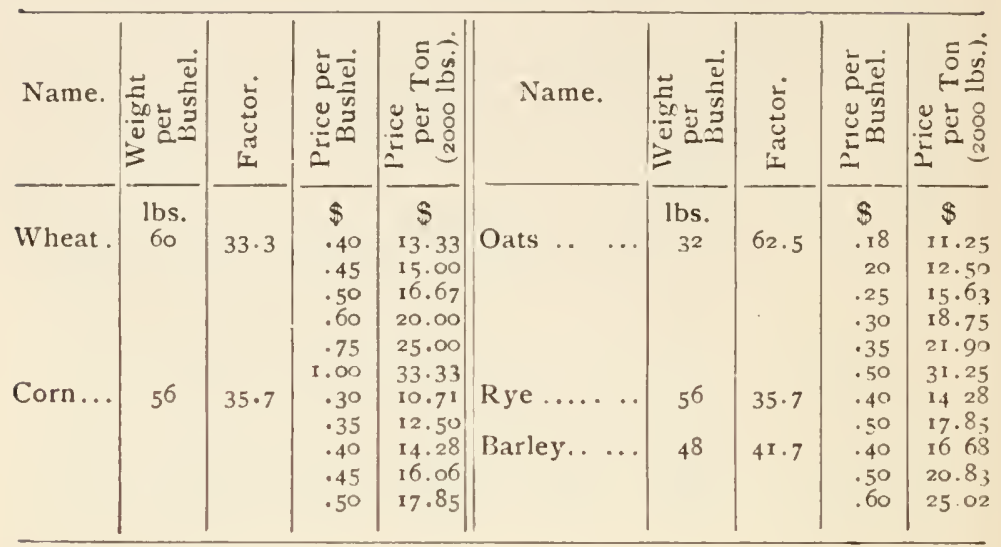

\section{VAIUATION OF FEEDING STUFFS.}

The commercial value of protein, fat, and carbohydrates in concentrated feeding stuffs has been calculated from the average composition and market price of common feeding stuffs as follows:

- Cost of one pound of -

Protein. Fat. Carbohydrates.

In Germany...(1890) 3: 2: I (König, Wolff.)

“ Connecticut (I888) r.6 cts. $4.2 \mathrm{cts} .96 \mathrm{cts}$. (Jenkins.)
“
(I 890$) \mathrm{I} \cdot 4$
2.9
I. 4
“Delaware...(I889) I.23
$4.45 \quad .52$
“ W'isconsin..(IS,I) I.5
$3.6 \quad .5$
“ Indiana....( ( $\varepsilon 9 \mathrm{I})$ r.o
$2.75 \quad .63$
(Penny.)
“ New Jersey.(I89I) .9I
$5.9 \mathrm{I} \quad \mathrm{I} . \mathrm{I} 2$
(Woll.)
(Huston.)
“ Minnesota..(I893) 3.I
3. I $\quad .24$
(Voorhees.)
“Vermont....(I895) 2.02
-.I9 .9I
(Hays.)
(Hills et al.) 


\section{FARM ANIMALS.}

\section{CHARACTEIRITICS OF BREEDS OF LIVE STOCK.}

By the late Prof. J. A. Craig, formerly of Iowa Agricultural College.

\section{Iight Horses.}

The Thuroughbred.-Leading characteristics: running speec

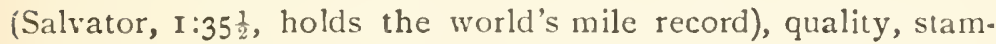
ina, and ambition. Common colors: brown, bay, chestnut. Distinctive features: refined appearance, lengthy neck, deep chest, long body, straight croup, long thighs and pasterns, dense bone, firm muscle, active temperament, rangy type standing I 6 hands. Most common defects: light bodies, lengthy pasterns, long legs, irritable temperament. Bred principally for racing, which has given them endurance and spirit. They are suited for mating with mares weighing II to I 2 cwt., with the object of producing strong drivers or stylish carriage and saddle horses.

The Anerican Trotter.-Chief characteristics: speed at the trotting gait. World's record for one mile against time is that of Alix, 2:03: The type of the leading campaigners is that towards which the trotter is tending; it is that of a horse required to have the endurance, ambition, and conformation to maintain trotting speed. Most general features: intelligent heads, light necks, low deep chests, oblique shouiders, long forearm, short cannons, round body rising slightly over loin, long croup and thighs, low hocks. Most common defects: undersize, deficiency in style, finish, and substance. Sphere: coach or carriage horses, roadsters, and trotters. 
Clevelind Bay. - Uniform in color, being bay with black points. They stand at least 16 hands and are horses of larger size and more power than those of most other breeds of light horses. Rough joints, coarse bone, and deficiency in actior are their most common defects. Their size, power, and erenuess of disposition arlapt them for general work on light farms, but owing to the defects mentioned they are not as popular for breeding road and carriage horses as those of other breeds.

French Coach.-Smooth, symmetrical, and generally of fine quality; very graceful in movement, with high knee-action and good back-action. Heads intelligent looking; necks graceful, bodies snugly ribbed, and quarters muscular. As a rule, they are striking in appearance, being upstanding and bigh-headed. Common colors: bay, brown, and black. Best suited fur breeding coach-horses with moderately fast and graceful action. Defects : coarseness and lack of prepotency in the stallions clue to their nixed breeding.

Hackney. - The typical hackney is a horse of extreme smoothness, with gracefully curved outlines. The head is light, neck muscular and curved, but free from heaviness: shoulders smooth and laid well back; body circular, compact, short; lips smooth; quarters plump with muscle; legs short, with tenclons clearly defined. Their action is noted for its gracefulness and stylishness, being very high in the forelegs, and the hock movement is regular. Common colors: bay and brown. They are usually about 15.3 hands. Best suited for production of high-stepping cab and coach horses for city driving.

\section{Heavy Horses.}

Clydesdale.-Usual colors: bay, brown, black, or chestnut with white markings. The head is intelligent in features, but sometimes out of proportion with the other parts. Shoulder exceptionally good; being sloping, it gives them a free, easy, and long stride in the walk or trot; arm well-muscled, and legs clean and flat, with the fine and long feather springing from the edge; pasterns sloping, easing the feet from concussion; 
feet large and durable. The croup is muscular and the quarters especially heavily-muscled. Their combination of weight, quality, and action is exceptional in draught-horses.

Shire.-The best type is low, broad, and stout. They are heavily built, muscular, with heavy bone and slow movement. The shoulder is usually too upright, making the action too short and stilted. The body is of large girth, deep and strongly coupled, with broad, short back and heavily-muscled quarters. Deficiencies: lack of quality, sluggish temperament, and limited action. In general they are heavier than the Clydesdale, though there is little clifference between representa. tive animals. The best type is suitable for breeding the heaviest class of draught-horses adapted to slow work demanding strength and heavy weight.

Percheron. - Types: the original gray in color, and the modern of black color. Most peculiar characteristics of the former were their action, style, endurance, and strength. They had intelligent heads, prominent chests, round bodies, large bone, inclined to roundness. The modern type is shorterlegged, more compact and stouter, but lacking the size of the original. The Percheron's excellencies are seen in their active temperament, intelligent heads, crested neck, deep body, and wide croup. Their deficiencies appear in defective legs, being light or round, straight pasterns, feet narrow at the hoof, heads and quarters lacking niuscle. Best type adapted for breeding energetic, quick-gaited, strong horses suited for draught work of light nature.

Suffolk.-Color uniform, being some shade of chestnut. They are low-set, short-leggred, deep-bodied, muscular horses, with clean bone and durable feet; dccile, easy keepers, and steady when working. Generaldeficiency: a lack of weight due to their smaller size in comparison with other draught-horses. Suited for general farm labor; they are not the highest-priced horses on the market owing to the demand for heavier weights. 


\section{Beef Cattle.*}

Short-horns. - The three family types are: Bates, Booth, and Cruikshank. Bates, noted for style, fine heads, clean necks, straight level backs, light bone, and combination of milk and beefing qualities. Booths are especially excellent in girch, wicie backs, lengthy quarters, deep flesh, and beefing qualities, though lacking in finish and style. Cruikshanks, noted for scale; low, broad, deep forms, heavy flesh, and mossy crats. The shorthorn breed is specially noted for beef form, early maturity, and thrift under a variety of conditions. Their weakness in con. stitution and sterility is traceable to in-and-in breeding and artificial treatment. Their chief utility is to give beef form, quality, and rapid fattening tendencies to grades for stall feeding. Some families possess unequalled combination of beefing and milking qualities.

Aberdeen Angus. - Characteristic color, black. Head, hornless; neck free from loose skin, exceptionally good shoulder-vein: shoulder oblique, fitting close to body; ribs deep, very circular: hips moderately far apart, smoothly curved ; rump long, level, smooth ; thighs muscular, twist low and full, quarters long and rounded. Type: cylindrical, distinguished for smoothness, symmetry and quality ; bone light, hide mellow, and coated with fine black hair. They are prepotent and prolific. Chief utility, production of beef of high quality.

Hereford.-Most popular color, dark claret or cherry, with white face, belly, switch, and small strip of white on neck and over shoulder. Type: low-set and broad; heavy in forequarters, with low heads; full, deep chest; hanging dewlap. !evel lack, wide thick loin, full quarters and thin thighs. Worst deficiencies, looseness in build and rough, coarse bone. They are strong-constitutioned, active rangers, prepotent and long-lived. Being active, hardy, and good feeders they make good grazing cattle, and on that account have been popular on ranches.

Galloway. - Color black, no white admissible, except on

* For description of breeds of dairy cattle, see Part II, Dairying. 
udder or below underline. 'Type: thick, close to ground, and symmetrical; hair long, wavy, and thick; head large, hornless, with no scurs; neck strong, giving a burly appearance to forequarters; shoulders snug, legs short and heary. barrel round, tight-ribbed ; quarter long and smooth ; flesh even over all parts; hardiness and strength of constitution, strong features. Require more time to mature and yield larger percentage of offal than most other breeds. They are liked as ranch cattle, as they are hardy, hornless, and yield excellent beef and robes.

\section{Fine-wooled Sheep.}

Merino.--The two types include those wrinkled and those smooth in body. They are chiefly noted for the heavy weights of fine wool that they shear. The fleece is dense, even, extending over all regions. The wool is bright, soft, fine, lustrous, and pure. They are hardy and strong in constitution, of a quiet disposition, and do well in large flocks.

\section{Mutton Sheep.}

Southdown.-Symmetrical, compact, close to the ground, and of fine quality; head medium size, hornless; forehead and face covered with wool, ears small, face brown or gray tint, neck short, breast broad, back and loin wide and straight, body deep, hips wide, twist full, fleece dense, and medium in length and fineness. The mutton is of high quality, and lambs mature early. They represent an exceptional combination of wool and mutton of fine quality.

Shropshire.-Face and legs dark brown in color. They are symmetrical and stylish. Rams are required to weigh $225 \mathrm{lbs}$. in full flesh, and ewes 175 lbs. Head short, covered with wool, hornless; neck well attached, full; body circular, round ribbed; quarters lengthy, inclined to narrowness and slackness. The fleece dense, fibre strong, about three and one half inches in length. The ewes are prolific and kind nurses. They combine quality and quantity of wool ancl mutton in a high clegree, and are adapted to conditions of general farming and rolling land.

Hampshire.-Color of face dark brown or black; head large, nose prominent, neck regular, taper from head to shoulder; 
strong-boned and lengthy. Especially noted for early development of lambs. They are vigorous and prepotent. 'The wool' is short, dense, strong, and slightly coarse.

Suffolk. - Faces and legs deep black color. They are large sheep when mature; lengthy and straight in form. Noted chiefly for prolificness and good milking and nursing qualities. A large percentage of lambs are reared in flocks of this breed; wool medium in quality and length.

Oxford.-Face either brown or gray, and lengthy. When mature they are the heaviest of the Down breeds, veing larger in size and heavier in bone. Their flece is also heavier and the fibre longer, coarser, and more open than most others. Squarer in form than the Shropshires, and not so closely covered with wool. Adapted to strong land; respond readily to ligh feeding.

Leicester.-Face bare ard pure white, body square, straight, forequarters exceptionally full, hindquarters rounded slightiy. Offal is light, bone fine, but fat too plentiful. The Border type is stronger bonel, heavier, and more vigorous than the English. The Leicester has been extensively used for crossing on grades. Wool lustrous, five or six inches long, soft, but too frequently open and absent on the belly.

Cotsuold.-Face white or slightly mixed with gray. Form large, square, upstanding, and stylish. A tuft of wool grows from forehead; flece open, long, and heavily yielding. Borly long, level, and wide. The gray-faced strain is considered hardier than the white-faced. The popularity of the breed lies in the large yield of wool and of mutton, though the quality of both is deficient.

Lincoln.-The largest of the long-wooled breeds. The wool is long and coarse, and especially lustrous. Square in form and, when mature, very heavy. The mutton lacks quality.

Cheviot.-Face bare, white, hornless; wool fine, and the fleece dense and even. Mutton agreeably flavored and finegrained. They are hardy, active, prolific, and the lambs come active. They clip about four pounds of fine wool. Adapted to rough and high pasturage.

Dorset.-Face white; rams and ewes horned. Type: long, round-bodied, and compactly built. Wool medium in length, fineness, and weight; average clip 6 pounds. Chief character. 
istics: prolificness, hardiness, and breeding early, so as to drop lambs in winter.

Highland.-Rams and ewes horned, face and legs black and white. Low and blocky in type; fleece long, coarse. Their mutton has a superior flavor. Mountain breed hardy, active, and very strong of constitution.

\section{Swine.}

Berkshire-Color black, white on face, feet, tip of tail. Face short, dished; ears sharp-pointed, erect; jaws full, back broad, straight, full over shoulder; loin thick, level ; hams exceptionally full, legs short, strong, and straight. Sorvs prolific, good nurses. Active and vigorous in temperament.

Poland-China.-Color dark, spotted, or black; head small, slightly dished; ears drooping, girth full, ribs well sprung, deep; nindquarters lengthy, though inclined to be drooping. They atten readily, reach heavy weights, and are quiet-dispositioned.

Yorkshire.-White in color; separated into large, middle, and small varieties. The first-mentioned, are strong-boned, longbodied, and deep-sided, and have mixed meat; middle or improved type, lighter in weight and bone, with smaller quantity of offal; small variety, quick in maturing and compact in form.

Chester-White.-White in color, strong-boned, vigorous, and attain to very heavy weights, though slow in maturing. Sows of good disposition and breeding qualities.

Duroc-Jerseys.-Deep, cherry red in color, large size, good breeders, and liked in Southern countries because of ability to withstand heat.

Victoria.-White in color with occasional black spots on skin; head small, face slightly dished; skin free from scurf; flesh of good quality and evenly laid over body. Yearling boars should weigh not less than 300 lbs.

Tamworth.--Red or dark brown color; snout very long, body narrow, exceptionally deep and long in sides. Their form and the mixture of fat and lean in their flesh make them a special bacon hog.

Essex.-Color black; type: small, compact, early ma.uring, and yielding a large percentage of edible meat. 


\section{MARKET CLASSES OF FARM ANIMAIS.}

\section{A.-Horses.}

Drafters.-A typical draft horse, so considered in the market. should stand 16 hands or over; light draft horses range in height from 15.3 to 16 . I hands. Drafters should weigh r600 lbs. and over in fair condition. Heavy weight in addition to desirable conformation, soundness, and action enhances value.

Loggers.-Horses of this class are heavy drafters, possessed of weight, great power, and strength of bone, but blemished or slightly unsound so that they cannot be sold to advantage for use in the cities. Largely bought by lumbermen for use in the woods.

Farm chunks. - These are usually of mixed draft blood, stand I5 hands or over and weigh 1 roo-1500 lbs.

General-purpose Horses. - These animals are not recognized as a standard market class, but form a large proportion of the entire number of horses marketed. They usually are serviceably' sound and often of fair to good quality, but they lack the characteristics fitting a horse for a distinct marlat class.

Expressers. - This class comprises active, light draft horses that are expected to do most of their work at a trot. 'The typical expresser stands 15.2 to 16 hands, and weighs 1350 to 1500 lbs. or over, according to the class of work to be done. They are commonly considered "draft horses with coach-horse finish."

Bussers.-Horses of this class stand I $_{5}$. I to 15.3 hands and weigh I 200-I foo lbs. Their chief work is done at a trotting gait, hence they must be active, energetic, straight, and somewhat stylish in carriage and gait. Many go abroad to serve as "trammers."

Artillery Horses.-In this class geldings are required. They should be uniform, of a hardy color, from $15^{\frac{1}{4}}$ to 16 hands high, quick and strong in action, well-bred, of a kind disposition, square trotters, well broken to harness, gentle under saddle, with easy mouths and gait. They should weigh rroo-1250 lbs. and be from 5 to $S$ years old. 
Drivers.-The typical roadster should stand I5.I to I5 3 hands high and weigh 950 to I 150 lbs. His purpose is to draw a light buggy on the road at a fairly rapid rate of speed for a considerable length of time. He should be graceful in form and action sprightly, pleasing, straight, and smooth in all gaits, his disposition good, and his legs and feet sound.

Standard Bred.- This class includes trotters and pacers eligible to record in the trotting register and possessed of notable speed, and breed prepotency in that direction.

Coachers.-A typical coacher stands $\mathrm{I}_{5} .2$ to $\mathrm{I} 6$ hands and weighs I I00 to I 250 lbs. He should have high knee action and corresponding high hock action that comes from breeding rather than artificial methods of development. He must move fairly fast with much gracefulness of carriage, possess fine quality, be beautifully molded in all of his curves, and carry his head and tail high. While heavier, smoother, and more compact than the roadster, he must be showy and stylish to carry fine harness and draw handsome equipages.

II agon Horses.-These are used for parcel-delivery service by large department stores, etc.; they are big overgrown coachers, stand 16.1 hands and weigh 1250 lbs.

Cobs.-A typical cob stands about I5.I, weighs 1000 to 1050 lbs., is more compact and blocky than the coacher, yet must have style and beauty in a marked degree. His action must be extremely high and "trappy."

Saddlers.-These horses vary considerably in type, size, and

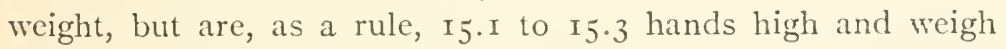
1000 to I 50 lbs. They should have great style and quality, smooth conformation, natural and thoroughly trained saddle gaits, intelligent, clean-cut countenances, sloping pasterns and shoulders, moderately high and narrow withers, short strongcoupled backs, strong and muscular thighs, and well-carried heads and tails. "Walk, trot, and canter" saddlers have become popular of recent years and sell at high prices. (See Alexander, Bull. No. I27, M̈isconsin Experiment Station; also Obrecht, Bull. No. I 22. Illinois Exp. Station.) 


\section{B.- Cattle.}

General Classes.

I. Beef Cattle.-This class includes all grades of fat steers and heifers; also everything from common to prime and from light to heavy. It is finished condition that brings animals into this class.

2. Butcher Stock.-This class includes animals that have not fattened well; also animals that have not been fed long enough to become properly fattened. It seldom includes steers of really good quality, as such will usually be sold as feeders. The bulk of butcher stock is made up of cows and heifers.

3. Cutters and Canners.-In this class are included old thin cows and very thin bulls, steers, and heifers. The cutters must carry sufficient flesh to permit of the loin or rib or both being used for cutting on the block. Those animals which are so thin that no part of the carcass can be used for block purposes constitute the canners.

4. Stockers and Feeders.-This class includer calves, yearlings, two-year-olds, and older cattle. Cattle 18 months old or older, which are reacly for immediate use in the feed lot, are called feeders. Those which are younger are referred to as stockers.

5. Veal Calves. - This includes all calves which are sold for immediate slaughter.

\section{Special Classes.}

In addition to the preceding general classes, a number of special classes are generally recognized and require to be named and defined.

I Texas and Western Range Cattle.-A few years ago the typical Texas steer had very long horns and legs, was thin and narrow bodied, and carried a large decp brand, and most of the cattle which came from Texas were of this descripticn. But this type is rapidly disappearing. Animals of the best beef breeds have been imported into the State and used for breeding purposes, especially for crossing with the native stock, so that actw many of the Texas cattle compare favorably with those i. m other sections of the country. There is, however, a wide range between the best nid the poorest. 
The Western range cattle are classed with the Texas rattle, because formerly they were made up largely of Southern cattle which were driven northward to winter on the ranges north of the quarantine line. Now, however, a large percentage of the animals in this class are bred on the ranges of the West and Northwest. All the cattle in this class are branded.

2. Distillers.-These are cattle that have been fattened on the by-products of distilleries. Formerly only inferior grades of cattle were purchased for feeding on distillery residues, but at present many feeders of better grades are used. When sent to market these cattle are preferred to many of the same grade, because they dress out a higher percentage of beef.

3. Baby Beef.-This term applies to choice or prime fat steers between I and 2 years old, weighing from Soo to rooo lbs.

4. Export Cattle.-The cattle exported are in the main good to choice steers, weighing from I 200 to I 500 lbs. Comparatively few prime beef steers are brought for export, because of the high price they bring in the home market.

5. Shipping Steers.-This term applies to the aninals purchased in the Western markets for shipment to the large Eastern markets of the United States. They are mainly of medium and good grades, and range in weight from II 50 to 1600 lbs.

6. Dressed Beef Cattle.-This class includes such cattle as are purchased by the large packing firms of the Middle West. The packers prefer medium to choice steers, weighing from I 200 to $1400 \mathrm{lbs}$., to make up the bulk of their purchases, but conditions of supply and demand cause them to purchase animals of a much wider range in grade and weight, the extreme range in weight being from 800 to $\mathrm{I} 700 \mathrm{lbs}$.

7. Stags.-This class includes such animals as have reacherl or at least approached maturity before castration and hence bave the general conformation of bulls. Comparatively few of these come to the general markets, and they are of a wide range in quality, condition, and weight. A few are good enough for export, while the poorest must be sold for canners. (See Mumford, Bull. No. 78 , Illinois Experiment Station, also Plumb, Marketing Live Stock, Farmers' Bull. No. I84.) 


\section{C.-Shcep.}

The market classification of sheep varies considerably in the different markets of our country. Ordinarily they are, however, classed as follows. Western wethers, ewes, yearlings, and lambs, and native wethers, ewes, and lambs. These terms are selfcxplanatory. Western sheep are from the ranges of Montana, Wyoming, and other States beyond the Mississippi, and are strongly impregnated with merino blood. They lack the middle wool or mutton characteristics of sheep from States cast of the Mississippi. Western sheep and lambs weigh lighter and dress out less fat than Eastern stock.

The various classes are graded on a range of quality, from common to choice or extra prime. (Sec Plumb, Farmers' Bull. No. $8_{4}$, and Coffee, 13ull. No. 1 20, I.1. Exp. Station.)

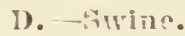

Prime Hea'y Hogs.-These are prime heary fat-back hogs, weighing 350-500 llss., the extreme of the fat or lard hog. Prime implies marked evidence of ripeness and maturity.

Butcher Hegs are principally barrows; they are used for the fresh-meat trade; about 25 per cent. of the hogs coming to Chicago are of this class; they range in age, with food care and feeding, from about 6 months for the light butchers to one year for the heary ones. They are subdivided into heary, $280-35^{\circ}$ lbs.; medium, 220-2SO llss.; and light butchers, ISO-220 lbs. The heary butchers include prime and good grades, and the two latter subclasses, prime, good, and common grades.

Packing Hogs.- These are, as a whole, of a poorer grade than the butcher hogs. 'They include old brood sows, and all other hogs that are heary enough for this class and not good enough for the butcher class, except the poorer classes, such as roughs, boars, and coarse stags. About 40 per cent of the hogs on the Chicago market are of this class. They range in age upwards to about 9 months and weigh in the three subclasses, 200-280, 250-300, and 300-500 lbs., each of these being graded as good, common, or inferior stock.

Light Hogs.---This class inclucles all hogs within the weight limits of 125 and 220 lbs., except roughs, stags, and boars, which 
form separate classcs. About I5 per cent of the hogs on the Chicago market belong here. They range in age from 5 to 8 months, and vary considerably in form, quality, and condition, hence the subclasses are of more importance than in the preceding classes.

Bacon Hogs are used for the production of bacon, which is pork that has been salted and then smoked. English bacon hogs weigh I60-220 lbs. and United States, I55-I95 lbs. The latter are graded as choice, good, and common.

Light Mixed Hogs.-This is a somewhat miscellaneous class, comprising about 55 per cent of the light hogs on the Chicago market. This class is the "dumping ground" for the outcasts of the two former classes of hogs. They range in age from 5 to 7 months, and weigh 150 to 220 lbs. They are principally used for the fresh-meat trade.

Light Light Hogs.-Hogs in this class range in weight from I 25 to 150 lbs., and in age from 5 to 6 months. About 25 per cent of the light hogs on the Chicago market belongs to this class and are used mainly for the fresh-meat trade. This and the preceding subclass include hogs of good, common, and inferior grades.

Pigs range in weight from 60 to $\mathrm{I} 25 \mathrm{lbs}$, and in age from $3 \frac{1}{2}$ to 6 months. They are choice, good, or common pigs in proportion to t: eir approach to the ideal of a fat hog.

Roughs. - This class includes hogs of all sizes that are coarse, rough, and lacking in condition. The pork from these hogs is used for the $\mathrm{c}$ :caper trade for both packing and fres.-meat purposes.

Stogs.-These are hogs that were boars beyond the pig stage and have been subsequently castrated. They sell with a dekage of 80 lbs. According to their frecdom from stagginess and their quality and condition, these hogs are sold in the class with the various grades of packing hogs or with boars.

Boars. - These are always sold in a class by themselves, and bring from two to three dollars per cwt. less than the best hogs on the market at the sime time. 'The pork from these hogs is used to supply the cheaper class of trate and also for making sausage. 
Miscellaneous Classes: Roasting Pigs.-Three to six weeks old and weighing $\mathrm{I}_{5}$ to $30 \mathrm{lbs}$. T. ey come to market in small numbers and only during the holiday season. They are usually of a very uniform grade and command prices ranging from those paid regular live hogs to that paid for poultry.

Feeders.-These are hogs that are bought on the market and taken back to the country to be further fed. This class is of but small importance, as this practice of feeding is followed only to a very small extent.

Governments. - These are hogs that are not considered sound in every respect by the Government inspectors, and are retained for further inspection. They are usually bought by local dealers and taken to one of the smaller packing houses, where they are slaughtered under the supervision of an inspector. If their flesh is found unfit for human food, they are tanked and used for fertilizers.

Pen Holders are long-legged hogs of poor form, coarse in quality, and much lacking in condition, kept at the stock yards simply for the purpose of holding pens for commission men.

Dead Hogs. - These are hogs killed in transit, and are used for the manufacture of grease, soap, and fertilizers. If they weigh 100 lbs. or over, they sell for 75 cents per cwt.; if less, they furnish no revenue to the producer or s'ipper, the cost of handling them being held equal to their value. (Sec Dietrich, Bull. No. 97, Illinois Experiment Station.) 
TABLE FOR ESTIMATING LIVE TVEIGHT OF CATTLL. (Whitcher.)

\begin{tabular}{|c|c|c|c|c|c|}
\hline \multirow{2}{*}{\multicolumn{2}{|c|}{$\begin{array}{l}\text { Girth in } \\
\text { Feet and } \\
\text { Inches. }\end{array}$}} & \multicolumn{2}{|c|}{ Store Cattle. } & \multicolumn{2}{|c|}{ Medium Fat. } \\
\hline & & Fair Shape. & Good Shape. & Fair Shape. & Good Shape. \\
\hline Ft. & In. & Lbs. & Lbs. & Lbs. & Lbs. \\
\hline 5 & $\circ$ & 650 & 700 & 700 & 750 \\
\hline 5 & $\mathbf{I}$ & 675 & 725 & 725 & 775 \\
\hline 5 & 2 & 700 & 750 & 750 & 800 \\
\hline 5 & 3 & 725 & 775 & 775 & 825 \\
\hline 5 & 4 & 750 & 800 & 800 & 850 \\
\hline 5 & 5 & 775 & 825 & $\begin{array}{l}825 \\
850\end{array}$ & 875 \\
\hline 5 & 6 & 800 & 850 & 850 & 900 \\
\hline 5 & 7 & 825 & 875 & 875 & 925 \\
\hline 5 & 8 & $\begin{array}{l}850 \\
875\end{array}$ & $\begin{array}{l}900 \\
925\end{array}$ & $\begin{array}{l}900 \\
925\end{array}$ & 950 \\
\hline 5 & $\begin{array}{r}9 \\
10\end{array}$ & $\begin{array}{l}875 \\
900\end{array}$ & $\begin{array}{l}925 \\
950\end{array}$ & $\begin{array}{l}925 \\
950\end{array}$ & $\begin{array}{r}975 \\
\text { I } 0000\end{array}$ \\
\hline $\begin{array}{l}5 \\
5\end{array}$ & $\begin{array}{l}10 \\
\text { I I }\end{array}$ & $\begin{array}{l}900 \\
925\end{array}$ & $\begin{array}{l}950 \\
975\end{array}$ & 975 & $\begin{array}{l}1000 \\
1025\end{array}$ \\
\hline 6 & $\begin{array}{r}11 \\
0\end{array}$ & 950 & $\begin{array}{r}9.5 \\
1000\end{array}$ & 1000 & $\begin{array}{l}1025 \\
1050\end{array}$ \\
\hline 6 & I & 1000 & 1050 & 1050 & I I OO \\
\hline 6 & 2 & 1050 & I I OO & I 100 & I I 50 \\
\hline 6 & 3 & I I 00 & I 150 & I I 50 & I 200 \\
\hline 6 & 4 & I I 50 & I 200 & I 200 & 1250 \\
\hline 6 & 5 & 1200 & 1250 & I 250 & 1300 \\
\hline 6 & 6 & I 250 & I 300 & I 300 & I 350 \\
\hline 6 & 7 & I 300 & I $35^{\circ}$ & I 350 & 1400 \\
\hline 6 & 8 & I $35^{\circ}$ & 1400 & I 400 & I $45^{\circ}$ \\
\hline 6 & 9 & I 400 & I 450 & $145^{\circ}$ & I 500 \\
\hline 6 & Io & I $45^{\circ}$ & I 500 & I 500 & 1550 \\
\hline 6 & I I & I 500 & 1550 & I $55^{\circ}$ & I 600 \\
\hline 7 & 0 & I 550 & I 600 & I 600 & $165^{\circ}$ \\
\hline 7 & I & 1600 & 1650 & I $65^{\circ}$ & 1700 \\
\hline 7 & 2 & I 650 & 1700 & 1700 & 1750 \\
\hline 7 & 3 & I 700 & I $75^{\circ}$ & 1750 & I Soo \\
\hline 7 & 4 & I 750 & I 800 & 1800 & $185^{\circ}$ \\
\hline 7 & 5 & I 800 & I 850 & I 850 & I 900 \\
\hline 7 & 6 & $185^{\circ}$ & 1900 & I 900 & I 950 \\
\hline
\end{tabular}




\section{DETERMINATION OF THE AGE OF FARM ANIMALS BY THEIR TEETH.}

(U. S. Department of Agriculture.)

Horse. - The horse has 24 temporary teeth. The male has 40 permanent teeth, the female 36 or 40 . The smaller number is more usual in females, due to the lack of the tusks. The temporary teeth consist of 12 incisors and 12 molars; the 4 center front teeth, 2 above and 2 below, are called pinchers; the next 4 are called intermediate or lateral, and the next 4 corner teeth. The permanent teeth consist of 12 incisors, 4 tusks, and 24 molars. The dental star is a yellowish ring appearing next the enamel on the table or crown of the tooth. The following table shows approximately the changes of the teeth with age:

3 to Io days: Temporary pinchers and 3 molars cut. 40 to 60 days: Temporary intermediates or laterals cut.

6 to 9 months: Temporary corner teeth cut.

19 to 25 months: Leveling of temporary corner teeth.

$2 \frac{1}{2}$ to 3 years: Pinchers replaced by permanent teeth.

$3 \frac{1}{2}$ to 4 years: Intermediates or laterals replaced.

4 to $4 \frac{1}{2}$ years: Tusks cut.

$4 \frac{1}{2}$ to 5 years: Corner teeth replaced.

5 to 6 years: Leveling of lower pinchers.

7 years: Leveling of permanent intermediates.

$S$ years: Dental star and notches in pinchers.

9 years: Dental star in intermediates.

Io years: Dental star in corner teeth.

Cattle.-Cattle have 20 temporary and 32 permanent teeth. The temporary are 8 incisors in the lower jaw and 12 molars. The permanent teeth are $S$ incisors and 24 molars. Cattle have no incisors in the upper jaw. The table for cattle is as follows:

At birth: Temporary incisors appear.

5 to 6 months: Teeth decayed on border.

6 to 7 months: Leveling of pinchers.

I 2 months: Leveling of first intermediates.

I5 months: Leveling of the second intermediates.

I 8 months: Intermediate incisors become stumps. 
2 years: Permanent pinchers cut.

$2 \frac{1}{2}$ to 3 years: Permanent first intermediates cut.

$3 \frac{1}{2}$ years: Second intermediates or laterals cut.

4 years: Corner tecth replaced.

5 to 6 years: Leveling of permanent pinchers.

7 years: Leveling of first intermediates.

8 ycars: Leveling of second intermediates.

9 years: Leveling of corner teeth.

Io to 2 years: Dental star in pinchers and intermediates.

13 years: Dental star in corner teeth.

Sheef. - Sheep have 20 temporary and 32 permanent teeth. The table for changes is as follows:

I month: Milk incisors appear.

3 months: Milk incisors decayed on border.

I5 months: Permanent incisors cut.

2 years: First permanent intermediates cut.

33 months: Second permanent intermediates cut.

40 months: Corner teeth cut.

Hogs.-Hogs have $2 S$ temporary and $4+$ permanent teeth. The table for changes is as follows:

At birth: Temporary corner incisors cut.

I to 2 months: Temporary central incisors cut.

3 months: Temporary lateral incisors cut.

9 to I 2 months: Permanent corner incisors cut.

I2 to I 5 months: Permanent central incisors cut.

I 8 to 20 months: Permanent lateral incisors cut. 


\section{BODY TEMPERATURE OF FARM ANIMALS.}

(DAMMANN.)

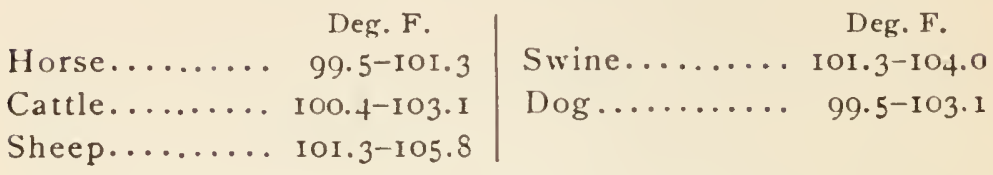

The temperature is greater after exercise than after rest, and in the evening, as a rule, $0.2-1 . I^{\circ} \mathrm{F}$. higher than in the morning.

\section{DURATION AND FREQUENCY OF HEAT IN}

NARM ANIMALS. (WOLFF.)

\begin{tabular}{|c|c|c|c|}
\hline & In Heat for & $\begin{array}{l}\text { If not } 1 \mathrm{mpreg}- \\
\text { nated, Heat will } \\
\text { Recur after }\end{array}$ & $\begin{array}{c}\text { After Coming ln, } \\
\text { Heat will } \\
\text { Recur after }\end{array}$ \\
\hline $\begin{array}{l}\text { Mares .... . . . } \\
\text { Cows ........... } \\
\text { Ewes........... } \\
\text { Sows.......... }\end{array}$ & $\begin{array}{ll}5-7 & \text { days } \\
2-3 & 6 \\
2-3 & 6 \\
2-4 & \cdots\end{array}$ & $\begin{array}{c}3-4 \text { weeks } \\
3-4 \\
17-28 \text { days } \\
9-12\end{array}$ & $\begin{array}{l}5-9 \text { days } \\
21-28 \text { months } \\
7 \text { month } \\
4-5 \text { weeks }\end{array}$ \\
\hline
\end{tabular}

* 8-9 weeks at the latest.

PERIOD OF INCUBATION OF POULTRT.

\begin{tabular}{|c|c|c|c|}
\hline Name of Fowl. & Days. & Name of Fowl. & Days. \\
\hline 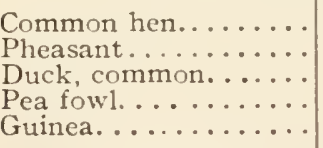 & $\begin{array}{l}21 \\
25 \\
28 \\
28 \\
25\end{array}$ & $\begin{array}{l}\text { Goose.............. } \\
\text { Partridge.......... } \\
\text { Duck, Barbary...... } \\
\text { Turkey............ }\end{array}$ & $\begin{array}{l}30 \\
24 \\
30 \\
28\end{array}$ \\
\hline
\end{tabular}




\section{GESTITION CALENDAR.}

\section{Arrease Gestation Period.}

Mares, $481 \frac{1}{2}$ weeks ( 340 days, extremes 307 and 412 days).

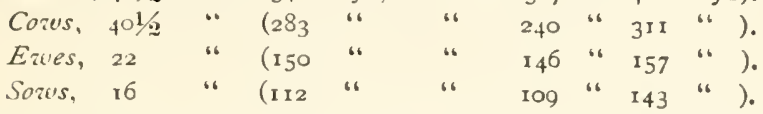

\begin{tabular}{|c|c|c|c|c|c|c|c|c|c|}
\hline \multicolumn{2}{|c|}{$\begin{array}{l}\text { Time of } \\
\text { Service. }\end{array}$} & \multicolumn{2}{|c|}{$\begin{array}{c}\text { Mares. } \\
340 \text { Days. }\end{array}$} & \multicolumn{2}{|c|}{$\begin{array}{c}\text { Cows, } \\
283 \text { Days. }\end{array}$} & \multicolumn{2}{|c|}{$\begin{array}{l}\text { Ewes, } \\
\text { 150 Days. }\end{array}$} & \multicolumn{2}{|c|}{$\begin{array}{l}\text { Sows, } \\
\text { 1 } 12 \text { Days. }\end{array}$} \\
\hline Jan. & I & Dec. & & Oct. I & & May & 30 & April & 22 \\
\hline 6 & 6 & $\therefore$ & II & $\because$ & I5 & June & 4 & 6 & 27 \\
\hline " & I I & " & 16 & " & 20 & ". & 9 & May & 2 \\
\hline " & 16 & " & $2 I$ & 162 & 25 & 6 & 14 & 6 & 7 \\
\hline "، & $2 I$ & 16 & 26 & " & 30 & 6 & 19 & $" 6$ & I 2 \\
\hline$" 4$ & 26 & " & $3^{I}$ & Nov. & 4 & $"$ & 24 & " & 17 \\
\hline & 31 & Jan. & 5 & $\therefore$ & 9 & & 29 & 16 & 22 \\
\hline Feb. & 5 & & ro & " & & July & 4 & "، & 27 \\
\hline$\because$ & 10 & & 15 & " & 19 & .. & 9 & June & I \\
\hline " & 15 & $" 6$ & 20 & $"$ & 24 & “ & 14 & " & 6 \\
\hline$" 6$ & 20 & “" & 25 & " 2 & 29 & 6 & 19 & 16 & I I \\
\hline " & 25 & "6 & 30 & Dec. & 4 & 6 & 24 & & I6 \\
\hline Mar. & 2 & Feb. & 4 & “ & 9 & 6 & 2.9 & "6 & $2 \mathrm{I}$ \\
\hline$\ddot{\prime}$ & 7 & " & 9 & "6 & 14 & Aug. & 3 & " & 26 \\
\hline " & 12 & "6 & 14 & 6 & 19 & $\because$ & 8 & July & I \\
\hline$"$ & 17 & $"$ & I9 & " & 24 & 6 & 13 & "6 & 6 \\
\hline " & 22 & " & 24 & " & 29 & $\dot{0}$ & 18 & $" 6$ & II \\
\hline & 27 & Mar. & I & Jan. & 3 & 66 & 23 & “ & I6 \\
\hline April & I & 16 & 6 & 46 & 8 & 6 & 28 & "๘ & $2 \mathrm{I}$ \\
\hline 6 & 6 & " & I I & "6 & 13 & Sept. & 2 & 6 & 26 \\
\hline " & II & 6 & 16 & "6 & 18 & in & 7 & " & $3 I$ \\
\hline " & & 16 & 21 & & 23 & $" 6$ & 12 & Aug. & 5 \\
\hline " & $2 \mathrm{I}$ & $\because$ & 26 & 62 & 28 & 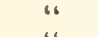 & 17 & 46 & I0 \\
\hline " & 26 & " & $3^{I}$ & Feb. & 2 & 16 & 22 & 6 & 15 \\
\hline May & I & April & 5 & 16 & 7 & 66 & 27 & " & 20 \\
\hline " & 6 & $\therefore$ & I0 & " & 12 & Oct. & 2 & "1 & 25 \\
\hline 6 & 11 & $\because$ & 15 & " & 17 & $\therefore$ & 7 & 16 & 30 \\
\hline$" 1$ & 16 & “ & 20 & 6 & 22 & $"$ & I 2 & Sept. & 4 \\
\hline 16 & 21 & 16 & 25 & " & 27 & "6 & I7 & ": & 9 \\
\hline " & 26 & $\because 3$ & 30 & Mar. & 4 & 6 & 22 & "6 & 4 \\
\hline " & $3^{I}$ & May & 5 & " & 9 & " & 27 & "“ & 19 \\
\hline June & 5 & " & Io & "6 & $x_{4}$ & Nov. & & “6 & 24 \\
\hline " & 10 & " & 15 & 6 & I9 & . & 6 & 16 & 29 \\
\hline "6 & 15 & $" 6$ & 20 & & 24 & " & II & Oct. & 4 \\
\hline 16 & 20 & " & 25 & " 2 & 29 & $"$ & 16 & " & 9 \\
\hline "6 & 25 & " & 30 & April & 3 & "6 & $2 I$ & $"$ & 14 \\
\hline 6 & 30 & June & 4 & & 8 & " & 26 & $" 1$ & 19 \\
\hline July & 5 & 16 & 9 & 66 & I 3 & Dec. & I & " & 24 \\
\hline 16 & 10 & " & 14 & 16 & 18 & $"$ & 6 & “" & 29 \\
\hline " & r 5 & $"$ & 19 & $" 6$ & 23 & "6 & II & Nov. & 3 \\
\hline 6 & 20 & "" & 24 & "6 & 28 & " & 16 & "6 & 8 \\
\hline
\end{tabular}


GESTITION CALENDAR.-(Continued.)

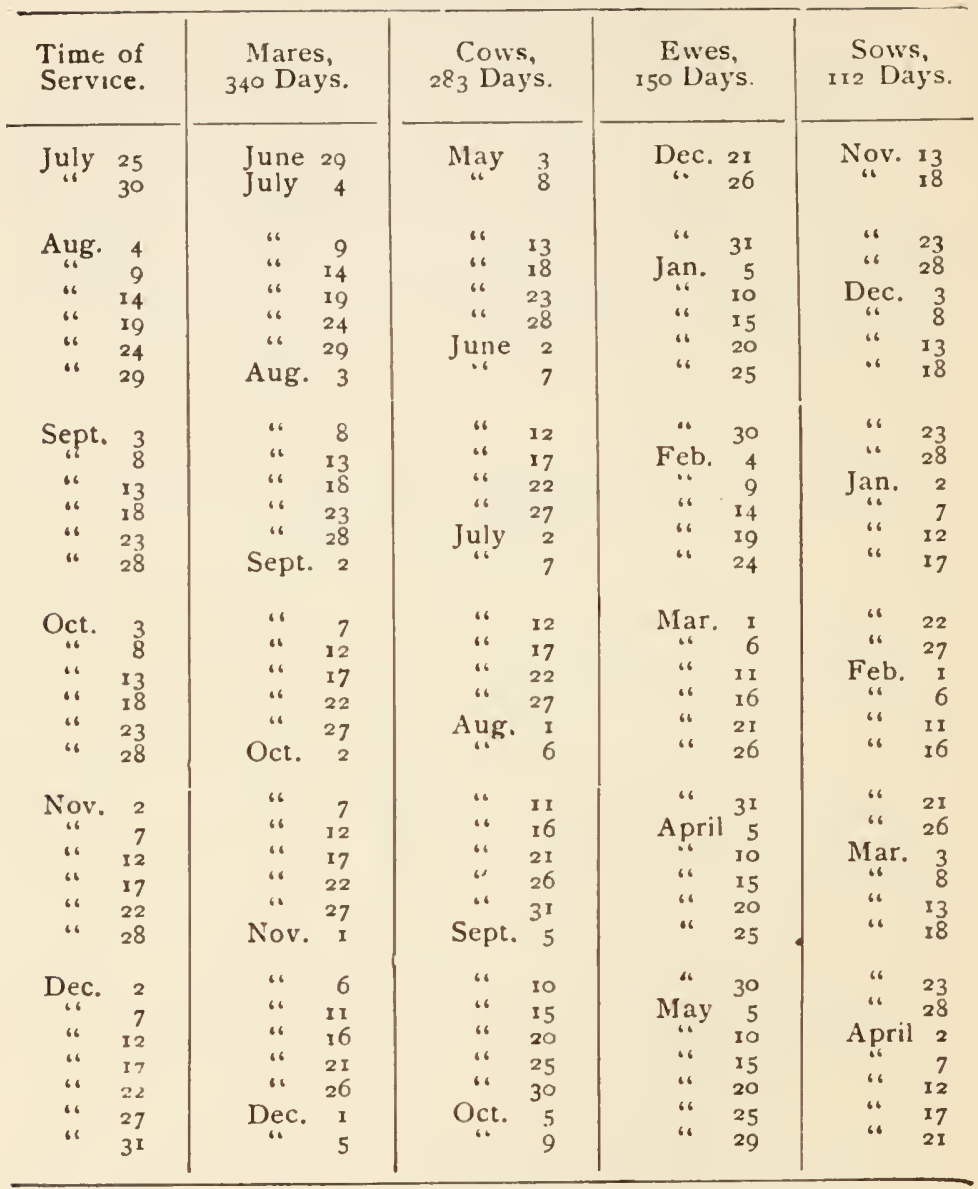

Directions.-Find the date of breeding in the first column, and follow the horizontal line in which it appears until the date in the proper column (Mares, Cows, etc.) is reached. If bred, e.g., July 26 , add one day to the required date; if July 27 or 28 , add 2 or 3 days, as the case may be. 


\section{FHEDING IND GENERAL CARE OF POULTRY.}

By Prof. War. P. Wheeler, of N. Y. (Geneva) Experiment Station.

Of the kinds of land birds and of water fowls under do. mestication the common " barnyard" fowls, of one general type, but of countless individual variations, and their pure-bred varieties, are those usually thought of when the subject of poultry is mentioned, and these are the fowls of most general practical interest. It is remarkable that the common fowl, although so widely bred, and for so long, in Europe and America has no distinctive English name.

Ducks, turkeys, and geese constitute greater or smaller portions of the market poultry according to the particular locality and season, but the common fowl, besides produc. ing most of the table poultry, is almost alone called upon for the egg supply.

The relative prices of eggs and market poultry, the proximity of markets, as well as the prices of foods, determine the relative profit in keeping larger or smaller breeds, even with eggs as the special object. The meat value of every fowl is of consideration sooner or later, and while the smaller hens will produce eggs cheaper, the greater net profit from hatching to market per hen may be with the larger breed.

Most of the pure-bred varieties have their characteristics fairly established, so that it is better business policy to employ them rather than the uncertain mongrels, which, besides their unknown capabilities, are not less likely to suffer from long and careless inbreeding. The fancier who is fitted by judgment and experience to inbreed his stock closely will know how far he can go with safety; but orie who finds it necessary to inquire about the advisability of inbreeding had better not attempt any.

Among the breeds that lay white-shelled eggs, Hamburgs, when of vigorous ancestry, probably are the most prolific. They certainly are exceptional layers, although the size of the egg is small. The Hamburg varieties possess in unusual degree pure-bred characteristics. Occasional complaints have been made in recent years concerning their stamina. 
For egg production the Leghorns are typical fowls, and where white-shelled eggs are wanted, the Leghorn varieties are more widely kept than any others.

The Minorcas, other members of the Mediterrancan class, excel the Leghorns in size of eggs, but do not equal them in number.

Some strains of several newer breeds are not far from the Leghorn in prolificacy.

Of the French breeds the Houdan is most widely bred in this country, and, for such an excellent table fowl, is an exceptional layer of large white eggs.

The Polish, often good layers, have sometimes suffered in vigor because of their beauty, which admirers hesitate to risk marring by introduction of distant blood.

Of the Asiatics, which lay brown-shelled eggs, the Langshan is high in favor with practical poultrymen. 'The Brahma, the: largest of the pure breeds, also ranks high and lays large eggs Those strains, however, bred for early laying are usually much inferior in size to the standard birds. The Cochin varieties are more particularly the pride of the fancier than of the farmer

Of the American bieeds the Plymouth Rock is undoubtedly the most popular. Its type of plumage possessses an unusual strength, even in blood much diluted, and faint reflections of the blue barring are seen in very distant relatives of the pure. breed. The perfect markings of the showroom bird are, however, quickly lost. The American breeds lay brown-shelled eggs. Different flocks vary as much as the breeds or varictie in productiveness.

Many other breeds and varieties recognized by the American Poultry Association are of considerable economic value, but are less commonly kept.

In feeding most farm animals the usual purpose is only to secure meat, wool, milk, or work, and not always is consideration necessarily given to the breeding condition and the breeding season. When poultry is kept for other than fancy purposes, the life of the individual fowl is so short that there is not only an annual necessity of growing young birds with several more or less complete sets of plumage, but egg production virtually 
implies continual reproduction, for the ultimate constituents of the egg are, with the exception of the amount obtained from the air, all that are combined in the living chick.

The body of a Leghorn pullet, about nine months old, in active laying, contains about 56 per cent of water, 2 I per cent of different nitrogenous constituents, is per cent of fat, 3 per rent of ash or mineral matter, and 2 per cent of other substances. Leghorn hens almost two years old and laying showed an average composition of 55.7 per cent water, 2 I.6 per cent nitrogenous matter, I 7.0 per cent fat, 3.8 per cent ash constituents, and I.7 per cent other substances. There was found in the body of a mature capon about 4 I.6 per cent of water, 19.4 per cent nitrogenous matter, 339 per cent fat, 3.7 per cent ash, and I.4 per cent other substances.

Notwithstanding the fact that the problem of poultry feeding $i_{S}$ much more complex than that of feeding most other farm stock, fewer carefully collected data are available in formulating feeding standards for poultry than for cattle. The following rations for laying hens are, however, near the average of those that have given best results. They are stated at the rate per rooo lbs. live weight, to compare with the standards which have been used in feeding other animals.

One thousand pounds live weight of laying hens, of about three pounds average weight, require from 65 to 100 pounds of total food, less bulky than that for the cow, or 55 pounds or more of water-free food per day, containing about ro pounds digestible protein, 35 pounds digestible nitrogen-free extract and fiber, and 4 pounds of fat. From this ration the hers would produce generally from $I_{5}$ to 30 pounds of eggs containing from 5 to ro lbs. dry matter, one pound of eggs being produced from about 3 lbs. water-free food, one pound of dry matter of eggs for each 9 lbs. water-free food.

For one thousand pounds live weight of he 's of about six pounds average weight, there should be fed from 50 to so lbs. of food per day, containing about 40 pounds of water-free food. There should be in this about 6 pounds of digestible protein, 23 pounds of digestible nitrogen-free extract and fiber, and 2 pounds of digestible fat. 
The amount of food required per day per hen varies according to the size and somewhat with the season. A smaller hen will eat more in proportion to live weight than a larger one. The difference in amount of food consumed by larger and smaller hens is less when laying than at other times when enough for maintenance only need be eaten.

A $\mathrm{Coc}^{*}$ in or Brahma hen when laying requires from $4 \frac{1}{2}$ to 8 ounces of food per day, of which $3 \frac{1}{2}$ ounces or more is dry matter. A hen of Leghorn size when laying requires from $3^{\frac{1}{2}}$ to 6 ounces of total food, or 3 ounces of water-free food per day.

A much larger amount of food in proportion to the live weight is required by the chicks than by the older fowls. The amount of water-free food required for every one hundred pounds live weight fed is 10.6 lbs. at atout one pound average weight; at two pounds $7.5 \mathrm{lbs}$; at three pounds $6.4 \mathrm{lbs}$; at four pounds $5.5 \mathrm{lbs}$; at five pounds $5.3 \mathrm{lbs}$; at six pounds $4.9 \mathrm{lbs}$; at seven pounds $4.7 \mathrm{lbs}$; at eight pounds 4 lbs.; at nine pounds $3.3 \mathrm{lbs}$; at ten pounds average live weight $3.2 \mathrm{lbs}$. The amounts of fresh food equivalent to these weights would be correspondingly greater. These are the amounts taken by growing fowls which normally attain to the higher weights given, and which are still immature and growing rapidly when at five and six pounds average weight.

For young chicks the nutritive ratio of the ration fed can be somewhat narrower than those given for laying hens, and for fattening the ration can have a very much wider ratio, although only for short periods.

For one hundred hens about 16 quarts of clean water per day is required, especially in dry hot weather. In each dozen eggs there is about a pint of water.

A variety of food is essential.

Young hens, especially of the better laying breeds, when in full laying, can be freely fed all they will readily eat, but older hens and the young ones when not laying should be fed only enough to keep them eager for food. Salt should be fed mixed with the food, but not large coarse crystals. One ounce of salt per day for one hundred hens is a good proportion.

Animal food and green or succulent vegetable food, as well 
as grain, should always be fed to hens that are confined. It is very important that ducks should have these foods, especially growing ducklings.

Some form of grit should be liberally supplied.

A largely grain ration will not contain the lime required by laying hens, and oyster-shells or some other form of carbonate of lime will supply this deficiency.

A grass run is better than any substitute in summer, but no run should contain hens in such a number as to kill the grass.

Common fowls, especially laying hens, must be kept in moderately small flocks. Where large numbers are kept, they should be divided in small lots in separate pens and yards. Ten to twenty in a pen give better results than larger numbers, although flocks twice as large can be profitably managed by experienced poultrymen. The laying hens should be kept separated from those not laying.

Hens will not always moult early enough to resume laying before midwinter. Chicks should be hatched in March and April if eggs are to be obtained from the pullets in November. Asiatics, to begin laying in the fall, should be hatched in February and March.

The best results in every respect cannot be secured where the average space of open run available per hen is much less than roo square feet. The average floor-space per hen indoors should be about io square feet.

Exercise is of the utmost importance, especially for laying and breeding stock, and a good way to assure this in winter-time is to scatter the grain in straw or any clean and dry substitute.

Dampness is fatal, and dry warm houses free from draughts are essential in winter. The floors should be of dry earth or fine gravel, or wooden floors covered with straw or dry sand. The houses should be warm enough to prevent freezing of water, but should not be warmed by heating apparatus more than will insure against freezing. 


\section{LOSS IN WEIGHT OF EGGS DURING INCUBATION.}

(Stewart and Atwood.)

Directions for ascertaining the loss in weight of eggs during incubation.

After placing the eggs upon the trays ready for the incubator, set the trays upon a pair of scales reading to ounces and note the total weight of the eggs and trays. (The trays should be thoroughly dry.) After a few days weigh again. Subtract this from the first weight. This will give the actual loss in the weight of the eggs.

Example.-Suppose that you have $20 \mathrm{~S}$ eggs on the trays; that the first weight with trays is $24 \mathrm{lb} .2 \mathrm{oz}$., and that on the sixth day the weight is $23 \mathrm{lb}$. $6 \mathrm{oz}$. Then the loss in weight is I 2 ounces. Now look in the table for the loss in weight of roo eggs for six days. This is ro ounces. Ten ounces multiplied by 208 gives 20.8 ounces, which is the calculated loss for 208 eggs for six days. Therefore the eggs have not been losing weight as rapidly as they should, and the eggs should be given more ventilation or the incubator should be removed to a drier location. (It is assumed that the eggs are kept uniformly at the proper temperature.) After the eggs have been tested for the infertile ones, weigh again and proceed as before.

Rules.-If the eggs have lost too much weight, give more moisture, or less ventilation, but in reducing ventilation great care should be used, as pure air in the egg chamber is absolutely necessary. If the eggs have not lost enough weight, open the ventilators, or place the incubator in a drier place. The table shows normal loss in weight of roo eggs in ounces for the first nineteen days of incubation.
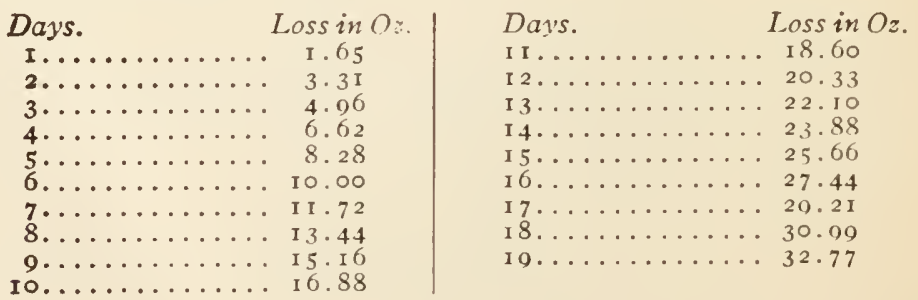


\section{STANDARD WEIGHTS OF POULTIY.}

(Am. Poultry Asso.)

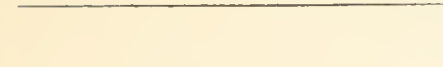

A. American Breeds.

Plymouth Rocks, Barred and Pea-combed Barred. . . . . lbs. Plymouth Rocks, White.... “ IV yandottes, Silver, Golden, and ivhite............... Javas, Black. ............... Javas, Mottled and White... “" American Dominiques. ..... ““ Jersey Blues.............

B. Asiatic Breeds.

Brahmas, Light. ..........” Brahmas, Dark.......... “ Cochins, Buff, Partridge, White and Black............. Langshans. . . . . . . . . . . . "

C. Other Breeds of Poultry.

Minorcas, Black and White. . lbs. Redcaps............... “ Houdans. .............." " Crevecoeurs.............” La Fleche. ..............” Dorkings, White.........." Dorkings Silver Gray......." Dorkings, Colored........."

Bantams, Game ........... oz. Bantams, Golden Sebright, Silver Sebright, Rose-combed White, Rose-combed Black, and Booted White....... oz. Bantams, Pekin or Cochin " Bantams, Japanese and Whitecrested White.......... oz.

Russians. .................

\section{Turkeys.}

Bronze..................lbs. Narragansett. . . . . . . . . “ Buff. Slate and Black........ white.

\section{E. Ducks.}

Pekin and Cayuga .......... lbs. Aylesbury and Rouen......" Muscovy Colored and White.. " Crested White..........."

\section{F. Geese.}

Toulouse and Embden.......lbs. African ................ Chinese, Brown and White.."

\begin{tabular}{|c|c|c|c|}
\hline Cock. & Cockerel. & Hen. & Pullet. \\
\hline $\begin{array}{l}9.5 \\
9.5\end{array}$ & $\begin{array}{l}8 \\
8\end{array}$ & $\begin{array}{l}7.5 \\
7.5\end{array}$ & $\begin{array}{l}6.5 \\
6\end{array}$ \\
\hline $\begin{array}{c}8.5 \\
10 \\
10 \\
8.5 \\
10\end{array}$ & $\begin{array}{l}7.5 \\
8.5 \\
8.5 \\
\frac{7}{7} .5\end{array}$ & $\begin{array}{l}6.5 \\
8.5 \\
8 \\
6.5 \\
8\end{array}$ & $\begin{array}{l}5.5 \\
6.5 \\
6.5 \\
5.5 \\
5\end{array}$ \\
\hline $\begin{array}{l}12 \\
11\end{array}$ & $\begin{array}{r}10 \\
9\end{array}$ & $\begin{array}{l}9.5 \\
8.5\end{array}$ & $\begin{array}{l}8 \\
7\end{array}$ \\
\hline $\begin{array}{r}11 \\
9.5\end{array}$ & $\begin{array}{l}9 \\
8\end{array}$ & $\frac{8}{7} .5$ & $\begin{array}{l}7 \\
6\end{array}$ \\
\hline $\begin{array}{l}8 \\
7.5 \\
7 \\
8 \\
8.5 \\
7.5 \\
8 \\
9.5 \\
22\end{array}$ & $\begin{array}{l}6.5 \\
6 \\
6 \\
7 \\
7.5 \\
6.5 \\
7 \\
8 \\
20\end{array}$ & $\begin{array}{l}6.5 \\
6.5 \\
6 \\
7 \\
7.5 \\
6 \\
6.5 \\
7.5 \\
20\end{array}$ & $\begin{array}{l}5.5 \\
5 \\
5 \\
6 \\
6.5 \\
5 \\
5.5 \\
6 \\
18\end{array}$ \\
\hline $\begin{array}{l}26 \\
28\end{array}$ & $\begin{array}{l}22 \\
24\end{array}$ & $\begin{array}{l}22 \\
24\end{array}$ & $\begin{array}{l}20 \\
22\end{array}$ \\
\hline $\begin{array}{l}26 \\
8.5\end{array}$ & $\frac{22}{7.5}$ & $\stackrel{22}{6.5}$ & $\begin{array}{r}20 \\
5.5\end{array}$ \\
\hline $\begin{array}{l}35 \\
32 \\
27 \\
26\end{array}$ & $\begin{array}{l}24 \\
22 \\
18 \\
16\end{array}$ & $\begin{array}{l}20 \\
22 \\
18 \\
16\end{array}$ & $\begin{array}{l}15 \\
14 \\
12 \\
10\end{array}$ \\
\hline $\begin{array}{c}\text { Adult } \\
\text { Drake. } \\
8 \\
9 \\
10 \\
7\end{array}$ & $\begin{array}{l}\text { Toung } \\
\text { Drake. } \\
7 \\
8 \\
8 \\
6\end{array}$ & $\begin{array}{l}\text { Adult } \\
\text { Duck. } \\
7 \\
8 \\
8 \\
6\end{array}$ & $\begin{array}{c}\text { Young } \\
\text { Duck. } \\
6 \\
7 \\
7 \\
5\end{array}$ \\
\hline $\begin{array}{l}\text { Alult } \\
\text { Gander. } \\
25 \\
20 \\
16 \\
16\end{array}$ & $\begin{array}{l}\text { Young } \\
\text { Cander. } \\
20 \\
16 \\
12 \\
12\end{array}$ & $\begin{array}{l}\text { Adult } \\
\text { Conse. } \\
23 \\
18 \\
14 \\
14\end{array}$ & $\begin{array}{c}\text { Young } \\
\text { Goose. } \\
18 \\
14 \\
10 \\
10\end{array}$ \\
\hline
\end{tabular}




\section{SYNOPSIS OF BREEDS OF POULTRY.}

(M. LEMOINE.)

\begin{tabular}{|c|c|c|c|c|c|c|}
\hline Breeds. & 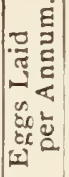 & 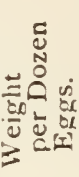 & 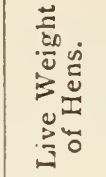 & 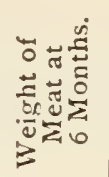 & 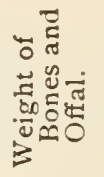 & 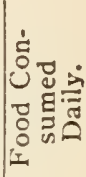 \\
\hline Andalusian & 150 & $\begin{array}{l}\mathrm{OZ} \text {. } \\
29^{1 / 4}\end{array}$ & $\begin{array}{l}\text { lbs. } \\
5-6\end{array}$ & 1b. oz. & lb. $\mathrm{Oz}$. & $\begin{array}{l}\text { Oz. } \\
63.4\end{array}$ \\
\hline 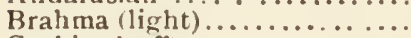 & 120 & $281 \%$ & $8-10$ & $\begin{array}{ll}3 & 1 \\
4 & 11\end{array}$ & 50 & $91 \frac{4}{2}$ \\
\hline Cochin (buff)................. & 115 & 24 & $8-10$ & 49 & $5 \quad 4 \% 4$ & $171 \frac{6}{2}$ \\
\hline Creve Coeur & 122 & 3.3 & $8-9$ & $91 / 8$ & $4 \quad 14 \%$ & $71 / 8$ \\
\hline Dorking (silver gray)... & 130 & $271 / 2$ & $7-10$ & $41 / 2$ & 14 & $63 / 4$ \\
\hline$" \quad($ dark $) ..$. & 130 & $271 / 2$ & $6-9$ & 5 & 12 & $61 / 2$ \\
\hline Game... ....... & 100 & 24 & $5-6$ & $15 \frac{1}{2}$ & $7^{3} 4$ & $41 / 3$ \\
\hline Hamburgs (silver & 239 & $201 / 4$ & $4-5$ & $31 / 2$ & $73 / 4$ & $41 / 4$ \\
\hline lan..... & $\begin{array}{l}225 \\
125\end{array}$ & $\begin{array}{l}191 / 2 \\
26\end{array}$ & $\begin{aligned} 31 / 2-4 \\
6-7\end{aligned}$ & $\begin{array}{c}15 \% 4 \\
7\end{array}$ & $\begin{aligned} 71 / 2 \\
101 / 4\end{aligned}$ & $\begin{array}{l}41 / 4 \\
63 / 4\end{array}$ \\
\hline La Flêche... & 140 & $291 / 2$ & $6-7$ & $5 \%$ & & $63 / 4$ \\
\hline Langshan...$\ldots \ldots \ldots \ldots \ldots$ & 115 & 27 & $7-10$ & $143 / 4$ & $11 / 4$ & $71 / 8$ \\
\hline Leghorn (brown)............ & 190 & 22 & $5-6$ & $3151 \%$ & $2101 / 4$ & $43 / 4$ \\
\hline linorca (black) & 180 & $281 / 2$ & $512-7$ & & & \\
\hline . & 120 & $271 / 2$ & $6-71 / 2$ & & & \\
\hline ay........... & 140 & 29 & & 3 & 12 & $63 / 4$ \\
\hline 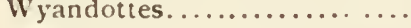 & $|140|$ & & $151 / 2-7$ & & & \\
\hline
\end{tabular}

\section{HerintTy.}

By Prof. Thos. Shaw, formerly of Minnesota Experiment Station.

Heredity in breeding relates to transmission. It is doubtless governed by fixed laws, but many of these are as yet imperfectly understood. It may be defined as the outcome of the operation of that law whereby properties and qualities of like kind with those of the parents are transmitted to the offspring. This transmission is certainly comprehensive in its character, since it relates to structure, function and qualities, and indeed to every feature of the organization. But in instances not a few there are apparent exceptions to this law of transmission. These, however, are apparent rather than real. They appear to us as exceptions because of the limitations of our knowledge of this great question. These supposed exceptions are doubtless the result of the predominant influence of other laws acting in opposition to the hereditary tendency, and it is characterized as normal, abnormal. and acquired, according to its nature. 
The heredity of normal characters means the transmission of those characters which are natural to the type. These may be original traits bestowed upon the species, as for instance, timidity in sheep; or they may have been acquired and rendered permanent by long-continued transmission, as in the changed form of all the improved breeds of domestic animals. The heredity of abnormal characters means the transmission of irregular characters, or those which have deviated from the natural and acquired characteristics of the type. These abnormal characters may appear as malformations of structure, derangement of function, or they may assume one or the other of various forms of disease. Illustrations of the first are found in certain families with an irregular number of fingers and toes; of the second in the inheritance of deafness, dumbness and impaired vision; and of the third, in the reappearance in the offspring of certain diseases possessed by the parents, as, for instance, any of the forms of scrofula

The laws which govern heredity are those also which determine the results in practical breeding. In practice the rules which govern it are almost entirely empirical in their origin, since they have been almost exclusively derived from the accepted methods of the most successful breeders. Those who have given thought to the question will concede that breeding live-stock is at once a science and an art. They will see in it a science in so far as it discovers and systematically arranges those truths and principles which relate to the improvement of live-stock, and it will appear to them an art in so far as they perceive that those principles can be successfully utilized in practice. It is apparent therefore that the relation between the science and the art of breeding is both close and intimate. Without some knowlege of the former the latter is not likely to be successfully practised, and the measure of success which attends the efforts of the breeder will be largely proportionate to the measure of the knowledge which he may possess of the principles of heredity.

Reference has been made to certain laws which govern transmission. Of these three may be considered as furda- 
mental, viz.: first, the law that "like begets like"; second, the law or principle of variation; and third, the law or principle known as atavism. Since these laws or principles appear to us to lack uniformity and regularity of action, the art of breeding is in consequence much more complicated and uncertain than it would otherwise be. This want of uniformity and of regularity of action, however, is apparent rather than real. But so long as we are ignorant of the cause or causes of these apparent irregularities in transmission, we arc unable to prevent them. And yet there is so much of uniformity in the action of these laws that the intelligent breeder cannot be said to play at a game of chance. If well posted in the art, his efforts will in the main he entirely successful.

The law that "like liegets like" implies that the characteristics of the parents will appear in their offspring. This law would seem to pervade all animated nature; generally speaking it is uniform in its action, but there are some exceptions. Were it not so, examples to illus. trate such a law of heredity and proofs to support it would not have been needed. That the existence of this law was recognized, and that many of its principles were well understood from an early period, finds ample illustration in the breeding operations conducted by the patriarch Jazob, in the monstrous forms that were bred for the amusement of the Romans when the decline of the empire was pending, and in the care with which the Arabs kept their pedizrees from a remote antiquity.

So uniform is this principle of heredity in its action that $t$ may be designated the compass which guides the breeder into the harbor of success. But before he can anchor there he must give attention to certain principles, a close adherence to which is absolutely essential to higher attainment in results. He must, for instance, breed to a standard of excellence; he must set a proper value on improved blood: and he must understand the art of selection and the principles of good management generally. Without a standard of excellence in his mind, that is, without an ideal type, the breeder does not himself know what he is secking. 
Without dominant or stable characters, in at least one parent, no stability in transmission can be looked for, and without purity of breeding for generations dominant characters cannot be secured. Hence the great importance of purity of blood in effecting improvement in domestic animals. Since some inferior animals will occasionally appear, even where the breeding is the most skilful, the necessity will always exist for the exercise of a most rigorous selection on the part of every breeder who is to stand on the upland of success. When aided by judicious selection, the law that like produces like enables us to effect improvement until a certain standard of excellence is reached, to maintain improvement when it has been secured, and to mould new types and form new breeds.

By the law or principle of variation is meant the tenlency sometimes found in animals to produce characters in the progeny which differ from those of the parental type. These changes relate to both form and function; in time they may become modificalions of the systems of animals. They may be classed as gradual, or general and ordinary; and as sudden, or spontaneous and cxtraordinary. General variation is that tendency to change from the original type which characterizes in a greater or a less degree all the individuals of a breed. Illustrations of the principle of general variation may be found, first, in the tendency of grain to deteriorate which has fallen upon an unkindly soil; and second, in the quick deterioration of the heavy breeds of sheep when confined to unproductive and rugged pastures. Chief among the numerous causes leading to general variation are changed conditions of life in animals, as climate, food, habit, and environment. Sometimes these influences act independently and sometimes in conjunction. The principle of spontaneous zariation may be defined as that tendency sometimes found in animals to produce progeny more or less unlike either of the parents or the ancestry of these. Illustrations of the operation of this principle may be found in the occasional production of progeny very unlike the parents or the ancestry in color, form, and other characteristics, and in the existence of hornless breeds of cattle. 
By atavism is meant that innate tendency in animals to revert to the original type. It differs from the principle that like produces like in the reproduction of resemblances to an ancestry more or less remote rather than to the parents, and differs from spontaneous variation in producing resemblances to an ancestry more remote than the immediate parents, whereas the latter produces characters unlike those of the ancestry, whether near or remote. I1lustrations of atavic transmission are found in the occasional apearance of scars or horns in the polled breeds of cattle bred pure for many successive generations, and in the occasional appearance of tan-colored spots on the ears and face of the American merino.

It is evident, therefore, that an intimate knowledge of the principles which govern breeding is highly important to those engaged in the production of live-stock. Hence they should study these with the utmost care and should embody them in their practice to the greatest possible extent. 


\section{VETERINARY SCIENCE.}

\section{COMMON DISEASES OF FAIM ANIMALS.}

By W. G. CLARK, M.D.C., Marinette, Wis.

\section{HORSES.}

The common method of administering medicine to the horse is in the form of a drench. In drenching a horse the bottle should be clean, strong, and smooth. The head should be elevated just enough to prevent the horse from throwing the iquid from the mouth. If the animal refuses to swallow, tickle the roof of the mouth with the finger or the neck of the bottle. Do not rub, pinch, or pound the throat, nor draw the tongue out. These in no way aid the horse to swallow and often do harm. If coughing occurs or by any mishap the bottle is crushed in the mouth, lower the head at once. Do not attempt to pour medicine through the nose; it is liable to strangle the animal.

Irritating substances, as turpentine, should be given in bland fluids such as oil or milk.

Warm-water injections are of great value in treating many bowel troubles. A very good injection pipe may be made with about 30 inches of inch rubber hose and an ordinary tin funnel. Oil the hose and insert it in the rectum from 12 to 18 inches, and elevate the funnel above the back and pour in the water. The force of gravitation will carry it into the bowels.

Soap and water, or salt and water, may be injected in this manner in quantitities of a gallon or more every hour.

\section{Spasmodic Colic.}

Causes.-Error in diet is the most prolific cause, as improper food in improper quantities at irregular intervals; large draughts of cold water when warm; eating when exhausted; intestinal parasites; or foreign bodies in the bowels.

Symproms. - The horse manifests uneasiness, moves forward and back in the stall, looks toward the flank, switches the tail, paws, lies down and rolls; after a little the spasm will subside and the animal become quiet. Soon the spasm returns with 
increased severity. As the disease progresses, the animal wiil become more violent and the intervals between the spasms shorter.

Treatment. - Always urgent, as it often runs a rapid course, terminating fatally in a few hours.

Give as a drench laudanum 1 oz., baking-soda one tablespoonful, sweet spts. nitre I oz., water one half-pint. This may be repeated in half an hour is not relieved. Always give injections of soap and warm water. Blanket the animal and rub the abdomen briskly. If inclined to hang on, apply a paste of mustard to the abdomen and give raw linseed oil I pt., chloral hydrate $4 \mathrm{dr}$., dissolved in warm water.

\section{Flatulent Colic.}

The causes and symptoms are similar to those of spasmodic colic.

The pain is not so severe at the outset and gradually increases in severity as the bowels become distended by gas. No intervals of ease as in spasmodic colic. The abdomen becomes rapidly distended and the animal dies from suffocation or rupture of the bowels unless soon relieved.

Treatment. - Usually necessary to puncture with a trocar and canula, which requires a knowledge of the anatomy of the parts. Internally give hyposulfite of soda $2 \mathrm{oz}$, fl. ex. ginger 4 dr., spts. turpentine 4 dr., water $\mathrm{I}$ pint. Repeat in half an hour if necessary. Give injection of soap and warm water at short intervals.

\section{Pneumonia-Lung Fever.}

The most common cause is exposure to a coid draught when tired and sweaty.

Symptoms. - It is usually ushered in with a chill, followed by fever. The ears and legs are cold, pulse-rate increased, labored breathing, elbows turned out, increased working of the ribs, the animal persistently stands, appetite usually lost.

Treatment.-Place in a comfortable well-ventilated boxstall. Blanket warmly, rub the legs and apply bandages. 
During the chill give large doses of stimulants, as whisky, slcohol, ginger, etc., at short intervals.

If the breathing is not relieved in a few hours, apply mustard over the ribs, just back of the shoulder-blades.

Give nourishing, easily digested food. Keep the animal perfectly quiet. Give $\frac{1}{2}-\mathrm{oz}$. doses of nitrate of potash in the drinking-water three times daily. After the chill is relieved keep a pail of fresh water before the animal at all times.

\section{Azoturia-Black-water.}

This disease is quite common among farm horses, and is due solely to overfeeding on nitrogenous foods and lack of exercise, followed by the accumulation in the system of waste matters.

Srmproms. - The animal is taken from the barn after a few days' rest on full rations, apparently as well as usual. After driving from half a mile to six or eight miles the hcrse will begin to lag and sweat profusely. Shortly will begin to go lame, usually in one hind limb. If urged on, will soon lose the use of the limbs and fall to the ground, unable to rise. The urine if passed will be dark and coffee-colored. This is a diagnostic symptom. The muscles over the hips become hard and swollen, and the animal will struggle convulsively and attempt to rise.

TREATMENT.-Unhitch the animal as soon as the first symptoms are noticed and take the horse to the nearest barn. Fold a woolen blanket and wring out of hot water and place over the hips, covering with a dry blanket. Repeat as soon as it becomes cool, and continue this until the more acute symptoms are re lieved. Internally give laudanum I oz., raw linseed oil one pint, and repeat the laudanum in an hour if the pain is not relieved. It possible, the urine should be drawn with a catheter, as it is rarely passed when the animal is down. Give injections of soapy warm water at frequent intervals.

\section{Distemper-Strangles.}

'This is a contagious disease due to a specific virus that very few horses escape. It usually runs a benign course and termi. nates favorably. 
TrEatMENT. - It is not of much use to attempt to check the course of the disease; in all cases proper shelter and nursing are most important.

Give laxative sloppy food and apply warm poultices to the throat, to hasten suppuracion. In no case give purging or depressing medicines. In fact, the whole treatment consists in producing and favoring the discharge of the abscess. As soon as fluctuation can be detected the abscess should be opened. When the disease assumes the malignant form or is complicated, apply to a competent veterinarian.

\section{Sprains.}

TREATMENT.-Rest in a quiet well-bedded stall. If the injury is below the knee or hock and the weather is warm, bathe the part three times daily for an hour at a time with cold water and rub dry.

If above the knee or hock, or the weather is cold, use hot water.

After bathing apply a mild stimulant, as spirits of camphor, arnica, etc.

If the lameness persists after the active inflammation is re. duced use the following liniment: aqua ammonia and spirits turpentine, $4 \mathrm{oz}$; of each linseed sil $8 \mathrm{oz}$. : mix and apply twice daily with friction.

\section{Punctured Wounds of the Foot.}

In all cases the horn around the seat of the injury should be thinned down and a free opening made for the escape of the products of suppuration. Cauterize the wound with 95 per cent carbolic acid and apply a poultice. Change twice daily and dress the wound with the following lotion: Zinc sulph. I oz., sugar lead I oz., carbolic acid 4 dr., water I pint.

\section{Thrush.}

The most common cause of thrush is the filthy condition of the stable in which the horse is kept. Muddy yards and roads, also hard work on rough, stony roads may excite this disease.

Symptoms.-Increased secretion in the cleft of the frog and an offensive odor. After a time considerable discharge takes place and there is rapid destruction of the rissue of the frog.

TrEaTMENT.-Remove the cause. Cut away all diseased tissue and cleanse the foot thoroughly. Take white vitriol I oz., and water 6 ozs. Saturate pledgets of tow or cotton with the solution and crowd into the cleft and each side of the frog. Dress once daily until the dicrhorce ceases. 


\section{Cuts from Barb-wire, etc.}

When bleeding to any extent follows a wound, this must first be checked.

A moderately tight bandage with oakum, tow, or cobwebs will usually stop the bleeding in a short time. If the blood is bright red and flows in jets,apply a compress between the wound and the heart.

If it is dark and the flow regular, apply pressure between the wound and the extremity. Cleanse the wound thoroughly with warm water and a soft sponge. Then dress with a 3 per cent solution of carbolic acid and apply a bandage so as to bring the edges together. If proud flesh appears, treat it with burnt alum.

\section{COWS.}

\section{Milk Fever.}

Symptoms. - Dulness, uneasy movements of the hind limbs, head and horns hot; the animal soon becomes weak and unable to rise, head laid back on the flank or dashed to the ground, bowels constipatcd, sensation usually lost.

Treatment.-Air treatment properly administered under antiseptic conditions has practically removed the danger of this disease. The necessary apparatus, which costs $\$_{2}$ to $\$_{3}$, can be purchased of veterinary instrument dealers or dairy-supply houses. Directions for use accompany the apparatus.

Prevention.-Do not milk the udder dry at any time for the first few days after calving, withdrawing a portion of the milk at intervals of 4 to 5 hours to relieve distention of the udder. Give a spare diet for a week before and after calving. If constipated after delivery, give a purgative dose of salts.

\section{Garget.}

Causes.-Irregularities of diet, overfeeding on stimulating food, exposure to cold, external injuries, as blows, etc.

Symptoms.-Seldom attacks the whole udder. Swelling, heat, pain, and redness of the inflamed portion. The mllk is curdled, whey-like, and mixed with blood. In severe cases there is much constitutional disturbance.

Treatment.-Endeavor to discover the cause and remove it. The food should be devoid of milk-producing constituents. Draw the milk frequently, using a milking-tube if 
necessary. If the weather is warm, bathe the udder for an hour or mure with hot water.

Take fluid extract belladonna I oz., glycerin 2 oz.; mix and apply three times daily with mild friction. Give two teasponnfuls fluid extract bellatonna three times daily. If constipated, give Epsom salts I ỉb, ginger I oz., water I qt.

\section{Abortion.}

The cow may abort from any cause profoundly disturbing the nervous system, inflammation of the internal organs, diarrhoea, acute indigestion, blows on the abdomen, expos. ure to cold storms, drinking ice-water, feeding on ergotized grains and grasses, and infection from abortion discharges of other animals.

Symproms. - If it occurs within the first two months it is not apt to be noticed. During the latter part of gestation abortion resembles normal delivery, except that more effort and straining are present.

TREATMEXT. - The most important object in an impending abortion is to recognize it as soon as possible and apply preventive measures. Place in a quiet dark stall and check straining by sedatives. Laudanum $\mathbf{I}$ oz.; repeat in twr hours if necessary; or fl. ex. black haw. in same doses.

After an abortion burn the fœtus and afterbirth and all litter that is soiled, or bury deeply and cover with quicklime.

Flood the womb with a $2 \%$ solution of carbolic acid and wash the external organs once daily with a $5 \%$ solution. Separate from the herd ior 30 days.

In epizootic abortion material benefit has in many cases been derived from phosphate of lime. Small doses ( $\frac{1}{2} \mathrm{dram}$ ) mav be given daily in the food.

\section{Hoven or Bloat.}

CAuses.-Overeating, choking, frosted roots, and fermentation of the food.

TrEatMEnT.- In urgent cases tap on the left side at a point equidistant from the point of the hip, the last rib and the processes of the lumbar vertebræ, pointing the troca: 
or knife downward, inward, and forward. If slight give spts. turpentire I oz., raw linseed oil $\frac{1}{2}$ pt., and place a gag in the mouth.

When relieved give a purgative and keep on a light diet for a few days.

\section{Diarrhoea in Calves.}

Always due to indigestion and caused usually by overfeeding or improper food.

Prevention.-Feed at least three times daily. The milk should be sweet and fed at a temperature of $90^{\circ}$ to $100^{\circ} \mathrm{F}$. The pails used in feeding should be kept sweet and clean.

TREATMENT.-Cut down the ration, scald the milk or add lime-water in the proportion of $I$ to 5 . If the discharges are bright yellow give castor oil I to 2 tablespoonfuls. If there is great weakness give small doses of stimulants (ginger, brandy, whisky).

\section{Choking.}

Common among cattle when fed on roots, etc. To prevent tie the head so that it cannot be thrown up, or with hold dangerous foods.

Symptoms.-Head extended, bloating, labored breathing, continuous coughing. If in the throat there is great distress and the animal may die quickly. If lower the symptoms are not as acute.

TREATMENT. - If in the throat remove with the hand. If below reach and the object can be located from the outside, give small drenches of linseed oil and manipulate from the outside. Take time. Do not apply too much force. Usually best to work the object toward the throat.

If unable to remove the object it must be pushed down; this may be done with a piece of $\mathrm{x}$-in. rubber-hose, $6 \mathrm{ft}$. ir length, well oiled, and inserted in the gullet, and gently force the object down.

\section{Tuberculosis.}

Tuberculosis is an infectious disease characterized by the formation in the various organs of the body of tubercles or 
nodules, and is due to a specific micro-organism, the bacillus tuberculosis.

Tuberculosis in animals is identical with tuberculosis (consumption) in the human family, the ravages of which are far greater than those of any other disease.

The death rate from consumption, which is but one of its many forms, is about one in seven.

All domestic animals are more or less subject to the disease. Dairy cattle, however, in consequence of their mode of life and the heavy drain on their system from cxcessive breeding and milking, are more predisposed to the discase than any other of the domestic animals.

Cause. - The essential cause is the specific germ, the tubercle bacillus, without which the discase could not exist. Since the disease is found in the lungs in a large proportion of cases, it is evident that tuberculosis is usually contracted by inhaling the germs with the air. It may also be caused by the ingestion of infected meat and milk and by direct inoculation.

The development of the disease is farored by anything that tends to impair the gencral health of the animal, as overcrowding in poorly ventilated stables, harcditary predisposition, in-and-in breeding, lack of exercise, errors in diet, etc.

Symptoms. - The symptoms are very obscure, and in some cases where the disease is well advanced there is seemingly little alteration in the health of the animal. The most prominent symptoms are a short, husky cough, enlargement of the lympl glands around the throat, dulness, capricious appetite, staring coat, and emaciation.

Persistent œestrum or heat, with barrenness, especially when there is a harsh, staring coat and general unthrifty condition, is suspicious.

The Tuberculin Test.-Tuberculin is a glycerin extract of the soluble products produced by the growth of the tubercle bacillus, concentrated, filtered, and sterilized. When properly prepared it contains no living germs and cannot produce tuberculosis. It was introduced to the medical profession by Dr. Koch as a cure for tuberculosis. 
Although it has not found practical application as a curative agent. it furnishes us the best diagnostic agent for bovine tuberculosis yet known (see page 69).

A summary of statistics indicates that about 88 per cent of tuberculous animals show the reaction fever on inoculation, while go per cent that were declared free from disease on account of the absence of fever did not show on autopsy any signs of the disease.

Prevention.- The stables should be light and well ventilated. Cattle should be kept from interchange of stalls or stanchions. Breed only from healthy animals. No consumptive person should be ailowed to care for stock.

Isolate all suspected animals. Such animals should be examined by a competent veterinarian, and if found to be tuberculous the whole herd should be tested. Tuberculous animals should be killed and the carcasses burned or buried deeply and covered with quicklime. Disinfection should be thorough. Remove and burn all litter. Burn sulphur in the closed stable. Wash or spray all woodwork with a solution of corrosive sublimate, one part, to nne thousand parts of water.

Corrosive sublimate is a deacly porson and should be used with care. Whitewash with freshly slaked lime.

\section{SHEEP.}

\section{Scal.}

Due to parasitic mites which infest the skin.

Symptoms.-Intense itching, small reddish pimples ap. pear, rupture, and discharge a watery fluid; scabs form, the wool falls out in patches. Large sores sometimes result from the incessant rubbing. The parasite may be seen with a low-power lens.

TREATMENT.-Take one pound of tobacco to each five gallons of water and boil until the strength is exhausted from the leaves. Strain and add one pound of sulphur to each five gallons. Allow each sheep to remain in the bath for five minutes, working the solution into all parts of the skin and breaking up the scabs. Place on a slooping rack and press the liquid out of the fleece, allowing it to run back into the trough. The same dip may be: used for ticks. 


\section{Foot-Rot.}

Separate the sound animals from the diseased ones and irom contaminated pastures and buildings. Carefully remove all diseased horn and foreign bodies and walk the sheep through a :rough containing one pound of blue vitriol to three gallons of water. Place the irfected flock on a dry upland pasture, if possible.

\section{Grub in the Head.}

This is the larvæ of a small gadfly (vestrus ovis) which deposits its eggs within the nostrils. It stays there during th. winter and spring, often proving harmless, but sometimes causing much irritation, a white muco-purulent dissharge, with dullness and stupor.

Prevention.-Smear the nose with tar, or feed salt from two-inch augur-holes bored in a log, the surface of which is smeared with tar.

TREATMENT.-Place in a warm building and introduce into the nostrils snuff, a solution of tobacco, or turpentine and olive-oil equal parts, to kill the larvæ or cause their expulsion by sneezing; or place in a close room and subjer to the fumes of burning sulphur for 15 min., as strong as can be endured, once daily for 3 or 4 days.

\section{SWINE.}

\section{Hog Cholera.}

A specific contagious fever of swine.

Symptoms. - The period of incubation varies from three to fifteen days. Shivering, nose hot and dry, later refuses focd, lies under the litter, eyes sunken, gait unsteady. Heat and soreness of the skin, with tenderness, red patches and black spots; labored breathing; hard, dry cough; soreness of the belly; costiveness, followed by a fœtid diarrhoea.

Prevention.-If it breaks out in a herd, kill and bury the diseased. Thoroughly disinfect everything they have come in contact with, using one-half ounce of corrosive sublimate in four gallons of water. Burn all straw and litter. Give the healthy ones clean, dry quarters. If possible, divide up the herd, placing a few in each pen. Allow free access to 
wood or animal charcoal and give in the drinking-water ter drops of carbolic acid for each one hundred and fifty pounds of live weight. Take the temperature daily, inserting a clinical thermometer in the rectum, and remove every animal showing a temperature of $103^{\circ}$ or over.

Kill and bury as soon as the symptoms of the disease are well manifested.

Medicinal treatment of the disease is of but little avail. A good dietetical treatment, including a strict obser vance of sanitary principles, is of much more importance than the use of medicines.

The pens should be kept scrupulously clean. The food given should be clean, of the best quality, and easily digested. The troughs used in feeding should be thoroughly cleaned at least once daily. Keep away from infected herds, as the germs may be carried on the shoes or clothing. It is said that the virus will blow half a mile on the wind. It may also be spread by birds and dogs.

\section{IntestinaI Worms.}

This is one of the most common troubles of swine.

Symptoms. - A cough is usually the first symptom noticed; animals have a voracious appetite, yet lose flesh and exhibit general signs of ill health. If the fæces are examined the worms or their eggs can usually be found.

TrEatMEnT.-Give one teaspoonful of spirits of turpentine for each one hundred and fifty pounds of live weight once daily in milk or oil. Place common salt where they can have free access to it. Give nutritious, easily digested food.

\section{VETERINARY REMEDIES AND DOSES.}

By W. G. Clark, M.D.C., Marinette, Wis.

Graduation of Doses.

\begin{tabular}{|c|c|c|}
\hline Horse. & $\mathrm{Ox}$ & Dose. \\
\hline $\begin{array}{l}3 \text { years. } \\
2 \text { ". } \\
1 \\
6 \text { months. } \\
1-6\end{array}$ & 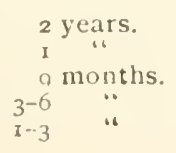 & $\begin{array}{l}\text { I part. } \\
2 / 36 \\
1 / 30 \\
1 / 8 \text { " } \\
\text { s/16--1/32 pirt. }\end{array}$ \\
\hline
\end{tabular}


When not specified, the doses given apply to a full-growr. horse of medium size. Dose for the ox, from $1 \frac{1}{2}$ to 2 parts: sheep, $\frac{1}{8}$ to $\frac{1}{4}$ part. Animals of a nervous temperament are usually more susceptible to the action of drugs.

No agent should be given until sufficiently diluted to prevent irritation of the mouth, and irritants that will not mix with water(turpentine, ete.) should be given in linseed oil, milk, or eggs, after being thoroughly mixed.

Raw Linseed Orl.-Dose: Horse, one half-pint to one quart. Laxative in small doses, purgative in large. Nor so active as castor oil. A valuable laxative in young and delicate animals. For calves and lambs it is more gentle and safer than salts. In adults it is the best laxative to use where there is an irritable condition of the bowels, and in all febrile diseases where a laxative is needed. In impaction of the bowels a pint may be given two or three times daily until relieved, supplemented by warm-water injections every two hours. Valuable in cases of choking on account of its lubricating qualities.

CAstor OrL.-Causes more griping and nausea than linseed oil and is more certain in its action. Used chiefly as a laxative for calves, foals, sheep, swine, and dogs.

Useful in diarrhoea of calves and other young animals when the discharges are bright yeilow and irritating. Dose for a calf, from I to + tablespoonfuls.

Epson Salts. -For cattle this is the purgative in most frequent and general use. Adult cattle take from I lb. to I $\frac{1}{2}$ lbs. In small doses in febrile diseases it lowers the temperature, improves the appetite, and helps to maintain a healthy and regular action of the bowels. Epsom salts is one of the best antidotes for lead poisoning. When used as a purgative, give from 1 to $20 z$. ginger with the salts.

Oil of Turpentine, (Spts. Turpentine), -Dose: Horse, $\frac{1}{2}$ to I oz. Very irritating to the mucous membrane, and when used internally should be given in oil or some bland fluid. Stimulant and anti-spasmodic. One of the most useful remedies in flatulent colic in the horse, and hoven or bloat in the ox. Also used to kill and expel intestinal worms. When used for this purpose, it is given after fasting in 
large doses, I $\frac{1}{2}$ io $2 \mathrm{oz}$. for the horse, followed in $\mathbf{2}$ hours by a purgative.

Applied externally it is an irritant and is used in many liniments. The following liniment may be used where a mild counter-irritant is desired : Oil of turpentine and aqua ammonia, of each $+\mathrm{oz}$, linseed oil $S \mathrm{oz}$. Mix. This liniment is used chiefly for rheumatic swellings, sprains, and bruises after the active pain is subdued by fomentations, and for sore throats, as seen in distemper.

Alconol.-Dose: Horse, $\frac{1}{2}$ oz. well diluted, whisky or brandy 2 to $4 \mathrm{oz}$. Alcohol is a narcotic poison. It first stimulates, then deranges, and ultimately depresses the functions of the brain and spinal cord. It kills, as a rule, by paralysis of respiration. Medicinally it is a very valuable, diffusible stimulant, anti-spasmodic heart tonic and antiseptic. Moderate doses increase the gastric secretions and aid digestion, but large doses destroy pepsin, arrest secretion, and interfere with absorption. There is probably no drug more extensively used than alcohol. It is useful in Indigestion, spasmodic colic, cases of poisoning by aconite or cobacco. It is valuable in influenza and debilitating diseases. In blood-poisoning whisky combined with quinine is one of the most effective agents we have in controlling the temperature and keeping up the strength of the animal.

The following is very useful in some cases of indigestion: Whisky I pt., quinine (sulfate) I oz., water I pt. Mix. Give 3 ounces at intervals of 3 to 4 or 6 hours, according to the nature of the case.

Saltpeter (Nitrate of Potash).-Dose: Horse, i teaspoonful to half an ounce. Large doses are irritant and cathartic and are liable to cause inflammation of the bowels. Medicinal doses are discretive, alterative, antiseptic, febrifugal, and refrigerant. In febrile, inflammatory, and rheumatic complaints it allays fever, lowers excessive tem. perature, and removes by the kidneys both solid and fluid matters. Dissolved in water and applied externally it ab. stracts heat and is a useful refrigerant. Combined with sulfate of iron it makes an excellent tonic for horses recovering from debilitating diseases. 
Saltpeter 2 oz., dried sulf. iron 3 oz. Mix. Give 2 teaspoonfuls with the feed 2 or 3 times daily.

Alum.-Alum is an astringent. Chiefly used externally. Use a saturated solution in hot water. Applied to the shoulders of horses in the spring it toughens the skin and prevents collargalls. Useful in healing harness.galls. One of the best lotions to apply to barb-wire cuts and other wounds of a similar nature to prevent growth of proud flesh. Sometimes dusted over the surface in the form of burnt alum; not so effective as the saturated solution.

Ginger.-Dose: Horse, $\frac{1}{2}$ to $\mathrm{I}$ oz. Ginger stimulates the various mucous membranes with which it comes in contact. Administered internally it increases the gas. tric secretions, facilitates digestion, and checks formation of gas. It is a useful adjunct to many medicines and is given with tonics and stimulants. Combined with purgatives it diminishes their liability to nauseate and gripe, and also hastens their effect. It is used in all domesticated animals to fulfil those purposes, and is espccially adapted to cattle and sheep.

CARBOLIC ACID.-One of the best and cheapest disinfectants known. For dressing fresh wounds it may be used in from 2 per cent to 5 per cent watery solution. In oil $\mathrm{I}$ part to 15. Inhalation of the vapor with steam is of great service in malignant sore throat and abscesses following strangles. Carbolic acid is a narcotic irritant poison, and considerable care must be exercised in its use, as it is liable to become absorbed and produce poisonous effects if ap. plied over a large surface in a strong solution. It has been highly recommended in the treatment of hog cholera. It may be given to hogs in doses of from I to 5 drops well diluted.

PINe TAR. - Not much employed internally. It is a good dressing in thrush and canker of the horse's foot. It is also of special service in foot-rot in sheep. It acts as a stimulant and deodorizer to foul-smelling wounds and prevents the attacks of fies.

LIME WATER. - Lime water is prepared by slaking a small quanticy of freshly burned lime with a large quantity of 
water, allowing the undissolved matter to settle and pour. ing off the clear solution. This should be kept in tightly corked bottles. Lime water is an alkali and is used in indigestion, bloat, and diarrhœa, especially among calves. Given with the milk in the proportion of $1: 5$. Scalds and burns may be treated with carron oil, which is composed of lime water and linseed oil, equal parts. Fresh lime in powder and solution is used in cleansing and disinfecting stables. For this purpose a little carbolic acid may be added to the solution.

SUlFur. - In large doses it is an active irritant poison. In medicinal doses it is a laxative, alterative, and stimulates secretion. Care should be taken to prevent the animal from taking cold when given sulfur. It opens the pores of the skin and stimulates perspiration. Chiefly used in treat. ing rheumatism and chronic skin diseases. Dose: Horse, $\frac{1}{4} \mathrm{Oz}$. to $2 \mathrm{oz}$.

\section{SUPPRESSION OF HOG CHOLERA AND SWINE Pliaue. (Craig.)}

CAuses.-Hog cholera and swine plague are caused by different bacteria, but they are equally dependent for the success of their attacks on the unhealthiness of the hogs, due in most instances to unwholesome food and filthy sur. roundings. The causes are so similar and the symptoms are so much alike and often complicated that it will be best to consider the diseases together in what follows. The germs that cause them are easily spread over large terri. tories by being carried by cars, wagons, or the shoes of persons that have been among infected hogs. Most frequently the origin of the outbreak may be traced to the importation of hogs from diseased districts or to spread from such centers by running streams.

Symptoms. - The first symptoms usually shown in attacks of these diseases are those that indicate fever-a rise in temperature, thirst, loss of appetite, and redness of the skin on the lower part of the neck and inner side of the thigh. Usually a hog so diseased begins to cough when started 
from its bed. A constipated condition of the bowels changes to diarrhoa as the disease progresses, and this results in a rapid loss of flesh. Dissection generally shows the lungs to be inflamed, the spleen enlarged, or the lining of the large intestine covered with numerous ulcers.

Prevention.- To protect hogs from attacks of these diseases it is necessary to observe the following recommendations: The hogs should not be watered at running streams, as the germs are readily carried by these. Persons coming from infected districts should not be allowed to go near your hogs, and you should not go among your neighbors' hogs if they are sick. When other hogs are brought to your farm, assume that they are infected and keep them away from yours at least for six weeks. Observe as much cleaniness as possible in regard to food and surroundings. Feed a mixture of foods in a sloppy or soft condition, and withold heavy grain feeding. Disinfect the quarters of the hogs by sprinkling liberally with a five per cent solution (by volume) of carbolic acid, and use a two per cent solution of the same for washing the hogs.

TrEaTMENT.-The hogs showing any of the symptoms described should at once be separated from the others, and put in cheaply constructed quarters, so that the latter may be burned when no longer required. The well hogs should be removed to disinfected quarters. Give all the hogs the following mixture, recommended by Dr. Salmon, Chief of the Bureau of Animal Industry:

Wood charcoal ................... I lb.

Sulfur....................... I “

Sait....................... 2 lbs.

Baking-soda..................... 2 "

Glauber's salts................... I lb.

Sodium hyposuifite................. 2 lbs.

Antimony sulfid.................. I $1 \mathrm{~b}$.

This should be given in soft food in the proportion of a teaspoonful daily to a two hundred pound hog. Remove all refuse from the pens in which the infected hogs were kept, and dig out the old soil, put in fresh earth. disinfect 
with carbolic acid solution, and allow the pens to remain vacant for at least six months. The same feeder should not attend the well and the sick hogs unless his shoes are changed after each visit to the sick hogs. The bodies of the dead hogs shouid be thrown into a rubbish heap and burned; but if this cannot be easily carried out, a long, deep trench should be dug, and when the carcases are thrown into it they should be covered with a layer of quicklime and at least six inches of earth. When the disease has spent itself or has been effaced, the entire mass in the trench should be covered with six inches of quicklime and at least six feet of earth. The place selected for the burial of the hogs should not drain towards a stream, and it would be better to fence it. The dead hogs should never be drawn over the ground, and the wagon used should be washed with a disinfectant.

During the last few years the serum treatment of swine plague and hog cholera has been introduced experimentally by the Bureau of Animal Industry of the U. S. Dept. of Agriculture. Although the results so far obtained are very promising, further studies are required before the efficacy and practicability of the method can be considered proved. Farmers whose hogs are attacked by hog cholera, or who fear such an attack, should at once communicate with the Bureau or with the State authorities and ascertain what assistance can be had.

\section{DIREC'TIONS FOR MAKING TUBERCULIN TESTS.}

Animals must be kept in as nearly a normal condition as possible during the test. Before injection take four temperatures, about two hours apart. Inject in the evening at about nine o'clock; begin taking temperatures eight to ten hours after the injection and continue until at least five temperatures, two hours apart, have been taken. In case an animal shows an abnormally high temperature at the end of this period continue taking temperatures until a decided drop toward the normal is noted.

A rise of 2 to $2.5 \mathrm{deg}$. F. above the average norma! body temperature, maintained for several hours, is considered a positive 
reaction, especially when the maximum temperature goes above I $0_{4}$ deg. F.

Precaution.-Water before beginning the temperature readings the first day of the test; on the second day give a small quantity (a pailful or so) in barn, if necessary, and turn stock out in the afternoon for further watering. Large quantities of cold water reduce the temperature, and if animals are watered at the usual time in the morning on the day following the injection, marked crrors may be caused in the test. (Wis. Exp. Station.)

\section{LIST OF IDINFECTANTS.}

(STEKNBERG.)

The most useful agents for the destruction of spore. containing infectious material are:

I. Fire-Complete destruction by burning.

2. Stedm under Pressuri, $105^{\circ} \mathrm{C} .\left(22 \mathrm{I}^{\circ} \mathrm{F} .,\right)$ for ten minutes.

3. Boiling in Walce for half an hour.

4. Chlorid of Lime (should contain at least 25 per cent of available chlorin). - A 4 per cent solution.

5. Mercuric Chlorid.-A solution of $\mathrm{I}-500$.

For the destruction of infectious material which owes its infecting power to the presence of micro-organisms not containing spores, any of the following agents are recom. mended:

I. Fire.-Conplete destruction by burning.

2. Boiling in water for ten minutes.

3. Dry Heat, i io" C. $\left(230^{\circ} \mathrm{F}\right.$.), for two hours.

4. Chlorid of Lime.-A 2 per cent solution.

5. Solution of Chlorinated Soda (should contain at least 3 per cent of available chlorin). - A ro per cent solution.

6. Mercuric Chlorid.-A solution of $\mathrm{I}-2000$.

7. Carbolic Arid.-A 5 per cent solution.

8. Sulfate of copper.-A 5 per cent solution.

9. Chiorid of Zinc.-A Io per cent solution.

IO. Sulfur Dioxid (this will require the combustion of between 3 and 4 lbs. of sulfur for every Iooo cubic feet of air-space).-Exposure for twelve hours to an atmosphere containing at least 4 volumes per cent of this gas, in presence of moisture. 


\section{RULES FOR DISINFECTION OF STABLES.}

In Case of Appearance of Contagious Diseases.

(TRUMBOWER.)

I. Have all loose litter, hay, and rubbish removed and burned.

2. Have all manure removed to land where cattle have no access.

3. Have all feed-troughs, hay-racks and all woodwork thoroughlycleaned by washing with hot water in which two ounces of carbolic acid to each gallon of water are dissolved.

4. Thoroughly whitewash the whole of the interior of the building with a whitewash containing one pound of chloride of lime to each four gallons of water. Enough freshly burned quicklime should be added to make the wash show where applied. Especially should this be applied to the sides and front of the stalls, feed-troughs and hay-racks (inside and outside).

5. All rotten woodwork to be removed and burned, and replaced with new.

6. All buckets, forks, shovels, brooms, and other objects used about the stable to be washed and covered with the same solution.

7. All drains to be thoroughly cleaned and disinfected with a solution of chloride of lime, one pound to four gal. lons of water.

8. In cases of glanders, all harness, poles, and shafts of wagons, neck-yokes and pole-straps should be thoroughly washed with hot water and soap, and afterwards oiled with carbolized oil (one part of carbolic acid to ten of oil). Before applying the oil, harness should be hung up in the open air for one week.

\section{REGUIATONS FOR THE GOVERNMENT OF Dairies and Dairy Farms in the District of Colum- bia.}

SECTION I.-No building shall be used for stabling cows for dairy purposes which is not well lighted, ventilated, drained, and constructed. 
SEc. 2.-No building shall be used for stabling cows for dairy purposes which is not provided with a suitable floor, la1d with proper grades and channels to immediately carry off all drainage; and if a public sewer abuts the premises upon which such building is situated, they shall be connected therewith whenever, in the opinion of the health officer, such sewer connection is necessary.

SEc. 3.-No building shall be used for stabling cows for dairy purposes which is not provided with good and sufficient feeding-troughs or boxes, and with a covered watertight receptacle, outside of the building, for the reception of dung and other refuse.

SkC. 4.-No water closet, privy, cesspool, urinal, inhabited room, or workshop shall be located within any building or shed used for stabling cows for dairy purposes, or for the storage of milk or cream, nor shall any fowl, hog, horse, sheep, or goat be kept in any room used for such purposes.

Sec. 5. - The space in buildings or sheds used for stabling cows shall not be less than five hundred cubic feet for each cow, and the stalls therefor shall not be less than four feet in width.

Skc. o. - It shall be the duty of each person using any premises for keeping cows for dairy purposes to keep such premises thoroughly clean and in good repair and well painted or whitewashed at all times.

SEc. 7.-It shall be the duty of each person using any premises for keeping cows for dairy purposes to cause the building in which cows are kept to be thoroughly cleaned, and remove all dung from the prenises so as to prevent its accumulation in great quantities.

SEc. 8. - It shall be the duty of any person having charge or control of any premises upon which cows are kept to notify the health officer, in writing, of the existence of any contagious or infectious disease among such cows, within twenty-four hours of the discovery thereof, and to thoroughly isolate any cow or cows affected or which may reasonably be believed to be infected, and to exercise such 
other precautions as may be directed, in writing, by the health officer.

SEC. 9.-Any person using any premises for keeping cows for dairy purposes shall provide and use a sufficient number of receptacles made of non-absorbent materials, for the reception, storage, and delivery of milk, and shall cause them at all times to be cleansed and purified, and shall cause all milk to be removed without delay from the rooms in which the cows are kept.

SEC. IO.-Every person keeping cows for the production of milk for sale shall cause every such cow to be cleaned every day and to be properly fed and watered.

SEC. Ir.-Every person using any premises for keeping cows shall cause the yard used in connection therewith to be provided with a proper receptacle for drinking water for such cows; none but fresh, clean water to be used in such receptacle.

SEC. I2.-Any enclosure in which cows are kept shall be graded and drained so as to keep the surface reasonably dry and to prevent the accumulation of water therein, except as may be permitted for the purpose of supplying drinking water; no garbage, urine, fecal matter, cr similar substances shall be placed or allowed to remain in such enclosure, and no open drain shall beallowed to run through it.

SEC. I3.-These regulations shall apply to all premises upon which cow's milk is produced for sale.

SEC. I4.-That any person violating any of these regulations shall, on conviction in the police court of said district, be punished by a fine of not less than five nor more than ten dollars for each and every offense, to be collected as other fines and penalties are collected.

(See also p. 272, Rules and Regulations to be observed in the care of cows and the handling of milk shipped to the City of New York.) 


\section{FIEI,D CROPS.}

QUANTITY OF SEED REQUIRED TO THE ACRE. (WARING.)

Designation. Quantity

Wheat......... I I to 2 bu.

Barley ....... I I to $2 \frac{1}{2}$ bu.

Oats.......2 to 4 bu.

Rye.......... I to 2 bu.

Buckwheat...... \& to $\mathrm{I} \frac{1}{8} \mathrm{bu}$.

Millet......... I to $\mathrm{I} \frac{1}{2} \mathrm{bu}$.

Corn........... $\frac{1}{4}$ to I bu.

Beans......... I to 2 bu.

Peas.........2 $2 \frac{1}{2}$ to $3 \frac{1}{2}$ bu.

Hemp......... I to $\mathrm{I} \frac{1}{2} \mathrm{bu}$.

Flax.......... $\frac{1}{2}$ to 2 bu.

Rice ........2 to $2 \frac{1}{2}$ bu.
Designation.

Quantity

of Seed.

Broom-corn.... I to $\mathrm{I} \frac{1}{8}$ bu.

Potatoes....... 5 to io bu.

Timothy....... I 2 to 24 qts.

Mustard...... 8 to 20 qts.

Herd grass..... I 2 to 16 qts.

Flat turnip..... 2 to 3 lbs.

Red clover...... Io to I 6 lbs.

White clover... 3 to 4 lbs.

Blue grass...... Io to I 5 lbs.

Orchard grass... 20 to $30 \mathrm{lbs}$.

Carrots....... 4 to 5 lbs. Parsnips...... 6 to 8 lbs.

When planted in rows or drills:

Broom-corn..... I to $I_{\frac{1}{2}}$ bu. Beans......... I I $\frac{1}{2}$ to 2 bu. Peas........... I $\frac{1}{2}$ to 2 bu.
Onions....... 4 to 5 lbs. Carrots........ 2 to $2 \frac{1}{2}$ lbs. Parsnips...... 4 to 5 lbs. Beets......... 4 to 6 lbs.

SEED USED PER ACRE. (MCKERROW.)

\begin{tabular}{|c|c|c|c|c|c|}
\hline & $\begin{array}{c}\text { Drilled, } \\
\text { Bus. }\end{array}$ & $\begin{array}{c}\text { Broad- } \\
\text { cast, } \\
\text { Bus. }\end{array}$ & & $\begin{array}{c}\text { Drilled, } \\
\text { Lbs. }\end{array}$ & $\begin{array}{c}\text { Broad- } \\
\text { cast, } \\
\text { Lbs. }\end{array}$ \\
\hline 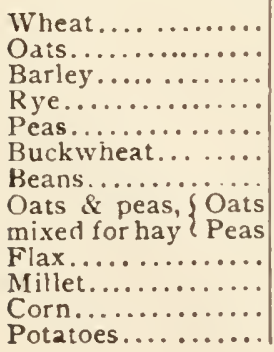 & $\mid \begin{array}{c}11 / 2 \\
2 \\
19 / 4 \\
2 \\
2 \\
116 \\
1 \\
2 \\
\cdots \cdots \\
10 \\
1 / 4\end{array}$ & 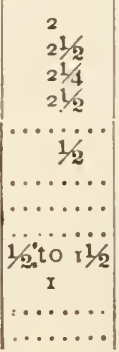 & 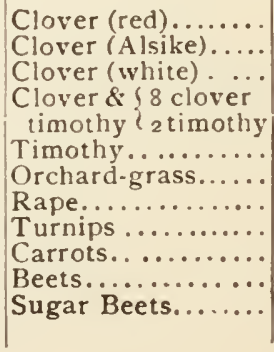 & 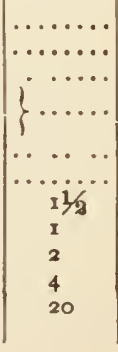 & $\begin{array}{r}12 \\
4 \\
3 \\
10 \\
5 \\
25 \\
3 \\
2 \\
\cdots \cdots \\
\cdots \cdots\end{array}$ \\
\hline
\end{tabular}




\section{SEED MITURES HOR HAY AND PERMANENT PASTURES}

In Pounds per acre.

\begin{tabular}{|c|c|c|c|c|c|c|}
\hline Names of Grasses. & $\begin{array}{c}\text { i. } \\
\text { Fiint }\end{array}$ & $\begin{array}{l}\text { II. } \\
\text { L.aw- } \\
\text { son. }\end{array}$ & $\begin{array}{c}\text { III. } \\
\text { For Good } \\
\text { Medium } \\
\text { Soils. } \\
\text { De Launé }\end{array}$ & $\begin{array}{c}\text { IV. } \\
\text { For Wet } \\
\text { Solls. } \\
\text { De Launé }\end{array}$ & $\begin{array}{c}\text { V. } \\
\text { For } \\
\text { Chatlky } \\
\text { Soils. } \\
\text { De Launé }\end{array}$ & $\begin{array}{c}\text { VI. } \\
\text { For } \\
\text { Perma- } \\
\text { nent } \\
\text { Launs. } \\
\text { Flint. }\end{array}$ \\
\hline Meadow foxtail...... & 2 & 2 & ro & 4 & $\ldots$ & 3 \\
\hline Orcl & 6 & 4 & $\ldots \ldots$ & $\ldots$ & . . & 3 \\
\hline ernal & I & .. & $\ldots$ & . $\ldots \ldots$ & $\ldots \ldots \ldots$ & 2 \\
\hline Meadow fescue....... & 2 & 2 & 6 & 3 & 2 & 2 \\
\hline Tall fescue ....... & ..... & 2 & 3 & 8 & .......... & 2 \\
\hline escue. ....... & $\ldots$ & 2 & I & $\mathbf{I}$ & 4 & 2 \\
\hline Sheep's fescue...... & $\ldots$ & . . & $\mathbf{I}$ & $\ldots \ldots$ & 4 & 2 \\
\hline Redtop ... ......... & 2 & 2 & $\ldots \ldots \ldots$ & $\ldots \ldots$ & $\ldots \ldots \ldots$ & 3 \\
\hline rass $\ldots . . . \ldots$ & & 2 & $\ldots \ldots \ldots$ & $\ldots \ldots \ldots$ & $\ldots \ldots \ldots$ & 4 \\
\hline tucky blue grass. & 4 & 6 & & $\cdots \cdots$ & $\cdots \cdots \cdots$ & .... \\
\hline $\begin{array}{l}\text { ita! } \\
\text { Per }\end{array}$ & $\begin{array}{l}4 \\
6\end{array}$ & $\begin{array}{l}6 \\
8\end{array}$ & $\cdots \cdots \cdots$ & $\begin{array}{l}\cdots \ldots \ldots \\
. \ldots \ldots \cdots\end{array}$ & $\ldots \cdots$ & $\begin{array}{l}3 \\
4\end{array}$ \\
\hline $\begin{array}{l}\text { Perennial rye grass... } \\
\text { Timothy } \ldots . .\end{array}$ & 3 & 3 & 3 & 3 & ......... & 3 \\
\hline Rough meadow grass & 2 & 2 & $1 \frac{1}{2}$ & 2 & ......... & 3 \\
\hline Wood meadow grass. & $\ldots \ldots$ & 2 & ...... & $\ldots \ldots$ & $\ldots \ldots \ldots$ & ... \\
\hline Red clo & .. . & ... & ... & $\ldots$ & ... & 2 \\
\hline Perennial red clover. & 3 & 2 & I & I & I & 2 \\
\hline White (Dutch) clover & 5 & 5 & I & $\mathbf{I}$ & $\mathbf{I}$ & 2 \\
\hline Alsike............. & $\cdots \cdots$ & $\ldots \ldots$ & $\mathbf{I}$ & I & I & .. \\
\hline Yellow oat grass..... & $\ldots \ldots$ & 1 & . & $\cdots$ & $\mathbf{I}$ & $\mathbf{I}$ \\
\hline Cock's-foot $\ldots \ldots \ldots$ & $\ldots \ldots$ & $\ldots \ldots$ & 7 & 10 & 14 & $\ldots \ldots$ \\
\hline Crested dog's-tail ... & $\ldots \ldots$ & $\ldots \ldots$ & 2 & 2 & 5 & $\ldots \ldots \ldots$ \\
\hline Fiorin.............. & $\ldots \ldots$ & $\ldots \ldots$ & I $\frac{1}{2}$ & 2 & & $\ldots \ldots \ldots$ \\
\hline Yarrow .............. & $\ldots \ldots$ & $\ldots \ldots$ & $\mathbf{I}$ & $\mathbf{I}$ & 2 & ..... \\
\hline Cat's-tail .......... & . $\ldots$. & $\ldots$ & $\cdots$ & $\cdots \cdots$ & 3 & . $\cdots$ \\
\hline \multirow[t]{2}{*}{ Cow grass........... } & $\cdots \cdots$ & & I & I & & …… \\
\hline & $4^{\circ}$ & 45 & $4 \mathrm{I}$ & 40 & $3^{8}$ & 43 \\
\hline
\end{tabular}

For the Northwest the following mixture will, according to Shaw, be found suitable:

Timothy 4 lbs., blue grass 3 lbs., redtop 2 lbs., orchard grass 2 lbs., meadow fescue I lb., tall oat grass I lb., meadow foxtail I lb., alsike clover 3 lbs., white clover 2 lbs., lucern (alfalfa) 2 lbs., yellow clover I lb., total 22 lbs.

And for the States east of Michigan and for the provinces of Canada eastward of Lake Huron:

Lucern (alfalfa) 5 lbs., orchard-grass 4 lbs., meadow fescue and alsike clover 3 lbs. each, tall oat grass, timothy, mearlow foxtail, and white clover 2 lbs. each, yellow clover I lb. : total $2+$ lbs. 
The following mixtures of seeds are suggested for meadows and for pastures by the U. S. Department of Agriculture :

\section{A. Hay Mixtures.}

No. I.

Pounds.

Tall oat grass........ 70 Red clover............ 30 (Sow 35 to to lbs. per acre.)

$$
\text { No. } 2 .
$$

Red top............. 30

Orchard grass ....... to

Meadow fescue....... 20

Red clover.......... Io (Sow to to 45 lbs. per acre.)
No. 3 . Jounds.

Italian rye grass...... 20

Orchard grass ........ 25

Red clover........... Io

Tall oat grass......... 20

Red top............. 25

(Sow 35 to fo lbs. per acre.)

$$
\text { No. } 4 \text {. }
$$

Timothy........... 40

Red top............. $4^{0}$

Tall oat grass........ 20

(Sow to lbs. per acre.)

\section{B. Pasture Mixtures.}

No. I.

Kentucky blue grass.... 25 White clover.......... ro Perennial rye........ 30 Red fescue.......... ro Red top............ 25 (Sow 35 lbs. per acre.)

$$
\text { No. } 2 .
$$

Canada blue grass ..... 5 Red clover.......... 5 Orchard grass....... 5 Tall oat grass........ 5 Perennial rye grass.... 20 Red top............. 35 (Sow 40 to 45 lbs. per acre.)

No. 3. For wet pastures.

Red top........... 35

Alsike.............. 20

Crecping bent........ I 5

Perennial rye........ $3 \mathrm{C}$

(Sow to lbs. per acre.)

No. 4. For light sandy soils.

Red fescuc......... 50 Red top............ 25 Kentucky blue grass... 20 White clover........ 5 (Sow 35 to to lbs. per acre.) 
FIELI CROPS.

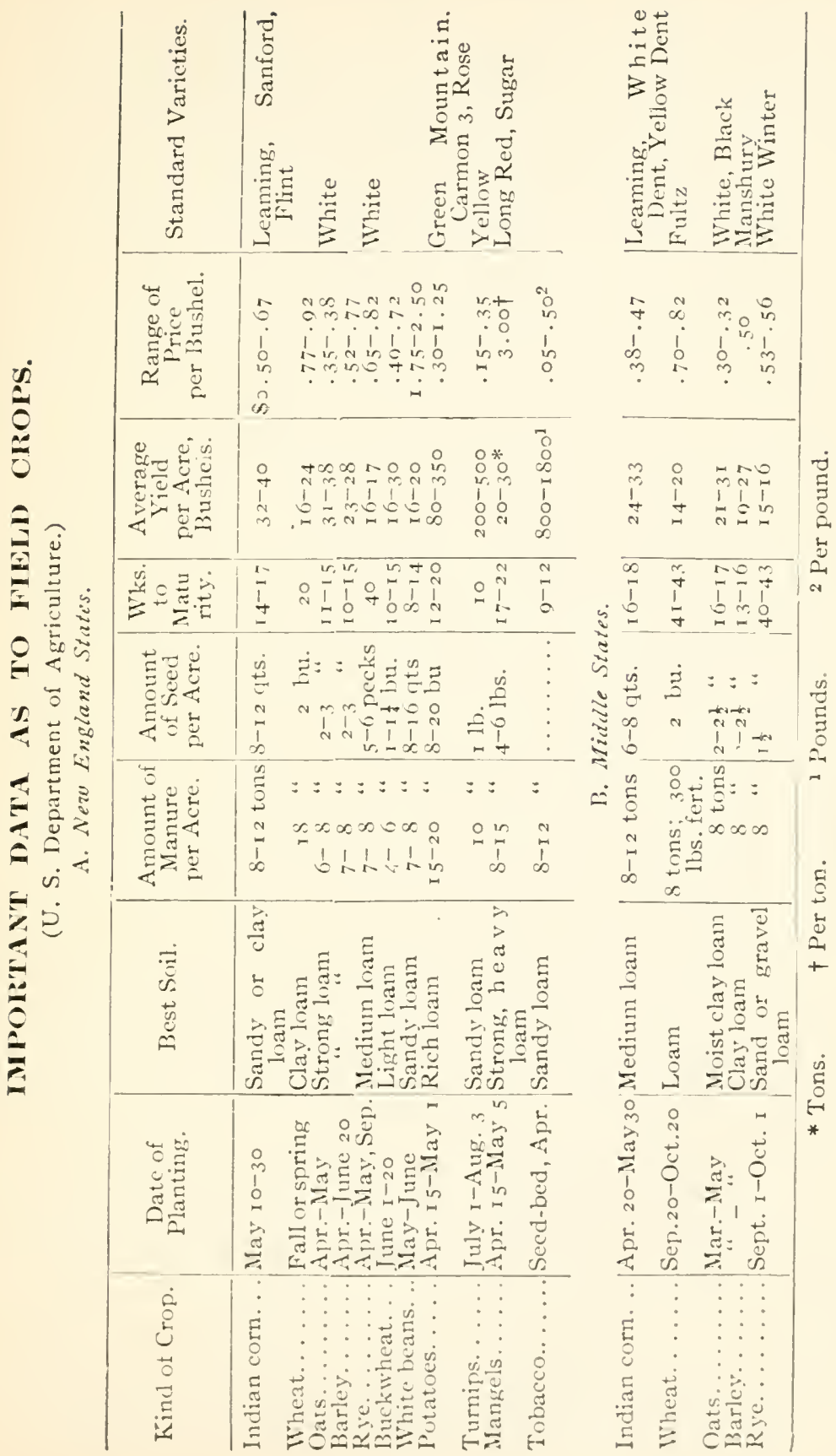




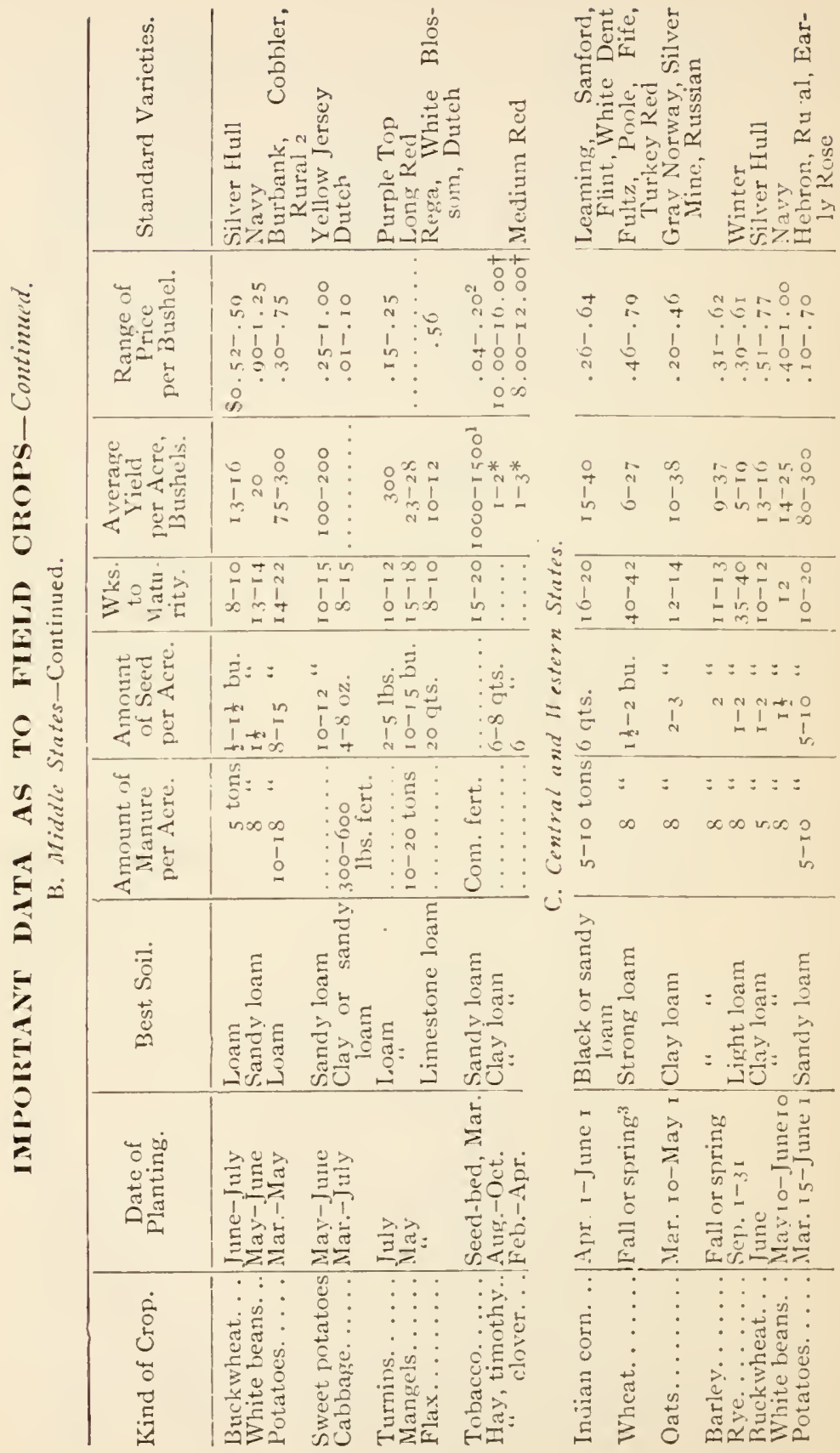




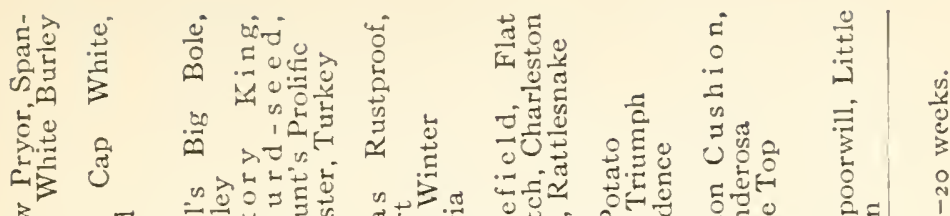

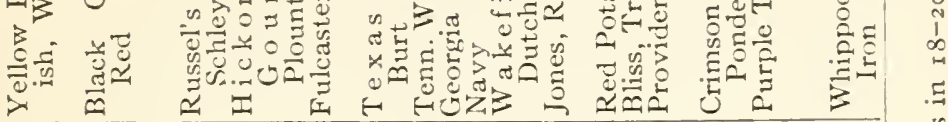

-1.

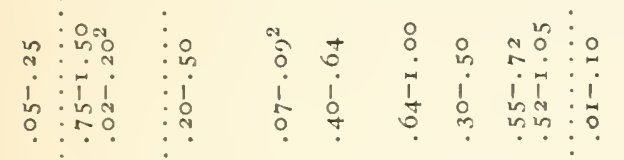

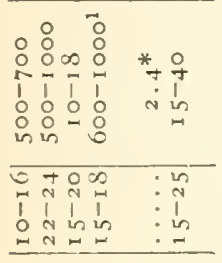

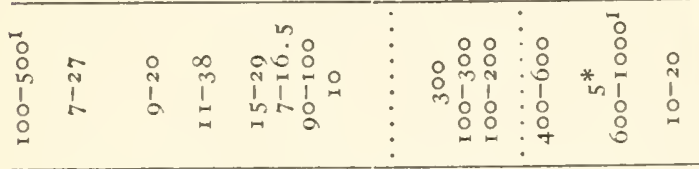

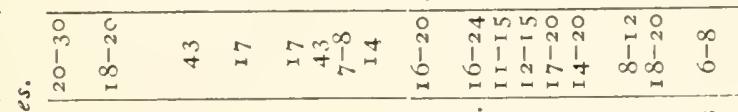

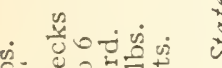

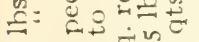

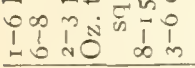

$::=:=$ :

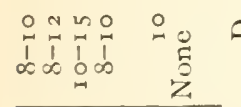

进

里

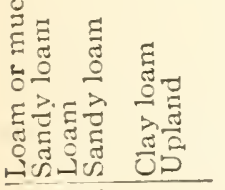

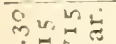

बiं $2=$

in

- $=\frac{1}{1}$ ।

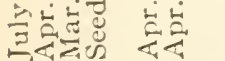

.

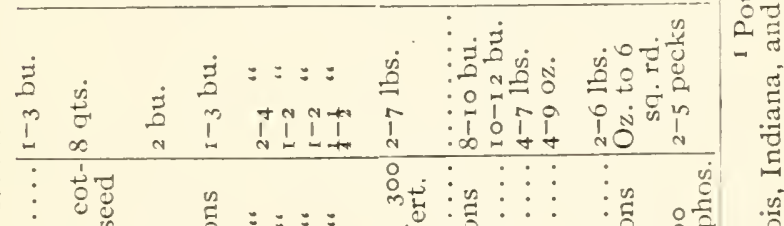

in

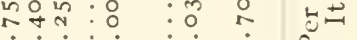

H: :

o)

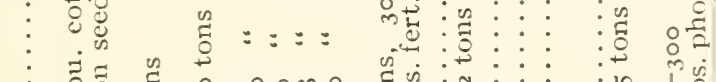

$\frac{\sin }{2}$

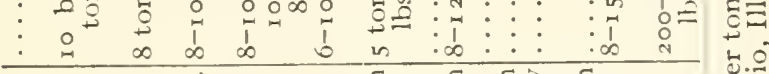

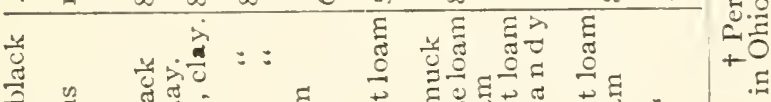

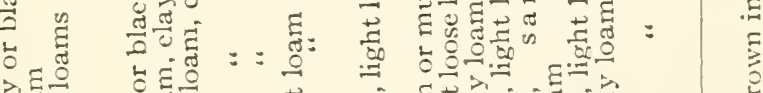

可

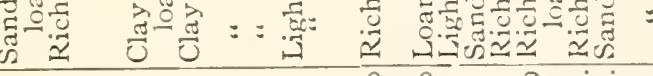




\section{THE WEIGHT AND AVERAGE COMPOSITION OF ORDINARY CROPS IN POUNDS PER ACRE.}

(ITARINGTON.)

Wheat :

grain, 30 bu.

straw.....

Total crop..

\section{Barley :}

grain, 40 bu.. straw.......

Total crop..

Oats :

grain, 45 bu.. straw........

Total crop..

\section{Maize :}

grain, 30 bu. . stalks, etc...

Total crop.

Meadow hay, $11 / 2$ tons. ...

Red clover hay, 2 tons ........

\section{Beans:}

grain, zo bu.. straw.......

Total crop.

Turnips :

root, 17 tons. ieaf..........

Total crop..

Swedes:

root, I4 tons.. leaf. It tor.

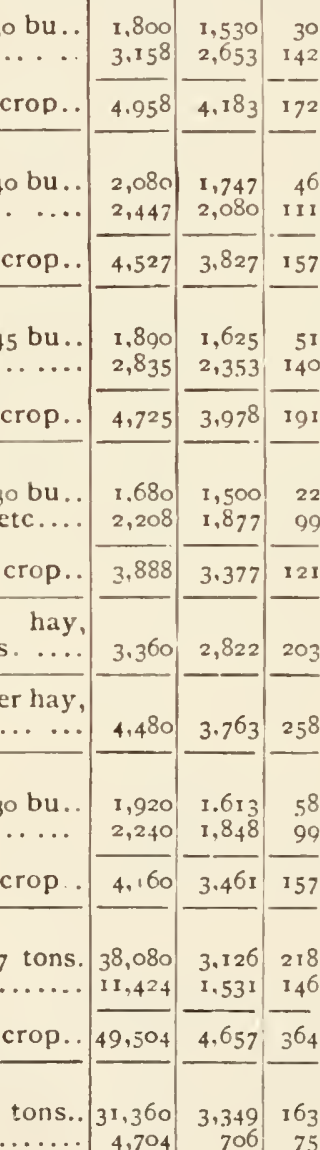

\section{Weight of Crop.}

$\begin{gathered}\text { At } \\ \text { Har- } \\ \text { vest. }\end{gathered} \mid \begin{gathered}\text { Dry. } \\ 0\end{gathered}$

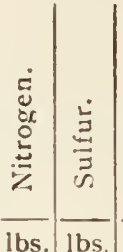

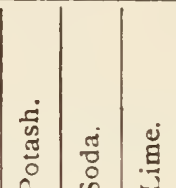

胥

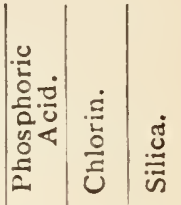

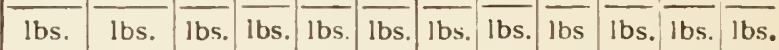

\begin{tabular}{lllll|l|l|llllllll}
1,800 & 1,530 & 30 & 33 & 2.7 & 9.3 & 0 & 6 & 1.0 & 3.6 & 14.2 & 0.1 & 0.6
\end{tabular} \begin{tabular}{ll|l|l|l|l|l|l|l|l|l|l|l}
3.158 & 2,653 & 142 & 15 & 5.1 & 19 & 5 & 2.0 & 8.2 & 3.5 & 6.9 & 2.4 & 96.3 \\
\hline
\end{tabular}

\section{2}

${ }_{48}^{8} \overline{7.8} \overline{28.8} \overline{2.6} \overline{9.2}$ $\begin{array}{llll}7.1 & & & \\ 21.1 & 2.5 & 96.9\end{array}$

\begin{tabular}{lll|l|l|l|l|l|l|l|l}
46 & 35 & 2.9 & 9.8 & I.I & I.2 & 4.0 & 16.0 & 0.5 & II.8
\end{tabular}

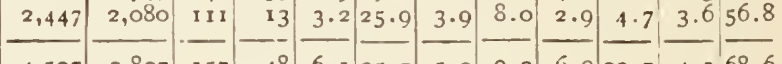
\begin{tabular}{lllllll|lll|l|l|l}
4.527 & 3.827 & 157 & 48 & 6.1 & 35.7 & 5.0 & 9.2 & 6.9 & 20.7 & 4.1 & 68.6
\end{tabular} $\begin{array}{llllllllllll}38 & 3.2 & 9.1 & 0.8 & 1.8 & 3.6 & 13.0 & 0.5 & 19.9\end{array}$ $2,353 \quad 140$

\begin{tabular}{ll|l|l|l|l|l|l|l}
4.8 & 37.0 & 4.6 & 9.8 & 5.1 & 6.4 & 6.1 & 65.4
\end{tabular}

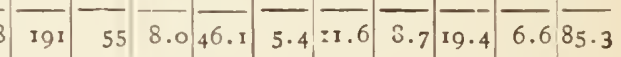

22 $\begin{array}{lllllllllll}28 & 1 & .8 & 6.5 & 0.2 & 0.5 & 3.4 & 10.0 & 0.2 & 0.5\end{array}$ 15 5 $\frac{29.8}{36 \cdot 3}$ 3 $203 \quad 495.750 .9 \quad 9232.1 \quad 14.4 \quad 12.3 \quad 14.656 .9$ \begin{tabular}{lllllllllllllll}
\hline & 258 & 102 & 9.4 & 83.4 & 5.1 & 90.1 & 28.2 & 24.9 & 9.8 & 7.0
\end{tabular} $\begin{array}{lllllllllllll}58 & 77 & 4.4 & 24.3 & 0.6 & 2.9 & 4.2 & 22.8 & 1.1 & 0.4\end{array}$ \begin{tabular}{lllll|l|l|l|l|l|l|l|l|l|l}
2,240 & 1,848 & 99 & 29 & 4.9 & 42.8 & 1.7 & 26.3 & 5.7 & 6.3 & $4 \cdot 3$ & 6.9
\end{tabular}

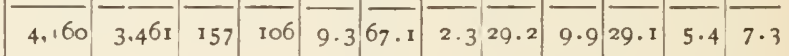

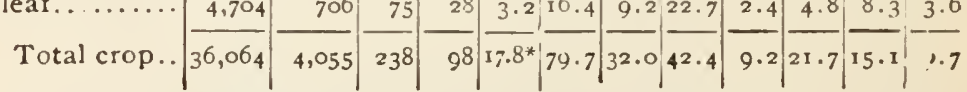


THE WEIGHT AND AVERAGE COMPOSITION OF ORDINARY CROPS.-Continued.

\begin{tabular}{|c|c|c|c|c|c|c|c|c|c|c|c|c|}
\hline & \multicolumn{2}{|c|}{$\begin{array}{c}\text { Weight of } \\
\text { Crop. }\end{array}$} & \multirow{2}{*}{ 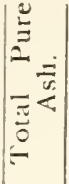 } & \multirow{2}{*}{ 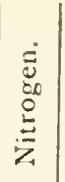 } & \multirow[b]{2}{*}{$\stackrel{\frac{5}{3}}{3}$} & \multirow[b]{2}{*}{ 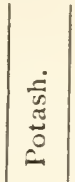 } & \multirow[b]{2}{*}{ 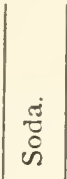 } & \multirow[b]{2}{*}{$\stackrel{\mathscr{J}}{\Xi}$} & \multirow{2}{*}{ 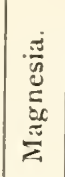 } & \multirow{2}{*}{ 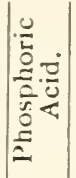 } & \multirow{2}{*}{$\frac{\dot{g}}{\frac{3}{3}}$} & \multirow[b]{2}{*}{$\stackrel{\stackrel{\tilde{j}}{\bar{n}}}{\bar{n}}$} \\
\hline & $\begin{array}{l}\text { At } \\
\text { Har- } \\
\text { vest. }\end{array}$ & Dry. & & & & & & & & & & \\
\hline $\begin{array}{l}\text { Mangolds: } \\
\text { root, } 22 \text { tons.. } \\
\text { leaf. ......... }\end{array}$ & $\begin{array}{c}\text { lbs. } \\
49.280 \\
18.233\end{array}$ & $\begin{array}{l}\text { lbs. } \\
5,914 \\
1,654\end{array}$ & $\begin{array}{r}\text { Ibs. } \\
426 \\
254\end{array}$ & $\begin{array}{r}\text { lbs. } \\
87 \\
5 \mathrm{I}\end{array}$ & $\mid \begin{array}{r}1 \text { bs. } \\
4.9 \\
9 \cdot 1\end{array}$ & $\mid \begin{array}{l}\text { Ibs. } \\
222.8 \\
77.9\end{array}$ & $\begin{array}{l}\text { lbs. } \\
69 \cdot 4 \\
49 \cdot 3\end{array}$ & $\begin{array}{l}1 \mathrm{bss} \\
15 \cdot 9 \\
27.0\end{array}$ & $\begin{array}{cc}\text { lbs. } \\
18 & 3 \\
24.2\end{array}$ & $\begin{array}{l}\text { Ibs } \\
36.4 \\
16.5\end{array}$ & $\begin{array}{l}1 \text { bs } \\
42.5 \\
40.6\end{array}$ & $\begin{array}{l}1 \text { bs. } \\
8.7 \\
9.2\end{array}$ \\
\hline Total c & 67,513 & $7: 568$ & 680 & 138 & 14.0 & 300.7 & 187.7 & 42.9 & $42 \cdot 5$ & 52.9 & 83 & 17.9 \\
\hline $\begin{array}{l}\text { Potato } \\
\text { tuber }\end{array}$ & $13.44^{\circ}$ & $3 \cdot 360$ & I 27 & 47 & $2 \cdot 7$ & $7^{6} .5$ & $3 . \delta$ & $3 \cdot 4$ & 6.3 & $2 I \cdot 5$ & $4 \cdot 4$ & 2.6 \\
\hline $\begin{array}{l}\text { Beech: } \\
\text { wood. ....... } \\
\text { leaf litter. ... }\end{array}$ & & $\begin{array}{l}2,822 \\
2,975\end{array}$ & $\begin{array}{r}26 \\
166\end{array}$ & $\begin{array}{l}10 \\
39 \\
\end{array}$ & $\cdots$ & \begin{tabular}{|l|}
4.2 \\
8.8
\end{tabular} & $\begin{array}{l}0.8 \\
1.6\end{array}$ & $\begin{array}{l}12.9 \\
73.1\end{array}$ & $\begin{array}{r}3.4 \\
10.9\end{array}$ & \begin{tabular}{|l|}
1.5 \\
$9 \cdot 3$
\end{tabular} & $\because$ & $\begin{array}{r}2.2 \\
53.9 \\
\end{array}$ \\
\hline T'l produce. & $\ldots \ldots$ & 5,797 & 192 & 49 & $\cdots$ & 13.0 & 2.4 & 86.0 & $14 \cdot 3$ & 10.8 & $\cdots$ & 56.1 \\
\hline $\begin{array}{l}\text { Scotch pine: } \\
\text { wood ....... } \\
\text { leaf litter..... }\end{array}$ & & $\begin{array}{l}2,884 \\
2,845\end{array}$ & $\begin{array}{l}15 \\
42\end{array}$ & & .. & $\begin{array}{l}2 \cdot 3 \\
4 \cdot 3\end{array}$ & $\begin{array}{l}0.2 \\
1.7 \\
\end{array}$ & $\begin{array}{r}9.0 \\
16.8 \\
\end{array}$ & $\begin{array}{l}1 \cdot 5 \\
4.3 \\
\end{array}$ & $\begin{array}{l}1.0 \\
3 \cdot 3\end{array}$ & $\begin{array}{l}\cdots \\
\cdots\end{array}$ & $\begin{array}{l}0.5 \\
5.8\end{array}$ \\
\hline T'l produce. & & 5,729 & 57 & $\cdots$ & $\cdots$ & 6.6 & I.9 & 25.8 & $5 \cdot 8$ & $4 \cdot 3$ & $\cdots$ & $6 \cdot 3$ \\
\hline $\begin{array}{l}\text { wood } \\
\text { leaf } 1\end{array}$ & & $\begin{array}{l}3.064 \\
2,68_{3}\end{array}$ & $\begin{array}{r}20 \\
121 \\
\end{array}$ & & & $\begin{array}{l}3 \cdot 6 \\
4 \cdot 3 \\
-\end{array}$ & $\begin{array}{l}0.4 \\
1.5 \\
\end{array}$ & $\begin{array}{r}8.2 \\
54 \cdot 4 \\
\end{array}$ & \begin{tabular}{|l|}
$\mathbf{1} .8$ \\
6.2 \\
\end{tabular} & $\begin{array}{l}\mathrm{I} \cdot 3 \\
5 \cdot 7\end{array}$ & $\cdots$ & $\begin{array}{r}2.9 \\
443 \\
\end{array}$ \\
\hline T'l produce. & & 5.747 & $\mid \begin{array}{l}1+1 \\
\end{array}$ & & $\ldots$ & 7.0 & \begin{tabular}{|l|}
$\mid 1.9$ \\
\end{tabular} & $62.6 \mid$ & $8.0 \mid$ & 7.0 & .. & 47.2 \\
\hline
\end{tabular}

SOILING CROPS ADAP'TED TO NORTHERN NEW ENGLANI) STATES. (LiNDSEY.)

(For 10 cows' entire soiling.)

\begin{tabular}{|c|c|c|c|c|}
\hline & Seed per Acre. & $\begin{array}{l}\text { Time of } \\
\text { Seeding. }\end{array}$ & Area. & Time of Cutting \\
\hline $\begin{array}{l}\text { Vye } \ldots . . . \ldots \ldots \\
\text { Vheat ........... } \\
\text { Red clover } . .\end{array}$ & $\begin{array}{c}2 \text { bush } \ldots \ldots \ldots \\
\ldots \ldots \ldots \\
20 \text { lbs........ }\end{array}$ & $\begin{array}{c}\text { Sept. }{ }^{10-15} \\
\text { July I5-Aug. I }\end{array}$ & $\begin{array}{c}1 / 2 \text { acre } \\
\text {." }\end{array}$ & $\begin{array}{l}\text { Jay } 20-\text { May } 30 \\
\text { June } 1-\text { June } 15 \\
\text { June } 15-\text { June } 25\end{array}$ \\
\hline $\begin{array}{r}\text { irass and clo- } \\
\text { ver............ }\end{array}$ & $\begin{array}{l}1 / 2 \mathrm{~b} \\
1 \mathrm{pe} \\
101 \mathrm{l}\end{array}$ & \} Sept. & $2 / 3$ acre & June $15-J u n$ \\
\hline Tetch and onts. ? & & April 20 & $1 / 2$ acre & June 25 -July 10 \\
\hline "، & & 30 & " & July $10-J u l y 20$ \\
\hline 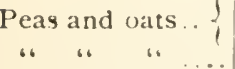 & $\begin{array}{l}11 / 3 \text { bu. Cana } \\
11 \% \text { bu. oats } \\
\text {.6 }\end{array}$ & $\begin{array}{ll}\text { “ } & 20 \\
\text { ، } & 30\end{array}$ & “ & June $25-J u l y$ ro \\
\hline $\begin{array}{l}\text { Barnyard millet.. } \\
\text { "oja bean (me- }\end{array}$ & I peck $\ldots \ldots \ldots$ & $\begin{array}{ll}\text { May } & \text { 10 } \\
\cdots & 25\end{array}$ & $1 / 3$ acre & $\begin{array}{l}\text { July 25-Aug. } 10 \\
\text { Aug. 10-Aug. } 20\end{array}$ \\
\hline $\begin{array}{l}\text { oja bean } \\
\text { dium gree } \\
\text { orn ........ } \\
\text { “. } \ldots \text {...... } \\
\text { lungarian. }\end{array}$ & $\begin{array}{c}18 \mathrm{q} \\
\cdots\end{array}$ & $\begin{array}{cc}، & 20 \\
، & 20 \\
\text { July } & 30 \\
15\end{array}$ & $\begin{array}{c}0 \\
\cdots \\
12 \text { acre }\end{array}$ & $\begin{array}{l}\text { Aug. } 25-\text { Sept.1 } \\
\text { Aug. } 25-\text { Sept.10 } \\
\text { Sept. 10-Sept.20 } \\
\text { Sept. } 20-\text { Sept. } 30\end{array}$ \\
\hline Barley and peas & $\begin{array}{l}1 / 2 \text { bu. peas. } \\
1 / 2 \text { bu barley.. }\end{array}$ & Aus. 5 & 1 acre & Oct. I-Oct. 20 \\
\hline
\end{tabular}




\section{TIME OF PLANTING AND FHeDiNg SOHANG CROPS. (PIETIR)}

\begin{tabular}{|c|c|c|c|}
\hline Kind of Fodder & $\begin{array}{l}\text { Amount w1 } \\
\text { Seed } \\
\text { per Acre }\end{array}$ & $\begin{array}{c}\text { Aprroxi- } \\
\text { mate Time } \\
\text { of Seeding. }\end{array}$ & $\begin{array}{c}\text { Approximate } \\
\text { Tims of Feedug }\end{array}$ \\
\hline 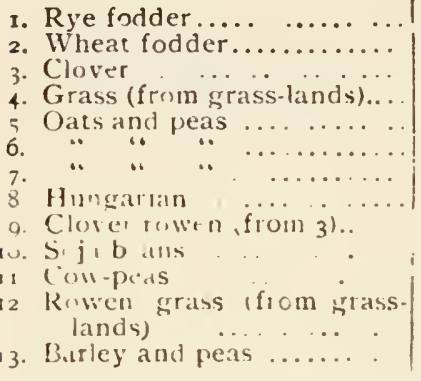 & 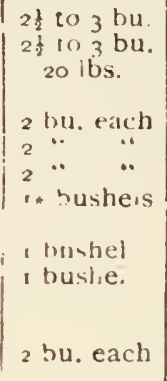 & $\begin{array}{l}\text { Sept. } 1 \\
\text { Sept. 5-10 } \\
\text { July } 20-30 \\
\text { Aprit in } \\
\text { June }{ }^{30} \\
\text { Jua } 25 \\
\text { June 5-10 } \\
\text { Aug. 5-10 }\end{array}$ & 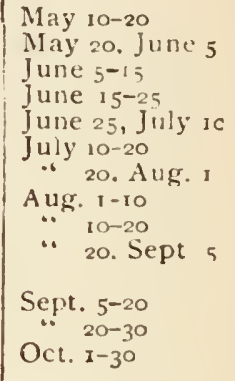 \\
\hline
\end{tabular}

The dates griven in the tabe afply to Central Connecticut and regions under approximalely similar conditions.

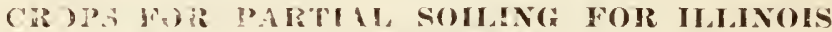

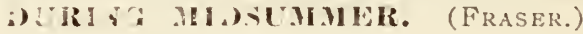

\begin{tabular}{|c|c|c|c|}
\hline Kinds of Irulder. & $\begin{array}{l}\text { An munt } \\
\text { of Siend } \\
\text { o's Aire. }\end{array}$ & $\begin{array}{l}\text { Aprorox. } \\
\text { Time of } \\
\text { Seetling. }\end{array}$ & $\begin{array}{l}\text { Aproxos. Time } \\
\text { of Fecding. }\end{array}$ \\
\hline 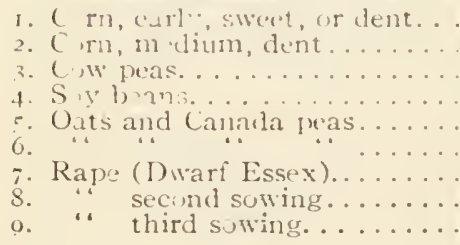 & $\begin{array}{l}6 \text { quts. } \\
5 \\
\text { I bu. } \\
\text { I } \cdots \\
\text { I bu. each } \\
\text { I } 11 \\
+11 \text { s. } \\
4 \cdots \\
4\end{array}$ & $\begin{array}{ll}\text { May } & \text { I } \\
\because \cdots & 15 \\
\cdots & \text { I } \\
\cdots & 15 \\
\text { Afril } & 15 \\
\text { Ilay } & 1 \\
\cdots & 1 \\
\text { June } & \text { I } \\
\text { July } & \text { I }\end{array}$ & 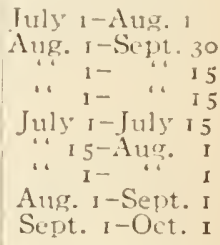 \\
\hline
\end{tabular}

\section{REPLACING WINTER-KITLEI) CLOVER:}

The following brief article gives a list of forage plants that will be found suitable for furnishing green feed for cattle and other farm animals in regions where the clover nas been winter-killed. It was originally published as a newspaper bulletin from the Wisconsin Experiment Station and is wrtten with special reference to conditions in the Norihivestern States.

How t" "et the Cailicest Pasture.-A ficld of oats or harley will furtash the quicliest pasture it is possible to obtain, barlev being a little earlier than oats. Sow oats or barley 
as for a grain crop, and when the young plants are a few inches high, turn in the stock and treat the field as though it were a pasture. If the cattle do not graze she field evenly, run the mower over the patches where the growth is excessive. By keeping the growth short it will last much longer than if allowed to head out. It is recommended that, as an experiment, clover and timothy seed be sown with a part at least of the oats or barley, in the hope of securing a stand for next season. The farmer who can pasture his oat or barley field and get a crop of clover started at the same time will be one year ahead. This recommendation must be regarded as an experiment, but it has been successfully tried in a number of cases.

Oats and Peas.-Let the farmer also put in a patch of oats and peas. Sow a bushel and a half of peas per acre, covering three or four inches deep on light soil, and one or two inches on heavy soil. After these are planted sow or drill the oats in the usual manner. Cut the green forage for the cattle, or cure for hay.

Millet.-For winter hay sow millet or Hungarian grass from the Ioth to the 3 oth of June, using from a bushel to a bushel and a half of seed per acre. When the seed-heads are coming into blossom, cut and cure for hay. Millet or Hungarian grass will yield from one ton to two and a half tons of good quality hay per acre. Horses should not be given over one feed of millet hay per day.

Corn Fodder. - Any variety of corn will do for green or dry forage, the early kinds being the most suitable for early fall feed. Sweet corn is very satisfactory because the stalks are soft and palatable. Plant in hills or drills just thick enough to decrease the size of the ears to about half their normal size. Begin feeding as soon as the ears are glaz. ing, and continue with the dry forage throughout the winter. From three to six tons per acre of winter forage, suitable for all kinds of farm stock, can be secured from a corn crop grown on good land. (Henry.) 


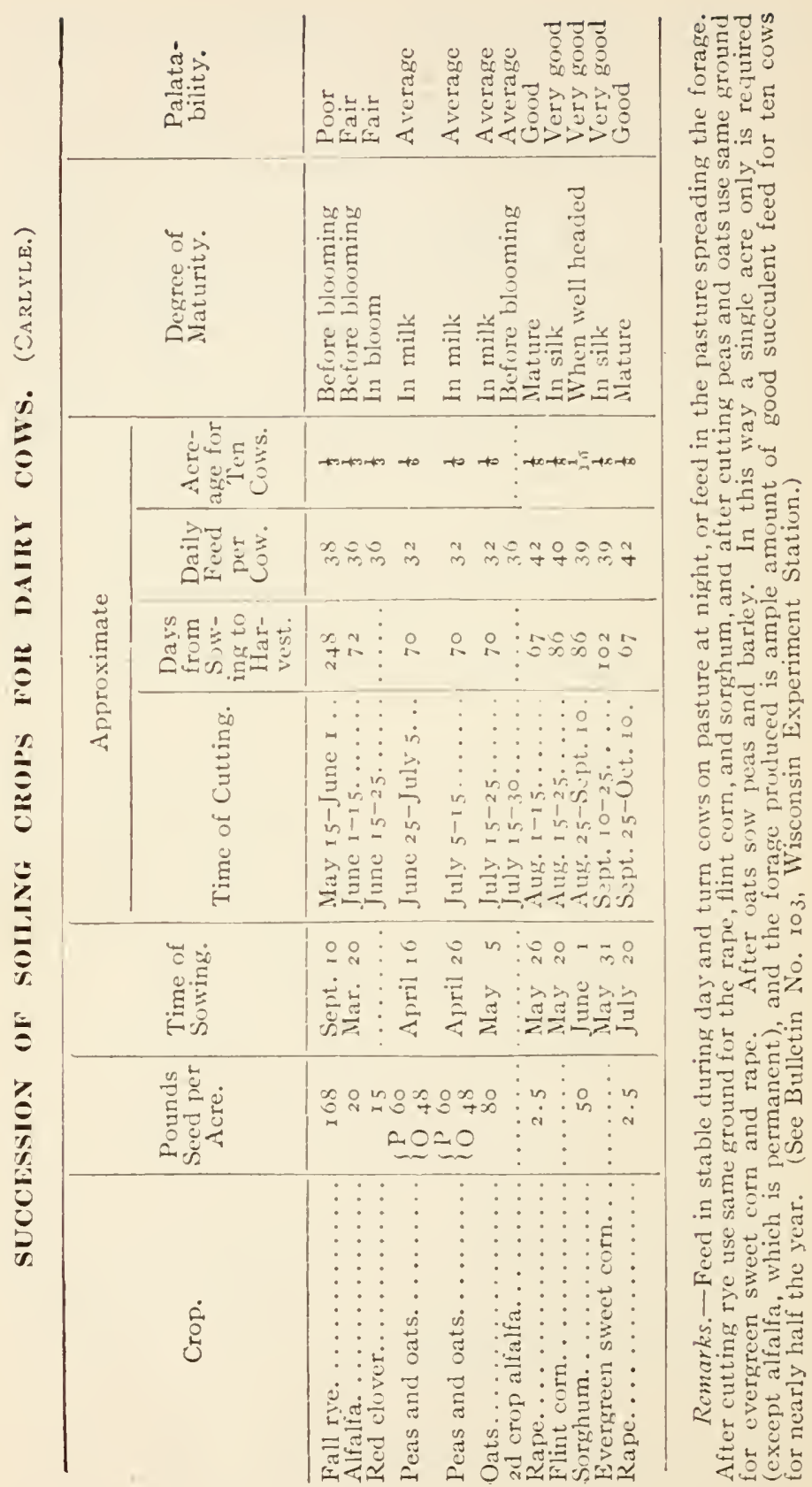


CYLINTRICAL SIIOS.

Approximate Capacity of Cylindrical Silos for Wellmatured Corn silage, in Tons. (KiNG.)

\begin{tabular}{|c|c|c|c|c|c|c|c|c|c|c|c|c|c|}
\hline 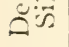 & 10 & 12 & I 4 & I 5 & 16 & I 8 & 20 & $2 \mathrm{I}$ & 22 & 23 & 24 & 25 & 26 \\
\hline 20 & 26 & $3 S$ & $5 \mathrm{I}$ & 50 & 67 & $S_{5}$ & 105 & I I 5 & 127 & 138 & I 5 I & 163 & 177 \\
\hline $2 \mathrm{I}$ & $2 S$ & 40 & 55 & 63 & 72 & $9 \mathrm{I}$ & I I 2 & 123 & I 35 & $I_{4} S$ & $16 I$ & 175 & 189 \\
\hline 22 & 30 & 43 & 59 & 67 & 77 & 97 & I 20 & 132 & I 45 & 158 & 172 & 187 & 202 \\
\hline & 32 & $4^{6}$ & 62 & 72 & $\mathrm{~S}_{2}$ & 103 & I $2 S$ & $I+I$ & 154 & I 69 & I $S_{4}$ & 199 & 216 \\
\hline & 34 & 49 & 66 & 76 & $S_{7}$ & I 10 & I 35 & 149 & 164 & 179 & I 95 & 212 & 229 \\
\hline 25 & 36 & 52 & 70 & $8 \mathrm{I}$ & 90 & I 16 & I 43 & 158 & 173 & 190 & 206 & 224 & 242 \\
\hline 26 & 38 & 55 & 74 & $8_{5}$ & 97 & 123 & I 52 & 168 & 184 & 201 & $2 \mathrm{I} 9$ & 237 & 257 \\
\hline 27 & 40 & 58 & 78 & 90 & 10,3 & 130 & 160 & 177 & I 94 & 212 & 231 & $25 \mathrm{I}$ & $27 \mathrm{I}$ \\
\hline 28 & 42 & $6 I$ & $8_{3}$ & 95 & 108 & 137 & 169 & I 86 & 204 & 223 & 243 & 264 & 285 \\
\hline 29 & 45 & 04 & 88 & 100 & I 14 & 144 & 178 & 196 & 215 & 235 & 265 & 278 & 300 \\
\hline 3 & 47 & 68 & 93 & 105 & I I 0 & $15 \mathrm{I}$ & 187 & 206 & 226 & 247 & 269 & 292 & 315 \\
\hline & 49 & 70 & 96 & I IO & I 25 & $15 S$ & I 95 & 215 & 236 & 258 & $2 S_{2}$ & 305 & 330 \\
\hline 3 & $5 \mathrm{I}$ & 73 & 101 & I I 5 & I 3 I & 166 & 205 & 226 & 248 & $27 \mathrm{I}$ & 295 & 320 & 346 \\
\hline 36 & 64 & 105 & 130 & 139 & 155 & 190 & 235 & $\ldots$ & $\ldots$ & $\ldots$ & $\ldots$ & $\ldots$ & $\ldots$ \\
\hline & 75 & I $2 \mathrm{I}$ & I 50 & 165 & 180 & 228 & 279 & & $\cdots$ & & $\ldots$ & $\ldots$ & $\ldots$ \\
\hline
\end{tabular}

IRELATION OF HORIZONTAI, FHEIING AREA AND NUMIBER OF COMS KEPT, FOR SILOS 24 AND 30 FIET DELP. (KING.)

\begin{tabular}{|c|c|c|c|c|c|c|c|c|}
\hline \multirow{4}{*}{$\begin{array}{l}\text { No. of } \\
\text { Cows. }\end{array}$} & \multicolumn{4}{|c|}{ Feed for 240 Days. } & \multicolumn{4}{|c|}{ Feed for i So Days. } \\
\hline & \multirow{2}{*}{\multicolumn{2}{|c|}{$\begin{array}{c}\text { Silo } \\
24 \text { Feet Deep. } \\
\text { Rate } \\
\text { I.2 In. Daily. }\end{array}$}} & \multirow{2}{*}{\multicolumn{2}{|c|}{$\frac{\begin{array}{c}\text { Silo } \\
\text { 30 Feet Deep. }\end{array}}{\text { Rate }} \begin{array}{c}\text { I.5 In. Daily. } \\
\text { In }\end{array}$}} & \multirow{2}{*}{\multicolumn{2}{|c|}{$\begin{array}{c}\text { Silo } \\
2+\text { Feet Deep. } \\
\begin{array}{c}\text { Rate } \\
\text { 1.6 In. Daily. }\end{array}\end{array}$}} & \multirow{2}{*}{\multicolumn{2}{|c|}{$\begin{array}{c}\text { Silo } \\
\text { 30 Feet Deep. } \\
\text { 2 In. Date }\end{array}$}} \\
\hline & & & & & & & & \\
\hline & Tons. & $\begin{array}{l}\text { Inside } \\
\text { Diam. }\end{array}$ & Tons. & $\begin{array}{l}\text { Inside } \\
\text { Diam. }\end{array}$ & Tons. & $\begin{array}{l}\text { Inside } \\
\text { Diam. }\end{array}$ & Tons. & $\begin{array}{l}\text { Inside } \\
\text { Diam. }\end{array}$ \\
\hline I0.... & $4^{8}$ & $\begin{array}{c}\text { Feet. } \\
12\end{array}$ & 48 & $\begin{array}{l}\text { Feet. } \\
\text { IO }\end{array}$ & 36 & $\begin{array}{c}\text { Feet. } \\
\text { Io }\end{array}$ & 36 & $\begin{array}{c}\text { Feet. } \\
9\end{array}$ \\
\hline $15 \ldots$ & $\div 2$ & I 5 & 72 & I 2 & 54 & 13 & 54 & I I \\
\hline $20 \ldots$. & $0^{6}$ & I 7 & 66 & 14 & 72 & 15 & 72 & 12 \\
\hline $25 \ldots \ldots$ & I 20 & I) & I 20 & I 6 & 90 & 16 & 90 & 14 \\
\hline $30 \ldots$. & I 4.4 & $2 \mathrm{I}$ & I. +4 & Is & IOS & Is & IOS & I 5 \\
\hline $35 \ldots \ldots$ & 168 & 22 & I 68 & IO & 126 & 19 & I 26 & 16 \\
\hline $40 \ldots$ & I02 2 & 24 & 102 & 20 & $I+4$ & 21 & I 44 & I $S$ \\
\hline $45 \ldots$ & 216 & 26 & 216 & $2 \mathrm{I}$ & 102 & 22 & I 62 & I 9 \\
\hline & 240 & 27 & 240 & 2.3 & I so & 23 & I So & 20 \\
\hline $63 \ldots \ldots$ & $2 S S$ & 20) & $2 S S$ & 25 & 216 & 25 & 210 & $2 \mathrm{I}$ \\
\hline$\mp 0 \ldots$ & 3.36 & 32 & 3.36 & 27 & 2.52 & 27 & 252 & 23 \\
\hline$\$ \ldots \ldots$ & 354 & 34 & $3 S_{4}$ & 20) & $2 S S$ & 20 & 288 & \\
\hline $01 \ldots .$. & 432 & 36 & +32 & 30 & 324 & $3 I$ & 324 & 26 \\
\hline I د...... & 4 So & $3 S$ & 480 & 32 & 360 & 3.3 & 300 & 28 \\
\hline
\end{tabular}


RELATION BETIEEN SIZE OF SILOS AND NUMBER OF COIVS TIEY WILI, KEEP.

\begin{tabular}{|c|c|c|c|}
\hline Dimensions. & Capacity, Tons. & $\begin{array}{c}\text { Acres to Fill, } \\
\text { I } 5 \text { Tons to } \\
\text { Acre. }\end{array}$ & $\begin{array}{c}\text { Cows it Will } \\
\text { Keep } 6 \text { Months, } \\
40 \text { lbs. Feed per } \\
\text { Day. }\end{array}$ \\
\hline $\begin{array}{l}10 \times 20 \\
12 \times 20 \\
12 \times 24 \\
12 \times 28 \\
14 \times 22 \\
14 \times 24 \\
14 \times 28 \\
14 \times 30 \\
16 \times 24 \\
16 \times 26 \\
16 \times 30 \\
18 \times 30 \\
18 \times 36\end{array}$ & $\begin{array}{l}28 \\
49 \\
49 \\
60 \\
61 \\
67 \\
83 \\
87 \\
93 \\
97 \\
119 \\
157 \\
180\end{array}$ & $\begin{array}{l}2 \\
3 \\
3 \frac{2}{5} \\
4 \\
4 \frac{1}{2} \\
4 \frac{3}{3} \\
5 \frac{2}{3} \\
6 \\
6 \frac{2}{5} \\
7 \\
8 \\
10 \frac{1}{5} \\
12 \frac{1}{3}\end{array}$ & $\begin{array}{l}8 \\
11 \\
13 \\
15 \\
17 \\
19 \\
22 \\
23 \\
24 \\
26 \\
29 \\
37 \\
45\end{array}$ \\
\hline
\end{tabular}

NUMHER OF PLANTS FOR AN ACRE OF GROUND.

Distance apart, Inches.

$3 \times 3 \ldots \ldots \ldots \ldots$

$4 \times 4 \ldots \ldots \ldots \ldots$

$6 \times 6 \ldots \ldots \ldots$

o $\times 9 \ldots \ldots \ldots \ldots$

Feet.

I $\times 1 \ldots \ldots \ldots \ldots . . \ldots 43,560$

$1 \frac{1}{2} \times 1 \frac{1}{2} \ldots \ldots \ldots \ldots . \ldots . . \ldots 19,360$

$2 \times 1 \ldots \ldots \ldots 21,780$

$2 \times 2 \ldots \ldots \ldots$ I0,800

$2 \frac{1}{2} \times 2 \frac{1}{2} \ldots \ldots \ldots \ldots .6060$

$3 \times 1 \ldots \ldots \ldots$ I 4,520

$3 \times 2 \ldots \ldots \ldots \ldots \ldots . \ldots \ldots$

$3 \times 3 \ldots \ldots \ldots . . \ldots 4,840$

$3 \frac{1}{2} \times 3 \frac{1}{2} \ldots \ldots \ldots \ldots . . . . .3,555$

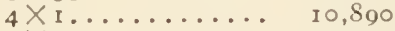

$4 \times 2 \ldots \ldots \ldots \ldots . \ldots \ldots$

$4 \times 3 \ldots \ldots \ldots . \ldots . \ldots .630$

$4 \times 4 \ldots \ldots \ldots \ldots . \ldots \ldots 2,722$

$4 \frac{1}{2} \times 4 \frac{1}{2} \ldots \ldots \ldots \ldots .2,151$

$5 \times 1 \ldots \ldots \ldots . \ldots \ldots, 8,7$ I I

$5 \times 2 \ldots \ldots \ldots \ldots \ldots$

$5 \times 3 \ldots \ldots \ldots \ldots . \ldots \ldots$

$5 \times 4 \ldots \ldots \ldots \ldots 2,178$

$5 \times 5 \ldots \ldots \ldots \ldots \ldots \ldots \ldots \ldots$

$5^{\frac{1}{2}} \times 5 \frac{1}{2} \ldots \ldots \ldots \ldots \ldots \quad$ I, 417
Distance apart, Number of Feet. Plants.

$6 \times 6 \ldots \ldots \ldots \ldots$ 1, 210

$6 \frac{1}{2} \times 6 \frac{1}{2} \ldots \ldots \ldots \ldots$ I, 03 1

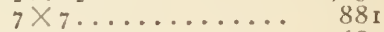

$8 \times 8 \ldots \ldots \ldots \ldots . . . .680$

$9 \times 9 \ldots \ldots \ldots \ldots . . \ldots 537$

$10 \times 10 \ldots \ldots \ldots \ldots . . \ldots 435$

I $\mathrm{X} 11 \ldots \ldots \ldots \ldots$

I $2 \times 12 \ldots \ldots \ldots \ldots \ldots, 302$

I $3 \times 13 \ldots \ldots \ldots \ldots 257$

$14 \times 14 \ldots \ldots \ldots \ldots . \ldots . \ldots 22$

I $5 \times$ I $5 \ldots \ldots \ldots \ldots$ I 93

$16 \times 16 \ldots \ldots \ldots \ldots$

$16 \frac{1}{2} \times 16 \frac{1}{2} \ldots \ldots \ldots \ldots$ I 60

$17 \times 17 \ldots \ldots \ldots \ldots$ I 50

I $8 \times$ I $8 \ldots \ldots \ldots$ I 34

I $0 \times 10 \ldots \ldots \ldots$ I 20

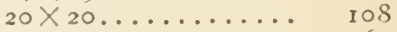

$25 \times 25 \ldots \ldots \ldots \ldots$

$30 \times 30 \ldots \ldots \ldots . . . \ldots . . . . .48$

$33 \times 33 \ldots \ldots \ldots . . . . .40$

$40 \times 40 \ldots \ldots \ldots \ldots . . . . .27$

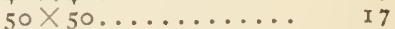

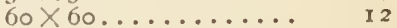

$66 \times 66 \ldots \ldots \ldots \ldots$ Io 
NUMBER OF HILLS OR PIANTS ON AN ACRE OF land, for any distance apart, from $10 \mathrm{in}$. to $6 \mathrm{ft}$., the lateral and longitudinal distances being unequaI. (WAR1NG.)

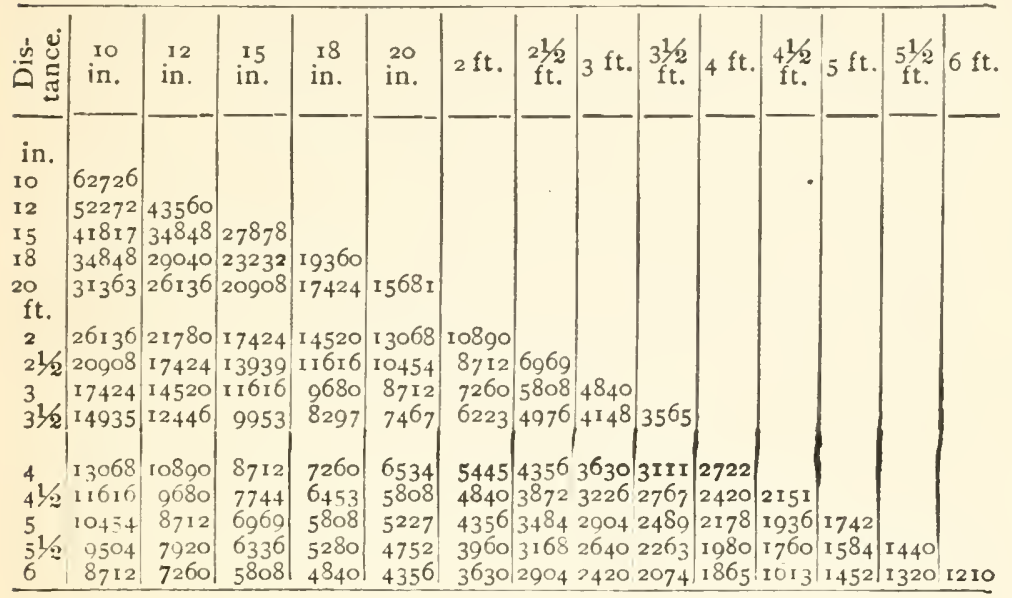

\section{YIELD OF A GOOD CROP OF FARM PRODUCTS}

Per aclic. (Various authorities.)

Alfalfa.......... 4 tons Barley ............ 50 bus. Beans, freld ........ 20 "“ Buckwheat ......... 20 "، Cabbage......... 3 tons Clover............ $2 \frac{1}{2}$ " " Corn (shelled) .....6.60 bus. Cotton........... I bale Cowpea.......... I 5 bus. Field peas......... 20 "“ Flax............. 15 " Hay ........... 2 tons Mangels......... 24 Millet.......... 3 "
Cats........... 50 bus. Potatoes......... 200 "“

Rape.......... 20 tons Rice ............ 5o bus. Rutabagas....... 25 tons Rye ........... 25 bus. Sorghum ......... Io tons Sugar beets........ I 5 " " Sugar-cane....... 20 " Sweet potatoes..... 200 bus. Tobacco ......... I $200 \mathrm{ll}$ s. Turnips......... 20 tons Wheat (spring) .... 25 bus. Wheat (winter) .... 30 "، 


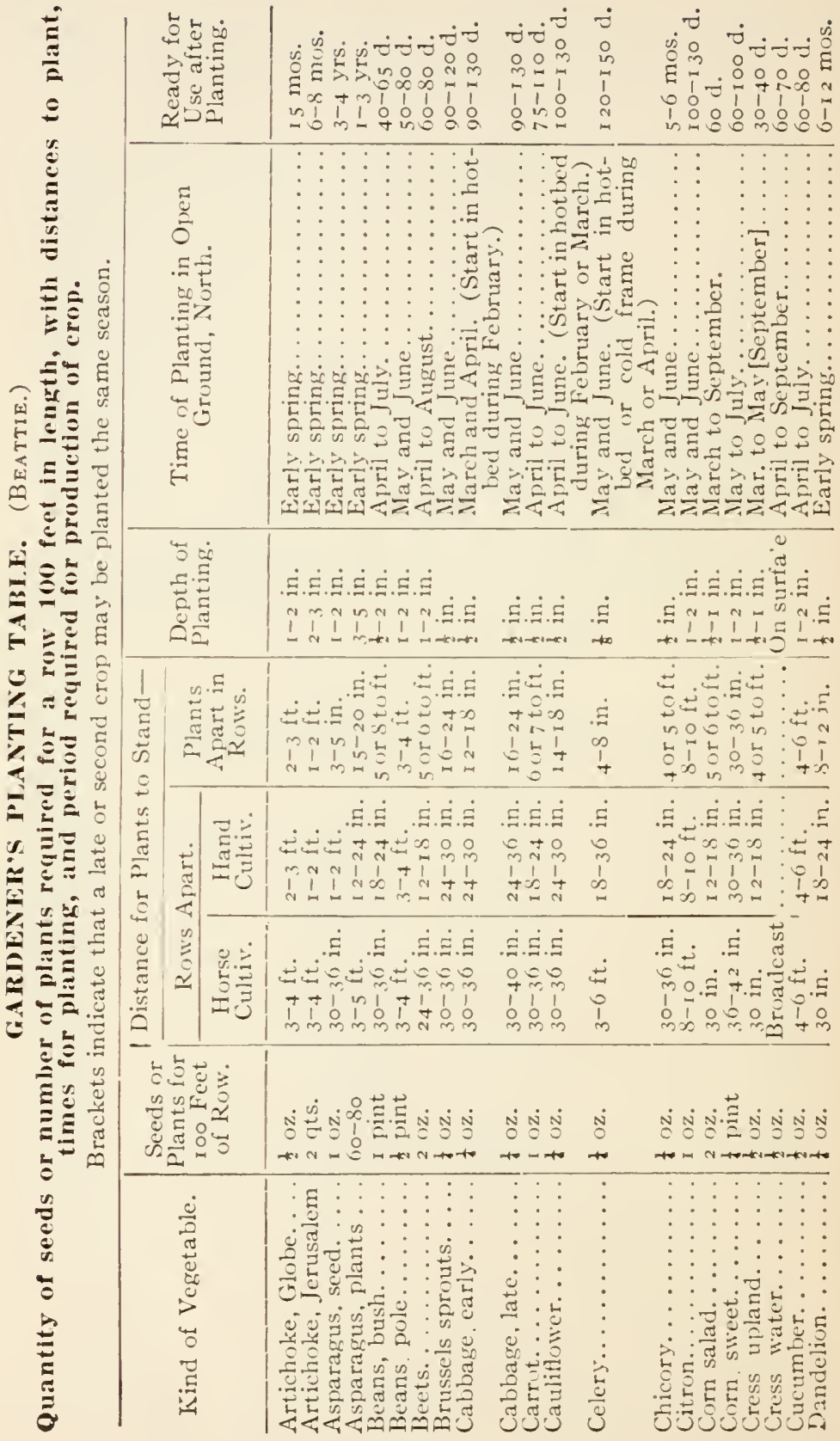




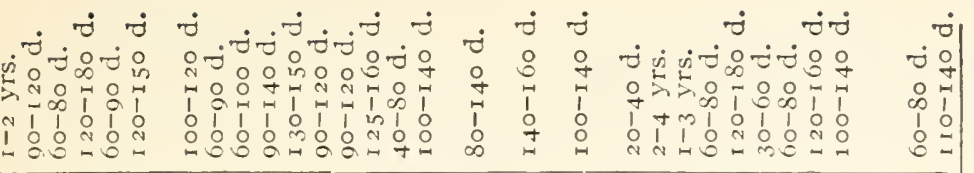

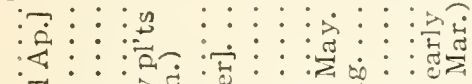

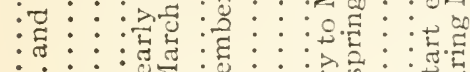

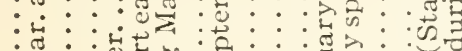

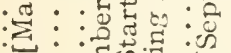

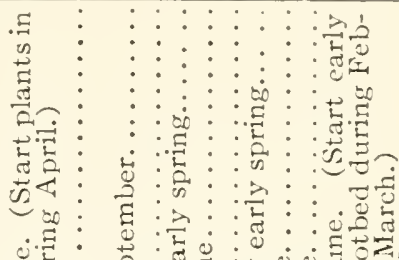

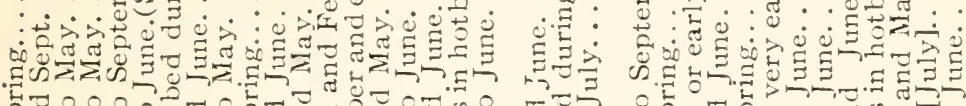

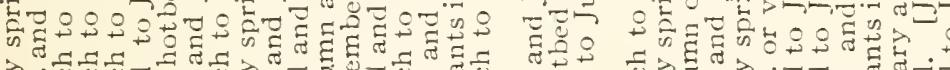

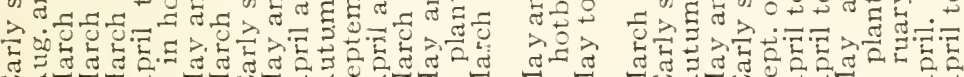

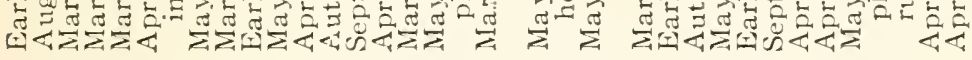

.

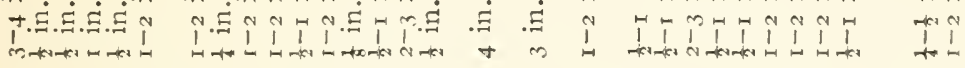

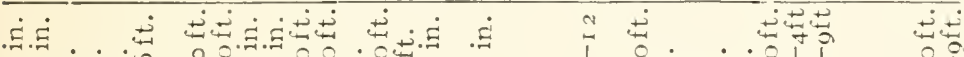

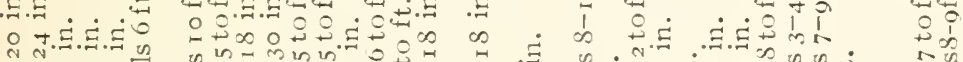

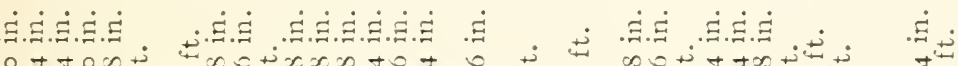
$\begin{array}{llllllll}4 & 0\end{array}$

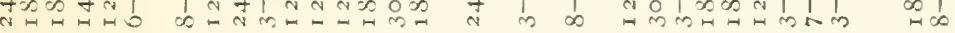

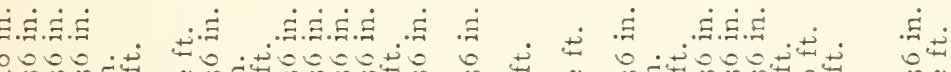

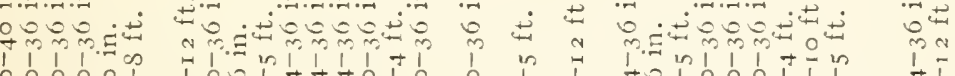
$\begin{array}{llllllllllll}1 & 1 & 1 & 1\end{array}$

\begin{tabular}{|c|c|c|c|c|}
\hline 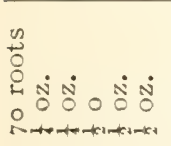 & 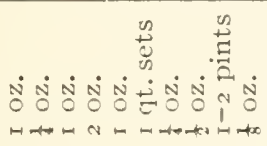 & 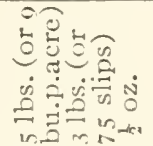 & 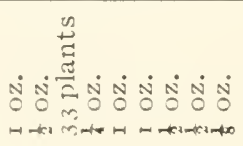 & \\
\hline
\end{tabular}

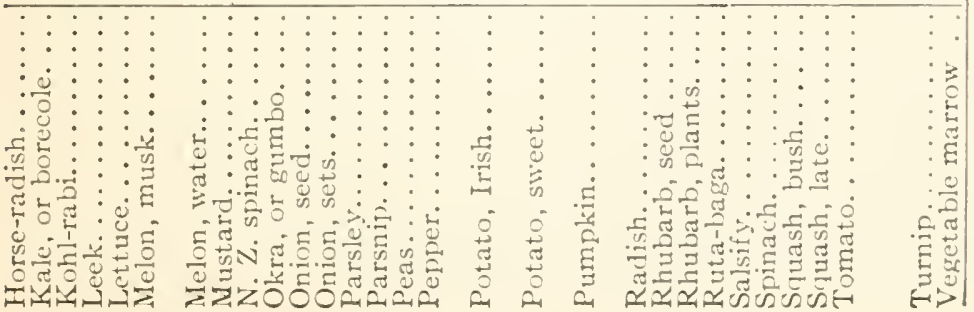


DISTANCES APART FOR FRUIT TREES, Time Required to Bear Fruit, and Longevity. (BALEY.

\begin{tabular}{|c|c|c|c|}
\hline & Usual Distances. & $\begin{array}{c}\text { Time Required to } \\
\text { Bear. }\end{array}$ & $\begin{array}{l}\text { Average } \\
\text { Profitable } \\
\text { Longevity } \\
\text { under high } \\
\text { Culture. }\end{array}$ \\
\hline 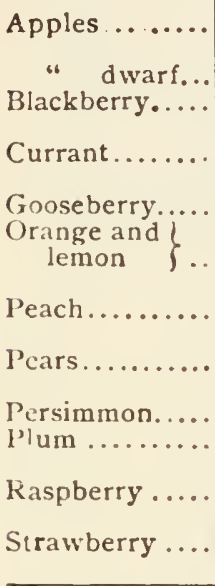 & 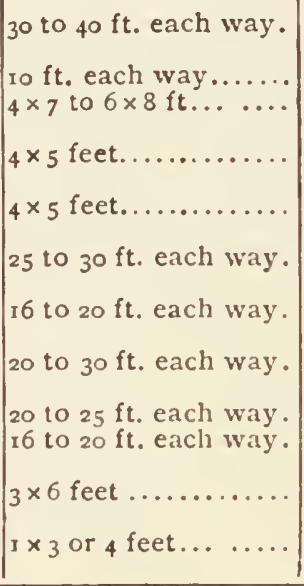 & 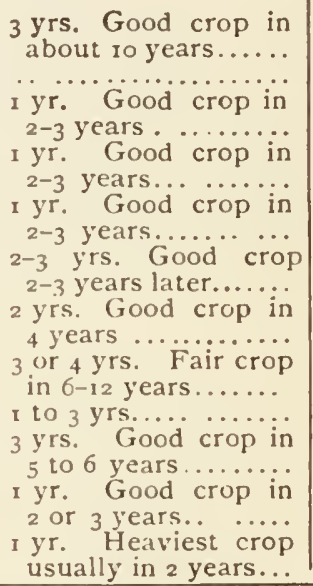 & $\begin{array}{l}25-40 \text { yrs. } \\
\text { 8-12 yrs. } \\
20 \text { years. } \\
20 \text { years. } \\
50 \text { or more. } \\
8-12 \text { yrs. } \\
50-75 \text { yrs. } \\
25-40 \text { yrs. } \\
20-25 \text { yrs. } \\
8-12 \text { yrs. } \\
3 \text { years. }\end{array}$ \\
\hline
\end{tabular}

'TIME OF GERMINATION OF VEGETABLE SEEIS AND MATURITY TABLE. (MORSE.)

\begin{tabular}{|c|c|c|c|c|c|}
\hline & $\begin{array}{l}\text { Time } \\
\text { of Ger- } \\
\text { mina- } \\
\text { tion. }\end{array}$ & $\begin{array}{c}\text { Maturity } \\
\text { Table. }\end{array}$ & & $\begin{array}{l}\text { Time } \\
\text { of Ger- } \\
\text { mina- } \\
\text { tion. }\end{array}$ & $\begin{array}{c}\text { Maturity } \\
\text { Table. }\end{array}$ \\
\hline 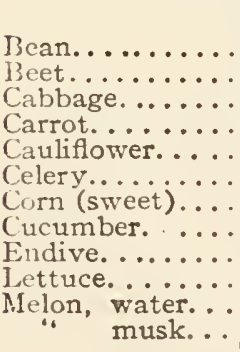 & $\begin{array}{c}\text { Days. } \\
5-10 \\
7-10 \\
5-10 \\
12-20 \\
5-10 \\
\text { I0-20 } \\
5-8 \\
6-10 \\
5-10 \\
6-8 \\
\ldots \ldots \\
\ldots \ldots\end{array}$ & \begin{tabular}{|c} 
Days. \\
$40-60$ \\
$40-50$ \\
$90-115$ \\
$90-110$ \\
$\ldots \ldots \ldots$ \\
$150-160$ \\
$65-90$ \\
$55-75$ \\
$6 \ldots \ldots \ldots$ \\
$65-75$ \\
I25-150 \\
$125-150$
\end{tabular} & 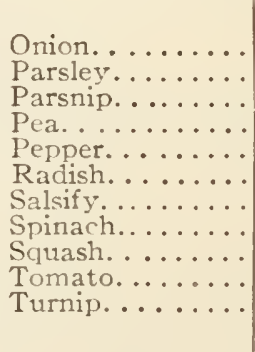 & $\begin{array}{c}\text { Days. } \\
7-10 \\
10-20 \\
6-10 \\
10-144 \\
3-6 \\
7-12 \\
\cdots \cdots \\
6-12 \\
4-8\end{array}$ & $\begin{array}{l}\text { Days. } \\
130-150 \\
90-120 \\
120-150 \\
40-90 \\
140-160 \\
20-30 \\
\ldots \ldots-80 \\
60-80 \\
120-150 \\
110-120 \\
60-75\end{array}$ \\
\hline
\end{tabular}




\section{AVERAGE YIELDS PER ACRE OF VARIOUS Crop's. (Bailey.)}

Apples........ A tree 20 to 30 years old may be expected to yield from 25 to 40 bus. every alter. nate year.

Artichoke..... 200 to 300 bus.

Beans, green or snap......... 75 to $\mathrm{I} 20$ bus.

Bean, Lima. ... 75 to Ioo bus. of dry beans.

Beet........ 400 to 700 bus.

Carrots........ too to 700 bus.

Corn.......... 50 to 75 bus., shelled.

Cranberry ...... I 00 to 300 bus.; 900 bus. have been reported.

Cucumber....... About 150 , 0 co fruits per acre.

Currant....... I00 bus.

Egg-plant...... I or 2 large fruits to the plant for the large sorts like New York purple, and from 3 to $S$ fruits for the smaller varieties.

Gooseberry...... Ioo bus.

Grape........ 3 to 5 tons. Good raisin vineyards in California, I 5 years old, will produce from io to 12 tons.

Horse-radish.... 3 to 5 tons.

Kohlrabi...... 500 to 1000 bus.

Onion, from seed 300 to 800 bus.; 600 bus. is a large average yield.

Parsnip........ 500 to 800 bus.

Pea, green, in pod 100 to I 50 bus.

Peach.......... In full bearing a peach-tree should produce from 5 to io bus.

Pear ......... A tree 20 to 25 years old should give from 25 to 45 bus.

Pepper ...... 30,000 to $\$ 0,000$ fruits.

Plum......... 5 to $S$ bus. may be considered an average crop for an average tree.

Potato......... I I oo to 300 bus.

Quince....... 200 to 400 bus.

Raspberry and blackberry.... 50 to Ioo bus.

Salsify........ 200 to 300 bus.

Spinach....... 200 barrels.

Strawberry..... 75 to 250 or even 300 bus.

Tomato....... 8 to I6 tons.

Turnip........ 600 to 1000 bus. 


\section{A COMBINED FRUIT AND VEGETABI GARDEN.}

(CORBETt.)

The following plan is suggested for a combined fruit and vegetable garclen for a farm or city home on a lot roo $\times$ So ft., the fruit garden occupying an area of $60 \times \mathrm{So} \mathrm{ft}$. and the vegetable garden an area of $40 \times 80 \mathrm{ft}$.

A. Fruit-bearing Plants that can be grown on an area of $60 \times 80$ ft.:

32 grape-vines, dispersed at intervals of to $\mathrm{ft}$. around the entire garden.

3 rows of dwarf pears, each containing 6 trees (rows Nos. 2, IO, If $)$.

I row of peaches, 6 trees (row No. 4 ).

I row of cherries, 6 trees (row No. 8 ).

I row of dwarf apples, 6 trees (row No. 6).

I row of plums, 6 trees (row No. 12).

I row, 20 specimens blackberries (row No. I).

2 rows, 40 specimens black-caps (rows Nos. 3 and 5 ).

2 rows, to specimens red rasplerries (rows Nos. 7 and 9).

3 rows, 300 specimens strawberries (rows Nos. I I, 13 , and ${ }_{5}$ ).

B. Vegetable Plants that can be grown on an area of $40 \times 80 \mathrm{ft}$ :

I row, $\frac{1}{2}$ row rhubarb, $\frac{1}{2}$ row asparagus (occupying $+\mathrm{ft}$.).

I row, salsify ( $\mathrm{I} \frac{1}{2} \mathrm{ft}$.).

I row, parsnips ( $\mathrm{I} \stackrel{1}{2} \mathrm{ft}$.).

2 rows, beets ( $3 \mathrm{ft}$.).

I row, egg-plant, plants set I $S$ in. apart, 2 doz. ( $3 \mathrm{ft}$.).

2 rows, tomatoes, plants set $2 \mathrm{ft}$. apart, 2 doz. (6 ft.).

I row, summer squash, I 2 hills, $3 \mathrm{ft}$. apart ( $3 \mathrm{ft}$.).

2 rows, cucumber, 24 hills, $3 \mathrm{ft}$. aj 2 rt (i ft.).

2 rows, early cabbage, 4 doz. plants, set is in. apart ( $4 \mathrm{ft}$.).

2 rows, late cabbage, 4 doz. plants, set is in. apart ( $4 \mathrm{ft}$.).

I row, early celery, 6 doz. plants, set $6 \mathrm{in}$. apart ( $2 \mathrm{ft}$.).

$S$ rows, peas, plant in double rows, 4 in. apart; follow by 6 rows, late celery, 36 plants ( $6 \mathrm{ft}$.).

2 rows, lima beans, 4 doz. hills, is $\mathrm{in}$. apart ( $+\mathrm{ft}$.).

6 rows, bunch beans; in succession sow seeds in drills, placing 
seeds about 6 in. apart in the row; follow by late cabbage, turnips, or spinach ( $2 \mathrm{ft}$.).

2 rows, radishes, 4 sowings, planted in double rows 6 in. $\operatorname{apart}(3 \mathrm{ft}$.$) .$

2 rows, lettuce, 2 sorts, adapted for early and late use ( $3 \mathrm{ft}$.$) .$

I row, parsley and pepper grass ( $\mathrm{I} \frac{1}{2} \mathrm{ft}$.).

The space occupied by the last three plants may be given over to winter squashes by planting these before other crops are off the ground. (See Farmers' Bull. No. 154.)

\section{A VEgETABLE FORCING CALENDAR. (WoOD.)}

\begin{tabular}{|c|c|c|c|c|c|}
\hline & $\begin{array}{l}\text { Night } \\
\text { Tem. } \\
\text { o F. }\end{array}$ & $\begin{array}{l}\text { Day } \\
\text { Tem. } \\
\text { of. }\end{array}$ & $\begin{array}{l}\text { From } \\
\text { Seed. }\end{array}$ & Soil. & Notes. \\
\hline Tomato. . & $60-65$ & 75 & 5 mos. & $\begin{array}{l}\text { Rich loose } \\
\text { loam. }\end{array}$ & $\begin{array}{l}\text { Transplant twice into } \\
\text { pots, hand pollinate, } \\
\text { grow on benches. }\end{array}$ \\
\hline Lettuce. . & $45^{-50}$ & $55-65$ & $10-12 \mathrm{~W}$. & $\begin{array}{l}\text { Open, porous, } \\
\text { dry on sur- } \\
\text { face. }\end{array}$ & $\begin{array}{l}\text { Solid or ground beds } \\
\text { best, transplant. }\end{array}$ \\
\hline Parsley.. & $45^{-50}$ & $55^{-65}$ & 8 whs. & $\begin{array}{c}\text { Open, well } \\
\text { drained. }\end{array}$ & $\begin{array}{l}\text { Best from spring-sown } \\
\text { plants transplant } \\
\text { and cut back. }\end{array}$ \\
\hline $\begin{array}{l}\text { Nater- } \\
\text { cress }\end{array}$ & $+5^{-50}$ & $55-65$ & ${ }_{4}-6 \mathrm{wks}$. & $\begin{array}{l}\text { Moist, cool } \\
\text { uniformly }\end{array}$ & $\begin{array}{l}\text { Not at all particular, } \\
\text { grow under tenchany- } \\
\text { where. }\end{array}$ \\
\hline $\begin{array}{l}\text { Pepper- } \\
\text { cress }\end{array}$ & $45-50$ & $55-65$ & 3-4 wks. & $\begin{array}{l}\text { Well drained } \\
\text { cool soil. }\end{array}$ & $\begin{array}{l}\text { Grow in beds with cau- } \\
\text { liflower, lettuce, etc. }\end{array}$ \\
\hline & $+5-50$ & $55-65$ & $5-6$ whs. & $\begin{array}{l}\text { Warm, quick } \\
\text { no coarse } \\
\text { manure. }\end{array}$ & $\begin{array}{l}\text { Rapid growth essential; } \\
\text { no old manure. }\end{array}$ \\
\hline Beans. & $60-65$ & $70-80$ & $6-S$ whs. & $\begin{array}{l}\text { "Quich," i.e., } \\
\text { loam and } \frac{1}{4} \\
\text { thoroughly" }\end{array}$ & $\begin{array}{l}\text { Best as catch crop be- } \\
\text { tween melons and to- } \\
\text { matoes. }\end{array}$ \\
\hline Peas... & $45-50$ & $55-65$ & $70-80 \mathrm{~d}$. & $\begin{array}{l}\text { Solid beds of } \\
\text { rich, sandy } \\
\text { zoil. }\end{array}$ & $\begin{array}{l}\text { Do not yield hearily, } \\
\text { and are useless after } \\
\text { April }\end{array}$ \\
\hline $\begin{array}{l}\text { Cauli- } \\
\text { flower }\end{array}$ & 50 & $60-65$ & $4-5$ mos. & $\begin{array}{l}\text { Solid bed gar- } \\
\text { den loam and } \\
\frac{1}{4} \text { rotten ma- } \\
\text { nure. }\end{array}$ & $\begin{array}{l}\text { Transplant once, abun- } \\
\text { dance of air and free } \\
\text { drainage, yet plenty } \\
\text { of water. }\end{array}$ \\
\hline $\begin{array}{l}\text { Mush- } \\
\text { rooms }\end{array}$ & $50-60$ & $50-60$ & $6-8$ wks. & $\begin{array}{l}\text { Moist (not } \\
\text { wet) manure, } \\
\text { + parts, loam, } \\
\text { I part. }\end{array}$ & $\begin{array}{l}\text { Grow under benches, or } \\
\text { anywhere that even } \\
\text { temperature can be } \\
\text { had. }\end{array}$ \\
\hline Asparagus & $50-55$ & $60-70$ & $2-3$ wks. & $\begin{array}{l}\text { Pack under } \\
\text { bencleses in } \\
\text { any material. }\end{array}$ & $\begin{array}{l}3^{-4} \text { years roots from } \\
\text { fielil crop depends } \\
\text { on vigor. }\end{array}$ \\
\hline Spinach. & $45^{-50}$ & $55-65$ & 8-10 w. & $\begin{array}{l}\text { Open, perous, } \\
\text { well enriched. }\end{array}$ & $\begin{array}{l}\text { Grow as a catch crop } \\
\text { between cauliflower. } \\
\text { etc. }\end{array}$ \\
\hline
\end{tabular}


SEASONS OF VARIETIES OF APPLES IN VARIOUS STORAGES. (BEACH AND CLARK.)

\begin{tabular}{|c|c|c|c|c|c|c|}
\hline & \multicolumn{3}{|c|}{ Season in } & \multicolumn{3}{|c|}{$\begin{array}{c}\text { Difference in Season } \\
\text { between }\end{array}$} \\
\hline & $\begin{array}{c}\text { Chemi- } \\
\text { cal Cold } \\
\text { Storage }\end{array}$ & $\begin{array}{c}\text { Ice } \\
\text { Storage }\end{array}$ & $\begin{array}{l}\text { Cellar } \\
\text { Storage }\end{array}$ & $\begin{array}{l}\text { Cellar } \\
\text { and } \\
\text { Ice } \\
\text { Stor- } \\
\text { age. }\end{array}$ & $\begin{array}{l}\text { Ice } \\
\text { and } \\
\text { Chem- } \\
\text { ical } \\
\text { Stor- } \\
\text { age. }\end{array}$ & $\begin{array}{c}\text { Cellax } \\
\text { and } \\
\text { Chem } \\
\text { ical } \\
\text { Stor } \\
\text { age. }\end{array}$ \\
\hline 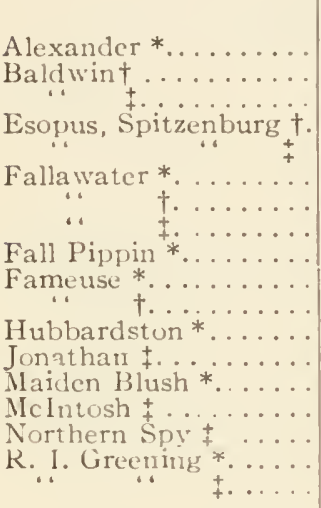 & $\begin{array}{l}\text { Nov. } \\
\text { June } 5 \\
\text { May } \\
\text { June I } 5 \\
\text { March } \\
\text { April } \\
\text { Mar. } 30 \\
\text { May } \\
\text { Nov. } \\
\text { Dec. } \\
\text { April I } \\
\text { March } \\
\text { March } \\
\text { Nor. } \\
\text { Jan. } \\
\text { April } \\
\text { Feb. } \\
\text { Ap:il }\end{array}$ & $\begin{array}{l}\text { Nov. } \\
\text { May 1 } \\
\text { April } \\
\text { June I } \\
\text { March } \\
\text { Mar. 20 } \\
\text { Nov. } \\
\text { Dec. } \\
\text { Feb. 15 } \\
\text { Feb. } \\
\text { Nov. } \\
\text { March } \\
\text { Feb. } \\
\text { March }\end{array}$ & $\begin{array}{l}\text { Oct. } \\
\text { April I } \\
\text { March } \\
\text { Mlay I } \\
\text { Jan. } \\
\text { Jan. } \\
\text { Mar. I } \\
\text { Jan. } \\
\text { Oct. } \\
\text { Oct. } \\
\text { Feb. I } \\
\text { Dec. } \\
\text { Jan. } \\
\text { Oct. } \\
\text { Nur. } \\
\text { Feb. } \\
\text { Dec. } \\
\text { Feb. }\end{array}$ & 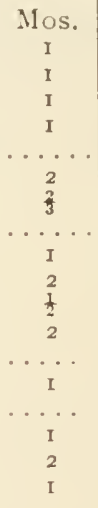 & $\begin{array}{c}\text { Mos. } \\
0 \\
\mathrm{I} \frac{1}{2} \\
\mathrm{I} \\
\frac{1}{2} \\
\ldots \ldots \\
\mathrm{I} \\
\frac{1}{3} \\
\ldots \ldots \\
0 \\
0 \\
\mathrm{I} \\
\mathrm{I} \\
\ldots \\
\ldots \\
0 \\
\cdots \cdots \\
\mathrm{I} \\
0 \\
\mathrm{I}\end{array}$ & $\begin{array}{c}\text { Mos. } \\
1 \\
2 \frac{1}{2} \\
2 \\
\mathrm{I} \frac{1}{2} \\
2 \\
3 \\
1 \\
4 \\
1 \\
2 \\
2 \\
3 \\
2 \\
1 \\
2 \\
2 \\
2 \\
2\end{array}$ \\
\hline
\end{tabular}

*.†,, \pm Reprorts of Chicago, Minneapolis, and New York Commission men, respectively.

PACKAGES USHI IN SHIPING HIRUT. (WAUgh.)

\begin{tabular}{|c|c|c|}
\hline Fruit. & Package. & Approximate Cost. \\
\hline Apple ..... & $\begin{array}{l}\text { Barrel, roo quarts, or } 3 \text { bushels ... } \\
\text { Boxes, various sizes . } \\
\text { Slat crate, mostly lialf bushel . . . . } \\
\text { Basket, mostly bushel .......... }\end{array}$ & $\begin{array}{l}\$_{25} \text { the I00 } \\
\text { Yariable } \\
\text { S. }_{40} \text { the } 100 \\
\text { SI to }_{1.25 \text { a doz. }}\end{array}$ \\
\hline $\begin{array}{c}\text { Peach ...... } \\
.\end{array}$ & $\begin{array}{l}\text { Delaware basket. ....fifth bushel . } \\
\text { Iichigan basket, one-fif. } \\
\text { Six-basket carrier. ............ }\end{array}$ & $\begin{array}{l}S_{2} \text { to } \$_{3} \text { the } 100 \\
S_{3} \text { the } 100 \\
\$_{7} \text { to } \$_{10} \text { the } 100\end{array}$ \\
\hline Peэr........ & 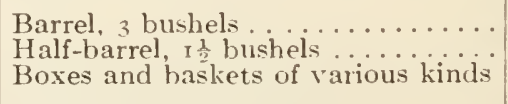 & $\begin{array}{l}\$_{25} \text { the } 100 \\
S_{1} 5 \text { to } \$ 20 \text { the } 100\end{array}$ \\
\hline Plum ...... & $\begin{array}{l}\text { Grape basket, ro pounds . . . . . . . . . . . . } \\
\text { Six-basket carrier. . }\end{array}$ & $\begin{array}{l}\$ 2.50 \text { the roo } \\
\$ 7 \text { to } \$ \text { io the roo }\end{array}$ \\
\hline
\end{tabular}




\section{PACKAGES USED IY SHIPPING IRUIL-Contin"}

\begin{tabular}{|c|c|c|}
\hline Fruit. & Package. & Approximate Cost. \\
\hline Cherry ...... & $\begin{array}{l}\text { Strawberry quart boxes and crates.. } \\
\text { 5-pound grape basket ........... }\end{array}$ & $\begin{array}{l}\text { Quart boxes, } \$_{\%} \text { to } \\
\$_{3} \text { the rooo; r } 6 . \\
\text { qt. crates, } \$ 5 \text { to } \$ 6 \\
\text { the roo } \\
\ldots \ldots \ldots \ldots \ldots \ldots\end{array}$ \\
\hline Quince...... & 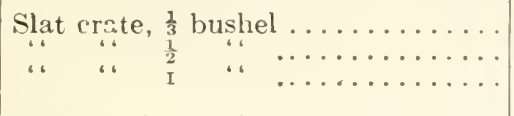 & $\begin{array}{l}\$ 3 \text { the } 100 \\
S_{4} \cdot 50 \text { the } 100 \\
\$ 7 \text { the } 100\end{array}$ \\
\hline Eerries..... & $\begin{array}{l}\text { Baskets in various styles. Also } \\
\text { barrels. } \\
\text { Quart boxes in crates............ }\end{array}$ & $\begin{array}{l}\text { Quart boxes, } \$_{2} \text { to } \\
\$_{3} \text { the rooo } \\
\text { I } 6-q \text { t. crates, } \$_{5} \text { to } \\
\$_{6} \text { the Ioo } \\
24 \text {-qt. crates, } \$_{7} \text { to } \\
\$_{15} \text { the Ioo }\end{array}$ \\
\hline
\end{tabular}

RELATION OF SPECIFIC GRAVITY, Dry Matter, and starch Content of Potatoes.

(ITOLFF)

\begin{tabular}{|c|c|c|c|c|c|c|c|c|}
\hline $\begin{array}{l}\text { Spec. } \\
\text { Grav. }\end{array}$ & $\begin{array}{c}\text { Dry } \\
\text { Sub- } \\
\text { stance. }\end{array}$ & $\begin{array}{l}\text { Starch } \\
\text { Con- } \\
\text { tent. }\end{array}$ & $\begin{array}{l}\text { Spec. } \\
\text { Gr..v. }\end{array}$ & $\begin{array}{c}\text { Dry } \\
\text { Siab } \\
\text { stance }\end{array}$ & $\begin{array}{l}\text { Starch } \\
\text { Con- } \\
\text { tent. }\end{array}$ & $\begin{array}{l}\text { Spec. } \\
\text { Grav. }\end{array}$ & $\begin{array}{c}\text { Dry } \\
\text { Sul. } \\
\text { stance. }\end{array}$ & $\begin{array}{l}\text { Starch } \\
\text { Con- } \\
\text { tent. }\end{array}$ \\
\hline & Per ct. & Per ct. & & Per ct. & Per ct. & & Perct. & Perct. \\
\hline 1. . 80 & IY. 7 & 139 & 1.107 & $25 \cdot 5$ & 19.7 & I 134 & $31 \cdot 3$ & 25.5 \\
\hline 081 & 19.9 & 14 I & .103 & 25.7 & 10.9 & .135 & 31.5 & 257 \\
\hline $\mathrm{C}_{2}$ & 20.1 & 14.3 & 109 & 25.9 & 20.1 & $.13 \mathrm{~F}$ & 31.7 & 25.0 \\
\hline 083 & 203 & I 4.5 & I.110 & $26 \mathrm{I}$ & 20.3 & .137 & 31.9 & 26.1 \\
\hline .08 .4 & 20.5 & 14.7 & . III I & 263 & 20.5 & 138 & $3^{2} .1$ & 26.3 \\
\hline 083 & 20.7 & 14.9 & III 2 & 26.5 & 207 & .139 & $32 \cdot 3$ & 26.5 \\
\hline $080^{\circ}$ & 20.9 & $15 \mathrm{I}$ & .113 & 267 & 20.9 & $1.1+0$ & $3^{2} 5$ & 267 \\
\hline 087 & $21 ?$ & 154 & 114 & 269 & $21 I$ & $.14 \mathrm{I}$ & 32.8 & 27.0 \\
\hline 083 & 21.4 & 15.6 & .115 & 272 & 21.4 & . $1+2$ & 33.0 & 27.2 \\
\hline .089 & 21.5 & 158 & .115 & 2.7 .4 & $<1.6$ & .143 & 332 & 27.4 \\
\hline 3.090 & 21.8 & 15.0 & . $1 \div 7$ & 27.6 & 21.8 & .144 & 334 & 276 \\
\hline .011 & 22.0 & 162 & .118 & $\because 78$ & 22.0 & .145 & $3: 0$ & 278 \\
\hline $0 y 2$ & 22.2 & 164 & 119 & 28.0 & 22.2 & .146 & 338 & 28.0 \\
\hline .093 & 22.4 & 166 & I. 120 & 28.3 & 22.5 & .1 .47 & 34.1 & 283 \\
\hline 091 & 227 & 16 9 & 121 & 28.5 & 22.7 & .148 & $34 \cdot 3$ & 285 \\
\hline .005 & 22, & 171 & $1<2$ & 28.7 & 22.0 & .149 & $3+.5$ & 28.7 \\
\hline .090 & $23 \mathrm{I}$ & 17.3 & 123 & 289 & 23.1 & I 150 & 34.7 & $28 . .1$ \\
\hline .197 & 233 & 175 & $.1 \%$ & $29 \mathrm{I}$ & 23.3 & $.15 \mathrm{I}$ & 34.0 & 201 \\
\hline .098 & 23.5 & 177 & 125 & $24 \cdot 3$ & 23.5 & .152 & 35.1 & 293 \\
\hline (1) & 237 & 179 & 126 & 29.5 & 23.7 & .153 & 35.4 & 206 \\
\hline (a) & 240 & 182 & .127 & 298 & 240 & .154 & $3=0$ & 298 \\
\hline . IS.T & $2 .+2$ & $18+$ & 123 & 300 & 24.2 & .155 & 358 & 30.0 \\
\hline$: n 2$ & $24+$ & 180 & .127 & $3^{0.2}$ & $24+$ & .156 & $3^{6} .0$ & 30.2 \\
\hline .103 & 24.0 & 188 & 1.130 & 304 & 24.6 & .157 & 362 & 304 \\
\hline 104 & 24.8 & 100 & .131 & 30,0 & 24.8 & 158 & 36.4 & 30.6 \\
\hline .105 & 250 & 19.2 & .132 & 30.8 & 25.0 & . 159 & 360 & 30.8 \\
\hline ICÓ & 25.2 & I. 4 & .133 & 31.0 & 25.2 & I. 160 & 36.9 & 31.1 \\
\hline
\end{tabular}




\section{SPECIFIC GRAVITY, SUGAR CONTENT, AND BOILING-POINT OF MAPLE SIRUI'.}

(COOKE AND Hills.)

\begin{tabular}{|c|c|c|c|c|c|c|}
\hline 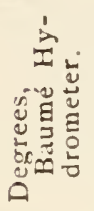 & 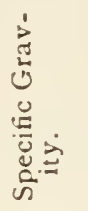 & 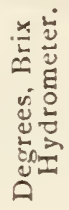 & 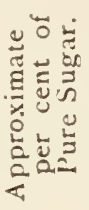 & 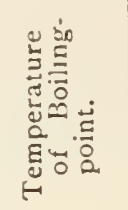 & 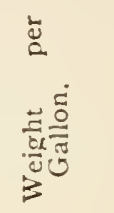 & 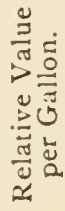 \\
\hline 25 & I. 205 & 44.9 & $4 I$ & $215.0^{\circ} \mathrm{F}$. & Io.olbs. & 68 \\
\hline 26 & I. 215 & 46.8 & 43 & 215.1 & IO. I & 72 \\
\hline 27 & 1.226 & $4^{8.7}$ & 45 & $215 \cdot 3$ & I0. 2 & 75 \\
\hline 28 & 1.236 & 50.5 & 47 & $25_{5} 6$ & 10.3 & $7^{8}$ \\
\hline 29 & 1. 246 & $5^{2} \cdot 4$ & 49 & 215.9 & 10.4 & 82 \\
\hline 30 & I. 257 & $54 \cdot 3$ & $5^{I}$ & 216.2 & J0. 5 & 85 \\
\hline $3^{I}$ & 1.268 & 56.2 & 53 & 216.6 & 10.6 & 88 \\
\hline 32 & I. 279 & $5^{8} x$ & 54 & 217.0 & 10.7 & 90 \\
\hline 33 & I. 290 & 600 & $5^{6}$ & 217.4 & 10. 7 & 93 \\
\hline 34 & 1.302 & 62.0 & $5^{8}$ & $218 . \mathrm{I}$ & 10.8 & 97 \\
\hline 35 & I. 313 & 63.9 & 60 & 218.6 & 10.0 & 100 \\
\hline 36 & I. 325 & 65.8 & 62 & $2 \times 9.5$ & II .O & 103 \\
\hline 37 & I. 337 & 67.8 & 64 & $220 \cdot 3$ & II. I & 107 \\
\hline $3^{8}$ & 1.350 & 69.8 & 66 & 221.2 & II. 2 & Iro \\
\hline 39 & I 362 & 71.8 & 68 & 222.0 & II $\cdot 3$ & $1 \times 3$ \\
\hline 40 & I. 374 & $73 \cdot 7$ & 70 & 223.2 & II. 4 & 117 \\
\hline $4 \mathrm{I}$ & 1. $3^{87}$ & $75 \cdot 7$ & $7^{2}$ & $224 \cdot 5$ & I 1.6 & 320 \\
\hline 42 & 1.400 & $77 \cdot 7$ & 74 & 226.0 & I I. 7 & 123 \\
\hline 43 & I. 415 & 798 & 75 & 227.8 & II. 8 & 125 \\
\hline 44 & I. 428 & $8 \mathrm{I} .8$ & 77 & 229.7 & II. 9 & 128 \\
\hline 45 & 1.442 & 83.9 & 79 & 231.8 & 12.0 & 132 \\
\hline $4^{6}$ & I. 457 & 86.0 & $8 \pi$ & 234.0 & 12. I & I 35. \\
\hline 47 & $1.47 \mathrm{I}$ & 88. I & 83 & $23^{6.3}$ & $12 \cdot 3$ & 138 \\
\hline 48 & I. $4^{86}$ & 90.2 & 85 & 238.7 & 12.4 & 142 \\
\hline
\end{tabular}

“The per cents of sugar given are calculated for a fairly good sirup. The relative values in the last column are based on these per cents, but will be nearly the same for all except the poorest of sirups. The relative value is made use of as follows: A weight of II pounds per gallon, and $35^{\circ}$ Baumé is taken as the standard; dividing the weight of the sirup by I g gives the number of standard gallons; multiplying the price that is to be paid for IIpound sirup by the relative value figure, and dividing by roo, gives the price to be paid per standard gallon.

"Example: If 75 cents a gallon is to be paid for II-pound 
sirup, how much should be paid for 671 pounds of sirup testing $3 \mathrm{I}^{\circ}$ by the Baumé hydrometer?

$67 \mathrm{I} \div \mathrm{II}=6 \mathrm{I}$ standard gallons.

$75 \times 8 S \div 100=66$ cents per gallon.

6 I $\times 66=\$ 4$ I.26, price to be paid."

\section{WEIGHT OF SUGAR OB'TAINED FROM 100 LBS. OI MAPLE' SIRUP}

Weighing 11 lbs, to the Gallon, when Sugared Off at Different Temperatures. (CoOkE AND Hir.s.)

\begin{tabular}{|c|c|c|c|c|c|c|c|}
\hline 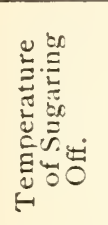 & 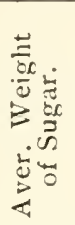 & 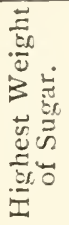 & 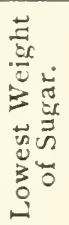 & 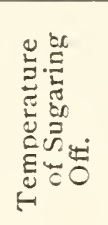 & 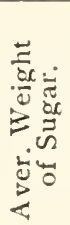 & 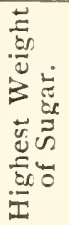 & 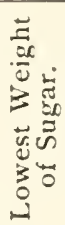 \\
\hline $\begin{array}{c}\text { Fahr. } \\
232 \\
233 \\
234 \\
235 \\
236 \\
237\end{array}$ & $\begin{array}{l}\text { Lbs. } \\
82.7 \\
81.9 \\
81.2 \\
80.8 \\
80.5 \\
80.0\end{array}$ & $\begin{array}{l}\text { Lbs. } \\
82.0 \\
80.5 \\
80.0 \\
79.5 \\
79.5 \\
79.0\end{array}$ & $\begin{array}{l}\text { Lbs. } \\
83.3 \\
82.8 \\
81.9 \\
81.6 \\
81.1 \\
80.9\end{array}$ & $\begin{array}{c}- \text { Fahr. } \\
238 \\
239 \\
240 \\
241 \\
242\end{array}$ & $\begin{array}{l}\text { Lbs. } \\
79.5 \\
79.2 \\
78.7 \\
78.5 \\
78.1\end{array}$ & $\begin{array}{l}\text { Lbs. } \\
78 \cdot 5 \\
78.4 \\
78.2 \\
77.9 \\
77 \cdot 4\end{array}$ & $\begin{array}{l}\text { Lbs. } \\
80.7 \\
80.3 \\
79.7 \\
79.3 \\
78.9\end{array}$ \\
\hline
\end{tabular}

SURGHUM SIRUP OBTAINED FROM JUICE OF DIFIERENT DENSITIES.

(Cleland)

\begin{tabular}{|c|c|c|c|c|}
\hline $\begin{array}{l}\text { Density } \\
\text { of Juice. }\end{array}$ & $\begin{array}{r}\mathrm{G} a \\
\text { Obta }\end{array}$ & $\begin{array}{l}\text { a1. Sirup } \\
\text { ained from }\end{array}$ & $\begin{array}{l}\text { Density } \\
\text { of Juice. }\end{array}$ & $\begin{array}{l}\text { Gal. Sirup } \\
\text { Obtained from }\end{array}$ \\
\hline $6^{\circ} \ldots \ldots \ldots$ & 10 & gal. juice. & $8.5^{\circ} \ldots$ & 7 gal. juice \\
\hline $6.5^{\circ} \ldots \ldots \ldots$ & 9 & $66 \quad 66$ & $9^{\circ} \ldots \ldots$ & $6.5 ،$ \\
\hline $7^{\circ}$. & 8.5 & “' & $10^{\circ} \ldots \ldots \ldots$ & 6 \\
\hline & 8 & "“ & II ${ }^{\circ} \ldots$ & $5 \cdot 5$ \\
\hline & $7 \cdot 5$ & “" & $12^{\circ} \ldots \ldots$ & "، \\
\hline
\end{tabular}

Sorghum juice usually shows $8^{\circ}$ to $10^{\circ}$ density; thin semisirup is $20^{\circ}$ density, heavy semi-sirtp is $30^{\circ}$, hot finished sirup is $36^{\circ}$ to $38^{\circ}$, and cold sirup about $40^{\circ}$ density. (Wiley.) 
THMPERATURES TO WHICH PERISHAH GOODS MAY BE SUB.JECTID WITHOUT IN-

JURY. (U. S. Departanes of Agricelture.)

\begin{tabular}{|c|c|c|c|c|c|}
\hline \multirow[b]{2}{*}{ Name of Aricle. } & \multicolumn{3}{|c|}{$\begin{array}{l}\text { Lnwsi Outside } \\
\text { Temperature }\end{array}$} & \multirow{2}{*}{ 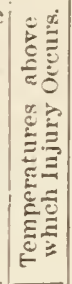 } & \multirow[b]{2}{*}{ Remarks. } \\
\hline & 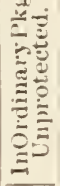 & 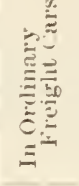 & 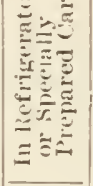 & & \\
\hline & $\bar{F}$ & $\circ$ is. & $\circ \mathrm{F}$. & $\overline{\circ F}$ & \\
\hline $\begin{array}{l}\text { Apples, in bbls .... } \\
\text { loose }\end{array}$ & 20 & 10 & -10 & 75 & Covered with straw. \\
\hline Apricots, baskets.... & $\begin{array}{l}28 \\
35\end{array}$ & $\begin{array}{l}15 \\
24\end{array}$ & $\begin{array}{r}-10 \\
10\end{array}$ & $\begin{array}{l}75 \\
70\end{array}$ & Packed in straw. \\
\hline Asparagus. ...... & 28 & 22 & $\ldots$ & 70 & In boxcs covered with mosw. \\
\hline Bunaras $\ldots . . .$. & 50 & 32 & . & 90 & Bulk or boxes with straw. \\
\hline Beans, snap. . .... . & 32 & 26 & $\cdots$ & 65 & In barrels or crates. \\
\hline & 26 & 20 & $\cdot$ & 70 & In ciates. \\
\hline $\begin{array}{l}\text { Cabbige, early or late } \\
\text { Cantalidipes. . . . }\end{array}$ & 25 & $\begin{array}{l}20 \\
25\end{array}$ & $\begin{array}{c}\text { zero } \\
\text { 10 }\end{array}$ & $\begin{array}{l}75 \\
80\end{array}$ & Barrels or crates. \\
\hline $\begin{array}{l}\text { Camtinoupes. ....... } \\
\text { Cauliflower } . . . . .\end{array}$ & $\begin{array}{l}32 \\
22\end{array}$ & $\begin{array}{l}25 \\
15\end{array}$ & $\begin{array}{l}10 \\
\ldots\end{array}$ & $\begin{array}{l}80 \\
70\end{array}$ & In barrels with straw. \\
\hline Celery $\quad . . .6 . .$. & 10 & zero & ... & 65 & l'acked in crates. \\
\hline Clseese. . .......... & 30 & 25 & Io & 75 & \\
\hline Cranberries. . ....... & 28 & 20 & zero & & \\
\hline Cucumbers $\ldots$... ... & 32 & 20 & & 65 & In boxes with moss. \\
\hline & 30 & 20 & zero & 80 & \\
\hline $\begin{array}{l}\text { Fish. } \quad \cdots \cdots \cdots \cdots \\
\text { Flowers. }\end{array}$ & 10 & zero & $\cdots$ & 65 & In barrels always iced. \\
\hline & $\begin{array}{l}35 \\
34\end{array}$ & $\begin{array}{l}20 \\
20\end{array}$ & $\begin{array}{l}\text {-10 } \\
\text { zero }\end{array}$ & $\cdots$ & $\begin{array}{l}\text { Packed in moss. } \\
\text { Packed in cork. }\end{array}$ \\
\hline Kale ............ & 15 & zero & $\ldots$ & 65 & Packed in boxes or crates. \\
\hline Leek $\quad \ldots \quad \ldots \ldots \ldots$ & 28 & 20 & $\cdots$ & 65 & Packed in boxes. \\
\hline l.emons. .......... & 32 & 20 & 10 & 75 & In boxes or crates. \\
\hline Lettuce. ............ & 26 & 15 & $\ldots$ & 70 & In boxes or crates. \\
\hline $\begin{array}{l}\text { Mandarins......... } \\
\text { Milk } \ldots\end{array}$ & $\begin{array}{l}32 \\
32\end{array}$ & $\begin{array}{l}20 \\
28\end{array}$ & $\begin{array}{l}\text { zero } \\
\text { zero }\end{array}$ & 75 & In boxes. \\
\hline $\begin{array}{l}\text { Milk } \\
\text { Olives, } \text { in bulk } \ldots . . .\end{array}$ & 28 & $\begin{array}{l}28 \\
25\end{array}$ & $\begin{array}{l}\text { zero } \\
\text { zero }\end{array}$ & 75 & In barrels. \\
\hline$\because \quad$ "glass ..... & 25 & 20 & zero & .. & \\
\hline Onions, boxes... .... & 20 & 15 & zero & & \\
\hline Onions................ & 20 & 10 & $\cdots$ & 80 & In barrels, boxes, or crates. \\
\hline Oranges......... & 28 & 20 & zero & 80 & Baskets.boxes, bbls., or crates. \\
\hline Parsley . ........... & $3^{2}$ & 20 & $\cdots$ & 75 & In baskets. \\
\hline Parsnips .... i... & 32 & 20 & $\because$ & 70 & In baskets or barrels. \\
\hline $\begin{array}{l}\text { Peaches, fresh, b'skets } \\
\text { P ads. } \quad \ldots \ldots \ldots \ldots\end{array}$ & $\begin{array}{l}3^{2} \\
3^{2}\end{array}$ & $\begin{array}{l}20 \\
20\end{array}$ & 10 & $\begin{array}{l}80 \\
80\end{array}$ & In baskets or barrels. \\
\hline Pincapples ........ & 32 & 25 & zero & 75 & In barrels, crates, or in bulk. \\
\hline Plum, $\quad \therefore . .$. & 35 & 32 & zero & 75 & In boxes with paper. \\
\hline Puiatoes, Irish $\ldots \ldots$ & 35 & 25 & 10 & 80 & In barrels or baskets. \\
\hline 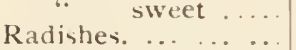 & $\begin{array}{l}35 \\
20\end{array}$ & $\begin{array}{l}28 \\
15\end{array}$ & 10 & $\begin{array}{l}80 \\
6=\end{array}$ & $\begin{array}{l}\text { In barrels or baskets. } \\
\text { In baskets. }\end{array}$ \\
\hline $\begin{array}{lll}\text { Rice. .. . . . . . } & \ldots \\
\text { Rices }\end{array}$ & 20 & $\begin{array}{l}15 \\
10\end{array}$ & $\cdots$ & $\begin{array}{l}65 \\
90\end{array}$ & $\begin{array}{l}\text { In baskets. } \\
\text { In baskets o }\end{array}$ \\
\hline Sirrubs, roses, or trees & 35 & 10 & -10 & . & In canvas or sacking. \\
\hline Spinach. $\quad$........... & 15 & ${ }^{15}$ & ... & 75 & In barrels or crates. \\
\hline Strawberries........ & 33 & 25 & -10 & 65 & \\
\hline Tangerines.. ........ & 25 & 15 & zero & 70 & In boxes. \\
\hline Thyme. ... .. $\cdots$ & 20 & 10 & $\cdots$ & 90 & In small baskets. \\
\hline Tom.tnes, fresh...... & 33 & $2 S$ & Io & 90 & \\
\hline $\begin{array}{l}\text { Turntp, late. ....... } \\
\text { Watermelons ...... }\end{array}$ & $\begin{array}{l}15 \\
20\end{array}$ & $\begin{array}{c}\text { zero } \\
\text { to }\end{array}$ & $\cdots$ & $\begin{array}{l}75 \\
85\end{array}$ & In barrels. \\
\hline & & & & & \\
\hline
\end{tabular}




\section{TEMPERATURES INJURIOCS TO PIANTS.}

(U. S. Dept. of Agriculture.)

The following table shows the temperatures at which the plants mentioned are liable to receive injury from frost. The temperatures are, as nearly as possible, those of the air in contact with the plant itself.

\begin{tabular}{|c|c|c|c|c|}
\hline Plant or Fruit. & In Bud. & $\begin{array}{c}\text { In } \\
\text { Blossom. }\end{array}$ & $\begin{array}{c}\text { In Setting } \\
\text { Fruit. }\end{array}$ & $\begin{array}{l}\text { At Other } \\
\text { Times. }\end{array}$ \\
\hline 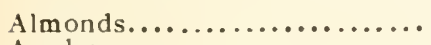 & 28 & 30 & 30 & 28 \\
\hline Apples .................... & 27 & 29 & 30 & 26 \\
\hline Apricots $\ldots \ldots \ldots \ldots \ldots \ldots \ldots \ldots$ & $3^{\circ}$ & $3^{1}$ & 32 & 30 \\
\hline Asparagus $\ldots \ldots \ldots \ldots \ldots \ldots \ldots$ & 29 & 29 & 29 & 26 \\
\hline 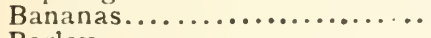 & $3 I$ & 31 & $3^{2}$ & $3 I$ \\
\hline 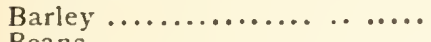 & . $\cdots \cdots$ & 29 & $\cdots \cdots \cdots \cdots$ & $\ldots \ldots \ldots$ \\
\hline Beans $\ldots \ldots \ldots \ldots \ldots \ldots \ldots \ldots \ldots$ & $\cdots \cdots \cdots \cdots$ & $3^{I}$ & $\cdots \cdots \cdots$ & $\cdots \cdots$ \\
\hline $\begin{array}{l}\text { Beets } \ldots \ldots \ldots \ldots \ldots \ldots \ldots \ldots \\
\text { Cabbage } \ldots \ldots \ldots \ldots \ldots \ldots \\
\end{array}$ & 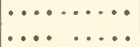 & $\cdots \cdots \cdots \cdots$ & $\mid \cdots \cdots \cdots$ & \\
\hline & $3^{2} \cdots \cdot$ & $\left|\begin{array}{c}\cdots \cdots \cdots \\
3^{2}\end{array}\right|$ & $\cdots \cdots \cdots$ & $3^{1-}$ \\
\hline 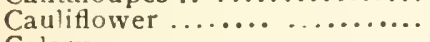 & $\ldots \ldots \ldots$ & $\ldots \ldots \ldots$ & $\cdots \cdots \cdots$ & $20-27$ \\
\hline$r y \ldots \ldots \ldots \ldots \ldots \ldots \ldots \ldots$ & $\ldots \ldots \ldots$ & $\ldots \ldots \ldots$ & .......... & 28 \\
\hline .............. & $3^{\mathrm{I}}$ & $3^{I}$ & $3^{I}$ & 32 \\
\hline lings or squash........... & $3 I$ & $3^{I}$ & $3^{I}$ & 30 \\
\hline 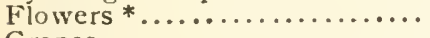 & 31 & $3 \mathbf{I}$ & $3^{r}$ & 30 \\
\hline$\ldots \ldots \ldots \ldots$ & $3^{I}$ & $3 \mathrm{I}$ & 30 & 28 \\
\hline 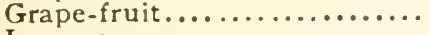 & 30 & $3 \mathrm{I}$ & $3 \mathrm{I}$ & 28 \\
\hline Lemons $\ldots \ldots \ldots \ldots \ldots$ & 30 & $3 \mathbf{I}$ & $3^{\mathrm{T}}$ & 28 \\
\hline $\begin{array}{l}\text { Lettuce } \ldots \ldots \ldots \ldots \ldots \ldots \ldots \ldots \\
\text { Mandarins } \ldots \ldots \ldots \ldots \ldots \ldots \ldots\end{array}$ & 31 & $\because \cdots$ & $\cdots \cdots$ & $12-28$ \\
\hline 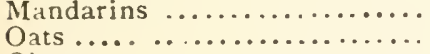 & $\begin{array}{l}3 \mathrm{I} \\
3 \mathrm{I}\end{array}$ & 31 & $3^{x}$ & 28 \\
\hline & $\ldots \ldots \ldots$ & $\mid \cdots \cdots \cdots$ & $\cdots \cdots \cdots$ & $\cdots \cdots \cdots$ \\
\hline 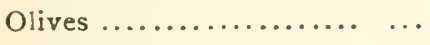 & 30 & $3 I$ & $\cdots$ & $\int 18 \neq$ \\
\hline 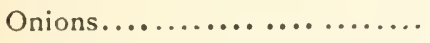 & $\ldots \ldots \ldots$ & $3^{*}$ & 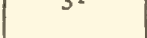 & $124 \S$ \\
\hline Oranges $+\ldots \ldots \ldots \ldots \ldots \ldots \ldots$ & 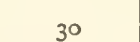 & & $\cdots \cdots \cdot$ & $\int_{20}^{20}$ \\
\hline Parsnips .................. & ... & . $\ldots \ldots$ & $3^{1}$ & $\left\{\begin{array}{l}20+ \\
29 \S\end{array}\right.$ \\
\hline 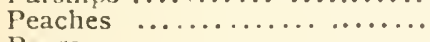 & $\ddot{29}$ & ${ }_{30} \ldots$ & $\cdots \cdots \cdots$ & 27 \\
\hline Pears ...................... & 28 & $\begin{array}{l}30 \\
29\end{array}$ & 30 & 29 \\
\hline 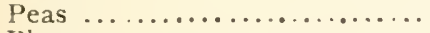 & 29 & $\begin{array}{l}29 \\
30\end{array}$ & 29 & 28 \\
\hline Plums.................... & 30 & $\begin{array}{l}30 \\
3 \mathrm{~T}\end{array}$ & 30 & 25 \\
\hline Potatoes: Irish $\ldots \ldots \ldots \ldots \ldots \ldots$ & 30 & $\begin{array}{l}3 \mathrm{I} \\
3^{\circ}\end{array}$ & $\begin{array}{l}3 \mathrm{I} \\
30\end{array}$ & 29 \\
\hline Sweet $\ldots \ldots \ldots \ldots \ldots$ & $3^{\mathbf{I}}$ & $3 \sqrt{5}$ & $\begin{array}{l}30 \\
31\end{array}$ & $\begin{array}{l}3 \mathrm{I} \\
3^{\mathrm{I}}\end{array}$ \\
\hline Prunes $\ldots \ldots \ldots \ldots \ldots \ldots$ & 30 & $3 \mathrm{I}$ & $3 \mathrm{r}$ & 29 \\
\hline 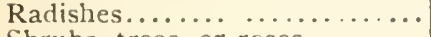 & & & $\cdots \cdot$ & 25 \\
\hline Shrubs, trees, or roses......... & $26-30$ & $28-32$ & & $30-26$ \\
\hline $\begin{array}{ccccccc}c h & \ldots & \cdots & \ldots & \ldots & \cdots & \ldots\end{array}$ & $\ldots \ldots \ldots$ & $\ldots \ldots$ & $\cdots \cdots \cdots$ & $2 \mathrm{I}$ \\
\hline Strawberries .... ........... & 28 & 28 & 28 & 30 \\
\hline Tangerines...$\ldots \ldots \ldots \ldots \ldots$ & $3 I$ & $3^{r}$ & $3 \mathbf{I}$ & 28 \\
\hline Tomatoes................... & $3^{1}$ & $3 I$ & $3 \mathrm{I}$ & $3 r$ \\
\hline ann. & ... & $\cdots \cdots$ & $\cdots \cdots$ & $\begin{array}{c}26 \\
28-31\end{array}$ \\
\hline 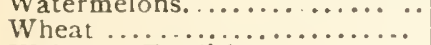 & .......... & $3_{3 r}$ & 31 & \\
\hline Walnuts, English............. & 30 & $3 r$ & $3^{r}$ & 28 \\
\hline
\end{tabular}

* Depends on variety. + Injured at 2 higher if continued $4^{-6}$ hours. ‡Ripe. \$Green. 


\section{BEST TEMPERATURES FOR PRISERVING HOR'TICULTURAI/PRODLCTS.}

(FAville AND Hall.)

\begin{tabular}{|c|c|c|c|}
\hline Product. & $\begin{array}{c}\text { Temperature. } \\
\text { Degrees. }\end{array}$ & Package. & Time. \\
\hline 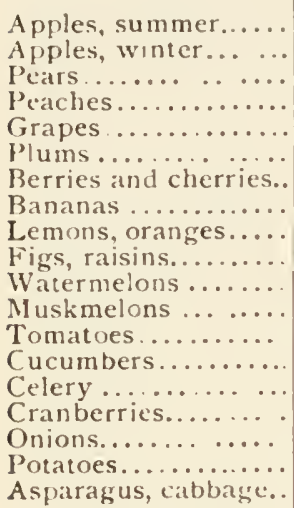 & $\begin{array}{l}38 \text { to } 42 \\
32 \text { to } 35 \\
33 \text { to } 3^{3} \\
36 \text { to } 3^{8} \\
38 \text { to } 40 \\
3^{8} \text { to } 40 \\
40 \\
40 \\
40 \\
40 \\
40 \\
40 \\
38 \text { to } 42 \\
38 \text { to } 40 \\
35 \\
34 \text { to } \\
34 \text { to } 40 \\
36 \text { to } 40 \\
34\end{array}$ & 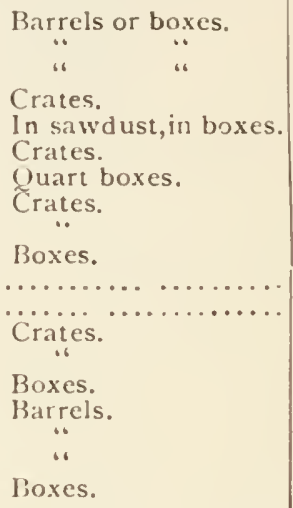 & 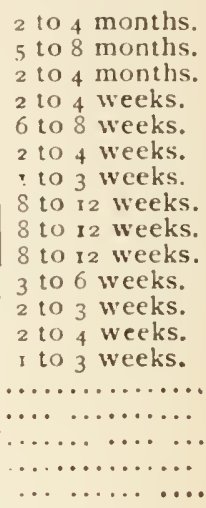 \\
\hline
\end{tabular}

\section{THE PIESERTATON OF" SOFT FRUITS FOR EXHIBITION PUIROSES.}

\section{(Departient of Agricuititre, Uttawa, Canada.)}

To preservestrawberries, raspberries, and other soft fruits, the following mixtures are recommended. The alcohol is not necessary except where the bottles will be exposed to frost. The chemicals mentioned in the list may be obtained at any drugstore.

General Directions.-Select the finest specimens of the fruit both as to form and size. Handle them carefully to avoid all bruising, and place them in bottles, arranging the specimens so as to show them to the best advantage. Fill each bottle to the neck with fruit, then pour on the fluid recommended, filling the bottles to within half an inch of the stopper so as to entirely cover the fruit. Then place the stopper in the bottle and run a little beeswax or paraffin over the joint to make it air-tight. Tie the stopper down with a piece of strong cotton and attach to each bottle 
a label containing the following particulars: Name of the variety of fruit, name and address of the grower. Write also in each case in one corner of the label the letter suggested to indicate the fluid which has been used. Wrap the bottles in paper to exclude the light, and preserve in a cellar or other cool place until required for shipment. Strawberries and raspberies should be cut from the plants or bushes with a pair of scissors, leaving a short piece of stem attached to each.

Fluld No. I.-Formalin (formaldehyde), one pound ( 6 oz.) ; water, 44 pounds; alcohol, 5 pints. Allow the mixture to stand, and should there be any sediment, pour of the clear liquid and filter the remainder through filteringpaper. This two-per-cent. solution of formalin has been found very useful for preserving strawberries so as to give them a natural appearance.

In each case where this fluid is used, mark $F$ on one corner of the label.

Fluid No. 2.-A solution of boric acid in the proportion of two per cent. Dissolve one pound of boric (boracic) acid in 45 pounds of water, agitate until dissolved, then add 5 pints of alcohol. If the fluid is not clear, allow it to stand and settle, when the clear upper portion may be poured off and the remainder filtered.

In each case where this fluid is used, mark B on one corner of the label.

Fluid No. 3.-A solution of zinc chlorid in the proportion of three per cent. Dissolve one-half pound of zinc chlorid in 5 pounds of water, agitate until dissolved, then add $1 \frac{2}{3}$ pints of alcohol. Allow the mixture to stand until settled, then pour off the clearfluid and filter the remainder.

In each case where this fluid is used, mark $Z$ on one corner of the label.

Fluid No. 4.-Sulfurous acid, I pint; water, $s$ pints ; alcohol, I pint. Allow the mixture to stand, and should there be any sediment, pour off the clear liquid and filter the remainder.

In each case where this fluid is used, mark $\mathrm{S}$ on the corner of the label. 


\section{List of Fruits with the Names of Ireservatizes to be L'sed in Each Case.}

(Where two fluids are named either may be used, but the first named is preferred.)

Strawberries._Solution No, r, formalın

Raspberries, Red.- No. 2, boric acid; No. 1. formalin.

Raspberries, White. - No. 4, sulfurous acid; No. 3, zinc chlorid.

Raspberries, Black. - No. 2, boric acid.

Blackberries. - No. 2, boric acid; No. 1, forma'in.

Cherries, Red and liark--No. r, formalin: No. 2, br ic acid

Cherries, White-No. 4 , sufurous acid.

Currants. Red.-No. I, fermalin; No 2 , boric acid.

Currants, 11 hite.-No. 4. sulfurous acid; No 3, zinc chiorid.

Currants, Black - No. 2, boric acid. Gooseberries - No. 1, formalin; No. 2 , boric acid.
Apples, fireen and Kusset.- No.3, zinc chiorid.

Apples more or less Red.-No. 2, boric acid.

App es, 11 hite and Yellow. -No. 4 , sulfurous acd.

Pears, Russet - No. 3, zinc chlorid.

l'ears. (ireen or Yeilow.-No 4 , sulfurous acid.

Plums dark-co'ored varieties.-No. 1. forma'in: No. ?, boric acid.

Plums. Green or Ye..ow.-No. 4 , sulfurous acid.

Peaches, Apricots, Nectarires, or Quinces.-No. 4, sulfurous acid; No. 3, zinc chiorid

Giapes, Red or l3lack.-No. I, formalin: No. 2. boric acid.

Grapes, (ireen or Ye'low.-No. 4, su.furous acid.

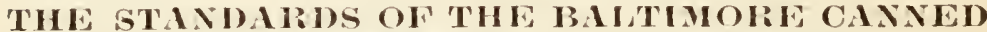 'GOOIDS IXCHINGI. (Y. Dept. of Agriculture.)}

\section{A. FirUits.}

Apples.-Pared and cored, clear in color; cans to be full of fruit, put up in water.

Blackberries. - Cans to cut out not less than two-thirds full after draining; fruit to be sound, put up in water.

Cherries, White $1 \mathrm{Tax}$ - Cans to be full of fruit, free of specks and decay, put up in not less than ten degrees of cold cane-sugar syrup.

Cherries, Red.-Cans full of fruit, free of specks or decay, put up in water.

Gooseberries.-Cans to cut out not less than two-thirds full after draining; fruit unripe and uncapped; put up in water.

Egg Plums and Green Gages.-Cans full, whole fruit, free from reddish color or specks, put up in not less than ten degrees of cold cane-sugar syrup.

Peaches.-Cans full, fruit good size, evenly pared, cut in half pieces, put up in not less than ten degrees of cold cane-sugar syrup.

Pic Peaches.-Cans full, fruit sound, unpared, cut in half pieces, put up in water.

Pears. Bartlett.-Cans full, fruit white and clear, pared, cut in 
half or quarter pieces, put up in not less than ten degrees of cold cane-sugar syrup.

Pears, Bell or Duchess. - Cans full, fruit pared, cut in half or quarter pieces, put up in not less than ten degrees of cold canesugar syrup.

Pineapples.-Cans full, fruit sound and carefully pared, slices laid in evenly, put up in not less than ten degrees of cold canesugar syrup.

Plums and Damsons.-Cans full, sound fruit, put up in water.

Quinces.-Cans full, fruit pared and cored, cut in half or quarter pieces, put up in not less than ten degrees of cold canesugar syrup.

Raspberries.-Cans to cut out not less than two-thirds full and after draining, fruit to be sound, put up in not less than ten degrees of cold cane-sugar syrup.

Strawberries.-Cans to cut out after draining not less than half full of fruit, which shall be sound, and not of the variety known as seedlings, put up in not less than ten degrees of cold cane-sugar syrup.

Whortleberries.-Cans full, fruit to be sound, put up in water.

\section{B. V'egetables.}

Lima Beans.-Cans full of green beans, clear liquor.

String Beans.-Cans full, beans young and tender and carefully strung, packed during growing season.

Corn.-Sweet corn only to be used from the cob while young and tender, cans to cut out full of corn.

Peas.-Cans full of young and tender peas, free of yellow or black eyes, clear liquor.

Pumpkin.-To be solid packed as possible, free from lumps and of good color.

Succotash.-Cans to be full of green corn and green lima beans.

Tomatoes.-Cans to be reasonably solid, of good, ripe fruit, cold packed.

STANDARD SIZES FOR CANS.

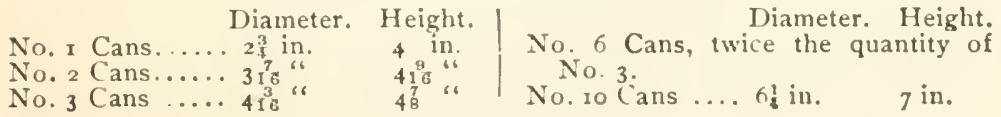




\section{SEEDS.}

\section{SEEI-TESTING FOR THE FARMER.}

Ey the late Gilbert H. Hicks, of U. S. Department of Agriculture.*

Not less important than good soil and suitable cultivation is seed of the best obtainable quality. In no feature of farm practice is niggardly econom or lack of proper attention more productive of disappointment and loss than in the failure to provide proper seed for sowing. The market gardener is fully alive to this fact, and makes the purcliase of desirable seed his foremost care. He wants not only seed which will grow, but also that which will produce an even stand and yield a large crop of the very best vegetables. The matter of paying a few cents or even a dollar extra per pound is to him of no significance, since he knows by long experience that the increased value of his crop will far outweigh the extra cost of the seed.

With many farmers this care in the selection of seed is often lacking. Frequently the land is all tilled and ready for sowing before the seed is bought. It is then too late to give it a careful preliminary test, even if the owner de. sired to do so. This results very often in a poor stand, perhaps in a failure of the crop, or in the scattering of hordes of weeds all over the farm, which usurp the place of the cultivated plants, and cost infinite trouble in their eradication. This is especially noticeable in the case of the clovers, grasses, and other forage plants. No maiter how poor the seed turns out to be, after once sown it is too late to secure any redress from the seedsman. Besides, there are very few places in this country where one can get seed tested in order that its real value may be ascer. tained before sowing. It becomes, ther, a matter of great importance to the farmer to provide himself with some simple but efficient means for testing his seed before it is sown.

All seed which is to be used for spring sowing should be procured whenever possible in the previous fall or winter.

* Revised by A. J. Pieters, late Kotanist in Charge of Seed and Plant Introduction, U. S. Department of Agriculture. 
The long winter months will give ample opportunity for close examination of the seed, and if any of it be found of inferior quality, as will not infrequently prove to be the case, there will be plenty of time to replace it with a desirable article. In all cases seed should be bought of the most reliable seedsmen. In many instances it will pay to get seed from the large dealers, as they have first-class opportunities for handling the very best seed in the country. The extra cost for carriage will be a small item compared with the chance for obtaining good seed.

No matter from what source the seed is obtained, nor how reliable the dealer, every farmer should test each lot of seed he expects to plant. Besides learning its quality, he will often obtain valuable information concerning the depth, temperature, and amount of moisture needed, etc. Furthermore, if the seed fails to come up well, the planter will have some intelligent data for ascertaining the reason, and will not be obliged to depend entirely upon the statement of seed catalogues, which convey the impression that failure to germinate is more likely to be the fault of the outdoor conditions than of the seed itself.

Good seed is marked by three characteristics : purityor freedom from foreign matter, whether seeds of weeds or other plants : vitality-or capacity for sprouting under favorable conditions; and genuineness-or trueness to name. If any of these qualities be lacking, the seed is unworthy of general trial.

Purity.-Most vegetable seeds, especially if grown in America, are quite free from admixture. Seed of the cabbage family, however, if grown abroad, and sometimes that of American origin, may contain a mixture of wild mustard or similar seed, often so near like the good seed as to be almost indistinguishable from it.

Clover and grass seed is very likely to contain more or less seed of noxious weeds or inferior grasses; hence a careful purity test is necessary in such cases. Hairy vetch and other leguminous forage seeds, excepting the clovers, generally come from Europe and are frequently impure. Often it will require considerable care to detect impurities 
in the seeds of forage plants, and in case of any doubt samples of such seed should be sent to the nearest experiment station or to the Department of Agriculture for examination.

Purity tests are usually made by weighing out a few ounces of seed which has been well stirred up so as to make the sample uniform. This seed is placed upon a pane of glass under whicl is a piece of light-colored paper, and the sample is carefully gone over seed by seed with a small forceps until all the inpurities are separated out. After again weighing, the percentage of impurity is easily obtained. If the impurity consists of chaff or dirt, the loss will consist only in paying for something which will not grow. This will render necessary the sowing of more than the usual amount of seed to the acre. If weed seeds are present, there will be greater or less loss according to the character of the weeds. Such seeds as Canada thistle, dodder, Russian thistle, chess, wild mustard. cockle, plantain, black medic, daisy, penny-cress, wild carrot, wild oats, and a few others, are serious pests. Every farmer should be able to recognize these weed seeds, and avoid all seed which contains any of them even in small amounts. He should also be familiar with the ordinary grass seeds of trade, such as June grass, orchard grass, the common fescues, red top, tall meadow oat grass, etc. Grass-seed mixtures almost invariably contain a large proportion of seed of inferior, if not worthless, species, dirt, and chaff, and should be avoided. It is much better to find out what grasses are adapted to one's fields or pastures and to buy such sted separately, mixing it at home.

If scales are not at hand, the amount of pure seed in a given sample can be approximately learned by placing the pure seed in a small bottle with the impurities in another bottle of similar shape and size. The names of the foreign seeds may be learned from some botanist or experiment station.**

* The following standards of purity are adopted by the U. S. Depart. ment of Agriculture :

Asparagus, beans, buckwheat, cabbage, cauliflower, celery, 
After determining the per cent of pure seed in a sample, the gorminative ability' should be ascertained. 'This is even more important. One can judge fairly well of the purity of seed by a casual inspection, but no one can tell by its looks whether a seed is capable of sprouting or not. Considering the great amount of labor and expense involved, it is surprising that so few farmers test their vegetable and field seeds before they are sown.

Even fresh seed is sometimes incapable of germination through improper care in harvesting or cleaning. Nor can fresh seed be told by its appearance with certainty. Add to this the fact that old seed is frequently offered for sale, and there is no lack of reason for testing the sprouting capacity of the seed one intends to sow.

If the heat and moisture are properly controlled, seedtesting will be found a very simple matter. Seventy to eighty degrees Fahrenheit must be maintained during the day, with a fall of not more than twenty degrees at night, and the seed must be kept constantly damp, but not wet. A good plan is to plant a hundred seeds of average quality -that is, an average number of large, small, plump, and shrivelled ones, etc. - in moist soil in a box or in a small flower-pot which is set inside of a large pot also containing soil. Water as needed is added from time to time in the larger pot and the whole is kept covered so as to prevent evaporation and sudden cooling. When the seeds begin to come up, the pots should be exposed to the light. After about two weeks for most seeds the seedlings are counted and the percentage of sprouts ascertained. If the soil has been previously heated to kill all weed seeds, and proper precautions have been taken, such a test will give a good indication of the value of the seed. To make sure, a dupli-

collards, Indian corn, cow pea, cucumber, eggplant, lettuce, melon, millet (common and pearl), oats, okra, onion, peas, pumpkin, radish, rutabaga, salsify, squash, tomato, turnip,

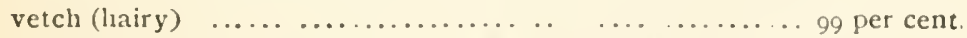
Alfalfa, beets, crimson clover, red clover, cotton, Kafir corn,

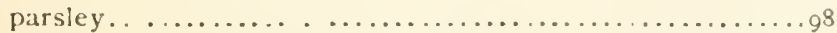

Parsnip

$\begin{array}{ll}6 & 6 \\ 6 & 6 \\ 6 & 6 \\ 6 & 6\end{array}$


cate lot of one hundred seeds should be tested at the same time under the same conditions and the results compared. If the variation exceeds ten per cent, the tests should be repeated until the source of error is discovered. Grasses and very fine seed will require more care than other kinds. Such seed should be barely covered with soil, while in all cases too deep planting must be avoided. In testing grass seeds, cxcept timothy, care must be taken that the heavier chaff, which looks like good secd, but does not contain a grain, is not counted with the good seed. Every seed should be gently pressed with the finger-nail or with a small penknife to determine whether or not it contains a grain. The chaff should count as impurity, but should not be tested for germination. Some hard-coated seeds may be soaked a few hours in warm water, but as a usual thing it is better not to do so.

Secds of clovers and most vegetables can be easily germinated between two folds of damp flannel cloth piaced be tween two plates. Such tests permit frequent inspection of the seed, which should be thrown away as fast as it germinates, count being kept of the same. Damp blotters, porous dishes, and various kinds of especially prepared germinating apparatus are sometimes used in seed-testing. The amount of moisture to be given varies greatly with the variety of seed and can be best learned by experience. In general, quick-sprouting seeds, like clover, cabbage, radish, etc., will stand more moisture than those varieties which sprout more slowly.

To make sure of the vitality of seed it is better to test it in the soil, as previously suggested, and also by the cloth or plate method. Soil tests should be continued a few days longer than those made between cloth or blotters. There is considerable difference of opinion as to the standards of germination to which first-class seed should attain. Those in use at present by the U. S. Department of Agriculture are given in the first table on page I09. While first-class seeds should reach the standards referred to, it may be said that seed which falls as much as ten per cent below them seed not be rejerted as bad. 


\section{TABIE OF GERMUNATION STANOARDS.}

(U. S. Dept. of Agriculture.)

\begin{tabular}{|c|c|c|c|c|c|}
\hline Seed. & & Seed. & & Seed. & \\
\hline Asparagus ...... & 85 & Cucumber...... & 90 & Okra & 90 \\
\hline Beaus, bush .... & 95 & Egg-plant ....... & 80 & Onion. ........ & 85 \\
\hline " lima ..... & 95 & Endive .......... & 94 & Parsley............. & 75 \\
\hline Beet. $\ldots \ldots \ldots \ldots \ldots$. & 150 & Gluerkin ... ...... & 92 & Parsnip.......... & 75 \\
\hline Borecole .. ...... & 95 & Grasses: & & Peas............. & 08 \\
\hline Broccoli ........ & 85 & Canada blue..... & 50 & Pepper ........ & 85 \\
\hline Brussels sprouts. & 95 & Fowl meadow... & 75 & Puimpkin. ....... & 90 \\
\hline wlieat ..... & 95 & Johnson .... ... & 75 & Radish... ........ & 95 \\
\hline age $\ldots \ldots \ldots$ & 95 & brome & 80 & Rape . . . . . . . . & 95 \\
\hline ot $\ldots \ldots \ldots \ldots$ & 85 & Kentucky blue.. & 50 & Rhubarb ....... & 85 \\
\hline Cauliflower....... & 85 & Meadow fescue.. & 80 & Kutabaga..... . & 95 \\
\hline Celeriac ......... & $\sigma_{5}$ & ind $\ldots \ldots \ldots$ & 80 & Salsify .... .... & 83 \\
\hline Celery ....... & 65 & blue...... & 50 & Sorghum........ & go \\
\hline Chicory ........... & 85 & Timothy .. .... & 90 & Sninach.......... & 89 \\
\hline Clover, alfalfa.... & $9 \circ$ & Kafir corn......... & 90 & Spurry ........ & 90 \\
\hline " alsike. & 80 & Kohl-rabi.......... & 90 & Squash ........ & 90 \\
\hline red....... & 90 & Leek. & 85 & Sunflower ........ & 90 \\
\hline scarlet. & 95 & Leit & 90 & Tobacc & 88 \\
\hline " white..... & 80 & Lupin, yellow..... & 90 & Tomato........... & go \\
\hline Collards .......... & 95 & Melon...$\ldots$. & $9 \circ$ & Turnip....... & 95 \\
\hline 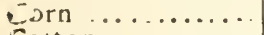 & 90 & Millet, common.... & 90 & Vetch, hairy... & 90 \\
\hline Cotton ...... & 90 & " pearl..... & 90 & Wheat ............ & 95 \\
\hline Cowpea ..... & 90 & Mustard... ...... & 95 & & \\
\hline & 90 & Oats................... & 90 & & \\
\hline
\end{tabular}

\section{AUMBER, WEIGHT, COST OF GRASS SEEDS, AND AMOUN'T' 'TO SOW PEI ACRE.}

\section{(Yearbook U. S. Dept. of Agriculture)}

[Columns 1, 2, 3, and 4 are compiled from "The Best Forage Plants," by Stebler and Schroeter. The figures in column 5 are obtained by multi. plying the amount of standard quality of seed required (col. 2) by the retail price quoted in N. Y. catalogues. The weight of ro,oos,ooo grains (col.6) is obtained by dividing this quantity by the number of seeds in one pound (col. 1).]

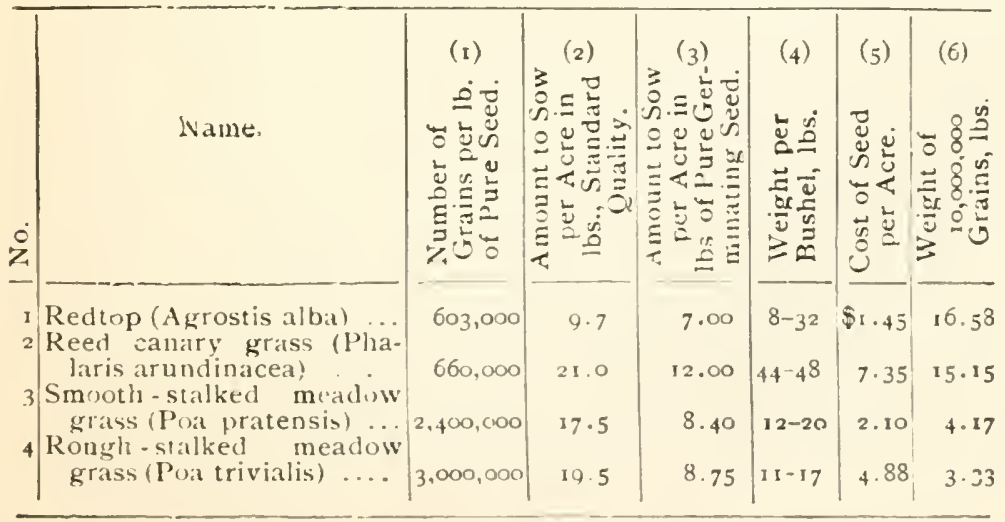




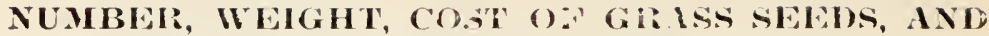
AMOUNT TO SOW PLI: ACIis-Continued.

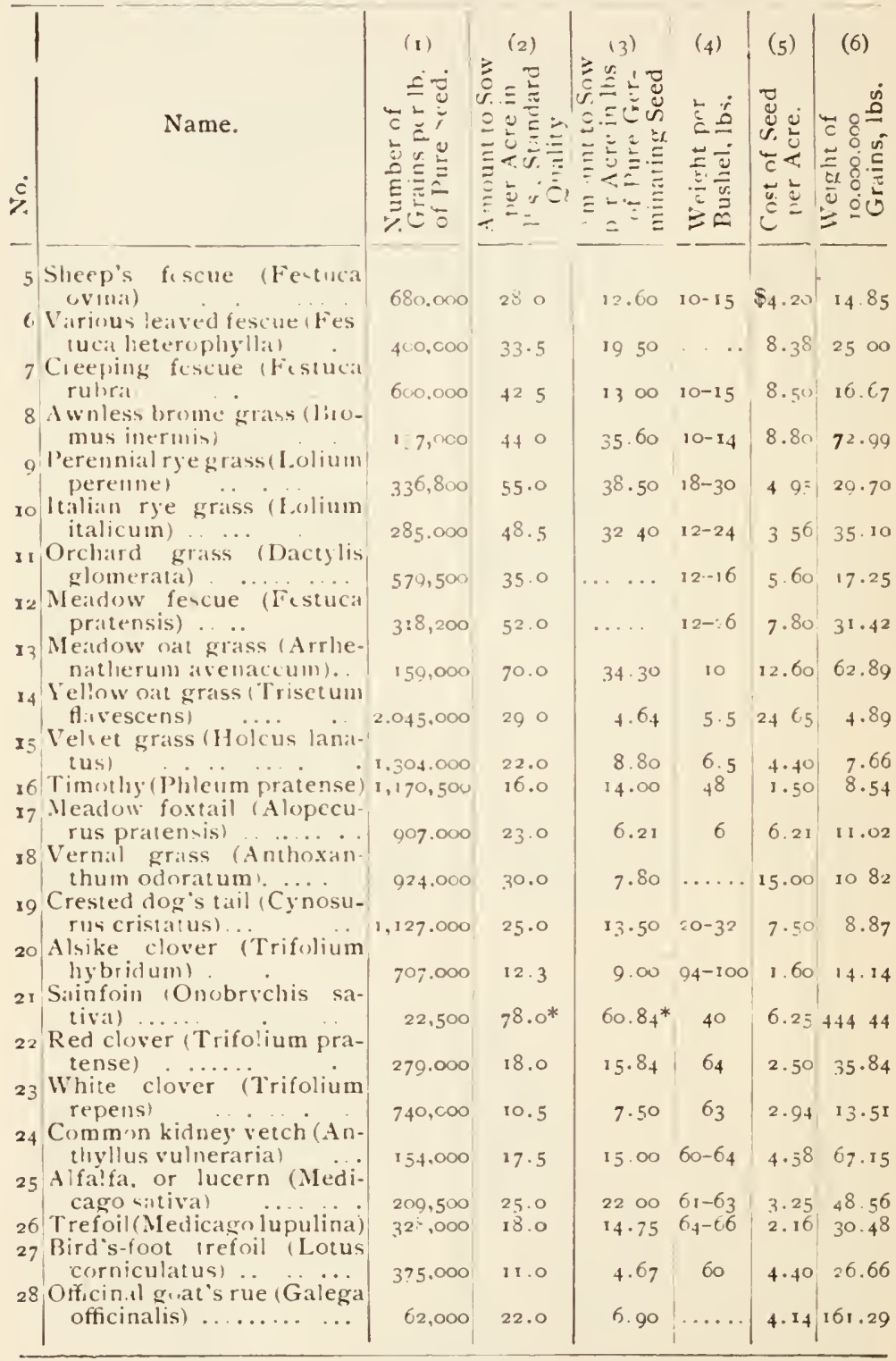

* Unshelled. 


\section{NOTES ON ADAPTABILITY AND USES OF PRE- CEDING GRASSES AND CLOVERS.}

No. 1. Requires moist climate or damp soil. Best propagated by transplanting small turf cuttings in autumn. Valuable for late pasturage or lawns in the New England and Middle States. Use 5-Io per cent in mixtures.

No. 2. Adapted to stiff, wet lands and flooded fields. Requires moisture. Valuable hay when cut young, and well suited for binding loose banks near running water or for forming a firm sod on marshy ground.

No. 3. Grows best on strongly calcareous soils. Well adapted for pasture, and makes a good bottom grass for meadows. An excellent lawn grass.

No. 4. Should be sown only on moist, fertile, and sheltered soils in mixtures.

No. 5. Light, dry soils, especially those which are poor, shallow, and silicious. Valuable bottom grass and for sheep pastures. Sown only in mixtures.

No. 6. Best on moist, low lands containing humus and sandy loams. Withstands drought; useful in pasture; unimportant for hay. Alone it makes no continuous turf.

No. 7. Valuable pasture or bottom grass. Withstands drought; endures both cold and shade. On poor land, especially moist sands and railway banks, serves to bind the soil. Product small.

No. 8. Valuable for light soils, especially in regions subject to extremes of heat or long periods of drought. Used alone or in mixtures for permanent meadows and pastures.

No. 9. Excellent and lasting pasture grass for heavy soils in moist, cool climates. On light, dry soils disappears after the second year. Rareiy sown alone.

No. Io. Excellent for rich and rather moist lands. Regarded in Europe as one of the best for hay. Lasts only two or three years.

No. II. Grows well on any soil, excepting that which is very wet; withstands shade. Affords a large amount of aftermath. Valuable alike for hay and pasturage.

No. I2. Thrives in either dry or wet soils. Valuable hay or pasture grass. 
No. I3. Thrives on moist, loamy sands or light clays which are not too moist, and marls. Spring most favorable seed-time. Valuable in the South for hay and winter pasture.

No. 14. Valuable for temporary or permanent pastures. Thrives on marly or calcareous soil, in all light land rich in humus.

No. I5. Sometimes sown on light, thin soils unsuited for more valuable sorts. Rarely used excepting in mix. tures.

No. 16. Best known and most extensively cultivated for hay. Sown alone or mixed with redtop or clover. Suc. ceeds best on moist loams or clays. On dry ground the yield is light.

No. 17. Endures cold. Likes strong soil, stiff loam, or clay. One of the best grasses for land under irrigation. Very early. Two to four pounds in mixtures for permanent pastures.

No. IS. Grows on almost any kind of soil; sown only in mixtures, I to 2 pounds, with permanent pasture or meadow grasses.

No. I9. Especially adapted for loams, light clays, marls, and moist, loamy sands. Níoist climates are most suitable. Withstands drought and thrives well in shade. Nutritive value high. Used in mixtures to form bottom grass either in pasture or hay.

No. 20. Grows on strongest clay or peaty soil: peculiarly adapted to damp ground. Bears heavy frosts without injury. Sown in August or February.

No. 2I. Requires good and open subsoil, free from water. Sown alone, from end of March to beginning of May.

No 22. Succeeds best in rich, loamy soil, on good clays, and on soils of an alluvial nature. A standard fodder plant.

No. 23. Thrives on mellow land containing lime, and on ail soils rich in humus. Resists drought. Generally used in mixtures for pastures or lawns.

No. 24. Cultivated for grazing; on warm soils, if manured 
and of proper depth. Hardy; resists drought. Sheep, goats, and horned cattle eat it greedily.

No. 25. Grows well on any calcareous soil having a permeable subsoil. Especially adapted to the warm and dry regions of the West and Southwest. Requires irrigation.

No. 26. Any soil containing sufficient moisture and lime is suitable. Most successful on clay marls. Cultivated only where the better kinds of clover cannot be grown.

No. 27. Thrives on dry or moist, sandy or clayey soils. Well suited to dry lands at high elevations, though poor.

No. 28. Excellent fodder plant for warm, sheltered situations. Thrives only in deep soil, and when subsoil is not wet.

\section{VITALITY OF SELDS I PROPEILY KEPT.}

(MCKERROW.)

Turnips........5 years

Rape........... 5

Pumpkin ........ 5

Peas............. 3

Beans............ 3

¿lover........... 3

Dats................ 3

Barley.
Wheat........2 2 years

Buckwheat......2 "

Corn.......... 2 "

Timothy........ "

Rye.......... "

Flax......... "

Millet.......... 2

Orchard-grass....2 " 


\section{SEEDSIEY'S CUSTOMIRY WEIGHTS PER IUSHEL OF SEEIS. (E. BROWN.)}

\begin{tabular}{|c|c|c|c|}
\hline Kind of Seed. & $\begin{array}{l}\text { Pounds } \\
\text { per } \\
\text { Bushel. }\end{array}$ & Kind of Seed. & $\begin{array}{l}\text { Pounds } \\
\text { per } \\
\text { Bushel. }\end{array}$ \\
\hline 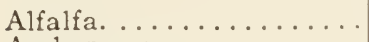 & 60 & Millet: & \\
\hline Amber cane............ & $45^{-60}$ & Barnyard. . . . . . . & $30-60$ \\
\hline Bent grass: & & Brorm corn......... & $45^{-60}$ \\
\hline 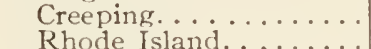 & $10-20$ & Common........... & $48-50$ \\
\hline & $10-15$ & German. . . . . . . . & $4 S-50$ \\
\hline $\begin{array}{l}\text { Bermuda grass. . . . . . . . } \\
\text { Bird's-foot cluver. . . . . }\end{array}$ & $24-36$ & Golden wonder. . . . . . & $48-50$ \\
\hline $\begin{array}{l}\text { Bird's-foot cluver. . . } \\
\text { Bitter vetch. . . . . . }\end{array}$ & $\begin{array}{l}60 \\
60\end{array}$ & & $48-50$ \\
\hline Blue grass: & & Milo maize... $\ldots \ldots \ldots \ldots$ & $\begin{array}{l}48-56 \\
50-60\end{array}$ \\
\hline Canada... & $14-20$ & Oat grass: & $10-14$ \\
\hline Kentucky. & $14-30$ & Tall..... & $7-14$ \\
\hline Texas. . . . . . . . . . & $\begin{array}{c}14 \\
50-60\end{array}$ & Yellow ............ & $45^{-60}$ \\
\hline $\begin{array}{l}\text { Broad bean. ........... } \\
\text { Brome, awnless. . . . }\end{array}$ & $\begin{array}{l}50-60 \\
10-14\end{array}$ & 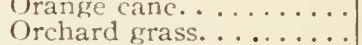 & \\
\hline Broom corn......... & $45-60$ & Pea: & $10-18$ \\
\hline Bur clover: & & 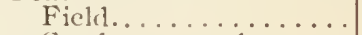 & 60 \\
\hline Hulled. . & 60 & Garden, smooth. ..... & 60 \\
\hline Enhulled. & $8-10$ & Garden, wrinkled.... & 56 \\
\hline Spotted.......... & 60 & 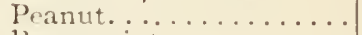 & $20-30$ \\
\hline Castor bean. . . . . . . . & $4^{6-60}$ & Rape, winter.......... & $50-60$ \\
\hline $\begin{array}{l}\text { Clover: } \\
\text { Alsike. ... . . . }\end{array}$ & 60 & Red ton: & \\
\hline Crimson!..... & 60 & Fanc $\ldots \ldots \ldots$ & $\begin{array}{l}10-14 \\
25^{-}-40\end{array}$ \\
\hline Egyptial & 60 & Rescue grass. . . . . . . . & $\begin{array}{l}25^{-4}+0 \\
12-28\end{array}$ \\
\hline Nammoth & 60 & Rice.............. & $+3-45$ \\
\hline Rrd..... & 60 & Ryc grass: & \\
\hline White... & 60 & English. . & $10-30$ \\
\hline Cowper. . & $56-60$ & Italian... & $14-25$ \\
\hline Crested dog's tail. ....... & $14-30$ & Sainf(in)... & $14-32$ \\
\hline Fescue: & & Sirradella. . & $28-36$ \\
\hline Hard... & I $2-16$ & Soy bean... & $58-60$ \\
\hline Meadow. & $14^{-24}$ & Spelt...... & $40-60$ \\
\hline Red.... & $12-15$ & Sunflowic.......... & $24-50$ \\
\hline Sheep's.. & $12-16$ & Sweet clover: & \\
\hline $\mathrm{d}^{\prime} \cdots$ & $14-24$ & Hulled. . . & 60 \\
\hline Flat pea. & $14^{-18}$ & Unhulled .......... & $2^{2} 3$ \\
\hline $\begin{array}{l}\text { Flat pea. } \\
\text { Flax..... }\end{array}$ & $50-60$ & Sweet curn (acc. to var.). & $36-56$ \\
\hline $\begin{array}{l}\text { Flax. } \\
\text { Hemp }\end{array}$ & $48-56$ & Swect vernal, perennial. & $6-15$ \\
\hline Japan clove & $40-60$ & $\begin{array}{l}\text { Tensinte } \ldots \ldots \ldots \ldots \ldots \ldots \\
\text { Timuthy. } \ldots \ldots \ldots \ldots \ldots\end{array}$ & $\begin{array}{c}40-60 \\
45\end{array}$ \\
\hline Hulled. & 60 & 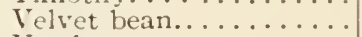 & $\begin{array}{l}45 \\
60\end{array}$ \\
\hline Unhulled........... & I $S-25$ & Vetch: & \\
\hline Johnson gráss. ........ & $14-2 S$ & $\mathrm{H}$-irs.... & $50-60$ \\
\hline Kafir corn $\ldots \ldots \ldots \ldots \ldots$ & $50-60$ & Spring. . . . . . . . & 60 \\
\hline Lentil. . . . . . . & 60 & Water grass, large. . . & I 4 \\
\hline Lupine, white. . . . . . . . & $50-60$ & Wild rice. ....... & $15-28$ \\
\hline Meadow foxtail.......... & $7-14$ & Yellow trefoil.......... & 60 \\
\hline $\begin{array}{l}\text { Meadow grass: } \\
\text { Fowl. ............. }\end{array}$ & $\mathrm{II}^{-} \mathrm{I}_{4}$ & & \\
\hline $\begin{array}{l}\text { Fowl. } \ldots \ldots \text { ilked. } \ldots \ldots \ldots \\
\text { Rough stalk }\end{array}$ & $14^{-20}$ & & \\
\hline 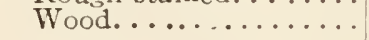 & $14-24$ & & \\
\hline
\end{tabular}


WEIGHT AND SIZW OF GARDEN SLIDS.

(VIHAORIN.)

\begin{tabular}{|c|c|c|c|c|c|}
\hline Name. & $\begin{array}{l}\text { Wt. of a } \\
\text { Qi. of } \\
\text { Seeds, } \\
\text { Uz. }\end{array}$ & $\begin{array}{l}\text { No. ot } \\
\text { Seeds } \\
\text { in a } \\
\text { Grain. }\end{array}$ & Name. & $\begin{array}{l}\text { Wt. of a } \\
\text { Qt. of } \\
\text { Seeds, } \\
\text { Oz. }\end{array}$ & $\begin{array}{l}\text { No. ct } \\
\text { Setds } \\
\text { in a } \\
\text { Graill. }\end{array}$ \\
\hline Anise. . & 11.7 & I.3 & Leek. . . & $2 I .4$ & 26 \\
\hline Asparagus bean & 20.9 & $32-42$ & Lettuce. & 16.7 & 52 \\
\hline Bean... & $24 \cdot 3$ & $* 5$ & aize.... & $24 \cdot 9$ & $+2-3$ \\
\hline Beet. . & 9.7 & 3 & Muskmelon..... & 14.0 & 4 \\
\hline $\mathrm{col}$ & 27.2 & 19 & Mustari, blick.. & 26.2 & 45 \\
\hline $\mathrm{col}$ & 27.2 & 24 & white & 29.1 & I 3 \\
\hline Cal & 27.2 & I0) & Nasturtiurn, 1all. & 13.2 & $t_{4}-5$ \\
\hline Carawa & 16.3 & 23 & dwart. & $23 \cdot 3$ & I \\
\hline Carrot: & & & Okra......... & 24.1 & $\dagger_{10-12}$ \\
\hline With spines. . & $9 \cdot 3$ & 45 & on. . . . . . . & 19.4 & I 6 \\
\hline Witho & 14.0 & 62 & a......... & $27.2-31.1$ & $+1-4$ \\
\hline Cauliflom & 27.2 & 24 & gray or field. & $26.4-31.1$ & $+3-5$ \\
\hline Celery.. & IS.6 & 102 & canut........ & $15 \cdot 5$ & $+1-2$ \\
\hline Chi & I 5.5 & 45 & er. . . . . . & $17 \cdot 5$ & 10 \\
\hline Cress, American.. & 21.0 & 02 & apkin...... & $9 \cdot 7$ & $\dagger_{2}$ \\
\hline com.garden & 28.4 & 29 & slane...... & 23.7 & 162 \\
\hline Cucumber, com. & 10.4 & 2 & ish. . . & 27.2 & 8 \\
\hline globe.. & 10.4 & 6 & Rhubarb... & $3 \cdot x-4 \cdot 7$ & 3 \\
\hline snake. & 17.5 & 3 & & 8.9 & 6 \\
\hline Dill. . . . . . & 11.7 & 58 & & 19.8 & 7 \\
\hline & 10.4 & I 6 & Ş̧uash.... & 16.7 & 6 \\
\hline End & 1.3 .2 & 39 & Tomato........ & I I. 7 & $10-26$ \\
\hline ris, fancy... & 17.5 & I & Turnip....... & 26.0 & 29 \\
\hline Ho & 0.7 & 13 & Watermelon... & 17.9 & $\dagger_{3}-4$ \\
\hline hlrabi....... & $27 \cdot 2$ & I0 & & & \\
\hline
\end{tabular}

* In roo grains. $\quad$ In ro grains.

AVERAGIS THA TEQUIRED FOR GARDEN SEIDS TO GIRMINATH. (BAILE.)

\begin{tabular}{|c|c|c|c|c|c|}
\hline Name. & Dayss. & Name. & Days. & Name. & Days. \\
\hline & & & & & \\
\hline & $7^{-1}$ & & & & $9^{-I}$ \\
\hline & $6-I$ & & & $\mathrm{R}$ & $3-6$ \\
\hline & I $2-18$ & & & & $7-1$ \\
\hline & $6-10$ & $\mathrm{Or}$ & $7^{-}$ & Tomato...... & $6-12$ \\
\hline ry.... & $10-20$ & & $6-10$ & Turnip....... & $4^{-8}$ \\
\hline
\end{tabular}

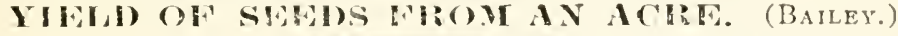

\begin{tabular}{|c|c|c|c|}
\hline & 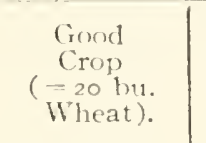 & $\begin{array}{l}\text { Maximum } \\
\text { Crop } \\
(=50 \text { bu. } \\
\text { Wheat }) .\end{array}$ & $\begin{array}{c}\text { Yicld Seedsmen } \\
\text { would Figure in } \\
\text { Making Contracts } \\
\text { lor Large Quan- } \\
\text { tities. }\end{array}$ \\
\hline 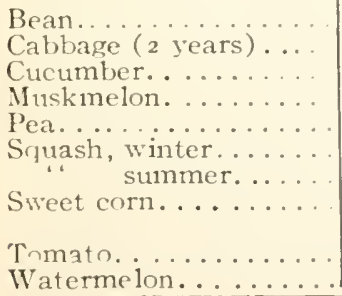 & $\begin{array}{l}600 \text { lbs. } \\
250 \\
150 \\
125 \\
900 \\
100 \\
100 \\
\text { 1000-2500 } \\
\text { (acc. to var.) } \\
100 \\
150\end{array}$ & $\begin{array}{l}1500 \mathrm{lbs} . \\
800 \\
700 \\
600 \\
2500 \\
400 \\
700 \\
2500-4000 \\
400 \\
1000\end{array}$ & $\begin{array}{l}500 \mathrm{lbs} . \\
200 \\
100 \\
100 \\
800 \\
100 \\
100 \\
800-2000 \\
100 \\
100\end{array}$ \\
\hline
\end{tabular}




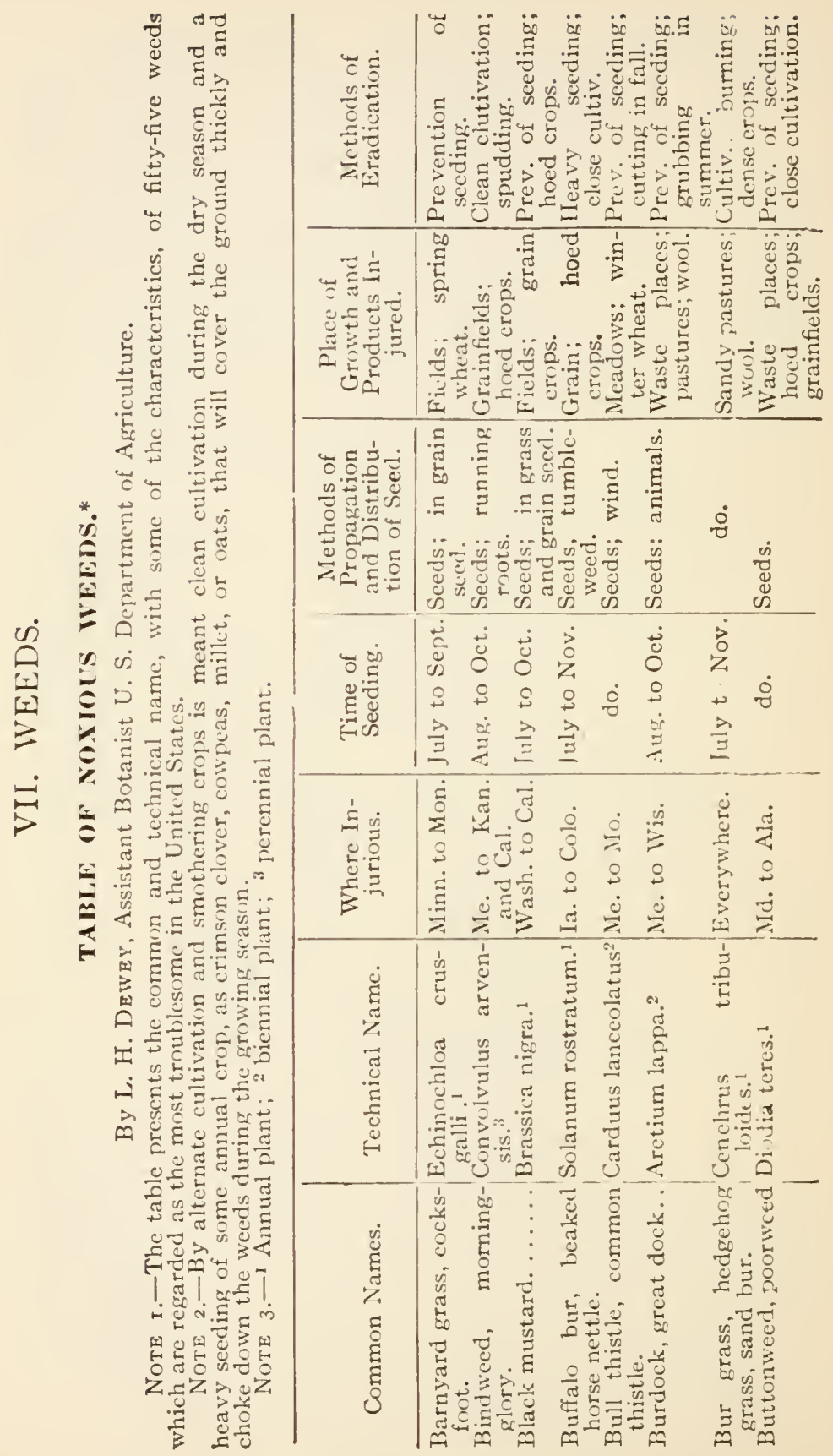




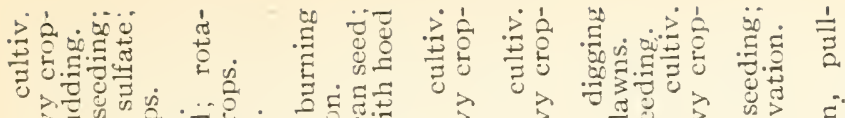

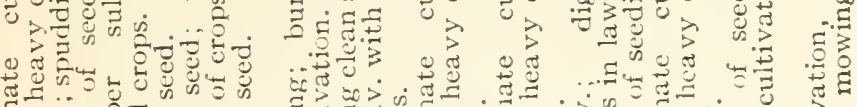
E.

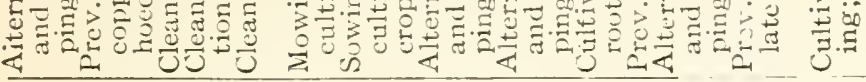

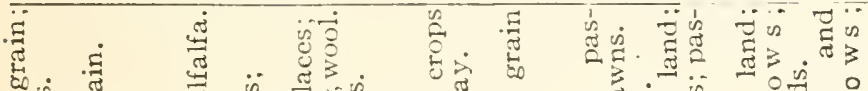
w

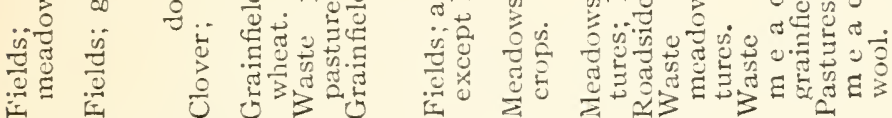

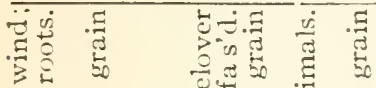

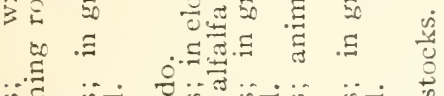

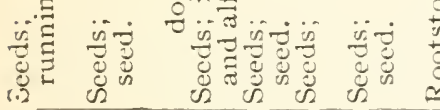

落

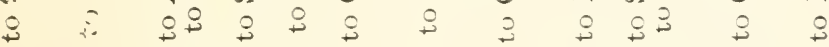

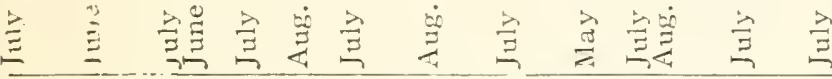

:

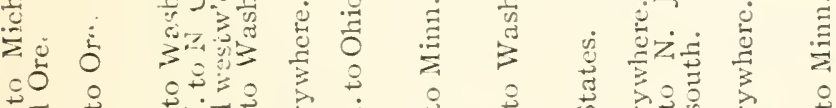

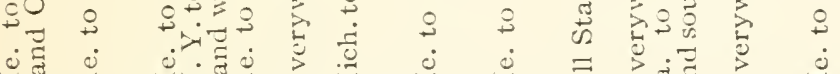

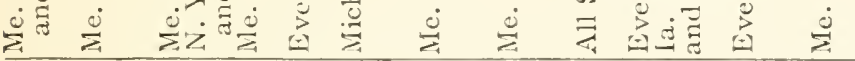

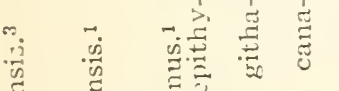

(3) $\quad$ व

¿ 2

-

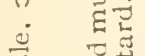

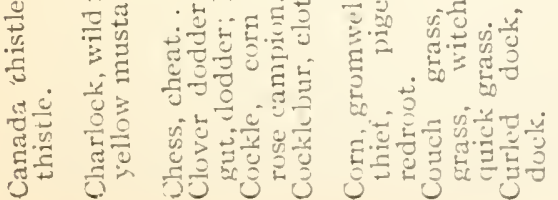

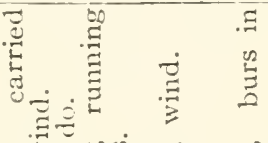

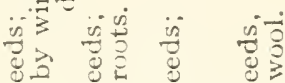

.

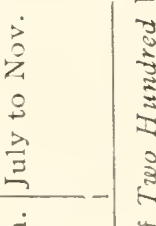

3

$\div$

$\underset{3}{3}$

H

范

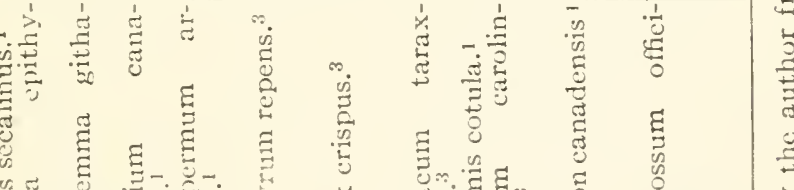

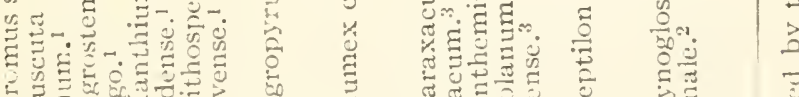

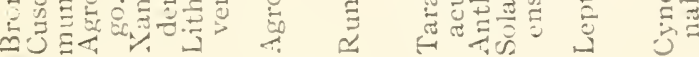

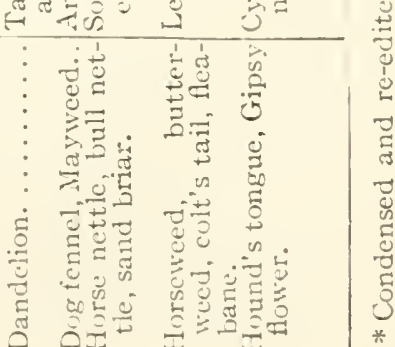




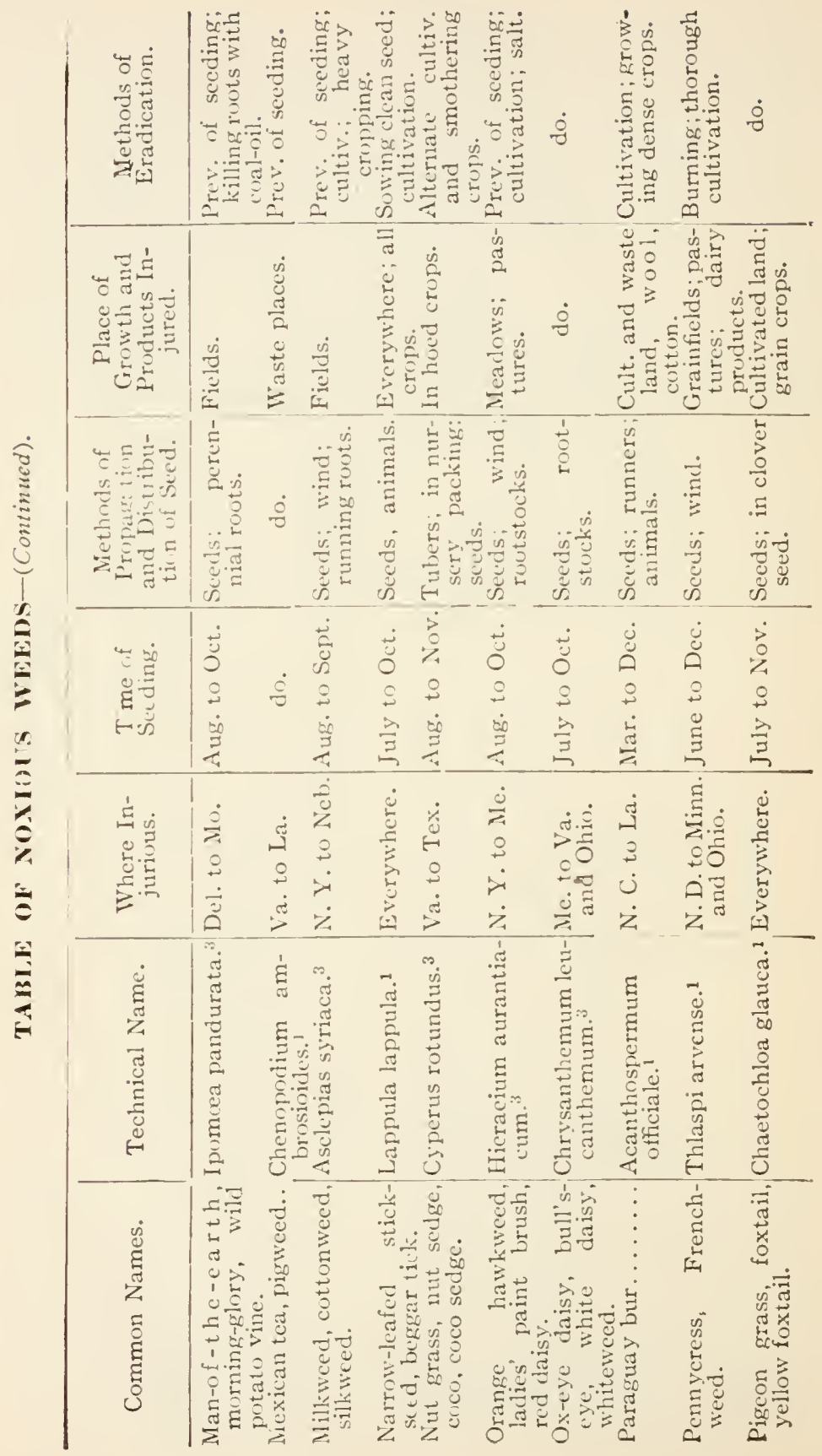




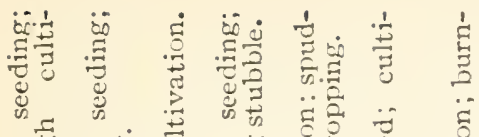

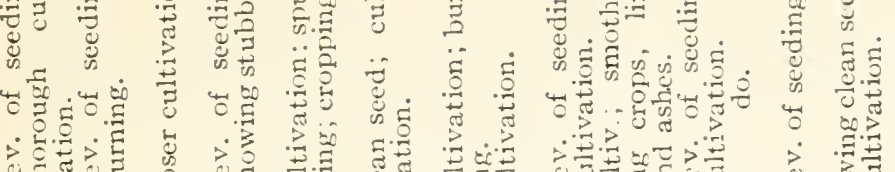

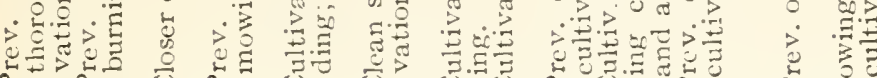
ه.

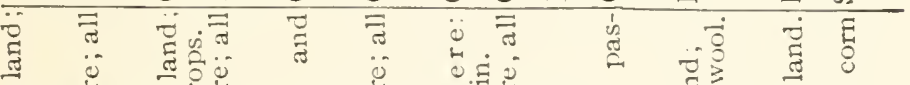

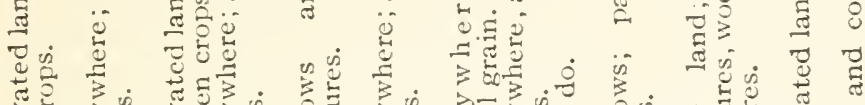

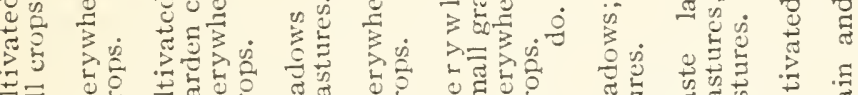

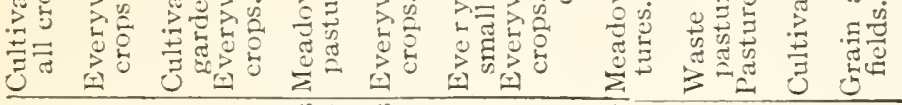

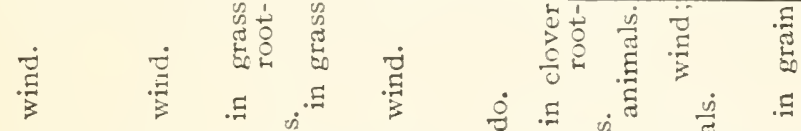

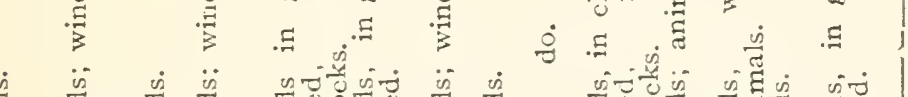

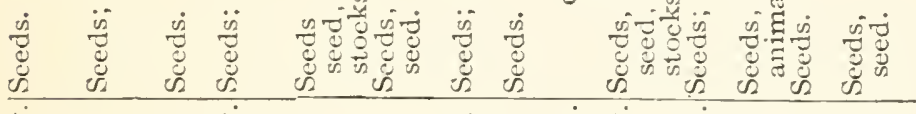

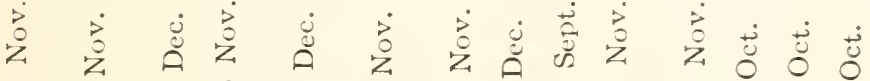

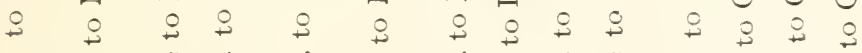

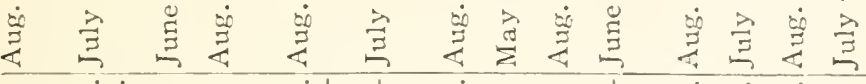
造

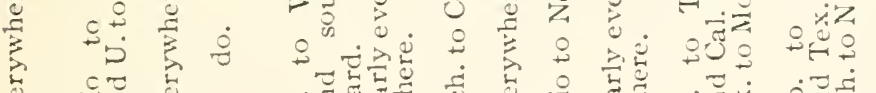
S

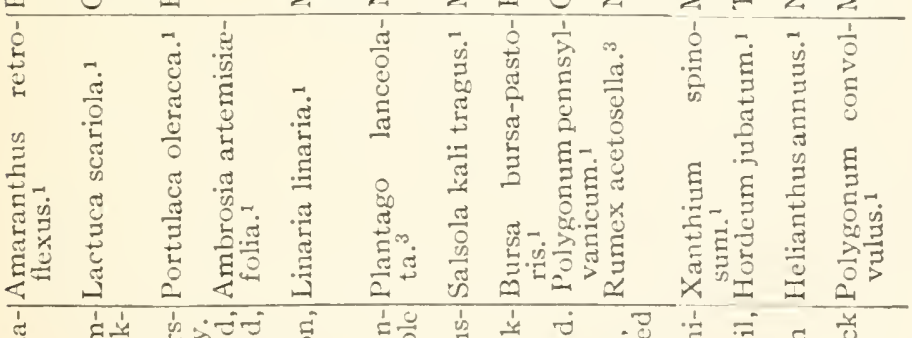

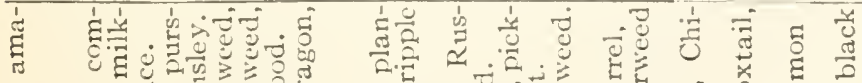
E 0

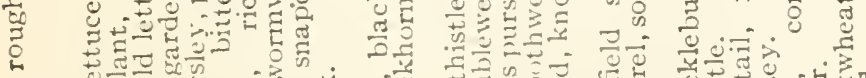

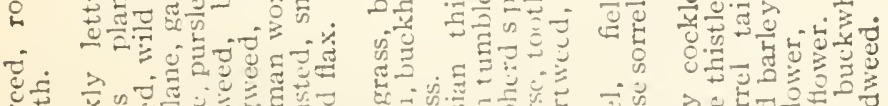

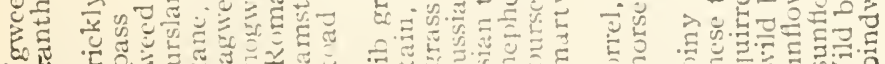

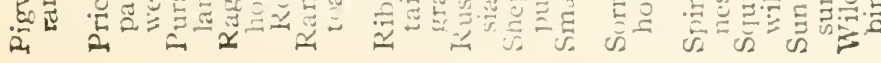




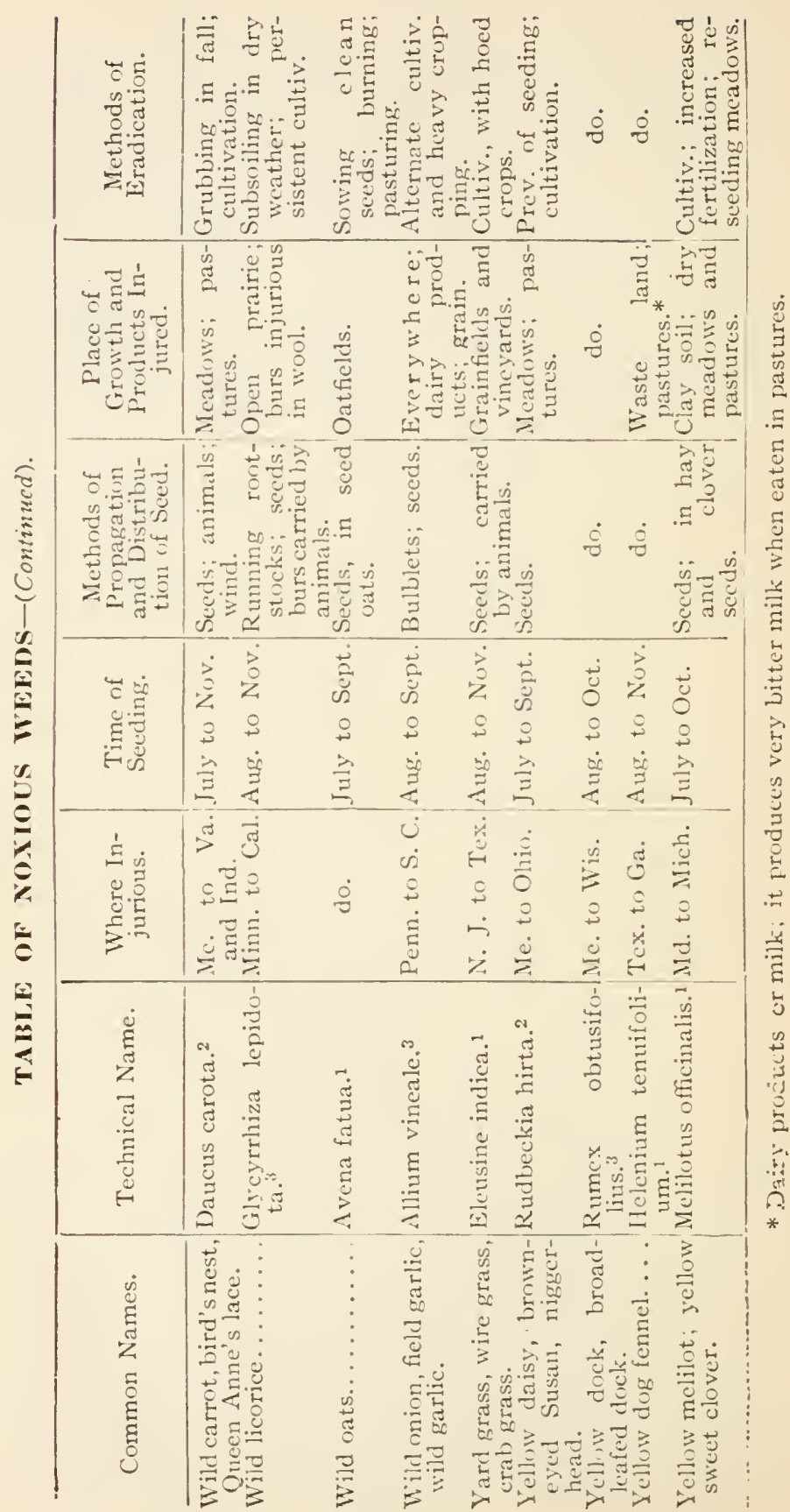




\section{ENEMIES OF FARM CROPS.}

\section{TREATMENTS HOR IXIURIOUS INSWCTS AND FUNGUS DISEASES OF PIANTS.}

By the late Prof. E. S. Goff, of Wisconsin Experiment Station.

The value of the following treatments for preventing injury to crops from insects and fungus diseases has been proved by abundant experience. It is essential that the treatments be given promptly and thoroughly. In the case of fungus diseases, it is generally essential that the applications be made bifor the disease appiars, since they are preventive, rather than curative. The treatments considered most imporant are frinted in italics. As a rule, those not so printed need be given only !n seasons or localities in which the attack is serious.

\section{Formulas.}

No. I. Bordeaux Fixture.-Place 4 pounds of coppersulfate in a cloth sack and suspend this over night in a wood vessel containing 4 gallons of water, immersing the sack. In another wood vessel slake 6 pounds of fresh lime in as many gallons of water. When the lime is cool, pour it and the coppersulfate solution into a barrel and add enough water to make 45 gallons. Apply at once with a force-pump, with spraying nozzle, stirring frequently during the application.

No. 2. Ammoniacal Copper Carbonate.-Dissolve I ounce of copper carbonate in 3 pints of strong ammonia and add this solution to 25 gallons of water. Apply as in No. I. No stirring is required.

No. 3. Copper Sulfate Soution.-Dissolve, as directed in No. I, I pound of copper sulfate in 15 gallons of water. Apply as in No 2.

No. 4. Stir 4 ounces of Paris green in 40 gallons of water, and add $\frac{1}{2}$ pound of fresh lime, slaked in 2 quarts of hot water. Apply as in No. 1 .

No. 5. Bordenux Mixture (No. I), with Paris green added at the rate of I ounce to Io gallons. Apply as in No. I.

* The following scheme for trealing crops is after a plan published by the late Mr. E. G. J.odemann of Cornell University, in Trans. N. I. State Agricultural Society for 1893, pp. $1700-179$. 
No. 6. London purple, 4 ounces, very thoroughly mixed with 25 pounds of land plaster. Apply with a sprinkling-box.

No. 7. Mix I ounce of fresh powdered while hellebore in 3 gallons of water. Apply at once with force-pumporsprinkling pot.

No. 8. Kerosene Emulsion.-Dissolve $\frac{1}{4}$ pound hard, or I quart of soft soap in 2 quarts of boiling water; place I pint of kerosene in a tin can; pour the boiling-hot solution into this, cork, and shake rapidly for I minute. Before using, dilute with its own bulk of warm soft-water. Apply as in No. 2.

No. 9. Mix I pound of fresh Fyrethrum fouder with an equal bulk of air-slaked lime in a bottle or tin can; cork tightly and leave 24 hours before use. Apply in still air, with sprinkling-box or powder-bellows.

No. Io. Air-slaked lime applied with a sprinkling-box.

No. Il. Cut small cards from thin tarred paper, slit one side to the centre, and make a short cross-cut near the end of the slit, as in drawing.

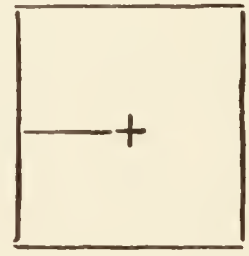

No. 12. Corrosize Sullimale Solution.-Dissolve $2 \frac{1}{4}$ ounces of corrosive sublimate in 2 gallons of hot water, and puur this solution into I5 gailons of cold water. Use wood. earthen, or glass vessels. For potuto scab the formaldeityd treatment is preferable (see p. 107).

No. I3. I'otassium Sulful Solution.-Dissolve $\frac{1}{2}$ ounce of potassium sulfid (liver of sulfur, sulfuret of potassium) in I quart of warm (not hot) water, and add this solution to 3 quarts of cold water. Apply as in No. 2. 

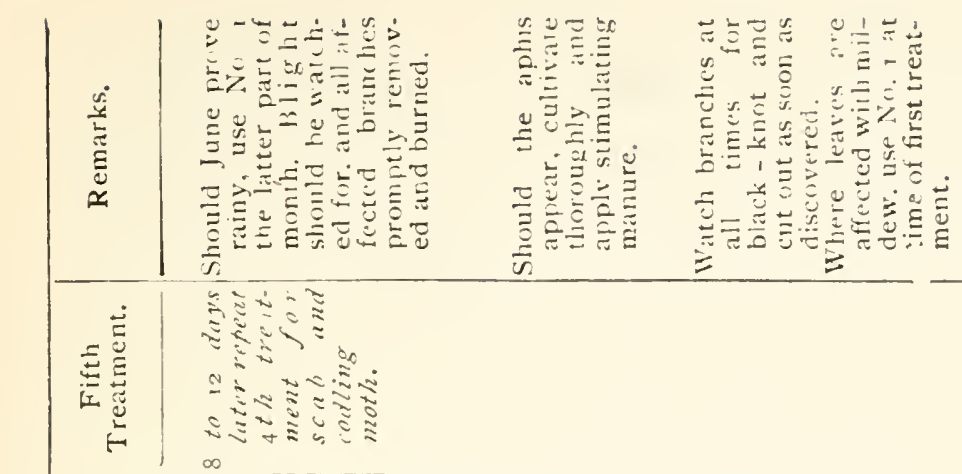

\begin{tabular}{|c|c|c|c|}
\hline 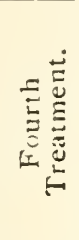 & 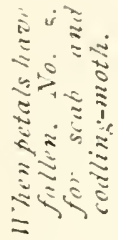 & 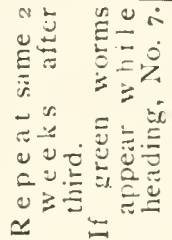 & 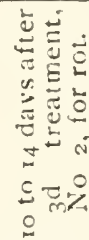 \\
\hline & & N $\dot{u}$ & $\dot{U}$ \\
\hline
\end{tabular}

$=$
$=$
$=$
$\frac{2}{2}$

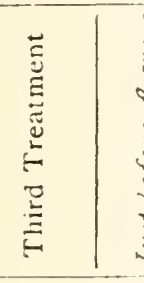

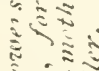

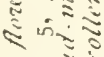

$\Leftrightarrow<5 \frac{1}{2}$

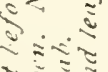

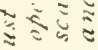

$\prod_{0}^{2}$

N

苋

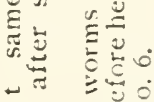

तै

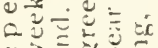

$0 \geqslant \overline{0}$

$\simeq \pm$

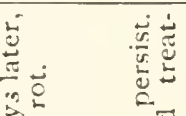

क क

อั

$\stackrel{5}{\longleftarrow} \infty$

2
0
0
0

¿ $\approx$ छ

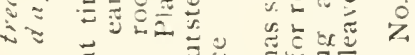

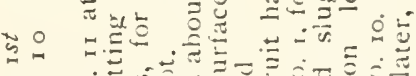

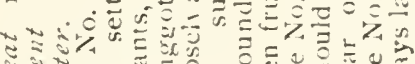

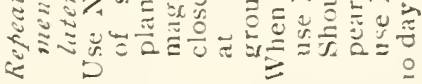

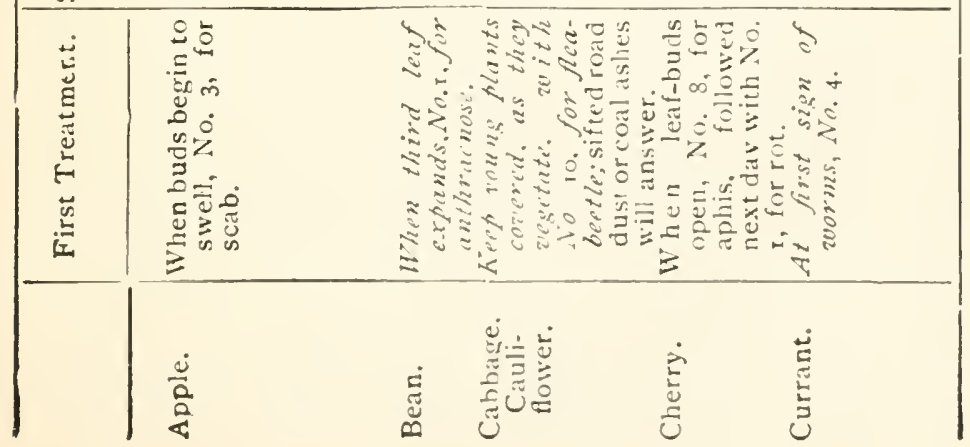




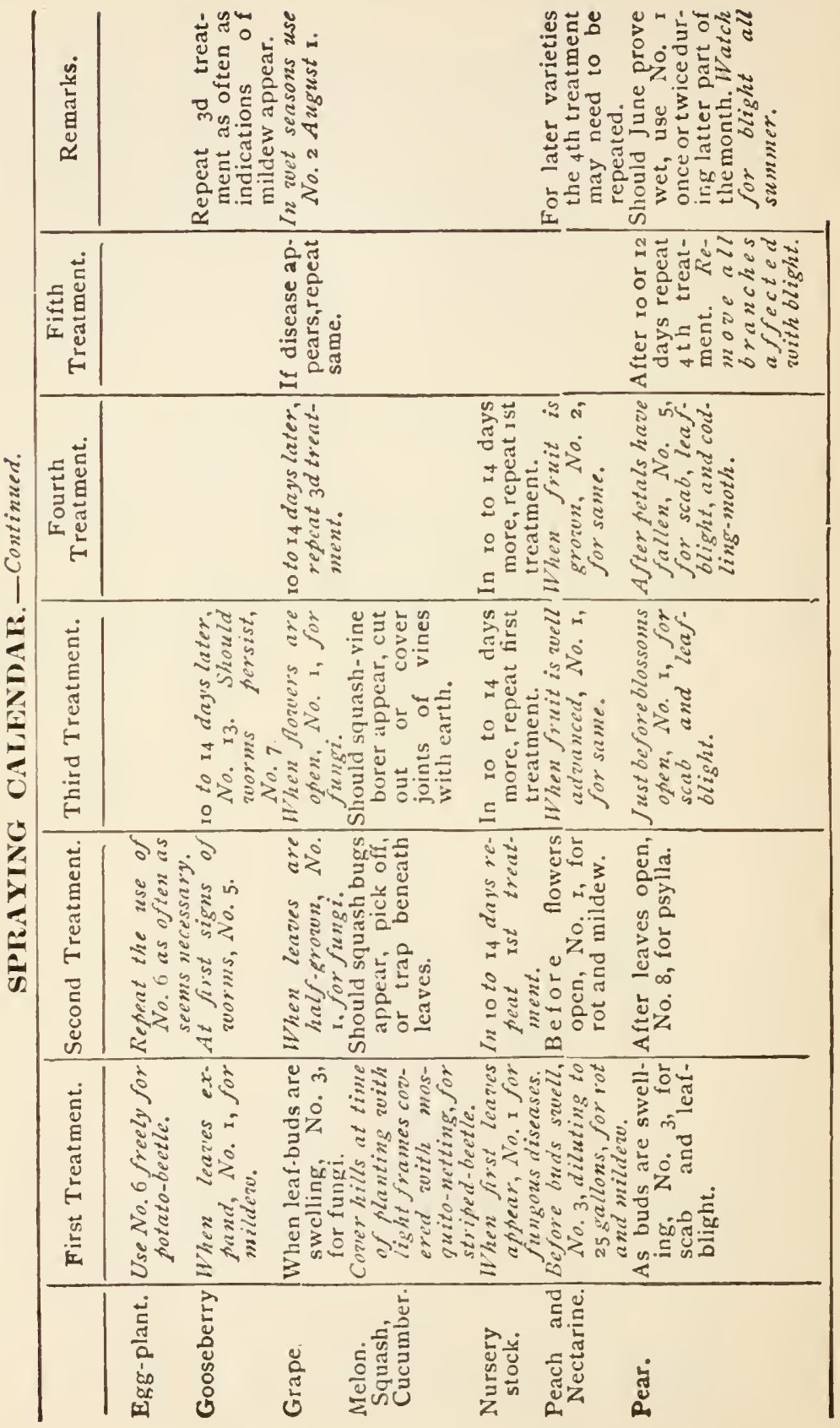




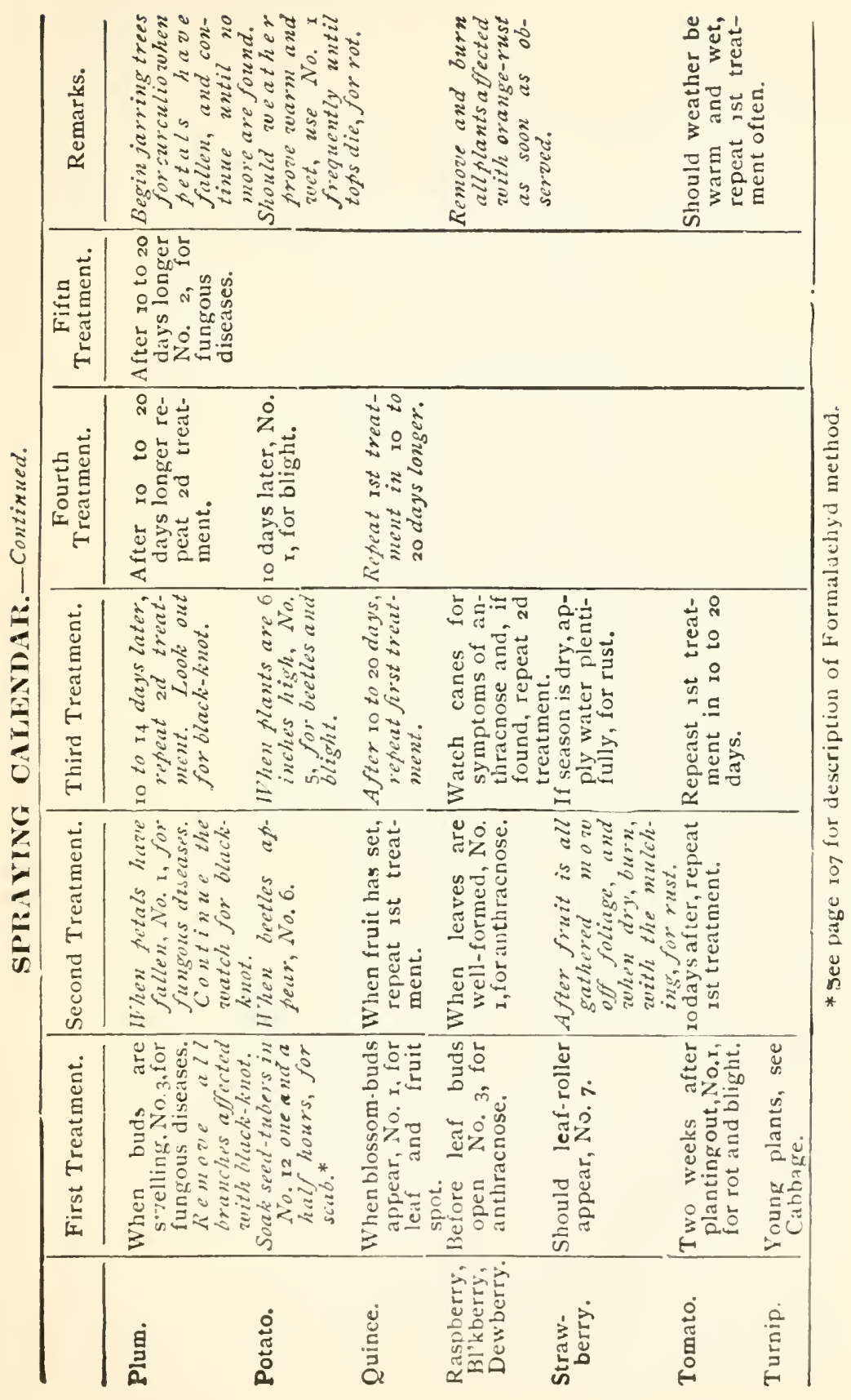




\section{A CHEAP ORCHARD-SPRAYING OUTFIT.}

(U. S. Dept. of Agriculture.)

Spraying to control various insect pests, particularly those of the orchard and garden, has reached so satisfactory and inexpensive a basis that it is recognized by every progres-

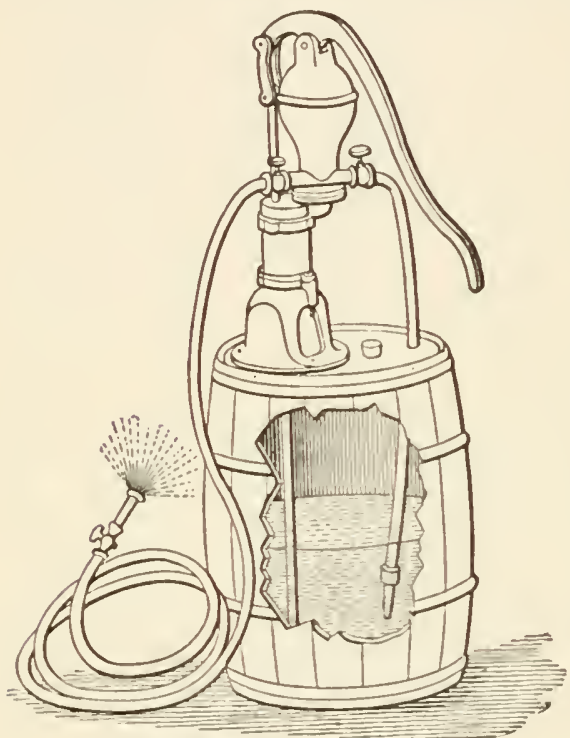

Orchard-spraying Apparatus. sive farmer as a necessary feature of the year's operations, and in the case of the apple, pear, and plum crops the omission of such treatment means serious loss. The consequent demand for spraying apparatus has been met by all the leading pump manufacturers of this country, and ready-fitted apparatus, consisting of pump, spray tank or barrel, and nozzle with ...vee, are on the market in numerous styles and at prices ranging from \$20 upward. The cost of a spraying outfit for orchard work may, however, be considerably reduced by purchasing merely the pump and fixtures, and mounting them at home on a strong barrel. An apparatus of this sort, representing a style that has proven very satisfactory in practical experience, is illustrated in the accompanying figure. It is merely a strong pump with an air-chamber to give a steady stream, provided with two discharge hose-pipes. One of these enters the barrel and keeps the water agritated and the poison thoroughly intermixed, and the other and longer one is the spraying hose and terminates in the nozzle. The spraying-hose should be about 20 feet long, and may be fastened to a light pole. preferably of bamboo, to assist in 
directing the spray. The nozzle should be capablz of breaking the water up into a fine mist spray, so as to wet the plant completely with the least possible expenditure of liquid. The two more satisfactory nozzles are those of the Niver and the Vermorel type. A suitable pump with nozzle and hose may be obtained of any pump manufacturer or hardware dealer at a cost of from $\$_{13}$ to $\$$ I5. If one with brass fittings be secured it will also serve for the application of fungicides. The outfit outlined above may be mounted on a cart or wagon, the additional elevation secured in this way facilitating the spraving of trees, or for more extended operations, the pump may be mounted on a large water tank.

\section{PREVENTION OF OAT-SMU'T. (GoF.)}

The smut of oats, which causes an annual loss to the farmers of the United States amounting in the aggregate to millions of dollars, may be entirely prevented by treating the seed oats before sowing, at a cost for labor and materials which need not exceed five cents per acre of oats sown.

Two methods of treatment have been found satisfactory. 'These we will call for convenience the Formaldehyd Treatment and the Hot-water Treatment. The first has the advantage of being the simpler, but it requires a small cash outlay for materials. The second requires no materials or apparatus except what the farmer already has, unless it be a good thermometer.

The Formaldehyd Treatment. - Soak the seed oats one hour in a solution of formaldehyd, made by adding one ounce of formaldehyd to every $3 \frac{1}{2}$ gallons of water. Place the water in a barrel, or other convenient vessel, add the formaldehyd to it, and pour in one and one-half bushels of seed oats for each $3 \frac{1}{2}$ gallons of the solution. At the end of one hour, draw off or pour off the part of the solution that is not absorbed by the oats, and spread the oats on a clean floor to dry. They shculd be shoveled over once or twice a day until dry enough to sow. 
Formaldehyd is a liquid that may be purchased at drugstores. Ask for forty-per-cent formaldehyd. It costs from 50 to 60 cents per pint, and a pint contains enough for about 30 bushels of seed oats. It is sold in smaller quantities at ro cents per ounce. If formaldehyd is purchased in consid. erable quantities, it will be well to have the druggist weigh out one ounce in a small bottle, and then mark on the bottle the height to which the ounce reaches. This bottle may then be used as a measure in adding the formaldehya to the water.

The Hot-water Treatment consists in soaking the seed ro minutes in water at a temperature of $133^{\circ} \mathrm{F}$. Heat the water in a large kettle, and close by sink a barrel in the ground to within a foot of the top. Pour a part of the hot water into the barrel, and take the temperature with a good thermometer. Then add either cold or hot water, stirring it in the mean time, until it shows a temperature of $138^{\circ}$. Put about a bushel of oats in a coarse gunnysack, tie this to one end of a pole and rest the pole over a post, thus making a lever, by which the sack of oats may be easily raised or lowered. Now dip the sack of oats into the water in the barrel. The water will be immediately cooled, and hot water must be added to keep the temperature about $133^{\circ}$. Let one person attend to the temperature, and another to handling the oats. Keep the oats moving in the barrel. Take them out at the end of ro minutes, dip the sack at once in cold water, then spread on a clean floor to dry. Shovel them over three times a day for a few days, when they may be sown with a force drill; or in two or three hours they may be sown broadcast. As the oats absorb considerable water, it is necessary to sow about half a bushel more per acre than when untreated seed is used. This is on the basis of two and one-half bushels per acre. Two men in one day can treat enough seed to sow twenty acres.

This treatment may also be applied with satisfactory results for the prevention of smut of other cereals than oats, and for prevention of potato-scab, as will be seen from the following article. 


\section{THE FORMALDEHYD TREATMENT FOR THE PREVENTION OF 'THE SMUTS OF CEREAI, GRAINS AND OH' P'TATO-SCAB. (BOLLEY.)}

For Wheat, Oats, Barley, and Millet.-Use formaldehyd (40 per cent solution) at the rate of $I$ pound of the liquid to 45 or 50 gallons of water. Use any method of wetting the grain most suited to your means. Sprinkling and shoveling is as effective as dipping, if carefully done.

It is well to treat one day and allow the grain to remain piled up overnight, thus allowing the fumes of the solution to act throughout the pile.

Cautions.-(I) In the case of oats or barley the wetting must be more thorough than in the case of wheat, so that the formaldehydor gas may penetrate beneath the husks of the grain.

(2) Do not allow wet grain to remain in a pile long enough to get hot. A very slight degree of fermentation may greatly reduce the yield.

For Potato-scab. - Soak the tubers before cutting one hour and a half in a solution of formaldehyd at she rate of one pound of the liquid to thirty gallons of water; or in a solution of corrosive sublimate, using one pound of the chemical to each fifty gallons of water.

Note: The potato-scab fungus lives from year to year in the soil and upon old vines. Hence it is wise to try to keep it off your lands, by treating all seed-tubers. (See Bull. 37, N. D. Experiment Station.) 


\section{FIGHTING THE CHINCI-BUG BY MEAYS OF KEROSENE FMULSION. (GOFF.)}

Experiments have established the fact that with thorough work according to the directions given below the kerosene emulsion will prevent the invasion of cornfields by chinchbugs, even though the bugs appear in great numbers.

How to Make and Apply the Kerosene Emulsion.-Slice half a pound of common bar soap, put it in a kettle with one gallon of soft water, and boil until dissolved; put two gallons of kerosene in a churn or stone jar, and to it add the boilinghot soap solution; churn from twency to thirty minutes, when the whole will afpear creamy. If properly made, no oil will separate out when a few drops of the emulsion are placed on a piece of glass. To each gallon of the emulsion add eight ga!ions of water and stir. Apply with a sprinkling-pot.

Every farmer should learn to make this emulsion, as it is a most useful insecticide. It is especially valuable for killing lice on cattle and hogs. Paris green will not kill chinchbugs.

The bugs will be very likely to enter cornfields bordering grainfields, after the grain is cut. Before they have had time to do this plough a deep furrow along the side of the field they will enter, and throw into it stalks of green corn. When the bugs have accumulated on the corn, sprinkle with the emulsion. Put in fresh stalks and sprinkle whenever the bugs accumulate. If they break over the barrier, as they probably will, run a few furrows a few rows back in the field, and repeat. When they have attacked stalks of standing corn, destroy by sprinkling.

If the remedy is tried, it should be used persistently. To kill one lot of bugs and then stop will do little or no good. When the bugs threaten to destroy as much as five or ten acres, it will pay for one or two men to devote their whole time to the warfare. Only a part of each day, however, will be needed. Some corn will he lnct at best, but the most of the field should be saved 


\section{FORESTRY. \\ FORESTRY FOR FARMERS.}

By Dr. B. E. Fernow, late Director of the New York State College of Forestry.

There has been much talk about forestry in the U. S., but there has been little application of the teachings of that science. This is easily explained in so far as the lumbermen are concerned, who are in the business of making money by cutting the virgin woods, similar to the mining of ore, but it is less intelligible with the farmer who is presumed to be in the business of making money by the production and harvesting of crops, which he grows on the soil of his farm.

That his wood-lot could and should by him be also treated as a crop seems rarely to have entered his mind. Whether he starts out, as in the prairie portions of the State, by planting a grove, or whether he cuts his wood from the virgin growth which he left after clearing enough for field and meadow, in either case he should fully realize that he is dealing with a valuable crop, which requires and will pay for the attention and application of knowledge in its management, such as a true husbandman would give to it.

The Wisconsin farmer, just as his neighbor in Minnesota, living in a State largely covered with timber of great value, has special reason to practise the principles of forestry in order to get the most out of this part of the property both for the present and the future. And those who are located in the prairie portions have noless need of maintaining a forest growth on some part of their farm as a matter of proper management of their resources.

The first thing, as with every other crop, that will have to be decided is on what portions of the farm this wood-crop is best propagated. In deciding about the location of the wood-lot the farmer must keep in mind:

r. 'That wood will.grow on almost any soil, which is unfit for agricultural use; that, although it grows best on the 
best sites, it is to be mainly considered and used as a "stop. gap" to make useful those parts which would otherwise be waste.

2. That a forest growth, besides furnishing useful material, is a condition of soil-cover which affects other conditions, namely, of climate and water-flow, and hence its location should be such as to secure the most favorable influence on these.

3. That the wood-crop does not live on the soil, but on the air, enriching the soil in nutritive elements by its decaying foliage rather than exhausting it, and hence that no manuring and no rotation of crops is necessary as in field crops; in other words, the location of the wood-crop can be made permanent.

A wood growth should therefore be maintained on the farm :

a. Wherever the ground is too wet or too dry, too thin or too rocky or too steep, for comfortable ploughing and for farm crops to do well, or for pasturage to last long, or, in general, where the ground is unfit for field and meadow.

$b$. On the highest portions of the farm, the tops of hills and also in belts along the hillsides, so as to interrupt continuous slopes, which might give rise to such a rusn of surface-waters as to gully the ground and make it unfit for field crops or pasture; the gentler slopes which are liable to washing should at least be kept in grass or terraced for crops to prevent the rush of surface-waters.

c. Along watercourses, where narrower or wider belts of timber should be maintained to prevent undermining of banks and washing of soil into the streams if ploughed too close to the border; the shade of a forest growth would also check rapid evaporation of smaller watercourses.

d. Wherever the protection by a wind-break against cold or hot winds is desirable, for which purpose the timber belt is of more far-reaching effect than the wind-break of a single: row of trees; the reduced evaporation from the fields due to this protection has been known to increase the yield of field crops by as much as 25 per cent.

e. On all unsightly places, which impair the general 
aspect of the farm-and there are few farms without these - a few trees, a small grove, will add to the thrifty appearance of the farm, make useful the otherwise waste spots, aid serve as shelter to grazing cattle, etc.

Altogether, the farmer should realize that husbandry of soil and water is the secret of future success, and that successful water management is best attained by the maintenance of properly located and well-managed forest areas.

There is much extravagant talk about the influence of forests on climate and on rainfall especially. We have but little definite knowledge on these subjects, but it takes no expert, only a little observation, to appreciate the effects of a wind-breaking timber belt on one's own feeling, and it takes but little reasoning to appreciate that the field crop in the shelter of the timber belt participates in this feeling. The dry winds are the great bane of field crops in the West, because they dissipate the moisture; a timber belt breaks their force and reduces thereby their evaporating power.

Just so it takes no great philosopher to see that when rain falls on naked ground it compacts that ground and by and by prevents itself from penetrating; the water is forced to drain off superficially and rapidly, instead of sinking into the ground and remaining there for the use of field crops. And that the washing and gullying of the soil is also a result of this rushing off of surface-waters, due to the clearing away of its plant-cover, requires no wise man to point out; every farmer experiences it more or less every year.

That any one farmer's neglect or the devastation of any small part of the forest growth should have an influence on the rainfall or climate of the whole country nobody should claim; but the conditions surrounding each particular farm, its local climate, soil, and water conditions, are changed, and finally the aggregate changres make themselves felt over the whole state.

Now as to the management of the wood-lot a few hints may be acceptable. The farmer may not necessarily employ the finer methods of managing the wood-crop, but by the mere application of common sense and a little knowledge of tree-life he may do better than he does at present. 
He should at least observe the following rules:

I. Fire should be carefully kept out of the wood-lot. for it has in no way a beneficial effect. It kills not only the undergrowth, which is desirable because it helps to shade the soil, and injures, if it does not kill, the young tree growth, which is to take the place of the older growth, but the worst effect is that it consumes the vegetable mould which has accumulated by the fall and decay of leaves, twigs, and other vegetation, and which forms the manure, the fertility, of the soil. Fire is to be used only when through bad management or otherwise a dense undesirable undergrowth has come in, which it is too expensive to remove in other ways when the time for natural reproduction has come or planting is to be done. It must then be used with caution in early spring or late fall, before the brush is too dry, when the fire will smoulder rather than burn fiercely and can be kept within bounds.

2. Cattle must be kept out where young forest growth is to be fostered. Sheep and goats especially are of no benefit to wood-crops, but horses and cattle may be allowed to browse through the wood-lot where the young growth has passed out of their reach. Pigs are a benefit by working over the ground and thereby burying seeds, especially acorns; but after the seed is so brought under ground where a young crop is expected to be reared next year they must be kept out. Altogether, the cattle and farm animals should be kept where you want them, and not where you do not want them. Sometimes, however, the roaming of cattle may be beneficial by keeping down too dense im. penetrable underbrush in young sapling growth.

It is better to so cut and manage the old timber that a desirable new growth will spring up than to cut clean and replant. Planting should be done only where there is no desirable natural tree glowth. Hence where there is a wellestablished wood-lot, the whole management of the crop consists in proper cutting.

How this is best done cannot be described readily within the short space of this article, but every farmer who is interested in learning the principles of using the axe to 
advantage in reproducing a wood crop or how to establish a wood-lot can obtain from the U. S. Department of Agriculture, free of charge, a pamphlet entitled "Forestry for Fa.mers," in which in plain language is discussed in detail how trees and forests grow, how to start a wood-crop, and how to manage the wood-lot.

It does not exhaust the subject, but merely teaches the first steps, and the thinking farmer will find his way of stepping farther.

\section{NUMBER OF TREES ON AN ACRE. (Eglestun.)}

The number of trees needed to plant an acre of ground, at various distances apart, is as follows:

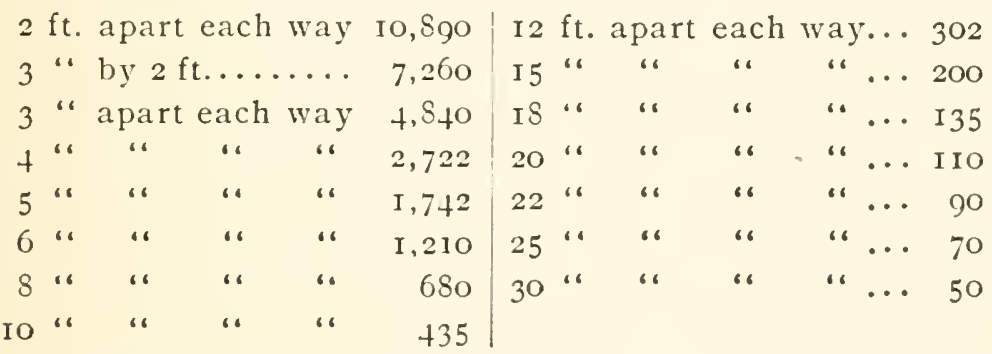

Rows six feet apart, and trees one foot apart in the row, 7260 trees per acre.

Rows eight feet apart, and one foot apart in the row. $5+45$ trees per acre.

Rows ten feet apart, and one foot apart in the row, 4356 trees per acre.

One mile of wind-breaks or shelter-belt requires 5280 trees, or cuttings for a single row one foot apart in the row. 


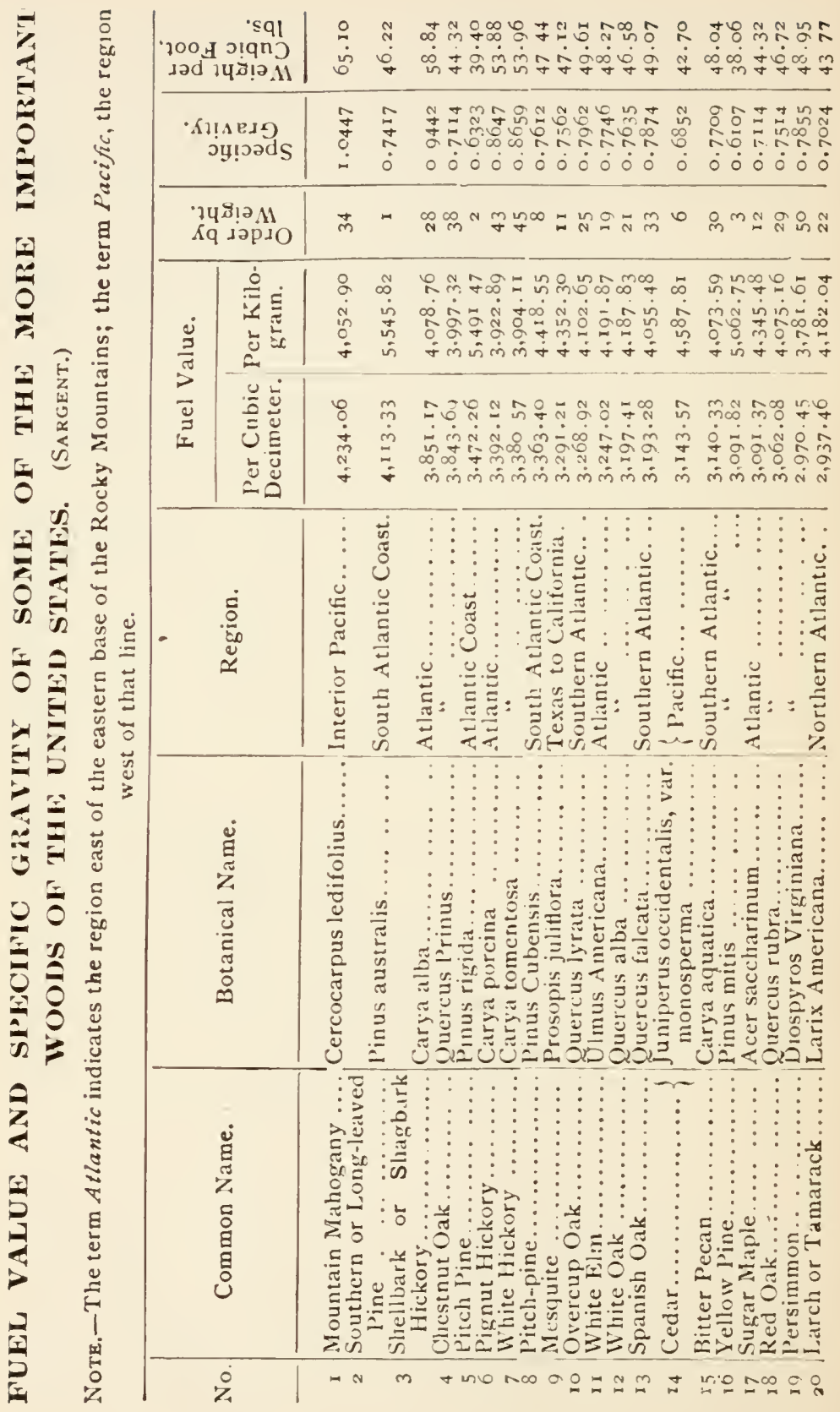


주

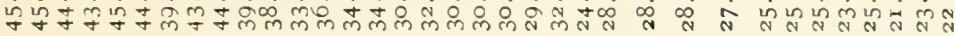

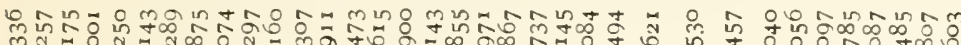
ma

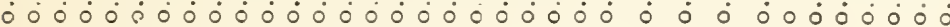

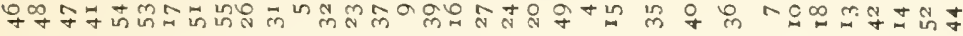

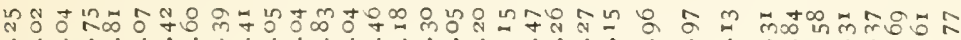
mo nं mont大 mo-

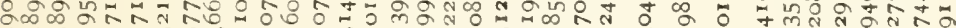

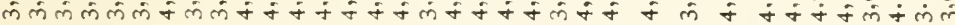

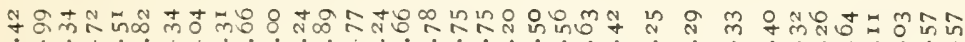
(i) i

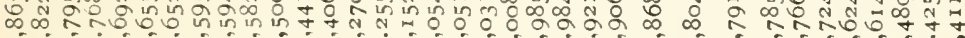
तरल

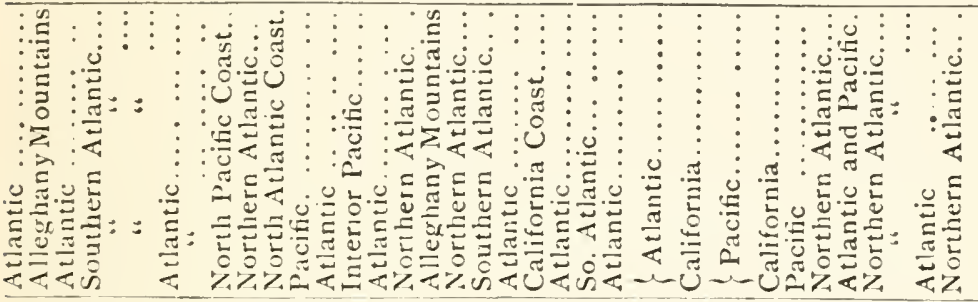

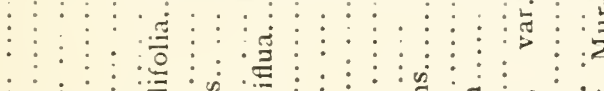

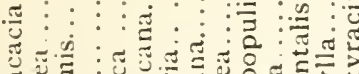

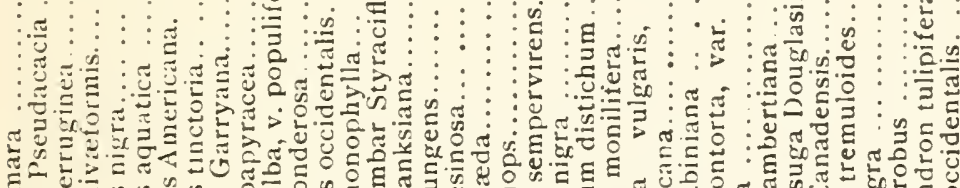

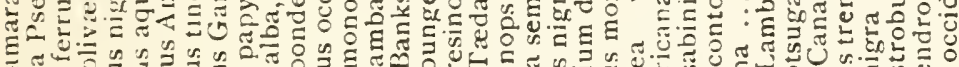

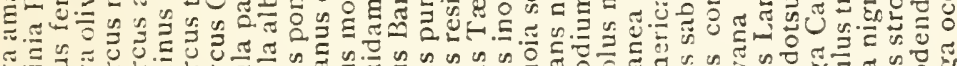

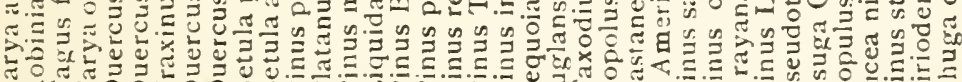

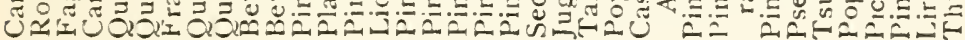

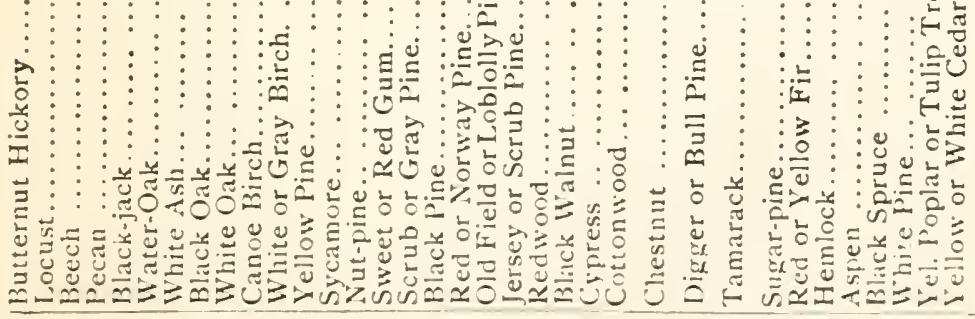

스 


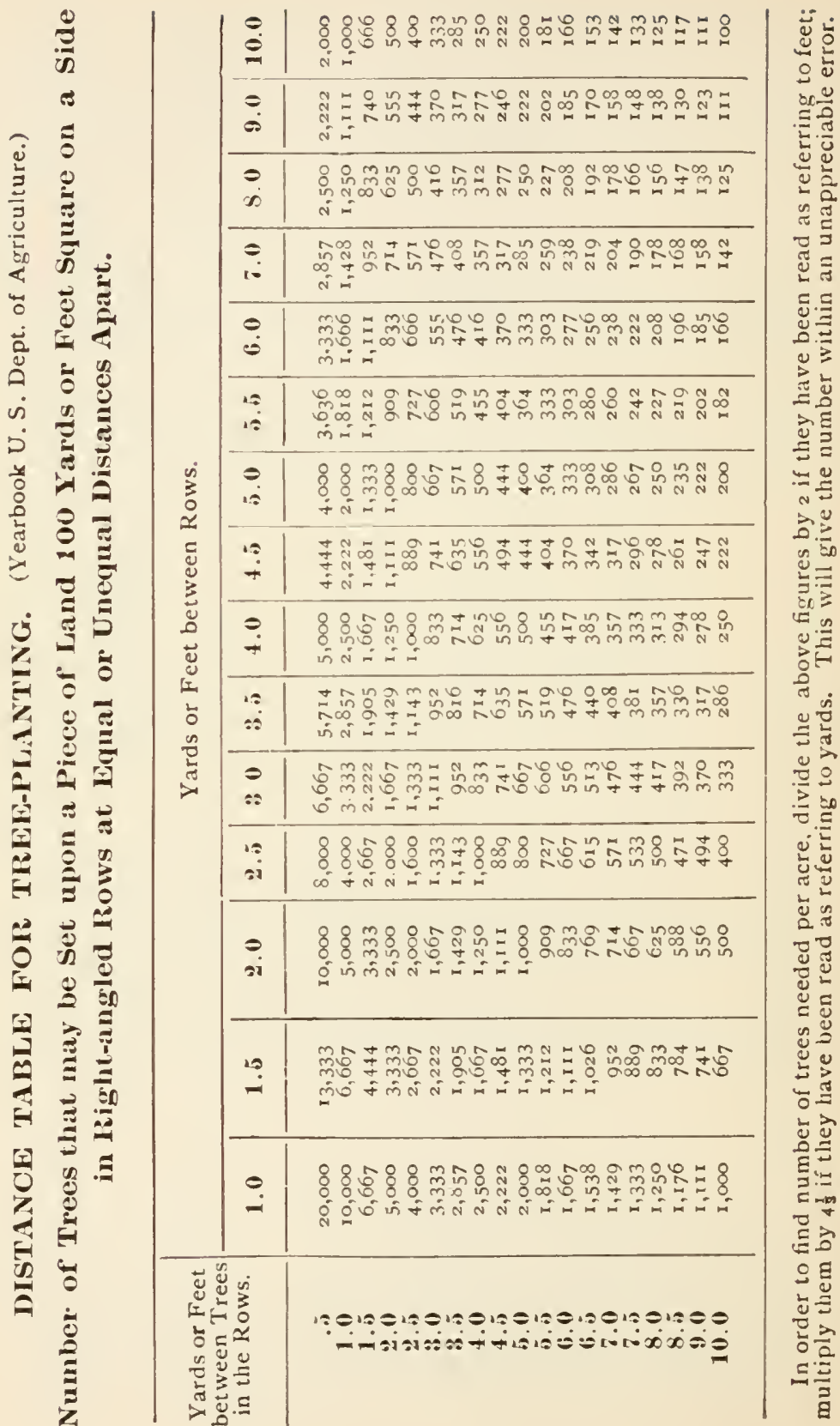




\section{STATES AND TERRITORIES OBSFRVING ARBOR}

\section{DAY, WITH DATES. (U.S. Department of Agriculture.)}

\begin{tabular}{|c|c|c|}
\hline States. & $\begin{array}{l}\text { Year of } \\
\text { First C b- } \\
\text { servance. }\end{array}$ & Time of Observance. \\
\hline 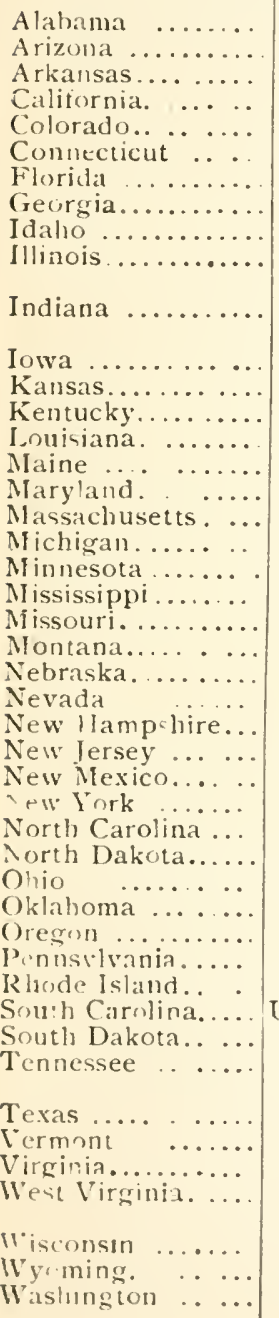 & 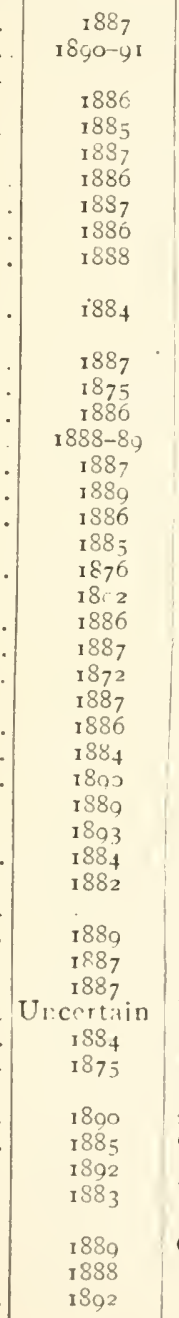 & 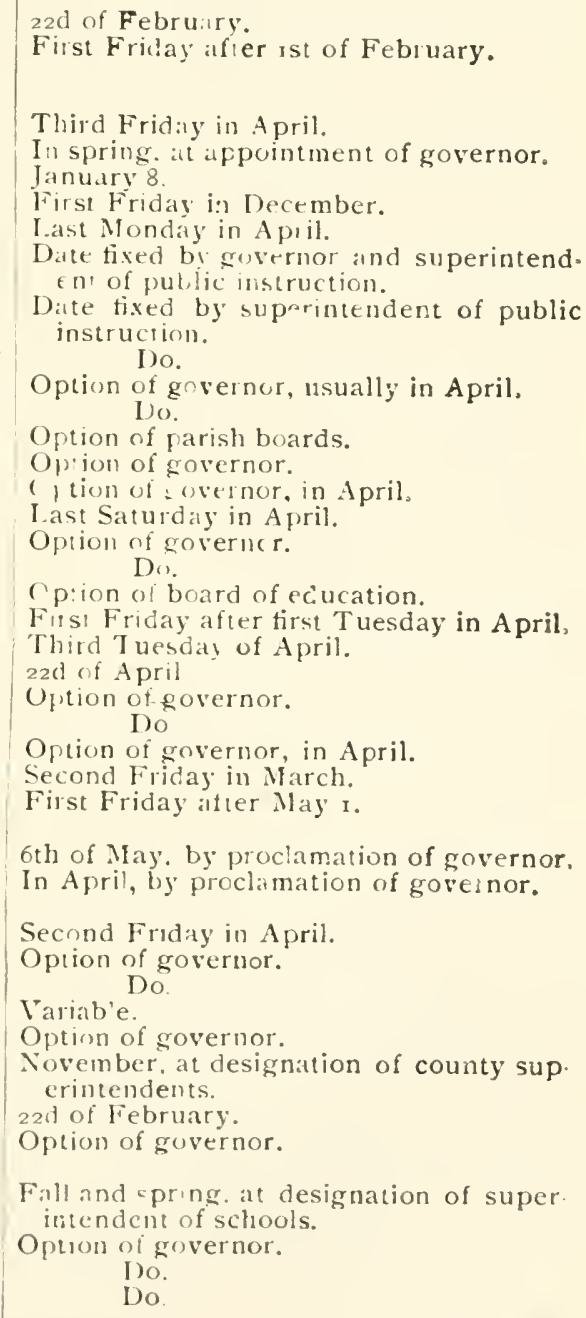 \\
\hline
\end{tabular}


FOREST-FIRE LAWS IN THF UNITFD STATES, (FERNOW.)

(See p. $1^{2}$ for penalties imposed.)

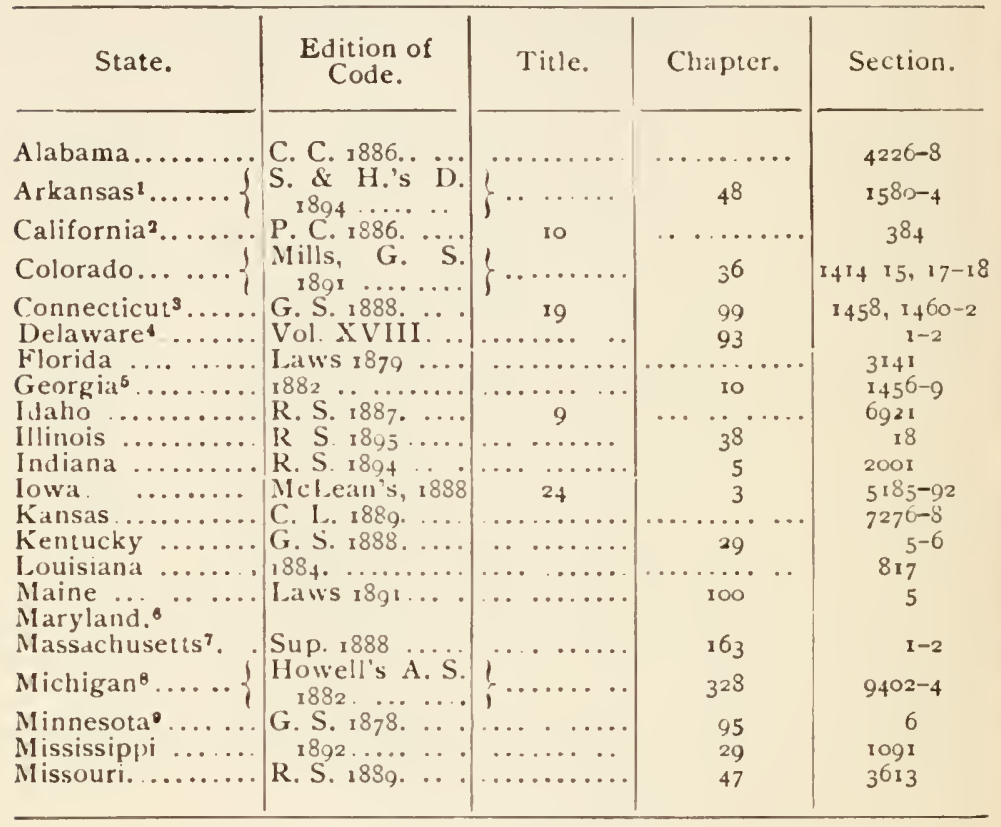

1 S. 1847 : Burning off permitted when consent of neighbors is secured after I day's notice.

2 Pol. Code, S. $3344^{-5}$ : Persons firing woods, etc., liable in treble dam. ages. Constable, etc., may order any inhabitants liable to poll-tax to assist in extinguishing fire.

s Must give notice, before burning off, to all residents within one mile. and can only be done between February 15 and March 31 , unless otherwise oudered by county commissioner.

4 Prohibits building fire in woods without owner's permission, and with out first clearing away combustibles, and extinguishing fire.

- Must give I day's notice, before burning off, to adjoining property owners, and then only betwen Feb. 20 and April I.

- No law included in Revised Statutes.

' Ch. 296 , S. 1-6, G. S. $188_{3}$ : Duty of fire wardens to post warnings, extinguish fires, and investigate causes of fires.

- Supervisors and highway commissioners to order assistance in putting out fires; fine $\$ 5-\$ 50$ for refusal to assist.

- See act of April 18, 1895. 


\section{FORLST-FIRE LAIVS-Continued.}

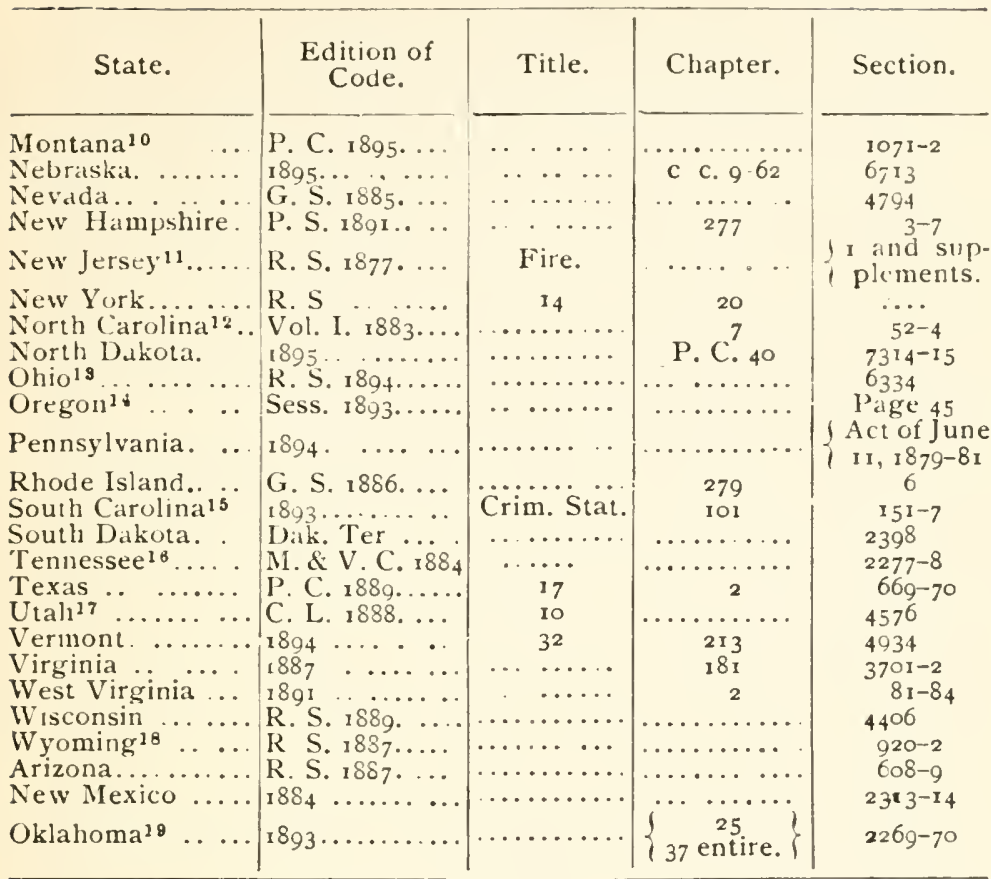

10 Penalty for failing to extinguish camp-file or malicious firing of woods, fine not exceeding $\$ 5000$, or imprisonment not exceeding 5 years, or both.

$11 \mathrm{Ch}$. 188, G. P. Laws 1888, provides detectives for violators of fire law. Ch. 119, Iaws 1892 , and Ch. 194, Laws 1894, provide for fire marshals and define their duties.

12 Fine \$1o for leaving unextinguished camp-fire. Two days' notice in writing before firing one's own woods.

19 S. $475^{-1}$ : Penalty for refusing to assist in extinguishing fires, fine $\$ 10$.

14 Requires governor to issue proclamation annually July I, warning people against forest fires.

16 If turpentine farm, fine $\$ 500$, or penitentiary y year.

16 Owner may fire his own woods after two day's' notice to neighbors.

$17 \mathrm{Ch}$. 27. Laws 1892 : Duty of county slueriffs to extinguish fires.

18 Permits firing grass and sage-bush March, April, and October, if kept within control.

19 Camp-fires, and regulations for burning off prairies, etc., Ch. 37 (enacted 189o) provides penalties for setting fires and failure to extinguish. 


\section{FOREST-FITE IAWS-Continued.}

\section{PENALTY PRESCRIBED BY STATE LAWS.}

1labama.-Fine \$ro-\$200; if turpentine forest, \$roo-\$1000. or hard jabor for not more than 12 months.

Arkansas. -Fine $\$ 25-\$ 300$, or jail $10-60$ days. Liable for doubie d.images.

California.-Fine not more than $\$$ rooo, or jail not more than y year, or both.

Colorado. -Fine $\$ 50-\$ 300$. or jail $\mathrm{r}_{5}$ days to 3 months, or both If on State lands, \$50 \$500, or jail 20 days to 6 months.

Connecticut. - Fine $\$ 20-\$ 200$, or jail $2-6$ months, or both. Fine $\$_{1}-\$_{50}$, or jail not more than 30 days.

Delazuare.--Fine $\$ 25$.

Florida. - Fine not more than $\$ 100$, or jail not more than 60 days

Georgia.-Fine not more than $\$ 1000$, or 1 year in cliain-gang, or both.

likho.-Misdemeanor.

lllinois.-Fine $\$ 5-\$ 100$.

lndiana.-Fine $\$ ;-\$ 100$, to which may be added imprisonment not more than 30 dajs.

lozu. - Fine not exceeding $\$_{500}$, or jail not exceeding I year.

Kansiss.-Fine $\$ 50-\$ 500$, or jail ro days to 6 months, or both.

kertucky. Fine $\$ 100$, or in discretion of jury.

Louisiana. - Fine $\$ 5-\$ 500$.

Maine.-Fine not exceeding $\$ 100$, or jail not exceeding zo days, or both.

Massachusetts.-Fine not more than \$10o, or jail not more than 6 montlis.

Michigan.-Fine not more than $\$ 100$, or jail not more than year, or both.

Minnesota-State prison 6 months to 2 years.

Mississipfi.-Fine $\$ 20-\$ 5 c o$, or jail not more than 3 months, or both.

Missouri-Fine nct more than $\$ 500$, or jail not more than $\mathbf{2}$ months.

Montana.-Fine not more than \$rooo, or jail not more than year.

Vebraska.-Fine \$5-\$roo, and jail 1-6 months.

Nevada.-Fine \$200-\$rooo, or jail ro days to 6 months, or both.

Newe Hampshive.-Fine \$io-\$200o, or imprisonment not mare than 3 years.

Nezu lersey.-Fine not more than $\$ 100$, or jail not more than year, or both.

New York - Fine not exceeding \$rooo, or imprisonment not exceeding 1 year.

North Carolina.-- Fine \$50.

North Dakota.-Wilful, a misdemeanor; negligent, fine \$ro-\$rco.

Ohio.-Fine not more than $\$ 100$, or jail not more than 20 days, or both.

Oregon.-Fine \$ro-\$1000, and in certain cases penitentiary not exceed. ing $x$ year.

Pennsylvania.-Fine not more than $\$ 300$, or jail not more than I year, or both. 
Rhode Island.-Imprisonment not exceeding 2 years.

South Carolina.-Fine $\$ 5-\$ 100$, or jail not more than 30 days.

South Dakota.-Fine not more than $\$ 200$, or jail not more than I year, or both.

Tennessee.-Forfeit $\$ 100$ to prosecutor and fine $\$ 5-\$ 50$ (S. 2277 , Code Sup. r893).

Texas.-Fine $\$ 50-300$.

Utah.-Misdemeanor.

Vermont.-Fine not more than $\$ 500$, or penitentiary not more than 5 years.

Virginia.-Fine $\$ 5-\$ 100$, and jail $1-6$ months.

West Virginia.-Fine $\$ 10-\$ 1000$, or jail not more than 12 months.

Wisconsin. - Fine not more than $\$ 500$, or jail not more than $x$ year.

Wyoming. - Fine not more than $\$ 500$, or jail 30 days to 6 months.

Arizonc.-Misdemeanor. If on State or U. S. lands, fine not more than $\$$ rooo, or jail not more than y year, or both.

New Mexico.-Fine $\$ 60-\$ 500$.

Oklahoma.--Fine $\$ 10-\$ 500$, or jail not more than I year, or both. 


\section{MANURES AND FERTILIZERS.}

It is a matter of common experience among farmers that the soil is impoverished by continuous cropping, and the yields obtained therefore gradually decreased. The decrease in yields can only be prevented by applications of farmyard manure or commercial fertilizers; ploughing and thorough cultivation of the soil bring the land in a better mechanical condition and increase the amount of available plant food present in the soil, but these operations are not sufficient to maintain the fertility of the land so that it will yield equally well from year to year under otherwise favorable conditions. Every crop harvested contains certain quantities of fertilizing ingredients, and taking away these amounts in general leaves the soil in a poorer condition for the production of crops than it was before.

The fertilizing ingredients of which the soil is thus liable to be robbed are potash, phosphoric acid, nitrogen, and sometimes lime. They are not present as such in the soil, or in the fertilizers applied to the soil, but in chemical combinations with a large variety of compounds. The soil will contain nearly all the different elements which chemists have so far succeeded in isolating, but it is mainly the three elements, potassium, phosphorus, and nitrogen, which are apt to be decreased in the soil below the amounts required for the nutrition of crops, or at least of maximum crops. In rational fertilization the effort therefore always is to return to the soil such quantities of fertilizing ingredients, in the shape of farmyard manure or commercial fertilizers, as will restore the loss sustained by the withdrawal of the crops harvested. Other mineral ingredients contained in the crops need not generally be returned to the soil, since they are nearly everywhere present in abundance. 
It is the grand work done for the farmer by agricultural chemistry during the past half century which has explained the causes of the decreased fertility of land due to continuous cropping, and has given the remedies for maintaining the fertility. The latter are as follows:

First, by selling only such products from the farm as will deprive the soil of the smallest quantities of fertilizing ingredients, i.e., manufactured products, like milk, cream, butter, meat, eggs, rather than grain crops, hay, etc. The tables given on pp. 148-I5 I show the amounts of fertilizing ingredients removed in farm products of various kinds and deserve a close study by all farmers.

Secondly, by carefully saving the manure produced by stock-both liquid and solid (the former by the use of absorbents, peat, land plaster, kainit, superphosphate, shavings, etc., or by building special cisterns for storing it; the latter by placing it under shelter, guarding against leakage) -and returning it to the land; as the products sold oft the land also contain certain quantities of fertilizing constituents, the loss must be repaired by purchase of concentrated food stuffs, at least three fourths of whose valuable ash ingredients will go into the manure and thus be saved for crops.

Thirdly, by following a rational system of rotation of crops, and by frequent culture of leguminous crops,-clovers, peas, beans, etc.,- - since these are able to so fix the free nitrogen of the air as to render it of value to animals and plants.

\section{APPROXIMATE LOSSES OF FERTILIZING MATE. RIALS IN DIFFERENT SYSTEMS OF FARMING.}

(SNYDER.)

\begin{tabular}{|c|c|c|c|}
\hline System of Farming. & Nitrogen. & $\begin{array}{c}\text { Phosphoric } \\
\text { Acid. }\end{array}$ & Potash. \\
\hline 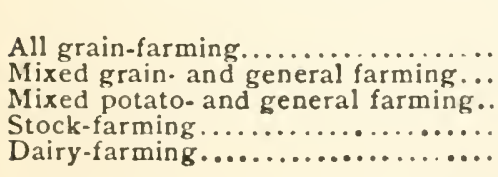 & $\begin{array}{r}\text { lbs. } \\
5600 \\
2600 \\
2300 \\
900 \\
800\end{array}$ & $\begin{array}{l}1 \mathrm{bs} \\
2500 \\
1000 \\
1000 \\
50^{*} \\
75^{*}\end{array}$ & $\begin{array}{r}16 s \\
4200 \\
1000 \\
2400 \\
60 \\
85\end{array}$ \\
\hline
\end{tabular}

- Gain. 
The figures given show the approximate losses on a r6o-acre farm wider the different systems of farming. With stock-and dairy-farming, as well as partly in mixed grain- and general farming. the loss of nitrogen may be avoided by growing clover. In stock and dairy-farming, therefore, no loss of fertility will occur under these conditions when all the skim-milk is fed on the farm and a part of the grain is exchanged for more concentrated milled products, but llere will on the contrary be a constant gain of fertility to the soil. (See Bull. 4I, Minn. Exp. Station.)

\section{AVERAGE CHWMICII COMPOSITION OF AMLIRCAy solls.}

(KiNG.)

\begin{tabular}{|c|c|c|c|c|c|c|c|}
\hline - & 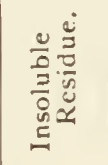 & 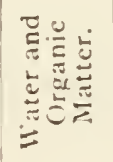 & 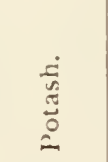 & 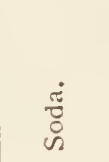 & 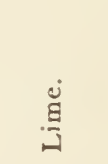 & 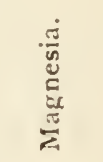 & 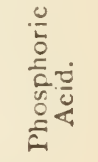 \\
\hline & Per ct. & Per ct. & Per cl. & Perct. & Per ct. & Per ct. & l'er ct. \\
\hline Sandy soils & 93.21 & 2.61 & $.12 \mathrm{t}$ & .051 & .085 & .048 & $.07_{7}$ \\
\hline Claycy soils & 68.21 & 6.53 & $\cdot 3^{x y}$ & .123 & .617 & .456 &.$I_{4} I$ \\
\hline Humus soils & 35.89 & 1344 & .639 & .109 & 3.786 & .886 & .150 \\
\hline f.oess suils . & 68.85 & I.2I & .435 & .165 & 5.820 & 3.692 & .200 \\
\hline Humid soils... & 84.03 & 3.64 & .210 & .091 & .108 & .225 & .113 \\
\hline Arid suils.... & 70.57 & 4.95 & .729 & .264 & I. 362 & 3.411 & .117 \\
\hline
\end{tabular}

Fertile soils contain the following percentages of different components, according to Snycler (averages for 200 samples):

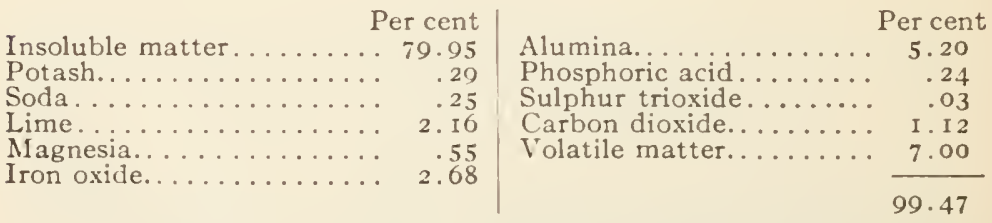

Volatile matter contained: Humus, 3.35 per cent; Nitrogen, 0.29 per cent. 


\section{MANURIAL VAIUE OF FEEDING STUFFS.}

Chart shoming Pounds of Fertilizing Constituents of Feeding Stuffs in one Ton, and the Mammial Value of Feeding Stuffs, according to the Valuation given.

Nitrogen Phosphoric Acid Potash
Price per pound $12 \mathrm{cts}$.

Black Bar represents IIanurial Value per Ton.

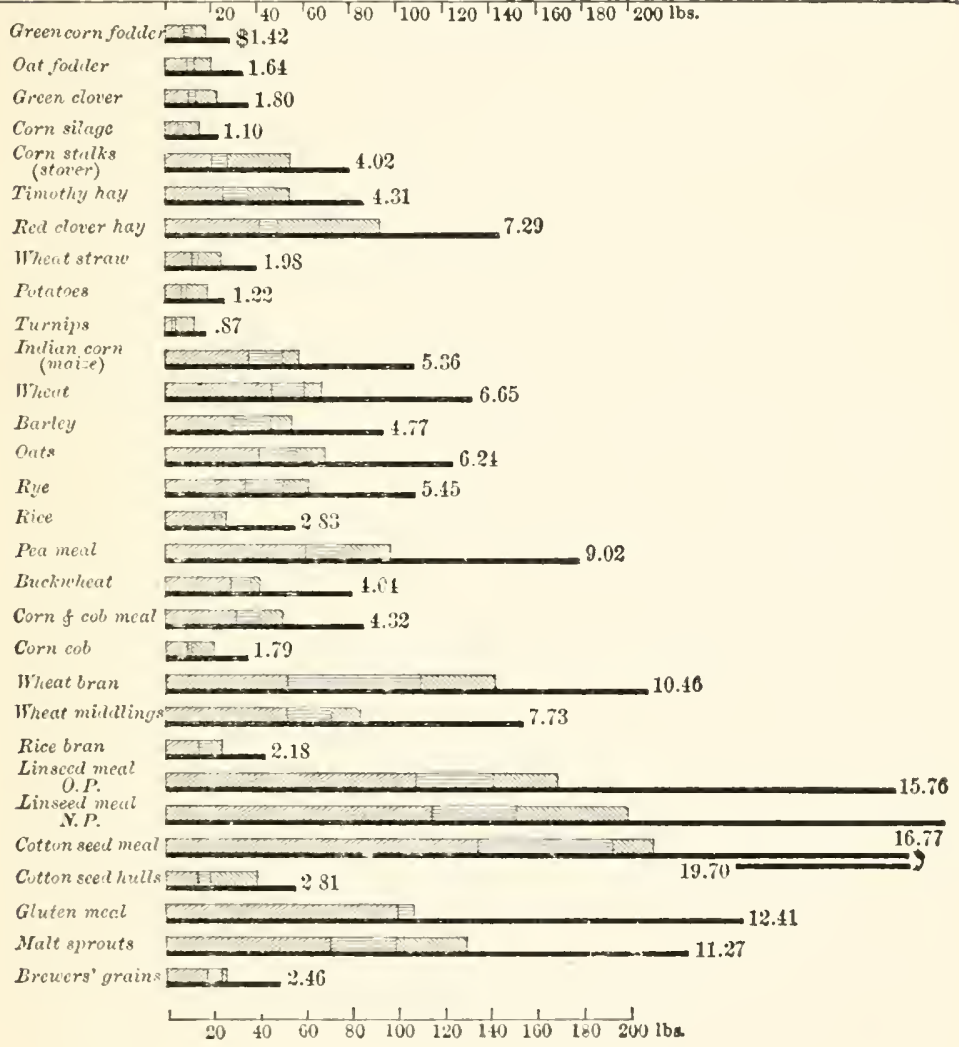




\section{FERTILIZING CONSTITUENTS OF FEEDING S'TUFFS AND FARM PRODUC'TS.}

(Yearbook U. S. Dept. of Agriculture.)

Material.

Green Fodders.

Pasture grass ... ...........

(rreen fodder corn............

Sorghum fodder. .............

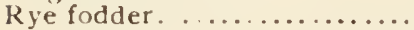

Oat fodder...................

Timothy grass...............

Red clover. ..................

White clover..................

Alsike clover .................

Scarlet clover.............

Alfalfa (lucern) .............

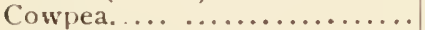

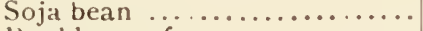

Prickly comfrey .............

Corn silage .................

Hay and Dry Coarse Fodders.

Fodder corn (with ears) .....

Corn stover (without ears).....

Hungarian grass. ..........

Common millet ..............

Hay of mixed grasses .........

Red.top................

Timothy. ................

Red clover.

Mammoth red clover..........

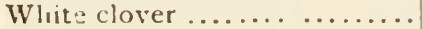

Scarlet clover..............

Alsike clover. ...............

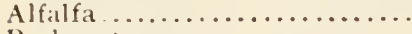

Barley straw................. chaff ..................

Wheat straw.................

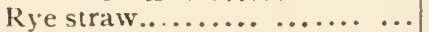

Oat " $\ldots \ldots \ldots \ldots \ldots \ldots . .$.

Buckwheat hulls.............

Kcots, Bulbs, Tubers, etc.

Potatoes................. 79.24

Siveet potatoes .............

Ked beets. ...................

Yellow fodder beets............

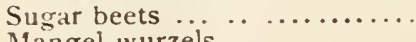

Mangel-wurzels...............

'jurmips...................

Rutabagas . ..............

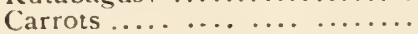

\begin{tabular}{|c|c|c|c|c|}
\hline 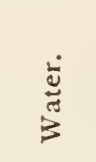 & $\frac{5}{\frac{1}{4}}$ & 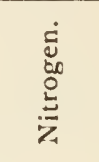 & 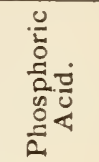 & 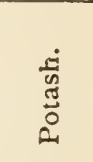 \\
\hline per ct. & per ct. & per ct. & per ct. & per $\mathrm{ct}$. \\
\hline 63.1 & 3.27 & .91 & .23 & .75 \\
\hline 78.6 & 4.84 & .41 & .15 & $\cdot 33$ \\
\hline 82.2 & $\ldots \ldots$ & .23 & .09 & .23 \\
\hline 62.1 & $\ldots \ldots \ldots$ & $\cdot 33$ & .15 & .73 \\
\hline 83.4 & I. 3 I & .49 & .13 & $\cdot 3^{8}$ \\
\hline 66.9 & 2.15 & .48 & .26 & .76 \\
\hline 80.0 & $\ldots \ldots$ & .53 &.$x_{3}$ & .46 \\
\hline 81.0 & $\ldots \ldots$ & .50 & .20 & .24 \\
\hline 8. 8 & I. 47 & .44 & . I I & .20 \\
\hline 42.5 & $\ldots \ldots$ & .43 & .13 & .49 \\
\hline 75.3 & 2.25 & .72 & .13 & .56 \\
\hline 788 & 1.47 & .27 & . Io & $\cdot 3 \mathrm{I}$ \\
\hline 73.2 & $\ldots \ldots \ldots$ & .29 & .15 & .53 \\
\hline 84.4 & 2.45 & .42 & . II & .75 \\
\hline 78.0 & ........ & .28 & . II & .37 \\
\hline 7.85 & 4.91 & 1. 76 & .54 & .89 \\
\hline 9.12 & $3 \cdot 74$ & I. 04 & .29 & I 40 \\
\hline 769 & 6.18 & I 20 & $\cdot 35$ & 1. 30 \\
\hline 9.75 & & I. 28 & .49 & 1.69 \\
\hline I1 99 & $6 \cdot 34$ & I.4I & .27 & 1. 55 \\
\hline $7 \cdot 71$ & $4 \cdot 59$ & I. 15 & .36 & I.O2 \\
\hline $7 \cdot 52$ & 4.93 & 1.26 & .53 & .90 \\
\hline I1 33 & 6.93 & 2.07 & $\cdot 3^{8}$ & 2.20 \\
\hline II. 4 I & 8.72 & 223 & .55 & 1.22 \\
\hline & & 2.75 & $.5^{2}$ & $1.8 \mathrm{r}$ \\
\hline 1830 & $7 \cdot 70$ & 2.05 & .46 & I. $3 \mathrm{t}$ \\
\hline $9 \cdot 94$ & II.II & $2 \cdot 34$ & .67 & 2.23 \\
\hline 6.55 & 7.07 & 2.19 & .51 & I. 68 \\
\hline I I . 44 & $5 \cdot 30$ & I. 3 I & .30 & 2.09 \\
\hline 1 $3 \circ 8$ & $\ldots \ldots$ & I.or & .27 & .99 \\
\hline x 2.56 & $3.8 \mathrm{I}$ & .59 & .12 & $.5^{I}$ \\
\hline 8.05 & $7 \cdot 18$ & .79 & .70 & .42 \\
\hline 7.61 & 3.25 & .46 & .28 & .79 \\
\hline 9.09 & $4 \cdot 76$ & .62 & .20 & 1.24 \\
\hline 11.90 & $\ldots \ldots \ldots$ & .49 & .07 & 52 \\
\hline 79.24 & 89 & .32 & .12 & .46 \\
\hline 71.26 & 1.00 & .24 & .08 & .37 \\
\hline 87.73 & I. I 3 & .24 & .09 & .44 \\
\hline 9060 & .95 & . I9 & .09 & .46 \\
\hline 86.95 & 1.04 & .22 & 10 & .48 \\
\hline 8729 & 1.22 & .19 & .09 & $\cdot 3^{8}$ \\
\hline 89.49 & I.OI & .18 & .10 & $\cdot 39$ \\
\hline 8913 & I.06 & . 19 & .32 & .49 \\
\hline $89 \cdot 79$ & 1.22 & .15 & .09 & $\cdot 5^{I}$ \\
\hline
\end{tabular}




\section{FERTILIZING CONSTITUFNTS OF FEEDING STUFAS AND FARM PRODUC'TS.-(Continud.)}

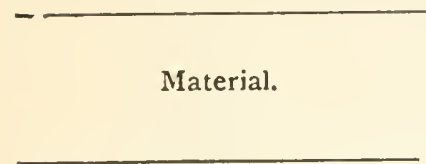

Grains and Other Seeds.

Corn.

Sorglium seed.

Barley

Oats..

Wheat, spring

Rye.

winter.

Millet, common

Japanese millet.

Rice

Buckwheat.

Soja beans

Other Concentrated Feeds.

Corn meal

Corn and cob meal................

Ground oats.

barley.................

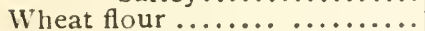

Pea meal. .

Corn cobs.

Hominy feed..................

Gluten meal

Starch feed (glucose refuse)..

Malt sprouts.

Brewers' grains, dry...........

wet.

Rye bran $\ldots . .$.

Wheat bran

middlings...............

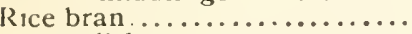
polish..................

Buckwheat middlings.........

Cotton-seed meal..... ......... hulls..............

Linseed meal (old process)..... " " (new process).... Apples, fruit................. Apple pomace................

\section{Dairy Products, etc.}

Whole milk

Skim milk.

('ream

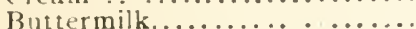

Whey .................

Butter

Clieese.

cattle..............

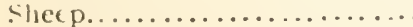

Swine

\begin{tabular}{|c|c|c|c|c|}
\hline 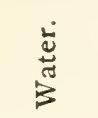 & $\frac{\dot{I}}{\infty}$ & 葛 & 递 & $\frac{\dot{\bar{c}}}{\tilde{\Xi}}$ \\
\hline $\begin{array}{l}\text { per ct. } \\
10.88\end{array}$ & per ct. & $\begin{array}{c}\text { per ct. } \\
\text { I. } 82\end{array}$ & $\begin{array}{c}\text { per ct. } \\
.70\end{array}$ & per ct. \\
\hline $\begin{array}{l}10.00 \\
14.00\end{array}$ & $\begin{array}{l}\text { I.53 } \\
. .\end{array}$ & $\begin{array}{l}1.82 \\
1.48\end{array}$ & $\begin{array}{l}.70 \\
.8 \mathrm{r}\end{array}$ & $\begin{array}{l}.40 \\
.42\end{array}$ \\
\hline I 4.30 & 2.48 & I. 5 I & .79 & .48 \\
\hline 18.17 & $\begin{array}{l}2.98 \\
1.57\end{array}$ & $\begin{array}{l}2.06 \\
2.36\end{array}$ & $\begin{array}{l}.82 \\
.70\end{array}$ & .62 \\
\hline I $4 \cdot 35$ & $\begin{array}{c}1.57 \\
\ldots .\end{array}$ & $\begin{array}{l}2 \cdot 36 \\
2.36\end{array}$ & .89 & $\begin{array}{l}.39 \\
.61\end{array}$ \\
\hline $\begin{array}{l}14.75 \\
14.90\end{array}$ & $\ldots \ldots$ & I. 76 & .82 & .54 \\
\hline 12.68 & ..... & 2.04 & .85 & .36 \\
\hline 13.68 & $\ldots \ldots$ & I. 73 & .69 & $.3^{8}$ \\
\hline I2. 60 & .82 & 1.08 & .18 & .09 \\
\hline 14.10 & $\ldots \ldots$ & I. 44 & .44 & $.2 x$ \\
\hline 18.33 & $4 \cdot 99$ & $5 \cdot 30$ & 1.87 & 1.99 \\
\hline 12.95 & I. $4^{\mathrm{I}}$ & $1.5^{8}$ & .63 & .40 \\
\hline 8.96 & ........ & $\mathrm{I} .4 \mathrm{I}$ & $\cdot 57$ & .47 \\
\hline 11.17 & $3 \cdot 37$ & I. 86 & .77 & $\cdot 59$ \\
\hline I 3.43 & 2.06 & I. .55 & .66 & $\cdot 34$ \\
\hline 9.83 & 1.22 & $2.2 \mathrm{I}$ & .57 & .54 \\
\hline 8.85 & 268 & 3.08 & .82 & .99 \\
\hline 12.09 & .82 & .50 & .06 & .60 \\
\hline 8.93 & 2.21 & I. 63 & .98 & .49 \\
\hline $8 \cdot 59$ & $\cdot 73$ & 5.03 & .33 & .05 \\
\hline 8.10 & ...... & 2.62 & .29 & . I 5 \\
\hline $18 \cdot 3^{8}$ & $12.4^{8}$ & $3 \cdot 55$ & I. 43 & 1.63 \\
\hline 9.14 & 3.92 & 3.62 & 1.03 & .09 \\
\hline 75.01 & $\cdots \quad \cdots$ & .89 & $\cdot 3^{\mathrm{I}}$ & .05 \\
\hline 12.50 & 460 & $2 \cdot 3^{2}$ & 2.28 & I. 40 \\
\hline 12.54 & $3 \cdot 5^{2}$ & I. 84 & I. 26 & $.8 \mathrm{I}$ \\
\hline 11.74 & 6.25 & 2.67 & 2.89 & 1. 61 \\
\hline $9 \cdot 18$ & $2 \cdot 30$ & 2.63 & .95 & .63 \\
\hline 10.20 & I2.94 & $.7 \mathrm{I}$ & .29 & .24 \\
\hline 10.30 & 9.00 & I. 97 & 2.67 & .71 \\
\hline 14.70 & I. 40 & 1.38 & .68 & .34 \\
\hline 7.81 & 6.95 & 6.79 & 2.88 & .87 \\
\hline 10.17 & 2.40 & .69 & .25 & 1.02 \\
\hline 8.88 & 6.08 & 5.43 & 1.66 & I. 37 \\
\hline $7 \cdot 77$ & $5 \cdot 37$ & 5.78 & 1.83 & 1.39 \\
\hline $85 \cdot 3^{\circ}$ & .39 & .13 & .01 & .19 \\
\hline 80.50 & .27 & .23 & .02 & .13 \\
\hline 87.00 & .75 & .53 & .19 & .18 \\
\hline 90.25 & .80 & .56 & .20 & .19 \\
\hline 74.05 & .50 & .40 & .15 & .13 \\
\hline 90.50 & .70 & $.4^{8}$ & .17 & .16 \\
\hline 92.97 & .60 & .35 & .14 & .18 \\
\hline 79.10 & .15 & .12 & 04 & .04 \\
\hline 3325 & 2.10 & 3.93 & .60 & .12 \\
\hline 502 & 440 & $24^{8}$ & $1.7^{6}$ & .16 \\
\hline 44.8 & 2.90 & ז.95 & 1.13 & .14 \\
\hline 420 & 1.80 & 1.76 & .73 & 10 \\
\hline
\end{tabular}




\section{AMOUNT OF SOIL INGREDIENTS WITHDRAWN BY VARIOUS CROP', IN IBSS. PER ACRE.}

(HILGARD.)

\begin{tabular}{|c|c|c|c|c|c|c|}
\hline Crops. & 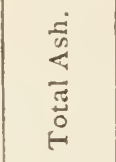 & $\begin{array}{l}\frac{1}{5} \\
\text { ڤ్ } \\
0\end{array}$ & 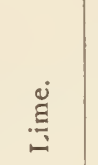 & $\begin{array}{l}\frac{0}{2} \\
\frac{2}{0} \\
\frac{0}{0} \cdot \frac{0}{4} \\
\frac{0}{a}\end{array}$ & $\frac{\dot{\Xi}}{\frac{0}{2}}$ & 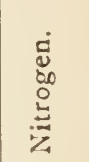 \\
\hline rapes, 1,000 lbs $\ldots \ldots \ldots$ & & 5.00 & 1.00 & 1.52 & .10 & I. 70 \\
\hline & & 50.00 & 10.00 & 15.20 & 1.00 & 17.00 \\
\hline . $\ldots \ldots, \ldots$ & & $1 .+8$ & . $\ldots$ & $5 \cdot 75$ & . & $\ldots \ldots$ \\
\hline$\ldots \ldots \ldots \ldots \ldots$ & $\ldots \ldots \ldots$ & $47 \cdot 44$ & & 8.93 & & $\cdots$ \\
\hline $1,2,010$ lbs $\ldots . . . \ldots \ldots \ldots$ & 53.42 & 15.69 & 21.60 & 8.74 & $.6 \mathrm{r}$ & \\
\hline$, 1,000 \mathrm{lbs}_{, .} \ldots \ldots \ldots \ldots \ldots$ & 3.03 & 2.66 & .13 & .53 & .01 & $1.4^{8}$ \\
\hline$\ldots \ldots \ldots \ldots \ldots$ & 120.90 & 79.70 & 3.9 & 15.95 & .22 & $44 \cdot 40$ \\
\hline r,635 lbs. $\ldots \ldots \ldots \ldots \ldots$ & 800 & 2.06 & .52 & 2.80 & .02 & $10.3^{\circ}$ \\
\hline 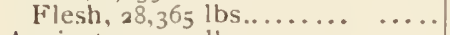 & I 12.30 & $77 \cdot 64$ & $3 \cdot 40$ & 13.15 & .20 & $34 \cdot 10$ \\
\hline$\ldots \ldots \ldots \ldots$ & $5 \cdot 16$ & 2.83 & .18 & $.7 \mathrm{I}$ & .02 & 2.29 \\
\hline bs $\ldots \ldots \ldots \ldots$. & I54.80 & 84.98 & $5 \cdot 45$ & $2 \mathbf{I} \cdot 3^{8}$ & .94 & 68.70 \\
\hline$\ldots \ldots \ldots$ & 12.25 & 1.36 & .83 & $5 \cdot 36$ & .19 & 15.00 \\
\hline$\ldots \ldots \ldots \ldots \ldots$ & 142.55 & 83.62 & 4.65 & 16.02 & .75 & 53.70 \\
\hline$\ldots \ldots \ldots \ldots$ & $+\cdot 32$ & 2. II & .99 & .53 & .04 & 1.83 \\
\hline bs............. & 86.40 & 42.28 & $19 \cdot 72$ & 10.60 & .80 & 36.60 \\
\hline$\ldots \ldots$ & 6.90 & 274 & $1 \cdot 32$ & 1.61 & .04 & $\ldots$ \\
\hline . & $79 \cdot 50$ & $39 \cdot 54$ & 18.40 & 899 & $\cdot 76$ & $\cdots \cdots$ \\
\hline ge............. & 100.12 & $15+3$ & 49.89 & $13 \cdot+7$ & .74 & $\cdots \cdots$ \\
\hline .. .......... & $100 . \infty$ & I 1.69 & $55 \quad 13$ & 17.09 &.${ }^{\prime} 5$ & $\cdots \cdots$ \\
\hline Leaves $\quad " \quad \quad \ldots \ldots \ldots \ldots$ & 99.91 & 16.51 & $56.3^{8}$ & 3.27 & 4.03 & \\
\hline Olives, 1,000 lbs................ & $9+.63$ & 8.55 & $2 \cdot 32$ & I. 18 & .23 & 5.85 \\
\hline ... & 208.18 & 1881 & $5 \cdot 10$ & $2 \cdot 59$ & .50 & 12.86 \\
\hline & 193.25 & 6.77 & 4.01 & 240 & $.4^{8}$ & 9.67 \\
\hline $\mathrm{F}$ & $14.5^{6}$ & 12.04 & $\mathrm{I} .09$ & .19 & .02 & 3.19 \\
\hline s $\ldots$ & 190.16 & $5^{8.05}$ & 88.53 & 20.08 & .28 & 6990 \\
\hline & 123.18 & $24 \cdot 46$ & 66.63 & 14.87 & $\ldots .1$ & 117.67 \\
\hline whole plant)... & 5 x. 26 & 9.15 & 2.30 & $4 \cdot 13$ & I. $5_{5}$ & 8.75 \\
\hline (hay). . .... & 246.04 & $43 \cdot 92$ & 11.04 & I 9.80 & 789 & 42.00 \\
\hline$\ldots \ldots \ldots$ & 24.00 & 7.85 & .72 & I I .90 & .02 & 2400 \\
\hline$\ldots \ldots \ldots$ & 222.04 & 36.07 & $10.3^{2}$ & 790 & 787 & 18.00 \\
\hline Alf: & 65.00 & I 3.49 & $22.86 !$ & 6.43 & 1. 59 & 12.96 \\
\hline & 780.00 & $161.88=$ & $274 \cdot 3^{2}$ & 77.16 & 19.081 & I 55.52 \\
\hline o lbs...... & 18.73 & $5 \cdot 3^{8}$ & 3.11 & I. $6 \mathbf{1}$ & & $2.3^{8}$ \\
\hline & $13+9 \cdot 72$ & $387 \cdot 44$ & 224.081 & I16. I6 & 61.681 & $\mathrm{I} 73.40$ \\
\hline & 287.00 & 152.00 & 16.00 & $3^{6.00}$ & 12.00 & $60 \cdot 40$ \\
\hline . $\ldots . .$. & 1062.72 & 235.44 & 20808 & 80.16 & 4968 & $1 \mathrm{I} 3.00$ \\
\hline$\cdots \ldots \ldots \ldots$ & 75.19 & 8.84 & 23.08 & 646 & 1.12 & 12.97 \\
\hline of $\mathrm{I}_{4}$ & 2143.57 & 251.98 & 657.82 & $155 \cdot 70$ & 51.85 & $369 \cdot 70$ \\
\hline & $16+1.35$ & 68.13 & 566.91 & & $41 \cdot 5^{6}=$ & 20610 \\
\hline $\begin{array}{l}\text { St.llk (without bark) } 7.25 \text { tons. } \\
\text { Bark (cuticle and tibre), } 2.75\end{array}$ & & $155 \cdot 99$ & $71 \cdot 77$ & $67 \cdot 7 \mathrm{I}$ & $2 \cdot 50$ & 105.85 \\
\hline$\ldots \ldots \ldots \ldots$ & $91 \cdot 74$ & 27.86 & 19.14 & 10.86 & $7 \cdot 79$ & $57 \cdot 75$ \\
\hline Cott & & 11.00 & $13 \cdot 76$ & 7.03 & $2.5^{8}$ & \\
\hline & 173.60 & $35 \cdot 26$ & 44.04 & 22.54 & 8.27 & $\ldots$ \\
\hline & 48.69 & $7 \cdot 99$ & 15.03 & 4.22 & 2.75 & $\ldots \ldots$ \\
\hline & $3^{8.44}$ & 9.17 & 10.58 & $4 \cdot 49$ & $2 \cdot 54$ & \\
\hline & $29 \cdot 37$ & 8.99 & 3.07 & 9.74 & $.4^{8}$ & 29.20 \\
\hline & 52.01 & $7 \cdot 42$ & 14.16 & $3 \cdot 57$ & 2. 14 & …… \\
\hline Lint, & & & 1.20 & .52 & & \\
\hline
\end{tabular}




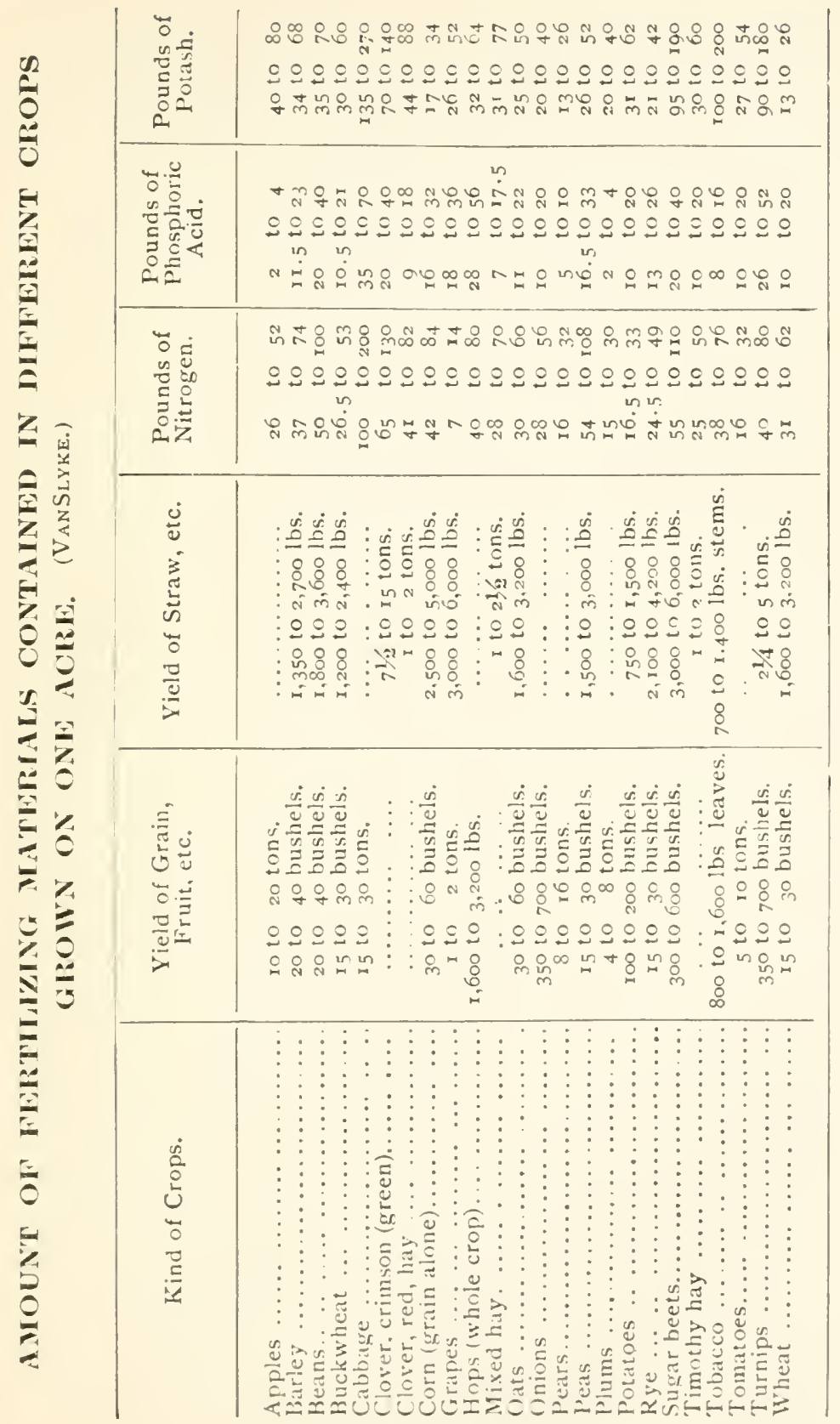


MINIMUM AMOUNT OF FARMYARD MANURE required to replace the Ingredients abstracted from the Soil by an Acre of Different Crops. (McConnell.)

Wheat........... 5 tons.

Barley........... 5

Oats ........... 5

Meadow hay...... 8

Red clover........ I 2

Beans........... Iо
Turnips.......... I 5 tons.

Swedes.......... I0

Mangolds......... 20

Potatoes......... Io

Cabbage ..........25

Carrots.......... ro

\section{AMOUNT AND QUALITY OF MANURE PRODUCED BY STOCK.}

The various classes of farm animals will produce about the following quantities of solid and liquid manure during a year, viz.:

Solid Manure. Liquid Manure

Horse................. I 2,000 lbs. 3,000 lbs.

Cow................. 20,000" 8,000 "

Sheep................ 760 " 380 “

Pig ................. I, SOO " 1,200 “

Since a considerable portion of the manure is lost while the animal is working or is out-doors, the quantities secured in the manure-pile will not come up to these figures.

The quantities of urine voided by farm animals during twenty-four hours are on the average as follows, according to Wilckens: cows, 15-20 lbs.; horses, 20-27 lbs.; sheep, 2 lbs.; swine, 7-9 lbs. The capacity for liquid manure-tanks or cisterns intended to hold the fluid excrements of a herd of a certain size may readily be calculated on a basis of these figures (see tables on p. I82). 6000 lbs. (about 720 gallons) of urine per Iooo lbs. live weight of cattle, is a liberal estimate.

The quality of the manure produced will depend on the character of the feeding and the kind of stock kept. Rich feeding produces a rich manure, since, as shown in the table given below, only a relatively small portion of the valuable fertilizing ingredients of the food is retained in 
the bodies of the animals, or is taken away in the products sold. Rich feeding, therefore, has a beneficial influence in two directions, larger yields of products being obtained, and a better quality of manure being produced.

\section{COMPOSITION, AMOUNT, AND VALUE OF MANURE Prodnced by Diflerent Kinds of Farm Animals.}

(Results of experiments conducted at Cornell University Expcriment St:ition.)

\begin{tabular}{|c|c|c|c|c|c|c|c|c|}
\hline & \multicolumn{5}{|c|}{$\begin{array}{c}\text { Analysis and Value per Ton of } \\
\text { Manure. }\end{array}$} & \multicolumn{3}{|c|}{$\begin{array}{c}\text { Amount and Value ner } \\
\text { rooo lbs. Live Weight } \\
\text { per Diy. }\end{array}$} \\
\hline & 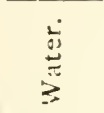 & 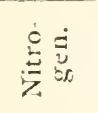 & $\stackrel{3}{3} \frac{3}{2} \frac{0}{2}$ & $\begin{array}{l}\stackrel{\vec{n}}{0} \\
\stackrel{\Xi}{0} \\
2\end{array}$ & 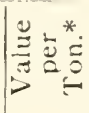 & 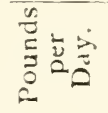 & 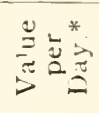 & 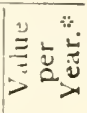 \\
\hline Sheep & $\begin{array}{r}\text { Per ct. } \\
59.52\end{array}$ & $\begin{array}{c}\text { Perct. } \\
.77\end{array}$ & $\begin{array}{c}\text { Per ct. } \\
9.30\end{array}$ & $\begin{array}{c}\text { Per ct. } \\
.50\end{array}$ & $\$ 3.30$ & $34 . \mathrm{I}$ & $\begin{array}{c}\text { Cents. } \\
7.2\end{array}$ & Sis \\
\hline Calves & 7773 & $=0$ & .17 & .53 & 2.18 & 68 & 6.7 & 2145 \\
\hline Pigs & $74 \mathrm{I} 3$ & .84 & $\cdot 39$ & $\cdot 3^{2}$ & $3 \%$ & $8 ; 6$ & 16.7 & 60.88 \\
\hline Cows ... & 75.25 & .43 & .29 & .44 & 2.02 & 74.8 & 8.0 & 29.27 \\
\hline Horses. & $4^{8.6}$ & .49 & .26 & .48 & 2.21 & $4^{8} .8$ & 7.6 & $27 \cdot 7+4$ \\
\hline
\end{tabular}

\section{geivt TIFS OF NITROGEN AND ASH CONSTITU-} ents Voided by Animals or Obtained in Animal Producls. (Lawes and Gilbert.)

\begin{tabular}{|c|c|c|c|c|c|c|}
\hline & \multicolumn{4}{|c|}{ Percentage of Nitrogen. } & \multicolumn{2}{|c|}{$\begin{array}{l}\text { Percentage of Ash } \\
\text { Constituents. }\end{array}$} \\
\hline & $\begin{array}{l}\text { Obtain- } \\
\text { ed as } \\
\text { Animal } \\
\text { Prod- } \\
\text { uct. }\end{array}$ & $\begin{array}{c}\text { Voided } \\
\text { as Solid } \\
\text { Excre- } \\
\text { ment. }\end{array}$ & $\begin{array}{l}\text { Voided } \\
\text { as } \\
\text { Liquid } \\
\text { Excre- } \\
\text { ment. }\end{array}$ & $\begin{array}{l}\text { In Total } \\
\text { Excre- } \\
\text { ment. }\end{array}$ & $\begin{array}{l}\text { Obtained } \\
\text { as Live } \\
\text { Weight } \\
\text { or Milk. }\end{array}$ & $\begin{array}{l}\text { Voided } \\
\text { as Excre- } \\
\text { ment or } \\
\text { Perspira- } \\
\text { tion. }\end{array}$ \\
\hline $\begin{array}{l}\text { Horse at rest .. } \\
\text { Hure :at work. } \\
\text { Fattening oxen. } \\
\text { ! ttening sheep. } \\
\text { lattoning pigs. } \\
\text { s!mking cows... }\end{array}$ & $\begin{array}{c}\text { None. } \\
\text { None. } \\
3 \cdot 9 \\
4 \cdot 3 \\
14 \cdot 7 \\
24 \cdot 5\end{array}$ & $\begin{array}{l}43.0 \\
29.4 \\
22.6 \\
16.7 \\
22.0 \\
18.1\end{array}$ & $\begin{array}{l}57 \cdot 0 \\
70.6 \\
73 \cdot 5 \\
79 \cdot 0 \\
63 \cdot 3 \\
57 \cdot 4\end{array}$ & $\begin{array}{r}100.0 \\
100.0 \\
96.1 \\
05.7 \\
85.3 \\
75.5\end{array}$ & $\begin{array}{c}\text { None. } \\
\text { None. } \\
2.3 \\
3.8 \\
4.0 \\
10.3\end{array}$ & $\begin{array}{r}100.0 \\
100.9 \\
97.7 \\
96.2 \\
96.0 \\
89.7\end{array}$ \\
\hline
\end{tabular}

* Valuing nitrogen at is cents, phosphoric acid at o cents, alla putash at 4 t cents per pound 


\section{PERCENTAGE COMPOSITION OF COMMERCIAL FERTLLIZING MATERALS. (Beal.)}

\begin{tabular}{|c|c|c|c|c|c|c|c|}
\hline \multirow[b]{2}{*}{ Name. } & \multirow[b]{2}{*}{ 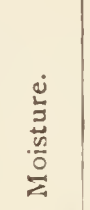 } & \multirow[b]{2}{*}{ 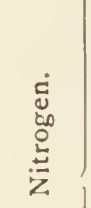 } & \multirow[b]{2}{*}{ 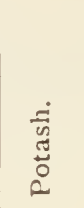 } & \multicolumn{3}{|c|}{ Phosphoric Acid. } & \multirow[b]{2}{*}{ 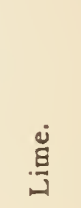 } \\
\hline & & & & $\frac{\frac{0}{0}}{3}$ & 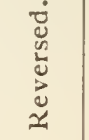 & 형 & \\
\hline Algae (Lynghia majuscula). & $x 6.26$ & 4.25 & $\cdot 79$ & & $\ldots$ & .19 & 2.06 \\
\hline 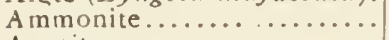 & 5.88 & $11 \cdot 33$ & $\ldots$. & ‥ & $\cdots \cdot$ & 3.43 & ..... \\
\hline Apatite. $\quad \ldots \ldots \ldots \ldots \ldots$ & $\cdots \cdots$ & $\ldots .$. & $\cdots \cdots$ & $\ldots \ldots$ & $\ldots$. & 36.08 & ... \\
\hline Aslies, anthracite coal..... . & $\ldots$. & $\cdots \cdots$ & . xo & $\ldots \ldots$ & $\cdots \cdots$ & . Io & \\
\hline " bituminous" ..... & $\cdots \cdots$ & $\ldots \ldots$ & .40 & $\ldots \ldots$ & $\cdots$ & .40 & \\
\hline ". lime-kiln. ... & I5.45 & .... & 1.20 & ..... & .... & I. I 4 & 48.5 \\
\hline wood, leached....... & 30.22 & $\cdots \cdots$ & I.27 & $\ldots$. & ... & I. $5^{x}$ & 28.0 \\
\hline ". $\quad$ " unleached.... & I2.50 & & 5.25 & & $\ldots \ldots$ & $x .70$ & 34.00 \\
\hline 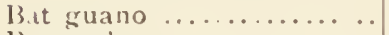 & 40.09 & 8.20 & $1 \cdot 31$ & $2 \cdot 37$ & 1.24 & 3.80 & \\
\hline Bone-ash. $\ldots \ldots \ldots \ldots \ldots$. & 7.00 & $\cdots \cdots$ & ...... & $\ldots \ldots$ & .... & 35.89 & 44.8 \\
\hline Bone-black................... & 4.60 & $\cdots \cdots$ & $\cdots \cdots$ & $\ldots \ldots$ & $\cdots \cdots$ & 28.28 & \\
\hline Bone ineal............ & $7 \cdot \ddot{50}$ & 4.05 & $\cdots \cdots$ & $\begin{array}{r}15.49 \\
.40\end{array}$ & $\begin{array}{l}1.30 \\
7.63\end{array}$ & $\begin{array}{l}17.00 \\
23.25\end{array}$ & \\
\hline "dissolve & & 2.60 & & & 53 & 17.60 & \\
\hline "free from fat... & 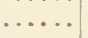 & 6.20 & & & & 20.10 & \\
\hline " " from glue factory & $\cdots \cdots$ & $\mathbf{1} .70$ & & $\ldots \ldots$ & & 29.90 & ‥ \\
\hline 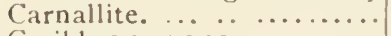 & $\cdots \cdots$ & $\ldots \ldots$ & 13.60 & ....... & $\ldots \ldots$ & $\cdots \cdots$ & ... \\
\hline Caribbean guano.... ....... & $7 \cdot 3 \mathrm{I}$ & $\cdots \cdots$ & ..... & ...... & 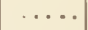 & 26.77 & $39 \cdot 9$ \\
\hline Castor poma & 9.50 & $5 \cdot 50$ & I. ro & $\ldots \ldots$ & & 1.75 & \\
\hline Cotton-hul' ashes...$\ldots \ldots$. & 7.80 & & 22.75 & $\mathbf{1} .25$ & 6.50 & 8.85 & $9.6 c$ \\
\hline Co:ton-seed meal, decort ... & $7 \cdot 75$ & 6.79 & I. 77 & $\ldots \ldots$ & . $\cdots$ & 2.88 & $\ldots \ldots$ \\
\hline " " " undecort.. & $\cdots \cdots$ & $4 \cdot 30$ & I. 50 & $\cdots \cdots$ & $\cdots \cdots \cdots$ & $3 \cdot 10$ & $\cdots$ \\
\hline Cuba guano...$\ldots \ldots \ldots \ldots$ & $24 \cdot 27$ & I.67 & ...... & $\cdots \cdots$ & ..... & $\mathbf{3} \cdot 35$ & $\cdots$ \\
\hline Dried blood................. & 12.50 & $10.5^{2}$ & $\ldots \ldots$ & $\ldots .$. &... & $1.9 \mathrm{I}$ & $\cdots$ \\
\hline Dried fish................. & 12.75 & $7 \cdot 25$ & $\cdots \cdots$ & .55 & 2.60 & 8.25 & - \\
\hline Ecl-grass (zostera marina).. & 81.19 & $\cdot 35$ & .32 & $\cdots \cdots$ & $\cdots \cdots$ & .07 & \\
\hline G.ls lime $\ldots \quad \ldots \ldots \ldots \ldots \ldots$ & 22.28 & $\cdots \cdots$ & $\cdots \cdots$ & ..... & $\cdots \cdots+$ & $\cdots \cdots$ & 43.6 \\
\hline Horn and hoof waste ...... & I0. 17 & 13.25 & $\cdots$ & $\cdots$ & $\cdots \cdots$ & 1.83 & $\cdots \cdots$ \\
\hline Kainit $\ldots \ldots \cdots \cdots \cdots$ & 3.20 & $\cdots \cdots$ & I $3 \cdot 54$ & $\cdots \cdots$ & $\cdots \cdots$ & $\cdots \cdots$ & I. 15 \\
\hline Kelp (laminaria)............. & 87.75 & .20 & .24 & $\cdots \cdots$ & $\cdots \cdots$ & .06 & .40 \\
\hline $\begin{array}{l}\text { Kieserite. } \ldots \ldots \ldots \ldots \\
\text { Krugite... } \\
n^{\prime}\end{array}$ & $\begin{array}{r}22.70 \\
4.82\end{array}$ & $\cdots \cdots$ & 8.42 & an. & $\cdots \cdots \cdot \mid$ & $(\cdots \cdots$ & $\begin{array}{r}2.82 \\
12.45\end{array}$ \\
\hline $\begin{array}{l}\text { Krugite } \\
\text { Lobster shells } \ldots \ldots \ldots \ldots \ldots\end{array}$ & $\begin{array}{l}4.82 \\
7.27\end{array}$ & $4 \cdot 50$ & $\ldots .42$ & $\left|\begin{array}{rl}\cdots & \cdots \\
\cdots & \cdots\end{array}\right|$ & $\ldots \ldots$ & 3.52 & $\begin{array}{l}12.45 \\
22.24\end{array}$ \\
\hline Marls, Kentucky.. … : : : & I. 50 & $\ldots$. & $\cdot \mathrm{x}-3$ & $\ldots \ldots$ & $\cdots \cdots$ & .2 & $3-34$ \\
\hline ". Maryland and Virginia & I. 50 & $\ldots$. & $.2-5$ & $\ldots .$. & $\ldots \ldots$ & $.0-2$ & $0-40$ \\
\hline "New Jersey green sand & I. 50 & $\ldots .$. & $3 \cdot 5^{-7}$ & $\ldots$. & $\ldots .$. & $. x-4$ & $I-9$ \\
\hline " North Carolina....... & 1.50 & $\cdots \cdots$ & $.2-1 \cdot 5$ & & & $0-.4$ & $5-45$ \\
\hline Meat scrap $\ldots . . . . \quad \ldots .$. & 12.09 & 10.44 & $\ldots \ldots$ & ..... & $\ldots \ldots$ & 2.07 & \\
\hline Mona Island guano ......... & $13 \cdot 32$ & .76 & $\cdots \cdots$ & $\cdots \cdots$ & $7 \cdot 55$ & 21.88 & $37 \cdot 49$ \\
\hline 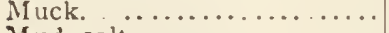 & 50.00 & ז. & .15 & $\cdots \cdots$ & & .10 & \\
\hline 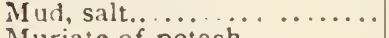 & 60.00 & .40 & .35 & $\cdots \cdots$ & $\cdots \cdots$ & .10 & .90 \\
\hline Muriate of potash........... & 2.00 & $\cdots \cdots$ & $5 \mathrm{I} \cdot 4^{8}$ & $\cdots \cdots$ & . $\cdots$ & $\cdots \cdots \cdot$ & $\cdots$ \\
\hline Navassa phosphate ........ & 7.60 & $\ldots$ & & & & 34.27 & $37 \cdot 45$ \\
\hline Nitrate of soda. .......... & I. 40 & I5 70 & $\cdots \cdots \cdots$ & $\cdots \cdots$ & $\cdots \cdots$ & $\cdots$ & \\
\hline Oleomargarine refuse....... & 854 & 12.12 & & & & & \\
\hline
\end{tabular}




\section{PERCENTAGE COMPOSITION OF COMMERCIAL FER'ILIZING MA'TERIAIS.-Continued.}

\begin{tabular}{|c|c|c|c|c|c|c|c|}
\hline \multirow[b]{2}{*}{ Name. } & \multirow[b]{2}{*}{$\begin{array}{l}0 \\
\stackrel{0}{\Xi} \\
\frac{n}{3} \\
\frac{0}{0}\end{array}$} & \multirow[b]{2}{*}{ 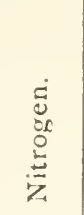 } & \multirow[b]{2}{*}{$\begin{array}{l}\frac{\text { ज् }}{0} \\
\text { 0 } \\
0\end{array}$} & \multicolumn{3}{|c|}{ Phosphoric Acid. } & \multirow[b]{2}{*}{$\stackrel{\stackrel{\Xi}{\Xi}}{\underline{\Xi}}$} \\
\hline & & & & $\frac{\frac{\dot{0}}{3}}{3}$ & 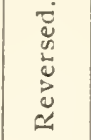 & $\begin{array}{l}\vec{J} \\
\stackrel{\Delta}{5} \\
\text { E }\end{array}$ & \\
\hline yster-shell lime*. & 15.00 & & .05 & $\cdots$ & $\cdots$ & .18 & 55.00 \\
\hline$\ldots \ldots \ldots$ & $6 \mathbf{r} \cdot 50$ & .85 & .18 & & & .08 & 35.6 \\
\hline guano................. & 14.81 & $7 \cdot 35$ & 2.65 & 3.20 & 4.10 & $15 \cdot 30$ & \\
\hline Phosphates, I & 2.25 & $\cdots \cdot \cdots$ & $\cdots \cdots$ & $\ldots \ldots$ & $\cdots \cdots$ & 2450 & 28.50 \\
\hline $\begin{array}{l}\text { Plaster, puret. .. .... } \\
\text { Seaweed... }\end{array}$ & $8 \mathrm{t} .00$ & $\cdots \cdot 20$ & 40 & & $\cdots \cdots$ & & 20.93 \\
\hline eaweed $\ldots{ }$ ashes. $\ldots \ldots \ldots \ldots$ & $\begin{array}{r}81.90 \\
1 \quad 47\end{array}$ & $\begin{array}{l}.29 \\
\ldots\end{array}$ & $\begin{array}{l}.40 \\
.92\end{array}$ & . . . & $\cdots \cdots$ & $\begin{array}{l}.08 \\
.30\end{array}$ & 6.00 \\
\hline ". mixe & $81 \cdot 50$ & & 1.50 & .... & . $\cdots$ & .18 & .23 \\
\hline Sewage sludge, precipitated & 88.49 & .05 & .05 & $\ldots \ldots$ & ...... & .10 & 1.58 \\
\hline oot & $5 \cdot 54$ & $\cdots \quad \cdots$ & I. 83 & $\because \cdots$ & & $\cdots$ & \\
\hline . Carolina rock, dissolved.. & & & & & .60 & 15.20 & \\
\hline d..... & 1.50 & $\ldots \ldots$ & $\cdots \cdots$ & .27 & .07 & 28.03 & 41.87 \\
\hline $\mathrm{e}^{\text {ark ashes......... }}$ & $\begin{array}{r}3 \cdot 61 \\
63.06\end{array}$ & i io & 2.04 & $\cdots \cdots$ & $\cdots \cdots$ & 1.61 & $33 \cdot 4^{6}$ \\
\hline mmonia ........ & $\begin{array}{r}3.00 \\
1.00\end{array}$ & 20.50 & $\begin{array}{l}3 \cdot 25 \\
\ldots . .\end{array}$ & $\cdots \cdots$ & $\cdots \cdots$ & $\cdots \cdots$ & 1.14 \\
\hline Sulfate of pota & & & & & & & $\cdots$. \\
\hline & 4.75 & $\cdots \cdots$ & $25 \cdot 50$ & & $\cdots \cdots$ & ...... & 2.57 \\
\hline sh, high grade & 2.54 & $\cdots$ & 33.40 & $\cdots \cdots$ & .. & ... & $\ldots$ \\
\hline$\ldots \ldots \ldots$ & 7.25 & 6.7 & 16.65 & $\cdots$ & $\cdots$ & & .. \\
\hline $\begin{array}{l}\mathrm{e} \\
\mathrm{e}\end{array}$ & 10.00 & 6.70 & $\cdots \cdots$ & $\cdot 30$ & 5.10 & II . 80 & 1866 \\
\hline $\begin{array}{l}\text { Thomas } s \operatorname{lag} \ldots \ldots \ldots \\
\text { Tovacco stalks. } \ldots \ldots \ldots \ldots\end{array}$ & $\begin{array}{l}1.45 \\
6.18\end{array}$ & & $\begin{array}{r}\cdots \\
5.02\end{array}$ & .00 & 3.06 & $\begin{array}{r}23.49 \\
.65\end{array}$ & $\begin{array}{r}48.66 \\
2.22\end{array}$ \\
\hline ms.................. & 10.00 & 2.35 & 8.20 & $\cdots \cdots$ & $\cdots$ & $\begin{array}{l}.05 \\
.70\end{array}$ & $\begin{array}{l}2.22 \\
4.20\end{array}$ \\
\hline$\ldots \ldots \ldots$ & & & 3.92 & $\ldots \ldots$ & $\cdots \cdots$ & $\ldots$. & .... \\
\hline Wool waste $\ldots \ldots \ldots \ldots \ldots$ & 15.80 & 6.50 & \pm 1.20 & $\cdots \cdots$ & $\cdots \cdots$ & $\cdot 35$ & .11 \\
\hline $\begin{array}{c}\text { Composition of Farm } \\
\text { llamures. }\end{array}$ & & & & & & & \\
\hline Barnyard manı & 68.87 & .49 & .43 & $\cdots$ & $\cdots \cdots$ & $\cdot 3^{2}$ & \\
\hline solid,fresh & $\cdots \cdots$ & .29 & .10 & $\ldots \cdots$ & $\cdots$ & .17 & .... \\
\hline$\ldots \ldots$ & & $\cdot 5^{8}$ & .49 & $\ldots \ldots$ & $\cdots \cdots$ & & $\ldots \ldots$ \\
\hline solid........ & $\left|\begin{array}{c}00.00 \\
\ldots \ldots\end{array}\right|$ & $\begin{array}{r}1.10 \\
.44\end{array}$ & $\begin{array}{r}.50 \\
.35\end{array}$ & $\cdots$ & $\cdots$ & .85 & $\cdots \cdots$ \\
\hline lid....... & & $\begin{array}{r}.04 \\
1.55\end{array}$ & $\begin{array}{r}.35 \\
1.50\end{array}$ & $\cdots \cdots$ & $\cdots \cdots$ & $\begin{aligned} \cdot 17 \\
\ldots . \cdot\end{aligned}$ & $\cdots$ \\
\hline $\begin{array}{l}\text { Hor } \\
\text { Hu }\end{array}$ & $77 \cdot 20$ & 1.00 & .25 & $\ldots \ldots$ & ...... & $\mathbf{1 . 0 9}$ & \\
\hline $\mathrm{Hu}$ & 95.00 & .60 & .20 & & $\ldots \ldots$ & .17 & $\cdots$ \\
\hline & 10.00 & 3.20 & 1.00 & $\ldots \ldots$ & . . & 1.90 & $2.1 \mathrm{C}$ \\
\hline Poi & 50.00 & .80 & $\cdot 30$ & $\cdots$ & $\ldots$. & 1.40 & .8 \\
\hline solid.fresh & $\cdots \cdots \cdot$ & $\cdot 55$ & .15 & & $\cdots \cdots$ & $\cdot 3^{I}$ & $\ldots \ldots$ \\
\hline She & & 1. 95 & 2.26 & & & .01 & $\ldots \ldots$ \\
\hline Stable manure, mixed........ & 73.27 & .50 & .60 & $\cdots$ & & $\cdot 30$ & $\cdots$ \\
\hline $\begin{array}{l}\text { Swine cxcle menl, solid, fresh } \\
\text { Swine urine, fresh . . . . . }\end{array}$ & -1 & .60 & .13 & & & $.4 \mathrm{x}$ & \\
\hline & & & & & & .07 & \\
\hline
\end{tabular}

* 18.5 per cent carbonate.

+ Nora Scotia plaster contains 94 per cent pure gypsum and 4 per cent carbonate of lime: Onondaga and Cayuga, 65-75 per cent gypsum and 18-28 per cent carbonate of lime.

\# Sometimes as high as 5 per cent. 
EXHAUSTION OF FERTILIZERS. (Scotch Authority.)

ON CULTIVATED CLAY LOAM.

\begin{tabular}{|c|c|c|c|c|c|c|c|}
\hline \multirow[t]{2}{*}{ Kind of Fertilizer. } & \multirow{2}{*}{ 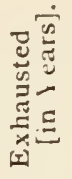 } & \multicolumn{6}{|c|}{$\begin{array}{c}\text { Per Cent remaining in the } \\
\text { Soil Untxhausted at } \\
\text { End of Each of First } \\
\text { Six Years. }\end{array}$} \\
\hline & & I & 2 & 3 & 4 & 5 & 6 \\
\hline Lime....... & 12 & 80 & $6_{5}$ & 55 & 45 & 35 & 25 \\
\hline 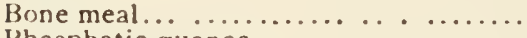 & 5 & 60 & $3^{\circ}$ & 20 & 10 & . & .. \\
\hline $\begin{array}{l}\text { Phosphatic guanos............................... } \\
\text { Dissolved bones and plain superphos. }\end{array}$ & 5 & 50 & 30 & 20 & 10 & . & $\cdots$ \\
\hline 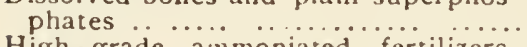 & 4 & 20 & 10 & 5 & $\ldots$ & .. & $\cdots$ \\
\hline $\begin{array}{l}\text { High-grade ammoniated fertilizers, } \\
\text { guano, etc... } \ldots \ldots \ldots \ldots \ldots \ldots \ldots \ldots\end{array}$ & & & & & & & \\
\hline 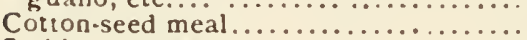 & $\begin{array}{l}3 \\
5\end{array}$ & $\begin{array}{l}30 \\
40\end{array}$ & $\begin{array}{l}20 \\
30\end{array}$ & $\ddot{20}$ & $\ddot{10}$ & $\because$ & $\because$ \\
\hline 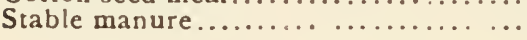 & $\begin{array}{l}5 \\
5\end{array}$ & 60 & 30 & 20 & 10 & $\because$ & $\ddot{\cdots}$ \\
\hline
\end{tabular}

\section{ON CULTIVATED LIGHT OR MEDIUM SOILS.}

Lime.....

Bone meal

Phosphatic guanos

Dissolved bones and plain superphos. phate .....................

High-grade ammoniates, guanos. .....

Cotton-seed meal....................

Stable manure

\begin{tabular}{l|c|c|c|c|c|c}
10 & 75 & 60 & 40 & 30 & 20 & 15 \\
4 & 60 & 30 & 10 & $\ldots$ & $\ldots$ & $\ldots$ \\
4 & 50 & 20 & 10 & $\ldots$ & $\ldots$ & $\ldots$ \\
3 & 20 & 10 & 5 & $\ldots$ & $\ldots$ & $\ldots$ \\
3 & 30 & 20 & $\ldots$ & $\ldots$ & $\ldots$ & $\ldots$ \\
4 & 40 & 30 & 20 & 10 & $\ldots$ & $\ldots$ \\
4 & 60 & 30 & 10 & $\ldots$ & $\ldots$ & $\ldots$ \\
\hline
\end{tabular}

ON CULTIVATED PASTURE LAND.

\begin{tabular}{|c|c|c|c|c|c|c|c|}
\hline Lime. & 15 & 80 & 70 & 60 & 50 & 45 & \\
\hline 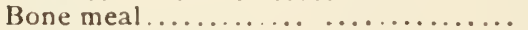 & -3 & 60 & 50 & 40 & 30 & 20 & Io \\
\hline Phosphatic guanos $\ldots . . . \ldots \ldots$..... & 6 & 50 & 40 & 30 & 20 & 10 & \\
\hline Dissolved bone, etc $\ldots \ldots . \ldots \ldots \ldots$ & 4 & 30 & 20 & Io & . & . & • \\
\hline High-grade ammoniated guanos ...... & 4 & 30 & 20 & 10 & .. & . & $\cdots$ \\
\hline Cotton-seed meal................... & 5 & 40 & 30 & 20 & 10 & .. & .. \\
\hline Stable mar & 7 & 60 & 50 & 40 & 30 & 20 & o \\
\hline
\end{tabular}

Sulfate of ammonia, nitrate of soda, sulfate, nitrate, and muriate of potash are generally held to be entirely exhausted by the crops grown the season of their application. 


\section{EQUIVALENT QUANTITISS OF FERTILIZING}

MATERIALS. (Wheeler and Hartwell.)

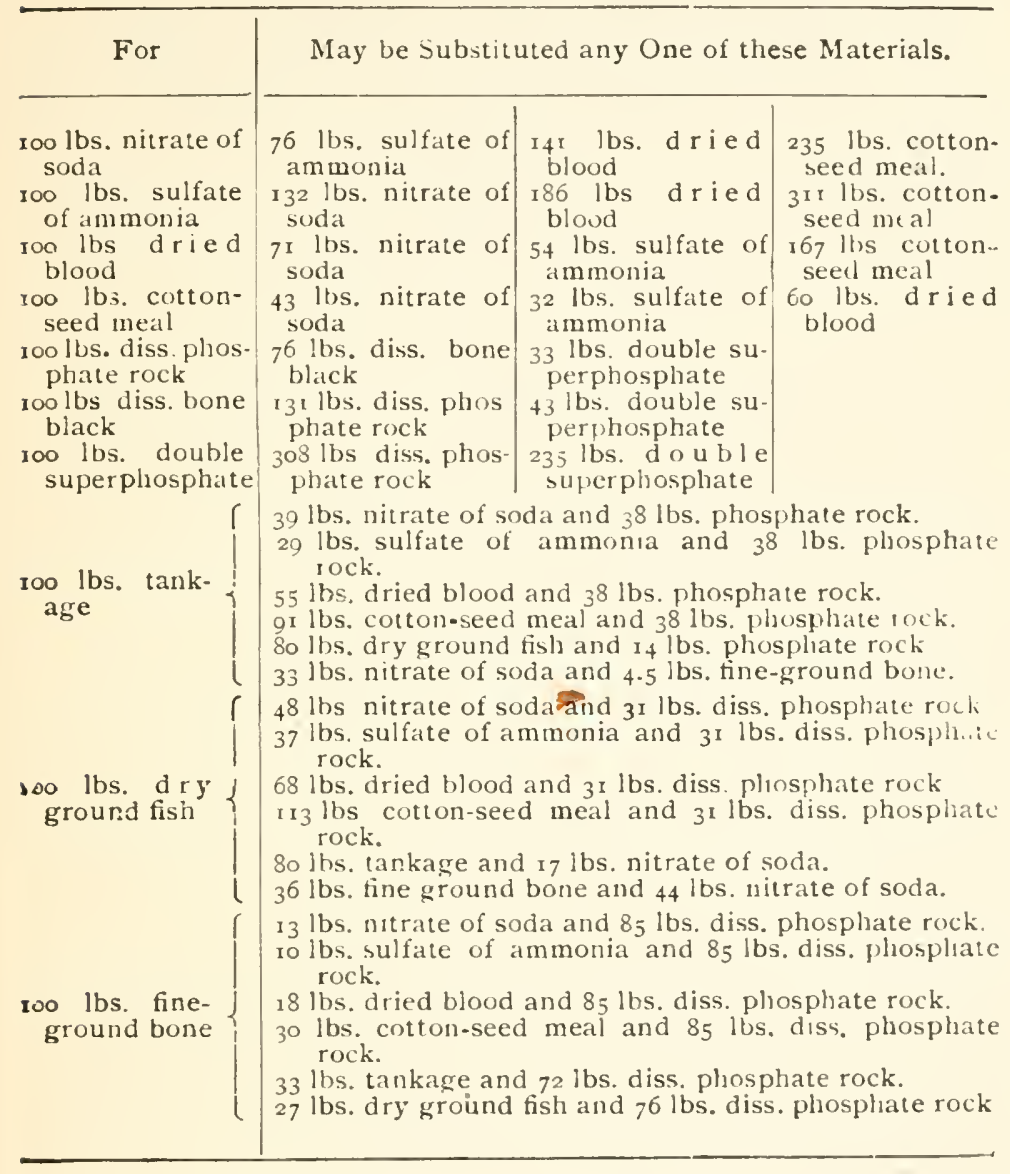


PROPORTION OF PLANT FOOD RECOMMENDED

For CRops. (Virginia Exp. Station.)

\begin{tabular}{|c|c|c|c|c|c|c|c|}
\hline Crop. & $\begin{array}{l}\text { Nitro- } \\
\text { gen. }\end{array}$ & $\begin{array}{l}\text { Phos- } \\
\text { phoric } \\
\text { Acid. }\end{array}$ & Potash & Crop. & $\begin{array}{l}\text { Nitro- } \\
\text { gen. }\end{array}$ & $\begin{array}{l}\text { Phos- } \\
\text { phoric } \\
\text { Acid. }\end{array}$ & Potash \\
\hline $\begin{array}{l}\text { Alfalfa .... } \\
\text { Barley .... } \\
\text { Buckwheat } \\
\text { Cabbage . . } \\
\text { Clover . . . } \\
\text { Corn ... . } \\
\text { Cotton .... }\end{array}$ & $\begin{array}{c}\% \\
1 \\
4 \\
4 \\
6 \\
1 \\
3 \\
3\end{array}$ & $\begin{array}{c}\% \\
8 \\
7 \\
8 \\
7 \\
8 \\
8 \\
8\end{array}$ & $\begin{array}{r}\% \\
10 \\
8 \\
9 \\
9 \\
10 \\
6 \\
4\end{array}$ & $\begin{array}{l}\text { Oats ..... } \\
\text { Peanuts ... } \\
\text { Potatoes ... } \\
\text { Rye ..... } \\
\text { Tobarco ... } \\
\text { Tomatoes.. } \\
\text { Wheat... }\end{array}$ & $\begin{array}{c}\% \\
4 \\
2 \\
4 \\
4 \\
5 \\
4 \\
3\end{array}$ & $\begin{array}{r}\% \\
9 \\
10 \\
7 \\
9 \\
6 \\
6 \\
8\end{array}$ & $\begin{array}{r}\% \\
6 \\
10 \\
10 \\
5 \\
10 \\
7 \\
4\end{array}$ \\
\hline
\end{tabular}

\section{VAIUATION OF MANURIS ANI FERTILIZERS.}

The valuation of fertilizing ingredients shown below (see p. I59) is the one agreed upon by a number of Eastern experiment and fertilizer cortrol stations after a careful study of the retail prices of crude products of fertilizers during the six months prior to March I, Igos. It expresses the commercial value of the fertilizers, and not their agricultural value; the latter will vary according to the requirements of the land and the character of the crops grown. Fertilizers are sold in States having fertilizer control, on the basis of a guarantee of a minimum content of potash, phosphoric acid, and nitrogen, singly or combined, and it is the office of the fertilizer control stations to watch that goods offered for sale in their respective States are up to the guarantee. Farmers living in States where fertilizer laws have been enacted (Alabama, Arkansas, California, Connecticut, Delaware, Florida, Georgia, Illinois, Indiana, Kansas, Kentucky, Louisiana, Maine, Maryland, Massachusetts, Michigan, Mississippi, Missouri, New Hampshire, New Jersey, New York, North Carolina, North Dakota, Ohio, Pennsylvania, Rhode Island, South Carolina, Tennessee, Texas, Vermont, Virginia, West Virginia, Wisconsin) should only buy fertilizers on guarantee, and should examine the fertilizer bulletins published by their respective stations to ascertain that the goods put on the market are not below the guarantee, and that the valuation price is not below the selling price of the article. Where a reasonable suspicion of fraud exists, apply to the director of the experiment station for information concerning the goods offered for sale or the firm placing them on the market. 


\section{TRADE VALUES OF FERTILIZING INGREDIENTS IN RAW MATERIALS AND CHEMICALS, 1913.}

Adopted by Eastern Experiment Stations for estimating the value of mixed commercial fertilizers.

Nitrogen-

Cents

in nitrates........................ 8.5

in ammonia salts.................. 18.5

Organic Nitrogen-

in dry and fine-ground fish, meat, and bloo $1 . \ldots \ldots .20$

in fine bone and tankage and in mixed fertilizor........ I9

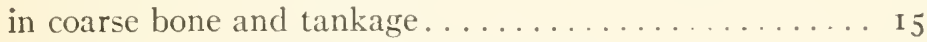

in cotton seed meal and castor pomace........... 20

Phosphoric Acid-

soluble in water...................... 4.5

soluble in neutral ammonium-citrate soluti $\ldots \ldots \ldots \ldots 4$

in dry fine-ground fish, bone, and tankegz........ 4

in coarse fish, bone, tankage, and a shes........ 3.5

in cotton-seed meal and castor pomace.......... 4

in mixed fertilizers, if insoluble in amnoniun-citrate solution . . . . . . . . . . . . . . . . .

Potash-

as high-grade sulfate, and in forms free from muriate... $5 \frac{1}{4}$

as muriate............................. $4^{\frac{1}{4}}$

in cotton-seed meal and castor pomace......... 5

The manurial constitutents contained in feeding stuffs may be valued as follows:

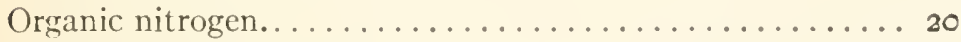

Phosphoric acid....................... 4

Potash............................... 5 


\section{CONVERSION TABLE FOIR CALCULATING FER. TILIZING INGREDIENTS.}

\begin{tabular}{|c|c|c|}
\hline Amount of & $\begin{array}{l}\text { Multiplicd } \\
\text { by }\end{array}$ & Gives Corresponding Amount \\
\hline 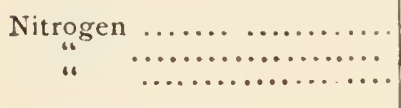 & $\begin{array}{l}1.214 \\
6.07 \\
4.7\end{array}$ & $\begin{array}{l}\text { Ammonia. } \\
\text { Nitrate of soda. } \\
\text { Sulfate of ammonia. }\end{array}$ \\
\hline 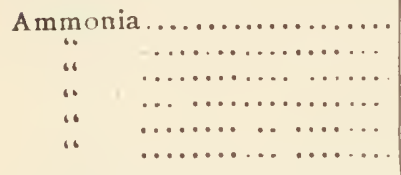 & $\begin{array}{l}.821 \\
3.882 \\
3 \cdot 147 \\
3 \cdot 706 \\
5 \cdot 0 \\
5 \cdot 15\end{array}$ & $\begin{array}{l}\text { Nitrogen. } \\
\text { Sulfate of ammonia. } \\
\text { Chlorid of ammonia. } \\
\text { Nitric acid. } \\
\text { Vitrate of soda. } \\
\text { Protein. }\end{array}$ \\
\hline 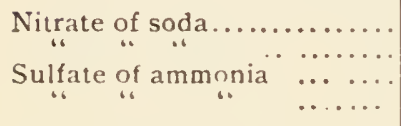 & $\begin{array}{l}.165 \\
.2 \\
.212 \\
.258\end{array}$ & $\begin{array}{l}\text { Nitrogen. } \\
\text { Ammonia. } \\
\text { Nitrogen. } \\
\text { Ammonia. }\end{array}$ \\
\hline 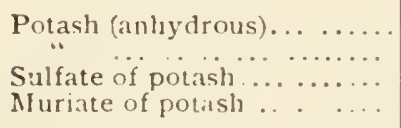 & $\begin{array}{l}1.85 \\
1.583 \\
.54 \\
.632\end{array}$ & $\begin{array}{l}\text { Sulfate of potash. } \\
\text { Mluriale of potash. } \\
\text { Potash. }\end{array}$ \\
\hline 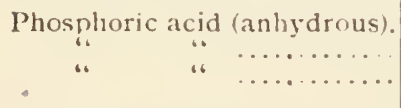 & $\begin{array}{l}2.183 \\
1.015 \\
1.648\end{array}$ & $\begin{array}{l}\text { Tri-calcium phosphate. } \\
\text { Di-calcium plosphate. } \\
\text { Mono-calcium plosphate. }\end{array}$ \\
\hline $\begin{array}{l}\text { Monn-calcium plrosphate ... } \\
\text { Di-calciun phospliate. . . . } \\
\text { Tri.calcium plosphate... . }\end{array}$ & $\begin{array}{r}1.325 \\
1.565 \\
.459\end{array}$ & $\begin{array}{l}\text { Tri-calcium phosphate. } \\
\text { Plosplyoric acid. }\end{array}$ \\
\hline 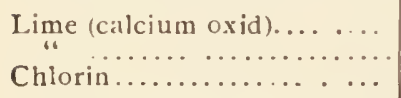 & $\begin{array}{l}\text { I. } 845 \\
\text { I. } 786 \\
1.648\end{array}$ & $\begin{array}{l}\text { Tri-calcium phosphate. } \\
\text { Carbonate of lime. } \\
\text { Sodium chlorid. }\end{array}$ \\
\hline
\end{tabular}

PRICES OF NITINTE OF SODA ON THE

AMMONIA'TE BASIS. (Chilean Nitrate Works.)

Figured on Basis 380 lbs. Ammonia in One Ton Nitrate of Soda.

\begin{tabular}{|c|c|c|c|c|}
\hline $\begin{array}{l}\text { Price per } \\
\text { Cwt. of } \\
\text { Nitrate. }\end{array}$ & $\begin{array}{l}\text { Price per } \\
\text { Ton of } \\
\text { Nitrate. }\end{array}$ & $\begin{array}{l}\text { Price Am- } \\
\text { monia per Lb. } \\
\text { as Nitrate. }\end{array}$ & $\begin{array}{l}\text { Eruivalent } \\
\text { Price Am- } \\
\text { monia per } \\
\text { Ton Unit. }\end{array}$ & $\begin{array}{l}\text { Equivalent } \\
\text { Cost of Nitro- } \\
\text { gen per Lb. }\end{array}$ \\
\hline$\$ 1.80$ & $\$_{36} 6.00$ & So. 0947 & $\$ 1.894$ & So. II 5 \\
\hline 1.85 & 37.00 & 0.0073 & 1.946 & 0.118 \\
\hline 1.90 & 38.00 & 0.1000 & 2.000 & O. 122 \\
\hline 1.95 & 39.00 & 0.1026 & 2.052 & 0.125 \\
\hline 2.00 & 40.00 & 0.1052 & 2.104 & 0.128 \\
\hline 2.05 & 41.00 & 0.1078 & 2.156 & 0.131 \\
\hline 2.10 & 42.00 & 0.1105 & 2.210 & 0.134 \\
\hline 2.15 & 43.00 & O. I I 3 I & 2.262 & 0.137 \\
\hline 2.20 & 44.00 & 0.1 I 57 & 2.314 & 0.140 \\
\hline 2.25 & 45.00 & 0.1184 & 2.368 & 0.144 \\
\hline 2.30 & 46.00 & 0.1210 & 2.420 & 0.147 \\
\hline 2.35 & 47.00 & 0.1236 & 2.472 & 0.150 \\
\hline 2.40 & 48.00 & 0.1263 & 2.526 & 0.153 \\
\hline 2.45 & 49.00 & 0.1239 & 2.578 & 0.156 \\
\hline 2.50 & 50.00 & 0.1315 & 2. & $0.15 n$ \\
\hline
\end{tabular}




\section{AGRICULTURAL ENGINEERING.}

\section{REASONS FOF TILE-DRAINING LAND.}

(Chamberlain.*)

Land should be drained, because:

I. Til= drainas makes all tillage and 'arvesting operations easier and more rapid, physically and mechanically.

2. Drainage removes both the excess surface-water, and the surplus water in the soil and the subsoil.

3. Drainage prerents loss of fertility by surface wash.

4. Drainage will add fertility to the soil with each rainfall.

5. Drainage helps to warm the soil as well as to dry it, giving best conditions for plant growth.

6. Drainage 1 ngthens the season of tillage, crop, growth, and warvest.

7. Drainage increases the extent of root pasturage.

8. Drainage helps to disintegrate the soil and make pulverieation possible.

9. Drainage greatly diminishes the effect of frost in heaving out wheat, clover, etc., in winter and spring.

Io. Drainage on clayey soils helps the crops to resist drought better.

I I. Drainage often, though not always, diminishes the sud. denness and violence of floods.

12. Drainage, both open and with tiles, improves the health of a region.

- Tile Drainage, by W. I. Chamberlain, Medina. Ohio, 189r, 35 cents. 
NUMBET OF RODS AND OF TILES PER ACIE, WITH DRAINS AT VARIOUS DISTANCES

A'ART. (Sсотт.)

\begin{tabular}{|c|c|c|c|c|c|}
\hline $\begin{array}{l}\text { Distance } \\
\text { between } \\
\text { the Drains. }\end{array}$ & $\begin{array}{c}\text { Rodi } \\
\text { (51/2 lards) } \\
\text { per Acre. }\end{array}$ & $\begin{array}{c}\text { 12-inch } \\
\text { Tile. }\end{array}$ & $\begin{array}{l}\text { I3-inch } \\
\text { Tile. }\end{array}$ & $\begin{array}{l}{ }^{14} \text {-inch } \\
\text { Tile. }\end{array}$ & $\begin{array}{l}\text { I5-inch } \\
\text { Tile. }\end{array}$ \\
\hline $\begin{array}{c}\text { Feet. } \\
15 \\
18 \\
21 \\
24 \\
27 \\
30 \\
33 \\
36 \\
39 \\
42\end{array}$ & $\begin{array}{l}176 \\
145 \\
125 \\
110 \\
07 \\
83 \\
80 \\
72 \\
67 \\
62\end{array}$ & $\begin{array}{l}2904 \\
2.420 \\
2074 \\
1815 \\
1613 \\
1452 \\
1320 \\
1210 \\
1117 \\
1037\end{array}$ & $\begin{array}{r}2680 \\
2234 \\
1915 \\
1676 \\
1480 \\
1340 \\
1219 \\
1117 \\
1031 \\
95^{2}\end{array}$ & $\begin{array}{r}2489 \\
2074 \\
1778 \\
1555 \\
1383 \\
1244 \\
1131 \\
1037 \\
957 \\
888\end{array}$ & $\begin{array}{r}2323 \\
1936 \\
1659 \\
1452 \\
1290 \\
1161 \\
1056 \\
968 \\
893 \\
829\end{array}$ \\
\hline
\end{tabular}

\section{SIZE OF TILE PIPES}

Required for Draining under Average Conditions.

(WARING.)

The drains being laid four feet, or more, deep, and laid on a well-regulated fall of three inches in a hundred feet :

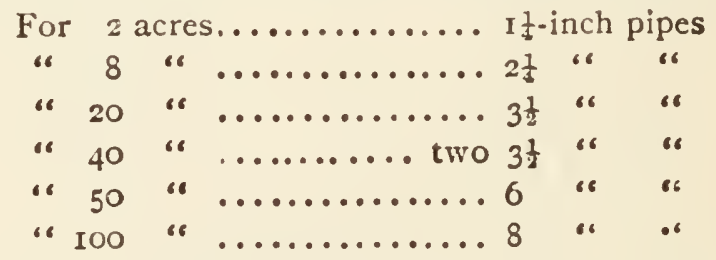

These drains will remove the water fast enough for all prac. tical purposes, even after heavy storms; if the pipes are securely laid, the drains will only be benefited by the occasional cleaning they will receive when running "more than full." 
Table of Size of Tile Pipe of Main Drain.

(McConnell.)

\begin{tabular}{|c|c|c|c|c|c|c|c|c|c|}
\hline & & & \multirow{2}{*}{ Fall. } & \multicolumn{6}{|c|}{ Acres Drained. } \\
\hline & & & & $\begin{array}{l}\text { 3-inch } \\
\text { Tile. }\end{array}$ & $\begin{array}{l}4-\text { inch } \\
\text { Tile. }\end{array}$ & $\begin{array}{c}\text { 6-inch } \\
\text { Tile. }\end{array}$ & $\begin{array}{c}\text { 8-inch } \\
\text { Tile. }\end{array}$ & $\begin{array}{c}\text { ro-inch } \\
\text { Tile. }\end{array}$ & $\begin{array}{l}\text { r2-inch } \\
\text { Tile. }\end{array}$ \\
\hline & foot & in & $20 \ldots \ldots \ldots$ & 18.6 & 26.8 & $74 \cdot 4$ & 150.0 & 270.0 & 426.0 \\
\hline $\mathbf{I}$ & "6 & “ & $30 \ldots \ldots \ldots$ & I5. I & 21.8 & 60.4 & 128.0 & 220.8 & 346.0 \\
\hline I & “ & " & $40 \ldots \ldots \ldots$ & 12.9 & I8.6 & 51.6 & 108.8 & 189.6 & 298.4 \\
\hline $\mathbf{I}$ & “6 & "6 & $50 \ldots \ldots \ldots$ & II.9 & 17.0 & $47 \cdot 7$ & 98.0 & 170.4 & 269.0 \\
\hline $\mathbf{x}$ & “ & “ & $60 \ldots . . . \ldots$ & I0.9 & $\mathrm{x} 5.6$ & $43 \cdot 4$ & 90.0 & 156.0 & 246.0 \\
\hline I & “ & $“ 6$ & $70 \ldots \ldots \ldots$ & 10.0 & $14 \cdot 5$ & 39.9 & 83.0 & I $44 \cdot 4$ & $228 . x$ \\
\hline I & “6 & “6 & $80 \ldots . . .$. & $9 \cdot 3$ & I $3 \cdot 4$ & 37.2 & 77.0 & I 35.0 & 213.0 \\
\hline $\mathbf{I}$ & $\because$ & 6 & $90 \ldots \ldots \ldots$ & 8.1 & 12.6 & $35 \cdot 0$ & $7^{2} \cdot 5$ & 127.0 & 200.5 \\
\hline $\mathbf{I}$ & $\because 6$ & “ & roo.......... & $7 \cdot 3$ & II.9 & 33.1 & 69.2 & 120.6 & 190.5 \\
\hline 1 & “6 & $“$ & $150 \ldots \ldots \ldots$ & 6.7 & $9 \cdot 5$ & 26.6 & 56.0 & $97 \cdot 3$ & 154.4 \\
\hline $\mathbf{x}$ & $\because$ & 6 & $200 \ldots \ldots \ldots$ & $5 \cdot 7$ & 8.2 & 22.8 & 48.0 & 83.9 & $13^{2} \cdot 5$ \\
\hline$x$ & “6 & 16 & $250 \ldots \ldots \ldots$ & 5.1 & $7 \cdot 5$ & 20.4 & 42.4 & $74 \cdot 4$ & $\operatorname{II} 7.0$ \\
\hline I & 66 & 6 & $300 \ldots \ldots \ldots$ & $4 \cdot 6$ & 6.9 & I 8.4 & $3^{8} .2$ & $65 \cdot 5$ & 107.0 \\
\hline I & $\because$ & $" 6$ & $400 \ldots \ldots \ldots$ & $4 \cdot I$ & $5 \cdot 9$ & 16.5 & 32.6 & 60.3 & 90.7 \\
\hline $\mathbf{I}$ & 6 & "6 & $500 \ldots \ldots \ldots$ & $3 \cdot 7$ & $5 \cdot 2$ & 14.8 & 30.1 & $54 . c$ & 81.6 \\
\hline I & $"$ " & $\because 6$ & $600 \ldots \ldots \ldots$ & $3 \cdot 3$ & $4 \cdot 7$ & $13 \cdot 3$ & 28.0 & 48.6 & 74.0 \\
\hline I & $“$ & $“$ & $800 \ldots \ldots \ldots$ & 2.9 & $4 \cdot 1$ & I I. 4 & 24.0 & 41.9 & 65.0 \\
\hline $\mathbf{I}$ & 66 & $" 1$ & rooo.......... & 2.6 & $3 \cdot 7$ & I0. 2 & 21.2 & 37.2 & 56.0 \\
\hline I & $" 1$ & 66 & $1500 \ldots \ldots$ & 2.1 & 3.0 & 8.5 & $x 6.8$ & 30.8 & 47.0 \\
\hline I & 46 & 16 & $2000 \ldots \ldots \ldots$ & 1.9 & 2.8 & $7 \cdot 4$ & 15.0 & 25.0 & 40.8 \\
\hline
\end{tabular}

Rule for Obtaining Size of Main Pipes.-Multiply the square root of the number of small drains (of fair average length) by the diameter of small pipes; the quotient gives the diameter of main.

If the distance apart of drains in feet be denoted by $F$, that in links by $L$, and the length of drains in chains per acre by $C$, then

$$
C=\frac{660}{F}=\frac{1000}{L}
$$


NUMBER OF ACRES WHICH A TILE OF A GIVEN DIAMETER ANI PER CENT GRADE WHL DRAIN WHEN USED AS AN OUTLET. (ELLOTt.)

Table 1.-Discharge of Tile from 4 to 20 inches in Diameter on a Grade of 1 foot per 100 feet.

\begin{tabular}{c|c||c|c}
\hline $\begin{array}{c}\text { Diameter of } \\
\text { Tile, Inches. }\end{array}$ & $\begin{array}{c}\text { Discharge in } \\
\text { Cubic Feet } \\
\text { per Second. }\end{array}$ & $\begin{array}{c}\text { Diameter of } \\
\text { Tile, Inches. }\end{array}$ & $\begin{array}{c}\text { Discharge in } \\
\text { Cubic Feet } \\
\text { per Second. }\end{array}$ \\
\hline & 0.16 & 12 & 3.40 \\
6 & 0.49 & 15 & 6.29 \\
8 & 1.11 & 18 & 10.37 \\
9 & 1.53 & 20 & 13.85 \\
10 & 2.05 & & \\
\hline
\end{tabular}

Table 2.-Grades per 100 feet, and their Square Roots.

\begin{tabular}{|c|c|c|c|c|c|}
\hline $\begin{array}{l}\text { Grade per } \\
\text { ro Feet } \\
\text { in Feet. }\end{array}$ & $\begin{array}{l}\text { Grade in } \\
\text { Inches } \\
\text { (approx- } \\
\text { imated). }\end{array}$ & $\begin{array}{l}\text { Square } \\
\text { Ront of } \\
\text { Grade. }\end{array}$ & $\begin{array}{l}\text { Grade per } \\
\text { roo Feet } \\
\text { in Feet. }\end{array}$ & $\begin{array}{l}\text { Grade in } \\
\text { Inches } \\
\text { (approx- } \\
\text { imated). }\end{array}$ & $\begin{array}{l}\text { Square } \\
\text { Root of } \\
\text { Grade. }\end{array}$ \\
\hline 0.04 & $1 / 6$ & 0.200 & 0.40 & $4^{3} 3 / 4$ & 0.632 \\
\hline .05 & 58 & .224 & .45 & $5 \%$ & $.67 \mathrm{x}$ \\
\hline .06 & $3 / 4$ & .245 & .50 & 6 & .707 \\
\hline .08 & $7 / 8$ & .283 & .55 & 65,6 & .742 \\
\hline .09 & I & $\cdot 300$ & .60 & $7^{1} / 8$ & .775 \\
\hline .10 & $11 / 8$ & .316 & .65 & 73 & .806 \\
\hline .12 & $1 \frac{1}{2}$ & $.34^{6}$ & .70 & $83 / 8$ & .837 \\
\hline.$I_{4}$ & I $9 / 4$ & .374 & .75 & & .866 \\
\hline .16 & 2 & .400 & .80 & $y^{5} / 8$ & .894 \\
\hline .18 & $21 / 4$ & .424 & .85 & $101 / 4$ & .922 \\
\hline .20 & $21 / 2$ & .447 & .90 & $103 / 4$ & .949 \\
\hline .25 & 3 & .500 & .95 & $\mathrm{x} 1 \frac{1}{4}$ & .975 \\
\hline$\cdot 30$ & $35 / 8$ & .548 & $1 . \infty 0$ & 12 & 1.000 \\
\hline$\cdot 35$ & $41 / 4$ & .592 & & & \\
\hline
\end{tabular}

To determine the number of acres that a tile main of given size and grade will drain, multiply the discharge of the tiles, according to size (see Table I), by the square root of the grade upon which it is proposed to lay the main (Table 2). When it is desired that the main shall carry I inch in depth per acre in twenty-four hours, multiply this result by 24 ; if one-half inch, multiply by 48 ; if one-fourth inch, multiply by 96 . (Farmers' Bulletin, No. 40.) 


\section{NUMBER OF ACRES DRAINED BY TILES REMOVING 1/4-INCH DEPTH OF WATER IN 24 HOURS.}

(AsHBAUGH.)

\begin{tabular}{|c|c|c|c|c|c|c|c|c|c|c|c|c|}
\hline \multicolumn{2}{|c|}{ Grades. } & \multicolumn{11}{|c|}{ Diameters of Tile Drains, Inches. } \\
\hline $\begin{array}{c}\text { Per } \\
\text { cent. }\end{array}$ & $\begin{array}{l}\text { In. per } \\
\text { Rod. }\end{array}$ & 3 & 4 & 6 & 8 & 10 & 12 & I 5 & 18 & 20 & 22 & 24 \\
\hline 0.03 & $\frac{1}{16}$ & $\cdots$ & $\cdots$ & $\ldots$ & & 37 & 59 & 109 & 159 & 205 & 254 & 319 \\
\hline 0.05 & $\frac{3}{32}$ & ... & 5 & 13 & 28 & 49 & 75 & $13 \mathrm{I}$ & 219 & 264 & 332 & 4 II \\
\hline 0.10 & $\frac{3}{16}$ & 4 & 7 & 19 & 40 & 69 & 109 & I 86 & 289 & 373 & 471 & 582 \\
\hline 0.15 & $\frac{9}{32}$ & 4 & 9 & 24 & 49 & 85 & I 32 & 232 & 355 & $45^{8}$ & 577 & 713 \\
\hline 0.20 & $\frac{3}{8}$ & 5 & 10 & 28 & 56 & 97 & 153 & 264 & 410 & 529 & 667 & $\mathrm{~S}_{23}$ \\
\hline 0.30 & $\frac{9}{76}$ & 6 & I 2 & 33 & 69 & 119 & I 88 & 322 & 502 & 648 & 808 & 1008 \\
\hline 0.40 & $\frac{13}{16}$ & 7 & 14 & 39 & 79 & I 38 & 216 & 371 & 580 & 748 & 942 & I 65 \\
\hline 0.50 & I & 8 & 16 & 44 & 89 & 154 & 246 & 416 & 648 & 838 & 1050 & 1300 \\
\hline 0.60 & $I^{\frac{3}{16}}$ & 9 & I 7 & $4^{8}$ & 97 & 169 & 266 & 457 & 710 & 911 & I 154 & 1422 \\
\hline 0.70 & $1 \frac{3}{8}$ & 10 & I 9 & 50 & 105 & 182 & 287 & 488 & 768 & 988 & 1242 & I 549 \\
\hline 0.80 & $1 \frac{9}{16}$ & 10 & 20 & 55 & I I 4 & 195 & 307 & 526 & 822 & 1059 & 1332 & 1645 \\
\hline 0.00 & $1 \frac{3}{4}$ & 10 & 21 & 59 & I I 9 & 207 & 326 & $55^{8}$ & 872 & I I 23 & I 4 I 4 & 1747 \\
\hline 1.00 & 2 & I I & 22 & 62 & เ 26 & $2 \mathrm{IS}$ & 343 & 589 & $9 \times 7$ & I 176 & I 495 & 18.38 \\
\hline I. 50 & 3 & I 3 & 28 & 75 & I 53 & 267 & 419 & 722 & $\begin{array}{llll}1 & 1 & 2 & 3\end{array}$ & 1450 & 1824 & 2256 \\
\hline 2.00 & 4 & I 5 & 31 & 88 & I 78 & 309 & 485 & 832 & I 297 & 1676 & 2110 & 2594 \\
\hline 3.00 & $5 \frac{15}{6}$ & I 9 & 39 & 107 & 216 & 377 & 593 & 1020 & 1580 & 1957 & $259^{2}$ & \\
\hline 4.00 & $7 \frac{15}{10}$ & 22 & 45 & I 23 & 253 & 437 & 683 & 1176 & & & & \\
\hline 5.00 & $9 \frac{7}{8}$ & 25 & 50 & I $3 \mathrm{~S}$ & $2 \mathrm{SO}$ & 456 & 765 & & & & & \\
\hline 7.50 & I $4 \frac{7}{8}$ & 30 & $6 \mathrm{I}$ & I 69 & 344 & & & & & & & \\
\hline 10.00 & I $9 \frac{13}{16}$ & 35 & $7 \mathrm{I}$ & 195 & & & & & & & & \\
\hline
\end{tabular}

The table is based on Poncelet's formula, and refers to drain. age of ground water only. If surface water is also to be removed, as in the case of ponds without other outlets, the tiles will drain safely only one-half to one-third the number of acres given in the table. When a part of the land in the watershed is rolling, not requiring tiling, count only one-third of such rolling land in addition to all of the low, flat land, in getting the size of tiles to remove ground water only.

If it is not practicable to use such a large tile as is required to carry a large amount of surface drainage, a broad shallow depression, cultivated or kept in grass, may be maintained alongside of the drain to carry the surface overflow from heavy rains. A I2-inch tile may thus often be used in place of the expensive I5-inch or 8 -inch tile. 


\section{NUMBER OF ACRES DRAINED BY OPEN DITCHES.}

Depth of Water, 3 feet.

Depth of Ditch, at least + feet.

\begin{tabular}{|c|c|c|c|c|c|c|c|c|c|}
\hline \multicolumn{2}{|c|}{ Grades. } & \multicolumn{8}{|c|}{ Average Width of Water, Feet. } \\
\hline $\begin{array}{l}\text { Per } \\
\text { cent. }\end{array}$ & $\begin{array}{l}\text { Feet } \\
\text { per } \\
\text { Mile. }\end{array}$ & 4 & 6 & 8 & IO & I 5 & 20 & 30 & 50 \\
\hline 0.02 & 1.0 & $\cdots \cdots$ & $\cdots \cdots$ & 725 & 970 & 1570 & 2240 & 5300 & I $S_{400}$ \\
\hline 0.04 & 2. I & 400 & 600 & 1000 & I 360 & 2250 & 4700 & -7470 & 26100 \\
\hline 0.06 & $3 \cdot 2$ & 492 & 850 & 1260 & I 690 & 2770 & 5770 & 18400 & 31900 \\
\hline 0.. 08 & $4 \cdot 2$ & 572 & 080 & 1460 & 1950 & 4820 & 6670 & 21400 & 37400 \\
\hline 0.10 & $5 \cdot 3$ & 636 & 1100 & 1630 & 2130 & 5360 & 7440 & 23700 & 4 I 400 \\
\hline 0.15 & 7.8 & $79 \mathrm{I}$ & 1330 & 2010 & 2670 & 6600 & I 9000 & 30200 & 52100 \\
\hline 0.20 & 10.6 & 905 & 1560 & 2310 & 4720 & 7870 & 21800 & 35000 & 60300 \\
\hline 0.25 & I 3.2 & 1020 & 1740 & 2660 & 5.300 & 17500 & 24600 & 39000 & 67700 \\
\hline 0.30 & I 5.8 & 1100 & 1970 & 2000 & $55^{\circ}$ & 19400 & 26800 & 42700 & 74000 \\
\hline 0.40 & 2 I. I & I 300 & 2290 & 5050 & 6740 & 22200 & 30800 & 49400 & 85700 \\
\hline 0.50 & 26.4 & 1475 & 2559 & 5620 & $=7500$ & 24800 & 34800 & 55300 & 95200 \\
\hline 0.60 & 31.7 & I 600 & 2790 & 6230 & 16500 & 27200 & 37600 & 60400 & \\
\hline 0.70 & 37.0 & 1720 & 3010 & 6650 & 17800 & 29400 & 41200 & & \\
\hline 0.80 & 42.2 & 1850 & 4850 & 7170 & I0100 & & & & \\
\hline 0.90 & $47 \cdot 5$ & 1955 & 5140 & 7550 & 20100 & & & & \\
\hline 1.00 & 52.8 & 2050 & 5400 & 7980 & & & & & \\
\hline
\end{tabular}

Depth of Water, 5 feet.

Depth of Ditch, at least $6 \frac{1}{2}$ feet.

Grades.

\begin{tabular}{|c|c|c|c|c|c|c|c|c|}
\hline $\begin{array}{l}\text { Per } \\
\text { cent. }\end{array}$ & $\begin{array}{l}\text { Feet } \\
\text { per } \\
\text { Nile. }\end{array}$ & 6 & 8 & 10 & I 5 & 20 & 30 & 50 \\
\hline 0.02 & I. 0 & 980 & 1470 & 1900 & 5000 & 7150 & 2.3800 & 43800 \\
\hline 0.04 & 2.1 & 1390 & 2090 & 2800 & 7200 & 20400 & 3.3500 & 62500 \\
\hline $\begin{array}{l}0.06 \\
0.08\end{array}$ & $\begin{array}{l}3.2 \\
4 \cdot 2\end{array}$ & $\begin{array}{l}1710 \\
1980\end{array}$ & $\begin{array}{l}2560 \\
2080 \\
\end{array}$ & $\begin{array}{l}5100 \\
6100\end{array}$ & $\begin{array}{l}17600 \\
20400\end{array}$ & $\begin{array}{l}24700 \\
30000\end{array}$ & $\begin{array}{l}40800 \\
48800\end{array}$ & $\begin{array}{l}75500 \\
88000\end{array}$ \\
\hline 0.10 & $5 \cdot 3$ & 2220 & 5010 & 7600 & 23400 & 33400 & 54500 & 98000 \\
\hline 0.15 & 7.8 & 2720 & 6300 & 17100 & 28700 & 40500 & 66700 & I 20000 \\
\hline 0.20 & I0. 6 & 4820 & 7300 & 19500 & 33000 & 47000 & 77000 & I 39000 \\
\hline $\begin{array}{l}0.25 \\
0.30\end{array}$ & I 3.2 & $\begin{array}{l}5370 \\
5000\end{array}$ & I 6300 & 21900 & 37500 & 53000 & 86000 & I 55000 \\
\hline 0.40 & 21.1 & $68_{30}$ & 20600 & $\begin{array}{l}23900 \\
27700\end{array}$ & 47000 & 67000 & & \\
\hline 0.50 & 26.4 & 7600 & 23000 & 31000 & & & & \\
\hline 0.60 & 31.7 & 16700 & 25200 & 33900 & & & & \\
\hline 0.70 & 37.0 & I 8100 & 27300 & & & & & \\
\hline 0.80 & 42.2 & I 9000 & & & & & & \\
\hline 0.90 & $47 \cdot 5$ & 20500 & & & & & & \\
\hline
\end{tabular}

Average Width of Water, Feet. 


\section{NUMBER OF ACRES DRAINED BY OPEN DITCHES-}

(Continued).

Depth of Water, 7 feet.

Depth of Ditch, at least 9 feet.

\begin{tabular}{|c|c|c|c|c|c|c|c|}
\hline \multicolumn{2}{|c|}{ Grade. } & \multicolumn{6}{|c|}{ Average Width of Water, Feet. } \\
\hline $\begin{array}{l}\text { Per } \\
\text { cent. }\end{array}$ & $\begin{array}{l}\text { Feet } \\
\text { per } \\
\text { Mile. }\end{array}$ & 8 & 10 & I 5 & 20 & 30 & 50 \\
\hline 0.02 & 1.0 & 2300 & 4700 & 16600 & 28000 & 48000 & 88500 \\
\hline 0.04 & $2 . I$ & 4850 & 6740 & 23400 & 35400 & 58000 & 106000 \\
\hline 0.06 & $3 \cdot 2$ & 5920 & 17000 & 29600 & 43400 & 72000 & \\
\hline $\begin{array}{l}0.08 \\
0.10\end{array}$ & $\begin{array}{l}4 \cdot 2 \\
5 \cdot 3\end{array}$ & $\begin{array}{l}6940 \\
7720\end{array}$ & $\begin{array}{l}19100 \\
21800\end{array}$ & $\begin{array}{l}34200 \\
38400\end{array}$ & $\begin{array}{l}50000 \\
56000\end{array}$ & $\begin{array}{l}83000 \\
92600\end{array}$ & $\begin{array}{l}\text { I } 50000 \\
167000\end{array}$ \\
\hline 0.15 & 7.8 & I 9400 & 27000 & 47200 & 68500 & I I 2000 & 202000 \\
\hline 0.20 & 10. 6 & 22400 & 31300 & 54200 & 78700 & I 30000 & 235000 \\
\hline 0.25 & I 3.2 & 25000 & 34800 & 60500 & 88000 & 146000 & \\
\hline 0.30 & I 5.8 & 27400 & 38200 & 66200 & 96500 & & \\
\hline 0.40 & $21 . I$ & 31700 & 44100 & & & & \\
\hline 0.50 & 26.4 & 35400 & & & & & \\
\hline
\end{tabular}

Depth of Water, 9 feet.

Depth of Ditch, at least i I $\frac{1}{2}$ feet.

\begin{tabular}{|c|c|c|c|c|c|c|}
\hline \multicolumn{2}{|c|}{ Grade. } & \multicolumn{5}{|c|}{ Average Width of Water, Feet. } \\
\hline $\begin{array}{l}\text { Per } \\
\text { cent. }\end{array}$ & $\begin{array}{l}\text { Feet } \\
\text { per } \\
\text { Mile. }\end{array}$ & ro & I 5 & 20 & 30 & 50 \\
\hline 0.02 & I. 0 & 6550 & 27800 & 40800 & 69500 & I 27000 \\
\hline 0.04 & 2. I & 18500 & 34400 & 50000 & 83500 & 157000 \\
\hline 0.06 & 3.2 & 22600 & 41600 & 61000 & 103000 & 193000 \\
\hline 0.08 & 4.2 & 26300 & 48300 & 71000 & 120000 & 221000 \\
\hline 0.10 & $5 \cdot 3$ & 30400 & 54000 & 79100 & 132000 & 244000 \\
\hline O. I 5 & 7.8 & 37300 & 66100 & 96200 & I 62000 & 298000 \\
\hline 0.20 & 10.6 & 42900 & 76200 & 10.4000 & & \\
\hline 0.25 & 13.2 & 48000 & 85300 & 125000 & & \\
\hline 0.30 & I 5.8 & 52500 & 93200 & & & \\
\hline 0.40 & $2 I . I$ & 60800 & & & & \\
\hline
\end{tabular}

The above tables are calculated by Kutter's formula, using a "coefficient of roughness" equal to 0.03 , as recommended for channels in moderately good condition, having stones and weeds occasionally. For ditches in first-class condition, the number of acres may be increased about 25 per cent. The tables have 
been calculated for ditches having sides with slopes of one foot horizontal to one foot vertical, but are approximately correct for other slopes.

The capacity of the ditches has been made as follows, the ditches to run not more than 8 -Io full for the capacities mentioned:

Above the upper heavy line, $\frac{3}{4}$ in. depth of water per 24 hours. Between the heavy lines, $\frac{1}{2}$ in. depth of water per 24 hours.

Below the lower heavy line, $\frac{1}{4}$ in. depth of water per 24 hours.

Local conditions may vary the size needed, and it is necessary to consult a drainage engineer in each case.

\section{ADVICE TO IAND OWNERS ABOUT TO CONSTRUCT DRAINS. (AshBAUGH.)}

I. Employ a reliable drainage engineer to make surveys, and plan your system of drainage. Otherwise you are very liable to throw away part of your money.

2. Require from your drainage engineer a complete map or plat of your drains, showing the exact location, sizes, grades, and depths. Remember that your drains will be out of reach (except at much cost and trouble) after they are covered.

3. Make your drains of ample size. Drains which are too small fail when you need them most, in wet seasons.

4. Put your tile down to a good depth. Other ise they will not draw well to any considerable distance. Make them four feet deep in the lowest ground if possible. The extra cost of good depth is small in proportion to the total cost.

5. Have your drainage engineer inspect the work during construction and test the grades of the $\mathrm{d}_{\mathbf{r}}$ ins and see that the work is well done. Many tile become choked with mud because not laid true.

6. Be sure to protect the outlet. Build a bulkhead wall of brick or stone to hold the end. Also use a piece of iron pipe at the end, if tile is not too large, or for large drains use a few feet of sewer-pipe cemented.

7. If you are obliged to construct an open ditch, make it at least five to seven feet deep, if possible, to give good outlets tor tile, and to avoid choking up. 
8. The bottoms of open ditches should be at least three feet wide, and the sides should be given slopes of at least one foot horizontal to one vertical to avoid choking. Dirt should not be piled near the edges of the bank.

\section{POINTS TO NOTE IN PLANNING A' DRAINAGE SYSTEM.}

I. Character of the land, as swampy, low, sloping, dry, etc., also retentive or open, depth of surface soil, condition of subsoil, etc.

2. Acreage of various kinds just described, their location relative to drains, etc.

3. The outlet, its character, capacity, depth, protection required for tile, etc.

4. Fall or grade for mains, submains, and laterals, with depth of cutting required.

5. Various expedients, such as the use of cut-offs across necks of land, to save distance and gain fall.

6. Your drainage engineer should be competent to handle these problems.

SIZES OF DRAIN-PIPE REQUIRED FOR CULVERTS IN

PROPORTION TO CAPACITY AND FALL. (ELDRIDGE.)

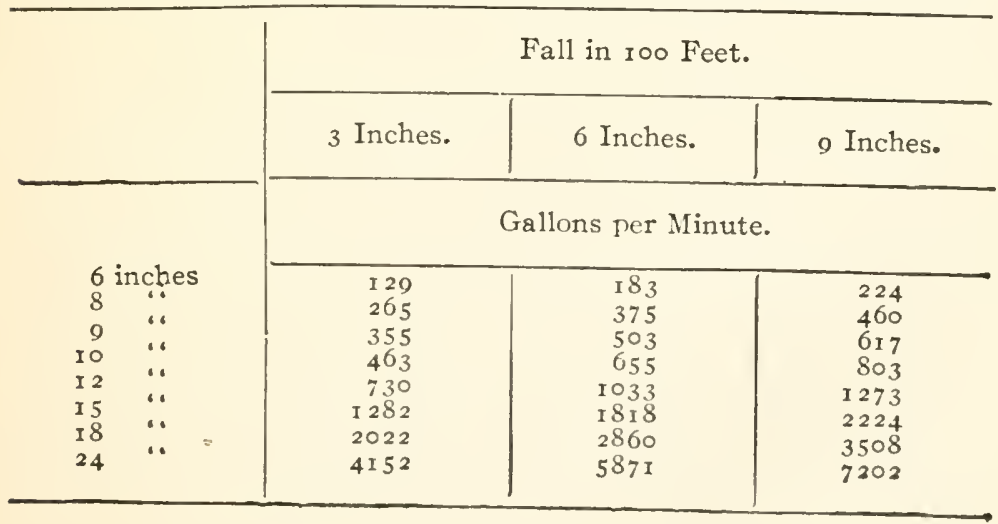




\section{AREAS FROM WHICH $1 / 4$ INCH OF WATER WILI. BE REMOVEI) IN 24 HOURS BY OUTIAT TILE IDRAINS OF DIFFERENT DIAMETERS AND LENGTHS WITH DIF- FERENT GRADES. (ELLIOTT.)}

\begin{tabular}{|c|c|c|c|c|c|c|c|c|c|c|}
\hline \multirow{5}{*}{$\begin{array}{l}\text { Diam- } \\
\text { eter of } \\
\text { Tile in } \\
\text { Inches. }\end{array}$} & \multicolumn{10}{|c|}{$\begin{array}{c}\text { Grade per } 100 \mathrm{ft} \text {. in Decimals of a Foot (with Approx. Equiv. } \\
\text { in Inches). }\end{array}$} \\
\hline & \multicolumn{2}{|c|}{$\left(\begin{array}{l}0.05 \\
\text { in. }) .\end{array}\right.$} & \multicolumn{2}{|c|}{ ( $\left(\begin{array}{c}0.08 \\
\text { in.). }\end{array}\right.$} & \multicolumn{2}{|c|}{$\begin{array}{l}0.10 \\
\left(1 \frac{3}{16} \text { in. }\right) .\end{array}$} & \multicolumn{2}{|c|}{$\left(\begin{array}{ll}\mathrm{O} \cdot \mathrm{I}^{2} \\
\text { in. }\end{array}\right.$} & \multicolumn{2}{|c|}{$\left(\begin{array}{l}\circ .16 \\
(2 \text { in. }) .\end{array}\right.$} \\
\hline & \multicolumn{10}{|c|}{ Length of Drain in Feet. } \\
\hline & 1000 & 2000 & 1000 & 2000 & I 000 & 2000 & 1000 & 2000 & 1000 & 2000 \\
\hline & \multicolumn{10}{|c|}{ Acres of Land Drained. } \\
\hline 5. & $17 \cdot 7$ & 14.0 & I 9.1 & 15.7 & I0.8 & I 6.7 & 20.6 & 17.6 & 22.1 & 19.4 \\
\hline & 28.0 & 22.2 & 29.0 & 24.8 & $3 \mathbf{I} .2$ & 26.4 & 32.5 & 27.8 & 34.8 & 30.5 \\
\hline & $4 \mathrm{I} . \mathrm{I}$ & 32.7 & 44 . I & 36.4 & 45.9 & 38.7 & 47.7 & 40.8 & $5 \mathrm{I} \cdot \mathrm{I}$ & 44. \\
\hline 8. & 57.3 & 45.6 & $6 \mathrm{t} .4$ & 50.7 & 64.0 & 53.9 & 66.5 & 57.0 & 71.2 & $\mathrm{O}_{2}$. \\
\hline & 76.5 & $6_{1} .2$ & 82.2 & $68 . I$ & 85.6 & 72.3 & 89.1 & 76.3 & $95 \cdot 3$ & 83. \\
\hline Io. & 99.5 & 79.5 & 106.7 & 88.5 & I 111 & 94.0 & 115.6 & 99.2 & 123.9 & 108. \\
\hline 12 . & I $56 . \mathrm{I}$ & I 24.9 & 167.7 & 130.3 & I 74.8 & 147.9 & 181.7 & I 56.2 & 194.6 & 171.6 \\
\hline 14. & 228.7 & 183.7 & $245 \cdot 3$ & 204.3 & $25^{6} .1$ & 217.4 & 265.8 & 229.7 & 284.9 & 251.7 \\
\hline & 317.8 & 255.9 & 341.4 & 284.6 & $355 \cdot 4$ & 302.5 & 369.5 & 350.7 & 306.3 & 350.4 \\
\hline & 424.9 & $34^{2} \cdot 5$ & 456.4 & $38 \mathrm{I} \cdot 3$ & 475.7 & 405.5 & 494.4 & 428.1 & 520.1 & 470.1 \\
\hline & $55 \mathrm{I} .6$ & $444 \cdot 9$ & $59 \mathrm{I} \cdot 5$ & 495.8 & 6.6 .4 & 526.7 & $1^{6.40 .4}$ & 556.6 & $686 \cdot 3$ & 610.5 \\
\hline
\end{tabular}

\begin{tabular}{|c|c|c|c|c|c|c|c|c|c|c|}
\hline \multirow{5}{*}{$\begin{array}{l}\text { Diam- } \\
\text { eter of } \\
\text { Tile in } \\
\text { Inches. }\end{array}$} & \multicolumn{10}{|c|}{$\begin{array}{c}\text { Grade per } 100 \mathrm{ft} \text {. in Decimals of a Fo t (with Approx. Equiv. } \\
\text { in Inches). }\end{array}$} \\
\hline & \multicolumn{2}{|c|}{$\left(\begin{array}{l}0.20 \\
\left(2 \frac{3}{8} \text { in. }\right)\end{array}\right.$} & \multicolumn{2}{|c|}{$\left(\begin{array}{l}0.25 \\
3 \text { in. })\end{array}\right.$} & \multicolumn{2}{|c|}{$\begin{array}{c}0.30 \\
\left(3 \frac{5}{8} \text { in. }\right) .\end{array}$} & \multicolumn{2}{|c|}{$\begin{array}{l}0.40 \\
(4: \text { in. }) .\end{array}$} & \multicolumn{2}{|c|}{$\left(\begin{array}{l}0.5 \circ \\
(6 \text { in. })\end{array}\right.$} \\
\hline & \multicolumn{10}{|c|}{ Length of Drain in Feet. } \\
\hline & 1000 & 2000 & 1000 & 2000 & 1000 & 2000 & 1000 & 2000 & 1000 & 2000 \\
\hline & \multicolumn{10}{|c|}{ Acres of Land Drained. } \\
\hline & 23.5 & 20.9 & $25 . \mathrm{I}$ & 22.7 & 26.7 & $24 \cdot 5$ & 29.5 & $27 \cdot 5$ & 32.0 & 30.3 \\
\hline & 37.0 & 33.0 & 39.6 & $35 \cdot 9$ & 42.0 & 35.6 & 46.4 & $43 \cdot 5$ & 50.5 & 47.8 \\
\hline & $54 \cdot 3$ & 48.5 & 58.0 & 52.8 & $6 \mathrm{r} .0$ & 56.7 & 68.2 & 63.8 & 74.0 & 70.1 \\
\hline & 75.6 & 07.7 & 80.9 & 73.6 & 85.8 & 79.0 & 95.0 & $89 . I$ & 103.3 & 98.0 \\
\hline & $10 \mathrm{I} .4$ & 90.7 & 108.4 & 98.6 & $\mathrm{I} I 4.9$ & 106.0 & $I 27.0$ & I 109.4 & I $38 . \mathrm{I}$ & I 31.3 \\
\hline IO. & 131.6 & 117.9 & 140.6 & I $28 . \mathrm{I}$ & I 49.3 & 137.6 & 165.2 & I 55.3 & 179.2 & 170.5 \\
\hline 12. & 206.8 & 185.6 & $22 \mathrm{I} . \mathrm{I}$ & 201.8 & 234.5 & 216.9 & 259.2 & $244 . \mathrm{I}$ & 281.8 & 208.6 \\
\hline 14. & 302.5 & 272.2 & 323.5 & 296.1 & 343.5 & 318.1 & 379.7 & 358.2 & $4 \begin{array}{lll}1 & 2 & .9\end{array}$ & 393.9 \\
\hline & 420.6 & 379.1 & $4+4 \cdot 9$ & 412.2 & $477 \cdot 4$ & 442.9 & 527.8 & 498.4 & $573 \cdot 7$ & 548.8 \\
\hline & 562.2 & $508 . \mathrm{I}$ & 601.8 & 552.5 & 638.1 & 593.7 & 705.2 & 668.0 & 767.4 & 735.1 \\
\hline & 729.2 & $600 \cdot 3$ & 780.0 & 718.2 & 826.9 & $77 \mathrm{I}, \mathrm{I}$ & $914 \cdot 7$ & 807.8 & $994 \cdot 5$ & $\cup 54.6$ \\
\hline
\end{tabular}

Three feet of soil above the top of the drain has been assumed. The grade, length of drain, and openness of soil are important factors in the capacity of a tile drain for discharging soil-water. 


\section{RISE OF THE SLOPE FOR 100 FEET. (WARING.)}

Table I. gives the rise of the slope for roo feet of the horizontal measurement.

Table II., the rise of the slope for roo feet of its own length.

\begin{tabular}{|c|c|c|c|c|c|c|c|}
\hline \multicolumn{4}{|c|}{ Table No. I. } & \multicolumn{4}{|c|}{ Table No. II. } \\
\hline Deg. & Feet. & Deg. & Feet. & Deg. & Feet. & Deg. & Feet. \\
\hline 5 & 8.749 & 50 & 119.175 & 5 & 8.716 & 50 & $7^{6.604}$ \\
\hline I0 & 17.633 & 55 & $1+2.815$ & I0 & 17.365 & 55 & 81.915 \\
\hline 15 & 26.795 & 60 & 173.205 & 15 & 25.882 & 60 & 86.602 \\
\hline 20 & 36.397 & 65 & $2 \mathrm{I} 4.45 \mathrm{I}$ & 20 & $34 \cdot 202$ & 65 & $90.63 \mathrm{t}$ \\
\hline 25 & 46.631 & 70 & $274 \cdot 74^{8}$ & 25 & 42.262 & 70 & 93.969 \\
\hline 30 & 57.735 & 75 & 373.205 & 30 & $5^{\circ}$ & 75 & 96.593 \\
\hline 35 & 70.021 & 80 & 567.128 & 35 & $\begin{array}{ll}57 & 358\end{array}$ & 80 & $98.48 \mathrm{I}$ \\
\hline 40 & 83.910 & 85 & 1143.010 & 40 & 64.279 & 85 & 99.619 \\
\hline 45 & IOO & & & 45 & 707 II & & \\
\hline
\end{tabular}

Example.-If the horizontal measurement is roo feet, and the slope is at an angle of $10^{\circ}$, the rise will be 17.633 feet.

If the sloping line (at an angle of $15^{\circ}$ ) is roo feet, it rises 25.882 feet.

QUANTIY OF EARTH REMOVED PER ROD OF DRAINS OF VARIOUS DIMENSIONS. (SсOTt.)

\begin{tabular}{|c|c|c|c|c|c|c|c|c|c|c|c|c|}
\hline \multirow{3}{*}{ 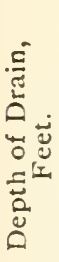 } & \multicolumn{12}{|c|}{ Mean Width of́ Drains. } \\
\hline & $\begin{array}{c}\text { In. } \\
7\end{array}$ & $\begin{array}{c}\text { In. } \\
8\end{array}$ & $\begin{array}{c}\text { In. } \\
9\end{array}$ & $\begin{array}{l}\text { In. } \\
\text { Io }\end{array}$ & In. & In. & $\begin{array}{l}\text { In. } \\
1_{3}\end{array}$ & $\begin{array}{l}\text { In. } \\
14\end{array}$ & $\begin{array}{l}\text { In. } \\
\text { I5 }\end{array}$ & $\begin{array}{l}\text { In. } \\
\text { I }\end{array}$ & $\begin{array}{l}\text { In. } \\
17\end{array}$ & $\begin{array}{l}\text { In. } \\
\text { I }\end{array}$ \\
\hline & \multicolumn{12}{|c|}{ Cubic Yards. } \\
\hline $21 / 2$ & 0.80 & 1.02 & I. 14 & 1.27 & ז. 40 & I. 53 & I. 65 & บ. 78 & I. $9^{1}$ & 2.04 & 2.16 & 2.29 \\
\hline 3 & 1.07 & 1.22 & $1 \cdot 37$ & 1.53 & I. 68 & I 83 & I. 98 & 2.14 & 2.29 & 2.24 & 2.60 & 2.75 \\
\hline $3^{1 / 2}$ & 1.25 & 1.42 & 1. 60 & 1.78 & 1.96 & 2.14 & 2.32 & 2.49 & 2.67 & 2.85 & 3.03 & 3.21 \\
\hline 4 & I. 42 & ז. & $\mathrm{x} .83$ & 2.04 & 2.24 & 2.44 & 2.55 & 2.85 & 3.05 & 3.26 & 3.46 & 3.66 \\
\hline 5 & 1.78 & 2.03 & 2.29 & 2. 54 & 2.80 & 3.05 & $3 \cdot 3 i$ & $3 \cdot 56$ & 3.82 & 4.07 & $4 \cdot 33$ & $4 \cdot 5^{8}$ \\
\hline
\end{tabular}

"If a 4 -ft. drain be cut If in. wide at top and 4 in. at bottom, the mean width will be 9 in., and the quantity of earth excavated in cutting each rod will be $I_{.83}$ cubic yards; if 
the same drain be cut $18 \mathrm{ir}$. at top and $8 \mathrm{in.}$ at bottom, the mean width will be 13 in., and 2.65 cubic yards of eartb will have to be removed in cutting eacb rod: so that if tne digging of the drain costs 6 cents per cubic yard of earth moved the narrow drain will cost I cents per rod, and the other nearly r 6 cents per rod, showing the cost to be one half larger, quite unnecessarily.

"The same table will be found useful in helping to fix the relative prices of deep and shallow drains; but it must be recollected that the deeper drains will be increased in cost not only by reason of the greater quantity of earth which has to be moved, but also because of the increased labor of :ifting the earth to the surface from a greater depth."

\section{LINIT OF SIZE OF TILE TO GRADE AND LENGTH.}

\begin{tabular}{c|c|c|c|c|c}
$\begin{array}{c}\text { Size of } \\
\text { Tile in } \\
\text { Inches. }\end{array}$ & $\begin{array}{c}\text { Minimum } \\
\text { Grade per } \\
\text { roo Feet. }\end{array}$ & $\begin{array}{c}\text { Limit of } \\
\text { Length in } \\
\text { Feet. }\end{array}$ & $\begin{array}{c}\text { Size of } \\
\text { Tile in } \\
\text { Inches. }\end{array}$ & $\begin{array}{c}\text { Minimum } \\
\text { Grade per } \\
\text { I00 Feet. }\end{array}$ & $\begin{array}{c}\text { Limit of } \\
\text { Length in } \\
\text { Feet. }\end{array}$ \\
\cline { 1 - 2 } 3 & .09 & 800 & 8 & .05 & 3000 \\
4 & .05 & 1600 & 9 & .05 & 3500 \\
5 & .05 & 2000 & 10 & .04 & 4000 \\
6 & .05 & 2500 & II & .04 & 4500 \\
7 & .05 & 2800 & I2 & .04 & 5300 \\
\hline
\end{tabular}

RAINFALL.（McConNell.)

\begin{tabular}{c|r|r|r|r|r|r|r}
\hline $\begin{array}{c}\text { Inches } \\
\text { of } \\
\text { Depth. }\end{array}$ & $\begin{array}{c}\text { Cubic } \\
\text { Feet } \\
\text { per } \\
\text { Acre. }\end{array}$ & $\begin{array}{c}\text { Imperial } \\
\text { Gallons } \\
\text { per } \\
\text { Acre. }\end{array}$ & $\begin{array}{c}\text { Tons } \\
\text { per } \\
\text { Acre. }\end{array}$ & $\begin{array}{c}\text { Inches } \\
\text { of } \\
\text { Depth. }\end{array}$ & $\begin{array}{c}\text { Cubic } \\
\text { Feet } \\
\text { per } \\
\text { Acre. }\end{array}$ & $\begin{array}{c}\text { Imperial } \\
\text { Gallons } \\
\text { per } \\
\text { Acre. }\end{array}$ & $\begin{array}{c}\text { Tons } \\
\text { per } \\
\text { Acre. }\end{array}$ \\
\hline I & 3,630 & 22,635 & 101.1 & 7 & 25,410 & 158,444 & 707.7 \\
2 & 7,260 & 45,270 & 202.2 & 8 & 29,040 & 181,072 & 808.8 \\
3 & 10,890 & 67,905 & 303.3 & 9 & 32,670 & 203,714 & 909.9 \\
4 & 14,520 & 90,539 & 404.4 & 10 & 36,300 & 226,349 & 1011.0 \\
5 & 18,150 & 113,174 & 505.5 & 11 & 39,930 & 248,984 & 1112.1 \\
6 & 21,780 & 135,809 & 606.6 & I2 & 43,560 & 271,619 & 1213.2 \\
\hline
\end{tabular}




\section{TABLE SHOWING THE FORCE AND VELOCITY OF WIND. (WARING.)}

\begin{tabular}{|c|c|c|c|}
\hline $\begin{array}{c}\text { Miles } \\
\text { per Hour. }\end{array}$ & $\begin{array}{c}\text { Feet } \\
\text { per Minute, }\end{array}$ & $\begin{array}{l}\text { Lbs. Press- } \\
\text { ure on } \\
\text { I sq. ft. }\end{array}$ & Description. \\
\hline $\begin{array}{r}1 \\
2 \\
3 \\
4 \\
5 \\
6 \\
8 \\
10 \\
15 \\
20 \\
25 \\
30 \\
35 \\
40 \\
45 \\
50 \\
60 \\
80 \\
100\end{array}$ & $\begin{array}{r}88 \\
176 \\
264 \\
352 \\
440 \\
528 \\
704 \\
880 \\
1320 \\
1760 \\
2200 \\
2640 \\
3080 \\
3520 \\
3960 \\
4400 \\
5280 \\
7040 \\
8800\end{array}$ & $\begin{array}{r}.005 \\
.020 \\
.045 \\
.080 \\
.125 \\
.180 \\
.320 \\
.500 \\
1.125 \\
2.000 \\
3.125 \\
4.500 \\
6.125 \\
8.000 \\
10.125 \\
12.500 \\
18.000 \\
32.000 \\
50.000\end{array}$ & $\begin{array}{c}\text { Barely observable. } \\
\text { Just perceptible. } \\
\text { Light breeze. } \\
\text { Gentle, pleasant wind } \\
\text { Brisk blow. } \\
\text { Very brisk. } \\
\text { High wind. } \\
\text { Very high. } \\
\text { Storm. } \\
\text { Great storm. } \\
\text { Hurricane. } \\
\text { Tornado, uprooting trees, sweeping } \\
\text { off buildings, etc. }\end{array}$ \\
\hline
\end{tabular}

NUMBER OF SQUARE FEET AND ACRES THAT A First-class Windmill can Irrigate One Inch in 8 Hours, Raising the Water 10, 15 or 25 Feet.

(A. R. Wolff.)

\begin{tabular}{|c|c|c|c|c|c|c|c|c|c|c|c|}
\hline \multirow{2}{*}{\multicolumn{6}{|c|}{ Size of Windmill. }} & \multicolumn{2}{|c|}{ ro Feet. } & \multicolumn{2}{|c|}{${ }_{5}$ Feet. } & \multicolumn{2}{|c|}{25 Feet. } \\
\hline & & & & & & Sq. Ft. & Acres & Sq. Ft. & Acres & Sq. Ft. & Acres \\
\hline $8 \frac{1}{2}$ & & am & & wheel & & I1,736.34 & .269 & $7,824 \cdot 74$ & .180 & $4,744.74$ & .109 \\
\hline 10 & "6 & 16 & ‘6 & $"$ & .. & $37,161.74$ & .853 & $24,774.75$ & $\cdot 569$ & $I_{4}, 767.83$ & $\cdot 339$ \\
\hline 12 & 6 & 6 & 6 & 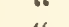 & & $66,765.16$ & ז.533 & 44.509 .85 & 1.022 & 26.134 .57 & .600 \\
\hline 14 & $" 6$ & 6. & 6 & $" 6$ & & $85,982.05$ & 1.974 & 57.321 .11 & $1 \cdot 316$ & $34,757.03$ & .798 \\
\hline 16 & 6 & 16 & & "6 & .. & $120,106.14$ & 2.757 & $80.0,0.76$ & 1.838 & $49,742.00$ & I. I 42 \\
\hline 18 & $\because$ & 66 & 6 & "“ & .. & $192,446.10$ & $4 \cdot 418$ & 123,16453 & 2.827 & 75.215 .14 & 1. 727 \\
\hline 20 & 16 & 16 & 6 & 6 & & 238.395 .08 & 5.473 & $158,930.3^{1}$ & 3.649 & $9,21 \times 50$ & 2.209 \\
\hline 25 & 6 & "6 & 66 & "6 & 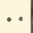 & $410,038.09$ & $9.4^{1} 3$ & 273.359 .24 & 6.275 & $x \sigma_{3} .533 .37$ & 3.75 \\
\hline 30 & "6 & & & & & $831,686 .=4$ & 19.093 & $5^{6} \mathrm{r}, 197 \cdot 5^{6}$ & 12.883 & $33^{1}, 75^{2.96}$ & 7.616 \\
\hline
\end{tabular}




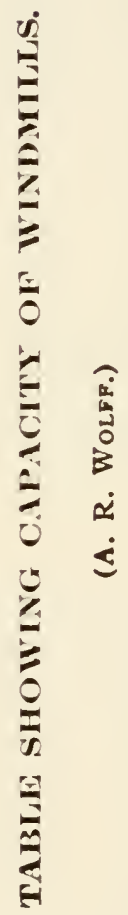

\begin{tabular}{|c|c|c|}
\hline \multicolumn{2}{|c|}{ 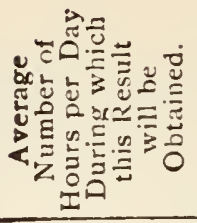 } & $\infty \infty \infty \infty \infty \propto \infty \infty$ \\
\hline \multicolumn{2}{|c|}{ 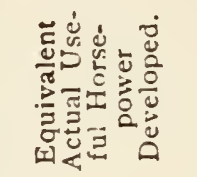 } & రำ \\
\hline \multirow{6}{*}{ 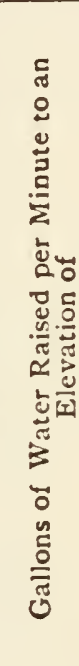 } & $\frac{8}{8}$ & 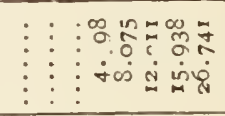 \\
\hline & $\stackrel{+}{\stackrel{0}{\circ}}$ & 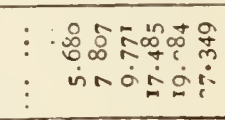 \\
\hline & $\stackrel{5}{8}$ & 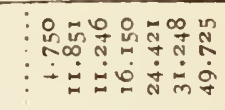 \\
\hline & $\underset{⿱ ㇒}{ \pm}$ & 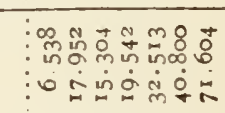 \\
\hline & $\begin{array}{l}\stackrel{3}{\circ} \\
\text { in }\end{array}$ & 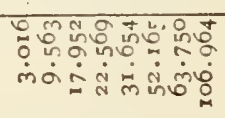 \\
\hline & $\underset{n}{\stackrel{ \pm}{*}}$ & 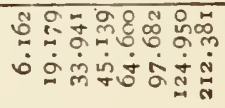 \\
\hline \multicolumn{2}{|c|}{ 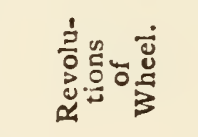 } & 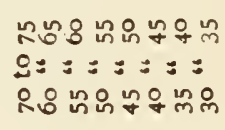 \\
\hline \multicolumn{2}{|c|}{ 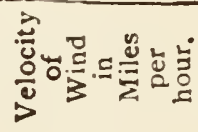 } & OOM OONO \\
\hline \multirow{2}{*}{\multicolumn{2}{|c|}{ 号 }} & 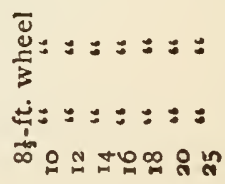 \\
\hline & & ーシシつつ5らま \\
\hline
\end{tabular}




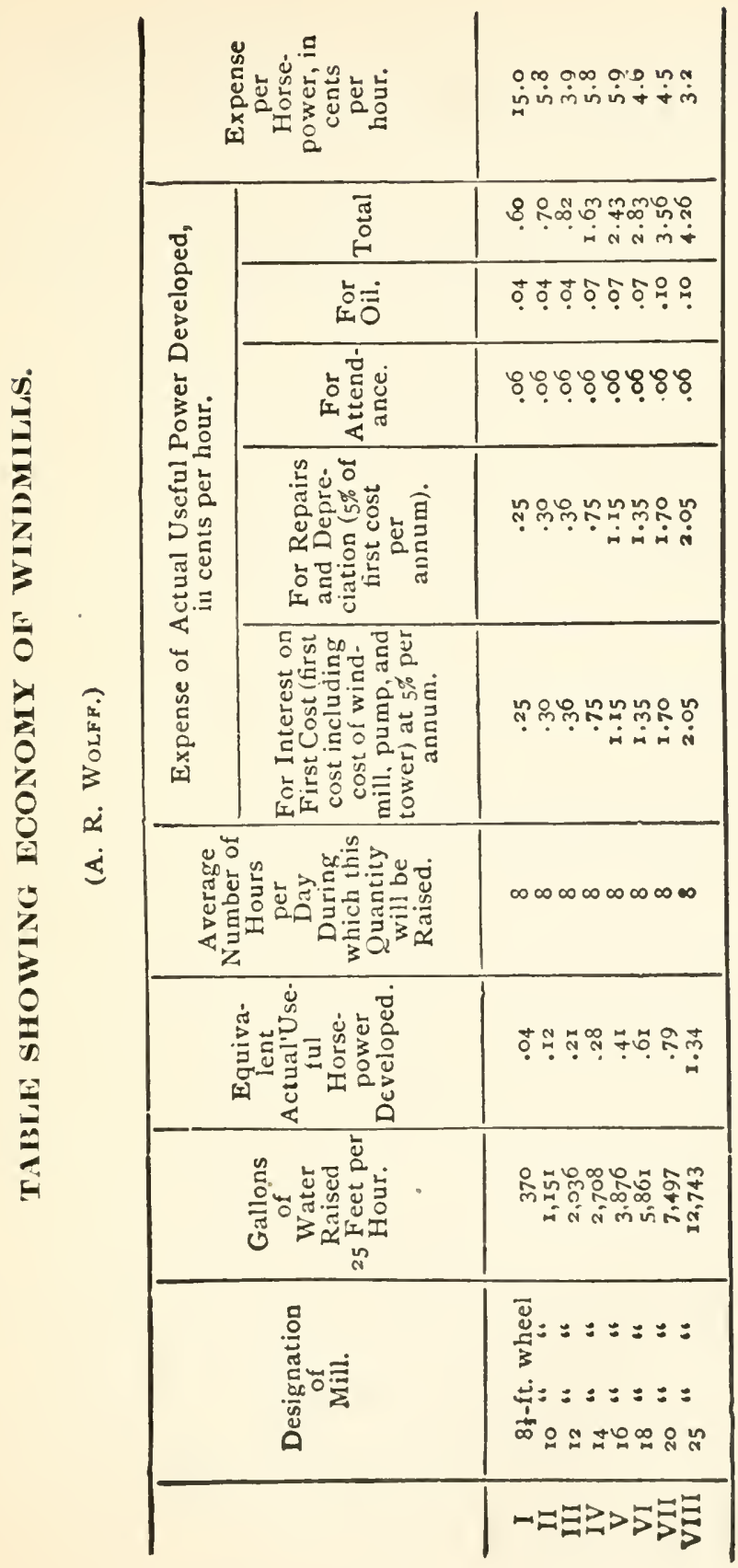


NOMINAI HORSE-POWER REQUIRED FOR THE DISCHARGE OF GIVEN QUANTIIES OF WATER WITH LIFTS OF 10 AND 20 FEET. (Scott.)

\begin{tabular}{c|c|c|c}
\hline $\begin{array}{c}\text { Diameter of Pipe, } \\
\text { Inches. }\end{array}$ & $\begin{array}{c}\text { Gallons } \\
\text { Discharged per } \\
\text { Minute. }\end{array}$ & $\begin{array}{c}\text { Nominal H.P. } \\
\text { required for a } \\
\text { Io-foot Lift. }\end{array}$ & $\begin{array}{c}\text { Nominal H.P. } \\
\text { required for a } \\
\text { 20-foot Lift. }\end{array}$ \\
\cline { 2 - 2 } & 100 & 1 & 2 \\
4 & 200 & $11 / 2$ & 3 \\
5 & 350 & 2 & 4 \\
6 & 500 & $21 / 2$ & 5 \\
7 & 759 & 3 & 8 \\
8 & 1000 & 4 & 8 \\
10 & 1500 & 8 & 10 \\
12 & 2300 & 10 & 14 \\
14 & 3800 & 12 & 20 \\
15 & 6000 & 20 & 35 \\
18 & & & \\
\hline
\end{tabular}

IRRIGITION. (Yearbook U. S. Dept. of Agriculture.)

A water right is the right or privilege of using water for irrigating purposes, either in a definite quantity or upon a prescribed area of land, such right or privilege being customarily acquired either by priority of use or by purchase. In many parts of the arid region a water right is an exceedingly valuable property. The average value of the water rights of the entire arid region, as determined by the census of I 890 , was $\$ 26$ per acre, and there are fruit-growing districts in California where water rights have been sold at as high as $\$ 1500$ per miner's inch, or from \$roo to $\$ 500$ per acre, according to the amount used on any given area of land.

The duty of zuater is the extent of the service it will perform when used for irrigating purposes, that is, the number of acres a given quantity of water will adequately irrigate under ordinary circumstances. This is usually from Ioo to 200 acres for each second-foot. Where water is abundant the duty has been known to be as low as 50 acres, and where very scarce as high as 500 acres, to the second-foot. 
A miner's inch is theoretically such a quantity of water as will flow through an aperture $I$ inch square in a board 2 inches thick under a head of water of 6 inches in one second of time, and it is equal to 0.194 gallon, or 0.5259337 cubic foot, per second, or to II.64 gal., or I.556024 cubic ft., per minute. The amount of water flowing through a given aperture in a given time varies, however, with the head of water over the opening, and also with the form of the opening. In Colorado the miner's inch legalized by statute equals Ir.7 gal. per min. The California miner's inch, however, equals only 9 gal. permin., roo Colorado inches being, accordingly, equal to I30 California inches. One hundred Colorado inches will cover an acre to a depth of $5.2 \mathrm{ft}$. in 34 hours; Ioo California inches will cover the same area only to a depth of $4 \mathrm{ft}$. in the same time. Fifty California inches are, therefore, approximately equal to I secondfoot, and 50 Colorado inches equal to about three tenths more.

An acre-foot of water is the amount required to cover an acre of ground to a depth of $I$ foot. This is 43,560 cubic feet, or $325,55 \mathrm{I} .45 \mathrm{gal}$. Its weight is I $2 \mathrm{I} 3$ tons 2 I I 3 pounds, at 2240 pounds to the ton.

The amount of water required to cover an acre of ground to a depth of I inch is 3630 cubic feet, or $27,154.29$ gal. Its weight is ror tons 3623 pounds, at 2240 pounds to the ton.

A second-foot is the most satisfactory because the most definite unit of measurement for flowing water. It is used by the U. S. Government in the gauging of rivers and streams, and is rapid!y superseding the miner's inch in the measurement of water for irrigation. It is the quantity represented by a stream $I$ foot wide and I foot deep flowing at the average rate of I foot per second. In other words, it is I cub. ft. per second, 60 cub. ft. per min., 3600 cub. ft. per hour, etc. A stream flowing continuously at the average rate of I second-foot would carry in one day of 24 hours $86,400 \mathrm{cub}$. ft., or 646,316.9 gal., sufficient to cover $1 \frac{119}{12}$ acres to a depth of $\mathrm{I} f \mathrm{t}$. Flowing continuously for one year of 365 days, such a strcam would carry $31,536,000$ cub. 
ft., or $235,905,678.7 \mathrm{gal}$, sufficient to cover $723 \frac{11 \frac{7}{1}}{1}$ acres to a depth of I $\mathrm{ft}$.

The sub-humid region is the strip of country running north and south between the arid region, where irrigation is absolutely necessary to the successful prosecution of agriculture, and those portions of the United States in which the rainfall is usually sufficient for agricultural purposes. It includes portions of North Dakota, South Dakota, Nebraska, Kansas, and Texas, and may be described as a region where irrigation is not always necessary, but where agricultural operations cannot, with any assurance of success, be undertaken without it.

The average value of the irrigated land in farms in the United States was ascertained by the census of 1890 to be $\$ 83.28$ per acre, and that of the non-irrigated land in farms $\$ 20.95$ per acre.

The average annual value of the agricultural products of the irrigated land was ascertained to be $\$ 14.89$ per acre irrigated, and that of those of the non-irrigated land $\$ 6.80$ for each acre improved.

The average first cost of the irrigated land, including purchase money, water rights, etc., was ascertained to have been $\$ 8.15$ per acre, and the average annual cost of the water supply $\$ 1.07$ per acre.

The total vaiue of the irrigated farms of the United States, as reported by the farmers themselves, was, in round figures, $\$ 296, \$ 50,000$, an increase of $\$ 219,360,000$, or 283 per cent, upon their cost, including land, water right, fences, and preparation for cultivation.

The total value of the productive irrigating systems was found to be $\$ 94,412,000$, an increase of $\$ 64,801,000, r, 2: 9$ per cent, upon their cost. 
CAIRYING CAPACITY OF PIPES, GALLONS PER MINUTE. (WILCOX.)

\begin{tabular}{|c|c|c|c|c|c|c|c|c|}
\hline $\begin{array}{l}\text { Size of } \\
\text { Pipe. }\end{array}$ & 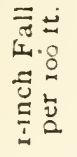 & 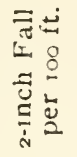 & 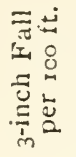 & 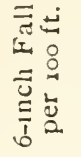 & 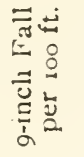 & 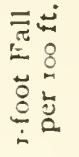 & 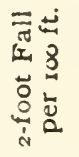 & 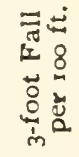 \\
\hline 3 inch. & 13 & 17 & 23 & $3^{2}$ & 40 & 46 & 64 & 79 \\
\hline $4 \quad$. & 27 & $3^{3}$ & 47 & 66 & $8 t$ & 93 & 131 & 163 \\
\hline$"$ " & 75 & 105 & 129 & 183 & 224 & 258 & $3^{6} 4$ & 450 \\
\hline "1 & 1.53 & 215 & 265 & 375 & $4^{60}$ & 527 & $75^{\circ}$ & 923 \\
\hline$"$ " & 205 & 200 & $35 \overline{3}$ & $5 \times 3$ & 617 & 712 & 1,006 & 1.240 \\
\hline 10 & $25_{7}$ & 378 & $4^{63}$ & 6.53 & 803 & 926 & 1,310 & 1,613 \\
\hline 12 & 422 & $59^{6}$ & 730 &., 033 & 1,273 & T. 468 & $2.07^{6}$ & 2.554 \\
\hline 15 & 710 & $1,02 \mathrm{I}$ & 1.282 & 1.818 & 2,224 & $2,4^{6} 4$ & 3,617 & 4,467 \\
\hline 18 & I. 168 & 1.651 & 2.022 & 2,860 & 3,508 & 4,045 & 5.704 & 7,047 \\
\hline 24 & 2. 305 & $3.3^{8} 7$ & 4.155 & 5.874 & 7.202 & $8,3 \circ 3$ & $11,7+4$ & 14,466 \\
\hline $3^{\circ}$ & 4,187 & 5,920 & 7,252 & 10.557 & 12,580 & 14,504 & 20,5 I 6 & 25,277 \\
\hline
\end{tabular}

FIOIV OF WATER THIOUGH STRAIGHT PIIES Nlowing Full, in Gallons per Minute.

(Collet.)

\begin{tabular}{|c|c|c|c|c|c|c|c|c|c|}
\hline \multirow{2}{*}{$\begin{array}{l}\Xi \stackrel{\dot{n}}{\nu} \\
\frac{E}{\tilde{U}} \\
\frac{\pi}{\sigma}\end{array}$} & \multicolumn{9}{|c|}{ Head of Water Divided by Length of Pipe. } \\
\hline & $\frac{1}{100}$ & $5 \frac{1}{5}$ & $\frac{1}{2}=$ & $\frac{1}{10}$ & $\frac{2}{10}$ & $\frac{3}{10}$ & $\frac{5}{30}$ & $\frac{8}{10}$ & $\frac{1}{3}$ \\
\hline$I^{1}$ & $\ldots$. & $\ldots \ldots$. & $\ldots$ & .024 & .036 & .046 & .06 & .077 & .086 \\
\hline है & $\cdots \cdots$ & $\ldots$ & $\ldots$ & .056 & .075 & .08 & .124 & .158 & .18 \\
\hline $1^{3} 6$ & $\ldots$. & & ...... & .14 & .21 & .26 & .34 & .44 & .50 \\
\hline$\frac{1}{2}$ & . & $\cdot$ & $\ldots \ldots$ & $\cdot 31$ & .44 & .52 & 72 & .92 & 104 \\
\hline 1 & .22 & .33 & .5 & .83 & 1.2 & 1.5 & 2.0 & 2.6 & 2.9 \\
\hline$\frac{1}{2}$ & $.4^{6}$ & .70 & 1. 0 & 1.8 & . 2.5 & 3.1 & $4 \cdot 1$ & $5 \cdot 3$ & 60 \\
\hline \& & I. 33 & $1.9^{8}$ & $\begin{array}{ll}2 & 9\end{array}$ & 49 & 7.1 & 8.9 & 11.7 & 15 & ז 6.9 \\
\hline I & 2.79 & 4.15 & 6.1 & 10 & 1.4 .8 & 18.4 & 24 & $3 I$ & 35 \\
\hline $1 \frac{1}{6}$ & $4.9^{6}$ & $7 \cdot 36$ & 10.8 & 18 & 26 & $3^{2}$ & 42 & 54 & 61 \\
\hline 14 & 7.93 & 11.75 & 17.2 & 28 & 41 & $5 \mathrm{I}$ & 67 & 86 & 97 \\
\hline 19 & 11.7 & 17.4 & 25.5 & 42 & 61 & 76 & 100 & 128 & 144 \\
\hline 2 & 16.0 & 24 & 36 & 50 & 86 & 106 & 140 & 179 & 202 \\
\hline $2 \frac{1}{2}$ & 29 & 43 & 63 & $10_{4}$ & 151 & 188 & 246 & 315 & 354 \\
\hline 3 & $4^{5}$ & 69 & 101 & 166 & 240 & 298 & 390 & $5^{\circ 0}$ & 562 \\
\hline 4 & 78 & 144 & 210 & 314 & 408 & 517 & E०8 & 1033 & 1162 \\
\hline 5 & 173 & 254 & 370 & 606 & 876 & 1085 & 1419 & 1815 & 2040 \\
\hline 6 & 227 & 404 & $5^{89} 9$ & 959 & $13^{89}$ & 1720 & 2248 & 2876 & $3^{2} 3^{\circ}$ \\
\hline
\end{tabular}

If the diameter be doubled, nearly 5.8 times the quantity can be passed. 
POWER REQUIRED TO RAISE WATER FROM DELP WELAS BY PUMPING. (APpleby.)

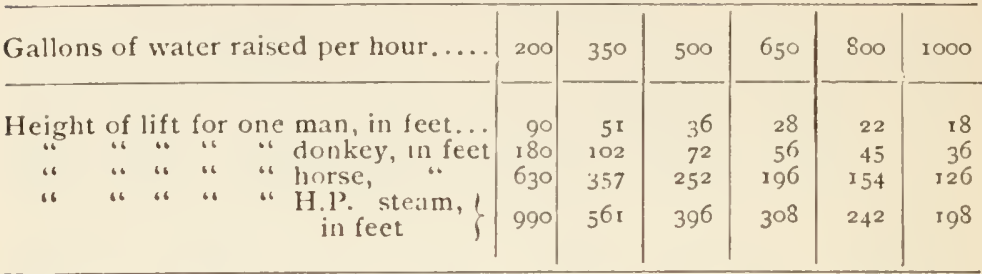

MPPROXIMATE COST OF DIFFERINT ININAS OH PIPE CSED FOR IRIIGNTION. (WILCOX.)

\begin{tabular}{|c|c|c|c|c|c|c|c|}
\hline 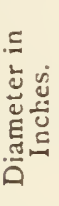 & 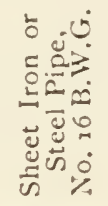 & 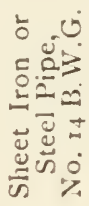 & 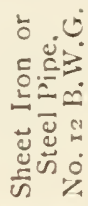 & 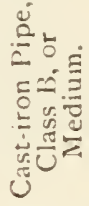 & 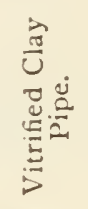 & $\begin{array}{l}\stackrel{0}{0} \\
0 \\
0 \\
0 \\
0 \\
0 \\
:\end{array}$ & 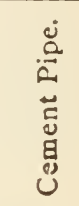 \\
\hline 6 & $\$ 0.32$ & $\$ 0.4 \mathrm{I}$ & So. 52 & So. $72 \frac{1}{2}$ & So. $16 \frac{1}{2}$ & $\ldots \ldots \ldots$ & $\$ 0.12$ \\
\hline 8 & .42 & $.5^{I}$ & .62 & I. $04 \frac{1}{2}$ & .22 & $\ldots$. & .20 \\
\hline 10 & .53 & .60 & .85 & I. 42 & .33 & $\ldots \ldots$ & .26 \\
\hline 12 & .63 & .68 & .98 & 1.84 & $.4 \mathrm{It}$ & & .32 \\
\hline I4 & .69 & .75 & 1.17 & $2 \cdot 30$ & .55 & So. 74 & $.3^{8}$ \\
\hline 16 & .82 & .93 & 1.25 & 2.83 & .68 & .94 & .45 \\
\hline 18 & .91 & $x .00$ & 1.43 & 3.37 &.$\varepsilon_{21}$ & 1.08 & .53 \\
\hline 20 & 1.00 & I. 44 & 1.63 & 3.97 & $.96 \div$ & 1.22 & .60 \\
\hline 22 & 1.05 & 1.30 & 1.85 & 4.62 & $1.2 \mathrm{I}$ & 1.32 & .68 \\
\hline 24 & & x. 46 & 2.00 & $5 \cdot 33$ & $x \cdot 37 \frac{1}{8}$ & 1.40 & .80 \\
\hline
\end{tabular}

AVERAGE COST PER MLE OF CONSTRUCTING IRIRIGATING CANALS AND DITCHES.

(Eleventh U.S. Census.)

\begin{tabular}{|c|c|c|c|}
\hline States and Territories. & $\begin{array}{l}\text { Under } 5 \text { Feet } \\
\text { in Width. }\end{array}$ & $\begin{array}{l}5 \text { to ro Feet } \\
\text { in Width. }\end{array}$ & $\begin{array}{l}\text { 1o Feet and } \\
\text { Over in } \\
\text { Width. }\end{array}$ \\
\hline General average.......... & $\$ 48 \mathrm{r}$ & 81.628 & $\$ 5.603$ \\
\hline Arizona ............. & $\$_{471}$ & \$1,674 & $\$ 5,274$ \\
\hline California...... & 885 & 5,957 & $15,5 \mathrm{II}$ \\
\hline 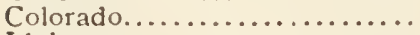 & $3^{80}$ & $1,1_{3} 1$ & 5,258 \\
\hline 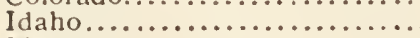 & 205 & 810 & 1,320 \\
\hline 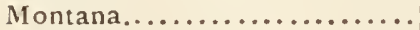 & 325 & $8 \infty 0$ & 2,300 \\
\hline 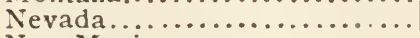 & 200 & $\mathbf{I}, \mathbf{1} 50$ & \\
\hline New Mexico................ & 3 ro & $58 \mathrm{I}$ & 6.666 \\
\hline Oregon $\ldots \ldots \ldots \ldots \ldots \ldots \ldots$ & 260 & 1,060 & 1,300 \\
\hline 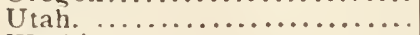 & 403 & I,, 025 & 3.072 \\
\hline 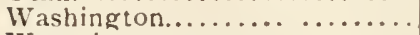 & 285 & 1,236 & 2.571 \\
\hline Wyoming $\ldots \ldots \ldots \ldots \ldots \ldots \ldots$ & $\ldots .$. & 837 & $3.88_{4}$ \\
\hline Sub-humid region........... & 303 & 447 & 1,88 \\
\hline
\end{tabular}




\section{CAPACITIES OF WINDMILLS AND I'UMPS.}

(IRRIGATION Age.)

Sizes of Irrigation Mills and Pumps best Adapted for each other to Work Successfully under Ordinary Conditions.

\begin{tabular}{|c|c|c|c|c|c|c|c|c|}
\hline 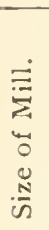 & 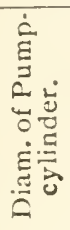 & 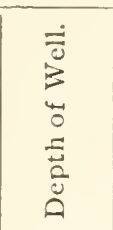 & 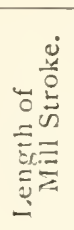 & 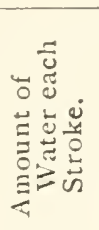 & 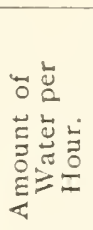 & 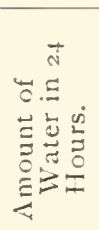 & 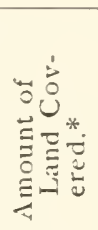 & 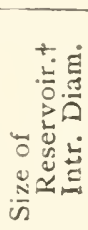 \\
\hline $\mathrm{Ft}$. & In. & $\begin{array}{l}\text { Ft. and } \\
\text { under. }\end{array}$ & In. & Gals. & Gals. & Gals. & Acres. & Fee \\
\hline
\end{tabular}

ro-foot Mills.

\begin{tabular}{l|l|l|l|l|l|l|l|l} 
ro & 8 & 30 & 10 & $1 \frac{8}{4}$ & 3,660 & 87,840 & $\ldots \ldots \ldots$ & $\ldots \ldots \ldots$ \\
ro & 6 & 50 & 10 & $1 \frac{1}{4}$ & 2,580 & 61,920 & $\ldots \ldots \ldots$ & $\ldots \ldots \ldots$ \\
10 & 4 & 75 & 10 & $\frac{5}{8}$ & 1,320 & 31,680 & $\ldots \ldots \ldots$ & $\ldots \ldots \ldots$
\end{tabular}

ra-foot Mills.

\begin{tabular}{l|r|r|r|r|r|r|r|r}
12 & 10 & 30 & 12 & $4 \frac{1}{2}$ & 7,500 & 180,000 & 103 & $90 \times 75$ \\
12 & 8 & 50 & 12 & $3 \frac{1}{2}$ & 6,300 & 151,200 & 86 & $90 \times 60$ \\
12 & 6 & 75 & 12 & $1 \frac{1}{2}$ & 2,700 & 64,800 & 37 & $60 \times 40$ \\
12 & 4 & 125 & 12 & $\frac{3}{4}$ & 1,320 & 31,680 & 18 & $50 \times 30$
\end{tabular}

$I f \cdot$ foot Mills.

\begin{tabular}{r|r|r|r|r|r|r|r|r}
14 & 12 & 30 & 14 & $6 \frac{1}{3}$ & 10,620 & $25+, 880$ & 146 & $125 \times 80$ \\
14 & 10 & 50 & 14 & $4 \frac{1}{3}$ & 7,260 & 174,240 & 100 & $90 \times 75$ \\
14 & 8 & 75 & 14 & $2 \frac{8}{8}$ & 4,620 & 100,880 & 63 & $75 \times 50$ \\
14 & 6 & 125 & 14 & 18 & 2,940 & 71,560 & 40 & $55 \times 40$ \\
14 & 4 & 175 & 14 & 1 & 1,680 & 40.320 & 23 & $50 \times 3 r$ \\
\hline
\end{tabular}

* Amount of land that can be covered I ft. deep with windmills working at the rate of 15 hours per day for 300 days in the year. Acres covered i ft. deep.

+ Capable of holding water for 24 llours continuous pumping. These sizes should hare ${ }_{4} \mathrm{ft}$. depth of water, height of bank $5 \mathrm{ft}$., width of base $16 \mathrm{ft..} 2 \mathrm{ft}$. of water below discharge-pipe not included. These reservoirs to connect with additional reservoir by overflow-pipe in order to utilize full capacity of mills and pumps. Overflow-reservoir should be of 1 - and 2 . acre capacity, $8 \mathrm{ft}$. dcep, banks $9 \mathrm{ft}$. higll, base of bank $45 \mathrm{ft}$, acre size $209 \mathrm{ft}$. on each side, comers rounded; 2 -acre size $200 \times{ }_{41} 8 \mathrm{ft}$. 
THE CALIF ORNIA WFIR TABLF, (WiLcox.)

\begin{tabular}{|c|c|c|c|c|c|c|c|}
\hline Depth. & $\begin{array}{l}\text { Miner's } \\
\text { Inches. }\end{array}$ & Depth. & $\begin{array}{l}\text { Miner's } \\
\text { Inches. }\end{array}$ & Depth & $\begin{array}{l}\text { Miner's } \\
\text { Inches. }\end{array}$ & Depth. & $\begin{array}{l}\text { Miner's } \\
\text { Inclies. }\end{array}$ \\
\hline $1 / 8$ & or & $3 \% / 8$ & 2.56 & $75 \%$ & 7.04 & $12^{3} / 4$ & 15.27 \\
\hline 1,4 & .04 & 4 & 2.69 & $7 \%$ & 7.22 & 13 & 15.72 \\
\hline $3 / 8$ & .07 & $41 / 8$ & $2.8 i$ & $7 \%$ & 7.40 & $131 / 4$ & 16.18 \\
\hline $1 / 3$ & .12 & $4 \frac{1}{4}$ & 2.93 & & $7 \cdot 5^{8}$ & $131 / 2$ & $16.6_{4}$ \\
\hline 98 & .17 & $43 \% 8$ & 3.07 & $81 / 8$ & $7 \cdot 76$ & $133 \%$ & 17.10 \\
\hline $3 / 4$ & .22 & $41 / 2$ & 319 & $81 / 4$ & 7.93 & 14 & 17.57 \\
\hline $7 / 8$ & .27 & 45 & $3 \cdot 33$ & $89 / 8$ & 8.12 & $x^{1 / 1}$ & 18.04 \\
\hline I & .33 & $4^{3} / 4$ & 3.47 & $81 \frac{1}{2}$ & 8.30 & 1416 & 18.52 \\
\hline $11 / 8$ & $\cdot 39$ & 478 & $3.6 t$ & $85 \%$ & $8.4^{8}$ & $14 \%$ & 19.00 \\
\hline $11 / 4$ & .46 & 5 & 3.75 & $83 \frac{4}{4}$ & 8.67 & 15 & 19.48 \\
\hline 136 & .54 & $5^{1 / 8}$ & 3.89 & $8 \pi / 8$ & 8.86 & $51 / 4$ & 19.98 \\
\hline $11 \frac{16}{2}$ & .62 & $51 / 4$ & 4.03 & 9 & 9.05 & $151 \%$ & 2047 \\
\hline 158 & .69 & $53 / 8$ & 4. 18 & $91 / 8$ & 9.23 & 1534 & 20.97 \\
\hline $13 / 4$ & .77 & $5 \frac{1}{2}$ & $4 \cdot 32$ & $9^{1 / 4}$ & 9.42 & I 6 & 21.47 \\
\hline 178 & .86 & $55 / 8$ & 4. 47 & $93 / 8$ & 962 & $161 / 2$ & 22.47 \\
\hline 2 & .95 & $5 \div 4$ & 4.62 & $91 / 2$ & 981 & 17 & 23.50 \\
\hline $21 / 8$ & 1.04 & $5 \% / 8$ & 477 & $9 \%$ & 1000 & $171 / 2$ & $24 \cdot 54$ \\
\hline $21 / 4$ & 1.13 & 6 & 4.92 & $0^{3} 4$ & 1019 & 18 & $25.5^{8}$ \\
\hline $23 \%$ & 1.22 & $62 / 8$ & 5.08 & $9 \%$ & 10.39 & $181 / 2$ & 26.65 \\
\hline $21 / 6$ & 132 & 64 & 5.24 & 10 & 10 50 & 19 & 27.74 \\
\hline $25 \%$ & 1.42 & 638 & $5 \cdot 39$ & $101 / 4$ & ro 99 & $101 \%$ & 28.83 \\
\hline $23 / 4$ & 1.52 & 013 & 5.54 & $101 / 2$ & 1130 & 20 & 29.95 \\
\hline $2 i / 8$ & 1.63 & 658 & $5.7 \mathrm{I}$ & $10^{3} .4$ & 11.80 & $201 / 2$ & 31.07 \\
\hline 3 & 1.74 & $6 \%$ & 5.87 & II & 12.22 & 21 & $32.2 \mathrm{I}$ \\
\hline $3 ! 6$ & $1.80^{\circ}$ & $0: 8$ & 6.04 & $\mathrm{II}^{1 / 4}$ & 12.65 & $211 / 2$ & 33.36 \\
\hline 31 & 1. 97 & 7 & 6.20 & $111 / 2$ & 1306 & & $34 \cdot 52$ \\
\hline $3, \frac{1}{6}$ & 2.08 & $71 / 8$ & 6.37 & $13 \frac{4}{4}$ & 13.50 & $221 / 2$ & 35.70 \\
\hline $3, \frac{1}{2}$ & 2.19 & $71 j$ & 6.53 & 12 & 13.94 & 23 & $3^{6}$ go \\
\hline $30 \%$ & $2 \cdot 3 I$ & $73 \%$ & 6.70 & $121 / 4$ & I 4.38 & $231 / 2$ & 38.10 \\
\hline 34 & 2.43 & $71 / 2$ & 6.87 & $121 / 2$ & 14.82 & 24 & $39 \cdot 32$ \\
\hline
\end{tabular}

CAPACITY OF CISTERNS AND TANKS, in Gallons, for Each Twelve Inches in Depth.

(A. R. WOLFr.)

\begin{tabular}{|c|c|c|c|c|c|}
\hline $\begin{array}{c}\text { Diameter in } \\
\text { Feet. }\end{array}$ & Gallons. & $\begin{array}{c}\text { Diameter in } \\
\text { Feet. }\end{array}$ & Gallons. & $\begin{array}{c}\text { Diameter in } \\
\text { Feet. }\end{array}$ & Gallons. \\
\hline 1.0 & 5.87 & 6.5 & 248.23 & II.O & 710.90 \\
\hline 2.0 & 23.50 & 7.0 & 287.88 & II .O & 777.05 \\
\hline 2.5 & $3^{6} 72$ & $7 \cdot 5$ & $330.4^{8}$ & 12.0 & 846.03 \\
\hline 3.0 & 52.88 & 8.0 & 376.00 & 13.0 & 992.91 \\
\hline 3.5 & 71.97 & 8.5 & $424 \cdot 48$ & 14.0 & 1151.54 \\
\hline 4.0 & 94.00 & 9.0 & 475.89 & I5.0 & 1321.92 \\
\hline $4 \cdot 5$ & 118.87 & 9.5 & 530.24 & 20.0 & 2350.08 \\
\hline 5.0 & $\mathrm{I}_{4} 6.88$ & 10.0 & $5^{8} 7.5^{2}$ & 25.0 & 3672.00 \\
\hline $5 \cdot 5$ & 177.72 & 10.5 & $647 \cdot 74$ & 30.0 & 5287.68 \\
\hline 6.0 & $2 \pi 1.51$ & & & & \\
\hline
\end{tabular}




\section{Capacity of Cisterns in Barrels, Per Foot in Depth. (HALL.)}

Square Cistern.

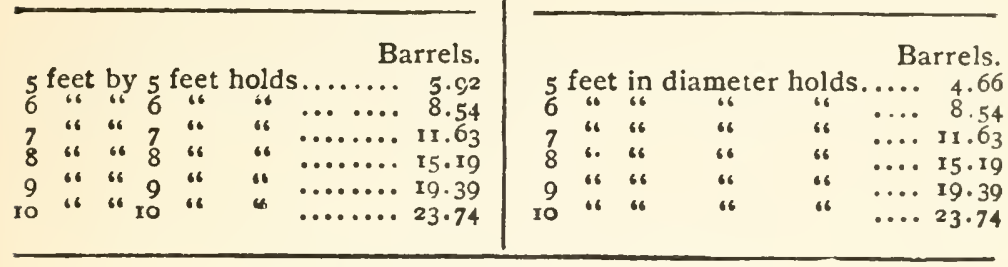

\section{ROAD-MAKING. (Campbell.)}

Drainage.-Perfect drainage, first of the foundation of the roadbed, secondly of the road surface, are the points in road-making on which too much stress cannot be laid.

The first is accomplished by underdrainage, tile drains being laid at a depth of three or more feet below the surface on each side of the roadbed at the foot of the grade and parallel to it. Care should be taken to fit and settle the tile in the trench so that, when refilling with earth, they will not be displaced. As a rule $2 \frac{1}{2}-$ to 4 -in. tile will be sufficient. The joints should be close, and the grade a true line. Loose joints and an uneven grade allow silt to pass into the tile and remain there, destroying the drain.

Surface drainage is accomplished by open drains on each side of the grade, having sufficient capacity to drain, both the roadbed and the land adjoining. With open drains and with tile drains make and maintain a free outlet to the nearest watercourse. A drain without an outlet is useless.

Crowning the Road. - The graded portion of the road should be wide enough to accommodate the travel upon it, and not greater, the slope being uniform, not heaped in the centre. The crown should be well above the overflow of storm water, and should have a grade sufficient to shed water readily to the open ditches on either side. Do not round it up so as to make the grade steep and dangerous, under the mistaken impression that better drainage will thereby be secured. Nor should it he so low as to allow water to stand upon it in depressions. Under ordinary ci:cumstances one inch or one incin and a half to the foot is 
a proper grade; that is, a roadbed twenty-six feet wide should be from thirteen to twenty inches higher at the center than at the side.

Quality of Gravel.-The gravel should preferably be sharp, clean, and of uniform size. Pit gravel usually contains too much earthy matter, and where the latter is in excess, the gravel, as a road-making material, is useless. Lake gravel is apt to be rounded, water-worn, and lacking in the necessary earthy matter to make a solid and compact surface, but is generally a better road material than pi: gravel. A coating of pit gravel with a surfacing of creek gravel is a good combination. All large stones should be removed, as they will work to the surface, and will then roll loosely or form rough protuberances.

Placing the Gravel. - The gravel should be spread evenly over the surface of the sub-grade to a depth of six or eight inches, and to the required width, then rolled with a heavy roller. Rolling should be performed in showery weather, as it is impossible to consolidate dry earth or gravel. The heavice the roller the better will be the results, but if a heavy roller cannot be obtained, a light roller is much bet.. ter than none. The roller should be passed over the sur. face until the gravel or earth is so compact as not to be displaced and rutted by the wheels of a wagon passing over it with an ordinary load. The surface must be maintained smooth and hard, to shed water and resist wear. Every municipality should have a roller, but whether one can be obtained or not the gravel should not be left in a heap just as it falls from the wagon. Spread it evenly.

Repairs. - Gravel roads alrcady constructed will need repair. By the use of road machinery, scrape the surface and cut off the corners, which will have formed at the foot of the grade by the washing down of dusty material from the crown of the road. Loosen the surface, particularly that part of the traveled portion and where the road is rutted, with picks, or, if possible, with road machinery ; then apply a coating of gravel, and roll thoroughly. It is of more importance, however, to see that the drains are not obstructed in their course and that their outlets are free and open. *

* See Farmers' Bulletin, No. 9פ, "Good Roads for Farmers," Washing ton, 1899 . 


\section{IMPORTANCE OF GOOD ROADS.}

It is estimated that it costs a farmer more to haul a bushel of wheat than it does a railroad to haul a ton ; that our poor roads cost the farmer at least $\$ 5.00$ a year for every horse, and that good earth roads would save more than half the cost of hauling, and good permanent roads more than three quarters of it. (GilMoRe.)

\section{Force Required to Draw a Load on Different Kinds of Roads.}

\begin{tabular}{|c|c|c|c|c|c|c|c|c|}
\hline & \multirow{2}{*}{$\begin{array}{c}\text { Force } \\
\text { Required to } \\
\text { Draw a Gross } \\
\text { Load of } \\
2240 \text { Pounds. }\end{array}$} & \multirow{2}{*}{$\begin{array}{l}\text { Steepest } \\
\text { Grade (rise } \\
\text { per Ioo ft.) } \\
\text { on which } \\
\text { Vehicle will } \\
\text { not Roll } \\
\text { Back. }\end{array}$} & \multicolumn{6}{|c|}{$\begin{array}{l}\text { Draught on a Level Com- } \\
\text { pared with that on Dif- } \\
\text { ferent Grades. Rise in } \\
\text { feet per roo feet. }\end{array}$} \\
\hline & & & 0 & 3 & 6 & 9 & 12 & I5 \\
\hline $\begin{array}{l}\text { Earth road....... } \\
\text { Gravel “ } \\
\text { Macadam road... } \\
\text { Telford " } \\
\text { Plank } \\
\text { Stone trackway.. }\end{array}$ & $\begin{array}{c}\text { Pounds } \\
200 \\
\text { I } 43^{\frac{1}{2}} \\
65 \\
46 \\
41 \\
12 \frac{1}{2}\end{array}$ & $\begin{array}{c}\text { Feet } \\
8.9 \\
6.4 \\
2.9 \\
2.0 \\
1.8 \\
.5\end{array}$ & $\begin{array}{l}\text { I } \\
\text { I } \\
\text { I } \\
\text { I } \\
\text { I } \\
\text { I }\end{array}$ & $\begin{array}{l}1.3 \\
1.5 \\
2.0 \\
2.5 \\
2.6 \\
6.4\end{array}$ & $\begin{array}{r}\mathbf{r} \cdot 7 \\
\mathbf{I} \cdot 9 \\
3 \cdot 1 \\
3 \cdot 9 \\
4 \cdot 3 \\
\mathrm{I} \cdot \mathbf{1} \\
\end{array}$ & $\begin{array}{r}2.0 \\
2.4 \\
4 \cdot 1 \\
5 \cdot 4 \\
5 \cdot 9 \\
17 \cdot 1\end{array}$ & $\begin{array}{r}2.3 \\
2.9 \\
5.1 \\
6.8 \\
7 \cdot 5 \\
22.3\end{array}$ & $\begin{array}{r}2.7 \\
3.3 \\
6.1 \\
8.2 \\
9.1 \\
27.5\end{array}$ \\
\hline
\end{tabular}

\section{TRACTIVE FORCE REQUHRDIOR CARRIAGES} of one ton, on a level road. (MCCONNEll.)

Description of Road.

Force of Traction per Ton.

I. On rails ...................... 8 lbs.

2. Well-made pavement.................. $33^{\text {" }}$

3. Macadamized road ............... H4 to 67 "

4. Turnpike, hard and dry ............... 68 "

5. " $\operatorname{dirty} \ldots \ldots \ldots \ldots \ldots \ldots \ldots \ldots \ldots . . \ldots \ldots$ ss “

6. Hard compact loam................. I19 "

7. Gravel........................... 150 "

8. Sancly and gravelly ................. 210

9. Ordinary by-road .................... 237 "

Io. Turnpike, newly-gravelled ............. 320 “

II. Loose sandy road .................. 457 “

A horse produces his greatest mechanical effect in drawing a load $2 \frac{1}{2}$ miles per hour with a tractive force of 150 lbs. 


\section{FRACTION OF THE WEIGHT OF A VEHICLE AND LOAl REQUIIED TO MOVE SAME ON A LEVEL ROAD. (MURIN.)}

\begin{tabular}{|c|c|c|c|c|c|c|}
\hline \multirow[b]{2}{*}{ Character of the Road. } & \multicolumn{6}{|c|}{ Character of the Vehicle. } \\
\hline & 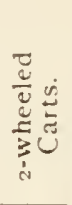 & 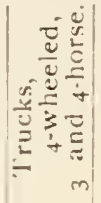 & 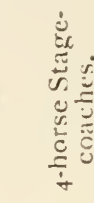 & & 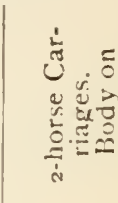 & 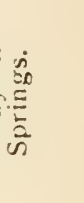 \\
\hline 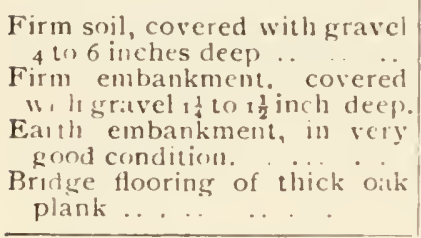 & $\begin{array}{l}1 / 2 \\
\frac{1}{16} \\
4_{1}^{1} \\
i \frac{1}{6}\end{array}$ & $\begin{array}{l}1 \\
6 \\
11 \\
29 \\
29 \\
16\end{array}$ & है & & $\begin{array}{l}16 \\
1^{1} 6 \\
4^{2}\end{array}$ & \\
\hline 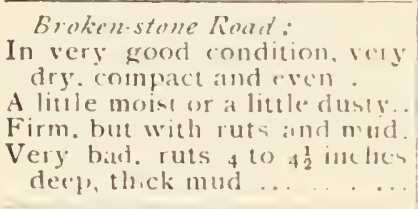 & $\begin{array}{l}1 \\
75 \\
53 \\
513 \\
113 \\
13 \\
19\end{array}$ & $\begin{array}{l}\frac{1}{51} \\
1 \\
38 \\
11 \\
21 \\
1 \\
11\end{array}$ & 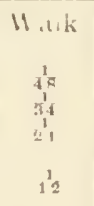 & $\begin{array}{l}\text { Trot. } \\
11 \\
11 \\
1 \\
27 \\
18 \\
18 \\
18 \\
18\end{array}$ & 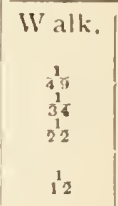 & $\begin{array}{c}\text { Trot } \\
1 \\
\frac{1}{42} \\
\frac{1}{1} \\
1 \\
19 \\
1 \\
11\end{array}$ \\
\hline $\begin{array}{l}\text { Gool parement. dru. } \\
\text { coscred with } \\
\text { mod }\end{array}$ & $0^{1}$ & $\begin{array}{c}6^{1} \\
b^{1}\end{array}$ & $\frac{1}{67}$ & $\begin{array}{l}\frac{1}{38} \\
33\end{array}$ & $\frac{1}{8}$ & $\frac{1}{33}$ \\
\hline
\end{tabular}

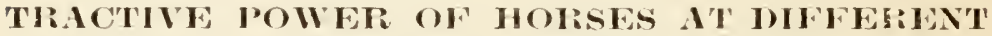 SPLIND. (TRALTWINE.)}

The average traction of a horse on a level and actually pulling for ten hours in the day may be assumed as follows:

\begin{tabular}{|c|c|c|c|}
\hline Miles per hour. & Lbs. Traction. & Miles per hour. & Lbs. Traction. \\
\hline $\begin{array}{l}\frac{1}{4} \\
1 \\
1 \frac{1}{2} \\
1 \frac{1}{2} \\
1 \frac{1}{2} \\
2\end{array}$ & $\begin{array}{l}333 \cdot 33 \\
250 \\
200 \\
166.66 \\
142.86 \\
125\end{array}$ & $\begin{array}{l}2 \frac{1}{5} \\
2 \frac{1}{2} \\
2 \frac{4}{6} \\
3 \\
31 \\
4\end{array}$ & $\begin{array}{l}\text { 111.11 } \\
100 \\
90.95 \\
83 \cdot 33 \\
71.43 \\
62.50\end{array}$ \\
\hline
\end{tabular}

If the horse works for a smaller number of hours, his traction may increase as the hours diminish, down to about 5 hours per day and for speeds of about from I $\frac{1}{4}$ to 3 miles per hour. 


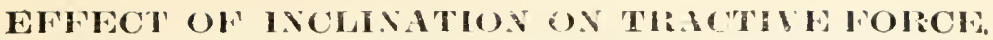

(U. S. DEPARTMENT OF ACRICLLITRE.)

\begin{tabular}{|c|c|c|c|c|c|}
\hline $\begin{array}{c}\text { Rate of } \\
\text { Inclination. }\end{array}$ & \multicolumn{3}{|c|}{$\begin{array}{l}\text { Angle with the } \\
\text { Level. }\end{array}$} & \multirow{2}{*}{$\begin{array}{c}\begin{array}{c}\text { Traciive Force, } \\
\text { Pounds. }\end{array} \\
3_{3}^{8}\end{array}$} & \multirow{2}{*}{$\begin{array}{l}\text { Equivaient } \\
\text { 1.ength of Level } \\
\text { Road in Miles. } \\
1 . \infty\end{array}$} \\
\hline Le el. & $0^{\circ}$ & $\infty o^{\prime}$ & $\infty "$ & & \\
\hline I in 503 & o & 6 & 53 & 42 & I.10 \\
\hline I in Ioo & o & 34 & 23 & 58 & 1.52 \\
\hline I in 80 & o & $4^{2}$ & 58 & 63 & 1.66 \\
\hline$x$ in 60 & o & 57 & 18 & 71 & I 87 \\
\hline I in 50 & I & ०8 & 16 & 78 & 2.05 \\
\hline$I$ in 40 & I & 25 & 57 & 88 & 2.30 \\
\hline I in 30 & I & 54 & 37 & 104 & 2.73 \\
\hline I in 25 & 2 & 17 & 26 & 11 8 & 3.10 \\
\hline$I$ in 20 & 2 & $5 \mathrm{I}$ & $2 \mathrm{I}$ & 138 & 3.63 \\
\hline 1 in 15 & 3 & $4^{8}$ & $5 t$ & 171 & $4 \cdot 50$ \\
\hline I in ro & 5 & 42 & $5^{3}$ & 238 & 6.26 \\
\hline
\end{tabular}

The table gives the tractive force necessary to draw I ton over the best macadam road of various grades, and the equivalent length of each mile of grade in miles of level road.

The effect of the inclination can be calculated from the following formula:

$$
R=F+a W
$$

where $F=$ force required to draw the load on the level, $a=$ the grade, expressed by a fraction, $W=$ the weight of the load in pounds, $\wedge=$ force required to draw the load up the incline in question.

According to Gillespie, if a horse can pull on a level 1000 pounds, on a rise of

I foot in

Ioo feet he draws goo lbs.

50 ". " " 810 "

44 “ “ ” “ 750 “

40 " " " 720 "

30 " " " 640 "
I foot in

25 feet he draws 540 lbs.

24 " " " 500 "

20 " " " " 400 "

IO “ " " 250 " 


\section{EFFEC'TS OF SURFACE ON TRACTIVE FORCE.}

(Various Authorities, compiled by Herking.)

\begin{tabular}{|c|c|c|c|}
\hline Description of Road. & $\begin{array}{c}\text { Tractive } \\
\text { Force, } \\
\text { Lbs. }\end{array}$ & Description of Road. & $\begin{array}{c}\text { Tractive } \\
\text { Force, } \\
\text { Lbs. }\end{array}$ \\
\hline 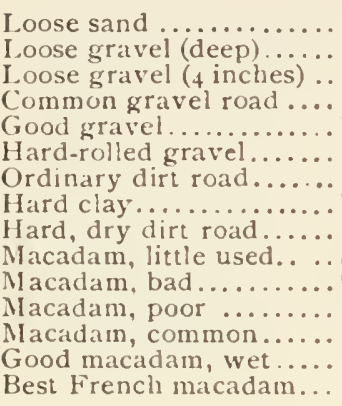 & $\begin{array}{c}448 \\
320 \\
222 \\
147 \\
88 \\
75 \\
224 \\
112 \\
89 \\
140 \text { to } 97 \\
160 \\
112 \\
64 \\
75 \text { to } 42 \\
45\end{array}$ & 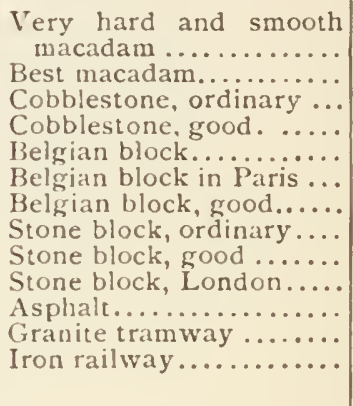 & $\begin{array}{l}52 \text { to } 32 \\
140 \\
75 \\
56 \text { to } 26 \\
54 \text { to } 34 \\
34 \frac{1}{2} \\
90 \\
45 \\
36 \\
17 \\
12 \frac{1}{2} \text { to } 13 \\
8 \text { to } 11 \frac{1}{8}\end{array}$ \\
\hline
\end{tabular}

The velocity is in all cases taken at 3 miles per hour.

\section{COS'T OF HAULING FARM PRODUCE IN THE UNITED STATES.}

\begin{tabular}{|c|c|c|c|c|}
\hline & 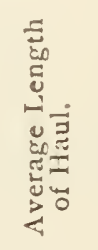 & 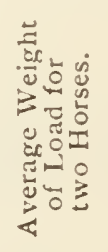 & 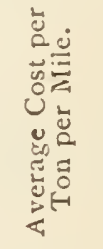 & 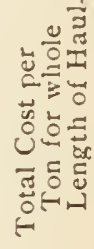 \\
\hline 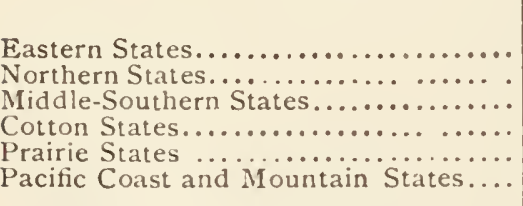 & $\begin{array}{c}\text { Miles. } \\
5.9 \\
6.9 \\
8.8 * \\
12.6 \\
8.8 \\
23.3\end{array}$ & 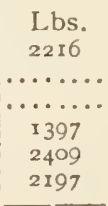 & $\begin{array}{c}\text { Cents. } \\
32 \\
27 \\
3 \text { r } \\
25 \\
22 \\
22\end{array}$ & $\begin{array}{r}\$ 1.89 \\
1.86 \\
2.72 \\
3.05 \\
1.94 \\
5.12\end{array}$ \\
\hline Averages for the United States.... & I2.I & 2002 & 25 & $\$ 3.02$ \\
\hline
\end{tabular}

* Middle States.

The total weight of farm products in 1895 was estimated at $219,824,227$ tons; if the forest products hauled over the public roads be added to this, we get $313,349,227$ tons, which at $\$ 3.02$ per ton, makes a total for the annual cost of 
hauling on the public roads of $\$ 946,4 \mathrm{I} 4,665$. Nearly, if not quite, two-thirds of this vast expense may be saved by road improvement, and this at a total cost not exceeding the losses of 3, or at most 4 , years by bad roads (Circ. I9, Office of Road lnquiry, U. S. Dept. Agr.).

TIANSHOI'TATION ON THE FARM. (U. S. Dept. Agr.)

An ordinary wagon drawn by two horses will carry at each load I ton to $1 \frac{1}{2}$ tons of hay, grain, manure, etc, over a good road; with four horses, $3-4$ tons. According to distance, the number of luads in a day should be as follows:

Number of Loads Hauled per Day.

Distance. No. if I.ouds wirh Dortance. No. of Loads with Eighth mile.. ... 16-18 It-16 Half mile........... I0-14 8-12 Quarter mile .... 12-16 ro-14 Mile to mile and a half. 6-9 5-7

\section{LABOR ONE HORSE IS ABLE TO PERFORM} at different rates of speed on canals, railroads, and turnpikes. (Drawing force, $83 \frac{1}{3}$ lbs.) (WARING.)

\begin{tabular}{|c|c|c|c|c|}
\hline \multirow{2}{*}{$\begin{array}{l}\text { Specd per } \\
\text { Hour, miles. }\end{array}$} & \multirow{2}{*}{$\begin{array}{c}\text { Duration of } \\
\text { Day's Work, } \\
\text { hours. }\end{array}$} & \multicolumn{3}{|c|}{ Useful Effect for r Day, drawn r mile. } \\
\hline & & $\begin{array}{c}\text { On a Canal, } \\
\text { tons. }\end{array}$ & $\begin{array}{c}\text { On a Railroad, } \\
\text { tons. }\end{array}$ & $\begin{array}{c}\text { On a Turnpike, } \\
\text { tons. }\end{array}$ \\
\hline $21 / 2$ & II16 & 520 & JI 5 & 14 \\
\hline 3 & & 243 & 92 & 12 \\
\hline $31 / 2$ & & I 54 & 82 & 10 \\
\hline 4 & $41 / 2$ & 102 & $7^{2}$ & 9 \\
\hline 5 & $29 / 10$ & 52 & 57 & $7 \cdot 3$ \\
\hline 6 & & 30 & $4^{8}$ & 6 \\
\hline $\begin{array}{l}7 \\
8\end{array}$ & $\begin{array}{l}11 / 3 \\
116\end{array}$ & 19 & $\begin{array}{l}4 \mathrm{I} \\
36\end{array}$ & 5 \\
\hline 9 & $9 / 10$ & 9 & $\begin{array}{l}30 \\
3^{2}\end{array}$ & $\begin{array}{l}4 \cdot 5 \\
4\end{array}$ \\
\hline I0 & $3 / 4$ & 6.5 & 28.8 & 3.6 \\
\hline
\end{tabular}

PERTORMANCE OF ONE TEAM ANI PLOUGH IN A DAY, IN ACRES AND INNTHS. (WARING.)

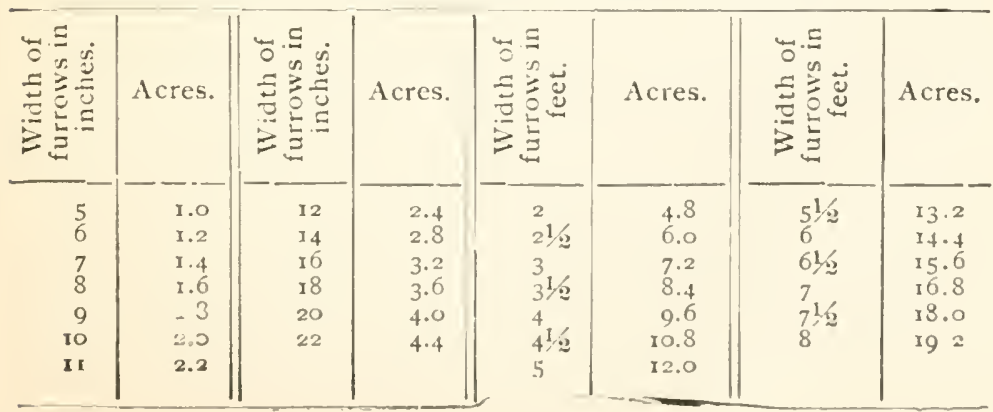




\section{THE EFFECT OF WIIE WAGON-TIRES.}

The effect of wide and narrow tires for wagons is well illustrated by the following results of carefully conducted experiments by the Studebaker Wagon Co., South Bend, Ind. In the trials given in the second column $\mathrm{I} \frac{1}{2}$-inch tires had been substituted for 4 -inch tires. (Agr. of Pa., I894; see also Mich. Exp. Sta., Bull. I65; Mo. Exp. Sta., Bull. I3, and Utah Exp. Sta., Bull.4.)

Weight of wagon and load

Draft to start load on block pavement.......... .

Dratt to moveload at a dead pull on block pave-

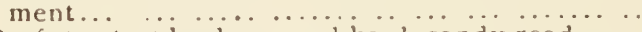

Draft to start load on good hard, sandy road........

Draft to move load at a dead pull on good hard.

sandy road $\ldots \ldots \ldots \ldots \ldots \ldots$

Draft to start load on good level gravel road.......

Draft to move load at a dead pull on good level

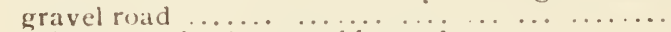

Draft to start load on muddy road.... ........

Draft to move load at a dead pull on muddy road..

Width of Tires.

\begin{tabular}{c|c}
\hline 4 inches. & $\frac{1}{2}$ inches. \\
\cline { 2 - 3 } Ibs. & Ibs. \\
4345 & 42.35 \\
350 & 300 \\
100 & 75 \\
700 & 725 \\
275 & 300 \\
600 & 650 \\
& 175 \\
75 & 900 \\
550 & 500 \\
\end{tabular}

AVERAGE QUANTTY OF STONE REQUTRED IPLA YEMR TO KEEP 10 FENT OH TOOA, WIDTH = go FeET, iN REPAir. (Herschel..)

Cub. ft. Cub. yds.

1. Good material and heavy travel...... I5-20 $=.55^{-} .74$

2. Good material and medium amount of

travel................... 10-15 $=.37-.55$

3. Good material and light travel...... 5- $10=.18-.37$

4. Medium material and heavy travel... 20-25 $=.74^{-} .92$

5. Medium material and medium amount

of travel................ r $5-20=.55-.74$

6. Medium material and light travel.... IO-I5 $=.37-.55$

7. Third-rate material and heavy travel.. 25-30 $=.92-$ I. Io

8. Third-rate material and medium amount

of travel................ 20-25 $=.74^{-} .92$

9. Third-rate material and light travel... I 5-20 $=.55^{-} .74$ 


\section{INTERIOR DIMENSIONS OF FARM BUILDINGS.}

\section{(MCCONNELL.)}

\begin{tabular}{|c|c|c|c|}
\hline & Length. & Breadth. & Height. \\
\hline & ft. & ft. & $\mathrm{ft}$. \\
\hline 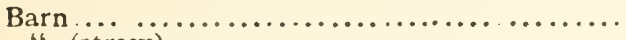 & 40 & 20 & 20 \\
\hline 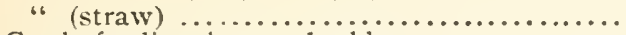 & 60 & 20 & 20 \\
\hline & 10 & 20 & 8 \\
\hline & 10 & 10 & 8 \\
\hline 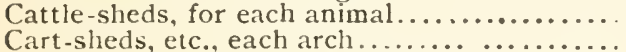 & 5 & 15 & 8 \\
\hline & 8 & 20 & 10 \\
\hline & 4 & 30 & Io \\
\hline Dairy $\ldots \ldots \ldots \ldots \ldots \ldots \ldots$ & $\begin{array}{r}4 \\
20\end{array}$ & $\begin{array}{l}20 \\
20\end{array}$ & 10 \\
\hline 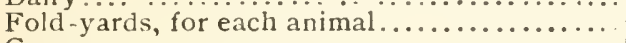 & 5 & 30 & $\begin{array}{r}10 \\
6\end{array}$ \\
\hline 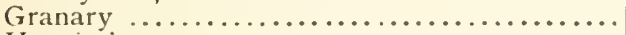 & 30 & 20 & 8 \\
\hline Hospital $\ldots \ldots \ldots \ldots \ldots \ldots \ldots \ldots \ldots \ldots \ldots \ldots$ & 58 & 18 & 9 \\
\hline Manure-house $\ldots \ldots \ldots \ldots \ldots \ldots \ldots \ldots \ldots \ldots \ldots$ & 18 & 18 & 8 \\
\hline 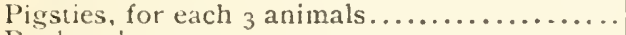 & 6 & 10 & 8 \\
\hline 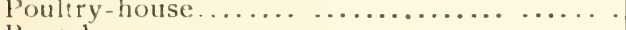 & 18 & 18 & 9 \\
\hline 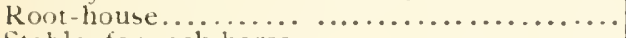 & 20 & 20 & 10 \\
\hline 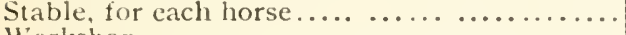 & 6.5 & 18 & 10 \\
\hline Workshop $\ldots{ }^{\prime} \ldots \ldots \ldots \ldots \ldots \ldots \ldots \ldots \ldots \ldots$ & 18 & 18 & 9 \\
\hline General dimensions of other apartments..... & $\cdots$ & 18 & 9 \\
\hline
\end{tabular}

$6 \frac{1}{2} \mathrm{ft}$. allowed to the length of the stable for each horse in it and 7 or $8 \mathrm{ft}$. for every pair of cows in cow-stable. Horses must each have I $200 \mathrm{cu}$. ft. of space, and cattle $800 \mathrm{cu} . \mathrm{ft}$, where stalled in stables. Cattle-boxes to be sunk $2 \mathrm{ft}$. below surface and raised by a dwarf wall $\mathrm{I} f \mathrm{ft}$. above. Cattle-folds and sheds should have a length of $5 \mathrm{ft}$. for every animal they are intended to contain; when covered, $\mathrm{I} 50 \mathrm{sq}$. $\mathrm{ft}$. allowed to every head. The pigsties have small open areas attached to each.

\section{RECIPE FOR WHITEWASH.}

Slake half a bushel of unslaked lime with boiling water, cover during the process to keep in steam, strain the liquid through a fine sieve or strainer, and add to it a peck of salt, previously dissolved in warm water, three pounds of ground rice boiled to a thin paste and stirred in while hot, half a pound of Spanish whiting, and one pound of clear glue, previously dissolved by soaking in cold water and then hanging over a slow fire in a small pot hung in a larger 
one filled with water. Add five gallons of hot water to the mixture, stir well, and let it stand a few days, covered from dirt. It should be applied hot, for which purpose it can be kept in a kettle or portable furnace. The east end of the White House in Washington is embellished by this whitewash. It is recommended by the government for whitewashing light-houses.

A pint of this wash mixture, if properly applied, will cover one square yard, and will be almost as serviceable as paint for wood, brick, or stone, and is much cheaper than the cheapest paint.

Coloring matter may be added as desired. For cream color add yellow ochre; pearl or lead, add lampblack or ivory-black: fawn, add proportionately four pounds of umber to one pound of Indian red and one pound of common lampblack; common stone color, add proportionately four pounds raw umber to two pounds lampblack.

\section{TABIL OF CUT NaIS. (Trautwine.)}

\begin{tabular}{|c|c|c|c|c|c|c|}
\hline & Name. & $\begin{array}{l}\text { I.ength, } \\
\text { Inches. }\end{array}$ & $\begin{array}{c}\text { No. per } \\
\text { Lb. }\end{array}$ & Name. & $\begin{array}{l}\text { Length, } \\
\text { Inches. }\end{array}$ & $\begin{array}{c}\text { No. per } \\
\text { I.b. }\end{array}$ \\
\hline "Common" nails & 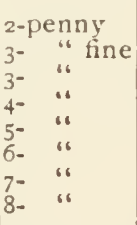 & $\begin{array}{l}1 \\
1 \frac{1}{8} \\
1 \frac{1}{4} \\
1 \frac{1}{2} \\
1 \frac{8}{4} \\
2 \\
2 \frac{1}{4} \\
2 \frac{1}{2}\end{array}$ & $\begin{array}{r}716 \\
626 \\
440 \\
300 \\
210 \\
163 \\
123 \\
93\end{array}$ & $\begin{array}{l}\text { ro-penny } \\
\text { r2- } \\
20- \\
30- \\
40- \\
50- \\
50-16 \\
60-\end{array}$ & $\begin{array}{l}3 \\
3 \frac{1}{5} \\
4 \\
4 \frac{1}{6} \\
5 \\
5 \frac{1}{6} \\
6\end{array}$ & $\begin{array}{l}66 \\
50 \\
32 \\
19 \\
16 \\
13 \\
10\end{array}$ \\
\hline Finishing-nails... & $\begin{array}{l}4-\text { penny } \\
5- \\
6- \\
6 \\
8-\end{array}$ & $\begin{array}{l}I \frac{1}{2} \\
1 \frac{8}{5} \\
2 \\
2 \frac{1}{2}\end{array}$ & $\begin{array}{l}470 \\
330 \\
196 \\
116\end{array}$ & $\begin{array}{l}\text { ro-penny } \\
12- \\
20-\end{array}$ & $\begin{array}{l}3 \\
3 \frac{1}{6} \\
4\end{array}$ & $\begin{array}{l}84 \\
65 \\
50\end{array}$ \\
\hline Slating-nails..... & $4_{4-}^{3-p e n u y ~}$ & $\begin{array}{l}1 \frac{1}{2} \\
1 \frac{1}{2}\end{array}$ & $\begin{array}{l}280 \\
200\end{array}$ & ${ }_{6}^{5-p e n n y}$ & $\begin{array}{l}1 \frac{8}{3} \\
2\end{array}$ & $\begin{array}{l}160 \\
128\end{array}$ \\
\hline Fence-nails...... & $\begin{array}{c}\ldots \ldots \\
\cdots \cdots \\
\cdots \cdots \\
\cdots\end{array}$ & $\begin{array}{l}2 \\
2 \frac{1}{2} \\
2 \frac{1}{2}\end{array}$ & $\begin{array}{l}80 \\
66 \\
60\end{array}$ & $\begin{array}{c}\ldots \ldots \ldots \ldots \\
\cdots \ldots \ldots \ldots \ldots\end{array}$ & $\begin{array}{l}2 \frac{8}{4} \\
3\end{array}$ & $\begin{array}{l}48 \\
40\end{array}$ \\
\hline Cut spikes....... & 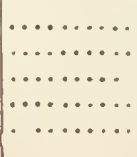 & $\begin{array}{l}3 \\
3 \frac{1}{2} \\
4 \\
4 \frac{1}{2} \\
5\end{array}$ & $\begin{array}{l}29 \\
21 \\
15 \\
13 \\
10\end{array}$ & 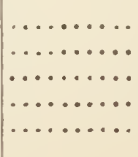 & $\begin{array}{l}5 \frac{1}{2} \\
6 \\
6 \frac{1}{3} \\
7 \\
8\end{array}$ & $\begin{array}{l}8 \\
7 \\
6 \\
5 \\
3 \frac{1}{2}\end{array}$ \\
\hline
\end{tabular}




\section{HUMAN FOODS.}

\section{COMPOSITION OF HUMAN FOOD MATERIALS.* (Atwater.)}

Ordinary food materials, such as meat, fish, eggs, pota. toes, wheat, etc., consist of-

Kefuse.-As the bones of meat and fish, shells of shellfish, skin of potatoes, bran of wheat, etc.

Edible Portion. - As the flesh of meat and fish, the white and yolk of eggs, wheat flour, etc. The edible portion consists of water and nutritive ingradients or mutrients.

The principal kinds of nutritive ingredients are protein, fats, carbohydrates, and minerrl matters.

The water, refuse, and salt of salted meat and fish are called non-nutrients. In comparing the values of different food materials for nourishment they are left out of account.

Classes of Nutrients. - The following are familiar examples of compounds of the four principal classes of nutrients.

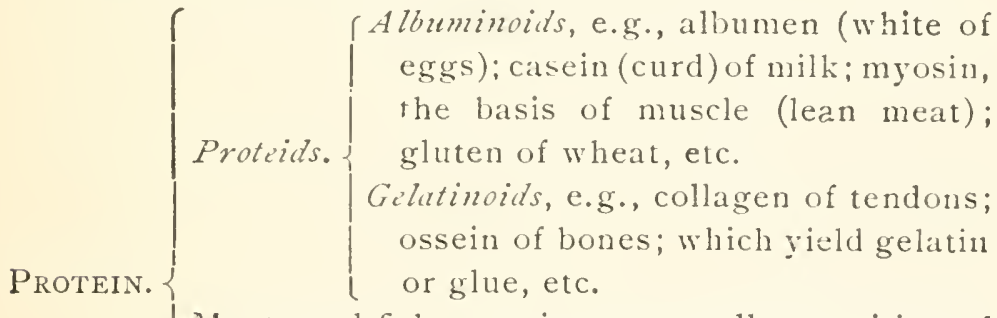

Meats and fish contain very small quantities of so-called "extractives." They include kreatin and allied compounds, and are the chief ingredients of beef-tea and neat-extract. They contain nitrogen, and hence are commonly classed with protein.

Fats, e.g., fat of meat; fat (butter) of milk; olive-oil ; oil of corn. wheat, etc.

Carbohydrates, e.g., sugar, starch, cellulose (woody fiber), etc. Mincral matters, e.g., phosphate of lime, sodium chlorid (common salt), etc.

- Extracts from "Foods, Nutritive Value and Cost" (Farmers" liulletin No. 23), and "Food and I)iet" (U. S. llept. of Agriculture lear liook, 1804). See also Farmers' Bull. No. ${ }^{+2}$, and. Circ. No. $4^{\prime}$, Rer., Office of lixp. Stations. 
The Fuel Value of Food.-Heat and muscular power are forms of force or energy. The energy is developed as the food is consumed in the body. It is measured in the laboratory by means of an apparatus called the calorimeter. The unit commonly used is the calorie, the amount of heat which would raise the temperature of a pound of water $4^{\circ} \mathrm{F}$. Instead of this unit, some unit of mechanical energy may be used, e.g., the fout-ton, which represents the force required to raise I ton I foot. One calorie is equal to very nearly I.53 foot-tons.

The following general estimate has been made for the average amount of potential energy in I pound of each of the classes of nutrients:

Calories.

In $\mathbf{I}$ pound of protein............. I, $8_{14}$

In I pound of fits .............. 4,037

In I pound of carbohydrates........... I, $8_{14}$

In other words, when we compare the nutrients in respect to their fuel values, their capacities for yielding heat and mechanical power, a pound of protein of lean meat or albumen of egg is just about equivalent to a pound of sugar or starch, and a little over two pounds of either would be required to equal a pound of the fat of meat or butter or the body fat.

Wuys in zulhich Food is Used in the Body.-Food supplies the wants of the body in several ways. It either-

Is used to form the tissues and fluids of the body:

Is used to repair the wastes of tissues;

Is stored in the body for future consumption;

Is consumed as fuel, its potential energy being trans. formed into heat or muscular energy, or other forms of energy required by the body; or,

In being consumed protects tissues or other food from consumption.

Uses of the Different Classes of Nutrients. - Protein forms tissue (muscle, tendon, etc., and fat) and serves as fuel.

Fats form fatty tissue (not muscle, etc.) and serve as fuel. Carbohydrates are transformed into fat and serve as fuel. 
All nutrients yield energy in form of heat and musculap strength.

In being themselves burned to yield energy the nutrients protect each other from being consumed. The protein and fats of body tissue are used like those of food. An important use of the carbohydrates and fats is to protect protein (muscle, etc.) from consumption.

Definition of Food and Food Economy.-The views thus presented lead to the following definitions: (I) Food is that which, taken into the body, builds tissues or yields energy; (2) the most healthful food is that which is best fitted to the wants of the user; $(3)$ the cheapest food is that which furnishes the largest amount of nutriment at the least cost; (4) the best food is that which is both rnost healthful and cheapest.

We have, then, to consider the kinds and amounts of nutrients in different food materials, their digestibility, and the kinds and amounts needed for nourishment by people doing different kinds of work.

In general, the animal foods have the most of protein and fats, while the vegetable foods are rich in the carbohydrates, starch, and sugar. The lean meats and fish abound in protein. Cheese has so large a quantity of protein because it contains the casein of the milk. Among the vegetable foods, beans and peas have a high proportion of protein. The proportion in oatmeal is also large. In wheat it is moderate, and in corn meal it is rather small. The materials with the highest fuel value are those with the most fat, because the fuel value of the fat is, weight for weight, two and one-fourth times as great as that of either sugar, starch, or protein. Hence fat pork and butter lead the other materials in fuel value. The fat meats in general stand high in this respect. So also do the grains, flour, and meal, as they have large quantities of carbohydrates. Potatoes are quite low in the list in respect to fuel value as well as protein, principally because they are three-fourths water. For the same reason, milk, which is seven-cighths water, ranks low in respect to both protein and fuel value. 
Dietaries and Dietary Standards.--As the ontcome of a great deal of observation and experiment, nearly all in Europe, standards have been proposed for the amounts of nutrients and energy in the daty food required by different classes of people. Those of Prof. Voit, of Munich, Germany, are most commonly accepted by specialists in Europe. Voit's standard for a laboring man at moderately hard muscular work calls for about 0.25 pound of protein and quantities of carbohydrates and fats sufficient, with the protein, to yield 3050 calories of energy. Taking into account the more artive life in the United States, and the fact that well nourished people of the working classes here eat more and do more work than in Europe, and in the belief that ample nourishment is necessary for doing the most and the best work. I have ventured to suggest a standard with $0,2 S$ pound of protein and 3500 calories of energy for the man at moderate muscular work. (For list of dietary standarls, see p. 203; also Farmers' Bull., No. 142, p. 35.)

Calculation of Daily Dieturies.-Due regard for health, strength, and purse requires that food shall supply enough protein to build tissue and enough fats and carbohydrates for fuel, and that it shall not be needlessly expensive.

On the basis of the standards for dietaries given on page 175 , various combinations of food materials for daily dietaries may be made by calculations from the table, showing percentages of nutrients, etc., in food materials (p. 169). Thus if a dietary for a man at moderately hard muscular work is to be made up of round beefsteak, butter, potatoes, and bread, it may be calculated as follows:

\begin{tabular}{|c|c|c|c|}
\hline & & Protein. & Calories. \\
\hline $\begin{array}{l}\text { Round steak......... } \\
\text { Butter ............. } \\
\text { Potatoes } \ldots \ldots \ldots \ldots \\
\text { Wheat bread ........ }\end{array}$ & $\begin{array}{l}\text { I pound contains......... } \\
\text { I pound contains......... } \\
\text { I pound contains } \ldots \ldots \ldots \\
\text { I pound contains........ }\end{array}$ & $\begin{array}{c}\text { Pounds. } \\
.18 \\
.01 \\
.019 \\
.088\end{array}$ & $\begin{array}{r}855 \\
3,615 \\
325 \\
1,280\end{array}$ \\
\hline $\begin{array}{l}\text { Round steak......... } \\
\text { Butter ................ } \\
\text { Potatoes ........... } \\
\text { Wheat bread...... }\end{array}$ & $\begin{array}{r}\text { I3 ounces contain........... } \\
3 \text { ounces contain.......... } \\
6 \text { ounces contain.......... } \\
22 \text { ounces contain......... }\end{array}$ & $\begin{array}{l}.14 \\
\cdots \\
.02 \\
.12\end{array}$ & $\begin{array}{r}695 \\
680 \\
320 \\
1,760\end{array}$ \\
\hline Wheat bread........ & $\begin{array}{l}\text { Total ................ } \\
\text { Standard tor man at mod- } \\
\text { erate muscular work..... }\end{array}$ & $\begin{array}{l}.28 \\
.28\end{array}$ & $\begin{array}{l}3.455 \\
3.500\end{array}$ \\
\hline
\end{tabular}


PERCENTAGES OF NUTRIENTS, WATER, AND REFUSE IN SPECIMLNS OF FOOD MATERIALS.

(ATWATER.)

\section{Food Materials.}

Animal Foods, as Purchased.

Beef: Neck....

Shoulder

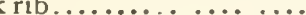

Sirloin. .

Round steak...................

Side without kidney fat......

Rump, corned.............

Flank, corned...............

Veal: Shoulder..................

Mutton: Shoulder..................

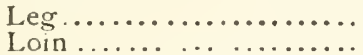

Side, without kidney fat..

Pork: Shoulder roast, fresh ........

Ham, salted, sinoked ........

Chicken............................

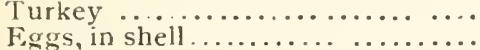

Fish, etc.: Flounder, whole.........

Bluefish, dressed........

Codfish, dressed ........

Shad, whole............

Mackerel, whole........

Halibut, dressed.........

Salmon, whole..........

Salt codfish...........

Smoked herring .........

Salt mackerel............

Canned salmon..........

Lobsters.................

Oysters..................

Animal Foods, Edible Portion.

Beef: Neck.....................

Shoulder...................

Chuck rib...................

Rib .......................

Sirloin ......................

Round ...........................

Sice, without kidney fat.....

Rump, corned................

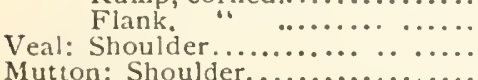

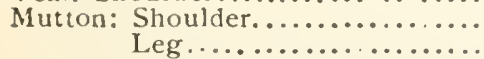

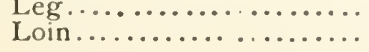

\begin{tabular}{|c|c|c|c|c|c|c|}
\hline \multirow{3}{*}{ 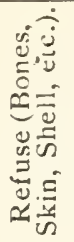 } & \multicolumn{6}{|c|}{ Edible Portion. } \\
\hline & \multirow[b]{2}{*}{ 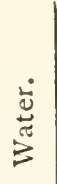 } & \multicolumn{5}{|c|}{ Nutrients. } \\
\hline & & $\begin{array}{l}\stackrel{\overrightarrow{5}}{0} \\
\stackrel{0}{\leftrightarrow}\end{array}$ & 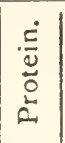 & 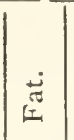 & 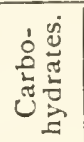 & 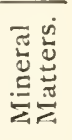 \\
\hline & 品 & $\%$ & $\%$ & $\%$ & $\%$ & \\
\hline 20.0 & 49.6 & 30.4 & 156 & 14.0 & $\ldots \ldots$ & 0.8 \\
\hline & 55.8 & 31.6 & 17.0 & & $\ldots \ldots$ & \\
\hline & 49.5 & 35.9 & 15.0 & & $\ldots \ldots$ & 0.8 \\
\hline & $3^{8} .2^{1}$ & 40.8 & 12.2 & & ..... & 0.7 \\
\hline & $\begin{array}{lll}4^{8} & 3\end{array}$ & 32.2 & 15.0 & & $\ldots$ & 0.8 \\
\hline & 60.9 & $3 \mathrm{I} \cdot 3$ & 8.0 & & $\ldots \ldots$ & \\
\hline & $4 \cdot 3$ & 36.5 & .9 & & . & 0.8 \\
\hline & 70.8 & 24.2 & .7 & & $\ldots$ & .4 \\
\hline & 43.7 & 44.2 & .4 & & $\ldots \ldots$ & .6 \\
\hline & & & .6 & & $\ldots \ldots$ & 0.9 \\
\hline & 9.0 & & 5.1 & & $\ldots$ & 0.8 \\
\hline & 50.6 & $3^{I}$ & & & $\ldots$. & .7 \\
\hline & .5 & & & & .. $\quad$. & \\
\hline & 1.2 & $3^{8} .5$ & .0 & & $\cdots$ & .8 \\
\hline & 3.0 & & .6 & & & 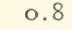 \\
\hline & 6.8 & .8 & 14.8 & 34 & & .4 \\
\hline & 44.6 & $\begin{array}{ll}17 & 2\end{array}$ & 15.1 & & & .9 \\
\hline & 447 & .9 & . I & & $\cdots$ & . \\
\hline & $6_{3} \cdot x$ & 23.2 & 12.1 & 10 & & .4 \\
\hline 6 & 27.2 & 6.0 & 5.2 & & & . \\
\hline 6 & 43.0 & II.I & 0.8 & & $\cdots$ & • \\
\hline & 8.5 & II. 6 & 10.6 & & & . \\
\hline & 35.2 & 14.7 & 9.2 & & & $\cdot 7$ \\
\hline & 40.4 & 15.0 & 10.0 & & . & .7 \\
\hline & 1.9 & 20.4 & 15.1 & & &. \\
\hline & 0.6 & 24 & $14 \cdot 3$ & & &.$c$ \\
\hline & & .6 & 16.0 & & $\cdots$ & - \\
\hline & .2 & 9 & 20.2 & & & . \\
\hline & 28.1 & $3^{1.5}$ & 14.7 & $1 I_{5} \cdot 1$ & & .2 \\
\hline & & 35.8 & 19.3 & & & \\
\hline & 31.0 & 69 & 5.5 & & & . \\
\hline & $15 \cdot 4$ & $2 \cdot 3$ & I.I & 0.2 & 0.6 & o. \\
\hline & 02.0 & 38.0 & 19.5 & & & I.C \\
\hline & 63.9 & 36.1 & & & & . \\
\hline & $5^{8.0}$ & 42.0 & 17.6 & 23 & & \\
\hline & 48.1 & 51.9 & 15.4 & & & . \\
\hline & 60.0 & 40.0 & 18.5 & & & . \\
\hline & 682 & 31.8 & 20.5 & & & I. \\
\hline & 54.8 & 45.2 & $17 \cdot 2$ & & & o. \\
\hline & $5^{8.1}$ & +1.9 & $13 \cdot 3$ & 26.6 & & 2.4 \\
\hline & & 50.2 & 14.2 & 33.0 & & 3. \\
\hline & & $3^{5.2}$ & 20.2 & & & I. \\
\hline & $5^{8} .6$ & & 18.1 & 22.4 & & $0 . c$ \\
\hline & & & 18.3 & & & 0. \\
\hline & $40=$ & & & & & . \\
\hline
\end{tabular}




\section{COMPOSITION OF FOOD MATERIALS.}

Nutritive ingredients, refuse, and fuel value.

Nutrients.

Protein Fats. Curbo. Mineral
hydrates. matters

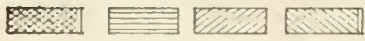
hydrates. matters

Protcin compounds, e. g., lean of meat, white of egg, easein (eurd) of milk, and gluten of wheat, make muscle, blood, bone, ete.

Fats, e. g., fat of ineat, butter, and oil, , serve as fuel to yield heat Carbohydrates, e. g., starch and sugar, $\}$ and museular power.

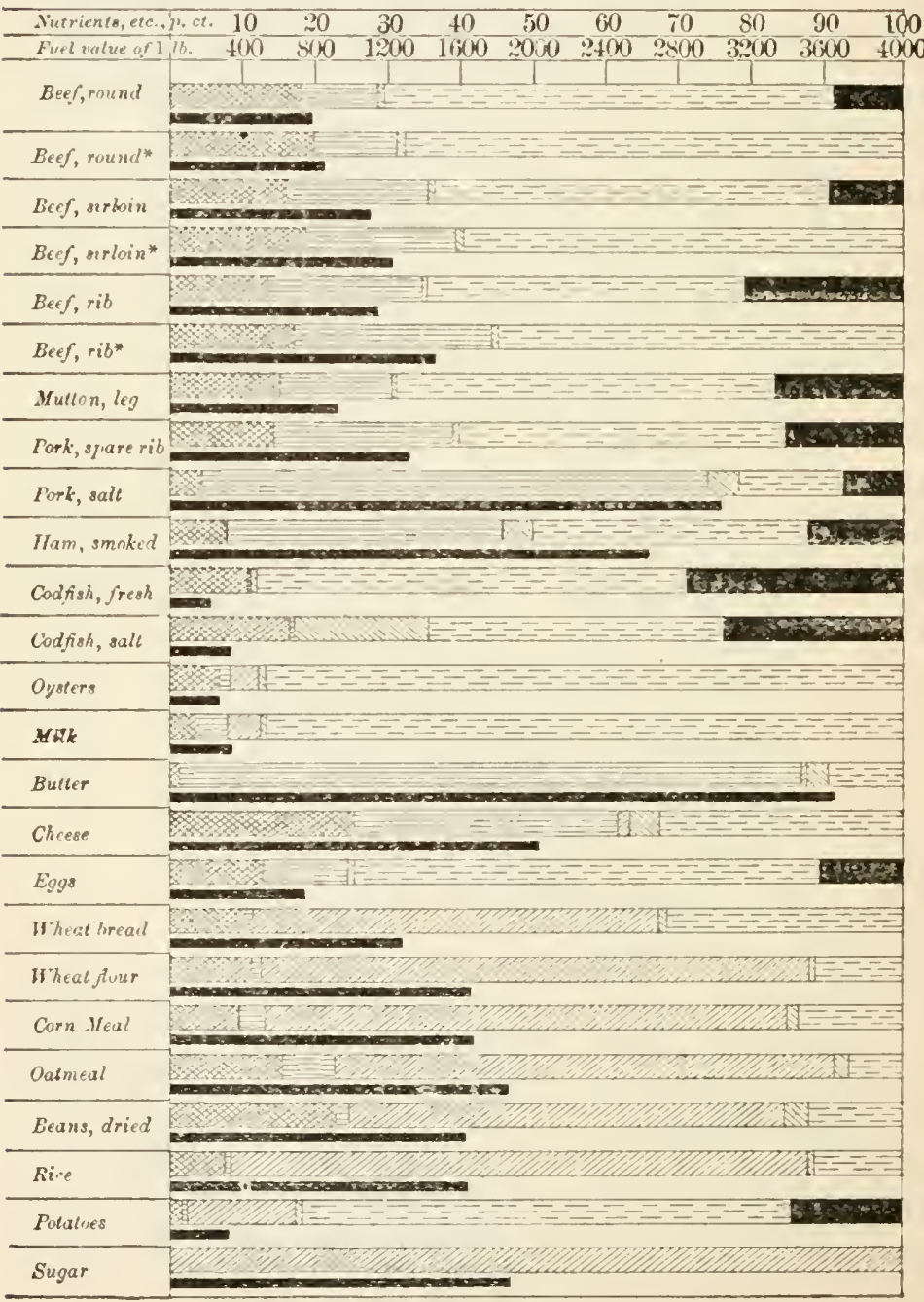

* Wilhout bone.

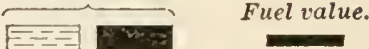

Haler. Refuse. Calories. 


\section{PERCENTAGES OF NUTRIENTS, ETC, IN FOOD MATERIALS.-Continued.}

\begin{tabular}{|c|c|c|c|c|c|c|}
\hline \multirow{3}{*}{ Food Materials. } & \multicolumn{6}{|c|}{ Edible Portion. } \\
\hline & \multirow[b]{2}{*}{ 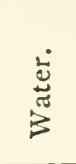 } & \multicolumn{5}{|c|}{ Nutrients. } \\
\hline & & స్తే & 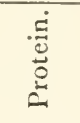 & 宅 & $\stackrel{0}{\tilde{U}}$ & 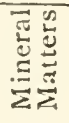 \\
\hline Animai Foods, Edible Portion. & $\%$ & $\%$ & $\%$ & $\%$ & $\%$ & $\%$ \\
\hline Mutton: Side, without kidney fat.. & $53 \cdot 5$ & $4^{6.5}$ & 16.9 & 28.7 & ... & 0.9 \\
\hline Pork: Should & 50.3 & $49 \cdot 7$ & 16.0 & 32.8 & ... & 0.9 \\
\hline alted, smoked........ & $41 \cdot 5$ & 58.5 & I6.7 & 39.1 & $\ldots \ldots$ & 2.7 \\
\hline Fat, salted $\ldots \ldots \ldots \ldots \ldots$ & $12 . \mathrm{I}$ & 879 & 0.9 & 82.8 & $\ldots \ldots$ & $4 \cdot 2$ \\
\hline 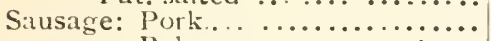 & 41.2 & 58.8 & 13.8 & 42.8 & & 2.2 \\
\hline 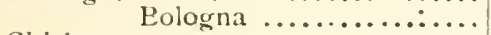 & 62.4 & 37.6 & I8.8 & 15.8 & & 30 \\
\hline Chicken $\ldots \ldots \ldots \ldots \ldots \ldots \ldots \ldots$ & 72. & 27.8 & $24+$ & 20 & & I 4 \\
\hline Turkey................. & 66.2 & 33.8 & 239 & 8.7 & ... & 1.2 \\
\hline Equs $\ldots \ldots$ & 73.8 & 26.2 & 149 & 10.5 & & - 8 \\
\hline yilk $\ldots \ldots \ldots \ldots \ldots \ldots \ldots \ldots \ldots, \ldots$ & 870 & I 3.0 & 3.6 & 4.0 & $4 \cdot 7$ & 07 \\
\hline 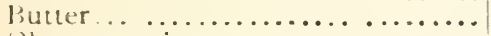 & 10.5 & 89.0 & 1.0 & 85.0 & 0.5 & 3.0 \\
\hline Oleomargarine...... ............. & 110 & 895 & 06 & 85.0 & $\circ 4$ & 3.0 \\
\hline Cheese: Full-cream............... & 30.2 & 09.8 & $28 \cdot 3$ & 35.5 & I 8 & $4 \cdot 2$ \\
\hline Skin-milk... ....... & $4 \mathrm{I} \cdot 3$ & 58.7 & 38.4 & 68 & 8.9 & $4 \cdot 6$ \\
\hline Fish: Floutud..... . $\ldots \ldots \ldots \ldots$ & 84.2 & 55.8 & 13.8 & 07 & $\ldots$. & I 3 \\
\hline 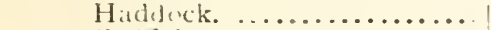 & 817 & 18.3 & 16.8 & 0.3 & $\ldots$ & 12 \\
\hline Codtish ... & 82.6 & 174 & 158 & $0+1$ & & I. 2 \\
\hline 1 $\quad \ldots \ldots \ldots \ldots \ldots \ldots \ldots \ldots$ & 70.6 & 29.4 & 18.6 & $9=$ & & 1. 3 \\
\hline 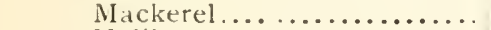 & $73 \cdot 4$ & 26.6 & 18.2 & $7 \cdot 1$ & $\ldots$. & I. 3 \\
\hline Halib & 754 & 24.6 & 183 & 52 & $\cdots$ & $x \quad 1$ \\
\hline$\ldots \ldots \ldots \ldots \ldots \ldots \ldots$ & 636 & $36+$ & 216 & 133 & & 1.4 \\
\hline Sale cod.................... & 536 & $\therefore$ & 21.4 & 03 & $\ldots$. & 16 \\
\hline , salt............... & 34.6 & . $\cdots$ & $36+$ & 15.8 & & I 5 \\
\hline Mackerel, salt.... . ... ... . & 43 . & .. & 173 & $26+$ & ... & 26 \\
\hline $\begin{array}{c}\text { Oysters } \ldots \ldots \\
\text { Vegetable Foods. }\end{array}$ & $87 \cdot 1$ & 12.9 & 6.0 & I.2 & $3 \cdot 7$ & 2.0 \\
\hline 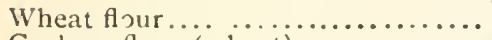 & 125 & $87 \cdot 5$ & 11.0 & I I & $74 \cdot 9$ & 0.5 \\
\hline Gra & $13 \mathrm{I}$ & 86.9 & 11.7 & I. 7 & 71.7 & I 8 \\
\hline flour $\ldots \ldots \ldots \ldots \ldots \ldots \ldots \ldots$ & I3.I & 86.9 & 6.7 & 0.8 & 787 & 0.7 \\
\hline Buckwheat flour.................. & I 46 & 854 & 60 & 1.4 & 76.1 & 1.0 \\
\hline (x) & $7 \cdot 6$ & $92 \cdot 4$ & 151 & $7 \cdot 1$ & 68.2 & 2.0 \\
\hline ............... & $15 \cdot 0$ & 85.0 & 9.2 & 3.8 & 706 & I. 4 \\
\hline Rice ....... & 12.4 & 87.6 & $7 \cdot 4$ & 04 & $79 \cdot 4$ & 0.4 \\
\hline Peas......... & $12 \cdot 3$ & $87 \cdot 7$ & 26.7 & 1. 7 & $56 .+$ & 29 \\
\hline . . . . . . . . . & 126 & $87 \cdot 4$ & $23 \cdot I$ & 2.0 & 592 & $3 \mathrm{t}$ \\
\hline ................ & $7^{8} 9$ & $21 \mathrm{I}$ & 2.1 & 0.1 & 17.9 & 1.0 \\
\hline s................. & 71. & 28.9 & I.5 & 04 & 26.0 & I.O \\
\hline 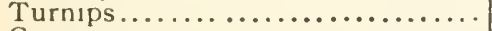 & $89 \cdot 4$ & 10 6 & $\mathrm{x} .2$ & 0.2 & 8.2 & 1.0 \\
\hline ts..... & 886 & I I 4 & I. I & 0.4 & 8.9 & 1.0 \\
\hline ns.. .. $\ldots \ldots \ldots \ldots \ldots \ldots \ldots \ldots$ & 876 & 124 & I. 4 & 0.3 & IO. I & 0.6 \\
\hline g beans.................... & 87.2 & 12.8 & 2.2 & 0.4 & $9 \cdot 4$ & 0.8 \\
\hline n peas.... .. & $7^{8} .1$ & $2 \mathfrak{\imath} .9$ & $4 \cdot 4$ & 0.6 & 16.0 & 0.9 \\
\hline$n \operatorname{cor} n \ldots \ldots \ldots \ldots \ldots \ldots \ldots$ & $8 \mathrm{I} \cdot 3$ & 18.7 & 2.8 & I.I & $\mathrm{I}_{3} \cdot 2$ & 0.6 \\
\hline atoes..................... & 1.6 .0 & 4.0 & 0.8 & 0.4 & 2.5 & 0.3 \\
\hline Cabbage............. & 91.9 & $8 . \mathrm{r}$ & 2. $\mathrm{I}$ & 0.3 & $5 \cdot 5$ & I. I \\
\hline 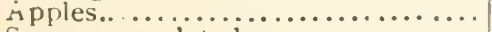 & 83.2 & 16.8 & 0.2 & 0.4 & 15.9 & 0.3 \\
\hline Sugar, granulated................ & 2.0 & 98.0 & ..... & ... & 97.8 & 0.2 \\
\hline 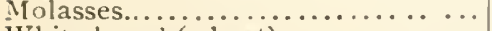 & 24.6 & $75 \cdot 4$ & $\cdots \cdot$ & $\cdots$ & 731 & $2 \cdot 3$ \\
\hline White bread (wheat).............. & $32 \cdot 3$ & 67.7 & 8.8 & I.7 & $5^{6.3}$ & o 9 \\
\hline Boston crackers................. & 8.3 & 91.7 & 10.7 & 9.0 & 637 & 2.4 \\
\hline
\end{tabular}




\section{PECUNIARY ECONOMY OF FOOD.}

Amounts of actually nutritive ingredients obtained in different

fuod malerials for 25 cents.
[Amount of nutrients in pounds. Fuel value in calories.]

Protein. Fals. Carbohydrates. Fuel ralue.

एक ॠ

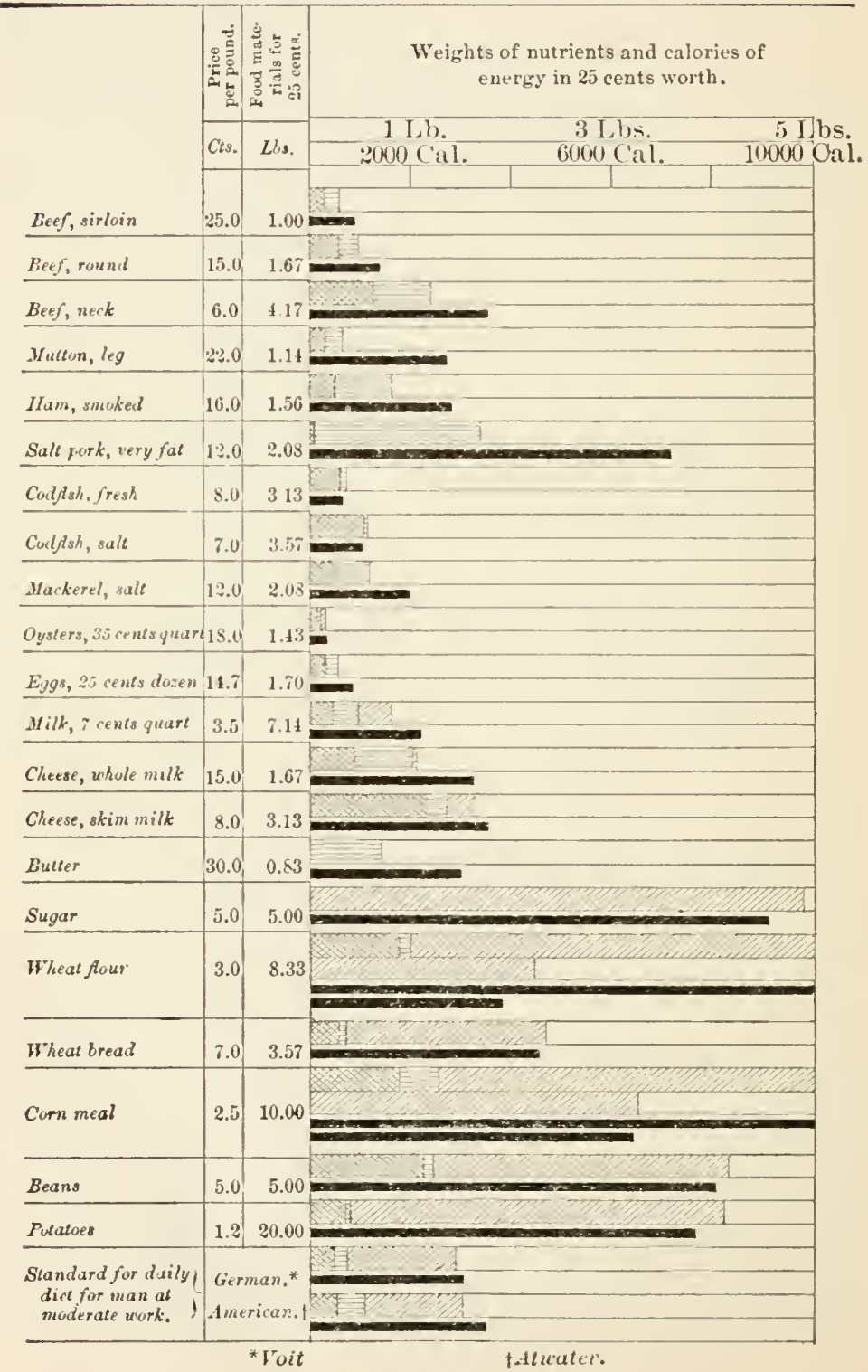


MMOUNTS OF NUTRIENTS FURNISHED FOR TWENTY-FIVE CENTS IN FOOD MATERIALS AT ORDINARY PRICES. (Atwater.)

\begin{tabular}{|c|c|c|c|c|c|c|c|}
\hline \multirow{3}{*}{ Food Materiais as Furnished. } & \multirow{3}{*}{ 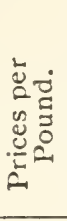 } & \multicolumn{6}{|c|}{ Twenty-five Cents will pay for } \\
\hline & & \multirow{2}{*}{ 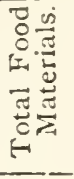 } & \multicolumn{4}{|c|}{ Nutrients. } & \multirow{2}{*}{ 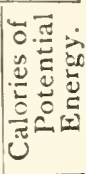 } \\
\hline & & & 芯 & $\frac{a}{0}$ & 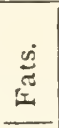 & 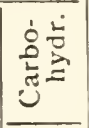 & \\
\hline & cts. & lbs. & lbs. & Ibs. & lbs. & lbs. & cals. \\
\hline \multirow{3}{*}{$\begin{aligned} \text { Beef: } & \text { Neck. } . . . \ldots \ldots \ldots \ldots \ldots \\
& \text { Chuck-ribs. } \ldots \ldots \ldots \ldots \ldots\end{aligned}$} & $\{8$ & 3.13 & .95 & .49 & .44 & $\cdots \cdots$ & 2765 \\
\hline & $\left\{\begin{aligned} 6 \\
16\end{aligned}\right.$ & $\begin{array}{l}4.17 \\
1.56\end{array}$ & $\begin{array}{r}1.27 \\
.56\end{array}$ & $\begin{array}{l}.65 \\
.23\end{array}$ & $\begin{array}{l}\cdot 5^{8} \\
\cdot 3^{1}\end{array}$ & $\begin{array}{ll}\cdots \\
\cdots & \cdots\end{array}$ & $3^{6} 55$ \\
\hline & 12 & 2.08 & .75 & $\cdot 3 \mathrm{I}$ & .42 & $\cdots \cdots$ & $\begin{array}{l}1735 \\
2350\end{array}$ \\
\hline \multirow{2}{*}{ Ribs.................. } & & I. 14 & .47 & .14 & $\cdot 3^{2}$ & $\ldots \ldots$ & 1610 \\
\hline & 18 & $\mathbf{1} \cdot 39$ & $\cdot 57$ & .17 & .39 & & 1960 \\
\hline \multirow{2}{*}{ Shoulder............. } & $\left\{\begin{array}{l}14 \\
10\end{array}\right.$ & $\begin{array}{l}1.79 \\
2.50\end{array}$ & $\cdot 5$ & $\cdot 30$ & .25 & $\ldots \ldots$ & 16 65 \\
\hline & $\left\{\begin{array}{l}10 \\
22\end{array}\right.$ & 2.50 & $\begin{array}{l}.79 \\
.37\end{array}$ & $\begin{array}{l}.43 \\
.17\end{array}$ & $\cdot 34$ & $\ldots \cdots$ & 2235 \\
\hline Sirloin............... & $\{18$ & $\begin{array}{l}1.34 \\
1.39\end{array}$ & .37 & $\begin{array}{l}.17 \\
.21\end{array}$ & $\begin{array}{l}.19 \\
.23\end{array}$ & $\mid \cdots \cdots$ & 1360 \\
\hline \multirow{2}{*}{ 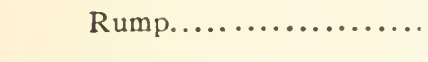 } & 18 & I. 39 & .6 & .19 & .43 & $\ldots \ldots$ & 2170 \\
\hline & I 5 & 1.67 & $\cdot 76$ & .23 & $.5^{2}$ & & 2020 \\
\hline \multirow{2}{*}{ Round, first cut......... } & $\left\{\begin{array}{l}18 \\
15\end{array}\right.$ & $\begin{array}{l}1.39 \\
1.67\end{array}$ & .44 & .25 & .17 & & 1180 \\
\hline & 10 & 2.9 & $\begin{array}{l}.5 \\
.5\end{array}$ & $\begin{array}{r}.30 \\
.35\end{array}$ & $.2 \mathrm{I}$ & .. & 1445 \\
\hline Round, second cut...... & \{ 8 & 3.1 & .65 & $\begin{array}{l}.35 \\
.44\end{array}$ & $\begin{array}{r}15 \\
18\end{array}$ & . & $\begin{array}{r}1285 \\
1580\end{array}$ \\
\hline \multirow{2}{*}{ Flank, corned........... } & $\{$ I 5 & I. 67 & 77 & $\begin{array}{l}.44 \\
.21\end{array}$ & .49 & $\cdots \cdots$ & $\begin{array}{l}1580 \\
2460\end{array}$ \\
\hline & & 2.50 & I. I I & $\cdot 31$ & .73 & $\cdots$ & 3655 \\
\hline Corned and canned.... & $\left\{\begin{array}{l}18 \\
14\end{array}\right.$ & I. 3 & .66 & $\cdot 37$ & .24 & & I 700 \\
\hline Liver ................. & $\begin{array}{r}14 \\
8\end{array}$ & $\begin{array}{l}1.7 \\
3.1\end{array}$ & .8 & .48 & $\cdot 3 \mathrm{I}$ & $\ldots$ & 2200 \\
\hline \multirow{2}{*}{ 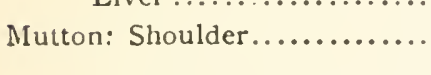 } & $\{20$ & $\begin{array}{l}3.1 \\
1.2\end{array}$ & .96 & $\begin{array}{r}.63 \\
.18\end{array}$ & .17 & . I I & $\begin{array}{l}095 \\
265\end{array}$ \\
\hline & I5 & I. 6 & $\begin{array}{l}.41 \\
.58\end{array}$ & .25 & .31 & $\cdots \cdots$ & $\begin{array}{l}1265 \\
1775\end{array}$ \\
\hline \multirow{2}{*}{ Leg $\ldots \ldots \ldots \ldots$} & & 1.0 & $\cdot 3$ & & . I6 & $\ldots \ldots$ & 955 \\
\hline & 20 & I. & $\cdot 3$ & . I & .20 & & \\
\hline Loin ................ & $\left\{\begin{array}{l}25 \\
120\end{array}\right.$ & & .4 & .13 & .29 & $\ldots \ldots$ & 1465 \\
\hline \multirow{2}{*}{ Pork: Rib roast .............. } & $\{12$ & 2.0 & .5 & .15 & $\cdot 37$ & & 1840 \\
\hline & & 2.50 & I.06 & .28 & $\begin{array}{l}.58 \\
.70\end{array}$ & & $\begin{array}{l}2970 \\
5885\end{array}$ \\
\hline \multirow{2}{*}{ Smoked ham, whole.... } & $\{\mathrm{r}$ & 1.56 & .86 & .2 & $.5^{8}$ & $\ldots \ldots$ & 2915 \\
\hline & 12 & $\begin{array}{l}2.0 \\
1.0\end{array}$ & 1.08 & $\cdot 3 \mathrm{I}$ & .72 & . & 3615 \\
\hline Salt fat pork........... & $\left\{\begin{array}{l}32 \\
12\end{array}\right.$ & 2.08 & $\begin{array}{l}\text { I. } 17 \\
1.03\end{array}$ & $\begin{array}{l}.02 \\
.02\end{array}$ & $\begin{array}{l}\text { I. } 38 \\
\text { I. }\end{array}$ & & 5860 \\
\hline Pork sausage........... & $\{15$ & I. 67 & .98 & .13 & .72 & & 3465 \\
\hline \multirow{2}{*}{ Poultry, etc.: Chicken......... } & $\int 22$ & $\begin{array}{l}2.08 \\
1.14\end{array}$ & I. 22 & .20 & .89 & & 4295 \\
\hline & $\left\{\begin{array}{l}22 \\
16\end{array}\right.$ & $\begin{array}{l}\text { I.1 } \\
\text { 1.5 }\end{array}$ & .32 & .28 & .02 & $\ldots \ldots$ & 605 \\
\hline \multirow{2}{*}{ Turkey $\ldots \ldots \ldots$} & $\{23$ & I. & $\begin{array}{l}.45 \\
.37\end{array}$ & $\begin{array}{l}-38 \\
.26\end{array}$ & $\begin{array}{l}.03 \\
.09\end{array}$ & & $\begin{array}{l}835 \\
865\end{array}$ \\
\hline & & I. $3^{8}$ & .47 & $\cdot 3^{2}$ & .12 &.$\cdots$ & I 100 \\
\hline & (18 & 1. 39 & .22 &. $\mathrm{I}_{4}$ & .06 & & \\
\hline Mackerel, whole & $\{15$ & & .2 & .17 & .07 & & $6 x$ \\
\hline & & 2.50 & & & . 11 & & 03 \\
\hline Bluefish, dressed... & $\{I$ & 1. 67 & . 1 & .16 & .01 & & 340 \\
\hline & 1 10 & 2.50 & $\begin{array}{r}.28 \\
-28\end{array}$ & .25 & .02 & $\cdots \cdots$ & 550 \\
\hline Cod, dressed.... & 8 & & .28 & & $\begin{array}{l}.01 \\
.01\end{array}$ & $\cdots \cdots$ & 8.5 \\
\hline & 0 & 4.17 & 48 & & .or & & \\
\hline
\end{tabular}


AMOUNTS OF NUTRIENTS FURNISHED FOR TWENTY-FIVE CENTS IN FOOD MATERIALS AT ORDINARY PRICES.-Continued.

\begin{tabular}{|c|c|c|c|c|c|c|c|}
\hline \multirow{3}{*}{ Food Alaterials as Furnished. } & \multirow{3}{*}{ 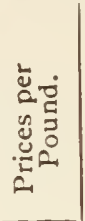 } & \multicolumn{6}{|c|}{ Twenty-five Cents will pay for } \\
\hline & & \multirow{2}{*}{ 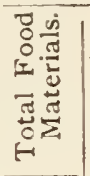 } & \multicolumn{4}{|c|}{ Nutrients. } & \multirow{2}{*}{ 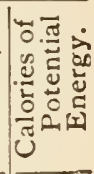 } \\
\hline & & & ڤึ & $\begin{array}{l}\frac{\Xi}{0} \\
\frac{2}{2} \\
2 .\end{array}$ & 它 & 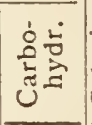 & \\
\hline Fish, & cts. & lbs. & lbs. & lbs. & lbs. & lbs. & \\
\hline Halibut steaks............... & $\left\{\begin{array}{l}20 \\
16\end{array}\right.$ & $\begin{array}{l}1.25 \\
1.56\end{array}$ & $\begin{array}{l}.26 \\
.32\end{array}$ & $\begin{array}{l}.19 \\
.24\end{array}$ & $\begin{array}{l}.06 \\
.07\end{array}$ & $\cdots \cdots$ & $\begin{array}{l}605 \\
540\end{array}$ \\
\hline 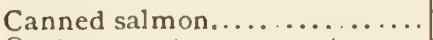 & 20 & 1.25 & .46 & .25 & .20 & $\cdots \cdots$ & 1310 \\
\hline 130 & 25 & $\mathbf{1} . \infty$ & $.3_{3}$ & .06 & .01 & .04 & 230 \\
\hline $\begin{array}{llll} & 6 & 35\end{array}$ & I7.5 & I. 43 & .18 & .09 & .02 & .05 & 345 \\
\hline Lobster, whole........... & $\left\{\begin{array}{l}12 \\
10\end{array}\right\}$ & 2.08 & .14 & $.1 \mathrm{I}$ & .01 & $\cdots \cdots$ & 34. \\
\hline " canned.............. & $\begin{array}{r}110 \\
20\end{array}$ & $\begin{array}{l}2.50 \\
\text { I. } 25\end{array}$ & $\begin{array}{r}.17 \\
.28\end{array}$ & .14 & $\begin{array}{l}.02 \\
.01\end{array}$ & $\begin{array}{ll}\cdots \cdots \\
\cdots \cdots\end{array}$ & 41 \\
\hline Eggs and Dairy Pro & & & & .23 & & & \\
\hline Eggs, 35 cts & 25 & $1 . \infty$ & .23 & .12 & .10 & $\cdots \cdot$ & 645 \\
\hline$\because \quad 25 \vdots$ & I8.2 & $\mathbf{1} \cdot 37$ & $\cdot 3^{2}$ & .17 & .14 & $\cdots$ & 9 IC \\
\hline " I5 " " " & II & 2.27 & $.53 !$ & .23 & .23 & $\cdots$ & I 490 \\
\hline Milk, 8 cts. per quart. & 4 & 6.25 & $.8 \mathrm{r}$ & .23 & .25 & .29 & 202 \\
\hline 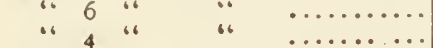 & 3 & 8.33 & 1.08 & $\cdot .30$ & $\cdot 33$ & $\cdot 39$ & 67 \\
\hline Butter............. & $\begin{array}{r}2 \\
35\end{array}$ & $\begin{array}{r}12.50 \\
.71\end{array}$ & $\begin{array}{r}\mathbf{1} .63 \\
.64\end{array}$ & $\begin{array}{l}.40 \\
.01\end{array}$ & .50 & .59 & $\begin{array}{l}4065 \\
2550\end{array}$ \\
\hline & $\left\{\begin{array}{l}35 \\
25\end{array}\right.$ & 1.00 & .90 & $.0 \mathrm{r}$ & .85 &.$c r$ & $\begin{array}{l}2550 \\
3635\end{array}$ \\
\hline Cheese, full cream. & $\{18$ & $\mathbf{1} \cdot 3^{8}$ & .96 & .40 & .49 & .02 & 3850 \\
\hline & 12 & 2.09 & 1.45 & .50 & .72 & .04 & 4210 \\
\hline Veget & & & & & & & \\
\hline Potatoes, $\$ \mathrm{r} .00$ & $\int 1.7$ & $14 \cdot 70$ & $\cdot 3^{I}$ & .03 & .01 & .26 & 580 \\
\hline .80 & $\{1.2$ & 20.0 & .42 & .04 & .02 & $\cdot 36$ & 790 \\
\hline $.50 \quad 1$ & $(0.85$ & $29 \cdot 40$ & .62 & .06 & .03 & .53 & 1225 \\
\hline Sweet potatoes. & $\{5$ & $5 . \infty$ & .14 &.$\infty$ &.$\infty$ & .13 & 240 \\
\hline areet pulatoes. & $\begin{array}{l}3 \\
2\end{array}$ & 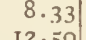 & .24 & .01 &.$\infty$ & .22 & $43^{\circ}$ \\
\hline Beets.... & $\begin{array}{l}2 \\
1\end{array}$ & 5.5 & $\begin{array}{l}.14 \\
.29\end{array}$ & $\begin{array}{l}.02 \\
.04\end{array}$ & .00 & $\begin{array}{l}.1 \mathrm{II} \\
.22\end{array}$ & $\begin{array}{l}24 \\
48\end{array}$ \\
\hline & 2 & 12.5 & .13 & .02 & .00 & . 10 & 225 \\
\hline & I & 25.0 & .27 & .03 & .01 & $.2 \mathrm{I}$ & 49 \\
\hline Sugar.... & 5 & 5.00 & 4.90 & .00 &.$\infty$ & $4 \cdot 8 y$ & 900 \\
\hline Drie & \{ & $\begin{array}{l}4.17 \\
5.00\end{array}$ & $\begin{array}{l}3.64 \\
4.37\end{array}$ & $\begin{array}{r}.96 \\
1.15\end{array}$ & $\begin{array}{l}.09 \\
.10\end{array}$ & $\begin{array}{l}2.47 \\
2.96\end{array}$ & $\begin{array}{l}676 \\
806\end{array}$ \\
\hline & 14 & & $\begin{array}{l}4.37 \\
5 \cdot 46\end{array}$ & 1.44 & .13 & & 300 \\
\hline Maize "corn" meal. & 3 & 8.33 & 7.08 & .77 & $\cdot 3^{2}$ & 5.88 & I 372 \\
\hline Oatmeal......... & I & 25.00 & 21.25 & $2 \cdot 30$ & .95 & 17.65 & 4 III 5 \\
\hline & 5 & $\begin{array}{l}5.00 \\
6.25\end{array}$ & $4.6 r$ & $\begin{array}{l}.74 \\
.60\end{array}$ & .36 & $\begin{array}{r}3 \cdot 42 \\
468\end{array}$ & 9255 \\
\hline Wheat flour.. & $3 \cdot 5$ & 7.14 & $\begin{array}{l}5.47 \\
6.25\end{array}$ & .09 & .08 & $5 \cdot 35$ & $\begin{array}{l}1020 \\
1175\end{array}$ \\
\hline & & & $7 \cdot 29$ & $.9^{2}$ & .09 & & 13695 \\
\hline Wheat bread.. & 7 & & 2.42 & $\cdot 3^{\mathrm{I}}$ & .06 & 2.01 & 4570 \\
\hline & 12 & 2.08 & $\begin{array}{l}3 \cdot 3^{8} \\
1.9\end{array}$ & $\begin{array}{l}.44 \\
.2 \mathrm{r}\end{array}$ & $\begin{array}{l}.09 \\
.20\end{array}$ & $\begin{array}{l}2.82 \\
1.47\end{array}$ & $\begin{array}{l}6445 \\
3970\end{array}$ \\
\hline & & & 2.88 & $|.32|$ & .29 & 2.21 & 5930 \\
\hline
\end{tabular}


DIETARY STINDARDS. (JIFFA.)

r. Cliildren, 1-2 years (average)

2. Children, 2-6 years (averave) .....

3. Chi dren, 6-15 years (average)......

4. Adult in full henith - Pliffur. .....

5 Active laboter-l’ayfair

0. Y.an at mud rate work-Voit …

7. Min at hard work-Vuit......

8. Man with hile physical exercise-

9. Mawater whin light mu-cular work-Atwater

10. Man wi li moderate work- Atwater.

I1 Man with actire wom: Amater.....

12. Man with h.1rd Worn-Atwater .....

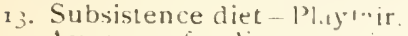

14. Average of 7 dielarte of panessional $\mathrm{m}=11$. Europe

I5. Aver.age of 5 dietaries of professiona? men, Lnited States..

\begin{tabular}{|c|c|c|c|c|}
\hline 站 & 空 & 我点 & 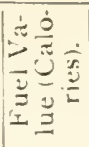 & 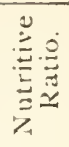 \\
\hline .06 & .08 & 6 & 765 & $1: 5.6$ \\
\hline .13 & .04 & .44 & $1+20$ & 5.0 \\
\hline .10 & .10 & .71 & 2040 & 52 \\
\hline .26 & 11 & 1.17 & 3140 & 5.5 \\
\hline$\cdot 34$ & . Tú & I. 25 & $3^{6} j 0$ & 47 \\
\hline .26 & .12 & 1.10 & 3055 & 53 \\
\hline$\cdot 3^{2}$ & .22 & 99 & $337^{\circ}$ & $4 \cdot 7$ \\
\hline .20 & .20 & .66 & 2450 & 55 \\
\hline .22 & .22 & .77 & 2300 & $5 \cdot 7$ \\
\hline .28 & .28 & .90 & 3520 & 5.8 \\
\hline$\cdot 33$ & $.3 i$ & 1.10 & 460 & 5.6 \\
\hline .39 & .55 & 143 & 5700 & 6.9 \\
\hline 13 & .03 & .75 & 1760 & 6.3 \\
\hline .25 & 22 & .63 & 2670 & 4. 7 \\
\hline .27 & .34 & 1. .08 & 3225 & 66 \\
\hline
\end{tabular}

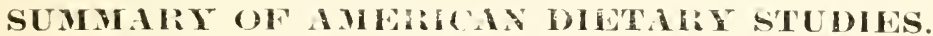

(BRYANT)

Average of 2 laburers' families in comfortable circumstances . .........

A verage of 15 college clubs in Me, Conts.. Tenn., and Mo

Average of so formers tamilies in $\ddot{\mathrm{Vt}}$., Conn, and N. Y.......

Averange of it mechaliles" fomilies in Comis., N. J., Ten:1, and Int.

Average of tis negro families in $\mathrm{Ala}$.

Averace of 5 Fr.neli-Cimadian famblies in Chicater Ill. $\ldots$...... .... .

Average of 11 professional men's families in Cinn, P: Ind, and III .......

Average of ; 1 mines of Russian Jews in Clitien $111+\ldots \ldots \ldots$

Av. of , Itaidan families in Chicagro. 111.t.

Averal re of 11 port families in N. Y. Ciaj

Avo of 12 l.timerers families in N. Y. City

Average of 3 Bolsemian fannilies in Chica. $\cdots$, Ill. + …

Averare of 2 laborers families in litis bu: l'as. very poor

Av.Food (onsump p. Man p.l)ay

\begin{tabular}{|c|c|c|c|c|}
\hline نُّ تُّكُ & 吾 & 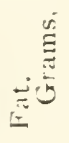 & 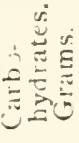 & 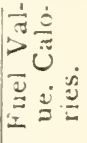 \\
\hline I9 & 120 & 157 & 534 & 4045 \\
\hline . & 107 & 148 & 459 & $3^{6} 90$ \\
\hline - & 97 & 130 & 4ñ 7 & 3515 \\
\hline I $9^{*}$ & 103 & 150 & 402 & 3465 \\
\hline 9 & 67 & 134 & 453 & 3375 \\
\hline 22 & 118 & I 58 & 345 & $33^{6} 5$ \\
\hline $23 \dagger$ & 104 & 125 & 423 & 3325 \\
\hline In & 120 & 101 & $40 \%$ & 3095 \\
\hline 16 & 103 & III & 391 & 3060 \\
\hline 15 & 93 & 45 & 407 & $2 y 15$ \\
\hline 19 & 101 & 116 & 344 & 2905 \\
\hline 12 & 115 & 101 & $3^{60}$ & $280 \overline{5}$ \\
\hline 11 & 8., & 95 & 308 & 2485 \\
\hline
\end{tabular}

$¥$ Food purchased; in the other averages the food actually eaten is given, 
DIAGRAMS OF CUTS OF MEAT.

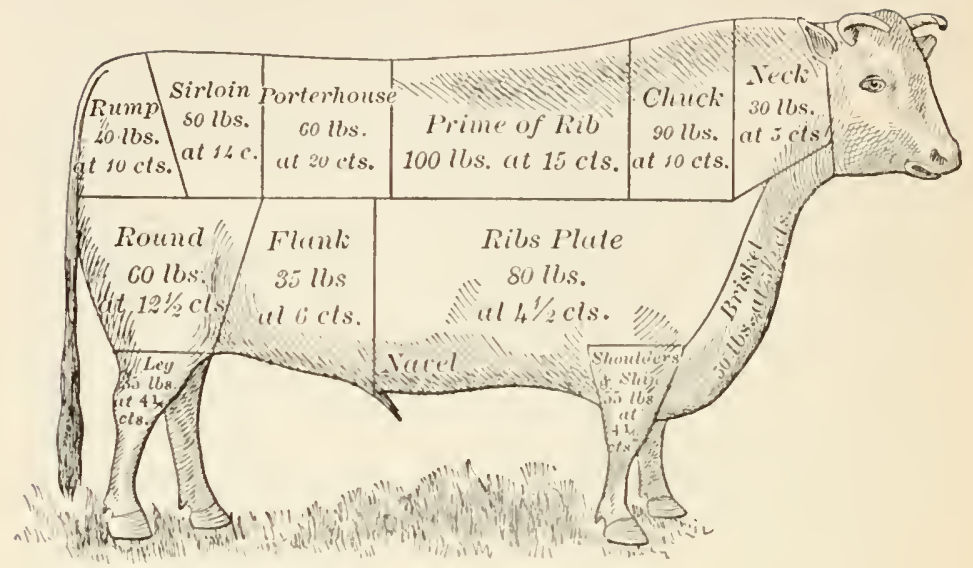

Diagram I. A Good Steer's Carcass, as Cut Up and Priced in the Eastern . Mirket.

A good r200-pound steer will dress about 800 pounds of beef cut up as above-7I5 pounds salable cuts, with 85 pounds of fat, bone, and waste.

The diagram illustrates what the breeder and feeder should ain to produce in the conformation of the beef- and mutton-producing animal, so that the highest possible per centage of the carcass will be cuts of the high-priced class, thereby giving the best possible return for food consumed. (McKERROW.)

The methods of dividing up the carcasses of slaughtered animals into parts, and the terms used for the "cuts," as these parts are commonly called, vary considerably in different localities. The accompanying diagrams will make clear the terms used in the table Composition of Human Foods (pp. 197-199). 
HUMAN FOODS.

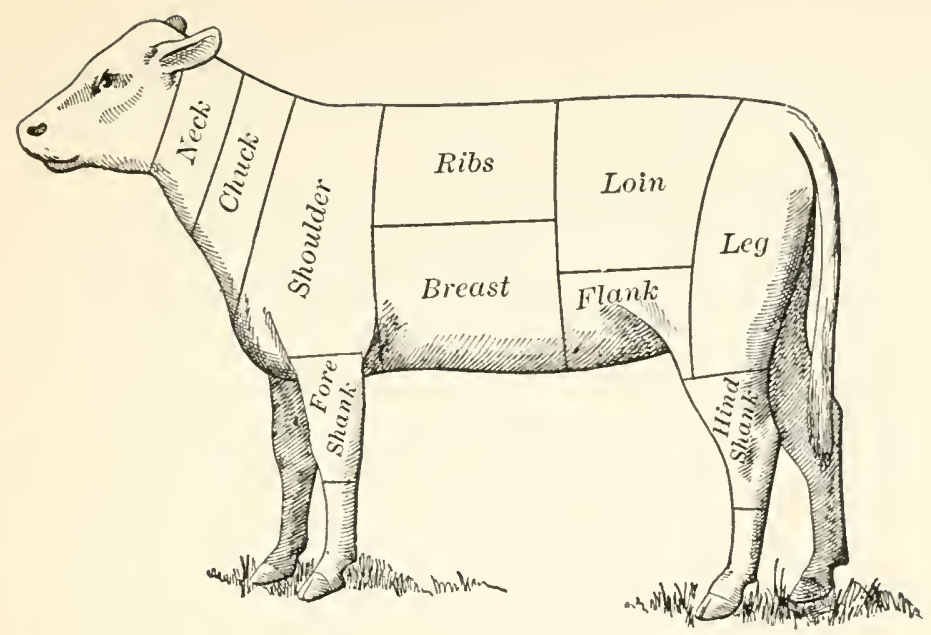

II. Diagram of Cuts of Veal.*

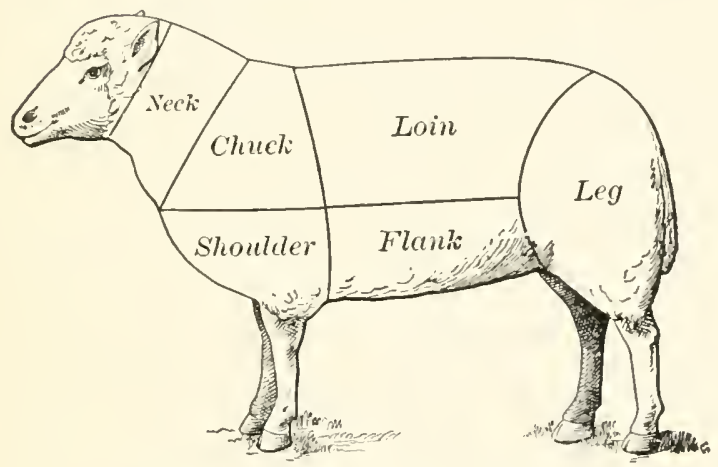

III. Diagram of Cuts of Mutton.*

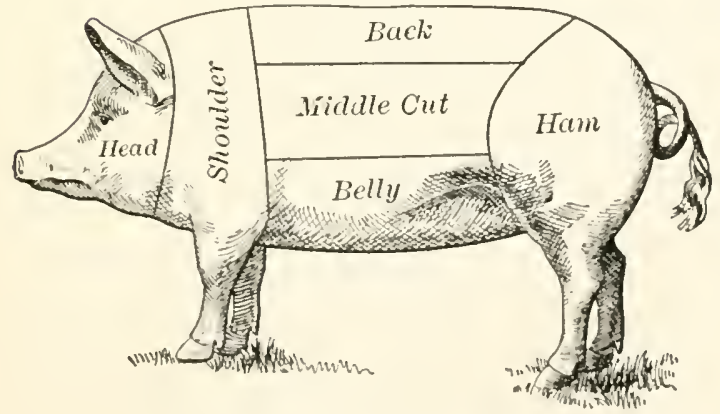

IV Diagram of Cuts of Pork.*

* U. S. Dep:. of Agriculture. 
LIVE WEIGHT AND DRESSED WFIGHT OF STEERS OF DIFEERENT BREEDS AND AGES. (HeNRY.)

\section{(Smithfield Showe, 1888-95.)}

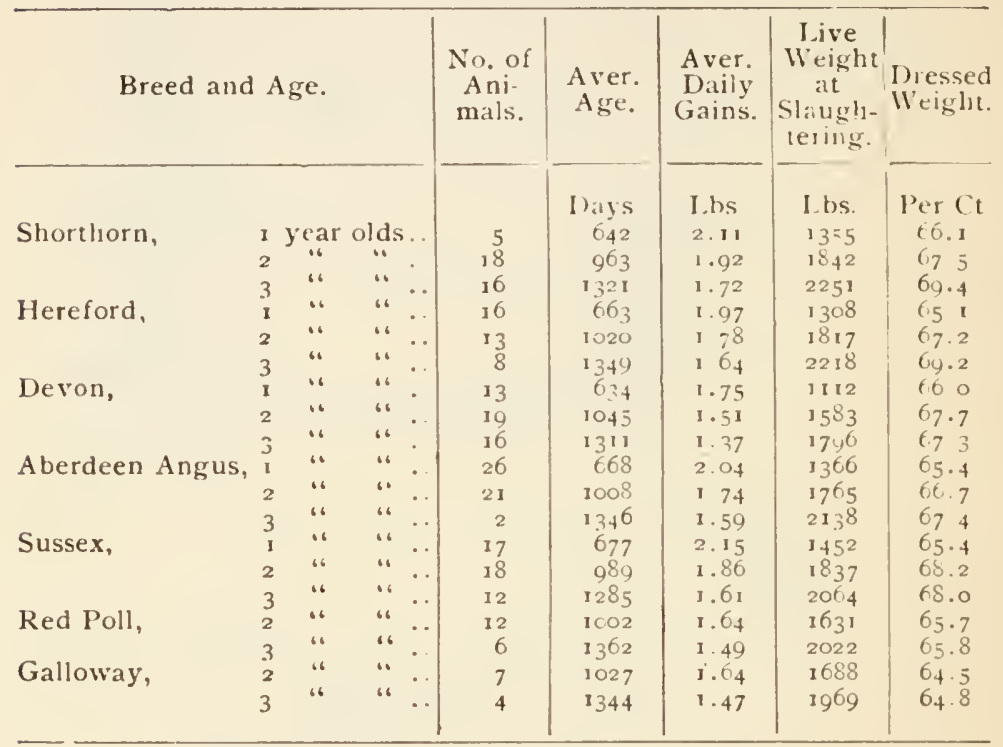

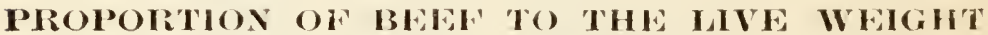

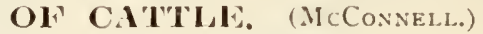

Heifers

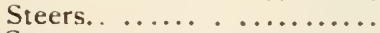

Steers....................

Heifers....................

Steers...................

Heifers

Steers........................

Heifers

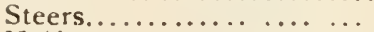

Heifers

Heifers
Per Cent of Beef.

Live Weight, Pounds Avoirdupois.

Under 2520 • 2520 1680-2100 $1400-1680$ $1400-1680$ $1260-1700$ I 260-1 400 I $120-1260$ $1120-1260$ 980-1 I 20 Under g8o
Per Cent of Beef.

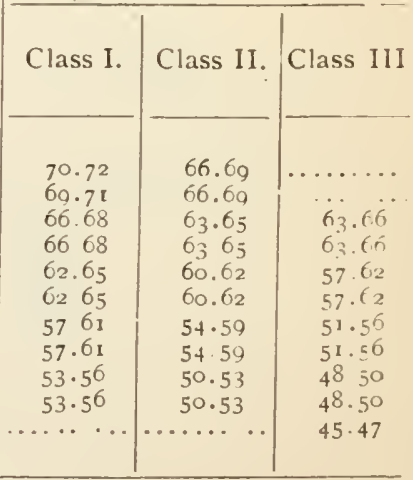


COMPARATIVE RESUITS OBTAINED WITH

Fat'ILNING ANIMALS. (Lawes and Gilbert.)

(a) Per Ico lbs. live weight per week.

\begin{tabular}{|c|c|c|c|c|c|}
\hline & \multicolumn{2}{|c|}{ Received by Animal. } & \multicolumn{3}{|c|}{ Results Produced. } \\
\hline & $\begin{array}{l}\text { Total } \\
\text { Dry } \\
\text { Food. }\end{array}$ & $\begin{array}{c}\text { Digestible } \\
\text { Organic } \\
\text { Matter. }\end{array}$ & $\begin{array}{l}\text { Food Con- } \\
\text { sumed for } \\
\text { Heat and } \\
\text { Work. }\end{array}$ & $\begin{array}{c}\text { Dry } \\
\text { Manure } \\
\text { Produced. }\end{array}$ & $\begin{array}{l}\text { Increase } \\
\text { in Live } \\
\text { Weiglit. }\end{array}$ \\
\hline $\begin{array}{l}\text { Oxen } \ldots . . . \\
\text { Sheep........ } \\
\text { Pigs......... }\end{array}$ & $\begin{array}{l}\text { lbs. } \\
\text { 12.5 } \\
16.0 \\
27.0\end{array}$ & $\begin{array}{r}\text { Ibs. } \\
8.9 \\
12.3 \\
22.0\end{array}$ & $\begin{array}{r}\text { lbs. } \\
6.86 \\
9.06 \\
12.58\end{array}$ & $\begin{array}{l}\text { lbs. } \\
4 \cdot 5^{6} \\
5 \cdot 10 \\
4 \cdot 5^{1}\end{array}$ & $\begin{array}{l}\text { lbs. } \\
1.13 \\
1.76 \\
6.43\end{array}$ \\
\hline
\end{tabular}

(b) In relation to food consumed.

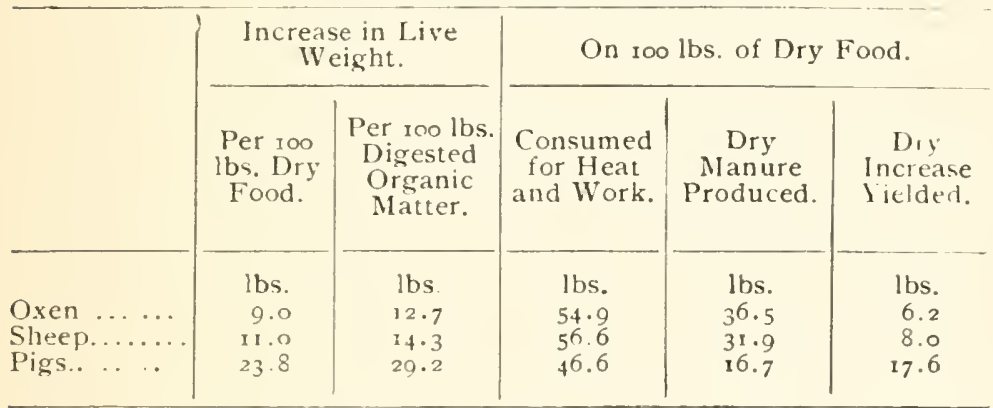

\section{LIVE WEIGHT AND GAINS MADE BY SWINE.}

(HENRY AND SANBORN.)

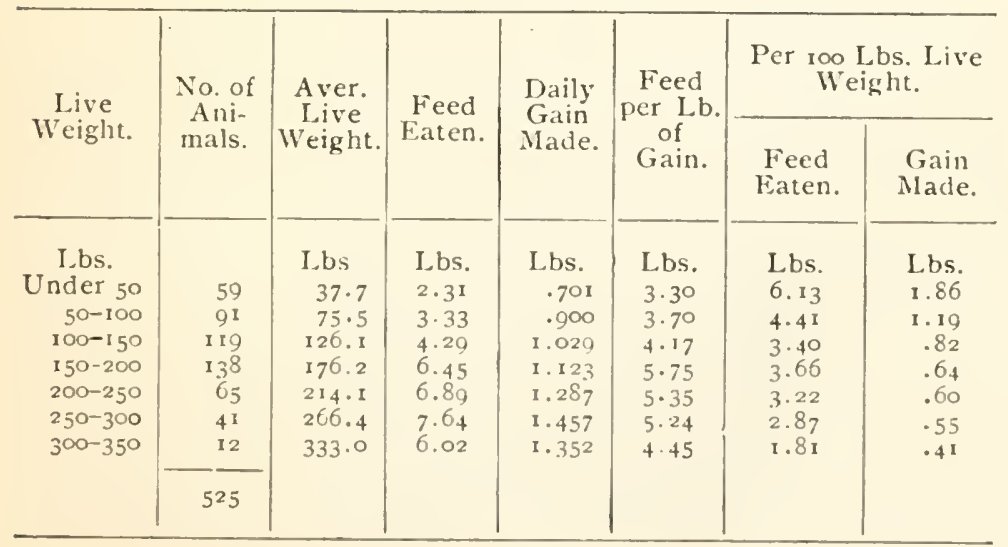




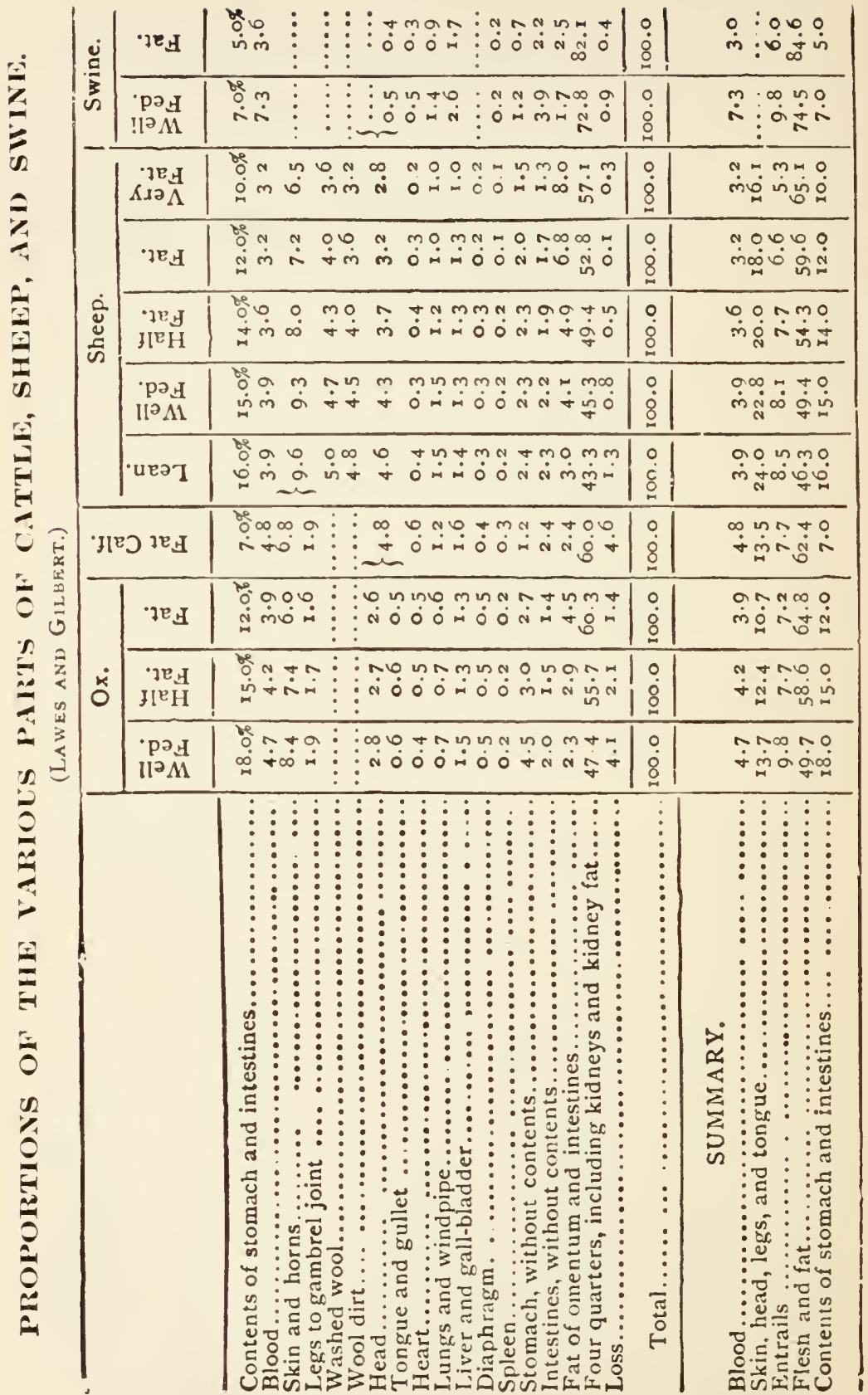




\begin{tabular}{|c|c|c|c|c|c|c|c|c|c|}
\hline \multirow{2}{*}{$\frac{\dot{e}}{\stackrel{E}{n}}$} & ' $1 \mathrm{E}_{4}$ & & 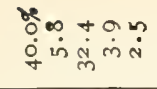 & $\begin{array}{l}0 \\
\dot{f}\end{array}$ & $\ddot{n}$ & $\stackrel{\circ}{\dot{q}}$ & & 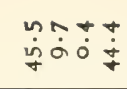 & $\stackrel{0}{8}$ \\
\hline & 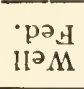 & & 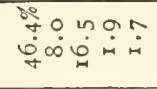 & $\stackrel{n}{\dot{t}}$ & $m \stackrel{m}{\infty}$ & $\frac{4}{4}$ & & ํㅜㅇㅛ & $\stackrel{\circ}{8}$ \\
\hline \multirow{5}{*}{$\frac{\dot{0}}{\dot{U}}$} & 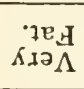 & & 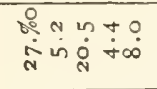 & $\ddot{0}$ & $\because \stackrel{9}{N}$ & $\stackrel{\leftrightarrow}{\hat{N}}$ & & 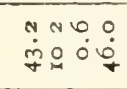 & $\stackrel{0}{8}$ \\
\hline & • & & 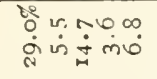 & o & $\dot{\dot{m}} \dot{\sim}$ & $\stackrel{\circ}{\dot{\alpha}}$ & & $\begin{array}{l}\dot{m} \\
\dot{m}=\dot{0}\end{array}$ & : \\
\hline & 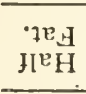 & & 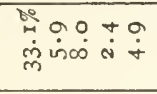 & ? & mo & $\ddot{m}$ & & 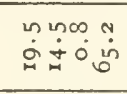 & $\stackrel{\circ}{8}$ \\
\hline & 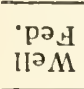 & & 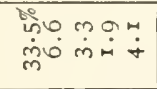 & $\dot{\dot{q}}$ & ن웅 & $\dot{\tilde{n}}$ & & $\dot{\circ} \ddot{0}$ & $\stackrel{\circ}{8}$ \\
\hline & •ueว I & & 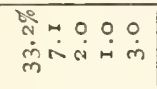 & $\ddot{q}$ & $\mathfrak{0}_{0}^{0}$ & $\stackrel{\sim}{m}$ & & no mo & $\begin{array}{l}\circ \\
8\end{array}$ \\
\hline \multicolumn{2}{|c|}{ } & & 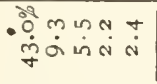 & पूं & $\stackrel{\infty}{\infty} \stackrel{\sim}{\dot{m}}$ & $\stackrel{\circ}{\dot{m}}$ & & 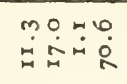 & $\stackrel{0}{8}$ \\
\hline \multirow{3}{*}{$\dot{0}$} & "7eH & & 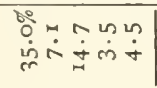 & $\underset{\dot{t}}{\infty}$ & & $\stackrel{p}{\text { in }}$ & & $\begin{array}{l}+ \text { no m } \\
\dot{0} \dot{i}=\dot{n}\end{array}$ & $\stackrel{0}{8}$ \\
\hline & $\begin{array}{l}\text { "1ен } \\
\text { נ[ए] }\end{array}$ & & 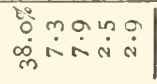 & $\stackrel{\infty}{\infty}$ & +o & $\stackrel{\circ}{\circ}$ & & 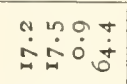 & $\dot{0}$ \\
\hline & 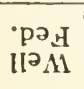 & & $\begin{array}{l}0 \\
\dot{0} \\
\dot{m}\end{array} \dot{\sim} \dot{\alpha} \stackrel{\dot{N}}{\dot{N}}$ & $\ddot{\leftarrow}$ & $\circ \stackrel{\circ}{\infty}$ & $\stackrel{0}{0}$ & & $\dot{m} \dot{\alpha} \dot{n}$ & $\stackrel{0}{\circ}$ \\
\hline & & 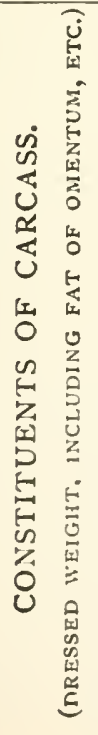 & 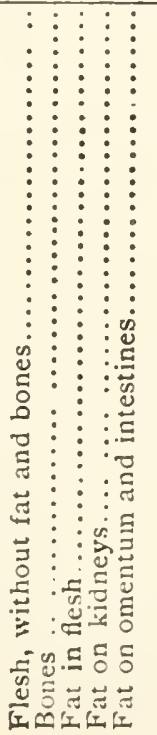 & $\begin{array}{c}\text { : } \\
\vdots \\
\vdots \\
\vdots \\
\vdots \\
\vdots \\
\vdots \\
\vdots \\
\vdots \\
\vdots \\
\vdots \\
\vdots \\
\text { त्ग } \\
\qquad \\
\end{array}$ & 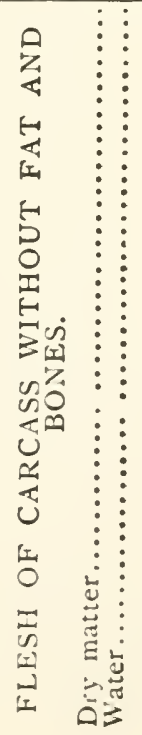 & $\begin{array}{c}\vdots \\
\vdots \\
\vdots \\
\vdots \\
\vdots \\
\vdots \\
\vdots \\
\vdots \\
\vdots \\
\vdots \\
\vdots \\
\vdots \\
\vdots \\
\vdots \\
\vdots \\
\vdots \\
\vdots \\
\vdots \\
\vdots \\
\tilde{\pi}\end{array}$ & 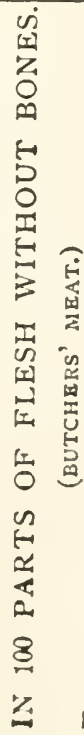 & $\begin{array}{c}0 \\
\vdots \\
\vdots \\
\vdots \\
\vdots \\
\vdots \\
\vdots \\
\vdots \\
\vdots \\
\vdots \\
\vdots \\
\vdots \\
\vdots \\
\vdots \\
\vdots \\
\vdots \\
\vdots \\
\vdots \\
\vdots \\
\vdots \\
\vdots \\
\vdots \\
\vdots \\
\vdots \\
\vdots \\
\vdots \\
\vdots \\
\vdots \\
\vdots \\
\vdots \\
\vdots \\
\vdots\end{array}$ & $\begin{array}{c}\vdots \\
\vdots \\
\vdots \\
\vdots \\
\vdots \\
\vdots \\
\vdots \\
\vdots \\
\vdots \\
\vdots \\
\vdots \\
\text { ปே } \\
\vdots\end{array}$ \\
\hline
\end{tabular}




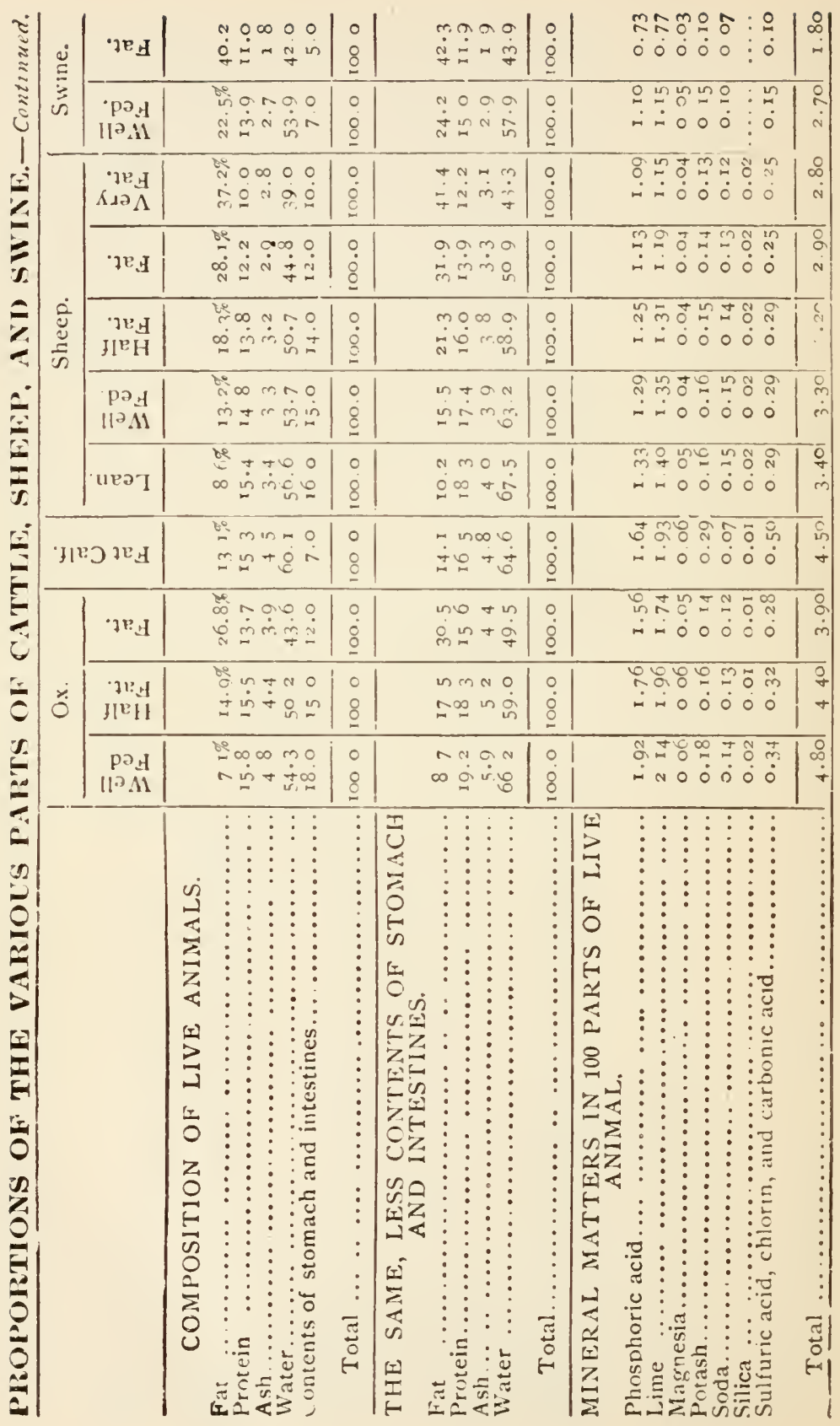




\title{
PART II. DAIRYING.
}

\section{DAIRY COWS.}

\section{ON THE ORIGIN AND CHARACTERISTICS OF THF DIFEERENT BREEDS OH DIIRY CATELE.}

\author{
I. Jersey Catthe.
}

The origin of the Jersey cattle, like many of our other improved breeds of live-stock, is not known with certainty. The theory is that they descend from cattle brought from the Scandinavian countries to Normand: France, during the tenth century or before, whence the were introduced into the Island of Jersey, off the French coast. The breed has been kept pure on this litile island for a longer period than any oth 2 r English breeds, as a result of the enactment in $I 7 S_{9}$ of a law forbidding importations of foreign cattle into the island. According to Flint, Jerseys were first imported into this country about 1838 , but heavy importations did not begin until after 1850 .

The following is a description of typical Jersey cows: Head fine and tapering; cheek small; throat clcan; the muzle fine and encircled with a slight stripe; the nostril high and open; the horns smooth, crumpled, not very thick at the base, tapering, and tipped with black; ears small and thin, deep orange color inside; eyes full and placid; neck straight and fine; chest broad and deep; barrel hooped, broad and dẹep, well ribbed up; back straight from the withers to the hip, and from the top of the hip to the setting on of the tail; tail fine, at riglit angles with the back, and hanging down to the hocls; skin thin, light color, and inellow, covered with fine soft hair; fotelegs short, straight and fine below the knee, arm swelling and full above; hind quarters long and well filled; hind legs 
short and straight below the hocks, with bones rather fine, squarely placed, and not too close together; hoofs small; udder full in size, in line with the belly, extending well up behind; teats of medium size, squarely placed and wide apart, milk veins very prominent; color is generally cream, dun, or yellow, with more or less white.

The Jerseys are generally considered a butter-producing breed, and justly so. The milk produced is as a rule richer in fat and solids than that of any other breed, but the quantity yielded, on the other hand, is apt to be lower. Milk from good Jersey cows often contains over six per cent of fat, the average being about five per cent. Production of rich milk has been the primary aim of Jersey breeders; in ISSI the secretary of the American Jersey Cattle Club wrote: "The sole office of the Jersey cow is to produce the largest possible amount of rich, highly colored cream from a given amount of food. Everything else in connection with the breeding of the race is, or should be, incidental."

The highest yields of butter-fat or butter, in case of Jersey cows as well as other dairy breeds, are not, however, apt to come from cows producing exceptionally rich milk, but rather from such producing an exceptionally large quantity of good milk; generally speaking, an extraordinarily high fat-content is accompanied by a small milk yield.

Typical Jerseys generally have a high-strung, nervous temperament, and in order to do their best must receive good care; they cannot be abused as to feed or treatment without injury; for this reason they will only prove a success in the hands of intelligent feeders who care for and take an interest in their stock. The dairy type predominates, viz.: a wedge-shaped, deep-chested body, with good digestive organs, large full udders, well-developed milk-veins, and a soft, mellow skin. The cows are gentle and docile, while the bulls have the reputation of being hard to handle, and often ugly and dangerous after a couple of years' service.

The maximum yields of milk and butter produced by Jersey cows are given on page 240 , the table giving the 
official records. In the breed-tests conducted by the experiment stations in Maine, New Jersey, and New York (Geneva), the Jerseys have ranked among the first, but have seldom been the foremost. As the average of all tests of dairy treeds up to date, we notice that the Jerseys rank after the Shorthorns and the Guernseys in total yield of fat during a full period of lactation, and after Guernseys in the cost of producing one pound of fat; they rank first as to richness of milk produced. In the English milking trials conducted by the British Dairy Farmers' Association, the Shorthorn cows have generally led the Jerseys in the total quantities of fat produced per day, and other breeds have also, on the average, given better results than these. The Jerseys came out victorious in the breed-tests conducted at the World's Columbian Exposition in 1893; they produced more milk, butter-fat, butter, and cheese, and gave a higher net gain than either of the two other breeds competing (Guernsey and Shorthorn); the Guernseys, on the other hand, led as regards the cost of the food consumed. Also in the Dairy Cow Demonstration at the La. Purchase Exposition in St. Louis, in 1904 , the Jersey cows produced more butter-fat, on the average, than either of the other competing breeds, and at a lower feed cost per pound (see p. 239). The champion Jersey cow in this demonstration, Loretta D., produced in 120 days $5 \mathrm{SO} 2.7 \mathrm{lbs}$. milk; average per cent of fat, 4.82 ; 280.16 lbs. butter-fat, equivalent to $330 \mathrm{lbs}$. of butter, and an average daily production of $2.334 \mathrm{lbs}$. butter-fat.

The American Jersey Cattle Club was organized in July, I868; the Herd Register of the club, the first volume of which was published in $\mathrm{I} 87 \mathrm{I}$, has been issued in seventy-two volumes up to date, including in all 92,000 bulls and 244,000 cows. Register of Mcril of Jersey Callle gives records of all Jersey cows and bulls entered in the Register of Merit, which was established by the club in 1903; the latest volume published is Vol. III, containing entries to Nov. Io, I9I3.

The present Secretary of the American Jersey Cattle Club is R. M. Gow, No. 324 W. 23 d St., New York City. 


\section{Guernsey Cattle.}

By Prof. W. H. Caldwell, Peterboro, N. H.. Sec'y Am. Guernsey Cattle Club.

The Guernsey breed takes its name from the Island of Guernsey, one of the Channel, or sometimes termed Alderney, Islands. The origin of the Channel Island cattle, while somewhat involved in controversy, is generally believed to have come from stock originally from the French provinces of Normandy and Brittany, and that the foundation for the Guernseys was laid by crossing the Normandy bull on the Brittany cow. It is very interesting to turn to the Island of Guernsey, cut off as it is from the main land by the little strip of sea, and protected on all sides by a rough, rocky coast, and note the characteristics which we find there that have played so important a part in moulding the character of the Guernsey of to-day. There the shrewd, careful, sturdy people have labored many years to produce a cow that should excel in butter production. Their labors have been rewarded in the Guernsey, which is noted the world over for producing butter of the highest natural color and with the least outlay for cost of feed. Fate might have been different with these people but for their insular situation, pride of self-government, habits and customs, which led them to zealously fight invasions, and even as early as $I 7 S_{9}$ to take measures against the fraudulent importation of stock. In 1826 came more stringent laws, that prohibited importation to the island except for slaughter. It thus isolated the islanders and their cows from the cattle kingdom.

The striking appearance of the Guernsey is at once seen in its rich yellow skin, which has always been noted as the characteristic of a good butter-cow. In appearance they are rangy, deep, business-looking animals, with a particularly quiet, gentle, tractable temperament, free from nervousness. The prevailing color is a delicate shade of fawn with white markings, and crean.colored nose; and their most remarkable characteristic of richness is apparent in the 
golden color around the eyc, on the udder and teats at base of horn, and at end of the bone of tail.

Until recently Guernseys in America were kept chiefl! for family use. They were introduced into private dairies around Philadelphia as early as 1840 , and since that time no other breeds have been permitted to replace them. The gentlemen who first introduced Guernseys had no motive to advertise them. They esteemed their golden-colored products so highly that they were kept for the supplying of families with the best milk and butter that could be produced. About 1865 a few Guernseys were introduced by the importers, which laid the foundation of some of our herds of to-day. A few years later the Massachusetts Society for the Promotion of Agriculture, realizing the great promise of the breed, imported some and distributed them at a public sale to dairymen in the State. A few years later a number of Connecticut farmers joined together and sent a man to the island to bring over a lot. It soon became obvious to these gentlemen that some organization was necessary to preserve the purity of these cattle and to encourage their recognition. Accordingly on February 7. I877, the American Guernsey Cattle Club was organized in New York City. At that time there were about one hundred and fifty pure-bred Guernseys in the country, whose pedigrees could be traced without question to importation from the island. At present there are about 60,000 animals in the Register. In the last few years-in fact since the World's Fair Dairy tests in IS93, and the work at the New York and New Jersey Experiment Stations-great interest has been taken in the Guernseys. More entries and transfers have been recorded, and more members have joined the Club than at any similar period in its history. The public are just realizing the straightforward work that has been quietly done for the last quarter of a century, and find in a study of it that there are many valuable records to the credit of the breed. These are all the more valuable as the Guernsey has not been forced for high records, but have honestly won their way.

The best records reported of Guernseys are those of Lilv 
of Alexandre, No. I059, and Imp. Bretonne, No. 3660. Lily of Alexandre gave $12,855 \frac{1}{2}$ pounds of milk in one year; and two months before calving tested 7.2 per cent of butter-fat. Bretonne gave in the year ending October 20, I894, I I,219 pounds of milk. Her milk was tested carefully once a month by taking a composite sample of eight consecutive milkings. The lowest test was 5.2 per cent and highest 6. I per cent butter-fat. Her milk yielded $602 \frac{91}{100}$ pounds of butter-fat, or equivalent to $753 \mathrm{I}^{5} \mathrm{~J}$ pounds of butter containing so oer cent butter-fat. She is a large, well-built ow, and weighed at the close of her year's work II50 pounds. In addition the cow Fantine 2d, No. 3730, owned by Mr. Chas. Solveson of Nashotah, Wis., gave in one year, besides dropping a fine calf and being dry four weeks, 9748 pounds of milk, the lowest test being 5 and the highest 5.6 per cent butter-fat, which would yield a year's record of $5 \mathbf{1 6 . 6}$ pounds butter fat or 602 pounds of butter. Mr. Ezra Michener of Carversville, Pa., owns the cow King's Myra, No. 5339, who has just completed the year's test under the direction of the Guernsey Breeders' Association and received their first prize. She is four years old, and gave in the year 86 I pounds of milk, which yielded 539 pounds of butter. Nearly a hundred cows have been reported that have made a record of $\mathrm{I}_{4}$ pounds or over of butter a week, and several that have made exceedingly fine single-day tests, as one cow, Pretty Dairymaid $2 \mathrm{~d}$ of Guernsey, No. 6366, who in an official test gave in three consecutive days 61 pounds 2 ounces, 62 pounds 12 ounces, and 52 pounds and 9 ounces of milk, a total of 176 pounds 7 ounces.

Their ability to produce butter-fat and butter at a low cost demands the careful attention of the dairymen. At the New York Experiment Station several of the dairy breeds are being carefully tested. The annual report of the director, which was recently issued, gives the result of the first two periods of lactation. In both instances the Guern. seys produced butter-fat at the least cost, as the following shows : 
Their ability to produce butter-fat and butter at a low cost demands the careful attention of the dairyman. At the N. Y.(Geneva) and N. J. Exp. Stations several of the dairy breeds have been carefully tested. In both instances the Guernseys produced butter-fat at the least cost, and the same result was obtained in the World's Fair test, IS9r, as the following shows:

COST OF BUTTER-FAT PER POUND, CENTS.

\begin{tabular}{|c|c|c|c|c|}
\hline \multirow{3}{*}{ Breed. } & \multicolumn{2}{|c|}{ N. Y. (Geneva.) } & \multirow{3}{*}{ New Jersey.* } & \multirow{3}{*}{$\begin{array}{c}\text { World's } \\
\text { Fair. }\end{array}$} \\
\hline & \multicolumn{2}{|c|}{ Lactation Period. } & & \\
\hline & First. & Second. & & \\
\hline Grnernsey............. & 18.4 & 15.6 & I 5.3 & 13.1 \\
\hline 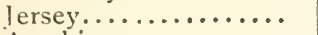 & 20.0 & 18.5 & $17 \cdot 9$ & $13 \cdot 3$ \\
\hline 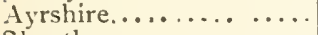 & $24 \cdot 3$ & 24.8 & 20.6 & \\
\hline Shorthorn ........ & $\cdots$ & $\ddot{\cdots} \cdot$ & 20.8 & 15.8 \\
\hline Holstein ........... & 26.3 & 26.4 & $22 \cdot 4$ & $\cdots$ \\
\hline Devon $\ldots \ldots \ldots \ldots \ldots$ & $23 \cdot 0$ & 19.0 & $\cdots$ & $\cdots$ \\
\hline Am. Holderness.... & 26.3 & 22.8 & $\cdots$ & $\cdots$ \\
\hline
\end{tabular}

* Cost of butter per pound.

This shows the Guernseys to be the most economical producers of butter: and such golden-yellow butter, too!

The American dairyman, in his endeavor to improve his own herd and collectively to improve the herds of his section, naturally takes a great deal of interest in the grade dairy cow. In the progressive dairy sections the influence which pure-bred bulls exert is readily acknowledged. They intensify the good qualities of the breed to which they belong, and make such a section a desirable place for the seeking of good family and profitable dairy cows. The value of the Guernsey bull in effecting this improvement has been well understood for many years. and especially is it realized to-day in the desire to secure in the dairy cattle of America greater physical strength and more profitable butter production without reducing size or sacrificing rich. ness of milk production. Mr. Lewis F. Allen, in his writings several years ago, spoke especially of his experience with the Guernsey for grading. He said his experience was good, large-sized animals, free and persistent milkers, and 
the making of the first quality butter for private family of hotel use. He believed that on a whole the Guernseys were more satisfactory for the dairy than any which in his forty years' experience he had ever had. His cows had good square udders, well set front and behind, teats of good size and easy to grasp.

The Herd Register is published by the American Guernsey Cattle Club, whose headquarters are at Peterboro, N. II. The breeders of Guernseys have always been harmonious in letting their favorites win their way by their own straightforward efforts in the dairy. liy addressing the Secretary of the Club at Peterboro, N. I1., further information will cheerfully be furnished.

\section{iII. Holstein-Friesian Cattle.}

By Malcolm H. Gardner, Delavan, Wis., Supt. Advanced Registry Holstein-Friesian Association of America.

The cattle known in America as Holstein-Friesians belong to the shorthorn, low-land race, native to the fertile lands of Europe bordering on the North Sea; of which race, from the dairy standpoint, the Holstein-Friesian family is the most highly developed. 'These cattle might have been better named Friesian, since Friesland, and the neighboring provinces of Holland, is the central home from which this breed of cattle has been so widely disseminated over the (.Id Morld, and from which some ro,000 liead of foundation stock has been brought to America. The Friesian people are among the most conservative of the Germanic race; still holding to and speaking among themselves the old Fricsian language, although also able to speak Dutch, the official language of Holland. They have been equally conservative in holding to their ancient industry of cattle-rearing, an occupation for which their low-lying lands are especially fitted; and as Tacitus speaks of them nearly 1900 years ago as cattle breeders, paying a tribute in cattle and hides to the Roman Empire, so we find them to-day making dairy husbandry their main industry. Holding mainly to one occupation down through the centuries, and passing the business from father to son, it would be strange indeed if their breed of cattle did not reach a very high degree of development; so it is in no way surprising that we should find these Friesian dairymen possessed of a breed 
of cattle which, as an all-around dairy breed, is superior to any other breed known.

While the Folstein-Friesians are essentially a dairy breed and are so regarded in Anerica, yet as an all-around dairy breed the matter of beef and veal must not be lost sight of, and in Holland these are very important points. There few cattle are allowed to pass their seventh year; but before they pass out of their prime they are fattened and sold as beef. Prof. I. P. Roberts in speaking of Holstein-Friesian beef said: "I ate it for three weeks, and the English beef for two; and while not so fat as the short-horn, it was to my taste superior." The breed reaches full growth and maturity at about five years of age; reaching full height at between two and one-half and three years of age, and each year for the two following years adding about one and three-fourth inches in length, three-fourths of an inch in width of hips, and two inches in girth of chest. Mr. S. Hoxie, former Supt. of H. F. Adranced Registry, states that the average measurements of cows upwards of five years of ag received to entry in the fourth volume of the Adranced Register were as follows: "Height at shoulders, 5 r.S inches; height at hips, 53 inches; length of body, 6.9 inches; length of rump, 21.4 inches; width of hips, 2 I.9 inches; width at thurl, I9.6 inches; girth at smallest circumference of chest, 75.6 inches." The average weight of these cows was I 262 lbs., and the average measurements are those of what might be deemed a typical animal of what is technically knowm as the milk-and-flesh form of the breed, the form most popular in America.

The first association of breeders of these cattle in this colintry was formed in $187 \mathrm{I}$, the first herd-book being published the following year. The present Holstein-Friesian Association was formed in $188_{5}$ by the union of two earlier associations, and is now the largest association of hreeders of pure-bred ditiry cattle in America. Iow many H.-I. cattle there are now living is unknown; but since the juncture of the two old associations in .I $88_{5}$, over I 80,000 females and o6,000 males have been recorded. The H.-F. Advaned Regi-ler, based for entry upon individual merit, was established in $3885 ; 2.3$ volumes having been published, containing entries of over 18,500 cows and 1,500 bulls. The age of any female is computed as that at the time of last calving 
or aborting, and the requirements for entry vary with the age, being not less than 7.2 lbs. butter-fat in seven consecutive days for a heifer calving at just two years of age or younger, and increasing proportionately to not less than I 2 lbs. butter-fat for a cow calving at five years old or older; there being no increased requirements for increased age after a cow reaches the age of five years. Only bulls having four or more daughters which have been entered in the Advanced Register on official records of butter-fat are accepted for entry.

The rules for the entry of cows in the H.-F. Advanced Register are very stringent, being designed to place every H.-F. record beyond even a shadow of doubt. Every milking during the period of test is watched, weighed, sampled, and tested by a representative of a State Agricultural College; and thus, because of resulting expense, the bulk of its records are for short periods, mainly for one week. It will be readily admitted that is lbs. of butter-fat will make $2 \mathrm{I}$ lbs. of the best of butter, or an average of three poùnds butter per day when $\mathrm{S} / \mathrm{lbs}$. of fat is produced in seven consecutive days, and that very few cows other than Holstein-Friesian have ever under strict rules produced such an amount. The records of the H.-F. Advanced Register show that 224 H.-F. cows have produced officially in excess of IS lbs. butter-fat; of which $S_{2}$ cows have produced between is and 19 lbs.; 64 cows, between 19 and 20 lbs.; 46 cows, between 20 and $2 \mathrm{I}$ lbs.; I 5 cows, between $2 \mathrm{I}$ and $22 \mathrm{lbs}$; 8 cows, between 22 and 23 lbs.; 6 cows, between 23 and 24 lbs.; I cow, between 24 and 25 lbs.; I cow, between 25 and $26 \mathrm{lbs}$; and I cow, over 27 lbs. It must be remembered that while many of these records were made by cows much under five years of age, there were a large number of records made by two and three-year-old heifers, which were, considering age, proportionately as large, yet fell short of the I S-lb. limit required for this list.

As to the per cent of fat in average H.-F. milk, I 545 cows and heifers of all ages entered in the $17^{\text {th }}$ volume of the H.-F. Advanced Register, of which more than one-half were heifers, produced in seven consecutive days an average of $376.7 \mathrm{lbs}$. milk, containing 12.75 lbs. butter-fat, showing an average of 3.39 per cent fat. There were 71 cows and heifers producing over 18 lbs. butter-fat; and these cows averaged 540.9 lbs. milk, 
containing $19.75^{\mathrm{S}}$ lbs. butter-fat, showing an average of 3.65 per cent fat. Eighty-three H.-F. cows and heifers have made 3o-day official records exceeding 72 lbs. butter-fat, of which 24 made from 72 to 76 lbs.; 27 , from 76 to 80 lbs.; I 8 , from So to 85 lbs.; 6, from 85 to 90 lbs.; 6, from 90 to Ioo lbs.; I, from IoO to I IO lbs.; and I made over I Io lbs. of butter-fat.

A few H.-F. cows have been officially tested for longer periods; and one cow produced in roo days over $2 S_{+}$lbs. fat, while a heifer under three years of age produced over $227 \mathrm{lbs}$. in the same length of time. At the Wo-ld's Fair at St. Louis, where three Missouri H.-F. breeders pitted their individual herd against the pick of the Jersey world, one H.-F. cow produced over $2 S_{2}$ lbs. fat in 20 days, surpassing the foremost Jersey by over two pounds; and since then a H.-F. cow has produced officially over 3 I 6 lbs. fat in the same time. One H.-F. cow has produced over 453 lbs. fat in I $S_{2} \frac{1}{2}$ days, while another produced over $72 \mathrm{I}$ lbs. fat in one year. This last was owned by the Michigan Agl. College. Prof. Oscar Erf, Kansas Agl. College, writes that one of their H.-F. cows has produced nearly I $6,000 \mathrm{lbs}$. of milk in one year, testing from 3.2 to 3.7 per cent fat, and that at the end of the year she was still giving from 25 to 30 lbs. milk per day; while Prof. A. L. Haecker, Nebraska Agl. College, states that a heifer calving at just past three years has given in 39 weeks I $_{5}, 063.9$ lbs. milk, containing +92.05 lbs. butter fat, and that she was still giving 45 lbs. milk per day, with 13 weeks before her in which to complete the year's record. A heifer, calving at just past three years of age, in semi-official test under the rules of the Wisconsin Exp. Station, produced in one year, I3,2 I3.6 lbs. milk containing $58_{4} .080$ lbs. butter-fat. Many H.-F. cows have made very large private records; but it is not the practice of the H.-F. Association to report private records.

It has been asserted by some persons illy posted as to the facts, that while H.-F. cows did yield large quantities of milk, the milk was below standard in quality. Ten gallons of milk per day, by weight $\delta_{4}$ lbs., might be considered more than any cow could ever produce; yet under the strictest official test 40 H.-F. cows have yielded in excess of $58 S$ lbs. in a period of seven consecutive days. This herd of to cows, of which some were not of full age, produced in a period of seren consecutive diys 25.032.2 11 s. milk, containing 821.497 lls.s. lutter-fat; thus showing an alverage 
of 3.28 per cent fat. The average for each cow was 625.8 lbs. milk, containing 20.537 lbs. butter-fat, equivalent to 89.4 lbs. milk (over $10 \frac{1}{2}$ gallons) per day, and nearly $2+1 \mathrm{lbs}$. of commercial butter per week. After such proofs of large production of both butter-fat and of milk, and showing that even in the largest yields of almost incredible amounts of milk the content of butterfat was to per cent in excess of the usual legal requirements, further comment would seem unnecessary.

Owners and breeders of Holstein-Friesian cattle base their claims for the superiority of this breed over all other dairy breeds mainly on the following points: First, that the Holstein-Friesian is a lirge, strong, vigorous cow, full of energy and abounding in vitality; second, that her physical organization and digestive capacity are such that she is able to turn to the best advantage the roughage of the farm, converting the same into merchantable products; third, that she yields large quantities of most excellent milk, fit for any and all uses, and especially well fitted for shipping purposes; fourth, that heredity is so firmly established through her long lineage that she is able to perpetuate herself through the production of strong, healthy calves; and fifth, that, when for any reason her usefulness in the dairy is at an end, she fattens readily and makes excellent beef.

\section{Ayrshires.}

By C. M. Winslow, Brandon, Vt., Secretary Association of Ayrshire Breeders.

The original home of the Ayrshire cow is in Scotland, in the county of Ayr. This county has always bcen noted for its dairy industry and the thrift of its inhabitants. The soil is strong, giving good pasturing and abundant crops, the climate is rough, and people and cattle hardy.

The Ayrshires began to attract the attention of dairymen in other parts of the world some sixty years ago, and there was an importation made into Canada and the New England States, where they are bred in considerable numbers and highly prized. They have been sent South, and are said to endure the heat better than any other breed. They also are said to stand the cold of Canada better than any other dairy breed.

The Ayrshire cow is of medium size, weighing about one thousand pounds, of blocky build, low on legs, and usually 
spotted in color, being red and white as a rule, though sometimes nearly red or nearly white. They are hardy and healthy, enduring changes of heat and cold with little discomfort, and quickly adapt themselves to surrounding conditions. They perhaps show to the best advantage where the food-supply is limited and they are compelled to hunt for a full supply.

It is claimed for the cows of this breed that they will give the largest return of dairy product for food consumed of any of the dairy breeds. There has never been much said or done by the owners of Ayrshires to bring their merits to the attention of the public. They are a popular cow for the milkman, because they are economical producers and give milk of good quality that satisfies the trade.

High-grade Ayrshire cows always command the highest fancy price in Brighton, to go into the stables of milk producers. It is said by the milk inspectors of Boston that they have no trouble with the milk from Ayrshire herds, it being up to the I 3 per cent total solids required by Massachusetts law.

The average yield of Ayrshire cows is a little over $6000 \mathrm{lbs}$. of milk in a year, on ordinary dairy food and care, but there are a large number of individual cows with authenticated records all the way from $7000 \mathrm{lbs}$. to over $12,000 \mathrm{lbs}$. of milk in a year.

It is only within a very few years that the Ayrshire Breeders' Association instituted a system of official tests, and only a few of the breeders have entered their herds, consequently we have the records of a comparatively small number of cows, but enough to show that the Ayrshire cow is by nature a wonderful dairy cow both in milk and butter production, and that it would be an easy matter to produce families of phenomenal cows adapted to the production of either butter or milk.

The association has confined itself chiefly to the yearly tests, believing that it is the long period that shows the staying quality of the breed and the true value of a dairy cow.

We have in the ordinary work of the dairy found a number of cows that gave from fourteen to nineteen pounds of butter in seven days, and from sixty to nearly roo pounds in the month.

Ve have compiled from the official files of the association tests the following yields from inclividual cows:

Milk. -78 cows gave over 8000 lbs. of milk in a year; 5 I cows gave over $8500 \mathrm{lbs}$. of milk in a year; 43 cows give over $9000 \mathrm{lbs}$.

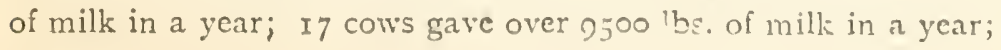


I4 cows gave over 10,000 lbs. of milk in a year; 7 cows gave over I0,500 lbs. of milk in one year; 6 cows gave over I $\mathrm{I}, 000 \mathrm{lbs}$. of milk in one year; 4 cows gave over I, $500 \mathrm{lbs}$. of milk in one year; 2 cows gave over 12,000 lbs. of milk in one year; I cow gave over I $2,500 \mathrm{lbs}$. of milk in one year.

Butter.-ISI cows gave over 300 lbs. of butter each in one year; 87 cows gave over $35^{\circ} \mathrm{lbs}$. of butter each in one year; 33 cows gave over $400 \mathrm{lbs}$. of butter each in one year; I 3 cows gave over $45^{\circ}$ lbs. of butter each in one ycar; 5 cows gave over $500 \mathrm{lbs}$. of butter each in one year; I cow gave nearly $55^{\circ} \mathrm{lbs}$. of butter in one year; I cow has for the last five consecutive years dropped five calves and given an official record of 52,000 lbs. milk and 2 I 30 lbs. butter.

The Ayrshire, being a clairy cow, has never been claimed for beef or even for a general-purpose cow, but her easy keepingqualities and hardy disposition cause her to lay on flesh rapidly when dry, and she will probably return to her owner in beef the full cost of raising her. Farmers who fatten calves for veal tell me the calves are small when born, but grow rapidly, so that when of age to sell they are large and heary for their age and are good handlers.

\section{Shorthorns as Damy Cows.}

By the late J. H. Pickrell, Springfield, I11., Secretary American Shorthorn Breeders' Association.

Away back in the early history of this country, there were occasionally cows imported from England. Buffalo and wild game were abundant for meat, but milk, butter, and cheese did not come that way.

As creatures of circumstances, cows were in demand. Soon after the Revolutionary War, cattle that were purebred Shorthorns were imported into Virginia, and afterwards, in 1797 , found their way into Kentucky. The cows were said to be great milkers, and are reported to have given as much as 32 quarts of milk per day, and were called by the natives "the milk breed." Later importations with more particular reference to their beef qualities were made, but, in spite of all that had been fed into them with that end in view, many of the cows developed into remarkably heavy milkers, and were very noted for their large yield of a good quality of milk.

The late L. F. Allen, in his history of "American Cattle," published in IS6S, says: "TWe have numerous well- 
authenticated instances of their (Shorthorns) giving six, seven, eight, and even nine gallons a day, on grass alone, in the height of their season, and yielding fourtcen to eighteen pounds of butter per week, and of holding out in their milk in proportionate quantity, as well as other breeds of cows, through the year. Cows so much larger in size than other kinds should be expected to give more than smaller ones that consume less food, and without asserting that they do give more, in proportion to their size, it is claimed that when eacated and used for the dairy chiefly, they give quite as much as others. That the inherent quality of abundant milking exists in the Shorthorns, no intelligent breeders of them need doubt. Our own observation in more than thirty years' experience with hundreds of them, first and last, under our own eyes, is to ourself evidence of the fact, both in thoroughbreds and grades."

The Columbian dairy tests, though made under unfavorable circumstances, proved the milking qualities of Shorthorns. I say unfavorable, because the matter was not taken hold of soon enough by the American Shorthorn Breeders' Association, under whose auspices the exhibit was made, to select the best cows in every instance so as to have them bred to produce and have them at their highest flow of milk at the proper time. As a consequence, cows had to be picked up that had produced at hap-hazard, and were not in every instance the best that might have been used, if selections had been made in season to have them bred so as to have them produce just prior to the tests. But with all these disadvantages, the two strictly acknowledged dairy breeds-bred for that purpose almost exclusively-which were selected with the greatest care, so much so that it is doubtful whether they could be duplicated, had but little the adrantage of the Shorthorns in the general "round-up," as a few comparisons will prove.

In test No. I (cheese), with 25 cows of each bieed the score stood as follows:

Jerseys................... 906.r points

Shorthorns............... 905.5

Guernseys................. S7r.9 
In the score for perfection of roo points flavor was counted 55 points.

Shorthorns headed the list by taking 504.3 points.

Jerseys................... 497.8

Guernseys................ 4 sg.t is

The cost of production was:

Shorthorns................ \$99.36

Jerseys.................... 98.14

Guernseys.................. 76.25

The champion cheese cow of the Jerseys netted..... \$6.97 “ " " " “ “ “

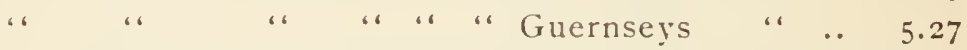

In the second test, 90 days, for butter, loss and gain in live weight, where maintenance was counted against the cows, the net gain was for

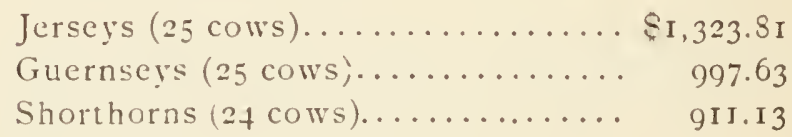

To produce this result it cost the

Jerseys $(25) \ldots \ldots \ldots \ldots \ldots \ldots \ldots \ldots 78.57$

Shorthorns (2t).............. 506.50

Guernseys $(25) \ldots \ldots \ldots \ldots \ldots \ldots \ldots+487.25$

The champion

Shorthorn cow (Nora) produced 3679.8 lbs. of milk. Jersey (Brown Bessie) “ 3634 “ “" “ Guernsey (Materna) “ “ 3548.8 “ “ “ “

When reduced to gain in the products over cost of pro. duction, the account stood as follows :

Jersey cow................. \$73.22

Guernsey cow................ 57.82

Shorthorn cow................. 52.63

$\Lambda$ gain, in tests 2.3 , and + (Guernseys were not in test $\mathrm{No} .4$ ) the three best Shorthorns ione in each test, including the two-year-old heifer) gave..... 556r lbs. While the Jerseys of the sane description gave.. 5330

Showing in favor of Shurthorns.......... 53 I 
In test No. 3 (butter), "go as you please," The champion Jersey cow at a cost of $\$ 8.57$ pro-

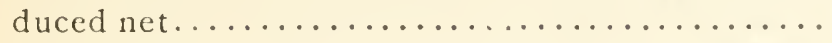

The champion Shorthorn cow at a cost of $\$ 8.18$

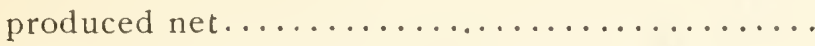

The champion Guernsey cow at a cost of $\$ 5.57$ produced net..................... \$19.37

In test No. 4 (heifers) 7 Jerseys cost for food $\$ 34.43$

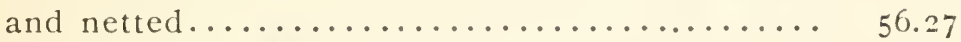

6 Shorthorns cost $\$ 23.52$ and netted........ 47.42 making an average of 13 cents per head in favor of the Jerseys.

While butter was rated by points, beef was not, and the Jerseys got as much allowance per pound for gain in live weight as the Shorthorns.

As hinted above, dairy cows are not always wanted for butter alone, or cheese alone, but very frequently to supply city customers with good milk for their tables. The tests at the Columbian Dairy School proved that for a large supply of milk of the best flavor, Shorthorns not only were good dairy cows in every sense of the term, but that they led the other two breeds. Therefore, if milk of good quality and lots of it is wanted, Shorthorn cows can supply it, to say nothing of their "general-use" qualities that will just suit the farmer who wants milk, butter, cheese, and beef.

\section{Red Polled Cattle.}

By the late J. McLain Surtir, Daytom, Ohi,, Secretary Red Polled Cattle Club of America**

Hornless or polled cattle have existed in the counties of Norfolk and Suffolk, England, from time immemorial. Originally there were two distinct types: the Suffolks, usually of a pale red or dun color, and hence known as Suffolk duns-large and rather rough cattle, but celebrated for their milking qualities; and the Norfolks, commonly deep red in color, smaller, finer, more compact in build, not so large milkers, but great favorites with the butrher. 
Youatt, speaking of the old Suffolk strain as it existed in his day (some half century ago), says: "In the height of the season some of these cows will give as much as eight gallons of milk (So lbs.) in a day, and six gallons (6o lbs.) is not an unusual quantity."

The modern Red Polled cow is a result of the combina. tion of these old strains, and it is the aim of the most progressive breeders to produce a cow of medium size, bloodred in color, of fine bone, smooth and compact of form, hardy, docile, fatting easily, and giving a good flow of fairly rich milk all the year round. The breed, in other words, is being developed as a general farm cow, suited to the wants of the general farmer. While the cows cannot, I think, compete in flow of milk with the best Holsteins, or in yield of butter with the best Jerseys, and the steers have not, as yet, taken a place in the front rank at the fat-stock shows, it is believed that the breed combines the several desirable traits as well at least as any other, and with them the equally essential qualities of hardiness, docility, and a hornless head. As an illustration of the points named, and a proof of their possible combination, the cow No. 2213, Gleaner, V, 9, is credited in 1894 , according to the accepted record of the owner, with a yield of $\mathrm{r}_{4}, \mathrm{ISg} \mathrm{lbs}$. of milk, an average of 3586 lbs. a day for the entire year. The cow was then twelve years old, and was milking with her tenth calf (or tenth calving, as one or more of them produced twins).

Among these is a pair of twins (Freemartins), shown as fat stock, at Norwich and London, England. The steer (Ist and cup at Norfolk and Ist at Smithfield) weighed at I year $5 \frac{8}{4}$ months old, 1238 lbs., and when shown again, at 2 years 6 months old, had a live weight of 1735 lbs., a gain in a few days over a year of 497 lbs., and a gain from birth of about 2.I2 lbs. a day. The heifer, twin to above (Ist and reserve for cup at Norfolk and Ist and reserve for cup at Smithfield), had a live weight when shown (2 years 6 months old) of 1452 lbs., a gain from birth of nearly r.s lbs. a day. 
An illustration nearer home is reported by Dr. J. R. Slingerland, Trustee of the Shaker Society at Union Village, O. In January, I895, he bought 35 head of Shorthorn steers, coming 2 years old, for feeding. At the same time they had 18 head, the same age, of their own breeding, the produce of a Red Polled bull on Shorthorn cows. At the time named the full-blood Shorthorns averaged 940 lbs. in weight, and the cross-breds $790 \mathrm{lbs}$. All were pastured the summer of $\mathbf{1} 895$, fed out in the late fall, and sold to the same buyer on the same day in January, 1896 .

The full-blood steers consumed an average of $8_{5}$ bushels of corn, besides hay and corn-fodder, in fatting, and weighed when sold an average of 1540 lbs. each-a gain of 600 lbs. in the year. They sold for $\$+4$ hundred. The polled crossbreds consumed an arerage of 50 bushels of corn, with corn-fodder only for roughage, and weighed when sold an average of 1492 lbs. - a gain in the year of 702 lbs. They sold for $\$ 4.25$ a hundred.

The Red Polled bull, Osman $125 \mathrm{I}$, used in producing the cross-bred steers in this trial, is the son of a full sister to Eleanor, and is the sire of many fine dairy cows.

In appearance the Red Polls greatly resemble Devons, save the horns, and except that they are somewhat larger, and the cows, as a rule, are better milkers. They have the same rich color, fine bone, round, smooth, compact form, free from prominent points, and the same muscular habit and active disposition; and their meat is of the same finegrained, juicy character.

Milking Qualities. - The modern Red Polled cow does not milk so largely as the old Suffolk, but her milk is of better quality. Sixty pounds a day, which Youatt says in his time was not unusual, is now, I think, somewhat rare. Four and a half to five gallons a day, or say 40 to $45 \mathrm{lbs}$, is a good yield from a mature cow in the flush of the season. But she will easily give, with proper care, 6000 to 8000 lbs. in a year, and some will considerably exceed this. In the report of English herds, published in the Red Polled Herd Book, the average yields of mature cows in the best herds is fiom 5000 to over 7000 lbs, a year. In Lord Rothchild's 
herd, 22 cows, seven milking with first or second calf, gave in 1995 an average of $7744 \frac{1}{2} \mathrm{lbs}$. of milk each. In my own little herd the mature cows will average over 6000 lbs. of milk a year and 4 per cent of fat.

Beef fualities. - In this line, so far, we are entirely dependent for facts on the English records. No full-blood steers of the breed have as yet been shown in this country. A few samples will suffice. At the Smithfield Club Show in I859, two Red Polled steers, two years old, showed the largest daily gain of anything on exhibition that old-2.18 lbs. and 2.29 lbs., respectively. At the Smithfield Club Show of $1 \$ 90$ a Red Polled steer dressed the highest per cent of his live weight of any animal slaughtered-73.72 per cent. This, according to the London Liz'e Stock Journal, has only once been exceeded in England-by a cross-bred steer, which dressed 74 per cent of his live weight.

At the fat-stock shows in England in IS94 the following live weights were recorded: A steer I year IO $\frac{1}{2}$ months, I 374 lbs., and a year later 1702 lbs. : a steer I year roł months, I323 lbs.; a steer I year IO months, I 208 lbs., and a year later 1656 lbs. ; a steer I year 9 months, I250 lbs., a year later I $725 \mathrm{lbs}$, and at 3 years 9 months $21 \mathrm{I} 2 \mathrm{lbs}$.

Mature Red Polled cows, in breeding condition, should weigh I 200 to I $400 \mathrm{lbs}$., and bulls I 800 to $2000 \mathrm{lbs}$. A few will greatly exceed these weights, but many, as now bred, are smaller. These, however, are about the weights attained in the best herds.

\section{Devon Catthe.}

By L. P. Susson, Wheeling, W. Va., Secretary American Devon Cattle Club.

The Deron breed of cattle is one of the oldest of the English cattle. Their native home is on the highlands of Devonshire, in southwestern England. Our records show that in the year ISoo Messrs. Winthrop \& Davenport imported Devons into Plymouth, Mass.; in ISo 5 General Eaton imported some into Otsego county, New York; in ISI M Mr. George Patterson came into possession of some Derons, brought over by T. W. Coke, who presented them to a 
brother of George Patterson; these afterward were the foundation of the above-mentioned herd (George Patterson of Sykesville, Md.). These and other animals imported by Mr. Patterson, our records show, were all brought from Devonshire, and from the best that could be found there.

Others were imported into New York State; among importers whom we might mention are John Cowlin of Truxton, N. J.; L. F. Allen, Miles Vernon, A. Becket, W. P. \& C. S. Wainwright, Col. L. G. Morris, D. W. Catlin, W. R. Sanford, J. Iloward McHenry of Pikesville, Md.; C. P. Halcomb of Delaware, and others. Later importations are by James Murray of Virginia, R. W. Cameron of New York, Frank Brown of Baltimore, Mid., and still later John Hudson, Moweaqua, I11., Dr. J. Cheston Morris, Philadelphia, Pa., and A. S. Worden, Ulysses, Pa.

As to the beef qualities of the Devons one only has to turn to the records of the markets of the country to see that they are among the leading beefers, bringing the top prices at all times. As to milk and butter production from Devons, it will be found from records that they produce from 12 to $25 \mathrm{lbs}$. of butter per week. Mr. A. E. Baker, of Wisconsin, says his cows average him 365 lhs. of butter per cow for the year, which is about as much as any breed will do on farmers' feed and care. Dr. J. Cheston Morris says, in regard to Devons for milk: "A herd of Devons may be relied upon to give an annul yield of 2000 quarts of milk from each cow; the length of the period averages between Io and I months, though single cows will continue in profit from 13 to 14 months. An average yield of seven quarts daily from each cow may therefore be expected, and an examination of milk records of Devon herds will show that they are remarkably uniform in their yields. As comparatively little attention has been paid to their milking qualities, a large improvement may be looked for by proper selection and breeding. As my animals weigh ouly 700 lbs. cach, it follows that each cow has given between five and six times her own weight in milk during the course of the year, besicles naintaining her own 
weight, and producing healthy offspring. This I consider a physiological fact well worthy of notice, and very creditable to the 'little red cow.' Of course the same. nutritive power applied in other directions would give beef-producing results, such as we all know of."

Devon cattle are active and very hardy, qualities that make them especially valuable in dry or mountainous regions. The bulls are quite intelligent and active, and are not as liable to be cross as some other breeds; they weigh from I 800 to $2000 \mathrm{lbs}$. at three to four years old. The cows have strong vital organs, and large digestive and assimilating powers. Their udders are not large for the amoun: of milk they give, with good elastic teats, seldom sore. The milk is of good quality, either as food for infants and invalids, for the inanufacture of butter or cheese, or for market delivery; it does not churn in the cans, nor look blue in the bottle.

Devons will pay their way at the dairy as well as in the feeder's stable; they will keep in good condition, and look plump and sleek on pasture that other breeds can hardly live on; they are easy keepers, good producers of the finest kind of milk, and also make the very best quality of beef.

\section{Vili. Dutch Belted Cattle.}

By H. B. Richards, Easton, Penna., Secretary Dutch Belted Cattle Assn. ciation of America.

Dutch belted cattle are natives of Ilolland, and originaterl in that country during the seventeenth century, when the cattle interests of Holland were in the most thrifty condition; in fact, it was the chief industry of the country. At that time breeding had been developed to a science, and cattle of remarkable contrast of color were bred whose foundation color was black, with a broad white band around the centre of the body, a white head, a black ring around each eye, and a full white tail. Wonderful and remarkable as it may appear, a feat was accomplished during that period that would defy our modern breeders and can be safely classified as a iost art.

Dutch belted cattle became a classified breed and were 
bred to a remarkably high standard. For several centuries they were owned and controlled by the nobility keeping them pure and limiting their number to their ownership. They were first imported into this country about the middle of the present century, the importers procuring the finest herds in Holland; the herds in the United States to-day are purely of American breeding.

The American Association have adopted as their standard of color a pure black, with a continuous white belt around their body, beginning behind the shoulders and extending nearly to the hips; this sharp contrast of colors makes a beautiful and imposing contrast and a most beautiful sight; when seen in number grazing on the green, they are admired by all, even if not interested in cattle or farming. This belt is almost invariably reproduced, and is so perfectly fixed that it will crop out in their grades for many generations, even against cold strains of blood; the potency of this feature is very striking, as the belt is often reproduced after the foundation color is lost; and grades of any foundation color can be produced to an unlimited extent.

Their form is a strong characterized dairy type, medium size, and possessing all the qualifications of an ideal dairy animal. They are strictly a dairy breed, and are large and persistent milkers; strong constitutions, peaceable and quiet dispositions of a very compact form. Cows range from eight to twelve hundred, and bulls reach eighteen to twenty hundred. The late P. T. Barnum, the showman of national fame, said: "They struck my tancy in Holland about I850; I imported a few, and then found their unique and novel appearance not their only 'quality, for they proved to be wonderful milkers, far superior to any other cattle to which my attention has been drawn."

Nearly all the herds now in the United States are owned in New York, Pennsylyania, and Massachusetts, with a few scattering South and West. A herd of eighteen were exhibited at the World's Columbian Exposition at Chicago, where they attracted great attention and were admired by thousards who had never heard of such novel and beatifu! 
cattle before. This herd was sold and exported to a wealthy resident of the City of Mexico, where they are now kept and are doing well in that congenial climate. There is an association of breeders of these cattle known as the Dutch Belted Cattle Association of America, who have adopted a high standard of excellence, requiring breeders to breed typical animals of correct markings, thereby gaining uniformity and correctness of type. The association issues a herd-book, of which vol. Io of recent issue, is the last number.

\section{Brown-Swiss Cattle.}

By N. S. Fisu, Groton, Conn., late Secretary Brown-Swiss Cattle Breeders' Association.*

Brown-Swiss cattle were first imported into this country by Mr. Henry M. Clarke of Belmont, Mas`., in $\mathbf{r} 869$. He imported seven cows and one bull; since then there have been several importations. Most of the animals have come from the famed Canton of Schwyz, and the adjacent Cantons of Zug, Uri, and Unterwalden. The Rigi mountains, covered to their tops with fine, rich herbage, lie here, and some of the finest breeds of cattle in the whole country are here produced, the cattle grazing in the valley in winter and on the mountains in summer.

The United States consul at Zurich in I\$S2 made a report to our government of the cattle and dairy interest of Switzerland. He writes: "For a hundred years Switzerland has been famous for the production of its dairies. Ait the cattle show of Paris, I878, every Swiss cow exhibited bore away a prize in competition with exhibits from Holland, England, Denmark, and other famous cattle countries.

The Brown-Swiss cattle are fed on grass or hay only the year through. A fair average for cows in Canton Zurich is ten quarts of milk per day the milking-year through; in Schwyz and Zug the average is but little less."

The consul of St. Gall says: "When a farmer in Germany, Italy, or France wishes to improve his breed, he

* Revised by C. D. Nixon, Secretary, Owego, N. Y. 
makes a selection from Swiss herds as the healthiest and hardiest known to the herd-book. . . The BrownSwiss is cons:dered the dairy breed par excellence of Switzerland; it not only gives more milk, but this is richer than any other European breed of cattle."

Marked Characteristics.-Size large; form firm; color shades from dark to light chestnut brown. The tuft of hair between the horns, on the inside of ear, and a narrow line along the back generally light. Horns rather short, waxey, with black tips. Nose black, with mealy-colored band surrounding nose. Switch, hoofs, and tongue black. Straight hind legs, wide thighs, and heary quarters. The cows often weigh I600 lbs., bulls 2000 lbs. Calves large, some weighing r Iolbs. when dropped. They mature fast, have healthy constitutions, yielding generous returns for whatever care, time, labor, or money is expended on them.

A cow shown at the Chicago Fat Stock Show in November. IS9I, gave in three days $245 \mathrm{lbs}$. of milk, showing $9.32 \mathrm{lbs}$. of butter-fat by the Babcock test, yielding during one day of the test $3 \frac{1}{4} \mathrm{lbs}$. of fat, the largest amount of butter-fat ever shown at an official test of any cow of any breed up to that time. The cow Muotta calved about November I, I893, and in February, I894, gave 67 lbs. of milk in one day.

The milk of Brown-Swiss cows has a sweet flavor which is very noticeable, and makes it very desirable for family use. With good farm care the cows give under favorable circumstances from 20 to 25 quarts of milk perday. They make the finest of beef and veal; when intended to be used for working oxen, they are easily broken and are fast walkers.

The cows are persistent milkers, with good teats; where used to produce grade animals they give the best of satisfaction, with the Swiss characteristics predominating. There are now about 8600 recorded animals in this country. located in almost every State, and some in Mexico. 


\section{YIELD OF MLK AND FAT FROM DAIRY COWS.}

A good dairy cow should give at least 5000 pounds ot milk during a whole period of lactation. As the quality or milk given by different cows varies greatly, however, as will be apparent from the tables given in the following, the yield of fat produced during a lactatior period is a better standard to go by than that of the milk; three-fourths of a pound of tat per day for an average of 300 days may be considered a good yield (total 225 pounds). Many dairy farmers aim to have all mature cows in their herds produce a pound of fat, on the average, for every day in the year. To do this, a cow whose milk tests about 4 per cent. must give 25 pounds of milk a day ( 3 gallons) as an average for the whole year; a cow producing 3 per cent milk must give $33 \frac{1}{3}$ pounds of milk daily, and one producing 5 per cent milk must yield 20 pounds of milk daily, on the average, etc.

The flow of milk is usually at its highest shortly after calving, and then gradually decreases, the rate of decrease being determined by the inbred milking qualities of the cow and the system of feeding practised. The average decrease in milk yield for good dairy cows on good feed is from one half to three fourths of a pound per head per ten days. Where cows are not fed liberally and receive but little concentrated feed, the decrease will be more marked, and often exceed one pound of milk per head per ten days. The decrease is more marked during the latter stages of the period of lactation than in the earlier ones, and is also more marked in cows with poorly developed milking qualities than in good dairy cows. A cow is considered at her best when from five to seven years old; the constitutional strength of the animal, the system of feeding practised, and the general treatment given the cow will determine her period of usefulness.

The quality of the milk produced by individual cows generally remains fairly uniform through the greater portion of the lactation period, and is not permanently influenced in any marked manner by feed or any external conditions. During the last couple of months, when the 
yield of milk is decreasing mort rapidly than before, the quality is generally improved to some extent, the variation being, as a rule. within I per cent. Variations of several per cents of fat may sometimes occur from day to day, or milking to milking, in the milk from single cows; variations amounting to $I$ per cent are common. Herd milk varies much less, the percentages of fat on subsequent days being as a rule within two tenths of one per cent, and only exceptionally near one per cent.

\section{RESULTS OF TESTS OF DAIRY BIEEDS}

Conducted by American Agricultural

Experiment stations.

\begin{tabular}{|c|c|c|c|c|c|c|c|c|}
\hline \multirow{2}{*}{ Breed. } & \multirow{2}{*}{ 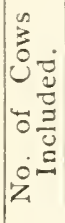 } & \multirow{2}{*}{ 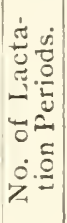 } & \multicolumn{2}{|c|}{$\begin{array}{c}\text { Average } \\
\text { Yields per } \\
\text { Lactation } \\
\text { Period. }\end{array}$} & \multirow{2}{*}{ 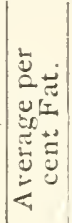 } & \multicolumn{3}{|c|}{ Average Cost of } \\
\hline & & & Milk. & Fat. & & $\begin{array}{c}\text { Food } \\
\text { Eaten } \\
\text { per Day. }\end{array}$ & $\begin{array}{l}\text { Produc- } \\
\text { ing roo } \\
\text { lbs. Milk. }\end{array}$ & $\begin{array}{l}\text { Produc } \\
\text { ing I lb. } \\
\text { Fat. }\end{array}$ \\
\hline 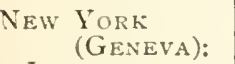 & & & lbs. & lbs. & & cents & cents & cents \\
\hline Jersey ...... & 4 & II & 5045 & 282.1 & 5.60 & 12.4 & 90 & 16.1 \\
\hline Guernsey..... & 4 & 6 & 5385 & 2855 & $5 \cdot 30$ & 12.5 & 86 & 16.1 \\
\hline Holstein ..... & 4 & 4 & 7918 & 266.1 & $3 \cdot 3^{i}$ & +3.9 & 65 & 19.1 \\
\hline Ayrshire...... & 4 & 12 & 6824 & 244.8 & 3.60 & 13.5 & 74 & 20.2 \\
\hline Sliort Horn... & I & 2 & 6055 & 269.0 & $4 \cdot+4$ & 12.7 & 78 & 17.2 \\
\hline $\begin{array}{l}\text { Devon } \\
\text { American Hoj-... }\end{array}$ & 3 & 5 & 3984 & $183 \cdot 3$ & 4.60 & 10.3 & 94 & 20.5 \\
\hline $\begin{array}{l}\text { derness....... } \\
\text { Ma1nis: }\end{array}$ & 2 & 4 & 5721 & 213.1 & $3 \cdot 73$ & 12.2 & $7^{6}$ & 20.1 \\
\hline Jersey......... & 2 & 4 & 5460 & 297.0 & 5.50 & 16.2 & I I 3 . & 20.4 \\
\hline Holstein....... & 2 & 3 & 8369 & 285.0 & 3.47 & 19.5 & 85.2 & 25.2 \\
\hline $\begin{array}{l}\text { Ayrshire....... } \\
\text { NEw Jersey: }\end{array}$ & 2 & 4 & 6612 & 233.0 & 3.67 & 17.1 & $94 \cdot 9$ & 26.8 \\
\hline Jersey ......... & 3 & 3 & 7695 & $376 \cdot 3$ & 4.89 & 16.1 & 87.1 & 17.9 \\
\hline Guernsey ..... & 4 & 4 & 7446 & 379.0 & 5.09 & 14.9 & 78.1 & $15 \cdot 3$ \\
\hline Holstein...... & 3 & 3 & 8455 & 300.2 & $3 \cdot 55$ & $19 \cdot 3$ & $79 \cdot 3$ & 22.4 \\
\hline Ayrshire....... & 4 & 4 & $7+6 \mathrm{I}$ & $275 \cdot 3$ & 3.69 & 15.0 & 76.0 & 20.6 \\
\hline Short Horn... & 3 & 3 & 10457 & $396 \cdot 3$ & 3.79 & $15 \cdot 4$ & 79.2 & 20.6 \\
\hline
\end{tabular}

Averages for all Breeds and Lactation P'riods.

\begin{tabular}{|c|c|c|c|c|c|c|c|c|}
\hline Jersey $\quad \ldots \ldots \ldots$ & 9 & I 8 & 5579 & 301.1 & $5 \cdot 40$ & 13.9 & $94 \cdot 7$ & 17.4 \\
\hline Guernsey ........ & 8 & 10 & 6210 & 3229 & 5.20 & 13.5 & 82.8 & I5.8 \\
\hline Holstein........ & 9 & 10 & $82 \div 5$ & 282.0 & $3 \cdot 43$ & 17.2 & $74 \cdot 7$ & 21.5 \\
\hline Ayrshire........ & ro & 20 & 6909 & 248.5 & 360 & 14.5 & 78.5 & 21.5 \\
\hline Short Horn...... & 4 & 5 & 8696 & $345 \cdot 4$ & 3.97 & $14 \cdot 3$ & 78.7 & $19 \cdot 4$ \\
\hline Devon ........... & 3 & 5 & 3984 & $183 \cdot 3$ & 4.60 & 10.3 & 94.0 & 20.5 \\
\hline derness ........ & 2 & 4 & 5721 & $213 \cdot 1$ & $3 \cdot 7.3$ & II. 2 & & 20.1 \\
\hline Total ........ & 45 & 72 & & & & & & \\
\hline
\end{tabular}


The animals included in the foregoing breed tests rank on the average as follows:

I. As to yield of fat: Shorthorn, Guernsey, Jersey, Holstein, Ayrshire, American Holderness, Devon.

2. As to cost of producing I lh. of fat: Guernsey, Jersey, Shorthorn, American Holderness, Devon, Holstein and Ayrshire.

3. As to yicld of milk: Shorthorn, Holstein, Ayrshire, Guernsey, American Holderness, Jersey, Devon.

4. As to cost of prolucing ino liss. of milk: Inolstein, American Holderness, Ayrshire, Shorthorn, Guernsey, Devon, Jersey.

5. As to cost of fool: Devon, American Holderness, Guernsey, Jersey, Shorthorn, Ayrshire, Holstein.

6. As to richness of milk: Jersey, Guernsey, Devon, Shorthorn, American Holderness, Ayrshire, Holstein.

\section{RESUITS OF MRLIA TESTS CONIDCTEID AT WORLD'S COLUMBIAN EXPOSITION, 1893.}

A. Breed Tesi No. 1 (Cheese Test), May zo to 25.

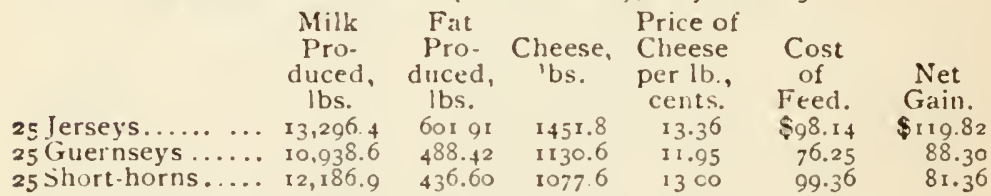

B. Breed Test No. 2 (Ninety.day Butter Test), Jure I to Aug. 29.

Butter Price of credited liutter.

$\begin{array}{llllllrr}25 & \text { Jerseys.......... } & 73,488.8 & 3516.08 & 4274.01 & \$ 17+7.37 & \$ 587.50 & \$ 1323.81 \\ 25 & \text { Guernseys ..... } & 61,781.7 & 2784.56 & 3360.43 & 1355.44 & 484.14 & 997.64 \\ 24 \text { Short-horns..... } & 66,263.2 & 2409.97 & 2890.87 & 1171.77 & 501.79 & 910.12\end{array}$

AVERAGES PER DAY PER COW.

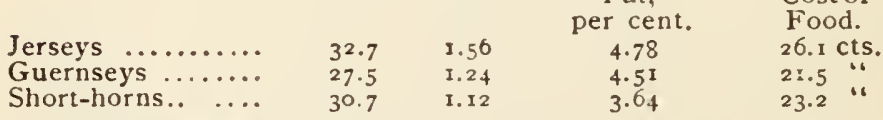

C. Breed Test No. 3 (Thirty-day Butter Test), Aug. 29 to Sept. 28.

Butter Price of credited Butter.

15 Jerseys......... $13,921.9$

$685.8 \mathrm{I} \quad 837.21 \quad \$ 385.59$

15 Guernseys ....... $13,518.4$

597.96

724.17

329.77

\$iri.24

$\begin{array}{rrrrr}597.96 & 724.17 & 329.77 & 92.77 & 237.00 \\ 555.43 & 662.67 & 303.69 & 104.55 & 19889\end{array}$

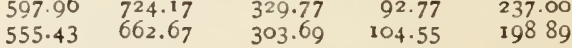

$\$ 274 \times 3$

D. Breed Test No. 4 (Heifer Test), Sept 30 to Oct. 20.

$\begin{array}{lllllll}7 \text { Jerseys. } \ldots \ldots \ldots . & 3356.6 & 155.38 & 194.23 & \$ 77.69 & \$ 34.44\end{array}$

5 Shlort horns...... $2581.0 \quad 97.89 \quad 122.36 \quad 48.95 \quad 23.53$ 
RESULTS OF "COIV DEMONSTRATION" A'T LOUISIANA PURCHASE EXPOSITION, S'T. LOUIS, 1904. (FARRINGTON.)

\begin{tabular}{|c|c|c|c|c|}
\hline & $\begin{array}{l}\text { Brown- } \\
\text { Swiss. }\end{array}$ & $\begin{array}{l}\text { Hol- } \\
\text { steins. }\end{array}$ & Jerseys. & $\begin{array}{l}\text { Short- } \\
\text { horns. }\end{array}$ \\
\hline $\begin{array}{l}\text { Average data for number of cows } \\
\text { milik per day (av. for } 120 \text { days) }\end{array}$ & 5 & 15 & 25 & 28 \\
\hline 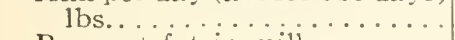 & $44 \cdot 2$ & 53.4 & $41 \cdot 5$ & 34.6 \\
\hline Per cent fat in milk... & 3.62 & 3.43 & $4 \cdot 70$ & 3.80 \\
\hline Butter-fat per day, lbs. ... & I. 596 & I. 832 & 1.936 & 1.277 \\
\hline Solids not fat per day, lbs. . & 3.92 & 4.24 & 3.63 & 2.98 \\
\hline $\begin{array}{l}\text { Feed cost per qt. of milk. cts. } \\
\text { "6 lb butter, cts. }\end{array}$ & $\begin{array}{l}1.24 \\
14.7\end{array}$ & $\begin{array}{l}1.07 \\
13.5\end{array}$ & $\begin{array}{l}1.16 \\
10.5\end{array}$ & 1.32 \\
\hline \multirow{5}{*}{$\begin{array}{l}\text { Data for best cows } \\
\text { Milk per day . lbs. } \\
\text { Per cent fat in milk........... } \\
\text { Butter-fat per day, ibs. } \ldots \ldots \\
\text { Solids not fat per day lbs. . }\end{array}$} & & & & \\
\hline & 51.0 & $67 \cdot 5$ & 48.4 & 43.4 \\
\hline & 3.4 & $3 \cdot 5$ & 4.8 & 4.0 \\
\hline & I. 748 & 2.355 & 2.334 & I. 737 \\
\hline & $4 \cdot 36$ & 5.17 & $4 \cdot 36$ & 3.72 \\
\hline
\end{tabular}

\section{HIGHEST RECORD FOR YIELD OF BUTTER-FAT}

During Twenty-four Hours Made by any Cow in is, Public Test.

\section{At a Fair.}

Brienz, Brown-Swiss, i I years old, weighing I 395 lbs.

Average daily yield of milk. ........ $8_{1.7}$ lbs.

Average daily yield of fat........... 3.r r " Average percent of fat in day's milk..... $3.8_{\mathbf{I}}$ (American Dairy Show, Chicago, I 89 I ; 3-day test.)

\section{At Home.}

Dekol IT atkop Wayne 2d, No. 58,709 , H. - F. H. B.

Yield of milk. ..... 70.7 lbs.

“ " fat ...... 4.77 "

Average per cent of

fat in day's milk . . 6.75

(Mareh I-2, 1 gos. 7-day test, Feb. 29-Mar. 7, I 908 , conducted by the Cornell Univ. (N. Y.) Experiment Station; total yield for week, ${ }_{4} 84.5$ lbs. milk and 23.005 lbs. fat; average per cent of fat in milk, $4.7 \%$ ); test commenced 6 days from last calving; age of cow, $c$ years ro months). 


\section{OFFICLAL RECORDS FOR MILK AND BUTTER-FAT} PRODUCTION.

\begin{tabular}{|c|c|c|c|c|}
\hline Breed. & Year. & Thirty Days. & Seven Days. & $\begin{array}{c}\text { Twenty-four } \\
\text { Hours. }\end{array}$ \\
\hline (A) MILK & & & & \\
\hline Ayrshire...... & $\begin{array}{c}\text { Auchenbrain } \\
\text { Brown Kate } \\
4 \text { th, } \\
23.022 .0 \text { lbs. }\end{array}$ & $\begin{array}{l}\text { Same, } \\
2322.9\end{array}$ & $\ldots \ldots \ldots$ & $\ldots \ldots$ \\
\hline Brown Swiss.. & $\begin{array}{c}\text { College Bra- } \\
\text { vura } 2 \mathrm{~d} \text {, } \\
2577 \\
\text { ro. } 460.6 \mathrm{lbs} .\end{array}$ & $\ldots \ldots \ldots \ldots$ & $\ldots \ldots \ldots \ldots$ & $\ldots \ldots \ldots$ \\
\hline Guernsey..... & $\begin{array}{c}\text { May Rilma } \\
22,76 \mathrm{I} \\
\mathrm{I9}, 673.0 \mathrm{lbs} .\end{array}$ & \begin{tabular}{|c} 
Murne Cowan \\
19.597 \\
2361.5 lbs.
\end{tabular} & $\begin{array}{l}\text { Same. } \\
56.4 .8 \mathrm{lbs} .\end{array}$ & $\begin{array}{l}\text { Same. } \\
82, \mathrm{r} \text { lbs. }\end{array}$ \\
\hline Holstein...... & $\begin{array}{c}\text { Pietertje } 2 \mathrm{~d} \text {, } \\
3273 \mathrm{H} \text {, } \\
30,318.5 \mathrm{lbs} .\end{array}$ & $\begin{array}{c}\text { Riverside } \\
\text { Sadie De } \\
\text { Kol Burke, } \\
70,708\end{array}$ & $\begin{array}{l}\text { Same, } \\
902 . \mathrm{I} \text { lbs. }\end{array}$ & $\begin{array}{l}\text { Margie New- } \\
\text { man, } 76.3 \text { I } 2 \\
\text { I36.5 lbs. }\end{array}$ \\
\hline Jersey.. & $\begin{array}{c}\text { Eminent's } \\
\text { Bess, 209,7 I9 } \\
\text { I8,782.9 } 1 \text { bs. }\end{array}$ & $\begin{array}{c}3707.2 \text { lbs. } \\
\text { Hector's } \\
\text { Fairy Belle, } \\
179.909 \\
\text { r6.41.9 lbs. }\end{array}$ & $\begin{array}{c}\text { Jacoba Irene, } \\
\text { I } 46,443 \\
444.1 \text { lbs. }\end{array}$ & $\cdots \ldots \ldots$ \\
\hline Shorthorn.... & $\begin{array}{c}\text { Rose of Glen- } \\
\text { side, } \\
\text { I8,075.2 lbs. }\end{array}$ & $\begin{array}{c}\text { Daisy Oxford } \\
\text { I } 788 \text { lbs. }\end{array}$ & $\begin{array}{c}\text { Rose of Glen- } \\
\text { side. } \\
434 \text {. I lbs. }\end{array}$ & $\begin{array}{l}\text { Same, } \\
62.8 \mathrm{lbs} \text {. }\end{array}$ \\
\hline Red Polled... & $\begin{array}{l}\text { Pear, } 24,888 \\
\text { I3, r6o. I lbs. }\end{array}$ & & $\begin{array}{l}\text { Popsey 3d, } \\
\text { U-43. } 9689 \\
393.25 \text { lbs. }\end{array}$ & $\begin{array}{c}\text { Hera N-6. } \\
3505 \\
63.5 \text { lbs. }\end{array}$ \\
\hline $\begin{array}{l}\text { (B) BUTTER- } \\
\text { FAT RECORDS. }\end{array}$ & & & & \\
\hline Ayrshire..... & $\begin{array}{c}\text { Auchenbrain } \\
\text { Brown Kate } \\
4 \text { th, } \\
917.60 \text { lbs. }\end{array}$ & $\begin{array}{c}\text { Gerranton } \\
\text { Dora 2d, } \\
23.853 \\
\text { I02.04 lbs. }\end{array}$ & $\begin{array}{l}\text { Same. } \\
23.03 \text { lbs.* }\end{array}$ & $\begin{array}{l}\text { Same, } \\
\text { 3.29 lbs.* }\end{array}$ \\
\hline Brown Swiss. . & $\begin{array}{l}\text { College Bra- } \\
\text { vura } 2 \mathrm{~d}, 2577 \\
708.16 \mathrm{lbs} .\end{array}$ & $\ldots \ldots \ldots \ldots$ & $\ldots \ldots \ldots \ldots$ & $\cdots \ldots \ldots \ldots$ \\
\hline Guernsey..... & $\begin{array}{c}\text { May Rilma, } \\
22,76 \text { I } \\
\text { I073.4 I lbs. }\end{array}$ & $\begin{array}{l}\text { Same, } \\
\text { ro3.03 lbs. }\end{array}$ & $\begin{array}{l}\text { Same, } \\
24.4 \text { lbs. } t\end{array}$ & $\begin{array}{c}\text { Golden Elsie } \\
2 \mathrm{~d}, 33,422 \\
3.70 \mathrm{bs} .\end{array}$ \\
\hline Holstein..... & $\begin{array}{c}\text { Banostine } \\
\text { Belle de Kol, } \\
90,44 \mathrm{I}\end{array}$ & $\begin{array}{l}\text { K. P. Pon- } \\
\text { tiac Lass, } \\
\text { I06,8 I } 2\end{array}$ & $\begin{array}{c}\text { Same, } \\
35.34 \text { lbs. }\end{array}$ & $\ldots \ldots \ldots \ldots$ \\
\hline Jersey........ & $\begin{array}{c}\text { I058.34 lbs. } \\
\text { Sophie Igth } \\
\text { of Hood } \\
\text { Farm. } \\
\text { I } 89.748 \\
999 . \text { I } 4 \text { lbs. }\end{array}$ & $\begin{array}{l}\text { r37. I9 lbs. } \\
\text { Hector's } \\
\text { Fairy Belle, } \\
\text { r 79,909 } \\
83.63 \text { lbs. }\end{array}$ & $\begin{array}{l}\text { Sophie roth } \\
\text { of Hood } \\
\text { Farm, } \\
\text { r } 89.748 \\
25.44 \text { lbs. }\end{array}$ & $\ldots \ldots \ldots \ldots$ \\
\hline Shorthorn.... & $\begin{array}{c}\text { Ruth 3d, } \\
20,440 \\
706.63 \text { lbs. }\end{array}$ & $\begin{array}{l}\text { Rose of } \\
\text { Glenside, } \\
63.45 \text { lbs. }\end{array}$ & $\ldots \ldots \ldots$ & $\ldots \ldots \ldots$ \\
\hline Red Polled... & $\begin{array}{l}\text { Pear. } 24.888 \\
603.66 \text { lbs. }\end{array}$ & $\begin{array}{l}\text { Same, } \\
68.85 \text { lbs. }\end{array}$ & $\begin{array}{l}\text { Nina, } 26,7 \text { Io } \\
\text { I } 7.80 \mathrm{lbs} .\end{array}$ & $\begin{array}{c}\text { Hera, } \mathrm{N}-6, \\
3505 \\
3.86 \mathrm{lbs} .\end{array}$ \\
\hline
\end{tabular}

* Aver. production calculated from 30-day record.

+ Tied with Murne Cowan, I9,597. 
RESULTS OF ENGLISH MILKING TRIALS.

(Averages of breed-tests conducted at the annual dairy shows of the British Dairy Farmers' Assoc., 1879-98, inclusive.)

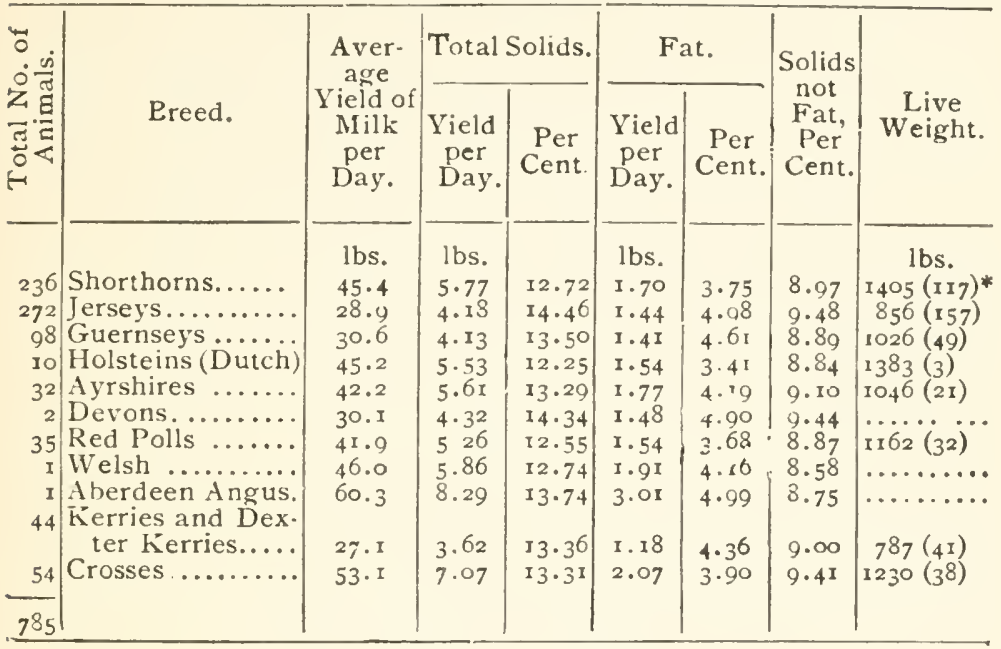

* Average for $\mathrm{I}_{7}$ animals.

\section{REQUIREMENTS FOR ADMISSION TO ADVANCED REGISTERS OF BIEED ASSOCLATIONS, 1913.}

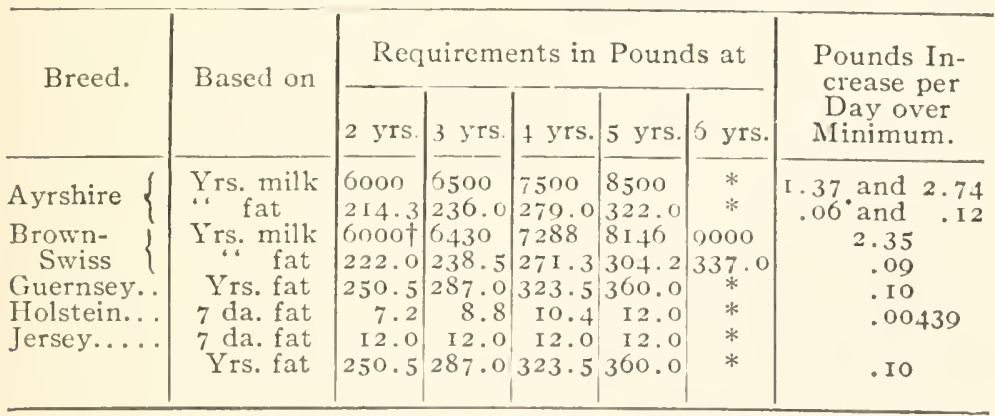

* No increase.

t At 2.5 years. 


\section{AVERAGE PER CENT OF FAT AND PRODUC TION OF MILK AND BUTTER FAT BY PURE- BRED DAIRY COWS, PER BIEED.*}

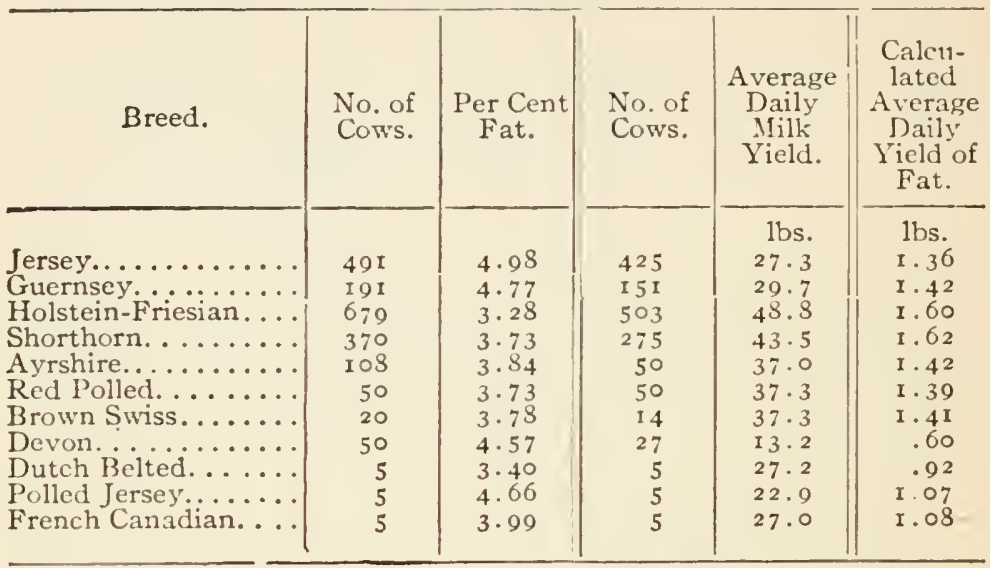

* See WVoll, On the Average Composition of Milk of Pure-bred Cows of Different Breeds (Wis. Exp. Sta., Report I90I).

\section{AVERAGE PERCENTAGE COMPOSITION OF MILK

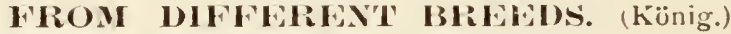

\begin{tabular}{|c|c|c|c|c|c|c|c|c|}
\hline Name of Breft. & 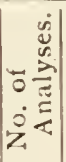 & 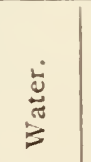 & 苟 & 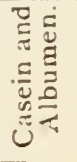 & 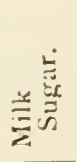 & $\frac{5}{4}$ & 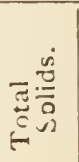 & 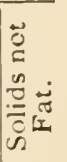 \\
\hline teyer & 12 & 86.90 & 477 & $3 \cdot 24$ & $+9^{\kappa}$ & 73 & 13.10 & 893 \\
\hline & 6 & 8726 & 3.79 & 2.64 & 5.81 & .70 & 12.74 & 8.95 \\
\hline Tillerthal (Tyrolean)... & 22 & $87 \cdot 43$ & 370 & 307 & $5 \cdot 10$ & .70 & 1257 & 8.87 \\
\hline Vorarlberg (Austrian).. & 19 & $87 \cdot 38$ & $3 \cdot 54$ & $29 x$ & $5 \cdot 4^{\circ}$ & .77 & 12.62 & 9.08 \\
\hline Algau (Bavarian) ..... & 4 & 87.88 & 3.20 & 3.22 & 5.13 & .57 & 12.12 & 8.92 \\
\hline$\ldots \ldots \ldots \ldots$ & 2 & $86 . \infty$ & 506 & 3.67 & 4.63 & .64 & 14.00 & 894 \\
\hline Hol & 24 & $88.0_{4}$ & 3.25 & 3.99 & 4.16 & .56 & I1.96 & $8.7 x$ \\
\hline $\operatorname{Irg}($ German)... & 18 & 87.95 & $3 \cdot 3^{8}$ & 3.10 & $4 \cdot 8 I$ & .76 & 12.05 & 8.67 \\
\hline (Danish)......... & 10 & $88 . \div 5$ & $3 \cdot 12$ & & $\cdots$ & & II. 85 & 8.73 \\
\hline n.......... & 67 & 87.20 & $3 \cdot 47$ & 3.21 & $5 \cdot 43$ & .69 & 12.80 & $9 \cdot 33$ \\
\hline Devon $\ldots \ldots \ldots \ldots$ & 20 & 86.57 & $4 \cdot 44$ & .. & .... & .64 & 1343 & 8.99 \\
\hline Ayrshire ... ......... & 43 & 86.93 & $3 \cdot 5^{8}$ & $3 \cdot 4^{2}$ & 543 & .64 & 13.07 & $9 \cdot 49$ \\
\hline . $\ldots \ldots \ldots \ldots \ldots$ & 31 & 85.90 & $4 \cdot 32$ & $3 \cdot 34$ & $5 \cdot 70$ & .74 & 14.10 & $9 \cdot 78$ \\
\hline sey............ & 26 & $85 \cdot 39$ & 5.11 & 398 & $4 \cdot 3^{8}$ & I.14(?) & 14.61 & $9 \cdot 5^{\circ}$ \\
\hline Fren & 12 & 87.20 & 3.90 & 3.07 & 5.06 & .77 & 12.80 & 8.90 \\
\hline Scandinavian.......... & 4 & 88.00 & $3 \cdot 51$ & 2.76 & 4.97 & .76 & $12 . \infty$ & 8.49 \\
\hline
\end{tabular}




\section{METHODS OF JUDGING THE VALUE OF DAIRY cows.}

The British Dairy Farmers' Association, which has conducted tests of dairy cows at their annual fair for the last twenty years, has during late years cored the dairy cows competing for premiums according to the following scale:

I point for each pound of milk;

20 points for each pound of fat;

4 points for each pound of solids not fat.

I point for each ten days in milk after the first twenty days (limit 200 days).

ro points are deducted from the total score for each per cent. of fat below three per cent in the milk.

The cows entered in the test are separated into four classes, according to the breed, each class being divided into two divisions, cows and heifers. The classes are Shorthorns, Jerseys, Guernseys, and cross-breeds.

Other associations abroad or in this country have not generally followed any definitc plan from year to year in awarding premiums to dairy cows at fairs, the awards having been given to cows producing most milk, or richest milk, or most butter-fat, or most solids, during the test, which may have lasted one to three days. At the Vermont State Fair, rS8g, the following points were given: For each 20 days since calving, I point; for each Io days of gestation, I point ' for each $2 \mathrm{oz}$. of total solids in 24 hours' milk, I point ; for each oz. of butter-fat in 24 hours' milk, 2 points; for each $2 \mathrm{oz}$. of salted butter from 24 hours' milk, I point. In the milking trials conducted by the Royal Agricultural Society of England, the size of the cows has been considered, the cows being, as a rule, separated into two classes, viz., over and under I Ioo lbs. live weight.

From the best information at hand at the present, the system of awards adopted by the British Dairy Farmers Association, and given above, must be considered the most perfect and the most just to all concerned Its main shortcomings lie, as it would secm, in its not considering the food eaten by each animal during the test, and in the fact that the test is made at the fair, and not at home under 
every-day conditions and in surroundings familiar to the animals. The former objection would be remored by taking into account the dry matter in the food eaten, as shown by chemical analysis. (See also Wisconsin Exp. Station, Research bull. No. 26 , pp. 7 S-So.)

\section{BUYING AND SEIAING COWS IBY THSTS OR 'THIR MILK. (ENGRY.)}

The money value of a cow may be estimated by muliplying the number of gallons of milk which the cow gives by 12 , adding to or subtracting from this product one dollar for every one fourth percent of fat in the milk abcve or below 3.5 per cent.

Value $=\frac{\text { pounds of milk perday }}{8 \%} \times 12+4($ percent faz -3.5$)$, (See Bull. No. II3, N. C. Exp. Station.)

\section{FIFTY DAIRY RUIASS.}

(U. S. DIEPARTMENT OF A(:RICUITURE.)

The Owner and his Helpers. - I. Read current dairy liter. ature and keep posted on new ideas.

2. Observe and enforce the utmost cleanliness about the cattle, their attendants, the stable, the dairy, and all utensils.

3. A person suffering from any disease, or who has been exposed to a contagious disease, must remain away from the cows and the milk.

The Stable.-4. Keep dairy cattle in a room or building by themselves. It is preferable to have no cellar below and no storage loft above.

5. Stables should be well ventilated, lighted, and drained; should have tight floors and walls and be plainly constructed.

6. Never use musty or dirty litter.

7. Allow no strong-smelling material in the stable for any length of time. Store the manure under cover outside the 
cow-stable, and remove it to a distance as often as practicable.

8. Whitewash the stable once or twice a year; use land plaster in the manure-gutters daily.

9. Use no dry, dusty feed just previous to milking; if fodder is dusty, sprinkle it before it is fed.

Io. Clean and thoroughly air the stable before milking; in hot weather sprinkle the floor.

II. Keep the stable and dairy-room in good condition, and then insist that the dairy, factory, or place where the milk goes be kept equally well.

The Cows.-I2. Have the herd examined at least twice a year by a skilled veterinarian.

I3. Promptly remove from the herd any animal suspected of being in bad health, and reject her milk. Never add an animal to the herd untilcertain it is free from disease, especially tuberculosis.

I4. Do not move cows faster than a comfortable walk while on the way to place of milking or feeding.

I5. Never allow the cows to be excited by hard driving, abuse, loud talking, or unnecessary disturbance; do not expose them to cold or storms.

I6. Do not change the feed suddenly.

I7. Feed liberally, and use only fresh, palatable feedstuffs; in no case should decomposed or moldy material be used.

18. Provide water in abundance, easy of access, and always pure; fresh, but not too cold.

I9. Salt should always be accessible.

20. Do not allow any strong-flarored food, like garlic, cabbage, and turnips, to be eaten, except immediately after milking.

2r. Clean the entire body of the cow daily. If hair in the region of the udder is not easily kept clean it should be clipped.

22. Do not use the milk within twenty days before calving, nor for three to five days afterwards.

Milking.-23. The milker should be clean in all respects; he should not use tobacco; he should wash and dry his hands just before milking. 
24. The milker should wear a clean outer garment, lised only when milking, and kept in a clean place at other times.

25. Brush the udder and surrounding parts just before milking, and wipe them with a clean, damp cloth or sponge.

26. Milk quietly, quickly, cleanly, and thoroughly. Cows do not like unnecessary noise or delay. Commence milking at exactly the same hour every morning and evening, and milk the cows in the same order.

27. Throw away (but not on the floor, better in the gutter) the first few streams from each teat; this milk is very watery and of little value, but it may injure the rest.

28. If in any milking a part of the milk is bloody, stringy or unnatural in appearance, the whole mess should be rejected.

29. Milk with dry hands; never allow the hands to come in contact with the ninilk.

30. Do not allow dogs, cats, or loafers to be around at milking-time.

31. If any accident occurs by which a pail full or partly full of milk becomes dirty, do not try to remedy this by straining, but reject all this milk and rinse the pail.

32. Weigh and record the milk given by each cow, and take a sample morning and night, at least once a week, for testing by the fat test.

Care of Milk. - 33. Remove the milk of every cow at once from the stable to a clean, dry room, where the air is pure and sweet. Do not allow cans to remain in stables while they are being filled.

34. Strain the milk through a metal gauze and a flannel cloth or layer of cotton as soon as it is drawn.

35. Aerate and cool the milk as soon as strained. If an apparatus for airing and cooling at the same time is not at hand, the milk should be aired first. This must be done in pure air, and it should then be cooled to 45 degrees if the milk is for shipment, or to 60 degrees if for home use or delivery to a factory.

36. Never close a can containing warm milk which has not been aerated. 
37. If cover is left off the can, a piece of cloth or mosquito. netting should be used to keep out insects.

35. If milk is stored, it should be held in tanks of fresh, cold water (renewed daily), in a clean, dry, cold room. Unless it is desired to remove cream, it should be stirred with a tin stirrer often enough 10 prevent forming a thick cream layer.

39. Keep the night milk under shelter so rain cannot get into the cans. In warm weather hold it in a tank of fresh cold water.

40. Never mix fresh warm milk with that which has been cooled.

4I. Do not allow the milk to freeze.

42. Under no circumstances should anything be added to milk to prevent its souring. Cleanliness and cold are the only preventives needed.

43. All milk should be in good condition when delivered. This may make it necessary to deliver twice a day during the hottest weather.

44. When cans are hauled far they should be full, and carried in a spring wagon.

45. In hot weather cover the cans, when moved in a wagon, with a clean wet blanket or canvas.

The Utensils.-46. Milk-utensils for farm use should be made of metal and have all joints smoothly soldered. Never allow them to become rusty or rough inside.

47. Do not haul waste products back to the farm in the same cans used for delivering milk. When this is unavoidable, insist that the skim-milk or whey-tank be kept clean.

45. Cans used for the return of skim-milk or whey should be emptied and cleaned as soon as they arrive at the farm.

49. Clean all dairy utensils by first thoroughly rinsing them in warm water; then clean inside and out with a brush and hot water in which a cleaning material is dissolved; then rinse and lastly sterilize by boiling water or steam. Use pure water only.

50. After cleaning, keep utensils, inverted, in pure air, and sun if possible, until wanted for use. 


\section{MILK.}

\section{PERCENTAGE COMPOSITION OF VARIOUS KINDS} OF MILK. (KüNIG.)

\begin{tabular}{|c|c|c|c|c|c|c|c|}
\hline & $\begin{array}{c}\text { No. of } \\
\text { Analy- } \\
\text { ses. }\end{array}$ & Water. & Fat. & $\begin{array}{c}\text { Casein } \\
\text { and Al- } \\
\text { bumen. }\end{array}$ & $\begin{array}{c}\text { Milk } \\
\text { Sugar. }\end{array}$ & Ash. & $\begin{array}{c}\text { Specific } \\
\text { Grav- } \\
\text { ity. }\end{array}$ \\
\hline Human........ & 107 & 87.41 & $3 \cdot 7^{8}$ & 2.29 & $6.2 \mathrm{I}$ & $\cdot 3^{I}$ & I. 0270 \\
\hline Mare ............ & 50 & 90.78 & I. 21 & 1.99 & $5 \cdot 67$ & .35 & 1.0347 \\
\hline Buffalo.......... & 8 & 82.25 & $7 \cdot 5 I$ & 5.05 & $4 \cdot 44$ & .75 & 1.0330 \\
\hline A ss................. & 7 & 89.64 & I. 64 & 2.22 & 5.99 & .51 & I. 0345 \\
\hline Cow ....... & 793 & 87.17 & 3.69 & 3.55 & 4.88 & $.7 \mathrm{I}$ & 1.0316 \\
\hline 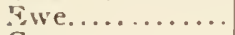 & 32 & 80.82 & 6.86 & $6.5^{2}$ & $4 \cdot 9 I$ & .89 & $\mathrm{x} .034 \mathrm{I}$ \\
\hline Goat.......... & 38 & 85.71 & $4 \cdot 7^{8}$ & 4.29 & $4 \cdot 46$ & .76 & 1.0328 \\
\hline Reindeer*....... & 2 & 67.20 & 17.10 & II. 39 & 2.82 & 1.49 & 1.0477 \\
\hline Sow ... . . . . & $=0$ & $82.5=$ & 578 & 6.3 .4 & $4 \cdot 37$ & 1.00 & 1.0385 \\
\hline Bitcli......... & 28 & 75.44 & 9.57 & 11.17 & 3.09 & .73 & 1.035 \\
\hline El phant....... & 3 & 79.30 & 9.10 & $2.5^{I}$ & 8.59 & .50 & $\mathrm{r} .0_{313}$ \\
\hline Hippopotamus. & I & 90.43 & $4 \cdot 51$ & $\ldots$ & $4 \cdot 40$ & .11 & $\ldots \ldots$ \\
\hline 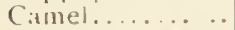 & 3 & 86.57 & 3.07 & 4.00 & $5 \cdot 59$ & .77 & 1.042 \\
\hline Llım.1 ....... & 3 & 8655 & 3.15 & 3.93 & 5.60 & .80 & 1.034 \\
\hline
\end{tabular}

* II erenskiold.

\section{AVERAGE ANATYSES OF AMERICAN SAMPIAS} OH' DAIRY P'RODLCTS. (Goessmann.)

\begin{tabular}{|c|c|c|c|c|c|}
\hline & $\begin{array}{l}\text { Whole } \\
\text { Milk. }\end{array}$ & $\begin{array}{l}\text { Skim- } \\
\text { milk. }\end{array}$ & $\begin{array}{l}\text { Butter- } \\
\text { milk. }\end{array}$ & $\begin{array}{c}\text { Cream } \\
\text { from } \\
\text { Cooley } \\
\text { Creamer. }\end{array}$ & Butter. \\
\hline \multirow{3}{*}{ 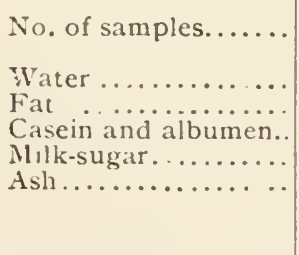 } & r889 & $34^{8}$ & $3^{I}$ & 197 & 25 \\
\hline & $\begin{array}{c}86.53 \\
4.14 \\
3.20 \\
5.43^{*} \\
.70\end{array}$ & $\begin{array}{c}90.52 \\
.32 \\
3.53 \\
4.83^{*} \\
.80\end{array}$ & $\begin{array}{c}91.67 \\
.27 \\
2.79 \\
4.47 * \\
.80\end{array}$ & $\begin{array}{r}73.90 \\
17.00 \\
\ldots \ldots . \\
\ldots . . . \\
.62\end{array}$ & $\begin{array}{c}10.89 \\
8.3 .95 \\
.42^{*} \\
\ldots . . \\
4.74\end{array}$ \\
\hline & 100.00 & $1: 0.00$ & 100.00 & $\ldots \ldots$ & 100.00 \\
\hline $\begin{array}{l}\text { Total solids.......... } \\
\text { Solids not fat....... }\end{array}$ & $\begin{array}{r}1347 \\
9 \cdot 33\end{array}$ & $\begin{array}{l}9.48 \\
9.16\end{array}$ & $\begin{array}{l}8.33 \\
8.06\end{array}$ & $\begin{array}{r}26.10 \\
8.44\end{array}$ & $\begin{array}{r}89.11 \\
5.16\end{array}$ \\
\hline
\end{tabular}




\section{AVERAGE COMPOSITION OF COWS' MILI, TITH VARIATIONS. (KöNIG。)}

\begin{tabular}{|c|c|c|c|}
\hline & $\begin{array}{c}\text { Average of } \\
705 \text { Analyses } \\
\text { (largely Euro- } \\
\text { pean). }\end{array}$ & Minimum. & Maximum. \\
\hline 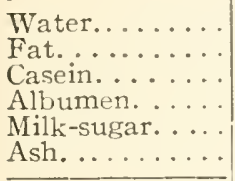 & $\begin{array}{r}87.27 \text { per cent } \\
3.68 \text { “ } \\
2.881 \\
.51 \\
4.95 \\
4.94 \text { per cent } \\
.72\end{array}$ & 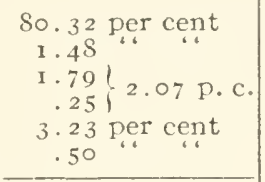 & 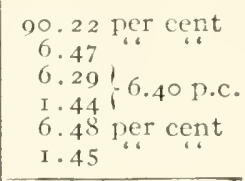 \\
\hline $\begin{array}{l}\text { Total solids. ... } \\
\text { Solids not fat... } \\
\text { Specific gravity. }\end{array}$ & $\begin{array}{l}100.00 \\
\text { I } 2.73 \text { per cent } \\
0.140 \\
\text { I.031 }\end{array}$ & $\begin{array}{l}9.3 \text { I per cent } \\
\cdots \cdots \cdots \cdots \\
\text { I.0264 }\end{array}$ & $\begin{array}{l}\text { 19.68 per cent } \\
\ldots \ldots \\
1.0368\end{array}$ \\
\hline
\end{tabular}

COMPOSITION OF MORNING AND EVINING MILK, AND OF IIORNING, NOON, AND EVISING MLK. (KöNIG.)

\begin{tabular}{|c|c|c|c|c|c|c|}
\hline & $\begin{array}{l}\text { No. of } \\
\text { Analy- } \\
\text { ses. }\end{array}$ & Water. & Fat. & $\begin{array}{l}\text { Casein } \\
\text { and A1- } \\
\text { bumens }\end{array}$ & $\begin{array}{l}\text { Milk- } \\
\text { sugar. }\end{array}$ & Ash. \\
\hline $\begin{array}{l}\text { Mlorning milk. . . } \\
\text { Evening }\end{array}$ & $\begin{array}{l}\text { I } 39 \\
139\end{array}$ & $\begin{array}{l}87.70 \\
87.20\end{array}$ & $\begin{array}{l}3 \cdot 38 \\
3 \cdot 58\end{array}$ & $\begin{array}{l}3.6 \mathbf{I} \\
3.64\end{array}$ & $\begin{array}{l}4.64 \\
4.8 I\end{array}$ & $\begin{array}{l}.67 \\
.69\end{array}$ \\
\hline $\begin{array}{l}\text { Morning milk. . . } \\
\text { Noon } \\
\text { Evening }\end{array}$ & $\begin{array}{l}52 \\
52 \\
52\end{array}$ & $\begin{array}{l}88.28 \\
87.43 \\
87.60\end{array}$ & $\begin{array}{l}3 \cdot 05 \\
3 \cdot 8 \mathbf{I} \\
3 \cdot 59\end{array}$ & $\begin{array}{l}3.24 \\
3.26 \\
3.20\end{array}$ & $\begin{array}{l}4.69 \\
4.75 \\
4.87\end{array}$ & $\begin{array}{l}.74 \\
.75 \\
.74\end{array}$ \\
\hline
\end{tabular}

COMPOSITION OH RIMLIBNT PARTS OF THE SAMIE MIIIINGS. (KöNig.)

\begin{tabular}{|c|c|c|c|c|c|c|c|}
\hline & $\begin{array}{l}\text { No. } \\
\text { of An. } \\
\text { alyses. }\end{array}$ & Water. & Fat. & $\begin{array}{l}\text { Casein } \\
\text { and } \\
\text { Albumen }\end{array}$ & $\begin{array}{l}\text { Milk- } \\
\text { sugar }\end{array}$ & Ash. & $\begin{array}{l}\text { Total } \\
\text { Solics. }\end{array}$ \\
\hline $\begin{array}{l}\text { First portion. } \\
\text { Second "c } \\
\text { Third " }\end{array}$ & $\begin{array}{l}7 \\
7 \\
6\end{array}$ & $\begin{array}{c}\text { Per ct. } \\
80.81 \\
88.12 \\
86.29\end{array}$ & $\begin{array}{c}\text { Per ct. } \\
\text { I. } 78 \\
3 \cdot 34 \\
4 \cdot 52\end{array}$ & $\begin{array}{c}\text { Per ct. } \\
2.88 \\
2.94 \\
2.59\end{array}$ & $\begin{array}{c}\text { Perct. } \\
4.81 \\
4.92 \\
5.88\end{array}$ & $\begin{array}{l}\text { P'rct. } \\
.69 \\
.68 \\
.72\end{array}$ & $\begin{array}{r}\text { Per ct. } \\
\text { ro. } 6 \\
11.88 \\
\text { r } 3.7 \mathrm{r}\end{array}$ \\
\hline
\end{tabular}




\section{CALCULATION OF COMPONENTS OF COWS' MILIK.}

According to Vieth the components of the non-fatty milk solids will stard in the ratio to one another of about

for casein and albumen : milk sugar : $\begin{gathered}\text { Io } \\ \text { for }\end{gathered}$

If the solids not fat in a sample of milk are 9 per cent, the per cent of casein and albumen in the same will be approximately $2_{5}^{9} \times 10=3.60$ per cent; sugar, $2^{3} \times 13=4.68$ per cent; and ash, $\frac{9}{25} \times 2=.72$ per cent.

TABLE SHOWING REIATION OF FAT TO CASEIN AND O'THER SOLIDS. (СоOKE.)

\begin{tabular}{c|c|c|c|c}
\hline Total Solids. & Fat. & $\begin{array}{c}\text { Casein and } \\
\text { Albumen. }\end{array}$ & $\begin{array}{c}\text { Milk-sugar } \\
\text { and } \text { Ash. }\end{array}$ & $\begin{array}{c}\text { Solids } \\
\text { not Fat. }\end{array}$ \\
\cline { 2 - 3 } Per Cent. & Per Cent. & Per Cent. & Per Cent. & Per Cent. \\
11.00 & 3.07 & 2.92 & 5.01 & 7.93 \\
11.50 & 3.29 & 3.00 & 5.21 & 8.21 \\
12.00 & 3.50 & 3.07 & 5.43 & 8.50 \\
12.50 & 3.75 & 3.19 & 5.56 & 8.75 \\
13.00 & 3.99 & 3.30 & 5.71 & 9.01 \\
13.50 & 4.34 & 3.44 & 5.72 & 9.16 \\
14.00 & 4.68 & 3.57 & 5.75 & 9.32 \\
14.50 & 4.93 & 3.79 & 5.68 & 9.47 \\
15.00 & 5.38 & 4.00 & 5.62 & 9.62 \\
15.50 & 5.69 & 4.15 & 5.66 & 9.81 \\
16.00 & 6.00 & 4.30 & 5.70 & 10.00 \\
& & & & \\
\hline
\end{tabular}

This table, which is summarized from the analyses of about 2400 American samples of milk, shows that while the percentage of fat varies from 3.07 to 6 per cent, or nearly three per cent, that of casein varies only from 2.92 tu $+.3-$ per cent, less than one and one half per cent. It also shows that a higher percentage of fat is always accom. panied by a higher percentage of casein. Milk sugar and ash increase but little as the milk grows richer. 
MILK。

\section{FER'TLIZING INGRIDIENTS IN DARY PROD UCTS.}

Average of American Analyses. (Сooke and Hir.s.)

\begin{tabular}{|c|c|c|c|c|}
\hline & Nitrogen. & $\begin{array}{c}\text { Phosphoric } \\
\text { Acid. }\end{array}$ & Potash. & $\begin{array}{c}\text { Value per } \\
\text { Ton. }\end{array}$ \\
\hline $\begin{array}{l}\text { Whole milk..... } \\
\text { Skim-milk...... } \\
\text { Cream ....... } \\
\text { Buttermilk..... } \\
\text { Whey ........... } \\
\text { Butter.......... } \\
\text { Cheese ........ }\end{array}$ & $\begin{array}{l}.53 \% \\
.56 \\
.40 \\
.48 \\
.15 \\
.12 \\
3.93\end{array}$ & $\begin{array}{l}.19 \% \\
.20 \\
.15 \\
.17 \\
.14 \\
.04 \\
.60\end{array}$ & $\begin{array}{l}.175 \% \\
.185 \\
.130 \\
.158 \\
.181 \\
.036 \\
.120\end{array}$ & $\begin{array}{r}2.17 \\
2.31 \\
.66 \\
1.98 \\
.84 \\
.49 \\
14.19\end{array}$ \\
\hline
\end{tabular}

COMPOSITION OF COLOSTREM. (Kövg.)

\begin{tabular}{|c|c|c|c|c|c|c|c|}
\hline & $\begin{array}{l}\text { No. of } \\
\text { Anal- } \\
\text { yses. }\end{array}$ & Water. & Casein. & $\begin{array}{l}\text { Albu- } \\
\text { men. }\end{array}$ & $\begin{array}{c}\text { Butter- } \\
\text { fat. }\end{array}$ & $\begin{array}{l}\text { Milk- } \\
\text { sugar. }\end{array}$ & Ash. \\
\hline Ewe.. ....... & II & 77.9 & 4.9 & $3 \cdot 4$ & 8.3 & 4.6 & .9 \\
\hline Goat ........ & I & 64.1 & 5.2 & 3.2 & 24.5 & . . . & 3.0 \\
\hline Sow.......... & $\mathbf{I}$ & 70.1 & 7.6 & 8.0 & 9.5 & 3.9 & .9 \\
\hline Cow.......... & 42 & 74.6 & $4 \cdot 0$ & 13.6 & 3.6 & 2.7 & $x .6$ \\
\hline
\end{tabular}

\section{COMPOSITION OF ASH OF COW' MIUK ANI COLOSTIRU.}

\section{Cows' Milk. Colostrum}

Total ash................ .7 per cent I.6 per cent

roo parts of ash will contain :

\begin{tabular}{|c|c|c|c|}
\hline 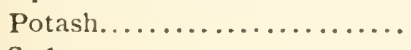 & 24 & “ & 7 \\
\hline Soda $\ldots \ldots \ldots \ldots \ldots \ldots \ldots$ & 6 & “ & 6 \\
\hline 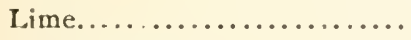 & 23 & “6 & 35 \\
\hline Phosphoric acid. ............ & 28 & “ & 47 \\
\hline 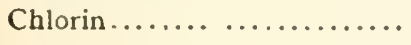 & 13 & "6 & 13 \\
\hline
\end{tabular}




\section{A CHAPTER ON MLK TESTING.*}

The Babcock milk test is the quick and simple method of determining the fat content of milk which has been most generally adopted in this country. The test was invented by Dr. S. M. Babcock, of Wisconsin Agricultural Experiment Station, and was first published in July, ISgo. The following is an outline of the method:

A known quantity of milk ( 77.6 cubic centimeters, or about $\frac{2}{3}$ of an ounce) is pipetted off into a graduated testbottle; $17.5 \mathrm{cc}$. of commercial sulfuric acid, of a specific gravity of $I_{. S}$ to $\mathrm{I}_{3} S_{3}$, is then measured out by means of a graduated cylinder or an automatic pipette, and added to the milk. The two fluids are mixed, and when the curd is dissolved, the test-bottles are placed in a centrifugal machine and whirled for 4 minutes at a rate of 80o-r 200 revolutions per minute, the small hand-machines on the market requiring the higher number of revolutions. Boiling ho: water is then filled into the botties, by which means the liquid fat is brought into the narrow graduated neck of the bottles; after an additional whirling of the bottles for a minute. the length of the column of fat is read off in per cent.

The whole process of testing a sample of milk according to this method will take less than a quarter of an hour when a little skill in manipulation has been reached.

The various dealers in dairy implements have placed Babcock machines on the market in sizes fiom 4- to 60bottle machines, and supply the necessary outfit, as testbottles, pipettes, graduates, and sulfuric acid. There are at present three different types of machines: hand-machires ffriction or cog-wheel machines; the latter ones are to be preferred, and have now practically replaced the friction machines), steam turbine, and belt-power machines. The Facile, Twentieth Century, and Agos Babcock testers are

* The subject of milk test ing is treatcul exluaustivcly, and detailed directions for using the Babcock test are given in Farrington-IVoll, Testing Milk and its Products, Menduta Bouk Cu., Madison, Wis., 2Ist Edition, I9I2. 
the pest hand-machines on the market at the present time. Steam turbine machines are to be recommended for factory use; they should always be provided with a speed indicator so as to avoid too slow or too rapid whirling; several accidents have happened where the bottles were unable to stand the pressure caused by too rapid whirling. In many turbine testers the bottles are heated to about $200^{\circ} \mathrm{F}$, and the bottles should in case of such machines be left to cool to about $150^{\circ} \mathrm{F}$. before results are read off. Readings taken at temperatures higher than this come too high, viz., in extreme cases, from .2 to .3 per cent too high in case of new milk, and toward one per cent too high in case of cream. (See Wis. Exp. Sta. Report for r8s9-1goo.)

In Sharples' Russian Babcock Tester (a steam-turbine test manufactured by the Dairy Specialty Co., West (hestter, l'at ) the bottles used can be filled with hot water while the machines, in motion; the test bottles used are arranged for half the usual quantity of milk.

Points to be watched in making tests by the Eabuock method:

The strength of the acid used is very important; its specific gravity should not go below 1.82 or above 1.84 ; if the acid is somewhat too strong less may be taken, and a little more if it is rather weak. It is, however, not possible to make a satisfactory test with acid of a specinc gravity t,elow I.S2. Keep the acid bottle corked when not in use, as the acid wili otherwise take up moisture from the air.

In testing separator skim-milk use a somewhat larger quanity of acid than usual, and whirl 5 to 6 minutes; this will insure a nearly perfect separation of all the fat present in such milks. The two-necked so-called Ohlsson bottles are recommended for testing separator skim-milk; the results should be increased by .05 per cent with these as with other test bottles, in testing separator skim-milk.

The centrifugal machine should run at a rate of about Soo to rooo revolutions per minute; if its diameter is small, whirl Iooo or I 200 .

Soft or rain-water is used in filling up the bottle after 
boiling, or hard water may be used if somedrops of sulfuric acid have bien aded to it before the boiling.

In adding the acid the bottle should be held at ain angle, so as to cause the acid to follow the inside of the wall. Mix the milk and ac:d at once, or within a short time, and proceed with the test without delay.

Read off results before the fat begins to crystallize. If many tests are made at a time, and the room is cold, place. the bottles in a pail with water of $140-150^{\circ}$ and keep them warm until results are recoric 1.

Application of Rubuck's Test.-The method may be used to advantage in determining the fat content of full milk, skim-milk, buttermilk, whey, cream, conclensed milk, and checse. It cannot be recommended for the estimation of fat in butter, since the error of analysis in this case is 100 large. In testing separatcr skim-milk, buttcrmilk, and whey by this method, no reading should be taken lower than onetenth of one per cent. If only a small drop or two of liquid fat appears in the neck of the bottles after finished whirling the result is thercfore to be put down as. I per cent, instead of estimates of .05 , and still lower, which are sometimes sade. (See Bull. No. 52, Wis. Experiment Stacion.)

Lactometer.-The Quevenne lactometer, with the thermometer tube extending into the narrow stem of the instrument, is recommended for dairy work. In the N. Y. Board of Health lactometer, often used, the srale is divided into I20 divisions, the mark 100 corresponding to a specific gravity of I.029, and that of $\mathrm{I} 20$ to a specific gravity of I.0348. These lactometer degrees can be coriverted into Quevenne lactometer degrees by multiplying by.29. The following table gives the readings of the two scales between 60 and 120 on the Board of Health lactometer: 
TABLE SHOWING THE QUEVENNE IACTOMETER DEGREES CORIREPONDING TO THE SCALE OF LACTOMETERS GRADUATED FROM 60 TO 120.

\begin{tabular}{|c|c|c|c|c|c|}
\hline $\begin{array}{l}\text { N. Y. Bd. } \\
\text { of Health } \\
\text { Sca!e. }\end{array}$ & $\begin{array}{l}\text { Quevenne } \\
\text { Scale. }\end{array}$ & $\begin{array}{l}\text { N. Y. Bd. } \\
\text { of Health } \\
\text { Scale. }\end{array}$ & $\begin{array}{l}\text { Querenne } \\
\text { Scale. }\end{array}$ & $\begin{array}{l}\text { N. Y. Bd. } \\
\text { of Health } \\
\text { Scale. }\end{array}$ & $\begin{array}{l}\text { Quevenne } \\
\text { Scale. }\end{array}$ \\
\hline $\begin{array}{l}60 \\
61 \\
62 \\
63 \\
64 \\
65 \\
66 \\
67 \\
68 \\
69 \\
70 \\
71 \\
72 \\
73 \\
74 \\
75 \\
76 \\
77 \\
78 \\
79 \\
80\end{array}$ & $\begin{array}{l}17.4 \\
17.7 \\
18 \\
18.3 \\
13.6 \\
18.8 \\
19.1 \\
19.4 \\
19.7 \\
20 \\
29.3 \\
20.6 \\
20.9 \\
21.2 \\
21.5 \\
21.7 \\
22 \\
22.3 \\
22.6 \\
22.9 \\
23.2\end{array}$ & $\begin{array}{r}81 \\
8 \mathbf{1} \\
83 \\
84 \\
85 \\
86 \\
87 \\
88 \\
89 \\
90 \\
91 \\
92 \\
93 \\
94 \\
95 \\
96 \\
97 \\
98 \\
99 \\
100\end{array}$ & $\begin{array}{l}23 \cdot 5 \\
23 \cdot 8 \\
24 \cdot 1 \\
24 \cdot 4 \\
24 \cdot 6 \\
24 \cdot 9 \\
25 \cdot 2 \\
25 \cdot 5 \\
25.8 \\
26 \cdot 1 \\
26.4 \\
26 \cdot 7 \\
27 \\
27 \cdot 3 \\
27.6 \\
27.8 \\
28.1 \\
28.4 \\
28.7 \\
29\end{array}$ & $\begin{array}{l}101 \\
102 \\
103 \\
104 \\
105 \\
106 \\
107 \\
108 \\
109 \\
110 \\
111 \\
112 \\
113 \\
114 \\
115 \\
116 \\
117 \\
118 \\
119 \\
120\end{array}$ & $\begin{array}{l}29.3 \\
29.6 \\
29.9 \\
30.2 \\
30.5 \\
30.7 \\
31 \\
31.3 \\
31.6 \\
31.9 \\
32.2 \\
32.5 \\
32.8 \\
33.1 \\
33.4 \\
33.6 \\
339 \\
34.2 \\
34.5 \\
34.8\end{array}$ \\
\hline
\end{tabular}

In taking the specific gravity of milk by means of a lactometer, the temperature of the milk should not vary more than $10^{\circ}$ either way from $60^{\circ} \mathrm{F}$. The following tables show the proper corrections for temperature to be made, if the milk was either warmer or colder than $60^{\circ} \mathrm{F}$., the temperature to which the specific gravities of all liquids are Lsually referred.

In practical work sufficiently accurate corrections for temperature may generally be made by adding. I to the lactometer reading for each degree above $60 \mathrm{~F}$., and by subtracting. I for each degree below $60^{\circ}$; e.g., if the reading at $64^{\circ}$ is 29.5 , it will be about $29.5+.4=29.9$ at $60^{\circ}$; if 34.0 at $52^{\circ}$, it will be about $34^{\circ} \cdot \mathrm{O}-. S=33.2$ at $60^{\circ}$. By reference to the following table we fine it is more correctly 33.0. 


\begin{tabular}{|c|c|c|c|c|c|}
\hline \multirow{16}{*}{ 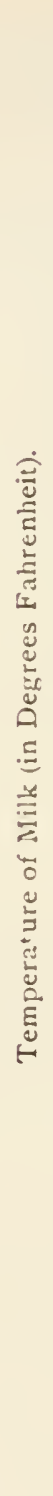 } & 8 & 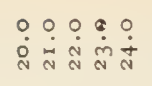 & 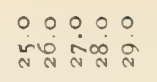 & 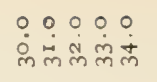 & $\stackrel{\circ}{\dot{m}}$ \\
\hline & भे & 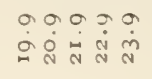 & 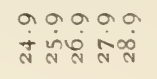 & $\begin{array}{l}q a q a \\
\dot{\sigma} \dot{m} \dot{m} \dot{m} \dot{m}\end{array}$ & 官 \\
\hline & $\stackrel{\infty}{\infty}$ & 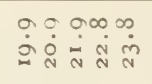 & 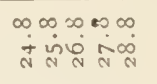 & 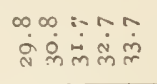 & ‡̇ \\
\hline & $\hat{n}$ & 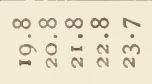 & 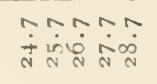 & 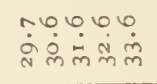 & $\stackrel{\circ}{\dot{j}}$ \\
\hline & in & 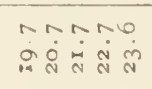 & 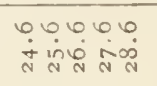 & 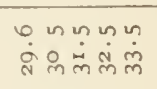 & $\stackrel{\text { m }}{\dot{m}}$ \\
\hline & ๓n & 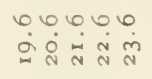 & 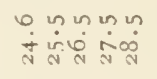 & $\begin{array}{l}++++m \\
\dot{0} \dot{0} \dot{m} m \dot{m}\end{array}$ & $\stackrel{m}{\dot{\dot{m}}}$ \\
\hline & in & 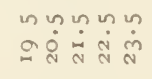 & 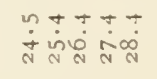 & $\begin{array}{l}m m m m N \\
\dot{\alpha} \dot{m} \dot{m} \dot{m}\end{array}$ & $\stackrel{\stackrel{\sim}{\dot{m}}}{ }$ \\
\hline & กิ & 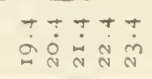 & 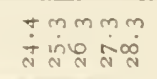 & 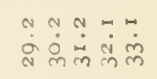 & $\stackrel{\circ}{\dot{m}}$ \\
\hline & in & 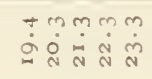 & 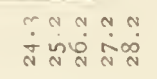 & 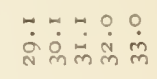 & $\stackrel{\mathfrak{m}}{\dot{m}}$ \\
\hline & in & $\begin{array}{l}m m m ? \\
\dot{0} \dot{\alpha} \tilde{\alpha} \dot{n}\end{array}$ & 年 & 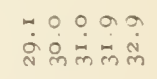 & $\stackrel{\infty}{m}$ \\
\hline & $\stackrel{\circ}{\mathrm{n}}$ & 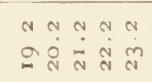 & 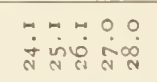 & 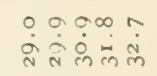 & $\dot{m}$ \\
\hline & 9 & 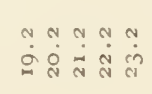 & "艹 & 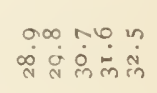 & $\ddot{n}$ \\
\hline & $\stackrel{\infty}{\longrightarrow}$ & 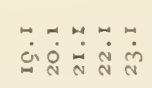 & $\begin{array}{l}0 \\
0 \\
\dot{\vec{n}} \\
\text { a } \\
0\end{array}$ & 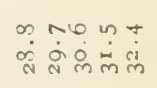 & $\dot{m}$ \\
\hline & f & 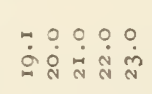 & 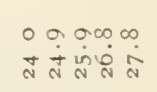 & 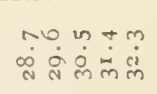 & $\dot{\sim}$ \\
\hline & $\stackrel{6}{+}$ & 일워 & 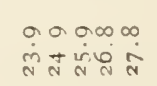 & 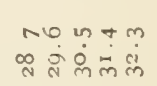 & $\ddot{m}$ \\
\hline & $\stackrel{n}{+}$ & $\begin{array}{l}0.00 \% \\
0.09 \\
0 \\
0\end{array}$ & 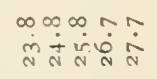 & $\begin{array}{l}0 m+m N \\
\infty 0 \dot{N} \dot{m} \dot{m} \dot{m}\end{array}$ & $\stackrel{\circ}{\dot{m}}$ \\
\hline & & $\stackrel{N}{\sim} \approx \widetilde{N} \tilde{N}$ & 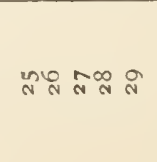 & 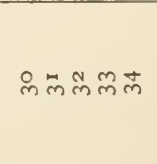 & m \\
\hline
\end{tabular}


MILK.

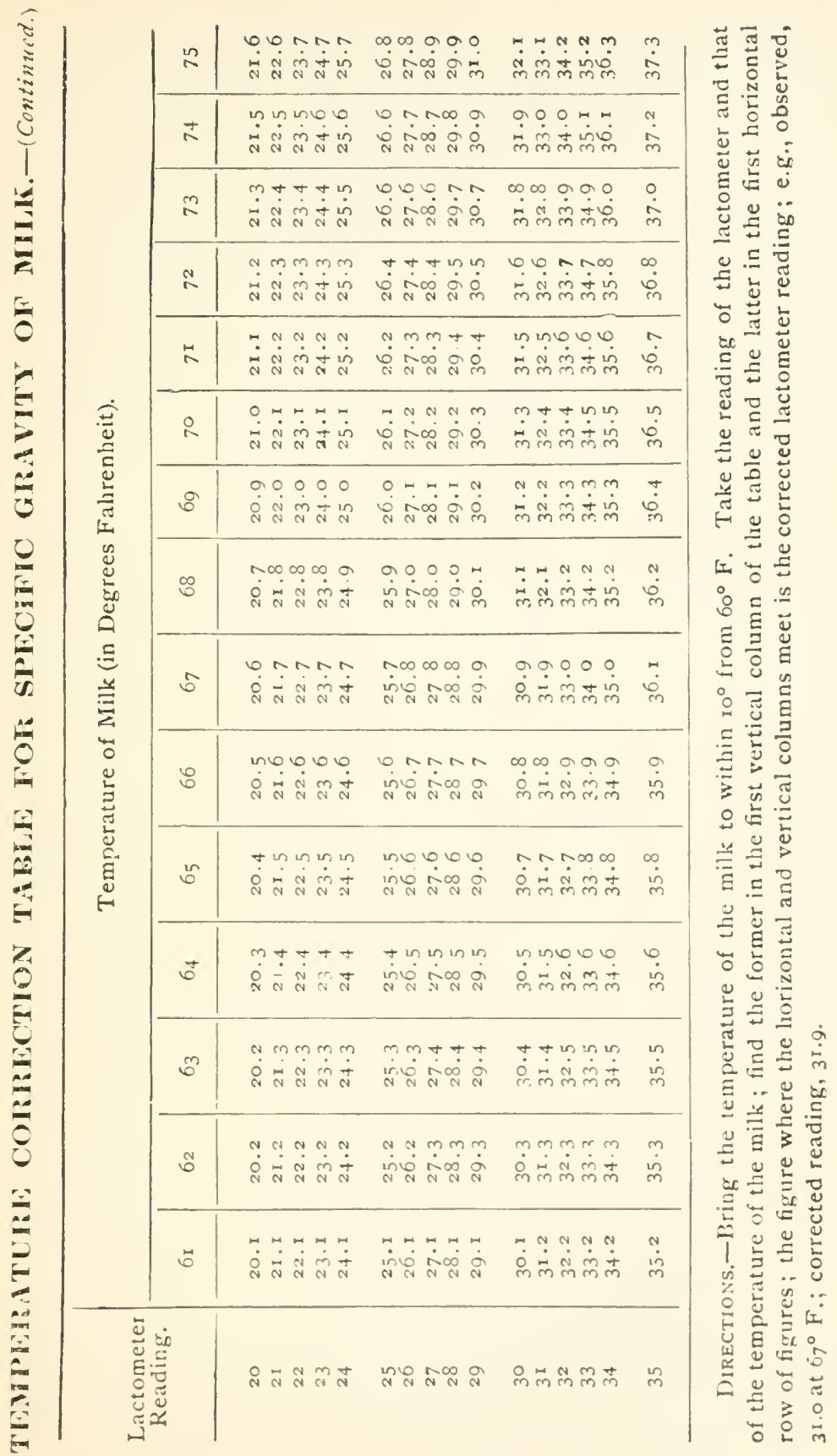




\section{CALCUIATION OF TOTAI, SOLIDS OF MILK.}

The relation existing between the various components of the milk is such as to make possible the calculation of the percentage of solids not fat, and total solids, in a sample of milk when the fat-content and the specific gravity (lactometer reading) of the milk are known. Several formulas have been worked out by chemists in different parts of the world, by the application of which the total solids may be calculated from the percentage of fat and the specific gravity of the milk. We give here Babcock's formula, pub. lished in the twelfth report of Wisconsin Experiment Station.

$$
\text { Solids not fat }=\left(\frac{\text { IOOs }-s f}{\text { IO0 }-1.0753 s f}-\mathrm{I}\right) \times(\text { IOO }-f) 2.5 \text {. }
$$

where $s=$ specific gravity of the milk and $f$ per cent of fat found. When $s$ and $f$ are known the per cent of solids not fat in the milk may be calculated by means of this formula. śt order to avoid making the lengthy calculations in every case, tables for solids not fat are given on the following pages; results obtained by the formula given above, or by means of the fullowing tables, will come within a couple of tenths from the actual percentages present, when reasonable care is taken in the determinations of fat and specific gravity (or lactometer reading).

Short formulas. The following formulas for solids not fat and for total solids are derived from the data given in the following tables. $L=$ lactometer reading at $60^{\circ} \mathrm{F}$. (specific gravity $\times$ I000 - I000); $f=$ per cent of fat in milk.

$$
\begin{aligned}
& \text { Solids not fat }=\frac{L}{4}+.2 f \\
& \text { Total solids }=\frac{L}{4}+\text { I.2f. }
\end{aligned}
$$


Rule: To find per cent of solids not fat, add two tenths of the per cint of fat to one fourth of the lactometer reading.

To find per cent of total solids, add one and two tenths times the per cent of fat to one fourth of the lactometer reading.

Results obtained by using the short formulas will agree very closely with those derived from the general formula, or from the tables published below, and may be safely relied upon in practical work.

The tables cover a range of .o to 6.0 per cent of fat, and from 26 to 36 lactometer reading. If intermediate values for $f$ and $L$ are at hand, corrections in the per cent of solids not fat found may easily be made, with .02 per cent for every tenth of one per cent of fat, and .25 per cent for every lactometer degree. Example: Given $f=$ 3.67 per cent and $L=32.5$. By referring to the table we find that $f=3.6$ and $L=32$ will give 8.73 per cent of solids not fat; correction for fat-content, or per cent $(3.67$ being nearer 3.65 than 3.70), and for lactometer reading. I 2 per cent; corrected per cent solids not fat, 8.86. 
TABLE SHOWING PER CENT OF TOTAL SOLIDS IN MILK.

\section{Corresponding to Quevenne Lactometer Readings and Per} Cent of Fat. (BABCOCK, modified by LeAch.)

\begin{tabular}{|c|c|c|c|c|c|c|c|c|c|c|c|}
\hline \multirow{2}{*}{$\begin{array}{c}\text { Per } \\
\text { Ct. } \\
\text { of } \\
\text { Fat }\end{array}$} & \multicolumn{10}{|c|}{ Lactometer Reading at $60^{\circ}$ Fahrenheit. } & \multirow{2}{*}{$\begin{array}{l}\text { Per } \\
\mathrm{Ct} . \\
\text { of } \\
\text { Fat }\end{array}$} \\
\hline & 27 & 28 & 29 & 30 & 31 & 32 & 33 & 34 & 35 & 36 & \\
\hline .0 & & & & & & & & .50 & 3.75 & 9.00 & \\
\hline . I & & & & & & & & & & & \\
\hline .2 & & & & & & & & & & & 0. \\
\hline .3 & & & & & & & & 8.86 & & & \\
\hline .4 & & $7 \cdot 4$ & & & 8.23 & 8.48 & & 8.98 & 9.23 & 9.48 & 0. \\
\hline . & & 7.60 & 7.85 & 8. I0 & 8.35 & 8.60 & & .10 & .35 & 9.60 & 0.5 \\
\hline .6 & & & & & & & & & & & 0.6 \\
\hline & & 7.84 & & & & & & & & & \\
\hline & & $7 \cdot 90$ & $.2 \mathrm{I}$ & 3.46 & $8.7 \mathrm{I}$ & 8. & & 9.46 & & & \\
\hline .9 & & 8.08 & .33 & 8.58 & 8.83 & 9. & .33 & 9.58 & 9.83 & 10.08 & 0.5 \\
\hline .0 & & 8.20 & & 8.70 & 8.95 & & & 9.70 & & & I.0 \\
\hline I & & 8. & & .82 & & & & & & & I. I \\
\hline . & & 8 & & .94 & & & & & & & I. 2 \\
\hline & & 8.5 & $.8 \mathrm{I}$ & .06 & & & & & & & 1.3 \\
\hline .4 & & 8.6 & & 9.18 & 9.43 & & & & Io. & & I. 4 \\
\hline .5 & & 8.80 & & & & & & & & & .5 \\
\hline .6 & & 8.9 & & & & & & & & & .6 \\
\hline .7 & & s & & & & & & & & & I. 7 \\
\hline .8 & & & & 9.66 & & & & & & & I. 8 \\
\hline .9 & 9 & 9.28 & 9.53 & 9.78 & IC & & & & 0.4 & 29 & 1.9 \\
\hline .0 & & & & & & & & & & & 2.0 \\
\hline & & & & & & & & & & & $2 . I$ \\
\hline .2 & & & & & & & & & & .65 & 2.2 \\
\hline & & & & & & & & & & .77 & 2.3 \\
\hline .4 & .63 & & & & & 10.88 & & & & & 2.4 \\
\hline & & & & & & & & & & & \\
\hline & & & & & & & & & & & 2.6 \\
\hline & & & & & & & & & & 25 & 2.7 \\
\hline 2.8 & & & & & & & & & & .37 & \\
\hline 2.9 & & & & & & & & & I 2 & I 2.49 & 2.9 \\
\hline & & & & & & & & & & & $3 . c$ \\
\hline & & & & & & & & & & & $3 . r$ \\
\hline & & & & & & & & & & & 3.2 \\
\hline $3 \cdot 3$ & & & & 47 & & & & & & & 3.3 \\
\hline $3 \cdot 4$ & & II.09 & & & & & & 412.60 & I 2.85 & & 3.4 \\
\hline & & & & & & & & & & & \\
\hline & & & & & & & & & & & \\
\hline & & & & & & & & & & & 3. \\
\hline & & & & & & & & & & & 3.8 \\
\hline ( & I I . +4 & & I I . 94 & & 12.44 & +12.69 & & & & & \\
\hline & & & & & & & & & & & 4. \\
\hline & & & & & & & & & & & 4 \\
\hline & & & & & & & & & & & $4 \cdot 2$ \\
\hline & & & & & & & & & & & \\
\hline & & & & & & . & 113.55 & 13.8 & 114.001 & 114.311 & 14. \\
\hline
\end{tabular}


TABLE FOR SOLIDS-(Continued).

\begin{tabular}{|c|c|c|c|c|c|c|c|c|c|c|c|}
\hline Per & & & Lactor & meter I & Readin & $g$ at 6 & $0^{\circ} \mathrm{Fah}$ & renhei & - & & Ler \\
\hline at & 27 & 28 & 29 & 30 & $3 \mathrm{I}$ & 32 & 33 & 34 & 35 & 36 & Fat \\
\hline & & & & & & & 13.67 & & . I 8 & & \\
\hline & & & & & & & & & & & \\
\hline .7 & & & & & & & & & & & \\
\hline & I 2 & & & & I & 8 & & & & & \\
\hline .9 & 12.64 & & & & & & & & & & 4.9 \\
\hline & 76 & & & & & & & & & & 0.0 \\
\hline & & & & & & & & & & & 5.1 \\
\hline 2 & & & & & & & & & & & 5.2 \\
\hline 3 & & & & & & & & & & & 5. \\
\hline $1 .+4$ & 13.24 & I 3.49 & 13.74 & 14.00 & $1+.25$ & 14.50 & 14.76 & 15.01 & I 5.26 & I $5.5 \mathrm{I}$ & 5.4 \\
\hline & & & & & & & & & & & 5 \\
\hline & & & & & & & & & & & \\
\hline & & & & & & & & & & & 5. \\
\hline & & & & & & & & & & & \\
\hline & & & 14.35 & 14.60 & & I $5 . \mathrm{II}$ & 15.36 & & & I6. I 2 & 5.9 \\
\hline & & 14. & 14 & & I 4 & & 1.5. & & & & 3. \\
\hline
\end{tabular}

Correction for Tenths of Lactometer Readinss.

\begin{tabular}{|c|c|c|}
\hline \multicolumn{3}{|c|}{ Difference. } \\
\hline & .25 & .26 \\
\hline . I & .03 & .03 \\
\hline .2 & .05 & .05 \\
\hline$\cdot 3$ & .08 & .08 \\
\hline .4 & .10 & . \\
\hline .5 & .13 & .13 \\
\hline .6 & .15 & .16 \\
\hline .7 & .18 & .18 \\
\hline .8 & .20 & $.2 \mathrm{I}$ \\
\hline .9 & .23 & .23 \\
\hline
\end{tabular}

\section{CALCULATION OF SP, GR, OF MILK SOLIDS.}

(FLEISCHMANN.)

$$
\text { Sp. gr. of milk solids }=S=\frac{t}{t-\frac{\text { I00s }- \text { I00 }}{s}}
$$

where $s=\mathrm{sp}$. $\mathrm{gr}$. of milk, $t=$ solids of milk. In pure whole milk $S$ varies but little, viz., between I.25 and I.34. When $S$ comes above I. 34 , the milk is suspicious; if above I.4O, it has been skimmed (see page $3{ }^{1} 3$ ). 


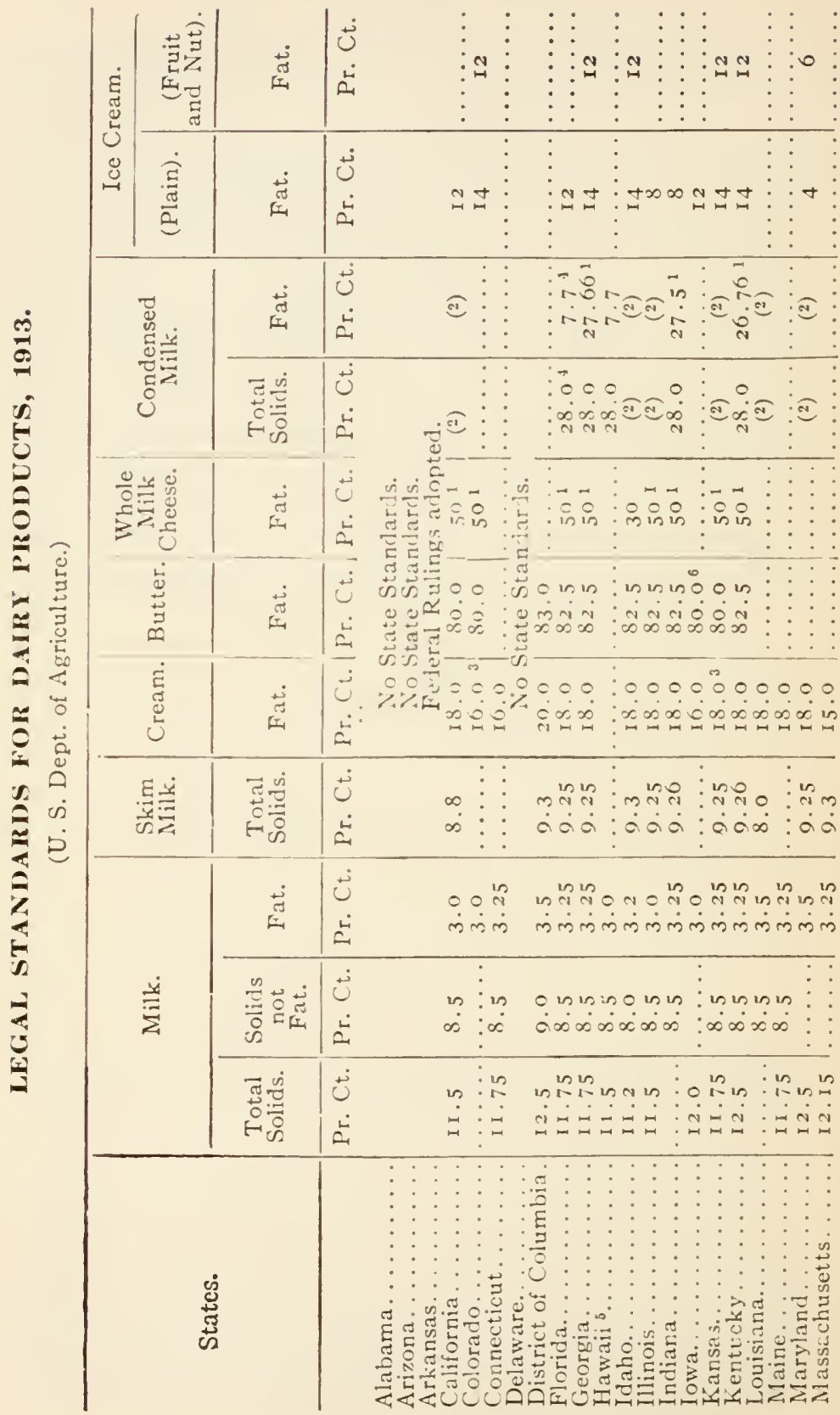




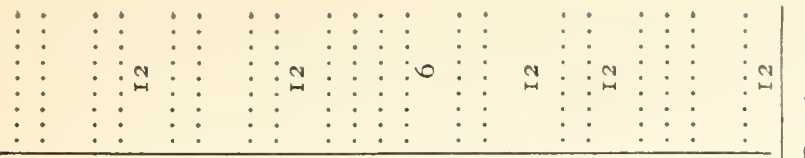

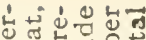

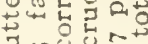

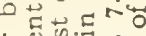

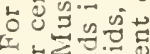
$\infty$

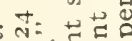

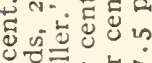
0 믈 N

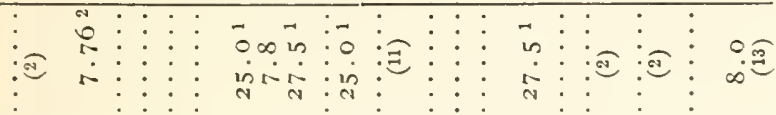

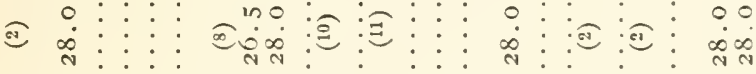

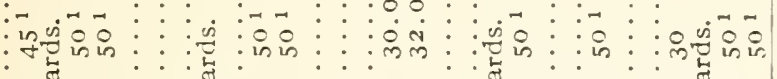
$\div: \overbrace{}^{-4}$ $\ln 2 \ln : 0$

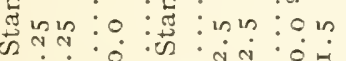
is

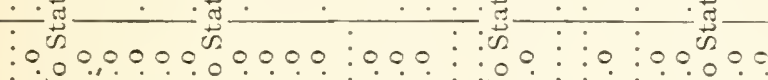

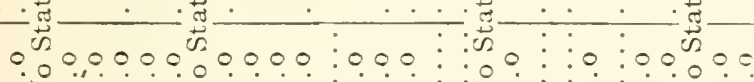
$\dot{\infty} \infty \dot{\infty}: \dot{\infty}$

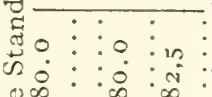
迎

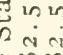

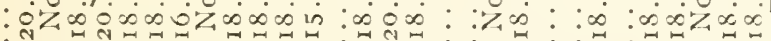

\begin{tabular}{|c|c|c|c|c|c|c|c|c|c|c|c|c|c|c|c|c|c|}
\hline • & & - & - & - & - & - & - & . & . & • & - & - & & - & - & - & \\
\hline • & in & - & - & - & - in in & - & - & - & . & • & - & - & in & - & & in & \\
\hline • & $\mathrm{N}$ & $\because$ & in & : & - N N & : & : & : & : & : & : & : & $\mathrm{Cl}$ & : & $: 0$ & $\therefore \mathrm{Cm}$ & \\
\hline - & $\dot{0}$ & . & $-i$ & . &.$\dot{0}$ & . & . & . & . & . & : & - & $\dot{0}$ & : & & - $\dot{0}$ & i \\
\hline - & a & . &.$\infty$ & - & .0 & . & . & . & . & . & • & . & o & & . & . $\mathrm{C}$ & 00 \\
\hline - & & - & - & - & - & - & - & • & - & . & • & - & & • & • & • & \\
\hline
\end{tabular}

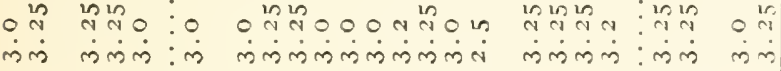

: n n

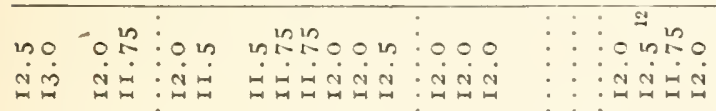

$\longrightarrow$

$: \vdots: \vdots: \dot{0}$

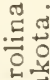

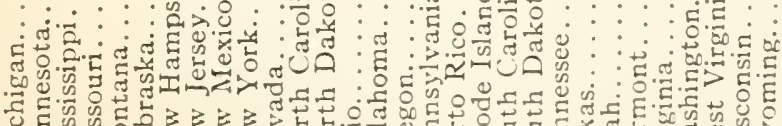

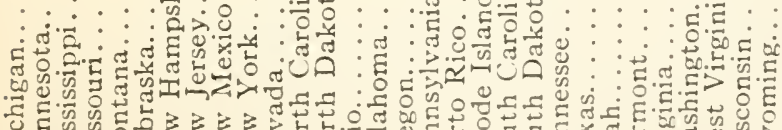

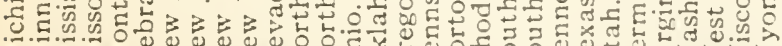

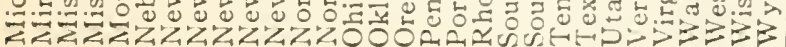

范:

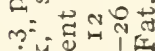
mis.

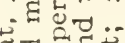

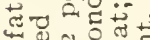
u

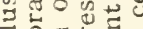

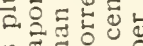
in

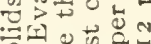

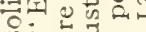

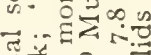

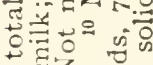

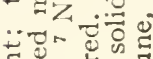
焉管 월음늠

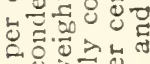
$\infty$ 的等

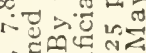
$+\operatorname{soc}^{\circ} 1$

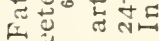

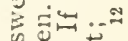
का है की

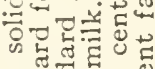

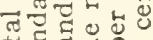

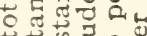

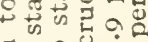
ㄷ.ㅇ을

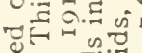
....

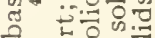
更 牙牙若焉

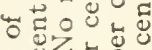
记出吕。 足造 的象

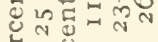

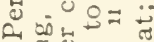

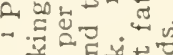
성 다웍

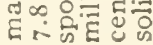




\section{GOVERNMENT STANDARDS OF PURTT FOR MILIK AND ITS PRODUCTS.*}

\section{A.-Milks.}

I. Milk is the fresh, clean, lacteal secretion obtained by the complete milking of one or more healthy cows, properly fed and kept, excluding that obtained within fifteen days before and ten days after calving, and contains not less than eight and one-half (8.5) per cent of solids not fat, and not less than three and one-quarter (3.25) per cent of milk-fat.

2. Blended milk is milk modified in its composition so as to have a definite and stated percentage of one or more of its constituents.

3. Skim milk is milk from which a part or all of the cream has been removed, and contains $\mathrm{n} n \mathrm{t}$ less than nine and one-quarter (9.25) per cent of milk solids.

4. Pasteurized milk is milk that has been heated below boiling, but sufficiently to kill most of the active organisms present, and immediately cooled to $50^{\circ} \mathrm{Fahr}$. or lower.

5. Sterilized milk is milk that has been heated at the temperature of boiling water or higher for a length of time sufficient to kill all organisms present.

6. Condensed milk, evaporated milk, is milk from which a considerable portion of water has been evaporated, and contains not less than twenty-eight (28) per cent of milk solids, of which not less than twenty-seren and five-tenths (27.5) per cent is milk-fat.

7. Sweetened condensed milk is milk from which a considerable portion of water has been evaporated and to which sugar (sucrose) has been added, and contains not less than twenty-eight (2S) per cent of milk solids, of which not less than twenty-seren and five-tenths $(27.5)$ per cent is milk-fat.

8. Condensed skim milk is skim milk from which a considerable portion of water has been evaporated.

9. Buttermilk is the product that remains when butter is removed from milk or cream in the process of churning.

* Proclaimed by the Secretary of Agriculture, June 26. 1906. (Circ. No. I9, Office of the Secretary, U. S. Dept. of Agriculture.) 
Iо. Goat's milk, cue's milk, et cetera, are the fresh, clean, lacteal secretions, free from colostrum, obtained by the complete milking of healthy animals other than cows, properly fed and kept, and conform in name to the species of animal from which they are obtained.

\section{B.-Cream.}

I. Cream is that portion of milk rich in milk-fat, which rises to the surface of milk on standing, or is separated from it by centrifugal force, is fresh and clean, and contains not less than eighteen (IS) per cent of milk-fat.

2. Evaporated cream, clotted cream, is cream from which a considerable portion of water has been evaporated.

\section{r.-Milk-Fat or Butter-Fat.}

I. Milk-fat, butter-fat, is the fat of milk and has a ReichertMeissl number not less than twenty-four (24) and a specific gravity not less than $0.905\left(\frac{40^{\circ} \mathrm{C}}{40^{\circ} \mathrm{C}}\right)$.

\section{D.-Butter.}

I. Butter is the clean, non-rancid product made by gathering in any manner the fat of fresh or ripened milk or cream into a mass, which also contains a small portion of the other milk constituents, with or without salt, and contains not less than eightytwo and five-tenths $\left(S_{2.5}\right)$ per cent of milk-fat. By acts of Congress approved August 2, IS86, and May 9, I902, butter may also contain added coloring-matter.

2. Renovated butter, process butter, is the product made by melting butter and reworking, without the ardition or use of chemicals or any substances except milk, cream, or salt, and contains not more than sixteen (I6) per cent of water and at least eighty-two and five-tenths (82.5) per cent of milk-fat.

\section{E.-Cheese.}

I. Cheese is the sound, solid, and ripened product made from milk or cream by coagulating the cascin thereof with rennet or lactic acid, with or without the addition of ripening ferments 
and seasoning, and contains, in the water-free substance, not less than fifty (50) per cent of milk-fat. By act of Congress, approved June 6, I 896 , cheese may also contain added coloringmatter.

2. Skim milk cheese is the sound, solid, and ripened product made from skim milk by coagulating the casein thereof with rennet or lactic acid, with or without the addition of ripening ferments and seasoning.

3. Goat's milk chcese, cuic's milk checse, et cetera, are the sound ripened products made from the milks of the animals specified by coagulating the casein thereof with rennet or lactic acid, with or without the addition of ripening ferments and seasoning.

\section{F. Ice Creams.}

I. Ice cream is a frozen product made from cream and sugar, with or without a natural flavoring, and contains not less than fourteen (i 4 ) per cent of milk-fat.

2. Fruit ice cream is a frozen product made from cream, sugar, and sound, clean, mature fruits, and contains not less than twelve (12) per cent of milk-fat.

3. Nut ice cream is a frozen product made from cream, sugar, and sound, non-rancid nuts, and contains not less than twelve (I2) per cent of milk-fat.

\section{G.-Miscellaneous Milk Products.}

I. Whey is the product remaining after the removal of fat and casein from milk in the process of cheese-making.

2. Kumiss is the product made by the alcoholic fermentation of mare's or cow's milk. 


\section{ADULTERATION OF MILK:}

The legal standards adopted in the different States of the Union determine the limits for fat or solids, below which the milk offered for sale must not fall. Where no control sample can be taken of a suspected sample of milk, calculations of the extent of the adulteration practised are made on basis of the legal standard in each State. Whenever possible, a control sample should be secured on the premises of the suspected party, and subjected to analysis. If the control sample contains appreciably less fat or solids not fat than did the suspected sample, the latter was skimmed or watered, or both skimmed and watered.*

SkIMMING.-I. If a sample is skimmed, the following formula will give the number of pounds of fat abstracted from Ioo lbs. of milk :

$$
\text { Fat abstracted }=x=\text { legal standard for fat }-f, \text {. }
$$

$f$ being the per cent of fat in the suspected sample.

In this and following formulas the percentages found in the control samples, if such are at hand, are always to be substituted for the legal standards.

II. The following formula will give the per ce.tt of fat abstracted, calculated on the total quantity of fat originally found in the milk:

$$
x=\mathrm{I} \text { оо }-\frac{f \times \text { гоo }}{\text { leg. stand. for fat } . . . ~ . ~}
$$

WATERING.-I. If a sample is watered, the calculations are most conveniently based on the percentage of solids not fat in the milk:

Per cent extraneous water in milk

$$
=x=\mathrm{roo}-\frac{s \times \mathrm{roo}}{\text { leg. stand. for solids not fat' }} .
$$

$s$ being ine per cent of solids not fat in the suspected sample.

Example.-A sample contains 8.5 per cent of solids not fat; if the legal standard for solids not fat be 9 per cent, I $00-\frac{8.5 \times \text { IOO }}{9}=5.6$, will give the per cent of extraneous water in the suspected sample of milk.

* Ece Farringiun-Hu!l, Testing Milk and its Products, $22 \mathrm{~d}$ Ed., PP. I I $1-I I 7$. 
II. Watering of milk may also be expressed in percent of water added to the original milk, by formula IV :

Per cent water added to original milk

$$
=x=\frac{\text { Ino } \times \text { leg. stand. for solids not fat }}{s}-\text { Ioo. }
$$

In the example given above, $\frac{100 \times 9}{5.5}-100=5.9$ per cent of water was added to the original milk.

Watering anil Skmming.- If a sample has been both watered and skimmed, the extent of watering is ascertained by means of formula III; and the fat abstracted found according to the following formula:

Per cent fat abstracted

$=x=$ leg.stand.for fat $-\frac{\text { leg. stand. for solids not fa: }}{s} \times f$.

Example.-A sample of milk contains 2.4 per cent of fat and S.I per cent solids not fat; then

extraneous water in milk $=100-\frac{S_{. I} \times 100}{9}=$ Io per cent;

1 at abstracted

$$
=3-\frac{9 \times 2.4}{\text { S.I }}=.33 \text { per cent. }
$$

100 lbs. of the milk contained ro lbs. of extraneous water and .33 lb. of fat had been skimmed from it.

\section{RANGES OF THE VARIATIONS IN THE COM- POSITION OF HERD MILK. (Fleischmans.)}

The specific gravity (expressed in degrees) may go above or below the yearly average by more than Io per cent.

The per cent of fat may go above or below the yearly average by more than 30 per cent.

The per cent of total solids may go above or below the yearly average by more than it per cent.

The per cent of solias not fat may go above or below the yearly average by more than io per cent. 
TABLE FOR CONVER'IING QUARTS OF MILK INTO POUNIS.

\begin{tabular}{|c|c|c|c|c|c|c|c|}
\hline Qts. & Lbs. & Qts. & Lbs. & Qts. & Lbs. & Qts & I.bs. \\
\hline I & $2 .: 5$ & 29 & $62 \cdot 3$ & 57 & 122.4 & 85 & 182.5 \\
\hline 2 & $4 \cdot 3$ & 30 & 6.4 .4 & $5^{8}$ & 124.5 & 86 & 184.6 \\
\hline 3 & 6.4 & 31 & 66.5 & 59 & เ26.6 & 87 & 186.8 \\
\hline 4 & 8.6 & 32 & 68.7 & 60 & I 28.8 & 88 & 1889 \\
\hline 5 & I0 7 & 33 & 70.8 & 61 & 130.9 & 89 & 1910 \\
\hline 6 & 12.9 & 34 & 73.0 & 62 & 133.1 & 90 & 193.2 \\
\hline 7 & 15.0 & 35 & $75 . \mathrm{I}$ & $6_{3}$ & 135.2 & $9 \mathrm{I}$ & 195.3 \\
\hline 8 & 17.2 & 36 & $77 \cdot 3$ & 64 & 137.4 & 92 & 197.5 \\
\hline 9 & 19.3 & 37 & 70.4 & $6_{5}$ & I 39.5 & 93 & 199.6 \\
\hline 10 & 21.5 & 38 & 81.6 & 66 & 141.7 & 94 & 2018 \\
\hline II & 23.6 & 39 & $83 \cdot 7$ & 67 & 1.43 .8 & 95 & 203.9 \\
\hline 12 & 25.8 & $4^{\circ}$ & 85.9 & 68 & $\mathrm{I}_{4} 6.0$ & 96 & 206.1 \\
\hline 13 & 27.9 & 41 & 88.0 & 69 & $\mathrm{I}_{4} 8 . \mathrm{I}$ & 97 & 208.2 \\
\hline 14 & 30.1 & 42 & 90.2 & 70 & I 50.3 & 98 & 210.4 \\
\hline i5 & $3^{2} .2$ & 43 & 92.3 & 71 & 152.4 & 99 & 212.5 \\
\hline 16 & $34 \cdot 3$ & 44 & 94.5 & 72 & 154.6 & 100 & 214.7 \\
\hline 17 & 36.5 & 45 & 96.6 & 73 & 156.7 & 200 & 420.3 \\
\hline 18 & $3^{8.6}$ & $4^{6}$ & 98.7 & 74 & 158.8 & 300 & 644.0 \\
\hline 19 & 40.8 & 47 & 100.9 & 75 & 161.0 & 400 & 8586 \\
\hline 20 & 42.9 & $4^{8}$ & 103.0 & $\because 5$ & $\mathrm{I} \sigma_{3} . \mathrm{I}$ & 500 & 1073.3 \\
\hline $2 \mathrm{I}$ & $45 . I$ & 49 & 105.2 & 77 & 165.3 & 600 & $=2880$ \\
\hline 22 & 47.2 & 50 & $107 \cdot 3$ & 78 & 167.4 & 700 & I 502.6 \\
\hline 23 & 49.4 & $5^{1}$ & 109.5 & 79 & 169.6 & 800 & 1717.3 \\
\hline 24 & $5^{1} \cdot 5$ & 52 & III.6 & 80 & 171.7 & 900 & 193 I. \\
\hline 25 & 53.7 & 53 & 113.8 & $8 \mathrm{r}$ & 173.9 & 1000 & $2: 46.6$ \\
\hline 26 & 55.8 & 54 & 115.9 & 82 & $1-6.0$ & & \\
\hline 27 & $5^{8} .0$ & 55 & II 8 . I & $8_{3}$ & 178.2 & & \\
\hline 28 & 60.1 & 56 & 120.2 & 84 & 180.3 & & \\
\hline
\end{tabular}

TABLE FOR CONVERTING POUNIS OF MILI I N'IOC QUAR'IS.

\begin{tabular}{|c|c|c|c|c|c|c|c|}
\hline Lbs. & $Q$ ts. & Lbs. & Qts & Lbs. & Qts. & Lbs. & Qts. \\
\hline I & .47 & 29 & 13.5 & 57 & 266.6 & 85 & 39.6 \\
\hline 2 & .93 & 30 & 14.0 & $5^{8}$ & 27.0 & 86 & 40.1 \\
\hline 3 & 1.40 & $3 \pi$ & 14.4 & 59 & 27.5 & 87 & 40.5 \\
\hline 4 & 1.86 & 32 & 14.9 & 60 & 28.0 & 88 & 41.0 \\
\hline 5 & 2.33 & 33 & 15.4 & $6 t$ & 28.4 & 89 & $4 \mathrm{I} \cdot 5$ \\
\hline 6 & 280 & 34 & I 5.8 & 62 & 28.9 & 90 & 41.9 \\
\hline 7 & 3.26 & 35 & 16.3 & $6_{3}$ & 29.4 & $9^{1}$ & 42.4 \\
\hline 8 & $3 \cdot 73$ & 36 & 16.8 & 64 & 29.8 & 92 & 42.9 \\
\hline 9 & 4. Iy & 37 & 17.2 & 65 & 30.3 & 93 & $43 \cdot 3$ \\
\hline Io & 4.66 & $3^{8}$ & 17.7 & 66 & 30.8 & 94 & $43 . \overline{8}$ \\
\hline II & 5.13 & 39 & 18.2 & 67 & 3 I. 2 & 95 & $44 \cdot 3$ \\
\hline 12 & 5.59 & 40 & 18.6 & 68 & $3^{1} .7$ & 96 & 44.7 \\
\hline 13 & 606 & $4 \mathrm{I}$ & 19.1 & 69 & 32.2 & 97 & 45.2 \\
\hline$I_{4}$ & 6.52 & 42 & 19.6 & 70 & 32.6 & 98 & 45.7 \\
\hline 15 & 6.99 & 43 & 20.0 & 71 & 33.1 & 99 & 46.1 \\
\hline 16 & $7.4^{6}$ & 44 & 20.5 & 72 & 33.6 & 100 & 46.6 \\
\hline 17 & 7.92 & 45 & 21.0 & 73 & 340 & 200 & 93.2 \\
\hline 18 & 8.39 & $4^{6}$ & 21.4 & 74 & 34.5 & 300 & 139.8 \\
\hline 19 & 8.85 & 47 & 21.0 & 75 & 35.0 & 400 & 186.4 \\
\hline 80 & $9 \cdot 32$ & 48 & 224 & $7^{6}$ & 354 & 500 & 233.0 \\
\hline 21 & 9.79 & 49 & 22.8 & 77 & 35.9 & 600 & 279.6 \\
\hline 22 & 10.3 & 50 & 23.3 & 78 & 36.3 & 700 & 326.2 \\
\hline 23 & 10.7 & $5 \mathrm{I}$ & 23.8 & 79 & 36.8 & 800 & 372.8 \\
\hline 24 & II 2 & $5^{2}$ & 24.2 & 80 & $37 \cdot 3$ & 900 & 419.4 \\
\hline 25 & II 7 & 53 & 247 & 81 & 37.7 & 1000 & 466.0 \\
\hline 26 & 12.1 & 54 & 25.2 & 82 & $3^{8.2}$ & & \\
\hline 2.7 & 12.6 & 55 & 25.6 & $8_{3}$ & 38.7 & & \\
\hline 28 & 13.1 & 56 & 26.1 & 84 & 39.1 & & \\
\hline
\end{tabular}


MILK PRICES BY MEASURES.

(N. Y. Farmer.)

\begin{tabular}{|c|c|c|c|c|c|}
\hline $\begin{array}{c}\text { Cents per } \\
\text { Quart. }\end{array}$ & $\begin{array}{c}\text { Cents per } \\
40-q t . \\
\text { Can. }\end{array}$ & $\begin{array}{l}\text { Cents per } \\
\text { roo Pounds. }\end{array}$ & $\begin{array}{c}\text { Cents per } \\
\text { Quart. }\end{array}$ & $\begin{array}{c}\text { Cents per } \\
40-\eta t . \\
\text { Can. }\end{array}$ & $\begin{array}{l}\text { Cents per } \\
\text { roo Pounds }\end{array}$ \\
\hline I. 100 & 44 & $51 \cdot 162$ & 2.375 & 95 & 110.465 \\
\hline I. I 25 & 45 & 52.325 & 2.400 & 96 & III. $62 \mathrm{~S}$ \\
\hline I. I 50 & 46 & $53 \cdot 488$ & 2.425 & 97 & $\mathrm{I} I 2.79 \mathrm{I}$ \\
\hline I. I 75 & 47 & $54.65 \mathrm{I}$ & 2.450 & 98 & 113.053 \\
\hline I. 200 & 48 & 55.813 & 2.475 & 90 & 115.116 \\
\hline I. 225 & 49 & 56.076 & 2.500 & 100 & 116.270 \\
\hline I. 250 & 50 & 58.189 & 2.525 & IOI & 117.442 \\
\hline 1.275 & $5 \mathrm{I}$ & 59.302 & 2.550 & 102 & IIS. 005 \\
\hline I. 300 & 52 & $60.4^{65}$ & 2.575 & 103 & 119.767 \\
\hline I. 325 & 5.3 & 61.627 & 2.600 & 104 & 120.930 \\
\hline I. $35^{\circ}$ & 54 & 62.790 & 2.625 & 105 & 122.093 \\
\hline I. 375 & 55 & 03.053 & 2.650 & 106 & I23.256 \\
\hline I. 400 & 56 & 65.116 & 2.675 & 107 & 124.410 \\
\hline I. +25 & 57 & 66.279 & 2.700 & $10 \$$ & 125.581 \\
\hline 1.450 & 58 & $67.4+1$ & 2.725 & 100 & 126.744 \\
\hline I. 475 & 59 & 68.604 & 2.750 & 110 & I 27.007 \\
\hline 1.500 & 60 & 60.767 & 2.775 & I I I & I 20.070 \\
\hline I. 525 & 61 & 70.930 & 2.800 & 112 & 130.233 \\
\hline 1.550 & 62 & 72.093 & 2.825 & I 13 & 131.305 \\
\hline I. 575 & 63 & 73.255 & 2.850 & I I 4 & I 32.558 \\
\hline I. 600 & 64 & 74.418 & 2.875 & I I 5 & 133.721 \\
\hline I. 625 & 65 & $75.58 \mathrm{I}$ & 2.000 & I I 6 & I 34.884 \\
\hline I. 650 & 66 & 76.744 & 2.025 & I 17 & I 36.047 \\
\hline I. 675 & 67 & 77.007 & 2.050 & I I 8 & I 37.209 \\
\hline I. 700 & 68 & 79.069 & 2.975 & I 19 & I 38.372 \\
\hline I.725 & 60 & So. 232 & 3.000 & I 20 & I 39.535 \\
\hline I. 750 & 70 & $81 \cdot 305$ & 3.025 & I 2 I & 140.608 \\
\hline I. 775 & 71 & 82.558 & 3.050 & I 22 & $\mathrm{I}+\mathrm{I} .86 \mathrm{I}$ \\
\hline I. 800 & 72 & $8_{3} .72 \mathrm{I}$ & 3.075 & I 23 & 143.023 \\
\hline I. 825 & 73 & $8_{4} .88_{3}$ & 3.100 & I 24 & 144.186 \\
\hline I. 850 & 74 & 86.046 & 3. I 25 & I 25 & 145.349 \\
\hline I. 875 & 75 & 87.209 & 3.150 & 126 & 146.512 \\
\hline 1.900 & 76 & 88.372 & 3.175 & I 27 & 147.675 \\
\hline I. 925 & 77 & So. 535 & 3.200 & I 28 & $\begin{array}{r}48.837 \\
\end{array}$ \\
\hline I. 950 & 78 & 90.697 & 3.225 & I 29 & I 50.000 \\
\hline I. 975 & 79 & 91.860 & 3.250 & I 30 & I 51.163 \\
\hline 2.000 & 80 & 93.023 & 3.275 & I 3 I & 152.326 \\
\hline 2.025 & $8 I$ & $94 \cdot$ I $\$ 6$ & 3.300 & 132 & I 53.489 \\
\hline 2.050 & 82 & 95.349 & 3.325 & I 33 & I $54.65 \mathrm{I}$ \\
\hline 2.075 & 83 & 96.511 & 3.350 & I 34 & 155.814 \\
\hline 2.100 & 8.4 & 97.674 & 3.375 & I 35 & I 56.977 \\
\hline 2. I 25 & $S_{5}$ & 98.837 & 3.400 & I 36 & 158.140 \\
\hline 2. I 50 & 86 & 100.000 & 3.425 & I 37 & I 50.303 \\
\hline 2.175 & 87 & IOI. I 63 & 3.450 & 138 & 160.465 \\
\hline 2.200 & 88 & 102.325 & 3.475 & I 39 & I 61.628 \\
\hline 2.225 & 89 & 103.488 & 3.500 & I 40 & $102.79 \mathrm{I}$ \\
\hline 2.250 & 90 & $104.65 \mathrm{I}$ & 3.525 & I 4 I & 163.954 \\
\hline 2.275 & $9 \mathrm{I}$ & 105.814 & 3.550 & 142 & I 65.117 \\
\hline 2.300 & 02 & 106.077 & 3.575 & I 43 & 166.279 \\
\hline 2.325 & 93 & 108.139 & 3.600 & $1+4$ & $167.4+2$ \\
\hline 2.350 & 94 & 109.302 & 3.625 & 145 & 168.605 \\
\hline
\end{tabular}


MHL PRICES BY MEASURES.-Continued.

\begin{tabular}{|c|c|c|c|c|c|}
\hline $\begin{array}{l}\text { Cents per } \\
\text { Quart. }\end{array}$ & $\begin{array}{c}\text { Cents per } \\
\text { 40-qt. } \\
\text { Canl. }\end{array}$ & $\begin{array}{c}\text { Cents ner } \\
\text { too Pounds. }\end{array}$ & $\begin{array}{l}\text { Cents per } \\
\text { Quart. }\end{array}$ & $\begin{array}{c}\text { Cents per } \\
40-q t . \\
\text { Can. }\end{array}$ & $\begin{array}{l}\text { Cents per } \\
\text { roo Pounds. }\end{array}$ \\
\hline 3.650 & 146 & 169.768 & 3.975 & I 59 & J 84.884 \\
\hline 3.675 & 147 & 170.931 & 4.000 & 160 & 186.047 \\
\hline 3.700 & 148 & 172.093 & 4.025 & I $6 \mathrm{I}$ & 187.210 \\
\hline 3.725 & I 49 & 173.256 & 4.050 & 162 & 188.373 \\
\hline 3.750 & I 50 & 174.419 & 4.075 & I 63 & 189.535 \\
\hline 3.775 & I 5 I & 175.582 & 4.100 & 164 & 190.698 \\
\hline 3. 300 & 152 & 176.745 & 4.125 & I 65 & I $9 \mathrm{I} .86 \mathrm{I}$ \\
\hline 3.325 & I 53 & 177.907 & 4.150 & I 66 & 193.024 \\
\hline $3.5,50$ & I 54 & 179.070 & 4.175 & 167 & $194.18 ?$ \\
\hline 3.875 & I 55 & 180.233 & $4 \cdot 200$ & I 68 & I $95.3 \div 9$ \\
\hline 3.900 & I 56 & I SI. 396 & 4.225 & I 69 & 196.512 \\
\hline 3.025 & I 57 & I 82.559 & 4.250 & 170 & 107.675 \\
\hline 3.950 & I 58 & 183.721 & 4.275 & I 7 I & I 98.838 \\
\hline
\end{tabular}

\section{RELATIVE VAIUE OF MILK AND CREAM OF DIFERENT FA'T CONTENTS.}

\section{(FRASER)}

The table gives the relative value per quart and number of quarts in a dollar's worth of milk or cream of different fat contents, calculated according to the food value of 3 -per-cent. milk at 5 cents per quart.

\begin{tabular}{|c|c|c|c|c|c|}
\hline $\begin{array}{l}\text { Per Cent } \\
\text { of Fat. }\end{array}$ & $\begin{array}{l}\text { Price per } \\
\text { Quart, } \\
\text { Cerits. }\end{array}$ & $\begin{array}{l}\text { No. of } \\
\text { Quarts } \\
\text { a Dollar. }\end{array}$ & $\begin{array}{c}\text { Per Cent } \\
\text { of Fat. }\end{array}$ & $\begin{array}{l}\text { Price per } \\
\text { Quart, } \\
\text { Cents. }\end{array}$ & $\begin{array}{l}\text { No. of } \\
\text { Quarts } \\
\text { a Dollar. }\end{array}$ \\
\hline $0 . I$ & 2.8 & 35.7 & I 7 & I 5.5 & 6.4 \\
\hline I & $3 \cdot 5$ & 28.6 & 18 & 16.3 & 6.1 \\
\hline 2 & $4 \cdot 2$ & 23.8 & I 9 & $I_{7} .0$ & 5.9 \\
\hline 3 & 5.0 & 20.0 & 20 & 17.7 & 5.6 \\
\hline 4 & $5 \cdot 7$ & 17.5 & 21 & I 8.4 & $5 \cdot 4$ \\
\hline 5 & 6.5 & 15.4 & 22 & I 9.2 & 5.2 \\
\hline 6 & 7.2 & 13.9 & 23 & 20.0 & 5.0 \\
\hline 7 & 8.0 & 12.5 & 24 & 20.7 & 4.8 \\
\hline 8 & 8.7 & I I $\cdot 5$ & 25 & $2 \mathrm{I} \cdot 5$ & 4.5 \\
\hline 9 & 9.5 & 10.5 & 26 & 22.2 & $4 \cdot 5$ \\
\hline 10 & 10.2 & 9.8 & 27 & 23.0 & $4 \cdot 3$ \\
\hline I I & I I . O & 90 & 28 & 23.7 & 4.2 \\
\hline I 2 & I 1.7 & 8.5 & 29 & 24.5 & $4 . I$ \\
\hline I 3 & 12.5 & 8.0 & 30 & 25.2 & 4.0 \\
\hline I 4 & 13.2 & 7.6 & $3 \mathrm{I}$ & 26.0 & 3.8 \\
\hline I 5 & 14.0 & $7 \cdot 1$ & 32 & 26.7 & $3 \cdot 7$ \\
\hline I 6 & 14.7 & 6.8 & & & \\
\hline
\end{tabular}




\section{AMOUNTS OF MHLK, CREAM, OR SLIM MILK TO BE USED IN MODIFYING MILK. (PEARSON.)}

The amounts of cream or skim milk that are to be used in modifying normal milk may be calculated by use of the following simple method:

Draw a square and write at the two left-hand corners the percentages of fat in the milk and the cream or skim milk that are to be mixed. In the centre place the persentage required. The differences between the latter fiģures and those at the lefthand corners are then placed at the wo corners with which they stand in line. The two right-hand figures will represent the proportions of milk and cream or skim milk that should be weighed out in making the modified milk.

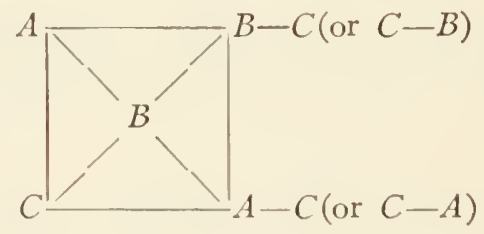

Example.-How much 5 per cent milk must be added to milk containing 3.5 per cent fat in order to raise its fat content to 4 per cent? In this case $A=3.5, B=4$, and $C=5$ (see above); then $B-C=1.0$ and $A-B=.5 . \quad \frac{\mathrm{I} .0}{\mathrm{I} .5} \times 100=66.7$ and $\frac{.5}{\mathrm{I} .5} \times 100=$ 3.33. To make, say, rooo lbs. of 4 per cent milk $667 \mathrm{lbs}$. of 3.5 per cent and $333 \mathrm{lbs}$. of 5 per cent milk must therefore be taken.

This method of calculation may be used to advantage in modifying or standardizing milk or cream, with either cream, new milk, or skim milk, whether a product of a higher or lower fa: content is wanted than that at hand. 


\section{STANDARDIZATION OF MILK.}

(ERF.)

Quantity of Skim Milk to be Added to, or Subtracted from, roo Pounds of Milk to Make Milk of a Desired Per Cent. of Fat.

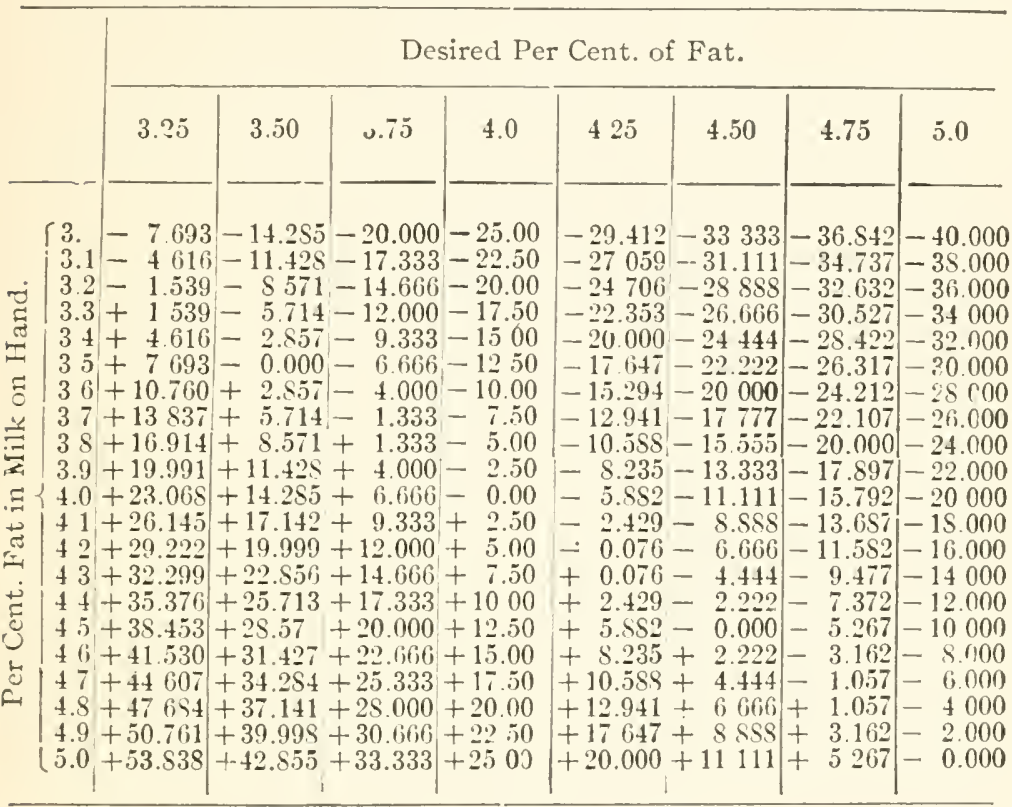

To find the pounds of skim milk to be added or removed, trace the vertical column of the desired per cent of fat to where the horizontal column representing the per cent. of fat in the milk on hand intersects; the result will be the number of pounds of shim milk to be added or removed to roo $1 \mathrm{bs}$. (f milk, as indicated by a plus or minus sign before the figure (see Ill. Bull. No. 75). 


\section{RULES ANU REGUIATIONS}

to be observed in the care of cows and the handling of milk shipped to the City of New York. (Dept. of Iealth, City of New York.)

The Cows.- I. The cows must be kept clean.

2. Manure must not be permitted to collect upon the tail, sides, udder, and belly of any milch-cows.

Stables.-I. Cow stables must be well lighted and ventilated.

2. Floors must be tight and well drained.

3. Manure must be removed from the stalls and gutters before the morning milking and also before the afternoon milking, where the cows remain in the stables all day.

4. Walls and ceilings must be kept clean.

5. The ceiling must be so constructed that dust and dirt therefrom shall not readily fall to the floor or into the milk.

6. Stables must be whitewashed at least once a year.

The Water-supply.-I. The water-supply used in the barn and for washing milk utensils must be free from contamination.

The Milk House.- $\mathrm{I}$. A milk house must be provided which is separated from the stable and the dwelling-house.

2. It must be lept clean and must not be used for any purpose except the handling of milk.

The Milkers.-I. No person having any communicable clisease, or one caring for persons having such disease, must be allowed to handle the milk or milk utensils.

The Uicnsils.- I. All milk-utensils, including pails, cans, strainers, and dippers, must be kept thoroughly clean and must be washed and scalded after each using.

The Milk.- I. Milk from diseased cows must not be shipped.

2. The milk must not be in any way adulterated.

3. The straining of milk must be done in the milk house only.

4. All milk must be cooled to a temperature not above $55 \mathrm{deg}$. F. within two hours after being drawn, and kept thereafter below that temperature, and must be cooled to $50 \mathrm{deg}$. or less if not delivered at the creamery twice daily.

5. The use of any preservative or coloring matter is an adulteration, and its use by a producer or shipper will be a sufficient cause for the exclusion of his milk from the City of New York. 
PERCENTAGE COMPOSITION OF CREAM. (KöNig.)

\begin{tabular}{|c|c|c|c|}
\hline & $\begin{array}{c}\text { Mean of } 47 \\
\text { Analyses. }\end{array}$ & Minimum. & Maximum. \\
\hline 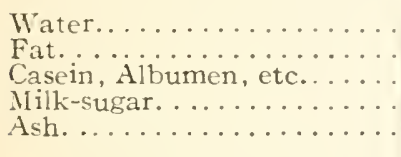 & $\begin{array}{r}67.61 \\
23.80 \\
4.12 \\
3.92 \\
.53\end{array}$ & \multirow[t]{2}{*}{$\begin{array}{r}43.04 \\
15.78 \\
1.75 \\
.62 \\
.11\end{array}$} & \multirow[t]{2}{*}{$\begin{array}{r}83.23 \\
30.19 \\
8.19 \\
6.23 \\
1.10\end{array}$} \\
\hline Specific gravity, I.I0o.. & 100.00 & & \\
\hline
\end{tabular}

\section{PEIRCENTAGE COMIOSITION GH IMIRY \\ IRODUCTS. ( (ÏN1G.)}

\begin{tabular}{|c|c|c|c|c|c|c|c|c|}
\hline & 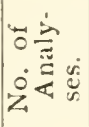 & 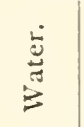 & تี & 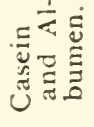 & 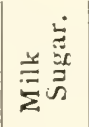 & $\frac{\dot{a}}{4}$ & \multicolumn{2}{|c|}{$\begin{array}{l}\text { Specific } \\
\text { Gravity. }\end{array}$} \\
\hline $\begin{array}{l}\text { Skim - milk, grav- } \\
\text { ity creaming } . . \\
\text { Centrifugal skim- }\end{array}$ & 56 & 90.43 & .87 & $3 \cdot 26$ & $4 \cdot 74$ & .70 & 1.0 & 357 \\
\hline milk $\ldots \ldots \ldots$ & 7 & 90.60 & .31 & 3.06 & $5 \cdot 29$ & .74 & 1.0 & 350 \\
\hline Butterınilk........ & 57 & 90.12 & I. .09 & 4.03 & 4.04 & .72 & 1.0 & 348 \\
\hline Whey. . * ... & 46 & $93 \cdot 3^{8}$ & 32 & .86 & $4 \cdot 79$ & .65 & 1.0 & 272 \\
\hline $\begin{array}{l}\text { Preserved milk } \\
\text { Condensed milk. }\end{array}$ & 4 & 8797 & 321 & $3 \cdot 34$ & $4 \cdot 74$ & $\cdot 74$ & 1.0 & 313 \\
\hline $\begin{array}{l}\text { (no sugar added) } \\
\text { Conclensed milk, }\end{array}$ & 36 & $5^{8.99}$ & 12.42 & 11.92 & $14 \cdot 49$ & 2.18 & & \\
\hline $\begin{array}{l}\text { (sugar added). } \\
\text { Scherff's condens- }\end{array}$ & 64 & $25.6 \mathrm{I}$ & 10.35 & I I.79 & $50.06^{*}$ & 2.19 & & \\
\hline $\begin{array}{l}\text { ed milk } \\
\text { Koumiss }\end{array}$ & 5 & 72.87 & 6.62 & 8.20 & 10.63 & 1. 68 & $\begin{array}{l}\text { Lactic } \\
\text { acid. }\end{array}$ & $\begin{array}{l}\text { Alco } \\
\text { hol. }\end{array}$ \\
\hline $\begin{array}{l}\text { mares milk) } \\
\text { Koumiss (from }\end{array}$ & 43 & 90.44 & 1. 46 & 2.24 & I. 77 & .42 & $.9 \mathrm{I}$ & I.9] \\
\hline cows' milk). ... & II & 89.20 & I. 83 & 2.66 & 4.09 & .43 & .55 & 1.14 \\
\hline Kepliri......... & 22 & 91.21 & 144 & 3.49 & $2.4 \mathrm{I}$ & .68 & 1.02 & .75 \\
\hline
\end{tabular}

* 13.84 per cent milk-sugar, 36.22 per cent cane-sugar. 
YIELD OF CREAM FROM MLK OF DIFFERENT RICHNESS.

\begin{tabular}{|c|c|c|c|c|c|c|c|c|c|c|c|c|}
\hline \multirow{3}{*}{$\begin{array}{c}\text { Fat in } \\
\text { Milk, } \\
\text { Per Cent. }\end{array}$} & \multicolumn{12}{|c|}{ Per Cent of Fat in Cream. } \\
\hline & I 2 & I 5 & 18 & 20 & 25 & 30 & 35 & 40 & 45 & 50 & 55 & 60 \\
\hline & \multicolumn{12}{|c|}{ Number of Pounds of Cream from 1000 lbs. of Milk. } \\
\hline 3.0 & 244 & I95 & 162 & 146 & I 6 & 97 & 86 & 73 & 65 & 58 & 53 & 48 \\
\hline 3.1 & 253 & $20 I$ & I 68 & 151 & I 20 & 100 & 89 & 75 & 67 & 60 & 55 & 50 \\
\hline 3.2 & $26 I$ & 208 & I 73 & 156 & I 24 & 104 & 92 & 78 & 60 & 62 & 56 & 52 \\
\hline $3 \cdot 3$ & 268 & 215 & 179 & I 6 I & I 20 & 107 & 05 & So & 71 & 64 & 58 & 53 \\
\hline $3 \cdot 4$ & 277 & $22 \mathrm{I}$ & I 84 & 106 & 133 & 110 & 97 & $8_{3}$ & 74 & 66 & 60 & 55 \\
\hline 3.5 & 286 & 228 & 190 & 171 & 137 & 114 & 100 & $\mathrm{~S}_{5}$ & 76 & 68 & 62 & 57 \\
\hline 3.6 & 294 & 235 & 196 & 176 & 141 & 117 & 103 & 88 & $7 S$ & 70 & 64 & 58 \\
\hline 3.7 & 303 & 242 & 201 & I 81 & 145 & 120 & 106 & 90 & So & 72 & 66 & 60 \\
\hline 3.8 & 3 I I & 248 & 207 & I 86 & 149 & 124 & 100 & 03 & $\delta_{2}$ & 74 & 67 & 62 \\
\hline 3.9 & 319 & 255 & 212 & 191 & 150 & 127 & I I 2 & 95 & $8_{5}$ & 76 & 69 & 63 \\
\hline $4 \cdot 0$ & 328 & 262 & 218 & 106 & 157 & 1.30 & 115 & 98 & $8_{7}$ & 78 & 71 & 65 \\
\hline $4 . I$ & 336 & 268 & 223 & 201 & 161 & 134 & 117 & 100 & So & So & 73 & 67 \\
\hline 4.2 & 345 & 275 & 229 & 206 & 165 & 137 & 120 & 103 & 91 & 82 & 75 & 68 \\
\hline $4 \cdot 3$ & 353 & 282 & 235 & $21 \mathrm{I}$ & 160 & 140 & I 23 & 105 & 94 & 84 & 77 & 70 \\
\hline $4 \cdot 4$ & 361 & $2 S_{9}$ & 240 & 216 & 173 & $1+4$ & I 26 & 108 & 96 & 86 & 78 & 72 \\
\hline $4 \cdot 5$ & 370 & 295 & 246 & 221 & 177 & 147 & I 29 & 110 & $9 \mathrm{~S}$ & 88 & 80 & 73 \\
\hline 4.6 & 378 & 302 & 251 & 226 & I $S_{1}$ & 150 & 132 & I 13 & 100 & 90 & 82 & 75 \\
\hline 4.7 & 387 & 309 & 257 & $23 \mathrm{I}$ & I 85 & 154 & 1 35 & I I 5 & 102 & 92 & $\mathrm{~S}_{4}$ & 77 \\
\hline 4.8 & 395 & 315 & 263 & 236 & 189 & 157 & 138 & I I 8 & 105 & 94 & 86 & 78 \\
\hline 4.9 & 403 & 322 & 268 & $24 I$ & 193 & I $6 I$ & 140 & 120 & 107 & 96 & 87 & So \\
\hline 5.0 & 412 & 329 & 274 & 246 & 197 & 164 & I 43 & I 23 & 109 & 98 & 89 & 82 \\
\hline
\end{tabular}




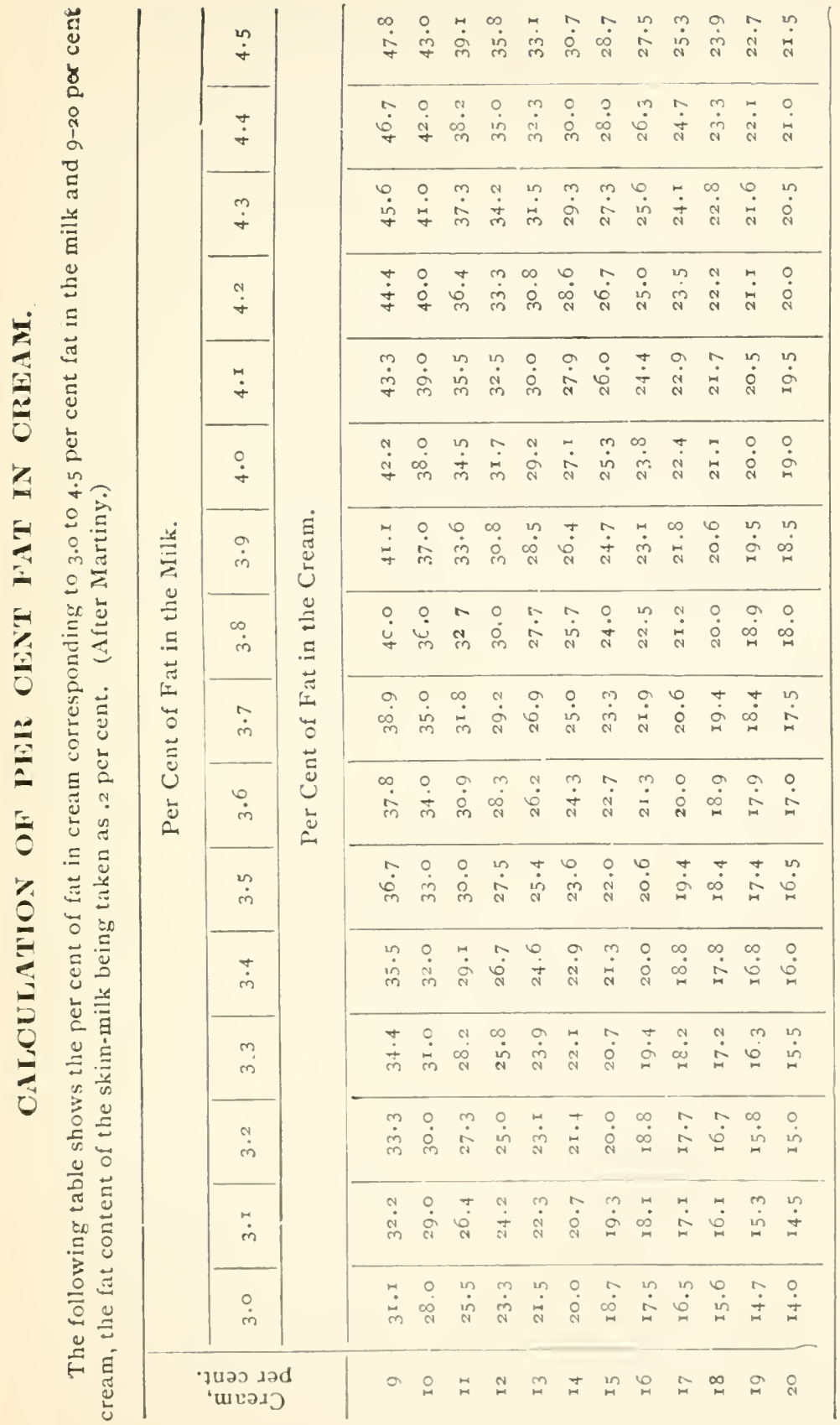


LIST OF HAND AND POWER CREAM SEPARATORS ON THE AMERICAN MARKET, 1913.

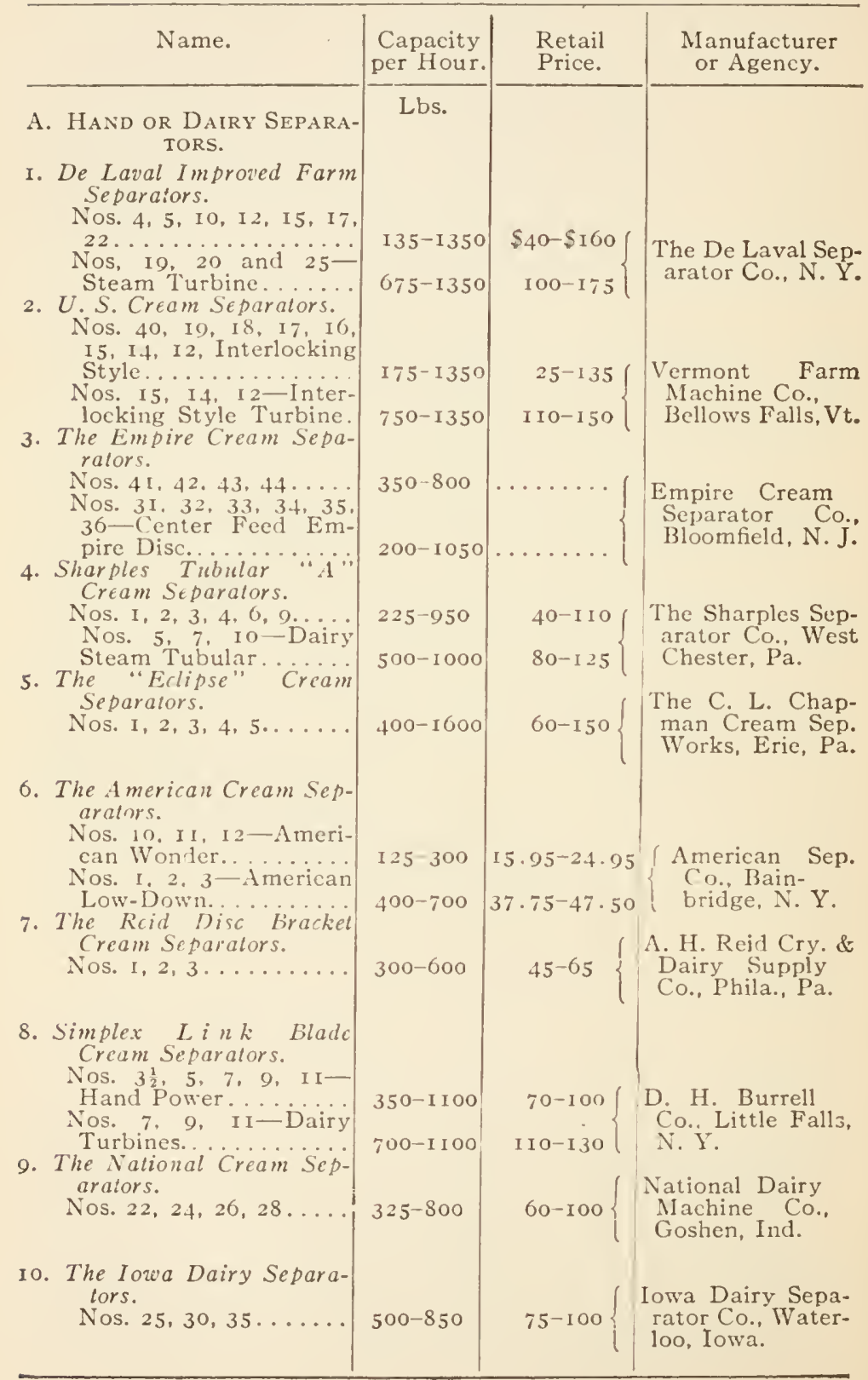


CREAM.

LIST OF HAND AND POWER CREAM SEPARATORS.

(Conlinued.)

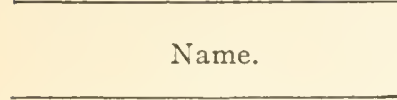

II. Peerless Cream Sepurators.

Nos. $5,7,9 \ldots \ldots \ldots$.

12. The Cleveland Separators

Nos. O, I, 2, 3 (models D, E, F, G) .........

13. Great Wiestern Cream Separators.

Nos. $20,30,40,60,70$, $90 \ldots \ldots \ldots$

14. Blue Bell, Dairy Maid, and Lily Cream Separalors.

Nos. I, 2, 3, 4-Blue Bell and Dairy Maid.

Nos. I, 2, 3, 4, 5-Lily

15. New Improved Golden Hariest Separator.

4 styles...............

I6. Economy Chief Separators.

3 styles. .

17. The King Sanitary

Cream Separalors.....

Nos. $2,4,6,8 \ldots \ldots \ldots$.

18. Hisconsin Dairy Cream Separalors.

Nos. $3,4,5,6,7-$ Gearless Victory.....

19. The Milwaukee Cream Separators.

3 styles.

20. The Slandard Cream Separalors.

Nos. 3, 5, 6, 9, $12-$ Champion $\mathrm{H}$ and Crank.............

Automatic gasoline engine and cream separator combined......

2 I. The Bealrice Cream Separalors.

Nos. $42,47,52 \ldots \ldots$.

22. Anker-IIollh Self Balancing Separalors.

Nos. $3,5,7,9 \ldots \ldots \ldots$ 300-900

\begin{tabular}{|c|c|c|}
\hline $\begin{array}{l}\text { Capacity } \\
\text { per Hour. }\end{array}$ & $\begin{array}{l}\text { Retail } \\
\text { Price. }\end{array}$ & $\begin{array}{l}\text { Manufacturer } \\
\text { or Ageney. }\end{array}$ \\
\hline $\begin{array}{c}\text { Lbs. } \\
500-900\end{array}$ & $40-60$ & $\begin{array}{l}\text { Peerless Cream } \\
\text { Separator Co., } \\
\text { Waterloo, Iowa. }\end{array}$ \\
\hline $350-800$ & $65-105$ & $\begin{array}{l}\text { The Cleveland } \\
\text { Cream Separator } \\
\text { Co.,Cleveland, O. }\end{array}$ \\
\hline $300-900$ & $55-1$ IO & $\begin{array}{l}\text { Rock Island Plow } \\
\text { Co., Rock Island, } \\
\text { Ill. }\end{array}$ \\
\hline $\begin{array}{l}350-850 \\
350-1050\end{array}$ & $\cdots$ & $\begin{array}{l}\text { Internat. Harv. } \\
\text { Co. of America, } \\
\text { Chicago, Ill. }\end{array}$ \\
\hline $350-900$ & $29.80-47.00$ & $\left\{\begin{array}{l}\text { Montgomery } \\
\text { Ward \& Co., } \\
\text { Chicago, Ill. }\end{array}\right.$ \\
\hline $250-600$ & $27 \cdot 65-42 \cdot 35$ & $\left\{\begin{array}{l}\text { Sears, Roebuck, } \\
\& \text { Co., Chicago, } \\
\text { Ill. }\end{array}\right.$ \\
\hline $250-800$ & $24.95-48.80$ & $\left\{\begin{array}{l}\text { King Separator } \\
\text { Wks., Buffalo, } \\
\text { T.Y. }\end{array}\right.$ \\
\hline $350-900$ & $40-75$ & $\begin{array}{l}\text { Starch Bros. Co., } \\
\text { La Crosse, Wis. }\end{array}$ \\
\hline $500-900$ & $50-60$ & $\begin{array}{l}\text { The Milwaukee } \\
\text { Separator Co.' } \\
\text { Milwaukee, Wis. }\end{array}$ \\
\hline $350-1200$ & $65-110$ & $\begin{array}{l}\text { Standard Separa- } \\
\text { tor Co.. Mil- } \\
\text { waukce, Wis. }\end{array}$ \\
\hline 738 & 125 & \\
\hline $550-1000$ & $55-75$ & $\begin{array}{l}\text { Beatrice Creamery } \\
\text { Co..Lincoln, Neb. }\end{array}$ \\
\hline $300-900$ & $55-105$ & $\begin{array}{l}\text { Anker-Holth MIfg. } \\
\text { Co., Purt Huron, } \\
\text { Mich. }\end{array}$ \\
\hline
\end{tabular}


LIST OF HAND AND POWER CREAM SEPARATORS. (Conlinued.)

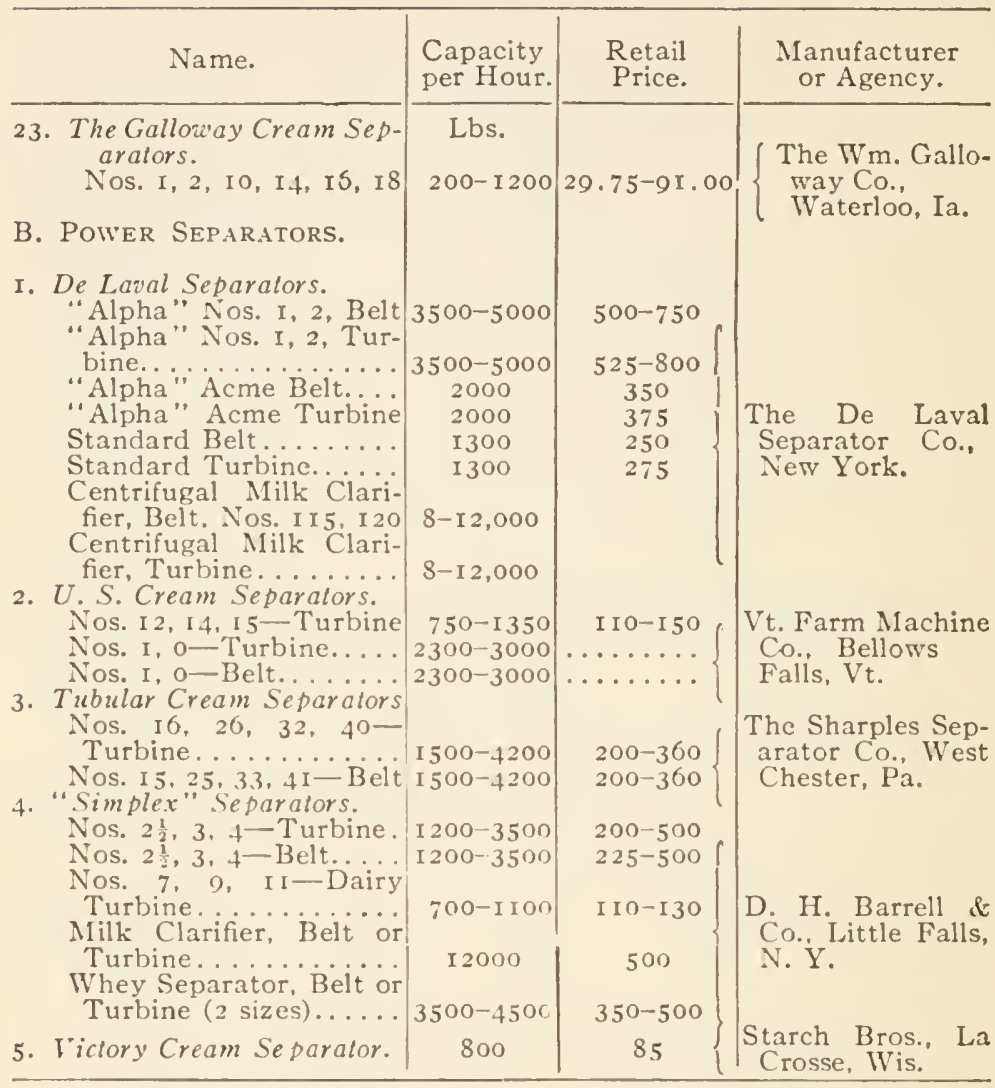

\section{FORMULAS FOR FINDING THE FAT CONTENT OF CREAM.}

Fleischmann's formula:

$$
\text { Per cent fat in cream }=f_{2}=\frac{\operatorname{IOO}\left(f-f_{\mathrm{I}}\right)}{R}+f_{1},
$$

where $R=$ per cent of cream obtained, $f=$ per cent fat in milk, $f_{1} \boldsymbol{\sim}$ per cent fat in skim-milk; or

$$
f_{:}=\frac{I 0 O F}{A R} \cdot B,
$$


where $F=$ per cent of fat in butter, $B=$ yield of butter from Ioo lbs. of milk, $A=$ percentage churning. Under ordinary conditions of creaming these formulas may be simplified to

$$
f_{2}=6.67 f-\mathrm{I} .42 \text {, and } f_{2}=5.77 \mathrm{~B} \text {. }
$$

Formula for finding the per cent cream to be separated when a certain fat content in the cream is wanted (Fleischmann):

$$
x=\frac{\operatorname{roo}\left(f-f_{1}\right)}{f_{2}-f_{1}} ;
$$

$f, f_{1}$, and $f_{2}=$ per cent of fat in full milk, skim-milk, and cream, respectively.

Formula for diluting cream to a desired fat content:

Separator skim-milk to be added $=x=\frac{c \times f_{1}}{f_{2}}-c$, $c$ being the pounds of original cream of a fat content of $f_{1}$, and $f_{2}$ the fat content wanted in the cream.

\section{HANDLING AND CARE OF CREAM SEPARATORS.}

By J. D. Frederiksen, Little Falls, N. Y., Manager Chr. Hansen's Laboratory.

In selecting a separator, local conditions, space at disposal, nearness to its manufacturer who can put it up, be held responsible, and quickly attend to repairs, etc., may be of importance, and the following points should be considered:

Thorough Separation. - All manufacturers claim that their machines do perfect work, but they do not always come up to the claims. Under normal conditions the measure for thoroughness of separation is the contents of butter-fat in the shim-milk as ascertained by the babcock test. The best modern separators skim practically absolutely clean, and there is now no excuse for anything but perfect skimming. With normal milk at the proper temperature run into the machine at the rate of the capacity claimed for it, no separator should leave more than O.I\% of butter-fat in the skimmilk, which is the smallest percentage that can be ascertained by the Babcock test with accuracy.

The table below gives the grand averages for the percentages of fat found in the trials of a number of the leading separators, conducted at the experiment stations of Delaware, Cornell (N. Y.), Vermont, Pennsylvania, and Wisconsin. 


\section{PER CENT FAT IN CENTIIFUGAL, SKIM-MILK.}

Style of Separator.

Averages of Trials at American Experiment Stations.

\begin{tabular}{|c|c|c|}
\hline \multirow{2}{*}{ Style of Separator. } & \multirow[b]{2}{*}{$\begin{array}{l}\text { Number } \\
\text { of Trials. }\end{array}$} & \multirow[b]{2}{*}{$\begin{array}{c}\text { Per cent } \\
\text { Fat in } \\
\text { Skim-milk. }\end{array}$} \\
\hline & & \\
\hline 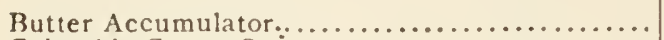 & II & \\
\hline 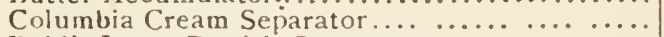 & 19 & .12 \\
\hline 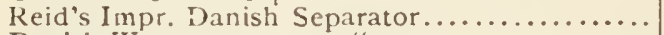 & 8 & .14 \\
\hline Danish-Weston & 3 & .10 \\
\hline De Laval Alpha No. I & 2 & . Io \\
\hline " Alpha Acme " & $2 I$ & .09 \\
\hline Alpha Turbine " $\quad \ldots \ldots \ldots \ldots \ldots$. & 51 & .09 \\
\hline Alpha Baby No. 2 Separator. ........ & I 12 & .08 \\
\hline Alplia Baby No. 3 ". ........ & 7 & .125 \\
\hline 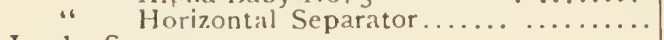 & 9 & 19 \\
\hline 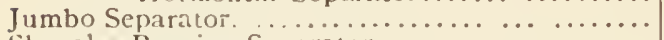 & 4 & .21 \\
\hline Sharples Russian Separator................ & 34 & .24 \\
\hline$" \quad$ Imperial $" \quad \quad \ldots \ldots \ldots \ldots \ldots \ldots \ldots$ & 30 & $\cdot 34$ \\
\hline 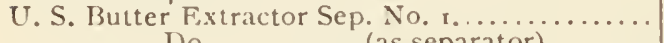 & 5 & .24 \\
\hline Do. (as separator) ........ & 2 & .14 \\
\hline 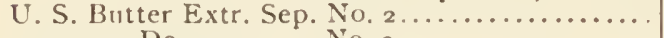 & 8 & $\cdot 34$ \\
\hline Do. No. $3 \ldots \ldots \ldots \ldots \ldots \ldots$ & Io & $.2 \mathbf{I}$ \\
\hline 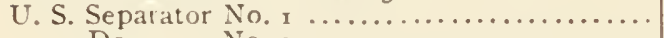 & 9 & .17 \\
\hline Do. $\quad$ No. $3 \ldots \ldots \ldots \ldots \ldots \ldots \ldots \ldots$ & 21 & .10 \\
\hline Do. $\quad$ No. $5 \ldots \ldots \ldots \ldots \ldots \ldots \ldots \ldots \ldots$ & 27 & .13 \\
\hline 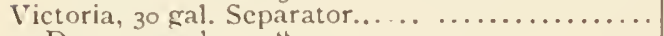 & 25 & .22 \\
\hline Do. zо gal. " $\quad \ldots \ldots \ldots \ldots \ldots \ldots \ldots$ & 12 & . 10 \\
\hline
\end{tabular}

With the constant improvement in machines it is not difficult to find separators which will do perfect work.

Simplicity, durability and safety of coustruction are considerations of vital importance. The separator must be simple in construction so as to be casy to handle, to clean, and to oil. It must be durable, so that it will need but few repairs, and, first of all, it must be absolutely safe. Too many deplorable fatal accidents are already due to bursting separator bowls, and too much stress cannot be laid on the demand that the machine must by strongly built, of firstclass material and workmanship, so that accidents are made impossible with reasonably careful handling.

As the pressure on the circumference of the bowl increases with the square of the speed, it is evident that the modern high-speed separators are exposed to a tremendous strain -in fact the tensile strain in some of them is as high as 20,000 to 30,000 lbs. to the square inch. Fortunately, the improvements in bearings and other features of construction 
which have enabled manufacturers to increase the speed, have caused them at the same time to reduce the diameter of the bowl, which makes the modern machine much safer than the first crude and heavy separators.

Power.-Considering its capacity, a well-built separator reyuires comparatively little power, whether coal or muscle. But as either is money, it is a matter of importance that none be wasted. Many so-called hand separators are altogether too heavy to run by hand, hence in selecting one see that it is easy to keep it running for several hours. The tests made at the experiment stations by dynamometer, as well as by measuring the steam consumed, show that there is a great deal of steam wasted in a creamery above that actually required to drive the separator; that "the turbines use steam extravagantly, but that the small engine of the creamery uses it still more extravagantly." Due allowance must therefore be made for this waste in comparing results obtained by various methods of testing. The following table gives some of the results published by the stations:

\section{Horse-power per 1000 lbs. Milk.}

\begin{tabular}{|c|c|c|c|c|}
\hline Style of Separator. & $\begin{array}{l}\text { Dela- } \\
\text { ware. }\end{array}$ & $\begin{array}{l}\text { New } \\
\text { York. }\end{array}$ & $\begin{array}{l}\text { Ver- } \\
\text { mont. }\end{array}$ & Wisconsin. \\
\hline 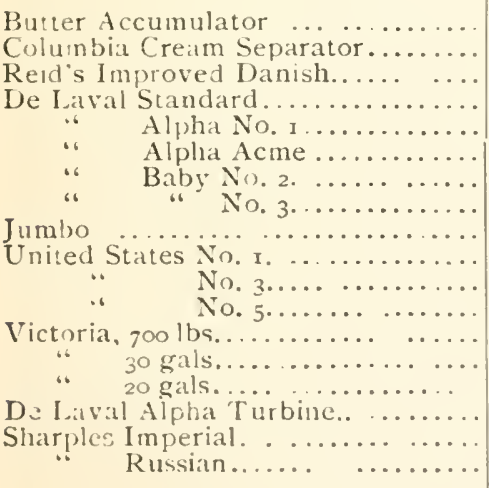 & \begin{tabular}{|c|}
$\cdots \cdots$ \\
$\cdots \cdots$ \\
$\cdots \cdots$ \\
$\cdots \cdots$ \\
$\cdots \cdots$ \\
0.37 \\
$\cdots \cdots$ \\
$\cdots \cdots$ \\
$\cdots \cdots$ \\
$\cdots \cdots$ \\
$\cdots \cdots$ \\
$\cdots \cdots$ \\
0.74 \\
0.85 \\
$\cdots \cdots$ \\
$\cdots \cdots$ \\
$\cdots \cdots$
\end{tabular} & $\begin{array}{l}2.69 \\
3 \cdot 17 \\
\cdots \cdots \cdots \\
\cdots \cdots \cdots \\
\cdots \cdots \cdots \\
\cdots \cdots \\
0.26 \\
\cdots \cdots \cdots \\
\cdots \cdots \\
0.76 \\
\cdots \cdots \\
\cdots \cdots \\
\cdots \cdots \\
\cdots \cdots \\
\cdots \cdots \\
\cdots \cdots\end{array}$ & $\begin{array}{l}\cdots \cdots \\
\cdots .83 \\
\cdots \cdots \\
\cdots \\
0.79 \\
\cdots \cdots \\
\cdots \cdots \\
1.87 \\
1.37 \\
\cdots \cdots \\
\cdots \cdots \\
\cdots \cdots \cdots \\
\cdots \cdots \cdots \\
\cdots \cdots \cdots \\
\cdots \cdots\end{array}$ & $\begin{array}{l}2.45 \\
1.52 \\
2.12 \\
0.81 \\
0.98 \\
0.46\end{array}$ \\
\hline
\end{tabular}

These tests are made with single machines and do not guarantee that all separators of the same makes consume 
the same power or steam. The accumulating results of such trials being compiled, however, become a guide in estimating the value of the various machines in the market. As between belt and turbine (or direct steam) power, the former is preferable in large creameries. In small plants one is about as economical as the other, and the choice may depend upon whether an engine is needed for churning, butter-worker, pump, and other purposes, or you can do without it.

Capacity.-In selecting a separator it is best to have plenty of capacity. In a large creamery it is better to have two separators of moderate size than one very large machine. Only in very large creameries may separators of largest capacity be preferable. The capacity should be such as to finish the day's work in + to 6 hours at the time when there is most milk. In the private dairy, using a hand separator, the work should require only one hour, rather less. The following would be our idea of the proper capacity:

\begin{tabular}{|c|c|c|c|}
\hline $\begin{array}{l}\text { Largest Supply of Milk } \\
\text { per Daty, lbs. }\end{array}$ & $\begin{array}{l}\text { Number of } \\
\text { Nachines. }\end{array}$ & $\begin{array}{l}\text { Capacity of Each } \\
\text { Machine, lbs. } \\
\text { per hour. }\end{array}$ & Power. \\
\hline 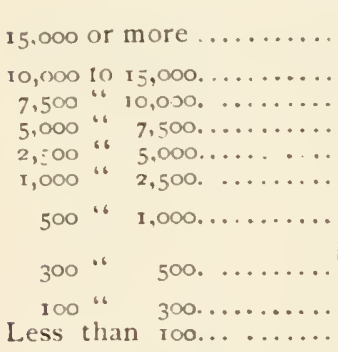 & $\left\{\begin{array}{c}2 \text { or } \\
\text { more } \\
2 \\
2 \\
2 \\
\text { I } \\
\text { I } \\
\text { I } \\
\text { I } \\
\text { I } \\
\text { I }\end{array}\right.$ & $\begin{array}{c}2.000 \text { to } 2,500 \\
1,500 \text { " } 2,000 \\
1,200 \text { " } 1.500 \\
1.000 \\
1,200 \\
600 \text { to } 1,000 \\
600 \\
300 \text { to } 500 \\
300 \\
150\end{array}$ & 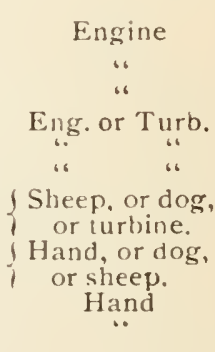 \\
\hline
\end{tabular}

Condition of Cream.-As discharged from the separator, the cream should be smooth and even, free from froth and of perfect " churnability."

As to cost, the best machine is alawy's the cheapest in the long run. Repairs, waste of fat in the skim-milk, of oil, and of coal, by an inferior machine, will more than make up any saving in first cost. 
RunNing The SeParator.

The Operator should understand his Business. - Ite should have thorough training in creameries as a helper and, if possible, in a dairy school, before undertaking to manage $\therefore$ creamery separator on his own responsibility. A new machine should be put up and started by the manufacturer or his agent, and prove in perfect shape and efficiency before he leaves. Every manufacturer gives detailed instructions as to the care of the separator, and such an instruction book should always be at hand. The operator of hand as well as of power machines should make himself familiar with every detail of the construction.

Condition and Temperature of the Milk.-Fresh and warm from the cow, the milk is in the best condition to be skimmed. If it cannot be had in that condition, it should be aerated and cooled on the farm, so that it arrives at the creamery or the dairy at not over $60^{\circ}$. Then reheat it to $80^{\circ}$ or $85^{\circ}$, not under $75^{\circ}$ and not over $90^{\circ}$. This heating is preferably done in some continuous heater, as it is dangerous to heat it in bulk, because milk standing some time at $85^{\circ}$ is apt to spoil. While the separator will skim at a lower temperature, either the skimming is not clean or less milk must be run through the machine in the same time. Of course, the milk must be sweet.

Starting.-Oil all bearings thoroughly, using only the very 3est oil. Ascertain that everything is in trim order, then start according to instructions, which vary for different kinds of machines. Always start carefully, and where the belt from the intermediate is shifted from loose to fixed pulley, do it slowly and gradually, helping with the hand on the belt to start the bowl. When the bowl appears to be running at full speed without shaking, ascertain if it really does so by means of the speed indicator, which should always be found on any power machine.

Never allow the machine to run faster than permitted by the manufacturer. If you do, it is at your risk and at the risk of the lives of your assistants. Use the speed indicator often. 
See that the feed of new milk is correct and that the pro. portion of cream to milk is as wanted. Hold a quart measure under the skim-milk spout and a measuring glass under the cream outlet, and, when the quart measure is full, see how much cream you have in the measuring glass, taking the time by your watch. If you have 6 ozs. of cream to I quart of skim-milk in 9 seconds, you have taken 6 parts of cream from 38 of new milk, or a little less than one sixth, or about $\mathrm{I} 6 \%$, and you are running at the rate of 950 lbs. per hour. How large a proportion of cream to take from the milk depends upon the richness of the milk and the consistency of cream desired. If you have $4 \%$ milk and you wish cream of $29 \%$ fat, you will take I part of cream from 7 of new milk, or $14 \%$.

keep the oil-cups filled and look frequently at all working parts of the machinery. Well started and regulated, it will run uninterrupted until all the milk is skimmed. When the last milk has entered the bowl, pour in sufficient skim-milk to crowd out all the cream left. If the skim-milk is removed from the building while the separator is running, take sumples frequently, or, if it is all left after the work is done, take a few average samples to test with the Babcock machine, so as to control the day's work.

Stop the machine cautiously, removing the motive power and letting the howl come to a stand-still of itself without applying any brake. Remove the skim-milk left in the bowl by a siphon or otherwise, take off the covers, etc., and lift out the bowl.

Cleaning.-First rinse the bowl and other parts which have been in contact with milk in cold or tepid water, and then scrub them in boiling water, frequently using some solution of sal-soda. Scrub and brush every corner. Rinse in clean boiling water and steam out the tin covers, etc. Wipe with a cloth and set the things to dry. Pump out every pipe that cannot be reached by hand and brush. If possible, avoid the use of rubber hose to conduct the milk from the vat or heater to the separator, but use open tin conductors or short tin pipes, which can be easily kept clean. Rubber hose cannot be washed in boiling water 
or soda, and is a source of contamination. Clean the separator stand carefully with a cloth and wipe the spindles, etc. Occasionally clean out the oil-chambers with kerosene oil, and always see to it that no gum is formed and that the oil-grooves and tubes are open.

If the separator shakes, or in any way works imperfectly, find the cause without delay and remedy it. If you fail to find the fault, or you cannot remedy it yourself, notify the manufacturer or his agent, and have him attend to it at once.

Treatment of the Cream.-As the cream leaves the separa. tor, it should at once be cooled to $50^{\circ}$ or lower. This insures "body" in the butter, and should not be neglected, at least not unless the cream is thoroughly chilled after it is ripened, before churning.

\section{LOSS OF BUTTER CAUSED BY INEFFICIENT SKIMMING.}

If three-tenths of one per cent of fat is left in the skimmilk, instead of two-tenths, in a separator creamery receiving Iooo lbs. of milk a day, there will be a loss of about 340 lbs. of buttur for the whole year, on the supposition that Iooo lbs. of milk yield 800 lbs. of skim-milk, and I lb. of butter contains $.86 \mathrm{lbs}$. of fat. If the separation is still poorer, greater losses will be sustained, as will be seen in the table given below. (Friis.)

\begin{tabular}{|c|c|c|c|c|}
\hline \multirow{3}{*}{$\begin{array}{c}\text { Lbs. of Milk } \\
\text { per Day. }\end{array}$} & \multicolumn{4}{|c|}{ Excess of Fat Left in Skim-milk. } \\
\hline & .05 per cent. & . ro per cent. & .20 per cent. & . 30 per cent. \\
\hline & \multicolumn{4}{|c|}{ Loss of Butter During Whole Year. } \\
\hline $\mathbf{1}, 000$ & 170 & & 680 & 1,020 \\
\hline 2,000 & 340 & 680 & $1 ; 60$ & 2,040 \\
\hline 3,000 & 510 & 1020 & $2 \mathrm{O}_{4} \mathrm{O}$ & 3,060 \\
\hline 4,000 & 680 & 1360 & 2720 & 4,089 \\
\hline 5,000 & 850 & 1700 & 3400 & 5,100 \\
\hline 6,000 & 1020 & 20,40 & 4080 & 6,120 \\
\hline 7,000 & I 190 & 2380 & 4760 & 7.140 \\
\hline 8,000 & 1360 & 2729 & 5440 & 8,160 \\
\hline 9.000 & 1530 & 3060 & 6120 & 9,180 \\
\hline io,, 000 & 1700 & 3400 & 6800 & 10,200 \\
\hline
\end{tabular}




\section{STANDARDIZATION OF CREAM. (ERF.)}

Percentage Quantity of Crean of a Desired Fat Content made From Creail of a Certain Fat Content by Diluting with Milk Containigg 4 Per Cent of Butter Fat.

\begin{tabular}{|c|c|c|c|c|c|c|}
\hline \multirow{2}{*}{$\begin{array}{l}\text { Per Cent } \\
\text { Fat in } \\
\text { Cream } \\
\text { on Hand. }\end{array}$} & \multicolumn{6}{|c|}{ Cream of Desired Fat Content. } \\
\hline & I 7 & 20 & 22 & 25 & 27 & 30 \\
\hline I 8 & 92.857 & & $\ldots \ldots$ & $\ldots \ldots$ & $\ldots \ldots$ & $\ldots \ldots$ \\
\hline I9 & 86.666 & & & & $\ldots$ & $\ldots \ldots .$. \\
\hline 20 & 81.250 & 100 & & $\ldots \ldots \ldots$ & $\ldots \ldots$ & $\ldots \ldots \ldots$ \\
\hline $2 \mathrm{I}$ & 76.4706 & 94.706 & $\ldots \ldots$ & $\ldots \ldots \ldots$ & $\ldots \ldots$ & $\ldots \ldots \ldots$ \\
\hline 22 & 72.2222 & 88.8888 & 100 & $\ldots \ldots \ldots$ & $\ldots \ldots$ & $\ldots \ldots \ldots$ \\
\hline 23 & 68.4222 & 84.2222 & 94.2125 & $\ldots \ldots \ldots$ & $\cdots \cdots$ & $\ldots \ldots \ldots$ \\
\hline 24 & 65.0000 & 80.0000 & 90.0000 & $\ldots \ldots \ldots$ & $\cdots \cdots \cdots$ & $\ldots \ldots \ldots$ \\
\hline 25 & $6 r .905$ & 76.1905 & 85.7143 & 100 & $\cdots \cdots$ & $\ldots \ldots \ldots$ \\
\hline 26 & 59.0009 & 72.7272 & $8 \mathrm{I} \cdot 8 \mathrm{I} 8 \mathrm{I}$ & $95 \cdot 4545$ & $\cdots \cdots$ & $\ldots \ldots \ldots$ \\
\hline 27 & 56.5217 & $60.565 \mathrm{I}$ & 78.2608 & 01.30 .44 & 100 & $\ldots \ldots \ldots$ \\
\hline 28 & 54.1666 & 66.6606 & 75.0000 & 87.5000 & 95.8333 & $\ldots \ldots \ldots$ \\
\hline 29 & 52.0000 & 64.0000 & 72.0000 & 54.0000 & $9 ? .0000$ & $\ldots \ldots$ \\
\hline 30 & 50.0000 & 61.5385 & 60.2308 & $80 \cdot 3+6 \mathrm{I}$ & $88 .+4615$ & 100.00 \\
\hline
\end{tabular}

If cream is to be standardized with 4 per cent milk, the result found by the intersecting columns represents the pounds per hundred, or the per cent of the q'uantity which is eream of the per cent fat on hand.

Example. - If eream containing 20 per cent of butter fat is desircd, and cream containing 26 per cent of tat is on hand, then $\mathbf{7 2 . 7}$ per cent of the quantity desired must be cream containing 26 per cent of fat, and 27.3 per cent of the quantity must be 4 per cent milk. (See Ill. Bull. No. 75; also p. 272.)

\section{STEAM BOILER AND ENGINE MANAGEMENT.}

By Prof. A. W. Remter, of the University of Montana.

\section{Boiler.}

Feed Apparatus. - Every boiler should be provided with a check-valve, placed between the feed apparatus and boiler, and in such a manner as to have the weight of the valve assist in closing it. Between this check-valve and boiler there should be an additional globe or gate-valve which may be closed, thus permitting repairing or cleaning of the check-valve while the boiler is in operation.

Water Supply.--Feed-water should enter a boiler in such a manner that the plates do not receive the direct impact of cold water. The usual practice is to have the feed enter through the blow-off pipe, thus preventing this pipe from clogging. The feed supply should be regulated so as to keep the water level as stationary as possible, The greatest care must be taken that the water level does not fall below the top of the flues. Neg. lect in this direction will cause the metal to become overheated and consequently weakened, causing leakage of joints and in. 
creased wear and tear, but more often resulting in an explosion of a more or less serious nature.

Water-glass and Water-gauges.--Every boiler should have ihree water-gauges in addition to a water-glass; these are usually attached to a hollow cast-iron cylinder or tube connected with the water and steam spaces.

The water-glass should be blown out daily, and, if clogged, can be safely cleaned with a bent wire.

In no case should the water glass alone be depended upon to indicate the water level.

Steam-gauge.--Each boiler should be provided with a steam. gauge, which gauge should be directly connected with it.

Safety-valve.--Every boiler should be provided with a safetyvalve having direct communication with the steam space, and there should, moreover, be an intervening valve. Some of the most cisastrous explosions can be traced to faulty arrangement in this respect. The valve thoughtlessly left closed after cleaning or repairs prevents the safety-valve from relieving the pressure when it rises above the safe working pressure of the boiler.

Safety-valves are of two kinds: spring and lever safetyvalves. Of the two valves the lever-valve has the most disadvantages, one of the most important being the ease with which it may be made useless by adding an additional weight to that already provided, in order to keep the valve on its seat, and therefore greatly increasing the pressure at which it will blow off.

A safety-valve should be raised each day by hand so as to allow steam to escape; this prevents clogging and rusting.

The dealer will usually set the spring-valve so that it will blow off at the desired pressure. It can be adjusted, however, by loosening or tightening a screw provided for that purpose.

The lever-valve may be set with the aid of the following formula:

$$
l=\frac{b P A}{l V b-v e}=
$$

$l=$ distance from weight to fulcrum;

$b=$ " " valve centre to fulcrum;

$c=$ distance from the centre of gravity of the lever of the ful. crum; 


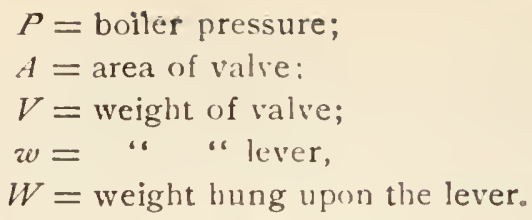

Firing.-Firing should be gradual, and the grate kept com. pletely covered with coal or ashes. The fire should not be more than four or five inches leep unless the pieces of coal are large, in which case the depth may be increased.

The fire-dours and flue-doors should not be opened in order to keep down the steam pressure. This practice not only wastes fuel but is injurious to the boiler, and will not be necessary if the boiler is properly attended to.

rriming or Foaming.-Foaming is a rapid disturbance of the water, in consequence of which it rises in the boiler in the form of spray or foam: it is usually caused by dirty water, presence of oil, etc., the boiler not having been cleaned for some time or not thoroughly cleaned. Foaming may, however, be due to other causes, such as too small a steam space, sudden demand of a great quantity of steam, etc. In case a boiler foams all steam connections should be shut off and the fire dampened by means of a fresh supply of live coal or ashes. These precautions will usually suffice to allow the water to settle, and to enable one to ascertain the true water level. If the glass shows a small amount of water, start the pump or injector, and fill the boiler to a point between the sccond and third gauge. The boiler may then be blown off to the first gauge by means of the surface blow-off, if one be present, and if not present the regular blow-off valve may be used. This operation being repeated, the impurities are gradually diminished, but care must be taken that the water level does not fall below the top of the flues. The toiler can now be used as before, but in all cases it should be thoroughly cleaned as soon as possible.

hemoval of Scale. - Potaloes, about eight or ten in number, are sometimes placed in the boiler after cleaning. Soda or herosene may also be injected with the feed-water in quantity to be determined by observation. Boiler compounds should be ased "ith caution, and when used should be obtained from a reliable dealer. Too great a quantity of any of the ahore will be harmful. 
Clenving.-The interval during which a boiler requires no cleaning depends upon the quantity and the quality of water evaporated. Under usual conditions, in order to obtain the best results, a boiler should be cleaned every six or eight weeks.

If a boiler is to be cleaned it should be allowed to stand until it is partially cooled off. When blown out cold the metal in the interior will usually be found covered with a thick coating of soft deposit, which can easily be scraped off or washed off with a hose and stream of water.

If a boiler be blown off while the metal is at a high temperature, the deposited matter is usually baked and forms a solid and hard coating, increasing rapidly if not carefully removed by the process of chipping.

Boiler Power. - The manner in which the horse-power of a boiler is usually calculated is far from satisfactory, depending rather upon its size than its power of evaporation.

In Is8, the American Society of Mechanical Engineers adopted the following definite standard:

"A horse-power shall be equivalent to an evaporation of thirty pounds of water into dry steam per hour from feedwater at $100^{\circ}$ Fahrenheit, and under a pressure of 70 lbs. ver square inch above the atmosphere."

Stean-engine. - The engine should be provided with a governor to regulate its speed, a lubricator to oil valve and piston, and a sufficient number of oil cups, so that all bearings may be properly oiled.

Starting the Engine.-Before starting, all bearings should be supplied with oil, and all waste pipes connected with cylinder and steam-chest opened. The engine should then be started slowly, so as to allow the water to escape. A quantity of steam will always condense as it comes in contact with the cold cylinder-walls, in addition to the water already present in the steam-pipe. This water does not pass off as readily as steam, neither can it be compressed to any great extent. Therefore, if more water be present in the cylinder than will fill the clearance space, and this water not be allowed to escape, the piston moving towards the end of its stroke will strike the water, and consequently be compelled to stop. The greater the speed of the piston as it advances, the greater the force with which it strikes the water, resulting in many cases in a broken cylinder bead. 
It is well to have a waste-pipe connected to the steam-pipe at a point just above the engine-valve, in order that the water which has coilected in the steam pipe may be blown out before opening the steam-valve.

After the engine has been in operation for a minute or two the waste-valves should be closed.

Ilorse-power.- The horse-power of an engine may be calculated by means of the following formula:

$$
\text { H. P. }=\frac{\text { PLan }}{33000}
$$

H. P. = horse power;

$P=$ mean effective pressure in the cylinder;

$L=$ twice the length of the stroke, in feet;

$\boldsymbol{a}=$ area of piston in square inches;

$\boldsymbol{n}=$ number of revolutions per minute.

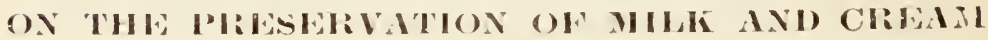

\section{IBY HEAT.}

By Dr. H. L. Russell, of Wisconsin Experiment Station, Author of "Dairy Bacteriology".

On account of the innumerable barteria that gain access to milk during the process of milking, and subsequent to that time, and the rapid increase of the same in this nutritious fluid, this material universally undergoes fermentative changes, the rapidity of which is largely dependent upon the surrounding temperature. To increase the keeping quality of milk, it is necessary to annihilate these bacteria or keep them under influences unfavorable to their growth.

Heat has been found to be the most efficacious agent in preserving milk in its natural condition. It is applied in two ways, viz., I. Pasteurization, where the milk or cream is heated for a short time (20-30 $\mathrm{min}$.) at a temperature near the coagulating point of the proteid constituents of the milk $\left(150^{\circ}-160^{\circ} \mathrm{F}.\right)$. 2. Sterilization, where the temperature approximates or exceeds the boiling-point and is applied for a longer time.

The object in both cases is to kill the bacteria present in the milk. 
Sterilization accomplishes this most successfully, but it changes the proteid compounds so that the milk has an undesirable "cooked" flavor and odor.

This defect is not found in pasteurized milk, and if properly handled, milk treated by this process will remain sweet from 4 to 8 days.

For use in the near future the pasteurized product is, on the whole, the most satisfactory; the sterilized material being best adapted for export purposes.

The essential condition in pasteurization is that the pasteurizing temperature shall exceed the thermal death point (the temperature at which growing bacteria are destroyed) of disease-producing as well as fermentative bacteria. This temperature for most forms is about $140^{\circ} \mathrm{F}$, but certain disease organisms like the tubeıcle germ of tuberculosis is not killed below $149^{\circ} \mathrm{F}$. for 30 minutes, or $155^{\circ} \mathrm{F}$. for 15 minutes. As this germ is often found in milk from tuberculous cows, prudence dictates the use of this temperature as a standard for the pasteurization of milk and cream. The proteids in the milk are slightly affected at this temperature, but if the milk is thoroughly chilled, the "cooked" flavor disappears.

The application of this temperature kills only the growing bacteria, and does not affect the latent spores. If after being heated the milk is allowed to cool slowly, and is left at a comparatively warm temperature (exceeding $55^{\circ} \mathrm{F}$.), these spores germinate and soon change the character of the milk, so that the value of the heating process is lost. To be efficient, it is necessary to rapidly cool the pasteurized product below the germinating point of the spores, for if they are once allowed to sprout, they will develop slowly at a very low temperature.

In pasteurizing milk or cream, the apparatus should be constructed so that a definite quantity of the fluid can be held at any desired temperature for any length of time, and during the process protected from infection from the air. The apparatus must also be made so as to be easily cleaned and thoroughly sterilized by steam throughout. The milk must be protected from air infection during its withdrawal frow the pasteurizing vat into storage vessels (cans and 
bottles), and should be thoroughly chilled in a refrigerator for several hours (better over night) before being delivered to the consumer. This chiling process should succeed the heating operation as quickly as possible, as the sudden transition in temperature from $155^{\circ} \mathrm{F}$. to $55^{\circ} \mathrm{F}$. or less has a paralyzing effect on the development of those organismis (spores) that are not killed by the heat. The machines that have been put on the market have for the most part been designed primarily from the dairyman's standpoint, and while they fulfill their requirements as to capacity, cheapness, etc., yet they cannot in general be relied upon to treat the milk in a way so as to free it with certainty from all possible disease-producing bacteria. The Potts' Pasteurizer, which has been sold quite extensively in this country during late years, may, however, be considered an entirely satisfactory and practical machine.

Pasteurization in this country is applied with great success to milk and cream where these products are used in the liquid form. It is used to some extent in this country, but much more widely in continental Europe, in the preparation of cream for the manufacture of butter by the use of a pure culture-starter. It can also be used advantageously in the hot months for increasing the length of time that by-products of the factory like skim-milk and whey may be preserved.

Pasteurization, as well as sterilization, reduces the body, consistency, of milk and cream, and these products therefor seem thinner after having been subjected to the process of heating than before. To obviate this, Dr. Babcock and the writer in I 806 recommended the addition of a small quantity of a solution of sucrate of lime ("viscogen") to the milk or cream, which will restore the consistency of the products, and in case of cream, greatly increase its whipping quality. (See Bull. No. 54 or thirteenth report c1 Wisconsin Experiment Station.) 


\section{DIRECTIONS FOR THE STERIIIZATION OF MILK.}

(U. S. Dept. of Agriculture.)

The sterilization of milk for children, now quite extensively practised in order to destroy the injurious germs which it may contain, can be satisfactorily accomplished witis very simple apparatus. The vessel containing the milk, which may be the bottle from which it is to be used or any other suitable vessel, is placed inside of a larger vessel of metal, which contains the water. If a bottle, it is plugged with absorbent cotton, if this is at hand, or in its absence, other clean cotton will answer. A small fruit-jar loosely covered may be used instead of a bottle. The requirements are simply that the interior vessel shall be raised about half an inch above the bottom of the other, and that the water shall reach nearly or quite as high as the milk. The apparatus is then heated on a range or stove until the water reaches a temperature of 155 degrees Fahrenheit, when it is removed from the heat and kept tightly covered for half an hour. The milk-bottles are then taken out and kept in a cool place. The milk may be used any time within twenty-four hours. A temperature of 150 degrees maintained for half an hour is sufficient to destroy any germs likely to be present in the milk, and it is found in practice that raising the temperature to 155 degrees and then allow ing it to stand in the heated water for half an hour insures the proper temperature for the required time. The tempera ture should not be raised above 155 degrees, otherwise the taste and quality of the milk will be impaired.

The simplest plan is to take a tin pail and invert a perforated tin pie-plate in the bottom, or have made for it a removable false bottom perforated with holes and having legs half an inch high to allow circulation of the water. The milk-bottle is set on this false bottom, and sufficient water is put into the pail to reach the level of the surface of the milk in the bottle. A hole may be punched in the cover of the pail, a cork inserted, and a chemical thermom eter put through the cork, so that the bulb dips into the water. The temperature can thus be watched without re- 
moving the cover. If preferred an ordinary dairy ther. mometer may be used and the temperature tested from time to time by removing the lid. This is very easily arranged, and is just as satisfactory as the patented apparatus sold for the same purpose.

\section{QUANTITY OF WATER OR ICE REQUIRED FOR COOLING MILK OR CIEAM. (Martiny.)}

The quantity of water or ice required to cool milk or cream may be calculated from the following formulas, where

$M=$ quantity of milk or cream to be cooled, in lbs.

$t=$ its temperature.

$W=$ quantity of water required for cooling, in lbs.

$I=$ “ “ ice " “ “ “ "

$t^{\prime}=$ temperature of water or ice at beginning.

$T=$ end temperature of cooled milk or cream.

$\tau=$ end temperature of cooling water.

$S=$ specific heat of milk $\left(.95^{*}\right)$ or of cream $\left(.92^{*}\right)$.

79.25 = latent heat of water.

(a) Water required for cooling milk or cream-

I. Cooled in tin cans holding milk or cream to be cooled:

$$
W=\frac{(M t-M T) S}{T-t^{\prime}}
$$

2. By application of coolers and running water:

$$
W=\frac{(M t-M T) S}{\tau-t^{\prime}}
$$

(b) Ice required for cooling milk or cream-

$$
I=\frac{(M t-M T) S}{T+t^{\prime} \times 79.25}
$$

In these formulas the influence of the surrounding air is not considered.

* Figures subject to varations; in practice the sp. heat of both milk and tream may be assumed = 1.- $\mathrm{W}$. 


\section{BUTTER.}

\section{BUTTER-MAKING.}

By H. B. Gurler, ex-President Ill. State Dairymen's Assn., Author of "The Farm Dairy."

Butter is made from milk. The cow manufactures the milk from the food she eats, hence the necessity sf sound food. Unsound food makes off-flavored milk and poor butter. Some cows can manufacture food into milk at a profit, others cannot; hence the necessity of knowing the individuality of each cow, or her ability to work at a profit to her owner.

At this stage of the dairy work there is no excuse for a dairyman not knowing what each and every cow is doing for him, thus being able to "weed out" the unprofitable ones.

Be careful and cleanly in milking. Remove the milk to a pure atmosphere as soon as drawn from the cows. If the cream is raised by gravity process be careful of the surroundings, as milk will absorb bad odors from decayed vegetables, the hog-pen, the cow-yard, the kerosene-can, a filthy stable, from cooking in the kitchen, and various other sources.

When milk is put through the separator as soon as it is drawn from the cow this source of danger is removed. Cream from the separator should be cooled immediately to a temperature of $60^{\circ} ; 55^{\circ}$ is better. A cooler that will xrate at the same time it is cooling is very desirable. This is a vital point which many butter-makers stumble over. When through separating and cooling, temper the cream to the temperature necessary to have it ripen at the time you wish to churn. If it is to be churned the following day this temperature should be $65^{\circ}-70^{\circ}$. If the second day, $55^{\circ}-60^{\circ}$; and if it is to stand four to seven days, cool to $40^{\circ}$, if possi- 
ble, as soon as practicable, and hold at that temperature until the day before you wish to churn, when it should be warmed to a temperature that will give the right acidity by the time you wish to churn. This temperature will depend on the kind of cream, whether separator cream or cream from some gravity process. Cream from shallow setting may be sufficiently ripened when taken from the milk. I recommend the use of Prof. Farrington's acid tablets for testing the acidity of cream (see p. 27o). They are a great help to a beginner.

Churn at as low a temperature as you can. This will depend on the per cent of fat in the cream. Rich cream can be churned at a much lower temperature than cream poor in fat. Cream from deep, cold setting may be churned at $58^{\circ}$ to $62^{\circ}$; and thick, rich cream from shallow setting at a much lower temperature. An ironclad rule cannot be made that will fit all cases. The separator will give cream containing various per cent of fat, from 15 to fo per cent. Separator cream containing 15 per cent fat will need to be churned at about the same temperature as deep, cold setting cream. Separator cream containing to per cent can be churned at a temperature of $50^{\circ}$, can be gathered at 50 , so the buttermilk will draw at that temperature. A low temperature gives the most exhaustive churning. At this teinperature the buttermilk should contain no more fat than the average separator skim-milk. Cream containing a large per cent of fat does not develop acid as fast as cream with more milk in it. Cool cream for churning about two hours before, so as to let the butter-fat have time to solidify or harden. This gives a more waxy texture to the butter.

Stop the churn when the butter granules are the size of wheat. If the granules are too small there is danger of a loss from its passing through the strainer. Wash no more than is necessary to remove the buttermilk. The colder it is churned the less washing is needed. When butter gathers at 54 one washing is sufficient; if at $62^{\circ}$ to $64^{\circ}$, two or three washings will be needed. Washing removes some of the delicate flavor or aroma. Remove the water from the churn as soon as possible-as soon as it has done its 
work. Never allow it to lie and soak unless there is no other way of hardening the butter to a temperature where you can handle it.

Salt to suit your trade. Work once or twice, as you prefer; twice working is preierable, as it makes the nicer-appearing butter. Work just enough to remove the mottled or streaked appearance. When worked twice this can be told at the time by the appearance of the butter. When worked but once it cannot be told until the butter has stood long enough for the salt to dissolve. If worked but once examine the butter the following day, until you make yourself a rule of thumb to work by. I have found this necessary. I am compelled to look after this point in my creamery work when the butter is irorked but once. Use the kind of butter-package that suits your trade, but always let it be neat. Never send a mussy-looking package to market. Yuu cannot afford to do it.

\section{ON THE USE OF PURE CULTURES IN BUTTER- AND CHEESE-MAKING.}

The ripening of cream is brought about through the action of minute plants, so-called bacteıia. These are practically omnipresent where man lives, and get into the milk during the milking and the handling of the milk and cream in the dairy. They multiply enormously in the cream during the ripening process, owing to the very favorable conditions of life which they find there. Some forms of bacteria are desirable and even essential in the manufacture of sour-cream butter; these feed largely on the milk-sugar of the cream, and decompose this component into lactic acid, which is the characteristic acid of sour cream (as well as of sour milk). Along with this formation of lactic acid in the cream other complicated, and yet but little understood. decomposition processes take place, the results of which show themselves in the fine aromatic flavor of the butter produced. Other forms of bacteria cause obnoxious fermentations in the cream, and produce a butter of "off" flavor, in aggravated cases making the product unfit to eat or at least unsalable as a first-class articlc. The 
process of sour-cream butter-making is therefore, at the bottom, a question of keeping the fermentations during the ripening of the cream in the right track, of controlling the same so as to exclude all but lactic-acid-producing bacteria. The old original way of reaching this end was to allow the cream to sour spontaneously, trusting to luck to obtain the desired fermentation of the cream by leaving it standing in a warm room for a couple of days. Later on, a buttermilk starter from a preceding churning or a skim-milk starter was added for the purpose of ripening the cream; by this means the lactic-acid bacteria contained in the starter were introduced in such large numbers that they generally were able to crowd out other kinds of bacteria that might be found in the cream, and which, if left alone, would produce undesirable fermentations in the cream and bad flavor in the butter. The next step in advance was the introduction of pure cultures of lactic-acid bacteria; these consist of one or a few forms of bacteria, and when introduced in milk or cream will be apt to overpower all other forms of bacteria therein, and thus produce the pure mild flavor of sourcream butter desired.

The honor of having first introduced pure cultures in butter-making belongs to Dr. V. Storch, the chemist of the Danish state experiment station in Copenhagen; the bulletin describing Dr. Storch's investigations of this subject, "On the Ripening of Cream," was publisled in I89o. Other bacteriologists in Europe and in this country have worked along this same line, and as a result we find that pure cultures are at the present time used almost universally in the manufacture of sour-cream butter in the creameries and dairies of northern Furope, and also in this country their use has become general and is spread. ing. The expected result of adding a pure culture-starter, viz., that of excluding all undesirable fermentations in the ripening of the cream, will not, however, follow with any certainty unless the seeding with the pure culture is preceded by pasteurization or sterilization of the cream, that is, at least a partial destruction of the bacteria already found therein. In Europe, notably in Denmark and the 
other Scandinavian countries, pasteurization of th: milk (or of the cream) is practised regularly in all the best creameries, in the former country at present in perhaps 95 per cent of the creameries in operation. In this country the firms manufacturing and selling pure cultures unfortunately did not insist on this point at the start, and where pure culture-starters were used with us it was nearly always without previous pasteurization. Ore reason why pasteurization has not been generally adopted in the manufacture of butter in this country is that the market demands a higher flavored, "stronger" butter than is wanted by the European market, and the pure cultures on the market, when used with pasteurized cream, do not produce such a butter. $\Gamma$ e expense of pasteurization of the cream and the absence of proper apparatus, or non-introduction of such as have proved successful in European practice, furthermore tend to explain why our butter-makers do not generally pasteurize the cream in using pure culture-starters. During late years, however, prsteurization of cream has become more general in American creaneries.

The five pure cultures now on the market in this country are Chr. Hansen's Lactic Ferment (Chr. Hansen's Laboratory, Little Fills, N. Y.), Ericsson Butter Culture (Elov. Ericsson, St. Paul, Minn.), Flavorone (Parke, Davis \& Co., Detroit, Mich.), Elgin Butter Culture (Creamery Pkg. Mfg. Co., Chicago, Ill.), and the Bosion Butter Culture (O. Douglas Improved Boston Butter Culture Co., Boston, Mass.). 'I hese cultures are placed on the market in dry form as a powder, or in liquid form. Directions for their use accompany each package sold. In general, the method to be followed is to seed the culture in a quantity of sterilized skim-milk or cream; this is kept for one to two days at a temperature below $90^{\circ}$; about 5 per cent. of the starter is then added and mixed with the crean to be ripened; some makers add considerably more than this amount. The cream will be ready for churning the next day. A portion of the starter prepared is used for the see ing of a new lot of sterilized skim-milk which will make the starter for the following day, and the same process is continued until deterioration of the starter sats in, as shown by lack of llavor in the ripened cream and in the butter; a fresh batch is then prepared from a new 
package of ferment. If proper care in sterilizing the skim-milk and in handling the starter is taken, the pure culture may be propagated in this manner for months. With lack of cleanliness and care it must be renewed every other week or of tener.

While the use of pure cultures has not as yet become general in American creameries, the agitation caused by their introduction and the discussions in dairy papers and dairy meetings which they have brought about have douhtless been of great benefit to cur dairy industry in empliasizing in the minds of butter-makers the necessity of thorough cleanliness in the creamery and the importance of the proper conduct of the ripening process for the manufacture of high-grade butter. They have enabled us to make butter of uniform fine flavor and of greater keeping quality than was previously possible.

Where abnormal fermentations appear, and the butter produced is diseased or "off flavor," the evil may be remedied by the use of pure cultures. In case of the establishment of an export trade of American butter of high quality, the pure cultures used in connection with previous pasteurization of the milk or cream will prove of great benefit, insuring uniform goods and perfect keeping quality in the product.

The use of pure culture-starters in the manufacture of Cheddar cheese is of recent date, and but limited experience has so far been gained in this line. According to the testimony of some of our leading cheese-makers, and of recent experiments conducted at Wisconsin experiment station, their use for this purpose is very beneficial, cheese of improved, clean flavor and high keeping qualities being produced. Pure cultures may therefore be safely recommended for this purpose. The general method of application is similar to that followed in the manufacture of pure culture butter. The starter is propagated in sterilized milk and kept at $90^{\circ} \mathrm{F}$. for one day, when it will be slightly Lobbered, having an acidity of about .8 per cent. Prof. Decker, late of the Wisconsin Dairy School, gives the fol. lowing hints on the use of the starter by the cheese-maker: "The starter is introduced into the milk by rubbing it 
throug! a fine laair sieve so as to break up curd particles. If too large quantities of starter are used, there is a tendency to produce a sour cheese. The best results are obtained when a 2 per cent starter, of the aeidity given, is added.

"In propagating the starter from day to day care must be taken to keep it free from contamination. It should always be prepared in a covered vessel that has previously been sterilized, and the milk used should first be pasteurized (or sterilized) and conled before adding the 'seed.' Some of the original starter should be taken for 'seed,' not the whole milk after the starter has been added.

" The starter cannot be used for cheese-making if the milk is overripe, which is the case when the rennet test is 65 seconds or under (see p. 282). In sweet milk, testing by the rennet test 120 seconds, the addition of a 2 per cent starter will increase the acidity, so that the rennet test will act in 70 seconds.

"With swcet milk the use of a pure lactic starter will result in the saring of $3^{-5}$ hours in time. With tainted milk in which the acid develops imperfectly the addition of the starter aids in producing the acidity required for the manufacture of Cheddar cheese."

\section{BOYD'S PROCESS OF CREAM RIPENING.}

\section{By John Bord, Chicago, Ill.}

It is an accepted fact that the fine aromatic flavor and also the keeping properties of butter depend largely upon the treatment of the cream from the time it is separated from the milk until it is ready for the churn, that is, in the best possible condition to yield the maximum quantity and the best quality as to flavor, texture, solidity, etc., free from casein and other undesirable substances. This perfect condition of cream is understood by the term "ripened cream," and when this condition can be produced by the butter-maker with uniformity, regardless of the seasons of the yearurextremes of climate, the process inay be reckoned as nearly perfect as possible, and not until then. It is most desirable that the process be as sim. 
ple as possible, in fact within the reach of cvery creaniery and dairyman in the country, and all the means required to attain these results can and should be a part of every dairy and creamery, large or small.

Boyd's process or system of ripening cream or milk is the result of years of practical work in a private dairy of about 40 Jersey cows. After it had been thorouglly tested and used, during all the seasons of the year, it was patented in the United States, Canada, and Great Britain, and given to the public in the year ISS9, a very considerable time in advance of any of the artificial methods of ripening, now being advocated under the representations of "pure cultures of bacteria."

When first introduced it was met by a sea of opposition from the experts, who would see nothing good in it, but gradually it has been making its way in a quiet manner into popularity lintil at present it is being successfully practised in every state in the Union, and is gaining favor every day with the most practical butter-makers.

The apparatus necessary to practise the process supplies all the conditions required to produce a uniform result every day in the year, the temperature of the lactive ferment and also of the cream being entirely under the control of the operator during the entire process.

The directions for using the process, which go with every purchase of the apparatus, are as follows:

To make the Best Ferment.-Take milk from fresh-milking cows (that from pregnant cows will not answer); submerge the milk warm from the cows in Cooley cans in ice water. Skim at twelve or twenty-four hours, as most convenient, and use this skimmed milk for making the ferment; or select milk as above, run it through a separator, and save the skimmed milk for making the ferment.

The skimmed milk so selected is then brought to a temperature of $90^{\circ}$, in a water bath, being constantly stirred during the operation of heating. As soon as the temperature of the milk reaches $90^{\circ}$, place it in the fermenting-can and close the cover tightly, having first rinsed out the can with warm water. Allow the can to remain closed for 
wenty or twenty-four hours, when the ferment will be found thick and in the proper condition for mixing with the cream or milk to be ripened.

How to use the Ferment.-First bring the cream or milk in the vat to a temperature of $66^{\circ}$ to $70^{\circ}$ Fahrenheit, when the ferment is to be thoroughly mixed with the cream or milk in the proportion of 2 per cent of the ferment to the amount of cream or milk to be ripened. Remove one or two inches of the top of the ferment, which is not desirable to use, and strain the rest through a fine strainer or hair sieve into the milk or cream. The finer the ferment is broken up the more effective its operation will be. After the cream or milk and ferment are well stirred and mixed at the above temperature, the vat must be closed and allowed to remain undisturbed until the cream is ripened, requiring from twenty to twenty-four hours for the operation; the cream when ripe will be found thick, mildly acid, and in the proper chemical condition, requiring only to be cooled to the proper temperature for churning.

Churning.-The best temperature for churning depends so much upon circumstances that the range is very wide, from $55^{\circ}$ to $65^{\circ}$ Fahrenheit. The richer the cream in butter-fat the colder the temperature should be, and the more milk the cream contains the higher the churning temperature should be. After the cream or milk and ferment are mixed, no more stirring is admissible, as any agitation of the cream afterwards retards the ripening process.

Butter by Shallow-pan Creaming.-Raise the cream in a temperature of about $60^{\circ} \mathrm{F}$; avoid as much as possibie kimming milk in with the cream; ripen at abuui $65^{\circ} F^{\prime}$; shurn at $60^{\circ}$ to $62^{\circ}$. Free the granules of butter from the buttermilk by washing in water, temperature about $55^{\circ}$. Salt, I oz. to I 1b. of butter.

Butter by' Deep Cold Setting and Cooley' System.-Raise the cream in ice-water; milk may be skimmed in with the cream or not as desired; with the Cooley cream a very considerable portion of milk added to the cream will produce no bad effects. Ripen at a temperature of $68^{\circ}$ by adding lactive ferment; churn at temperature of $58^{\circ}$ to $65^{\circ}$ : 
wash the granules in water, temperature $50^{\circ}$ to $55^{\circ}$, and salt as above.

Butter from Separator Cream.- Cool the cream from separator to $66^{\circ}$ to $68^{\circ}$, add lactive ferment, and churn at 55 to $55^{\circ}$, according to the percentage of butter-fat in the cream. The cream should be cooled after ripening so that the temperature of the cream will register not over 55 ". This cooling requires time and patience, but will be rewarded writh solid granules. Wash in water at $50^{\circ}$ to $52^{\circ}$. Salt, I oz. to I lb. of butter.

Good butter should not contain more than $16 \%$ of water (and may contain as little as $5 \%$ ) when properly worked. It is sufficiently worked when it presents a delicate elasticity to the touch, and when broken should show a perfect uniformity of grain and color.

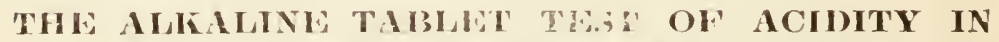 MILK OR CRLAM.*}

By Prof. E. H. FakRINGTon, of Wisconsin Dairy School.

This test is now extensively used by persons interested in either one or all of the dairy products: milk, cream, butter, and cheese. It shows the extent to which acidity has developed in a given sample and gives this information quickly. Briefly stated, it may be used for the following purposes:

First.-For testing the acility of milk. To detect those lots which are apparently sweet, but too nearly sour for pasteurizing, for retailing, or for making the best butter or cheese.

Second.-For testing the acidity of each lot of cream during its ripening, to trace the progress of its souring, and to show whether the fermentations should be hastened or checked in order to have the cream in a certain acid condition at a given time and ready for churning.

Rapid Method of Testing Many Lots of Milk. - In addi ion to the tablets, the only aplaratus necessary for testing the acidity of cither milk or cream is a common white teacup, it 4, 6, or 8 oz. bottle, and a No. 10 brass cartridge shell or similar measure. The testing solution is preparerl by dissoling one tablet in one ounce of water. This is the standard solution. Four ounces of

* For a more detailed discussion of the alkaline tablet test, sce Furrington-Woll, Testing Milk and its Prolucts, 22I Z1., P?. 124-131. 
the tablet solution are made by filling a four-ounce bottle with water and adding to it four tablets. The No. ro shell is filled with the milk or cream to be tested. This measured quantity is poured into a white cup. The same measure is then filled with the tablet solution and this is poured into the cup. The two liquids are thoroughly mixed, and the color of the mixture is noted. If there is no change of color, another measure of tablet solution is added. This is continued until the sample which is being tested retains a pink color. As soon as the pink color is obtained no more tablet solution is added. The per cent of acid in the sample tested is found from the number of measures of tablet solution it is necessary to add to one measure of the milk or cream sample in order to produce the pink color. Each measure of tablet solution represents one-tenth of one per cent acid when tests are made in this way.

The Most Delicate Method.-A more exact testing of acidity can be made by using a I7.6-cc. pipette for measuring the milk or cream to be tested and a 100-cc. graduated cylinder for measuring the tablet solution.

Five tablets are dissolved in $97 \mathrm{cc}$. of water in the cylinder, and this solution is gradually poured into the $17.6 \mathrm{cc}$. of milk or cream in a white cup. When sufficient tablet solution has been added to produce the pink color in the sample tested, the operator observes on the scale of the graduated cylinder the number of cc. tablet solution used. Each cc. of this tablet solution is equal to $0.0090 \mathrm{gr}$. lactic acid, and when $17.6 \mathrm{cc}$. of a sample is tested, each cc. of the tablet solution is equal to . Or per cent acid in the sample. The per cent of acid in each sample is therefore indicated by the amount of tablet solution used in each case.

Milk does not smell or taste sour until it contains about threetenths of one per cent acid. It has been found, however, that milk containing over two-tenths per cent acid cannot be safely pasteurized, because such milk sours very soon. These tablets supply a quick means of sorting different lots of sweet milk, by showing which contain less and which more than two-tenths of one per cent acid.

Cream is often ripened so far that the quality of the butter is injured. The usual method of the butter-maker for testing 
the sourness of the cream is by the sense of smell and taste. A tablet test shows exactly what per cent of acid each lot of cream contains, so that the butter-maker is better able to manufacture a uniform grade of butter by always ripening his crean to the same point before it is churned. Sweet cream contains about $0.15 \%$ acid. Cream has reached the proper point for churning when it contains about six-tenths per cent acid. As the souring of cream is largely influenced by the temperature at which it is lrelel, the butter-maker is able to know from an acid test of the cream whether it should be warmed or cooled in order to have it ready for churning at a given time and just sour enough for making butter of good flavor (see page 3I3).

Cheese-makers are beginning to use this test as a substitut: for the hot-iron and other tests, because of the exactness witl which it shows the acidity of the milk, the whey, and the curd.

\section{DIRECTIONS FOR THE USE OF MANNS' TEST FOR ASCERTAINIS THE ACIDITY OF CREMII.}

I. Stir the cream thoroughly; insert small end of pipette in cream and draw until nearly full; then put the finger over upper end of pipette and allow cream to escape slowly (by admitting air) until mark on neck of pipette is reached. Transfer to a tumbler, rinse the pipette three times with lukewarm water, adding the rinsing water to the cream in the tumbler. Now add to contents of the tumbler three drops of the solution marked "Indicator" (phenolphtalein).

2. Fill the burette up to the o mark with the solution marked "Neutralizer" (alkali solution).

3. While constantly stirring the cream with the glass rod, allow the liquid to flow from the burette into the tumbler until the entire contents of the tumbler shows a pink tinge. Stop adding the solution from the burette tre moment the color is permanent.

4. Read the level of the liquid remaining in the burette. The reading shows the amount of acid present.

The experience of those using the test indicates tha? where the acidity of the cream is right, to secure the bes' results in yicld and flavor of butter, from 35 to $12 \mathrm{cc}$. of the neutralizer $w, \ldots$ be required for the test. It is a simple 
matter for each butter maker to learn by experiment the exact degree of acidity and churning temperature suited to the best results, and with these as standards reduce the process of butter-making to a certainty. By testing his cream in the afternoon the butter-maker will be able to set it to ripen at such a temperature that it will show the proper acidity for churning next morning.

In testing the milk for cheese-making the same directions are to be followed, excepting that a much less acid condition

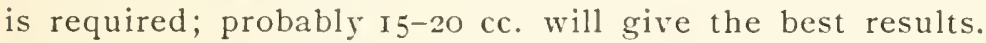
The whole numbers are cubic centimeters; the intermediate divisions are fractions of a cubic centimeter.

Precautions in Using the 7'est. - The solution marked "Neu. tralizer" is prepared of a certain strength. It is essentia! that this strength remain constant. Never let this solution stand without a stopper. Keep in glass or stoneware.

PERCENTAGE COMPOSITION OF BUTTER. (KöNIG.)

\begin{tabular}{|c|c|c|c|c|c|}
\hline & $\begin{array}{c}\text { Aver- } \\
\text { age. }\end{array}$ & $\begin{array}{l}\text { Mini- } \\
\text { mum. }\end{array}$ & $\begin{array}{l}\text { Maxi- } \\
\text { mum. }\end{array}$ & $\begin{array}{l}\text { Sweet } \\
\text { Cream } \\
\text { Butter. }\end{array}$ & $\begin{array}{l}\text { Sour } \\
\text { Cream } \\
\text { Butter. }\end{array}$ \\
\hline 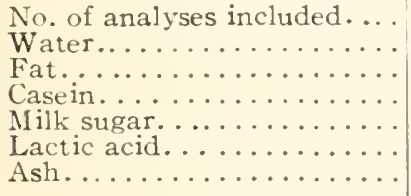 & $\begin{array}{r}35 \mathrm{I} \\
\mathrm{I} 3.45 \\
83.70 \\
.76 \\
.50 \\
.12 \\
\mathrm{I} .59\end{array}$ & $\begin{array}{r}\ldots . . \\
4.15 \\
69.96 \\
.19 \\
.45 \\
.02\end{array}$ & $\begin{array}{r}35.12 \\
90.92 \\
4.78 \\
\text { I. } 63 \\
\text { I } 5.08\end{array}$ & $\begin{array}{l}\text { I0 } \\
\text { I } 2.93 \\
84.53 \\
.61 \\
.68 \\
\ldots . .2 \\
1.25\end{array}$ & 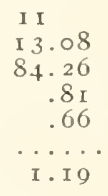 \\
\hline
\end{tabular}

\section{AVERAGE CHEMICAT COMPOSITION OF SWLW} CREAM- ANI) SOUR CRWAM-BUTTER.

(FleischaAn.)

Water $\ldots \ldots \ldots \ldots \ldots \ldots \ldots \ldots$

Fat $\ldots \ldots \ldots \ldots \ldots \ldots \ldots \ldots$

Casein and albumen...

Other organic substances.....

Ash, or ash and sait...........
Made from Sweet Cream, not Salted.

\begin{tabular}{c|r}
\hline $\begin{array}{c}\text { Not } \\
\text { washed. }\end{array}$ & Washed. \\
\hline Per ct. & Per ct. \\
15.00 & r 5.00 \\
83.47 & 83.73 \\
.60 & .55 \\
.80 & .60 \\
.13 & .12
\end{tabular}

\section{Made from Sour}

Cream, Salted.

\begin{tabular}{r|r}
$\begin{array}{c}\text { Not } \\
\text { washed. }\end{array}$ & Washed. \\
\cline { 1 - 2 } Per ct. & Per ct. \\
12.00 & 12.50 \\
84.75 & 84.62 \\
.50 & .48 \\
.55 & .40 \\
2.20 & 2.00
\end{tabular}




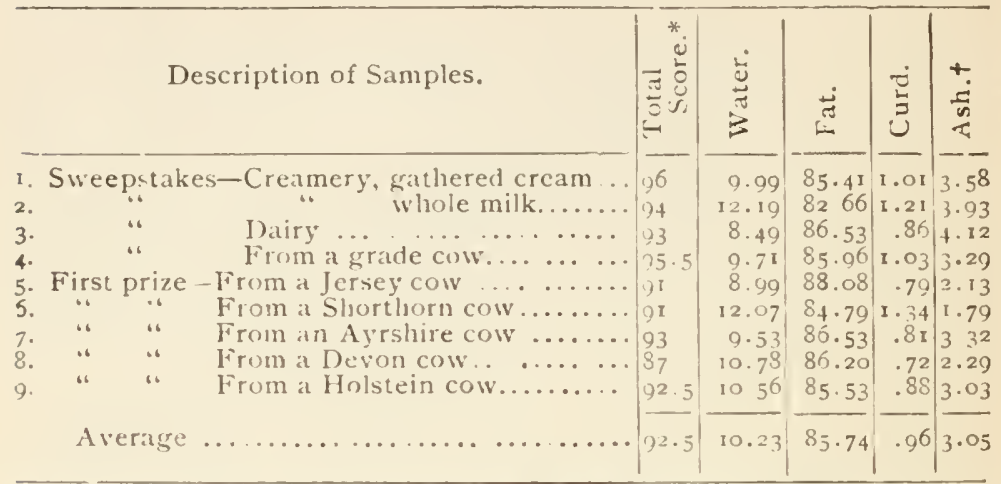

ANMISES OW FOREIGN SAMPLES OF BUTTER. (In Per Cent.)

Country. $\left|\begin{array}{c}\text { No. of } \\ \text { Anal- } \\ \text { yses. }\end{array}\right|$ Water. Fat. Curd. $\mid \begin{gathered}\text { Ash } \\ \text { (Salt). }\end{gathered}$

A. Salted Butter.

\begin{tabular}{|c|c|c|c|c|c|}
\hline Denmark ............. .... & 55 & 12.86 & 83.78 & 1.21 & 2.15 \\
\hline Sweden...$\ldots \ldots \ldots \ldots \ldots \ldots$ & 139 & 14.13 & $82 \cdot 57$ & .98 & $2 \cdot 32$ \\
\hline 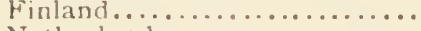 & 2 & 13.05 & 84.11 & I. 58 & I. 26 \\
\hline Netlierlands ................... & 4 & 1297 & 84.13 & I. 39 & $\mathbf{x} \cdot 5^{1}$ \\
\hline e $\quad \because \ldots \ldots \ldots \ldots \ldots$ & 235 & $13 \cdot 32$ & $84 \cdot 48$ & I. 43 & .77 \\
\hline Britain.............. & 322 & 12.09 & .66 & 1.14 & .11 \\
\hline $\operatorname{many} . \ldots \ldots \ldots \ldots \ldots . . . .$. & 162 & $13 \cdot 3^{8}$ & .70 & I.25 & I. 67 \\
\hline & 6 & 1152 & 85.56 & $\mathrm{I} .07$ & 1.8 \\
\hline$\cdots \ldots \ldots \ldots \ldots \ldots$ & 59 & 11.16 & $85 \cdot 3^{2}$ & .96 & $2 \cdot 5^{6}$ \\
\hline D. & 207 & 8.97 & & 1.44 & $5 \cdot 1$ \\
\hline tates.............. & 473 & II. 44 & 84.64 & 1.02 & 2.9 \\
\hline
\end{tabular}

B. Unsalted Butter.

\begin{tabular}{|c|c|c|c|c|c|}
\hline 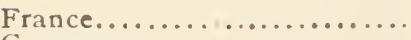 & $5^{8}$ & $13 \cdot 73$ & 85.80 & 1.39 & .08 \\
\hline Germany.................... & 86 & 12.03 & 85.70 & 2.15 & .12 \\
\hline Great Britain............... & 24 & 13.43 & 8564 & .80 & .13 \\
\hline Austria $\ldots \ldots \ldots \ldots \ldots \ldots \ldots \ldots$ & 5 & $14 \cdot 15$ & $84 \cdot 14$ & I. 54 & .17 \\
\hline Ita!y $\ldots \ldots \ldots \ldots \ldots \ldots \ldots \ldots$ & 53 & $=3.67$ & 85.08 & I. II & .15 \\
\hline Sivitzerland ..... $\ldots \ldots \ldots \ldots$ & 14 & $13 \cdot 7^{6}$ & 84.65 & $\mathbf{1} \cdot 55$ & .04 \\
\hline 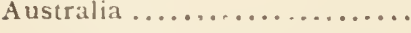 & 2 & 10.63 & $87.7 t$ & I. $3^{8}$ & .28 \\
\hline Average for salted butter.... & ז676 & II.95 & & I. 26 & $2 \cdot 5^{8}$ \\
\hline " unsalted butter. & 242 & 13.07 & 85.24 & I. 57 & .12 \\
\hline
\end{tabular}

* The standard of the scale of points in a total of roo was: Flavor, 4: grain, 30 ; color, 15 ; salting. 10 .

+ Chiefily salt. 


\section{COMMERCIAL GRADES OF BUTTER.}

(New York Mercantile Exchange.)

\section{EXTRAS.}

Shall be composed of the lighest grades of butter made in the season when offered under the different classifications; 90 per cent. shall be up to the following standard. The balance shall not grade below Firsts.

Flavor.-Must be fine, sweet, clean, and fresh if of current make, and fine, sweet, and clean, if held.

Body.-Must be firm, smooth, and uniform.

Color.-A light straw shade, even and uniform.

Salt.-Medium salted.

Package.-Good, uniform, and clean.

Score.-Shall average 93 points, or higher.

\section{FIRSTS.}

Shall be a grade just below Extras, and must be fine butter for the season when made and offered under the different classifications, and up to the following standard:

Fluvor.-Must be good, sweet, clean, and fresh if of current make, and good, sweet, and clean, if held.

Body.-Good and uniform.

Color.-Reasonably uniform. Neither too high nor too light. Salt.-Medium salted.

Package.-Good and uniform.

Score.-Shall average $\$ 7$ points, or higher.

\section{SECONDS.}

Shall be a grade just below Firsts and must be good for the season when offered under the different classifications and up to the following stanclard:

Flavor.-. Must be reasonably good and sweet.

Body.-If creamery or clairy, must be solid boring. If factors or renovated, must be go per cent. solid boring. 
Color.-Fairly uniform.

Salt.-May be high, medium, or light salted.

Package.-Good and uniform.

Score.-Shall average So points, or higher.

\section{TuIRns.}

Shall be a grade just beluw Seconds.

Flavor.-Must be reasonably good; may be strong on tops and sides.

Body.-Fair boring, if creamery or dairy, and at least $5^{\circ}$ per cent. boring a full trier, if factory or renovated.

Color.-May be irregular.

Salt.-High, light, or irregular.

Package.-Fairly uniform.

Score.-Shall average 75 points, or higher.

\section{Fourths.}

Shall be a grade just below thirds, and may consist of pre. miscuous lots.

Flar'or.- May be off flavored, and strong on tops and sides.

Body.-Not required to draw a full trier.

Color.-May be irregular.

Salt.-High, light, or irregular.

Packuge.-Any kind of package mentioned at time of sale.

\section{PACKing Stock.}

No. I-Shall be original butter, without additional moisture or salt, sweet and sound, packed in large, new barrels, having a wooden head in each end, or in new tubs, both to be parchmentpaper lined, or a good uniform second-hand barrel having a wooden head in each end and parchment-paper lined. Barrels and tubs to be packed full.

No. 2-Shall be original butter, without additional salt or water, sweet and sound, and can be packed in promiscuous or different kind of barrels, tubs, or tierces, without being parchmentpaper lined, and may be packed in either two-headed or clothcovered barrels.

No. 3.- Shall be of any grade or quality above grease, and packed in any and all kinds of packages.

Charges for inspection shall be the same as the rules call for on other grades.

\section{GREASE.}

Shall consist of all grades of butter below FouRTHs, free from adulteration. 


\section{FORMULA FOR CALCULATIYG THE YIELD OF BUTTER.}

In ordinary dairy or creamery practice, where modern methods of creaming and churning are applied, the yield of butter will exceed that of fat in the milk by 12 to 15 per cent, or I pound of fat in the milk will produce about I.I 5 pounds butter, i.e., yield of butter from Ioo lbs. of milk = I. I $f f, f$ being the per cent of fat in the milk.

Fleischmann's formula:

$$
\text { Yield of butter }=\text { I. I6 } f-.25
$$

Conversion Factor for Calculating Yield of Butter from the A mount of Butter-fat.-The following resolution was passed by the Association of American Agricultural Colleges and Experiment Stations at the annual convention of the association, July, I 895 :

"Resolved, That this association recommends to the several stations that the results of tests of dairy cows or herds be expressed in terms of butter-fat, and that when desirable to express these records in terms of approximate equivalent in butter such equivalent be computed by multiplying the amount of butter-fat by $I_{6}^{\frac{1}{6}}$." (Report of Curtiss, Armsby, and Cooke.)

The factor $I_{6} \frac{1}{6}$ is based upon the results of the Columbian dairy test, in which it was found that II7.3 lbs. or butter were, on the average, made from each Ioolbs. of butter-fat in the whole milk, and 96.67 lbs. of butter-fat of the milk was recovered in the butter.

YIELD OF BUTTER FROM 100 POUNDS OF CREAM OF DIFFERENT RICHNESS.

(MARTINY.)

\begin{tabular}{|c|c|c|c|c|c|}
\hline $\begin{array}{l}\text { Per Ct. Fat } \\
\text { in Cream }\end{array}$ & $\begin{array}{l}\text { Yield of } \\
\text { Butter. }\end{array}$ & $\begin{array}{l}\text { Per Ct. Fat } \\
\text { in Cream. }\end{array}$ & $\begin{array}{l}\text { Yield of } \\
\text { Butter. }\end{array}$ & $\begin{array}{l}\text { Per Ct. Fat } \\
\text { in Cream. }\end{array}$ & $\begin{array}{l}\text { Yield of } \\
\text { Butter. }\end{array}$ \\
\hline I 5 & $\begin{array}{l}\text { lbs. } \\
\text { x } 5.7\end{array}$ & 22 & $\begin{array}{l}\text { lbs. } \\
23.0\end{array}$ & 29 & $\begin{array}{l}\text { lbs. } \\
30.3\end{array}$ \\
\hline 16 & 16.7 & 23 & $2+.0$ & 30 & 31.4 \\
\hline 17 & 17.7 & 24 & $25 . I$ & 31 & 32.4 \\
\hline I 8 & 18.8 & 25 & $26 . \mathrm{I}$ & 32 & 33.5 \\
\hline 19 & 19.9 & 26 & 27.2 & 33 & 34.5 \\
\hline 20 & 21.0 & 27 & $2 S .2$ & 34 & 35.5 \\
\hline $2 \mathrm{I}$ & 22.0 & $2 S$ & 21). 3 & .35 & 36.6 \\
\hline
\end{tabular}



in Pounds.

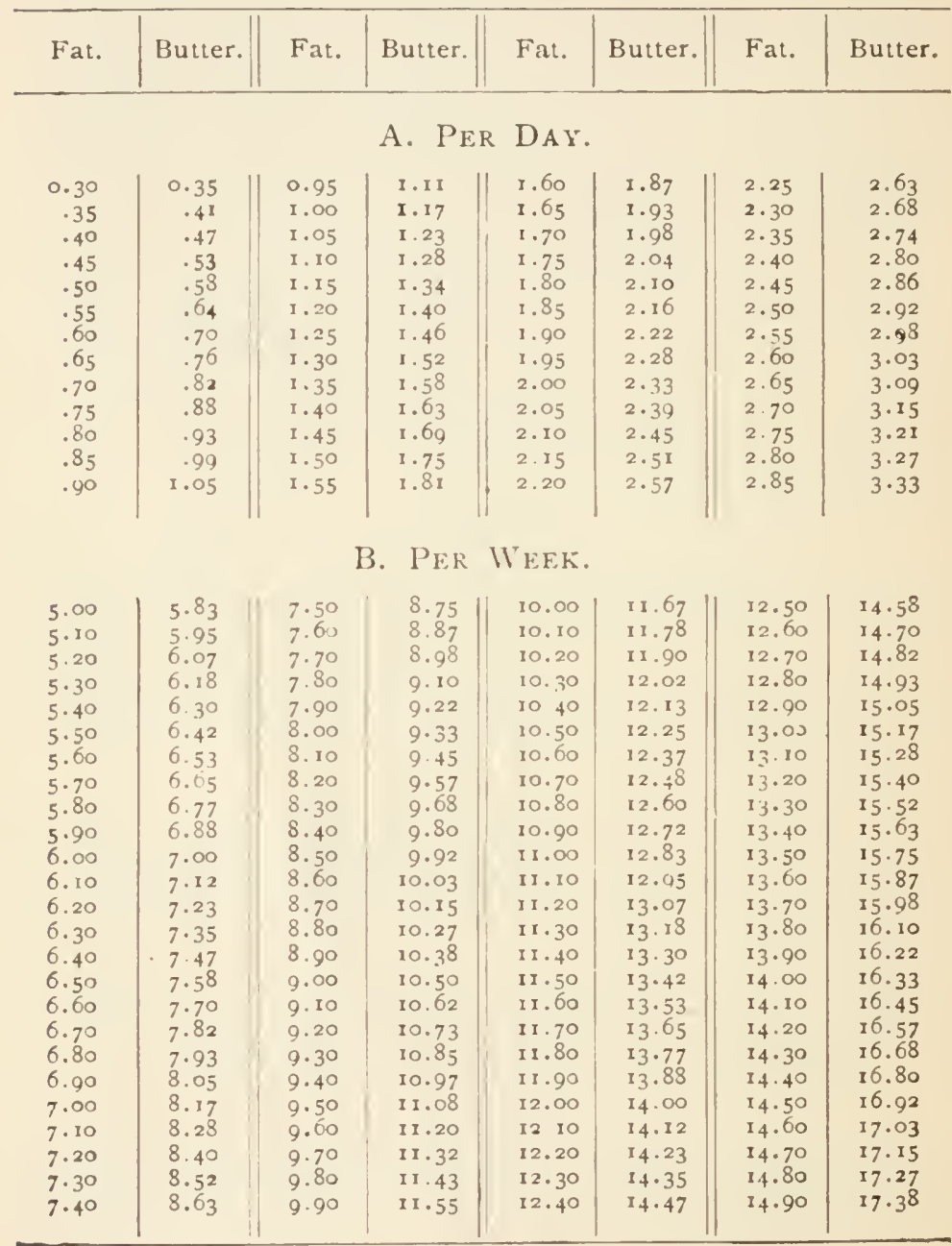

\begin{tabular}{|c|c|c|c|}
\hline Fat. & Butter. & Fat. & Butter. \\
\hline .01 & .01 & .06 & .07 \\
.02 & .02 & .07 & .08 \\
.02 & .04 & .08 & .09 \\
.03 & .09 & .11 \\
.04 & .05 & .09 \\
.05 & .06 & .10 & .12 \\
\hline
\end{tabular}


VALUE OF $\frac{100 s-104}{s}$ FOI SP. GR. OF MUL FROM $1.019 \mathrm{rO} 1.0399$

(See p. 26r.)

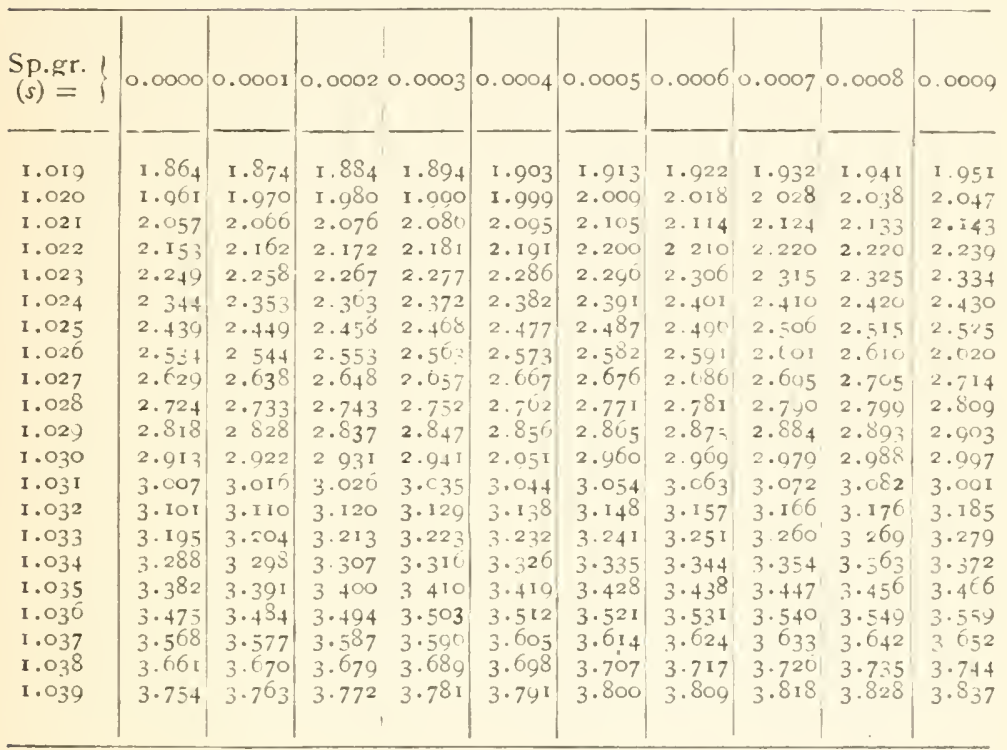

\section{REIATION OF FA' CONTENT TO ACIDITY OF SIIM-MILI, MILK, AND CIEAM. (A. VIND.)}

(See p. 306.)

\begin{tabular}{|c|c|c|c|c|c|c|c|c|c|c|c|c|c|c|}
\hline \multirow{3}{*}{\multicolumn{3}{|c|}{ Fat contents.... }} & \multirow{2}{*}{\multicolumn{2}{|c|}{$\begin{array}{c}\begin{array}{c}\text { Skim- } \\
\text { milk. }\end{array} \\
\text { o per ct. }\end{array}$}} & \multirow{2}{*}{\multicolumn{2}{|c|}{$\begin{array}{c}\begin{array}{c}\text { Whole } \\
\text { Milk. }\end{array} \\
5 \text { per ct. }\end{array}$}} & \multicolumn{8}{|c|}{ Cream. } \\
\hline & & & & & & & \multicolumn{2}{|c|}{25 perci. } & \multicolumn{2}{|c|}{30 perct. } & \multicolumn{2}{|c|}{35 perct. } & \multicolumn{2}{|c|}{40 perct. } \\
\hline & & & cc. & $\%$ & cc. & $\%$ & cc. & $\%$ & cc. & $\%$ & cc. & $\%$ & cc. & $\%$ \\
\hline \multicolumn{3}{|c|}{ Equal acidity test } & 10 & .18 & $9 \cdot 5$ & .17 & $7 \cdot 5$ & .14 & 7 & $+I_{3}$ & 6.5 & .12 & 6 & \\
\hline$\because$ & $\because "$ & $\because$ & +5 & .81 & & .77 & & $.6 \mathrm{I}$ & $3 \mathbf{I} \cdot 5$ & .57 & 29 & .52 & 27 & .47 \\
\hline “ & $\because$ & “ & +5 & .80 & $45 \cdot 5$ & $\begin{array}{r}82 \\
80\end{array}$ & 36 & .05 & $33 \cdot 5$ & .60 & & .56 & 20 & $\cdot 5^{2}$ \\
\hline "4 & “" & ، & 50 & .90 & 48 & .80 & $\begin{array}{l}37 \cdot 5 \\
30\end{array}$ & .07 & 35 & .63 & 32.5 & .58 & 30 & .54 \\
\hline " & "“ & “" & 54 & .07 & 51 & .42 & $10 .=$ & $\begin{array}{r}.70 \\
.73\end{array}$ & 38.5 & $\begin{array}{l}.10 \\
.63\end{array}$ & $\begin{array}{l}34 \\
35\end{array}$ & $\begin{array}{l}.61 \\
.63\end{array}$ & 13 & .5 \\
\hline “ & $\because$ & “ & 55 & .09 & 52 & .4 .4 & $4 t$ & .74 & 33.5 &.$\sigma_{y}$ & 30 & & $33^{3}$ & .5 \\
\hline “ & $\because$ & $\because$ & 57 & $\begin{array}{lll}1 & 0 & 9\end{array} \mid$ & 54 & .97 & +3 & .77 & 4) & .72 & 37 & 67 & 34 & (i) $\mathrm{I}$ \\
\hline$"$ & $\because$ & 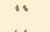 & 59 & 1.00 & 50 & 1.01 & tt & .79 & 11.5 & .75 & : 8.5 &.$(3)$ & 35.5 &. $\mathrm{C}_{4}$ \\
\hline 16 & $"$ & " & 00 & 1.08 & & 1.03 & 45 & .31 & +2 & .70 & 5.0 & & & \\
\hline
\end{tabular}


THE SLIDING-SCALE OVERRUN. (FARRINGTON.)

\begin{tabular}{|c|c|c|c|c|c|c|c|c|}
\hline $\begin{array}{c}\text { Fat } \\
\text { in } \\
\text { Milk. }\end{array}$ & $\begin{array}{l}\text { Fat Re- } \\
\text { covered } \\
\text { in } \\
\text { Butter. }\end{array}$ & $\begin{array}{l}\text { Butter } \\
\text { from } \\
\text { Ioo lbs. } \\
\text { Fat. }\end{array}$ & $\begin{array}{l}\text { Fat } \\
\text { in } \\
\text { Milk. }\end{array}$ & $\begin{array}{l}\text { Fat Re- } \\
\text { covered } \\
\text { in } \\
\text { Butter. }\end{array}$ & $\begin{array}{c}\text { Butter } \\
\text { from } \\
\text { I oo lbs. } \\
\text { Fat. }\end{array}$ & $\begin{array}{c}\text { Fat } \\
\text { in } \\
\text { Milk. }\end{array}$ & $\begin{array}{c}\text { Fat Re- } \\
\text { covered } \\
\text { in } \\
\text { Butter. }\end{array}$ & $\begin{array}{l}\text { Butter } \\
\text { from } \\
\text { roo lbs. } \\
\text { Fat. }\end{array}$ \\
\hline $\begin{array}{c}\text { Per } \\
\text { Cent. } \\
2.5 \\
2.6 \\
2.7 \\
2.8 \\
2.9 \\
3.0 \\
3.1 \\
3.2 \\
3.3 \\
3.4 \\
3.5 \\
3.6 \\
3.7 \\
3.8 \\
3.9 \\
4.0\end{array}$ & $\begin{array}{c}\text { Per } \\
\text { Cent. } \\
95.80 \\
95.96 \\
96.12 \\
96.25 \\
96.38 \\
96.51 \\
96.62 \\
96.73 \\
96.83 \\
96.91 \\
97.00 \\
97.10 \\
97.10 \\
97.24 \\
97.31 \\
97.38\end{array}$ & 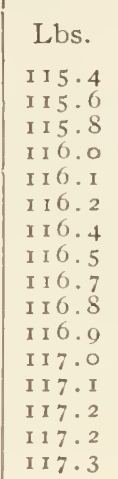 & $\begin{array}{c}\text { Per } \\
\text { Cent. } \\
4.1 \\
4.2 \\
4.3 \\
4.4 \\
4.5 \\
4.6 \\
4.7 \\
4.8 \\
4.9 \\
5.0 \\
5.1 \\
5.2 \\
5.3 \\
5.4 \\
5.5\end{array}$ & $\begin{array}{c}\text { Per } \\
\text { Cent. } \\
97.45 \\
97.51 \\
97.56 \\
97.62 \\
97.67 \\
97.72 \\
97.77 \\
97.82 \\
97.86 \\
97.90 \\
97.95 \\
97.99 \\
98.03 \\
98.06 \\
98.10\end{array}$ & 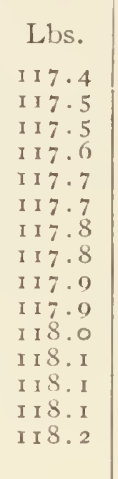 & $\begin{array}{c}\text { Per } \\
\text { Cent. } \\
5.6 \\
5.7 \\
5.8 \\
5.9 \\
6.0 \\
6.1 \\
6.2 \\
6.3 \\
6.4 \\
6.5 \\
6.6 \\
6.7 \\
6.8 \\
6.9 \\
7.0\end{array}$ & $\begin{array}{c}\text { Per } \\
\text { Cent. } \\
98.13 \\
98.16 \\
98.20 \\
98.22 \\
98.25 \\
98.28 \\
98.31 \\
98.33 \\
98.36 \\
98.38 \\
98.41 \\
98.43 \\
98.46 \\
98.48 \\
98.51\end{array}$ & 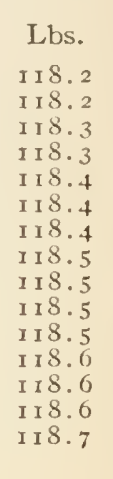 \\
\hline
\end{tabular}

The table is based on the assumptions that 85 per cent skim-milk and ro per cent buttermilk are nbtained, testing . I and .2 per cent of fat. respectively; furthermore, that the butter contains $8_{3}$ per cent fat.

Example. $-345^{\circ}$ lbs. of milk testing 4.2 per cent fat contain $3450 \times$ $.042=144.9 \mathrm{lbs}$. of butter-fat; this multiplied by the overrun for milk testing 4.2 per cent, I. 75 gives I 70.25 lbs. as the calculated amount of butter which the milk would make.

\section{COMPARATIVE PRICES OF MILK, CREAM, BUTTER-FA'T AND BUT'THR. (DoANE.)}

\begin{tabular}{|c|c|c|c|c|c|c|}
\hline $\begin{array}{l}\text { Cream } \\
\text { Per Cent } \\
\text { Fat. }\end{array}$ & $\begin{array}{c}\text { Price } \\
\text { per } \\
\text { Ciullon. }\end{array}$ & $\begin{array}{l}3.5 \% \\
\text { Milk. } \\
-\quad-1\end{array}$ & $\begin{array}{l}4.5 \% \\
\text { Ilitk. } \\
\text { yer } Q\end{array}$ & $\begin{array}{l}5.5 \% \\
11 \text { ilk. } \\
\end{array}$ & $\begin{array}{l}\text { Butter } \\
\text { Fat per } \\
\text { Pound. }\end{array}$ & $\begin{array}{l}\text { Butter } \\
\text { per } \\
\text { Pound. }\end{array}$ \\
\hline 20 & $\begin{array}{c}\text { Cents. } \\
50\end{array}$ & $\begin{array}{l}\text { Cents. } \\
\text { I } 2\end{array}$ & $\begin{array}{c}\text { Cents. } \\
\mathrm{I}+5\end{array}$ & $\begin{array}{l}\text { Cents. } \\
\text { I } 7\end{array}$ & $\begin{array}{c}\text { Cents. } \\
28\end{array}$ & $\begin{array}{c}\text { Cents. } \\
23.5\end{array}$ \\
\hline 20 & 55 & I 2 & I 5.5 & 18 & 3 I & 26 \\
\hline 20 & 60 & I 3.5 & I 6.5 & 19.5 & 34 & 28 \\
\hline 20 & 65 & I 4.5 & I 8 & $2 I$ & 37 & $3 I$ \\
\hline 20 & 70 & I 5.5 & I 9 & 22 & 40 & 33 \\
\hline 22 & 50 & I I & I 3 & I 5 & 25 & $2 \mathrm{I}$ \\
\hline 22 & 55 & I 2 & I 4.5 & 17 & 28 & 23.5 \\
\hline 22 & 60 & 13 & 15.5 & I 8 & $3 I$ & 26 \\
\hline 22 & 65 & I 3.5 & 16.5 & 19.5 & $33 \cdot 5$ & 28 \\
\hline 22 & 70 & I 4.5 & 17.5 & 20.5 & 36 & 30 \\
\hline 22 & 75 & I 5 & 18.5 & 22 & 39 & 32.5 \\
\hline 25 & 55 & I I & I 3 & I 5 & 25 & $2 \mathrm{I}$ \\
\hline 25 & 60 & I I. 5 & 14 & 16.5 & 27 & 22.5 \\
\hline 25 & 65 & I 2.5 & 15 & 17.5 & 29.5 & $24 \cdot 5$ \\
\hline 25 & 70 & I 3 & 16 & 18.5 & 32 & 26.5 \\
\hline 25 & 75 & 14 & 17 & 19.5 & $34 \cdot 5$ & 28.5 \\
\hline 25 & So & 14.5 & 17.5 & 20.5 & 36.5 & 30.5 \\
\hline
\end{tabular}




\section{POUNDS OF MILK REQUIRED TO MAKE ONE POUNI OF BUTTER.}

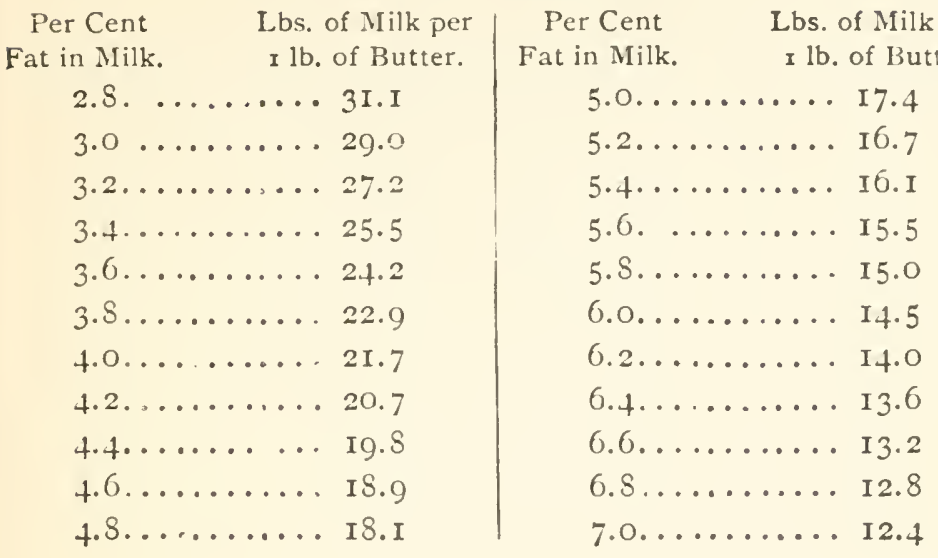

I.3s. of Milk per I lb. of Butter.

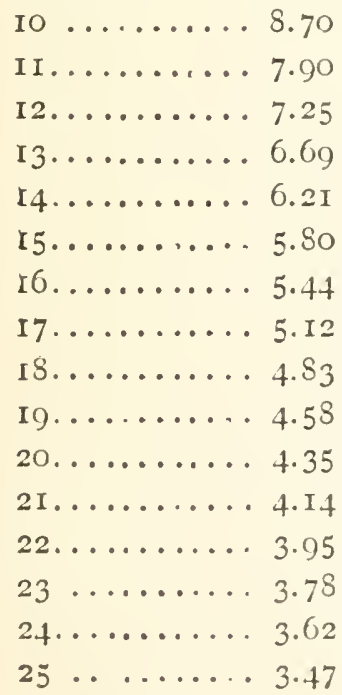

\begin{tabular}{c|cc} 
Per Cent & Cos. of Milk per & Per Cent \\
Fat in Milk. & : lb. of Butter. & Fat in Milk
\end{tabular}

$26 \ldots \ldots 3.34$

$27 \ldots \ldots \ldots 3.22$

$2 S \ldots \ldots \ldots . . . . .3 .11$

$29 \ldots \ldots \ldots 3.00$

$30 \ldots . .2 .2 .90$

$3 I \ldots \ldots \ldots 2.8$ I

$32 \ldots . . . \ldots 2.72$

$33 \ldots \ldots \ldots 2.64$

$34 \ldots \ldots \ldots 2.56$

$35 \ldots \ldots \ldots 2.48$

$36 \ldots \ldots 2.42$

$37 \ldots \ldots \ldots 2.35$

$35 \ldots \ldots . .29$

$39 \ldots \ldots . .2 .23$

$40 \ldots . . .2 .27$

The two preceding tables are based on ordinary creamery experience, I pound of fat in the milk producing I.I5 younds of butter. 
NUMBER OF POUNIS GF MILI REQUTRED FOR MAKING ONE POINI) OF BUTEER. (KirChNer.)

\begin{tabular}{|c|c|c|c|}
\hline $\begin{array}{l}\text { Lbs. Butter per } \\
\text { roc lbs. of Milk. }\end{array}$ & $\begin{array}{l}\text { I.bs. Milk per } \\
\text { lb. of Butter. }\end{array}$ & $\begin{array}{l}\text { Lbs. Butter per } \\
\text { roo lbs. of Milk. }\end{array}$ & $\begin{array}{l}\text { Lbs. Milk per } t \\
\text { lb. of Butter. }\end{array}$ \\
\hline 2.4 & 41.67 & 3.8 & 26.32 \\
\hline 2.5 & 40.00 & 3.9 & 25.64 \\
\hline 2.6 & $3^{8} .4^{6}$ & 4.0 & 25.00 \\
\hline 2.7 & 37.04 & $4 \cdot x$ & $24 \cdot 39$ \\
\hline 2.8 & 3571 & 4.2 & $23.8 \mathrm{I}$ \\
\hline 2.9 & $34 \cdot 4^{8}$ & $4 \cdot 3$ & 23.26 \\
\hline 3.0 & $33 \cdot 33$ & $4 \cdot 4$ & 22.73 \\
\hline 3.1 & 32.26 & 4.5 & 2222 \\
\hline 3.2 & $3 \mathbf{I} \cdot 25$ & 4.6 & $21 \cdot 74$ \\
\hline $3 \cdot 3$ & 30.30 & $4 \cdot ?$ & 21.28 \\
\hline $3 \cdot 4$ & $29.4^{\mathrm{I}}$ & 4.8 & $20.8_{3}$ \\
\hline $3 \cdot 5$ & 28.57 & 4.9 & $20.4^{I}$ \\
\hline 3.6 & 27.68 & 5.0 & 20.00 \\
\hline $3 \cdot 7$ & 27.03 & $5 \cdot 5$ & 1 8.18 \\
\hline
\end{tabular}

\section{DISTRIBUTION OF MILK INGREDIENTS IN BUTTER MAKING. (COOKE.)}

\begin{tabular}{|c|c|c|c|c|c|c|c|}
\hline & 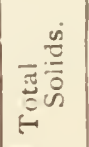 & $\underset{\square}{\dddot{Z}}$ & 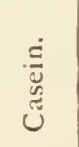 & 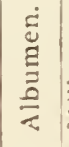 & 紊 & $\frac{\dot{\pi}}{4}$ & $\begin{array}{l}\text { Proportion } \\
\text { of the Total } \\
\text { llilk liat } \\
\text { found in the } \\
\text { Product. }\end{array}$ \\
\hline rooo lbs, of whole milk... & $\begin{array}{c}\text { lbs } \\
\text { r } 30.0\end{array}$ & $\begin{array}{l}\text { Ibs. } \\
40.0\end{array}$ & $\begin{array}{l}\text { Ibs. } \\
26.0\end{array}$ & lbs. & lbs. & $\begin{array}{r}1 \text { ths. } \\
7.5\end{array}$ & \\
\hline 800 lbs, of skim-milk. ... & 78.0 & 24 & 22.0 & 6.0 & $4+3$ & 6.4 & 6 \\
\hline 200 lbs. of cream. . . . . & 52.0 & 37.6 & $4 \cdot 0$ & 1.o & $8 \cdot 3$ & I. I & 94 \\
\hline 187 lis. of buttermilk... & $\mathrm{I} 4.9 \mathrm{I}$ & .8 & $3 \cdot 77$ & .94 & $8 \cdot 3$ & $\mathrm{I} \cdot \mathrm{I}$ & 2 \\
\hline 433 lbs. nf butter......... & 37.09 & $3^{6.8}$ & .23 & .06 & & & द2 \\
\hline
\end{tabular}

SCORE IOR JUDGING BUTTER GRARRALLY ADOPTED IN AMERICAN CONTESTS.

Flavor................... 45

Grain $(\operatorname{bod} y) \ldots \ldots \ldots \ldots \ldots \ldots, 25$

Color..................... 15

Salt................... 10

Packing (style)............ 5 
This score has been adopted in judging butter exhibits at various State fairs and dairymen's conventions during late yeas; in some cases the score has been changed to 50 for flavor and 5 for salting, otherwise as above, or to flavor 40, grain 30 , with other points as above.

Minimum number of points entitling exhibitors to a premium:

Wisconsin Dairymen's Association, 93, 95, and 94 points, for dairy, separator creamery. and gathered-cream butter, respectively.

New York State Fair, 75 points.

\section{ENGUISH SCALE OF POINTS FOR JUDGING}

\section{BUTIER. (McCunnel.)}

Perfection, Ioo.

25 Flavor: nutty, aromatic, sweet.

20 Moisture: as free from beads of water as possible.

Io Solidity: firm, not melting easily, nor softening.

25 Texture: closeness of grain, distinct fracture; no: greasy.

Io Color: natural, even.

Io Make: remaining points, cleanliness, salting, nicely

IOO put up, etc.

\section{SCORE IN JUDGING PROFICIENCY OF BUTTER: MAKERS.}

(Adopted by British Dairy Farmers' Association.)

\section{Butter-making.}

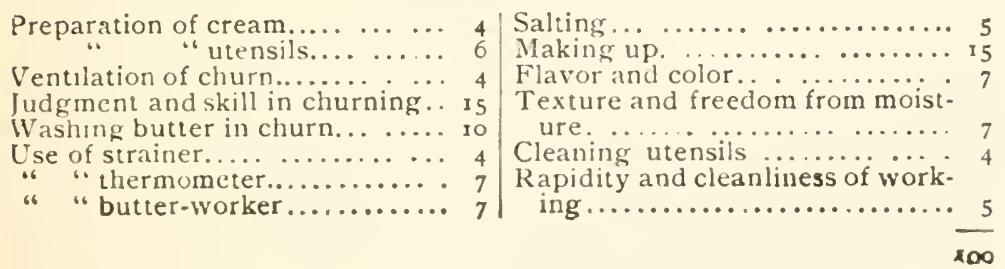




\section{ANALYSLS OF MMERICAN DAIRY SALTS.}

(In Per Cent.*)

\begin{tabular}{|c|c|c|c|c|c|c|c|c|}
\hline Name of Brand. & 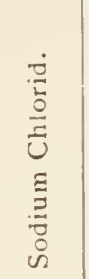 & 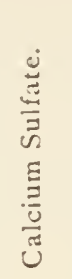 & 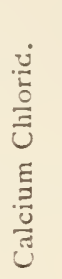 & 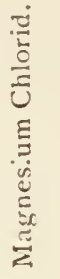 & 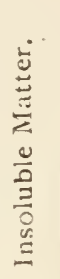 & 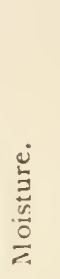 & 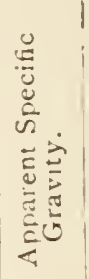 & 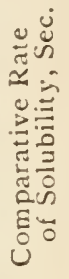 \\
\hline Acme........ & 98.39 & I. 22 & .12 & .07 & .03 & .17 & $.9+4$ & 24 \\
\hline Anchor............... & 97.79 & 1.48 & .28 & .08 & .06 & $.2 \mathbf{I}$ & 1.125 & 31 \\
\hline Ashton. $\ldots \ldots \ldots \ldots$ & $98.0 \mathrm{t}$ & 1.42 & .20 & .16 & .03 & .13 & .703 & 39 \\
\hline Bradley............. & 98.27 & .90 & .40 & .07 & .22 & $\cdot 34$ & .876 & 63 \\
\hline Cantield \& llheeler.... & 98.18 & 1. 21 & .22 & .12 & .04 & .23 & 1. .062 & 26 \\
\hline Diamond Crystal..... & 99.18 & .54 & .19 & .05 & .03 & $.0 \geq$ & .880 & 33 \\
\hline Empire............. & $98 \cdot 5^{8}$ & .66 & .54 & .10 & .02 & .10 & .933 & $3^{2}$ \\
\hline Genesee ......... & 98.27 & $1.1 \mathrm{I}$ & .24 & .07 & .0 .4 & .16 & $.875^{\dagger}$ & $3 \mathrm{it}$ \\
\hline Higgins $\ldots . . . . .$. & 98.19 & I. 44 & .14 & .10 & .02 & . II & .907 & 28 \\
\hline Le koy............. & 98.15 & I. 31 & .33 & .08 & .01 & $.00^{\circ}$ & $1.094+$ & $25 \ddagger$ \\
\hline Lone Star ........... & $9^{8} \cdot 24$ & 1.46 & .06 & .08 & .06 & .10 & 1.072 & 28 \\
\hline Vacuum Pan......... & 98.00 & I. 15 & $\cdot 3^{6}$ & .15 & .03 & $\cdot 31$ & 1.075 & 30 \\
\hline Warsaw........... & 98.43 & .95 & .40 & .06 & .03 & .12 & .62 & 39 \\
\hline Worcester........... & 98.57 & .92 & .25 & .07 & .02 & .17 & 1.149 & 29 \\
\hline Colcman...$\ldots \ldots \ldots$ & 98.21 & 1.48 & .10 &.$c_{4}$ & .08 & .09 & .805 & 28 \\
\hline Rice ................. & $97 \cdot 57$ & $x .85$ & .12 & .09 & .07 & .30 & .828 & 30 \\
\hline Windsor............. & $9^{8.43}$ & .90 & $\cdot 5^{1}$ & .04 & .02 & .11 & $1.107 \$$ & $20 \S$ \\
\hline
\end{tabular}

* See II oil, "A Siudy of Dairy Salt," Bulletin No. 74, Wis. Exp. Sta. + Butter-salt; clieese-sialt, appit:. sp. gr. .ój r; rate of solubility 34 sec. $\ddagger$ Butter-salt; checse silt, appar. si)。 sr. .044; rate f solubility 37 sec. $\S$ Butter-salt; cheese-salt, appur. sp. gr. .891; rate of solubility $32 \mathrm{sec}$.

TEMPERATURES AT WHICH DAIRY TRODICTS SHOULD IBE STURED IN COLD STORAGE. (DOUGLAS.)

\begin{tabular}{|c|c|c|c|}
\hline Article. & $\begin{array}{c}\text { Temper- } \\
\text { ature, } \\
\text { deg. F. }\end{array}$ & Article. & $\begin{array}{l}\text { Temper- } \\
\text { ature, } \\
\text { deg. F. }\end{array}$ \\
\hline 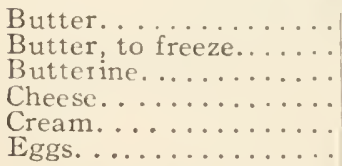 & $\begin{array}{l}25-38 \\
20 \\
20-35 \\
28-35 \\
35 \\
28-35\end{array}$ & $\begin{array}{l}\text { Milk. . . . . . . . . . } \\
\text { Ole margarine. . . . } \\
\text { Poultry, frozen. . . . } \\
\text { Poultry, to freeze... } \\
\text { Puultry, long storage. }\end{array}$ & $\begin{array}{l}32 \\
20-35 \\
28-30 \\
10-18 \\
10\end{array}$ \\
\hline
\end{tabular}




\section{CHEESE.}

\section{HOIV AMERICAN CHEESE IS MADE.}

By the late Prof. JohN W. DEcker, of Ohio Dairy School, Author of "Cheese Making: Cheddar, Swiss, Prick, etc."

\section{A. Factory or Cheddar Cheese.}

As soon as the milk is received at the factory it is heated to $86^{\circ} \mathrm{F}$. and a rennet test made.*

If the milk is not ripe enough it is held till the proper acidity is reached. If the milk is rery sweet a starter of sour milk is added to hasten it. The milk should be set at such a ripeness that there will be one eighth of an inch of acid (fine strings) on the hot-iron in two hours and a hals from the time rennet is added.

If the cheese is to be colored the color is added just before setting the milk. When it is thoroughly stirred in, the rennet may be added. The amount of rennet to be used depends on the kind of cheese desired. Iî a soft fast-curing cheese is wanted, enough rennet is used to coagulate the milk in fifteen to twenty minutes: if a slow-curing cheese, enough to coagulate in thirty to forty-five minutes. ]t is stirred in thoroughly in four or five minutes and then the dipper is run lightly over the top, to keep the cream down till the milk begins to thicken, when a cloth cover is spread over the vat and the coagulation allowed to continue cill the curd will break clean over the fingers.

* The Monrad reninet test is recommended. It consists of a r6o cc. tin cylinder for measuring the miik, a $5 \mathrm{cc}$. pipette, a $50 \mathrm{cc}$. graduated flask, and a half-pint tin basin. The rennet is measured with the $5 \mathrm{cc}$. pipette and delivered into the $50 \mathrm{cc}$. flask, the rennet adhering to the pipette being rinsed into the flask with a little water. The flask is then filled with water to the $50 \mathrm{cc}$. mark, and the solution mixed by shaking. The milk, the temperature of which should be $86^{\circ} \mathrm{F}$. , is measured in the tin cylinder, emptied into the half-pint basin, and $5 \mathrm{cc}$. of the dilute extract is measured nto the r6o cc, of milk, and the number of seconds required to curdle it noted. If a few specks of clarcoal are scattered on the milk and the milk started into motion around the dish with a thermometer, the instant of curdiing san be noted by the stopping of the specks. They will stop so suddenly as to seem to start back in the opposite direction. The Marschall rennet test is a very convenient device for ascertitining the exact moment of coagulation, and is used extensively in cheese factories. 
The curd is then cut, using the horizontal knife first and cutting lengthwise of the vat. The cutting is finished from this point with the perpendicular knife, the curd being thus cut into cubes one-half inch in diameter. Without waiting for the curd to settle, begin stirring very carefully with a wire basket, and rub the curd off from the sides of the vat with the hand. As soon as this is done, turn on the heat carefully and raise the temperature slowly to $9^{\circ} \mathrm{F}$; when the curd is firm enough a wooden rake is used to stir it. The temperature is raised at the rate of one deg. in $\$-5$ min.

As soon as the temperature of $9 \mathrm{~S}^{\circ} \mathrm{F}$. is reached, begin trying the curd on the hot iron for acid. The curd must be firm enough when the whey is drawn, so that a double handful pressed together will fall apart readily. This is the test for a proper cooking. When fine threads $\frac{1}{3} \mathrm{in}$. long show on the lot iron the whey is ready to draw.* This should be $2 \frac{1}{2}$ hrs. from the time the milk was set. The whey is drawn off by means of a whey gate and s'rainer, and the curd dipped into a curd-sink or on racks placed in the vat, over which a linen strainer-cloth is thrown. The curd should be stirred on the cloth to facilitate the escape of the whey, and ${ }^{\circ}$ then left to mat tongeticer. In $5_{5}$ or 20 min. it can be cut into blocks $S$ or Io ins. squa:? and turned over. After turning several times these blocks can be piled two or three deep. The acid will continue to develop in the curd; when it will string about an inch it will have assumed a stringy or meaty texture, so that it will tear like the meat on a chicken's breast.

It is then run through the curd-mill and cut up into small pieces. These pieces are stirred up every little while to air. In the course of another hour and a half there will be $2 \mathrm{in}$. of acid on the curd; it will smell like toasted cheese when pressed against the hot iron, and half fat and half whey will run out

* The acidimeter is sometimes used to take the place of the rennet test and hot iron. The apparatus is sold by firms handling dairy supplies. The milk is set at an acidity of .2 per cent. When cut the whey will have a lower acidity, probably .17 per cunt. When the acidity in the whey reaches .2 per cent the whey is drawn. The drawings from the curd will show a rapid incrcase in acid. This test should be used with care and in combination with renust test and hot iron. 
when a handful is squeezed. It is then ready to salt. It is cooled to $80^{\circ} \mathrm{F}$. betore salting. It a fast-curing cheese is wanted use 2 lbs. per 100 lbs. of curd, 2: lbs. are used for a medium checse, 3 lbs. for a slow-curing cheese. The curd should be spread out at an eren thickness and the salt applied eventy. It should then be thoroughly stirred several times.

As soon as the harsh feeling has left the curd it is ready to go to press. The screw should be turned slowly, but fast enough so that a stream of brine is kept flowing. The full pressure should not be applied for ten minutes. In an hour the bandages can ke turned down, and full pressure is then applied. The Helmer continuous-pressure gang-press is the most satisfactory, as the cheese will not loosen during the night. The next day the cheese are placed on the shelves and the rinds greased. They should be turned and rubbed every day. The temperature of the curing-room should be $60^{\circ}$ to $65^{\circ} \mathrm{F}$, and moisture should be supplied in dry weather. The cheese are boxed and shipped in about a month.

\section{B. Cheese Made on the Farm.}

For a farm dairy it will be much easier to make up sweet-curd cheese than sour-curd cheese, described in the preceding. For this purpose it is necessary to have a curd-knife, a cheese-vat, and a cheese-press; the method of procedure is as follows:

The milk, which must be clean and sweet, is heated to $90^{\circ} \mathrm{F}$, and if any artificial color is required it is added at this time. Set the milk with enough rennet extract to coagulate in 20 to $3^{\circ}$ minutes. About four ounces of Hansen's rennet extract per I000 lbs. of milk will prove a sufficient amount.

As soon as the curd will break over the finger cut it fairly fine; then raise the temperature one degree in 3 minutes until Io $\mathcal{S}^{\circ} \mathrm{F}$. is reached, at the same time stirring carefully to keep the curd particles a part. Hold at $\operatorname{Iog}^{\circ} \mathrm{F}$. till the curd is firm, that is, till the pieces do not feel mushy. Then draw the whey and stir till the whey is well drained out. Salt at the rate of $2 \frac{1}{2} 1 \mathrm{bs}$. of salt to 100 lhs. of curd, and when the salt is well worked in it may be put to press. It will, however, improve the quality if kept warm and allowed to stand a number of hours before salting and pressing. The e'neese shoul 1 be cured in a room (preferably 
a cellar) where the temperature can be kept at $60^{\circ} \mathrm{F}$. Higher temperatures may spoil it. The cheese should be cured for two to three months before it is sold.

\section{CAUSAS OS THNTH MILK.}

The causes of tainted milk have been classified as tollows, by the Swiss scientist, Dr. Gerber:

1. Poor, decayed fodders, or ir rational methods of feeding.

2. Poor, dirty water, used for drinking-water or for the washing of utensils.

3. Foul air in cow-stable, or the cows lying in their own dung.

4. Lack of cleanliness in milking; manure particles on udder.

5. Keeping the milk long in too warm, poorly ventilated and dirty places.

6. Neglecting to cool the milk rapidly, directly after milking.

7. Lack of cleanliness in the care of the milk, from which cause the greater number of milk taints arise.

8. Poor transportation facilitics.

9. Sick cows, udder diseases, etc.

Io. Cows being in heat.

II. Mixing fresh and old milk in the same can.

12. Rusty tin pails and tin cans (Böggild).

\section{DETECTING BAD MILK: DIRECTIONS FOR OP. ERATING THE WISCONSIN CURD-TEST.}

Cheese-makers are often troubled with so-called floating, pinholed, or gassy curds which produce cheese defective in flavor and texture. The cause of this poor quality of cheese often seems beyond the power of the operator to determine. While he has heretofore usually laid it to "bad" milk, it was often impossible for him to locate the trouble. By means of the curd-test the operator is usually able to tell which patron or patrons are furnishing the bad milk; and often in the patron's herd it will be shown to be due to a single cow. This test as here described originated at the 
Wisconsin Dairy School in 1895 . Apparatus for making the test is now furnished by dairy supply-houses, although a home-made test can be improvised by using pint fruitjars and a wash-tub or some small tank, in which the jars of milk can be heated in warm water.

Detalls of THE TeSt. - I. A pint glass jar which has been thoroughly cleancd, and sterilized with live steam, is filled about two thirds full with the milk to be tested.

2. It is not necessary to take an exact quantity of milk, but each jar should be plainly labeled.

3. The numbered jars of milk are placed in a tank or tub of water which is heated until the milk in the jars has a temperature of $98^{\circ} \mathrm{F}$.

4. The thermometer used should first be rinsed in boiling water before being placed in another sample, to avoid contamination of good milk with bad milk.

5. When the milk has reached a temperature of $9 S^{\circ} \mathrm{F}$., add io drops of rennet extract to each jar of milk, and mix by giving the jar a rotary motion.

6 . The rennet soon curdles the milk, and the curd is allowed to stand for about twenty minutes until it is firm.

7. The curd should then be cut into small pieces with a case-knife, and after settling the whey is poured off. The best tests are made when the separation of whey is most complete. By allowing the samples to stand for a short time, more whey can be poured off, and the curd thereby rendered firmer.

8. The jars containing the curd are then again placed in the tub and the tempcraturc of the water around the jars is maintained at or near $9 S^{\circ} \mathrm{F}$. by adding hot water from time to time. The tub or vat is covered, the curds are allowed to ferment in the sample jars for six to twelve hours and are then examined.

9. The impurities in any particular sample will cause gases to be developed in the curd, so that when it is cut with a knife pin-holes or gas-holes can be easily detected. Milks having a putrefactive or stinking odor should be classed as bad, even though the curd has a good texture and is free from pin-holes. 
The curds in this test are made under conditions most favorable for developing in them any defects which may be caused by the presence of undesirable bacteria that are brought to the milk by dust, dirt, and other impurities.

The odor of a curd should be noticed as soon as the cover is taken from a jar. This is often sufficient to convince a patron that the milk is tainted, and may suggest to him the particular cause of the odor by its resenblance to some fa miliar smell that he recognizes and can remove.

$A$ solid firm curd shows that the milk is pure and clean and has been properly handled. The rather firm curds which show fine pin-holes when cut with a knife are indi. cations of some of the worst impuritics in milk, while the spongy curds show the presence of bacteria which in some cases have developed sufficient gas to float the curd. Persons familiar with milk soon learn to use the evidence obtained by this test to distinguish between good and bad milk, and to convince the milk-producers of the value of the test. (Dairy Bull., IVis. Exp. Station.)

\section{THE FERMINTATION TEST.}

The Gerber fermentation test (modified by Monrad) furnishes a convenient method for discovering tainted milk on the farm or at the factory. The test consists of a tin tank wheh can be beated by means of a small lamp, and into which a rack fits holding a certain number of cylindrical glass tubes; these are all numbered and provided with a mark and a tin cover. In making the test the tubes are filled to the mark with milk, the number of each tube being recorded in a notebook opposite the name of the particular patron whose milk was placed therein. The tubes in the rack are put in the tank, which is two thirds full of water; the temperature of the water $1 \mathrm{~s}$ kept at $10+-106^{\circ} \mathrm{F}$. for six hours, when the rack is taken out, the tubes gently shaken, and the appearance of the milk, its odor, taste, etc., carefully noted in each rase. The tubes are then again heated in the tank at the same temperature as before for another six hours, when observations are once more taken of the ap. 
pearance of the milk in each tube. The tainted milk may then easily be discovered on account of the abnormal coagulation of the sample.

Gerber concluded from over 1500 tests made by this method:

I. That good and properly handled milk should not coagulate 1 ln less than 12 hours, nor show anything abnormal when coagulated.

2. If it does, it shows the milk to be abnormal, either on account of its chemical composition or because it is impregnated with too much ferment (rather, abnormal ferments, causing an undesirable fermentation).

3. Milk from sick cows, cows that are strongly in heat, or cows with diseased udders will always coagulate in less than 2 hours.

4. Only about 20 per cent of the tests coagulated within $\mathrm{r} 2$ hours.

Monrad proposes the following rules for the adoption of this test by cheese factories:

r. "A proper journal is kept of all the tests.

2. "The patrons whose milk is tainted have to pay the cost of making the test.

3. "The patrons whose milk is tainted will be kept track of, and in case there is any loss caused thereby they will have to stand it.

4. "Patrons having tainted milk shall be notified at once, and another test made three days later. If then the milk is still bad, a test of each cow's milk is made on the farm and otherwise the reason sought to be discovered, and until then the milk will be refused." 


\section{DETERMINATON OF HUMIDTY IN CHEESE- CURING ROOMS.}

The propar degree of humidity in the cheese-curing room will vary with different kinds of cheese and at different stages of the curing process. Green cheese should be placed in a somewhat drier curing-room than older; the latter kinds, according to Fleischmann, require a relative humidity of $90^{\circ}-95^{\circ}$, against $85-90^{\circ}$ for green cheese.

Kirchner states that the humidity of curing-rooms should not, in general, go below So' or above $95^{\circ}$. Temperatures from $50^{\circ}-70 \mathrm{~F}$. are preferable in the curing-room.

The following temperatures and percentages of humidity are recommended by Martiny:

Per Cent

Deg. Fahr. Humidity

(a) For hard cheeses (Siviss, etc.).

$20-9 j$

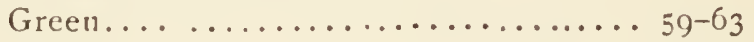

$85-90$

Half cured................... 54-59

So-9=

Cured $\ldots \ldots \ldots \ldots \ldots \ldots \ldots \ldots \ldots \ldots \ldots \ldots \ldots \ldots \ldots+54$

$80-95$

(b) For soft cheeses (Limburger, etc.)...... 50-59

In the interior of our continent it is somewhat difficult tu obtain as much moisture in the air of curing-rooms as is: represented by the preceding figures; the relative humidity of ordinary curing-rooms in this region, therefore, but rarely goes over $60^{\circ}$. A higher degree of humidity may be obtained by hanging wet sheets of canvas in the curing. room (Decker), or by similar devices, as described in the thirteenth ann. report of Wis. Experiment Station.

Self-recording thermometers are to be recommended for use in curing-rooms. For observation of relative humidity a wet and dry bulb thermometer, a Mittchoff's hygrometer, or a Lambrechi's polymeter may be used to advantage. Any of these instruments may be obtained through dealers in chemical glassware or dairy cupplies; the prices range from $\$$ to $\$ 30$. 


\section{TABLE SHOWING THE REIATIVE HUNIDITY IN} THE AIR OF CURING-ROOMS. (King.)

DiRections. - Notice that the table is in three column sections. Find air temperature in first column. then find wet-bulb temperature in second column, same division. In third column opposite this is relative humidity. Example.-Air temperature is $50^{\circ}$, in first column: wet-bulb is $44^{\circ}$, in second column, same division. Upposite $44^{\circ}$ is 61 , which is the per cent of saturation, or the relative humidity of the air.

Caution. - Fan the bulb briskly for a munte or two before taking reading.

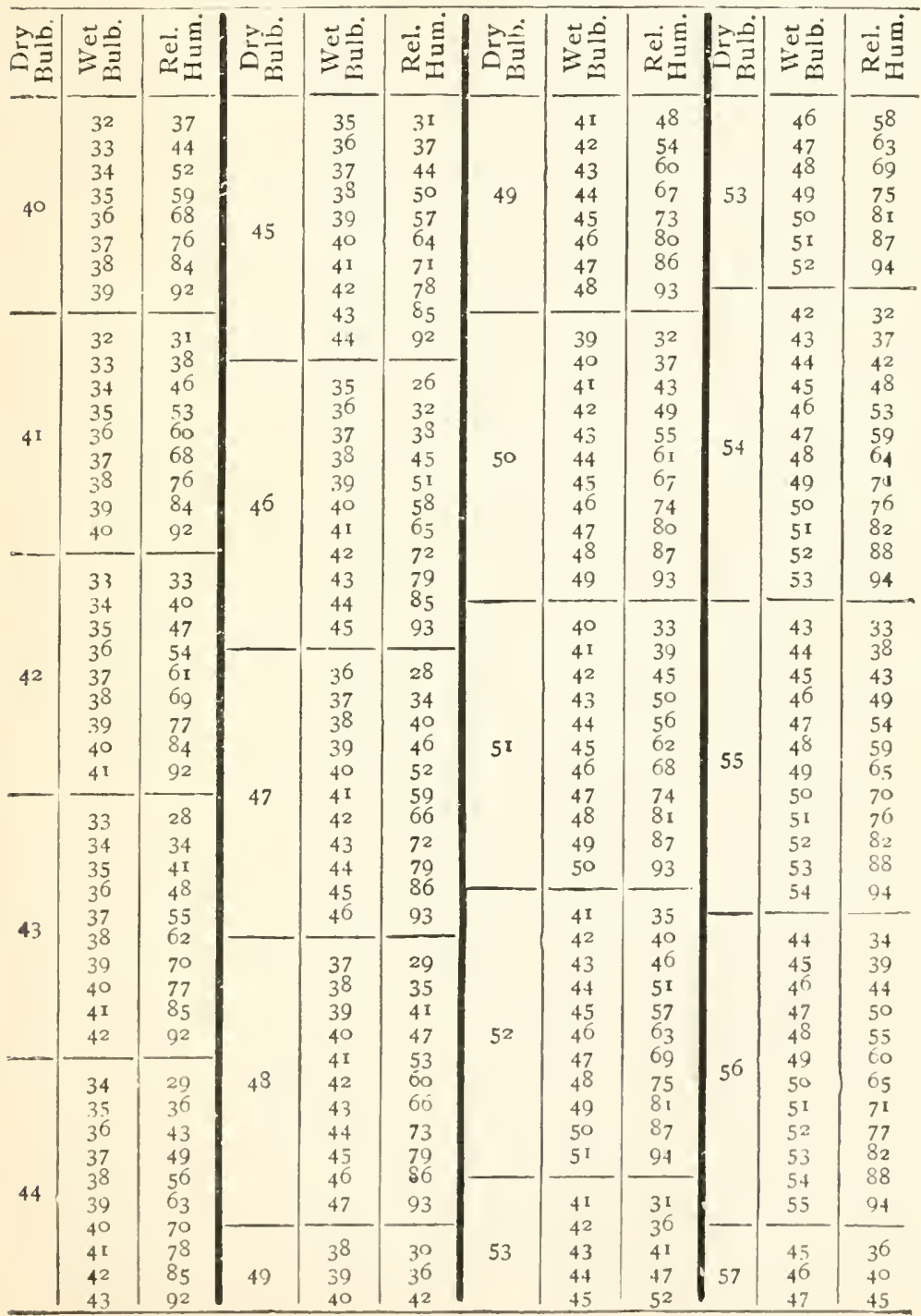


HUNIBITY IN THE AIR OF CURING-ROONS.-CON.

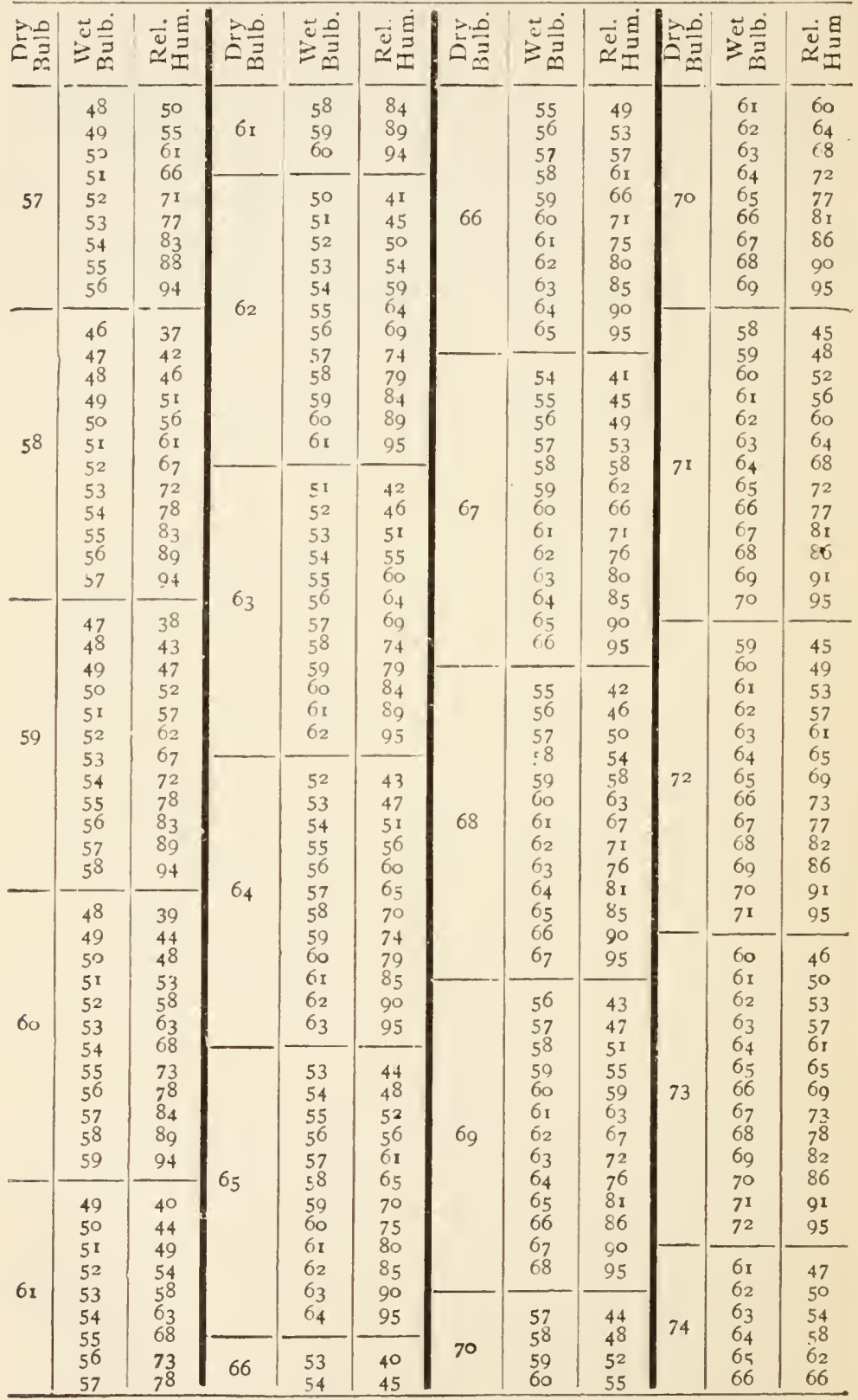


HUMIDITY IN THF AIR OF CURING-ROOIIS.-Con.

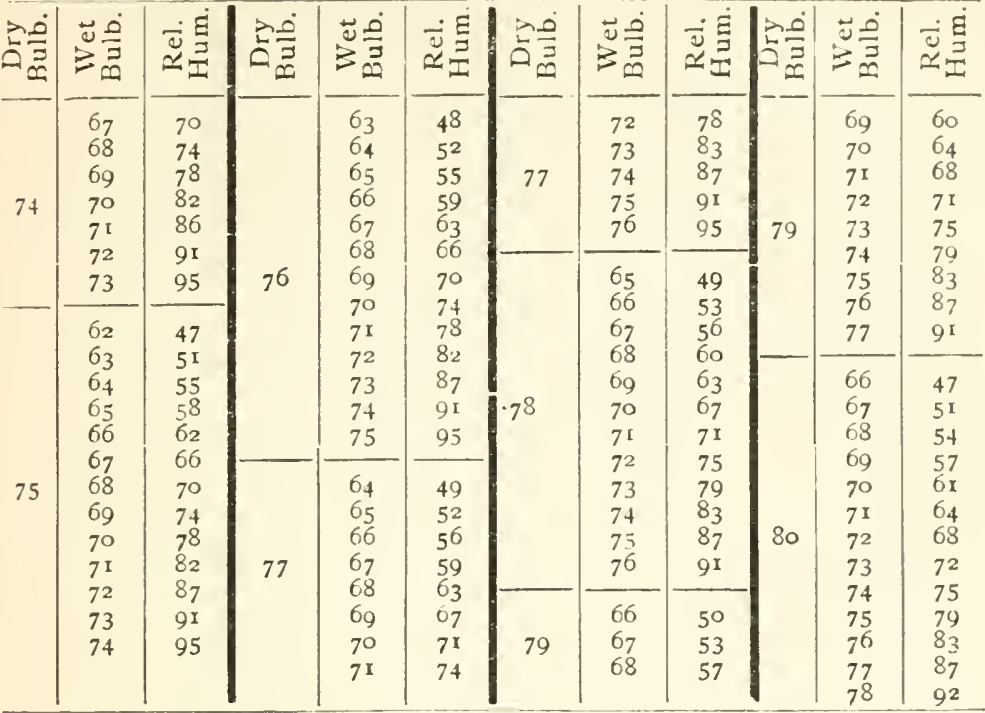

SCORE FOR JUDGING CHEESE.

\begin{tabular}{|c|c|c|c|c|}
\hline & \multirow{2}{*}{$\begin{array}{l}\text { World's } \\
\text { Fair } \\
\text { 1893. }\end{array}$} & \multicolumn{2}{|c|}{ New York, i 894.} & \multirow{2}{*}{$\begin{array}{l}\text { Wisconsin } \\
\text { Dairymen's } \\
\text { Assoc. } 1894 \text {. }\end{array}$} \\
\hline & & $\begin{array}{c}\text { For } \\
\text { Export. }\end{array}$ & $\begin{array}{c}\text { For Home } \\
\text { Trade. }\end{array}$ & \\
\hline 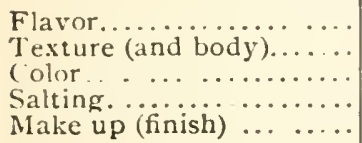 & $\begin{array}{l}45 \\
20 \\
15 \\
\text { 10 } \\
\text { 10 }\end{array}$ & $\begin{array}{l}45 \\
30 \\
15 \\
\because\end{array}$ & $\begin{array}{l}50 \\
25 \\
15 \\
\ldots \\
10\end{array}$ & $\begin{array}{l}45 \\
30 \\
15 \\
\cdots \\
\text { 10 }\end{array}$ \\
\hline Make up (finish) $\ldots \ldots$. & $x 00$ & 100 & 100 & 100 \\
\hline
\end{tabular}

PERCENTAGE COMPOSITION OF CHEESE. (KöNiG.)

\begin{tabular}{|c|c|c|c|c|c|c|}
\hline & 范苛 & 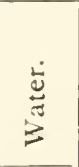 & is & 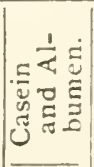 & 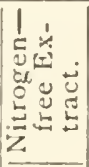 & $\frac{\text { जी }}{4}$ \\
\hline Cream chee & 27 & 36.33 & $40.7 x$ & $x 884$ & I. 02 & 3.10 \\
\hline Full cream cheese ......... & 143 & 38.00 & 30.25 & $25 \cdot 35$ & 1.43 & 4.97 \\
\hline Hali-skin cheese............ & $2 \mathrm{I}$ & 39.79 & 23.92 & 29.67 & $1 \cdot 70$ & $4 \cdot 73$ \\
\hline Skim cheese. ............. & ${ }_{4} \mathrm{I}$ & $4^{6.00}$ & $\mathrm{x} \times .65$ & 34.06 & $3 \cdot 42$ & 4.87 \\
\hline Sour-milk cheese............... & 15 & $5^{2} \cdot 3^{6}$ & 16.03 & 36.64 & .90 & 4.07 \\
\hline Whey cheese ... ....... & 7 & 23.66 & $16.9 \mathrm{I}$ & 8.90 & $45 \cdot 75$ & $4 \cdot 7^{8}$ \\
\hline
\end{tabular}


VARIETIES AND ANALYSES OF CHEESE. (MCCONNell.)

\begin{tabular}{|c|c|c|c|c|c|}
\hline & Water. & Casein. & Fat. & Sugar. & Ash. \\
\hline British, pressed- & Per ct. & Per ct. & Per ct. & Per ct. & Per $\mathrm{ct}$ \\
\hline Cheddar, 3 months........ & $3^{6 .} \cdot 7$ & 24.93 & $3 \mathrm{I} .83$ & $3.2 \mathrm{I}$ & 3.86 \\
\hline $\begin{array}{llll}* & 6 & * & \ldots\end{array}$ & $3 \mathrm{I}, 17$ & $26 \cdot 3^{I}$ & 33.68 & $4 \cdot 9 \mathrm{r}$ & $3 \cdot 9.3$ \\
\hline " average.. ..... & $34 \cdot 3^{8}$ & 26.38 & $32.7 \mathrm{r}$ & & $3 \cdot 5^{8}$ \\
\hline Cheshire, new.......... & 36.96 & 24.08 & $29 \cdot 34$ & $5 \cdot 17$ & $4 \cdot 45$ \\
\hline " old. $\quad \ldots \ldots \ldots$ & 32.59 & $32 \cdot 5 \mathrm{I}$ & 26.06 & $4 \cdot 53$ & $4 \cdot 3 I$ \\
\hline 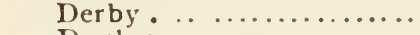 & 31.68 & $24 \cdot 50$ & $35 \cdot 20$ & $4 \cdot 3^{8}$ & $4 \cdot 24$ \\
\hline Dunlop $\quad, \ldots \ldots \ldots \ldots \ldots$ & $38 \cdot 4^{6}$ & 25.87 & 31.86 & $\ldots \ldots$ & 3.81 \\
\hline Gloucester $(\operatorname{single}) \ldots . . .$. & $32 \cdot 50$ & $28.5^{1}$ & 28.23 & $\ldots \ldots \ldots$ & 4.66 \\
\hline British, soft- (double)........ & $35 \cdot 96$ & $21 \cdot 74$ & 26.83 & $\ldots \ldots \ldots$ & 4.07 \\
\hline Cream $\ldots \ldots \ldots \ldots$ & $30.6_{5}$ & $4 \cdot 94$ & 62.99 & ... & 1.15 \\
\hline Stilton $\ldots \ldots \ldots \ldots \ldots \ldots \ldots$ & 30.35 & 28.85 & $35 \cdot 39$ & ...... & 3.82 \\
\hline $\begin{array}{l}\text { French, soft }- \\
\text { Brie.. } \\
\end{array}$ & & & & & \\
\hline 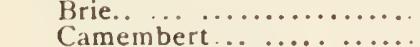 & 50.35 & 17.18 & 25.12 & ........ & $5 \cdot 4^{\mathrm{I}}$ \\
\hline 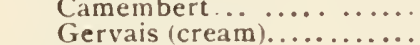 & 50. 16 & 21.95 & 21.13 & $\cdots \cdots$ & 3.89 \\
\hline Neufchatel... ........... & $\begin{array}{l}52.94 \\
44.47\end{array}$ & $\begin{array}{l}11.80 \\
14.60\end{array}$ & $\begin{array}{l}20.75 \\
33.70\end{array}$ & $\begin{array}{c}2 \cdot 5^{8} \\
\ldots \ldots \ldots\end{array}$ & $\begin{array}{l}2.93 \\
2.99\end{array}$ \\
\hline French, pressed- & 74.47 & & $20 \%$ & & \\
\hline Gruyere................. & 34.87 & 25.87 & $28.9 \pi$ & $\ldots \ldots$ & 3.84 \\
\hline$\underset{\text { Dutch- }}{\text { Roquefort... }}$ & 31.20 & 27.63 & $33 \cdot 16$ & $\ldots \ldots$ & 6.01 \\
\hline Edam (round)...................... & 35.28 & 24.06 & 30.26 & ... & $A .90$ \\
\hline Gouda (flat).......... & 21.90 & $4^{6.95}$ & $24.8 I$ & ....... & $6.3^{2}$ \\
\hline German- & & & & & \\
\hline 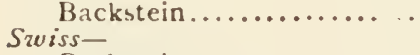 & $73 \cdot 10$ & 19.80 & 2.80 & 2.20 & 2.10 \\
\hline Backstein ..... & 35.80 & 24.44 & $37 \cdot 40$ & & $2 \cdot 3^{6}$ \\
\hline Bellelay $(s o f t) \ldots \ldots \ldots \ldots$. & $37 \cdot 59$ & 28.88 & 30.05 & $\ldots \ldots \ldots$ & $3 \cdot 4^{8}$ \\
\hline Emmenthaler.............. & 35.14 & 30.86 & $3 x \cdot 0$ & $\ldots \ldots \ldots$ & 4.00 \\
\hline Italian- & & & & & \\
\hline 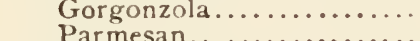 & 44.04 & 28.06 & 29.84 & ...... & 3.87 \\
\hline$\underset{\text { Various- }}{\text { Parmesan.. }} \ldots \ldots \ldots \ldots \ldots \ldots$ & $3 x \cdot 34$ & 41.99 & 19.22 & ..... & 6.25 \\
\hline American factory.......... & 25.93 & $38 \quad 12$ & $3 \mathbf{I} \cdot 55$ & & $4 \cdot 3^{8}$ \\
\hline Foreign skım, alerage..... & 46.08 & 3337 & 10.54 & 6.12 & $38 \mathbf{r}$ \\
\hline German sour milk.......... & 63.63 & 25.27 & 4.85 & .... . & 3.67 \\
\hline Whey cheese (cow)....... & 24.21 & 9.06 & 20.80 & $4^{\mathrm{r}} .0 \mathrm{I}$ & 4.02 \\
\hline " " (goat)........ & 25.29 & 9.10 & 20.98 & 29.21 & 3.88 \\
\hline Centrifugal skim-milk cheese & 50.5 & 43.1 & I. 2 & $\ldots \ldots$ & 52 \\
\hline
\end{tabular}

\section{DISTRIBUTION OF INGREDIENTS IN CHEESF.} MAKING. (COOKr.)

\begin{tabular}{|c|c|c|c|c|c|}
\hline & $\begin{array}{l}\text { Total } \\
\text { Solids. }\end{array}$ & Fat. & $\begin{array}{c}\text { Casein } \\
\text { and } \\
\text { Albumen. }\end{array}$ & $\begin{array}{l}\text { Milk- } \\
\text { sugar. }\end{array}$ & Ash. \\
\hline \multirow[t]{2}{*}{$\begin{array}{l}\text { Cheese............. } \\
\text { Cheese-press drips... } \\
\text { Whey.............. }\end{array}$} & $\begin{array}{c}\text { Percent } \\
54.2 \\
.9 \\
44.9\end{array}$ & $\begin{array}{c}\text { Per cent } \\
90.6 \\
.4 \\
9.0\end{array}$ & $\begin{array}{c}\text { Per cent } \\
77.4 \\
.6 \\
22.0\end{array}$ & $\begin{array}{c}\text { Per cent } \\
5.0 \\
\mathbf{1} \cdot 5 \\
9.5\end{array}$ & $\begin{array}{c}\text { Percent } \\
36 \\
6 \\
63\end{array}$ \\
\hline & 100.0 & 100.0 & 100.0 & 100.0 & roo \\
\hline
\end{tabular}




\section{DISTRIBUTION OF FERTILIZING INGREDIENTS IN CHEESE-MAKING. (Cооке.)}

\begin{tabular}{|c|c|c|c|}
\hline & Nitrogen. & Phosphoric Acid & Potash. \\
\hline $\begin{array}{l}1000 \text { lbs. of whole milk....... } \\
900 \text { lbs. of whey............... } \\
100 \text { lbs. of cheese........... }\end{array}$ & $\begin{array}{l}\text { lbs. } \\
5 \cdot 30 \\
1 \cdot 35 \\
3 \cdot 95\end{array}$ & $\begin{array}{l}\text { Ibs. } \\
1.90 \\
1.23 \\
.65\end{array}$ & $\begin{array}{l}\text { lbs. } \\
1.75 \\
1.63 \\
.12\end{array}$ \\
\hline
\end{tabular}

YIELD OF CHEFSE FROM MIIK OF DIFFERENT FA'T CONTENTS.

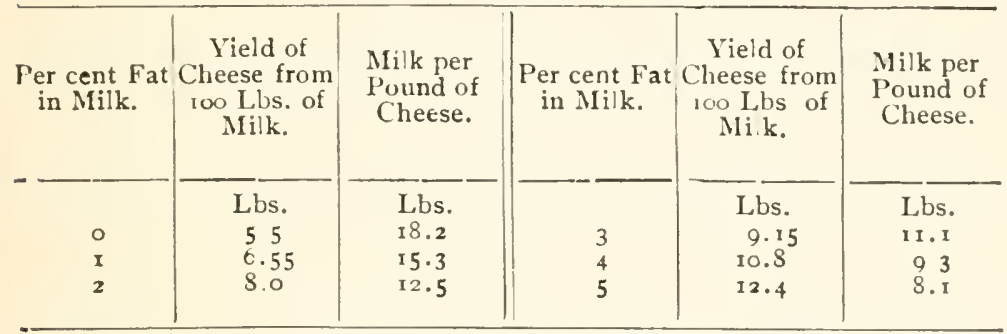

The quality of the cheese and its food value improve with the increase of fat in the milk from which it is made. (Decker.)

\section{FORMIUAS FOR FINDING YIELD OF CHEDDAR CHEESE.}

The approximate yield of green cheddar cheese from Ioo lbs. of milk may be found by multiplying the per cent of fat in the milk by 2.7; if $f$ designate the per cent of fat in the milk, the formula will therefore be:

$$
\text { Yield of cheese }=2.7 f \text {. }
$$

The factor 2.7 will only hold good as the average of a large number of cases. In extensive investigations during three consecutive years Van Slyke found that the number of pounds of green cheese manufactured for one pound of fat in the milk varied from 2.5 I to 3.06 , the average figures being 2.73. 2.7 I, and 2.72, for $1892-94$, respectively. For cured cheese the factor will be somewhat lower, viz., about 2.6 on the average.

If the percentage of solids not fat and of fat in the sample of milk are known, the following formula, published by Dr. Babcock in the twelfth report of the Wisconsin Ex- 
periment Station, will give close results $(s=$ solids not fat; $f=\mathrm{fat}$ ):

Yield of green cheese $=\mathrm{I} \cdot 5 \delta\left(\frac{1}{3} s+.9 \mathrm{I} f\right)$.

This formula is based on a water content of 37 per cent in the cheese; it may be readily changed to suit any particular per cent. The average percentages of water in green cheese in Van Slyke's investigations referred to above were $36.1 \mathrm{I}, 3705$, and 36.70 per cent for the years Is92-94, respectively.

If the percentages of casein and fat in the milk are both known, the yield of cheese may be calculated from the following formula, which will give fairly correct results:

Yield of cheese $=$ I. I $f+25$ casein.

(Babcock.)

\section{YIELD OF DIFAERINT IINDS ON CHELSE FROM 100 IBS. OF MIIK. (Fleischmann.)}

\begin{tabular}{|c|c|c|}
\hline & $\begin{array}{c}\text { Green } \\
\text { Cheese. }\end{array}$ & $\begin{array}{l}\text { Cured } \\
\text { Cheese. }\end{array}$ \\
\hline 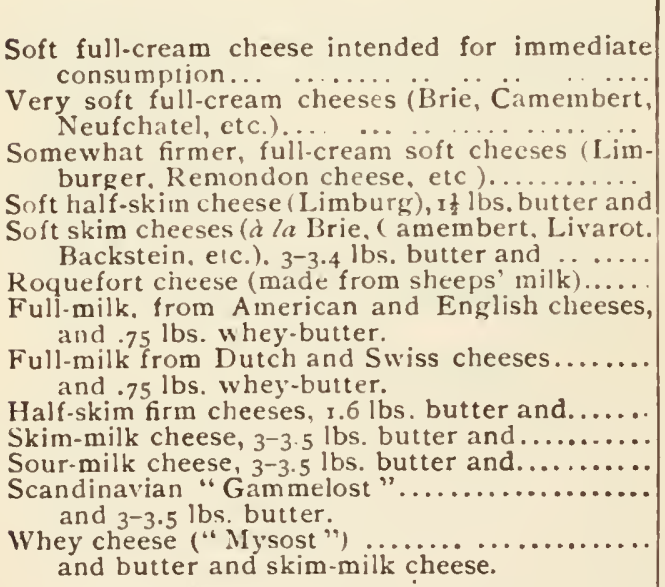 & $\begin{array}{l}16 s . \\
25-33 \\
18-22 \\
13-16 \\
12-13 \\
7 \cdot 5-12 \\
18 \\
9-11 \\
8-11 \\
7-10 \\
5-7 \\
7 \cdot 5-9 \\
3 \cdot 5-5 \cdot 5 \\
6-7\end{array}$ & $\begin{array}{c}\text { Ibs. } \\
\ldots \ldots . . . \\
12-15 \\
9-11 \\
9-1 \mathrm{I} \\
6.5-0 \\
12-14 \cdot 5 \\
8-9 \\
7-10 \\
\\
5-8 \\
4-6 \\
5-6 \\
2-3 \\
\\
\ldots \ldots . . . .\end{array}$ \\
\hline
\end{tabular}

Whey in manufacture of full-cream cheese, 73-88 lbs., average $8 \mathrm{r}$ lbs.

" " " " " " " "

Under similar conditions 5-7 lbs. less of whey are obtained in the manu. facture of soft cheese than in that of firm cheese.

The loss sustained in the manufacture of cheese amounts on the avera!e to $3 \mathrm{lbs}$. per roo lbs. of milk, not considering the loses incurred in the suring of the cheese. 


\section{AHERAGH LOSS OF AMGLICAN CHEDDAR}

\section{CHEIAS IN CURING. (BABCUCK.)}

\begin{tabular}{|c|c|c|c|c|c|c|c|}
\hline $\begin{array}{l}-5 \\
0.5 \\
0.5\end{array}$ & $\begin{array}{l}\text { Period } \\
\text { Covered }\end{array}$ & $\begin{array}{c}\text { Arerage } \\
\text { Ase. }\end{array}$ & $\begin{array}{l}\text { No of } \\
\text { Cheese. }\end{array}$ & $\begin{array}{l}\text { Total } \\
\text { Weight } \\
\text { Gree }\end{array}$ & $\begin{array}{l}\text { Total } \\
\text { Weight }\end{array}$ & \multicolumn{2}{|c|}{ Loss. } \\
\hline I & Days. & Darss. & 19 & $\begin{array}{l}\text { I.bs. } \\
2,812\end{array}$ & $\begin{array}{l}\text { I.bs. } \\
2.741 .5\end{array}$ & $\begin{array}{l}\text { Lbs. } \\
70.5\end{array}$ & Per Cent. \\
\hline 2 & I I -20 & 16 & 242 & $7: 355.9$ & 7.077 .0 & 2709 & 3.0 \\
\hline 3 & $2:-30$ & 25 & 298 & 8.530 .5 & 8.160 .4 & 370.1 & $4 \cdot 34$ \\
\hline 4 & $3^{i-50}$ & $4 \pi$ & 417 & $\mathrm{I} 2,353 \cdot 3$ & I $1,684.4$ & 668.9 & $5 \cdot 41$ \\
\hline 5 & Over 60 & $1+1$ & 172 & $6.244 \cdot 4$ & $5,736.0$ & 508.4 & 8. i 1 \\
\hline
\end{tabular}

Totảl number of cheese in preceding trials ......... . $\mathbf{2} 2=5$. Average weight of green cheese .......... . . . 30.2 lbs.

" tempcralure of curing-room...6.6 ${ }^{\circ} \mathrm{F}$. (range $55^{-70^{\circ}}$ ).

“ humidity of air in curing-room ..... 5 p per cenı.

\section{LOSS IN WHGHT OF DEFEIENT KINDS OF CHELAE DUTING CURING. (MARTINY.)}

Swiss (Emmenthal) -

Per Cent.

made from whole milk will lose in......5 months. 8-I 4

“ “ half-skimmed milk will lose in 8 “ “ I5-20

“ “ skim-milk will lose in.....6 “ “ $12-\mathbf{1 5}$

Tilsit-

made from whole milk will lose in...... “ “ $12-25$

Dutch (Gouda) -

made from whole milk will lose in...... " $20-28$

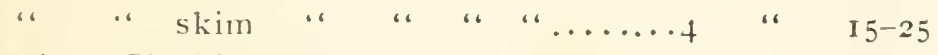

American Cheddar-

made from whole milk will lose in.. ....2 " 5

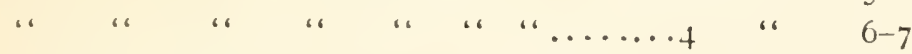

Limburger or Remoudon-

made from whole milk will lose in......2 “2 “ I6-2S

Brick cheese-

made from skim-milk will lose in...... $22^{1}$ " I5-30

Camembert, Brie, Neufchatel, eu.-

made from whole milk will lose in...... " 20-35

Sour-milk cheese-

made from whole milk will lose in.....3 " 50-60 


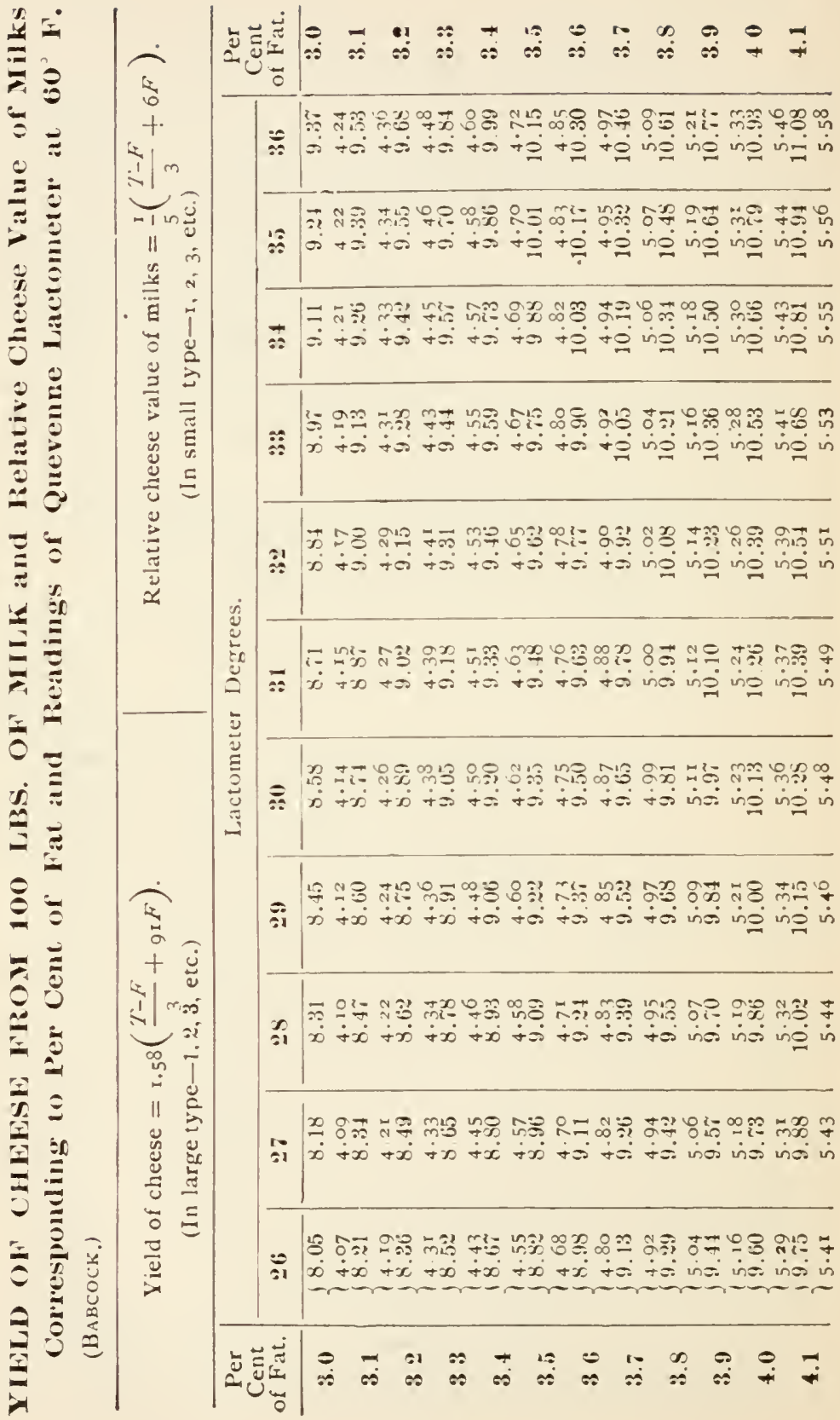




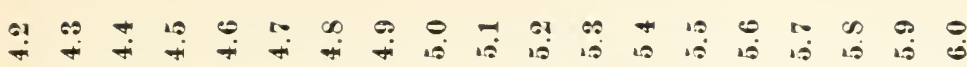

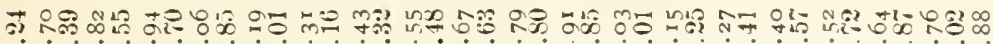
二 ம்

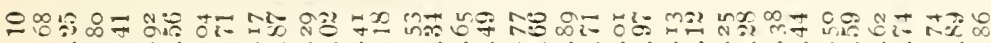

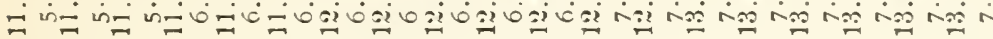

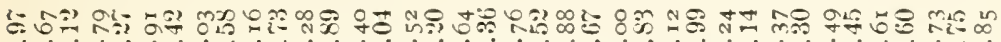

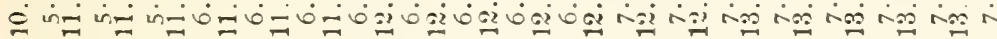

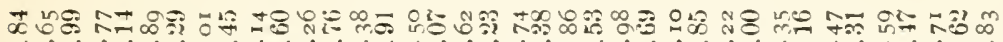

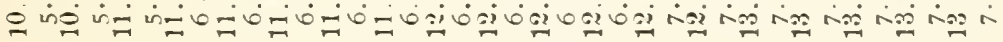

대

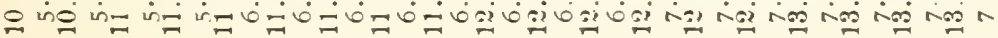

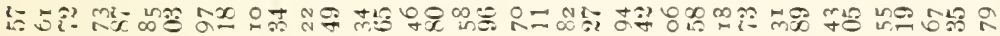

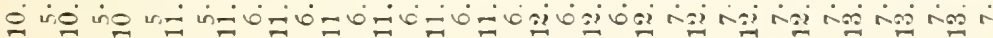

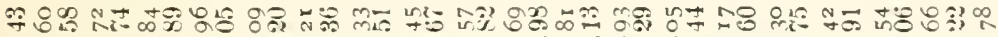

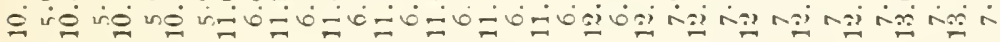

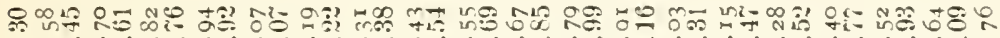

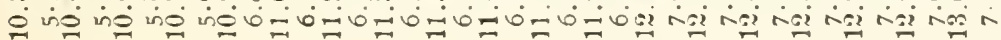

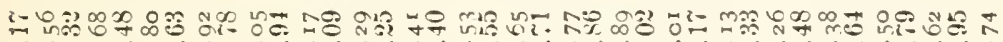

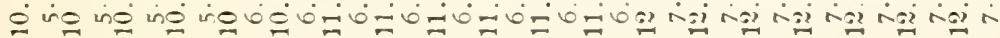

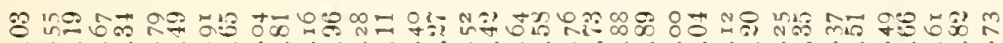

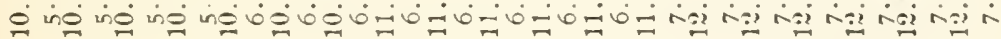

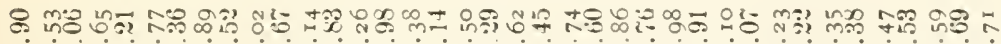

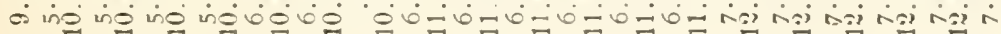

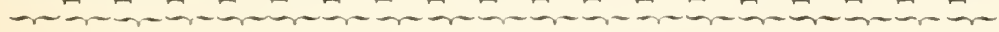

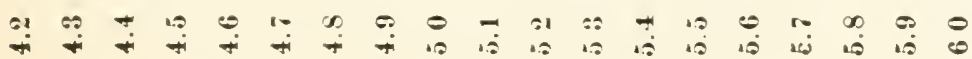




\begin{tabular}{|c|c|c|c|c|c|c|c|c|c|}
\hline 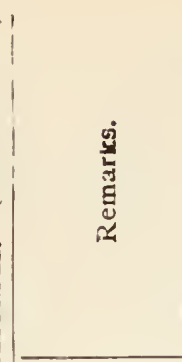 & 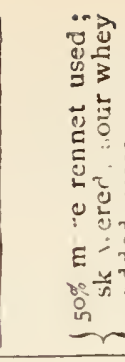 & 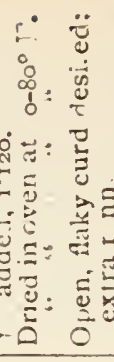 & 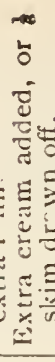 & 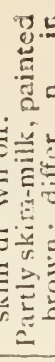 & 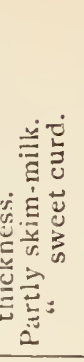 & 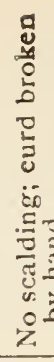 & 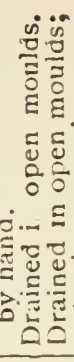 & 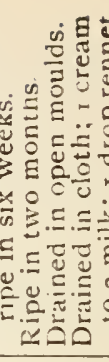 & 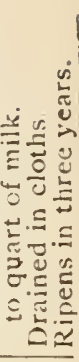 \\
\hline 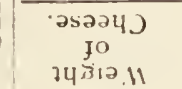 & 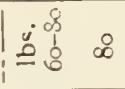 & $\therefore \circ$ 요 & $\approx$ & 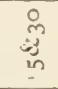 & 요 요. & & ? & $\frac{1}{1} \overbrace{}^{x}$ & t \\
\hline $\begin{array}{c}\text { asaay.) } \\
\text { adius } \\
\end{array}$ & Ü & $:::$ & : & $\frac{\vec{z}}{E}$ & 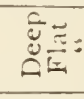 & $\stackrel{\Xi}{\vdots}$ & 芯递 & 茫: 苛 & $:$ \\
\hline "PIOJI & $\vdots \quad:$ & $\vdots \vdots$ : & $\stackrel{y}{\infty}$ & $:$ & $\vdots \stackrel{0}{\Xi}$ & $\vdots \vdots \vdots$ & $\stackrel{0}{\Xi}$ & $\vdots \vdots$ & $\stackrel{\cong}{\cong}:$ \\
\hline $\begin{array}{c}\text { Ie } \\
\text { pauad } y\end{array}$ & 188 & 888 & ஜூ & in & 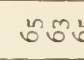 & & 옹요 & & \\
\hline $\begin{array}{l}\text { pa!jddy } \\
\text { a.nssadd }\end{array}$ & $\approx \stackrel{\varpi}{0}$ & 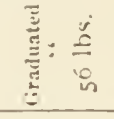 & $\begin{array}{l}\circlearrowright \\
\check{0}\end{array}$ & 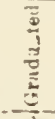 & $::$ & & こू & 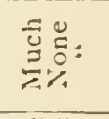 & $: \stackrel{\varrho}{\Xi}$ \\
\hline $\begin{array}{l}\text { pappy } \\
\text { Hes }\end{array}$ & $\begin{array}{ll}0 & \text { un } \\
\dddot{N} & \because\end{array}$ & 울울 & $\stackrel{8}{:}$ & $\stackrel{\frac{1}{u}}{\underline{E}}$ & 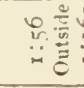 & $\dddot{0}$ & 童: & : & 咅: \\
\hline $\begin{array}{c}\text { p!jo } \\
\text { p!os }\end{array}$ & 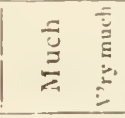 & 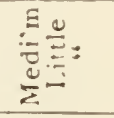 & $=$ & $=$ & $=\stackrel{0}{0}=$ & 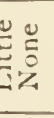 & $::$ & & $=\frac{a}{\frac{a}{0}}$ \\
\hline 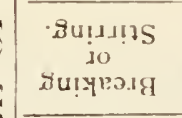 & $\equiv 3 \quad \mathrm{~m}$ & 암 & 递 & : & $\stackrel{\varrho}{\leftrightarrows}:$ & 용 & $\stackrel{\circlearrowright}{\check{0}}$ & ñ & : \\
\hline 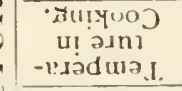 & $18 \%$ & 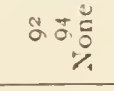 & : & $\omega^{+}$ & $\begin{array}{c}8 \stackrel{0}{\circ} 0 \\
y^{\circ}\end{array}$ & 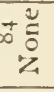 & $:=$ & $::=$ & $=\stackrel{\circ}{m}$ \\
\hline 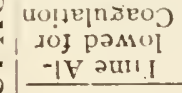 & $\sum_{\bar{z}}$ in & $8 ㅇ$ & in & 8 & $88 \%$ & $\therefore 8$ & 울 & 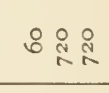 & ב् : \\
\hline 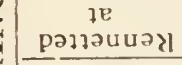 & $\underbrace{+}_{0}$ & ஸి \&̊ & $\stackrel{\infty}{\infty}$ & $\infty$ & $\infty \infty \propto$ & నే & $\infty \varnothing$ & nֻֻ & 오 \\
\hline 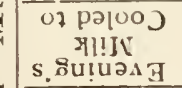 & $\underbrace{\infty}_{0} \infty$ & రొళ & ๒ొ & 20 & ถึ๐్ & ๒ே์ & & $\begin{array}{l}: \vdots \vdots \\
: \vdots\end{array}$ & : \\
\hline & 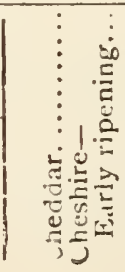 & 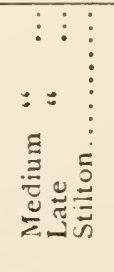 & 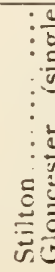 & 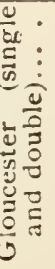 & 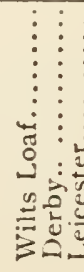 & 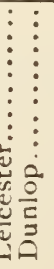 & 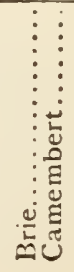 & 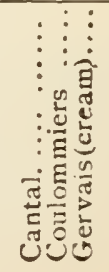 & 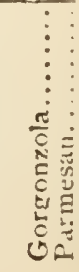 \\
\hline
\end{tabular}




\section{THE CHELS: MARKLT OF THE INITED STATES.}

('I'1 On.

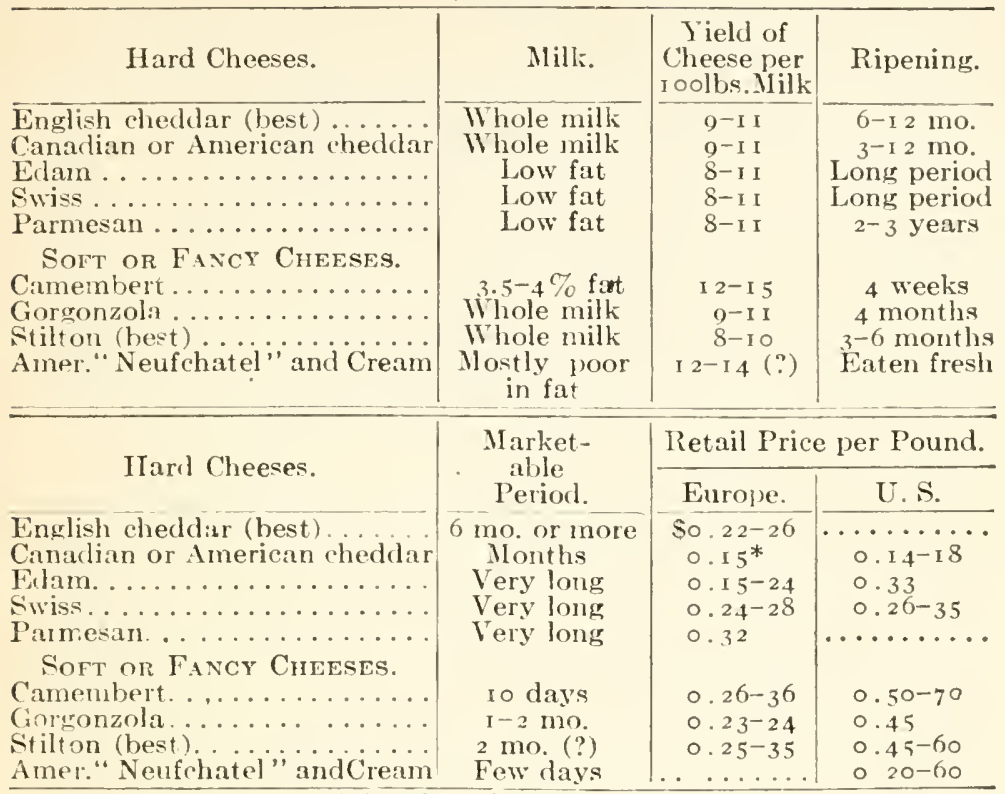

* L.ondon, October, i 905.

\section{COMMHICIAL GIRDES OF AMERICAN CHED-}

dar chelese. (ONtakio Dept. of doriculture.)

First Grade.-Flavor.-Clean, sound, and pure.

Body and Texture.-Close, firm, and silky.

Color.-Good and uniform.

Finish.-Fairly even in size, smoothly finished, sound and clean surfaces, straight, and square.

Boxes.-Strong, clean, well made, and nailed. Ends to be of seasoned timber. Close fitting. Weights stenciled or marked with rubber stamp.

Second Grade.-Flaz'or.- "Fruity," not clean, "turnipy," or other o! jectionable Ravor.

Body and Texture.-Weak, open, loose, "acidy," too soft, too dry.

Color.-Uneven, motiled, or objectionable shade.

Finish.-Tery uneven in size, showing rough corners, black mold, dirty or cracked surfaces, soft rinds.

Boxes.-Too large in diameter; top edre of box more than $\frac{1}{2}$ an inch below the top of the checse. Made of light material. Ends made of improperly seasoned material. 
ThIRD GRADE.-Flavor.-Rancid, badly "off," anything inferior to Second Grade.

Body and Texture.-Very weak, very open, showing pinholes or porous, very "acidy," very soft or very dry.

Color.-Badly mottled, or very objectionable shade.

Finish.-Anything worse than second grade.

Boxes.-No question of boxes sufficient to make Third Grade if other qualities are good.

Explanations.-It would be impossible to define exactly the qualities or defects which may appear in cheese. The standards given are intended to indicate the range of quality for the different grades rather than to establish hard and fast rules to guide the grader.

The expression "good color" means that the color must be of proper shade. There are cheap, inferior cheese colors used which do not give the proper shade, no matter what quality is used.

The expression "clean surfaces" in the definition for First Grade does not exclude from that grade cheese with a slight growth of blue mold, although it is desirable that the cheese should not show any signs of mold. "Black mold" (sce definition for Second Grade), is simply the advanced stage of the ordinary blue mold.

The following scale of points will indicate the relative values of the different divisions of quality: Flavor, 40; body and texture, 30 ; color, 15 ; finish and boxing, $15 ;=100$.

It is obvious that a defect in flavor of a certain degree counts nearly three times as much in determining the grade as a defect in finish or boxing of the same grade.

Cheese which are strictly sour, or otherwise inferior to Third Grade, will be designated as "Culls," for which there is no classification.

Any lot of cheese shall be considered third grade if it shows three or more defects of Second Grade class.

If there are not more than ${ }_{5} 5$ per cent of defective cheese in any lot, the inferior ones may be sorted out and classed separately. If more than 15 per cent are defective, the classification for the defective cheese may apply to the whole lot.

This does not apply when inferior cheese have been properly marked so as to be identified, in which case the inferior cheese shall be treated as a separate lot. 
WHEY TO BE ALLOWED AT CHELSE FACTORIES FOR QUANTITIES OH MILK FHOM 30 'TO 360 POUNDS. (Rolertson.)

The figures in the columns denote the inches of whey.

\begin{tabular}{|c|c|c|c|c|c|c|c|c|c|}
\hline \multirow{2}{*}{$\begin{array}{l}\text { Welght of } \\
\text { Milk in } \\
\text { Pounds. }\end{array}$} & \multicolumn{9}{|c|}{ Diameters of Milk-cans in Inches. } \\
\hline & 20 & I9 & 18 & 17 & 16 & 15 & 14 & 13 & 12 \\
\hline 30 & 2 & 2 & 3 & 3 & 3 & 3 & 4 & 5 & 6 \\
\hline 35 & 2 & 3 & 3 & 3 & 3 & 4 & 5 & 6 & 7 \\
\hline 40 & 3 & 3 & 3 & 4 & 4 & 5 & 6 & 6 & 7 \\
\hline 45 & 3 & 4 & 4 & 4 & 4 & 5 & 6 & 7 & 8 \\
\hline 50 & 3 & 4 & 4 & 5 & 5 & 6 & 7 & 8 & 9 \\
\hline 55 & 4 & 4 & 5 & 5 & 6 & 7 & 8 & 9 & 10 \\
\hline 60 & 4 & 5 & 5 & 6 & 6 & 7 & 8 & 9 & I I \\
\hline 65 & 4 & 5 & 5 & 6 & 7 & 8 & 9 & 10 & 12 \\
\hline 70 & 5 & 5 & 6 & 7 & 7 & 8 & 10 & II & 13 \\
\hline 75 & 5 & 6 & 6 & 7 & 8 & 9 & 10 & 12 & 14 \\
\hline 80 & 5 & 6 & 7 & 8 & 8 & 10 & I I & I 2 & 15 \\
\hline 85 & 6 & 6 & 7 & 8 & 9 & 10 & 12 & 13 & 16 \\
\hline 90 & 6 & 7 & 7 & 9 & 9 & II & 12 & 14 & 17 \\
\hline 95 & 6 & 7 & 8 & 9 & 10 & II & 13 & 15 & 18 \\
\hline 100 & 7 & 7 & 8 & 9 & 10 & 12 & I4 & 16 & 19 \\
\hline 105 & 7 & 8 & 9 & 9 & II & 13 & $: 5$ & 16 & 19 \\
\hline 110 & 7 & 8 & 9 & 10 & II & I3 & I 5 & 17 & 20 \\
\hline 115 & 8 & 9 & 10 & 10 & 12 & 14 & 16 & 18 & $2 \pi$ \\
\hline 120 & 8 & 9 & 10 & II & 12 & 14 & 17 & 19 & 22 \\
\hline 125 & 8 & 9 & 10 & II & 13 & I 5 & 17 & 19 & 23 \\
\hline 130 & 9 & 10 & I I & 12 & 13 & 16 & 18 & 20 & 24 \\
\hline 135 & 9 & 10 & II & 12 & 14 & 16 & 19 & 21 & \\
\hline 140 & 9 & 10 & 12 & 13 & 14 & 17 & 20 & 22 & \\
\hline 145 & ro & 11 & 12 & 13 & 15 & 17 & 20 & 23 & \\
\hline 150 & IO & 11 & 12 & 14 & 15 & 18 & 21 & 24 & \\
\hline 155 & 10 & II & 13 & 15 & 16 & 19 & 22 & & \\
\hline 160 & II & 12 & 13 & 15 & 16 & 19 & 22 & & \\
\hline r65 & II & 12 & 14 & 15 & 17 & 20 & 23 & & \\
\hline 170 & II & 12 & 14 & 16 & 17 & 20 & 23 & & \\
\hline 175 & 12 & 13 & 15 & 16 & 18 & 21 & 24 & & \\
\hline 180 & I 2 & 13 & 15 & 17 & 18 & 22 & 24 & & \\
\hline $18 j$ & 12 & 14 & 15 & 17 & 19 & 22 & & & \\
\hline 190 & 13 & 14 & 16 & 18 & 19 & 23 & & & \\
\hline 195 & 13 & 14 & I 6 & 18 & 20 & 23 & & & \\
\hline 200 & 13 & I 5 & 17 & 18 & 20 & 24 & & & \\
\hline 205 & 14 & 15 & 17 & 19 & 21 & & & & \\
\hline 210 & 14 & í & 18 & 19 & $2 \mathrm{I}$ & & & & \\
\hline 215 & 14 & I 6 & 18 & 20 & 22 & & & & \\
\hline 220 & 15 & I6 & 18 & 20 & 23 & & & & \\
\hline 225 & 15 & 17 & 19 & 21 & 24 & & & & \\
\hline 230 & 15 & 17 & 19 & $2 \mathrm{I}$ & 24 & & & & \\
\hline 235 & 16 & 18 & 19 & 22 & & & & & \\
\hline 240 & 16 & 18 & 20 & 22 & & & & & \\
\hline 245 & 16 & 18 & 20 & 23 & & & & & \\
\hline 250 & 17 & 19 & 21 & 23 & & & & & \\
\hline 2 ťo & 17 & 19 & 22 & 24 & & & & & \\
\hline 270 & 18 & 20 & 22 & & & & & & \\
\hline 280 & 19 & 21 & 23 & & & & & & \\
\hline 290 & 19 & 22 & 24 & & & & & & \\
\hline $\begin{array}{l}300 \\
310\end{array}$ & 20 & 23 & 24 & & & & & & \\
\hline $\begin{array}{l}310 \\
320\end{array}$ & $\begin{array}{l}21 \\
2 I\end{array}$ & $\begin{array}{l}23 \\
24\end{array}$ & & & & & & & \\
\hline $33^{\circ}$ & 22 & & & & & & & & \\
\hline 340 & 23 & & & & & & & & \\
\hline 350 & 23 & & & & & & & & \\
\hline $3^{\text {fro }}$ & 24 & & & & & & & & \\
\hline
\end{tabular}




\section{MANAGEMENT OF CREAMERIES AND CHEESE FACTORIES. •}

\section{DIRECTIONS FOR TAKING AND PISESERVING COMIOSITH SAMPIAS OH MILK IN CREMMHA- IES AND CHELSW-TCTORIES. (FARRINGTON).}

The modern creamery and cheese-factory uses the Babcock test for determining the quality of the milk delivered by each patron. The most common and satisfactory method of paying for the milk according to its test is to take a small sample of each lot of milk each day, pour this into a covered glass jar containing a small amount of some preserviltive, and at the end of a week or ten days test this composite sample. The essential features of the process are given in the following directions:

I. Provide a pint or quart jar or bottle for each patron.

2. Label cach bottle with a number, giving the same number to a patron on the milk-recording shect.

3. Composite test sample-bottles made for this purpose with a tin cover and numbered brass tag wired to the neck of each bottle can be obtained of creamery supply-firms.

4. These sample-bottles should be placed on shelves within easy reach of the man at the weigh-can, and protected from the light.

5. A small quantity of powdered potassium bichromate, corrosive sublimate, formaldehyd, borax, or preservaline is nut into each clean bottle, to lieep the misk from souring until testing-day. Some of these preservatives are put up in tablet form, each tablet containing the necessary amount to use in one sample.

6. After each lot of milk is poured into the factory weigl1can and weighed, a small amount of it is dipped from the can and poured into the proper sample-bottle.

7. These samples are usually taken with a sinall ( $\mathrm{I}-\mathrm{OZ})$ 
tin dipper, a Scovell sampling-tube, or from a drip in the conductor-spout.

8. Each lot of milk sampled must be sweet, containing no clots, lumps of curdled milk, or small butter-granules. The sample should be taken just as soon as the milk is weighed, and while it is evenly mixed.

9. The use of a small ( $\mathrm{I}-\mathrm{Oz}$.) tin dipper for taking the composite sample has been proved to be practically correct. As the quantities of milk delivered from day to day by each patron vary but little, the error introduced by taking the same amount of milk for each sample is too small to be worth considering in factory work, and this method of composite sampling is usually adopted in separator creameries and in cheese-factories, where the payment of the milk is based on its quality.

Io. When it is desired to vary the size of the samples according to the quantity of milk delivered each day by a patron, it is necessary to use a "milk-thief" or a Scovell sampling-tube. In using either of these tubes, the size of the sample is regulated by the amount of milk in the weighcan. In all cascs cylindrical sampling-cans must be used.

Ir. Continue adding a sample of each patron's milk to his particular jar every time he delivers milk, for a week or ten days; then test this composite sample.

I2. The composite sample-jars should be kept covered, to prevent loss by evaporation, and in a cool, dark place. Every time a new portion of milk is added to the jar it should be given a horizontal rotary motion to mix the cream already formed in the jar with the milk, and to rinse off the cream sticking to its side. Unless this is done every time fresh portions of milk are added to the jar the cream on the milk becomes lumpy and sticks in patches to the side of the jar, thus making it nearly impossible to evenly distribute this cream through the entire sample.

13. Composite samples having patches of dried cream on the inside of the jar are the result of careless'ness or ignorance on the part of the operator.

14. A test of the composite sample takes the place of the daily tests of each lot of milk and gives accurate informa- 
tion regarding the average quality of the milk delivered by each patron during the period of sampling.

15. The weight of butter-fat which each patron brought to factory in his milk during the time covered by the sampling is obtained by muliplying the total weight of milk delivered during the sampling period by the test of the conposite sample, divided by 100.

\section{PAYMENT OF MLK AT CREAMERIES AND CHEESL WACTORIES.*}

Numerous systematic and extensire experiments by varqous scientists have proved that the value of milk for both butter and cheese production stands in direct proportion to ts fat content. Patrons of separator cheese and butter factories should therefore receive payment for the milk delivered by them according to the percentage of fat in the milk, i.e., according to the quantity of fat delivered in their milk. The same applies to gathered-cream factories as well.

The tables given on PP. 305-306 will aid in the calculation of the value of millis of different ricliness, according to prices agreed upon. In paying for the nilk delivered by patrons, four, or, essentially, three, different metho.ls are followed at different factories, all of which are just to all parties concerned. The methods and the directions for using the tables in each case are given below. The tables and discussions entered upon are largely taken from Vermont Experiment Station Bulletin No. I6.

* See Farrinton-IYo!l, Testing Milk and its Products, $22 \mathrm{~d}$ Ed., pp. 203-216, 286-289. 


\section{METHODS OF PAYMENT FOR MIL AT CHEESE AND BU'TER FAC'TORHES.}

I. A certain price is to be paid per one hundred lbs. of milk containing a definite per cent of fat (e.g., \$1.0O per Ioo lbs. of four per cent milk). By referring to the second half of the table on p. $27 \mathrm{I}$ we find $\$ 1.00$ opposite 4.00 per cent of fat; the figures in the same column as \$r.oo then give the value of roo lbs. of milk containing percentages of fat ranging from 3.00 to 5.00 ; e.g., Ioo lbs. of 3 per cent milk is worth 75 cents, of 4.5 per cent milk \$I.I3, of 5.40 per cent milk $\$ \mathrm{I} .35$, etc.

2. A certain price is to be paid per pound of fat delivered. If 2 I cents is the price agreed upon we multiply. 2 I by three, and the product, .63 , gives the amount in dollars to be paid per Ioo lbs. of three per cent milk. The column in which the figure .63 occurs opposite 3.0 per ct. is then to be used in the calculations as long as the price is paid, and 3.5 per cent milk will be paid with 73 cents per Ioo lbs., 5.3 per ct. milk $\$$ I. Io per Ioo lbs., etc.

Example: Patron A delivers 8 to lbs, of milk during one week, containing, according to the test made, 4.3 per cent fat. If the price agreed upon per ${ }_{2}^{n}=$ und of fat was as before stated, he is to receive go cents per Ioo lbs. of milk, or $\$ 7.56$ in all.

Patron B, sending $625 \mathrm{lbs}$. of milk testing 3.45 per cent, will receive $6.25 \times .72=\$ 4.50$, etc. In the table only tenths of per cents are given; $3 .+5$ being half-way between 3.40 and 3.50 , for which percentages $7 \mathrm{I}$ and 73 cents are to be paid respectively, we multiply by the mean of the two values, or .72. If a test differs less than five-hundredths from any percentages given in the table, the nearest figure is chosen.

3. Patrons are to be paid what is received for the butter, less a certain amount for cost of making and marketing. Multiply each man's milk by the per cent of fat it contains, and the sum of the several products will be the total amount of fat contained in the day's milk. Divide the pounds of butter made from the milk by the pounds of fat it contained, to 
find how much butter each pound of fat makes. Multiplying the amount received per pound of butter, less the cost of making, etc., by this last result will give the amount to be paid for each pound of fat delivered.

Example: Suppose the patrons furnish milk containing in all $400 \mathrm{lbs}$. of fat, which made $460 \mathrm{lbs}$. of butter, selling for 27 cents per pound. The expense of making the butter is found to be, e.g., 4 cents per pound. 27-4 = 23 cents; 460 divided by 400 equals I. I $5 ; 23$ multiplied by I. I 5 equals 26.45, which is the amount, in cents, to be paid per pound of fat delivered; $26.45 \times 3=79.35$, or nearest 79 cents, is then the money to be paid for Ioolbs. of 3 per cent milk, and (see table) 90 cents for Ioo lbs. of 3.40 per cent milk, $\$ 1.24$ for Ioo lbs. of 4.7 per cent milk, etc.

4. A certain price is to be paid per Ioo lbs. of milk of average quality. Find the total fat contained in the milk as before; divide this amount by the total weight of milk delivered, and the result will be the average per cent of fat in the milk. Starting from this percent at the left of the table, go to the right until the price per $100 \mathrm{lbs}$. agreed upon is reached; the perpendicular column in which this figure is found is the one to be used. Example: Suppose milk of average quality is to be paid $\$ I .00$ per hundred pounds, and the farmers furnish 8500 lbs. of milk, containing in all 440 lbs. of fat; 440 divided by 85.00 then equals 5.18 , the number nearest to which in the table is 5.20 per cent. To the right of 5.20 per cent $\$ 1.00$ is found in the column headed .58 , which column would be the one to use. 


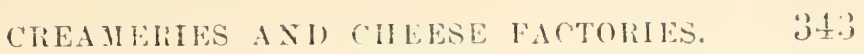

\section{PRICE OF MILK OF DIFEERENT RICHNESS PET 100 POUNDS.}

\begin{tabular}{|c|c|c|c|c|c|c|c|c|c|c|}
\hline $\begin{array}{c}\text { P. ct. } \\
\text { Fat. }\end{array}$ & & Pri & e per & lbs. & f Milk & , in do & lars an & d cen & & \\
\hline 3.00 & 1.00 & .97 & .94 & $.9 \mathbf{I}$ & .88 & .86 & .83 & $.8 \mathrm{I}$ & .79 & .77 \\
\hline $3 \cdot 10$ & I. 03 & 1.00 & .97 & .94 & $.9 \mathbf{I}$ & .89 & .86 & .84 & .82 & .79 \\
\hline 3.20 & 1.07 & I. O3 & 1.00 & .97 & 94 & .91 & .89 & .86 & .85 & .82 \\
\hline $3 \cdot 3^{\circ}$ & 1. 10 & 1.07 & 1.03 & 1.00 & .97 & .94 & .92 & .89 & .87 & .84 \\
\hline 3.40 & I. I 3 & I. IO & 1.06 & 1.03 & 1.00 & .97 & .94 & .92 & .90 & .87 \\
\hline $3 \cdot 50$ & I. 7 & I. I 3 & I.०9 & г. .06 & I. 03 & 1.00 & .97 & .95 & .93 & .89 \\
\hline 3.60 & I . 20 & I. 16 & 1.12 & I.09 & 1.06 & 1.03 & I. .00 & .97 & .95 & .92 \\
\hline 3.70 & I. 23 & I. 19 & I. 16 & I. I 2 & 1.09 & 1.06 & I. 03 & 1.00 & .98 & .94 \\
\hline 3.80 & 1.27 & 1.23 & 1.19 & I. I 5 & 1. 12 & 1.09 & 1.06 & 1.03 & 1.00 & .97 \\
\hline 3.90 & $1.3^{\circ}$ & 1.26 & I. 22 & I. 18 & I. 15 & I. I I & 1. .08 & 1.06 & 1.03 & 1.00 \\
\hline 4.00 & I. 33 & I . 29 & I. 25 & I. 2 I & I. 18 & I. I 4 & I. I I & I. .08 & 1.06 & 1.02 \\
\hline 4.10 & I. 37 & $1 \cdot 3^{2}$ & I. 28 & I.24 & I. $2 \mathrm{I}$ & I. I 7 & 1.14 & I. I I & 1.08 & 1.05 \\
\hline 4.20 & 1.40 & I. 35 & I. 3 I & 1.27 & 1.24 & 1.20 & I. 17 & I. I 4 & I. I I & 1.07 \\
\hline $4 \cdot 30$ & 1. 43 & 1. 39 & I. 34 & $1 \cdot 30$ & 1.26 & 1.23 & I. 19 & I. 17 & 1.14 & I . IO \\
\hline $4 \cdot 4^{\circ}$ & I. 47 & 1.42 & $1 \cdot 3^{8}$ & $1 \cdot 33$ & I. 29 & 1. 26 & 1. 22 & 1.19 & 1.16 & I. 12 \\
\hline $4 \cdot 5^{\circ}$ & I. 50 & I. 45 & I. $4^{\mathrm{I}}$ & I. $3^{6}$ & I. 32 & 1.29 & I. 25 & I. 22 & I. 19 & I. 15 \\
\hline 4.60 & I. 53 & I. $4^{8}$ & I. 44 & I. 39 & I. 35 & I. 3 I & I. 28 & 1.25 & I. 2 I & 1.17 \\
\hline 4.70 & I. 57 & I. 52 & I. 47 & 1.42 & I. $3^{8}$ & I. 34 & I. 3 I & I. 28 & I. 24 & I 20 \\
\hline 4.80 & 1.60 & 1. 55 & I 50 & I. 45 & I. $4 \mathrm{I}$ & $1 \cdot 37$ & $1 \cdot 33$ & $1 \cdot 30$ & 1.27 & I. 23 \\
\hline 4.90 & 1.63 & 1.58 & I. 53 & I. $4^{8}$ & I. 44 & 1.40 & $1 \cdot 3^{6}$ & 1. 33 & 1.29 & 1.25 \\
\hline 5.00 & 1. 67 & 1. 61 & I $5^{6}$ & I. 52 & I. 47 & I. 43 & 1. 39 & 1. 36 & I. 32 & 1.28 \\
\hline 5.10 & I. 70 & 1. 65 & I. 59 & 1.55 & $1 \cdot 50$ & $14^{6}$ & I. $4^{2}$ & I. 39 & I. 35 & 1.30 \\
\hline 5.20 & I. 73 & 1.68 & I. 63 & 1.58 & I. 53 & 1.49 & I. 44 & I. $4 \mathrm{I}$ & I $\cdot 37$ & I. 33 \\
\hline $5 \cdot 30$ & I. 77 & I. $7 \mathrm{I}$ & 1.66 & r. $\hat{n}_{t}$ & I. 56 & I. 51 & I. 47 & I. 44 & I. $4^{\circ}$ & I. 35 \\
\hline $5 \cdot 40$ & 1.80 & 1. 74 & I. 69 & 1.64 & r.59 & I. 54 & I. 50 & I. 47 & I. $4^{2}$ & $1 \cdot 3^{8}$ \\
\hline $5 \cdot 50$ & I. 83 & 1.77 & I. 72 & x.67 & 1. 62 & I. 57 & I. 53 & 1. 50 & 1.45 & I 4 I \\
\hline 5.60 & I. 87 & I. $8 \mathrm{I}$ & I. 75 & I. 70 & 1. 65 & 1. 60 & I. 56 & I. 52 & I. 48 & I. +4 \\
\hline $5 \cdot 7^{\circ}$ & I . ģo & I 84 & I. $7^{8}$ & I. 73 & I 68 & 1.63 & 1.58 & I. 55 & I. 50 & I. 46 \\
\hline 5.80 & I. 93 & 1. 87 & I. $8 \mathrm{I}$ & I. 76 & $1.7 \mathrm{I}$ & 1. 66 & $1.6 \mathrm{I}$ & I. 57 & I. 53 & 1. 49 \\
\hline 5.90 & I.97 & 1.90 & I .84 & 1.79 & 1. 74 & 1.69 & 1.64 & 1.60 & I. $5^{6}$ & I. 5 I \\
\hline 6.00 & 2.00 & I. 94 & I. 88 & I. 82 & $1 \cdot 7^{6}$ & 1.71 & 1.67 & 1. 62 & I. 58 & I. 54 \\
\hline 3.00 & .75 & .73 & $\cdot 7 x$ & $\cdot 70$ & .68 & .67 & .65 & .64 & .63 & $.6 \mathrm{r}$ \\
\hline 3.10 & 78 & .75 & .73 & .72 & .70 & .69 & .67 & .66 & .65 & .63 \\
\hline 3.20 & .80 & .78 & .76 & .75 & $\cdot 73$ & $.7 \mathrm{I}$ & .69 & .68 & .67 & .55 \\
\hline $3 \cdot 30$ & .83 & .80 & .78 & .77 & .75 & .74 & .72 & .70 & .69 & .67 \\
\hline $3 \cdot 40$ & .85 & .83 & $.8 \mathbf{I}$ & .79 & .77 & .76 & .74 & $\cdot 73$ & .71 & .69 \\
\hline $3 \cdot 50$ & .88 & .85 & .83 & .82 & .79 & .78 & $\cdot 76$ & $\cdot 75$ & .73 & $\cdot 7 x$ \\
\hline 3.60 & .90 & .88 & .85 & .84 & .82 & .80 & .78 & .77 & .75 & .73 \\
\hline $3.7^{\circ}$ & .93 & .90 & .88 & .86 & .84 & .83 & .80 & .79 & .77 & .75 \\
\hline $\begin{array}{l}3.80 \\
3.80\end{array}$ & $\begin{array}{l}.95 \\
.98\end{array}$ & .03 & .90 & .89 & .86 & .85 & $\begin{array}{l}.82 \\
.85\end{array}$ & $\begin{array}{l}.8 i \\
.83\end{array}$ & $\begin{array}{l}.80 \\
.82\end{array}$ & $\begin{array}{r}.77 \\
70\end{array}$ \\
\hline 3.90 & & $\cdot 95$ & $\cdot 9^{2}$ & $.9 \mathrm{I}$ & .88 & .87 & & & & .79 \\
\hline $4 . \infty 0$ & I., 0 & .97 & .95 & .93 & $.9 \mathbf{I}$ & .89 & .87 & .85 & .84 & $.8 \mathrm{I}$ \\
\hline 4. 10 & I. 03 & I.00 & .97 & .96 & .93 & .91 & .89 & .87 & .86 & .83 \\
\hline 420 & I. 05 & 1.02 & 1.00 & .98 & .95 & .94 & .91 & .90 & .88 & .85 \\
\hline $4 \cdot 30$ & I. 08 & 1.05 & 1.02 & 1.00 & .93 & .96 & .93 & .92 & .90 & .88 \\
\hline $4 \cdot 40$ & I. 10 & I.07 & I.05 & 1.02 & I.OO & .98 & .95 & .94 & .92 & .90 \\
\hline
\end{tabular}


PRICF OF MILK PER 100 POUNDS.-Continued.

\begin{tabular}{|c|c|c|c|c|c|c|c|c|c|c|c|}
\hline $\begin{array}{l}\text { P.ct. } \\
\text { Fat. }\end{array}$ & & & pe & $00 \mathrm{lbs}$ & s. of $\mathrm{M}$ & ilk, in & dollars & $s$ and & cents. & & \\
\hline $4 \cdot 50$ & I. I 3 & I. IO & 1.07 & I.05 & 1.0 & 1.0 & & 97 & .96 & 94 & .92 \\
\hline 4.60 & I. 15 & I. 12 & I. 10 & I 07 & 1.0 & 1.0 & I. & & .98 & 96 & .94 \\
\hline $4 \cdot 70$ & 1.18 & I. 15 & I. I 2 & 1.09 & 1.0 & 1.0 & I. 0 & & .00 & 98 & .96 \\
\hline 4.80 & I. 20 & I. I 7 & 1.14 & 1.12 & 1.0 & 1.0 & 1.0 & & .02 & $\infty$ & .98 \\
\hline $4 \cdot 90$ & I. 23 & I. 20 & I. 17 & I. 14 & I. I & 1.0 & 1.0 & & .04 & $\mathrm{O} 2$ & 1.00 \\
\hline 5.00 & 1.25 & 1.22 & I. 19 & x. 16 & I. I & I. I & 1.0 & & .06 & 04 & 1.02 \\
\hline 5.10 & I. 28 & I. 24 & $\mathrm{I} .2 \mathrm{I}$ & 1. 19 & I. I & I. I & I. I & & .09 & 06 & I.O. \\
\hline 5.20 & 1.30 & 1.27 & 1.24 & I. 2 I & I. 1 & I. I & I. I & & II & 08 & $x .06$ \\
\hline $5 \cdot 3^{\circ}$ & I. 33 & 1.29 & 1.26 & I. 23 & I. 2 & I. I & I. I & & .13 & 10 & 1.08 \\
\hline $5 \cdot 40$ & $x \cdot 35$ & $\mathrm{I} \cdot 32$ & I. 29 & 1. 26 & I. 2 & I. 2 & I. I & & .15 & 12 & I. 10 \\
\hline 5.50 & $1 \cdot 3^{8}$ & 1. 34 & I. 3 I & 1. 28 & I. 2 & 1.2 & I. 2 & & .17 & I 4 & I. 12 \\
\hline 5.60 & I. 40 & 1.37 & I. 34 & 1.30 & I. 2 & I. 2 & I. 2 & & 19 & 17 & I. $x_{4}$ \\
\hline 5.70 & I. 43 & I.39 & 1. 36 & 1. 33 & I. 3 & 1.2 & I. 2 & & .21 & 19 & 1. 16 \\
\hline 5.80 & I. 45 & I. 4 I & 1. 39 & 1. 35 & I. 3 & I. 2 & 1.2 & & .23 & 21 & 1. 18 \\
\hline 5.90 & 1. 48 & I. 44 & I. 4 I & 1. $3^{8}$ & 1. 3 & I. 3 & I. 2 & & .26 & 23 & I. 20 \\
\hline 6.00 & I. 50 & I. 46 & 1.43 & 1.40 & I. 3 & 1. 3 & I. 3 & & .28 & 25 & I. 22 \\
\hline 3.00 & .60 & .59 & $.5^{8}$ & .57 & .56 & .55 & .54 & .53 & $.5^{2}$ & $.5 \mathrm{I}$ & .50 \\
\hline 3.10 & .62 & .61 & .60 & .59 & .58 & .57 & .56 & .55 & .54 & .53 & .52 \\
\hline 3.20 & .64 & .63 & .62 & .61 & .60 & .59 & $.5^{8}$ & .57 & .55 & .54 & .53 \\
\hline $3 \cdot 30$ & .66 & .65 & .64 & .63 & .62 & .60 & .59 & $.5^{8}$ & .57 & $.5^{6}$ & .55 \\
\hline 3.40 & .68 & .67 & .66 & .65 & .63 & .62 & .61 & .60 & .59 & .58 & .57 \\
\hline 3.50 & .70 & .69 & .68 & .66 & .65 & .64 & .63 & .62 & $.6 \mathrm{r}$ & .59 & $5^{8}$ \\
\hline & .72 & .71 & .70 & .68 & .67 & .66 & 65 & .64 & .62 & $.6 \mathbf{I}$ & coo \\
\hline 3.70 & .74 & .73 & $.7 \mathrm{I}$ & .70 & .69 & .68 & .67 & .65 & .64 &.$\epsilon_{3}$ & .62 \\
\hline 3.80 & .76 & .75 & .73 & .72 & .71 & .70 & .68 & .67 & .66 & .65 & .63 \\
\hline 3.90 & .78 & .77 & .75 & .74 & .73 & .71 & .70 & .69 & .67 & .66 & .65 \\
\hline 4.00 & .80 & .79 & .77 & .76 & .75 & .73 & .72 & .71 & .69 & .68 & 67 \\
\hline 4.10 & .82 & $.8 \mathrm{I}$ & .79 & .78 & .76 & .75 & .74 & .72 & .71 & .70 & .68 \\
\hline 4.20 & .84 & .83 & $.8 \mathrm{I}$ & .80 & .78 & .77 & .75 & .74 & .73 & .71 & .70 \\
\hline $4 \cdot 30$ & .86 & .84 & .83 & .82 & .80 & .79 & .77 & .76 & .74 & .73 & .72 \\
\hline $4 \cdot 40$ & .88 & 86 & .85 & .83 & .82 & .80 & .79 & .78 & .76 & .75 & .73 \\
\hline $4 \cdot 50$ & .90 & .88 & .87 & .85 & .84 & .82 & $.8 \mathrm{I}$ & .79 & .79 & .76 & .75 \\
\hline 4.60 & .92 & .90 & .89 & .87 & .86 & .84 & .83 & $.8 I$ & .80 & .78 & .77 \\
\hline 4.70 & .94 & .92 & $.9 \mathrm{I}$ & .89 & .88 & .86 & .84 & .83 & $.8 \mathrm{I}$ & .80 & .78 \\
\hline 4.80 & .96 & .94 & .93 & .91 & .90 & .88 & .86 & .85 & .83 & .81 & .80 \\
\hline 4.90 & .98 & .96 & .94 & .93 & .91 & .90 & .88 & .86 & .85 & .83 & .82 \\
\hline 5.00 & 1.00 & .98 & .96 & .95 & .93 & $.9 \mathrm{I}$ & .90 & .88 & .86 & .85 & .93 \\
\hline 5.10 & 1.02 & 1.00 & 8 9 & .96 & .95 & .93 & .92 & .90 & .88 & .86 & .85 \\
\hline 5.20 & I. 04 & 1.02 & $1 . \infty$ & .98 & .97 & .95 & .93 & .92 & .90 & .88 & .87 \\
\hline $5 \cdot 30$ & 1.06 & 1.04 & 102 & 1.00 & .99 & .97 & .95 & .93 & .92 & .90 & .88 \\
\hline 540 & 1.08 & 1.06 & I. 04 & 1.02 & 1.00 & .99 & .97 & .95 & .93 & .92 & .90 \\
\hline $5 \cdot 50$ & I. IO & 1.08 & 1.06 & 1. 04 & 02 & $1 . \infty$ & .99 & .97 & .95 & .93 & .92 \\
\hline & I. 12 & I. IO & 1. 08 & 1.06 & & 1.02 & 1.00 & .98 & .97 & .95 & .93 \\
\hline 5.70 & I. I 4 & I. 12 & I. 10 & 1.08 & 1. .06 & 1.04 & I. 02 & $1 . \infty 0$ & .98 & .97 & .95 \\
\hline 5.80 & I.16 & I. 14 & I. 12 & 1.09 & $x .07$ & 1.05 & 1. 04 & 1. .02 & 1.00 & .98 & .97 \\
\hline $5 \cdot 90$ & I. 18 & 1.16 & I. 13 & I. II & 1.09 & 1.07 & 105 & 1.04 & r. 02 & 1.00 & .93 \\
\hline 6.00 & I. 20 & I. 18 & I. 15 & 1. 13 & I. II & x.09 & 1.07 & I. 05 & I.03 & $\begin{array}{lll}1 & 0.2\end{array}$ & 1.010 \\
\hline
\end{tabular}




\section{DIRECTIONS FOR MAKING DIVIDENDS IN CREAMLIRES AND CHEESE FACTORIES According to the Per Cent of Fat in Milk Delivered. (S. M. BABCOCK, in "Hoard's Dairyman.")}

Find the amount of fat contained in the milk of each patron for any period desired, by multiplying the pounds of milk expressed in hundreds by the per cent of fat found by the test. Add together the amount of fat from all the patrons, thus obtaining the total pounds of fat delivered at the factory. Deduct the expenses of manufacture, etc., from the money received from sales, and divide the remainder by the total fat. This gives the price to be paid for each pound of fat. Multiply the pounds of fat delivered by each patron by the price; the product will be the amount which he is to receive.

If it is desired to know the number of pounds of butter made from each patron's milk, divide the total yield of butter by the total fat delivered; the quotient will be the amount of butter made from one pound of fat. The fat delivered by each patron multiplied by this figure will give the pounds of butter to be credited to each patron.

The accompanying table gives the butter yield from Ioo lbs. of milk, when the pounds of butter from one pound of fat range from I.IO to I.20, and for milks containing from 3 to 6 per cent of fat. To use the table find in the upper horizontal line the number corresponding most nearly to the number of pounds of butter from one pound of fat. The vertical column in which this falls gives the pounds of butter from Ioo pounds of milk containing the per cents of fat given in the outside columns.

Example: A creamery receives during one month 250,000 lbs. of milk, which contained 953 I lbs. of fat; the yield of butter for the same period was $10,9 \$_{3}$ lbs., which sold for 29 cents per pound, bringing $\$_{3}{ }_{1} \$_{5} .07$. The expense for making, etc., was four cents per pound, amounting to $\$ 439.32$, leaving $\$ 2745.75$ to be divided among the patrons. Dividing this sum by $953 \mathrm{I}$, the total number of pounds of fat gives 28.5 cents per pound for the fat. This multiplied by the number of pounds of fat in each patron's milk gives the amount which he should be paid. 
The number of pounds of butter, ro,9S3, divided by 953 , the number of pounds of fat, gives I.I52 pounds of butter from each pound of fat. The column headed I.I5 in the table is nearest to this ratio, and will therefore give the butter obtained from Ioo lbs. of milk containing different per cents of fat.

If a patron delivered $9+20$ lbs. of milk containing 3.2 per cent of fat during the perind considered, his milk would have contained $30 r .44$ bs. O. ...t, which at 23.5 cents per pound would have amounted to \&86.8I. It would have made $301.4+\times 1.152=3+7.26$ lbs. of butter. In the column headed I.I5 inthe table, opposite 3.2 per cent of fat, we find 3.65, which is the number of pounds of fat from roo lbs. of this patron's milk. The error from the use of the table in this way will never amount to more than $\frac{1}{2}$ ounce per Ioo lbs. of milk.

Yield of Butter from Oni Mundred L,bs. of Milk, in Lls.

\begin{tabular}{|c|c|c|c|c|c|c|c|c|c|c|c|c|}
\hline ( & & & & Ss. $u^{f}$ & & & & & & & & \\
\hline 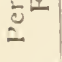 & 1.10 & I . I I & 1. 12 & 1. 13 & 1.14 & I. I 5 & 1. 16 & I. 17 & 1. 18 & I. I 9. & 1.20 & 2 \\
\hline .0 & $3 \cdot 30$ & & $3 \cdot .36$ & $3 \cdot 39$ & $3 \cdot 4^{2}$ & & $3 \cdot 4^{8}$ & 3.51 & & & 3.60 & 3.0 \\
\hline $3 \cdot x$ & & & 472 & & & & 5,6 & 3627 & & & 3.72 & 3.1 \\
\hline $3 \cdot 2$ & & & & 3 & & & & 3744 & .770 & 808 & .84 & $3 \cdot 2$ \\
\hline 3.3 & 3.63 & 3603 & 0 & 3.729 & & & & 3.561 & & 3.027 & .46 & 3 \\
\hline $3 \cdot 4$ & $3 \cdot 74$ & $3 \cdot 77+$ & $3.8,28$ & $3 x^{2}+2$ & 3 & & 944. & 3.973 & +.012 & $4.04^{6}$ & 18 & 1.4 \\
\hline 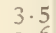 & & & 3.920 & 3955 & 3.9 & +025 & 60 & $4.0,5$ & 4. 130 & 4. & 4.20 & $3 \cdot 5$ \\
\hline 36 & .96 & & 4.0321 & 4063 & 410 & $4.1+0$ & $4 \cdot 176$ & 4.212 & 1.248 & 4.284 & +.32 & 3.0 \\
\hline 37 & & & $4+$ & +181 & 4 & 4.255 & 292 & $4 \cdot 329$ & $+\cdot 3^{66}$ & 4.403 & +.41 & \\
\hline 38 & 4 & & +.256 & 4.294 & $\cdot 33$ & & 408. & $4.4+6$ & $4.4^{8}+$ & $4 \cdot 522$ & $1.5^{n}$ & \\
\hline 3.9 & $.2 n$ & & +254 & $4+07$ & 4 & 35 & $4 \cdot 5^{2} 4$ & 4503 & 4.602 & 4.641 & 4.68 & $3 \cdot 9$ \\
\hline 40 & $4 \cdot 4^{\circ}$ & & 4400 & .520 & + & & & 4.080 & & 4.700 & 4.80 & $4 \cdot 0$ \\
\hline +. 1 & $4 \cdot 5^{1}$ & & 5,2 & 633 & .674 & & $75^{6}$ & 4.797 & 4.8 & +.87 & +.9 & $4 \cdot \mathrm{I}$ \\
\hline+.2 & & & & $4^{h}$ & 788 & & & 4.914 & 4.056 & 499 & 35.04 & 4.2 \\
\hline 3 & 73 & 73 & 810 & 850 & & & 4.958 & 5.031 & $5.07 t$ & 5.117 & 5.10 & 43 \\
\hline+4 & & & 4.923 & 972 & & & 5.104 & 5.148 & 5.192 & $5.23^{6}$ & 5.28 & $4 \cdot 4$ \\
\hline $4 \cdot 5$ & 4.95 & & 5.040 & .085 & 5.130 & 75 & 220 & 5.265 & $5 \cdot 310$ & $5 \cdot 355$ & 5.40 & $4 \cdot 5$ \\
\hline+6 & 5 & & 5.152 & $5 . \cdot 9^{8}$ & 5.244 & 90 & $\cdot 33^{6}$ & $5 \cdot 3^{82}$ & $j \cdot 4^{2}$ & 5.474 & 5.52 & 4.0 \\
\hline 47 & 5 & & $52 n$ & 5311 & $5 \cdot 35^{8}$ & 5.405 & 52 & 15.409 & $5 \cdot 546$ & $\mid 5 \cdot 593\}$ & $315 \cdot 6_{4}$ & \\
\hline+.8 & & & 5.376 & $5+t^{2}+4$ & $5 \cdot 47=$ & & & 5.616 & vit & 5.712 & $5 \cdot 76$ & + \\
\hline $4 \cdot 9$ & & & $5+30$ & $5.5 j 7$ & $5 \cdot 536$ & 5.635 & 5.684 & 5.733 & 5.782 & $5 \cdot 8_{3}^{1}$ & 5.88 & t. \\
\hline 5.0 & 5.50 & & 5.600 & 5650 & 5700 & & 5870 & $5.85^{\circ}$ & 5.9 & 5.950 & 6.00 & $5 \cdot c$ \\
\hline I & $5.0 \mathrm{I}$ & & 712 & $5 \cdot 73$ & 3814 & 5.805 & 5.916 & & 018 & 6.060 & 6.12 & $5 \cdot 1$ \\
\hline $5 \cdot 2$ & $5 \cdot 72$ & $77^{2}$ & & & 5.025 & 5.930 & & & & & 36.2 & 5. \\
\hline $5 \cdot 3$ & 5.83 & & 5.9 .37 & & 6.0 & 0. & 6. 148 & 6.2 & 6.254 & 16.307 & 76.36 & 5 \\
\hline $5 \cdot 4$ & & & $60+3$ & 610. & 6. $1 ; 6$ & 6213 & 6261 & $63 \mathbf{1 8}$ & 6.372 & 6.426 & 5.6 .48 & 5 \\
\hline & & & 6.100 & 6.215 & $627^{\circ}$ & 0.325 & 6.330 & $6 .+35$ & 6.4 & 6.545 & 50.60 & 5 . \\
\hline 5.6 & & & $62 \% 2$ & 6.323 & $0.38 t$ & $6+11$ & $6 .+40$ & 6.5 .52 & 6.608 & & +6.72 & 5. \\
\hline $5 \cdot 7$ & 6.27 & 6. $3^{27}$ & $6.3^{8}+$ & $6.4+1$ & $6+45$ & 7.557 & $(1012$ & 6650 & 0.726 & 6.7 & 6684 & 5. \\
\hline 5. & & & 640 & & 6612 & & & 0.780 & 0.844 & 0.902 & 26.90 & 5 . \\
\hline & 6.4 & $\begin{array}{l}6.549 \\
6600\end{array}$ & $\begin{array}{l}6.603 \\
6 \\
727\end{array}$ & & $\begin{array}{l}67 \\
0.3\end{array}$ & $\begin{array}{l}0.7 \\
6.90\end{array}$ & & 5.003 & 3.962 & 7.021 & 7.03 & 5. \\
\hline & & & & & & & & & & & & \\
\hline
\end{tabular}


CHEESE.

TABLE SHOWING IVELAGL PHR CHX' OF FNT

IN MILI. (Partly after Martiny.)

\begin{tabular}{|c|c|c|c|c|c|c|c|c|c|c|c|}
\hline \multicolumn{3}{|c|}{ Sum of } & \multirow{2}{*}{ 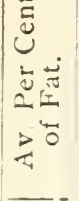 } & \multicolumn{3}{|c|}{ Sum of } & \multirow{2}{*}{ 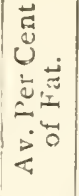 } & \multicolumn{3}{|c|}{ Sum of } & \multirow{2}{*}{ 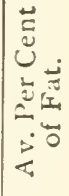 } \\
\hline $\begin{array}{l}\dot{s} \\
\stackrel{\tilde{U}}{E} \\
\text { in }\end{array}$ & $\begin{array}{l}\dot{D} \\
\stackrel{0}{0} \\
\stackrel{+}{*}\end{array}$ & 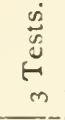 & & $\underset{n}{\stackrel{\dot{\Xi}}{\tilde{U}}}$ & $\begin{array}{l}\stackrel{\dot{D}}{\mathscr{D}} \\
\stackrel{H}{H} \\
+\end{array}$ & $\begin{array}{l}\tilde{n} \\
\stackrel{0}{0} \\
m\end{array}$ & & $\begin{array}{l}\dot{D} \\
\tilde{U} \\
\text { En } \\
\text { in }\end{array}$ & \begin{tabular}{l}
$\dot{n}$ \\
\multirow{5}{*}{} \\
$\stackrel{5}{*}$ \\
+
\end{tabular} & $\underset{m}{\stackrel{s}{s}}$ & \\
\hline $4 \cdot 5^{\circ}$ & 11.60 & 8.70 & 2. 90 & 16.50 & 13.20 & 9.90 & 3.30 & 18.50 & $\times 4.80$ & IT.10 & 3.70 \\
\hline $\begin{array}{l}55 \\
60\end{array}$ & 64 & 73 & & 55 & 24 & 93 & & 55 & $\begin{array}{l}84 \\
88\end{array}$ & & \\
\hline $\begin{array}{l}60 \\
65\end{array}$ & 68 & 70 & & 60 & 28 & 96 & $3^{2}$ & 00 & 88 & I6 & \\
\hline $\begin{array}{l}05 \\
70\end{array}$ & $\begin{array}{l}72 \\
76\end{array}$ & $\begin{array}{l}79 \\
82\end{array}$ & $\begin{array}{l}93 \\
94\end{array}$ & $\begin{array}{l}05 \\
70\end{array}$ & $\begin{array}{l}32 \\
36\end{array}$ & $\begin{array}{r}99 \\
\text { г.02 }\end{array}$ & $\begin{array}{l}33 \\
34\end{array}$ & $\begin{array}{l}05 \\
70\end{array}$ & $\begin{array}{l}92 \\
96\end{array}$ & $\begin{array}{l}19 \\
22\end{array}$ & 73 \\
\hline & & & $\because 95$ & 1675 & 2,40 & 10.07 & 3.3 .5 & & & & \\
\hline $\begin{array}{r}14.75 \\
80\end{array}$ & $\begin{array}{r}1.80 \\
84\end{array}$ & $\begin{array}{r}.05 \\
88\end{array}$ & 96 & $\begin{array}{r}.75 \\
80\end{array}$ & $\begin{array}{r}40 \\
44\end{array}$ & 08 & 36 & $\begin{array}{r}10.75 \\
80\end{array}$ & $\begin{array}{r}15.00 \\
04\end{array}$ & $\begin{array}{r}11.25 \\
28\end{array} \mid$ & $\begin{array}{r}3.10 \\
76\end{array}$ \\
\hline 85 & 88 & $9 \mathrm{I}$ & 97 & 85 & 48 & II & & $8_{5}$ & 08 & 31 & 77 \\
\hline 90 & 92 & 94 & 98 & 90 & 52 & 14 & $3^{8}$ & 90 & I 2 & 34 & 78 \\
\hline 95 & 96 & 97 & 99 & 95 & 56 & 17 & 39 & 95 & & 37 & 74 \\
\hline 15.00 & 12.00 & 9.00 & 300 & 17.00 & $x_{3} .60$ & 10.20 & $\ddot{8} 40$ & 19.00 & I5.20 & 11.40 & 3. 50 \\
\hline 05 & 04 & 03 & or & $0_{5}$ & 64 & 23 & $4 \mathrm{r}$ & 05 & 24 & 43 & $8 \mathbf{r}$ \\
\hline 10 & 08 & 06 & $\mathrm{O} 2$ & 10 & 68 & 26 & 42 & 10 & 28 & $4^{6}$ & 82 \\
\hline 35 & 12 & 09 & O3 & 15 & 72 & 29 & 43 & 15 & 32 & 49 & 83 \\
\hline 20 & I 6 & 12 & $\mathrm{O}_{4}$ & 20 & $7^{6}$ & $3^{2}$ & 44 & 20 & $3^{6}$ & $5^{2}$ & 84 \\
\hline 15.25 & 12.20 & 9.15 & 30.5 & 17.25 & 13.80 & 10. 35 & 315 & 19.25 & 15.40 & & 3.85 \\
\hline 30 & 24 & x 8 & 06 & 30 & 84 & $3^{8}$ & $4^{6}$ & 30 & 44 & $5^{8}$ & 86 \\
\hline 35 & 28 & $2 \mathrm{I}$ & 07 & 35 & 88 & $4^{I}$ & 47 & 35 & $4^{8}$ & $6 I$ & 87 \\
\hline 40 & 32 & 24 & 08 & 40 & 92 & 44 & $4^{8}$ & 40 & 52 & 64 & 88 \\
\hline 45 & $3^{6}$ & 27 & 09 & 45 & 96 & 47 & 49 & 45 & 56 & 67 & 89 \\
\hline I 5.50 & 12.40 & $9 \cdot 30$ & 3.10 & 17.50 & 14.00 & 10. 50 & $3 . .50$ & 19.50 & 15.60 & II 70 & 3.90 \\
\hline 55 & 44 & 33 & II & 55 & 04 & 53 & 51 & 55 & 64 & 73 & $9 \mathbf{I}$ \\
\hline 60 & $4^{8}$ & $3^{6}$ & 12 & 60 & 08 & 56 & 52 & 60 & 68 & $7^{6}$ & 92 \\
\hline 65 & 52 & 39 & I3 & $6_{5}$ & 12 & 59 & 53 & $\epsilon_{5}$ & 72 & 79 & 93 \\
\hline 70 & 56 & $4^{2}$ & 14 & 70 & 16 & 62 & 54 & 70 & $7^{6}$ & 82 & 94 \\
\hline I 5.75 & 12.60 & $9 \cdot 45$ & 315 & 17.75 & 14.20 & 10.65 & $(3 . .5 \mathrm{j}$ & 19.75 & 15.80 & I I .85 & 395 \\
\hline & 64 & $4^{8}$ & I6 & 80 & 24 & 68 & $5^{6}$ & & 84 & & 96 \\
\hline 85 & 68 & 51 & I 7 & 85 & 28 & $7 \mathrm{I}$ & 57 & 85 & 88 & $y^{3}$ & 97 \\
\hline y3 & 72 & 54 & 18 & 90 & 32 & 74 & $5^{8}$ & 90 & 92 & 94 & 98 \\
\hline 95 & $7^{6}$ & 57 & I9 & 95 & 36 & 77 & 59 & 95 & 96 & 97 & 99 \\
\hline 16.00 & 12.80 & 9.60 & 3.20 & 1800 & 14.40 & 10.80 & $: 3.60$ & 20.00 & 16.00 & 12.00 & $\div .00$ \\
\hline 05 & 84 & 63 & 21 & 05 & 44 & $8_{3}$ & $6 \mathbf{I}$ & 05 & $0_{4}$ & 03 & OI \\
\hline Io & 88 & 66 & 22 & 10 & $4^{8}$ & 86 & 62 & 10 & 08 & 06 & 02 \\
\hline 15 & $9^{2}$ & 69 & 23 & 15 & 52 & 89 & 63 & 15 & 12 & O9 & 03 \\
\hline 20 & 96 & 72 & 24 & 20 & $5^{6}$ & 92 & 64 & 20 & 16 & 12 & 04 \\
\hline I6.25 & $I_{3} .00$ & 9.75 & $3.2 \pi$ & 18.25 & 14.60 & 10.95 & $3.6 \%$ & 20.25 & 16.20 & 12.15 & 4.05 \\
\hline 30 & $\mathrm{O}_{4}$ & $7^{8}$ & 26 & 30 & 64 & 98 & 66 & & 24 & 18 & 06 \\
\hline 35 & 08 & 81 & 27 & 35 & 68 & $1 \mathrm{t} .01$ & 67 & 35 & 28 & 21 & 07 \\
\hline 40 & 12 & 84 & 28 & $4^{\circ}$ & 72 & $\mathrm{O}_{4}$ & 68 & 4 이 & 32 & 24 & o8 \\
\hline 45 & & 87 & 29 & 45 & 76 & 07 & 69 & 45 & $3^{6}$ & 27 & $\alpha 9$ \\
\hline
\end{tabular}


TABLE SHOWING AVERAGE PER CENT OF FAT

IN MILK.-(Continued.)

\begin{tabular}{|c|c|c|c|c|c|c|c|c|c|c|c|}
\hline \multicolumn{3}{|c|}{ Sum of } & \multirow{2}{*}{ 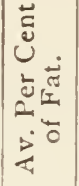 } & \multicolumn{3}{|c|}{ Sum of } & \multirow{2}{*}{ 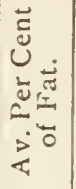 } & \multicolumn{3}{|c|}{ Sum of } & \multirow{2}{*}{ 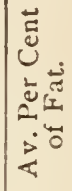 } \\
\hline 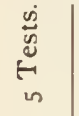 & $\begin{array}{l}\stackrel{\dot{D}}{E} \\
\stackrel{+}{E} \\
+\end{array}$ & $\stackrel{n}{\infty}$ & & $\stackrel{D}{u}_{i n}^{\infty}$ & 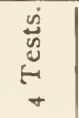 & $\stackrel{\dot{w}}{\stackrel{w}{*}}$ & & $\begin{array}{l}\dot{n} \\
\tilde{u} \\
\dot{u} \\
\text { in }\end{array}$ & 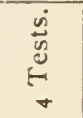 & $\frac{\dot{y}}{\tilde{J}}$ & \\
\hline 20.50 & 16.40 & 12.30 & 4.10 & 22.50 & 18.00 & 13.50 & 4.50 & 24.50 & 19.60 & 14.70 & 4.90 \\
\hline $\begin{array}{l}5.5 \\
60\end{array}$ & $\begin{array}{l}44 \\
48\end{array}$ & $\begin{array}{l}33 \\
36\end{array}$ & $\begin{array}{l}11 \\
12\end{array}$ & $\begin{array}{l}55 \\
60\end{array}$ & $\begin{array}{l}0.4 \\
08\end{array}$ & $\begin{array}{l}53 \\
56\end{array}$ & & & $\begin{array}{l}64 \\
68\end{array}$ & $\begin{array}{l}73 \\
76\end{array}$ & $\begin{array}{l}91 \\
92\end{array}$ \\
\hline 65 & 52 & 39 & 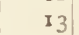 & 65 & 12 & 59 & & 65 & 72 & 79 & 93 \\
\hline 70 & 56 & & & 70 & 16 & 62 & 54 & 70 & 76 & 82 & 94 \\
\hline 20.75 & 16.60 & 12.45 & $41 i$ & 22.75 & 18.20 & 1365 & $4.5 \%$ & $24 \cdot 75$ & 19.80 & 14.85 & $4.9 \%$ \\
\hline 80 & 64 & $4^{8}$ & I6 & 80 & 24 & 68 & $5^{6}$ & & 84 & 88 & \\
\hline 85 & 68 & $5 I$ & I 7 & 85 & 28 & 71 & 57 & 85 & 88 & Q1 & 97 \\
\hline 90 & 72 & 54 & I 8 & 90 & 32 & 74 & $5^{8}$ & 90 & 92 & 94 & $9^{8}$ \\
\hline 95 & 76 & 57 & 10 & 95 & $3^{6}$ & 77 & 59. & 95 & 96 & 97 & 9? \\
\hline 21.00 & 16.80 & 12.60 & $t: 0$ & 23.00 & $18.40^{\prime}$ & 13.80 & 4. (i) & 25.010 & 20.00 & 15.00 & 5. 00 \\
\hline 05 & 84 & $6_{3}$ & $2 \mathrm{I}$ & 05 & 44 & 83 & $6 r$ & & & & ( ) \\
\hline 10 & 88 & $6 u$ & 22 & 10 & $4^{8}$ & 86 & 62 & 10 & 08 & 06 & 02 \\
\hline 15 & 92 & 69 & 23 & 15 & $5^{2}$ & 89 & $6_{3}$ & 15 & 12 & o9 & $0 ;$ \\
\hline 20 & 96 & 72 & 24 & 20 & 56 & 92 & 64 & 20 & 16 & 12 & 14 \\
\hline 21.25 & 17.00 & 12.75 & 4. ..5 & 23.25 & 18.60 & 13.95 & 4.65 & 25.25 & 20.20 & $15 \cdot 15$ & 50 \\
\hline 30 & $\mathrm{O}_{4}$ & 78 & 26 & 30 ? & 64 & 98 & 66 & 30 & 24 & 18 & 06 \\
\hline 35 & 08 & 81 & 27 & 35 ! & 68 & 14.01 & 67 & 35 & 28 & 21 & (17 \\
\hline 10 & 12 & 84 & 28 & 40 & 72 & $\mathrm{O}_{4}$ & 68 & 40 & 32 & 24 & co \\
\hline 45 & 16 & 87 & 29 & 45 & 76 & 07 & 69 & 45 & 36 & 27 & og \\
\hline 21.50 & 17.20 & 12.90 & 4.30 & 23.50 & 18.80 & 14.10 & 470 & $25 \cdot 50$ & 20.40 & $15 \cdot 30$ & 5) 10 \\
\hline 55 & 24 & 93 & $3^{1}$ & 55 & 84 & 13 & 71 & 55 & 44 & 33 & 11 \\
\hline 60 & 28 & 96 & 32 & 60 & 88 & 16 & 72 & 60 & $4^{8}$ & $3^{6}$ & 12 \\
\hline 65 & 32 & 99 & 33 & 65 & 92 & 19 & 73 & 65 & $5^{2}$ & 39 & 13 \\
\hline 70 & 36 & 1302 & 34 & 70 & 96 & 22 & 74 & 70 & $5^{6}$ & $4^{2}$ & 14 \\
\hline 21.75 & 17.40 & 13.05 & 4.35 & & 19.00 & 14.25 & 4.7 .5 & 25.75 & 20.60 & 15.45 & 5. 15 \\
\hline 80 & 44 & 08 & $3^{6}$ & 80 & $0_{4}$ & 28 & 76 & 80 & 64 & $4^{8}$ & \\
\hline 85 & $4^{8}$ & I I & 37 & 85 & 08 & $3 \mathrm{I}$ & & 85 & 68 & $5^{x}$ & 17 \\
\hline 90 & 52 & 14 & $3^{8}$ & 90 & 12 & 34 & 78 & 90 & 72 & 54 & 18 \\
\hline 95 & 56 & 17 & 39 & 95 & 16 & 37 & 79 & 95 & 76 & 57 & 19 \\
\hline 22.00 & 17.60 & 13.20 & 4.40 & 24.00 & 19.20 & 14.40 & 4.50 & 26.00 & 20.80 & 15.60 & 5.20 \\
\hline 05 & 64 & 23 & $4^{I}$ & 05 & 24 & 43 & $8 I$ & 05 & 84 & $6_{3}$ & 21 \\
\hline 10 & 68 & 26 & 42 & 10 & 28 & 46 & 82 & 10 & 88 & 66 & 22 \\
\hline I5 & 72 & 29 & 43 & 15 & 32 & 49 & $8_{3}$ & 15 & 92 & 69 & 23 \\
\hline 20 & 76 & $3^{2}$ & 44 & 20 & 36 & $5^{2}$ & 84 & 20 & 96 & 72 & 24 \\
\hline 22.25 & 17.80 & I 3.35 & 4. 45 & 24.25 & 19.40 & $\mathrm{I} 4.55$ & 4.85 & 26.25 & 21.00 & 15.75 & (5.25 \\
\hline 30 & 84 & $3^{8}$ & 46 & 30 & 44 & $5^{8}$ & 86 & 30 & $\mathrm{O}_{4}$ & 78 & 26 \\
\hline 35 & 88 & $4^{I}$ & 47 & 35 & $4^{8}$ & 61 & 87 & 35 & os & $8 \mathrm{I}$ & 27 \\
\hline 40 & 92 & 44 & $4^{8}$ & 40 & 52 & 64 & 88 & 40 & 12 & 84 & 28 \\
\hline 45 & 96 & 47 & 49 & 45 & $5^{6}$ & 67 & 89 & 45 & 16 & 87 & 29 \\
\hline
\end{tabular}




\section{SUgGestions TO PATRONS OF CHEESE FAC. TORIES AND CIIAMERILS. (Curts.) \\ Care of Milk.}

I. All mill: for the checse factory must be clean, pure, and wholesome, or the cheese will be bad. One hundred ponnds of bad milk will injure 10,000 pounds of good milk.

2. The law is very strict against watering or skimming. A fine of $\$ 10.00$ to $\$ 100.00$ is imposed if convicted.

3. After a cow has dropped her calf, the milk should not be taken to the factory until the tenth milking.

4. Milk run through an aerator as soon as drawn from the cow, in open air, is better for cheese and butter making than when set in a tub of water and dipped. By any means at your command thoroughly air the milk until cooled.

5. Stagnant water, dead carcasses, or filth of any kind in the pasture or barn-yard produces tainted milk. For this reason set the can of night's milk in a clean place.

6. Milk with clean hands; never wet them with milk; it is positively filthy.

7. See that the cow's udder is brushed clean and free from fine dirt and dust before milking.

8. Never mix the night's and morning's milk. It will many times sour them both by pouring the warm milk into the cold.

9. Small cans (Io to I5 gallons) are much preferred to larger ones, as the milk is kept in a better condition.

ro. Whey should be taken home in separate cans from that in which the milk is brought in.

II. If whey is taken home in the milk-cans, empty at once, wash with tepid water, then scald and turn them out to the sun.

I2. Insist that the cheese-maker keep the whey-vat clean, by washing and scalding at least twice a week.

13. Insist that your factory shall take in milk by the Babcock test, paying each patron according to what he de. livers.

I4. Use a Babcock test yourself and know just what you produce: turn off the poor cows and fill their places with 
good ones. Every patron should know for himself whether he is boarding unprofitable cows. There is no better way of knowing this than by the use of the Babcock test at the barn. The cost of the iest is but little, but its instruction is very valuable.

15. It should always be remembered that pure milk can only be had through healthy cows, pure feed, pure water, pure air, and cleanly handling. Every patron is affected in the cash outcome by the way his brother patrons produce and handle their milk, hence the necessity of each adhering to sound rules based on sound dairy sense. There is not a first-class factory in the land where good prices are obtained for cheese but what the patrons practise thorough cleanliness in the care of milk. Remember, it is a matter of profit to each to do this.

\section{Care of Cows.}

Pay special attention to the comfort of your cows. Do not let them remain out in cold rain-storms; it will reduce the flow of milk. Feed liberally. The cow must at all times have all the grood feed she can cat and digest. Be sure and provide some soiling-crop against the July and August drought; if the cow shrinks then you will lose money in the fall, when butter and cheese are high. Oats and peas, sweet corn or field corn, drilled $3 \frac{1}{2}$ feet apart, are a good soiling-crop.

A silo is a great help in the economical production of cow feed. Thousands of successful dairymen have proved this. It is no longer an experiment.

Dairy farming at high profit calls for close study concerning the cow, concerning her feed, and how to produce it at the best and cheapest. Every dairy neighborhood will show men who make nearly double the profit from the business that others do. We believe that it will pay every man to be intelligent and as well posted as he can be on these important questions. We must bring up the grade of our reputation by making better butter and cheese. This will bring on a larger and better paving demand. Tu cheat the 
consumer with poor goods will, in the end, destroy the business. Better dairymen, better milk, better products, better reputation in the world's markets, will surely bring better profits, and is the only true road to DAIRY Success.

\section{BY-LAWS ANI RULES WOR CO-OPERATIVE CREAMERY ASSOCATIONS.}

I. This association shall be known as the - Cooperative Creamery Association.

II. The purpose of the association shall be to locate, establish and carry on the manufacture and sale of milk products, in such a manner as will conduce to the greatest convenience and profit of the producers over the greatest amount of territory in the town of - and vicinity. Also to purchase, use, and hold real and personal estate necessary for the transaction of the business of the association.

III. The capital stock of the association shall be - dollars, divided into - - shares of ten dollars each.

IV. This association shall be co-operative. Cream and milk may be purchased or accepted from any person not a stockholder on the same terms and conditions as may be prescribed for stockholders.

V. Any person directly engaged in agricultural pursuits may become a member of this association by taking one or more shares of the stock of the association.

VI. I. The regular meetings of the association shall be held semi-annually, viz., on the first Mondays in - - and -. - - in each year, at such time and place as the board of directors may determine; and notice of such meeting shall be given by the clerk to each member by mail seven days at least previous to the date of said meeting. 2. Special meetings may be called either by the president, with the advice and consent of a majority of the directors, or upon written request of one third of the stockholders of the association, upon seven days' notice as above. 3. Meetings of the board of directors may be called by the president or by any two directors.

VII. I. The officers of the association shall consist of a president, clerk, treasurer, five directors, and two auditors. 2. The president shall be closen annually by the board of 
directors, by written ballot, at the regular meeting in October. 3. The clerk, treasurer, board of directors, and auditors shall be chosen by the stockholders annually, by written ballot, at the regular meeting in October, and all officers shall hold office till others are chosen and qualified in their stead. Vacancies in the above-named offices may be filled at any meeting of the stockholders: in the meantime by the board of directors. In case of the absence of the clerk a temporary clerk may be chosen and qualified in his stead.

VIII. At any regularly called meeting of the association, nine of the members thereof, and at any meeting of the board of directors, three members thereof, shall constitute a quorum for the transaction of business. A less number may adjourn from time to time.

IX. It shall be the duty of the president, who shall be a director, to preside at all mectings of the association and of the board of directors, preserve order therein, put all questions, announce all decisions, and, in case of an equal division, to give the casting vote. He shall receive and safely preserve all bonds required of the officers of the association and sign all certificates or documents issued by the association or board of directors. In the absence of the president, it shall be the duty of one of the board of directors, in order of their seniority, to preside at any meeting.

$X$. It shall be the duty of the clerk to attend all meetings of the association and of the board of directors, and to keep a correct record of the same, which record shall be open for the inspection of any member. He shall give notice of all meetings and of all appointments on committees, to cach member thereof, and to each officer chosen, of his election; and shall serve all such other notices as appertain to his office or as may be directed from time to time by the association or board of directors. He shall attest all certificates or documents issued signed by the president, shall file all bills and reports and such other documents as may be ordered to be filed, and shall carry on all such correspondence as may be directed; shall act as secretary of all committees when called upon; shall keep a correct 
financial account between the association and its members, and shall have charge of all property not otherwise disposed of. He shall give such bonds for the faithful performance of his duty, and receive such compensation for his services, as the board of directors may determine.

$\mathrm{XI}$. It shall be the duty of the treasurer to receive all money belonging to the association, giving his receipt therefor. He shall draw all money for the payment of claims against the association under the direction of the board of directors. He shall make a report to the board of directors at such times as they may require. He shall perform all duties required of him by the laws of the commonwealth and shall give such bonds for the faithful performance of his duty as the board of directors may require.

XII. It shall be the duty of the board of directors to attend to the general affairs of the association, invest the funds of the same, appoint such other agents and officers as in their judgment the interests of the association require, and fix all compensations. They shall keep or cause to be kept a correct account of all cream or milk furnished by the stockholders or patrons, and a correct account of all sales. They shall prescribe the rules and regulations governing the collection and delivery of the cream and milk; may cause the quality of the same to be tested as often as may be deemed expedient; may authorize the premises of any stockholder or patron to be inspected, and may reject and refuse to collect or receive any cream or milk that is unsatisfactory or not furnished in compliance with the prescribed regulations. They shall establish prices and have full power over the business of the association, and shall in all cases pursue such measures as in their judgment will tend to the best interests of the association. They shall make a full report of their doings, and a full statement of the business at each regular meeting, or whenever called upon to do so by vote of the stockholders.

XIII. The duties of the auditors shall be to audit all accounts of the association, making a report to the board of directors at the time of the regular meetings, and at such other times as they may require. 
XIV. The net profits of the business of the association, after such deductions have been made as the laws of the commonwealth require, shall be divided fre rata among the stockhoiders, according to the number of shares held by each. $\left[\Lambda^{*}\right.$ ote. - It is understood that the profits shall not exceed 6 per cent on capital, all receipts in excess of this sum and necessary reserves being declared in payment to patrons for cream or milk furnished.]

XV. I. Any person doing business for the association or incurring expense therefor shall receive a just remuneration for such services or expense. 2. All documents issued by the association shall bear the seal thereof, said seal to De in charge of the clerk. 3. The directors shall procure a corporate seal. 4. No member of the association can transfer his stock to any person not directly engaged in agricultural pursuits. 5. In case shares are transferred by ore person to another, the certificate thereof must be surrendered to the treasurer, and the board of directors shall cause another certificate to be issued to the person to whom the transfer is made.

XVl. These by-laws shall not be altered or amended unless such alceration or amendment be proposed in writing one meeting previous to action being taken : provided also that two thirds of the members vote in the affirmative.

\section{BY-IAWS MND RELES FOR CO-OPERATIVE CHEFSL FACTORILS.}

ARTICI.E I. This assoc ation shall be known as the - - Cheese Fatery Association.

AkT. 2. There shall be two meetings beld yearly at the factory-one in the spring and one in the fall or winter, to be called by the president.

ART. 3. At the first meeting in each year there shall be chosen by the patrons a president and a trea-urc $r$ and salesman.

ART. 4. The salesinan and treasurer shall sell all the cheese, and as soon as he shall have sold and collected for one "lonth's - make of cheese, he stall after paying the proprietor for mak- 
ing and deducting the other cxpenses, divide the proceeds pro rata, according to the amount of butter-fat delivered by each patron, as determined by the Babcock test.

ART. 5. It shall also be the duty of the treasurer and salesman to keep the books of the association, and malie final dividend yearly to all the patrons whenever all the cheese is sold and paid for. He shall also keep a milk book, showing the number and amount of cheese made each month, to be taken from the factory's books. Said treasurer's milk an 1 cheese books shall be subject to the inspection of the patrons and the president.

ART. 6. The manager shall keep an accurate account with each patron of the number of pounds of milk delivered each day and make and record daily (every week or month) tests of same to show its fat content; also an account of the number and amount of cheese made, which accounts shall be subject to the inspection of the officers and patrons.

ART. 7. The president shall be authorized to preside over the entire transactions of patrons or officers, and constitute a committee to investigate all matters pertaining to said factory, and if any contingency should arise, he shall be authorized to bring suit in law against any delinquent.

ART. S. The manager (cheese-maker) shall be authorized to criticise all milk offered, and he shall reject the same if in his judgment said milk is unfit to run into cheese; also to determine the fat content of any milk, and if found to be below the legal standard of the State, shall report the same to the president, whose duty it shall be to send out a committee of three to the premises of said delinquent, witnessing the transit of the milk on the ensuing day from the cow to the factory, which shall again be tested as on the previous day, and if found to vary, the party in question shall be adjudged guilty of having diluted or adulterated the same, as shall appear, and shall forfeit and pay to the association as liquidated damages the sum of twenty-five dollars for each and every day such dilution shall occur.

ART. 9. The president shall also have power to call special meetings of the patrons at any time he may deen it necessary. and he shall be required to call a meeting of the patrons when 
ever a request is presented to him signed by ten patrons. Whenever a meeting is to be called, the president shall give patrons at least two days' notice.

ART. 1O. The action of the trensurer and salesman in regard to selling or holding cheese shall be governed by a vote of a majority of the patrons. If no vote is taken, he is to exercise his best judgment in the matter.

ART. Ir. In voting at any annual or special meeting of this association the patrons shall be allowed one vote for every cow the milk of which is brought to the factory. [This may be altered to one vote on each share of the capital stock or one vote to each shareholder.]

ART. I2. The treasurer and salesman shall attend all meet ings of the association whenever possible, and shall take min. utes of the procecdings, and place the same on file in his office, and in other respects act as secretary. In case he should be absent, a temporary secretary may be chosen. In case th president is absent at any meeting, a temporary president may be chosen for a presiding officer.

\section{RULES FOR PATRONS AND INSTRUCTIONS TO CREAM OR MILI GA'THERERS.}

These rules may be made to apply to either whole-milk or gathered cream creameries.

Feeding.-We insist upon only such food being fed to cowe as will produce the largest and best quality of milk or cream. Turnips, onions, cabbage, or anything likely to injure the quality of milk, cream, or butter is prohibited.

Milking.-Cows must be carefully cleaned before milking, to avoid odors that taint the milk. The milk must be strained through two strainers-one of them cloth-before going into the cans. Thorough cleanliness must be observed in everything.

Creamers and Cans.-Creamers must be kept in a place free from odors, and cleanliness maintained in their vicinity. Tanks and cans must be kept sweet and clean, and the water free and clear. Cans must be ithshed, then scalded every time they are used. The water in the creamers should not go below $45 \mathrm{de}$. grees in summer and to degrees in winter. 
Setting Milk. -All cans must be filled full of fresh milk, so far as possible, and immediately placed in the tank. After cans are set in water they must not be disturbed. Patrons are not allowed to draw off the milk except on Sundays, or with permission from the trustees.

Mixing Milk.-Cans must not be partly filled at one milking and after standing long e'rough for the cream to begin to separate be filled with milk from another milking, or with anything whatever. After a can has once been set it must not in any way be disturbed or meddled with, nor the milk drawn off by the patrons, except on Sunday.

Night's Milk.-When milk is delivered but once each day, the cans containing the night's milk must be set in cold water immediately after milking and the milk thoroughly stirred by using a dipper and pouring until the milk is thoroughly cooled. A better plan is to use a cooler to thoroughly cool and aerate the milk before it is put in the cans. The night's milk must be left setting in cold water until it is hauled to the creamery.

Cream and Milk Gatherers.-Cream and milk gatherers are forbidden to take any cream or milk which is dirty, or for any reason, in their judgment, is not of satisfactory quality or condition, or which has been in any way so treated as to indicate that an attempt has been made to interfere with the proper and natural separation of the cream, or of its being correctly counted on the gauge, or in violation of these rules.

Any patron found neglecting or violating any of these rules must at once be reported to some one of the board of trustees or directors, and his cream or milk must not again be taken till he has satisfied the trustees that his neglect was, for good reasons, excusable; and if any patron shall more than once be so reported it shall be deemed a sufficient reason for refusal to again receive his cream at all.

Cream or milk gatherers are especially directed to take all possible pains to discover all violations or neglect of any of these rules, and strictly enforce them in every case.

These rules and instructions are found by experience and observation to be necessary for the protection of the association and the best grood of all its members. Copies thereof will be securely posted conveniently near cach tank where milk-cans are set, so that ignorance can be no excuse for neglect. 
Patrons are requester to notify lihe board of trustees or directors if any cream or milk gatherer is in any way delinquent or careless in his obsenance of these insirucious.

Patrons who are not disposed to be governed by these riles are requested to so advise the trustees or directors, and the treasurer will make prompt settlement with any who wish to withdraw.

By order of the trustees or directors. 


\section{PART III. GENERAL TOPICS.}

1. CONSTITUIIONS OF AGRICULTURAL ASSOCIATIONS.

CONSTITUTION ANI BY-LAIVS OE AGRICULTURAL CIIUIS.

Tugether With Rules of Order, and Onder of Business. (196KкR⿴囗十)

\section{Constitution.}

PREAMBI.F.-We, the undersigned, interested in agriculture and horticulture, and desirous to secure the benefits to be derived from organization, for the purpuse of practical discussion and the promotion of the common interests of ou: puisuits, do subscribe the following Constitution:

ARTICLE I. Name.-This association shall be styled and known as the - Agricultural Club.

Article II. Objects.-The objects of this club are to ad. vance the knowledge and promote the general interests of agriculture and horticulture in this community.

ARTICLE IIl. Officers. - The officers shall consist of a president, vice-president, recording secretary, corresponding secretary, treasurer, and librarian.

Article IV. Duties of Offiers.-Section I. It shall be the duty of the president to preside at all meetings of the club; to enforce a due observance of the Constitution, By. laws, and Rules of Order; to assign topics of discussiun at the suggestion of members. He shall neither make nor second any motion, but shall have the privilege of taking part in debate; and while he has the fluor the meeting for tine time being shall be in charge of the vice-president; but the presirent shall have no vote unless the club shall be equaily dusded.

Section 2. It shall be the duty of the vice-president to preside at all times when the president is absent, and while he shall have temporarily rucated the chair. 
Section 3. The recording secretary shall keep a record of the proceedings of the club; also the name of each member, and shall on the regular last meeting of each year prepare and read the names of all members; and he shall have charge of the archives of the club.

Section 4. The corresponding secretary shall conduct the correspondence of the club and act as recording secretary in the absence of that officer. He shall also render such assistance to the recording secretary as that officer may require in the performance of his duties.

Section 5. The treasurer shall keep all money belonging to the club, and disburse the same under the direction of the club, according to its laws. Ile shall collect all fees and dues of members, and shall at some time during the month of December of each year notify such as are in arrears and request their dues. 11 e shall keep a correct account of all moneys received and expended.

Section 6. The librarian shall have charge of the library and its appurtenances, regulating the use of the same by the members, according to the rules and regulations prescribed. He shall make a written report of the condition of the library at the annual meeting, and at such other times as the club may direct. He shall, within one week, deliver to his successor in office the library and its appurtenances, and all books, papers, and documents in his possession belonging to the club.

Article V. Elections.-All elections for officers shall be by ballot, and shall be held at the first regular meeting in January of each year; and their terms shall commence immediately after their election, to continue for one year, or until others are elected to fill their places. In the case of vacancy occurring in any office the club shall go immediately into an election to fill the same. A majority of all the votes cast shall be necessary to a choice.

ARTICle VI. Membership.-Section I. Any person interested in agriculture or horticulture, and of good moral standing, may become a member of this club by signing this Constitution, agreeing to support all laws and regulations made in pursuance thereof, and paying fifty cents annually into the treasury.

Seition 2. Honorary membership mav be conferred in 
consideration of eminent character and services in honor of agriculture or horticulture and shall be conferred without fee or dues. The recipient shall not be entitled to hold office, but may take part in all discussions and vote on all questions.

Article VII. Amendments.-No alteration, amendment, or addition can be made to this Constitution, neither can any part of it be repealed, without a vote of two thirds of the members present. Any proposed alteration, amendment, addition, or repeal must be submitted in writing, filed with the recording secretary, and read at two regular meetings next preceding that on which the vote is taken.

\section{By-laws.}

Article I. This club shall assemble weekly (or twice a month) on - evenings from November Ist to April Ist, and at such intervals thereafter as may be agreed upon by the club, or appointed by the president. The time and place of meeting may be altered at any regular meeting of the club by a vote of two thirds of all of the members present.

Article II. Section I. Seven members shall constitute a quorum for the transaction of business of the club. A less number may meet, maintain a discussion on any topic, and adjourn to any given time.

Section 2. Persons present, not members of the club, may be invited to take part in all discussions of agricul. tural topics; but they shall take no part in the business of the club.

Article III. Section I. If the funds of the club should at any time be exhausted, or inadequate to meet the demands contemplated by the Constitution, there shall be an equal assessment upon each member to make up the deficiency.

Section 2. No appropriation of money from the funds of the club shall be lawful, except in furtherance of the objects contemplated by the Constitution, as stated in article 2, or as especially provided by these By-laws.

ArTicle IV. Section I. There shall be a library estab- 
lished for the use of the club in furtherance of the objects contemplated in aricle 2 of the Constitution.

Section 2. The library shall be open to the free use of the members of the club, who shall not be more than three months indebted to the treasury, subject to the prescribed rules and regulations.

Section 3. The library shall be maintained by the surplus fund, after defraying the expenses of the club, and by the voluntary contributions and donations of the members, to be duly accredited to each contributor and donor.

Section 4. The library sha!l be in charge of the librarian, as provided in articte 4 , section 6 , of the Constitution. There shall be a stani ng linary committee of three members apno nted at warh annual meet ng, of whom the librarian shail be one, and ex-fficio cnairman, which shall have charge of the purchase and collection of books, papers, and pamphlets for the hiorary, and perform such other duties as may be ordained.

Section 5. Rules.-Rule I. No member shall have from the library more than one (two) book(s) at a time.

Rule 2. No volume shall be retained longer than two weeks, under penalty of a fine of ten cents for the first week of detention, and five cents for every week thereafter.

Rule 3. There shall be assessed for injuries as follows: Ist. For an injury beyond ordinary wear, an amount proportionate to the injury, ascertained by the librarian. $2 \mathrm{~d}$. For the loss of the volume, the cost of the book; and if one of a set, an amount sufficient to replace it, or purchase a new volume.

Rule 4. No person having incurred a fine shall be permitted to take books from the library until the fine is paid. ARTICLE V. A vote of two thirds of all the members present shall be required to pass any appropriation of money by the club, other than for its necessary contingent expenses.

ARTicle VI. Section I. Any member who shall suffer his account with the treasurer to go unsettled for more than one year shall cease to be considered as belonging to tle club, and his name shall be stricken from the roll accurdingly. 
Section 2. Any member who shall be guilty of any gross violation of the rules of order, or of profane or indecent language or conduct, at any of the meetings of the club shall be fined, reprimanded, or expelled, as the club may, by a two thirds vote, decide.

Section 3. Any member who shall become guilty of any heinous offence or disgraceful practice, such as to render him an unfit associate, shall, on conviction thereof, be expelled from the club.

ARticle VII. These By-laws may be amended in the same manner as the Constitution.

\section{Standing Resolutions.}

Resolv'ed, That after this date the weekly meetings of this club shall be held on -, at - or at the resicences of the members of the club, at o'clock.

Resolved, That there shall be an Executive Committee, cunsisting of the president, recording secretary, and treasirer, having power to transact the necessary business of the club, during the term when the meetings are not l'eld.

\section{Rules of Order.}

I. No question shall be stated unless lioved by two nembers, nor open for discussion until stated by the presitent.

2. When a member intends to speak on a question, ine shall rise in his place and respectfully address his remarks to the chair, confine his remarks to the question, and avoid personalities. Should more than one person rise at a ime, the president shall determine who is entitled to the floor.

3. When a member is called to order by the president, or any other member he shall at once take his seat, and every point of order shall be decided by the president, without debate, subject to an appeal to the club.

4. In case of an appeal from the lecision of the chair the question shall be put to the club thus: "Shall the decision of the chair be sustained" "which shall be decided wilhout debate. 
5. No member shall interrupt another while he is speak. ing, except to call to order.

6. Any member may call for a division of the question, when the sense will admit of it.

7. When any three members call for the jeas and nays, they shall be taken and recorded on the minutes.

8. All resolutions shall, when required by the president or any member, be submitted in writing, and signed by the memler offering the same.

9. Cushing's "Manual of Parliamentary Practice" shall be adopted as authority in all matters pertaining to parliamentary order in the club.

Io. These Rules may be amended in the same manner as the Constitution and By-laws.

\section{Order of Business.}

I. Calling the roll of officers and necessary filliıg of vacancies.

2. Reading of minutes of last meeting.

3. Reports of committees.

4. Unfinished business.

5. New business.

6. Reception of new members.

7. Has any member any question to ask for information in regard to his farm, stock, etc.?

8. Reading of communications and essays.

9. Discussion of regular topic.

IO. Assignment of subject for next discussion.

\section{CONSTITUTION OF VILLAGE-IMPROVEMENT SOCIE'TIEAS.}

ARTICLE I. This society shall be called the - Improvement Society.

ART. 2. The object of this socicty shall be to improve and ornament the streets and public grounds of the village by planting and cultivating trees, establishing and protect. ing grass-plats and borders in the avenues, and generally doing whatever may tend to the improvement of the village ds a place of residence. 
ART. 3. The business of the society shall be conducted by a board of nine directors, five gentlemen and four ladies, to be elected annually by the society, who shall constitute the board. This board shall, from its own number, elect one president, two vice-presidents, a secretary, and treasurer, and shall appoint such committees as they may deem advisable to further the ends of the society.

ART. 4. It shall be the duty of the president, and, in his absence, of the senior vice-president, to preside at all meetings of the society, and to carry out all orders of the board of directors.

ART. 5. It shall be the duty of the secretary to keep a correct and careful record of all proceedings of the society and of the board of directors in a book suitable for their preservation, and such other duties as ordinarily pertain to the office.

ART. 6. It shall be the duty of the treasurer to keep the funds of the society, and to make such disbursements as may be ordered by the board of directors.

ART. 7. No debt shall be contracted by the board of directors beyond the amount of available funds within their control to pay it, and no member of this society shall be liable for any debt of the society beyond the amount of his or her subscription.

ART. S. Any adult person may become a member of this fociety by paying two dollars $(\$ 2.00)$ annually. Any per6on not of age who shall plant and protect a tree, under the direction of the board of directors, or shall pay the sum of s.os annually, may become a member of this society until of age, after which time the annual dues shall be increased to two dollars (\$2.00), the same as other adults.

AR'T. 9. The annual meeting of the society shall be held during the first week in October at such place as the board of directors may select, and a notice of such meeting shall be posted in prominent places through the village. Other meetings of the society may be called by the board of directors when desirable.

ART. 10. At the annual mecting tle luard of directors 
shall report the amount of money received during the year and the source from which it has been received: the amount of money expended during the year, and the objects for which it has been expended; the number of trees planted at the cost of the society, and the number planted by individuals; and, generally, all acts of the board that may be of interest to the society. This report shall be entered on the record of the society.

ART. II. This constitution may be amended with the approval of two thirds of the niembers present at any annual meeting of the society, or at any special meeting called for that purpose, a month's notice of the proposed amendment, with its object, having been given.

\section{CONSTITUTION OH ROAD IEAGULS.}

ARTICLE I. This organization shall be known as the Road League of County, (State).

ART. 2. Its object shall be the improvement of public roads in - and ricinity.

AkT. 3. Any person may become a member on payment of one dollar per anmum, and shall be entitled to vote at annual meetings.

ART. 4. The annual meeting shall be held in November on Mondays on or preceding the full moon.

ART. 5. The business of the Road League shall be intrusted to a council of twelve, who shall be chosen by ballot at the annual meetings, and they shall hold office until their successors are elected.

\section{By-laws.}

ART. I. The council of twelve shall convene as soon as possible after the election, and shall choose from their number a president, also a secretary and treasurer (who may be one and the same person), and the council shall hold meetings monthly at the call of the secretary.

ART. 2. The president shall preside at all meetings, and when absent a member present shall be called to the chair in the usual way. 
ART. 3. The secretary shall keep a record of the proceedings of all meetings and conduct the correspondence of the league.

ART. 4. The treasurer shall keep an accurate account of receipts and disbursements in a book for that purpose, and all disbursements shall be authorized or approved by the council.

ART. 5. Meetings of the council may be called by order of the president, or at the request of three of its members, and five shall constitute a quorum.

ART. 6. The president shall appoint a monthly committee of two members of the council, who shall give special supervision to the work of the overseer in charge of the roads under the jurisdiction of the league, and serve until their successors are appointed.

ART. 7. The council shall fill all vacancies occurring by resignation or otherwise, and they may drop from their number any nember who shall persistently neglect his duty, or manifest indifference by non-attendance of the monthly meetings.

ART. S. The constitution and by-laws of this league may be changed by a two thirds vote of the entire council. notice of such change having been given in writing at 2 preceding meeting.

The order of business of the council shall be as follows. 1. Roll-call. 2. Reading of minutes of previous meeting. 3. Report of treasurer. 4. Unfinished business. 5. New business. 6. Reports of committees and of the overseers. 7. Adjournment. 


\section{CO-OPERATIVE BREEDERS' ASSOCIATION.}

\section{By-Laws Governing Co-operative Breeders' Association.}

(I) It shall be the purpose of this association to procure and use pedigreed sires for the purpose of improving our live stock through a system of up-grading. This method of improvement implies the continued use of some one kind of pure blood on the grade and mixed bred stocks. The association opposes the admixture of the blood of several breeds and the use of cross-bred grade and scrub sires. The association also pledges itself to exert every possible influence for the improvement and furtherance of the live stock interests of the community.

(2) It shall be the duty of the officers of this association to purchase the necessary sires and negotiate with competent parties within the association, centrally located, to care for and handle the bulls at a sum not to exceed - per annum.

(3) All bulls must be purchased subject to the tuberculin test as a safeguard against the introduction of tuberculosis.

(4) No bulls or other breeding animals shall be purchased from any herd in whicl three or more cases of alortion have occurred during the past three years. ('This will make reasonable allowance for accidental abortion and act as a safegua d against rise ravages of contagious a! ortion.)

(5) Should any contagious or infectious disease appear in the herd of any member of this association he must forfeit the right to patronize males of the association until such time as his herd is declared free from disease by a competent veterinarian.

(6) A service fee of $\$ 1.00$ shall be charged members of the association, to be collected at time of service. A charge of $\$ 2$ will be made to non-members in case the association should decide to accept the patronage of the same. Refund of service fee is to be made in the case of animals proving to be non-breeders.

(7) Service fees shall be used to defray cost of maintenance and handling of sires. Any surplus accumulations from this source may be divided among stockholders as dividends.

(S) It shall be the duty of the officers of this association to require and see to it that each sire is kept in a strong, vigorous, 
healthy condition, in moderate flesh, with plentiful supplies of suitable food and sufficient yardage to afford exercise in the open air and sunshine, in addition to the protection of the stable.

(9) Bulls shall not he used for service under one year of age, nor shall heifers be bred to calve under twenty-four months of age. During the rush of the breeding season single services only will be allowed.

\section{DAIRY TEST ASSOCIATIONS.}

r. The organization shall be known as the ..... District Dairy Test Association.

2. The officers shall consist of a president, a vice-president, and a secretary and treasurer. Three other members shall be appointed to act along with the officers as a committee of management.

3. The officers shall be elected to hold office for one year or until their successors are elected.

4. The annual meeting shall be held at the call of the president.

5. Meetings of the committce of management shall be held at the call of the secretary-treasurer. Three members shall form a quorum.

\section{BY-LAWS}

I. Any person who will agree to keep a record of individual cows during the whole milking period, to the extent of weighing the morning's and evening's milk on at least three days every month and also take a sample for testing, will be admitted to membership. The number of members may be limited at the discretion of the committee of management.

2. The milk will be preserved and a composite sample tested once a month with a Babcock milk-tester.

3. Members will be expected to provide themselves with a dipper, scales and sample bottles for each cow and a box for holding the samples.

4. Nembers shall assume the responsibility of delivering the samples to the place where the testing is to be done, on such days as may be directed by the person in charge of the work. 


\section{MISCELLANEOUS SUBJECTS AND TABLES.}

\section{EX PLANATION OF' THE FIAG SIGNAIS ADOPTED BY THE UNITED STATLE WEATHER BUIRAU.}

The U.S. Weather Bureau furnishes, when practicable, for the benefit of the general public and those interests dependent to a greater or less extent upon weather conditions, the "Forecasts" which are prepared daily, at Io A.M. and Io P.M., for the following day. These weather forecasts are telecraphed to observers at stations of the Weather Bureau, railway officials, and many others, and are so worded as to be readily communicated to the public by means of tlags or steam whistles. The flags adopted for this purpose are five in number, and of the form and dimensions indicated below:

\section{Weather Flags.}

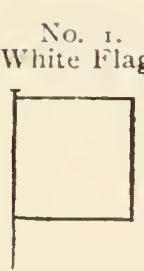

Clear or fair weather.
No. 3 . No. 2. White and Biue Blue Flag.

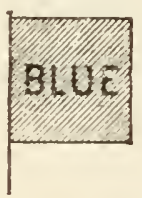

Rain or snow. Local rains or snow

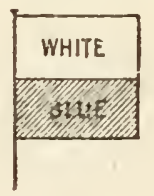

No $4 . \quad$ No. 5. Black Tri- White Flag angular with black Flag. square in centre.

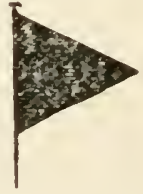

Temperature signal.

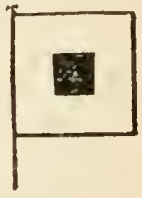

Cold wave.

\section{Interpretation of Displays.}

No. I, alone: fair weather, stationary temperature.

No. 2, alone: rain or snow, stattionary temperature.

No. 3, alone : local rain or snow, stiltionary temperature.

No. I, with No. 4 above it: filir weather, warmer.

No. I, with No. 4 below it : fair weather, colder. 
No. 2, with No. 4 above it: warmer weather, rain or snow

No. 2, with No. 4 below it : colder weather, rain or smow.

No. 3, with No. 4 above it: warmer weather, with local rains or snow.

No. 3, with No. 4 below it: colłer weather, with local rains or snow.

\section{Explanation of Whistle Signals.}

A warning blast of from fifteen to twenty seconds' diration is somded to attract attention. After this warning the longer blasts (of from four to six seconds' duration) refer to weather, and shorter blasts (of from one to three seconds' duration) refer to temperature; those for weather are sounded first.

Blasts.

Indicate.

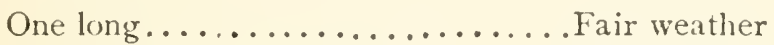

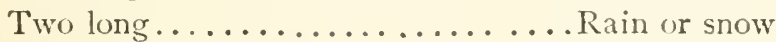

Three long ......................... rain or snow

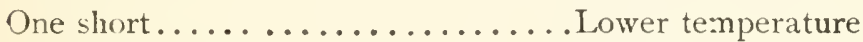

Two short................. Higher temperature

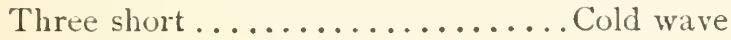

By repeating each combination a few times, with intervals of ten seconds, liability to error in reading the signals may be a voided.

\section{Explanation of Storm and Hurricane Warutugs.}

Storm warning.-A red flag with a black center indicates that a storm of marked violence is expected.

The pennants displayed with the flags indicate the direction of the wind: red, easterly (from northeast to south); white westerly (from southwest to north). The pennant above the flag indicates that the wind is expected to blow from the northerly quadrants; below, from the southerly quadrants.

By night a red light indicates easterly winds, and a white light abo e a reil light, westerly winds.

Hurricane warning. - Two red flags with black centers, displayed one above the other, indicate the expected approach of a tropical hurricane, or one of those extremely severe and dangerous storns which occasionally move across the Lakes and northern Atlantic roast.

No night hurricane warnings are displayed. 


\section{LIST OF HEADQUARTEIS OF STATE WEATHER SERVICES.}

The headquarters of the state weather services are as follows:

Auburn, Alabama.

Little Rock, Arkansas.

Sacramento, California.

Denver, Colorado.

Atlanta, Gcorgia.

Springfield, Illinois.

Indianapolis or Lafayette,

Indiana.

Des Moines, Iowa.

Topeka, Kansas.

Louisville, Kentucky.

New Orleans, Louisiana.

Baltimore, Maryland.

Cambridge, Massachusetts.

Lansing, Michigan.

Minneapolis, Minnesota.

University, Mississippi.

Columbia, Missouri.
Crete, Nebraska.

Carson City, Nevada.

New Brunswick, New Jersey. Santa Fé, New Mexico. Ithaca, New York.

Raleigh, North Carolina.

Bismarck, North Dakota.

Columbus, Ohio.

Portland or Oswego, Oregon. Philadelphia, Pennsylvania. Columbia, South Carolina. Huron, South Dakota.

Nashrille, Tennessee.

Galveston, Texas.

Lynchburg, Virginia.

Olympia, Washington.

l'arkersburg, West Virginia. Milwaukee, Wisconsin.

\section{BENEFICII, MND HARMIUI, HWIS AND OWLS.}

(Vearbook U'. S. Dept. of Agriculture.)

Much misapprehension exists among farmers as to the habits of birds of prey. Examination of the contents of the stomachs of such birds to the number of several thousand has established the fact that their food consists almost entirely of injurious mammals and insects, and that accordingly these birds are in most cases positively beneficial to the farmer, and should be fostered ana protected.

Among those wholly beneficial are the large, rough-legged hawk: its near relative, the squirrel-hawk, or ferruginous roughleg; and the four kites: the white-tailed kite, Mississippi kite, swallow-tailed kite, and everglade kite.

The class that is beneficial in the main-that is, whose depredations are of little consequence in comparison with 
the good it does-includes a majority of the liawks and owls, among them being the following species and their races: March hawk, Harris's hawk, red-tailed hawk, redshouldered hawk, short-tailed hawk, white-tailed hawk, Swainson's hawk, short-winged hawk, broad-winged hawk, Mexican black hawk, Mexican goshawk, sparrow-hawk, Audubon's caracara, barn-owl, long-eared owl, short-eared owl, great gray owl, barred owl, Western owl, Richardson's owl, Acadian owl, screech-owl, flammulated screech.owl, snowy owl, hawk-owl, burrowing owl, pygmy owl, ferrugrinous pygmy owl, and elf-owl.

The class in which the harmful and the beneficial qualities about balance each other includes the golden eagle, bald eagle. pigeon-hawk, Richardson's hawk, Aplomado falcon, prairie falcon, and the great horned owl.

The harmful class comprises the gyrfalcons, duck-hawk, sharp shinned hawk, Cooper's hawk, and goshawk.

\section{HOW PATENTS ARE ISSUED.}

Patents are issued in the name of the United States, and under the seal of the Patent Office, to any person who has invented or discovered any new and useful art, machine, manufacture, or composition of matter, or any new or useful improvement thereof, not known or used by others in this country, and not patented or described in any printed publication in this or any foreign country before the invention or discovery thereof, and not in public use or on sale for more than two years prior to his application, unless the same is proved to have been abandoned; and any person who by his own industry, genius, efforts, and expense has invented and produced any new and original design for a manufacture, bust, statua, alto-relievo or bas-relief, or any new and original design for the printing of woolen, silk, cotton, or other fabrics, any new and original impression, ornament, patent, pattern, print, or picture to be painted. printed, cast, or otherwise placed on or worked into any 
article of manufacture; or any new, useful, and original shape or configuration of any article of manufacture, the same not having been known or used by others before his invention or production thereof, or patented or described in any printed publication, may, upon payment of the fec pre. scribed and other due proceedings had, obtain a patent on the same.

Every patent contains a short title or description of the invention or discovery, correctly indicating its nature and design, and a grant to the patentee, his heirs or assigns, for the term of seventeen years of the exclusive right to make, use, and vend the invention or discovery throughout the United States and the Territories, referring to the specification for the particulars thereof.

If it appears that the inventor, at the time of making his application, believed himself to be the original and first in. ventor or discoverer, a patent will not be refused on account of the invention or discovery or any part thercof having been known or used in a foreign country before his invenvention or discovery thereof, if it had not been patented or described in a printed publication.

No person shall be debarred from receiving a patent for his invention by reason of its having been first patented in a foreign country, unless the application for the foreign patent was filed more than seven months prior to the filing of the application in this country. But every patent granted for an invention which has been previously patented in a foreign country shall be so limited as to expire at the same time with the foreign patent, or if there be more than one, at the same time with the one having the shortest term, but in no case shall it be in force more than seventeen years.

Joint inventors are entitled to a joint patent; neither can claim one separately. Independent inventors of distinct and independent improvements in the same machine cannot obtain a joint patent for their separate inventions; nor does the fact that one furnishes the capital and another makes the invention entitle them to make application as joint inventors; but in such cases they may become joint patentees. 
Applications.-Application for a patent must be made in writing to the Commissioner of Patents. The applicant must also file in the Patent Office a written description of the same, and of the manner and process of making, constructing, compounding and using it, in such full, clear, concise, and exact terms as to enable any person skilled in the art or science to which it appertains, or with which it is most nearly connected, to make, construct, compound, and use the same; and in case of a machine, he shall explain the principle thereof, and the best mode in which he has contemplated applying that principle, so as to distinguish it Irom other inventions; and particularly point out and dislinctly claim the part, improvement, or combination which he claims as his invention or discovery. The specification and claim shall be signed by the inventor and attested by fwo witnesses.

When the nature of the case admits of drawings, the applicant must furnish a drawing of the required size, signed by the inventor or his attorney in fact, and attested by two witnesses, which shall be filed in the Patent Office. In ' ases of inventions that admit of representation by model, the applicant, if required by the Patent Office, shall furnish a model of convenient size to exhibit advantageously the s sveral parts of the invention or discovery.

The applicant shall make oath that he does verily believe limself to be the original and first inventor and discoverer of the art, machine, manufacture, composition, or improveuent for which he solicits a patent; that he does not know and does not believe that the same was ever before known or used, and shall state of what country he is a citizen and where he resides. Such oath may be made before any person within the United States authorized by law to administer oaths, or, when the applicant resides in a foreign country, before any minister, chargé d'affaires, consul, or commercial agent holding commission under the Government of the United States, or before any notary public of the foreign country in which the applicant may be, provided such notary is authorized by the laws of his country to administer oaths. 
On the filing of such application and the payment of the fees required by law, the Commissioner of Patents shall cause an examination to be made, and if, on such examination, it appears that the claimant is justly entitled to a patent under the law, and that the same is sufficiently useful and important, the Commissioner shall issue a patent therefor.

Assignments. - Every patent or any interest therein shall be assignable in law by an instrument in writing, and the patentee or his assigns or legal representatives may in like manner grant and convey an exclusive right under his patent to the whole or any specified part of the United States.

Caveats. - A caveat, under the patent law, is a notice given to the office of the caveator's claim as inventor, in order to prevent the grant of a patent to another for the same alleged invention upon an application filed during the life of the caveat without notice to the caveator.

Any citizen of the United States who has made a new invention or discovery, and desires more time to mature the same, may, on payment of a fee of ten dollars, file in the Patent Office a caveat setting forth the object and the distinguishing characteristics of the invention, and praying protection of his right until he shall have matured his invention. Such caveats shall be filed in the confidential archives of the office and preserved in secrecy, and shall be operative for the term of one year from the filing thereof.

An alien shall have the privilege herein granted if he has resided in the United States one year next preceding the filing of his caveat, and has made oath of his intention to become a citizen.

Fees.-The following are the rates for patent fees, and these are payable in advance:

On filing each original application for a patent (except in design cases), Sis.

On issuing each original patent (except in design cases), $\$ 20$.

In design cases: For three years and six months, \$10: for seven years, \$15; for fourteen years, \$30. 


\section{On filing each caveat, \$IO.}

On every application for the reissue of a patent, $\$ 30$.

On filing each disclaimer, \$ro.

On every application for the extension of a patent, $\$ 50$.

On the granting of every extension of a patent, $\$ 50$.

For certified copies of patents and other papers in manuscript, Io cents per hundred words.

For recording every assignment, agreement, power of attorney, or other paper of three hundred words or under, iे ; of over three hundred words and under one thousand words, $\$ 2$; of over one thousand words, $\$ 3$. For copies of drawings, the reasonable cost of making them.

\section{LEGAL HOLIDAYS. ${ }^{\ddagger}$}

January I, New Year's: All States except Massachusetts, Minnesota, New Hampshire, and Rhode Island.

January 8, Anniversary of Battle of New Orleans: Louisiana.

January I9, Lee's Birthday': Florida, Georgia, North Carolina, and Virginia.

February I2, Lincoln's Birthday: Illinois, Minnesota, New Jersey, New York, and Washington.

February 22, Washington's Birthday': All States except Iowa, Mississippi, and New Mexico.

March 2, 'Texan Independence Anniversary: Texas.

April, first Saturday, Arbor Day: Utah.

April, first Wednesday, Election Day': Rhode Island.

April I9, Concord Day': Massachusetts.

April 21, Anniversary of Battle of San Jacinto: Texas.

Aprii 22, Arbor Day: Nebraska.

April 26, Memorial Day: Alabama, Florida, Georgia, and Tennessee.

May, first Friday, Arbor Day: Rhode Island and Idaho.

May ro, Memorial Day': North Carolina.

May 20, Mecklenburg Declaration of Independence: North Carolina.

May 30, Memorial Day: All States except Alabama, Arkansas, Florida, Georgia, Kentucky, Louisiana, New 
Mexico, North Carolina, South Carolina, Texas, and Virginia.

June 3, Jefferson Davis' Birthday': Florida.

July 4, Independence Day': All States and District of Columbia.

July 24, Pioneers' Day': Utah.

Angust I6, Bennington Battle Day': Vermont.

September, first Monday, Labor Day: All States and Dis. trict of Columbia.

September 9, Admission Day: California.

October $\mathrm{y}_{5}$, Lincoln Day: Connecticut.

October 3I, Admission into the Union Anniversary: Nevada.

November, General Election Day' (first Tuesday after first Monday): Arizona, California, Colorado, Florida, Idaho, Indiana, Illino1s, Maryland, Minnesota, Missouri, Montana, Nevada, New Hampshire, New Jersey, New York, North Dakota, Ohio, Oregon, Pennsylvania, Rhode Island, South Carolina, South Dakota, Tennessee, Texas, Washington, West Virginia, Wisconsin, and Wyoming.

November, last Thursday, Thanksgizing Day': In all States, though not a stationary holiday in some.

December 25, Christmas Da $y^{\prime}$ : All States and District of Columbia.

Arbor Day is a legal holiday in Idaho, Kansas, Rhode Island, and Wyoming, the day being set by the governor.

Mardi Gras (the last day before Lent) is observed as a holiday in Alabama and Louisiana.

Good Friday is observed as a holiday in Alabama, Georgia, Louisiana, Maryland, Minnesota, Pennsylvania, and Tennessee.

Every Saturday after I 2 o'clock noon is a legal holiday in New York, New Jersey, and New Orleans; also from June to September in Colorado and Pennsylvania. 


\section{WHAT TO DO IN CASE OF ACCIINATS.}

By J. Noer, M.D., Stoughton, Wis.

To consider the cause, nature, effect, and treatment of the multiplicity of injuries due to accidents is impossible, except in a treatise deroted to the subject. The object here is to instruct the layman to use his reason and good sense to aid the afflicterl till skilled help arrives. It is especially important that he refrains from doing a lot of foolish things, and does not give or apply remedics about which he knows nothing, the effects of which are often more dangerous to the patient than the injury itself.

The symptoms demanding urgent attention after an injury are usually shock, pain, bleeding, support, and adjustment of mangled or broken limbs, protection to open wounds, burned surfaces, bruises, etc.

Wounds.-The all-important item in the treatment of wounds or cuts is absolute cleanliness or asepsis. Asepsis can be secured Ly having everything that is to be used for the wound boiled just 1 efore applying it.

Before dressing a wound:

Ist. Wash your hands, scrub and clean finger-nails thoroughly with soap and hot boiled water.

$2 \mathrm{~d}$. Wash the limb or parts around cut or wound with boiled water and soap, being careful not to wash dirt from around the sore into it.

3d. Wash out the wound with hot boiled water. If there is still oozing from the cut surfaces,press clean cloths wrung out of biled water as hot as hands can bear against the bleeding surfaces till it stops.

4th. Draw the edges of the wound together with strips of court-plaster.

5 th. Lay over the wound so as to cover it well ten to twelve thicknesses of clean boiled and baked dry cheesecloth, sheeting, or linen, and fasten on with a bandage. !

6 th. Let the injured parts be at rest. If you hav? secured asepsis and gotten the edges of the wound togetine: closely, keep the wounded parts at rest for from three to six rays; the wound will then heal without pain or pus, at:d - vithout swelling, inflammation, or ferer. Don't hinder 
the healing of a wound by putting pitch, tobacco juice, " healing ointments," liniments, or other filth into it.

Broken or Mangled Limls should be supported by temporary splints, made from boards, pasteboard, shingles, etc. Put one on each side of the limb and tic on with handkerchief or bandages. The splints should be long enough to support entire limb.

Burns and Scalds-If the burn is extensive, place the person in a bath of lukewarm water, keep the body immersed up to the chin, see that the water is kept warm; patient may be left in bath indefinitely. If the burn is not large, but painful, cover the burned surface with a thick layer of flour, powdered starch, zinc ointment, or cotton batting. Equal parts of limewater and linseed oil may be applied, and the burn covered with cotton. It is important in burns to apply a dressing that will exclude the air. In large burns there is always severe shock: treat this as directed below.

Shock.-When a person has been severely injured or badly frightened, there follows a condition of the nervous system which is known as shock. A person suffering from shock generally becomes pale, cold, faint, and trembling, with a small weak pulse. The mind is dull and the person looks anxious and distressed. Sometimes the person is excited and restless.

Treatment.-Let the person rest in a quiet cheerful place. If he is little injured, tell him so calmly. If the $i_{n j u r y}$ is severe, and there is pain, broken bones, bleeding, etc., you must still be calm, cheerful, and helpful. Give a tablespoonful ( 2 or 3 , if a drinker) of whiskey in water every quarter or half hour. Wrap him in warm blankets and lay hot water bottles around him. If there is much pain, give ro drops of laudanum. In case of bleeding, open wounds, or broken bones, treat them as directed. A flushed face and fever show that the patient is reviving and does not need hot-water bottles or whiskey. Never let an injured person be surrounded by a crowd of people.

Pain is frequently relieved by the adjustment and support of mangled limbs, by protecting exposed open wounds, burns, bruises, etc, with clean gauze dressings. Morphin $\frac{1}{4}$ grain, or 20 drops of laudanum, or I grain of opium can be given if pain 
is unbearable. Unless absolutely necessary this treatment should be left to the physician.

Hemorrhage or Bleeding always occurs after an iniury. It is the result of the tearing or cutting off of the blood-vessels. A personsulfering from hemorrhage either internal or external is pale, faint, with fecble pulse.

Treatment.--Keep the person quiet. If the bleeding zomes from a wound in the upper or lower limbs, it will stop by raising the iimb up above the rest of the hody. Tie clean cloths tightly over the sore. If the blood comes in spurts, tie a rope or handkerchief tightly around limb above cut nearest to body. If bleeding is slight, it will stop by tying clean cloths tightly over the cut. Ice may be applied over the bleeding vessels. Clean cloths wrung out of water as hot as hands can bear is often effective.

Never use cobwebs, tobacco juice, or other filthy things to stop bleeding. If a person spits or coughs up red frothy bluod, he is probably bleeding from the lungs. Let him lie down, and if it continues to come up apply ice to chest and give a teaspoonful of extract of ergot.

sunstroke and Heat Exhaustion.-ln suistroke the person has a red face; skin is hot and dry; there is high Ever; breathing and pulse are very rapid. There is often delirium and convulsions. Put the pa.ien: in a cold bath; apply ice to the head and rub the skin with picces of ice. If he cannot be put into a bath, put him in the shade and pour cold water over him, or wrap him in cold wet blankets and pour cold water over his head. In heat exhaussion the patient is pale and the skin cool. There is no fever. Let the person rest in the shade. Givestimulants, as hot coffee or whiskey.

Poisoniun.-In any case of poisoning when the kind of poison is unknown, incluce vomiting at once by gring warm water with or without a tablespoonful of ground mustard, or double this amount of salt to the ceacup. Thrust your finger down his throat to help the emetic. Milk, raw eggs, gruel, oil should be giren freely if irritant poisons, like potash, lye, or acids, have been taken. The following table contains suggestions for the proper treatment of the forms of poisoning occurring most frequently. 


\begin{tabular}{|c|c|}
\hline Poison. & Treatment. \\
\hline $\begin{array}{l}\text { Acids: } \\
\text { Sulfuric, } \\
\text { Nitric, } \\
\text { Muriatic, } \\
\text { Oxalic. }\end{array}$ & $\begin{array}{l}\text { Give soap, soda, whitewash, or magnesia mixed in } \\
\text { water. Produce vomiting. } \\
\text { Give gruel, milk, eggs (uncooked). } \\
\text { Relieve pain by giving ro. drops of laudanum in } \\
\text { water. }\end{array}$ \\
\hline $\begin{array}{l}\text { Carbolic acid and } \\
\text { creosote. }\end{array}$ & $\begin{array}{l}\text { Give Epsom salts, raw eggs. } \\
\text { Produce vomiting. Alcohol is the antidote. Give } \\
\text { whisky, brandy, or alcohol freely if arid has been } \\
\text { swallowed. Ixternally apply alcohnl or cloths } \\
\text { or cotton soaked in alcohol to the surface burned } \\
\text { by the acid. }\end{array}$ \\
\hline $\begin{array}{l}\text { Alkalies: } \\
\text { Ammonia, } \\
\text { Suda, } \\
\text { Potash, } \\
\text { Lye. }\end{array}$ & $\begin{array}{l}\text { Give vinegar, lemon or orange juice, or any acid } \\
\text { diluted in plenty of water. } \\
\text { Give mik, grucl, white of egg, oils. } \\
\text { For pain give ro drops of laudanum. }\end{array}$ \\
\hline $\left.\begin{array}{l}\text { Arsenic, } \\
\text { Paris green, } \\
\text { Poison fly-paper, } \\
\text { Rough on rats. }\end{array}\right\}$ & $\begin{array}{l}\text { Produce vomiting if these is none already. } \\
\text { Hydrated oxid of iron with magnesia in water is } \\
\text { the antidote. } \\
\text { Give } 2 \text { tablespoonsful of castor oil. }\end{array}$ \\
\hline $\begin{array}{l}\text { Corrosive subli- } \\
\text { mate. }\end{array}$ & $\begin{array}{l}\text { Produce romiting. Give a teaspoonful of tann } \\
\text { in water. } \\
\text { Give raw eggs, milk, castor oil. }\end{array}$ \\
\hline Iodin. & $\begin{array}{l}\text { Produce vomiting. } \\
\text { Give starch and water, raw eggs, milk, or grucl. }\end{array}$ \\
\hline $\begin{array}{l}\text { Opium, } \\
\text { Morphin, } \\
\text { Laudanum } \\
\text { Parc.goric, }\end{array}$ & $\begin{array}{l}\text { Produce vomiting. Inject from a pint to a ouart } \\
\text { of strong coffee into rectum, or give by mouth if } \\
\text { patient can swallow. } \\
\text { Potassium permanganate is antidote. } \\
\text { Keep patient awalic. }\end{array}$ \\
\hline $\begin{array}{l}\text { Poison gas from } \\
\text { coal stove. }\end{array}$ & Fresh air; stimulants, as coffee, ammonia. \\
\hline
\end{tabular}


The following additional suggestions are offered:

Lightning.-Dash cold water over person struck.

Math-dog- or Snake-bite.-Tie cord tight above wound. Suck the wound and cauterize with caustic or white-hot iron at once, or cut out adjoining parts with a sharp linife. Give stimulants, as whisky, brandy, etc.

Sting of Venomous Insects, etc.-Apply weak ammonia, oil, salt water, or iodin.

Fainting.-Place flat on back, allow fresh air, and sprinkle with water. Place head lower than rest of body.

Cinders in the Eye.-Roll soft paper up like a lamplighter and wet the tip to removecinder, or use a medicinedropper to draw it out. Rub the other eye.

Fire in One's Clothing.-Don't run, especially not down-stairs or out-of-doors. Roll on carpet, or wrap in woolen rug or blanket. Keep the head down so as not to inhale flame.

Fire in a Buildins.-Crawl on the floor. The clearest air is the lowest in the room. Cover head with woolen wrap, wet if possible.

Fire from kerosenc.-Don't use water, it will spread the flames. Dirt, sand, or flour is the best extinguisher; or smother with woolen rug, table-cloth or carpet.

suffocation from Inhaling Illuminating-gas.-Get into fresh air as soon as possible, and lie down. Keep warm. Take ammonia, 20 drops to a tumbler of water, at frequent intervals; also $2-4$ drops tincture of nux vomica every hour or two for 5 or 6 hours. (World Almanac, IS9g.) 


\section{INTEREST TABLES.}

\begin{tabular}{|c|c|c|c|c|c|c|c|c|c|c|c|c|c|}
\hline & $4 \%$ & $\$_{1}$ & $\$ 2$ & $\$ 3$ & $\hat{\$}_{4}$ & $\$_{j}$ & $\$ 6$ & \$7 & $\$ 8$ & $\$ 9$ & $\$ 10$ & $\$ 100$ & $\$ 1000$ \\
\hline 4 & DAY. & o & o & o & o & 0 & o & o & 0 & o & 0 & 5 & 45 \\
\hline 8 & $"$ & o & 0 & 0 & o & o & o & o & o & I & I & 9 & 89 \\
\hline 12 & $" 6$ & o & o & 0 & $\circ$ & o & I & I & I & I & 2 & 13 & I. 34 \\
\hline 16 & $" 6$ & o & o & o & o & I & I & $\mathbf{I}$ & 2 & 2 & 2 & 18 & $1.7^{8}$ \\
\hline 20 & $" 6$ & o & o & o & I & I & 2 & 2 & 2 & 3 & 2 & 22 & 2.22 \\
\hline 24 & & o & $\circ$ & I & I & 2 & 2 & 2 & 2 & 3 & 3 & 27 & 2.67 \\
\hline 28 & $"$ & $\circ$ & 0 & I & I & 2 & 2 & 2 & 3 & 3 & 3 & $3 I$ & 3.11 \\
\hline I & MO.. & 0 & o & I & 2 & 2 & 2 & 3 & 3 & 3 & 3 & 33 & $3 \cdot 34$ \\
\hline 2 & "6 & o & 2 & 2 & 3 & 4 & 4 & 5 & 6 & 6 & 7 & 67 & 6.67 \\
\hline 3 & (6) & I & 2 & 3 & 4 & 5 & 6 & 7 & 8 & 9 & I0 & 1.00 & 10.00 \\
\hline 6 & 6 & 2 & 4 & 06 & 8 & 10 & I 2 & 14 & 16 & 18 & 20 & 2.00 & 20.00 \\
\hline I & YR... & 4 & 8 & 12 & 16 & 20 & 24 & 28 & 32 & 36 & 40 & 4.00 & 40.00 \\
\hline & $5 \%$ & SI & $\$ 2$ & $\$ 3$ & $\$ 4$ & \$5 & \$6 & $\$ 7$ & $\$ 3$ & \$) & Sio & \$roo & $\$ 1000$ \\
\hline 4 & DAY. & o & 0 & o & o & $\circ$ & o & o & o & o & o & 6 & $5^{6}$ \\
\hline 8 & $"$ & o & $\circ$ & o & o & o & 0 & I & 1 & I & 1 & II & I. I I \\
\hline 12 & $"$ & ○ & o & o & o & I & I & I & 2 & 2 & 2 & I 7 & 1.67 \\
\hline 16 & $"$ & o & o & o & I & I & 2 & 2 & 2 & 2 & 2 & 22 & 2.22 \\
\hline 20 & $"$ & 0 & o & I & I & 2 & 2 & 2 & 2 & 3 & 3 & 27 & 2.74 \\
\hline 24 & " & o & o & I & 2 & 2 & 2 & 3 & 3 & 3 & 3 & 33 & $3 \cdot 34$ \\
\hline 28 & " & o & I & I & 2 & 2 & 3 & 3 & 3 & 4 & 4 & 38 & 3.84 \\
\hline I & мо.. & o & I & 2 & 2 & 2 & 3 & 3 & 4 & 4 & 4 & 42 & $4 \cdot 17$ \\
\hline 2 & $\ddot{~ " 6 ~}$ & I & 2 & 3 & 4 & 4 & 5 & 6 & 7 & 8 & 9 & 83 & 8.34 \\
\hline 3 & $" 6$ & 2 & 3 & 4 & 5 & 6 & 7 & 9 & Io & II & I 3 & I. 25 & I 2.50 \\
\hline 6 & 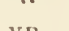 & 3 & 5 & 8 & I0 & 13 & 15 & 18 & 20 & 23 & 25 & 2.50 & 25.00 \\
\hline I & YR. & 5 & 10 & 15 & 20 & 25 & 30 & 35 & 40 & 45 & 50 & 5.00 & 50.00 \\
\hline
\end{tabular}

\begin{tabular}{|c|c|c|c|c|c|c|c|c|c|c|c|c|c|}
\hline & $6 \%$ & $\$ r$ & $\$ 2$ & $\$_{3}$ & 84 & $\$ 5$ & $\$ 6$ & 87 & $\$ 8$ & $\$ 9$ & \$10 & $\$ 100$ & \$rooo \\
\hline 4 & DAY. & 0 & o & o & 0 & 0 & o & 0 & I & I & $I$ & 7 & 67 \\
\hline 8 & $\because$ & 0 & 0 & o & I & 1 & I & I & 1 & I & I & 13 & 1. 33 \\
\hline 12 & 6. & o & o & I & I & I & 1 & $I$ & 2 & 2 & 2 & 20 & 2.00 \\
\hline 16 & " & 0 & I & I & I & I & 2 & 2 & 2 & 2 & 3 & 27 & 2.67 \\
\hline 20 & 16 & I & I & I & 2 & 2 & 2 & 2 & 3 & 3 & 3 & 33 & $3 \cdot 33$ \\
\hline 24 & "6 & I & I & I & 2 & 2 & 2 & 3 & 3 & 4 & 4 & 40 & 4.00 \\
\hline I & MO. & I & I & 2 & 2 & 3 & 3 & 4 & 4 & 5 & 5 & 50 & 5.00 \\
\hline 2 & " & I & 2 & 3 & 4 & 5 & 6 & 7 & 8 & 9 & 10 & 1.00 & 10.00 \\
\hline 3 & " & 2 & 3 & 5 & 6 & 8 & 9 & II & 12 & 14 & 15 & I. 50 & $1_{5} .00$ \\
\hline 6 & "6 & 3 & 6 & 9 & 12 & 15 & 18 & $2 x$ & 24 & 27 & 30 & 3.00 & $3^{n} .00$ \\
\hline I & YR... & 6 & 12 & 18 & 24 & 30 & 36 & 42 & 48 & 54 & 60 & 6.00 & 60.00 \\
\hline & $7 \%$ & SI & $\$ 2$ & 83 & 84 & $\$ 5$ & $\$ 6$ & $\$ 7$ & $\leqslant 3$ & S7 & Sio & Sroo & S1000 \\
\hline 4 & DAY. & 0 & o & o & 0 & 0 & 0 & o & o & 0 & 0 & 8 & 77 \\
\hline 8 & .. & 0 & 0 & 0 & o & 0 & 0 & I & I & I & I & 15 & I. 53 \\
\hline 12 & ' & o & o & o & o & I & I & I & I & 2 & 2 & 23 & $2.3^{I}$ \\
\hline 16 & " & 0 & 0 & o & I & I & I & 2 & 2 & 2 & 3 & 31 & 3.10 \\
\hline 20 & 16 & o & 0 & I & I & I & 2 & 2 & 3 & 3 & 4 & 38 & 3.84 \\
\hline 24 & " & ○ & 0 & I & I & 2 & 2 & 3 & 3 & 4 & 5 & $4^{6}$ & 4.62 \\
\hline I & MO.. & o & I & 2 & 2 & 3 & 3 & 4 & 4 & 5 & 6 & $5^{8}$ & 5.83 \\
\hline 2 & “. & I & 2 & 3 & 5 & 6 & 7 & 8 & 9 & 10 & 12 & I. 17 & I1. 67 \\
\hline 3 & $" 6$ & 2 & 3 & 5 & 7 & 9 & 10 & 12 & 14 & I 6 & 18 & 1. 75 & 17.50 \\
\hline 6 & " & 4 & 7 & I I & I4 & 18 & $2 I$ & 25 & 28 & $3^{2}$ & 35 & 3.50 & 35.00 \\
\hline I & YR... & 7 & 14 & $2 I$ & 28 & 35 & 42 & 49 & $5^{6}$ & 63 & 70 & 7.00 & 70.00 \\
\hline
\end{tabular}


TAFIA OF WAGES BY THE IVEFK.

(Computed on a basis of ten hous labor per day.)

\begin{tabular}{|c|c|c|c|c|c|c|c|c|c|c|c|}
\hline $\begin{array}{l}0 \\
0 \\
o \infty \\
3 \\
3\end{array}$ & $\mathrm{Hr}^{\mathrm{I}}$. & $\mathrm{Hrs.}^{2}$ & Hrs. & $\begin{array}{c}8 \\
\text { Hrs. }\end{array}$ & $\stackrel{9}{\text { Hrs. }}$ & $\begin{array}{c}\text { I } \\
\text { Day. }\end{array}$ & ${ }^{2}{ }^{2} y^{2}$. & Days. & Days. & Days. & $\begin{array}{c}6 \\
\text { Days. }\end{array}$ \\
\hline 3 & & & .25 & .40 & .45 & .50 & I. 00 & I. 50 & 2.00 & 2.50 & 3.60 \\
\hline 4 & $6 \frac{2}{3}$ & .13 & $.33 \frac{1}{3}$ & $.53^{\frac{1}{3}}$ & & & $1 \cdot 3 \geq \frac{1}{3}$ & 2.00 & $2.66 \frac{2}{3}$ & 3 $33 \frac{1}{3}$ & 4.00 \\
\hline 3 & $8 \frac{1}{3}$ & .16 & .413 & $.66 \frac{2}{3}$ & $\cdot 75$ & $.83^{\frac{1}{3}}$ & $1.66 \frac{2}{3}$ & 2.50 & $3 \cdot 33 \frac{1}{3}$ & $4.16 \frac{2}{3}$ & 5.00 \\
\hline 5 & IO & .20 & & .80 & .90 & 1.00 & 2.00 & 3.00 & & 5.00 & 6.0 \\
\hline 7 & $.11 \frac{2}{3}$ & $.23 \frac{1}{3}$ & $\cdot 5^{8 \frac{1}{3}}$ & $.93 \frac{1}{3}$ & I.05 & $16 \frac{2}{3}$ & $2.33^{\frac{1}{3}}$ & 3.50 & 4.6 & $5.83^{\frac{1}{3}}$ & 700 \\
\hline 8 & $13 \frac{1}{3}$ & $.26 \frac{2}{3}$ & .66 & I. $00_{3}^{2}$ & I. 20 & I. $33^{\frac{1}{3}}$ & $2.66 \frac{2}{3}$ & 4.00 & & $6.66 \frac{2}{3}$ & 8.00 \\
\hline 9 & & $\cdot 30$ & .75 & I. 20 & I. 35 & . 50 & $3 . c$ & $4 \cdot 50$ & & $7 \cdot 50$ & 9.00 \\
\hline & & $\begin{array}{r}\cdot 33 \hat{3} \\
36 \frac{2}{3}\end{array}$ & $.83 \frac{1}{3}$ & I. $333^{\frac{1}{3}}$ & I. 50 & $60 \frac{2}{3}$ & $3.33^{\frac{1}{3}}$ & 5.00 & $666 \frac{2}{3}$ & $8.3 .3^{\frac{1}{3}}$ & 10.0 \\
\hline II & $.18 \frac{1}{3}$ & $\cdot 36 \frac{2}{3}$ & $.91 \frac{2}{3}$ & $1.46 \frac{2}{3}$ & 1.65 & 1. $83^{\frac{1}{3}}$ & $3.66 \frac{2}{3}$ & $5 \cdot 50$ & $7 \cdot 33 \frac{1}{3}$ & $9.16 \frac{2}{3}$ & II $1 . \infty$ \\
\hline & & .40 & I. 00 & .60 & .80 & 2.00 & 4.00 & 6.00 & & I0. & 12.00 \\
\hline 13 & $.2 \mathrm{I} \frac{2}{3}$ & $.43 \frac{1}{3}$ & $1.08 \frac{1}{3}$ & $1.73 \frac{1}{3}$ & I. 95 & $2.16 \frac{2}{3}$ & $433^{\frac{1}{3}}$ & 6.50 & $8.66 \frac{2}{3}$ & $10.83^{\frac{1}{3}}$ & 13.00 \\
\hline I4 & $.23^{\frac{1}{3}}$ & $.46 \frac{2}{3}$ & I. I $6 \frac{2}{3}$ & I. $86 \frac{2}{3}$ & 2.1 & $2.33 \frac{1}{3}$ & $4.66 \frac{2}{3}$ & 7.00 & $9.33 \frac{1}{3}$ & $1: .66 \frac{2}{3}$ & 14.00 \\
\hline 1 & .25 & .50 & I. 25 & 2.00 & 2.25 & 2.50 & 500 & 7.50 & 10. 00 & $12.50^{\circ}$ & 15.00 \\
\hline IE & $.26 \frac{2}{3}$ & $.53 \frac{1}{3}$ & I. $33 \frac{1}{3}$ & 2. $13 \frac{1}{3}$ & 2.40 & $266 \frac{2}{3}$ & $5 \cdot 33 \frac{1}{3}$ & 8.00 & I0 $66 \frac{2}{3}$ & & 16.00 \\
\hline 17 & $.28 \frac{1}{3}$ & $\cdot 5^{6 \frac{2}{3}}$ & $\mathrm{I} .4 \mathrm{I} \frac{2}{3}$ & $2.26 \frac{2}{3}$ & 2. 55 & $2.83 \frac{1}{3}$ & $5.66_{3}^{2}$ & $8.5^{\circ}$ & I I $.33 \frac{1}{3}$ & $14 \cdot 16 \frac{2}{3}$ & 17.00 \\
\hline I & $3^{\circ}$ & .60 & 1.50 & 2.40 & $2.7^{\circ}$ & 300 & 6.00 & 900 & $12 . \mathrm{C}$ & I 5.00 & 18.00 \\
\hline Ig & $3 I \frac{2}{2}$ & $63 \frac{1}{3}$ & I. $58^{\frac{1}{2}}$ & $253 \frac{1}{3}$ & 2.85 & $3.16 \frac{2}{3}$ & 6.3 & 0.50 & & 15. & 19.00 \\
\hline 20 & & $.00 \frac{2}{3}$ & & $2.606 \frac{2}{3}$ & & & 6. $66 \frac{2}{3}$ & & & I $666 \frac{2}{3}$ & 20.0 \\
\hline 24 & 40 & .80 & 2.00 & 3.20 & 3.00 & 4.00 & 8.00 & 12.00 & 16.00 & 20.00 & 24.00 \\
\hline
\end{tabular}

TABHE OF WIGES BY THE DAY.

(Computed on a basis of ten hours' lahor per day )

\begin{tabular}{|c|c|c|c|c|c|c|c|c|c|c|}
\hline & & $25 \mathrm{C}$. & $37 \frac{1}{2} \mathrm{C}$. & joc. & $62 \frac{3}{2} \mathrm{c}$. & $75 \mathrm{C}$. & $87 \frac{1}{2} \mathrm{c}$. & $\$ 1.00$ & SI. I $2 \frac{1}{2}$ & $\$ 1.25$ \\
\hline$\frac{1}{2}$ & hour.. & $.01 \frac{1}{4}$ & $.01 \frac{7}{6}$ & $.02 \frac{1}{2}$ & $.03 \frac{1}{6}$ & $.03 \frac{8}{4}$ & $.04 \frac{3}{8}$ & .05 & $.05 \frac{5}{3}$ & $.06 \frac{1}{t}$ \\
\hline I & $"$ & $.02 \frac{1}{2}$ & $.03 \frac{8}{4}$ & .05 & $.06 \frac{1}{1}$ & $.07 \frac{1}{2}$ & $.08 \frac{8}{4}$ & ס10 & . $T T_{\frac{1}{4}}$ & $.12 \frac{1}{2}$ \\
\hline 2 & 66 & .05 & $.07 \frac{1}{2}$ & . 10 & $.12 \frac{1}{2}$ & . I 5 & . $17 \frac{3}{2}$ & .20 & $.22 \frac{1}{2}$ & .25 \\
\hline 5 & $" 6$ & $.12 \frac{1}{2}$ & $.18 \frac{8}{4}$ & .25 & $\cdot 3 I^{\frac{1}{4}}$ & $.37 \frac{1}{2}$ & $.43^{\frac{8}{4}}$ & .50 & $.56 \frac{1}{4}$ & $.62 \frac{1}{2}$ \\
\hline & $\because:$ & .20 & .30 & .40 & .50 & .60 & .70 & .80 & .90 & S I 00 \\
\hline 9 & " & $.22 \frac{8}{4}$ & $\cdot 33^{\frac{8}{4}}$ & .45 & $.56 \frac{1}{4}$ & $.67 \frac{1}{2}$ & $.78 \frac{3}{4}$ & .90 & $1.01 \frac{1}{3}$ & I. $12 \frac{1}{2}$ \\
\hline I & day... & .25 & $\cdot 37 \frac{1}{2}$ & .50 & $.62 \frac{1}{2}$ & .75 & $.87 \frac{1}{2}$ & $\$ 1.00$ & $1.12 \frac{1}{3}$ & I. 25 \\
\hline 2 & days.. & .50 & .75 & $\$ 1.00$ & $\$ 1.25$ & $\$ \mathrm{I} .5 \mathrm{O}$ & \$1.75 & 200 & 2.25 & 2.50 \\
\hline 3 & & .75 & $\$ \mathrm{I}, 12 \frac{1}{2}$ & 1.50 & I. $87 \frac{1}{2}$ & 2.25 & $2.62 \frac{1}{2}$ & 3.00 & $3 \cdot 37^{\frac{1}{2}}$ & 3.75 \\
\hline 4 & $"$ & $\$ 1.00$ & & 2.00 & 2.50 & 300 & $3 \cdot 50$ & 4.00 & & 5.00 \\
\hline 5 & 16 & & I. $87 \frac{1}{2}$ & 2.50 & $3 \quad 12 \frac{1}{2}$ & $3 \cdot 75$ & $4 \cdot 37 \frac{1}{2}$ & 5.00 & $5.62 \frac{1}{2}$ & 6.25 \\
\hline 6 & 16 & 1.50 & 2.25 & 3.00 & $3 \cdot 75$ & $4 \cdot 5^{\circ}$ & $5 \cdot 25$ & 6.00 & 6.75 & $7 \cdot 5^{\circ}$ \\
\hline
\end{tabular}

\begin{tabular}{|c|c|c|c|c|c|c|c|c|c|c|}
\hline & & \$r.37! & $\$ 1.50$ & $\$ 1.62 !$ & S1.75 & SI. $87 \frac{1}{2}$ & $\$ 2.00$ & $\$ 2.12 \frac{1}{2}$ & $\$ 2.25$ & $\$ 2.37\}$ \\
\hline & 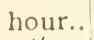 & & .07 & $8 \frac{1}{4}$ & $.08\}$ & $.00 ?$ & & $.10 \frac{5}{3}$ & & . II $\frac{7}{4}$ \\
\hline & & & & . $16 \frac{1}{4}$ & $.17 \frac{1}{2}$ & $.18 \%$ & & $.21 \frac{3}{4}$ & & .23 \\
\hline & " & & & $\cdot 32 \frac{1}{2}$ & & & & & & \\
\hline & "4 & .68 & .7 & & $.87 \frac{2}{2}$ & & Sir. & Sr.06i & $\$ I$ & \$I. 18 \\
\hline & "6 & \$I. & $\$ 1.20$ & S1.30 & $\$ 1.40$ & $\$ 1.50$ & 1.60 & I. 70 & & 1.90 \\
\hline & "" & & & 461 & $57 \frac{1}{2}$ & $68:$ & 80 & $9 \div \frac{1}{4}$ & & 2.139 \\
\hline & day.. & $37 \frac{1}{2}$ & I. 5 & $62 \frac{1}{2}$ & I. 75 & 1. $87 \%$ & 2.00 & 2.12 & & 2.37 \\
\hline & days & & 3.0 & & 3.50 & 375 & 40 & 42 & & 4.7 \\
\hline & 6 & & & $87 \frac{1}{2}$ & 5.25 & 562 ? & & 6.271 & & $7.12 \frac{1}{2}$ \\
\hline & "“ & & 6 & & & $7 \cdot 5 c$ & $8 \infty$ & 8.50 & & \\
\hline & " & & 7.5 & 8.121 & 8.75 & ? 37! & Io ro & 10 62 & II.? & 11.875 \\
\hline & 6 & & 9.00 & 9.75 & $10.5^{\circ}$ & 11.25 & 12 on & 12.75 & 13.50 & 14.25 \\
\hline
\end{tabular}




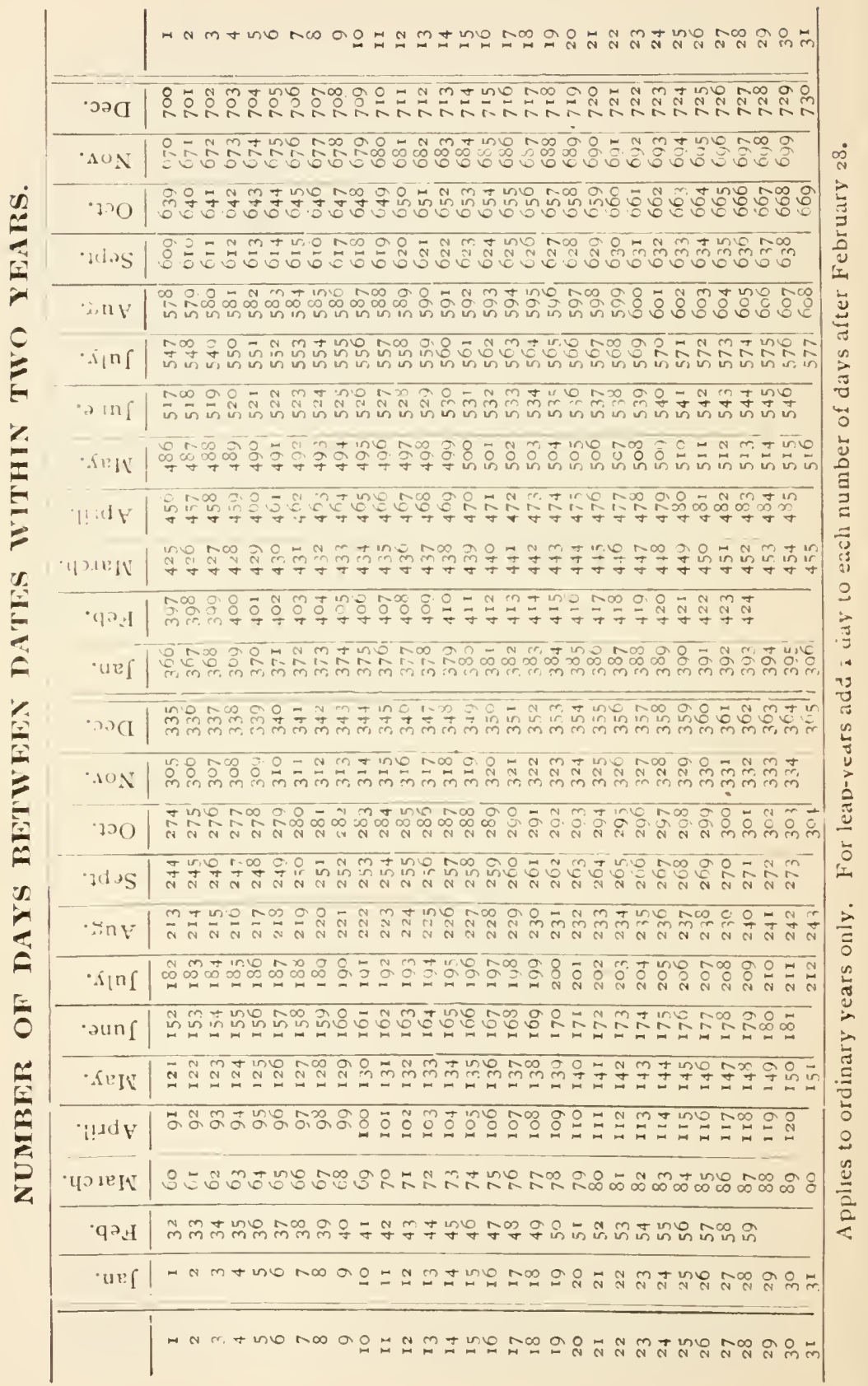




\section{DOMESTIC POSTAGE.}

First-class. Letters ard olher matter, wh lly or partly in writing, and matter sealed or otherwise closed against inspecinoil, 2 cerits for each ounce or fraction thereof.

Post a ards, ard pustal cards, I cent each.

"Drop letter:s," I cent for each ounce or fraction thereof when mailed at post-offices where letter carrier service is not established and at offices where the patrons can not be served by rural or star route carriers.

A "drop letter" is one addressed for delivery at the office where mailed. Letters deposited in boxes along a rural or star route are subject to postage at the rate of 2 cents an ounce or fraction thereuf. There is no drop rate on mail other than letters.

Second-cluss-Lnsealed. Newspapers and periodical publications of the second class, when sent by others than the publizher or a rews agent, I cent for each four ounces or fraction thereof, on each separately addressed copy or packige of unaddressed copies, to be prepaid by stamps afixed.

To be er titled to the rate of I cent for four ounces, copies of rewipapers or periodical publications must be complete. Partial or inconiplete copies are third-class matter.

Third-class-Cnsculed. Printed matter, I cent for each two ounces or fraction thereof, on each individually addressed piece or parcel.

Fourlh-class-Lnsealed. Merchandise, I cent for each ounce or fraction therecf, on eacli individually addressed piece or parcel, except sceds, bulbs, roots, scions, and plants, on which the rate is $I$ cent for each two ounces or fraction thereof.

Conceulcd Litar. Matter of a higher class e ic'osed with matter of a lower class subjects the whole packige to the higher rate.

For knowingly concealing or enclosing any matter of a higher class in that of a lower class, and depositing or causing the same to be deposited in the mails, at a less rate than would be charged for such higher-class matter, the offender is liable to a fine of not more than one hundred dollars.

\section{FOREIGN IOSTAGE.}

The rates of postage applicable to articles for foreign countries are as follows: 
Letters for England, Ireland, Newfoundland, Scotland and Wales

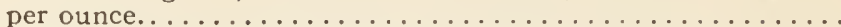

Letters for Germany by direct steamers, per ounce...........

Letters for all other foreign countries, and for Germany when not dispatched by direct steamers:

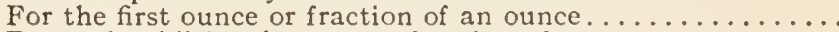

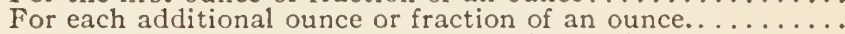

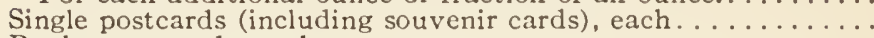

Reply post cards, each..........................

Printed matter of all kinds, for each two ounces or fraction of two

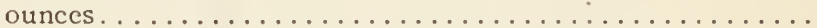

Commercial papers, for the first ten ounces or less..........

For each additional two ounces or fraction of two ounces....

Samples of merchandise, for the first four ounces or less.......

For each additional two ounces or fraction of two ounces....

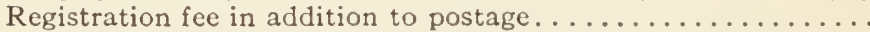

Cents.

2

2

5

3

2

4

I

5

I

2

I

Io

\section{PARCEL Post, For U. S. AND possessions.}

Weight limit, 50 pounds (first and second zones), 20 pounds (other zones). Size, length and girth combined, 72 inches. 4 ozs. or less, I cent an ounce, regardless of distance. Over + ozs. at following rates, a fraction of a pound being considered a full pound.

\begin{tabular}{|c|c|c|c|}
\hline Zone. & Distances. & First Pound. & $\begin{array}{l}\text { Each Addi- } \\
\text { tional Pound. }\end{array}$ \\
\hline $\begin{array}{l}\text { Local..... } \\
\text { First...... } \\
\text { Second.... } \\
\text { Third..... } \\
\text { Fourth... } \\
\text { Fifth .... } \\
\text { Sixth.... } \\
\text { Seventh... } \\
\text { Eighth... }\end{array}$ & 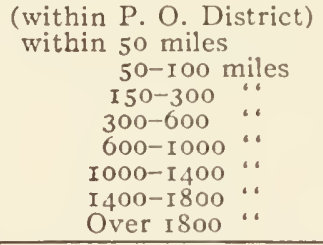 & $\begin{aligned} & 5 \text { cents } \\
& 5 \cdots \\
& 5 \cdots \\
& 6 \cdots \\
& 7 \cdots \\
& 8 \cdots \\
& 9 \cdots \\
& \text { I } \cdots \\
& \text { I } 2 \cdots \\
&\end{aligned}$ & 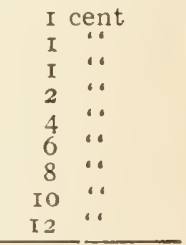 \\
\hline
\end{tabular}

Address of sender, preceded by the word "From," required. Insurance against loss not to exceed $\$ 25,5$ cents extra; and not to exceed $\$ 50$, Io cents extra.

Money Order Fees.-For Money Orders in denominations of $\$ 100$ or less, the following fees are charged: Orders not exceeding $\$ 2.50,3 \mathrm{c}$; over $\$ 2.50$ to $\$ 5,5 \mathrm{c}$; $\$ 5$ to $\$ \mathrm{IO}, 8 \mathrm{c}$; $\$$ io to $\$ 20$, roc.; $\$ 20$ to $\$ 30$, r $2 \mathrm{c}$; $\$ 30$ to $\$ 40$, I 5 c.; $\$ 40$ to $\$ 50$, r $8 \mathrm{c}$; $\$ 50$ to $\$ 60,20 c$; $\$ 60$ to $\$ 75,25 \mathrm{c}$; $\$ 75$ to $\$ 100,30 \mathrm{c}$.

\section{INTERNATIONAL OR FOREIGN MONEY-ORDER FEES.}

For orders of $\$$ Io, or less Ioc. Over $\$ 50$, not exceeding $\$ 60,60 c$. Over $\$ 10$, not exceeding $\$ 20,20 c$. Over $\$ 60$, not exceeding $\$ 70,70 c$. Over $\$ 20$, not exceeding $\$ 30,30 c$. Over $\$ 70$, not exceeding $\$ 80$, 80c. Over $\$ 30$, not exceeding $\$ 40,40 c$. Over $\$ 80$, not exceeding $\$ 90,90 c$. Over $\$ 40$, not exceeding $\$ 50$, 50c. Over $\$ 90$, not exceeding $\$ I 00, \$ I$.

Express Money Orders may be bought of the leading express companies at the following rates: Not over $\$ 2.50,3 \mathrm{c}$; $\$ 2.50$ to $\$ 5,5$ c.; $\$ 5$ to $\$ 10,8 \mathrm{c}$; $\$$ I0 to $\$ 20$, IOc.; $\$ 20$ to $\$ 30$, I 2 c.; $\$ 30$ to $\$ 40, I_{5} \mathrm{C}$; $\$ 40$ to $\$ 50$, I 8 c.; $\$ 50$ to $\$ 60,20 \mathrm{c}$; $\$ 60$ to $\$ 75,25 \mathrm{c}$; $\$ 75$ to $\$ 100,30 c$; over $\$ 100$ at above rates. 


\section{WEIGHTS AND MEASURES.}

\section{CUSTOMARY SISTEM OF WEIGHTS AND MLASUIRES.}

\section{Weights.}

\section{A. AVOIRDUPOIS WEIGHT.}

$$
\text { I ton }=2000 \text { pounds (lbs.) } ;^{*}
$$

I Ib. $=16$ ounces $(\mathrm{oz})=.256 \mathrm{drams}=768$ scruples $=7680$ grains $;$

I oz.

$$
\begin{aligned}
& =16 \text { drams }=48 \text { scruples }=480 \text { grains : } \\
& \text { I dram }=3 \text { scruples }=30 \text { grains: } \\
& \text { I scruple }=\text { } 10 \text { grains. }
\end{aligned}
$$

B. A'OTHECARIES' WEIGHT, FOR DRU'GS.

Ib. $=12$ oz. $=96$ drams $=288$ scruples $=5760$ grains;

I oz. $=8$ drams $=24$ scruples $=480$ grains ;

I dram $=3$ scruples $=60$ grains:

I scruple $=20$ grains.

C. TROY WEIGHT, FOR JEWELS AND PRECIOUS METALS.

$\mathbf{I} \mathbf{b}$. $=12 \mathrm{oz} .=24$ carats $=240$ pennyweight $(\mathrm{dwt})=$.5760 grains ;

$$
\begin{aligned}
& \text { I oz. }=2 \text { carats }=20 \text { dwts. } \quad=480 \text { grains; } \\
& 1 \text { carat }=\text { ro dwts. } \quad=240 \text { grains: } \\
& \text { I dwt. } \quad=24 \text { grains. }
\end{aligned}
$$

\section{Measures.}

\section{A. LINEAR.}

$$
\begin{aligned}
& 1 \text { mile }=8 \text { furlongs }(\text { frlgs. })=80 \text { chains }=32.0 \text { rods }=5280 \text { feet } ; \uparrow \\
& 1 \text { furlong } \quad=\text { io chains }=40 \mathrm{rods}=660 \mathrm{feet}: \\
& \mathbf{1} \text { chain }=4 \text { rods }=66 \text { feet : } \\
& 1 \mathrm{rod}=\mathrm{I} 6 \frac{1}{\frac{1}{3}} \text { feet: } \\
& \text { I chain }=100 \text { links ; } \\
& \text { I link }=7.92 \text { inches; }
\end{aligned}
$$

1 yard $=3$ feet $=36$ inches: I foot $=12$ inches.

B. SURFACE.

I square mile $=640$ acres ;

$$
\begin{aligned}
\mathbf{x} \text { acre } & =\text { ro square chains }=160 \text { sq. rods }=4840 \text { sq. } \mathbf{y} \text { ds. } \\
& =43,560 \text { square feet. }
\end{aligned}
$$




\section{CAPACITY.}

I. DRY MEASURE.

- bushel $=$ the volume of 77.627 lbs. of distilled water at $4^{\circ} \mathrm{C}$.;

$\times$ bushel $=4$ pecks $=8$ gallons $=32$ quarts $=2150.4$ cubic inches ;

$$
\begin{aligned}
& 2 \text { peck }=2 \text { gallons }=8 \text { quarts }=537.6 \text { " " } \\
& 1 \text { gallon }=4 \text { quarts }=268.8 \text { " " } \\
& 1 \text { quart }=67.2 \text { " } 6
\end{aligned}
$$

\section{LIQUID MEASURE.}

1 gailon $=$ the volume of 8.3383822 lbs. $=58,373$ troy grains of distilled

1 gallon $=4$ quarts $=8$ pints $=32$ gills $=231$ cubic inches; water at $4^{\circ} \mathrm{C} .{ }^{*}$

$$
\begin{aligned}
\text { 1 quart }= & 2 \text { pints }=8 \text { gills }=57.75 \text { “ “ } \\
& \text { I pint }=4 \text { gills }=28.88 \text { “ }
\end{aligned}
$$

\section{Metric System of Weights and Measures.}

\section{LINEAR MEASURES.}

1 meter $(\mathrm{m})=$ ro decimeters $(\mathrm{d} m)=$ roo centimeters $(\mathrm{cm})=$ rooo millimetes $(\mathrm{mm})=$. idecameters $(\mathrm{Dm})=$. or Hectometer $(\mathrm{Hm})=. \infty$ r Kilometes $(K \mathrm{~m})=.00$ i Mymeter $(\mathrm{Mm})$.

$1 \mathrm{Mm}=$ 10 $\mathrm{Km}=100 \mathrm{Hm}=1000 \mathrm{Dm}=10,000 \mathrm{~m}$;

I $\mathrm{Km}=$ 10 $\mathrm{Hm}=100 \mathrm{Dm}=1,000 \mathrm{~m}$ :

$$
\text { I } \mathrm{Hm}=10 \mathrm{Dm}=100 \mathrm{~m} \text {; }
$$

I $\mathrm{Dm}=10 \mathrm{~m}$ :

I $\mathrm{m}=10 \mathrm{dm}=100 \mathrm{~cm}=1000 \mathrm{~mm}$;

$$
\begin{aligned}
\mathrm{dm}= & 10 \mathrm{~cm}=100 \mathrm{~mm} ; \\
1 \mathrm{~cm}= & 10 \mathrm{~mm} .
\end{aligned}
$$

3. SURFACE MEASURES.

1 Are $(a)=$ :oo square nueters (sq. m.) $=$. or bectare (ha);

I Are $=\mathrm{I} \mathrm{sq.} \mathrm{Dm.} \mathrm{=} 100$ square m ;

sq. $\mathrm{K} m=100 \mathrm{Ha}=10,000 \mathrm{~A}=1,000,000$ sq. $\mathrm{m}$;

$$
\text { I } \mathrm{Ha}=100 \mathrm{~A}=\text { ro,000 sq. m; }
$$

$$
\text { I } A=\text { roo sq. m. }
$$

\section{MEASURES OF CAPACITY.}

- liter $(1)=$ I cubic decimeter $(\mathrm{cdm})=\mathrm{I}, 000$ cubic centimeters (c. c.) = 0.00 r cubic meter $(\mathrm{cbm})=$ I0 deciliters $(\mathrm{dl})=100$ centiliters $(\mathrm{cl})=.0 \mathrm{z}$ hiectoliter (hl).

$$
\begin{aligned}
1 \mathrm{Hl}=10 \mathrm{Dl}=100 \mathrm{l} & =1,000 \mathrm{dl}=10,000 \mathrm{cl} \\
1 \mathrm{Dl}= & 101=100 \mathrm{dl}=1,000 \mathrm{cl} \\
1 \mathrm{l} & =10 \mathrm{dl}=100 \mathrm{cl}
\end{aligned}
$$

4. WEIGHTS.

r kilogram $(\mathrm{kg})=100$ decagrams $(\mathrm{Dg})=$ rooo grams $(\mathrm{g})$;

I 2 ram $=10$ decigrams $(\mathrm{ag})=100$ centigrams $(\mathrm{cg})=1,000$ milligrams $(\mathbf{m g} \boldsymbol{r}$ t $\operatorname{ton}=1000 \mathrm{Kg}=100,000 \mathrm{Dg}=1,000,000 \mathrm{~g}$;

$$
\begin{array}{rr}
100 \mathrm{Kg}= & 10,000 \mathrm{Dg}= \\
\mathbf{K g}= & 100,000 \mathrm{gg} ;
\end{array}
$$

* I Imperial gallon $=277.274$ cub. inches, or $.16046 \mathrm{cub}$. foot; it equals I.20032, or very nearly I $\mathrm{I}_{\mathrm{g}} \mathrm{U}$. S. liquid gallons. I cub. foot $=1728 \mathrm{cub}$. inches $=7.48$ U. S. liquid gallows $=6.43 \mathrm{U} . \mathrm{S}$. dry gallons $=6.23$ Imperial 


\section{Conversion of U. S. Weights and Measures to Metric, and vice versa.}

LINEAR.

Inches to Millimeters.

$r=25.400 \mathrm{I}$

Meter to Inches.

$I=39.3700$
Feet to Meters. Yards to Meters.

$$
.3048
$$

Meter to Feet. 3.2808

$$
.9144
$$

Meter to Yards.

1.0936
Miles to Kilometers. 1.6094

Kilometer to Miles. .6214

SQUARE.

Sq. Inches to Sq. Centmr.

$=6.452$

Sq. Centime. to sq. in.

$=.1550$
Sq. Feet to Sq. Decimeters. 9.290

Sq. Meters to Sq. Feet. 10.764
Square Yards to Square Meters. .836

Square Meters to Square Yards. I. 196
Acres to Heclares. .4047

Hectares to Acres. 2.47I

CUBIC.

Cubic In. to Cu. Centmr. $=16387$

Cu. Centmrs to Cubic In.

$\mathrm{r}=.0610$
Cubic Feet to

Cubic Meters. .0283

$\mathrm{Cu}$. Decimeters to Cubic Inches.

61.023
Cubic Yards to Cubic Meters. .765

Cubic Meters to Cubic Feet. 35.314
Bushels to Hectoliters. .3524

Cubic Meters to Cubic Yards. s. 308

\section{CAPACITY.}

Fluid Drams

to $\mathrm{Cu}$. Centimeters.

$\mathbf{I}=3.70$

Cu. Centimeters to Fluid Drams.

Fluid Ounces to

Cubic Centimeter. Quarts to Liters. Gallons to Liters.

20. 57

.9464

3.7854

Centiliters to Liters Decaliters to Hectoliters Fluid Ounces. to Quarts. Gallons. to Bushels.
$\mathrm{I}=.27$
.338
I.0567
2.6417
2.8377

\section{WEIGHT.}

Grains to Milligrams.

$$
\mathbf{I}=64.7089
$$

Milligrams to Grains.

$$
r=.01543
$$

Quintals to Founds Av. $=220.46$

Troy Ounces to Grams. 31. 1035 .4536

Kilograms to Pounds Av. 2. 2046

Kilograms to Ounces Troy. 32. 1507 


\section{KILOGRAMS CONVERTED INTO POUNDS AVOIRDUPOIS.}

\begin{tabular}{|c|c|c|c|c|c|c|c|c|c|c|}
\hline Kilos, & 0 & I & 2 & 3 & 4 & 5 & 6 & 7 & 8 & 9 \\
\hline 0.0 &.$\infty 00$ & .022 & .044 & .066 & .088 & . IIo & .132 & - I 54 & .176 & .194 \\
\hline . I & .220 & .243 & .265 & .287 & $\cdot 309$ & .331 & $\cdot 353$ & .375 & .397 & .419 \\
\hline .2 & $.44^{1}$ & .463 & .485 & .507 & .529 & $\cdot 55^{\mathrm{I}}$ & .573 & .595 & .617 & .639 \\
\hline$\cdot 3$ & $.66 \mathrm{I}$ & $.63_{3}$ & .705 & $\cdot 728$ & $.75^{\circ}$ & .772 & .794 & .816 & $.83^{8}$ & .860 \\
\hline .4 & .882 & .904 & .926 & .948 & .970 & .992 & 1.014 & 1.036 & I.058 & 1.080 \\
\hline .5 & 1.102 & I. 124 & 1. 146 & I. I 68 & I. 190 & 1.213 & 1.235 & 1.257 & I. 279 & 1.301 \\
\hline .6 & $1 \cdot 3^{2} 3$ & 1. 345 & 1. $36^{6}$ & 1.389 & I. 4 II & I. 433 & 1.455 & $x+477$ & I . 499 & 1.521 \\
\hline .7 & 1.543 & 1.565 & I. $5^{87}$ & 1. 609 & $1.6_{3} \mathrm{x}$ & I. 653 & 1.676 & I. 698 & 1.720 & 1.742 \\
\hline .8 & 1764 & I. 786 & 1.808 & 1.830 & 1.852 & 1.874 & 1.896 & 1.918 & 1.940 & 1.962 \\
\hline .9 & 1984 & 2.006 & 2.028 & 2.050 & 2.072 & 2.094 & 2.116 & 2.138 & $2.16 \mathrm{I}$ & 2183 \\
\hline
\end{tabular}

POUNDS CONVERTED INTO KILOGRAMS.

\begin{tabular}{c|c|c|c|c|c|c|c|c|c|c}
\hline Pounds. & 0 & 1 & 2 & 3 & 4 & 5 & 6 & 7 & 8 & 9 \\
\hline 0.0 & .000 & .005 & .009 & .014 & .018 & .023 & .027 & .032 & .036 & .041 \\
.1 & .045 & .050 & .054 & .059 & .064 & .068 & .073 & .077 & .082 & .086 \\
.2 & .091 & .095 & .100 & .104 & .109 & .113 & .118 & .122 & .127 & 132 \\
.3 & .136 & .141 & .145 & .150 & .154 & .159 & .163 & .168 & .172 & .177 \\
.4 & .181 & .186 & .191 & .195 & .200 & .204 & .209 & .213 & .218 & .222 \\
.5 & .227 & .231 & .236 & .240 & .245 & .249 & .254 & .259 & .263 & .208 \\
.6 & .272 & .277 & .281 & .286 & .290 & .295 & .299 & .304 & .308 & .313 \\
.7 & .318 & .322 & .327 & .331 & .336 & .340 & .345 & .349 & .354 & .358 \\
.8 & .363 & .367 & .371 & .376 & .381 & .386 & .390 & .395 & .399 & .404 \\
.9 & .408 & .413 & .417 & .422 & .426 & .431 & .435 & .440 & .445 & .449 \\
\hline
\end{tabular}

INCHES REDUCED TO DECIMALS OF A FOOT. (TRAITWINE.)

\begin{tabular}{|c|c|c|c|c|c|c|c|c|c|}
\hline Ins. & Foot. & Ins. & Foot. & Ins. & Foot. & Ins. & Foot. & Ins. & Foot. \\
\hline $\begin{array}{l}\frac{1}{32} \\
18 \\
16 \\
1 / 8 \\
1 / 4 \\
3 / 8 \\
1 / 2 \\
5 / 8 \\
3 / 4 \\
7 / 8\end{array}$ & $\begin{array}{l}.0026 \\
.0052 \\
.0104 \\
.0208 \\
.0313 \\
.0417 \\
.0521 \\
.0625 \\
.0729\end{array}$ & $\begin{array}{l}1 \\
116 \\
11 / 4 \\
138 \\
11 \% 8 \\
15 \% 8 \\
13 / 4 \\
1 \% 8\end{array}$ & $\begin{array}{l}.0833 \\
.0938 \\
.1042 \\
.1146 \\
.1250 \\
.1354 \\
.1458 \\
.1563\end{array}$ & $\begin{array}{l}2 \\
21 / 2 \\
3 \\
31 / 2 \\
41 / 2 \\
41 / 2 \\
5 \\
51 / 2\end{array}$ & $\begin{array}{r}.1667 \\
.2083 \\
.2500 \\
.2917 \\
.3333 \\
.3750 \\
.4167 \\
.4583\end{array}$ & $\begin{array}{l}6 \\
61 / 2 \\
7 \\
71 / 2 \\
8 \\
81 / 2 \\
9 \\
91 / 2\end{array}$ & $\begin{array}{l}.5000 \\
.5417 \\
.5833 \\
.6250 \\
.6667 \\
.7083 \\
.7500 \\
.7917\end{array}$ & $\begin{array}{l}10 \\
101 / 2 \\
11 \\
111 / 2 \\
12\end{array}$ & $\begin{array}{r}.8333 \\
.8750 \\
.9167 \\
.9583 \\
1.0000\end{array}$ \\
\hline
\end{tabular}

OUNCES REDUCED TO DECIMALS OF A POUND.

$$
\begin{aligned}
& \text { г } \mathrm{oz}_{0}=.06 \mathrm{lb} \text {. } \\
& \text { 2 " }=.13 " \text { " } \\
& 3 "=.19 " \\
& 4 "=.25 " 6 \\
& 5 " \text { " } 6=.31 \text { 1 } 6 \\
& 6=.38 \text { " } \\
& \begin{array}{l}
7 " \text { " } \\
8=.43 \%
\end{array}
\end{aligned}
$$$$
\begin{array}{rl}
90 \mathrm{oz} & =.56 \mathrm{lb} \\
10 & =.63 \\
11 & 0.69 \\
12 & =.69 \\
13 & =.75 \% \\
14 & =.81 \\
14 & =.88 \\
15 & =.94 \\
16 & 6
\end{array}
$$ 
WVEGHT AND MEASURE CONVERSION TABIE.

\begin{tabular}{|c|c|c|c|c|c|c|c|c|}
\hline 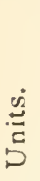 & 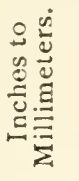 & 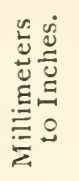 & 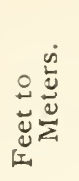 & 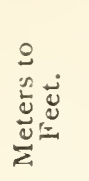 & 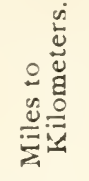 & 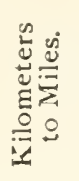 & 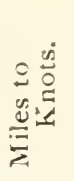 & 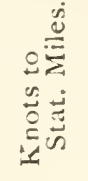 \\
\hline I & 25.4 & .0394 & .305 & 3.28 & 1.609 & $.62 \mathrm{I}$ & .868 & I. I 53 \\
\hline 2 & 50.8 & .0787 & .610 & $6.5^{6}$ & 3.219 & I. 24.3 & 1.735 & $2 \cdot 306$ \\
\hline 3 & 76.2 & . II $18 \mathrm{I}$ & .914 & 9.84 & 4.828 & 1.864 & 2603 & 3.458 \\
\hline 4 & 101.6 & .1575 & I. 219 & 13.12 & 6.437 & 2.486 & 3.470 & $4.6 \mathrm{II}$ \\
\hline 5 & 127.0 & . 1069 & I. 524 & 16.40 & 8.047 & 3.107 & $4 \cdot 33^{8}$ & $5 \cdot 7^{6} 4$ \\
\hline 6 & I 52.4 & .2362 & 1. 820 & 19.69 & 9.656 & 3.728 & 5.205 & 6.917 \\
\hline 7 & 177.8 & .2756 & 2.134 & 22.97 & II.265 & $4 \cdot 350$ & 6.073 & 8.070 \\
\hline 8 & $20 i .2$ & .3150 & $2.43^{8}$ & 2625 & I 2.875 & 4.971 & 6.940 & 9.222 \\
\hline 9 & 228.6 & $\cdot 3543$ & 2.743 & 29.53 & $14.4^{84}$ & $5 \cdot 593$ & 7.808 & 10.375 \\
\hline
\end{tabular}

\begin{tabular}{|c|c|c|c|c|c|c|c|c|}
\hline & 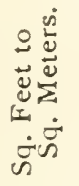 & 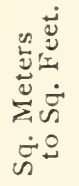 & 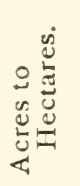 & 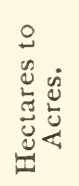 & 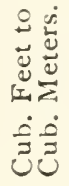 & 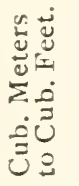 & 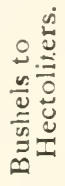 & 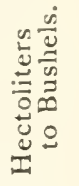 \\
\hline$I$ & .0929 & $10.7^{6}$ & .405 & 2.47 & .028 & $35 \cdot 3$ & .35 & 2.84 \\
\hline 2 & . 1858 & $2 \mathrm{x} .53$ & .809 & 4.94 & .057 & 70.6 & .70 & 5.68 \\
\hline 3 & .2787 & $3^{2} .29$ & I. $2 I_{4}$ & $7 \cdot 4 \mathrm{I}$ & .085 & 105.9 & 1.06 & $8.5 \mathrm{I}$ \\
\hline 4 & .3716 & 43.06 & 1.6́rg & 9.88 & . II 3 & 141.3 & $1.4^{\mathrm{I}}$ & II. 35 \\
\hline 5 & .4645 & 53.82 & 2.024 & 12. 36 &. $\mathrm{I}_{42}$ & 176.6 & I. 76 & $\mathrm{I}_{4} \mathrm{Ig}$ \\
\hline 6 & .5574 & $64 \cdot 5^{8}$ & 2.428 & 14.83 & . I70 & 211.0 & 2. II & 17.03 \\
\hline 7 & .6503 & $75 \cdot 35$ & 2.833 & $17 \cdot 3^{\circ}$ & . 193 & 247.2 & 2.47 & I9.86 \\
\hline 8 & .7432 & 86.11 & 3.238 & 19.77 & .226 & 282.5 & 2.82 & 22.70 \\
\hline 9 & .8361 & 96.88 & 3.642 & 22.24 & .255 & 317.8 & 3.17 & $25 \cdot 54$ \\
\hline
\end{tabular}

\begin{tabular}{|c|c|c|c|c|c|c|c|c|}
\hline & 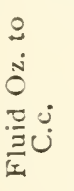 & 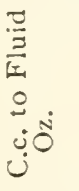 & 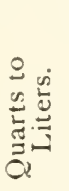 & 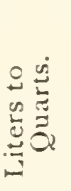 & 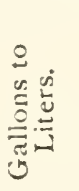 & 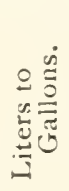 & 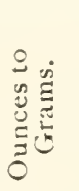 & 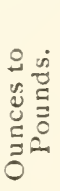 \\
\hline I & 29.6 & $.33^{8}$ & .95 & 1. 06 & 3.79 & .26 & 28.3 & .063 \\
\hline 2 & 59. I & .676 & 1.89 & 2.11 & 7.57 & .53 & 56.7 & .125 \\
\hline 3 & 88.7 & 1.014 & 2.84 & 3.17 & I I. 36 & .79 & 85.1 & .188 \\
\hline 4 & 118.3 & I. 352 & $3 \cdot 79$ & 4.23 & $\mathrm{I}_{5} . \mathrm{I}_{4}$ & 1.06 & 113.4 & .250 \\
\hline 5 & 147.9 & 1.690 & 4.73 & 5.28 & 18.92 & $1.3^{2}$ & 141.8 & $.3^{1} 3$ \\
\hline 6 & 177.4 & 2.028 & 5.68 & 6.34 & 22.71 & I. 59 & 170.1 & .375 \\
\hline 7 & 207.0 & $2 \cdot 3^{66}$ & 6.62 & $7 \cdot 4^{\circ}$ & 26.50 & I. 85 & 198.5 & $.43^{8}$ \\
\hline 8 & 236.6 & 2.704 & $7 \cdot 57$ & 8.45 & 30.28 & $2.1 I$ & 226.8 & .500 \\
\hline 9 & 266. I & $3 \cdot 04^{2}$ & 8.52 & $9 \cdot 5^{1}$ & 34.07 & $2.3^{8}$ & $255 . I$ & $.5 \sigma_{3}$ \\
\hline
\end{tabular}




\section{TABLE OF RECIPROCALS OF NUMBERS.}

The reciprocal of a number is the quantity obtained by dividing one by that number.

\begin{tabular}{|c|c|c|c|c|c|c|c|}
\hline No. & $\begin{array}{l}\text { Recip- } \\
\text { rocal. }\end{array}$ & No. & $\begin{array}{l}\text { Recip- } \\
\text { rocal. }\end{array}$ & No. & $\begin{array}{l}\text { Recip- } \\
\text { rocal. }\end{array}$ & No. & $\begin{array}{l}\text { Recip- } \\
\text { rocal. }\end{array}$ \\
\hline I & 1.00000 & 26 & .03846 & $5 \mathrm{I}$ & $.0196 r$ & 76 & .01316 \\
\hline 2 & 0.50000 & 27 & .03704 & $5^{2}$ & .01923 & 77 & .01299 \\
\hline 3 & .33333 & 28 & $.0357 \mathrm{I}$ & 53 & .01887 & 78 & .01282 \\
\hline 4 & .25000 & 29 & .03448 & 54 & .01852 & 79 & .01266 \\
\hline 5 & .20000 & 30 & .03333 & 55 & .01818 & 80 & .01250 \\
\hline 6 & . 16667 & $3^{I}$ & .03226 & 56 & .01786 & 81 & .01235 \\
\hline 7 & .14286 & $3^{2}$ & .03125 & 57 & .01754 & 82 & .01220 \\
\hline 8 & .12500 & 33 & .03030 & $5^{8}$ & .01724 & 83 & .01205 \\
\hline 9 & - IIIII & 34 & $.0204 \mathrm{I}$ & 59 & .01605 & $8+$ & .01190 \\
\hline 10 & .10000 & 35 & .02857 & 60 & .01667 & 85 & .01176 \\
\hline I I & $.0909 \mathrm{I}$ & 36 & .02778 & 61 & .01639 & 86 & $.011 \sigma_{3}$ \\
\hline 12 & .08333 & 37 & .02703 & 62 & .01613 & 87 & .01149 \\
\hline 13 & .07692 & 38 & .02632 & $6_{3}$ & .01587 & 88 & .01136 \\
\hline 14 & .07143 & 39 & $.025_{5} 6$ & 64 & $.015 \sigma_{3}$ & 89 & .01124 \\
\hline 15 & .06667 & 40 & .02500 & 65 & .01538 & 90 & .01 III \\
\hline 16 & .06250 & $4 I$ & .02439 & 66 & .01515 & $9 t$ & .01099 \\
\hline 17 & .05882 & 42 & .02381 & 67 & .01493 & $9^{2}$ & .01087 \\
\hline 18 & .05556 & 43 & .02326 & 68 & .01471 & 93 & .01075 \\
\hline 19 & $.0526_{3}$ & 44 & .02273 & 69 & .01449 & 94 & .01064 \\
\hline 20 & .05000 & 45 & .02222 & 70 & .01429 & 95 & .01053 \\
\hline $2 \mathrm{I}$ & .04762 & 46 & .02174 & 71 & .01408 & 96 & .01042 \\
\hline 22 & .04545 & 47 & .02128 & 72 & .01389 & 97 & .01031 \\
\hline 23 & .04348 & 48 & .02083 & 73 & .01370 & 98 & .01020 \\
\hline 24 & .04167 & 49 & .02041 & 74 & .01351 & 99 & . огіo \\
\hline 25 & $.0,4000$ & 50 & .02000 & 75 & .01333 & 100 & .01000 \\
\hline
\end{tabular}


COMPARISONS OF FAHRENHEIT, CFNTIGRADE (CETSIES), AND REIUMUR THERMOMETER SCAIIES.

\begin{tabular}{|c|c|c|c|c|c|}
\hline $\begin{array}{c}\text { Fahren- } \\
\text { heit. }\end{array}$ & $\begin{array}{l}\text { Centi- } \\
\text { grade. }\end{array}$ & Réaumur. & $\begin{array}{c}\text { Fahren- } \\
\text { heit. }\end{array}$ & $\begin{array}{l}\text { Cenil- } \\
\text { grade. }\end{array}$ & Réaumur. \\
\hline+212 & +100 & $\div 80$ & +158 & +70 & +56 \\
\hline 211 & $99 \cdot 44$ & $79 \cdot 56$ & 157 & 69.44 & $555^{6}$ \\
\hline 210 & 98.89 & 79.11 & 156 & 68.89 & 55.11 \\
\hline 209 & 98.33 & 78.67 & 155 & $68 \cdot 3.3$ & 54.67 \\
\hline 208 & $97 \cdot 7^{8}$ & 78.22 & 154 & $67 \cdot 7^{8}$ & $54 \cdot 22$ \\
\hline 207 & 9722 & $77 \cdot 78$ & 153 & $67 \cdot 22$ & $53 \cdot 78$ \\
\hline 206 & 96.67 & $77 \cdot 33$ & 152 & 66.67 & $53 \cdot 33$ \\
\hline 205 & 96.11 & 76.89 & $15 \mathrm{I}$ & 66.11 & 52.89 \\
\hline 204 & 95.55 & 76.44 & 150 & $65 \cdot 55$ & $52 \cdot 44$ \\
\hline 203 & 95 & 76 & 149 & 65 & 52 \\
\hline 202 & $94 \cdot 44$ & $75 \cdot 5^{6}$ & 148 & $\epsilon_{4} \cdot 44$ & $5 I \cdot 5^{6}$ \\
\hline 201 & 9389 & 75.11 & 147 & 63.89 & $5 I \cdot 11$ \\
\hline 200 & 9333 & 74.67 & $\mathrm{I}+6$ & 6333 & 50.07 \\
\hline 199 & 02.78 & $74 \cdot 22$ & 145 & $62 \cdot 78$ & 50.22 \\
\hline 199 & 02.22 & $73 \cdot 73$ & 144 & 62.22 & $49 \cdot 78$ \\
\hline I 97 & 91.67 & $73 \cdot 33$ & 143 & $\begin{array}{ll}61 & 67\end{array}$ & 49.33 \\
\hline 190 & 91.11 & 7289 & 142 & $6 \mathrm{I} . \mathrm{I} \mathbf{I}$ & 48.89 \\
\hline 10,5 & 00.55 & 72.44 & $14 I$ & $60 \cdot 5.5$ & $4^{8} \cdot 44$ \\
\hline 194 & ou & 72 & I 40 & 60 & $4^{8}$ \\
\hline 193 & $89 \cdot 4 t$ & $71 \cdot 5^{6}$ & 139 & $59 \cdot 44$ & $47 \cdot 56$ \\
\hline 192 & 88.89 & 71.11 & $13^{8}$ & 58.89 & 47.11 \\
\hline$I, I$ & 88.33 & 70.67 & 137 & $5^{8} \cdot 33$ & 40.67 \\
\hline 190 & $87 \cdot 78$ & 70.22 & $13^{6}$ & 5778 & 46.22 \\
\hline 189 & 87.22 & $69 \cdot 7^{8}$ & 135 & 57.22 & $45 \cdot 78$ \\
\hline 188 & 86.67 & $60 \cdot 33$ & I 34 & $5^{6} .67$ & $45 \cdot 33$ \\
\hline 187 & 86.11 & 68.89 & 133 & 56.11 & 44.89 \\
\hline 186 & $85 \cdot 55$ & 6844 & $1.3^{2}$ & $55 \cdot 55$ & $44 \cdot 44$ \\
\hline 185 & 85 & 68 & 131 & 55 & 44 \\
\hline 134 & $84 \cdot 44$ & $67 \cdot 5^{6}$ & $I_{50}$ & $54 \cdot 44$ & $43 \cdot 56$ \\
\hline 183 & 8,39 & 67.111 & 129 & 53.89 & 43 . I I \\
\hline 182 & 83.33 & 66.67 & I 28 & $53 \cdot 33$ & 42.67 \\
\hline $18 i$ & $82 \cdot 78$ & 66.22 & 127 & $52 \cdot 78$ & 42.22 \\
\hline 180 & 82.22 & $6_{5} \cdot 78$ & I 26 & $5^{2} \cdot 22$ & $4 I \quad 78$ \\
\hline 179 & 81.67 & $65 \cdot 33$ & I 25 & 51.67 & $41 \cdot 33$ \\
\hline 178 & 81.11 & 64.89 & 124 & 51.11 & 40.89 \\
\hline 177 & 80.55 & $64 \cdot 44$ & 123 & $50 \cdot 55$ & 40.44 \\
\hline 176 & 80 & 64 & 122 & 50 & 40 \\
\hline 175 & $79 \cdot 44$ & $63 \cdot 5^{6}$ & I 2 I & 49.44 & 3956 \\
\hline $17+$ & 7889 & 63.11 & 120 & 48.80 & 32. II \\
\hline 173 & 78.33 & 62.67 & 119 & $48: 33$ & 38.67 \\
\hline 172 & $77 . ; 8$ & 62.22 & 118 & $47 \cdot 7^{8}$ & $3^{8} .22$ \\
\hline 171 & $77 \cdot 22$ & $6 \mathrm{I} \cdot 78$ & 117 & $47 \cdot 22$ & $37 \cdot 7^{8}$ \\
\hline 170 & 76.67 & $6 \mathrm{I} \cdot 23$ & 116 & 46.67 & $37: 3$ \\
\hline I09 & 76.11 & 60.89 & 115 & $4^{0} .11$ & 36.89 \\
\hline I 68 & $75 \quad 55$ & 60.44 & 114 & $45 \cdot .55$ & 36.44 \\
\hline 167 & 75 & 60 & 113 & 45 & $3^{6}$ \\
\hline 166 & $74 \cdot 44$ & $59 \cdot 50 ́$ & 1 I 2 & $44 \cdot 44$ & $35 \quad 56$ \\
\hline 165 & 7389 & 50.11 & 111 & 4380 & 35.11 \\
\hline 164 & $72 \cdot 33$ & 5867 & I 10 & 43.33 & 34.67 \\
\hline $\mathrm{I}_{3}$ & 7278 & 58.22 & 10) & $4^{\prime} \cdot 7^{8}$ & $34 \quad 22$ \\
\hline 162 & 71.23 & $57 \cdot 7^{9}$ & $1 \div 8$ & 42.22 & $3 i \cdot 7$ \\
\hline $16 \mathrm{i}$ & 71.67 & $57 \cdot 33$ & $10 ?$ & +167 & $33 \cdot 33$ \\
\hline 160 & 71.11 & 50.89 & 106 & $4 I .11$ & 3289 \\
\hline 159 & 70.55 & 56.47 & 105 & 40.55 & $3^{2} \cdot 44$ \\
\hline
\end{tabular}


COMPARISONS OF HAHRENHGIT, CENTIGRADE (CELSIUS), AND REAUMUR THERMOMETER SCALES. - Continued.

\begin{tabular}{|c|c|c|c|c|c|}
\hline $\begin{array}{c}\text { Fahren- } \\
\text { heit. }\end{array}$ & $\begin{array}{l}\text { Centi- } \\
\text { grade. }\end{array}$ & Réaumur. & $\begin{array}{c}\text { Fahren- } \\
\text { helt. }\end{array}$ & $\begin{array}{l}\text { Centi- } \\
\text { grade. }\end{array}$ & Réaumur \\
\hline+104 & +40 & +32 & +50 & +10 & +8 \\
\hline 103 & 39.44 & $31 \cdot .56$ & 49 & 9.44 & $7 \cdot 56$ \\
\hline 102 & $3^{8.89}$ & $3 \mathrm{I} . \mathrm{II}$ & 48 & 8.89 & 7.11 \\
\hline IOI & 38.33 & 3०. 67 & 47 & 8.33 & 6.67 \\
\hline 100 & 37.78 & 30.22 & $4^{6}$ & $7 \cdot 78$ & 6.22 \\
\hline 99 & 37.22 & 29.78 & 45 & 7.22 & $5 \cdot 78$ \\
\hline 98 & 36.67 & $29 \cdot 33$ & 44 & 6.67 & $5 \cdot 33$ \\
\hline 97 & $3^{6.11}$ & 28.89 & 43 & $6.1 \mathrm{I}$ & 4.89 \\
\hline 96 & 35.55 & 28.44 & 42 & $5 \cdot 55$ & 4.44 \\
\hline 95 & 35 & 28 & $4 \mathrm{I}$ & 5 & 4 \\
\hline 94 & $34 \cdot 44$ & $27 \cdot 56$ & 40 & $4 \cdot 44$ & $3 \cdot 56$ \\
\hline 93 & 33.89 & 27.11 & 39 & 3.89 & $3.1 \mathrm{I}$ \\
\hline 92 & $33 \cdot 33$ & 26.67 & 38 & $3 \cdot 33$ & 2.67 \\
\hline $9 \mathrm{I}$ & $3^{2} .78$ & 26.22 & 37 & 2.78 & 2.22 \\
\hline 90 & 32.22 & $25 \cdot 7^{8}$ & 36 & 2.22 & 1.78 \\
\hline 89 & 31.67 & $25 \cdot 33$ & 35 & 1. 67 & 1. 33 \\
\hline 88 & 31.11 & 24.89 & 34 & I.1 I & 0.89 \\
\hline 87 & jo. 5.5 & $24 \cdot 44$ & 33 & 0.55 & 0.44 \\
\hline 86 & $3^{\circ}$ & 24 & $3^{2}$ & 0 & o \\
\hline 85 & 29.44 & $23 \cdot 56$ & 31 & -0.55 & -0.44 \\
\hline 84 & $2^{2} .89$ & 23.11 & 3० & I. II & 0.89 \\
\hline 83 & 28.33 & 2267 & 29 & 1.67 & 1.: 3 \\
\hline $\mathrm{Z}_{2}$ & 27.78 & $22 \quad 22$ & 28 & 2.22 & 1.78 \\
\hline 81 & 2722 & 2178 & 27 & 2.78 & 2.22 \\
\hline 80 & 26.67 & $21 \cdot 33$ & 26 & $3 \cdot 33$ & 2.67 \\
\hline 79 & 26. II & 20.89 & 25 & 3.89 & 3.11 \\
\hline $7^{8}$ & 25.55 & 20.44 & 24 & 4.44 & $3 \cdot 56$ \\
\hline 77 & 25 & 20 & 23 & 5 & 4 \\
\hline $7^{6}$ & 24.44 & 19.56 & 22 & 5.55 & 4.44 \\
\hline 75 & 23.89 & 19.11 & 21 & 6.11 & 4.89 \\
\hline 74 & 23.33 & 18.67 & 20 & 6.67 & 5.33 \\
\hline 73 & 22.78 & 18.22 & 19 & 7.22 & 5.78 \\
\hline $7^{2}$ & 22.22 & 17.78 & 18 & 7.78 & 6.22 \\
\hline 71 & 2167 & $17 \cdot 33$ & I 7 & 833 & 6.67 \\
\hline 70 & 2 I.I I & I689 & 16 & 8.89 & $7.1 \mathrm{I}$ \\
\hline 69 & 20.55 & 16.44 & I5 & $9 \cdot 44$ & 7.56 \\
\hline 68 & 20 & 16 & 14 & Io & 8 \\
\hline 67 & 19.44 & 15.56 & 13 & 10.55 & 8.44 \\
\hline 66 & I8.89 & 15.11 & 12 & I I. I I & 8.89 \\
\hline 65 & 18.33 & 14.67 & II & II. 67 & 9.33 \\
\hline 64 & 17.78 & $I_{4} .22$ & 10 & 12.22 & 9.78 \\
\hline 63 & 17.22 & $13 \cdot 78$ & 9 & 12.78 & 10 22 \\
\hline 62 & 16.67 & I3. 33 & 8 & 13.33 & 10. 67 \\
\hline $6 I$ & 16.11 & 12.89 & 7 & 13.89 & II.II \\
\hline 60 & 15.55 & 12.44 & 6 & 14.44 & 11.56 \\
\hline 59 & $\mathrm{I}_{5}$ & 12 & 5 & 15.00 & 12 \\
\hline $5^{8}$ & 14.44 & II. 56 & 4 & I 5.55 & 12.44 \\
\hline 57 & $I_{3} .89$ & I I . I I I & 3 & $\mathbf{I 6 . 1} \mathbf{I}$ & 12.89 \\
\hline $5^{6}$ & I 3.33 & 10. 67 & 2 & 16.67 & 13.33 \\
\hline 55 & 12.78 & 10.22 & I & 17.22 & 13.78 \\
\hline 54 & 1222 & 9.78 & 0 & I7. 78 & 14.22 \\
\hline 33 & โ1. 67 & 9.33 & $-I$ & 18.33 & 14.67 \\
\hline 52 & II. I I & 8.89 & 2 & 18.89 & 15 II \\
\hline $5 I$ & Io. 55 & 8.44 & 3 & 19.44 & $15 \cdot 5^{6}$ \\
\hline
\end{tabular}


COMPAIISONS OF FAHRFNHEET, CENTIGRAIE (CLISIUS), AND REAUMUR THERMOMETER SCALES-continued.

\begin{tabular}{|c|c|c|c|c|c|}
\hline $\begin{array}{c}\text { Fahren- } \\
\text { heit. }\end{array}$ & $\begin{array}{l}\text { Centi- } \\
\text { grade. }\end{array}$ & Réaumur. & $\begin{array}{c}\text { Fohren- } \\
\text { heit. }\end{array}$ & $\begin{array}{l}\text { Centi- } \\
\text { grade. }\end{array}$ & Réaumur. \\
\hline-4 & -20 & -16 & -23 & -30.55 & -24.44 \\
\hline 5 & 20.55 & I 6.44 & 24 & 31.11 & 24.89 \\
\hline 6 & 21.11 & 16.89 & 25 & 3167 & $25 \cdot 33$ \\
\hline 7 & 21.67 & 17.33 & 26 & 32.22 & 25.7 \\
\hline 8 & 22.22 & $17 \cdot 78$ & 27 & $3^{2} \cdot 70^{\circ}$ & 26.22 \\
\hline$c$ & 22.78 & I 8.22 & 28 & $33 \cdot 33$ & 26.67 \\
\hline 10 & $23 \cdot 33$ & I 8.67 & 29 & 33.69 & 27.11 \\
\hline II & 23.89 & 19.11 & 30 & $34 \cdot 2 t$ & $27 \cdot 56$ \\
\hline 12 & 24.14 & 19.56 & 31 & 35 & 28 \\
\hline 3 & $: 5$ & 20 & $3^{2}$ & $35 \cdot 55$ & 28.44 \\
\hline 14 & 25.55 & 20.44 & 33 & 36. I & 28.89 \\
\hline I5 & 26.11 & 20.89 & 34 & $3^{6.67}$ & $29 \cdot 33$ \\
\hline 16 & 26.67 & $21 \cdot 33$ & 35 & 37.22 & 29.78 \\
\hline 17 & 27.22 & $21 \cdot 78$ & $3^{6}$ & $37 \cdot 79$ & 30.22 \\
\hline 18 & $27 \cdot 78$ & 22.22 & 37 & 38.3 & 30.67 \\
\hline 19 & 28.33 & 22.67 & $3^{8}$ & 38.8 & 31 . II \\
\hline 20 & 28.89 & 23.11 & 39 & $39 \cdot 44$ & $21 \cdot 5^{6}$ \\
\hline 21 & 29.44 & $23 \cdot 56$ & 40 & 40 & 32.00 \\
\hline 22 & 30 & 24 & & & \\
\hline
\end{tabular}

Formula for Converting Degrees Centigrado to Fahrenheit, and vice versa:

$$
\begin{aligned}
& n^{\circ} \mathrm{C}_{0}=\left(\frac{9 n^{\circ}}{5}+32\right)^{\circ} \mathrm{F} \cdot ; \\
& n^{\circ} \mathrm{F}_{0}=\left(\frac{5\left(n^{\circ}-3-\right)}{9}\right) \mathrm{C} .
\end{aligned}
$$

For Degrees Kéumur, substitute 4 for the figure 5 in the preceding formulas. 


\section{GOVERNMENT IAND MHASURES.}

In the system of government survey, lines running north and south are drawn parallel to a fixed line (principal meridian) at a distance of six miles apart; these are called range lines. At right angles with these, other parallel lines (town lines) are drawn, which then run east and west. The two sets of lines form squares containing 36 square miles each, called townshifs. A certain number of townships form a counly. Each square mile of a township is called a setion, containing 6 fo acres, and these are numbered regularly i to 36 , commencing at the northeast corner, as shown in the accompanying diagram. Section 16 in each township is set apart for school purposes.

Sections are divided by lines running north and south, and east and west, into quarter sections, designated as the northeast quarter, northwest quarter, southwest quarter, and south-east quarter of the section. These quarters contain 160 acres of land each, and are again divided into quarters, each containing forty acres, which is the smallest sub-division recognized in government survey. Lands are usually sold in tracts of forty acres, or a multiple thereof, except in case of land bordering on lakes, which are fractional sections and may contain more or less than forty acres. Thesc are called gozernment lots.

TOWNSHJP

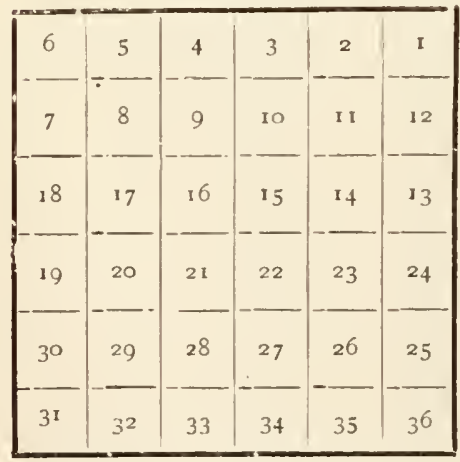

SECIION.

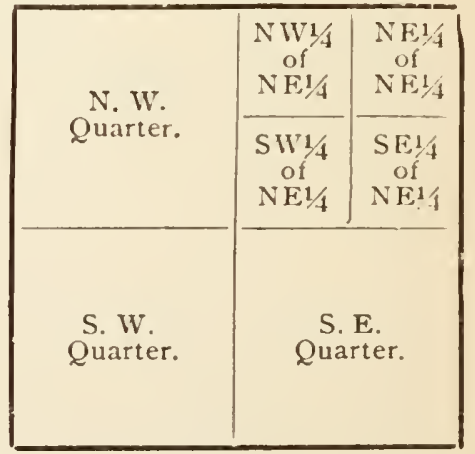

The description of a fo-acre lot would then, for example, read as follows: The northeast quarter of the northeast quarter of section $t$ in township 24 north, range 7 west. 


\section{TO MEASURE CORN ON THE COB IN CRIBS.}

(WARING.)

\section{When the Crib is Equilateral.}

Rule.-Multiply the length in inches by the breadth in inches, and that again by the height in inches, and divide the product by $27+8$ (the number of cubic inches in a heaped bushel), and the quotient will be the number of bushels of ears. Take two thirds of the quotient for the number of bushels of shelled corn.

Example.-Required the number of bushels of shelled corn contained in a crib of ears, $15 \mathrm{ft}$. long by $5 \mathrm{ft}$. wide and $\mathrm{to} \mathrm{ft}$. high.

Solution: ISo in. (length) $\times 60$ in. (width) $\times 120$ in. (height) $=1,296,000 \div 2748=471.6$ heaped bushels, two thirds of which is 314.6 bushels, shelled.

When the Crib is Flared at the Sides.

Multiply half the sum of the top and bottom widths in inches by the perpendicular height in inches, and that again by the length in inches, and divide the product by 2745; the quotient will be the number of heaped bushels of cars. Take twothirds of the quotient for the number of bushels of shelled corn.

\section{HAY AND S'TRAW IN MOWS OR S'TACKS.}

Four hundred and fifty cubic feet of hay is roughly estimated as a ton, but there is great variation in the ratio of wcight to volume, ranging from less than 400 to $500 \mathrm{cu} . \mathrm{fl}$, according to the kind of hay, time of cutting, and height of mow or stack. In general, the finer the stalk of the plart, and the larger the mow, the heavier the hay; also, of course, the more closely packed in putting away, and the nearer the bottom of the mow the heavier. Grass allowed to stand till nearly ripe before cutting will be the lighter; loose hay in loft will take toward 500 cubic feet to the ton: in case of timothy hay about 420 , and in case of clover hay, about 500 cubic feet will makc a ton. One ton of straw will measure 600-rooo cubic feet, according to kind of straw and length of time in stack or mow. The longer the time in stack, the smaller the number of cubic feet per ton.

In estimating by measurement, multiply together the figures representing the length, width, and height of hay, and 
divide the product by the number of feet in a ton. For example, if the hay is $40 \mathrm{ft}$. long, $16 \mathrm{ft}$. wide, and $18 \mathrm{ft}$ from the bottom to the top of the mow, and the bulk agreed is $450 \mathrm{cub}$. $\mathrm{ft}$. to the ton, the mow will contain $40 \times 16 \times 18$. which equals II,520 cub. ft.; II,520 divided by 450 equals 25.6 , or $25 \frac{3}{5}$ tons.

The following table is from the American Agriculturist

'Table for Finding the Value of Hay.

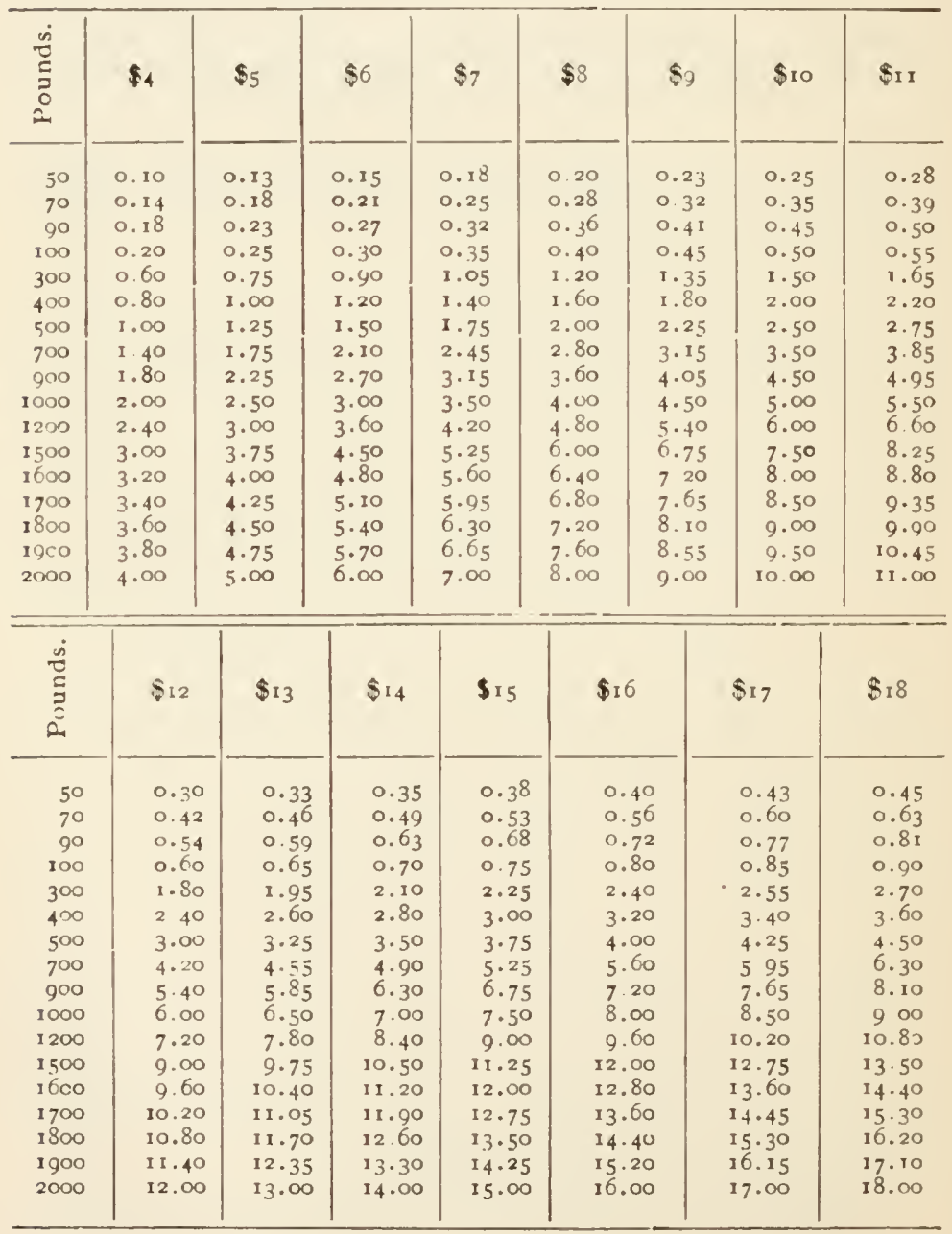


Annual. The price perton of 2000 lbs. being known, it is eas $y$ to find the value of any fraction of a ton at $\$+$ to $\$$ is per ton If a farmer has 1565 lbs of hay on his wagon, and the dealer has bought it at $\$ 7$ per ton, he finds by looking across the table from I 500 lbs. to the column at the top of which is $\$ 7$, that the value of 1500 lbs, at $\$ 7$ is $\$ 5.25$, the value of $601 \mathrm{bs}$. 2 I cents, and the value of 5 lbs. 2 cents, making a total of $\$ 5 \cdot 48$.

To find the value of any fraction of a ton at $\$ 7.40, \$ 7.60$, $\$ 7.80$, etc., find the value at $\$ 7$ and add to it one tenth the value at $\$ 4, \$ 6, \$ 8$, etc.

\section{STRENGTH OF HEMP ROPES.}

Hemp rope, I in. in circumference, is calculated to sustain a weight of 200 lbs.; $\mathrm{I} \frac{1}{2}$ in., 450 lbs.; 2 in., 800 !bs.; $2 \frac{1}{2}$ in., I250 lbs.; 3 in., I 800 lbs.; 4 in., 3200 lbs.; 5 in., 5000 lbs.; 6 in., 7200 lbs. Hemp is considered twice as strong as manila, and wire rope twice as strong as hemp. (Yearbook U. S. Dept. Agric.)

The diameters corresponding to the circumferences given are, in the preceding order: .318,.477,.636,.795,.955, I.27, I.59, and I.9I inches.

\section{'THE STRENG'TH OF MANILA AND WIRE ROPES. (Cornell Univ.)}

\begin{tabular}{|c|c|c|c|c|c|c|}
\hline \multicolumn{2}{|c|}{$\begin{array}{c}\text { Manila Rope. } \\
3 \text { strands, } \\
36 \text { in. long. }\end{array}$} & \multicolumn{2}{|c|}{$\begin{array}{c}\text { Manila Rope. } \\
4 \text { strands, } \\
36 \text { in. long. }\end{array}$} & \multicolumn{3}{|c|}{$\begin{array}{c}\text { Cast-steel Wire Rope. } \\
6 \text { strands. }\end{array}$} \\
\hline $\begin{array}{l}\text { Circum- } \\
\text { ference. }\end{array}$ & $\begin{array}{c}\text { Breaking } \\
\text { Load. }\end{array}$ & $\begin{array}{l}\text { Circum- } \\
\text { ference. }\end{array}$ & $\begin{array}{c}\text { Breaking } \\
\text { Load. }\end{array}$ & $\begin{array}{l}\text { Circum- } \\
\text { ference. }\end{array}$ & $\begin{array}{l}\text { No. of } \\
\text { Wires in } \\
\text { Strand. }\end{array}$ & $\begin{array}{l}\text { Breaking } \\
\text { Load. }\end{array}$ \\
\hline ins. & lbs. & ins. & lbs. & ins. & & lbs. \\
\hline I. 625 & 1,750 & 2.825 & 4,250 & 1.062 & 6 & $6.2 S_{5}$ \\
\hline 2.25 & 3,680 & 3.375 & 6,050 & I. 375 & I9 & I 1.850 \\
\hline 2.375 & 4,750 & 3.75 & 7.700 & I. 563 & 19 & I 2,590 \\
\hline 2.812 & 5,400 & 4.25 & I I, I 40 & I. 595 & 19 & I 9,500 \\
\hline 3. ISS & 6,800 & 4.825 & 14,020 & I. 780 & I 9 & 19.150 \\
\hline 3.625 & 7,635 & 5.375 & 16,550 & I. 938 & I 9 & 21,5 IO \\
\hline $4 \cdot 375$ & 8,080 & 3.188 & 7.700 & $\ldots \ldots \ldots$ & $\ldots \ldots$ & $\ldots \ldots \ldots$ \\
\hline 4.75 & I I, 870 & 3.I 25 & 7,630 & $\ldots \ldots \ldots$ & $\ldots \ldots$ & $\ldots \ldots \ldots$ \\
\hline 5.125 & I 5,100 & $\ldots \ldots$ & $\ldots \ldots$ & $\ldots \ldots$ & $\cdots \cdots$ & $\cdots \cdots$ \\
\hline 2.562 & 2,850 & $\ldots \ldots \ldots$ & $\ldots \ldots \ldots$ & $\ldots \ldots \ldots$ & $\begin{array}{ll}\cdots \cdots \\
\cdots \cdots\end{array}$ & $\ldots \ldots \ldots$ \\
\hline $\begin{array}{l}3 \cdot 0.33 \\
4 \cdot 188\end{array}$ & $\begin{array}{r}4,0,30 \\
11,650\end{array}$ & $\ldots \ldots \ldots$ & $\ldots \ldots \ldots$ & $\ldots \ldots \ldots$ & $\cdots \cdots \cdots$ & $\ldots \ldots \ldots$ \\
\hline
\end{tabular}




\section{LEGII WEIGHTS ON GRIIN, SEEDS, ETO,}

The table shows the number of pounds per bushel re. quired by law or custom, in the sale of articies specified, in the several States of the Union.

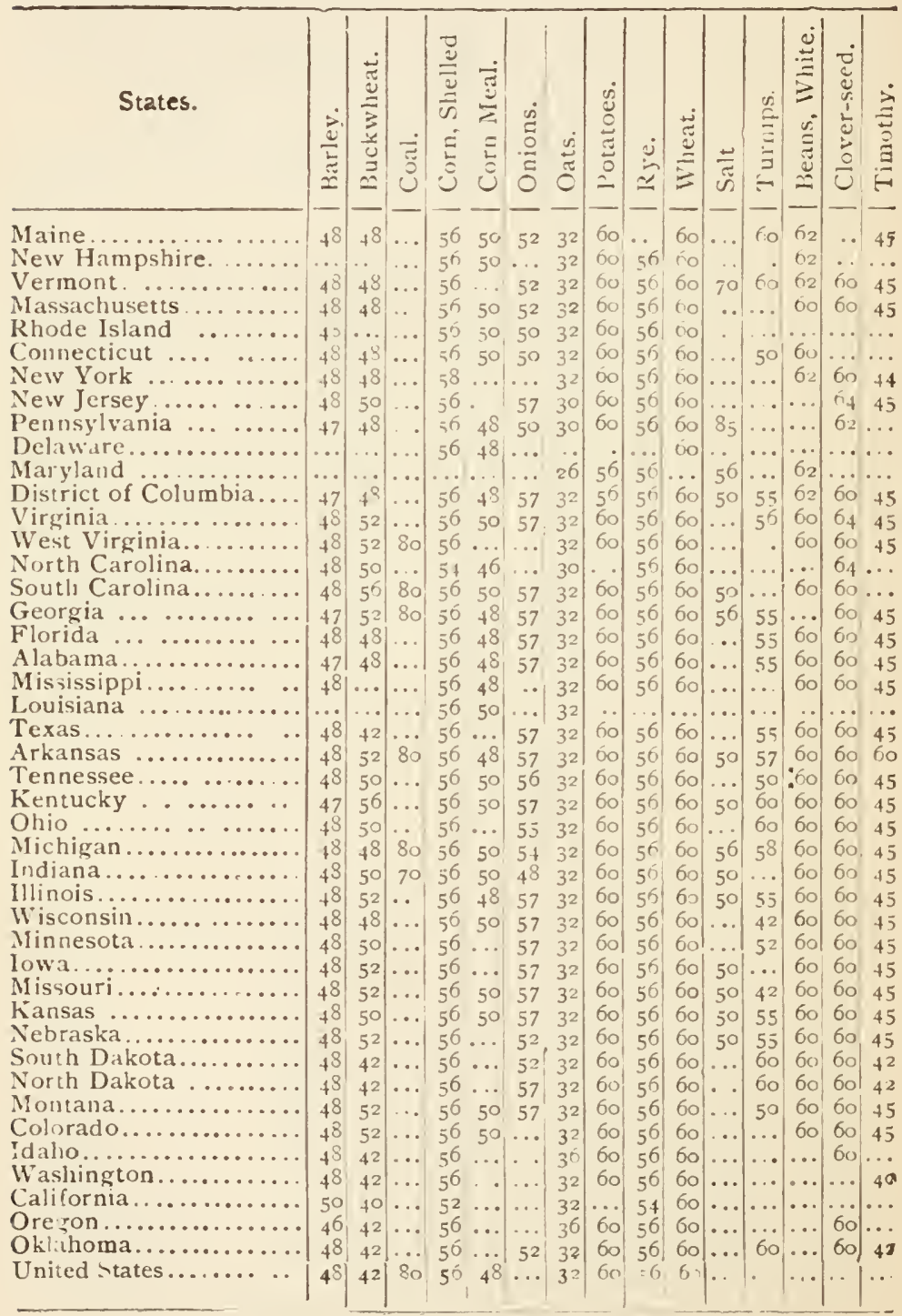


COMMERCIAL GRADES OF GRAIN.

(Minneapolis and Duluth Grain Inspection Board.)

\section{IVHEAT.}

No. I Hard Spring ITheat.-No. I Hard Spring Theat must be sound, bright, and well cleaned, and must be composed mostly of Hard Scotch Fife, and weigh not less than fifty-eight pounds to the measured bushel.

No. I Northern Spring Wheat.-No. I Northern Spring Wheat must be sound and well cleaned; it may be composed of the hard and soft varieties of spring wheat, but must contain a larger proportion of the hard varieties, and weigh not less than fifty-seven pounds to the measured bushel.

No. 2 Northern Spring Wheat.-No. 2 Northern Spring Wheat must be reasonably sound and clean and of good milling quality, this grade to include all wheat not suitable for the higher grades, and must weigh not less than fifty-six pound's to the measured bushel.

No. 3 Spring II heat.-No. 3 Spring Theat shall comprise all inferior, shrunken spring wheat, weighing not l'ss than fifty-four pounds to the measured bushel.

No. 4 Spring Wheat.-No. 4 Spring Theat shall include all inferior spring wheat that is badly shrunken or damaged, and must weigh not less than forty-nine pounds to the measured bushel.

Rejected Spring ITheat.-Rejected Spring Wheat shall include all spring wheat grown, badly bleached, or for any other cause unfit for No. 4 Wheat.

Note.-Hard, flinty wheat of good color, containing no appreciable admixture of soft wheat, may be admitted into the grades of No. 2 Nurthern Spring and No. 3 Northern Spluing Wheat, provided weight of the same is not more than one pound less than the minimum tost weight required by the existing rules for said grales, and provided further that such wheat is in all other respects qualified for admission into such grades. 


\section{WESTERN WHite AND ReD WHeAt.}

No. I Western II'hite.-No. I Western White shall be sound, well cleaned, plump, and composed of the western varieties of white wheat.

No. 2 Western White.-No. 2 Western White shall be sound, reasonably clean, and composed of western varieties of white wheat.

No. 3 Western White.-No. 3 Western White shall be composed of all western white wheat fit for warehousing, weighing not less than fifty-four pounds to the measured bushel, and not sound enough or otherwise unfit for the higher grades.

Rejected W"estern White.-Rejected Western White shall comprise all western white wheat fit for warchousing, but unfit for higher grades.

Note.-Western Red Wheat and Western Wheat shall correspond in all respects with the grades of Nos. I, 2, 3, and Rejected.

\section{Minter Mheat.}

No. I White Winter.-No. I White Winter shall be sound, well cleaned, reasonably ptump, and composed of the white varieties.

No. 2 White Winter.-No. 2 White Winter to be sound, reasonably clean, and composed of the white varieties.

No. I Red IV inter.-No. I Red Winter to be sound, well cleaned, reasonably plump, and composed of the red varieties.

No. 2 Red Winter.-No. 2 Red Winter to be sound, reasonably clean, and composed of the red varicties.

No. I Winter.-No. I Winter to be ound, well cleaned, reasonably plump, and composed of the mixed white and red winter.

No. 2 Winter.-No. 2 Winter to be sound, clean, and composed of the mixed white and red winter.

No. 3 ITinter. -No. 3 Winter shall comprise all winter wheat fit for warehousing, weighing not less than fifty-four pounds to the measured bushel, not sound enough or otherwise unfit for No. 2 of the other grides. 
Rejected IIinter.-Rejected Winter fit for warchousing, but otherwise unfit for No. 3 .

\section{DURUM (MACARONI) ITHEAT.}

No. I Durum.-No. I Durum shall be bright, practically sound, and well cleaned, and be composed of Durum, commonly known as Macaroni Wheat.

No. 2 Durum.-No. 2 Durum must be reasonably sound and clean, and of good milling quality. It shall include all Durum Wheat that for any reason is not suitable for No. I Durum.

No. 3 Durum.-No. 3 Durum shall include all wheat that is for any cause unfit for No. 2.

No. 4 Durum.-No. 4 Durum Wheat shall include all wheat that is badly bleached and grown, or for any cause unfit for No. 3 .

\section{Mrxed Wheat.}

In case of any appreciable admixture of Durum, Western, Winter or Western White, and Red Wheat, with Xinnesota Grades of Northern Spring Wheat, or with each other, it shall be graded according to the quality thereof, and classed as Nos. I, 2, 3, etc., Mixed Wheat, with inspector's notation describing its character.

\section{CORN.}

No. I Yellow Corn.-No. I Yellow Corn shall be sound, yellow dry, plump, and well cleaned.

No. 2 Fellow Corn.-No. 2 Yellow Corn shall be three-fourths yellow, dry, reasonably clean, but not plump enough for No. I.

No. 3 I ellow Corn.-No. 3 Yellow Corn shall be three-fourths yellow, reasonably dry, reasonably clean, but not sufficiently sound for No. 2.

No. I White Corn.-No. I White Corn shall be sound, dry, plump, and well cleaned.

No. 2 White Corn.-No. 2 White Corn shall be seven-eighths white, dry, and reasonably clean, but not plump enough for No. I.

No. 3 White Corn.-No. 3 White Corn shall be seven-eighths 
white, reasonably dry and reasonably clean, but not sufficiently sound for No. 2.

No. I Corn.-No. I Corn shall be mixed corn of choice quality, sound, dry, and well cleaned.

No. 2 Corn.-No. 2 Corn shall be mixed corn, dry, reasonably clean, but not good enough for No. I.

No. 3 Corn.-No. 3 Corn shall be mixed corn, reasonably dry and reasonably clean, but not sufficientiy sound for No. 2.

No. ${ }_{4}$ Corn.-No. ${ }_{4}$ Corn shall include all corn not w: and not in heating condition that is unfit for No. 3 .

\section{OATS.}

No. I White Oats.-No. I White Oats shall be white, dry, sweet, sound, clean, and free from other grain, and shall weigh not less than thirty-two pounds to the measured bushel.

No. 2 White Oats.-No. 2 White Oats shall be seren-eighths white, dry, sweet, sound, reasonably clean, and practically free from other grain, and shall weigh not less than thirty-one pounds to the measured bushel.

No. 3 White Oats.-No. 3 White Oats shall be seren-eighths white, dry, sweet, sound, reasonably clean, and practically free from other grain, and shall weigh not less than twenty-nine pounds to the measured bushel.

No. + White Oats.-Shall include all oats not sufficiently sound and clean for No. 3 White Oats, and shall weigh not less than twenty-five pounds to the measured bushel.

Yellow Oats. - The grades of Nos. I, 2, and 3 Yellow Oats shall eorrespond with the grades of Nos. I, 2, and 3 White Oats, excepting that they shall be of the yellow varieties.

No. I Oats.-No. I Oats shall be dry, sweet, sound, clean, and free from other grain, and shall weigh not less than thirtytwo pounds to the measured bushel.

No. 2 Oats.-No. 2 Oats shall be dry, sweet, sound, reasonably clean, and practically free from other grain, and shall weigh not less'than thirty-one pounds to the measured bushel.

No. 3 Oats.-No. 3 Oats shall be all oats that are merchantable and warehousable and not fit for the higher grades. 
No. I Clipped White Oats.-No. I Clipped White Oats shall be white, dry, sweet, sound, clean, and free from other grain, and shall weigh not less than forty pounds to the measured bushel.

No. 2 Clipped White Oats.-No. 2 Clipped White Oats shall be seven-eighths white, dry, sweet, sound, reasonably clean, and practically free from other grain, and shall weigh not less than thirty-eight pounds to the measured bushel.

No. 3 Clipped White Oats.-No. 3 Clipped White Oats shall be seven-eighths white, dry, sweet, sound, reasonably clean, and practically free from other grain, and shall weigh not less than thirty-six pounds to the measured bushel.

\section{RYE.}

No. I Rye.-No. I Rye shall be sound, plump, and well cleaned, and shall weigh not less than fifty-six pounds to the measured bushel.

No. 2 Rye.-No. 2 Rye shall be sound, reasonably clean, and reasonably free from other grain, and shall weigh not less than fifty-four pounds to the measured bushel.

No. 3 Rye.-All rye slightly damaged, slightly musty, or from any other cause unfit for No. 2 shall be graded as No. 3 .

\section{BARLEY.}

No. I Barley.-No. I Barley shall be plump, bright, clean, and free from other grain, and shall weigh not less than fortyeight pounds to the measured bushel.

No. 2 Barley.-No. 2 Barley shall be sound and of healthy color, not plump enough for No. I, reasonably clean, and reasonably free from other grain, and shall weigh not less than forty-six pounds to the measured bushel.

No. 3 Barley.-No. 3 Barley shall include all slightly shrunken and otherwise slightly damaged barley not good enough for No. 2 , and shall weigh not less than forty-four pounds to the measured bushel.

No. 4 Barley.-No. 4 Parley shall include all barley fit for malting purposes not good enough for No. 3 .

No. I Feed Barley.-No. I Feed Barley must test not less than 
forty pounds to the measured bushel, and be reasonably sound and reasonably clean.

No. 2 Feed Barley.-No. 2 Feed Barley shall include all barley which is for any cause unfit for the grade of No. I Feed Barley.

Chevalier Barley.-Nos. I, 2, and 3 Chevalier Barley shall conform in all respects to the grades of Nos. 1, 2, and 3 Barley, except that they shall be of a Chevalier variety, grown in Montana, Oregon, and on the Pacific Coast.

No Grade.-All Wheat, Barley, Oats, Rye, and Corn that is in a heating condition, too musty or too damp to be safe for warehousing, or that is badly bin-burnt, badly clamaged, exceedingly dirty, or otherwise unfit for store, shall be classed as No Grade with inspector's notation as to quality and condition.

\section{FLAYSEED.}

All flaxseed inspected shall be classed according to quality and conditions as follows:

No. I Northwestern Flaxseed.-Flaxseed to grade No. I Northwestern shall be mature, sound, dry, and sweet. It shall be northern grown. The maximum quantity of field, stack, storage, or other damaged seed intermixed shall not exceed twelve and one-half ( $2 \frac{1}{2}$ ) per cent. The minimum weight shall be fifty-one (5I) pounds to the measured bushel of commercially pure seed.

No. I Flaxsecd.-No. I Flaxseed shall be northern grown, sound, dry, and free from mustiness, and carrying not more than twenty-five (25) per cent of immature or field, stack, storage, or other damaged flaxseed, and weighing not less than fifty (50) pounds to the measured bushel of commercially pure seed.

No. 2 Flaxseed.-Flaxseed that is bin-burnt, immature, field damaged, or musty, and yet not to a degree to be unfit for storage, and having a test weight of not less than forty-seven (47) pounds to the bushel of commercially pure seed shall be No. 2 Flaxseed.

No Grade Flaxseed.-Flaxseed that is damp, warm, moldy, very musty, or otherwise unfit for storage, or having a weight of less than forty-seren (47) pounds to the measured bushel of commercially pure seed shall be No Grade. 


\section{GRADES OF HAY AND STRAV"}

(National Hay Association, I909.)

A. HAY.

Choice Timothy Hay.-Shall be timothy not mixed with over one-twentieth other grasses, properly cured, bright, natural color, sound, and well baled.

No. I. Timothy Hay.- Shall be timothy not more than oneeighth mixed with clover or other tame grasses, properly cured, good color, sound, and well baled.

No. 2, Timothy Hay.-Shall be timothy not good enough for No. I, not over one-fourth mixed with clover or tame grasses, fair color, sound and well baled.

No. 3, Timothy Hay.-Shall include all hay not good enough for other grades, sound, and well baled.

Light Clover-mixed Hay. - Shall be timothy mixed with clover, the clover-mixture not over one-fourth, properly cured, sound, good color, and well baled.

No. I, Clover mixed Hay - Shall be timothy and clover mixed, with at least one-half timothy, good color, sound, and well baled.

No, 2, Clover-mixed Hay. - Shall be timothy and clover mixed, with at least one-third timothy, reasonably sound, and well baled.

No. I, Clover Hay. - Shall be medium clover, not over onetwentieth other grasses, properly cured, sound, and well baled.

No. 2, Clover Hay. - Shall be clover, sound, well baled, not good enough for No. I.

No Grade Hay.-Shall include all hay badly cured, stained, thrashed, or in any way unsound.

Choice Prairie IIay. - Shall be upland hay, of bright natural color, well cured, sweet, sound, and may contain 3 per cent of weeds.

No. I, Prairie Hay.- Shall be upland, and may contain onequarter midland, both of good color, well cured, sweet, sound, and may contain $S$ per cent of weeds.

No. 2, Prairic IIay. - Shall be upland of fair color, and may contain onc-half milland, both of grood color, well cured, sweet, sound, and may contain $12 \frac{1}{2}$ per cent of weeds.

No. 3, Prairic Hay-Shall include hay not good enough for other grades and not caked. 
No. I, Midland Hay.-Shall be hay of good color, well cured, swect, somind, and may contain 3 per cent of weeds.

No. 2, Midland IIay-Shall be fair color or slough hay of good color and may contain $\mathrm{I} 2 \frac{1}{2}$ per cent of weeds.

Packing May. - Shall include all wild lua not good enough for other grades and not caked.

No-grade Prairic IIay-Shall include all hay not good enough for other grades.

Choice Alfalfa - Shall be reasonably fine, leafy alfalfa of bright green color, properly cured, sourd, sweet, and well baled.

No. I, Alfalfa. - Shall be coarse alfalfa of natural color or reasonably finc, lcafy alfalfa of good color, and may contain 5 per cent of foreign grasses, must be well baled, sound, and swect.

No 2, Alfalfa - Shall include alfalfa somewhat bleached, but of fair color, reasonably leaf $\because$, not more than one-eighth foreign grasses, sound, and well baled.

No. 3, Alfulfa. - Shall include bleached alfalfa or allalfa mixed with not to exceed. one-fourth foreign grasses, but when mixed must be of fair color, sound, and well baled.

No-grade Alfalfu. - Shall include all alfalfa not good enough for other grades, caked, musty, greasy, or thrashed.

\section{B. Striw.}

No. I, Straight Rye Straw.-Shall be in large bales, clean, bright, long rye straw, pressed in bunclle's, sound, and well baled.

No. 2, Straight Rye Straw. - Shail be in liarge bales, long rye straw, pressce' in Lundles, sound, and well baled, not good enough for No. I.

No. I, Tangled Rye Straw.-Shall be reasonably clean rye straw, good color, sound, and well baled.

$N^{\top}$ o. 2, Tangled Rye Straw.-Sha'l be reasonably clean, may be some stained, but not good enough for No. I.

No. I, Whicut Straw.-Shall be reasonably clean wheat straw, sound, and wel: baled.

No. 2, Itheat Straw.-Shall be reasonably clean, may be some stained, but not good enough for No. I.

No. I, Oat Straw.-Shall be reasonably clean oat straw, sound, and well baled.

No. 2, Oat Strau'.- Shall be reasonably c'ean, may be some stained, but not good enough fur No. J. 
SPECIFIC GRAVITY OF VARIOUS SUBSTANCES

(Trautwink.)

Aluminum

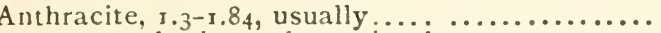

broken, of any size, loose ..........

(A ton, loose, averages from 40 to 43 cubic feet.)

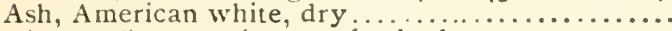

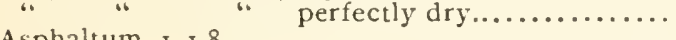

Asphaltum, $1-\mathrm{r} .8 \ldots \ldots \ldots \ldots \ldots \ldots \ldots \ldots \ldots . . . \ldots$.

Boxwood, dry.

Brass (copper and zinc) cast, $7.8-8.4 \ldots \ldots \ldots \ldots$

Bronze (copper 8 parts, tin I part, gun metal), $8.4-$

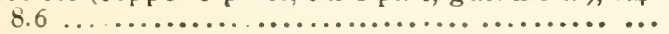

Sement, English Portland

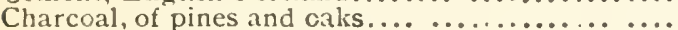

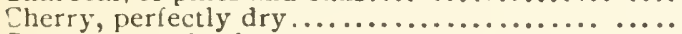

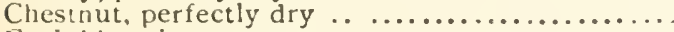

Coal, bituminous $1.2-1.5$

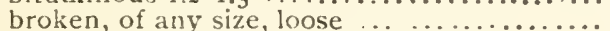

(A ton occupies from 43 to 48 cubic feet.)

Copper, cast, $8.6-8.8 \ldots \ldots \ldots \ldots \ldots \ldots \ldots \ldots \ldots \ldots \ldots$

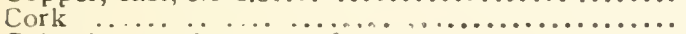

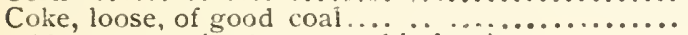

in ion occupies 80 to 97 (ubic feet.)

Elm, perfectly dry........................ ${ }^{.5} 6$

\begin{tabular}{|c|c|}
\hline $\begin{array}{l}\text { Average } \\
\text { Specific } \\
\text { Gravity. }\end{array}$ & $\begin{array}{c}\text { Average } \\
\text { Weight o: } \\
\text { I cu. foot } \\
\text { in Pounde. }\end{array}$ \\
\hline 2.6 & 162. \\
\hline I. 5 & $\begin{array}{l}93 \cdot 5 \\
52-56\end{array}$ \\
\hline $.6 r$ & $3^{8}$. \\
\hline $\begin{array}{l}.75^{2} \\
1.4\end{array}$ & $\begin{array}{l}47 . \\
83 \cdot 3\end{array}$ \\
\hline $8 . .^{.96}$ & $\begin{array}{c}60 . \\
504 .\end{array}$ \\
\hline 8.5 & 529. \\
\hline$\cdots$ & $8 \mathrm{r}-\mathrm{ros}$ \\
\hline $\begin{array}{l}.1672 \\
.60\end{array}$ & $\begin{array}{l}15.36 \\
42 . \\
41\end{array}$ \\
\hline 1.35 & $\begin{array}{l}84 . \\
47-52\end{array}$ \\
\hline $\begin{array}{l}8.7 \\
.25\end{array}$ & $\begin{array}{l}12 \\
15\end{array}$ \\
\hline$\cdots$ & $23-3^{2}$ \\
\hline .56 & 35. \\
\hline .93 & 58. \\
\hline
\end{tabular}

Glass, 2.5-3.45

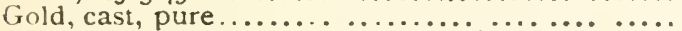

Gravel, about the same as sind, which see.

Hemlock, perfectly dry.

Hickory, perfectly dry...

Ice, .917-.925

India rubber .

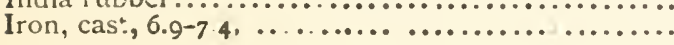

Lard

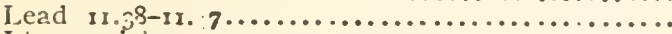

Lime, q ick ...................................

Limestone : nd markles

\begin{tabular}{c|c}
19.258 & 1.04. \\
& \\
.4 & 25. \\
.85 & 53. \\
.92 & 57.4 \\
.93 & 58. \\
7.15 & 446. \\
.95 & 59.3 \\
11.38 & 709.6 \\
1.5 & 95. \\
2.6 & 164.4 \\
.85 & 53. \\
.79 & 49. \\
13.58 & 846. \\
.77 & 48.
\end{tabular}

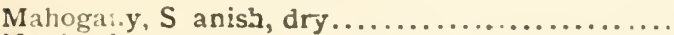

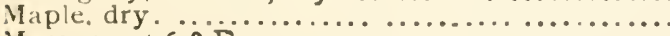

Mercury, at $60^{\circ} \mathrm{F}$.

Oak, white, perfesly dry, .66-.88. 


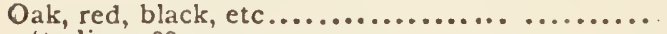

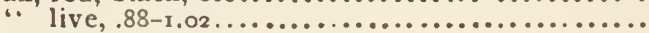

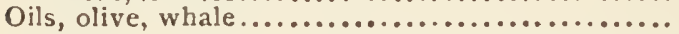

Peat

Petroleum

Pine, white, perfectly dry, $35-.45 \ldots \ldots \ldots \ldots \ldots$

"vellow, Northern. .48 to $.62 \ldots \ldots \ldots \ldots \ldots \ldots$.

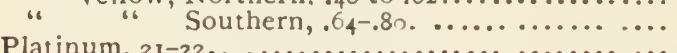

Quartz, common. pure, $2.64-2.67 . \ldots \ldots \ldots \ldots \ldots$

Rosin

Salt, coarse, per struck bu., Sy racuse, N. Y., 56 lbs.

Sand of pure quartz, dry and loose, per struck bu.

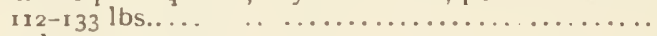

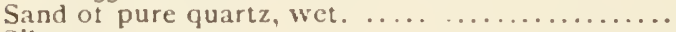

Silver .............................

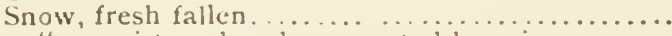

" moistened and compacted by rain........

Soils, common loam, perfectly dry, loose..........

Soils, common loam, perfectly dry, moderately rammed.

Soils, common loam, slightly moist, loose .......... " .6 as a soft, flowing mud.......

Spruce, perfectly dry ...................

Sulphur. .............................

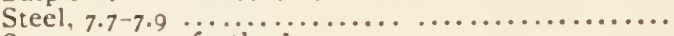

Sycamore, perfectly dry...................

Tar...............................

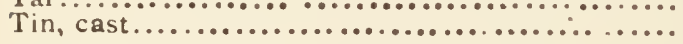

WValnut, perfectiy dry.

Water, pure rain or d stilled, at $32 \circ \mathrm{F}$. (barometer

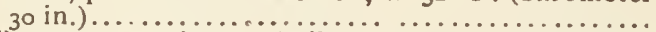

Water, pure rain or $\because$ illed at $6_{2}^{\circ} \mathrm{F}$. (barometer

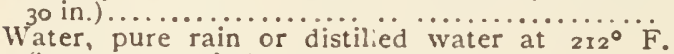

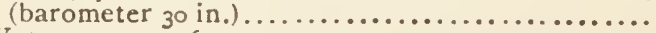

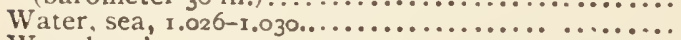

Wax, bees'

Zinc. $6.8-7 \cdot 2$

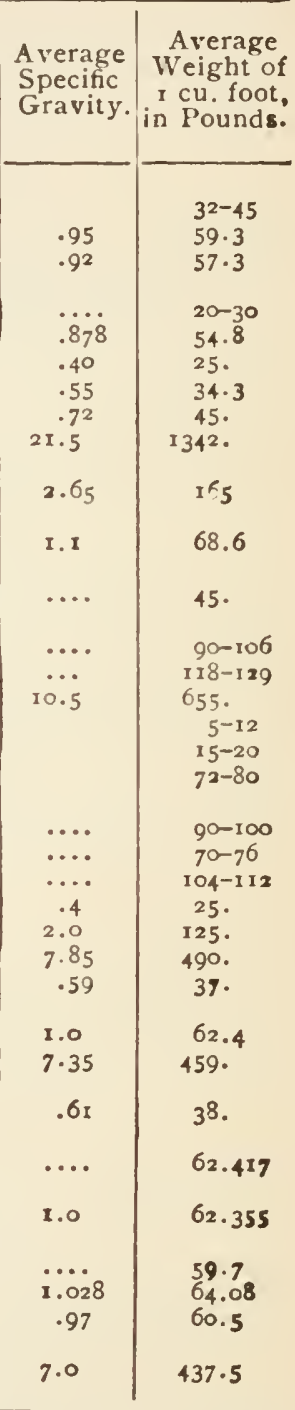

Note.-Green timbers usually weigh from one fifth to nearly one half more than dry and ordinary bui'd ig timbers when tolerably seasoned; about one sixth more than perfec ly dry. 


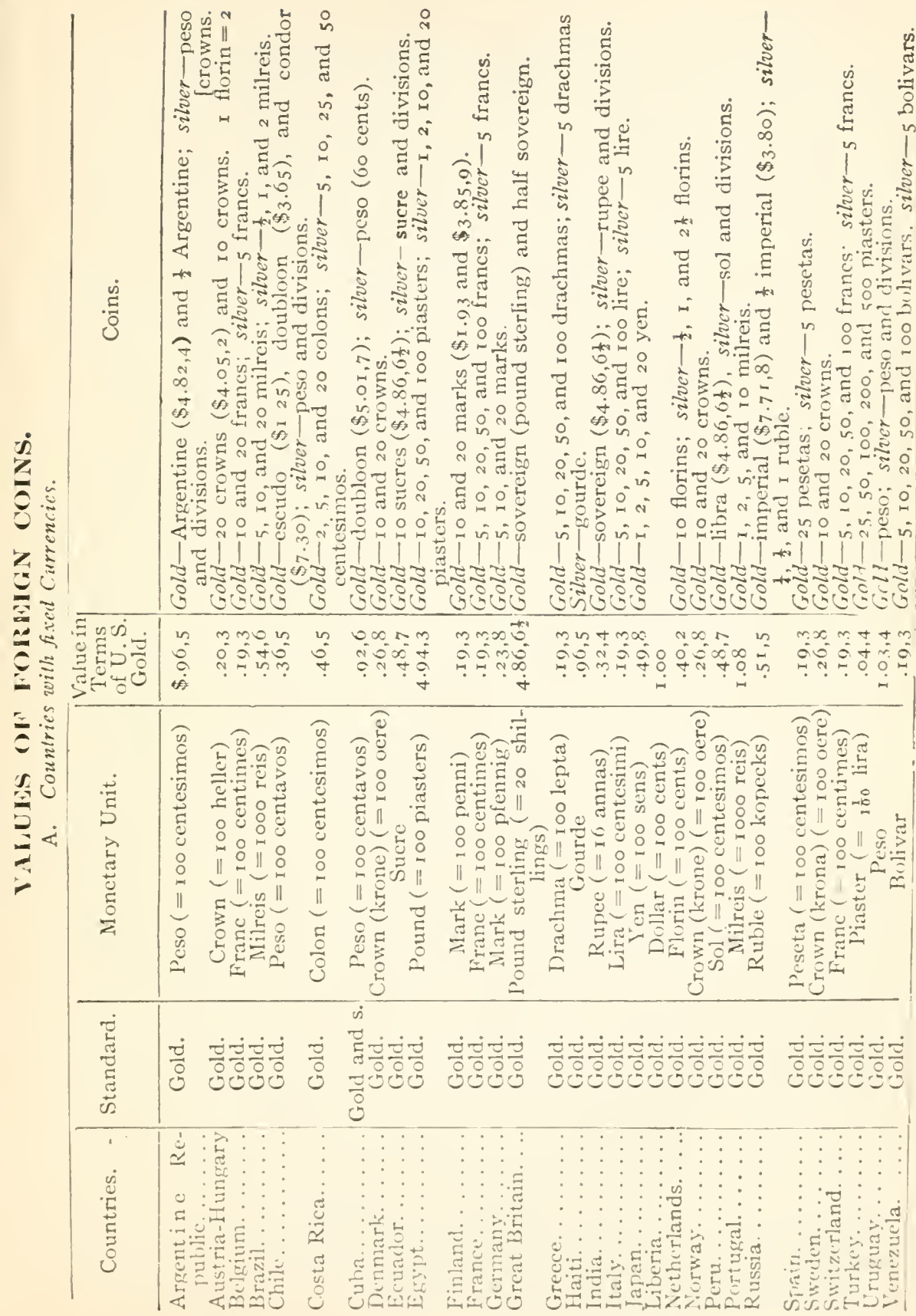


B. Conntries with Fluchuating Currencies.

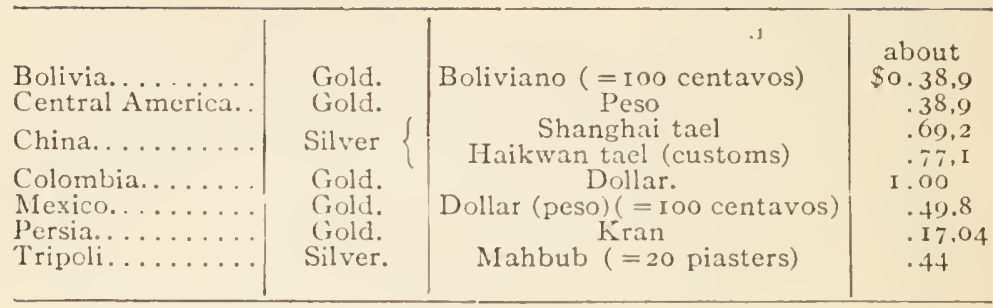

\section{MONEY CONVEISSION TABI,E.}

\begin{tabular}{|c|c|c|c|c|c|c|c|}
\hline & 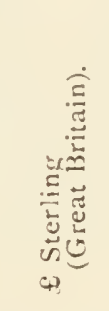 & 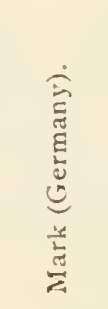 & 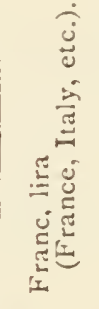 & 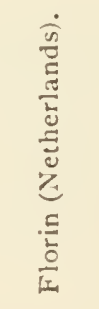 & 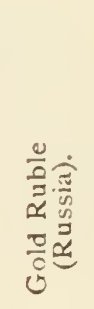 & 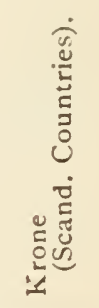 & 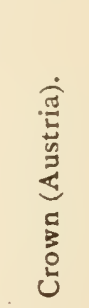 \\
\hline I & 34.87 & $\$ 0.24$ & $\$ 0.19$ & $\$ 0.40$ & $\$ 0.5^{2}$ & $\$ 0.27$ & $\$ 0.20$ \\
\hline 2 & 9.73 & $.4^{8}$ & .39 & .80 & I 03 & $\quad=4$ & $.4 \mathrm{I}$ \\
\hline 3 & 14.60 & $\cdot 71$ & $\cdot 5^{8}$ & I. 2 I & I. 55 & .80 & $.6 r$ \\
\hline 4 & 19.47 & .95 & .77 & I. $6 \mathrm{I}$ & 2.06 & 1.07 & $.8 \mathrm{I}$ \\
\hline 5 & 24.33 & 1.19 & .97 & 2.01 & $2.5^{8}$ & 1.34 & $x .02$ \\
\hline 6 & 29.20 & I. 43 & 1. 16 & $2.4 \mathrm{I}$ & 3.09 & $1.6 \mathrm{I}$ & 1.22 \\
\hline 7 & 34.07 & I. 67 & 1.35 & $2.8 \mathrm{I}$ & $3.6 \mathrm{I}$ & I. 88 & $\mathrm{I} .42$ \\
\hline 8 & $3^{8} .93$ & I.yo & 1. 54 & 3.22 & $4 \cdot 12$ & 2.14 & 1.62 \\
\hline 9 & 43.80 & 2.14 & 1.74 & 3.62 & 4.64 & 2.41 & 1.83 \\
\hline 10 & 48.67 & $2.3^{8}$ & 1.93 & 4.02 & 5.15 & 2.68 & 2.03 \\
\hline 20 & $97 \cdot 33$ & $4 \cdot 7^{6}$ & 3.86 & 8.04 & 10.30 & $5 \cdot 3^{6}$ & 4.06 \\
\hline 30 & 146.00 & 7.14 & 5.79 & 12.06 & 15.45 & 8.04 & 6.09 \\
\hline 40 & 194.66 & $9 \cdot 5^{2}$ & 7.72 & I 6.08 & 20.60 & 10.72 & 8.12 \\
\hline 50 & $243 \cdot 33$ & 11.90 & $9.6_{5}$ & 20.10 & $25 \cdot 75$ & $I_{3} 40$ & xo. 15 \\
\hline 100 & $4^{36.65}$ & 23.80 & 19.30 & 40.20 & 5 I. 50 & 26.80 & $20 \cdot 30$ \\
\hline
\end{tabular}




\section{STATISTICAL TABLES.}

\section{AREA AND POPULATION OF THE UNITED \\ STATES, 1910. (Thirteenth Census.)}

\begin{tabular}{|c|c|c|c|c|c|}
\hline $\begin{array}{l}\text { States or } \\
\text { Territories. }\end{array}$ & $\begin{array}{l}\text { Land } \\
\text { Area, } \\
\text { Sq. Mi. }\end{array}$ & $\begin{array}{l}\text { Popula- } \\
\text { tion. }\end{array}$ & $\begin{array}{l}\text { States or } \\
\text { Territories. }\end{array}$ & $\begin{array}{c}\text { Land } \\
\text { Area } \\
\text { Sq. Mi. }\end{array}$ & $\begin{array}{c}\text { Popula- } \\
\text { tion. }\end{array}$ \\
\hline 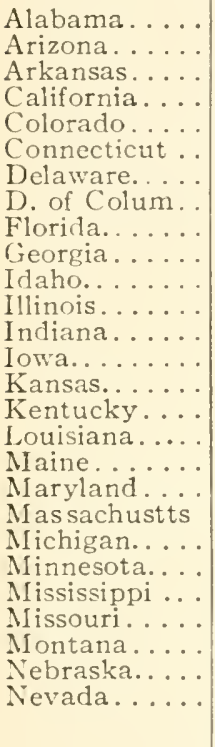 & $\begin{array}{r}51,279 \\
\text { I } 13,810 \\
52,525 \\
155,652 \\
103,658 \\
4,820 \\
1,965 \\
60 \\
54,861 \\
58,725 \\
83,354 \\
56,043 \\
36,045 \\
55,586 \\
81,774 \\
49,181 \\
45,409 \\
29,895 \\
9,941 \\
8,039 \\
57,480 \\
80,858 \\
46,362 \\
68,727 \\
146,201 \\
76,808 \\
109,821\end{array}$ & $\begin{array}{r}2,138,093 \\
204,354 \\
1,574,449 \\
2,377,549 \\
799,024 \\
1,114,756 \\
202,322 \\
3.31,069 \\
752,619 \\
2,609,121 \\
325,594 \\
5,638,591 \\
2,700,876 \\
2,224.771 \\
1,690,949 \\
2,289,905 \\
1,056,388 \\
742,371 \\
1,295,346 \\
3,366,416 \\
2,810,173 \\
2,075,708 \\
1,797,114 \\
3,293,335 \\
376,053 \\
1,192,214 \\
81,875\end{array}$ & 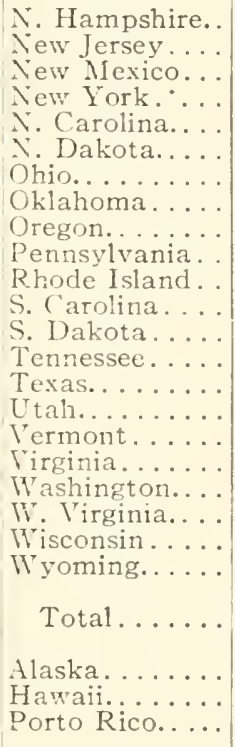 & $\begin{array}{r}9,031 \\
7,514 \\
122,503 \\
47,654 \\
48,740 \\
70,183 \\
40,740 \\
69,414 \\
95,607 \\
44,832 \\
1,067 \\
30,495 \\
76,868 \\
41,687 \\
262,398 \\
82,184 \\
9,124 \\
40,262 \\
66,836 \\
24,022 \\
55,256 \\
97,594 \\
\end{array}$ & $\begin{array}{r}430,572 \\
2,537,167 \\
327,301 \\
9,113,614 \\
2,206,287 \\
577,056 \\
4,767,121 \\
1,657,155 \\
672,765 \\
7,665,111 \\
542,610 \\
1,515,400 \\
583,888 \\
2,184,789 \\
3,896,542 \\
373,351 \\
355,956 \\
2,061,612 \\
1,141.990 \\
1,221,119 \\
2,233,860 \\
145,965 \\
\end{array}$ \\
\hline
\end{tabular}

AREA AND POPCLATION OF CANADA, 1911.

\begin{tabular}{|c|c|c|c|c|c|}
\hline $\begin{array}{c}\text { Provinces } \\
\text { and } \\
\text { Districts. }\end{array}$ & $\begin{array}{c}\text { Land } \\
\text { Area, } \\
\text { Sq. Mi. }\end{array}$ & $\begin{array}{c}\text { Popula- } \\
\text { tion. }\end{array}$ & $\begin{array}{l}\text { Provinces } \\
\text { and } \\
\text { Districts. }\end{array}$ & $\begin{array}{l}\text { Land } \\
\text { Area. } \\
\text { Sq. Mi. }\end{array}$ & $\begin{array}{l}\text { Popula- } \\
\text { tion. }\end{array}$ \\
\hline \multirow[t]{2}{*}{$\begin{array}{l}\text { Ontario....... } \\
\text { Quebec. ..... } \\
\text { Nova Scotia.. } \\
\text { N. Brunswick. } \\
\text { Manitoba.... } \\
\text { Brit. Colun... }\end{array}$} & \multirow[t]{2}{*}{$\begin{array}{r}365,880 \\
600,865 \\
21,068 \\
27,911 \\
231.926 \\
353,416\end{array}$} & \multirow[t]{2}{*}{$\begin{array}{r}2,523,274 \\
2,003,232 \\
492,3.38 \\
351,88 r \\
455,614 \\
392,480\end{array}$} & \multirow{2}{*}{$\begin{array}{l}\text { Pr. Ed. Island.. } \\
\text { Saskatchewan. } \\
\text { tlberta...... } \\
\text { Yukon ..... } \\
\text { N. W. Territ's.. } \\
\text { Total....... }\end{array}$} & $\begin{array}{r}2,184 \\
243,382 \\
252,925 \\
206,427 \\
1,207,926 \\
\end{array}$ & $\begin{array}{r}93,728 \\
492,432 \\
374,663 \\
8,512 \\
18,481 \\
\end{array}$ \\
\hline & & & & $3,603,910$ & $7,206,643$ \\
\hline
\end{tabular}




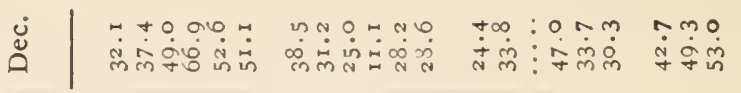

b

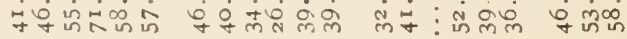

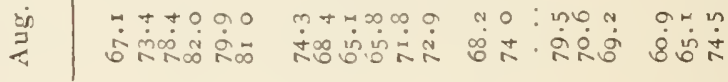

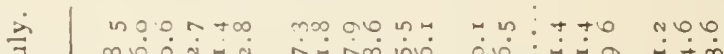

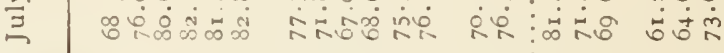

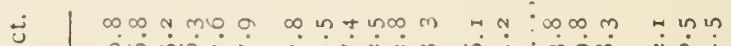

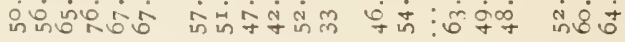

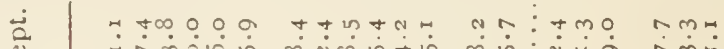

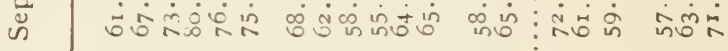

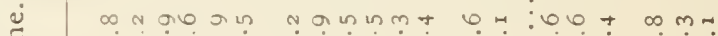

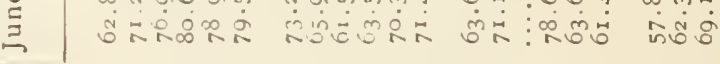

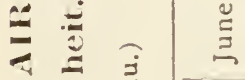

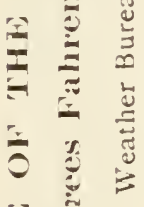

$\frac{3}{\pi}$

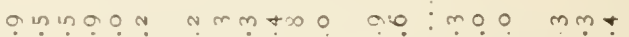

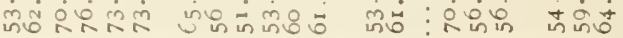

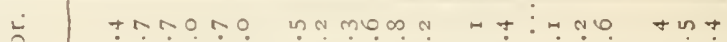

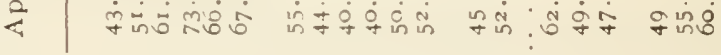

$\because \cos +n+\infty \cos a+a n-1$

$0, n: n n \in$ log m

$\doteq \risingdotseq$ อ

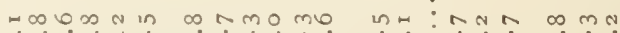

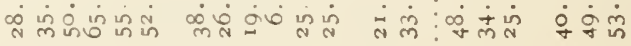

E

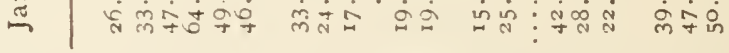

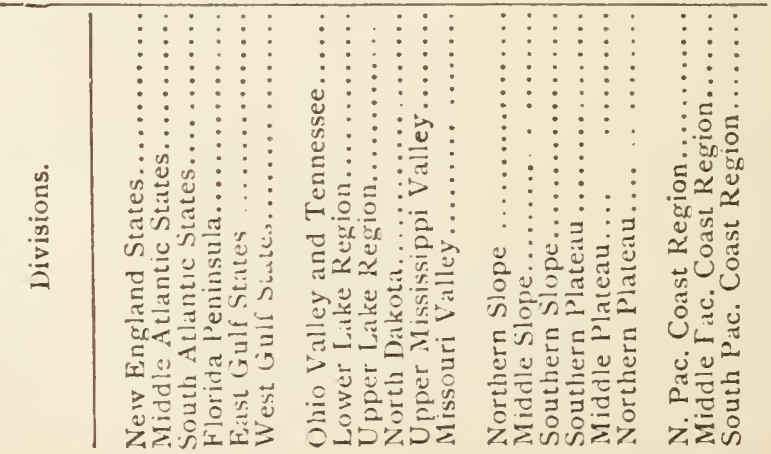




\section{AVERAGE AND ACTUAL DATE OF LAST AND FIRST KILIING FROST.}

(U. S. Weather Burgau.)

\begin{tabular}{|c|c|c|c|c|}
\hline \multirow{2}{*}{ State. } & \multirow{2}{*}{ Locality. } & \multicolumn{2}{|c|}{ Spring. } & \multirow{2}{*}{$\frac{\text { Fall. }}{\text { Earliest. }}$} \\
\hline & & Average. & Last. & \\
\hline A labama...... & Mobile .. & Feb. 24 & April 6 & Nov, 2 \\
\hline " $\quad . . . \ldots \ldots$ & Montgomery......... & Mar. 10 & April 6 & Oct. 21 \\
\hline & Little Rock......... & Mar. 21 & April 14 & Oct. 8 \\
\hline Colorado........... & Fort Smith......... & Mar. 22 & April 6 & Oct. 7 \\
\hline $\begin{array}{l}\text { Colorado............ } \\
\text { Connecticut........ }\end{array}$ & $\begin{array}{l}\text { Denver.............. } \\
\text { New Haven.... }\end{array}$ & May 25 & June 6 & Sept. ro \\
\hline ist. of $\mathrm{Col} . . . . . . .$. & $\begin{array}{l}\text { New Haven.......... } \\
\text { Washington....... }\end{array}$ & May 30 & May. & Sept. Is \\
\hline Florida $\ldots \ldots \ldots$ & $\begin{array}{l}\text { Washington. ......... } \\
\text { Cedar Key........ }\end{array}$ & $\begin{array}{l}\text { April } 4 \\
\text { Feb. } 4\end{array}$ & $\begin{array}{l}\text { April } 20 \\
\text { Mar. 12 }\end{array}$ & $\begin{array}{l}\text { Oct. } 4 \\
\text { Noy. } 25\end{array}$ \\
\hline$\because \quad \ldots \ldots \ldots \ldots$ & Jacksonville .......... & Feb. 24 & Mar. 27 & Nov. 12 \\
\hline Georgia.......... & Pensacola............ & Mar. 7 & Aprii 6 & Nov. 12 \\
\hline Georgia.................... & Atlanta............... & Mar. 25 & May 21 & Oct. 16 \\
\hline$\because \quad \quad \ldots \ldots \ldots \ldots \ldots$ & Augusta... ....... & Mar. 7 & Apri & Oct. 8 \\
\hline Illinois................ & 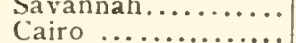 & r. I & & Nov. 2 \\
\hline (6........... & Chicago ........... & April ${ }_{23}^{31}$ & $\begin{array}{l}\text { May } 8 \\
\text { May } 25\end{array}$ & $\begin{array}{l}\text { Oct. } 2 \\
\text { Sept. } 2\end{array}$ \\
\hline " $\quad \ldots \ldots \ldots \ldots$ & Springfield.......... & April I 6 & May & Sept. \\
\hline Indiana........... & Indianapolis....... & April 17 & May & Sept. 26 \\
\hline Iowa............... & Des Moines.......... & ril 24 & May & Sept. 1 2 \\
\hline$\because{ }^{\prime} \quad \ldots \ldots \ldots \ldots$ & Dubuque........... & April 27 & May & pt. 5 \\
\hline$" \quad \ldots \ldots \ldots \ldots \ldots$ & Keokuk.......... & April so & $\mathrm{May}_{2}$ & Sept. 18 \\
\hline Kansas .............. & Dodge City.......... & April 22 & May 23 & Sept. 23 \\
\hline Kentucky... $\ldots \ldots \ldots$ & Leavenworth......... & April 6 & May & Sept. I3 \\
\hline $\begin{array}{l}\text { Kentucky... } \ldots \ldots \\
\text { Louisiana........... }\end{array}$ & $\begin{array}{l}\text { Louisville ........... } \\
\text { New Orleans........ }\end{array}$ & $\begin{array}{l}\text { April } 8 \\
\text { Feb.2 }\end{array}$ & $\begin{array}{l}\text { May } \\
\text { Mar. }\end{array}$ & Sept. 30 \\
\hline $6 \quad \ldots \ldots \ldots \ldots$ & $\begin{array}{l}\text { New Orleans........ } \\
\text { Shreveport......... }\end{array}$ & Feb. 26 & $\begin{array}{l}\text { Mar. } 27 \\
\text { Mar. 31 }\end{array}$ & $\begin{array}{l}\text { Nov. II } \\
\text { Oct. I3 }\end{array}$ \\
\hline Maine .............. & nouth .......... & April ${ }_{4}$ & May 5 & Sept. 7 \\
\hline Maryland ....... & Baltimore .......... & April 6 & $M a$ & Oct. 6 \\
\hline Massachusetts ..... & Boston ............ & 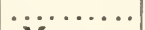 & May 17 & Sept. 30 \\
\hline Michigan........... & Detroit.............. & May 2 & May 28 & Sept. 23 \\
\hline$\because \quad \ldots \ldots \ldots$ & Grand Haven... & May 30 & MIay 28 & Aug. 21 \\
\hline $6 \quad \ldots \ldots \ldots \ldots$ & Marquette........... & May I 8 & June II & Aug. 22 \\
\hline Minnesota......... & St. Paul........... . & May r & May 25 & Sept. I \\
\hline$"$ " $\quad \ldots \ldots \ldots$ & Duluth...... & May 6 & June 8 & Sept. 13 \\
\hline${ }^{66} \quad \ldots \ldots \ldots$ & Moorhead... & May 18 & June 5 & Aug. 25 \\
\hline Mississippi......... & Vicksburg.. . . & Mar. 3 & April 22 & Oct. 19 \\
\hline Missouri .. ....... & St. Louis....... & Mar $3 \mathbf{I}$ & May 2 & Oct. I 4 \\
\hline 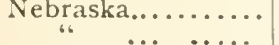 & $\begin{array}{l}\text { Omaha...... } \\
\text { North Platte }\end{array}$ & April 15 & $\ldots \ldots \ldots$ & Sept. 20 \\
\hline New Jersey ... & $\begin{array}{l}\text { North Platte......... } \\
\text { Atlantic City ...... }\end{array}$ & $\begin{array}{l}\text { May I } \\
\text { April } 6\end{array}$ & April 20 & $\begin{array}{l}\text { Sept. Io } \\
\text { Oct. }\end{array}$ \\
\hline & Cape May.............. & April 6 & $\mathrm{May}_{3}$ & Oct. 29 \\
\hline New Mexico..... .. & Santa Fé........... & April 22 & May 22 & Sept. 19 \\
\hline New York.......... & Albany ............ & April 21 & May 22 & Oct. 15 \\
\hline " $\quad \cdots \cdots \cdots$ & Buffalo ......... & $\operatorname{May}_{27}$ & May 29 & Sept. 2 I \\
\hline - $\cdots \cdots \cdot$ & New York...... & April I4 & April 25 & Oct. Is \\
\hline " $\quad$ ….... & $\begin{array}{l}\text { Oswego......... } \\
\text { Rochester...... }\end{array}$ & April 26 & $\begin{array}{l}\text { May } 29 \\
\text { May } 20\end{array}$ & $\begin{array}{l}\text { Sept. } 26 \\
\text { Sept. } 26\end{array}$ \\
\hline North Carolina.... & $\begin{array}{l}\text { Rochester............. } \\
\text { Charlotte........ }\end{array}$ & $\begin{array}{l}\text { May } 3 \\
\text { April }\end{array}$ & $\begin{array}{l}\text { May } 29 \\
\text { May } 3\end{array}$ & $\begin{array}{l}\text { Sept. }{ }^{20} \\
\text { Oct. } 8\end{array}$ \\
\hline & Hatteras.......... & Feb. 27 & April 5 & Nov. 22 \\
\hline
\end{tabular}


DATE OF LAST: AND FIRST IILLING FROSTContinued.

\begin{tabular}{|c|c|c|c|c|}
\hline \multirow{2}{*}{ State. } & \multirow{2}{*}{ Locality. } & \multicolumn{2}{|c|}{ Spring. } & \multirow{2}{*}{$\begin{array}{c}\text { Fall. } \\
\text { Earliest. }\end{array}$} \\
\hline & & Average. & Last. & \\
\hline 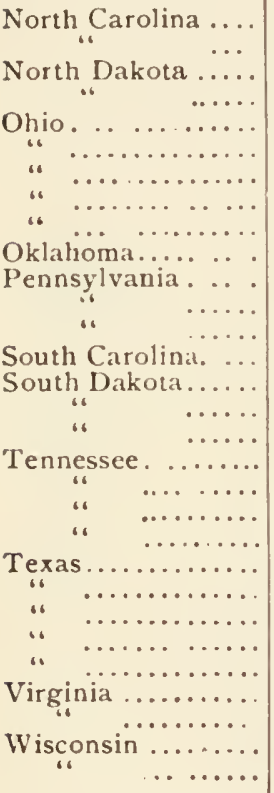 & 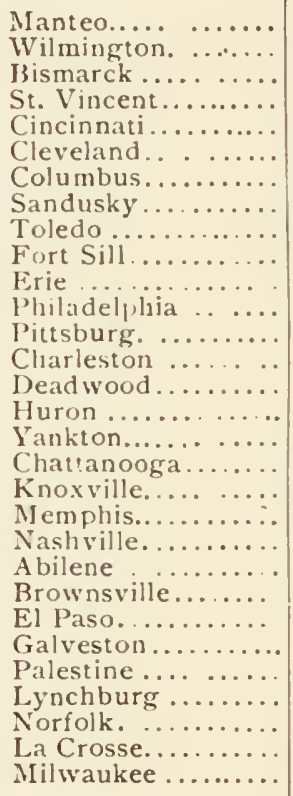 & 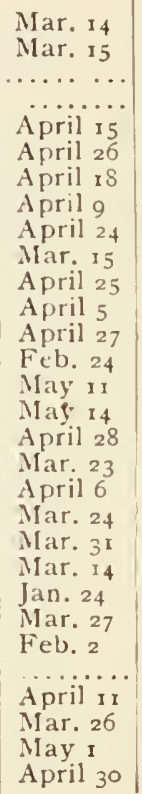 & 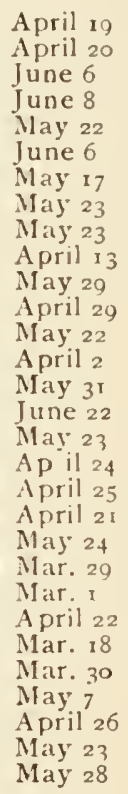 & $\begin{array}{l}\text { Oct. 16 } \\
\text { Oct. } 13 \\
\text { Aug..... } 4 \\
\text { Sept. } 30 \\
\text { Sept. } 24 \\
\text { Sept } 29 \\
\text { Oct. } 8 \\
\text { Sept. } 9 \\
\text { Oct. 1 } \\
\text { Sept. 16 } \\
\text { Oct. } 2 \\
\text { Sept. } 25 \\
\text { Nuv. } 8 \\
\text { Scpt. } 7 \\
\text { Sept. } 3 \\
\text { Sept. 13 } \\
\text { Scpt. } 30 \\
\text { Oct. } 8 \\
\text { Oct. } 2 \\
\text { Oct. } 8 \\
\text { Oct. } 24 \\
\text { Dec. } 5 \\
\text { Oct. } 24 \\
\text { Nov. 18 } \\
\text { Nov. 10 } \\
\text { Oct. } 3 \\
\text { Oct. 10 } \\
\text { Sept. } 21 \\
\text { Sept. 17 }\end{array}$ \\
\hline
\end{tabular}




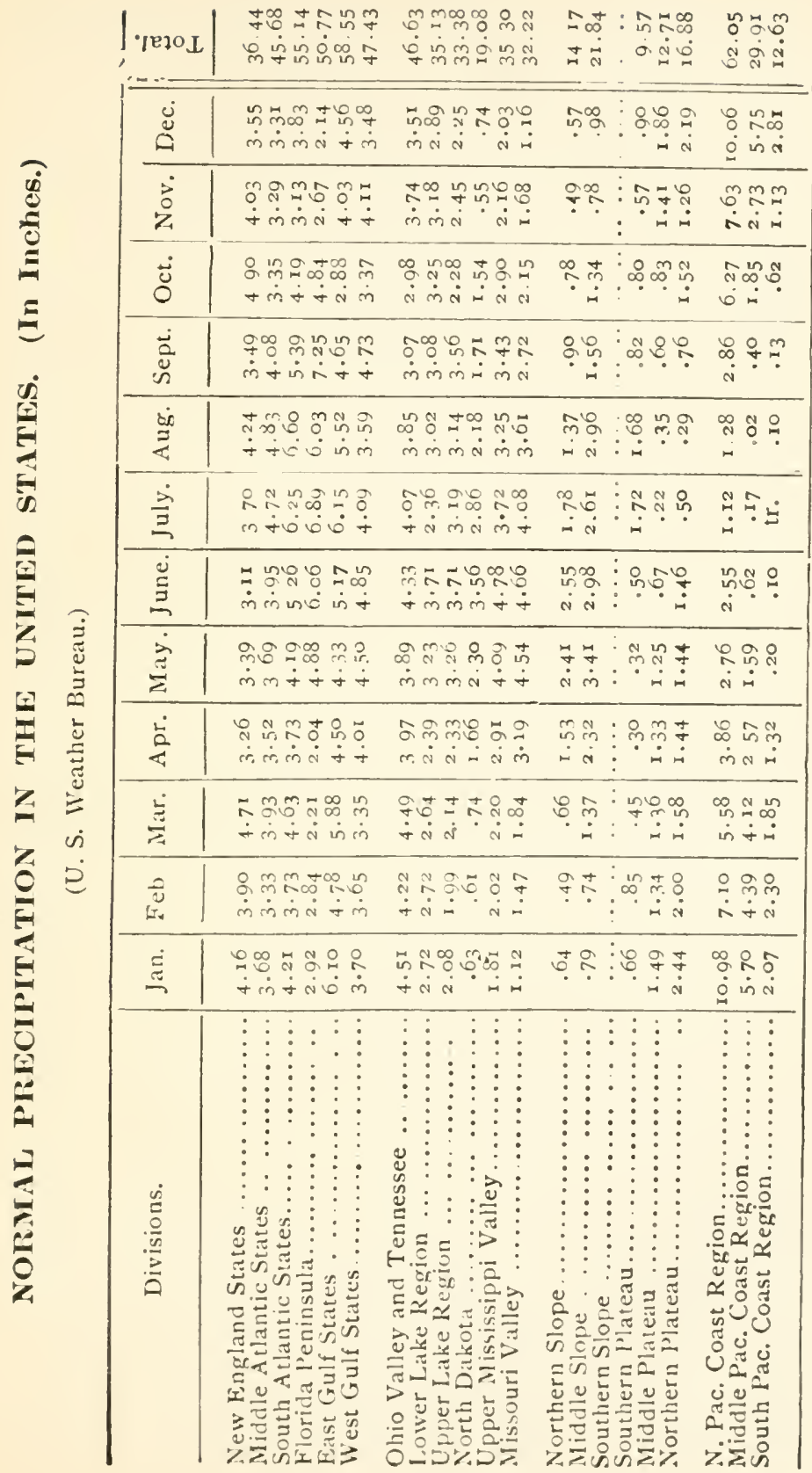




\section{METEOROLOGICAL DA'A FOR CANADA.}

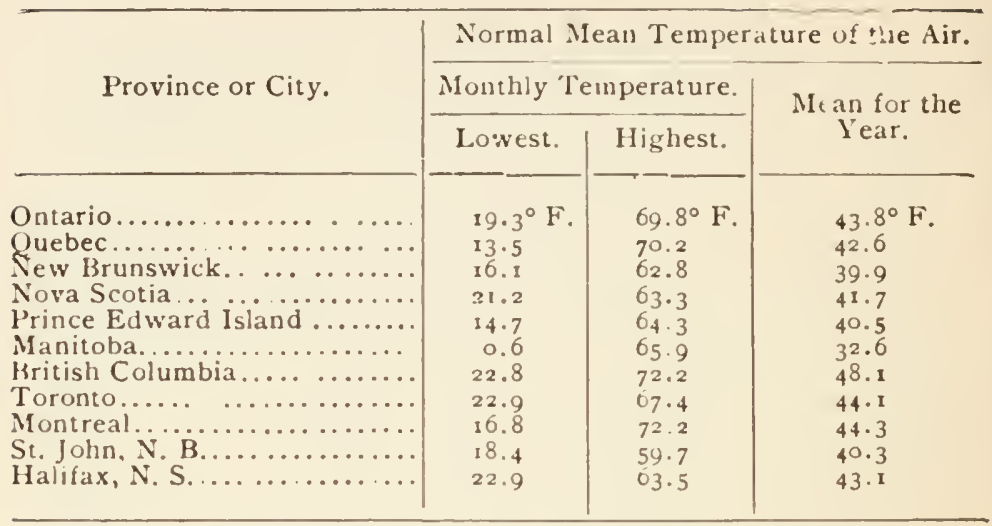

Normal rainfall in inches per year: Toronto 29.42, Windsor 23.78, Peterborough 20.55, Montreal 27.26, Quebec 19.26, St. John 33.27, Halifax 43.08, Glace Bay 53 49, Sydney 49.42, Winnipeg 16.83 , Spence's Bridge 3.88 .

\section{COMPARISON OF LEADING INDUSTRIES IN THE}

UNITED STATES. (U.S. Census of 1890 . in Round Numbers.)

\begin{tabular}{|c|c|c|c|c|c|}
\hline & 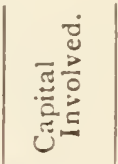 & $\frac{\underbrace{u}_{0}}{\stackrel{0}{0}}$ & 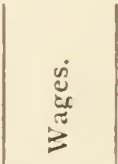 & 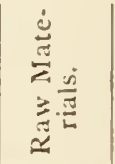 & $\begin{array}{l}0 \\
0 \\
0 \\
J \\
0 \\
0 \\
0\end{array}$ \\
\hline Agriculture $\ldots \ldots \ldots \ldots$. & $\begin{array}{c}\text { Jillions. } \\
15,982\end{array}$ & $\begin{array}{l}\text { Thousands. } \\
8,286\end{array}$ & $\begin{array}{c}\text { Nillions. } \\
\ldots\end{array}$ & $\begin{array}{c}\text { Millions. } \\
\quad \ldots\end{array}$ & $\begin{array}{c}\text { Millions. } \\
2.460\end{array}$ \\
\hline $\begin{array}{l}\text { Forest products, total.. } \\
\text { Forest industries, enu- } \\
\text { merated................. }\end{array}$ & $\cdots$ & - & … & $\cdots$ & 1,044 \\
\hline $\begin{array}{l}\text { Forest products, not enu- } \\
\text { merated (estimated) }\end{array}$ & & 340 & 102 & 245 & $\begin{array}{l}44^{\circ} \\
59^{8}\end{array}$ \\
\hline Manufactures using wood & 543 & 513 & 274 & $44^{2}$ & 907 \\
\hline $\begin{array}{c}\text { Mineral products, total..... } \\
\text { Coal } \ldots\end{array}$ & $\cdots$ & 300 & $\because 09$ & $\cdots$ & $\begin{array}{l}610 \\
160\end{array}$ \\
\hline 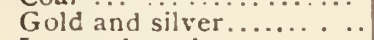 & $\begin{array}{l}343 \\
486\end{array}$ & 57 & 40 & $\cdots$ & 99 \\
\hline $\begin{array}{l}\text { Iron and steel ........ } \\
\text { Manufactures of iron and }\end{array}$ & 414 & 176 & 96 & 327 & 479 \\
\hline steel.................. & 86 & 60 & 32 & 79 & 131 \\
\hline $\begin{array}{l}\text { I.eather } \ldots . . . . . . . \\
\text { Leather manufactures.... }\end{array}$ & $\begin{array}{l}102 \\
118\end{array}$ & $\begin{array}{r}48 \\
186\end{array}$ & $\begin{array}{l}25 \\
88\end{array}$ & $\begin{array}{l}136 \\
153\end{array}$ & $\begin{array}{l}178 \\
280\end{array}$ \\
\hline Woolen " $\quad$..... & 297 & 219 & 77 & 203 & 338 \\
\hline Cotton & 354 & 222 & 70 & 155 & 268 \\
\hline
\end{tabular}




\section{ARFAS OF APPROPRIATED, VACANT, AND RE- SERVED IANDS IN IHE UNITED STATES, 1898.}

(U. S. Dept. Agr.)

\begin{tabular}{|c|c|c|c|c|c|}
\hline $\begin{array}{l}\text { States and } \\
\text { Territories. }\end{array}$ & Total Area. & $\begin{array}{l}\text { Unap- } \\
\text { prop. } \\
\text { and Un- } \\
\text { reserved. }\end{array}$ & Reserved & $\begin{array}{l}\text { Total } \\
\text { Govern- } \\
\text { ment } \\
\text { Land. }\end{array}$ & $\begin{array}{l}\text { Appropri. } \\
\text { ated. }\end{array}$ \\
\hline & & per cent. & per cent. & per cent. & per cent. \\
\hline $\begin{array}{l}\text { Alabama........... } \\
\text { Arizona.......... }\end{array}$ & $\begin{array}{l}32,658,000 \\
72,792,500\end{array}$ & $\begin{array}{r}1.60 \\
71.07\end{array}$ & $\begin{array}{r}.26 \\
21.12\end{array}$ & $\begin{array}{r}1.86 \\
92.16\end{array}$ & $\begin{array}{r}98.14 \\
7.81\end{array}$ \\
\hline$\ldots \ldots \ldots$ & $, 543,500$ & .02 & .01 & 11.03 & $88^{\circ}$ \\
\hline$a \ldots \ldots$. & $1,08_{3}$ & $42 \cdot 72$ & 16.35 & 59.07 & .93 \\
\hline Colorado .......... & 0,650 & $59.8 \mathrm{I}$ & $9 \cdot 3^{8}$ & 69. & \\
\hline Florida ............ &, 500 & $4 \cdot 98$ & .06 & $5 \cdot 04$ & $94 \cdot 96$ \\
\hline Idaho ....... & $52,8,30,200$ & 83.68 & 3.67 & $87 \cdot 35$ & 12.65 \\
\hline $\begin{array}{l}\text { Indian Territory... } \\
\text { Kansas } \ldots \ldots \ldots \ldots\end{array}$ & $19,575,040$ & $\cdots \ldots$ & 100.00 & 100.00 & \\
\hline & $5^{2,}, 3^{8}$ & 2.02 & 1.89 & 3.91 & 96.09 \\
\hline an $\ldots \ldots \ldots \ldots$ & $28,863,188$ & 2.62 & $5 \cdot 11$ & $7 \cdot 7$ & 92.27 \\
\hline$\ldots \ldots$ & $3^{6,8} \times 9,000$ & I. 37 & .24 & & 98.39 \\
\hline$\cdots$ & $51,689,444$ & 11.07 & 9.64 & $20.7 \mathrm{I}$ & 79.29 \\
\hline$\cdots \cdots$ & $29,685,000$ & I. 29 & $\cdots \cdots$ & 1. & 98.71 \\
\hline ........ & $43,796,000$ & 1.02 & & I. & 98.98 \\
\hline$\ldots \ldots$ & 720 & $75 \cdot 13$ & 12.03 & 87 . & 12.84 \\
\hline ......... & .339 & 21.47 & .14 & 21.61 & $78 \cdot 39$ \\
\hline$\ldots \ldots$ & 500 & $87 \cdot 33$ & 8.51 & 95 . & $4 \cdot 26$ \\
\hline$\ldots \ldots$ & $78,197,005$ & $69 \cdot 76$ & 10.69 & & 19.55 \\
\hline North D & $44,902,987$ & 45.82 & 6.79 & 52.6 & $47 \cdot 39$ \\
\hline$\ldots \ldots$ & 3.663 & $28 \cdot 3^{1}$ & 29.11 & 57 & $42 \cdot 5^{8}$ \\
\hline & $61.626,218$ & 58.25 & 8.87 & & 32.88 \\
\hline$\ldots \ldots$ & $4^{8}, 15^{8}, 555$ & 26.55 & 23.09 & & $50.3^{6}$ \\
\hline & $52,580,000$ & $8.3 \cdot 43$ & 10.37 & & 6.20 \\
\hline Wash & $42,68_{4}, 08_{4}$ & $3^{1} \cdot 49$ & 26.08 & $57 \cdot 57$ & 42.43 \\
\hline W isc & $35,275,000$ & 1.17 & 1.04 & & 97.79 \\
\hline & $62,433,000$ & $7^{8} \cdot 54$ & $13 \cdot 16$ & $91 \cdot 70$ & 8.30 \\
\hline Other States.. & $579,024,029$ & ........ & .04 & .04 & 99.96 \\
\hline Total. & $1,900,01$ & 30.21 & 7.64 & 37.85 & 62.15 \\
\hline
\end{tabular}

\section{FARMING POPULATION OF THE UNITED} STATES, 1880, 1890, AND 1900.

\begin{tabular}{|c|c|c|c|}
\hline & $\begin{array}{l}\text { Tenth } \\
\text { Census. }\end{array}$ & $\begin{array}{c}\text { Eleventh } \\
\text { Census. }\end{array}$ & $\begin{array}{l}\text { Twelfth } \\
\text { Census. }\end{array}$ \\
\hline 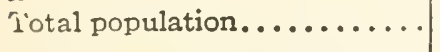 & $50,152,866$ & $62,622,250$ & $75,994,575$ \\
\hline $\begin{array}{l}\text { Total engaged in agriculture... } \\
\text { Professional service............ } \\
\text { Domestic and personal service } \\
\text { Trade and transportation. .... } \\
\text { Mfg. and mechan. pursuits.... }\end{array}$ & $\begin{array}{r}7,7 \text { I } 3,875 \\
603,202 \\
3,723,815 \\
1,866,481 \\
3,784,726 \\
\end{array}$ & $\begin{array}{r}8,565,026 \\
944,333 \\
4,220,812 \\
3,326,122 \\
5,678,468 \\
\end{array}$ & $\begin{array}{r}10,381,765 \\
1,258,739 \\
5,580,657 \\
4,766,964 \\
7,085,992 \\
\end{array}$ \\
\hline 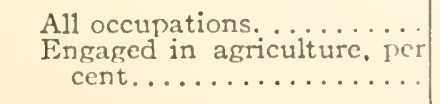 & $\begin{array}{c}17,302,009 \\
4.4 .3\end{array}$ & $\begin{array}{c}22,735,661 \\
37 \cdot 7\end{array}$ & $\begin{array}{c}29,074,117 \\
35 \cdot 7\end{array}$ \\
\hline
\end{tabular}


NUMBER MNO CIASSICATION OF THE IGRICULTURAL POPULATION, 16 VAMS OF AGE AND OVER.

(Twelfth Census.)

\begin{tabular}{|c|c|c|c|}
\hline Occupation. & Male. & Fenuale. & Total. \\
\hline 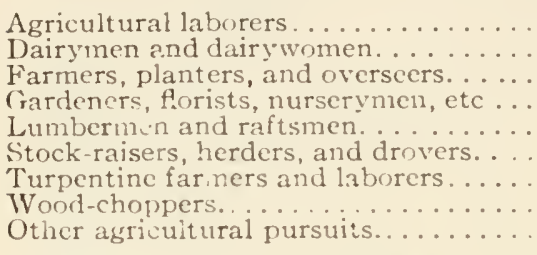 & $\begin{array}{r}3,7+7,668 \\
9,983 \\
5,367,169 \\
58,028 \\
71,920 \\
83,056 \\
24,456 \\
35,962 \\
5,287\end{array}$ & $\begin{array}{r}663,200 \\
802 \\
307,706 \\
2,860 \\
100 \\
1,932 \\
281 \\
113 \\
243\end{array}$ & $\begin{array}{r}4,410,877 \\
10,875 \\
5,674,875 \\
61,788 \\
72,020 \\
84,988 \\
24,737 \\
36,075 \\
5,530\end{array}$ \\
\hline Total engaged in agriculture. . . . . . & $0,404,429$ & 977,336 & $1038_{1,765}$ \\
\hline
\end{tabular}

\section{NUMBER OF FARMS IN THE UNITHA STATES ANI) 'THEIR VAlCL.}

(Thirteenth Census.)

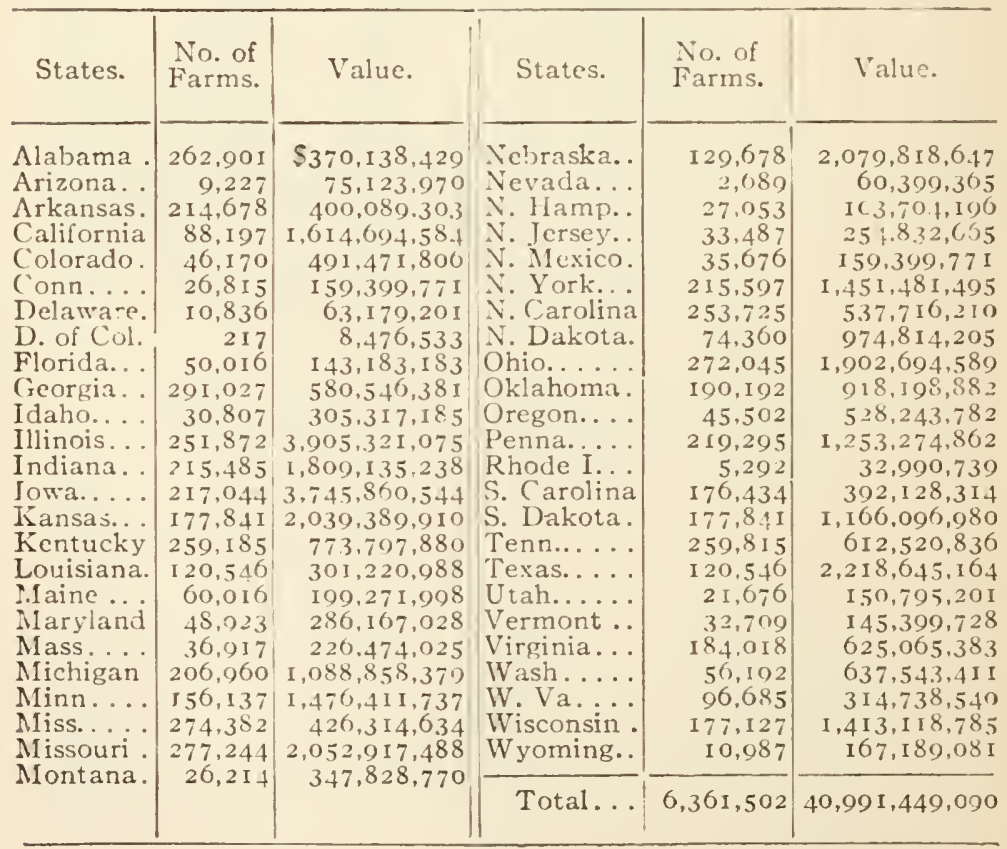




\begin{tabular}{|c|c|c|c|}
\hline & 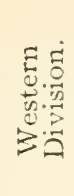 & 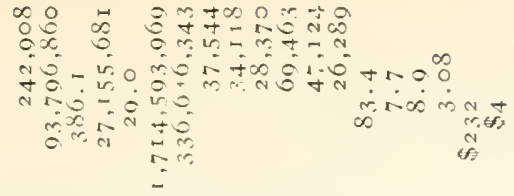 & 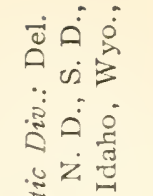 \\
\hline 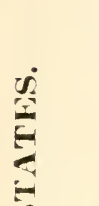 & 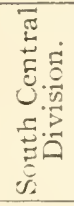 & 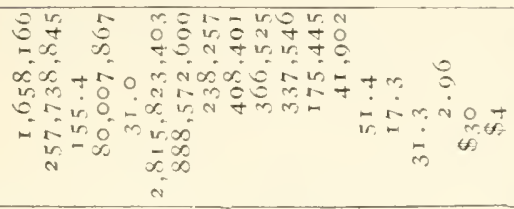 & 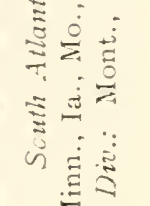 \\
\hline$\frac{1}{2}$ & 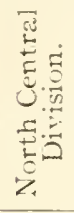 & 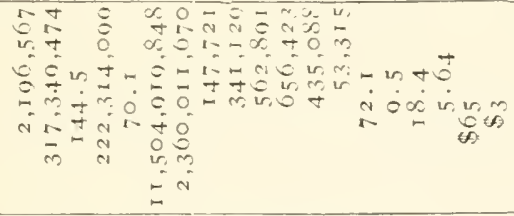 & 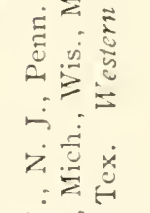 \\
\hline $\begin{array}{l}E \\
E \\
E\end{array}$ & 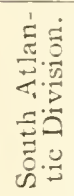 & 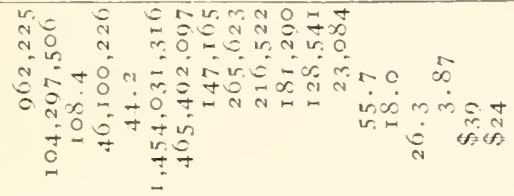 & 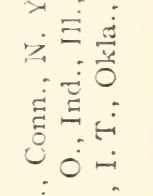 \\
\hline$=$ & 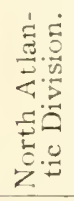 & 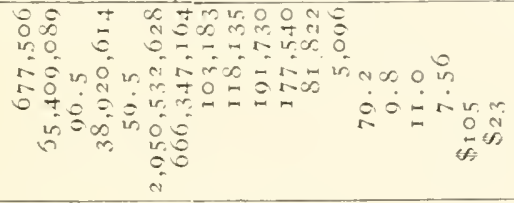 & 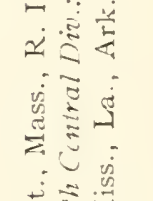 \\
\hline$\frac{1}{2}$ & 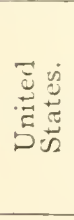 & 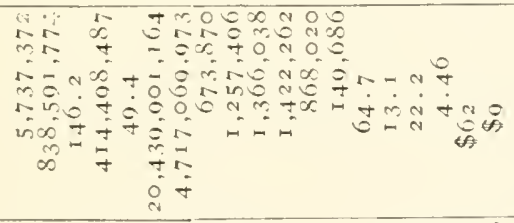 & 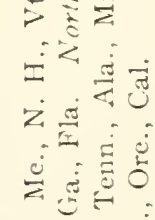 \\
\hline $\begin{array}{l}0 \\
= \\
= \\
= \\
= \\
=\end{array}$ & & 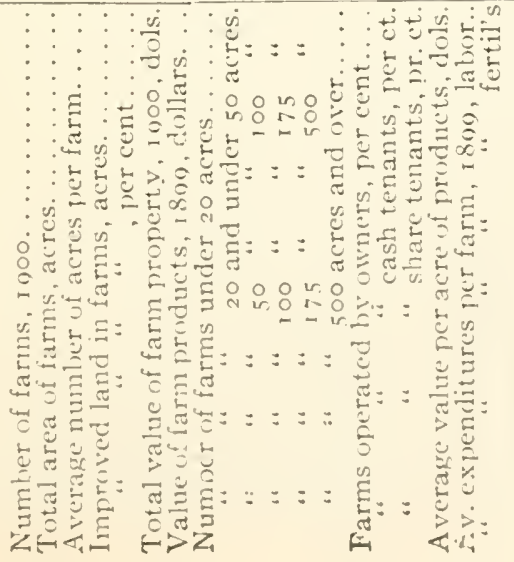 & 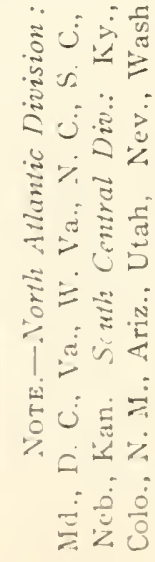 \\
\hline
\end{tabular}




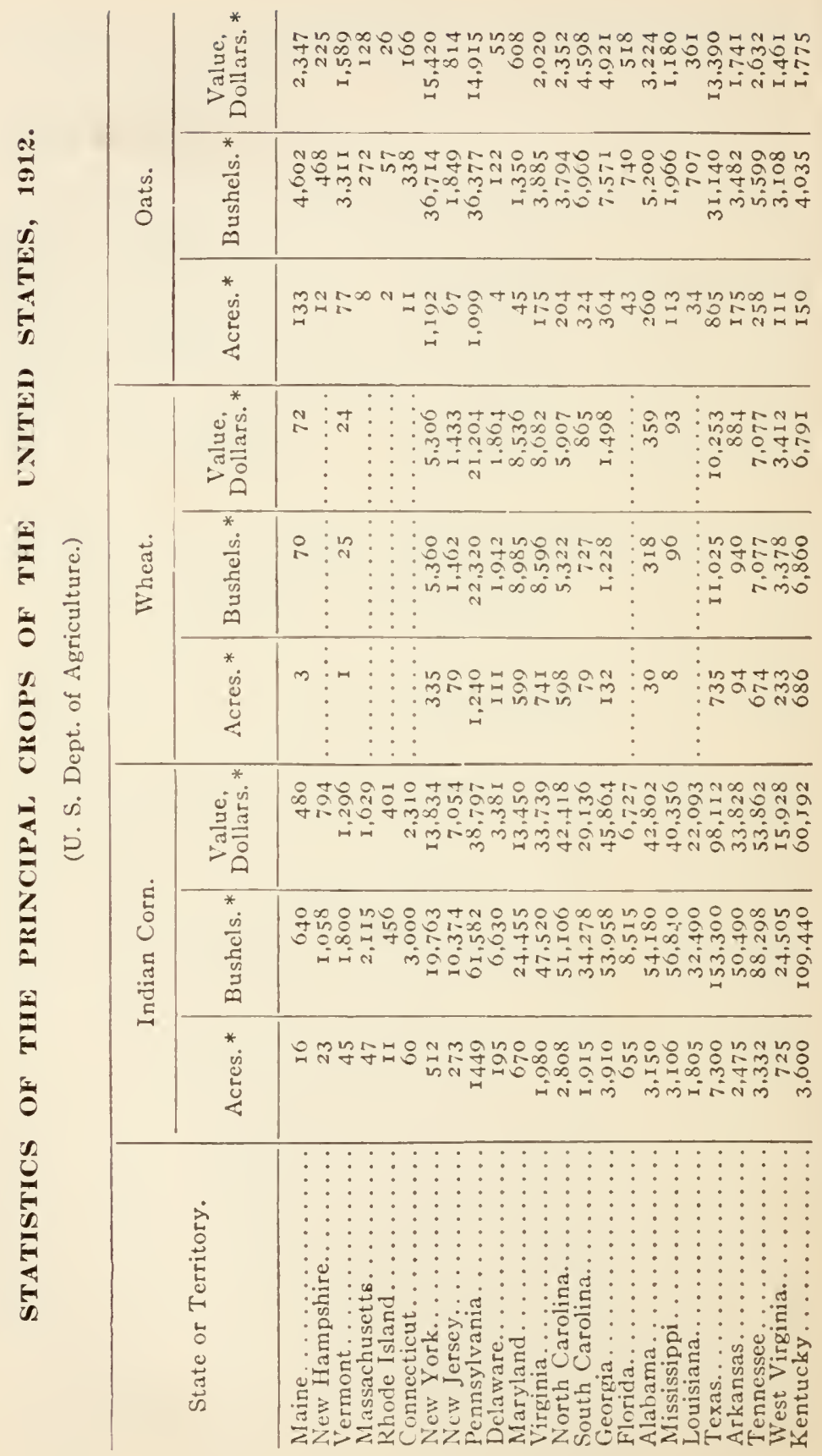


N

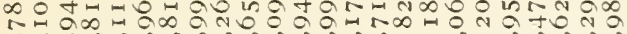

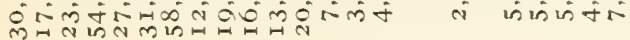

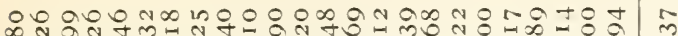

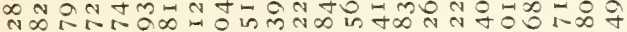

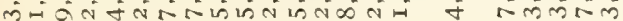

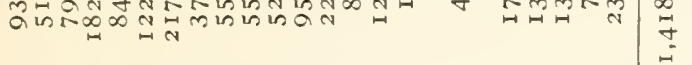

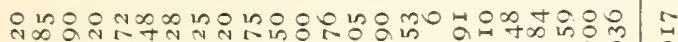

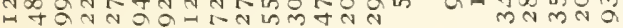

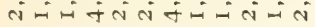

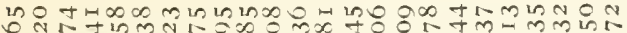
แN वं́ó

Oᄋ 0 O no on $1200 \mathrm{n}$ n

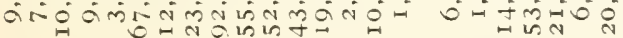

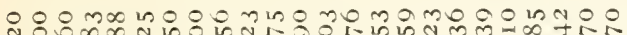
4. = म

thm 制a

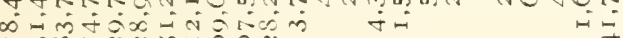

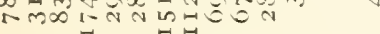
을 पतmm

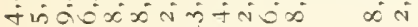
I น

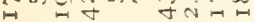




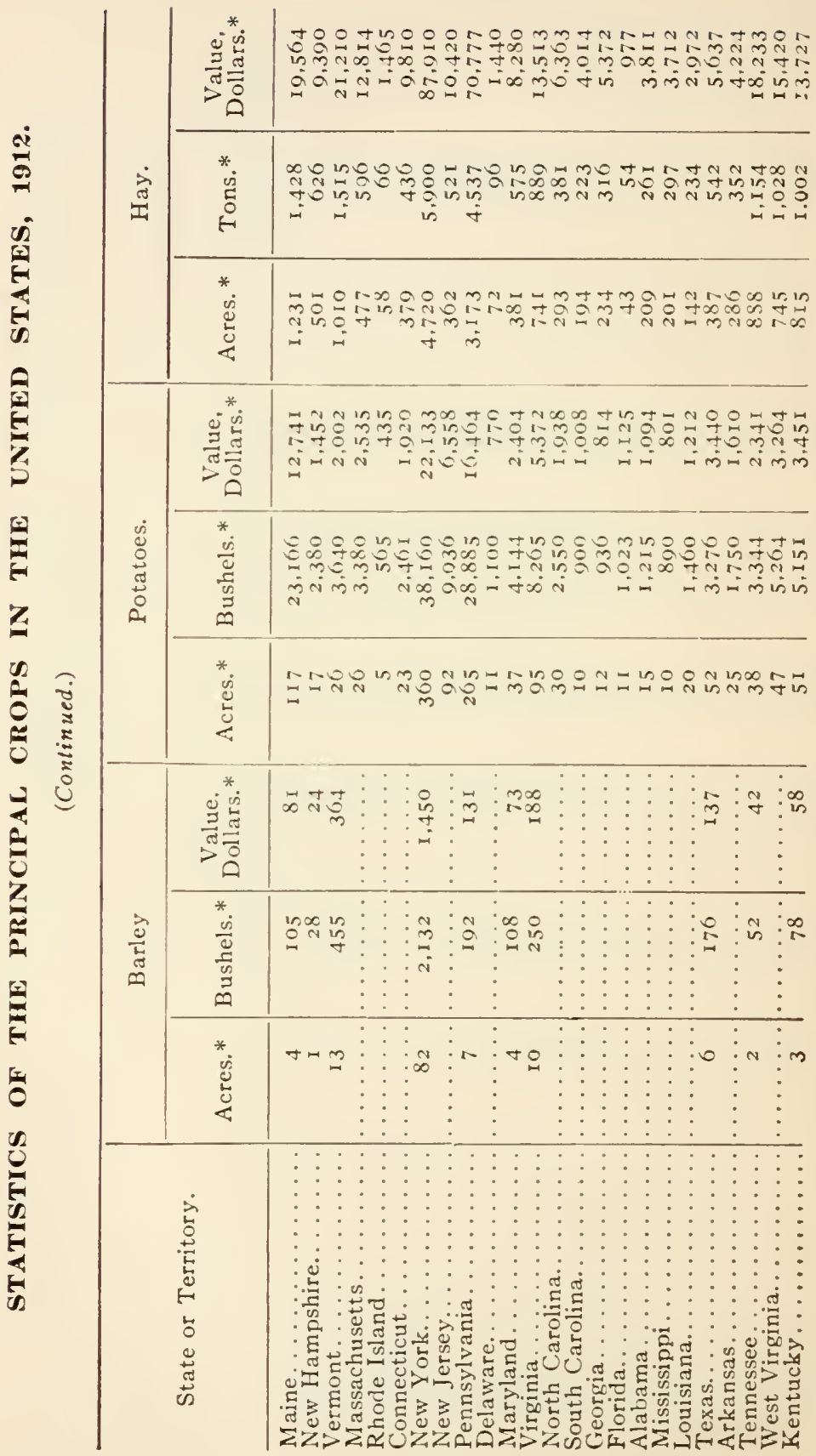




\section{AVERIGE IGRICULTURAI WAGES IN THEU.S. IN 189:3-1895, INCIUSIVE. (L . S. Dent. of Agriculture.)}

\begin{tabular}{|c|c|c|c|c|c|c|}
\hline \multirow{2}{*}{ Years. } & \multicolumn{2}{|c|}{$\begin{array}{l}\text { Per Month for } \\
\text { Season or Ycar. }\end{array}$} & \multicolumn{2}{|c|}{$\begin{array}{l}\text { Per Day in } \\
\text { Harvest. }\end{array}$} & \multicolumn{2}{|c|}{$\begin{array}{l}\text { Per Day other } \\
\text { than Ilarvest. }\end{array}$} \\
\hline & $\begin{array}{l}\text { With } \\
\text { Board. }\end{array}$ & $\begin{array}{l}\text { Without } \\
\text { Board. }\end{array}$ & $\begin{array}{l}\text { With } \\
\text { Board. }\end{array}$ & $\begin{array}{c}\text { Without } \\
\text { Board. }\end{array}$ & $\begin{array}{l}\text { With } \\
\text { Board. }\end{array}$ & $\begin{array}{l}\text { Without } \\
\text { Board. }\end{array}$ \\
\hline $\begin{array}{l}\text { I } 893 \ldots \ldots \\
1894 \ldots \ldots \ldots \\
1895 \ldots \ldots \ldots\end{array}$ & $\begin{array}{r}\$ 13.29 \\
12.16 \\
12.02\end{array}$ & $\begin{array}{r}\$ 19.10 \\
17.74 \\
17.60\end{array}$ & $\begin{array}{r}\text { S1.03 } \\
.93 \\
.02\end{array}$ & $\begin{array}{r}\text { SI. } 24 \\
\text { I. } 13 \\
\text { I. } 14\end{array}$ & $\begin{array}{r}\text { So. } 69 \\
.63 \\
.62\end{array}$ & $\begin{array}{r}\text { \$o. S9 } \\
.8 \mathrm{I} \\
.8 \mathrm{I}\end{array}$ \\
\hline
\end{tabular}

\section{INDUSTRY GROUPS IN THE UNITED STATES.}

(Twelfth Census.)

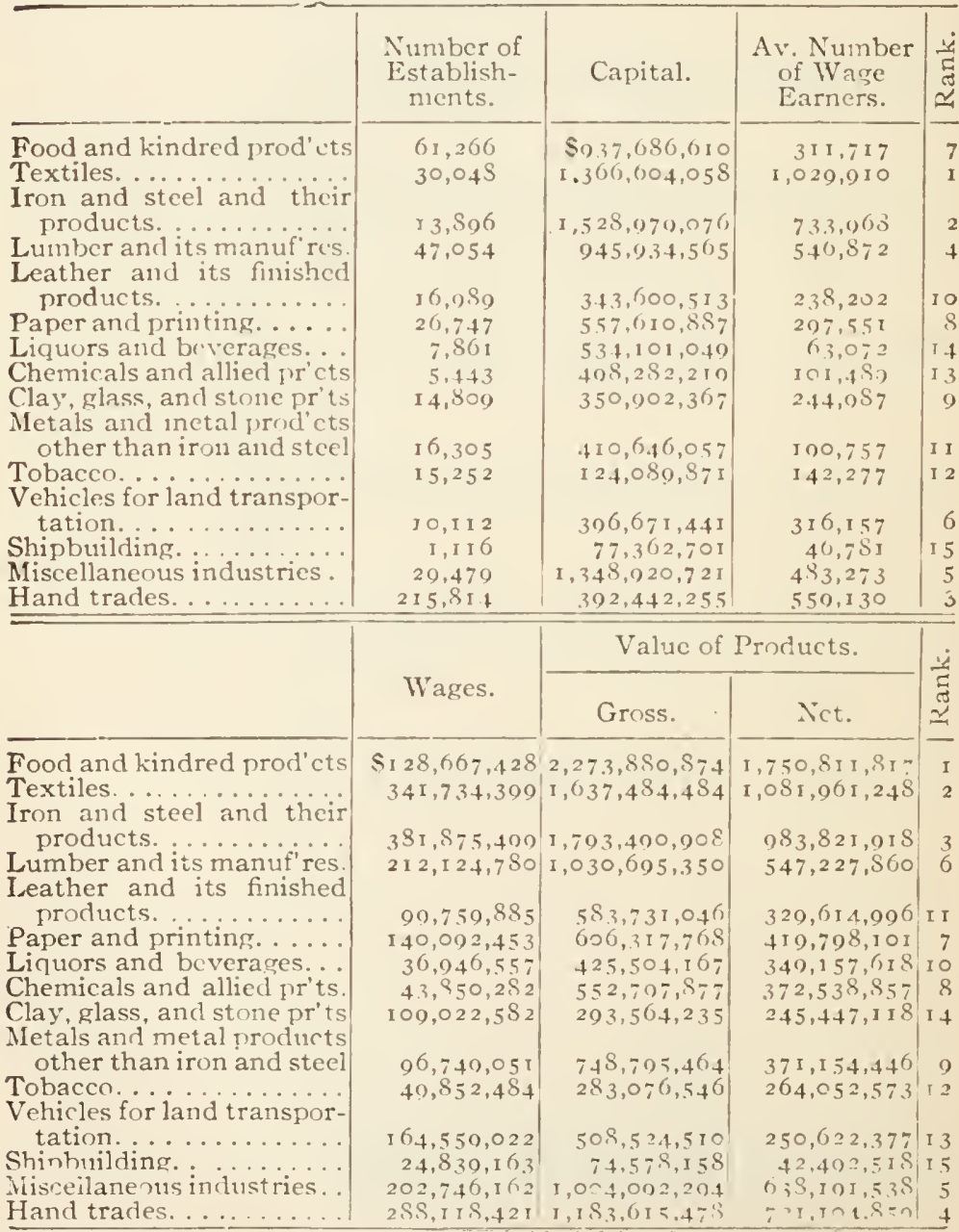




\section{AREA, PROIUC'TION, AND VALIE OF PRINCYPAL, CROPS IN THE UNITED STATES, 1912}

(U. S. Dept. of Agriculture.)

\begin{tabular}{|c|c|c|c|c|c|c|c|}
\hline \multicolumn{2}{|l|}{ Crop. } & $\begin{array}{l}\text { Total Pro- } \\
\text { duction.* }\end{array}$ & $\begin{array}{c}\text { Total } \\
\text { Area, } \\
\text { Acres.* }\end{array}$ & $\begin{array}{c}\text { Total } \\
\text { Value, } \\
\text { Dollars.* }\end{array}$ & $\begin{array}{c}\text { Ave. } \\
\text { Yield } \\
\text { per Acre. }\end{array}$ & \begin{tabular}{|} 
Ave. \\
Farm \\
Price per \\
Unit. \\
Cents.
\end{tabular} & $\begin{array}{c}\text { Ave. } \\
\text { Value } \\
\text { per Acre, } \\
\text { Dollars. }\end{array}$ \\
\hline Indian corn. & . bu. & $3.124,746$ & I 07,083 & I $, 520,454$ & 29.2 & $48 \cdot 7$ & I 4.22 \\
\hline Wheat, & & 730,267 & $45.8 \mathrm{I} 4$ & 555,280 & 15.9 & 76.0 & I 2.08 \\
\hline Oats, & $\because$ & $1,418,337$ & 37,917 & 452,469 & $37 \cdot 4$ & 31.9 & I I. 93 \\
\hline Barley, & $\because$ & 223.824 & 7,530 & I I 2,957 & 29.7 & 50.4 & I 4.97 \\
\hline Rye, & $\because$ & 35.664 & 2, I I 7 & 23,636 & I6.8 & 66.3 & I I. I 4 \\
\hline Buckwheat & $\because$ & I 9,249 & $8.4 \mathrm{I}$ & I 2,720 & 22.9 & 66.1 & 15.14 \\
\hline Potatoes, & & $420,6.47$ & $3.7 \mathrm{II}$ & 212.550 & I I 3.4 & 50.5 & 57.27 \\
\hline Hay, & tons & $72,69 \mathrm{I}$ & 49.530 & 856.695 & I. 47 & I I. $79 \dagger$ & 17.33 \\
\hline Cotton $\neq$ & bales & I 5,693 & 36,045 & 732,420 & 207.7 & 8.8 & I 8.28 \\
\hline Tobacco, & lbs. & 962,855 & 1,226 & I 04,063 & $785 \cdot 5$ & 10.8 & 84.83 \\
\hline Flaxseed & bu. & 28,073 & $2,85 \mathrm{I}$ & 32,202 & 9.8 & I I $4 \cdot 7$ & I I. 24 \\
\hline Rice, & $\because$ & 25,054 & 723 & 23,423 & 34.7 & $93 \cdot 5$ & 32.44 \\
\hline Hops $\neq$. & 1bs. & 51,672 & $\ldots \ldots \ldots$ & $\ldots \ldots \ldots$ & $\ldots \ldots$ & $\ldots \ldots$ & $\ldots \ldots$ \\
\hline
\end{tabular}

* Expressed in thousands; ooo omitted.

+ Dollars.

$\ddagger$ Data for I9I I.

\section{THE PRINCIPAL CEREAL PRODUCTS OF THE UNITED STA'TES.}

\section{As Shown by the Census Returns, from 1850 to 1910.}

\begin{tabular}{|c|c|c|c|c|c|c|}
\hline $\begin{array}{l}\text { Cen- } \\
\text { sus }\end{array}$ & $\begin{array}{c}\text { Indian } \\
\text { Corn. }\end{array}$ & Wheat. & Oats. & Barley. & Ryre. & $\begin{array}{l}\text { Buck- } \\
\text { wheat. }\end{array}$ \\
\hline I 850 & $\begin{array}{l}\text { Bushels. } \\
592,07 \mathrm{I}, \mathrm{I}_{4}\end{array}$ & $\begin{array}{c}\text { Bushels. } \\
\mathrm{I} 00,485,944\end{array}$ & $\begin{array}{l}\text { Bushels. } \\
\text { I } 46,584,179\end{array}$ & $\begin{array}{l}\text { Bushels. } \\
5,167,015\end{array}$ & $\begin{array}{l}\text { Bushels. } \\
14, I_{88,8}{ }_{3}\end{array}$ & $\begin{array}{l}\text { Bushels. } \\
8,956,9 \text { I } 2\end{array}$ \\
\hline 1860 & $838,792,742$ & $173,104,924$ & I $72,6,43,185$ & I $5,825,803$ & $21,101,380$ & I $7,57 \mathrm{I}, 8 \mathrm{I} 8$ \\
\hline I 870 & $760,944,549$ & $287,745,626$ & $282,107,157$ & $29,761,30.5$ & I $(0.9)$ I 8,795 & $9.821,721$ \\
\hline I 880 & $\mathrm{I}, 754,86 \mathrm{I}, 525$ & $459,479,505$ & $407.858,999$ & 4.4, I I 3,495 & 10 $9.8,31, .505$ & I I , 8 I 7,227 \\
\hline I 890 & $2,112,327,547$ & $468,373,968$ & $809,250,666$ & $78,332,976$ & $28,421,308$ & 12, I 10,349 \\
\hline 1900 & $2,666.324 .37^{\circ}$ & $658,534,252$ & 943.389 .375 & I $19,634.877$ & $25,568,625$ & I $1,233,515$ \\
\hline 1910 & $2,552,189,630$ & 683.379 .259 & $1,007,142,980$ & I $73,344,2$ I 2 & $29.520,457$ & $14,8,49,332$ \\
\hline
\end{tabular}

\section{PRODUCTION OF VARIOUS CROPS IN CANAIA, 1912.}

\begin{tabular}{|c|c|c|c|}
\hline Crops. & Total Yields. & Crops. & Total Yields. \\
\hline 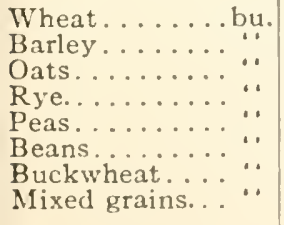 & $\begin{array}{r}199,235,000 \\
44,014,000 \\
361,733,000 \\
2,594,000 \\
3,773,500 \\
1,040,800 \\
10,193,000 \\
17,952,000\end{array}$ & 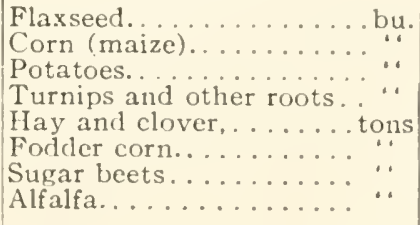 & $\begin{array}{r}21,681,500 \\
16,569,800 \\
81,343,000 \\
87,505,000 \\
11,189,000 \\
2,858,000 \\
204,000 \\
310,100\end{array}$ \\
\hline
\end{tabular}




\section{AVERAGE COST PER ACRE OF RAISING WHEAT, CORN, AND COTTON IN THL UNITED STATES. 18933.*}

(U. S. Dept. of Agriculture.)

\begin{tabular}{|c|c|c|c|c|}
\hline & Wheat. & Corn. & $\begin{array}{l}\text { Cotton. } \\
\text { Uplatid. }\end{array}$ & $\begin{array}{l}\text { Cotton, } \\
\text { Se:tb'd. }\end{array}$ \\
\hline Rent of land ................ & $\$ 2.8 \mathrm{r}$ & $\$ 3.03$ & $\$ 2.88$ & $\$ 2.36$ \\
\hline Manure or fertilizers............ & 2.16 & 1.80 & 1. 46 & 3.75 \\
\hline Preparing ground $\ldots \ldots \ldots \ldots$ & 1.87 & t. 62 & 2.81 & 3.65 \\
\hline Seed $\ldots \ldots \ldots \ldots \ldots \ldots \ldots \ldots \ldots$ & .96 & $\ldots$ & .21 & $.3^{3}$ \\
\hline Sowing or planting ............. & .37 & $.4^{2}$ & .28 & .46 \\
\hline Cultivating................ & $\ldots$ & 1.80 & $1 \cdot 3 \mathrm{I}$ & 1.73 \\
\hline Harvesting, gathering, or picking.. & 1.19 & 1.22 & $3 \cdot 37$ & 5.17 \\
\hline Thrashing $\ldots \ldots \ldots . . . . . . . . .$. & I. 20 & ... & … & \\
\hline Ginning and pressing. ......... & . & $\ldots$ & 1.65 & $2.6 \mathrm{t}$ \\
\hline Housing $\quad . \ldots \ldots \ldots \ldots$. $\ldots \ldots$ & $\cdot 37$ & .50 & .... & $\ldots$. \\
\hline Kepairmg implements............ & & & .42 & .42 \\
\hline Marketing. ... & .76 & 1.26 & .64 & .91 \\
\hline Other expenses..... $\quad \ldots \ldots \ldots$ & $\cdots$ & $\cdots$ & $\cdot 41$ & $.5 \mathrm{r}$ \\
\hline 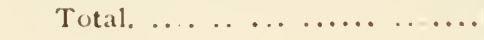 & $\$ 11.69$ & Sir.71 & $\$ 15.42$ & $\$ 21.95$ \\
\hline
\end{tabular}

AVERAGIE FIRAI PRICE OF VARIOUS AGRICUITURAI

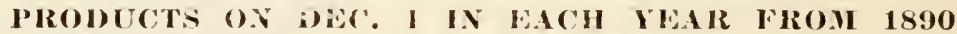
TO 1910 .

(U. S. Dept. of Agriculture.)

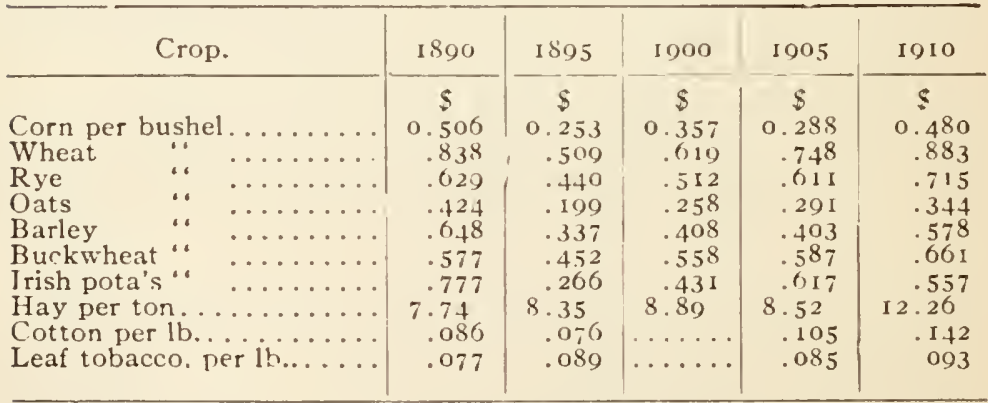

* Data for wheat and corn consolidated from réurns from nearly 30,000 leading farmers scattered throughnut the United States. The data for cotton were secured in 1897 , and are the averages of returns from over 3400 planters. 


\section{NUMBER AND VALUE OF FARM ANIMALS IN THE UNITED STATES, 1880-1910. (U.S. Dept. of Agriculture.)}

\begin{tabular}{|c|c|c|c|c|}
\hline Farm Animals. & Jan. I, I 880. & Jan. I, I89o. & Jan. $1,1900$. & Jan. I, I9Io. \\
\hline \multirow{2}{*}{$\begin{array}{r}\text { Horses, number } \\
\text { value.. }\end{array}$} & II,20I,800 & 14,2 I 3,837 & $I 3,537,524$ & $21,040,000$ \\
\hline & $\$ 613,29$ & $\$ 978,5$ & $\$ 603,969,442$ & $\$ 2,276,363,000$ \\
\hline \multirow{2}{*}{$\begin{array}{l}\text { Mules, number } \\
\text { value.. }\end{array}$} &, 500 & 2,027 & $2,086,027$ & $4.123,000$ \\
\hline & $\$ 105,9$ & $\$ 182,3$ & $\$ 1$ I I, 7I 7,0 & $\$ 494,095.000$ \\
\hline \multirow{2}{*}{$\begin{array}{r}\text { Milch cows, No. } \\
\text { value.. }\end{array}$} & I $2,027,000$ & $15,952,883$ & 16,29 & $21,801,000$ \\
\hline & $\$ 279,899,420$ & $\$ 352,152,133$ & $\$ 514,8$ I 2,106 & $\$ 780,308,000$ \\
\hline \multirow{2}{*}{$\begin{array}{c}\text { Other cat., No. } \\
\text { value. }\end{array}$} & $21,321,000$ & $36,849,024$ & 27,6 I 0,054 & $47,279,000$ \\
\hline & $\$ 341,761,154$ & $\$ 560,625,137$ & $\$ 689,486,260$ & $\$ 9$ I $7,453,000$ \\
\hline $\begin{array}{l}\text { Sheep, number } \\
\text { value.. }\end{array}$ & $\begin{array}{r}40,765,900 \\
\$ 00,230,537\end{array}$ & $\begin{array}{r}44,336,072 \\
\text { \$1 } 00,650,76 \mathrm{I}\end{array}$ & $41,883,065$ & $\begin{array}{r}57,216,000 \\
\$ 233,664,000\end{array}$ \\
\hline \multirow{2}{*}{$\begin{array}{ll}\text { Swine, } & \text { number } \\
& \text { value.. }\end{array}$} & $\begin{array}{r}\$ 90,2 \\
34,0\end{array}$ & $\begin{array}{r}\text { \$I } 00,659,76 \mathrm{I} \\
5 \mathrm{I}, 602,780\end{array}$ & $\begin{array}{r}\$ 122,665,913 \\
37,079,000\end{array}$ & $\begin{array}{r}233,004,000 \\
47,782,000\end{array}$ \\
\hline & $\$ 145,781,5$ I 5 & $\$ 243,418,336$ & $\$ 85,472,32 \mathrm{I}$ & $\$ 436,603,000$ \\
\hline $\begin{array}{l}\text { Total value of } \\
\text { farm animals. }\end{array}$ & $\$ 1,576,917,556$ & $\$ 2,418,766,028$ & $\$ 2,228,123,134$ & $\$ 5$, I $38,486,000$ \\
\hline
\end{tabular}

\section{VALUES OF FARM PROPERTY AND PRODUCTS IN CANADA, 1901.}

(Census of rgor.)

Farm property, i 90 .

Total value.......\$ $\$$ r, $787, \mathrm{r}_{02}, 6_{3 \mathrm{C}}$ Land and buildings... $\mathrm{I}, 403,269,50 \mathrm{x}$ Implements and machinery.........

Horses..............

Milch cows.........

Other horned cattle..

Sheep...............

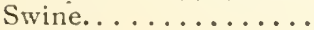

Poultry . . . . . . .

Bees..............

$108,665,502$

II $8,279,4$ I 8

$60,237,970$

$54,197,341$

$10,490,594$

I $6,4,45,702$

$5,723,890$

792,7 II
Agricultural products, I $90 \mathrm{r}$.

Total value....... \$364,906,866 Field crops.......... I 94,953,420 Fruits and vegetables ... I $2,994,900$ Nursery stock sold in year. ........... Live stock sold in year. Meats, etc., of animals slaughtered on farm.

Dairy products.......

Wool. .............

Eggs................

Honey and wax......

Maple sugar. ........
$469,50 \mathrm{I}$

$52,755,375$

$22,951,527$

$66,470,953$

$1,887,064$

$10,286,828$ 356,8 г 6

$\mathbf{1 , 7 8 0 , 4 8 2}$

\section{NUMBER OF FARM ANIMALS AND ANHAL PRODUCTS IN CANADA, 1901.}

(Census of rgor.)

Horses over 3 years old. . Horses under 3 years old. . Nilch cows. . . . . . . . . Other horned cattle..... Sheep............... Swine.............. Hives of bees.............
I, 304,9 I0 272,583 $2,408,677$

$3,167,774$ $2,510,239$ х $7,922,658$ $\times 89,986$ $2,353,82 \mathrm{~S}$
Cattle, killed or sold. ... Sheep, killed or sold. ... Swine, killed or sold... . Poultry, killed or sold .. Butter, home made, lbs. Wool, lbs............ Honey, lbs.............

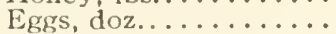

I , I I O, 209

I, 342, 288

$2,555,4$ I 3 $7,063,507$ I $5,343,076$ х० 657,597 $3,569,567$ $84,132,802$ 


\section{BREEDS AND NUMBER OF REGISTERED LIVE STOCK} IN THE UNITED STATES, DEC. $31,1905$.

(U. S. Dept. of Agriculture.)

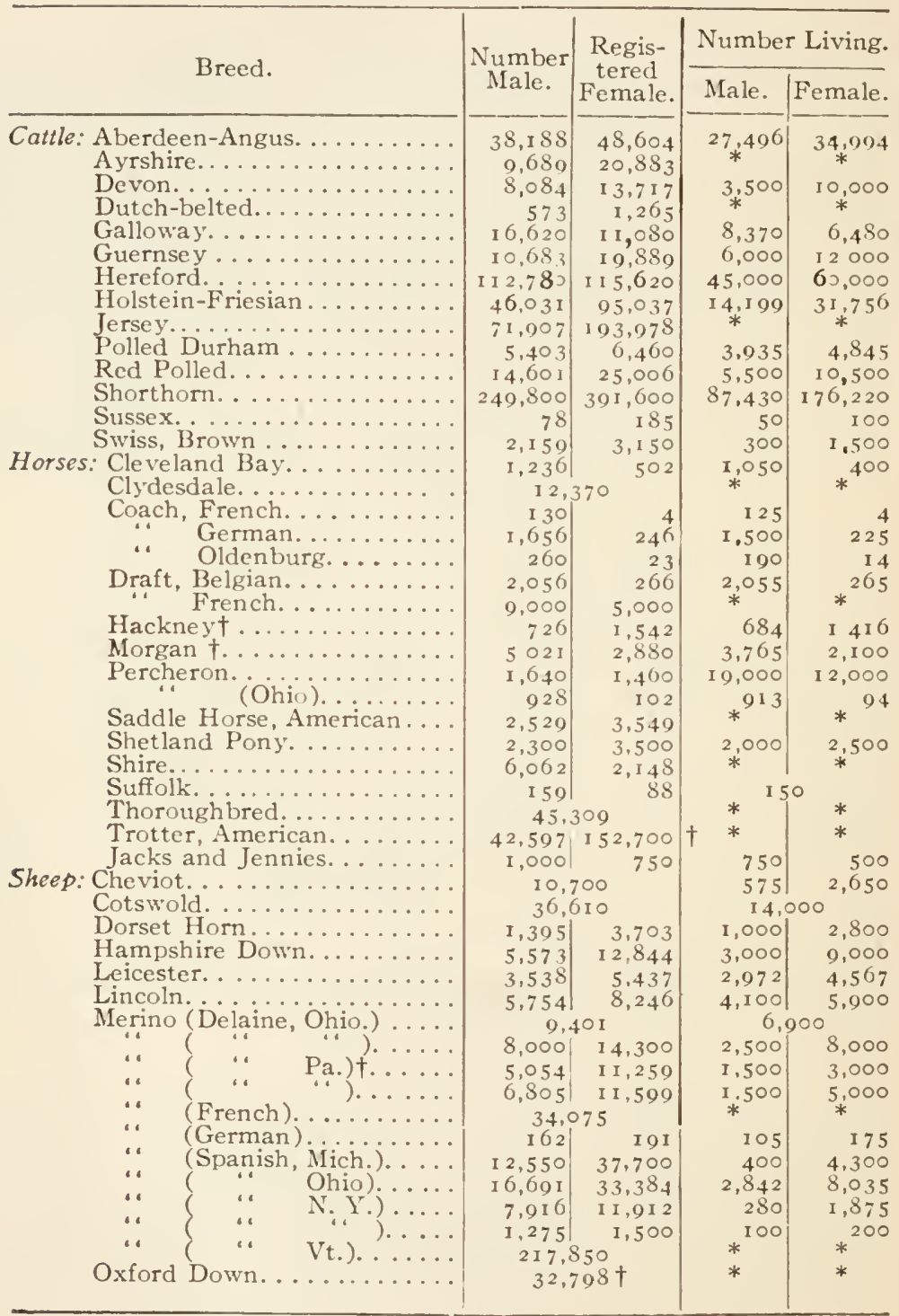


BIREEDS AND NUNBERS OF REGISTERED LIVE STOCK IN THE UNITED STATES-Continued.

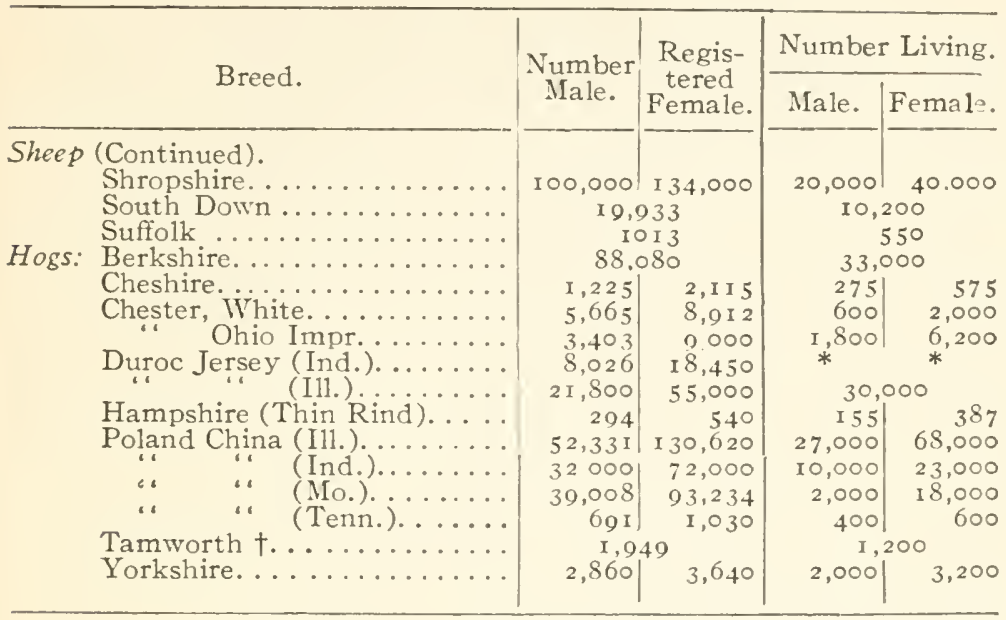

* No data. † Estimates for r 904.

\section{PURE-BRED CATTLE OF BREEDS GSED FOR \\ DAIRYING. (U. S. Dept. of Agriculture.)}

Estimates of numbers living in the United States, I905, and values of same.

\begin{tabular}{|c|c|c|c|c|c|c|c|}
\hline Breeds. & $\begin{array}{l}\text { Num- } \\
\text { ber } \\
\text { Regis- } \\
\text { tered. }\end{array}$ & $\begin{array}{l}\text { Est. } \\
\text { No. } \\
\text { Liv- } \\
\text { ing. }\end{array}$ & $\begin{array}{c}\text { Ar. } \\
\text { Val. } \\
\text { per } \\
\text { Headt }\end{array}$ & Breeds. & $\begin{array}{l}\text { Num- } \\
\text { ber } \\
\text { Regis- } \\
\text { tered. }\end{array}$ & $\begin{array}{l}\text { Est. } \\
\text { No. } \\
\text { Liv, } \\
\text { ing. }\end{array}$ & $\begin{array}{c}\text { Av. } \\
\text { Val. } \\
\text { per } \\
\text { Headt }\end{array}$ \\
\hline $\begin{array}{l}\text { Ayrshire..... } \\
\text { Brown-Swiss. } \\
\text { Devon...... } \\
\text { Dutch Belted } \\
\text { Guernsey . . } \\
\text { Holstein-Frie- } \\
\quad \text { sian....... }\end{array}$ & $\begin{array}{r}30,572 \\
5,309 \\
21,801 \\
1,838 \\
30,572 \\
141,068\end{array}$ & $\begin{array}{c}* \\
I, S 00 \\
\text { I } 3,500 \\
* \\
\text { I } 8,000 \\
45,955\end{array}$ & $\begin{array}{r}\text { S100 } \\
75 \\
75 \\
200 \\
140 \\
\\
130\end{array}$ & $\begin{array}{l}\text { Tersey ... } \\
\text { Polled Dur- } \\
\text { ham ... } \\
\text { Red Polled. } \\
+ \text { Shorthorn }\end{array}$ & $\begin{array}{r}265,885 \\
11,863 \\
39,607 \\
641,400\end{array}$ & $\begin{array}{r}8,780 \\
16,000 \\
263,650\end{array}$ & $\begin{array}{r}\text { S100 } \\
\text { So } \\
150 \\
170\end{array}$ \\
\hline
\end{tabular}

* No data. †Figures published r $903 . \quad \ddagger$ Chiefly beef stock. 


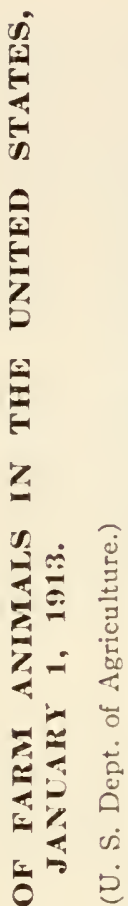

\begin{tabular}{|c|c|c|}
\hline \multirow{2}{*}{ 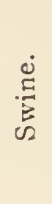 } & $\begin{array}{l}\dot{0} 0 \\
\dot{0} 0 \\
\dot{L}=\end{array}$ & 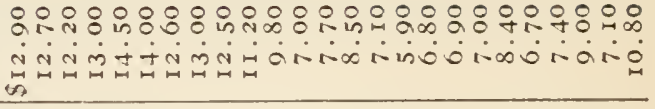 \\
\hline & 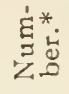 & 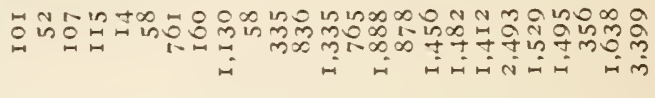 \\
\hline \multirow{2}{*}{ 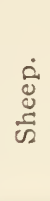 } & 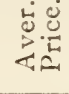 & 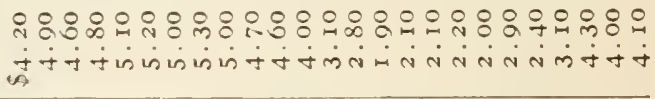 \\
\hline & 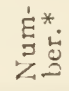 & 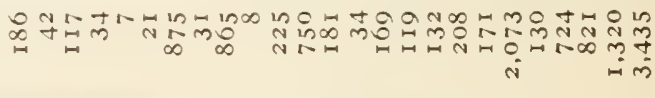 \\
\hline
\end{tabular}

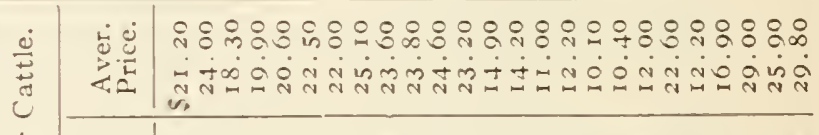

㟧 定.

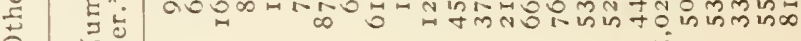
Z. in

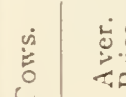

$\therefore$

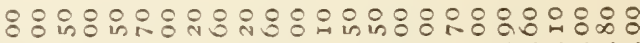

- F ox

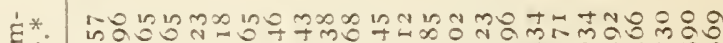
苞

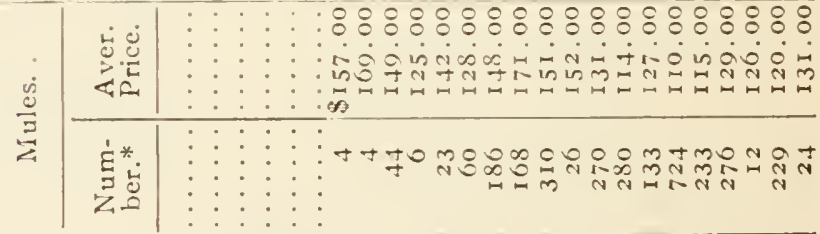

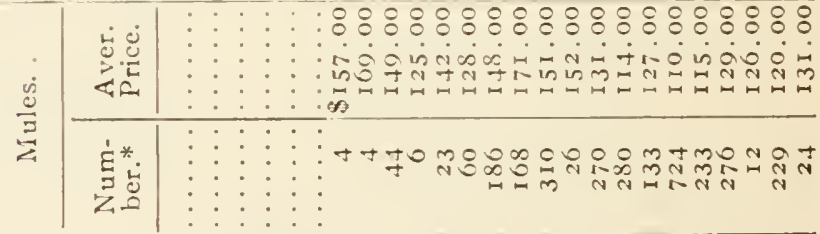

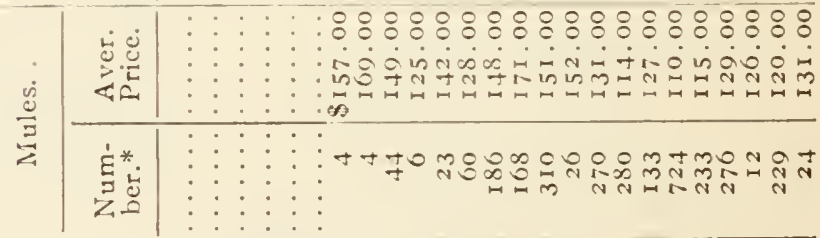

\begin{tabular}{|c|c|c|}
\hline \multirow{2}{*}{ 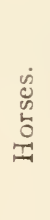 } & 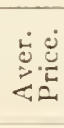 & 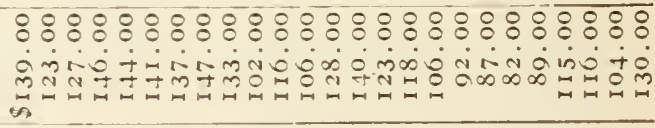 \\
\hline & 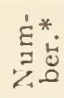 & ㄱㅇㅇㅇㅛ \\
\hline \multicolumn{2}{|c|}{ 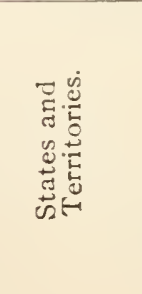 } & 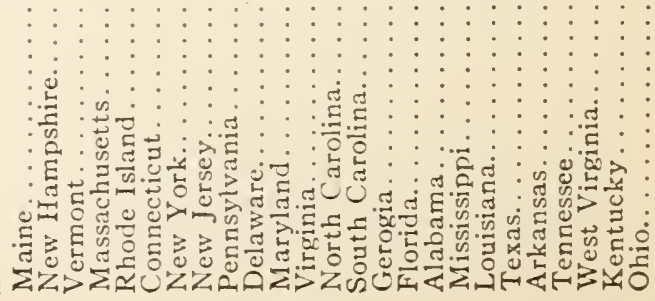 \\
\hline
\end{tabular}




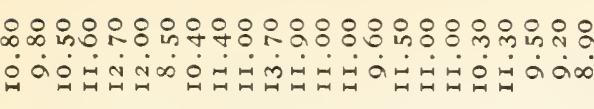

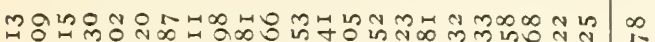
monos

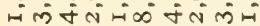

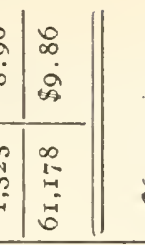

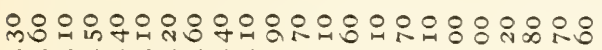

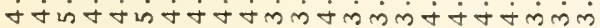

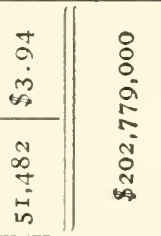

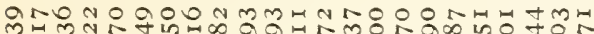

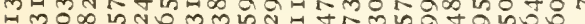

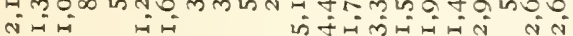

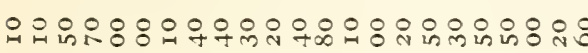
त 0 m

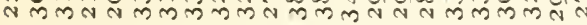

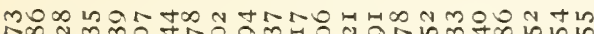
no n m mo tho o m

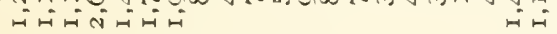

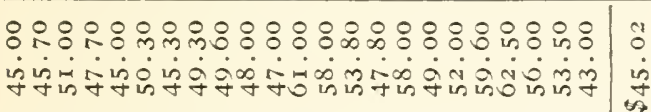

कtrtongon

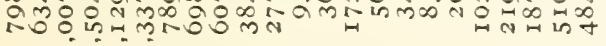
$\mapsto \mapsto \mapsto$

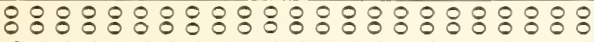

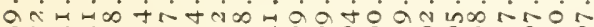

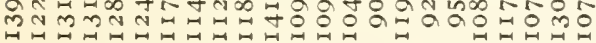

$\operatorname{lin}_{\pi}$

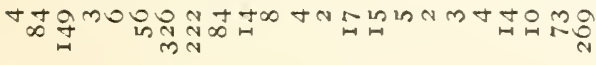
m

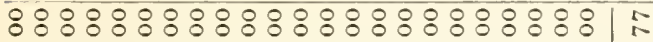

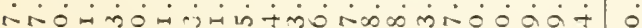

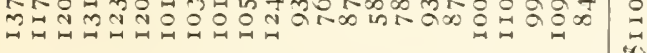

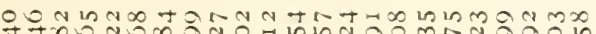

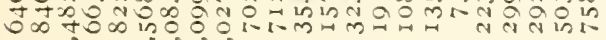
म

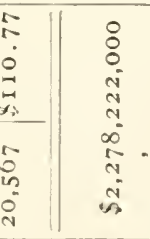




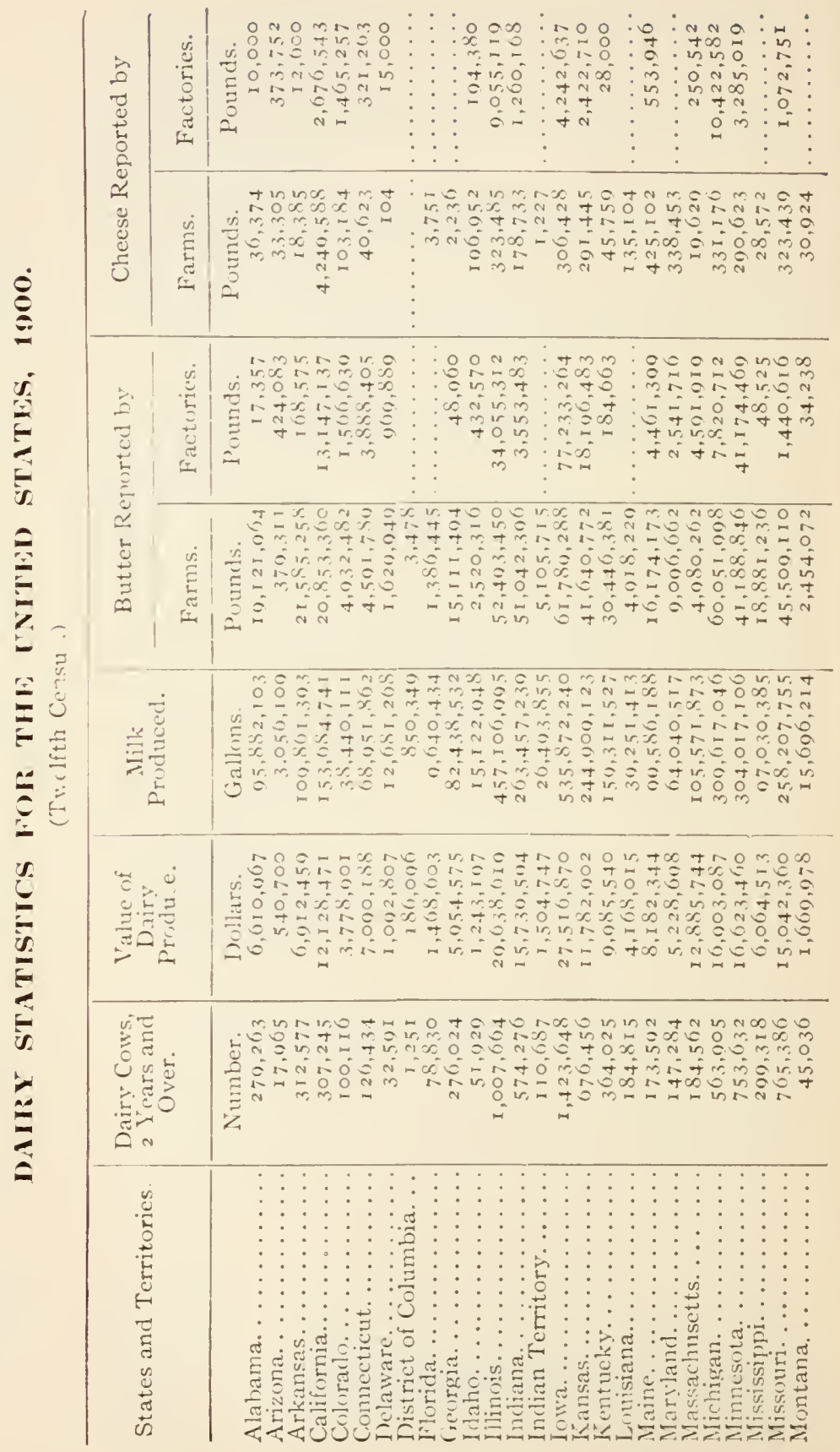




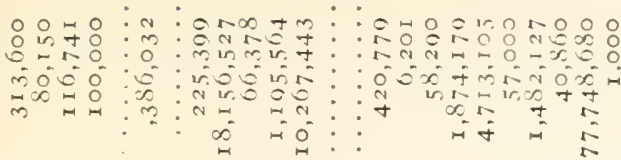

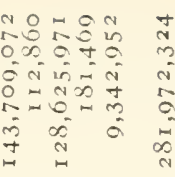

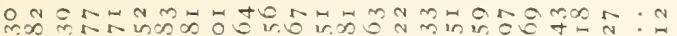

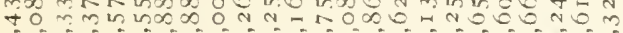

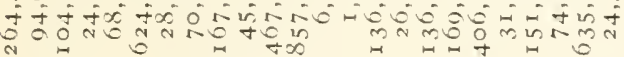

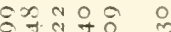

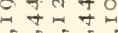
$000 \div 0$ 0 क ल No in $7 m+$ in + in in $0^{\circ}$

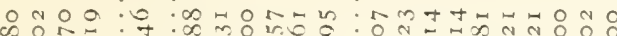

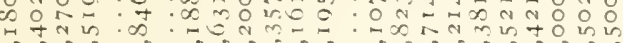

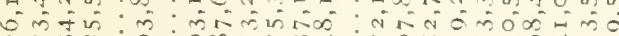

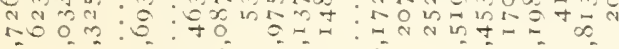

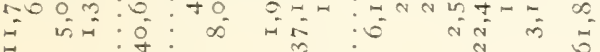

in $=$ m

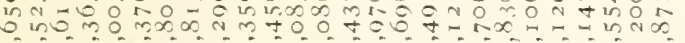

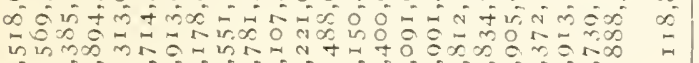
i on

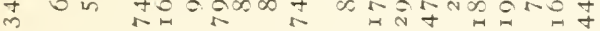

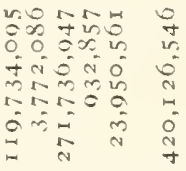

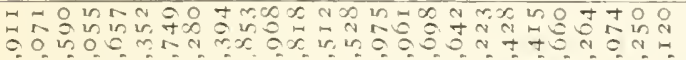
no

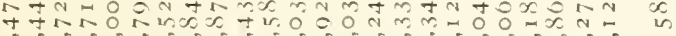

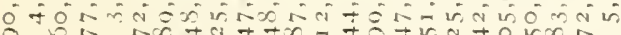
in 0000 tarma $\dot{A}=\hat{t} \dot{m}$

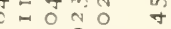
$4=0$ a 0 को is in (⿻ n口 ;

t

$\sin \infty \infty 0$ $\operatorname{lin} x \sin x$

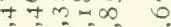
$1 \infty 001$ $7 m 0$ ir. 0 $2-0,0.0$ तथ कल क a $00 \mathrm{No}$ $\infty$ न $00 \mathrm{~m}$

क

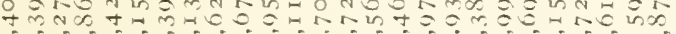
मिं

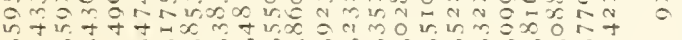

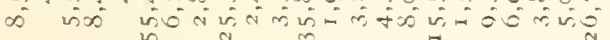

$x \rightarrow 0 \infty 0$ in int in in in $\operatorname{lom} m \mathrm{~N}$ in 10 ing

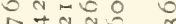
$\operatorname{tin} 2$ $+m 0$ in

Jow $\mathrm{x}$ -

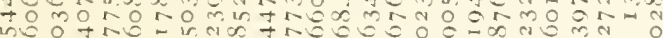

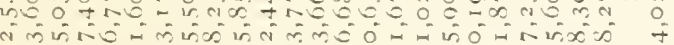

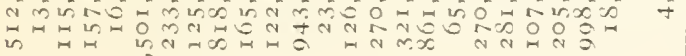

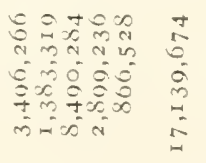




\section{STATISTICS OF BUTTER, CHEESE, AND CON DENSED-MIL FACTORIES IN THE UNITED STATES.}

(Twelfth Census.)

Number of establishments reporting.

Capital employed, total. ............ dollars

Land.

Totaks for the United States.

1900.

Buildings. ........... "

Machinery, tools, and implements... “

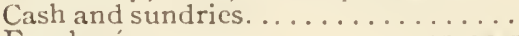

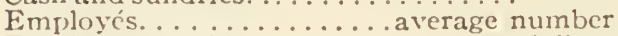

Total wages paid. ................ dollars

Materials used:

Aggregate cost. . . . . . . . . . . dollars

For butter:

Gathered cream. .......... pounds

Milk.

Total cost. . . . . . . . . . . . dullars

For chcese:

Milk. ................ pounds

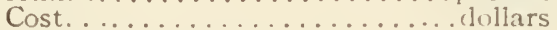

For condensed milk:

Milk................. pounds

Sugar.

".

Products:

Total cost. ................. dollars

Aggregate value. .............dollars

Butter made:

Packed solid. . . . . . . . . . pounds

Prints or rolls. . . . . . . . . . . .

Total value. . . . . . . . . . . dollars

Cream sold................ gallons

Value. .................. dollars

Skim milk sold, fed, or returned to patrons. . . . . . . . . . . pounds Value................... dollars

All other ereamery products....

Cheese, standard factory:

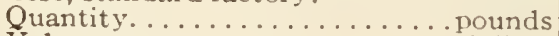

Value.................. dollars

Cheese, all other made:

Quantity................ pounds

Value ................... dollars

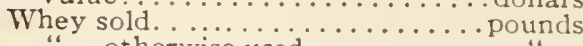

" otherwise used. ..........

Total value. ............... dollars

All other cheese-factory products

Condensed milk:

Quantity. .............. pounds

Value .................... dollars

\begin{tabular}{|c|c|}
\hline \multicolumn{2}{|c|}{ I 900.} \\
\hline $\begin{array}{c}\text { Butter and } \\
\text { Cheese } \\
\text { Factories. }\end{array}$ & $\begin{array}{l}\text { Urban } \\
\text { Estabs. }\end{array}$ \\
\hline 9,242 & I I 3 \\
\hline $36,303,164$ & $204,85 \mathrm{I}$ \\
\hline I, 8 I 8,519 & 20,875 \\
\hline $11,514,10 S$ & 42,246 \\
\hline $13,827,667$ & 60,485 \\
\hline $9,142,780$ & 63,245 \\
\hline I 2,799 & 66 \\
\hline $6,145,501$ & 25,109 \\
\hline $108,841,200$ & 310,005 \\
\hline $203,673,958$ & I , 066,756 \\
\hline $8,514,806,6,34$ & $20,104,778$ \\
\hline $73,480,355$ & 250,670 \\
\hline 2,74 I 898 , I I 4 & $7,415,490$ \\
\hline $21,258,712$ & 44,755 \\
\hline $421,378,073$ & $\ldots \ldots$ \\
\hline $50,873,850$ & $\ldots \ldots$ \\
\hline $7,252,124$ & $\ldots \ldots$ \\
\hline I $30,783,349$ & 415,928 \\
\hline $328,95^{6}, 590$ & 334.588 \\
\hline 9 I , I 69,956 & 492,882 \\
\hline $84,079,754$ & 195,662 \\
\hline $7,720,560$ & I 64, I I 4 \\
\hline $4,435,444$ & 112,092 \\
\hline $2,253,494,156$ & $5,517,877$ \\
\hline $2,531,460$ & 24,008 \\
\hline$I, 023,402$ & $5^{83}$ \\
\hline $225,776,1 \circ 5$ & 360,450 \\
\hline $2 \mathrm{I}, 363,477$ & 36,050 \\
\hline 56, I 96,2 I 9 & $30 \pi, 714$ \\
\hline 5, I 56,352 & I $4,60 \mathrm{I}$ \\
\hline $44,500,752$ & 75,000 \\
\hline I 64,476, I 95 & $\ldots \ldots \ldots$ \\
\hline $\begin{array}{r}204,277 \\
66,7 \text { I I }\end{array}$ & $\begin{array}{r}75 \\
508\end{array}$ \\
\hline $\begin{array}{r}\text { I } 86,92 \mathrm{I}, 787 \\
\text { I I }, 888,792\end{array}$ & $\ldots \ldots$ \\
\hline & \\
\hline
\end{tabular}




\section{BUTTER AND CHEESE MAKING IN CANADA, 1901.}

(Census of i $90 \mathbf{I}_{\text {.) }}$

Number of factories..

Value of buildings and plant.........

Persons employed...

Aggregate working days. ...............

Salaries and wages...

Cream for butter, in. .

Cream for butter, libs.

Milk for cheese, lbs. . 2,296,950,966

Cost of delivery to factory............
Patrons of butter factories...............

Patrons of cheese fac76,394

tories. . . I 24,726
Paid patrons for butter. $\$ 6,036,600$ cheese.\$1 $9,265,832$

Butter made, lbs..... 36,066,739

Cheese made, lbs. . . . . 220,833260

Value of butter made. $\$ 7,240,972$ "cheese " . \$22,22I,430

Total value of products. $\$ 29,402,402$

\section{WOOL PRODUCT OF THE UNITED STATES, 191:.}

Total.

Number of sheep of shearing age, April r, r9r2.. 38,48 I,000

Average weight of fleece, lbs. ............. $6.8_{2}$

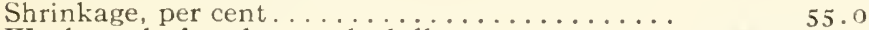

Wool, washerl and unwashed, lbs.......... 304,043,400

Wool, scoured, lbs...................... $136,866,652$

PRODUCTION OF SUGAR IN THE UNITED STATES, 1870-1911.

\begin{tabular}{|c|c|c|c|c|c|c|c|}
\hline \multirow[b]{2}{*}{ Year. } & \multirow{2}{*}{$\begin{array}{l}\text { Beet } \\
\text { Sugar, } \\
\text { Long } \\
\text { Tons. }\end{array}$} & \multicolumn{5}{|c|}{ Cane Sugar, Long Tons. } & \multirow[b]{2}{*}{ Total. } \\
\hline & & $\begin{array}{c}\text { Louisi- } \\
\text { ana. }\end{array}$ & $\begin{array}{l}\text { Other } \\
\text { South. } \\
\text { States. }\end{array}$ & $\begin{array}{l}\text { Porto } \\
\text { Rico. }\end{array}$ & Hawaii. & $\begin{array}{l}\text { Philip- } \\
\text { pine } \\
\text { Islands. }\end{array}$ & \\
\hline I $870-7 \mathrm{I}$ & 400 & 75,392 & 4,208 & 103,304 & & 87,465 & 270,760 \\
\hline I $880-8$ I & 500 & I 21,867 & 5.500 & 61,715 & 41,870 & $20.5,508$ & 436,960 \\
\hline $1890-91$ & 3.459 & 215,844 & 6,107 & 50,000 & I 25,000 & 136,035 & $536,4+45$ \\
\hline I000-O I & 76,859 & 275,579 & $2,89 \mathrm{I}$ & 72,800 & $32 \mathrm{I}, 46 \mathrm{I}$ & 55,244 & 804.834 \\
\hline I9IO-I I & 455,5 I I & 306,000 & I I, OOO & 312,357 & 506,090 & $1+7,016$ & $1,737,974$ \\
\hline
\end{tabular}




\section{STATISTICS OF SUGAR-BEET FACTORIES IN THE} UNITED STATES FOR 1912.

(U.S. Dept. of Agriculture.)

\begin{tabular}{|c|c|c|c|c|c|c|c|c|}
\hline & 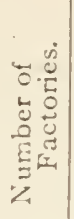 & 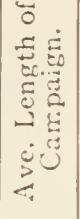 & 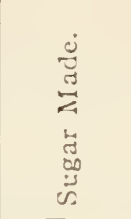 & 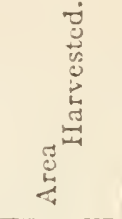 & 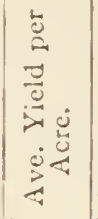 & 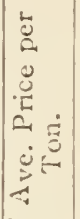 & 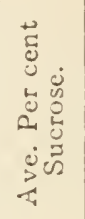 & 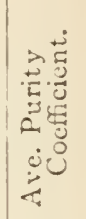 \\
\hline 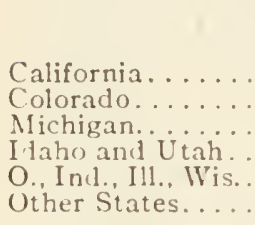 & $\begin{array}{l}11 \\
17 \\
16 \\
10 \\
11 \\
8\end{array}$ & $\begin{array}{c}\text { Days } \\
90 \\
91 \\
117 \\
74 \\
87 \\
87 \\
88\end{array}$ & $\begin{array}{c}\text { Short- } \\
\text { 10ns. } \\
158,00.7 \\
216,010 \\
95.19+4 \\
84.332 \\
57.921 * \\
80,340\end{array}$ & $\begin{array}{r}\text { Acres. } \\
\text { I 1 } 1,416 \\
141.099 \\
124.241 \\
56.952 \\
53.086 \\
63.706\end{array}$ & $\begin{array}{c}\text { Sh'rt. } \\
\text { tons. } \\
9.01 \\
11.32 \\
6.75 \\
10.81 \\
9.00 \\
9.25\end{array}$ & $\begin{array}{l}\text { 1)ol- } \\
\text { lars. } \\
5.46 \\
5.96 \\
5.69 \\
4.97 \\
5.60 \\
5.81\end{array}$ & $\begin{array}{l}18.79 \\
18.79 \\
16.19 \\
14.72 \\
14.65 \\
16.61\end{array}$ & $\begin{array}{l}\text { Per } \\
\text { cent. } \\
84.0 \\
84.8 \\
83.8 \\
86.8 \\
82.3 \\
84.1\end{array}$ \\
\hline United States. . & 73 & 86 & $602.55^{6}$ & 5.55 .300 & $9 .+1$ & 5.82 & 16.31 & 84.5 \\
\hline
\end{tabular}

* Including estimates of one factory, based on acreage of beets.

\section{PROIECTION OF CANE- ANI) BHET-SECAR, 1903-11.}

\begin{tabular}{|c|c|c|c|c|}
\hline & \multicolumn{2}{|c|}{ The IVnrl.1. } & \multicolumn{2}{|c|}{ The United States. } \\
\hline & Cane. & Beet. & Cane. & Beet. \\
\hline $1003-1004$ & Tons. * & Tons. * & Tons. * & Tons. * \\
\hline $1904-1005$ & 6.754 .328 & $4,926,456$ & $8,5,576$ & 200,722 \\
\hline $1905-1905$ & $6,5 \cap 2,133$ & $7,255,13^{\prime}$ & 922,000 & 283,717 \\
\hline $1906-1907$ & $7 .+68,900$ & $6,774,400$ & 820,700 & $+32,000$ \\
\hline $1907-100 S$ & 7.076 .800 & $6,598.000$ & $1,022,400$ & $41+, 000$ \\
\hline $1008-1909$ & $7,726,500$ & 6.562 .000 & 1.095 .400 & 380,000 \\
\hline $1909-1910$ & 8.412 .995 & $6,241,630$ & $1,071,095$ & $4+7.930$ \\
\hline I9IO-I9I I & $8,429.300$ & $8,0,0,800$ & I, I35, 100 & 456,000 \\
\hline
\end{tabular}

* Long tons, except in case of European beet-sugar production, which is given in metric tons (2204.6 lbs.). 


\section{MAPIE-SUGAR AND SIRUP, AND SORGHUM SIRUP PRODUCED IN THE UNTED STATES, 1899. \\ (Twelfth Census.)}

\begin{tabular}{|c|c|c|c|c|}
\hline & \multirow{2}{*}{ Sugar. } & \multirow{2}{*}{ Sirup. } & \multicolumn{2}{|c|}{ Value of Products. } \\
\hline & & & Sugar. & Sirup. \\
\hline $\begin{array}{l}\text { Maple. . . . . . . . } \\
\text { Sorghum. . . . }\end{array}$ & $\begin{array}{c}\text { Pounds. } \\
\text { I I }, 928,770 \\
\ldots \ldots \ldots \ldots\end{array}$ & $\begin{array}{c}\text { Gallons. } \\
2,056,6 \text { I I } \\
\text { I } 6,972,783\end{array}$ & $\begin{array}{l}\text { Dollars. } \\
1,074,260 \\
\ldots \ldots \ldots \ldots\end{array}$ & $\begin{array}{l}\text { Dollars. } \\
1,5612,451 \\
5,288,083\end{array}$ \\
\hline
\end{tabular}

STATISTICS OF THW IUMBER INUUSTIY OF THE UNTED STATIS, 1906. (U. S. DEPT. OF Agriculture.)

\begin{tabular}{|c|c|c|c|c|c|}
\hline Lumber. & $\begin{array}{c}\text { Leading } \\
\text { State. }\end{array}$ & $\begin{array}{l}\text { Cut, } \\
\text { M. Feet. }\end{array}$ & $\begin{array}{c}\text { Per } \\
\text { Cent. }\end{array}$ & $\begin{array}{c}\text { Total } \\
\text { Value. }\end{array}$ & $\begin{array}{c}\text { Mill } \\
\text { Valıe } \\
\text { per M. } \\
\text { Feet. }\end{array}$ \\
\hline Yellow pine ......... & 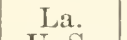 & $2,120,6$ I 5 & I 8.2 & $\$ 31,910,636$ & $\$ 15.05$ \\
\hline & U.S. & I I, 66 I, 077 & & I $75,178,446$ & 15.02 \\
\hline Douglas fir ......... & II ash. & $3,405,510$ & $68 \cdot 5$ & $48,8+1,166$ & I 4.34 \\
\hline White pine & U.S. & $4,969,8+3$ & $\cdots \cdots$ & $70,567, \mathrm{I}+\mathrm{I}$ & 14.20 \\
\hline White pine. & M.s. & $\begin{array}{l}1,664,734 \\
4,583,727\end{array}$ & $\begin{array}{l}30 \cdot 2 \\
\ldots \ldots\end{array}$ & $\begin{array}{l}29,072,+99 \\
83,052,701\end{array}$ & $\begin{array}{l}17.46 \\
18.32\end{array}$ \\
\hline Hemlock & Penna. & 966,480 & $27 \cdot 3$ & I $6,589,522$ & $\begin{array}{l}10.32 \\
17.16\end{array}$ \\
\hline Oak.... & U. S. & $\begin{array}{l}3,537,329 \\
330,820\end{array}$ & $\cdots \cdots$ & 54, I 53,242 & I 5.3 I \\
\hline Uak... & U. & $\begin{array}{r}339,829 \\
2,820,393\end{array}$ & $\begin{array}{ll}\mathrm{I} 2.0 \\
\ldots \ldots\end{array}$ & $\begin{array}{r}6,667,701 \\
61,377,266\end{array}$ & I 9.62 \\
\hline Spruce. & Me. & 557,975 & 33.8 & $\begin{array}{r}01,377,260 \\
9,802,083\end{array}$ & $\begin{array}{l}21.76 \\
17.57\end{array}$ \\
\hline Yotonn in & U.S. & $1,644,9 S_{7}$ & $\cdots \cdots$ & $2 \mathrm{~S}, 5$ I 5,439 & 17.33 \\
\hline Western pine $\ldots . . .$. & Calif. & 347,249 & 25.0 & $4,826,436$ & I 3.90 \\
\hline Maple. & Mich. & $\begin{array}{l}\mathrm{I}, 386,777 \\
402,845\end{array}$ & $\cdots \dot{8}$ & & I 4.01 \\
\hline & U. S. & $\begin{array}{l}492,845 \\
882,87 \mathrm{~S}\end{array}$ & $\begin{array}{l}55.8 \\
\ldots \ldots\end{array}$ & $\begin{array}{r}7,090,204 \\
13,7 \mathrm{I}_{4}, 08_{3}\end{array}$ & $\begin{array}{l}14.40 \\
15.53\end{array}$ \\
\hline Cypress. & La. & 573,096 & 68.3 & I $2,849,9$ I I & 22.42 \\
\hline ( & $\mathrm{U} \cdot \mathrm{S}$. & 839,276 & $\ldots \ldots$ & I $, 403,392$ & 21.94 \\
\hline & $\mathrm{Ky} \mathrm{y}_{\mathrm{i}}$ & I 60,123 & 23.4 & $3,732,465$ & $23 \cdot 31$ \\
\hline Redwood .......... & Calif. & $\begin{array}{l}083,132 \\
650,6-8\end{array}$ & ioo. & I $6,53 \mathrm{~S}, 260$ & 24.21 \\
\hline Red guin & Ark. & I 40,8 I 0 & $\begin{array}{r}100.0 \\
31.0\end{array}$ & $\begin{array}{r}10,078,759 \\
1,774,304\end{array}$ & $\begin{array}{l}10.04 \\
12.60\end{array}$ \\
\hline & U. s. & $45.3,67 \mathrm{~S}$ & & $6,102,886$ & 13.46 \\
\hline Cliestnut & Penna. & $7.3,006$ & I 8.0 & $\mathrm{I}, 268,080$ & I $7 \cdot 36$ \\
\hline & U.S. & 407.370 & $\cdots \cdots$ & $7,128,864$ & 17.49 \\
\hline & U.s. & $\begin{array}{l}102,15.5 \\
376,838\end{array}$ & $\begin{array}{l}+3 \cdot 0 \\
\ldots\end{array}$ & $2,890,178$ & $\begin{array}{l}17.52 \\
18.66\end{array}$ \\
\hline Bireh.. & Wisc. & 151,063 & 40.8 & $\begin{array}{l}7,020,050 \\
2,3,34,163\end{array}$ & 15.45 \\
\hline & U. S. & 370,432 & & 6.384 .705 & 17.24 \\
\hline Cenlar.. & II ash. & $2.36,6,48$ & 66.2 & $4,415,054$ & 15.66 \\
\hline Ilickory . & Ark. & $\begin{array}{r}357,8+5 \\
2.3,364\end{array}$ & i $\ddot{5} \dot{8}$ & $\begin{array}{r}6,484,600 \\
902,201\end{array}$ & $\begin{array}{l}\text { I } 8.12 \\
38.62\end{array}$ \\
\hline & U. S. & $1+8,212$ & & $4,508,583$ & $30 .+2$ \\
\hline " soft woods ...... & U. . . & $\begin{array}{r}7,315,4(1) 1 \\
30,235,2+5\end{array}$ & $\cdots \cdots\}$ & $62 \mathrm{r}, \mathrm{x} 5 \mathrm{I}, 3 \mathrm{SS}$ & r6.60 \\
\hline
\end{tabular}


POULTRY AND EGG PRODUCTS IN THE UNITED STATES. (Tenth to Twelfth Censuses.)

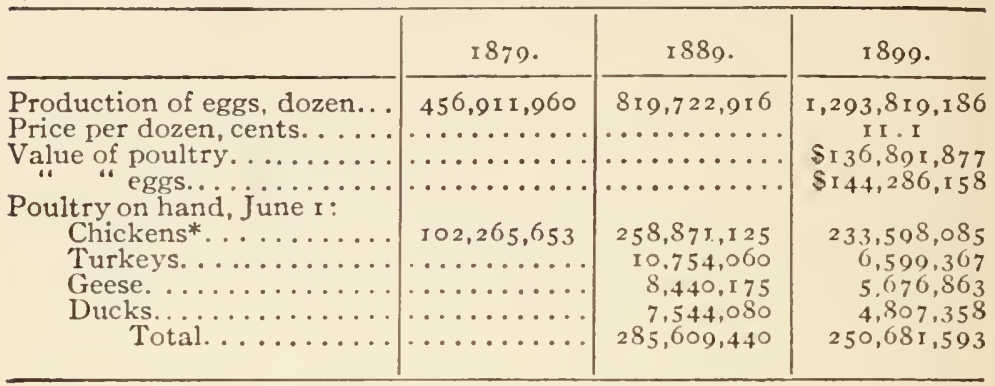

* Including Guinea fowls.

\section{PRODUCTION OF HONEY AND BEESWAX IN THE UNITED STATES ACCORDING 'TO CENSUS RE- TURNS OF 1869, 1879, 1889, AND 1899.}

\begin{tabular}{|c|c|c|c|c|}
\hline & I 860. & I 879. & I 889. & I 899. \\
\hline $\begin{array}{l}\text { Honey, lbs. ....... } \\
\text { Beeswax, lbs. . . . }\end{array}$ & $\begin{array}{r}14,702,815 \\
631,129\end{array}$ & $\begin{array}{r}25,741,485 \\
1,105,556\end{array}$ & $\begin{array}{r}63,894,186 \\
1,166,543\end{array}$ & $\begin{array}{r}61,196,160 \\
1,765,315\end{array}$ \\
\hline
\end{tabular}

\section{BEES, HONEY, AND WAX PRODUCED IN THE UNI'EED STATES.}

(Twelfth Census.)

Swarms of bees, June $1,1900 \ldots \ldots \ldots \ldots \ldots \ldots \ldots \ldots, 4,100,625$

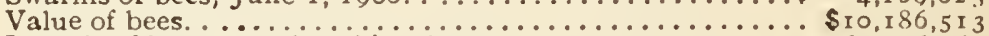

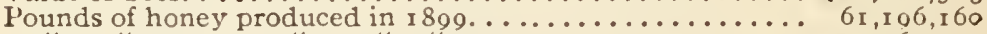
" "wax " " " $\ldots \ldots \ldots \ldots \ldots \ldots \ldots$ I,765,315 Value of honey and wax produced in i $899 \ldots \ldots \ldots \ldots \ldots \ldots \ldots \$ \ldots 664,904$ 


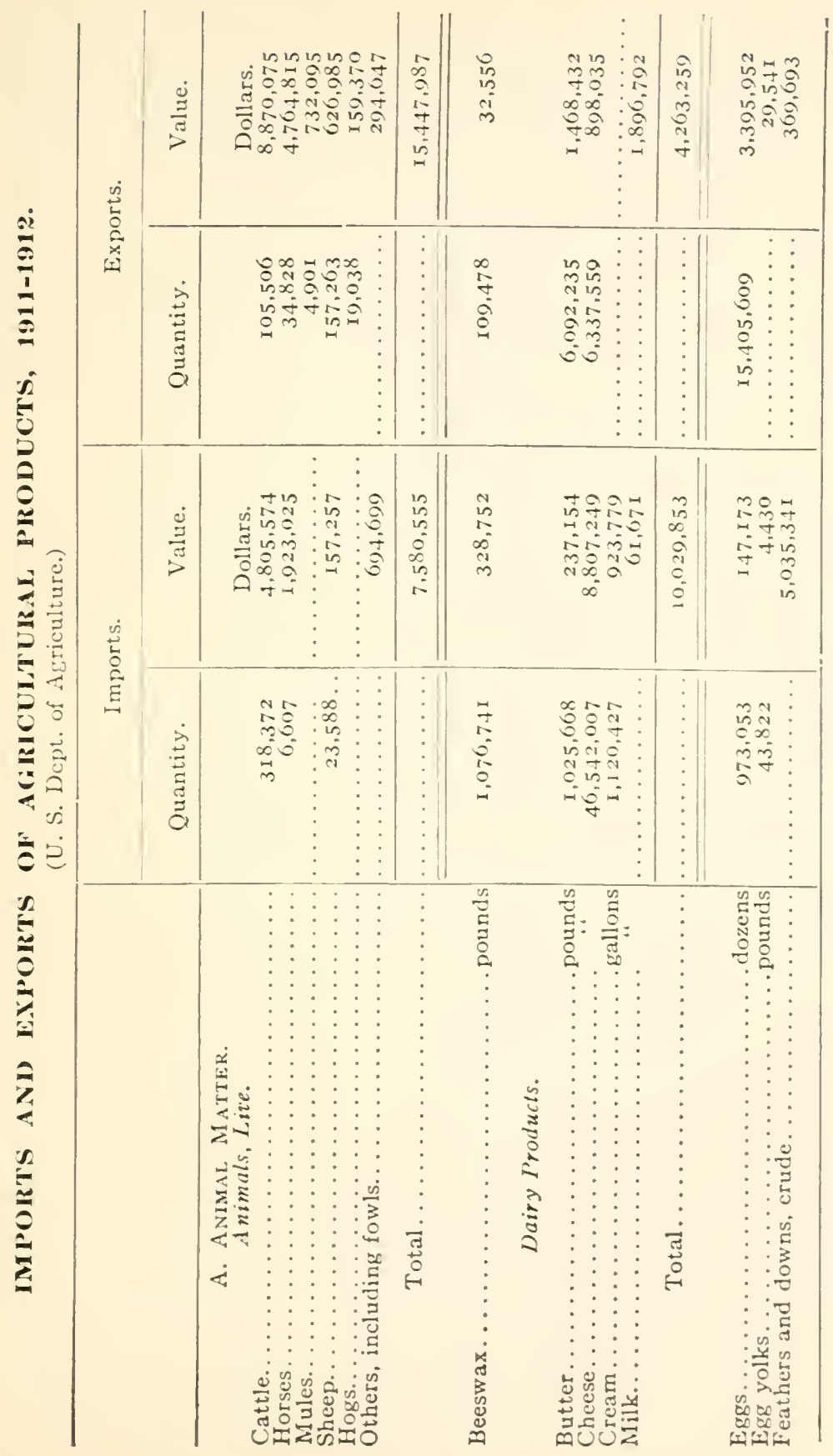




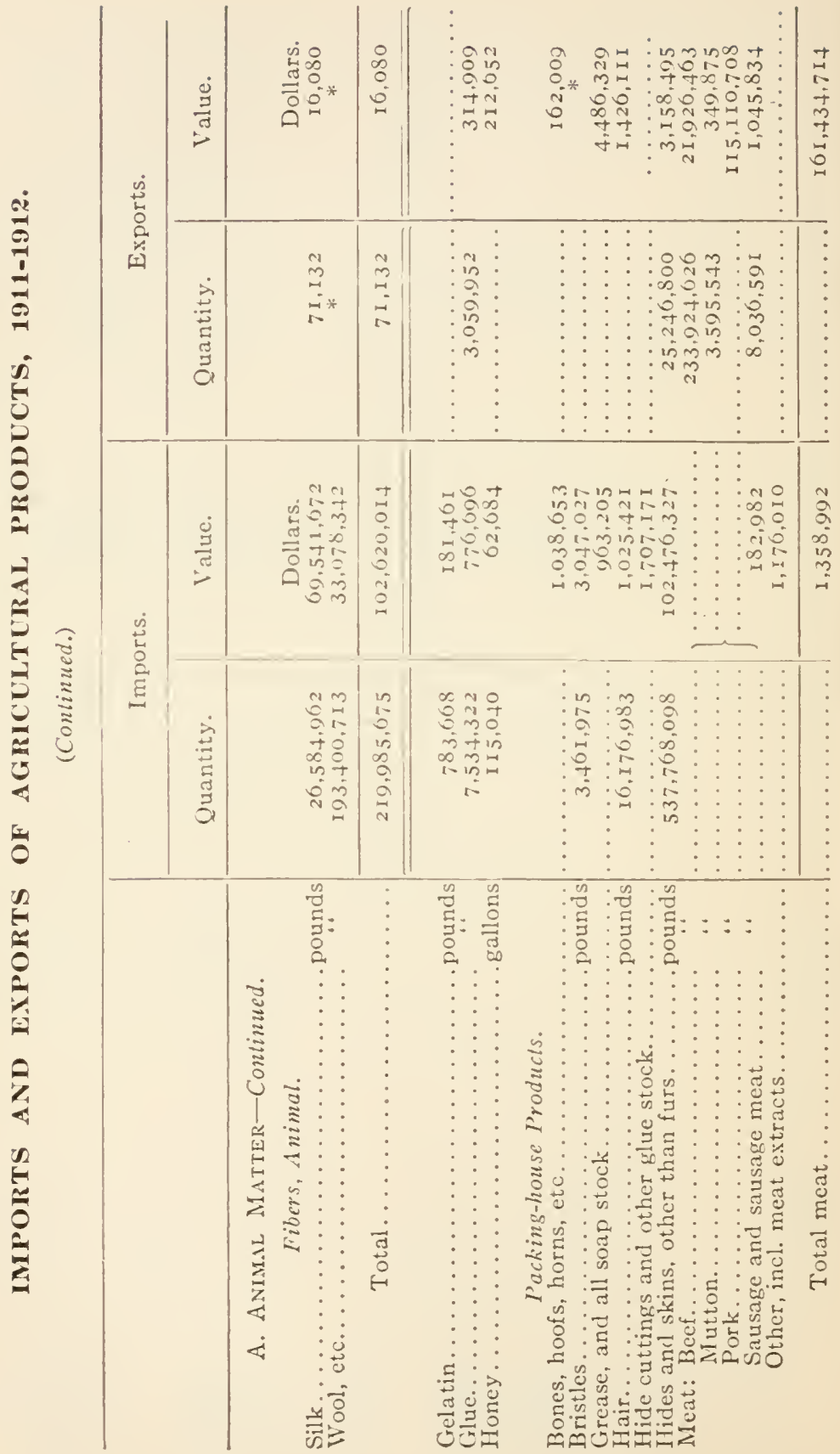




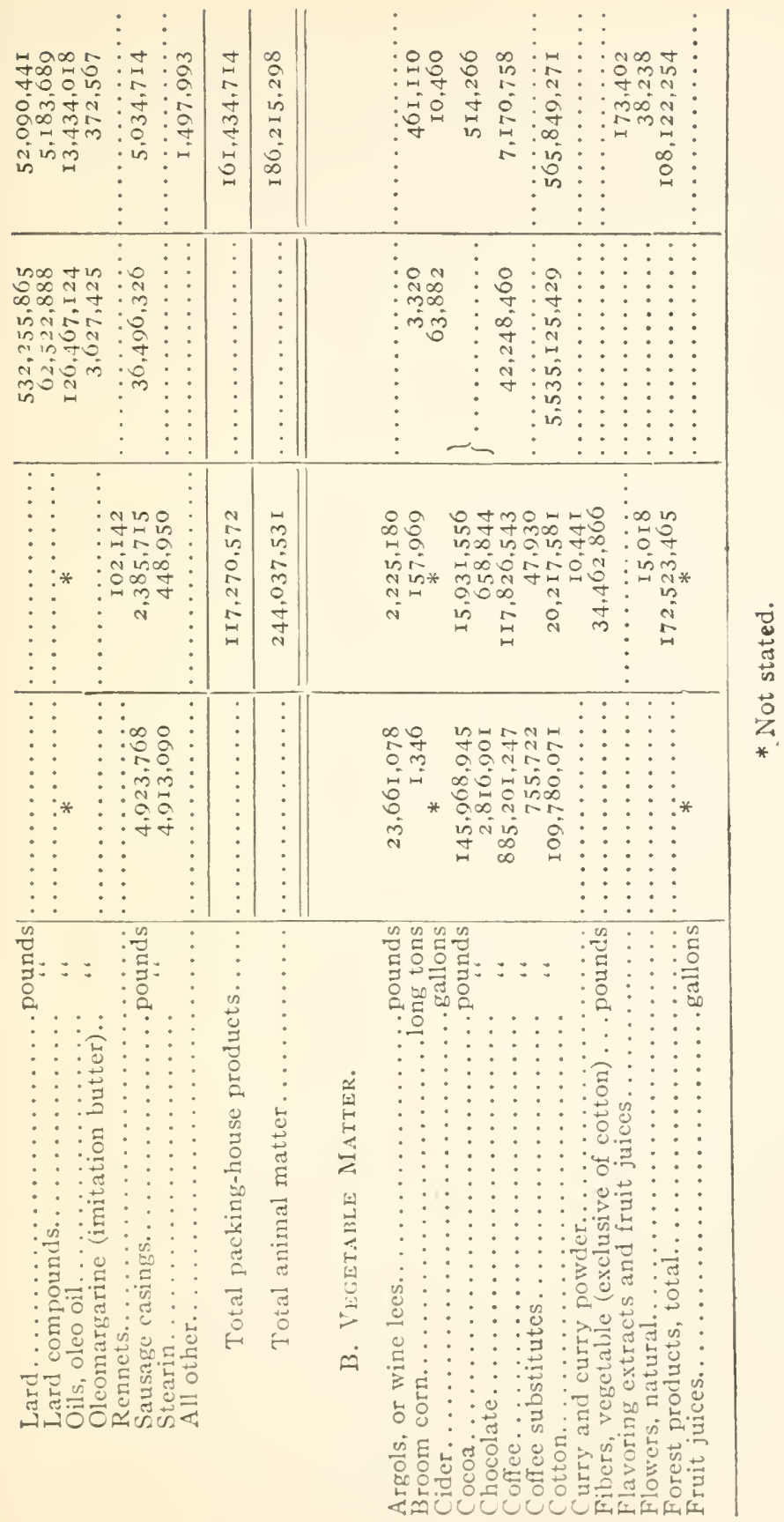




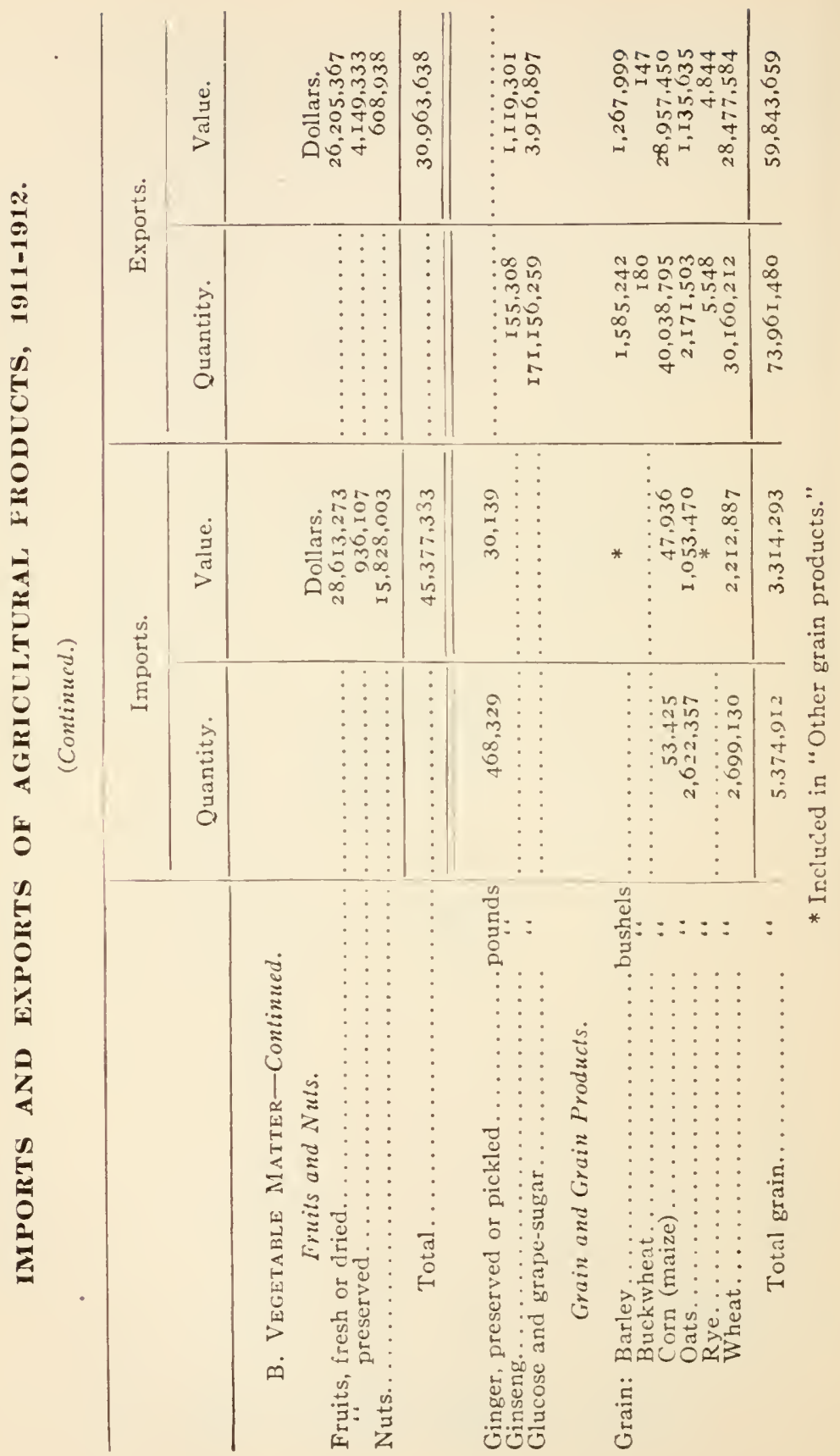




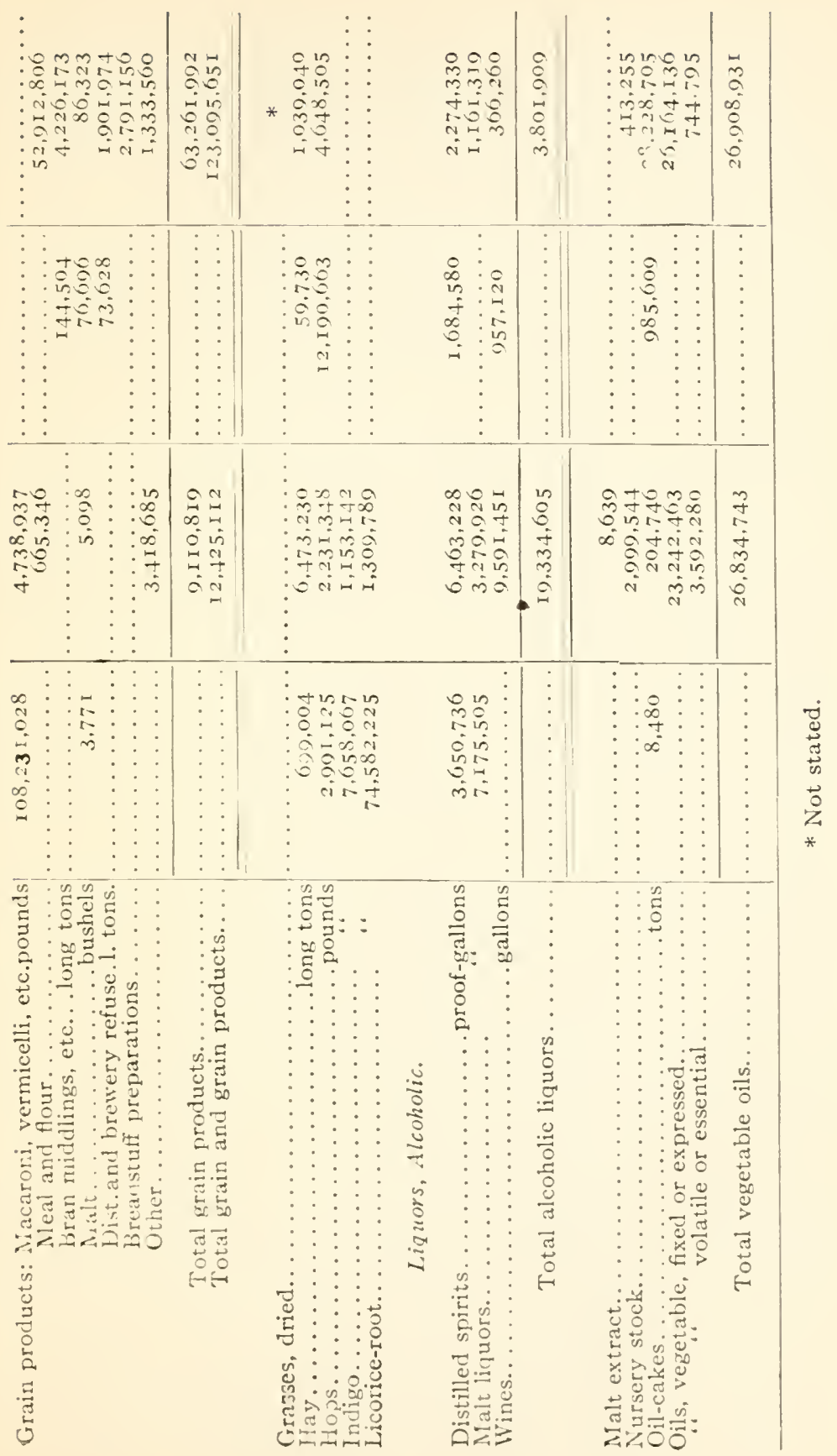




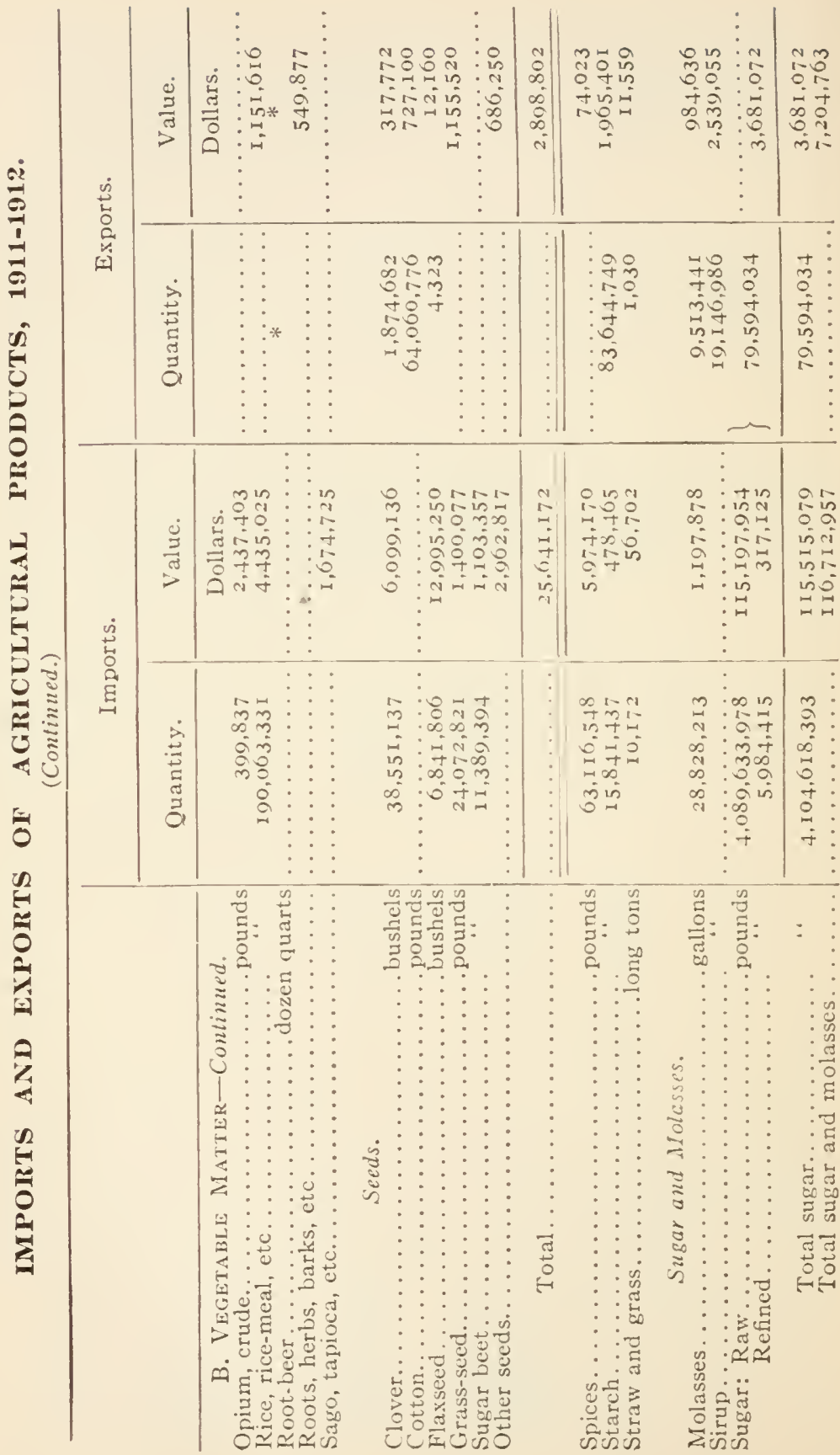




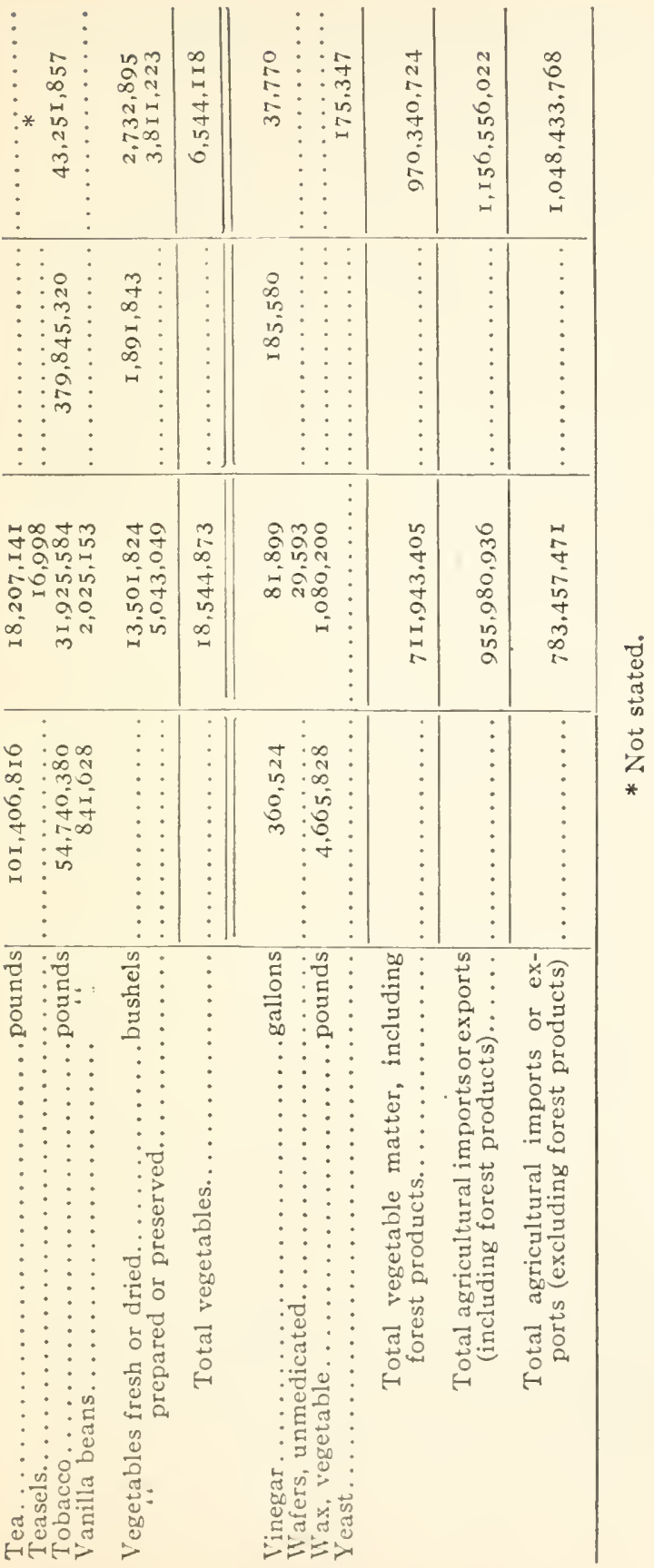


EDOMESTIC EXPORTS OF BUTTER AND CHEESE, 1870-1912.

(U. S. Dept. of Agriculture.)

\begin{tabular}{|c|c|c|c|c|}
\hline \multirow{2}{*}{ Year. } & \multicolumn{2}{|c|}{ Butter. } & \multicolumn{2}{|c|}{ Cheese. } \\
\hline & Pounds. & Value. & Pounds. & Value. \\
\hline I 870 & $2,019,288$ & $\$ 592,229$ & $57,296,327$ & $\$ 8,881,934$ \\
\hline 1875 & 6.360 .827 & $1,506,996$ & IOI, O IO, 853 & I $3,659,603$ \\
\hline 1880 & $39,236,658$ & $6,690,687$ & $127,553,907$ & $12, I 71,720$ \\
\hline I 885 & $2 \mathrm{I}, 683, \mathrm{I} 4^{8}$ & $3,643,646$ & I I I $, 992,990$ & I $0,444,409$ \\
\hline 1890 & $29,74^{8}, 042$ & 4.187 .489 & $95,376,053$ & $8,591,042$ \\
\hline I 895 & $5.598,812$ & 915.533 & $60,448,42 I$ & $5,497,539$ \\
\hline 1900 & I $8,266,37 \mathrm{I}$ & $3,143.509$ & $48,419.353$ & $4,943,609$ \\
\hline 1905 & $10,071,487$ & $1,648,28 I$ & $10,134,424$ & $\mathrm{I}, 084,044$ \\
\hline 1910 & $3,140,545$ & $785.77 \mathrm{I}$ & $2,846,709$ & 441,017 \\
\hline 1911 & $4,877,797$ & $1,059,432$ & $10.366,605$ & $1,288,279$ \\
\hline I9I 2 & $6,092,235$ & $1,468,432$ & $6,337,559$ & 898,035 \\
\hline
\end{tabular}

EXPORTS OF DAIRY PRODUCTS FROM CANADA, 18r0-1910.

(The Canada Year-Book.)

\begin{tabular}{|c|c|c|c|c|}
\hline \multirow[b]{2}{*}{ Year. } & \multicolumn{2}{|c|}{ Butter. } & \multicolumn{2}{|c|}{ Cheese. } \\
\hline & Quantity. & Value. & Quantity. & Value. \\
\hline 1870 & $\begin{array}{l}\text { Pounds. } \\
12,260,887\end{array}$ & $\$ 2,353,570$ & $\begin{array}{l}\text { Pounds. } \\
5,827,782\end{array}$ & $\$ 674,486$ \\
\hline 1875 & $9,268,044$ & 2.337 .324 & $32,342,030$ & $3,886,226$ \\
\hline 1880 & I $8,535,362$ & $3.058,069$ & $40,368,678$ & $3,893.366$ \\
\hline 1885 & $7,330,788$ & $1,430,905$ & 79.655 .367 & $8,265,240$ \\
\hline I 890 & $1,951,585$ & 340,131 & $94,260,187$ & $9.372,2$ I 3 \\
\hline I 895 & $3.650,258$ & 697,476 & $146,004,650$ & $14,253,002$ \\
\hline 1900 & $25,259,737$ & $5,122,156$ & I $85.984,430$ & $19,856,324$ \\
\hline 1901 & $16,335,528$ & $3,295,663$ & 195.926 .397 & $20,696,051$ \\
\hline 1902 & 27.855 .978 & $5,660,54 \mathrm{I}$ & $200,9.46,40 \mathrm{I}$ & I $9,686,29 \mathrm{I}$ \\
\hline 1903 & $34,128,944$ & $6,954,618$ & $229,099,025$ & $24,712,943$ \\
\hline 1904 & $24.568,001$ & $4,724,155$ & $233.980,7$ I 6 & 24, I 84,566 \\
\hline 1905 & $31,764,303$ & $5.930,379$ & $215,733,259$ & $20,300,500$ \\
\hline 1906 & $34.031,525$ & 7.075 .539 & 2 I $5,834,543$ & $24,433,169$ \\
\hline $1907 *$ & $18,078,508$ & $4,011,609$ & $178,141,567$ & $22,006,584$ \\
\hline 1908 & $4,786,954$ & $1,068,703$ & $189,710,463$ & $22,887,237$ \\
\hline 1909 & $6,326,355$ & $1,521,436$ & $164,907,139$ & $20,384,666$ \\
\hline 1910 & $4,615.380$ & $1,010,274$ & I $80,859,886$ & $21,607,692$ \\
\hline
\end{tabular}

* Nine months. 


\section{THE FERTILIZER INDUSTRY OF THE UNITED}

STATHS. (U. S. Departuent of Agriculture.)

Commercial fertilizers sold in 1896 ,

in 23 Eastern and Central States

in rest of United States

Total for the United States

Census returns, 1890 , value of fertilizers purchased:

North Atlantic Division

South Atlantic

North Central

South Central

Western

a

Total for the United States..

\begin{tabular}{|c|c|}
\hline $\begin{array}{c}\text { 'Tons } \\
\text { (of } 2000 \text { lbs.) }\end{array}$ & $\begin{array}{c}\text { Value } \\
\text { (wholesule). }\end{array}$ \\
\hline $\begin{array}{r}1,624,063 \\
270,854\end{array}$ & $\begin{array}{r}32,301,5^{82} \\
5,3^{87}, 287\end{array}$ \\
\hline $1,894,917$ & $\$ 37,688,869$ \\
\hline$\ldots \ldots \ldots \ldots \ldots$ & $\begin{array}{l}\text { (retail) } \\
\mathrm{r}, 449,069\end{array}$ \\
\hline ............ & $18,759, \simeq 39$ \\
\hline$\ldots \ldots \ldots \ldots \ldots$ & $3,067,5 \times 5$ \\
\hline 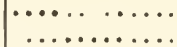 & $\begin{array}{r}4,952,013 \\
241,862\end{array}$ \\
\hline$\ldots \ldots \ldots \ldots \ldots$ & $\$ 3^{\succ}, 459,59^{8}$ \\
\hline
\end{tabular}

IMPORTS AND EXPORTS OF FERTILIZERS IN 1896. (U.S. Treasury Department.)

\begin{tabular}{|c|c|c|c|c|c|}
\hline \multicolumn{3}{|c|}{ IMPORTS. } & \multicolumn{3}{|c|}{ EXPORTS. } \\
\hline Tons. & Valuc. & $\begin{array}{l}\text { Value } \\
\text { per Ton. }\end{array}$ & Tons. & Value. & $\begin{array}{l}\text { Value } \\
\text { per Ton. }\end{array}$ \\
\hline $375,7: 33 \cdot 93$ & $\$ 7,376,615$ & $\$ 19.04$ & 514,143 & $\$ 4,400,59.3$ & $\$ 8.56$ \\
\hline
\end{tabular}

\section{IMPORTS OF FERTILIZERS AND HERTILIZER MATERIALS, 1896.}

\begin{tabular}{|c|c|c|c|}
\hline Articles. & Tons. & Value. & $\begin{array}{c}\text { Value } \\
\text { per Ton. }\end{array}$ \\
\hline 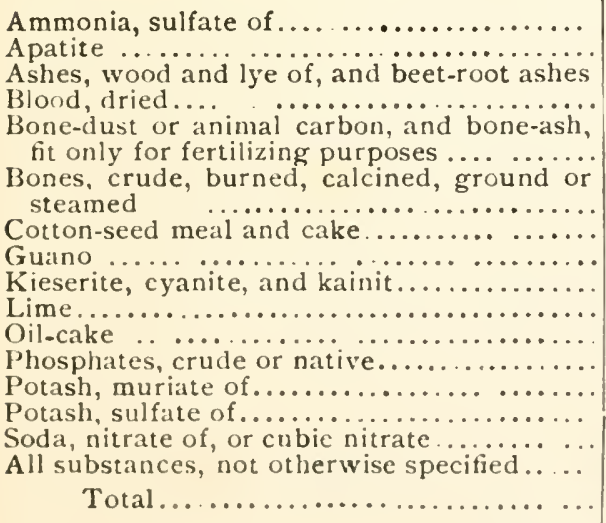 & 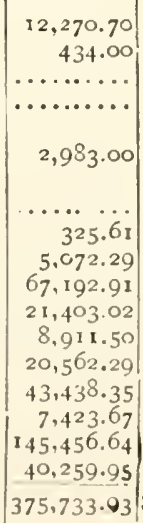 & $\begin{array}{r}\$ 480,971 \\
3,030 \\
67,394 \\
1,014 * \\
37,992 \\
154,610 \\
3,170 \\
52,697 \\
320,765 \\
76,302 \\
52,867 \\
153,370 \\
1,372,743 \\
269,810 \\
3,870,734 \\
460, x 60 \\
\$ 7.376,615\end{array}$ & $\begin{array}{r}\ldots . . . \\
9.74 \\
10.39 \\
4.77 \\
3.57 \\
5.93 \\
7.46 \\
31.60 \\
36.34 \\
26.61 \\
11.43 \\
\$ 1904\end{array}$ \\
\hline
\end{tabular}




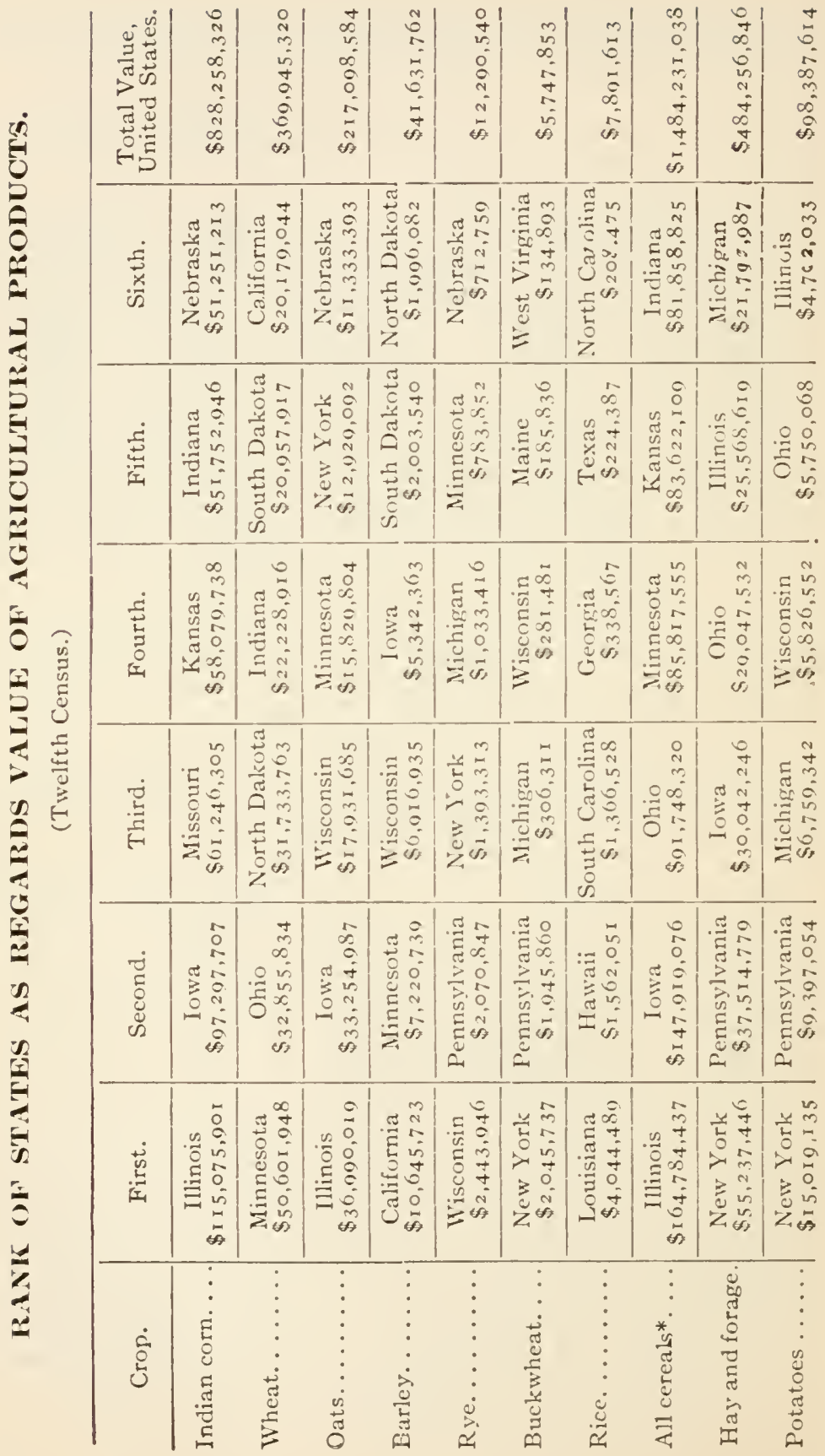




\begin{tabular}{|c|c|c|c|c|c|c|c|c|c|}
\hline $\begin{array}{c}0 \\
0 \\
0 \\
0 \\
1 \\
0 \\
0 \\
0 \\
0\end{array}$ & 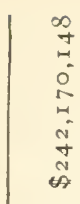 & $\stackrel{2}{\infty}$ & $\begin{array}{l}0 \\
0 \\
\vdots \\
+ \\
0 \\
0 \\
0 \\
0 \\
0\end{array}$ & $\begin{array}{c}0 \\
7 \\
1 \\
0 \\
0 \\
0 \\
0 \\
0 \\
0 \\
0 \\
0\end{array}$ & 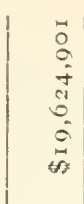 & 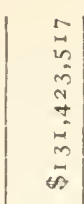 & 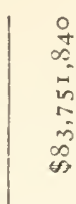 & $\begin{array}{l}\hat{1} \\
0 \\
0 \\
0 \\
0 \\
0 \\
\text { in } \\
0 \\
0\end{array}$ & $\begin{array}{l}\infty \\
0 \\
\infty \\
\infty \\
0 \\
0 \\
0 \\
0 \\
0\end{array}$ \\
\hline 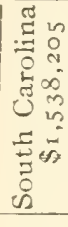 & 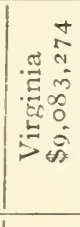 & 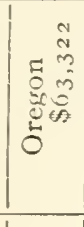 & 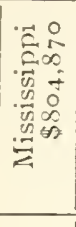 & 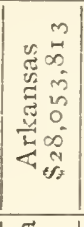 & 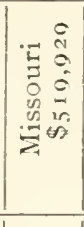 & 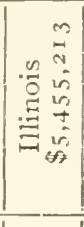 & 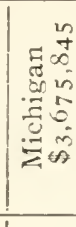 & 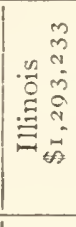 & 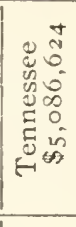 \\
\hline 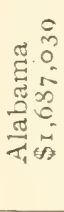 & 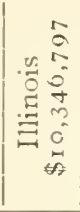 & 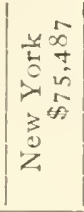 & 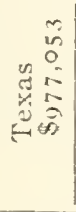 & 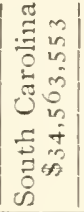 & 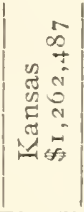 & 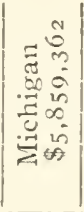 & 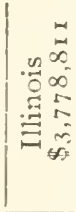 & 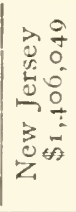 & 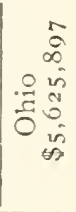 \\
\hline 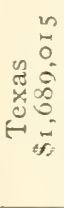 & 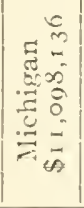 & 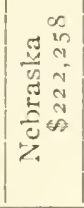 & 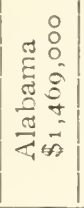 & 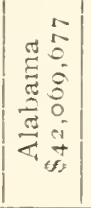 & 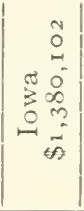 & $\left|\begin{array}{r|r}0 \\
0 \\
0 \\
0 \\
0 \\
0 \\
0 \\
0 \\
0 \\
0 \\
0 \\
0\end{array}\right|$ & 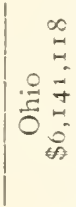 & 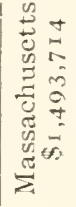 & 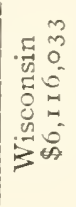 \\
\hline 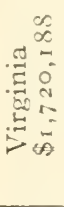 & 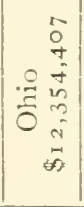 & 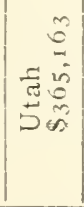 & 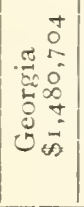 & 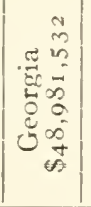 & 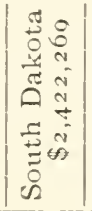 & 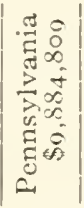 & 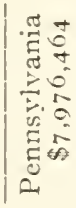 & 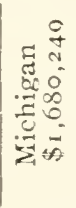 & 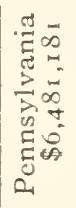 \\
\hline 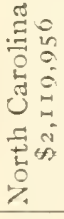 & 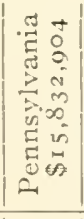 & 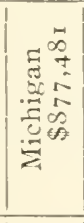 & 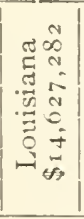 & 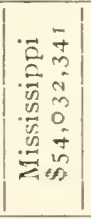 & 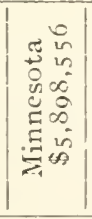 & 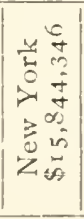 & 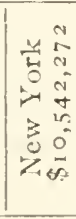 & $\begin{array}{r}2 \\
2 \\
0 \\
0 \\
0 \\
0 \\
0 \\
\frac{1}{6}\end{array}$ & 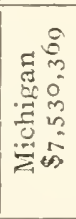 \\
\hline 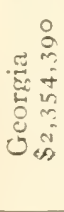 & 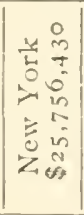 & 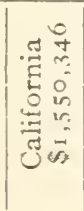 & 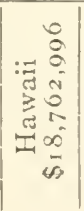 & 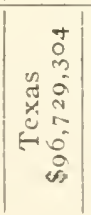 & 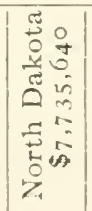 & 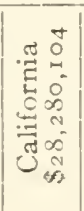 & 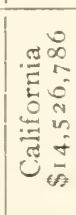 & 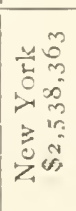 & 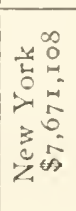 \\
\hline 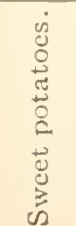 & 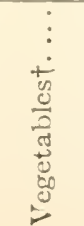 & & 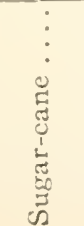 & 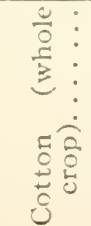 & 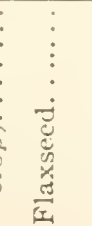 & 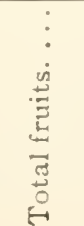 & 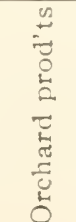 & 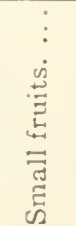 & 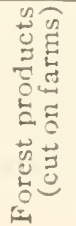 \\
\hline
\end{tabular}




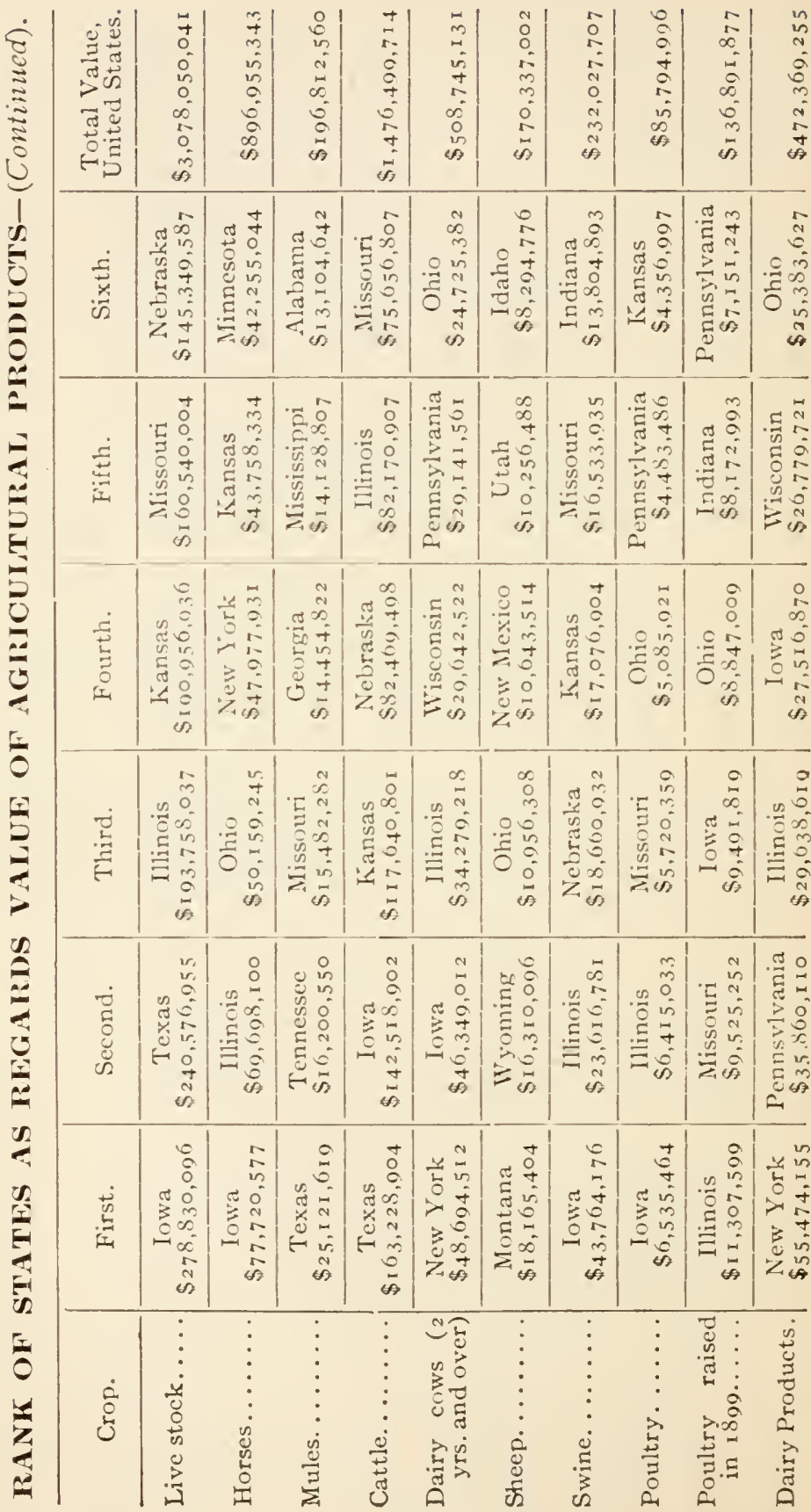




\begin{tabular}{|c|c|c|c|c|c|c|c|c|c|}
\hline 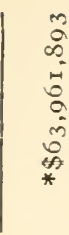 & 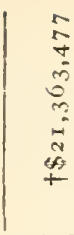 & 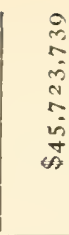 & 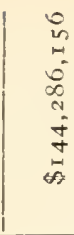 & $\begin{array}{l}+ \\
0 \\
0 \\
0 \\
0 \\
0 \\
0 \\
0\end{array}$ & $\begin{array}{l}\text { in } \\
\text { in } \\
\dot{J} \\
0 \\
0 \\
\text { in } \\
n\end{array}$ & 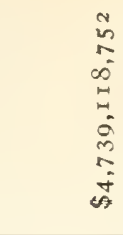 & $\begin{array}{l}+ \\
\text { ñ } \\
0 \\
0 \\
0 \\
0 \\
0 \\
0 \\
0\end{array}$ & $\bigcup_{\mathscr{H}}$ & $\stackrel{\vec{n}}{A}$ \\
\hline 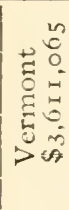 & 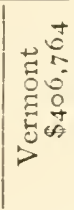 & 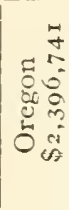 & 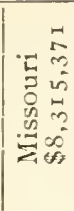 & 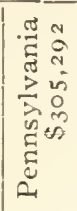 & 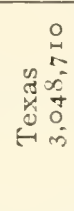 & 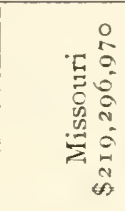 & 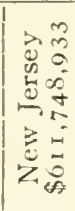 & 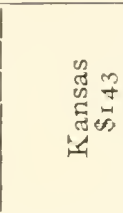 & 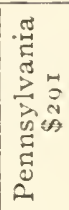 \\
\hline 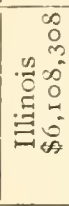 & 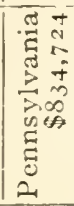 & 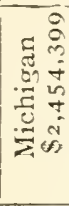 & 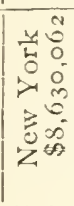 & 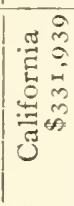 & 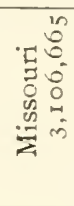 & 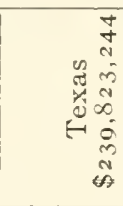 & 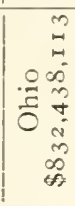 & 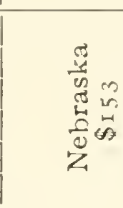 & 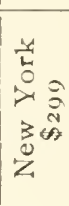 \\
\hline 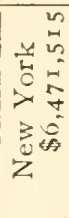 & 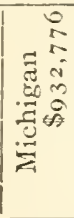 & 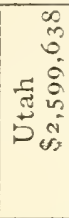 & 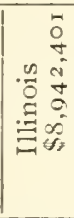 & 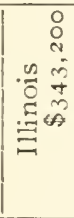 & 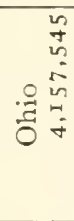 & 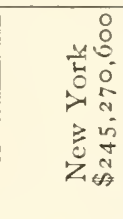 & 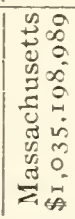 & 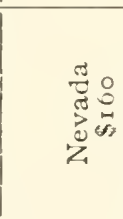 & 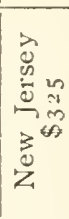 \\
\hline 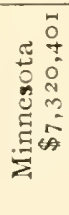 & 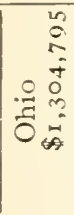 & 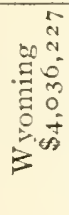 & 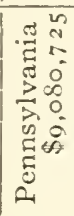 & 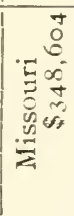 & 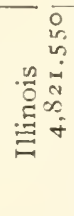 & 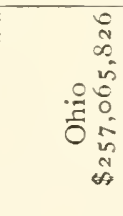 & 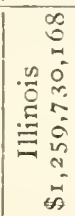 & 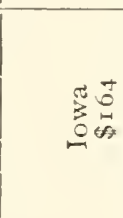 & 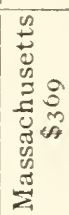 \\
\hline 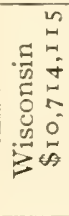 & 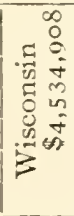 & 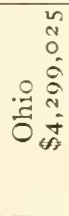 & $\begin{array}{r}1 \\
0 \\
0 \\
0 \\
0 \\
0 \\
0 \\
0 \\
0 \\
0 \\
0\end{array}$ & 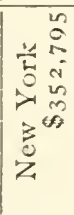 & 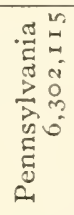 & 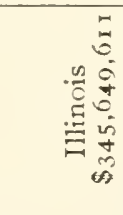 & 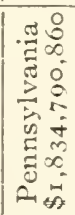 & 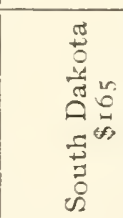 & 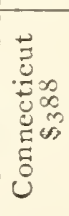 \\
\hline 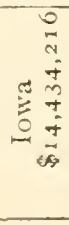 & 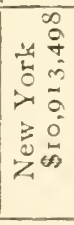 & 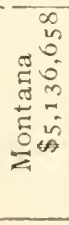 & $\begin{array}{c}8 \\
0 \\
0 \\
0 \\
0 \\
0 \\
0 \\
0 \\
0 \\
0 \\
0\end{array}$ & 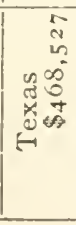 & 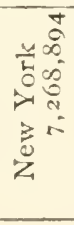 & 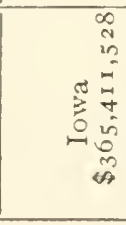 & $\begin{array}{rl} & c \\
0 \\
4 & 0 \\
5 & 0 \\
0 & 0 \\
7 & 0 \\
0 & 0 \\
0 & = \\
2 \\
0 \\
0\end{array}$ & 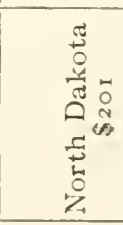 & 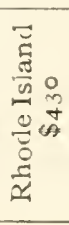 \\
\hline 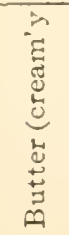 & 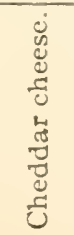 & $\begin{array}{l}\vdots \\
\vdots \\
\vdots \\
0 \\
0\end{array}$ & 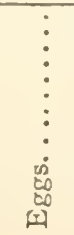 & 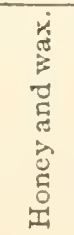 & 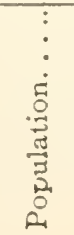 & 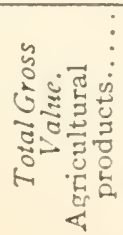 & 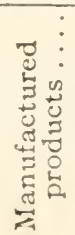 & 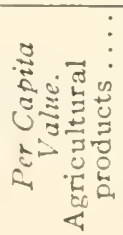 & 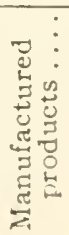 \\
\hline
\end{tabular}




\section{DIRECTORY.}

\section{DIRECTORY OF OFFICIAI AGRICUITURAI, INSTITUTIONS.}

\section{Organization of the U. S. Department of Agriculture, Washington, D. C.}

Secretary of Agriculture-D. F. Hoilito.

Assistant Secretary of Agriculture-B. T. Galloway.

Weather Bureau-II. E. Williams, Acting Chief.

Bureau of Animal Industry-1. 1). Melvin, Chief.

Dairy Division-B. H. Rawl, Chief.

Bureau of Plant Industry- $\mathbf{W m}$. A. Taylor, Pathologist, Physiologist and Chief.

Forest Service-Henry S. Graves, Forester and Chief.

Bureau of Chemistri-Carl L. Alsberg, Chemist and Chief.

Bureau of SoIls-Milton Whitney, Soil Physicist and Chief.

Bureau of Extomologr-L. O. Howard, Entomologist and Chief.

Bureau of Brological Survey-H. W. Henshaw, Biologist and Chief.

Bureau of Statistics-Victor H. Olmsted, Statistician and Chief.

Office of Experiment Stations-A. C. True, Director.

Office of Public Roads-L. W. Page, Director.

Division of Publications-Jos. A. Arnold, Editor and Chief.

Division of Accounts And Disbursements-A. Zappone, Chief and Disbursing Clerk.

LIBRARY-Claribel R. Barnett, Librarian. 


\section{Canada.}

Ministers of Agriculture-

Dominion, Martin Burrell, Ottawa.

Prov. of Ontario, Nelson Monteith, Toronto.

Prov. of Quebec, A. Tessier, Quebec.

Prov. of British Columbia, R. G. Tatlow, Victoria.

Prov. of Manitoba, R. P. Roblin, Winnipeg.

Commissioners of Agriculture-

New Brunswick, L. P. Farris, Fredericton.

N. IV. Territories, G. H. V. Bulyea, Regina.

Pr. Edw. Island, Benjamin Rogers, Charlottetown.

Secretary of Agriculture-

Nova Scotia, B. IV. Chipman, Halifax.

Minister of Agriculture And Mines-

Newfoundland, Eli Dawe, St. Johns.

State Offleials in Charge of Agricuiture in the United States.

Commssioners of Agriculture-Montgomery, Ala.; Little Rock, Ark.; Tallahassee, Fla.; Atlanta, Ga.; Boise, Idaho; Frankfort, Ky.; Baton Rouge, La.; Augusta, Me.; Jackson, Miss.; Helena, Mont.; Albany, N. Y.; Raleigh, N. C.; Bismarck, N. D.; Harrisburg, Pa.; Manila, P. I.; San Juan, P. R.; Columbia, S. C.; Nashville, Tenn.; Austin, Texas; Plainfield, Vt.; and Richmond, Va.

Secretaries of State Boards of Agriculture-Sacramento, Cal.; Fort Collins, Colo.; Hartford, Conn.; Dover, Del.; Honolulu, H. I.; Springfield, Ill.; Indianapolis, Ind.; Des Moines, Ia.; Topeka, Kan.; Baltimore, Md.; Boston, Mass.; East Lansing, Mich; St. Paul, Minn.; Columbia, Mo.; Lincoln, Neb.; Carson City, Nev.; Concord, N. H.; Trenton, N. J.; Columbus, Ohio; Oklahoma City, Okla.; Salem, Ore.; Providence, R. I.; Huron, S. D.; Charleston, W. Va.; Madison, Wis.; and Cheyenne, Wyo.

Secretaries of State-Tucson, Ariz.; Santa Fe, N. M.; Salt Lake City, Utah; and Olympia, Wash. 


\section{EDUCATIONAL INSTITUTIONS IN THE UNITED STATES AND CANADA HAVING COURSES IN AGRICUI'TURE. (U. S. Department of Agriculture.)}

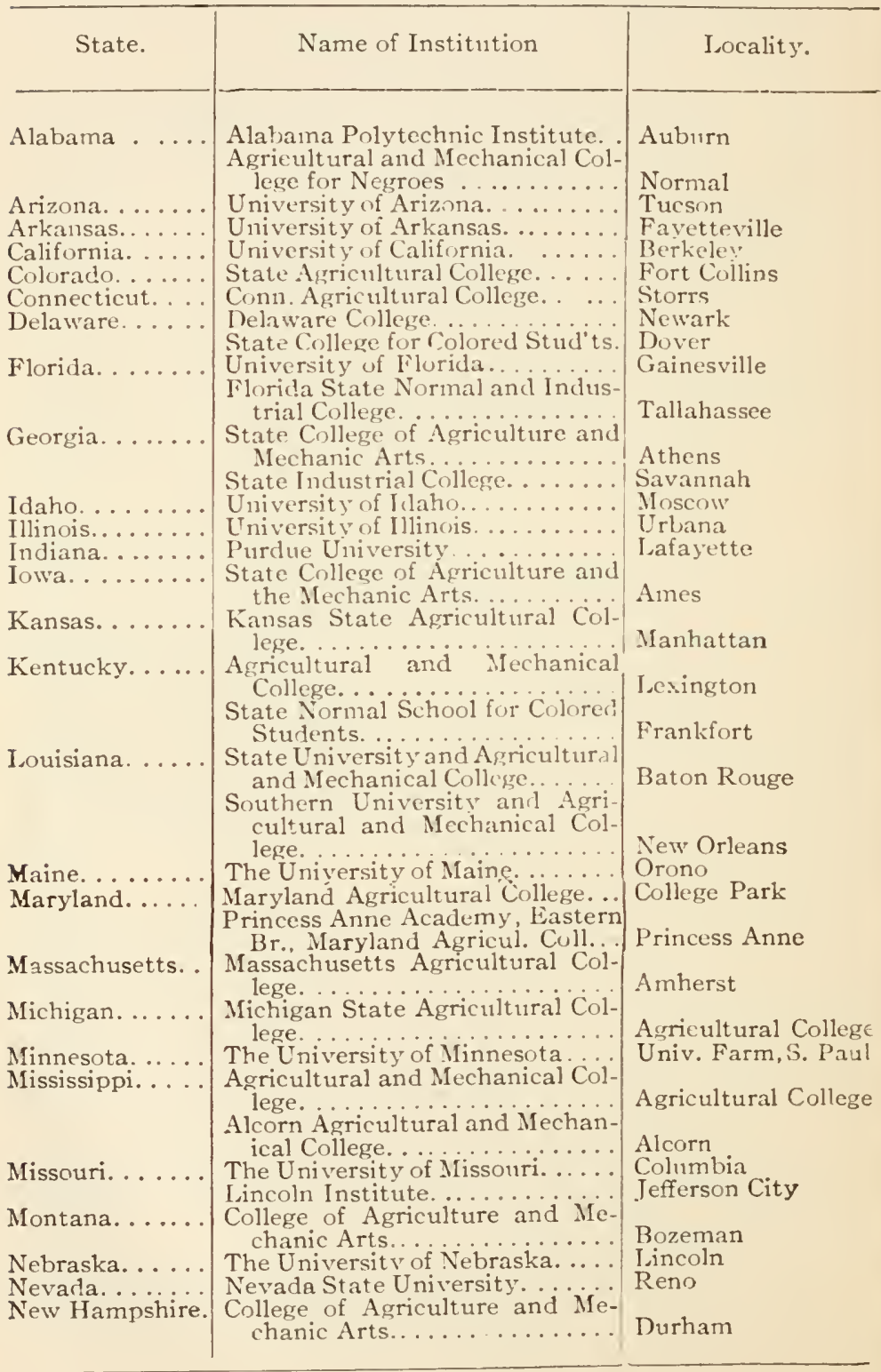


EDUCATIONAL INSTITUTIONS-(Continued).

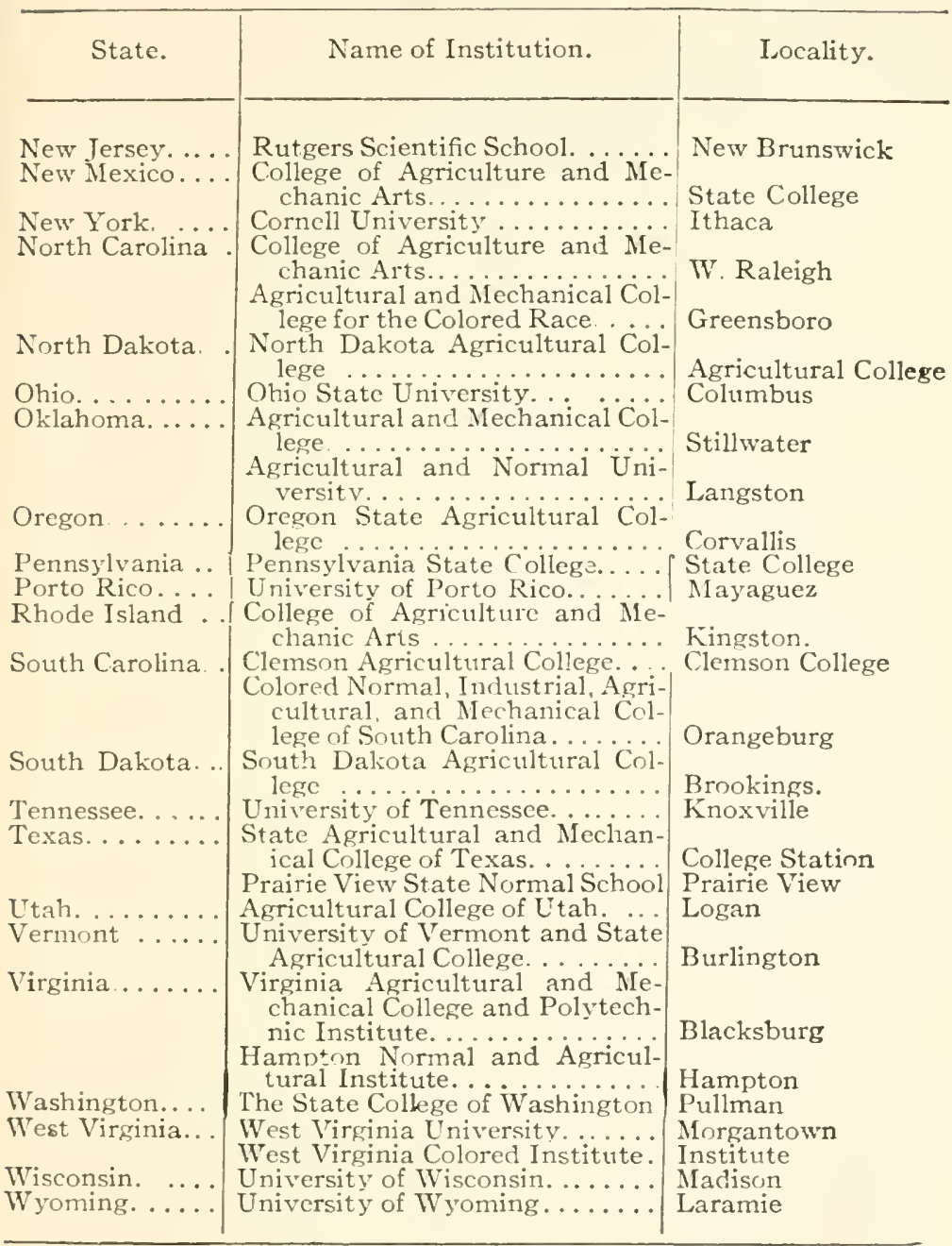




\section{AMERICAN VETERINARY COLLEGES.}

California Veterinary College, San Francisco, Cal.

National Veterinary College, Washington, D. C.

Chicago Veterinary College, Chicago, Ill.

McKillip Veterinary College, Chicago, Ill.

Veterinary Department, Iowa State Agricultural Collegr, Ames, Iowa.

School of Veterinary Medicine, Harvard University, Boston, Mass.

Kansas City Veterinary College, Kansas City, Mo.

American Veterinary College, University of the State OF NEw York, New York City.

New York College of Veterinary Surgeons, New York City.

Veterinary College, Cornell University, Ithaca, N. Y.

School of Veterinary Medicine, Ohio State University, Columbus, $\mathrm{O}$.

Veterinary Departmext, University of Penngylyania, I'hiladelphia, $\mathrm{Pa}$.

Ontario Veterinary College, Toronto, Canada.

McGill University, Department of Comparative Meclicine, Montreal, P. Q., Canada.

\section{LIST OF STATE VETERINARIANS.}

\begin{tabular}{|c|c|c|c|}
\hline $\begin{array}{l}\text { State or } \\
\text { Territory. }\end{array}$ & $\begin{array}{l}\text { Post-office } \\
\text { Address. }\end{array}$ & $\begin{array}{l}\text { State or } \\
\text { Territory. }\end{array}$ & $\begin{array}{l}\text { Post-office } \\
\text { Address. }\end{array}$ \\
\hline 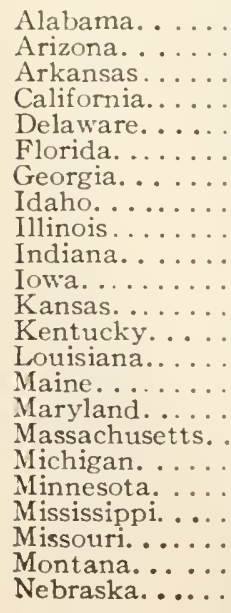 & $\begin{array}{l}\text { Auburn } \\
\text { Phounix } \\
\text { Fayetteville } \\
\text { Sacramento } \\
\text { Wailmington } \\
\text { Lake City } \\
\text { Atlanta } \\
\text { Boisé } \\
\text { Princeton } \\
\text { Lafayette } \\
\text { Forest City } \\
\text { Peabody } \\
\text { Louisville } \\
\text { Baton Rouge } \\
\text { Saco } \\
\text { Chestertown } \\
\text { Boston } \\
\text { Saline } \\
\text { Minneapolis } \\
\text { Agricul. College } \\
\text { Columbia } \\
\text { Helena } \\
\text { Lincoln }\end{array}$ & 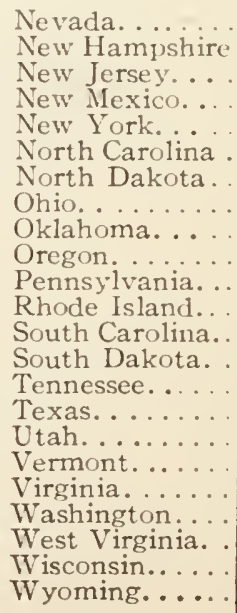 & $\begin{array}{l}\text { Reno } \\
\text { Concord } \\
\text { Trenton } \\
\text { Las Vegas } \\
\text { Albany } \\
\text { Raleigh } \\
\text { Fargo } \\
\text { Columbus } \\
\text { Guthrie } \\
\text { Portland } \\
\text { Philadelphia } \\
\text { Providence } \\
\text { Clemson College } \\
\text { Huron } \\
\text { Murfreesboro } \\
\text { Corpus Christi } \\
\text { Heber City } \\
\text { Morrisville } \\
\text { Blacksburg } \\
\text { Pullman } \\
\text { Charleston } \\
\text { Madison } \\
\text { Cheyenne }\end{array}$ \\
\hline
\end{tabular}




\section{DAIRY SCHOOLS IN THE UNITED STATES AND CANADA.}

\begin{tabular}{|c|c|c|c|}
\hline $\begin{array}{l}\text { State or } \\
\text { Province. }\end{array}$ & Location. & $\begin{array}{l}\text { State or } \\
\text { Province. }\end{array}$ & Location. \\
\hline 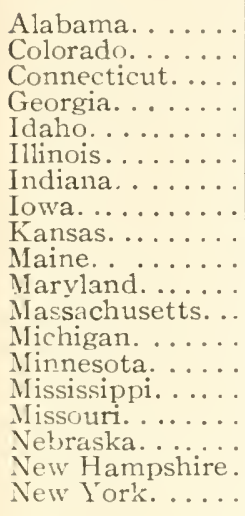 & $\begin{array}{l}\text { Tuskegee } \\
\text { Fort Collins } \\
\text { Storrs } \\
\text { Experiment } \\
\text { Moscow } \\
\text { Urbana } \\
\text { Lafayette } \\
\text { Ames } \\
\text { Manhattan } \\
\text { Orono } \\
\text { College Park } \\
\text { Amherst } \\
\text { Agricultural Col. } \\
\text { St.AnthonyPark } \\
\text { Agricultural Col. } \\
\text { Columbia } \\
\text { Lin oln } \\
\text { Durham } \\
\text { Ithaca }\end{array}$ & 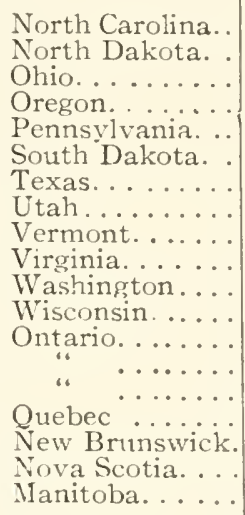 & $\begin{array}{l}\text { Raleigh } \\
\text { Fargo } \\
\text { Columbus } \\
\text { Corvailis } \\
\text { State College } \\
\text { Brookings } \\
\text { College Station } \\
\text { Logan } \\
\text { Burlington } \\
\text { Blacksburg } \\
\text { Pullman } \\
\text { Madison } \\
\text { Kingston } \\
\text { Guelph } \\
\text { Strathroy } \\
\text { St.Hyacinthe } \\
\text { Sussex } \\
\text { Nappan. } \\
\text { Winnipeg }\end{array}$ \\
\hline
\end{tabular}

\section{SCHOOLS OF HORESTRY.}

Yale Forest School, Yale University, New Haven, Conn. Biltmore Forest School, Biltmore, N. C. University of Michigan Forest School, Ann Arbor, Mich. Howard University Forest School, Cambridge, Mass.

Iowa State College of Agriculture and Mechanical Arts, Forestry Course, Ames, Iowa.

University of Maine, Department of Forestry, Orono, Me.

Michigan Agiricultural College, Department of Forestry, Agricultural College P. O., Mich.

University of Minnesota, Forest School, St. Anthony Park, Minn.

Unipersity of California, Forest School, Berkeley, Cal. 


\section{AGRICULTURAL EXPERIMENT STATIONS IN THE UNITED STATES.}

\begin{tabular}{|c|c|c|}
\hline State. & Location. & $\begin{array}{l}\text { Year Es- } \\
\text { tablished. }\end{array}$ \\
\hline 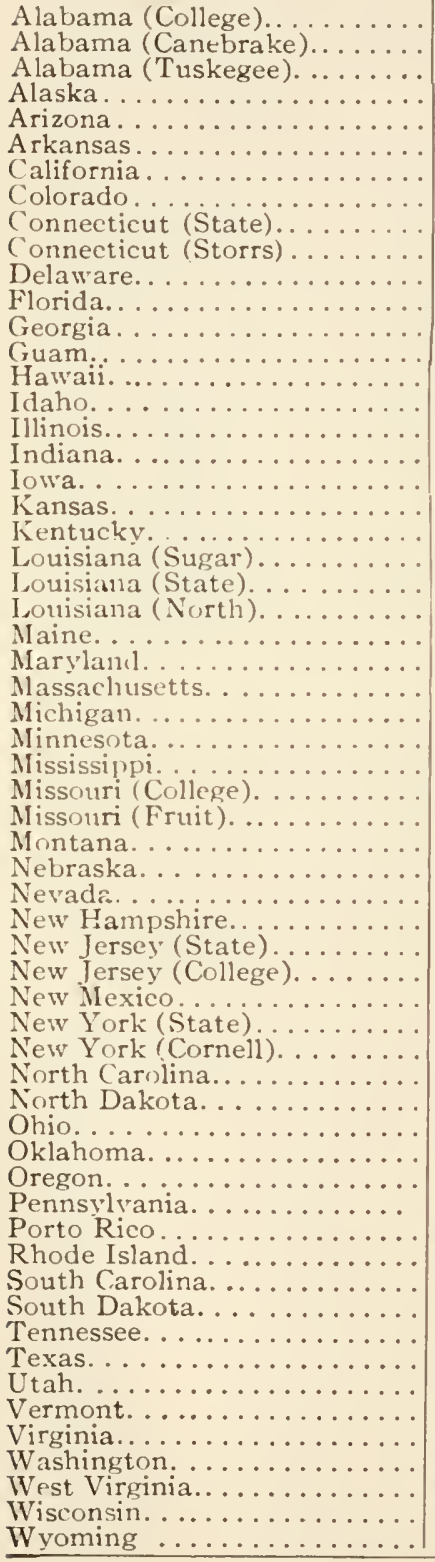 & 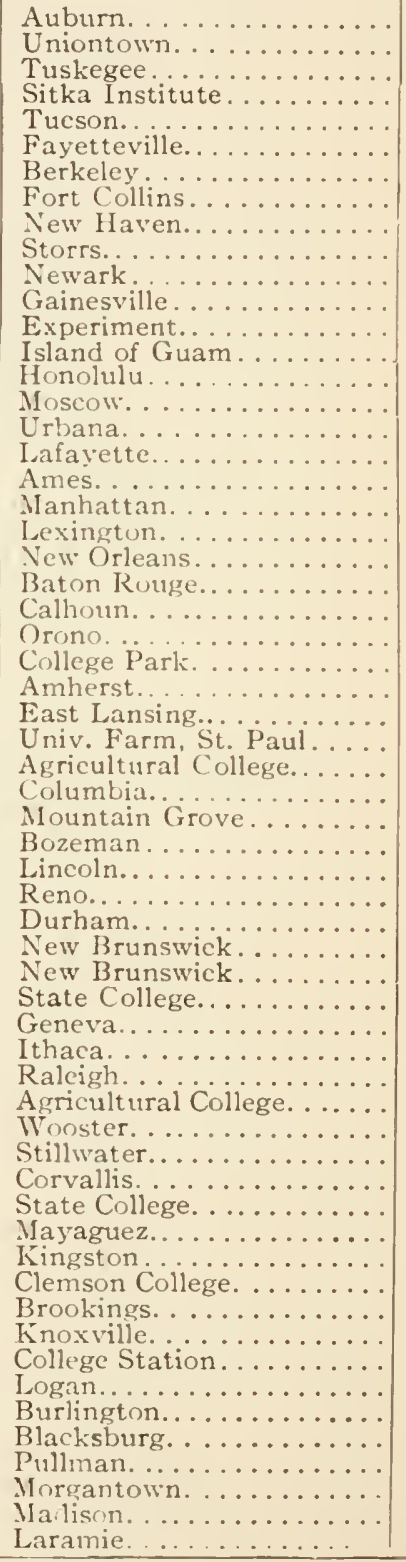 & 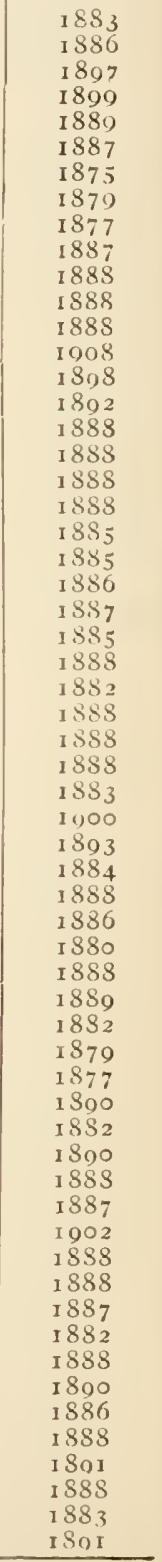 \\
\hline
\end{tabular}




\section{Canadian Fxperiment Stations.}

Central Experimental Farm-Ottawa, Ont.

Experimental Farm-Nappan, N. S.
“
"-Brandon, Manitoba.
《6
" -Indian Head, N. W. T.
"
"-Agassiz, 1. C.
Experiment Station-Ontario Agricultural Collegre, Guelph, Ont.

\section{OFFICLALS IN CHARGE OF FARMERS' INSTITUTES.}

(Farmers' Institute Specialist, U. S. Dept. of Agriculture, John Hamilton, Washington, D. C.)

\begin{tabular}{|c|c|c|c|}
\hline $\begin{array}{l}\text { State or } \\
\text { Territory. }\end{array}$ & Address. & $\begin{array}{l}\text { State or } \\
\text { Territory. }\end{array}$ & Address. \\
\hline 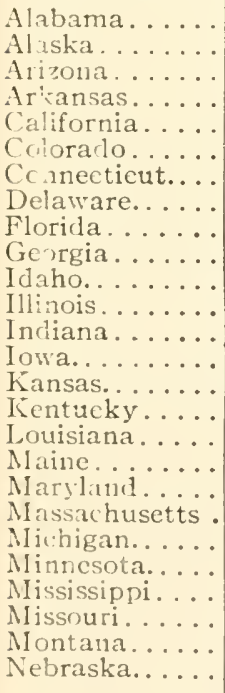 & $\begin{array}{l}\text { Auburn } \\
\text { Sitka } \\
\text { Tueson } \\
\text { Fayetteville } \\
\text { Berkeley } \\
\text { Fort Collins } \\
\text { N. Stonington } \\
\text { Dover } \\
\text { Lake City } \\
\text { Atlanta } \\
\text { Moscow } \\
\text { Springfield } \\
\text { Lafayette } \\
\text { Des Moines } \\
\text { Manhattan } \\
\text { Frankfort } \\
\text { Baton Rouge } \\
\text { Augusta } \\
\text { Penson } \\
\text { Ioston } \\
\text { Agricultural Coll. } \\
\text { Lyud } \\
\text { Agricultural Coll. } \\
\text { Columbia } \\
\text { Bozeman } \\
\text { Lincoln }\end{array}$ & 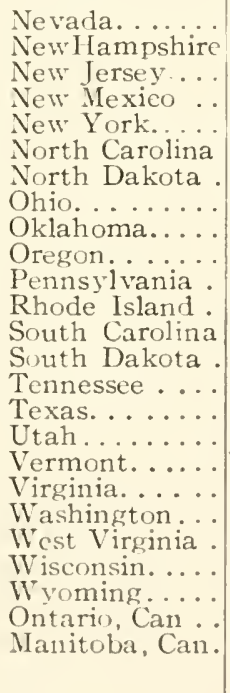 & $\begin{array}{l}\text { Reno } \\
\text { Concord } \\
\text { Trenton } \\
\text { Agricultural Coll. } \\
\text { Fayette ville } \\
\text { Raleigh } \\
\text { Bismarck } \\
\text { Columbus } \\
\text { Guthrie } \\
\text { Corvallis } \\
\text { Harrisburg } \\
\text { Providence } \\
\text { Clemson College } \\
\text { Gary } \\
\text { Nashville } \\
\text { College Station } \\
\text { Logan } \\
\text { Woodstock } \\
\text { Richmond } \\
\text { Pullman } \\
\text { Sunlight } \\
\text { Madison } \\
\text { Laramie } \\
\text { Toronto, Ont. } \\
\text { Brandon, Manit. }\end{array}$ \\
\hline
\end{tabular}




\section{AGRICULTURAL AND DAIRY LITER. ATURE.}

\section{MORE IMPORTANT WORIS ON DAIRYING.}

\section{American.}

Arnold, American Dairying. Rochester, N. Y., is $\$ 76$. (Out of print.)

Conn, Practical Bacteriology, N. Y., I907, 340 pp. \$1.25.

Dean, Canadian Dairying. 'Toronto, 1903. 260 pp. \$1.00.

Decker, Cheese Making: Cheddar, Swiss, Brick, Edam, etc. Fifth edition, by F. W. Woll. Madison, Wis., I9I3. 21 I pp. \$1.75.

1)ecker, Elements of Dairying. Columbus, O., I903. II 4 pp. \$I.00.

Eckles, Dairy Cattle and Milk Production. N. Y., I9II. \$1.60.

Farrington-Woll, Testing Milk and its Products. Twentysecond edition. Madison, Wis., I9I4. 297 PI. \$I.25.

Flint, Milch Cows and Dairy Farming. Boston, I888.

Grotenfelt-Woil, Modern Dairy Practice. Third edition, Nvised. New York, I9io. $2 S 6$ pp. \$2.00.

Gurler, The Farm Dairy. Chicago, I908. I64 pp. \$r.oo.

Jensen-Pearson, Essentials of Milk Hygiene. Philadelphia, 1907. $275 \mathrm{pp}$. $\$ 2.50$.

Lane, Business of Dairying. N. Y., I909. \$1.25.

Larsen and White, Dairy Technology. N.OY:, I9I3. \$1.50.

Michels, Creamery Butter Making. Lansing, Mich., I904. 27 I pp. Si.oo.

McKay-Larsen, Principles and Practice of Butter Making. New York, I906. 329 pp. \$r.5०.

Monrad, ABC in Cheese Making. Winnetka, Ill. Second edition. $68 \mathrm{pp} .50$ cents.

Monrad, ABC in Butter Making. Winnetka, Ill., IS99. I I p p. 50 cents. 
Monrad, Pasteurization and Milk Preservation. Winnetka, Ill. 7 S pD. 50 cents.

Monrad, Cleese Making in Switzerland. Winnetka, Ill. 68 pp. 50 cents.

Rosenau, The Milk Question. Boston, I912. 309 pp. \$2.00.

Russell, Outlines of Dairy Bacteriology. Seventh edition. Madison, Wis., I906. I90 pp. \$1.00.

Snyder, Dairy Chemistry. New York, i906. I90 pp. \$r.o0. Schoenman, Butter-fat and Dividend Calculator. Madison, Wis., I $\$ 95.66$ pp. $\$ 2.00$.

Van Slyke, Modern Methods of Testing Milk. New York, I906. 2 I4 Pp. 75 cents.

Vye, Creamery Accounting. Delano, Minn., IS99. 42 pp. \$1.00.

Ward, Pure Milk and the Public Health. Ithaca, N. Y., I000. 2 IS PP.

Willard, Practical Dairy Husbandry. N. Y., I $\$ 77.546$ pp.

Wing, Milk and its Products. N. Y., I912. $324 \mathrm{pp}$.

Winslow, The Production and Handling of Clean Milk. New York. 1907. 207 pp.

\section{English.}

Fleischmann, Book of the Dairy. London, I896. Ios. 6 d.

Richmond, Dairy Chemistry: London, I $899 . \quad 38+\mathrm{PP}$.

Sheldon, Dairy Farming. London. 570 pp. $4^{\text {to. }}$

Sheldon, The Farm and the Lairy. London, I SS9. I 54 pp. 2s. $6 \mathrm{~d}$.

Sheldon, Brivish Dairying. 2d ed., i $S_{9} 6$. I $70 \mathrm{PT}$.

Aikman, Milk, its Nature and Composition. Iondon, IS95. I So.pp.

Willoughby, Milk, its Production and Lses. London, I904. 259 Pp. $\$ 2.00$.

Long, The Dairy Farm. London, isso. I 5 pp.

Matthews, Economics in Tairy Farming. London, 1903. 6S pp. $\$ 2.25$.

Oliver, Milk, Cheese, and Butter. London, i $S_{94} 362 \mathrm{pp}$.

Barthel, Milk and Dairy Products. London, r9io. 260 pl).

Freudenreich, Dairy Bacteriology. London, is 95. II 5 PP.

Swithinbank and Newmin, Bacteriology of Milk. London, 190.4. $605 \mathrm{Pp} . \quad \$ 8.00$. 


\section{Other European.}

Martiny, Die Milch, I-II. Danzig, I87 I. 438 and 366 pp.

Martiny, Kirne und Girbe. Berlin, I 895.404 pp), 4 to.

Martiny, Milchwirtschaftl. Taschenbuch. Published annually, Leipzig.

Fleischmann, Das Molkereiwesen. Braunschweig, I876. I074 pp.

Fleischmann, Lehrbuch d. Milchwirtschaft. Fourth edition. Leipzig, I $90 \mathrm{~S} .536 \mathrm{pp}$.

Grimmer, Chemie und Physiologie der Milch. Berlin, I9 Io. $364 \mathrm{pp}$.

Sommerfeld, Handbuch der Milchkunde. Wiesbaden, I909. 999 pp.

Stohmann, Die Milch- und Molkereiproducte. Braunschweig, I 898. IO3I Pp.

Kirchner, Handbuch d. Milchwirtschaft. Fifth edition. Berlin, 1907. 700 [P.

Anderegg, Geschichte der Milchwirtschaft. Zurich, I894. 207 pp.

v. Klenze, Handb. d. Käserei-Technik. Bremen, is84. 643 pp.

Eugling, Praktische Käserei. Bremen, IS92. 260 pp.

Weigmann, Dic Methoden der Milch-conservirung. Bremen, I $893.72 \mathrm{pp}$.

Duclaux, Le Lait. Paris, I887. 336 pp.

Duclaux, Principes de Laiterie. Paris. $370 \mathrm{pp}$.

Lézé, Les Industries de Lait. Paris, I891. $6+7$ pp.

Pouriau, La Laiterie. 5th ed. Paris, I\$95. S98 pp.

Böggild, Mälkeribruget i Danmark. Third edition. Copen. hagen, I907. $627 \mathrm{pp}$.

\section{A LIST OF SIXTY AGIICULTURAL AND HORTICUL- TERAL BOOKS.}

bailey, Cyclopedia of American Agriculture. N. Y., I907I909. + volunies.

Hunt, How to Choose a Farm. N. I., igo6. 4I2 pp.

Failey, Principles of Agriculture. N. Y'., ISgS. 300 I'p.

Fream, Elements of Agriculture. Sih ed. Lo:ndon, IgIr. $692 \mathrm{pp}$.

Warren, Elements of Agriculture. N. Y., I poj. 43+ pp. 
Webb, Advanced Agriculture. London, IS94. $672 \mathrm{pp.}$

Goff-Mayne, First Principles of Agriculture. N. Y., I904. $248 \mathrm{pp}$.

Hall, Feeding of Crops and Stock. London, I9 I I. 298 pp.

Storer, Agriculture in some of its Relations with Chemistry. 7 th ed. N. Y., I897. 3 vols.

Voorhees, First Principles of Agriculture. N. Y., IS96. 2 I 2 pp. Roberts, The Fertility of the Land. N. Y., I 897 . 4I5 pp.

Voorhees, Fertilizers. N. Y., I $\$ 99.335$ pp.

Warington, Chemistry of the Farm. 2Ist ed. London, I9I3. $247 \mathrm{pp}$.

Johnson, How Crops Feed. N. Y., 375 pp.

Johnson, How Crops Grow. N. Y., I89o. 4 I6 pp.

Hunt, Cereals in America. N. Y., I904. 421 pp.

Plumb, Indian Corn Culture. Chicago, I 895.250 pp.

Woll, A Book on Silage. Revised ed., Chicago, I900. 234 pp. Allen, American Cattle. N. Y., ISSr. 528 pp.

Wallace, Farm Live Stock of Great Britain. Edinburgh, 1907. $75^{8} \mathrm{pp}$.

Craig, Judzing Live Stock. 4th ed. Des Moines, Ia., I902. I93 pp.

Plumb, Types and Breeds of Farm Animals. N. Y., I9o6. 563 pp.

Marshall, Brecding Farm Animals. Chicago, I9II. 287 pp.

Day, The Horse, How to Breed and Rear Him. $2 \mathrm{~d}$ ed. London, I $890.453 \mathrm{pp}$.

Johnstone, 'The Horse Book. Chicago, I9oS. 299 pp.

Armsby, Manual of Cattle Feeding. N. Y., I887. 525 pp.

Henry, Feeds and Feeding. Madison, Wis., rgro. 6 I $_{3}$ pp.

Jordan, Feeding Animals. N. Y., I90I. 450 pp.

Craig, Sheep Farming in North America. N. Y., I9I3. $302 \mathrm{pp}$.

Day, Productive Swine Husbandry. Philadelphia, I9r3. $330 \mathrm{pp}$.

Dawson, The Hog Book. Chicago, IgIr. 4 If pp.

Harris, On the Pig. N. Y., I8S9. 3 IS plp.

Collingwood, The Business Hen. N. Y., I904. I 25 pp.

Robinson, Principles and Practices of Poultry Culture. Boston, I9I2. 6I I pp. 
Cook, Bee-keeper's Guide. Lansing, Mich., rS84. th $^{\text {th }}$ ed. $337 \mathrm{Pp}$.

Law, Farmer's Veterinary Adviser. Ithaca, N. Y., 1880. 426 pp.

Reynolds, Veterinary Studies. 328 pp. St. Anthony Park, Minn., I 903.

Hilgard, Soils. N. Y., 1906. 593 PP.

King, Physics of Agriculture. Madison, Wis., I904. 60+ pp.

King, The Soil. N. Y., I903, 303 Pp.

Elliott, Land Drainage. N. Y. 232 pp.

Ogden, Rural Iygiene. New York, ror r. 434 pp.

* Wilcox, Irrigation Farming. N. Y., 1902. 494 pp.

Bailey, et al., Cyclopedia of American IIorticulture, 4 vols. N. Y., I 902 .

Golf, Principles of Plant Culture. 2d ed. Madison, Wis., I898. $276 \mathrm{pP}$.

Bailey, The Nursery Book. 2d ed. N. Y., I $\&_{92} .30+\mathrm{Pp}$.

Fletcher, How to Make a Fruit Garden. N. Y., 1905.

Rawson, Success in Market Gardering. N. Y., I910. $27 \mathrm{I} \mathrm{p}_{1}^{\prime}$.

Watts, Vegetable Gardening. New York, Igi 2.

Card, Bush Fruits. New York, i S99. 5-19 pp.

Fuller, Grape Culturist. N. Y. 2 I 8 pp.

Henderson, P'ractical F'oriculture. N. Y., r 89 г. 325 pp.

Weed, Insects and Insecticides. Hanover, N. Il., Is9 r. 2SI PP.

Lodeman, The Spraying of Plants. N. Y., I908. 399 pp.

Gifford, Practical Forestry. N. Y., 1902. $2 S_{4}$ Pp.

Graves, Principles of Handling Woodlands. N. Y., I9I. $325 \mathrm{pp}$.

Halsted, Barn Plans and Outbuildings. N. Y., 1903. 385 Pp.

Bailey, The Farm and Garden Rule-Book. N. Y., 19II. 587 pp.

Adams, The Modern Farmer. San Francisco, I \$99. 662 pp.

Roberts, The Farmers' Business Handbook. N. Y., I903. $300 \mathrm{pp}$.

Carver, Rural Economics. N. Y., I005. 327 pp.

Warren, Farm Management. N. Y., 1913. 590 pp.

Green, Law for the American Farmer. N. Y., I9II. 438 pp. 
AGRICULTURAT, AND DAIRT IITERATERE. Hij

Butterfield, Chapters in Rural Progress. Chicago, Igo\$. 25 I Pr.

Carney, Country Life and the Country School. Chicago, rgr 2. $405 \mathrm{pp}$.

\section{AMERICAN DAIRY PAPERS.}

American Checse-Maker. Grand Rapids, Mich. Monthly. 50 cents.

Chicago Dajry Produce. Chicago, Ill. Weckly, \$r.5०.

Creamery Journal. Waterloo, Ia. Monthly, \$r.০o.

Dairy Record, St. Paul, Minn. Weckly, \$r.oo.

Elgin Dairy Report. E!gin, IIl. Weekly, \$r.০o.

Guernsey Breeder's Journal. Peterboro, N. H. Monthly. $\$ 2.00$.

The Jersey Bulletin and Dairy World. Indianapolis, Ind. Weekly, \$r.o०.

Hoard's Dairyman. Fort Atkinson, Wis. Weckly, Sr.oo.

Holstein-Friesian Register. Brattleboro, Vi. Simi-monthly, \$1.50.

Holstcin-Friesian World, Ithaca, N. Y. Semi-monthly, 5o cents.

Kimball's Dairy Farmer. Waterloo, Ia. Semi-monthly, 5o cents.

The Michigan Dairy Farmer. Detroit, Mich. Semi-monthly, \$I.00.

The Milk Dealer. Milwaukee, Wis. Monthly, Sr.oo.

The Milk Reporter. Syracuse, N. Y. Monthly, \$I.oo.

New York Produce Review and American Creamery. New York City. Weckly, \$I.০o.

Practical Dairyman. New York City. Weekly, \$r.oo.

Pacific Dairy Review. San Francisco, Cal. Weekly, \$r.oo.

Canadian Dairyman. Toronto. Monthly, Sr.oo.

\section{MAIN FOREIGN DAIRY PAPIRS.}

The Dairy. I 44 Fleet Street, London, England. Monthly, 35. The Dairyman. I 7 New Castle Street, Farringdon St., London, England.

The Dairy World and British Dairy Farmer. 3 Io Strand, London, England. Monthly, 3 s. 
Nordisk Mejeri-Tidning. Stockholm, Sweden. Weekly, $5 \mathrm{kr}$. Mälkeritidende. Odense, Denmark. Weekly.

Milchwirtschaftliches Zentralblatt. Leipzig, Germany. Monthly.

Deutsche Molkerei-Zeitung. Berlin, Germany. Weekly, 9.20 mk.

Molkerei-Zeitung. Hildesheim, Germany. Weekly, $6 \mathrm{mk}$.

Oesterreich. Molkerei-Zeitung. Vienna, Austria. Semimonthly, $6 \mathrm{mk}$.

L'Industrie Laitière. 33 Rue J. J. Rousseau, Paris, France. Weekly, $20 \mathrm{fr}$.

La Laiterie. I 8 Rue des Martyrs, Paris. Bi-weekly, 13 fr. Schweizerische Molkerei Zeitung. Zurich. Weekly, $6.60 \mathrm{fr}$.

Die Milch Industric. Berne, Switzerland.

Revue Generale du Lait. Brussels. Semi-monthly, I6 fr.

New Zealand Dairyman, Mellington, N. Z. Monthly, 6s. 6d.

\section{MAIN AMERICAN AGRICULTURAL AND HORTICUL-} TURA, PAPLRS.

American Agriculturist. New York City. Weekly, Si.oo. American Bee Journal. Chicago, Ill. Weckly, Sr.oo.

American Cultivator. Boston, Mass. Weekly, \$2.50. American Fertilizer. Philadelphia, Pa. Monthly, \$2.00.

American Gardening. New York City. Semi-monthly, \$r.oo. American Hay, Flour, and Feed Journal. N. Y. Monthly, \$1.00.

American Poultry Journal. Chicago, Ill. Monthly, \$r.oo. American Poultry World. Buffalo, N. Y. Monthly, 50 cents. American Sheep Breeder and Wool Grower. Chicago, Ill. Monthly, \$r.oo.

American Sugar Industry and Beet-sugar Gazette. Chicago, Semi-monthly, \$2.50.

American Swine Herd. Chicago, Ill. Monthly, 50 cents. American Thresherman. Madison, Wis. Monthly, \$r.oo. American Veterinary Review. New York City. Monthly, $\$ 3.00$.

Acker- und Gartenbau Zeitung. Milwaukee, Wis. Weekly, \$1.00.

Better Fruit. Hood River, Ore. Monthly, \$r.oo. 
Breeders' Gazette. Chicago, Ill. Weekly, \$r.oo.

California Cultivator and Poultry Keeper. Los Angeles, Cal. Monthly, \$r.oo.

Canadian IIorticulturist. Peterboro, Ont. Monthly, \$I.əว.

Chicago Live Stock Morld. Chicago, Ill. Daily, \$3.0ว.

Colman's Rural World. St. Louis, Mo. Weekly, \$r.oo.

Connecticut Farmer. Hartford, Conn. Weekly, \$r.5ว.

The Country Gentleman. Philadelphi.., Pa. Weekly, \$r.5ว.

Country Life in America. N. Y. Monthly, \$4.

The Dakota Farmer. Aberdees, S. D. Semi-muxhiy, Sr.os.

Drover's Joumal. Chicago, Ill. Weekly, \$i.5ว.

Farm and Fireside. Springfild, O. Semi-monthly, 50 cents.

Farm and Home. Chicago, and Springfield, Mass. Semimonthly, 50 cents.

The Farm Poultry. Boston, Mass. Monthly, 50 cents.

The Farmer. St. Paul, Minn. Semi-monthly, 50 cents.

Farm Implement News. Chicago. Weekly, \$2.00.

The Farmers' Adrocate. London, Ont. Weekiy, \$r.jo.

Farmers' Guide. Huntington, Ind. Weekly, 75 cents.

The Farmer's Magazine. Montreal. Month'y, \$2.00.

The Farmers' Tribune. Sioux City, Ia. IVeckly, Sı.oว.

Farmers' Review. Chicago, Ill. Weekly, \$r.25.

Farm, Field, and Fireside. Chicag,, 11l. Weekly, SI.os.

Farm News. Springfield, Ohio. Montlily, 50 ce t.

Farm, Stock, and Home. Minneapolis, Minn. Seni-monthly, 50 cents.

Farming. N. Y. Monthly, \$r.oo.

Farming World. Toronto, Canadx. Weekly, Sr.os.

The Farm Journal. Philadelphia, Pa. Monthly, 5o cents.

The Field Illustrated. N. Y. Weekly, \$3.00.

Florida Agriculturist. De Land, Fli. Weekly, \$2.00.

Flour and Feed. Milwaukee, Wis. Monthly, \$r.oo.

Garden Magazine. N. Y. Monthly, Sr.oo.

Gardening. Chicago, Ill. Semi-monthly, \$2.00.

Horse Review. Chicago, Ill. Weekly, \$2.0o.

Indiana Farmer. Indianapolis, Ind. Weekly, \$r.oo. The Homestead. Des Moines, Ia. Weekly, Sr.oo.

Irrigation Age. Chicago, Ill. Monthly, \$2.oo.

Journal of Agriculture. St. Louis, Mo. Weekly, Si.oo. 
Journal of Agriculture and Horticulture. Montreal, Canada. Monthly, \$r.oo.

Kansas Farmer. Topeka, Kan. Weekly, \$r.oo.

Kentucky Stock Farm. Lexington, Ky. Weekly, \$2.00.

Live Stock and Dairy Journal. Sacramento, Cal. Monthly, 75 cents.

Live Stock Journal. Chicago, Ill. Weekly, \$r.oo.

Live Stock Report. Chicago, III. Weekly.

Louisiana Planter and Sugar Manufacturer. New Orleans, La. Weekly, $\$ 3.00$.

Market Growers' Journal. Louisville, Ky. Semi-monthly. \$i.oo.

Massachusetts Ploughman, Boston. Weckly, $\$ 2.00$.

Michigan Farmer. Detroit, Mich. Weckly, \$r.oo.

Mirror and Farmer. Manchester, N. H. Weekly, Sı.oo.

Montana Stockman and Farmer. IIelena, Mont. Scmimonthly, \$2.00.

National Grange Monthly. Westfield, Mass. 50 cents.

National Stockman and Farmer. Pittsburgh, Pa. Weekly, \$1.50.

Nebraska Farmer. Lincoln, Ncb. Wcekly, \$1.25.

New England Farmer. Boston, Mass. Weckly, \$2.00.

New England Homestead. Springficld, Mass. Weekly, Sr.oo.

The Nor'-west Farmer. Winnipeg, Manitoba. Weekly, Sr.50.

Northwestern Agriculturist. Minneapolis, Minn. Semimonthly, 50 cents.

Ohio Farmer. Cleveland, Ohio. Weekly, \$r.oo.

Ohio Poultry Journal. Dayton, Ohio. Monthly, \$r.oo.

Orange Judd Farmer. Chicago, Ill. Weekly, \$r.oo.

Orchard and Farm. San Francisco, Cal. Monthly, \$r.oo.

Pacific Rural Press. San Francisco, Cal. Weekly, $\$_{3} .00$.

Poultry Husbandry. Waterville, N. Y. Monthly, 5o cents.

Practical Farmer. Philadelphia. Weekly, \$1.০o.

Prairie Farmer. Chicago, Ill. Weekly, Si.oo.

Ranch. Seattle, Wash. Semi-monthly, \$r.oo.

Rural Californian. Los Angeles, Cal. Monthly, \$r.50.

Rural New Yorker. New York City. Weekly, \$r.oo.

The Shepherds' Journal. Chicago, Ill. Monthy, 50 cents.

Southern Cultivator. Atlanta, Ga. Monthly, \$r.oo. 
Southern Planter. Richmond, Va. Monthly, \$1.০o.

Successful Poultry Journal. Chicago, Ill. Monthly, 50 cents. Sugar-beet. Philadelphia. Quarterly, \$2.00.

Swine-Breeders' Journal. Indianapolis, Ind. Semi-monthly \$r.oo.

Twentieth Century Farmer. Omaha, Neb. Weekly, \$r.oo. Texas Stockman. San Antonio, Tex. Weekly, Sr.oo. Turf, Field, and Farm. New York City. Weekly, \$5.०o. Wallace's Farmer. Des Moines, Ia. WVeekly, \$r.oo. Western Swine-breeder. Lincoln, Neb. Monthly, 50 cents. Wisconsin Agriculturist. Racine, Wis. Weekly, 75 cents. Wool Markets and Sheep. Chicago, Ill. Weekly, \$r.oo. 



\section{INDEX.}

Aberdeen Angus cattle, 24

Accidents, what to do in case of, 377

Acidity of milk or cream, determination of, by alkaline tablet test, 304

Acre-foot of water, 177

Manns' test, 306

Adulteration of milk, 267

Advanced register of, American cattle clubs, requirements for admission,

24 I

Age of farm animals, determination of, 36

Agricultural and dairy literature, 460

horticultural books, list of, 462

papers, main American, 466

Agricultural associations, constitution of, 359

books, a list of, 462

clubs, constitutions and by-laws of, 359

crops, rank of states in production of, 448

educational institutions in the United States and Canada, 454

engineering, $\mathrm{I} 6 \mathrm{I}$

experiment stations in the United States and Canada, 458

imports and exports, I 904-I905, 439

population, number, and classification, 4I 7

products, average farm price of, I890-I9I0, 426

rank of states in value of, 448

schools and colleges in the United States, 454

wages in the United States, 424

Agriculture, officials in charge of, in the U. S., 453

Alkaline tablet test of acidity in milk or cream, 304

American trotter, the, 2 I

agricultural colleges, 454

experiment stations, 458

dairy schools, 457

schools of forestry, 457

soils, chemical composition, I 46

veterinary colleges, 456

Apples, seasons of varieties, in various storages, 94

Arbor Day, dates of, in different states and territories, 139

Ash of cows' milk and colostrum, composition of, $25 \mathrm{r}$

Atavism, 52

Ayrshire cattl., 222 
Babcock milk test, the, 252

application of, 254

points to be watched, 253

Baltimore Canned Goods Exchange, standards of, IO2

Barley, commercial grades of, 405

Barnyard manure, I 52, I 53

composition, 155

Beef cattle, 24

proportion of, to live weight of cattle, 206

Bees, honey, and wax produced in the United States, 438

Beet-sugar production in the United States, 1901-1903,436

Berkshire swine, 27

Board of Health (N. Y.) lactometer, 254, 255

Boiler, care of, 286

power, 280

Bordeaux mixture, I 2 I

Boyd, John, Boyd's process of cream-ripening, 301

Brecd tests of cows, Columbian, 1893,238

St. Louis, 1904,239

Brceds of live stock, cliaracteristics of, 21

registered live stuck in U. S., 428

dairy cattle, 429

Brecders' Associations, co-operative, Constitution, $367 a$

Brown-Swiss Cattle, 234

Butter, 295

American premium, analyses of, 308

by deep, cold setting and Cooley system, 303

shallow-pan creaming, 303

cheese and condensed-milk factorics in the United States, 434

commercial grades of, 309

composition of, 307

conversion factor for calculating yicld of, 3 I I

domestic exports of, $1870-1005,446$

English scale of points for judging, 3 I 7

factories in the United States, statistics of, 434

fat, highest record for $2+$ hours, 239

official records, 240

standard of purity, government, 265

foreign samples of, composition of, 308

fresh, composition of, 308

from separator cream, 304

foreign, analyses of, 308

formula for calculating yield of, 3 I I

loss of, through inefficient skimming, 285

makers, score in judging proficiency of, 317

making, 295

distribution of milk ingredients in, 316

use of pure cultures in, 297

milk, composition of, 273

milk required for making I $1 \mathrm{~b}$. of, 3 I 5,3 I 6

overrun, the sliding-scale, 3 I 1 


\section{INDEX.}

Butter, records, official, $24^{\circ}$

salted, composition of, 308

score for judging, 316

sliding-scale overrun, 3 i 4

sour cream, composition of, 307

standard of purity, government, 265

standards for, 262

sweet cream, composition of, 307

unsalted, composition of, 308

yield from cream of different richness, 3 I I

milk of different richness, 314,346

By-laws and rules for co-operative cheese factories, 354

Cald vell, Prof. W. H., Guernsey cattle, 2 I 4

creamery associations, 35 I

California weir table, $1 S_{2}$

Canada, area and population, 4 I I

butter and cheese-making in, 435

crops, production of, 425

dairy schools, 459

experiment stations, 459

exports of dairy products, 446

meteorolngical data, 4 i6

Ministers and Commissioners of Agriculture, 453

number of farm animals, I90I, 427

production of various crops, I90I, 425

veterinary colleges, 458

Canned Goods Exchange, Baltimore, standards, I02

Carcass, a steer's, 204

of farm animals, constituents of, 209

Cattle, breeds, 24

clubs, American, requirements for dimission to adv. registers, 24 I

determination of age of, 28

diseases of, 57

live weight, estimation of, 35

market classes, 30

proportion of beef to live weight 206

the various parts of, 208

pure bred, used for dairying, in the United States, 429

Cattle foods, classification, I I

comparative value, Io

Centrifugal skim-milk, per cent fat in, 280

Cereals, prevention of smut in, r 29

prices per bushel and per ton, 20

Cheddar cheese, formulas for finding yield of, 33 I

commercial grades of, $336 a$

losses in curirs, 333

manufacture of, 3 ro

Cheese, butter, and condensed-milk factories in the United States in r 900,434

Cheese, comnosition, 320,330

curing-r mms, determitro in s inmidity in, 326 
Cheese, domestic exports of, r 870-r 905,446

factories, co-operative, by-laws and rules for, 354

in the United States, statistics of, 434

management 333

whey to be allowed patrons of, 337

loss in weight during curing, 333

manufacture of, 3 I 9

market of the United States, $336 a$

score for judging, 329

standard of purity, government, 265

Cheere making, distribution of ingredients, 330

fertilizing ingredients, $33 \mathrm{I}$

use of pure cultures, 297

synopsis of manufacture of "principal varieties, 336

varieties and analyses, 330

yield from roo lbs. of milk, 332, 334

Chester White pigs, 27

Che viot sheep, 26

Chinch-bugs, fighting the, by means of kerosene emulsion, 130

Cisterns, capacity of, 182, I 83

Clark, W. G., M.D.C., Common discases of farm animals, 53

Veterinary remedies and doses, 63

Cleveland Bay horses, 22

Clover, winter-killed, replacing, 82

Clovers, notes on adaptability and uses, I r r

Clydesdale horses, 22

Coins, foreign, value of, 4 on

Cold storage, temperatures for dairy products in, 3 I 8

Colostrum, composition of, $25 \mathrm{I}$

ash, composition of. 25 I

Components of cow's milk, calculation of, 250

Composite samples of milk, directions for taking and preserving, 338

Composition and weight of ordinary crops per acre, 80

of ash of cows' milk and colostrum, $25 \mathrm{I}$

butter, 307,308

colostrum, 25 I

commercial fertilizing materials, I 54

cows' milk, variations in, 249

cream, 273

dairy products, 273

dairy salt, 3 I 8

different parts of same milkings, 249

feeding-stuffs, $x, 3,6$

live animals, 208

milk of different breeds, $\mathbf{2 4 2}$

morning and evening milk, 249

morning, noon, and evening milk, 249

sweet- and sour-cream butter, 307

varions kinds of milk, $24 \mathrm{~s}$

Concentrated feeding-stuffs, weight of, $\mathrm{r} 8$

Condensed milk, composition, 273 
Condensed-milk, butter, and cheese factories in the United States, 434

Constitution and by-laws of agricultural clubs, 359

breeders' associations, $367 a$

dairy test associations, 3676

road leagues, 366

village-improvement societies, 364

Contagious diseases, rules for treatment in case of, $7 \mathrm{r}$

Conversion factor for calculating yicld of butter, 3 I I

of U.S. weights and measures to metric, and vice versa. $389,39 \mathbf{I}$

foreign mone $y^{*}$ to dollars and cents, 4 Io

table for calculating fertilizing ingredients, 160

pounds of milk into quarts, and vice versa, 269

Cooling milk or cream, water or ice required, 294

Corn, cost per acre of raising, 426

commercial grades of, 403

Corn on the cob, measurement of, in cribs, 397

Cost of irrigating canals and ditches, iso

raising wheat and corn, per acre, 426

Cotswold sheep, 26

Cotton, a verage cost per acre, 426

Cows, buying and selling by tests of their milk, 244

care of, $245,272,35^{\circ}$

diseases of, 57

See also under Dairy Cows

Craig, Prof. John A., Characteristics of breeds of live stock, aI,

Cream, application of viscogen, 292

calculation of per cent fat in, 275

composition of, 273

formula for diluting, to a desired fat content, 279

finding fat content of, 278

gatherers, instructions to, 356

ice required for cooling, 294

of different fat contents, relative value of, 270

yield of butter from, $32 \mathrm{I}$

preservation of, by heat, 290

quantity of water or ice required for cooling, 294

relative value of, $269 a$

ripening, Boyd's process of, $30 \mathrm{I}$

separators, capacity of, 282

economy of, $28 \mathrm{r}$

liandling and care of, 279

list of, 276

power required for skimming I000 lbs. milk, 28I

standard of purity, government, 265

standards for, 262

standardization of, 286

use of alkaline tablet test with, 304

yichl from milk of different richness, 274

Creameries and cheese factories, directions for making diviclends in, 345 suggestions to patruns of, 349

Creamery associations, co-operative by-laws and rules for, 35 I

management of, 338 
Crops, farm, enemies of, I 2 I

field, important data as to, 74,77

fertilizing materials in, I50, 151

soiling, $8 \mathrm{I}, 82,84$

various yields per acre, 91

weight and average composition of, per acre, 80

Culverts, sizes of drain-pipe required for, in prop. tocapacity and fall, 169

Curd test, the Wisconsin, 322

Curing of cheese, losses in, 3.33

rooms, humldity in, 326

Cuts of meat, diagrams of, 204, 205

Dairy breeds, composition of milk from, 242

1) results of tests of, $237-2.4$ I

cattle, origin and characteristics of breeds, 2 I I

pure.bred, in the United States, 429

cows, 21 I

advanced register of, requirements for admission, $24 \mathrm{I}$

dry matter, digestible matter and digestible protein to be furnished in rations, $10 b$

methods of judging the value of, $2+3,2.44$

pure-bred, average per cent of fat and production, 242

rations for, 1 2, I 4,16

size of silo for different number of, 86

soiling crops for $8+$

yield of milk and fat from, 236. 239, 242

farms, regulations for the government of, $7 \mathbf{I}$

papers, American, 464

main foreign 465

products, American analyses of, 248

composition of 273

exports of, from Canada I 868-1904, 446

the United States, I 870-1 905,446

fertilizing ingredients in, 251

legal standards for, 262

standards of purity, government, 264

temperatures for cold storage of, 318

rules, fifty, 244

salt, analyses, 3 i 8

schools in the United States and Canada, 457

statistics for the United States, 1900, 432

test associations, constitution, $367 b$

Dairies and dairy farms, regulations for the government of, 71

Dairying, 2 I I

more important works on, 460

pure-bred cattle, used for, in the U. S., number and value, 429

Dates of killing frost, $4 \mathrm{I} 3$

Days between dates within two years, number of, 384

Decker, Prof. John W., How American cheese is made, 319

Dentition of farm animals, 36

Detection of bad milk, 322

Devon cattle, 230 
Dewey, L. H., Table of noxious weeds, i I 6

Dew-point, table of, 327

Dietaries, r 96

daily, calculation of, 196

Dietary standards, 196

studies, American, summary, 203

Digestion coefficients, 2

Dimensions, interior, of farm buildings, I 9 r

Directory of official agricultural institutions, 452

Diseases of farm animals, 53

Disinfectants, list of, 70

Disinfection of stables, rules for, 7 I

Distance table for planting vegetables, 88

tree-planting, $90,{ }_{3} 8$

Ditches, open, number of acres drained by, i 66

Dividends, directions for making, in creameries and cheese factories, 345

Dorset sheep, 26

Doses, veterinary, graduation of, 63

Drainage systems, points to note in planning, 169

Draining of area of land by tiles, removing $t$ in. depth of water in 24 hours, 165,170

area of land by open ditches, I 66

land, reasons for, $6_{\mathrm{I}}$

Drains, of various dimensions, earth removed for I 7 I

advice to landowners about to construct, 168

Duroc-Jersey swine, 27

Durum wheat, commercial grades, 403

Dutch belted cattle, 232

Duty of water, i 76

Economy, pecuniary, of food, 200

Egg products in the U. S., I $879-99,437$

Eggs, loss in weight, during incubation, 46

Engine management, $2 S_{9}$

Engineering, agricultural, i 6 I

English milking trials, results of, $24 \mathrm{I}$

Essex swine, 27

Exhaustion of fertilizers, ${ }_{5} 6$

Exhibition purposes, preservation of soft fruits for, roo

Experiment stations, agricultural, in the U. S. and Canada, 458

Exports, agricultural, in the U. S., $1904^{-1905,439}$

domestic, of butter and cheese, 446

Fair tests of dairy cows, 239, 243

Farm, transportation on the, i 89

Farm animals, bndy temperature of, 38

characteristics of breeds of, 2 I

common diseases of, 53

constituents of carcass, 200

determination of age of, 36

estimated number on farms and ranches, 1905,430

feeding-standards for 12 
Farm animals, food requirements of, 18

gestation period, average, 39

heat in, duration and frequency, 38

in Canada in 1901,427

in the United States in $1870-1900,427$

live, composition of, 208

market. classes of, 28

Farm buildings, interior dimensions of, $\mathrm{I} 9 \mathrm{I}$

crops, enemies of, $12 \mathrm{I}$

products, fertilizing constituents of, 147

cost of hauling, 188

yield of, per acre, $8 \mathrm{r}$

Farmyard manure, amount required to replace ingredients abstracted by various crops, 152

composition, amount, and valuc, I 53, I55

Farmers, forestry for, 13 I

Farmers' institutes, officials in charge of, 459

Farming population of the United States, 4 I 7

approximate losses of fertilizing materials in different systems, I 45

Farms in the United States, statistics concerning, 4I9

Farrington, Prof. E. H., The alkaline tablet test for acidity in milk or cream, 304

Fat content of milk from pure-bred cow's, 242

Fat, relation of, to casein and other solids of milk, 250

Fattening animals, comparative results obtained with, 207

Feeding and general care of poultry, $4 \mathrm{r}$

standards for farm animals, i 2

stuffs, chart showing manurial value of, 147

composition of, $1,3,6$

comparative value of, In

concentrated, classification, I I

weights of, is

fertilizing constituents, $147, I_{4} 8$

manurial value, 147

ready reference table of composition, 6

valuation of, 20

Feed rations, calculation of components of, I 4

Feed unit system, 19a

Fermentation tests, 322, 324

Fernow, Prof. B. E., Forestry for farmers, I3I

Fertilizer industry of the United States, 447

laws, states having, 158

Fertilizing constituents of feeding-stuffs and farm products, 147,148

materials, commercial, composition, 154

conversion table for calculation, 160

equivalent quantities of, 157

in dairy products, $25 \mathrm{I}$; in different crops, $15 \mathrm{I}$

in raw materials and chemicals, trade value of, I59

losses of, in different systems of farming, 145

voided by animals, 153 
Fertilizing materials withdrawn by various crops, I50, I 5 I

Fertilizers, I 45

commercial, composition, I 54

exhaustion of, 156

imports and exports, 447

industry of the U. S., 447

valuation of, 158

Field crops, 74

important data as to, 77

Fish N. S., Brown-Swiss cattle, 234

Flag signals adopted by the U.S. Weather Bureau, explanation of, 368

Flaxseed commercial grades of, 406

Food economy; 195

fuel value, 194

Foods, human, 193

Food materials, human, composition of, 197, I98

nutrients furnished for 25 cents in, 201

pecuniary economy of, 200

Forcing calendar, a vegetable, 93

Foreign coins, value of, 409

Forestry, I3 I

for farmers, I $3 \mathrm{I}$

schools of, 457

Forest fire laws in the United States, I 40

Formaldehyd treatment for the prevention of smut of cereal grains and of potato scab, I 27,129

Formulas for calculation of total solids in milk, 258

yield of butter, 3 I I

converting degrees Centigrade or Réaumur to Fahrenheit, and vice versa, 395

diluting cream to a desired fat content, 279

finding adulteration of milk, 267

fat content of cream, 278

quantity of water or ice required for cooling milk

or cream, 294

yield of Cheddar cheese, $33 \mathrm{I}$

Frederiksen, J. D., Handling and care of cream separators, 279

French coach horses, 22

Frost, killing, dates of average and actual, 4 I 3

Frinit and vegetable garden, a combined, 92

Fruit packages, kinds of, 94

Fruit trees, distances apart, 90

longevity, ,o

time required to bear fruit, 90

Fruits, soft, preservation of, for exhibition purposes, roo

calculated value of, compared with hay, grains, etc., 19

temperatures for preserving, 100

Fuel value of food materials, 194

of woods, 136

Fungous diseases of plants treatments for I 2 I

Galloway cattle, 24 
Gardener's planting table, 88

Gardner, M. H., Holstein-Friesian cattle, 218

Gerber fermentation test, the, 324

Germination standards of seeds, 109 of vegetable seeds, time of, 90

Gestation calendar, 39 period in farm animals, 39

Goff, Prof. E. S., Treatments for insect and fungous diseases, I II

Government land measures, 396 standards of purity for milk and its products, 264

Grades of butter, commercial, 309 grain, commercial, $40 \mathrm{I}$

barley, 405

corn, 403

durum wheat, 403

flaxseed, 406

oats, 404

rye, 405

wheat, 401

hay and straw, $406 a$

Grades per roo ft., and their square roots, i 64

Grain, commercial grades of, 401

Grains, prices of, per bushel and per ton, 20

Grass seeds, amounts to sow per acre, 109

number, weight, and cost of, rog

Grasses, notes on adaptability and uses of, III

Guernsey cattle, 2 I 4

Gurler, H. B., Butter-making, 295

Hackney horses, 22

Hampshire sheep, 25

Hand separators, list of, 276

Hauling farm products, cost of, I 88

Hawks and owls, beneficial and harmful, 370

Hay in mows or stacks, reckoning amount and value of, 397

Hay, commercial grades of, $406 a$

seed mixtures for, 75

Heat in farm animals, duration and frequency, 38

Hemp ropes, strength of, 309

Herd milk, ranges in composition of, 268

Heredity, 48

Hereford cattle, 24

Hicks, Gilbert H., Seed-testing for the farmer, 104

Highland sheep, 27

Hills, number of, on an acre of land, 87

Hog cholera, suppression of, 67

Holidzys, lorn1, 375

Hol itein-Friesian cattle, 2tS

Hon'v a 11 hers vaxin tha Unite 1 States, proluction of, $43 \varepsilon$

Horse, determination of age, 36 
Horse, labor done by, r 89

Horse-power, 290 required for discharge of given quantities of water, 176

Hotses, dentition of, 38 separating $1000 \mathrm{lbs}$. of milk, $28 \mathrm{I}$

diseases of, 53

heavy, 22

light, 2 I

market classes of, 28

Horticulture, 88

Horticultural books, a list of, 462

products, best temperatures for preserving, roo

Hot-water treatment for smut, I 27, I 28

Human foods, I 93

composition, I 98

Humidity in cheese-curing rooms, 326

relative, in curing-rooms, table showing, 327

Hurricane warnings, 369

Ice required for cooling milk or cream, 294

Icc-cream, standard of purity, government, 266

Imports, agricultural, in the U. S., 1904-1905, 439

of sugar into the United States, 436

Inches reduced to decimals of a font, 390

Incubation, loss in weight of eggs during, 46

Industry groups in the United States, 424

Indian corn, commercial grades of, 403

Insects, injurious, treatments for, I 2 I

Interest tables, 382

Irrigated land in farms, value of, i $7 \mathrm{~S}$

Irrigating canals and ditches, cost per mile, rSo )

Irrigation, 176

efficiency of windmills for. I 73, I 8 I

pipes, carrying capacity. I 79

cost of, I 80

Jersey cattle, 2 I I

Kephir, composition of, 270

Kerosene emulsion, 122 , 130

Kilograms converted into pounds avoirdupois, 390

Koumiss, composition, 270

standard of purity, government, 266

Lactometer, 254 scales, comparison of, 255

Land, acres of appropriated, vacant, and reserved, in the U. S., $4 \mathbf{I}$ measures, government, 396

Legal holidays, 375

Legal standards for dairy products, 262

wcights of grain, seeds, etc., 400

Leicester sheep, 26

Lincoln sheep, 26

Live animals, composition of, 2 ro 
Live mineral matters in roo parts, 210

Live stock, characteristics of breeds of, 21 registered, breeds and number of, in the U. S., 428

Live weight of cattle, estimation of, 28

London purple, 122

Loss of butter from inefficient skimming, 285

cheese in curing, 333

Losses of fertilizing materials in different systems of farming, 145

Lumber industry of the U. S., statistics, 437

Main pipe, rule for obtaining size of, $\mathrm{r} 63$

Manila ropes, strength of, 390

Manns' test, direction for use, 306

Manure, amount and quality produced by stock, 152

amount required to replace ingredients abstracted by various crops, $1 ; 2$

Manures a 2 d fertilizers, 144 composition, amount, and value of, from different farm animals, I 52, I 53

valuation of, 158

Manurial value of feeding-stuffs, 147, I 48

Maple sirup, specific gravity, sugar content, and boiling-point, 96 production of, in the United States, 1899,437 sugar obtained from, 97 production of, in the United States, 1905-1906, 435

Market classes of farm animals, 28

Marschall rennet test, 319

Maturity table for vegetable seeds, 90

Meat, diagrams of cuts, 204, 205

Merino sheep, 25

Mineral matters in roo parts of live animals, 210

Milch cows, diseases of, 57

Milk, adulteration, 267

ash, composition, 25 I

average composition, with variations, 249

bad, detection of, 322

calculations of components, 250

total solids, 258

care of, 246

composition of, from different breeds, 242

different parts of the same milkings, 249

various kinds, 248

cream, butter-fat, and butter, comparative prices, 314

fertilizing ingredients in, 251

gatherers, instructions to, 356

ingredients, distribution of, in butter-making, 3 r 6

cheese-making, 33r

measures, prices of, $260 a$

modified, amounts of cream or skim-milk used in making, 270

morning and evening, composition of, 249

morning, noon, and evening, composition of, 249

of different fat enntents, relative value of, 270

payment of, at creameries and cheese factories, 340 
Milk, power required for skimming 1000 lbs., $28 \mathrm{I}$

preservation of, by heat, 290, 293

price of, per 1000 lbs., 343

prices. by measures $272 a$

products, standards of purity for, 266

quantity of water or ice required for cooling, 294

records, official, $24^{\circ}$

relation of fat to casein, and other solids of, 250

relative cheese value of, 334

reciliced for making one $1 \mathrm{~b}$. of butter, 315,316

rules for laandling, 272

skimming and watering of, 267,268

solids, calculation of, $250,258,260$

sulids, calculation of specific gravity of, 26r

specific gravity of, temperature correction tables for, 256

standards, 262

standards of purity, government, 264

standardization of. $27 \mathrm{I}$

table for converting pounds of, into quarts, 269

quarts of, into pounds, 269

finding average per cent of fat in, 347

testing, a chapter on, 252

use of alkaline tablet test with, 304

variation in composition, 268

watering of, 267

yield and composition of, of different breeds, 242

Milking trials, English, results of, 24I

rules for, 245

utensils, care of, 247

Milkings, composition of different parts of same, 249

Miner's inch, 177

Money, conversion table, 410

foreign, value of, 409

order fees, 386

Monrad rennet test, the, 3 I 9

Mutton, diagrams of cuts, 205

sheep, 25

Nails, cut, table of, 192

New York Board of Health lactometer, comparison with Quevenne lactometer, 255

Nitrate of sola, prices of, on the ammoniate basis, r 60

Nitrogen roided by animals, i 53

Noer, J., M.D., What to do in case of accidents, 377

Noxious weeds, table of i i 6

Number of plants for an acre of ground, 86,87

trees on an acre, 135

Nutrients, i 93

furnished for 25 cents in food materials, $20 \mathrm{x}$

Nutritive ratio, 2

Oats, commercial grades of, 404

Oat-smut, prevention of, 127 
Official milk- and butter-fat records, 240

Orchard-spraying outfit, a cheap. I 26

Ounces reduced to decimals of a foot, 390

Oxford sheep, 26

Overrun of butter, 309,3 I 4

Parcel post, 386

Pasteurization of milk and cream, 290

Pastures, permanent, seed mixtures for, 75

Patents, how issued, $37 \mathrm{I}$

Patrons of creameries, riles for, 356

Patrons of chees 3 factorics and creameries, suggestions to, 340

Payment of milk at creameries and cheese factories, $34^{\circ}$

Percheron horses, 23

Perishable goods, tomperatures in juring, 98

Pickrell, J. H., Shorthurns as dairy cows, 224

Pipes, carrying calucity of, 179

cost of, for irrigation, 180

straight, flow of water through, I 79

Plant diseases, treatments for, 121

food, proportion recomnended for different crops, 158

Planting table, a gardener's, 88

Plants, temperatures injurious to, 90

Plants, number of, for an acre of ground, 86,87

Plowing, performance of team in, i 89

Poisoning, antidotes in cases of, 380

Puland China sivine, 27

Population, agricultural, number and classification, 4 7

Pork, diagram of cuts of, 205

Postage, domestic, 385

foreign, 385 ; parcel post. 386

Potatoes, relation of sp. gr., dry matter, and starch content of, 95

Potatoes, prevention of scab, I 29

Poultry and egg products in the United States, I 879-1899, 437

breeds of, 47,48

feeding and care of, $4 \mathrm{r}$

period of incubation, 38

standard weights of, 47

Pounds converted into kilograms, 390

Power required for discharge of water, i 76

to raise water from deep wells, i 80

separators, list of, 276

Precipitation, normal, in Canada, 416

the United States, 4I 5

Preservation of horticultural products, best temperatures for, ro

milk and cream by heat, 290

soft fruits for exhibition purposes, roo

Preservatives for soft fruits for exhibition purposes, roa

Prevention of oat-smut, 127

smuts of cereal grains and potatoes, 129

Pumps, capacities of, i $8 \mathrm{I}$

Pure cultures, use of, in butter-and cheese-making, 297 
Purity sta idards of seeds, 106

Quevenne lactometer, 255

Rainfall, 172

Rations for dairy cows, practical. I4, I6; standard, I 2 dry matter, digestible matter, and digestiblfarm animals, I2 protein in, Igh.

Reciprocals of numbers, 392

Record, highest, for yield of fat, 239

Records, milk-and butter-fat, official, 240

Red-polled cattle, 227

Rennet tests, 3 19

Richards, H. B., Ditch belted cattle, 232

Richter, Prof. A. W., Steam boiler and engine management 286

Road leagues, constitution of, 366

Road-making, i 8.3

Roads, drainage, 183

Roads, different :-:mis ot. Eorce required to draw a load on 185 I 86 good, importanc, $-Q_{5}$

gravel for, is 8

repairs, 184

stowe required for maintenance of, i go

Ropes, strength of, 399

Russell, Prof. H. L., Preservation of milk and cream by heat, 290

Rye, commercial grades of, 405

Salt. American dairy, analyses of, 318

Second-foot of water, 177

Seed mixtures for grass, clover, hay and permanent pastures, ; 5.76

quantity required per acre, 74,77

testing for the farmer, 104

vegetable, quantity required per acre, 90

Seeds, 104

germination standards, rog

grass, number, weight, cost, and amount to sow per acre ros

purity, 105

purity standards, 106

vegetable, time of germination and maturity table $9 \circ$

vitality, I 3

weights, legal, 400

seedsmen's, I 14

Separator skim-milk, per cent fat in, 280

Shaw. Prof. Thomas, Heredity, 48

Sheep, breeds, 25

determination of age of, 36

diseases of, $6 \mathrm{r}$

fine-wooled. 25

market classes of, 32

mutton, 25

proportions of the various parts of, 208

Shire horses, 23 
Shorthorn cattle, 24, 224

Shropshire sheep, 25

Silos, cylindrical, horizontal feeding area for different sized herds, $2_{3}$ capacity of, 85 relation between size of, and number of cows they will keep, 86

Sirup, sorghum, obtained from juice of different densities, 97

Sisson, L. P., Devon cattle, 230

Skim-milk, composition of, 273 per cent fat in, 280

Skimming of milk, detection of, 267 inefficient, loss of butter caused by, 285

Slope, rise per 100 feet, I 7 I

Smith, J. McLain, Red-polled cattle, 227

Smut of cereal grains, prevention of, i 29

oats, prevention of, i 27

Sodium nitrate, prices of, on the ammoniate basis, I 60

Soiling crops adapted to Northern New England states, 8I succession of, for dairy cows, 84 time of planting and feeding, 82

Soils, American, analyses of, 146

Solids of milk, calculation of, 258 sp. gr. of, $26 \mathrm{I}$

tables for obtaining, from specific gravity and per cent of fat, 266 Sorghum sirup obtained from juice of different densities, 97

Southdown sheep, 25 produced in the United States, 1899, 437

Specific gravity of buttermilk, 273

cream, 273

maple sirup, 96

milk, 249

milk solids, $26 \mathrm{r}$

potatoes, 95

skim-milk, 273

various substances, 407

woods, 136

Spraying calendar, 123

temperature correction tables for, of milk, 256

outfit for orchards, 126

Standard rations for farm animals, I 2, I 4

varieties of poultry, 47

Standards for dairy products, 262

of purity of seeds, I06

for milk and its products, government, 264

Standardization of cream, 286

milk, 272

Starch content, dry matter, and sp. gr. of potatoes, relation of, 95 equivalent, 2

Statistical tables, 4 I I

Steam boiler and engine management, 286

Steers, diagram of carcass, 204 
Steers, live and dressed weights of, 206

proportions of the various parts of, 206

Sterilization of milk and cream, 290, 293

Storm and hurricane warnings, 369

Straw, commercial grades of, $406 a$

Sub-humid region, 178

Suffolk horses, 23

sheep, 26

Sugar in the United States, production, 436

factories in the U. S., statistics of, 436

imports, I $901-1905,436$

Swine, breeds, 27

determination of age by their teeth, ${ }_{3} 6$

diseases of, 62

live weight and gains made, 207

market classes of, 321

plague, suppression of, 67

proportions of the various parts of, 208

Tainted milk, causes of, 322

Tamworth swine, 27

Tanks, capacity of, 182

Temperature correction tables for specific gravity of milk, 256

Temperature of the air, normal mean, in Canada, 4 I 6

the United States. $4^{12}$

farm animals, normal, 38

Temperatures injuring perishable goods, 98

for preserving horticultural products, roo

injurious to plants, 99

Test associations, dairy, constitution, $367 \mathrm{~b}$

Testing milk and other dairy products by Babcock's method, 252

Tests of dairy breeds at American experiment stations, 237

British Dairy Farmers' Assoc., 24 I

La. Purchase Exposition, 239

World's Columbian Exposition, 238

Thermometer scales, comparisons of, 393

Thoroughbred horse, the, 2 I

Tile, limit of size to grade and length, 172

Tile draining land, reasons for, $16 \mathrm{r}$

pipe of main drain, size required, 163

Tiles, discharge of, on different grades, 164

number required per acre, table showing, I 62, I 63

of acres drained by, of different diameters and per cenć grade, 164,165

size required for drainage, $x 62,163$

Tires, wide, effect of, 190

Tractive force required for carriages, i 85

of horses at clifferent speed, 186

effect of inclination on, 187

surface on, I 88

Trade values of fertilizing ingredients, I 59

Transportation on the farm, 189 
Tree-planting, distance table, I 38

Trees, number on an acre, I.35

Trotter, the American, 2 I

Tuberculin tests, directions for making, 69

United States, agricultural experiment stations in, 458

- imports and exports. 439

population, 4 I 1,418

products, prices of, I $890-1905,426$

schools and colleges, 454

wages, 1893-1895, 424

area and population, 4 II

areas of appropriated, vacant, and reserved land in, 4Ig

bees, honey, and wax produced, 438

beet-sugar factories in, statistics of, 436

production, $1903^{-1} 1906,436$

breeds and number of registered live stock, 428

butter, exports, I 870-I 905,446

factories, statistics of, 434

cattle, pure-bred, used for dairying, number and valus, 423

cereal products, principal, 425

cheese factories, statistics of, 434

exports, I 870-1 905,446

comparison of leading industries, 4 I 6

condensed-milk factories, statistics of, 434

cost per acre of raising wheat, corn, and cotton, 1893,426

crops, principal, statistics of, 420,425

dairy schools 457

statistics for I 900,432

Department of Agriculture, organization, 452

educational institutions, 454

farm animals, 430

farming population, 417

farmers' institutes, officials in charge, 459

farms in, number of, and their value, 4 I 8

farms, statistics concerning. 419

fertilizer industry, 447

imports and exports, 1896,447

forestry schoo!s, 457

industry groups in. 424

live-stock interests, veterinary and sanitary officers in charge of, 456

number and value of farm animals, 427,430

of farms in, and their value, 4 i 8

of pure-bred cattle used for dairying, 429

of registered live stock, 428

officials in charge of agriculture, 453

poultry and egg product, 1850-r 900,437

precipitation, normal, 4 i 5

production and value of principal crops, 425

production of honey and beeswax, 438

rank of states in as to value of agricultural products, 443

soils, analyses of, I 46 
United States, statistics of butter, cheese, and condensed-milk factories, 434

statistics of farms. 419

principal crops. 420,425

sugar crop in the United States, 435

factories, beet, statistics of, 436

production of beet- and cane-, 436

temperature of the air, normal mean, 4 I 2

value of principal farm products, 425

veterinary colleges in, 456

wages, agricultural, r $893-1895,424$

wool product, 435

Valuation of feeding-stuffs, 20

manures and fertilizers, $15^{8}$

Value of foreign coins, $4 \circ 9$

Veal, diagram of cuts, 205

Vegetable and fruit garden, a combined, 92

Vegetable forcing calendar, a, 93

Vegetable seed required per acre, $9 \circ$

time of germination and maturity table, 90

Tegetables, usual distances for planting, 72

Veterinary colleges, American, list of, 456

remedies and doses, 63

science, 53

Victoria swine, 25

Village-improvement societies, constitution of, 364

$\mathrm{V}$ iscogen, 292

Yitality of seeds, i 13

Wages, agricultural, in the United States, $1893-1895,424$

by the week and the day, table of, 383

Wagon tires, wide, effect of, r 90

Nater, acre-foot of, $17 z$

carrying capacity of pipes, I 79

duty of, 176

flow through straight pipes, 79

miner's inch, I 77

power required for discharge of, i 76

to raise, from deep wells, i 80

required for cooling milk or cream, quantity, 294

right, i 76

second-foot, 177

Watering of milk, detection of, 267

and skimming, detection of, 268

Weather Bureau, the, explanation of flag signals adopted by, 368

Weeds, i i 6 services, state, list of headquarters of, 370

noxious, table of, 116

Weight of cattle, estimation of, 35

eggs, loss in, during incubation, 46

Weights of poultry, standard, 47 
Weights and measures, 387

$$
\text { conversion table, } 389,39 x
$$

customary system of, 387

metric system of, 388

Weights, legal, of grain, seeds, etc., I I 4,400 seedsmen's customary, per bu. of seeds, II 4

Wcir table, the California, 182

Wheat, cost per acre, of raising, 426 commercial grades of, $40 \mathrm{I}$

Wheeler, Prof. Wm. P., Feeding and general care of poultry, 4 s

Whey, composition of, 273

standard of purity, government, 266

to be allowed patrons, 337

Whitewash, recipe for, r $9 \mathrm{r}$

Wind, force and velocity of, 173

Windmills, capacity, $173,174,181$ economy, 175

square feet and acres irrigated by, $\mathbf{7} 73$

Winslow, C. M., Ayrshires, 22

Winter-killed clover, replacing, 82

Wire ropes, strength of, 399

Wisconsin curd test, 322

Wonds, fuel value and specific gravity, i 36

Wool product of the United States, 1905, 435

World's Columbian Exposition, results of breed tests at, 238

World's Fair, St. Louis, results of breed tests at, 239

Yield of butter, formula for calculating, 3 I I

from roo lbs, cream of different richness, $32 \mathrm{~T}$

Cheddar cheese, formula for calculating, $33 x$

cheese from 100 lbs. of milk, 332, 334

fat, highest record, 2.30

milk and fat from dairy cows, 237

of dairy breeds, $237-242$

Yielis, a verage, per acre of various crops, 87,91

Yorkshire swine, 27 




$$
\frac{\text { wate }}{\text { aes }} x
$$




\section{DAY USE}

RETURN TO DESK FROM WHICH BORROWED

AGRICULTURE LIBRARY

40 Giannini Hall - Tel. No. 642-4493

This book is due on the last date stamped below, or on the date to which renewed. Renewed books are subject to immediate recall.

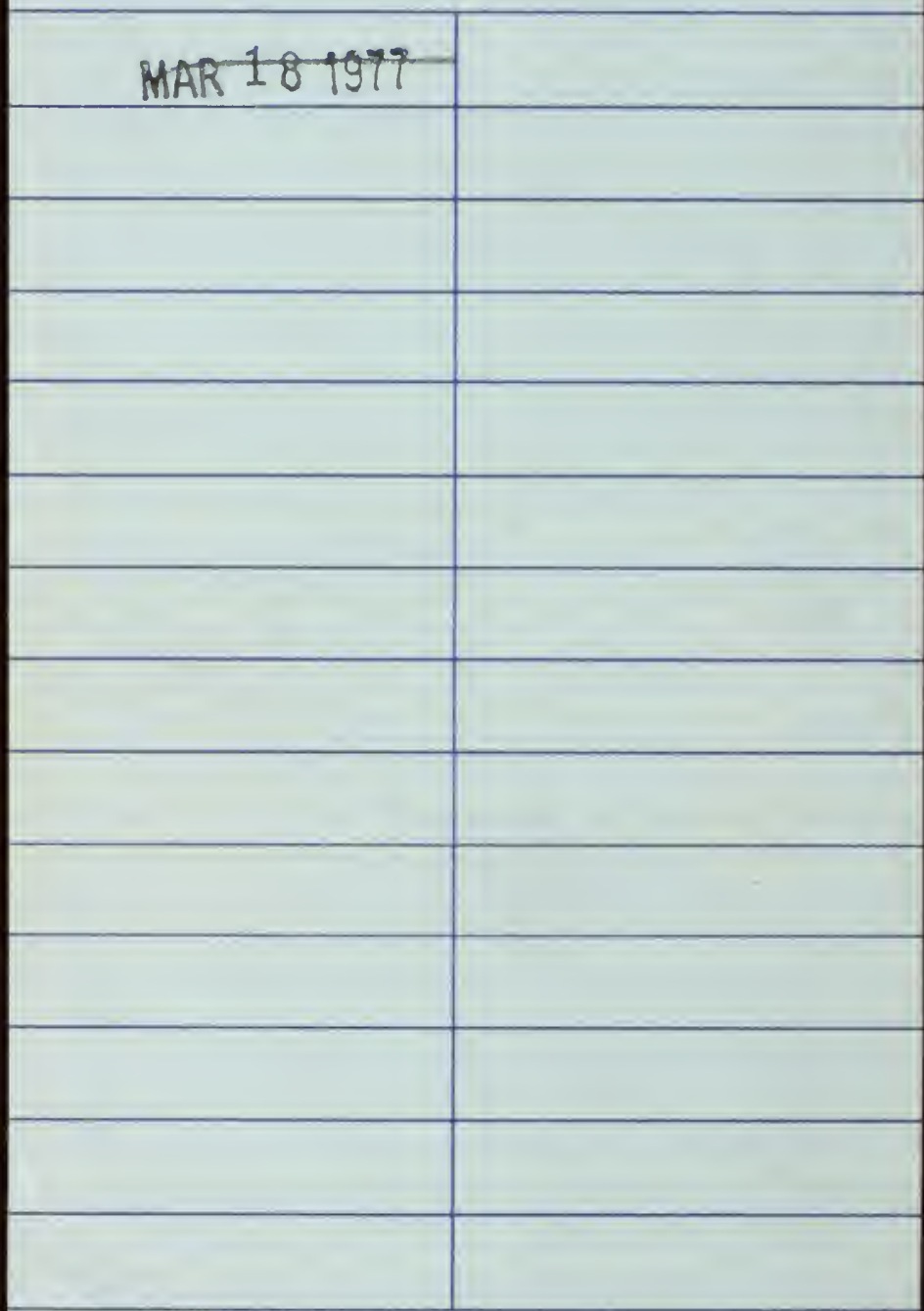



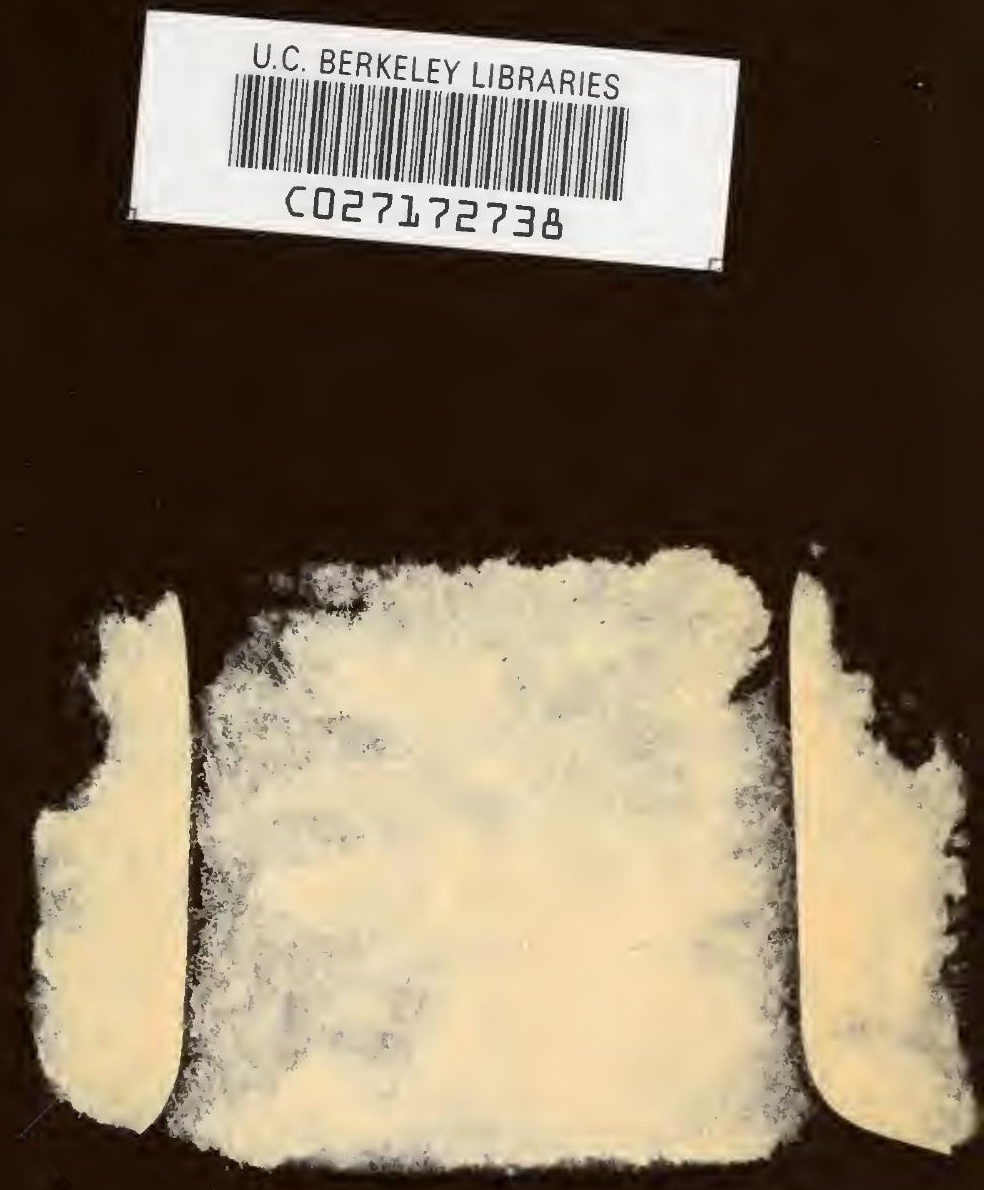
